\title{
ADERÊNCIA DE CORDOALHAS EM CONCRETOS DE ALTA RESISTÊNCIA COM E SEM FIBRAS DE AÇO
}

\author{
TATIANA BITTENCOURT DUMÊT
}

Tese apresentada à Escola de Engenharia de São Carlos, da Universidade de São Paulo, como parte dos requisitos para a obtenção do Título de Doutor em Engenharia de Estruturas.

ORIENTADOR: Libânio Miranda Pinheiro, Prof. Dr.

São Carlos, 2003 
Ficha catalográfica preparada pela Seção de Tratamento

da Informação do Serviço de Biblioteca - EESC/USP

Dumêt, Tatiana Bittencourt

D888a Aderência de cordoalhas em concretos de alta Dumêt. -- São Carlos, 2003.

Tese (Doutorado) -- Escola de Engenharia de São

Carlos-Universidade de São Paulo, 2003.

Área: Engenharia de Estruturas.

Orientador: Prof. Dr. Libânio Miranda Pinheiro.

1. Concreto. 2. Concreto protendido. 3. Pré-tração. 4. Aderência. 5. Cordoalhas. 6. Fibras de aço. 7. Concreto de alta resistência. I. Título. 
FOLHA DE JULGAMENTO

Candidata: Engenheiro TATIANA BITTENCOURT DUMET

Tese defendida e julgada em 25-07-2003 perante a Comissão Julgadora:

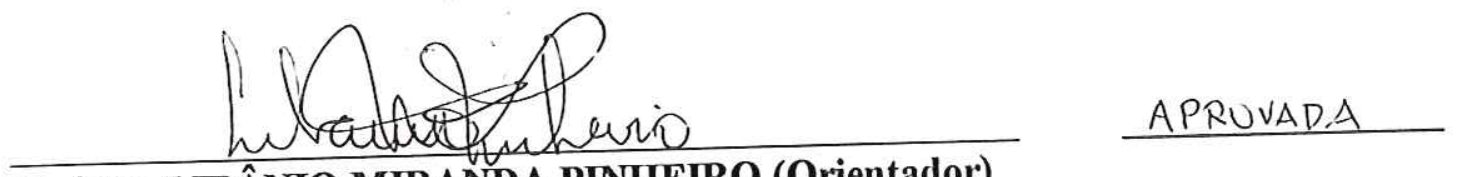

Prof. Dr. LIBÂNIO MIRANDA PINHEIRO (Orientador)

(Escola de Engenharia de São Carlos/USP)

$\frac{1 \text { uch a che }}{\text { Profa. Dra. ANA LÚCIA HOMCE DE CRESCE EL DEBS }}$

Aprovids

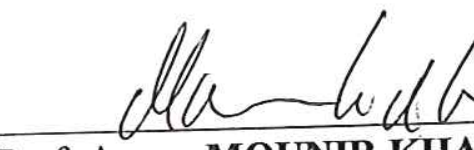

Prof. Assoc. MOUNIR KHALIL EL DEBS

(Escola de Engenharia de São Carlos/USP)

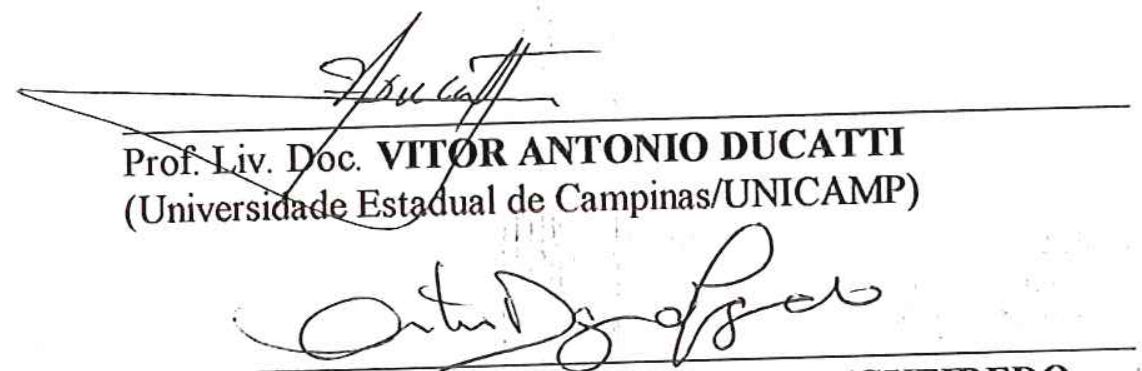

Aprovada

Prof. Dr. ANTONIO DOMINGUES DE FIGUEIREDO

Aprovado

(Escola Politécnica/USP)
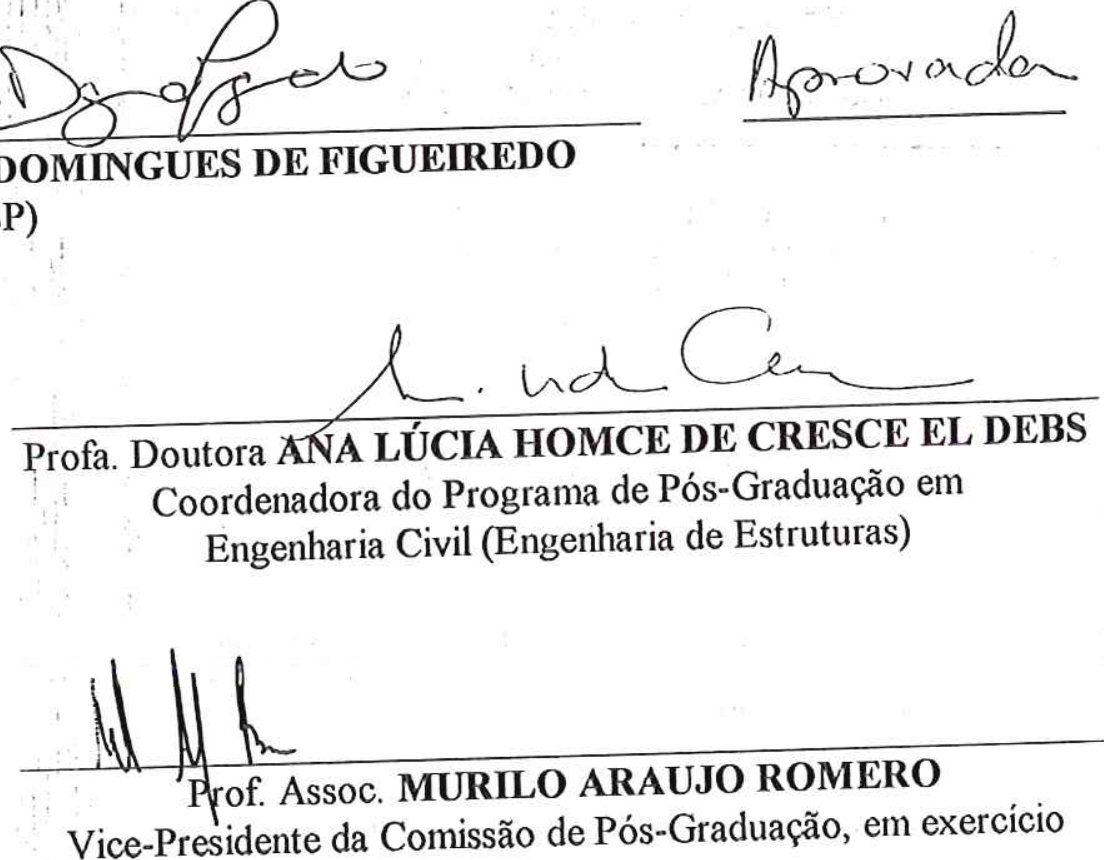
Dedico este trabalho a meu avô, Rogério Tarquínio Bittencourt, que sempre foi e sempre será um exemplo de bondade, respeito, otimismo, inteligência, amor e carinho. A ele, o meu muito obrigado, a minha admiração, e eterna saudade. 


\section{AGRADECIMENTOS}

Ao Prof. Dr. Libânio Miranda Pinheiro pela orientação e amizade durante todo o tempo deste trabalho.

Aos funcionários do Laboratório de Estruturas, do Departamento de Engenharia de Estruturas, Eng. Dr. Luiz Vicente Vareda, Amaury Ignácio da Silva, Jorge Luís Brabo, Mário Botelho, Mauri Sérgio Dias Guillen, Valdir Carlos de Lucca e aos estagiários João Domingos Pereira Filho, Juliano Linares Santos, Fabiano Dornelas e Waldemir Francisco Júnior, pela constante ajuda na preparação e execução de todos os ensaios.

Aos funcionários do Departamento de Engenharia de Estruturas, em especial a Maria Nadir Minatel, Rosi Aparecida Jordão Rodrigues e Marta Regina C. Faria, pela constante ajuda durante todo o tempo do meu trabalho, e a Francisco Carlos G. de Brito pela ajuda e execução de algumas das figuras.

Ao Laboratório de Geotecnia, na pessoa de Antonio, pelo corte dos prismas de concreto.

Ao Dr. Mariano Espinoza pela inestimável ajuda na análise estatística dos dados experimentais.

Ao Prof. José Zamarion pela ajuda no início dos trabalhos, e aos professores Antônio Carlos Laranjeiras e Sydney Furlan Júnior pela atenção e ajuda dedicadas às minhas dúvidas.

Ao Departamento de Construção e Estruturas da Universidade Federal da Bahia pelo apoio e pelo afastamento concedido para o desenvolvimento deste trabalho.

À CAPES, pela concessão de bolsa PICDT, e à FAPESP pelo auxílio financeiro a esta pesquisa.

Às empresas Holcim Brasil S. A. pela doação do cimento, Belgo Bekaert Arames S. A. pela doação das cordoalhas e das fibras de aço, Mac Protensão pela doação do sistema de encunhamento das cordoalhas, Jeruelplast pela doação dos espaçadores de armaduras, e Fosroc Reax Industrial e Comercial Ltda. pela doação dos aditivos superplastificantes.

Aos amigos Joel Neto, Vanessa Castilho, Kristiane Accetti, Osvaldo Holanda, Anamaria Miotto, Fabiana Oliveira e Fernando Filho pelo apoio e amizade durante todo o tempo.

Em especial, às amigas Tatiana Almeida, Juliana Lima e Mônica Guarda pelo apoio, pelo incentivo, pela ajuda na elaboração do trabalho e, principalmente, pela amizade.

A meu pai, minha mãe, minhas irmãs e minhas sobrinhas por simplesmente existirem, e a toda minha família e amigos que de uma maneira ou de outra estão sempre me ajudando e me apoiando no meu dia a dia. 


\section{RESUMO}

DUMÊT, T. B. - Aderência de cordoalhas em concretos de alta resistência com e sem fibras de aço. São Carlos, 2003. Tese (Doutorado). Escola de Engenharia de São Carlos, Universidade de São Paulo, 490 pp.

Este trabalho apresenta os resultados das investigações teórica e experimental sobre a aderência de cordoalhas pré-tracionadas, em concretos de alta resistência com e sem fibras de aço. Foram utilizadas cordoalhas de sete fios com $\phi_{\mathrm{p}} 12,7 \mathrm{~mm}$ e fibras de aço curtas, com ganchos nas extremidades (DRAMIX) e fator de forma $\ell / d=45$. Foram realizados dois tipos de ensaios: arrancamento e flexão em viga. Os parâmetros estudados foram: comprimento de ancoragem $\left(5 \phi_{\mathrm{p}}, 7 \phi_{\mathrm{p}}\right.$ e $\left.15 \phi_{\mathrm{p}}\right)$, volume de fibra (zero, $40 \mathrm{~kg} / \mathrm{m}^{3}$ e $\left.60 \mathrm{~kg} / \mathrm{m}^{3}\right)$ e grau de protensão (zero e $0,8 \mathrm{f}_{\text {ptk }}$ ). $\mathrm{O}$ concreto apresentou resistências à compressão de $50 \mathrm{MPa}$ no momento da transferência da protensão e 68MPa na data de ensaio, aproximadamente. Os resultados dos dois tipos de ensaio foram analisados e comparados com as prescrições normativas da NBR 6118 (2001), da FIB Bulletin 1 (1999) e do ACI 318 (2002), onde verificou-se que as prescrições se encontram a favor da segurança. A conclusão principal resultante desta pesquisa foi que a utilização de fibras com $40 \mathrm{~kg} / \mathrm{m}^{3}$ não influi na aderência. Já para um volume de fibra de $60 \mathrm{~kg} / \mathrm{m}^{3}$ há um ganho de aproximadamente $28 \%$ na aderência, em relação aos concretos sem fibras de aço, nos ensaios de arrancamento. Para as vigas, não houve ganho de aderência para os volumes de fibra utilizados, nem na determinação do comprimento de transferência, nem na do comprimento de ancoragem necessário.

Palavras-chave: concreto, concreto protendido, pré-tração, aderência, cordoalhas, fibras de aço, concreto de alta resistência. 


\section{ABSTRACT}

DUMÊT, T. B. - Bond of strands embedded in plain and steel fiber reinforced high strength concrete. São Carlos, 2003. Thesis (Doctorate). Escola de Engenharia de São Carlos, Universidade de São Paulo, 490 pp.

This study presents the results of a theoretical and an experimental investigation of the bond of pretensioned strands embedded in plain and steel fiber reinforced high strength concrete. There were used seven wires strands with $12,7 \mathrm{~mm}$ diameter and short hooked steel fibers with an aspect ratio of $\ell / d=45$. Two types of tests were carried out to obtain the bond characteristics of the strands: pullout tests and beam under flexure tests. The parameters studied were the volume fraction $(0 \%, 0,51 \%$ and $0,76 \%)$ of the fibers, and the degree of prestress of the strand (zero and $0,8 \mathrm{f}_{\text {ptk }}$ ). The concrete compressive strength was $50 \mathrm{MPa}$ at transfer ( 3 days of age) and 68MPa at 28 days of age (test date), approximately. The results were analyzed and compared to the provisions of the following Codes: NBR 6118 (2001) (Brazilian code under public consult), ACI-318 (2002) and FIB-Bulletin 1 (1999). The comparison indicated that the codes give a safe design. The main conclusion of this work was that the use of $0,5 \%$ of steel fibers does not influence the bond strength of the strand. The use of $0,76 \%$ of steel fibers increases the bond stress in $28 \%$ when compared with plain concrete, for the pullout tests. For the beam's tests there was no bond improvement due to the steel fibers, in both case $(0,5 \%$ and $(0,76 \%)$, neither for the transfer length nor for the development length.

Keywords: concrete, prestressed concrete, pretensioned concrete, bond, strands, steel fibers, high-strength concrete. 


\section{SUMÁRIO}

\section{LISTA DE ABREVIATURAS \\ LISTA DE SÍMBOLOS}

1. INTRODUÇÃ

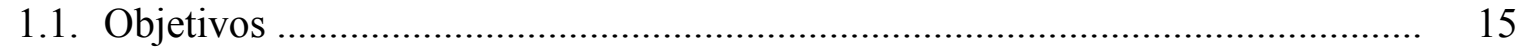

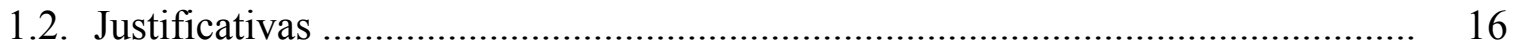

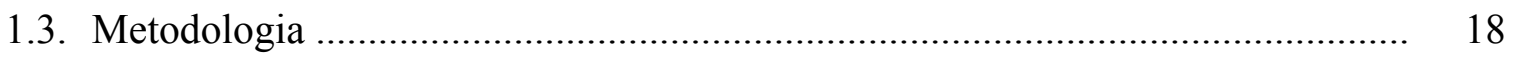

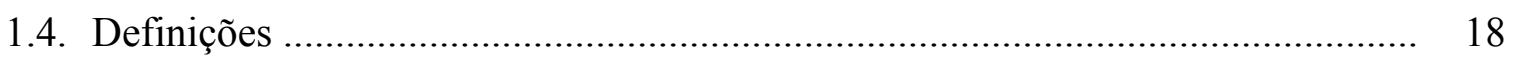

1.5. Conteúdo da Tese ................................................................................. 20

2. REVISÃO BIBLIOGRÁFICA E COMENTÁRIOS ............................................. 23

2.1. As Fibras e o Concreto ............................................................................... 23

2.1.1. Tipos de fibras de aço e processos de fabricação do CRFA ……................. 26

2.1.2. Eficiência das fibras ................................................................................ 28

2.1.3. Aplicações do CRF ............................................................................. 34

2.1.4. Comentários e parâmetros adotados na pesquisa ........................................ 36

2.2. A Aderência, sua Importância e suas Implicações ............................................. 37

2.2.1. Tipos de aderência ................................................................................. 38

2.2.2. O estudo da tensão de aderência .............................................................. 41

2.2.3. Representação da aderência ...................................................................... 47

2.2.4. Os comprimentos de ancoragem ......................................................... 51

2.2.5. Modos de ruptura por perda de aderência ............................................... 54

2.2.6. A aderência no concreto armado ........................................................... 59

2.2.7. As fibras e a aderência no concreto armado ............................................... 63

2.2.8. Conclusões sobre a influência das fibras na aderência ................................. 73

2.3. A Aderência no Concreto Protendido …….......................................................... 73

2.3.1. Pesquisas sobre a aderência no concreto protendido ................................. 74

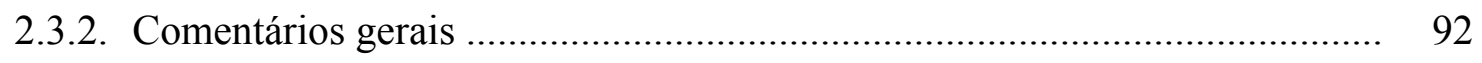

2.3.3. As fibras e a aderência no concreto protendido ...................................... 93 


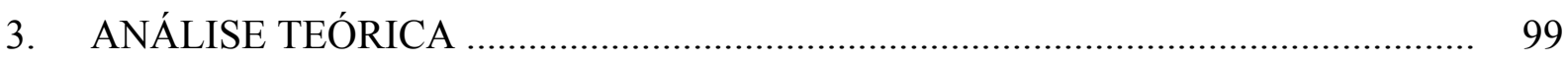

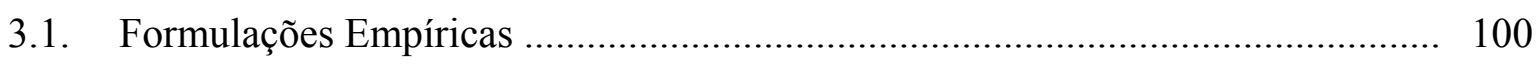

3.1.1. Tensão de aderência _............................................................................. 103

3.1.2. Comprimentos de ancoragem ............................................................. 118

3.2. Prescrições Normativas .............................................................................. 124

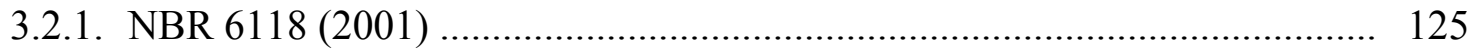

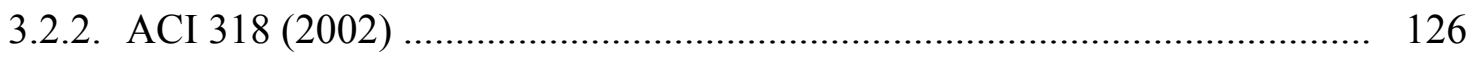

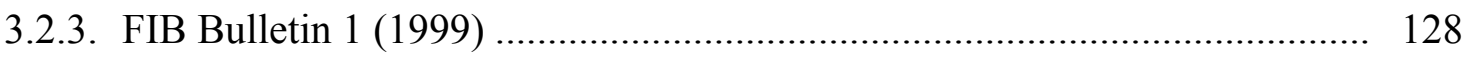

3.2.4. Comentários sobre as prescrições normativas ........................................ 130

3.3. Análise Comparativa das Formulações Teóricas ............................................. 135

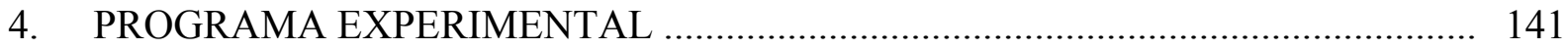

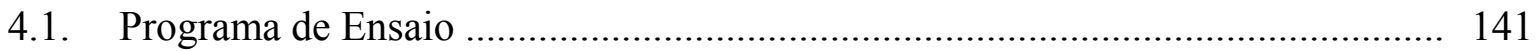

4.1.1. Projeto dos modelos ..................................................................... 147

4.1.2. Projeto de execução dos ensaios ........................................................... 152

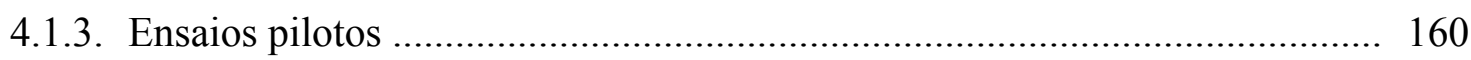

4.1.4. Ensaios de caracterização dos materiais .................................................... 168

4.1.5. Ensaios de arrancamento .......................................................................... 169

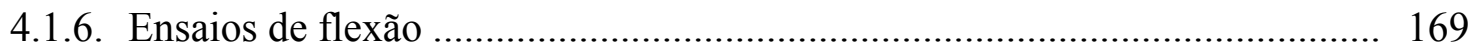

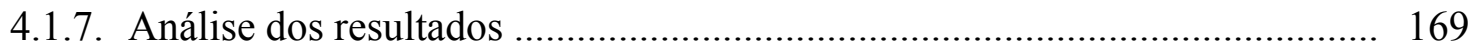

4.2. Ensaios de Caracterização dos Materiais ........................................................... 169

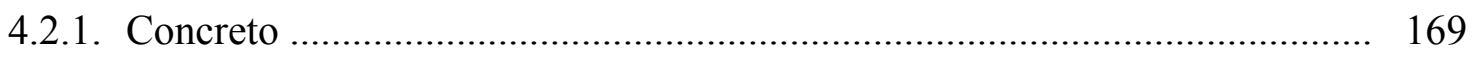

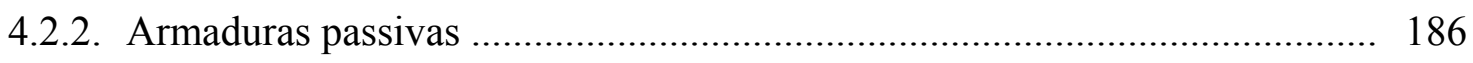

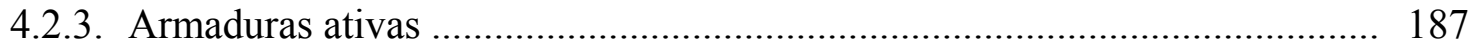

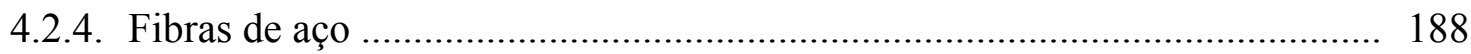

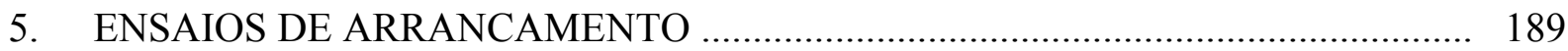

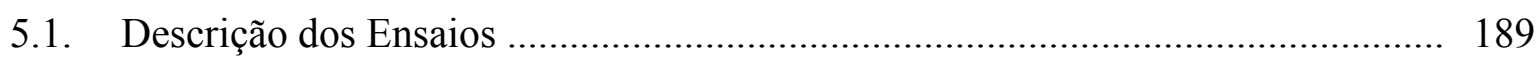

5.1.1. Ensaios dos prismas da Série 1 ............................................................ 195

5.1.2. Ensaios dos prismas da Série 2 ......................................................... 215

5.2. Análise Estatística dos Ensaios de Arrancamento ............................................ 224 
5.3. Análise Comparativa dos Resultados Experimentais ..................................... 230

5.3.1 Análise da fissuração dos modelos ........................................................ 230

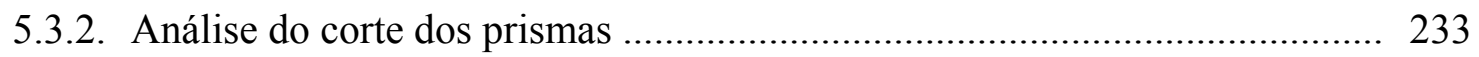

5.3.3. Análise do comportamento Tensão de aderência versus Escorregamento .... 234

5.3.4. Análise dos valores característicos ....................................................... 241

5.4. Confrontação dos Resultados Teóricos e Experimentais .................................. 243

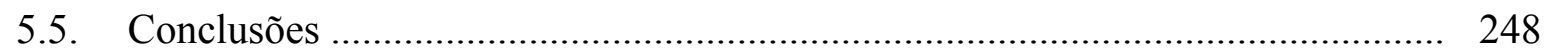

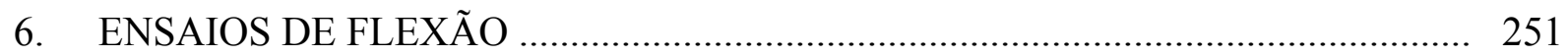

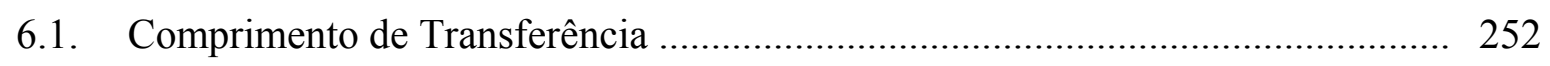

6.1.1. Descrição dos ensaios ....................................................................... 252

6.1.2. Análise comparativa dos resultados experimentais ............................... 267

6.1.3. Confrontação dos resultados teóricos e experimentais .............................. 273

6.2. Comprimento de Ancoragem Necessário ......................................................... 274

6.2.1. Descrição dos ensaios .............................................................................. 274

6.2.2. Análise comparativa dos resultados experimentais ................................ 313

6.2.3. Confrontação dos resultados teóricos e experimentais ............................ 317

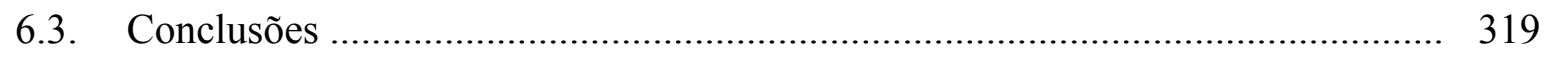

6.3.1. Comprimento de transferência .......................................................... 319

6.3.2. Comprimento de ancoragem necessário ................................................... 319

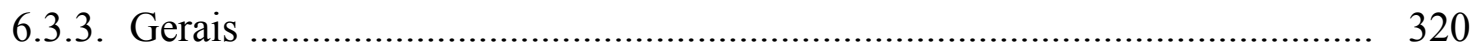

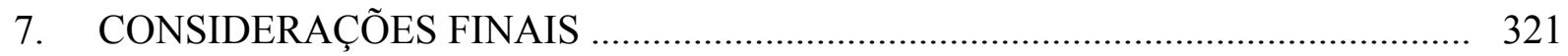

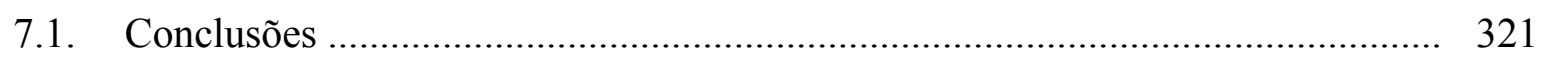

7.2. Sugestões para Pesquisas Futuras ........................................................... 322

7.2.1. Ensaios de arrancamento variando a armadura ativa ................................ 322

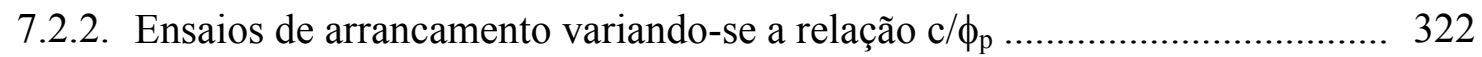

7.2.3. Ensaios de arrancamento variando-se o grau de protensão .......................... 323

7.2.4. Ensaios de arrancamento variando-se o tipo de fibra de aço ..................... 323

7.2.5. Estudo da influência do tipo de alívio da protensão ................................... 323

7.2.6. Estudo da utilização de fibras de aço em vigas sem armaduras passivas ...... 323

7.2.7. Determinação de um modelo analítico para as cordoalhas .......................... 323

7.2.8. Determinação do comprimento de ancoragem necessário .......................... 323 
REFERÊNCIAS BIBLIOGRÁFICAS

APÊNDICE A

APÊNDICE B

APÊNDICE C

APÊNDICE D

APÊNDICE E

APÊNDICE F

APÊNDICE G

ANEXO A 


\section{LISTA DE ABREVIATURAS}

AASHTO - American Association of State Highway and Transportation Officials

ABNT - $\quad$ Associação Brasileira de Normas Técnicas

ACI - $\quad$ American Concrete Institute

ARI - $\quad$ Alta Resistência Inicial

ASTM - $\quad$ American Society for Testing and Materials

BBA - $\quad$ Belgo Bekaert Arames

CAD - $\quad$ Concreto de Alto Desempenho

CADRF - $\quad$ Concreto de Alto Desempenho Reforçado com Fibras

CAR - $\quad$ Concreto de Alta Resistência

CAPES - Coordenação de Aperfeiçoamento de Pessoal de Nível Superior

CEB - $\quad$ Comité Euro-International du Béton

CP - $\quad$ Corpo-de-Prova

CRC - $\quad$ Compósitos Compactos Reforçados

CRF - $\quad$ Concreto Reforçado com Fibras

CRFA - $\quad$ Concreto Reforçado com Fibras de Aço

CRFP - $\quad$ Concreto Reforçado com Fibras Plásticas

DIN - Deutsches Institut für Normung

EC - $\quad$ Eurocode

EESC - $\quad$ Escola de Engenharia de São Carlos

FAPESP - Fundação de Amparo à Pesquisa do Estado de São Paulo

FHWA - $\quad$ Federal Highway Administration

FIB - $\quad$ Fédération Internationale du Béton

FIP - $\quad$ Fédération Internationale de la Précontrainte

GFRC - Concreto Reforçado com Fibra de Vidro

JSCE - $\quad$ The Japan Society of Civil Engineers

LE - $\quad$ Laboratório de Estruturas (da EESC/ USP)

NBR - $\quad$ Normas Técnicas Brasileiras

PCI - Precast/ Prestressed Concrete Institute

PP-FRC - $\quad$ Concreto Reforçado com Fibra de Polipropileno

RILEM - Réunion Internationale des Laboratoires d'Essais et de Recherches sur les Matériaux et les Constructions 
RPC - $\quad$ Concreto de Pós-Reativos

SIFCON - Concreto com Fibra Infiltrado com Nata de Cimento

SFRC - $\quad$ Concreto Reforçado com Fibra de Aço

USP - $\quad$ Universidade de São Paulo

\section{LISTA DE SÍMBOLOS}

A seguir são apresentados, em ordem alfabética, os principais símbolos usados ao logo deste trabalho.

\section{Letras romanas minúsculas}

$\mathrm{b}_{\mathrm{w}}=\quad$ Largura da alma da viga

$\mathrm{c}=\quad$ Cobrimento

$\mathrm{d}_{\mathrm{f}}=\quad$ Diâmetro da fibra de aço

$\mathrm{f}_{\mathrm{b}}=\quad$ Tensão de aderência

$\mathrm{f}_{\mathrm{c}}=\quad$ Resistência do concreto à compressão

$\mathrm{f}_{\mathrm{c}, \text { transf }}=$ Resistência do concreto à compressão na transferência da protensão

$\mathrm{f}_{\mathrm{ck}}=\quad$ Resistência característica do concreto à compressão

$\mathrm{f}_{\mathrm{cm}}=\quad$ Resistência média do concreto à compressão

$\mathrm{f}_{\mathrm{ct}}=\quad$ Resistência do concreto à tração

$\mathrm{f}_{\mathrm{ct}, \mathrm{fl}}=\quad$ Resistência do concreto à tração na flexão

$\mathrm{f}_{\mathrm{ct}, \mathrm{sp}}=\quad$ Resistência do concreto à tração na compressão diametral

$\mathrm{f}_{\mathrm{ptk}}=\quad$ Resistência característica da armadura ativa à tração

$\mathrm{f}_{\text {pyd }}=\quad$ Resistência de cálculo da armadura ativa à tração

$\mathrm{f}_{\text {pyk }}=\quad$ Resistência característica da armadura ativa ao escoamento

$\mathrm{f}_{\mathrm{r}}=\quad$ Módulo de ruptura do concreto

$\mathrm{f}_{\mathrm{st}}=\quad$ Resistência do aço de armadura passiva à tração

$\mathrm{f}_{\mathrm{yd}}=\quad$ Resistência de cálculo da armadura passiva à tração

$\mathrm{f}_{\mathrm{yk}}=\quad$ Resistência característica da armadura passiva ao escoamento

$\mathrm{h}=\quad$ Altura da seção transversal da viga

$\ell=\quad$ Comprimento da fibra de aço

$\ell / \mathrm{d}=\quad$ Fator de forma das fibras 
$\ell_{\mathrm{ef}}=\quad$ Comprimento aderente disponível

$\ell_{\mathrm{bp}}=\quad$ Comprimento de ancoragem básico, para armadura ativa

$\ell_{\text {bpd }}=\quad$ Comprimento de ancoragem necessário, para armadura ativa

$\ell_{\text {bpt }}=\quad$ Comprimento de transferência, para armadura ativa

$\ell_{\mathrm{p}}=\quad$ Distância de regularização da força de protensão

$\mathrm{S}=\quad$ Espaçamento da armadura transversal

$\mathrm{z}=\quad$ Braço de alavanca

\section{Letras romanas maiúsculas}

$\begin{array}{ll}\mathrm{A}_{\mathrm{c}}= & \text { Área da seção transversal de concreto } \\ \mathrm{A}_{\mathrm{p}}= & \text { Área da armadura ativa } \\ \mathrm{C}= & \text { Resultante das forças de compressão } \\ \mathrm{E}_{\mathrm{c}}= & \text { Módulo de elasticidade do concreto } \\ \mathrm{E}_{\mathrm{p}}= & \text { Módulo de elasticidade da armadura ativa } \\ \mathrm{L}= & \text { Vão livre da viga } \\ \mathrm{L}_{\mathrm{pista}}= & \text { Comprimento da pista de protensão } \\ \mathrm{M}= & \text { Momento fletor } \\ \mathrm{P}= & \text { Força externa variável aplicada } \\ \mathrm{P}_{0}= & \text { Força de protensão após as perdas imediatas } \\ \mathrm{P}_{\infty}= & \text { Força de protensão após todas as perdas } \\ \mathrm{P}_{\mathrm{i}}= & \text { Força de protensão máxima inicial } \\ \mathrm{S}= & \text { Escorregamento } \\ \mathrm{SD}= & \text { Desvio padrão } \\ \mathrm{T}= & \text { Resultante das forças de tração } \\ \mathrm{T}_{\mathrm{b}}= & \text { Tenacidade } \\ \mathrm{V}_{\mathrm{f}}= & \text { Volume de fibras } \\ \mathrm{V}= & \text { Força cortante }\end{array}$

\section{Letras gregas minúsculas}

$\delta=\quad$ Penetração da cordoalha

$\varepsilon=\quad$ Deformação específica

$\varepsilon_{\mathrm{cu}}=\quad$ Deformação última de compressão do concreto

$\varepsilon_{\mathrm{pd}}=\quad$ Alongamento total de cálculo da armadura ativa

$\varepsilon_{\text {pnd }}=\quad$ Pré-alongamento de cálculo da armadura ativa 
Diâmetro da armadura passiva

$\phi_{\mathrm{p}}=$

Diâmetro da armadura ativa

$\mu=$

Coeficiente de atrito entre o aço e o concreto

$\overline{\sigma_{\mathrm{b}}}=$

Coeficiente de tenacidade na flexão

$\sigma_{\mathrm{c}}=$

Tensão no concreto

$\sigma_{\mathrm{p}}=$

(1) Tensão na armadura ativa

(2) Grau de protensão dos modelos ensaiados (em função de $f_{\text {ptk }}$ )

$\sigma_{\mathrm{p} 0}=$

Tensão na armadura ativa correspondente $\mathrm{a} \mathrm{P}_{0}$

$\sigma_{\mathrm{p} \infty}=$

Tensão na armadura ativa após todas as perdas

$\sigma_{\mathrm{pd}}=$

Tensão de cálculo na armadura ativa

$\sigma_{\mathrm{pi}}=$

Tensão na armadura ativa imediatamente após a aplicação da protensão

$\tau_{\mathrm{b}}=$

Tensão de aderência

\section{Letras gregas maiúsculas}

$\Delta \mathrm{P}=\quad$ Perdas de protensão relativas às forças

$\Delta \sigma_{\mathrm{p}}=\quad$ Perdas de protensão relativas às tensões 


\section{INTRODUÇÃO}

Desde o seu aparecimento, no início do século XIX, até hoje, o concreto vem se desenvolvendo, seja com o surgimento de novas tecnologias, seja com o surgimento de novos materiais, tais como os aditivos e as fibras.

Hoje existem inúmeros materiais e técnicas de construção diferentes, que podem ser usados independentemente ou em conjunto, como as estruturas mistas, por exemplo.

O concreto teve seu desenvolvimento alavancado após a 2 ${ }^{\underline{a}}$ Guerra Mundial, o que foi resultado, principalmente, do progresso da indústria do cimento e da indústria de aditivos, em especial os superplastificantes. Existe, hoje, uma variedade enorme de tipos de cimento e de aditivos, cada um visando melhorar ou fornecer uma característica específica ao concreto. A evolução do conhecimento da química do cimento, e conseqüentemente do concreto, também vem desempenhando um papel importante no progresso tecnológico da Engenharia Civil.

Esse progresso tem procurado resolver, em especial, o problema que as estruturas de concreto têm apresentado em relação à durabilidade. Há 40 ou 50 anos, acreditava-se que as estruturas de concreto eram bastante duráveis, não precisando de manutenção. Com o passar dos anos, essa crença foi desmentida. Além da deterioração natural que as estruturas de concreto sofrem, surgiu um outro agravante: essas estruturas estão ficando cada vez mais esbeltas.

A perda de robustez das estruturas é fruto do avanço tecnológico da ciência dos materiais, que vem desenvolvendo concretos cada vez mais resistentes, possibilitando a redução das seções transversais das peças, e do avanço da ciência da computação, que com o advento de microcomputadores cada vez mais rápidos e potentes permite o refinamento dos 
processos de cálculo, levando a estruturas mais otimizadas. Como resultado desse progresso, especialmente na área de materiais, chegou-se aos concretos de alta resistência (CAR) e de alto desempenho (CAD).

No final da década de 70 e no início da década de 80, países como o Canadá, os Estados Unidos, a França, a Inglaterra, a Itália, o Japão, a Noruega e a União Soviética, devido ao uso de superplastificantes, já utilizavam o CAR comercialmente. O uso do CAR é mais motivado pela sua maior durabilidade do que pela sua maior resistência. Segundo SHAH et al (1999), devem ser levados em conta, simultaneamente, três fatores distintos na obtenção de concretos duráveis; são eles: resistência, permeabilidade e início de fissuração.

Para garantir que essas propriedades atuem de maneira desejável, podem ser adicionados ao concreto materiais de efeitos pozolânicos, como a sílica ativa, ou fibras. O uso de fibras no concreto, mais do que melhorar sua resistência, aumenta sua ductilidade e sua tenacidade, dificulta o início da fissuração, e melhora o seu comportamento pós-físsuração. Dessa filosofia de obter concretos com características melhoradas, em relação ao concreto comum, é que surgiu o conceito de CAD.

Segundo NEVILLE (1997), o CAD vem se desenvolvendo nos últimos 25 anos, especialmente com a obtenção de concretos com resistências cada vez maiores, apesar de CAD e CAR não serem a mesma coisa. No CAD a característica principal pode não ser apenas a resistência, e sim uma outra característica, que seja desejável para um determinado tipo de estrutura. São elas: elevada densidade, elevado módulo de elasticidade, baixa permeabilidade, resistência a certos tipos de ataque, concretos auto-adensáveis ou, ainda, elevada resistência. Todas essas características visam a uma maior durabilidade do concreto. O resultado, geralmente, é um material de elevada resistência e baixa porosidade. Porém, tanto o CAD como, principalmente, o CAR são materiais mais frágeis do que o concreto comum. Para torná-los mais dúcteis, a adição de fibras de aço tem se mostrado uma ótima solução.

Segundo BENTUR \& MINDESS (1990), há aproximadamente 3500 anos o homem vem fazendo uso das fibras para reforçar materiais que apresentem uma resistência à tração bem inferior à resistência à compressão, como no uso de palha para a confecção de tijolos. Porém, o primeiro compósito largamente utilizado feito pelo homem foi o cimento amianto, em torno de 1900.

Ao longo desses cento e poucos anos têm surgido diversos tipos de fibras (de aço, de vidro, de polipropileno, naturais, poliméricas, etc.) que têm sido usadas para reforçar diversos tipos de materiais (epoxi, plásticos, cerâmica, concreto, etc.). Essas fibras diferem não só nas 
suas propriedades mecânicas, como também na sua geometria, apresentando uma variação considerável quanto a sua eficiência e a seu custo.

Atualmente, o uso de fibras de aço na Construção Civil, em peças de concreto protendido, tem uma grande aplicação, principalmente nas lajes planas, nos pisos industriais e nos dormentes. Nas peças de concreto submetidas à fadiga, o uso de fibras, hoje, é uma excelente opção.

Porém, o grande avanço da área tecnológica do concreto nem sempre é acompanhado por atualização constante de normas e códigos. Apesar de já se usar comercialmente o concreto reforçado com fibras no mercado brasileiro, as NBR 6118 (1978), NBR 7197 (1989) e NBR 6118 (2001), assim como os demais códigos e normas internacionais que tratam de concreto estrutural, não fazem referência a tal material, e também não se encontram na literatura técnica nacional atual referências suficientes quanto ao dimensionamento de concreto reforçado com fibras (CRF). Como se sabe, as fibras mudam o comportamento pósfissuração do concreto, logo é de se esperar que seu comportamento em relação à aderência, por exemplo, também seja diferente. Portanto, o comportamento e, conseqüentemente, o dimensionamento do CRF quanto à aderência é diferente do comportamento e, conseqüentemente, do dimensionamento do concreto comum.

Também, no que diz respeito à utilização do CAR, ainda existem dúvidas a serem sanadas. Independentemente do uso de fibras de aço, a aderência em peças de CAR apresenta diferenças em relação aos concretos de resistências normais.

É de fundamental importância que as normas acompanhem, o mais próximo possível, o desenvolvimento tecnológico, especialmente no que diz respeito ao dimensionamento das estruturas, para que não se cometam erros que possam levar essas estruturas a um desperdício de material ou, ainda pior, a um colapso, seja ele total ou parcial.

\subsection{Objetivos}

O objetivo principal deste trabalho é o estudo teórico-experimental da aderência, e conseqüentemente dos comprimentos de ancoragem (comprimento de transferência e comprimento de ancoragem necessário) de cordoalhas de sete fios, com diâmetro de 12,7mm, pré-tracionadas e pré-aderentes, em concretos de alta resistência, sem e com fibras de aço. Essa cordoalha foi escolhida por ser uma das mais usadas nas construções de concreto protendido, assim como, a fibra de aço por ser a mais usada nas construções civis.

Para isso, pretende-se fazer um estudo comparativo entre as equações encontradas na literatura técnica internacional, com os resultados obtidos nesta pesquisa, e com as diversas 
equações encontradas nos seguintes códigos e normas, nacionais e internacionais: NBR 6118 (2001), ACI 318 (2002) e FIB Bulletin 1 (1999). Essas publicações encontram-se listadas nas Referências Bibliográficas.

Este trabalho pretende responder às seguintes perguntas:

- As fibras de aço usadas em baixos teores influenciam, de algum modo, na aderência das cordoalhas pré-tracionadas embutidas em CAR?

- Se influenciam, de que maneira? Aumentam a tensão de aderência, diminuem os comprimentos de transferência e de ancoragem necessário, melhoram $\mathrm{o}$ comportamento em relação à aderência (pré e/ ou pós-fissuração)?

- As fibras de aço influenciam no modo de ruptura? Por arrancamento ou por fendilhamento?

\subsection{Justificativas}

A motivação para esta pesquisa teve como base os resultados obtidos por BASTOS (1999), que estudou dormentes monoblocos de concreto protendido reforçado com fibras de aço. Nos seus comentários finais, ele sugere o seguinte: "Não só para os dormentes como também para outros elementos, como as vigas, seria útil um estudo experimental para determinar equações teóricas para predizer o comprimento de ancoragem de armaduras de protensão inseridas em concreto com fibras. Fios e cordoalhas brasileiros poderiam ser avaliados em concretos com diferentes tipos e teores de fibras, porém, espera-se que as fibras curtas apresentem melhores resultados do que as fibras longas".

$\mathrm{Na}$ literatura técnica brasileira não se encontram trabalhos que apresentem equações próprias para o concreto reforçado com fibras de aço (CRFA), no que diz respeito à tensão de aderência e aos comprimentos de ancoragem.

$\mathrm{Na}$ literatura técnica internacional, especialmente nas revistas do American Concrete Institute (ACI) e do Precast/ Prestressed Concrete Institute (PCI), encontram-se vários artigos relacionados a esse tema. Os periódicos do ACI (ACI Material Journal e ACI Structural Journal) apresentam, principalmente, trabalhos sobre o estudo da tensão de aderência e dos comprimentos de ancoragem para as armaduras passivas (fios e barras), tanto no concreto sem fibra, como no CRFA. Já no periódico do PCI (Journal of the Precast/ Prestressed Concrete Institute), encontram-se muitos trabalhos sobre a aderência das armaduras de protensão, inclusive as pré-tracionadas, quando inseridas em concretos sem fibras de aço. Porém, não existem muitas referências ou artigos sobre a aderência de peças pré-tracionadas em concretos 
reforçados com fibras de aço. Existem, sim, vários trabalhos sobre os concretos reforçados com fibras plásticas (CRFP), que, no caso, substituem a armadura de protensão.

Em vista da falta de informação e de normalização, em relação às cordoalhas prétracionadas em CRFA, é que se pretende estudar a aderência das armaduras mais utilizadas no nosso mercado, no caso a cordoalha de sete fios, com $\phi 12,7 \mathrm{~mm}$, visando esclarecer o seu comportamento em relação à aderência, quando inseridas em concretos de alta resistência com fibras de aço.

Esta pesquisa, portanto, tem um caráter pioneiro no que diz respeito ao tema escolhido. Por este motivo, optou-se por fazer um trabalho com a seguinte abordagem: (1) um estudo teórico mais amplo, dos temas ligados à pesquisa, na parte de revisão bibliográfica e na análise teórica, para caracterizar melhor o problema; e (2) um estudo experimental mais simples, com carregamento monotônico, poucos parâmetros de ensaio e muitos modelos, para que se pudesse obter um controle melhor e uma confiabilidade maior dos resultados.

A sugestão de BASTOS (1999) para que se determinassem equações teóricas para os comprimentos de ancoragem não foi seguida neste trabalho. Para isso, seria necessário um trabalho experimental muito mais extenso, e com um número maior de parâmetros de ensaio, principalmente em relação às armaduras analisadas. Para se obter equações confiáveis para o dimensionamento, é necessário analisar armaduras de vários diâmetros, diferentes conformações superficiais, e diversos tipos de aço, entre outros parâmetros. Além disso, seria fundamental não só ensaios monotônicos como, também, cíclicos.

Este trabalho pretende ser o ponto de partida para uma linha de pesquisa na área de armaduras pré-tracionadas inseridas em concretos com fibras de aço. O capítulo 7 apresenta uma série de sugestões para pesquisas futuras, que poderão dar continuidade a este trabalho.

O estudo da aderência e a determinação dos comprimentos de ancoragem são muito importantes para algumas peças pré-tracionadas. Apesar de que, para boa parte das estruturas protendidas, que em serviço não apresentam fissuração, a aderência não represente um problema, não precisando preocupar-se com ela, para algumas peças, a aderência pode ser determinante no caso de uma ruptura prematura. Isso ocorre nas peças curtas, lajes alveolares por exemplo, onde há o risco do ponto de momento máximo invadir a zona de transferência de esforços. Já para os dormentes pré-tracionados, o comprimento dos trechos externos aos trilhos é o próprio comprimento de transferência. Em ambos os casos, a determinação dos comprimentos de ancoragem, ou a possibilidade de redução dos mesmos, é um fator determinante no dimensionamento das peças, seja na garantia de sua capacidade resistente (peças curtas e dormentes), seja na economia de material (dormentes). 


\subsection{Metodologia}

A pesquisa é de caráter teórico-experimental, e foi dividida em três partes: revisão bibliográfica, análise teórica e análise experimental.

A primeira parte da pesquisa foi composta de uma revisão bibliográfica, abrangendo, principalmente, os seguintes temas: fibras de aço, aderência, comprimentos de ancoragem em peças de concreto armado e protendido, concretos reforçados com fibras de aço, estado-daarte de ensaios de flexão e de arrancamento em peças de concreto armado e protendido sem e com fibras de aço.

A segunda parte consistiu em uma análise teórica sobre a determinação da tensão de aderência e dos comprimentos de ancoragem em peças de concreto armado e protendido, em especial as pré-tracionadas, com e sem o uso das fibras de aço. Para isso, foram utilizados modelos analíticos já estabelecidos na literatura corrente. Os valores obtidos nessa análise foram comparados aos valores encontrados nas formulações estabelecidas nos seguintes códigos e normas: NBR 6118 ( 2001), ACI 318 (2002) e FIB Bulletin 1 (1999).

A terceira parte da pesquisa consistiu em ensaios de laboratório, realizados no Laboratório do Departamento de Engenharia de Estruturas, da Escola de Engenharia de São Carlos (EESC/ USP). Os ensaios foram divididos em três partes: (1) ensaios de arrancamento, nos quais estudou-se a tensão de aderência; (2) medição do comprimento de transferência das vigas nas operações de retirada da protensão; e (3) ensaios de flexão de viga pré-tracionada, em que foram avaliados os comprimentos de ancoragem necessário, e foi estudado o comportamento das peças à flexão. Os resultados experimentais foram comparados aos resultados teóricos, podendo-se então avaliar o comportamento da tensão de aderência e o cálculo dos comprimentos de ancoragem em peças de concreto pré-tracionadas reforçadas com fibras de aço.

\subsection{Definições}

Este item define alguns termos e expressões que foram usados ao longo deste trabalho, com o intuito de facilitar a sua compreensão. Uma das dificuldades encontradas ao longo deste estudo foi achar o termo correto para expressar determinadas situações e fenômenos, principalmente quando resultantes de traduções.

Neste trabalho foram usadas, em alguns casos, nomenclatura e simbologia diferentes do que sugere a nova versão da NBR 6118 (2001), que se encontra em fase de conclusão, por uma questão de preferência pessoal. A Tabela 1.1 apresenta alguns exemplos das diferenças de nomenclatura e de simbologia entre este trabalho e a NBR 6118 (2001). 
Tabela 1.1 - Exemplos de diferenças de nomenclatura e simbologia, em relação à NBR 6118 (2001).

\begin{tabular}{c|c}
\hline NBR 6118 (2001) & Esta Tese \\
\hline Resistência à compressão do concreto $\left(\mathrm{f}_{\mathrm{c}}\right)$ & Resistência do concreto à compressão $\left(\mathrm{f}_{\mathrm{c}}\right)$ \\
\hline Resistência à compressão do concreto & Resistência característica do concreto à \\
característica $\left(\mathrm{f}_{\mathrm{ck}}\right)$ & compressão $\left(\mathrm{f}_{\mathrm{ck}}\right)$ \\
\hline Resistência à tração do aço de armadura & Resistência do aço de armadura passiva à \\
passiva $\left(\mathrm{f}_{\mathrm{st}}\right)$ & tração $\left(\mathrm{f}_{\mathrm{st}}\right)$ \\
\hline $\mathrm{f}_{\mathrm{b}}$ (tensão de aderência) & $\tau_{\mathrm{b}}$ (tensão de aderência) \\
\hline
\end{tabular}

A seguir são listados alguns dos termos, e respectivas definições, utilizados neste texto.

Aderência: representa a capacidade resistente da peça, ou da armadura, em relação à aderência (o equivalente ao termo em inglês "bond strength" - resistência de aderência)

Comportamento Tensão de aderência versus Escorregamento: representa o conjunto das propriedades aderentes das peças em estudo, e é representado pelo diagrama Tensão de aderência versus Escorregamento.

Compósito: de maneira geral, um compósito é qualquer material constituído por pelo menos dois componentes, que trabalhando em conjunto formam um novo material, de propriedades diferentes das dos componentes isolados; nesta pesquisa, mais especificamente, o termo compósito se refere à combinação de um elemento básico, que é a matriz de concreto, com um elemento de reforço, que são as fibras.

Comprimento aderente disponível: é o comprimento aderente existente de ensaio.

Comprimento(s) de ancoragem: representa qualquer, ou todos os comprimentos de ancoragem específicos, entre os quais o comprimento de transferência, o comprimento básico de ancoragem, o comprimento de ancoragem necessário, etc. (estes termos estão definidos no Capítulo 2).

Concreto comum: este termo pode ter dois significados - (1) concreto com resistência à compressão de até $40 \mathrm{MPa}$ sem nenhuma adição, entre elas as fibras; ou (2) concreto de desempenho normal, e não CAD.

Concreto simples: concreto sem armadura.

Extremidade livre: representa a extremidade sem esforço, nos ensaios de arrancamento. 
Extremidade ativa: representa a extremidade onde há a introdução de esforços, nos ensaios de arrancamento, ou seja, a extremidade que está presa à máquina de ensaio e que está sendo tracionada.

Penetração: representa o valor de escorregamento da cordoalha, em relação ao concreto, nas extremidades da viga, na retirada de protensão, ao final da transferência de tensões (o equivalente ao termo em inglês “draw-in").

Taxa volumétrica das fibras: os artigos em língua inglesa, na sua maioria, representam o volume de fibras de aço no concreto em termos de taxa volumétrica percentual em relação ao peso específico do aço, ou seja, se um compósito possui um volume de fibra de aço de $2 \%$, significa que tem, aproximadamente, um consumo de $157 \mathrm{~kg} / \mathrm{m}^{3}$, isto é, $2 \%$ de $7850 \mathrm{~kg} / \mathrm{m}^{3}$, que é o peso específico do aço, e que representaria 100\% em volume por metro cúbico.

\subsection{Conteúdo da Tese}

Este trabalho foi dividido em sete capítulos, e mais bibliografia, apêndices e anexo.

O Capítulo 1 introduz o trabalho, e define alguns termos importantes para a sua melhor compreensão.

O Capítulo 2 apresenta o resultado da revisão bibliográfica. Ele foi dividido em subitens que englobam diferentes assuntos abordados. São eles: o concreto com fibras; a aderência no concreto armado; a aderência no concreto protendido; as fibras e a aderência no concreto armado e no protendido. No final do capítulo é feito um resumo dos aspectos mais relevantes da revisão bibliográfica para esta pesquisa.

O Capítulo 3 aborda a análise teórica sobre a tensão de aderência e sobre os comprimentos de ancoragem. Nessa análise foram utilizadas formulações empíricas encontradas na literatura técnica internacional, e as prescrições normativas da NBR 6118 (2001), da FIB Bulletin 1 (1999) e do ACI 318 (2002). Os resultados obtidos foram comparados entre si.

O Capítulo 4 apresenta o programa experimental desenvolvido neste trabalho. Foram realizados três tipos de ensaios: (1) ensaios de arrancamento - para medir a tensão de aderência das cordoalhas; (2) retirada da protensão das vigas - no qual foram medidos os comprimentos de transferência; e (3) ensaios de flexão nas vigas pré-tracionadas - em que se analisaram o comportamento das vigas e os seus comprimentos de ancoragem necessário. Nesse capítulo estão detalhados os arranjos de ensaio e a instrumentação utilizada, assim como a descrição e os resultados dos ensaios-pilotos e dos ensaios de caracterização dos materiais. 
O Capítulo 5 contém a descrição e a análise de resultado dos ensaios de arrancamento. Esses resultados foram apresentados na forma de gráficos e de tabelas, e foram comparados entre si. Esse capítulo também apresenta a comparação entre os resultados teóricos e os experimentais, referentes ao tipo de ensaio citado.

O Capítulo 6 considera a descrição e a análise de resultados dos ensaios de viga, e foi dividido em duas partes: uma que diz respeito à retirada da protensão, para estudos do comprimento de transferência; e a outra, aos ensaios de flexão, que analisa os comprimentos de ancoragem necessários. Os resultados foram apresentados na forma de gráficos e de tabelas, e foram comparados entre si. Esse capítulo também apresenta a comparação entre os resultados teóricos e os experimentais, referentes aos tipos de ensaio citados.

O Capítulo 7 apresenta as conclusões deste trabalho e algumas sugestões para pesquisas futuras, dentro do tema aqui abordado.

A bibliografia foi dividida em duas partes: referências bibliográficas e bibliografia complementar. Esta inclui as obras consultadas, mas que não foram citadas no texto.

Após a bibliografia foram adicionados sete apêndices e um anexo. Nos apêndices se encontram alguns cálculos complementares, a análise estatística dos dados dos ensaios de caracterização do concreto e dos ensaios de arrancamento, todos os resultados dos ensaios de caracterização do concreto e das armaduras, e o restante dos resultados dos ensaios de flexão que não foram apresentados no texto principal. No anexo se encontram gráficos e especificações, fornecidos pelos fabricantes das fibras de aço e da cordoalha. 


\section{REVISÃO BIBLIOGRÁFICA E COMENTÁRIOS}

Este capítulo apresenta um estado-da-arte sobre os principais assuntos envolvidos neste trabalho. São eles: as fibras, a aderência, e o concreto protendido. Cada um desses temas é apresentado em itens diferentes. Ao final de cada item são feitos alguns comentários e são discutidos os aspectos mais relevantes para esta pesquisa.

\subsection{As Fibras e o Concreto}

Este item apresenta noções básicas e gerais sobre as fibras, em especial as de aço, e a sua utilização como reforço do concreto, e também um breve estado-da-arte das pesquisas que estão em desenvolvimento nessa área.

Não se pretende discutir detalhadamente as propriedades das fibras e dos CRF, como a estrutura da fibra e da matriz de cimento, a interface fibra-matriz e os mecanismos de aderência e de transferência de tensões entre elas. Esses assuntos são encontrados muito bem detalhados em várias referências: BENTUR \& MINDESS (1990), BALAGURU \& SHAH (1992), FURLAN (1995), NAAMAN \& REINHARDT (1996), BASTOS (1999), entre outras.

$\mathrm{O}$ uso de fibras no concreto tem como motivos principais o aumento da ductilidade e da tenacidade, e o melhor controle da fissuração das peças, e não o aumento da resistência do compósito. Isso ocorre devido aos baixos teores de fibra 
que são usados. Na prática, no que diz respeito às fibras de aço, uma boa faixa de utilização (binômio custo - eficiência) para as obras onde elas serão utilizadas em grande quantidade é entre $30 \mathrm{~kg} / \mathrm{m}^{3}$ e $80 \mathrm{~kg} / \mathrm{m}^{3}$ (aproximadamente, entre $0,4 \%$ e $1 \%$ ), dependendo do tipo de peça. Para pisos, por exemplo, usa-se em torno de $40 \mathrm{~kg} / \mathrm{m}^{3}$ (aproximadamente, 0,5\%); já para os dormentes, chega-se até a $80 \mathrm{~kg} / \mathrm{m}^{3}$ (aproximadamente, 1\%). Para aplicações mais localizadas, esses valores podem ser bem mais elevados, como por exemplo, nos nós de pórticos em edificações sujeitas a terremotos. Para que haja um ganho significativo nas propriedades mecânicas, como a resistência à tração, por exemplo, deve-se usar teores de fibras bem mais elevados. Este assunto será tratado com mais detalhes posteriormente.

Hoje em dia existem vários tipos de fibras que diferem no material, na geometria, na eficiência e no custo, cada um deles com características e aplicações próprias. Alguns exemplos dessas fibras são: fibras de aço, de vidro, de amianto, de carbono, naturais (celulose, sisal, etc.), e plásticas (nylon, polipropileno, polietileno, etc.). A Tabela 2.1 apresenta algumas das propriedades para alguns tipos de fibra.

Tabela 2.1 - Propriedades típicas de fibras (BENTUR \& MINDESS, 1990).

\begin{tabular}{l|c|c|c|c}
\hline \multicolumn{1}{c|}{ Fibra } & $\begin{array}{c}\text { Diâmetro } \\
(\mu \mathrm{m})\end{array}$ & $\begin{array}{c}\text { Módulo de } \\
\text { Elasticidade } \\
(\mathrm{GPa})\end{array}$ & $\begin{array}{c}\text { Resistência } \\
\text { à tração } \\
(\mathrm{GPa})\end{array}$ & $\begin{array}{c}\text { Alongamento } \\
\text { na ruptura } \\
(\%)\end{array}$ \\
\hline Aço & $5-500$ & 200 & $0,5-2$ & $0,5-3,5$ \\
\hline Vidro & $9-15$ & $70-80$ & $2-4$ & $2-3,5$ \\
\hline Polipropileno fibrilado & $20-200$ & $5-77$ & $0,5-0,75$ & 8 \\
\hline Carbono (alta resistência) & 9 & 230 & 2,6 & 1 \\
\hline Nylon & --- & 4 & 0,9 & $13-15$ \\
\hline Celulose & --- & 10 & $0,3-0,5$ & --- \\
\hline Polietileno & --- & 0,3 & $7 \times 10^{-4}$ & 10 \\
\hline Sisal & $10-50$ & --- & 0,8 & 3 \\
\hline Matriz de cimento (para & --- & $10-45$ & $3,7 \times 10^{-3}$ & 0,02 \\
comparação) & & & & \\
\hline
\end{tabular}

Como já foi dito, o uso de fibras para reforçar materiais frágeis com baixa resistência à tração, como é o caso do concreto, não é uma idéia nova. Segundo 
BENTUR \& MINDESS (1990), há 3500 anos o homem já fazia uso de fibras (palha) para reforçar materiais frágeis (tijolos de barro).

O primeiro compósito utilizando fibras feito pelo homem foi o cimento amianto, por volta de 1900. Porém, os primeiros estudos envolvendo o CRF surgiram entre as décadas de 50 e 60 , e utilizaram fibras de aço e de vidro, retas e lisas (BENTUR \& MINDESS, 1990). O uso comercial do CRF tem aproximadamente 30 anos.

No Brasil, o uso de fibras na Construção Civil teve início na década de 70, na construção de Itaipu. Por volta do final da década de 80 e início da década de 90 suas aplicações se espalharam um pouco mais, com um crescimento significativo a partir de 1995. Na Construção Civil a fibra mais utilizada, sem sombra de dúvida, é a de aço. No que se refere às fibras, no Brasil, $65 \%$ a $75 \%$ diz respeito à construção de pisos, $15 \%$ a $20 \%$ à utilização de concreto projetado (revestimento de túneis e estabilização de taludes), e $10 \%$ a $15 \%$ a outras aplicações, como as peças préfabricadas, os dormentes de concreto, as plataformas marítimas e as fundações de máquinas. Uma das primeiras obras com fibras de aço no Brasil foi a Linha Amarela (Rio de Janeiro), que utilizou concreto projetado na estabilização de taludes e no revestimento de túneis (Figura 2.1).

Um dos estados que mais tem utilizado as fibras de aço na construção é São Paulo. Por exemplo, na construção de pisos industriais como o do terminal de cargas de Viracopos ( $\approx$ 1997), o do depósito das Casas Bahia (Figura 2.1) em Jundiaí, com aproximadamente $80.000 \mathrm{~m}^{2}$ de piso ( $\left.\approx 1996\right)$, e o da fábrica da Volkswagen em São Carlos, com aproximadamente $15.000 \mathrm{~m}^{2}$ de piso (1996).
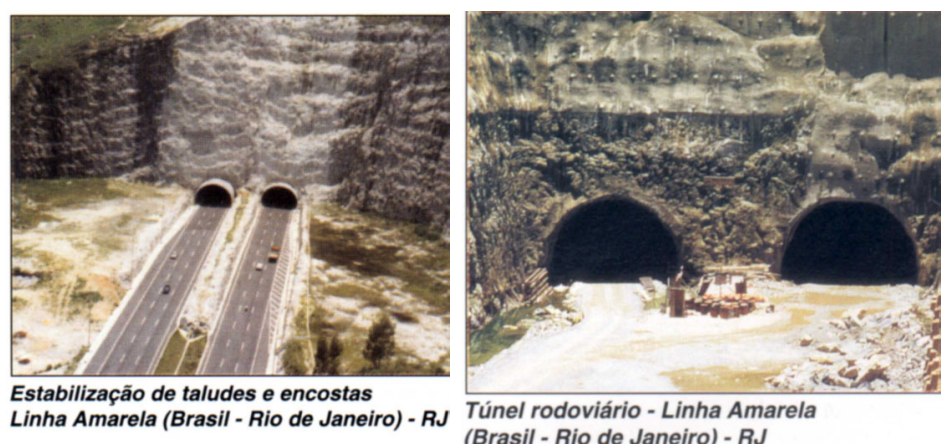

Túnel rodoviário - Linha Amarela (Brasil - Rio de Janeiro) - RJ

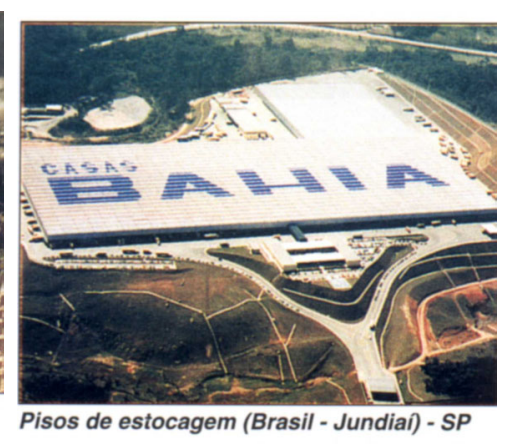

Figura 2.1 - Exemplos da utilização de fibras de aço na Linha Amarela e no depósito das Casas Bahia. 
Apesar do crescente número de obras com a utilização do CRF, não existe no Brasil uma normalização que regulamente o seu uso, principalmente no que diz respeito ao dimensionamento. Normalmente, ou se dimensiona o CRF para o estádio I e se adota o valor de $f_{c m}$ (resistência média) para a resistência do concreto à compressão, ou recorre-se, quando possível, a normas estrangeiras, tais como: ACI 544.1R (1986), ACI 544.2R (1989), ACI 544.3R (1993) e ACI 544.4R (1988) (normas americanas) e a DIN (norma alemã). Ainda como referências para o dimensionamento do CRF tem-se as revistas do ACI (ACI Structural Journal e ACI Materials Journal), que tem apresentado nesses últimos 20 anos uma vasta quantidade de artigos na área de CRF, englobando desde a caracterização dos materiais até as suas aplicações práticas. Alguns desses artigos estão listados nas Referências Bibliográficas e na Bibliografia Complementar deste trabalho.

\subsubsection{Tipos de fibras de aço e processos de fabricação do CRFA}

Não existe uma padronização mundial para as fibras de aço. Cada país, ou região, tem a sua própria fabricação, tanto no que se refere ao material e à geometria, como também ao seu processo de produção. Entretanto, não existem grandes diferenças de um país para o outro, sendo a mais usada em todo o mundo a fibra de fio trefilado, de seção transversal circular, com ganchos nas extremidades (tipo DRAMIX -BBA). A Figura 2.2 apresenta um exemplo deste tipo de fibra.

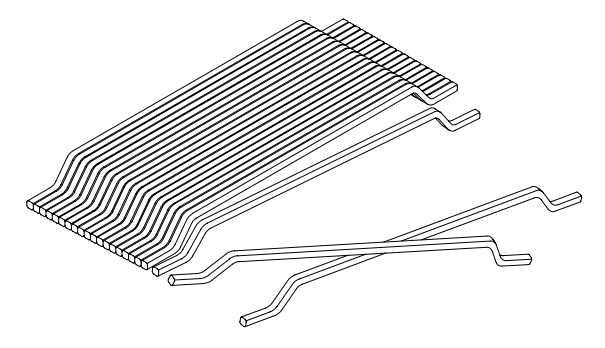

Figura 2.2 - Fibra de aço DRAMIX-BBA.

Nos Estados Unidos, por exemplo, o ACI 544.1R (1986) apresenta algumas definições e padronizações para o uso do CRF. Segundo esse código, o CRF é o concreto feito com cimento hidráulico contendo agregado miúdo ou miúdo e graúdo e fibras discretas e descontínuas. Ainda segundo esse código, um parâmetro numérico conveniente para descrever a fibra é o seu fator de forma (ou razão de aspecto), que é definido pela razão entre o comprimento da fibra $(\ell)$ e o seu diâmetro equivalente $\left(\mathrm{d}_{\mathrm{f}}\right)$, que é o diâmetro do círculo de área equivalente à área da seção 
transversal da fibra. Os fatores de forma ( $/$ d) típicos variam entre 30 e $150(30 \leq \ell / d$ $\leq 150)$, para comprimentos variando entre $6,4 \mathrm{~mm}$ e $76 \mathrm{~mm}(6,4 \mathrm{~mm} \leq \ell \leq 76 \mathrm{~mm})$. As fibras de aço, por exemplo, podem apresentar seção circular com diâmetros variando entre $0,25 \mathrm{~mm}$ e $0,76 \mathrm{~mm}\left(0,25 \mathrm{~mm} \leq \mathrm{d}_{\mathrm{f}} \leq 0,76 \mathrm{~mm}\right)$, ou seção retangular com dimensões que variam de $0,15 \mathrm{~mm}$ a $0,41 \mathrm{~mm}$ de espessura por $0,25 \mathrm{~mm}$ a $0,90 \mathrm{~mm}$ de largura, como mostra a Figura 2.3.

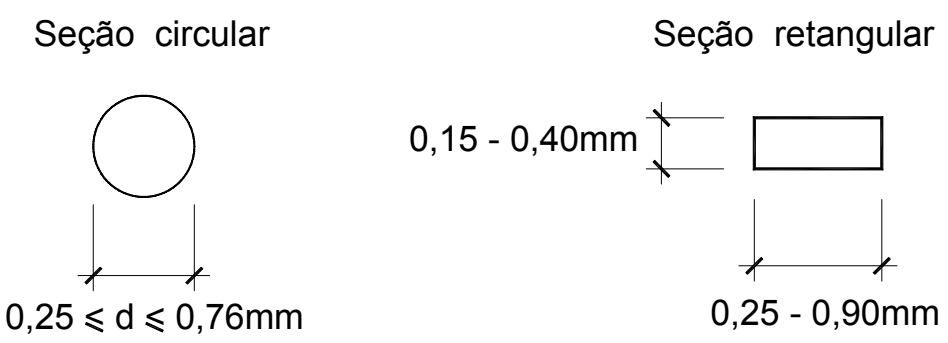

Figura 2.3 - Dimensões-padrão para as fibras de aço segundo o ACI 544.1R (1986).

No Brasil, no que se refere às fibras de aço, existem basicamente três tipos: as de seção circular, fio trefilado com ganchos nas extremidades, produzidas pela Belgo Bekaert Arames S. A. (DRAMIX-BBA), como mostra a Figura 2.4a; as de seção retangular resultantes do corte de chapas, também com ganchos nas extremidades, produzidas pela Vulkan do Brasil Ltda. (HAREX), como mostra a Figura 2.4b; e as de seção transversal irregular, que são um subproduto da lã de aço, como mostra a Figura 2.4c. A mais utilizada das três é a DRAMIX-BBA (Figura 2.4a).

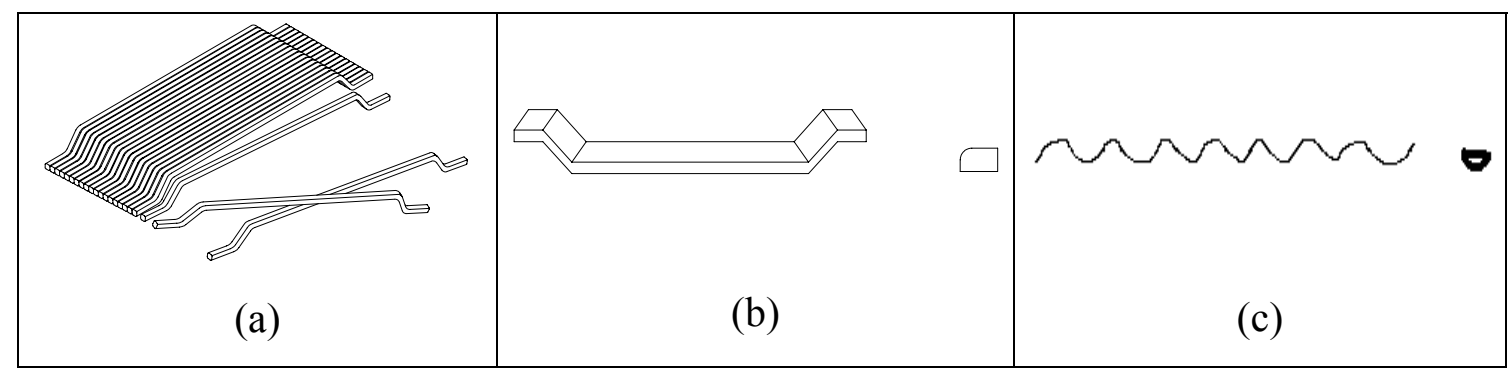

Figura 2.4 - Tipos de fibra de aço do mercado brasileiro. (a) DRAMIX; (b) HAREX; (c) Subproduto da lã de aço.

Quanto aos processos de fabricação do CRF, também não existe uma padronização; porém, os mais usados comercialmente são o método de mistura direta e o concreto projetado. Na maioria das obras brasileiras o método mais utilizado é o da mistura direta na betoneira, ou seja, a fibra é adicionada ao concreto dentro da betoneira. A ordem de colocação dos materiais pode variar um pouco. Se a fibra for 
adicionada na usina de pré-fabricação do concreto, ela pode ser adicionada junto com o agregado. Se for adicionada na obra, ela entra por último na betoneira. BENTUR \& MINDESS (1990), o ACI 544.1R (1986) e o ACI 544.3R (1993) apresentam uma descrição mais detalhada desses métodos de produção do $\mathrm{CRF}$, e vários outros métodos que não são citados neste trabalho.

Apesar de existirem procedimentos-padrão para a dosagem e a utilização do CRF (ACI 544.1R (1986), por exemplo), na prática procura-se não interferir na dosagem e na produção do concreto ao se acrescentarem as fibras, pois isso poderia levar os engenheiros de obra a não se interessarem pelo seu uso. Para o dimensionamento das fibras procura-se, simplesmente, acrescentá-las, no teor indicado, ao concreto especificado no projeto.

\subsubsection{Eficiência das fibras}

As fibras, na realidade, funcionam como uma ponte de transferência de tensões através das fissuras. Segundo BENTUR \& MINDESS (1990), a eficiência das fibras pode ser julgada com base em dois critérios: o aumento na resistência, e o aumento na tenacidade do compósito, em relação à matriz quebradiça. Ainda segundo os mesmos autores, a eficiência das fibras na melhoria das propriedades mecânicas da matriz de cimento quebradiça é regida por: (1) o processo de transferência de tensões da matriz para a fibra; e (2) o efeito de ponte de tensões através das fissuras da matriz que as fibras apresentam, e que ocorre num estágio mais avançado de carregamento.

$\mathrm{Na}$ literatura técnica encontram-se vários parâmetros que tentam definir e quantificar a eficiência das fibras. Os principais são: o comprimento $(\ell)$, a orientação, e o volume de fibras $\left(\mathrm{V}_{\mathrm{f}}\right)$.

\section{a) Comprimento}

O comprimento interfere diretamente na aderência entre a fibra e a matriz. Quanto maior for o comprimento, melhor será a aderência e, conseqüentemente, levará a uma ruína por escoamento da fibra, que é dúctil. Isso proporciona, de maneira geral, um aumento da tenacidade do compósito. Porém, quanto maior for o comprimento da fibra, pior será a trabalhabilidade do compósito. Por outro lado, se a fibra for muito curta, não haverá comprimento suficiente para que seja feita a transferência de tensões e ela não atingirá o escoamento, o que acarretará numa 
ruptura por arrancamento da fibra. Isso leva a um ganho maior de tenacidade, devido à maior energia necessária para que se dê esse arrancamento. $\mathrm{Na}$ prática, a ruptura por arrancamento da fibra é a mais comum, e no que se refere à tenacidade é também a mais desejada.

BENTUR \& MINDESS (1990) definem um comprimento crítico da fibra $\left(\ell_{c}\right)$, que seria o comprimento mínimo necessário para que ela atingisse o escoamento, como sendo a relação entre a resistência limite da fibra $\left(\sigma_{\text {fu }}\right)$ e a tensão limite de cisalhamento por atrito $\left(\tau_{\mathrm{fu}}\right)$ vezes o raio da seção transversal da fibra $(\mathrm{r})$ :

$$
1_{c}=\frac{\sigma_{\mathrm{fu}}}{\tau_{\mathrm{fu}}} \cdot \mathrm{r}
$$

Para que haja a garantia de que a ruína seja pela ruptura da fibra, deve-se ter $\ell>>2 \ell_{c}$.

A utilização desse parâmetro, porém, é limitada, pois os estudos que levaram a essa formulação foram feitos em fibras retas e lisas. No caso das fibras com ganchos nas extremidades, a aderência é função da ancoragem mecânica devida aos ganchos, e não em função das tensões de cisalhamento por atrito. Logo, não seria válido o uso da equação (2.1).

Na prática, procura-se utilizar $\ell \geq 2 \mathrm{~d}_{\text {máx }}$ (diâmetro máximo do agregado) e $\ell / \mathrm{d}$ $\leq 80$, para que se possa controlar melhor a fissuração (melhora na eficiência), e para que os problemas de trabalhabilidade sejam minimizados. No Brasil, os comprimentos das fibras de aço variam entre $30 \mathrm{~mm}$ e $60 \mathrm{~mm}(30 \mathrm{~mm} \leq \ell \leq 60 \mathrm{~mm})$.

Seja com a utilização de fibras curtas ou longas, há um aumento significativo da tenacidade no compósito resultante, em comparação com a matriz quebradiça. Deve-se procurar utilizar a fibra curta, o que leva a uma ruptura mais dúctil, como afirma BALAGURU \& SHAH (1992), que ressaltam que, na maioria das aplicações da Engenharia Civil, é preferível que se tenha uma ruptura por arrancamento da fibra, pois esse modo de ruptura fornece uma ductilidade maior.

\section{b) Orientação}

O segundo fator que influencia na eficiência das fibras é a orientação delas dentro do compósito. Se as fibras estiverem alinhadas na direção dos esforços, elas 
serão muito mais eficientes. Entretanto, é muito trabalhoso e caro alinhar as fibras na direção desejada. Normalmente as encontramos de maneira aleatoriamente dispersa, seja em duas ou em três dimensões. A Figura 2.5 apresenta um gráfico que relaciona a eficiência das fibras com o efeito combinado da orientação e do comprimento. Porém sua determinação, mais uma vez, foi baseada na transferência de tensões, entre a fibra e a matriz, através do cisalhamento por atrito, não se referindo, então, às fibras com ganchos nas extremidades.

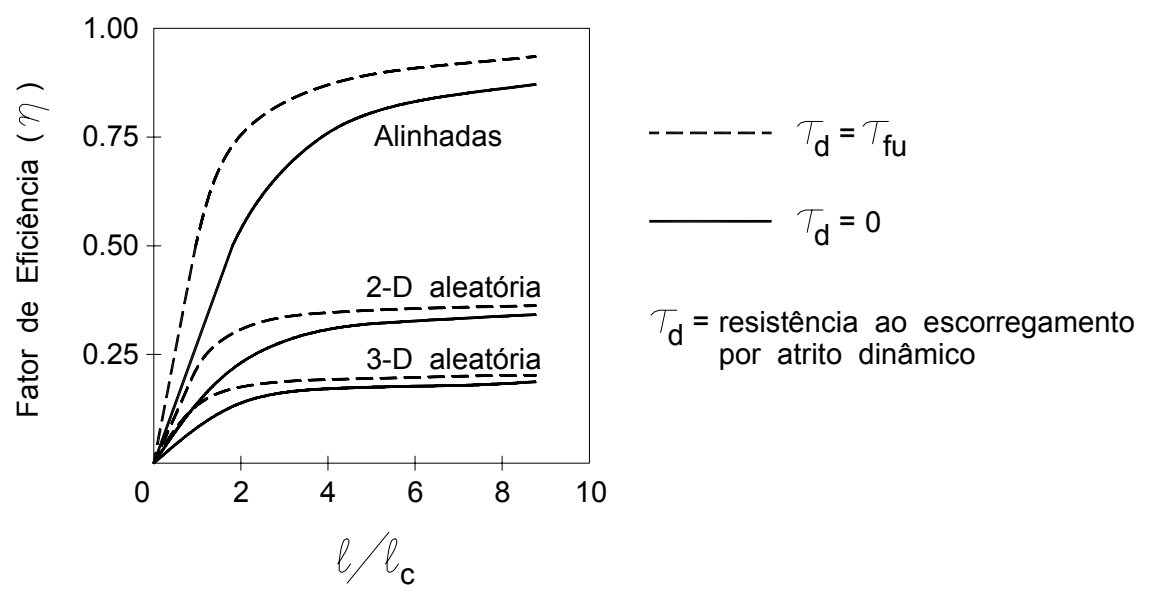

Figura 2.5 - Gráfico Fator de eficiência $(\eta)$ versus Razão entre o comprimento da fibra $(\ell)$ e seu comprimento crítico $\left(\ell_{c}\right)(B E N T U R \&$ MINDESS, 1990).

Quando se têm fibras alinhadas na direção das tensões de tração, pode-se ter um aumento significativo da resistência do compósito à tração. Porém, na grande maioria das vezes, isso não ocorre, ou seja, esse é um fator sobre o qual não se tem muito controle, exceto em casos particulares.

\section{c) Volume}

O terceiro fator que influencia na eficiência das fibras é o seu volume, ou teor, a ser adicionado ao compósito. Esse é um fator sobre o qual se tem total controle.

No Brasil normalmente se indica o volume, ou consumo, de fibra por peso $\left(40 \mathrm{~kg} / \mathrm{m}^{3}\right)$. Já nos Estados Unidos é mais comum indicar-se o volume por percentagem $(0,5 \%)$.

Como já foi dito, na maioria das obras o consumo de fibra de aço utilizado é pequeno, não ultrapassando $157 \mathrm{~kg} / \mathrm{m}^{3}(2 \%)$. Isso se deve, principalmente, ao custo das fibras e à trabalhabilidade desejada para o compósito. É certo que se pode usar 
aditivos superplastificantes para melhorar a trabalhabilidade, porém o seu uso é limitado, pois além de haver uma dosagem limite, que acima dela não há mais ganho de eficiência, quanto maior a quantidade de aditivo, mais rápido ele perde sua função, ou seja, melhora a trabalhabilidade inicial, mas rapidamente o aditivo perde o seu efeito. Outra forma de se melhorar a trabalhabilidade é utilizar as fibras em forma de pente, agrupadas com uma cola solúvel em água. Este tipo de fibra melhora a dispersão e diminui o risco de empelotamento do compósito. A Figura 2.4a apresenta um exemplo de fibra de aço em pente.

Também no que se refere ao volume das fibras, assim como para o comprimento, tem-se tentado definir parâmetros que quantifiquem a eficiência dessas fibras. BENTUR \& MINDESS (1990) apresentam um estudo sobre a determinação do volume crítico de fibras $\left(\mathrm{V}_{\mathrm{fcr}}\right)$ baseado na lei da mistura para materiais compostos. O volume crítico é definido como sendo o volume a partir do qual o compósito apresenta ganho de resistência na fase de pós-fissuração. Os gráficos das Figuras 2.6 e 2.7 apresentam alguns resultados obtidos desse estudo.

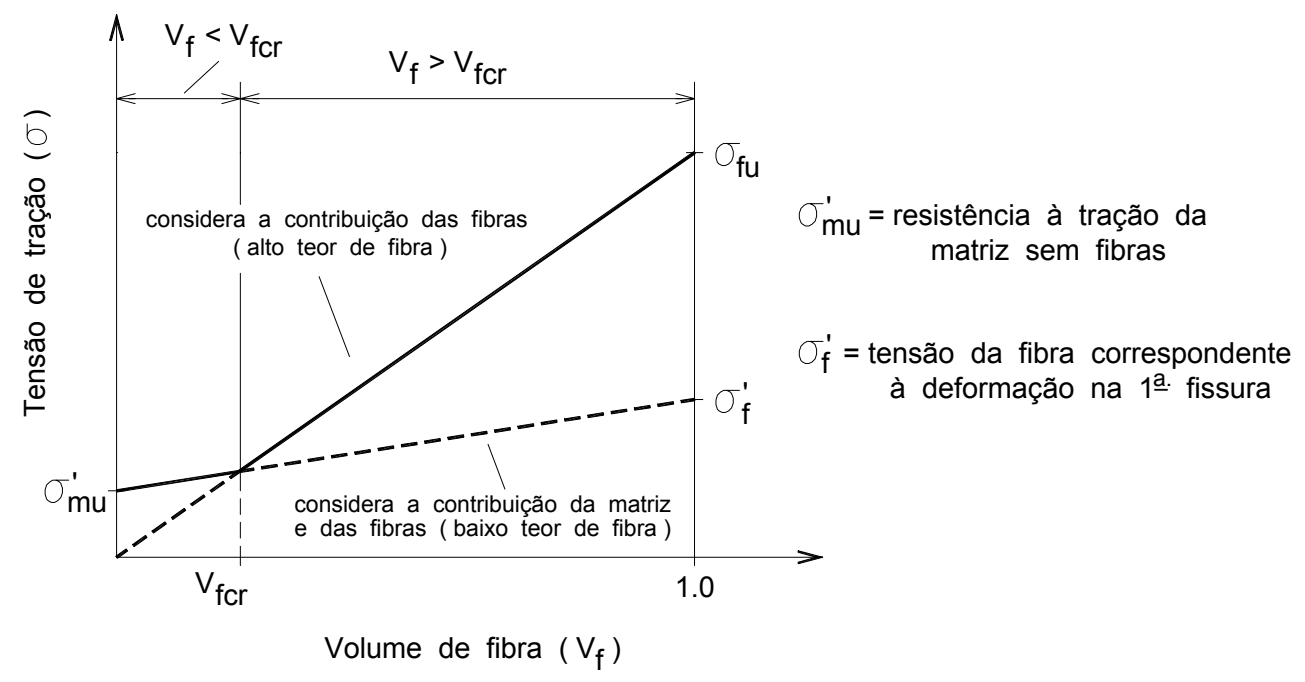

Figura 2.6 - Gráfico Tensão de tração versus Volume de fibra, para fibras contínuas e alinhadas

(BENTUR \& MINDESS, 1990).

Segundo o parâmetro adotado por BENTUR \& MINDESS (1990), que utilizaram fibras retas e lisas para defini-lo, tem-se que:

- As fibras só contribuem para o aumento da resistência do compósito se $\mathrm{V}_{\mathrm{f}}$ $>\mathrm{V}_{\text {fcr, }}$, pois nestes casos o compósito apresenta um ganho de resistência na fase de pós-fissuração (encruamento), com um quadro de fissuração múltipla. 
- $\operatorname{Se} \mathrm{V}_{\mathrm{f}}<\mathrm{V}_{\text {fcr, }}$ o modo de ruptura será pela propagação de uma única fissura, não havendo ganho significativo na resistência.

- Seja para $\mathrm{V}_{\mathrm{f}}>\mathrm{V}_{\text {fcr }}$ ou para $\mathrm{V}_{\mathrm{f}}<\mathrm{V}_{\text {fcr }}$, sempre haverá um aumento da tenacidade (absorção de energia) do compósito em relação à matriz quebradiça.

Esses comportamentos estão representados na Figura 2.7.

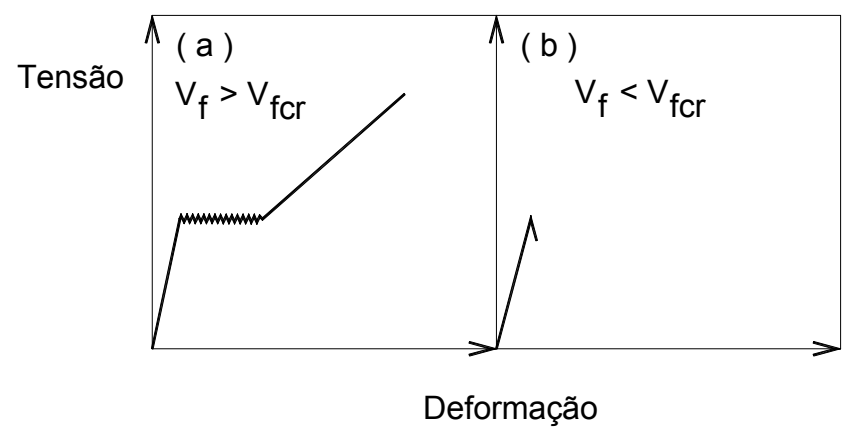

Figura 2.7 - Representação esquemática do gráfico Tensão versus Deformação, para compósitos com diferentes volumes de fibra (BENTUR \& MINDESS, 1990).

Já NAAMAN \& REINHARDT (1996) apresentaram um estudo mais completo sobre o volume crítico de fibras, que inclui as fibras de aço com ganchos nas extremidades. Eles definem o volume crítico de fibras como sendo aquele a partir do qual o material apresenta um encruamento (ganho de resistência com a deformação), ou seja, uma resistência pós-fissuração maior do que a resistência à fissuração do compósito, que vem acompanhada de uma fissuração múltipla do material (mesmo conceito de BENTUR \& MINDESS, 1990), e pode, então, ser considerado um material de alto desempenho. Logo, o volume crítico de fibras seria o divisor entre um material de desempenho normal e um de alto desempenho. O gráfico da Figura 2.8 apresenta uma comparação entre os comportamentos da matriz quebradiça, do CRF, e do concreto de alto desempenho reforçado com fibra (CADRF). Nesse estudo, NAAMAN \& REINHARDT (1996) apresentam três formulações diferentes para se chegar ao volume crítico de fibras, uma deles próprios e outras duas de diferentes pesquisadores. A formulação desenvolvida por eles é baseada na mecânica dos materiais compostos. As outras duas são baseadas nos conceitos da mecânica da fratura: a primeira se baseia no efeito de ponte entre as fissuras, trabalhando em micro-escala, e a segunda se baseia no cálculo da energia necessária para que haja o arrancamento das fibras. 
O gráfico da Figura 2.9 apresenta uma comparação entre alguns compósitos de CRF, para diferentes tipos e volumes de fibra. A Tabela 2.2 apresenta alguns valores de volumes críticos, para as três formulações estudadas por NAAMAN \& REINHARDT (1996), para as fibras de aço com ganchos nas extremidades.

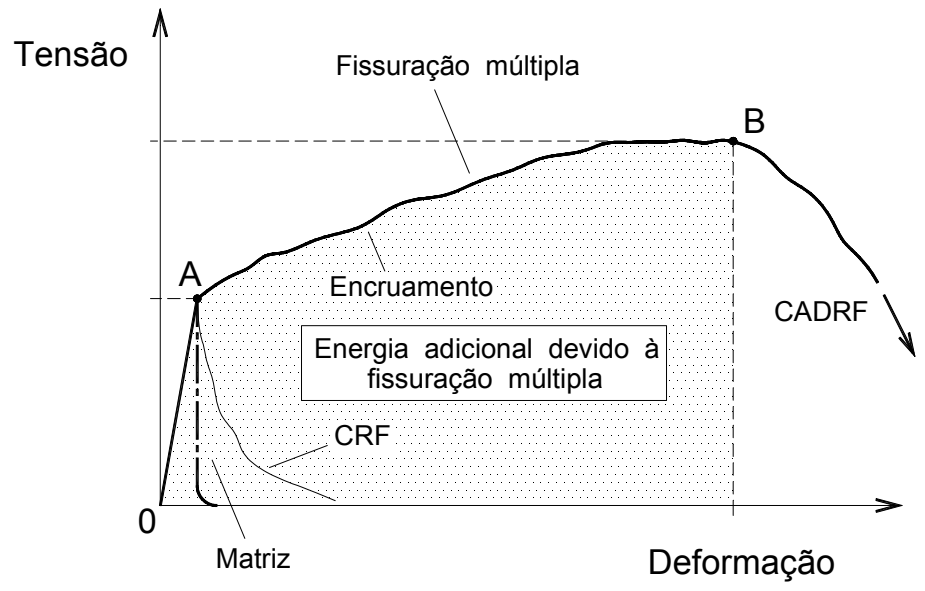

Figura 2.8 - Gráfico Tensão versus Deformação, para vários compósitos (NAAMAN \& REINHARDT, 1996).

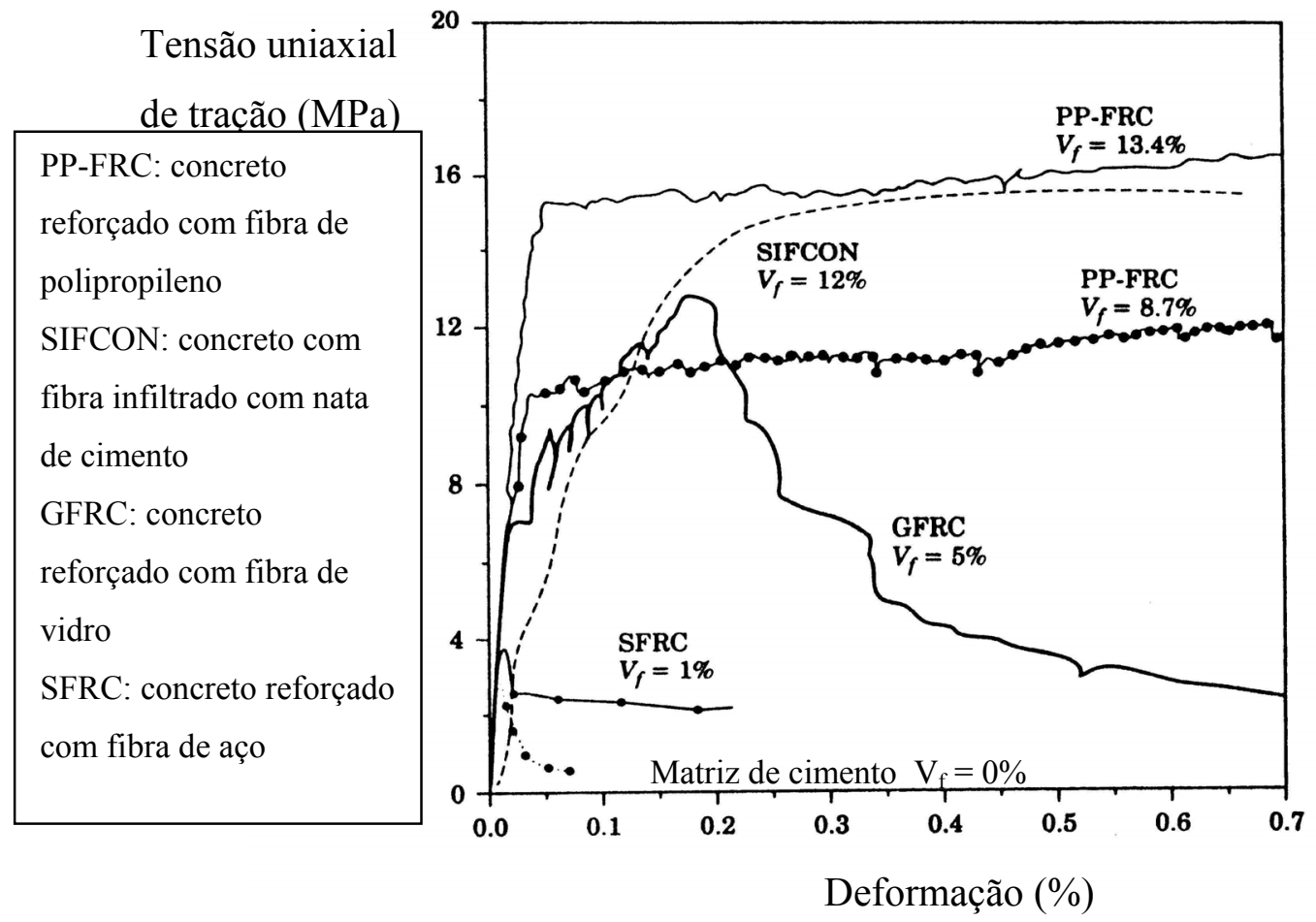

Figura 2.9 - Gráfico Tensão uniaxial de tração versus Deformação, para vários compósitos à base de cimento (BALAGURU \& SHAH, 1992).

Em resumo, para que se tenha um aumento significativo na resistência do compósito, o volume de fibras tem que ser maior do que o volume crítico. Para o 
caso das fibras de aço, para valores de fator de forma entre 50 e $80(50 \leq \ell / d \leq 80)$, o valor de $\mathrm{V}_{\text {fcr }}$ é em torno de $157 \mathrm{~kg} / \mathrm{m}^{3}$ (2\%), que é o limite usual da prática. Logo, a adição de fibras no concreto tem como resultado principal o aumento da tenacidade e da ductilidade das peças, e não o aumento da resistência dos elementos estruturais.

Tabela 2.2 - Comparação do volume crítico de fibras (NAAMAN \& REINHARDT, 1996).

\begin{tabular}{|c|c|c|c|c|}
\hline \multicolumn{5}{|c|}{$V_{\text {fcr }}(\%)$} \\
\hline \multirow{2}{*}{$\begin{array}{l}\text { Fator de } \\
\text { forma } \\
(\ell / d)\end{array}$} & \multicolumn{2}{|c|}{$\begin{array}{l}\text { Naaman \& Reinhardt } \\
\text { (mecânica dos materiais } \\
\text { compostos) }\end{array}$} & \multirow[t]{2}{*}{$\begin{array}{c}\text { Li \& Wu }{ }^{1} \\
\text { (apud NAAMAN \& } \\
\text { REINHARDT, 1996) } \\
\text { (MF - micro-escala) }\end{array}$} & \multirow{2}{*}{$\begin{array}{c}\text { Tjiptobroto \& } \\
\text { Hansen }^{2} \\
\text { (apud NAAMAN \& } \\
\text { REINHARDT, 1996) } \\
\text { (MF - energia de } \\
\text { arrancamento) }\end{array}$} \\
\hline & $\tau / \sigma_{\mathrm{mu}}{ }^{*}=1$ & $\tau / \sigma_{\mathrm{mu}}=2$ & & \\
\hline 0 & 100 & 100 & Negativo & 209 \\
\hline 1 & 80 & 67 & Negativo & 71,8 \\
\hline 10 & 28,6 & 16,7 & Sem solução & 10,3 \\
\hline 20 & 16,7 & 9,1 & Sem solução & 5,28 \\
\hline 50 & 7,41 & 3,85 & 2,73 & 2,14 \\
\hline 100 & 3,85 & 1,96 & 0,55 & 1,07 \\
\hline 200 & 1,96 & 1 & 0,13 & 0,54 \\
\hline
\end{tabular}

\subsubsection{Aplicações do CRF}

O CRF tem sido pesquisado e utilizado em praticamente todo o mundo, a partir da década de 60. A utilização do CRF tem se espalhado por diversas áreas, desde pequenos reparos em peças isoladas até em obras de grande extensão, como os túneis, por exemplo. Para cada tipo e teor diferentes de fibra tem-se uma aplicação mais específica. BENTUR \& MINDESS (1990) listam algumas aplicações:

- Amianto: tubos e telhas onduladas;

- Vidro: painéis pré-moldados não estruturais;

- Aço: pavimentos, concreto projetado, represas;

- Polipropileno: controle da fissuração plástica de retração;

1 LI, V. C.; WU, H. C. (1992). Conditions for pseudo strain-hardening in fiber reinforced brittle matrix composites. Journal of Applied Mechanics Review, v. 45, no 8, August, pp.390-398, apud NAAMAN \& REINHARDT (1996).

2 TJIPTOBROTO, P.; HANSEN, W. (1993). Tensile strain hardening and multiple cracking in highperformance cement based composites. ACI Materials Journal, v. 90, nº 1, Jan/Feb, 1993, apud NAAMAN \& REINHARDT (1996). 
- Vegetais: materiais de construção de baixo custo.

O ACI 544.3R (1993) no que se refere às fibras de aço discretas e descontínuas dá alguns exemplos de mais aplicações: estruturas hidráulicas (represas, canais, peças submetidas à cavitação); pavimentos de aeroportos, rodovias e pontes; pisos industriais; concreto refratário; concreto projetado (revestimento de túneis e estabilização de taludes); e em estruturas resistentes à explosão.

O ACI 544.1R (1986) estabelece que as fibras de aço discretas e descontínuas não podem substituir as armaduras. Estas devem estar presentes, e são as responsáveis por resistir aos esforços de tração.

Pesquisas mais recentes, entre outras as efetuadas por VAN MIER et al (1996), REINHARDT et al (1996) e SHAH et al (1999), sugerem a substituição da armadura por fibras de aço alinhadas ou não, presentes em alto teor, chegando a valores de até $1570 \mathrm{~kg} / \mathrm{m}^{3}$ (20\%), ou ainda maiores. A seguir serão descritos brevemente alguns desses compósitos.

- RPC (concreto de pós-reativos): é um compósito feito com partículas ultrafinas (pós), como a sílica ativa, por exemplo, e fibras de aço curtas $(3 \mathrm{~mm} \leq \ell \leq 12 \mathrm{~mm})$, adicionadas num teor elevado, entre $157 \mathrm{~kg} / \mathrm{m}^{3}$ e $628 \mathrm{~kg} / \mathrm{m}^{3}\left(2 \% \leq \mathrm{V}_{\mathrm{f}} \leq 8 \%\right)$, dependendo da resistência que se pretende obter. Esse compósito atinge resistências à compressão da ordem de $680 \mathrm{MPa}$, e é um material ainda em estudo, mas sugere-se que seja usado em peças de concreto protendido sem armadura passiva, e em vigas e pilares sem armadura.

- CRC (compósitos compactos reforçados): é um compósito que consiste de uma matriz bastante densa, contendo sílica ativa, cimento, agregados bem resistentes, um alto teor de fibras de aço curtas, $707 \mathrm{~kg} / \mathrm{m}^{3}(9 \%)$, e um baixo fator $\mathrm{A} / \mathrm{C}$ (da ordem de 0,20$)$. Esse compósito atinge resistências à compressão da ordem de $350 \mathrm{MPa}$. É um material usado em pisos industriais e como camada protetora de outras estruturas ou peças.

- SIFCON (concreto com fibra infiltrado com nata de cimento): é um material que surgiu em torno de 1984 e é feito da seguinte forma: primeiro são jogadas as fibras sobre um molde e depois elas são impregnadas com uma nata de cimento de baixa viscosidade. Pode-se usar qualquer tipo de 
fibra, porém as que têm sido mais utilizadas são as fibras de aço tipo DRAMIX (com ganchos nas extremidades), $\ell=30 \mathrm{~mm}$ e $\mathrm{d}_{\mathrm{f}}=0,5 \mathrm{~mm}$. Normalmente utiliza-se um consumo de fibras entre $314 \mathrm{~kg} / \mathrm{m}^{3}$ e $942 \mathrm{~kg} / \mathrm{m}^{3}$ ( $4 \%$ e $12 \%)$, mas pode-se chegar a teores de até $2120 \mathrm{~kg} / \mathrm{m}^{3}(27 \%)$. É um material usado em reparos de pavimentos e em camadas sobrepostas em pisos industriais. Existem estudos como o de Naaman ${ }^{3}$, apud VAN MIER et al (1996), que sugerem o uso desse material em rótulas plásticas deformáveis em pórticos de concreto pré-moldado, especialmente em estruturas sujeitas a terremoto. Já Fritz et al ${ }^{4}$, apud VAN MIER et al (1996), sugerem o uso de SIFCON para vigas sem armadura de cisalhamento. Essas aplicações se encontram em estudo.

Enfim, a aplicação do CRF é muito vasta. Como foi visto, estudos atuais indicam que o CRF pode ser usado tanto em pequenos reparos como em substituição das armaduras transversais e longitudinais. Não importa como ele vai ser usado, o importante é que o CRF é um material que já garantiu o seu lugar no mercado.

\subsubsection{Comentários e parâmetros adotados na pesquisa}

Esta pesquisa utilizou as fibras de aço da DRAMIX. São fibras de fio trefilado, com ganchos nas extremidades, com fator de forma $\ell / d=45$, e comprimento de $30 \mathrm{~mm}$. Foram utilizadas em baixos teores: $40 \mathrm{~kg} / \mathrm{m}^{3}(\approx 0,51 \%)$ e $60 \mathrm{~kg} / \mathrm{m}^{3}(\approx$ 0,76\%). Os parâmetros escolhidos para esta pesquisa se basearam no mercado brasileiro, ou seja, procurou-se escolher as fibras que mais são utilizadas no nosso mercado, nos seus respectivos teores. Nesta pesquisa as fibras não foram utilizadas como substitutas das armaduras convencionais. As peças foram dimensionadas para que os esforços de tração fossem resistidos pelas armaduras longitudinais e transversais.

3 NAAMAN, A. E. (1992). SIFCON: Tailored properties for structural applications. In High Performance Fiber Reinforced Cement Composites, REINHARDT, H. W. e NAAMAN, A. E. editores, Chapman \& Hall/ E\&FN Spon, Londres/ Nova Iorque, pp. 18-38, apud VAN MIER (1996).

4 FRITZ, C.; NAAMAN, A. E.; REINHARDT, H. W. (1992). SIFCON matrix in RC beams. In High Performance Fiber Reinforced Cement Composites, REINHARDT, H. W. e NAAMAN, A. E. editors, Chapman \& Hall/ E\&FN Spon, London/ New York, pp. 518-528, apud VAN MIER (1996). 
Como esperado, para os teores e comprimentos de fibras que foram utilizados, não houve ganho significativo na resistência do concreto, e sim um aumento na sua tenacidade e ductilidade, e um melhor controle da fissuração das peças, nas fases de pré-fissuração e, principalmente, na de pós-fissuração. Esperava-se, também, que as fibras não entrassem em escoamento, e sim sofressem arrancamento. Porém, não foi possível determinar o tipo de ruptura das fibras.

\subsection{A Aderência, sua Importância e suas Implicações}

O concreto armado, assim como o concreto protendido, é o material resultante da ação conjunta de dois outros materiais: o concreto e o aço. Para que estes dois materiais trabalhem em conjunto é fundamental que haja uma solidariedade entre eles, que não permita o escorregamento de um em relação ao outro. Essa solidariedade é garantida pela aderência que existe entre o aço e o concreto.

O princípio básico do concreto armado é que o aço resista à tração enquanto o concreto resiste à compressão. Para isso, é necessário que haja uma transferência de esforços de um para o outro, o que é possível devido à aderência.

Nas peças de concreto armado, as armaduras sofrem variação de tensão ao longo do comprimento, especialmente nas zonas de ancoragem e de variação do momento fletor. Para que não haja o escorregamento da armadura e a peça permaneça em equilíbrio, é necessário que surjam as tensões de aderência. A Figura 2.10 ilustra esse comportamento.
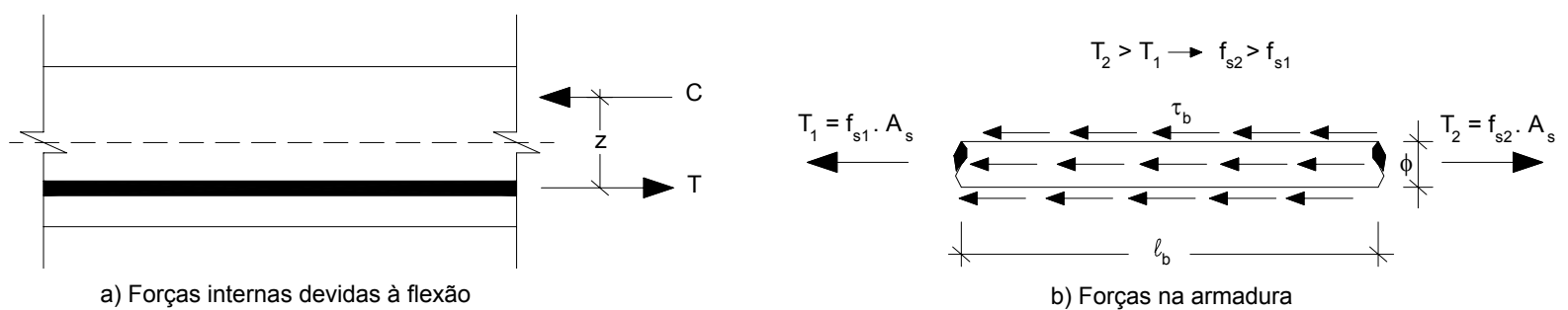

Figura 2.10 - Surgimento da tensão de aderência.

Para que a armadura da Figura 2.10 não escorregue é necessário que apareça uma força de aderência $\left(\mathrm{F}_{\text {ader }}\right)$ que equilibre a diferença $\left(\mathrm{T}_{2}-\mathrm{T}_{1}\right)$. Montando-se a equação de equilíbrio para as forças horizontais, tem-se que:

$$
\begin{array}{ll}
\mathrm{T}_{2}=\mathrm{T}_{1}+\mathrm{F}_{\mathrm{ader}} \quad \mathrm{F}_{\mathrm{ader}}=\tau_{\mathrm{b}} \cdot \mathrm{A}_{\text {lat }} & \mathrm{A}_{\text {lat }}=\pi \cdot \phi \cdot \ell_{\mathrm{b}} \\
\mathrm{f}_{\mathrm{S} 2} \cdot \mathrm{A}_{\mathrm{S}}=\mathrm{f}_{\mathrm{S} 1} \cdot \mathrm{A}_{\mathrm{S}}+\tau_{\mathrm{b}} \cdot \pi \cdot \phi \cdot \mathrm{l}_{\mathrm{b}} & \mathrm{A}_{\mathrm{s}}=\frac{\pi \cdot \phi^{2}}{4}
\end{array}
$$




$$
\Delta \mathrm{f}_{\mathrm{S}}=\mathrm{f}_{\mathrm{S} 2}-\mathrm{f}_{\mathrm{S} 1}=\frac{4 \cdot \pi \cdot \phi \cdot \ell_{\mathrm{b}} \cdot \tau_{\mathrm{b}}}{\pi \cdot \phi^{2}}=\frac{4 \cdot \ell_{\mathrm{b}} \cdot \tau_{\mathrm{b}}}{\phi}, \mathrm{ou} \quad \tau_{\mathrm{b}}=\frac{\Delta \mathrm{f}_{\mathrm{S}} \cdot \phi}{4 \cdot \ell_{\mathrm{b}}}
$$

onde: $\mathrm{T}=$ Forças de tração;

$\mathrm{C}=$ forças de compressão;

$\mathrm{z}=$ braço de alavanca interno;

$\mathrm{f}_{\mathrm{s}}=$ tensão na armadura;

$\mathrm{A}_{\mathrm{s}}=$ área da seção transversal da armadura;

$\tau_{\mathrm{b}}=$ tensão de aderência;

$\mathrm{A}_{\text {lat }}=$ área de atuação de $\tau_{\mathrm{b}}$;

$\phi=$ diâmetro da barra (armadura).

Se o elemento for de comprimento infinitesimal $\mathrm{dx}$, pode-se reescrever a equação da seguinte forma:

$$
\frac{\Delta \mathrm{f}_{\mathrm{S}}}{\mathrm{dx}}=\frac{4 \cdot \tau_{\mathrm{b}}}{\phi}
$$

Logo, se a armadura estiver sob tensão constante $\left(\Delta \mathrm{f}_{\mathrm{s}}=0\right)$, a peça já se encontra em equilíbrio, não havendo necessidade da atuação da força de aderência. Porém, sempre que haja a variação de tensão $\left(\Delta f_{s} \neq 0\right)$, precisa-se da força de aderência para que a armadura não escorregue em relação ao concreto, o equilíbrio seja mantido, e possa ser feita a transferência dos esforços.

\subsubsection{Tipos de aderência}

A aderência entre o concreto e o aço, nas peças de concreto armado e protendido, é composta de três parcelas distintas: a aderência química (adesão), a aderência por atrito, e a aderência mecânica.

\section{a) Aderência química}

A aderência química, ou adesão, é proveniente das ligações físico-químicas que ocorrem na interface do aço com o concreto, durante a pega do cimento. Essa parcela tem um valor muito pequeno. Segundo Tassios ${ }^{5}$ apud ELIGEHAUSEN et al (1983), para as peças de concreto armado, é da ordem de $0,5 \mathrm{MPa}$ a $1 \mathrm{MPa}$.

5 TASSIOS, T. P. (1979) - Properties of bond between concrete and steel under load cycles idealizing seismic action. Comité Euro-International du Béton, Bulletin nํ131, Paris, apud ELIGEHAUSEN et al (1983). 


\section{b) Aderência por atrito}

A aderência por atrito é função do coeficiente de atrito $(\mu)$ entre o aço e o concreto (aproximadamente $\mu=0,3$ ), que depende da rugosidade superficial da armadura, e é proveniente de pressões transversais que a barra sofre devido à retração do concreto (FUSCO, 1995), ou às forças externas de compressão, para o caso do concreto armado. Além dessas, para o concreto protendido, as pressões transversais podem ser causadas pelo traçado helicoidal das cordoalhas (VARGAS, 2001), já que o espaçamento dos fios, ou da hélice, varia de acordo com a variação de tensão na armadura, contribuindo para aumentar as pressões de compressão por contato. A aderência por atrito tem valores maiores que a adesão. Segundo ELIGEHAUSEN et al (1983), para concretos com $\mathrm{f}_{\mathrm{ck}}=30 \mathrm{MPa}$ em peças de concreto armado, a tensão de aderência por atrito pode variar de $0,4 \mathrm{MPa}$ a $10 \mathrm{MPa}$. Esse intervalo grande se explica pelo fato de não se ter muita pesquisa nessa área. Para o concreto pré-tracionado, a aderência por atrito é uma parcela importante, e, às vezes, é a maior responsável pela capacidade resistente da peça.

\section{c) Aderência mecânica para barras lisas ou nervuradas}

A aderência mecânica é função da irregularidade da superfície da armadura, ou seja, da conformação superficial da barra. Quanto mais irregular for a superfície da armadura, maior será a aderência mecânica, pois as saliências na superfície da barra funcionam como pontos de apoio que mobilizam as tensões de compressão no concreto (FUSCO, 1995), o chamado efeito de cunha, como ilustra a Figura 2.11.

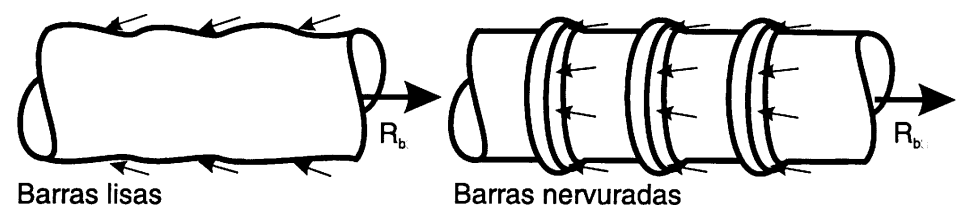

Figura 2.11 - Aderência mecânica (FUSCO, 1995).

As barras podem apresentar superfícies lisas ou nervuradas. Mesmo nas barras ditas lisas, existe uma certa irregularidade na sua superfície devida ao processo produtivo (Figura 2.11), porém o valor da aderência mecânica não é muito grande. Já nas barras nervuradas, ou barras de alta aderência, a aderência mecânica é a grande 
responsável pela ancoragem da armadura. O estudo da aderência em barras nervuradas tem sido objeto de várias pesquisas em todo o mundo.

\section{d) Aderência mecânica nas cordoalhas}

No caso das cordoalhas de sete fios, a aderência mecânica depende da possibilidade, ou não, da armadura girar dentro do concreto. A cordoalha apresenta uma forma helicoidal, logo existem reentrâncias ao longo do seu comprimento, que se assemelham às nervuras das barras. Porém, para que exista o efeito de cunha, o giro da cordoalha, dentro do concreto, tem que ser impedido, o que faz aparecer as forças radiais, que são as responsáveis pelo fendilhamento. Se o giro não for impedido, a cordoalha vai torcer dentro do concreto, à medida que vai escorregando, não sendo mobilizada a aderência mecânica. Por outro lado, a aderência mecânica também pode ser mobilizada pela existência de pequenos grãos de agregados ou de cimento nos canais entre os fios da cordoalha e o concreto, o que pode levar a um certo travamento.

A separação da aderência nos três tipos descritos anteriormente tem uma função apenas didática, conceitual, não sendo possível medir separadamente, num mesmo ensaio, as três parcelas.

\section{e) Efeito Hoyer}

Para as peças de concreto protendido pré-tracionadas, existe mais uma parcela que melhora a aderência da peça: é o chamado Efeito Hoyer. Segundo FUSCO (1995), “Ao se transferir a força de protensão $\mathrm{P}$ à peça de concreto, por meio da liberação das ancoragens externas existentes no banco de protensão, na extremidade da peça o fio de protensão retoma o seu diâmetro inicial $\phi_{0}$, sendo aí nula a tensão de protensão, $\sigma_{\mathrm{p}}=0$. A uma certa distância da extremidade da peça, sob a ação da força de protensão $\mathrm{P}$, o diâmetro efetivo do fio é $\phi<\phi_{0}$, em virtude do efeito de Poisson. Ao longo do comprimento em que $\phi=$ constante, exerce-se a pressão transversal de retração $\mathrm{p}_{\mathrm{ts}}$ (transversal, shrinkage). No trecho inicial do fio, onde o diâmetro é variável, dá-se um efeito de cunha, capaz de solidarizar os dois materiais por meio de pressões radiais de compressão $\mathrm{P}_{\mathrm{c}}$ ”. Esse fenômeno está representado na Figura 2.12. 
O efeito Hoyer nada mais é do que a manifestação do efeito de Poisson nas extremidades das peças protendidas (VARGAS, 2001). A diminuição da tensão na cordoalha, devida às perdas de protensão, também podem causar um efeito semelhante.

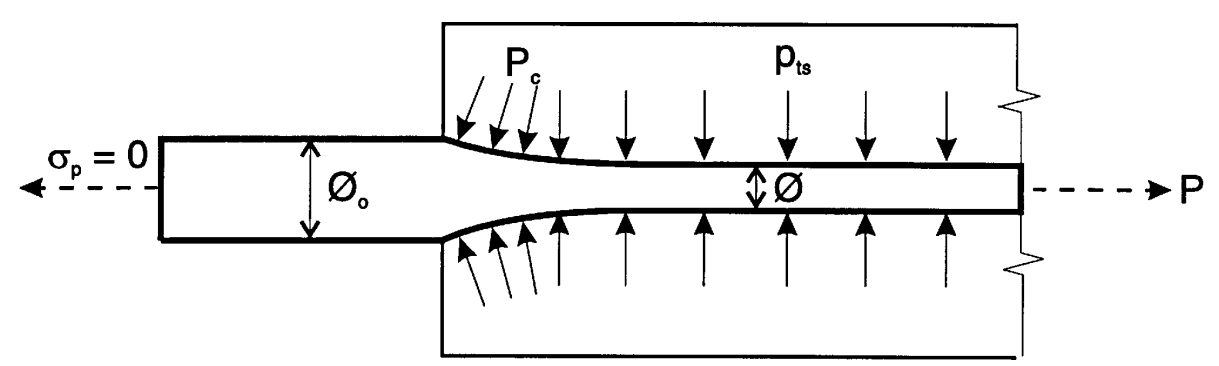

Figura 2.12 - Efeito Hoyer (FUSCO, 1995).

\subsubsection{O estudo da tensão de aderência}

A tensão de aderência tem sido objeto de vários estudos em todo o mundo, inclusive com simpósios e congressos totalmente dedicados a esse tema. Isso se justifica pela sua importância nas peças de concreto armado e protendido, já que, para se garantir um bom comportamento dessas peças, é fundamental que se tenha uma excelente compreensão do fenômeno da aderência, para que elas sejam dimensionadas de modo a garantir a ancoragem das armaduras.

Nas peças de concreto armado, costuma-se estudar a tensão de aderência por meio de três modelos distintos: o de viga à flexão, o de prisma carregado axialmente, e o de arrancamento. As Figuras 2.13, 2.14 e 2.15, respectivamente, mostram uma representação esquemática dos três modelos citados.

\section{a) Viga à flexão}

Numa viga de concreto armado submetida à flexão (Figura 2.13), a força que atua na armadura numa fissura vale:

$$
\mathrm{T}=\frac{\mathrm{M}}{\mathrm{z}}
$$

Fazendo-se o equilíbrio das forças horizontais na barra, como foi visto no início do item 2.2, tem-se que:

$$
\Delta \mathrm{T}=\pi \cdot \phi \cdot \tau_{\mathrm{bm}} \cdot \mathrm{dx}
$$

onde $\tau_{\mathrm{bm}}$ é o valor médio da tensão de aderência. Porém, 


$$
\Delta \mathrm{T}=\frac{\Delta \mathrm{M}}{\mathrm{z}} \quad \text { e } \quad \frac{\Delta \mathrm{M}}{\mathrm{dx}}=\mathrm{V}
$$

Logo:

$$
\tau_{\mathrm{bm}}=\frac{\Delta \mathrm{T}}{\mathrm{dx} \cdot \pi \cdot \phi}=\frac{\Delta \mathrm{M}}{\mathrm{dx} \cdot \pi \cdot \phi \cdot \mathrm{z}}=\frac{\mathrm{V}}{\pi \cdot \phi \cdot \mathrm{z}}
$$
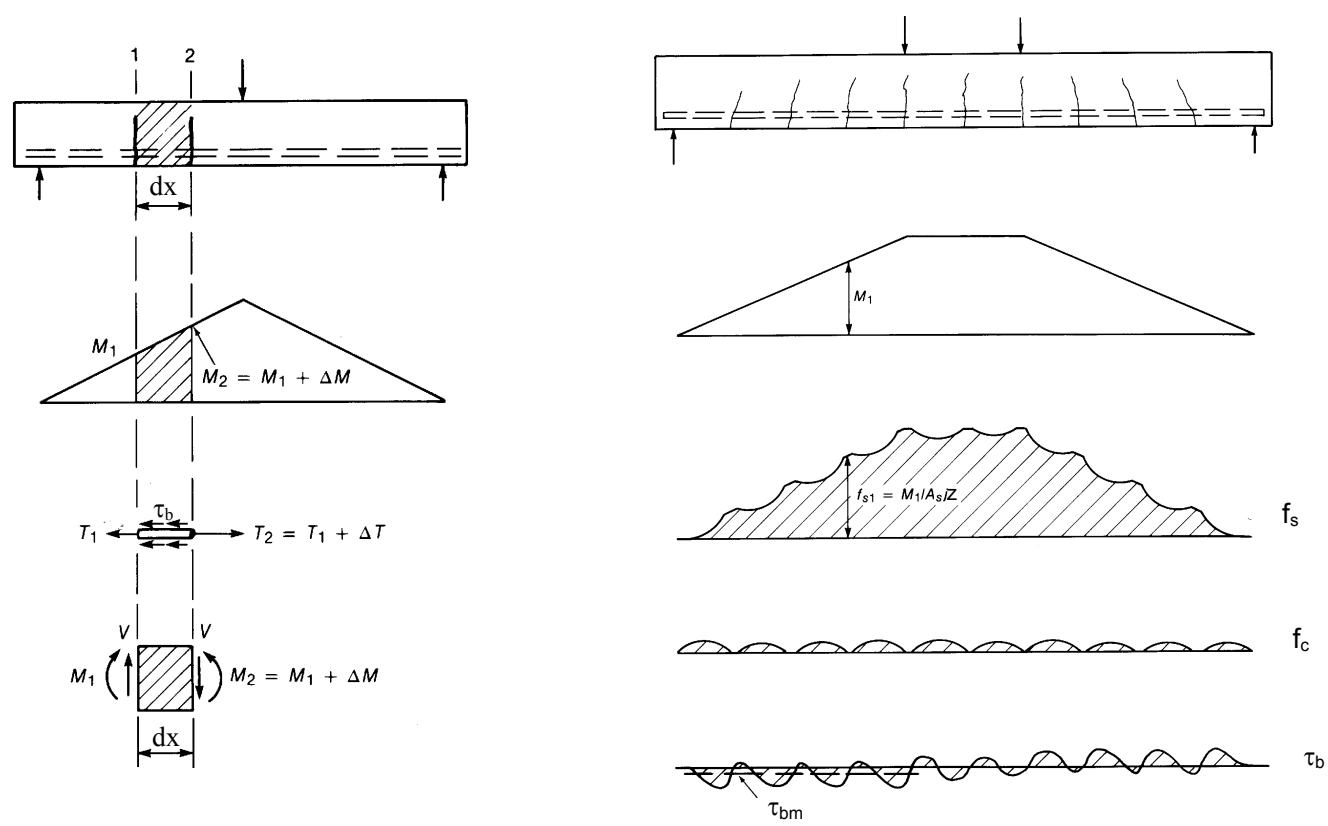

Figura 2.13 - Tensões numa viga fissurada submetida à flexão (MACGREGOR, 1988).

O valor calculado da tensão de aderência é um valor médio, pois há a variação de tensão, no concreto e na armadura, ao longo da viga. A tensão no concreto é sempre nula onde há fissura, e entre as fissuras há a transferência de esforços do aço para o concreto, e vice-versa. Porém, devido à variação do momento fletor, o valor da tensão na armadura nos pontos de fissura não é constante. Há também uma variação da tensão na armadura ao longo de toda a viga, e não apenas entre as fissuras.

Os ensaios em vigas para o estudo da aderência podem ter formas variadas. Para as peças de concreto armado, o estudo de vigas biapoiadas é o mais comum, tanto se analisando as barras tracionadas, como se analisando as barras traspassadas em zonas de momento constante (Figura 2.34). Pode-se estudar também meias-vigas e/ou vigas contínuas, como bem descreve FERGUSON et al (1988). 


\section{b) Prismas tracionados axialmente}

Já para os prismas tracionados axialmente (Figura 2.14), a tensão média de aderência é nula, pois não há variação de tensão na armadura $\left(\Delta \mathrm{f}_{\mathrm{s}}=0\right)$ de um ponto de fissura em relação a outro; há variação da tensão apenas entre as fissuras. $\mathrm{O}$ valor da tensão de aderência pode ser calculado ponto a ponto pela equação (2.2). Este modelo não é muito usado no estudo da tensão de aderência, porém, foi utilizado por GOTO (1971), um dos estudos mais importantes e conhecidos sobre a formação de fissuras ao redor de barras tracionadas.

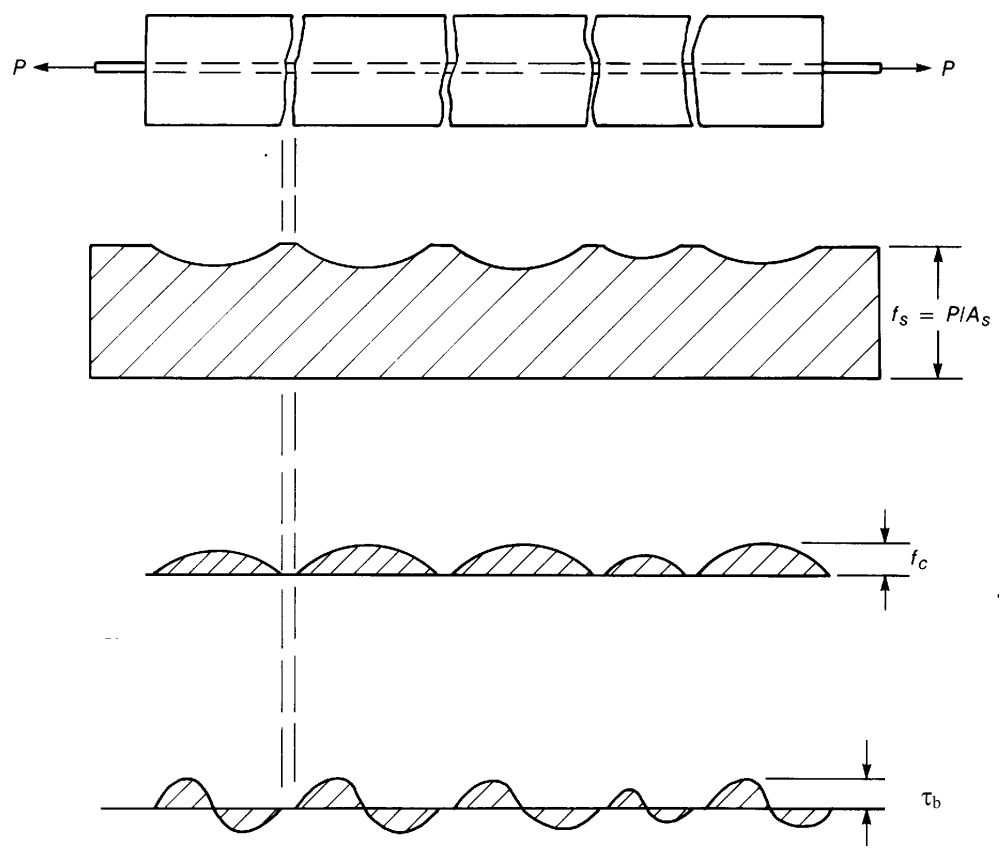

Figura 2.14 - Tensões num prisma fissurado carregado axialmente (MACGREGOR, 1988).

EDWARDS \& PICARD (1972) também utilizaram o modelo de tirante para o estudo da aderência em cordoalhas de $\phi 12,7 \mathrm{~mm}$. Esse tipo de modelo visa, principalmente, verificar a relação entre o escorregamento e a abertura de fissuras.

\section{c) Ensaio de arrancamento padrão}

O ensaio de arrancamento padrão (Figura 2.15) tem sido o mais usado no estudo da aderência, e antes da década de 50 era praticamente o único utilizado (MACGREGOR, 1988).

Esse ensaio é muito simples de ser executado e fornece uma leitura direta da tensão de aderência. Porém, há o inconveniente do concreto ficar comprimido, não 
havendo fissuração, o que faz com que os resultados obtidos não sejam muito representativos para outras peças, como as vigas, por exemplo. Além disso, há um confinamento da armadura devido ao cobrimento exagerado de concreto e há um impedimento da expansão transversal do corpo-de-prova, devido ao atrito com a placa de apoio da máquina de ensaio. Mesmo com esses problemas, os ensaios de arrancamento fornecem resultados satisfatórios. Mais do que resultados quantitativos, esses ensaios fornecem resultados qualitativos do comportamento das peças em relação à aderência, principalmente quando se quer avaliar parâmetros distintos que influenciam na aderência. E por isso, apesar de todos os inconvenientes, esse tipo de ensaio ainda é bastante utilizado.

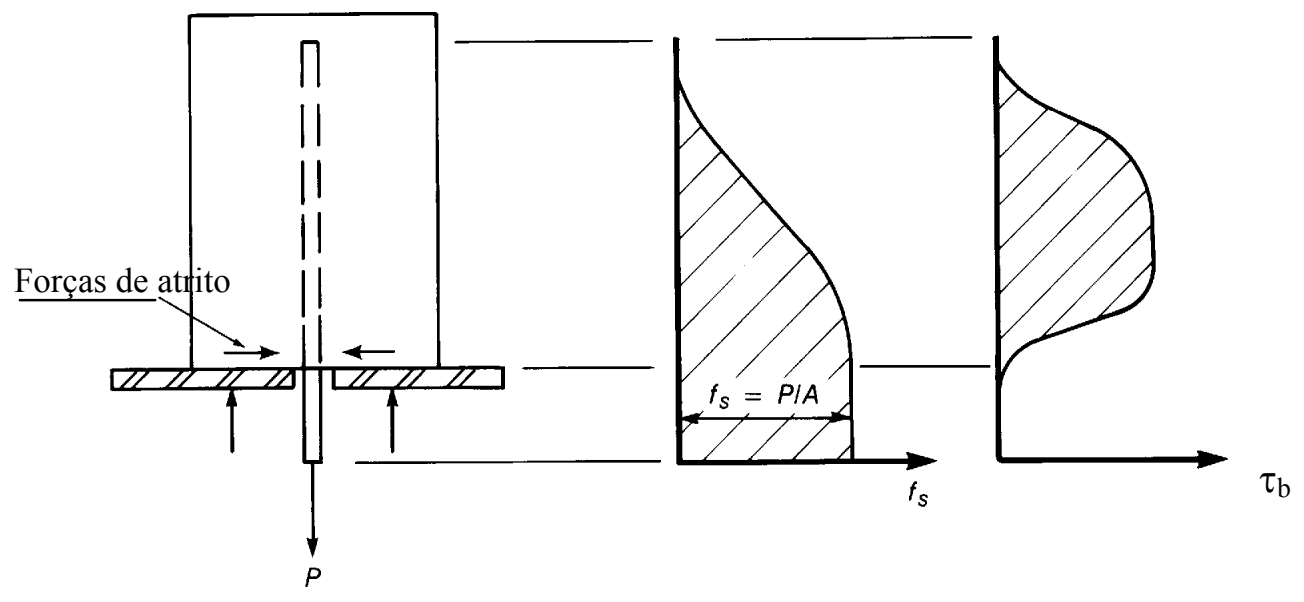

Figura 2.15 - Tensões num ensaio de arrancamento (MACGREGOR, 1988).

Ao longo do tempo algumas medidas vêm sendo tomadas para minimizar esses problemas, fazendo com que o modelo seja mais representativo das peças de concreto armado e protendido. Uma dessas modificações é a redução do cobrimento de concreto. Alguns pesquisadores sugerem que este valor fique em torno de $2 \phi$ (que é o valor adotado nesta pesquisa), para diminuir o efeito de confinamento da armadura.

Outra modificação é no número de barras utilizadas no ensaio. Ao invés de se ter apenas uma barra, pode-se utilizar quatro ou duas barras.

\section{d) Ensaio de arrancamento com quatro barras}

No chamado "ensaio de quatro barras" (VALLE, 1994), a barra central é tracionada e o corpo-de-prova fica preso pelas outras três barras, como mostra a Figura 2.16, evitando assim que o concreto fique comprimido e que haja o atrito com 
a placa de apoio. Este arranjo, porém, já não é tão simples como o do ensaio com apenas uma barra.

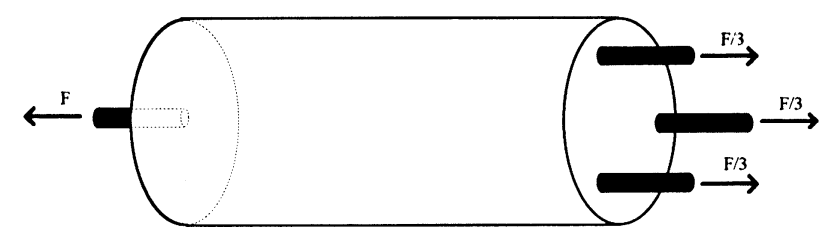

Figura 2.16 - Esquema do corpo-de-prova para o "ensaio de quatro barras" (VALLE, 1994).

\section{e) Ensaio de arrancamento com duas barras}

Podem ser usados, também, ensaios com duas barras tracionadas, como o modelo adaptado da Norma Dinamarquesa DS $2082^{6}$ apud EZELDIN \& BALAGURU (1989), e apresentado na Figura 2.17.

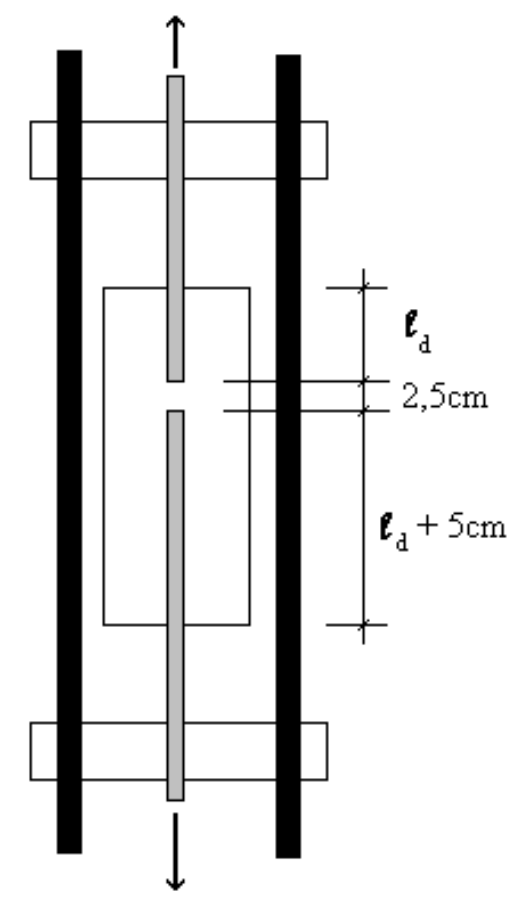

Figura 2.17 - Arranjo de ensaio utilizado por EZELDIN \& BALAGURU (1989).

As duas barras são separadas por um pequeno espaçamento. Uma delas é menor que a outra, para induzir a ruptura na mais curta. Esta possui o comprimento de ancoragem em estudo. Para as armaduras passivas, esse tipo de ensaio fornece

6 Pullout Test (DS 2082), Danish Standards Organization, Copenhagen, Dec. 1980, 2pp., apud EZELDIN \& BALAGURU (1989). 
resultados mais próximos da realidade, já que o concreto permanece tracionado. É mais simples do que o "ensaio de quatro barras".

\section{f) Outros ensaios de arrancamento}

Alguns pesquisadores, como YERLICI \& ÖZTURAN (2000), por exemplo, sugerem um ensaio de arrancamento com a armadura excêntrica, que simula melhor o comportamento de viga, em comparação com a armadura centrada.

$\mathrm{Na}$ literatura encontram-se sugestões para novos métodos de ensaio de arrancamento para as peças pré-tracionadas, como o proposto por COUSINS et al (1992), por exemplo.

COUSINS et al (1992) propuseram um método de ensaio que leva em conta o efeito Hoyer durante o arrancamento. Nos ensaios de arrancamento padrão, por tração direta, o comprimento aderente é pequeno, em geral bem inferior ao comprimento de transferência. Logo, a cordoalha não desenvolve a pré-tração total, nem apresenta o efeito Hoyer, que é favorável em relação à aderência. Para que este efeito fosse levado em conta, eles desenvolveram um ensaio em que o arrancamento se dá enquanto a cordoalha permanece pré-tracionada. A Figura 2.18 apresenta um esquema do arranjo de ensaio.

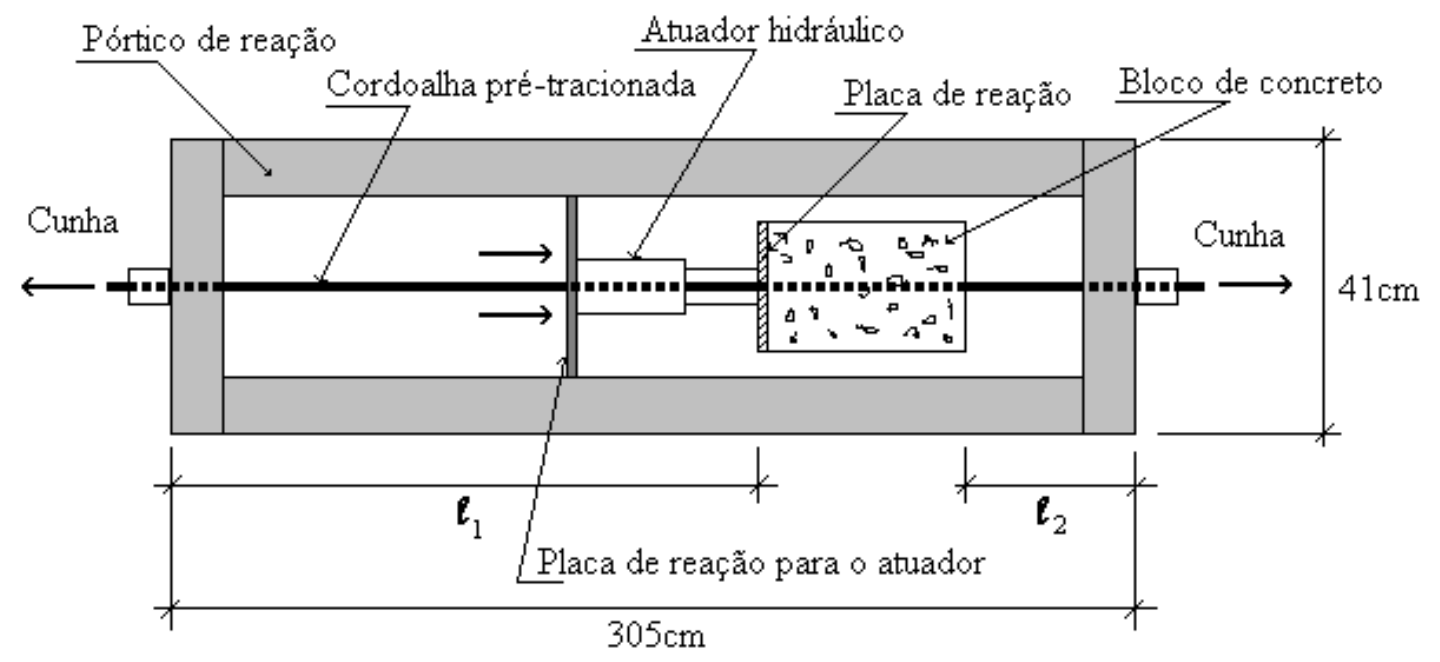

Figura 2.18 - Método de ensaio proposto por COUSINS et al (1992).

O procedimento de ensaio é o seguinte: (1) a cordoalha é pré-tracionada; (2) o bloco de concreto é confeccionado; (3) o atuador hidráulico é acionado, e empurra o bloco de concreto para a direita. À medida que o atuador hidráulico exerce uma força 
para a direita, a tensão na cordoalha ao longo de $\ell_{1}$ vai aumentando, ao passo que ao longo de $\ell_{2}$ a tensão vai diminuindo, mobilizando assim o efeito Hoyer.

Um processo semelhante foi desenvolvido por VARGAS (2001), que estudou a aderência de cordoalhas pré-tracionadas em concretos de altas resistências iniciais. O autor propõe um método de ensaio em que tanto a medição do comprimento de transferência como a execução do ensaio de arrancamento são feitos em seqüência, no mesmo pórtico de protensão. Esse método está descrito mais detalhadamente no item 2.3, deste capítulo.

\subsubsection{Representação da aderência}

Independentemente do tipo de ensaio, o que se pretende obter é a representação do comportamento da aderência. Segundo DUCATTI (1993), "O modelo do comportamento da aderência é representado pela relação entre a tensão de aderência e o escorregamento. A primeira é identificada idealizadamente pela tensão de cisalhamento na interface barra-concreto, e o segundo pelo deslocamento relativo entre a armadura e o concreto, deslocamento este provocado pela diferença entre as deformações específicas do aço e do concreto".

Existem alguns modelos representativos do comportamento Tensão de aderência local versus Escorregamento local, como a curva típica para peças de concreto armado com $\mathrm{f}_{\mathrm{c}}=30 \mathrm{MPa}$, apresentada por ELIGEHAUSEN et al (1983), a partir de ensaios de arrancamento com deformação controlada, e mostrada na Figura 2.19 .

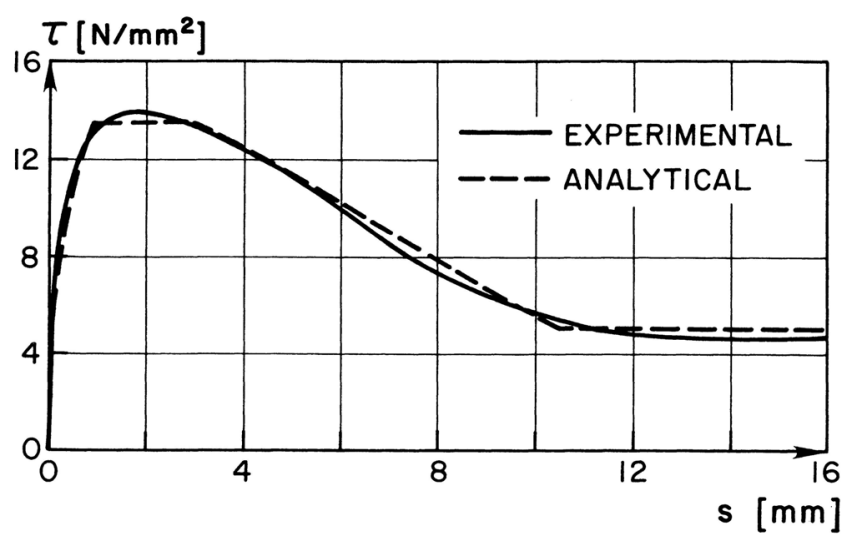

Figura 2.19 - Tensão de aderência local $(\tau)$ versus Escorregamento local $(\mathrm{S})$, para concretos com $\mathrm{f}_{\mathrm{c}}=30 \mathrm{MPa}$ (ELIGEHAUSEN et al, 1983). 
Um dos modelos analíticos mais usado e mais citado na literatura técnica, para o concreto armado, é o modelo do CEB-FIP (1990), que é uma curva média baseada em dados estatísticos, apresentada na Figura 2.20.

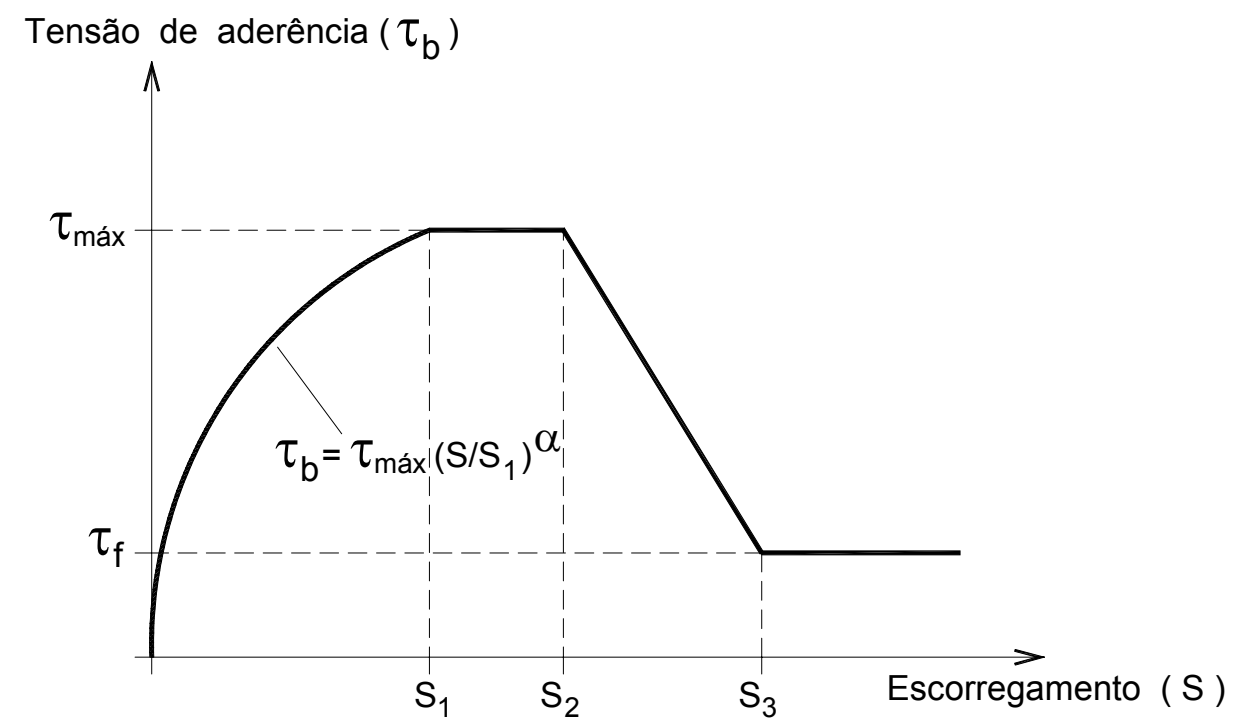

Figura 2.20 - Relação analítica da Tensão de aderência versus Escorregamento (CEB-FIP, 1990).

Segundo o CEB-FIP (1990), o primeiro trecho (entre 0 e $\mathrm{S}_{1}$ - curva ascendente) representa a fase de fissuração inicial da matriz e onde há o esmagamento local do concreto pelas nervuras (Figura 2.21). O segundo trecho (entre $\mathrm{S}_{1}$ e $\mathrm{S}_{2}$ - reta horizontal) só ocorre para o concreto confinado e representa um estágio mais avançado do esmagamento e do corte do concreto entre as nervuras. $\mathrm{O}$ terceiro trecho (entre $\mathrm{S}_{2}$ e $\mathrm{S}_{3}$ - reta descendente) se refere à redução da aderência devida ao fendilhamento ao longo das barras. $\mathrm{O}$ último trecho (a partir de $\mathrm{S}_{3}$ - reta horizontal) representa a capacidade resistente residual da aderência, que é garantida por uma armadura transversal mínima.

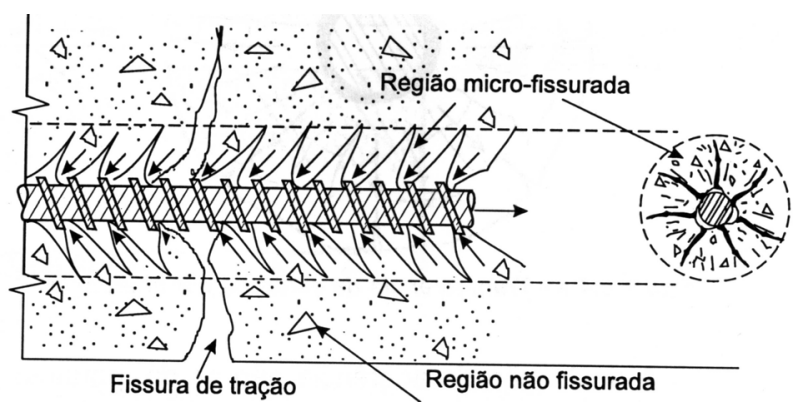

Figura 2.21 - Fissuras e forças ao redor de barra tracionada, segundo GOTO (1971), (FUSCO, 1995).

Para as cordoalhas pré-tracionadas, na grande maioria dos casos, ou se faz o ensaio de arrancamento com a cordoalha sem protensão (como armadura passiva), ou 
faz-se ensaio de vigas pré-tracionadas, biapoiadas, sob flexão para se medir os comprimentos de ancoragem da peça. Pode-se fazer, também, ensaios em prismas pré-tracionados, nos quais são medidos os comprimentos de transferência de esforços. A partir dos resultados obtidos (tensão de aderência da armadura sem protensão, comprimento de transferência e comprimento de ancoragem) é estimada a tensão de aderência para as armaduras protendidas.

Para essas peças pré-tracionadas, não se tem um modelo único que represente o comportamento da aderência, pois elas apresentam dois comportamentos distintos: um na fase da transferência da protensão, e outro quando a peça se encontra solicitada à flexão. Daí a representação através de um diagrama bilinear que relaciona a tensão na armadura com a distância em relação à extremidade da peça, como o indicado na Figura 2.22.

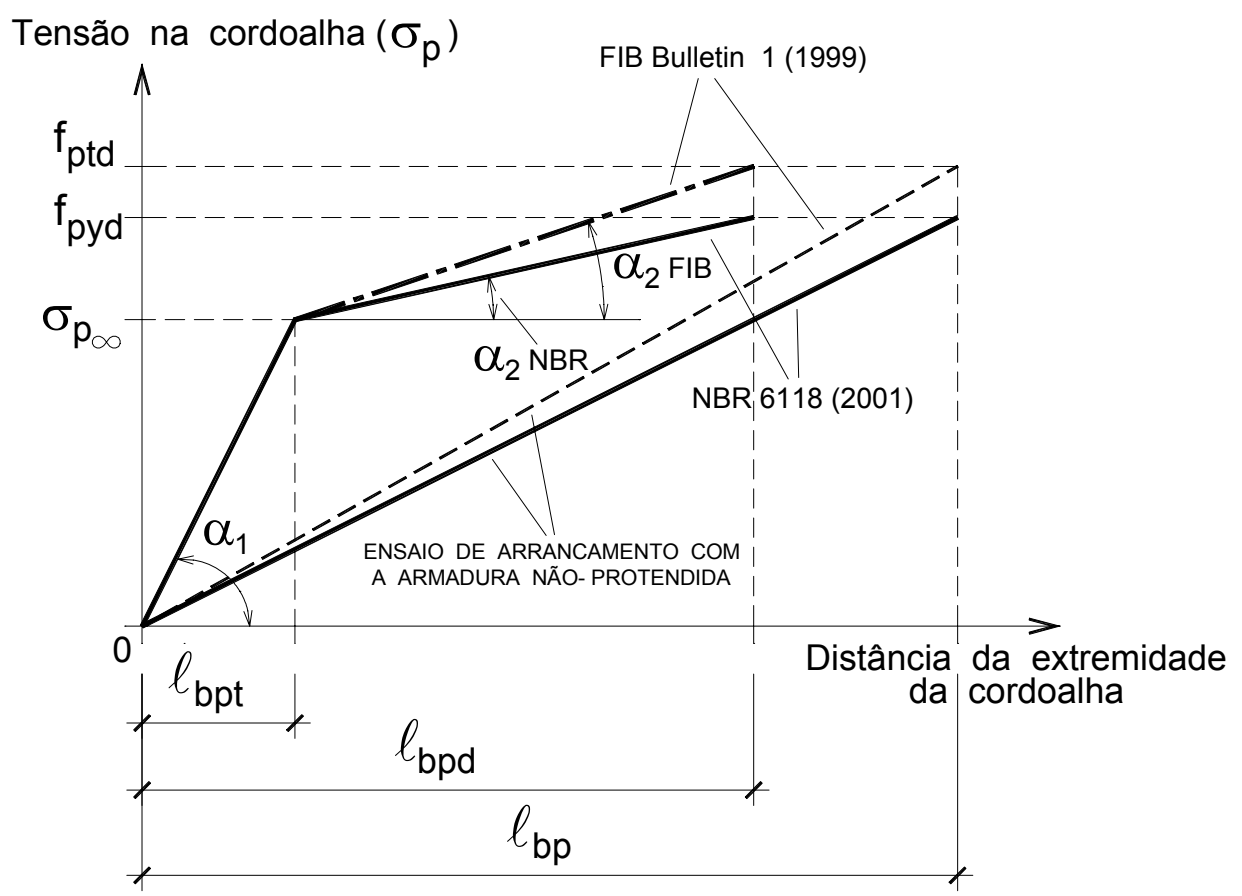

Figura 2.22 - Ancoragem de armaduras pré-tracionadas.

No momento da transferência da protensão, à medida que vai ocorrendo o alívio da protensão na cabeceira da pista, a força vai sendo transferida do aço para o concreto, ou seja, vai havendo uma diminuição da tensão na armadura e um aumento de tensão no concreto. Com essa diminuição de tensão, ocorre uma tendência de aumento do diâmetro da cordoalha, que tenta voltar ao valor inicial, antes da protensão (efeito Hoyer). Porém, o contato com o concreto impede que isso ocorra ao 
longo de toda a extensão da peça. Esse fenômeno aumenta o confinamento do concreto ao redor da cordoalha e o atrito entre o aço e o concreto, devido à pressão transversal exercida pela tendência da cordoalha de restaurar o seu diâmetro original. Isso leva a uma tensão de aderência maior, que está representado na primeira parte do gráfico por uma reta com inclinação maior $\left(\alpha_{1}\right)$. Essa primeira reta indica que a tensão na cordoalha vai de zero, na extremidade da peça, ao valor da força de protensão que se quer ancorar $\left(\sigma_{\mathrm{p} \infty}\right)$, e o comprimento ao longo do qual se dá essa transferência é chamado de comprimento de transferência $\left(\ell_{\mathrm{bpt}}\right)$.

O segundo trecho, que vai de $\sigma_{\mathrm{p} \infty}$ até a tensão de escoamento da armadura $\left(f_{p y d}\right)$, representa a cordoalha sendo solicitada à flexão. Após a peça ser posta em serviço, começam a atuar os diversos carregamentos que solicitam a peça à flexão. Quando isso ocorre, há um aumento de tensão na armadura, fazendo com que haja uma tendência de diminuição do diâmetro da cordoalha. Ou seja, ocorre o fenômeno inverso ao descrito anteriormente, quando da transferência de protensão. Isso faz com que a tensão de aderência mobilizada seja menor, o que é representado no gráfico por uma reta com inclinação menor $\left(\alpha_{2}\right)$. O comprimento ao longo do qual se dá esse processo é chamado, segundo o ACI 318 (2002), de comprimento de ancoragem na flexão ( $\ell_{\mathrm{b}}$, "flexural bond length").

Tanto a NBR 6118 (2001), como a FIB Bulletin 1 (1999), e o ACI 318 (2002) se baseiam nesse diagrama de comportamento duplo para a representação da aderência de peças pré-tracionadas. No ACI 318 (2002) aparece pela primeira vez o diagrama bilinear. Nas versões anteriores, até o ACI 318 (1999), era utilizado um diagrama onde o segundo trecho não é linear, e sim curvo, como mostra a Figura 2.23 .

Nesta pesquisa, foram elaborados os gráficos Tensão de aderência versus Escorregamento para as peças submetidas ao ensaio de arrancamento. Para as vigaspiloto ensaiadas à flexão, foram elaborados os gráficos Tensão na cordoalha versus Distância da extremidade da cordoalha, para as peças ensaiadas. 


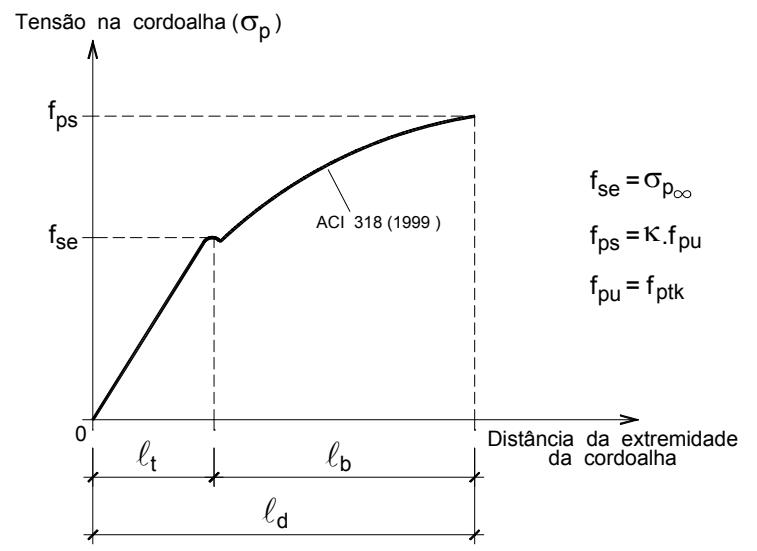

(a)

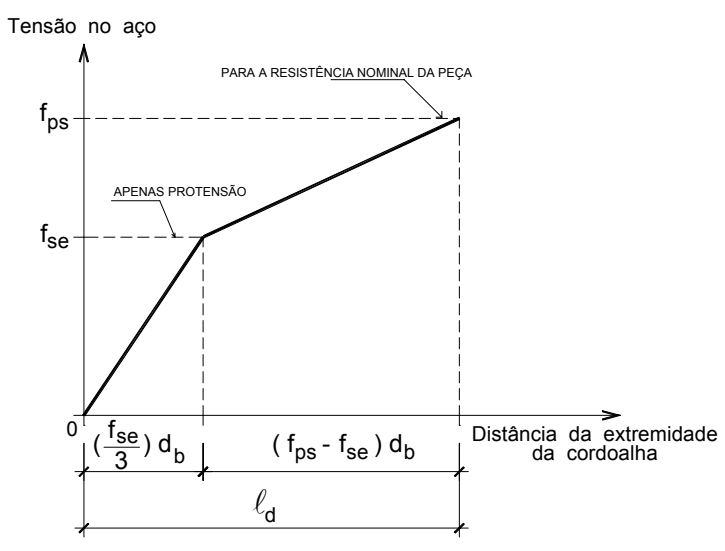

(b)

Figura 2.23 - Ancoragem das armaduras ativas: (a) para versões anteriores ao ACI 318 (2002); (b) para o ACI 318 (2002).

\subsubsection{Os comprimentos de ancoragem}

Como se sabe, a transferência de esforços do aço para o concreto, e vice-versa, se dá ao longo de um determinado comprimento. Para que os esforços sejam transferidos de maneira satisfatória é necessário que se garanta um comprimento mínimo para a peça atingir o equilíbrio, que é chamado de comprimento de ancoragem. Em outras palavras, o comprimento de ancoragem é o menor comprimento necessário para que a tensão na armadura vá de zero à tensão desejada. Caso o comprimento existente seja menor que o necessário, a barra poderá sofrer um arrancamento, antes de atingir o valor esperado. Os comprimentos de ancoragem para barras submetidas à tração e à compressão são diferentes, pois na tração há a fissuração do concreto, fazendo com que o comprimento de ancoragem necessário seja maior do que na compressão. Neste trabalho tratar-se-á apenas do comprimento de ancoragem de barras tracionadas.

Rearrumando a equação (2.2), pode-se dizer que o comprimento de ancoragem $\left(\ell_{\mathrm{b}}\right)$, para as peças de concreto armado, vale:

$$
\ell_{\mathrm{b}}=\frac{\phi \cdot \mathrm{f}_{\mathrm{S}}}{4 \cdot \tau_{\mathrm{b}}}
$$

Ou seja, quanto maior a tensão de aderência, menor o comprimento necessário para ancorar a armadura. Logo, os principais fatores que influenciam no comprimento de ancoragem são os principais fatores que influenciam na tensão de aderência. São eles: as resistências do concreto à tração e à compressão, a retração, a 
presença de armadura de confinamento (estribos ou armaduras de fretagem), o cobrimento, o tipo e a distribuição das barras de aço, a posição das barras durante a concretagem, e o histórico de carregamento da peça. Esses fatores são levados em conta no cálculo do comprimento de ancoragem através de coeficientes que multiplicam, diminuindo ou aumentando, o valor do comprimento de ancoragem básico (equação 2.4). Os vários códigos e normas apresentam diferentes coeficientes. No item 3.2 deste trabalho são apresentados os cálculos, e respectivos coeficientes, para o comprimento de ancoragem de peças pré-tracionadas de acordo com a NBR 6118 (2001), o ACI 318 (2002) e a FIB Bulletin 1 (1999). Além da diferença nos coeficientes, existe também a diferença no cálculo da tensão de aderência, o que também será tratado no item 3.2.

Para as peças de concreto protendido, pode-se dizer que o comprimento de ancoragem básico $\left(\ell_{\mathrm{bp}}\right)$ vale:

$$
\ell_{\mathrm{bp}}=\frac{\phi_{\mathrm{p}}\left(\mathrm{f}_{\mathrm{p}}-\sigma_{\mathrm{p} \infty}\right)}{4 \cdot \tau_{\mathrm{b}}}
$$

onde: $\phi_{\mathrm{p}}=$ diâmetro da armadura de protensão;

$\mathrm{f}_{\mathrm{p}}=$ tensão atuante (final) da armadura de protensão;

$\sigma_{\mathrm{p} \infty}=$ tensão na armadura de protensão após todas as perdas;

Para as peças pré-tracionadas, o cálculo do comprimento básico de ancoragem se baseia na diferença $\left(f_{\mathrm{p}}-\sigma_{\mathrm{p} \infty}\right)$, que é a variação de tensão que ocorre na cordoalha quando submetida à flexão.

$\mathrm{Na}$ literatura técnica encontram-se várias definições dos comprimentos de ancoragem, cada uma referente a uma determinada situação. Para as peças prétracionadas tem-se:

- Comprimento de transferência: é o comprimento necessário para que a tensão na armadura vá de zero à tensão de protensão após todas as perdas $\left(\sigma_{\mathrm{p} \infty}\right)$, no momento da transferência da protensão, e, a partir desse ponto, enquanto a peça não entrar em serviço, a tensão na armadura permanecerá constante. O símbolo usado para esse comprimento varia de uma norma para a outra. Para as normas e os códigos citados neste trabalho tem-se:

$\ell_{\text {bpt: NBR }} 6118$ (2001) e FIB Bulletin 1 (1999);

$\ell_{\mathrm{t}}$ : ACI 318 (2002). 
- Comprimento de ancoragem na flexão: é o comprimento necessário para que a tensão na armadura vá de $\sigma_{\mathrm{p} \infty}$ até o valor final admitido. Esse valor limite varia de uma norma para a outra. As NBR 6118 (2001) e FIB Bulletin 1 (1999) não atribuem um nome para esse comprimento, tampouco um símbolo. A NBR 6118 (2001) admite como valor último, que a armadura pode atingir, o limite de escoamento de cálculo da armadura de protensão ( $f_{\text {pyd }}$ ) (Figura 2.22), já a FIB Bulletin 1 (1999) admite como limite o valor da resistência de cálculo da cordoalha à tração $\left(\mathrm{f}_{\mathrm{ptd}}\right)$ (Figura 2.22), onde: $\mathrm{f}_{\text {pyd }}=0,9 . \mathrm{f}_{\mathrm{ptd}}$.

O ACI 318 (2002), que é quem intitula esse trecho de comprimento de ancoragem na flexão, e o representa por $\ell_{\mathrm{b}}$ (“flexural bond length"), limita o valor da tensão na cordoalha a um percentual da resistência característica do aço à tração $\left(\mathrm{f}_{\mathrm{pu}}\right)$ (Figura 2.23b), tal que: $\mathrm{f}_{\mathrm{ps}}=($ coef $) . \mathrm{f}_{\mathrm{pu}}$

- Comprimento de ancoragem necessário: é a soma do comprimento de transferência com o comprimento de ancoragem na flexão $\left(\ell_{t}+\ell_{b}\right)$. Para as normas e códigos citados neste trabalho tem-se:

$\ell_{\text {bpd: NBR }} 6118$ (2001) e FIB Bulletin 1 (1999);

$\ell_{\mathrm{d}}$ : ACI 318 (2002).

- Comprimento de ancoragem básico: este termo está definido nas NBR 6118 (2001) e FIB Bulletin 1 (1999), e representa o comprimento necessário para a tensão na armadura ir de zero ao valor último admitido ( $f_{\text {pyd }}$ ou $\mathrm{f}_{\text {ptd }}$, respectivamente) (Figura 2.22). Esse valor é determinado para a cordoalha em ensaio de arrancamento, porém com a armadura sem protensão, como se fosse passiva. Tanto a NBR 6118 (2001) como a FIB Bulletin 1 (1999) o identificam por $\ell_{\mathrm{bp}}$.

- Distância de regularização da força de protensão: distância a partir da qual as tensões induzidas no concreto podem ser consideradas linearmente distribuídas ao longo da seção transversal da peça. Esse comprimento é, normalmente, um pouco maior que o comprimento de transferência. Tanto a NBR 6118 (2001) como a FIB Bulletin 1 (1999) o identificam por $\ell_{\mathrm{p}}$. 


\subsubsection{Modos de ruptura por perda de aderência}

Existem, basicamente, dois modos de ruptura relacionados à perda da aderência: a ruptura por arrancamento, e a ruptura por fendilhamento. A Figura 2.24 apresenta o gráfico característico para os dois tipos de rupturas,em que a letra (a) corresponde a arrancamento e a letra (b), a fendilhamento.

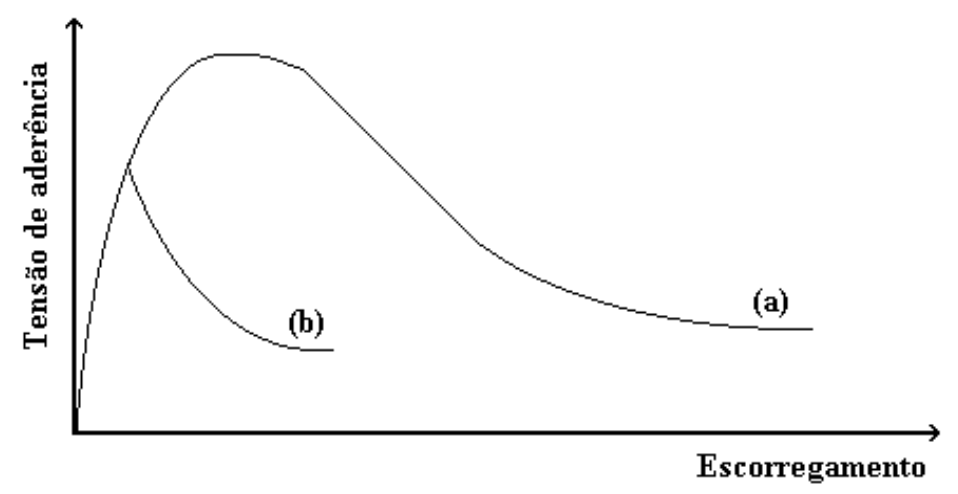

Figura 2.24 - Representação gráfica para as rupturas por arrancamento (a) e por fendilhamento (b).

Pelo gráfico, percebe-se que a ruptura por arrancamento é mais dúctil que a por fendilhamento, e mobiliza uma tensão de aderência maior, para peças semelhantes.

Existe, porém, uma grande variedade de modos de ruptura associados a esses dois, especialmente quando a peça é posta em serviço e passam a atuar as solicitações normais e tangenciais. O tipo de ruptura que uma peça irá sofrer é influenciado por vários fatores: o tipo da armadura (barra, fio, cordoalha), o tipo de conformação superficial da armadura (lisa ou nervurada), o diâmetro da barra, a existência ou não de armaduras de confinamento, a distância entre barras de uma mesma camada, o cobrimento, a tensão na armadura, a qualidade do concreto, e a condição superficial da barra, entre outros. Esses são fatores que, obviamente, influenciam na aderência das peças de concreto armado e protendido. Na literatura técnica, porém, existem várias discordâncias sobre a maior ou menor influência desses fatores na aderência, chegando mesmo, em alguns casos, a conclusões contrárias. Isso se deve, principalmente, ao fato de que os parâmetros de ensaio, os materiais utilizados e as condições ambientes apresentam variações muito grandes de uma pesquisa para a outra, o que dificulta a generalização dos resultados.

De maneira geral, quando uma barra começa a ser solicitada, inicialmente a aderência é mantida pelas forças coesivas provindas da adesão. Essa parcela, porém, é rapidamente destruída, seja devido a pequenos escorregamentos localizados, seja 
pela redução do diâmetro da armadura (efeito de Poisson), por conta do aumento da tensão. Passam, então, a agir as forças de atrito. A partir do momento que o concreto começa a fissurar, as forças de atrito vão sendo reduzidas e a aderência passa a ser função, praticamente, da aderência mecânica proveniente da irregularidade da superfície das barras.

Para as barras lisas, como a aderência mecânica não fornece grande ajuda, a barra vai perdendo a aderência à medida que vão sendo destruídas as forças de atrito. Esse processo leva, normalmente, a uma ruptura por arrancamento da barra.

Já para as barras nervuradas, como a aderência passa a ser governada pela aderência mecânica, quando começa a diminuir a aderência por atrito, as nervuras agem como pontos de apoio de bielas comprimidas, que impedem o deslocamento relativo da barra. Em contrapartida, aparecem tensões de tração perpendiculares às das bielas, que geram um anel de tensão ao redor da armadura, como mostra a Figura 2.25 .

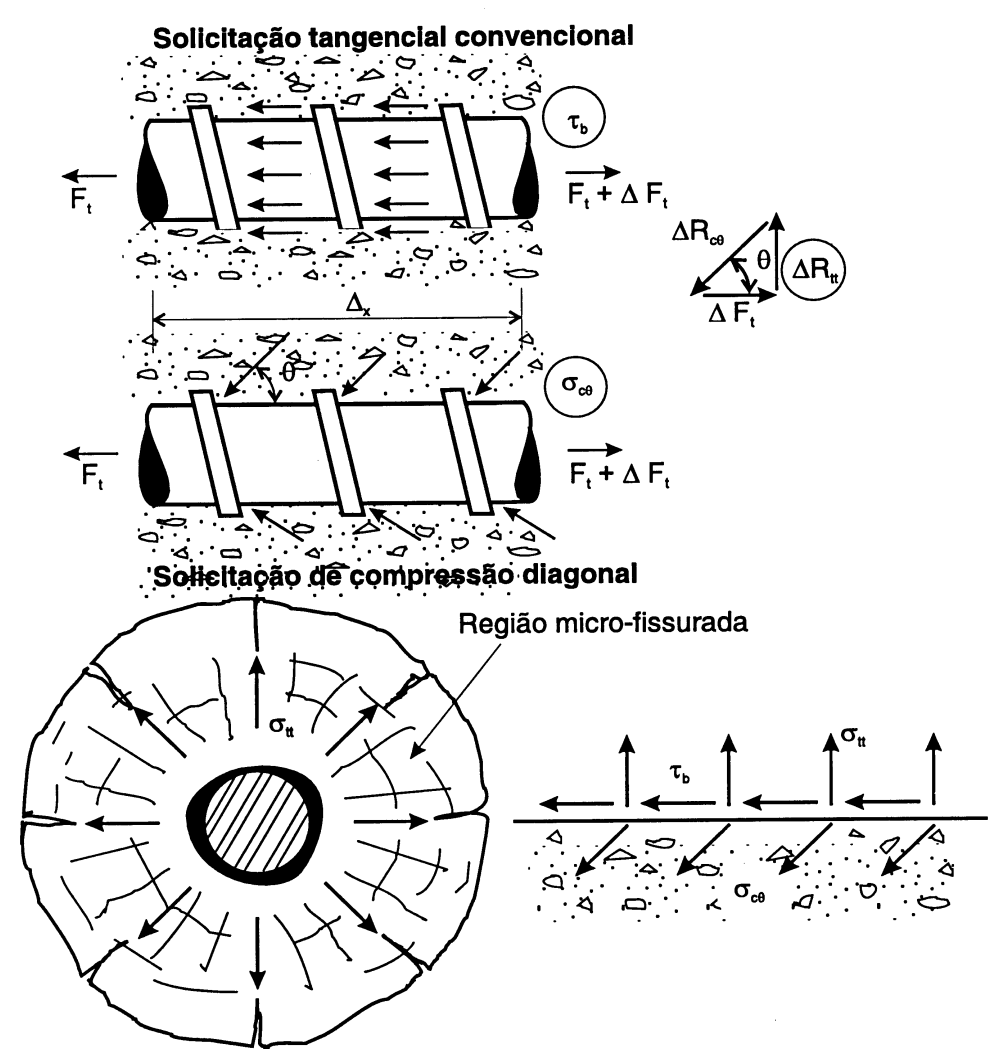

Figura 2.25 - Transferência de esforços por aderência (FUSCO, 1995).

À medida que se vai aumentando a força na armadura, vai havendo uma pulverização do concreto ao redor da barra, devido à compressão exercida pelas 
nervuras (Figura 2.21). Para as barras de alta aderência (nervuradas), antes que ocorra a pulverização total do concreto, e a barra escorregue (deixando um buraco no concreto com diâmetro igual à soma do diâmetro da barra mais 2 vezes a altura das nervuras), dá-se o fendilhamento da peça, devido às altas tensões radiais de tração (Figura 2.26).

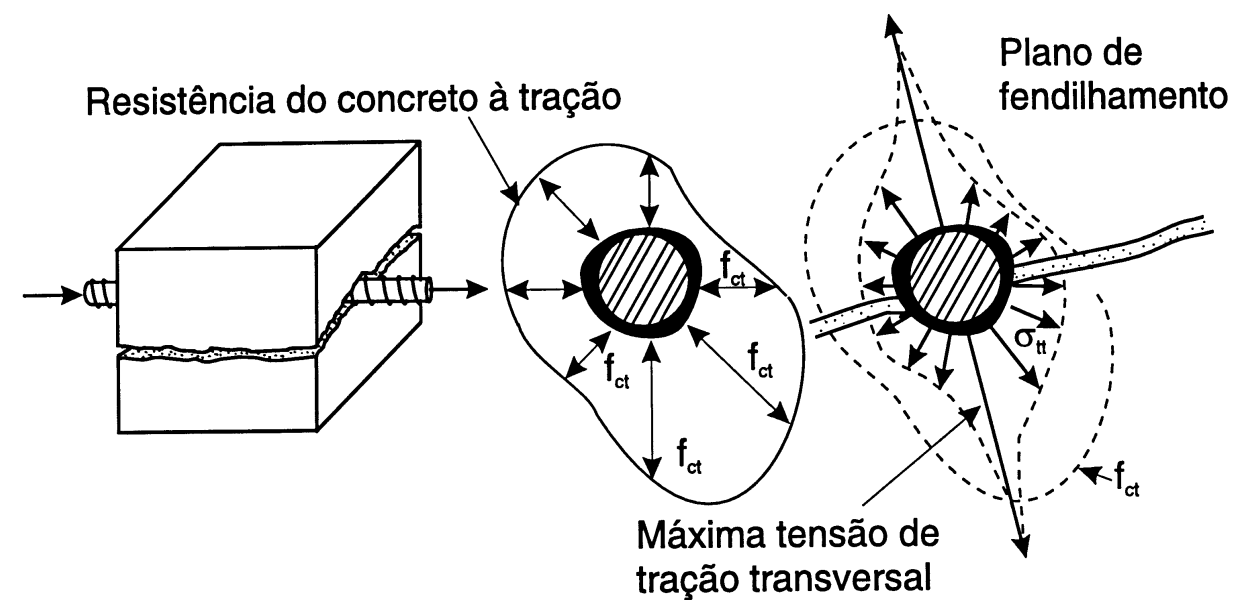

Figura 2.26 - Fendilhamento longitudinal do concreto (FUSCO, 1995).

Esses dois modos de ruptura apresentam padrões de fissuração distintos, como mostra a Figura 2.27 .

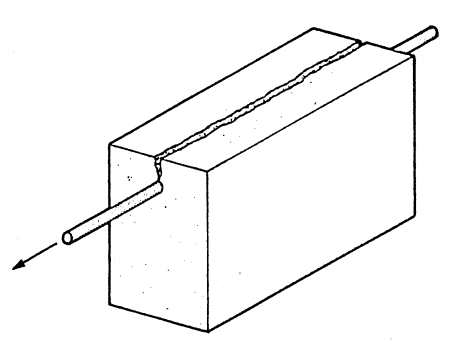

(a)

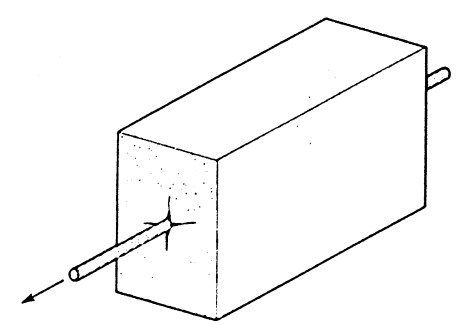

(b)

Figura 2.27 - Rupturas por fendilhamento (a) e por arrancamento (b) (COLLINS \& MITCHELL, 1997).

As cordoalhas apresentam um comportamento próprio, devido à forma helicoidal dos fios. Se for permitido o giro da cordoalha, enquanto ela vai perdendo a aderência, sua ruptura será por arrancamento, pois não serão mobilizadas tensões radiais de tração. Se o giro for impedido, seja por uma ancoragem externa, seja pelo efeito Hoyer, a cordoalha gera tensões radiais de tração, podendo apresentar o fendilhamento.

Vale ressaltar que a descrição anterior é característica, principalmente, do comportamento durante ensaios de arrancamento. Quando a peça é posta em serviço, 
esses comportamentos são afetados, em maior ou menor grau, pelos diversos fatores citados no início deste item, podendo inclusive levar ao fendilhamento de barras lisas, ou ao arrancamento de barras nervuradas. Outro aspecto que influencia na aderência é o cisalhamento, pois as fissuras diagonais de cisalhamento estão intimamente associadas ao fendilhamento. Ressalta-se, também, que apesar de tratados, tradicionalmente, como fenômenos separados, a aderência e o cisalhamento são tópicos que, na verdade, estão relacionados (FERGUSON et al, 1988).

A seguir são discutidos os aspectos mais relevantes, em relação aos parâmetros que influenciam no modo de ruptura das peças por aderência. Na realidade, apesar de apresentados separadamente, esses fatores são inter-relacionados, tanto no fenômeno físico, como no dimensionamento das peças.

\section{a) Tipo da armadura e conformação superficial}

Os dois parâmetros são inter-relacionados, já que o tipo ou a classificação da armadura depende da conformação superficial da barra. Os diversos tipos de armadura apresentam comportamentos diferentes em relação à aderência: os fios e as cordoalhas, que têm a superfície lisa, são mais susceptíveis à ruptura por arrancamento; já as barras, que são nervuradas, são mais propensas à ruptura por fendilhamento. Isso ocorre devido às tensões radiais de tração originadas nas nervuras (Figura 2.11), onde, normalmente, se iniciam as microfissuras internas que se estenderão até a face externa do concreto (Figura 2.21).

\section{b) Diâmetro da barra e tensão na armadura}

O diâmetro da barra e a tensão na armadura são fatores diretamente proporcionais um ao outro. Quanto menor o diâmetro da barra, mais ela será suscetível à ruptura por arrancamento, enquanto que as barras de grande diâmetro $(\phi \geq 25 \mathrm{~mm})$ são mais propensas à ruptura por fendilhamento, pois quanto maior o diâmetro, maior será a área da barra e, conseqüentemente, maior será a tensão instalada nela, levando a elevadas tensões radiais de tração.

\section{c) Armadura de confinamento}

As armaduras de confinamento, que podem ser estribos ou espirais, ajudam na resistência às solicitações radiais de tração, impedindo o fendilhamento. A presença 
dessas armaduras pode, inclusive, fazer com que barras nervuradas de grande diâmetro apresentem ruptura por arrancamento. As normas e códigos apresentam o cálculo dessas armaduras.

\section{d) Espaçamento entre as barras e cobrimento}

Esses dois fatores estão intimamente ligados. Quanto menores forem o cobrimento e a distância entre as barras, mais a peça estará suscetível ao fendilhamento. Na literatura encontram-se alguns padrões de fissuração de fendilhamento que levam em conta o cobrimento e a distância entre as barras. A Figura 2.28 apresenta alguns desses padrões.

Para peças com grandes cobrimentos, a ruptura por fendilhamento é menos comum, devido ao efeito de confinamento exercido pelo grande volume de concreto.
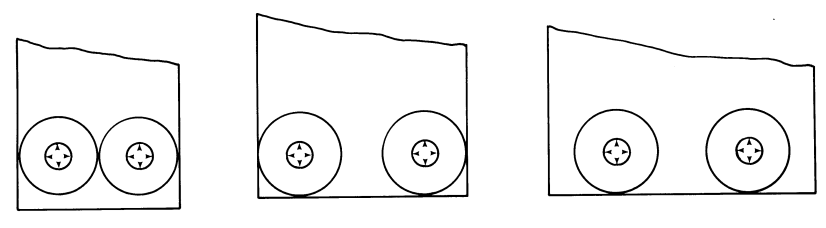

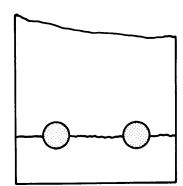

(a)

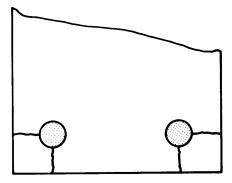

(b)

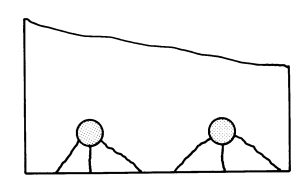

(c)

Figura 2.28 - Fissuras de fendilhamento: (a) cobrimento lateral e metade da distância entre as barras, menores que o cobrimento em relação à face inferior da peça; (b) cobrimento lateral=cobrimento inferior, e ambos menores que metade da distância entre as barras; (c) cobrimento inferior menor do que o cobrimento lateral e a metade da distância entre as barras (MACGREGOR, 1988).

\section{e) Qualidade do concreto}

A qualidade do concreto pode ser entendida sob dois aspectos: a resistência do concreto à compressão, e a qualidade da matriz de cimento. Quanto maior a resistência do concreto, melhor a aderência, já que as resistências do concreto à tração e à compressão são fatores intimamente ligados. Em relação à qualidade da matriz cimentícia, acredita-se que quanto mais compacta e com menos vazios for a matriz, melhor será a aderência, porém este conceito ainda se encontra em discussão. 


\section{f) Condição superficial da barra}

Um aspecto muito importante é a condição superficial das barras (limpa, lubrificada, enferrujada), principalmente para as barras lisas, os fios, e as cordoalhas que têm giro livre. Nestes casos, uma superfície mais rugosa, como a provocada pela ferrugem, pode melhorar a aderência mecânica das armaduras. Porém, este é um tema muito delicado, pois uma oxidação maior pode levar à redução excessiva do diâmetro da armadura, diminuindo a sua capacidade resistente. Todas as pesquisas que ensaiaram barras limpas e enferrujadas confirmam a melhora na aderência dessas últimas. Porém, confirmam também que este é um parâmetro muito difícil de ser quantificado, e que não é recomendável o uso intencional de barras oxidadas, apesar da melhoria que isto implica.

\section{g) Outros parâmetros}

Além dos já citados, outros fatores também influenciam na aderência; são eles: o tipo de carregamento, os efeitos da retração e da fluência, a posição da armadura na peça, a posição e a direção da armadura em relação à direção do lançamento do concreto, a retração e a fluência do concreto, o tipo de cura da peça, e, para as armaduras protendidas, o tipo de alívio da protensão (súbito ou gradual) e a idade da peça em relação à retirada da protensão.

\subsubsection{A aderência no concreto armado}

Os estudos e as pesquisas sobre a aderência entre o aço e o concreto começaram por volta do final do século XIX e do início do século XX, e desde então tem crescido, cada vez mais, o interesse nesta área de pesquisa, seja na parte de materiais seja na parte estrutural. A seguir são relatados três dos principais artigos, escritos ao longo dos últimos trinta anos, referentes à aderência em peças de concreto armado. Foi mantida a nomenclatura usada em cada trabalho, não sendo feita uma padronização dos símbolos utilizados.

\section{a) GOTO (1971)}

Um dos trabalhos mais importantes sobre a fissuração de aderência é o de GOTO (1971). Ele estudou a formação de fissuras ao redor de barras nervuradas tracionadas. Até então o estudo da distribuição interna de tensões se baseava na 
fissuração longitudinal das peças (FERGUSON et al, 1988). Esse autor constatou que existem diferenças entre a fissuração de barras lisas e de barras nervuradas, que são descritas no seu trabalho. Além da fissuração longitudinal, existe uma fissuração radial. Para as barras nervuradas, as fissuras começam a partir da nervura e vão aumentando em direção à face externa do concreto (Figura 2.21). Uma de suas principais conclusões é de que a formação de fissuras longitudinais (características do fendilhamento) é bastante influenciada pela forma e pelo tipo de nervura. Como já foi comentado, sabe-se que as barras lisas rompem basicamente por arrancamento, enquanto que as nervuradas, devido à aderência mecânica, têm mais propensão a romperem por fendilhamento.

\section{b) ORANGUN et al (1977)}

Um dos trabalhos mais citados na literatura técnica, no que se refere à ancoragem de barras em peças de concreto armado, é o de ORANGUN et al (1977). Esse trabalho apresenta uma equação para a tensão de aderência e conseqüentemente para os comprimentos de ancoragem e de traspasse de barras nervuradas. Segundo esses autores, a equação foi baseada numa análise por regressão não-linear de resultados de ensaios de vigas com traspasse e refletiram os efeitos do comprimento de ancoragem, do cobrimento, do espaçamento entre as barras, do diâmetro da barra, da resistência do concreto e da presença de armadura transversal na aderência das barras ancoradas. Os resultados dos ensaios analisados, considerando apenas as armaduras que não escoaram, levaram à seguinte expressão:

$$
\frac{\mathrm{u}}{\sqrt{\mathrm{f}_{\mathrm{c}}^{\prime}}}=1,22+3,23 \cdot \frac{\mathrm{c}}{\mathrm{d}_{\mathrm{b}}}+53 \cdot \frac{\mathrm{d}_{\mathrm{b}}}{\ell_{\mathrm{d}}}
$$

onde: $\mathrm{u}=$ tensão de aderência;

$\mathrm{f}_{\mathrm{c}}=$ resistência característica do concreto à compressão;

$\mathrm{d}_{\mathrm{b}}=$ diâmetro da barra;

$\ell_{\mathrm{d}}=$ comprimento de ancoragem básico;

$c \leq\left\{\begin{array}{l}1 / 2 \text { espaçamento entre as barras }\left(c_{s}\right) ; \\ \text { cobrimento }\left(c_{b}\right) ;\end{array}\right.$ 
A partir da expressão anterior, os autores propuseram a seguinte equação para o cálculo do comprimento de ancoragem básico, para os aços com $\mathrm{f}_{\mathrm{yk}}=60 \mathrm{ksi}$ (415MPa):

$$
\ell_{\mathrm{d}}=\frac{10200 \cdot \mathrm{d}_{\mathrm{b}}}{\sqrt{\mathrm{f}_{\mathrm{c}}^{\prime}} \cdot\left(1+2,5 \cdot \frac{\mathrm{c}}{\mathrm{d}_{\mathrm{b}}}+\mathrm{K}_{\mathrm{tr}}\right) \cdot \phi}
$$

$\mathrm{O}$ valor de $\mathrm{K}_{\mathrm{tr}}$ é dado por:

$$
\mathrm{K}_{\text {tr }}=\frac{\mathrm{A}_{\text {tr }} \cdot \mathrm{f}_{\mathrm{yt}}}{600 \cdot \mathrm{s} \cdot \mathrm{d}_{\mathrm{b}}} \leq 2,5 \quad \text { (psi) }
$$

onde: $\phi=$ coeficiente de minoração da capacidade resistente $=0,8$;

$\mathrm{c} / \mathrm{d}_{\mathrm{b}} \leq 2,5$

$\mathrm{A}_{\mathrm{tr}}=$ área da armadura transversal;

$\mathrm{f}_{\mathrm{yt}}=$ resistência característica de escoamento do estribo;

$\mathrm{s}=$ espaçamento da armadura transversal.

O comprimento de ancoragem básico deve ser multiplicado, simultaneamente ou não, pelos seguintes coeficientes:

\begin{tabular}{l|c}
\hline \multicolumn{1}{c|}{ Situação } & Coeficiente \\
\hline Aço com $\mathrm{f}_{\mathrm{yk}}=40 \mathrm{ksi}(276 \mathrm{MPa})$ & 0,6 \\
\hline Aço com $\mathrm{f}_{\mathrm{yk}}=75 \mathrm{ksi}(517 \mathrm{MPa})$ & 1,3 \\
\hline Armadura superior (mais de 12 '(30,48cm) de concreto sob a barra) & 1,3 \\
\hline Quando $\mathrm{c}_{\mathrm{s}} / \mathrm{c}_{\mathrm{b}} \cdot \mathrm{d}_{\mathrm{b}}>3$ & 0,9 \\
\hline Quando $\mathrm{c}_{\mathrm{s}} / \mathrm{c}_{\mathrm{b}} \cdot \mathrm{d}_{\mathrm{b}}>6$ & 0,7 \\
\hline Armadura de flexão em excesso & $\mathrm{A}_{\mathrm{s}, \mathrm{nec}} / \mathrm{A}_{\mathrm{s}, \mathrm{e}}$ \\
\hline
\end{tabular}

A equação proposta pelos autores tem sido usada como referência de cálculo para os comprimentos de ancoragem e de traspasse até os dias de hoje, e será uma das formulações teóricas que servirão como base de comparação com os resultados experimentais para este trabalho.

Na Figura 2.29 tem-se uma representação esquemática dos valores de c. 


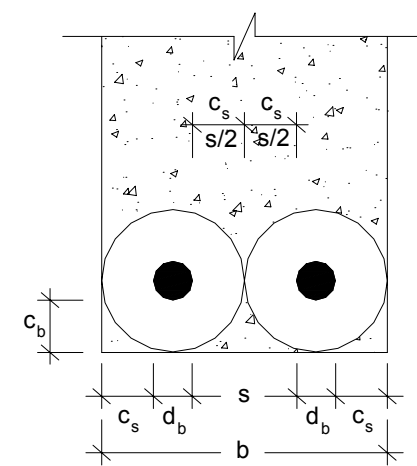

Figura 2.29 - Definição de $c_{s}$ e $c_{b}$ (ORANGUN et al, 1977).

\section{c) ELIGEHAUSEN et al (1983)}

Outro trabalho de grande importância sobre o estudo da aderência de barras sob carregamentos monotônicos e cíclicos é o apresentado por ELIGEHAUSEN et al (1983). Eles fizeram um estudo experimental e analítico integrados. Foram realizados 125 ensaios de arrancamento em modelos que representavam a região confinada de nós de pórtico (ligação viga-pilar). Foi utilizado aço com $\mathrm{f}_{\mathrm{yk}}=60 \mathrm{ksi}$ (415MPa) e um comprimento de ancoragem de $5 \mathrm{~d}_{\mathrm{b}}$. Os parâmetros dos ensaios foram: tipo de carregamento, armadura de confinamento, diâmetro da barra, resistência do concreto à compressão $\left(30 \mathrm{kN} / \mathrm{mm}^{2}\right.$ e $\left.50 \mathrm{kN} / \mathrm{mm}^{2}\right)$, espaçamento das barras, pressão transversal e incremento de carga durante o ensaio. Com base nos resultados obtidos foi elaborado um modelo analítico capaz de predizer satisfatoriamente o comportamento Tensão local de aderência versus Escorregamento local, de barras nervuradas confinadas, submetidas a carregamentos monotônicos e cíclicos. A Figura 2.30 dá uma idéia do modelo proposto.

Esses autores também observaram que a aderência para determinados valores do escorregamento varia consideravelmente. Vários estudos mostraram que o desvio padrão médio para a aderência, para valores do escorregamento variando de $\mathrm{S}=0,01 \mathrm{~mm}$ a $\mathrm{S}_{\text {máx }}$, foi em torno de $1,3 \mathrm{~N} / \mathrm{mm}^{2}$, para condições ideais de ensaio (por exemplo, ensaios de arrancamento de barras idênticas com comprimento de ancoragem pequeno e modelos moldados de uma mesma betonada). Esperava-se uma dispersão bem maior para condições não tão ideais. Esta observação foi levada em conta na análise experimental desta pesquisa. 
Esse modelo proposto por ELIGEHAUSEN et al (1983) tem sido a base para o desenvolvimento de modelos mais específicos, já que é um modelo para concreto confinado, e que leva em conta uma série de parâmetros.

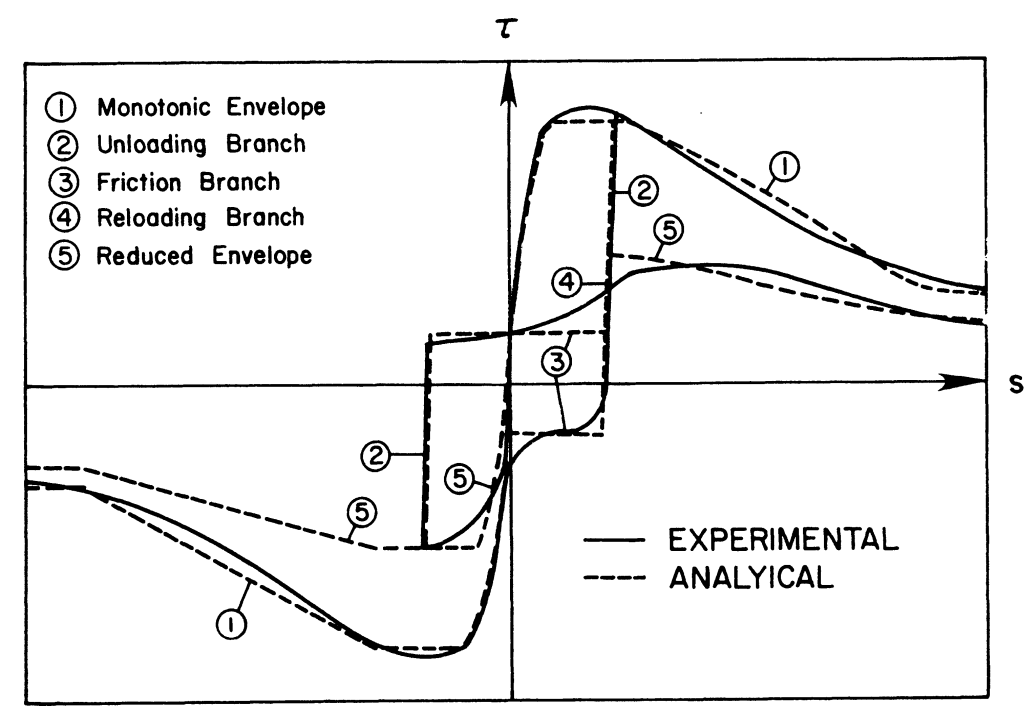

Figura 2.30 - Modelo analítico proposto por ELIGEHAUSEN et al (1983).

\subsubsection{As fibras e a aderência no concreto armado}

Assim como a existência do concreto armado como material de construção está vinculada à aderência entre o aço e o concreto, a existência do CRF está vinculada à aderência entre a fibra e a matriz de cimento. $\mathrm{O}$ estudo desta última é um assunto bastante complexo, pois envolve uma série de parâmetros que influenciam no comportamento da interface fibra-matriz. Neste trabalho não foi abordado este tema, visto que esse não foi o objeto de estudo desta pesquisa, e que ele se encontra muito bem caracterizado e explicado em várias referências que já foram citadas (BENTUR \& MINDESS (1990), BALAGURU \& SHAH (1992), FURLAN (1995), NAAMAN \& REINHARDT (1996), BASTOS (1999), entre outras).

Segundo BALAGURU et al (1996), uma das contribuições importantes das fibras é a melhora na aderência. A adição de fibras melhora significativamente a aderência entre a matriz e a armadura, especialmente na zona pós-fissuração. Isso resulta num arrancamento das barras mais dúctil e estável, o que em contrapartida contribui para um comportamento mais dúctil de toda a peça estrutural. Este é o enfoque que se deu às fibras, neste trabalho, no que diz respeito à aderência.

Segundo alguns pesquisadores (SOROUSHIAN et al (1994), HARAJLI (1994), HARAJLI et al (1995), HARAJLI \& SALLOUKH (1997), HOTA \& 
NAAMAN (1997), entre outros) a influência das fibras na aderência, utilizadas em baixos teores, é mais significativa na ruptura por fendilhamento, onde elas atuam no controle da fissuração. Quando a ruptura se dá por arrancamento, sem muita fissuração, a contribuição das fibras é pequena. Para teores elevados de fibra a contribuição é significativa tanto na ruptura por fendilhamento como na por arrancamento. Isso ocorre devido ao aumento significativo da resistência do concreto à tração, por causa da presença de fibras em alto teor $\left(\mathrm{V}_{\mathrm{f}}>\mathrm{V}_{\mathrm{fcr}}\right)$. As fibras influenciam também na redução do escorregamento das armaduras longitudinais.

Como já foi visto, os estudos sobre concretos reforçados com fibras começaram por volta da década de 60, e desde então tem crescido, cada vez mais, o interesse nesta área de pesquisa, seja na parte de materiais seja na parte estrutural. A seguir são relatados alguns artigos, escritos ao longo dos últimos quarenta anos, referentes à aderência em peças de concreto armado com fibras. Foi mantida a nomenclatura usada em cada trabalho, não sendo feita uma padronização dos símbolos utilizados.

\section{a) ROMUALDI \& MANDEL (1964)}

Um dos primeiros estudos na área do CRFA é o de ROMUALDI \& MANDEL (1964). Eles pesquisaram a influência de armaduras de pequenos comprimentos, uniformemente distribuídas e com espaçamentos pequenos, na resistência do concreto à tração. Essas armaduras nada mais eram do que fibras de aço. Foram ensaiados sete cilindros à tração indireta (fendilhamento) e vinte vigas à flexão. Os parâmetros de ensaio foram o consumo de fibras, de zero a $251 \mathrm{~kg} / \mathrm{m}^{3}(3,2 \%)$ para os cilindros e de zero a $338 \mathrm{~kg} / \mathrm{m}^{3}(4,3 \%)$ para as vigas, e o comprimento das fibras, de 0,75 " $(1,905 \mathrm{~cm})$ a $1,12 "(2,845 \mathrm{~cm})$ para os cilindros e de $0,62 ”(1,575 \mathrm{~cm})$ a 2”(5,08cm) para as vigas. ROMUALDI \& MANDEL (1964) concluíram que os resultados da investigação confirmaram que a tensão de fissuração de tração do concreto reforçado com armaduras de pequenos comprimentos dispersas uniformemente é uma função inversa do espaçamento dessas armaduras, e que as tensões de fissuração de tração observadas estavam em boa concordância com as previsões teóricas. Estas conclusões estão representadas no gráfico da Figura 2.31. 


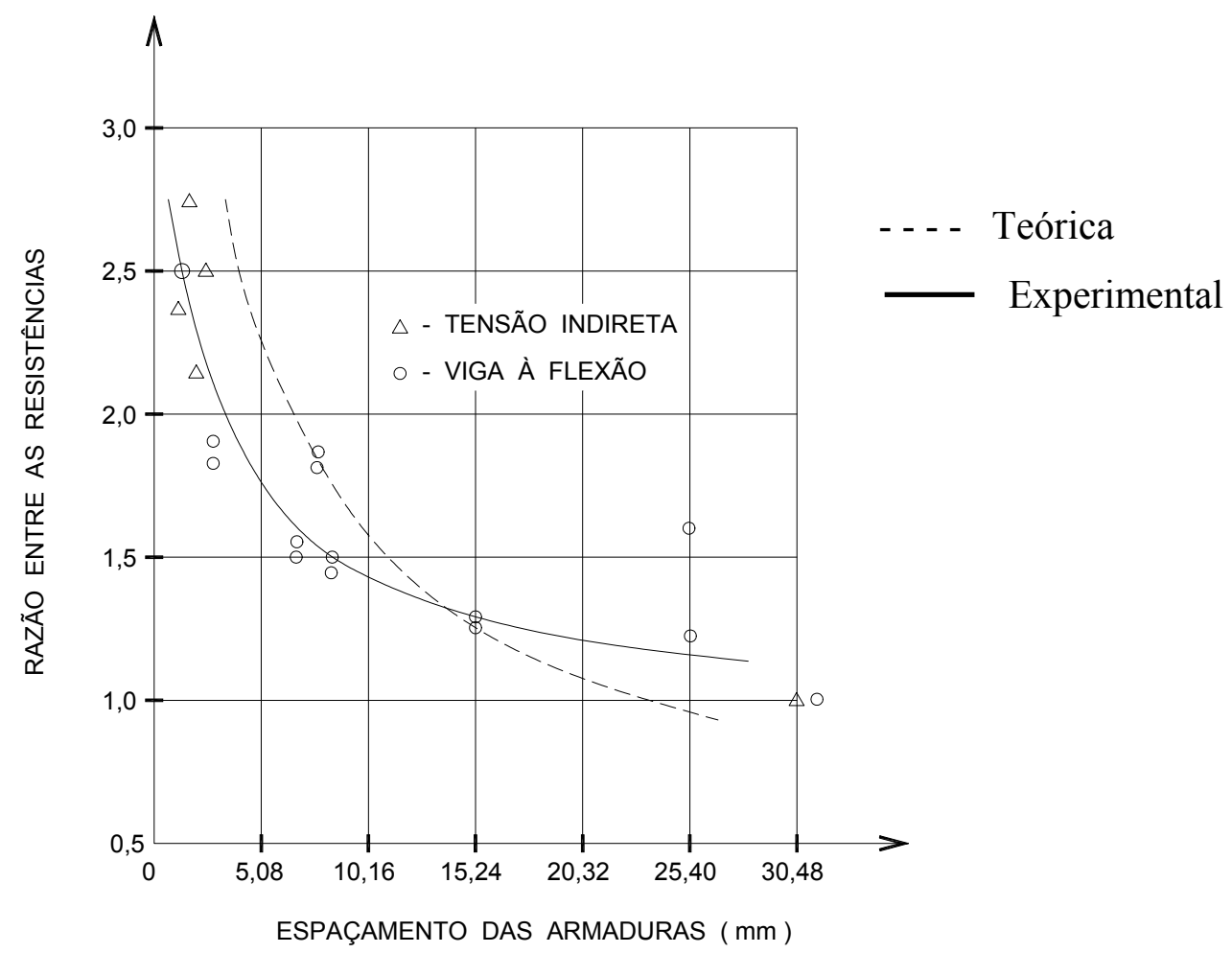

Figura 2.31 - Razões teórica e experimental entre a resistência teórica à tração e a resistência à tração para um espaçamento de 1 ” $(2,54 \mathrm{~cm})$, em função do espaçamento das armaduras (ROMUALDI \& MANDEL, 1964).

\section{b) SWAMY \& AL-NOORI (1974)}

SWAMY \& AL-NOORI (1974) apresentaram um trabalho sobre a aderência em CRFA. Eles fizeram vários ensaios de arrancamento, variando o diâmetro das barras $(10 \mathrm{~mm}, 12 \mathrm{~mm}, 16 \mathrm{~mm}, 20 \mathrm{~mm}$ e $25 \mathrm{~mm})$, o tipo de fibra (reta e deformada) e o volume das fibras [zero, $275 \mathrm{~kg} / \mathrm{m}^{3}(3,5 \%)$ e $\left.589 \mathrm{~kg} / \mathrm{m}^{3}(7,5 \%)\right]$.

Eles concluíram que:

- A direção do carregamento em relação à direção do lançamento do concreto durante a concretagem tem uma influência maior no CRF do que no concreto comum;

- A presença das fibras contribui claramente no controle do aumento das fissuras e microfissuras internas;

- A aderência é aproximadamente $40 \%$ maior em CRF do que nos concretos comuns, independentemente do tipo de fibra, apesar das fibras deformadas terem apresentado um desempenho um pouco superior ao das retas.

Alguns desses resultados são apresentados no gráfico da Figura 2.32. 


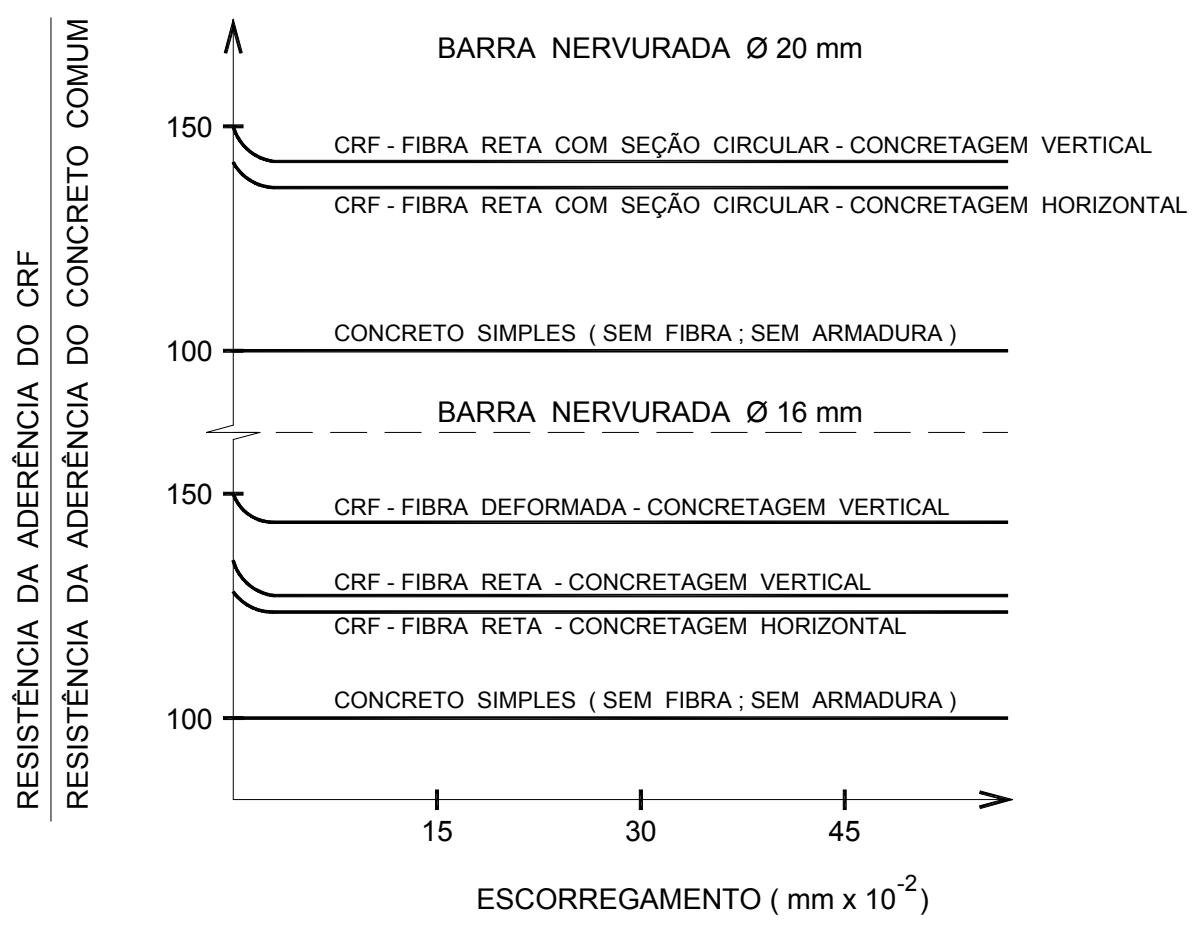

Figura 2.32 - Resistência da aderência relativa para barras de $16 \mathrm{~mm}$ e $20 \mathrm{~mm}$ em CRF e concreto comum (SWAMY \& AL-NOORI, 1974).

\section{c) EZELDIN \& BALAGURU (1989)}

Os autores estudaram o comportamento, em relação à aderência, de concretos de resistência normal e alta resistência, reforçados com fibras de aço com ganchos nas extremidades. Os parâmetros de ensaio foram: resistência do concreto à compressão (de $34,5 \mathrm{MPa}$ a $75,9 \mathrm{MPa}$ ), consumo de fibras (zero, $30 \mathrm{~kg} / \mathrm{m}^{3}, 45 \mathrm{~kg} / \mathrm{m}^{3}$ e $\left.60 \mathrm{~kg} / \mathrm{m}^{3}\right)$, comprimento das fibras $(30 \mathrm{~mm}, 50 \mathrm{~mm}$ e $60 \mathrm{~mm})$, teor de sílica ativa (zero, $10 \%$ e $20 \%$ ), e diâmetro da barra $(9 \mathrm{~mm}, 16 \mathrm{~mm}, 19 \mathrm{~mm}$ e $25 \mathrm{~mm})$. Foram observados, basicamente, dois tipos de ruptura nos ensaios de arrancamento: por fendilhamento e por perda de atrito. A primeira foi frágil e explosiva, principalmente nos compósitos sem fibras, enquanto que a segunda foi dúctil. Os autores também observaram que a resistência de aderência é proporcional a $\sqrt{\mathrm{f}_{\mathrm{c}}}$, o que já havia sido observado por vários outros pesquisadores. Os autores utilizaram o modelo modificado da Norma Dinamarquesa (Figura 2.17), para trabalharem com o concreto tracionado.

As principais conclusões foram:

- A ruptura por arrancamento é normalmente obtida para barras com $\phi \leq 9 \mathrm{~mm}$, com ou sem fibras; 
- Para barras com $\phi \geq 16 \mathrm{~mm}$ e sem fibras, a ruptura é por fendilhamento e explosiva; com a adição de fibras de aço, a ruptura se torna mais dúctil;

- A adição de fibras não contribui muito na aderência em modelos com barras de pequeno diâmetro $(9 \mathrm{~mm})$, pois a ruptura ocorre pelo colapso das bielas de compressão, que não são muito reforçadas pelas fibras de aço. Mas a presença das fibras de aço, dando um efeito comparável a concreto confinado, tem uma contribuição mais efetiva na aderência das barras com $\phi \geq 16 \mathrm{~mm}$;

- O valor do escorregamento correspondente à carga máxima de arrancamento aumenta com a adição de fibras de aço;

- A presença das fibras melhora a ductilidade do concreto.

\section{d) HARAJLI (1994) e HARAJLI et al (1995)}

HARAJLI (1994) e HARAJLI et al (1995) apresentaram um estudo sobre o comprimento de ancoragem de barras em concreto comum e em concreto com fibras. Eles apresentaram uma avaliação analítica e experimental da aderência e da ancoragem das barras. $\mathrm{O}$ estudo envolveu as rupturas por arrancamento das barras e por fendilhamento. Os autores sugerem um modelo analítico para representar o comportamento Tensão local de aderência versus Escorregamento local, e uma expressão para a tensão de aderência, que é comparada com as expressões propostas por ORANGUN et al (1977) e DARWIN et al (1992).

No estudo experimental realizado por HARAJLI et al (1995), foram ensaiados mais de 100 modelos ao arrancamento, cujos parâmetros de ensaio foram: diâmetro das barras (\#6 e \#8 - 19 e 25mm, aproximadamente), modo de ruptura, cobrimento, tipo de fibras (fibras de aço com ganchos nas extremidades e fibras de polipropileno), volume [zero, $71 \mathrm{~kg} / \mathrm{m}^{3}(0,9 \%), 78,5 \mathrm{~kg} / \mathrm{m}^{3}(1 \%), 110 \mathrm{~kg} / \mathrm{m}^{3}(1,4 \%)$ e $157 \mathrm{~kg} / \mathrm{m}^{3}(2 \%)$ para as de aço; e 1,5\% para as de polipropileno], e fator de forma das fibras (60 e 100 para as de aço; e 150 para as de polipropileno). Com base nos resultados obtidos, foi proposto o modelo analítico que está apresentado na Figura 2.33. O modelo apresentado descreve o comportamento do concreto comum (linha tracejada), do CRF na ruptura por fendilhamento e do CRF na ruptura por 
arrancamento da barra. A primeira parte do gráfico $\left(0 \leq \mathrm{S} \leq \mathrm{S}_{1}\right)$ é representada pela seguinte expressão:

$$
u=u_{1} \cdot\left(\frac{S}{S_{1}}\right)^{\alpha}
$$

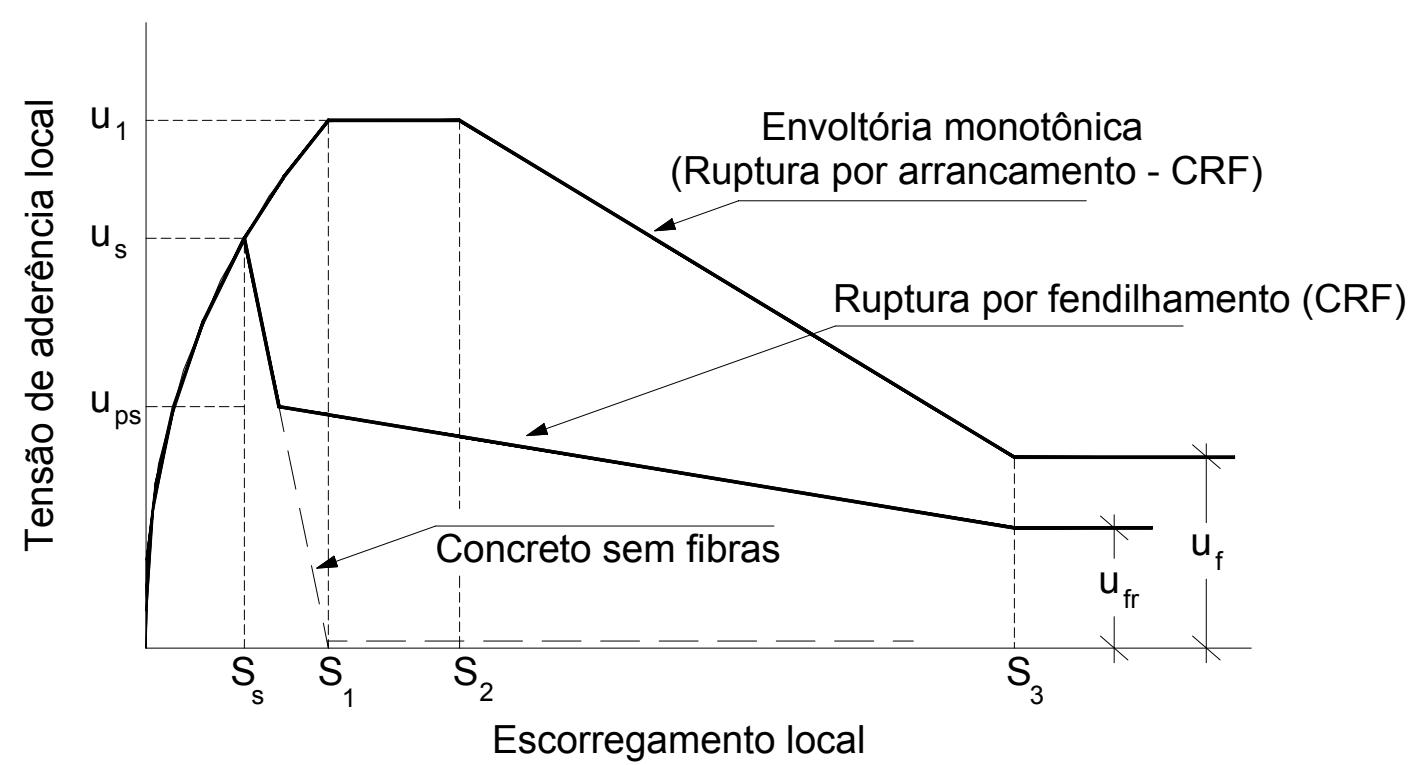

Figura 2.33 - Modelo analítico proposto para a representação do comportamento Tensão local de aderência versus Escorregamento local de barras (HARAJLI et al, 1995).

Para os parâmetros de ensaio utilizados foram estabelecidos os valores apresentados a seguir, para os vários pontos característicos do modelo:

$\mathrm{u}=$ tensão de aderência;

$\mathrm{u}_{\mathrm{s}}=$ tensão de aderência resistente ao fendilhamento;

$\mathrm{u}_{\mathrm{ps}}=$ tensão de aderência resistente no pós-fendilhamento;

$\mathrm{u}_{\mathrm{f}}=$ tensão de aderência resistente de atrito;

$\mathrm{u}_{\mathrm{fr}}=$ tensão de aderência reduzida resistente de atrito;

$\mathrm{S}=$ escorregamento;

$\sigma_{\mathrm{s}}=$ resistência à tração da matriz reforçada com fibra, imediatamente antes do fendilhamento;

$\sigma_{\mathrm{ps}}=$ resistência à tração da matriz reforçada com fibra, imediatamente após o fendilhamento;

$\mathrm{c}_{0}=$ distância entre as nervuras das barras. 
$\alpha=0,3$

$\mathrm{u}_{\mathrm{s}}=\frac{2 \cdot \sigma_{\mathrm{s}}}{\pi}\left(\frac{\mathrm{c}}{\mathrm{d}_{\mathrm{b}}}\right)$

$\mathrm{u}_{\mathrm{f}}=0,35 \cdot \mathrm{u}_{1}=11 \cdot \sqrt{\mathrm{f}_{\mathrm{c}}^{\prime}}$

$\mathrm{S}_{\mathrm{s}}=\left(\mathrm{S}_{1}\right) \cdot \mathrm{e}^{(1 / \alpha) \cdot \ln \left(\mathrm{u}_{\mathrm{s}} / \mathrm{u}_{1}\right)}$

$\mathrm{S}_{2}=1,75 \cdot \mathrm{S}_{\text {máx }}=0,35 \cdot \mathrm{c}_{0}$

$$
\begin{aligned}
& \mathrm{u}_{\mathrm{ps}}=\frac{2 \cdot \sigma_{\mathrm{ps}}}{\pi}\left(\frac{\mathrm{c}}{\mathrm{d}_{\mathrm{b}}}\right) \\
& \mathrm{u}_{1}=31 \cdot \sqrt{\mathrm{f}_{\mathrm{c}}^{\prime}} \\
& \mathrm{u}_{\mathrm{fr}}=0,3 \cdot \mathrm{u}_{\mathrm{ps}} \leq 0,35 \cdot \mathrm{u}_{1} \\
& \mathrm{~S}_{1}=0,75 \cdot \mathrm{S}_{\text {máx }}=0,15 \cdot \mathrm{c}_{0} \\
& \mathrm{~S}_{3}=\mathrm{c}_{0}
\end{aligned}
$$$$
\mathrm{S}_{\text {máx }}=\frac{\mathrm{c}_{0}}{5}
$$

Com base nos resultados anteriores, HARAJLI (1994) propôs a seguinte equação para o cálculo da tensão de aderência:

$$
\begin{aligned}
& \frac{\mathrm{u}}{\sqrt{\mathrm{f}_{\mathrm{c}}^{\prime}}}=1,2+3 \cdot \frac{\mathrm{c}}{\mathrm{d}_{\mathrm{b}}}+50 \cdot \frac{\mathrm{d}_{\mathrm{b}}}{\ell_{\mathrm{d}}}+\mathrm{K}_{\mathrm{tr}}+\frac{1}{25} \cdot\left(\mathrm{K}_{\mathrm{f}}-50\right), \quad \text { para } \mathrm{K}_{\mathrm{f}} \geq 50 \\
& \mathrm{~K}_{\mathrm{f}}=\left(\frac{\mathrm{V}_{\mathrm{f}} \cdot \ell}{\mathrm{d}_{\mathrm{f}}}\right) \cdot\left(\frac{\mathrm{c}}{\mathrm{d}_{\mathrm{b}}}\right) \cdot\left(\frac{l_{\mathrm{d}}}{\mathrm{d}_{\mathrm{b}}}\right)
\end{aligned}
$$

onde: $\mathrm{V}_{\mathrm{f}}=$ volume de fibras;

$\ell=$ comprimento das fibras;

$\mathrm{d}_{\mathrm{f}}=$ diâmetro das fibras

Com base nesses estudos, os pesquisadores chegaram às seguintes conclusões:

- Quando se tem ruptura por arrancamento da barra, as fibras não têm um efeito significativo na aderência;

- Quando se tem ruptura por fendilhamento, as fibras têm um efeito significativo, pois restringem o crescimento das fissuras, levando a uma aderência maior na fase pós-fendilhamento do concreto;

- A presença das fibras melhora a ductilidade da ruptura por fendilhamento, especialmente onde há o escoamento da armadura longitudinal;

- A presença de fibras de aço aumenta a resistência à aderência das barras, para valores de $\mathrm{K}_{\mathrm{f}}>50$.

Os resultados dessas pesquisas abrangem barras nervuradas com diâmetros entre $8 \mathrm{~mm}$ e $30 \mathrm{~mm}$, razão $\left(\mathrm{c} / \mathrm{d}_{\mathrm{b}}\right) \leq 5,25$, e valores de índice de fibras $\left(\mathrm{V}_{\mathrm{f}} \cdot \ell / \mathrm{d}_{\mathrm{f}}\right)$ menores ou iguais a 1,2 , ou seja: 


$$
\mathrm{V}_{\mathrm{f}} \cdot \frac{\ell}{\mathrm{d}_{\mathrm{f}}} \leq 1,2
$$

Nesta tese, o modelo analítico proposto por HARAJLI et al (1995) foi utilizado como ponto de partida para a análise do comportamento das cordoalhas, assim como a expressão para a tensão de aderência proposta por HARAJLI (1994).

\section{e) SOROUSHIAN et al (1994)}

SOROUSHIAN et al (1994) apresentaram um estudo sobre a aderência entre o concreto confinado reforçado com fibras de aço e as barras nervuradas. Foram realizados 22 ensaios estáticos de arrancamento em modelos que representavam as regiões de concreto confinado nas ligações viga-pilar. Foram utilizadas barras \#8 $(\phi 25 \mathrm{~mm})$ com $\mathrm{f}_{\mathrm{yk}}=60 \mathrm{ksi}(415 \mathrm{MPa})$ e comprimento de ancoragem de $4 \mathrm{~d}_{\mathrm{b}}$. Os parâmetros de ensaio foram: tipo (reta, com gancho e deformada), volume [zero, $39 \mathrm{~kg} / \mathrm{m}^{3}(0,5 \%), 78,5 \mathrm{~kg} / \mathrm{m}^{3}(1 \%)$ e $\left.118 \mathrm{~kg} / \mathrm{m}^{3}(1,5 \%)\right]$ e fator de forma $(60,80$ e 100$)$ das fibras de aço.

Os pesquisadores chegaram às seguintes conclusões:

- As fibras têm um efeito significativo na melhoria do comportamento da aderência local das barras nervuradas. Com um volume de fibras de $39 \mathrm{~kg} / \mathrm{m}^{3}(0,5 \%)$ há um aumento de aproximadamente $30 \%$ na tensão de aderência local, em relação ao concreto sem fibras. Entretanto, acima de $39 \mathrm{~kg} / \mathrm{m}^{3}(0,5 \%)$, o concreto não apresenta mais um aumento significativo na tensão de aderência;

- O valor do escorregamento no pico da tensão de aderência foi reduzido na presença das fibras;

- Os efeitos do fator de forma na tensão de aderência local não foram significativos;

- Os efeitos dos tipos diferentes de fibras, no comportamento da aderência local em concretos confinados reforçados com fibras, foram comparáveis;

- A força de aderência local foi mais relacionada com a tenacidade do CRF na flexão do que com a tensão de compressão do material na flexão. 


\section{f) HARAJLI \& SALLOUKH (1997)}

HARAJLI \& SALLOUKH (1997) estudaram o efeito das fibras na aderência na ancoragem e no traspasse de barras sob tração. Foram ensaiadas quinze vigas à flexão, com o traspasse no meio do vão, como mostra a Figura 2.34.
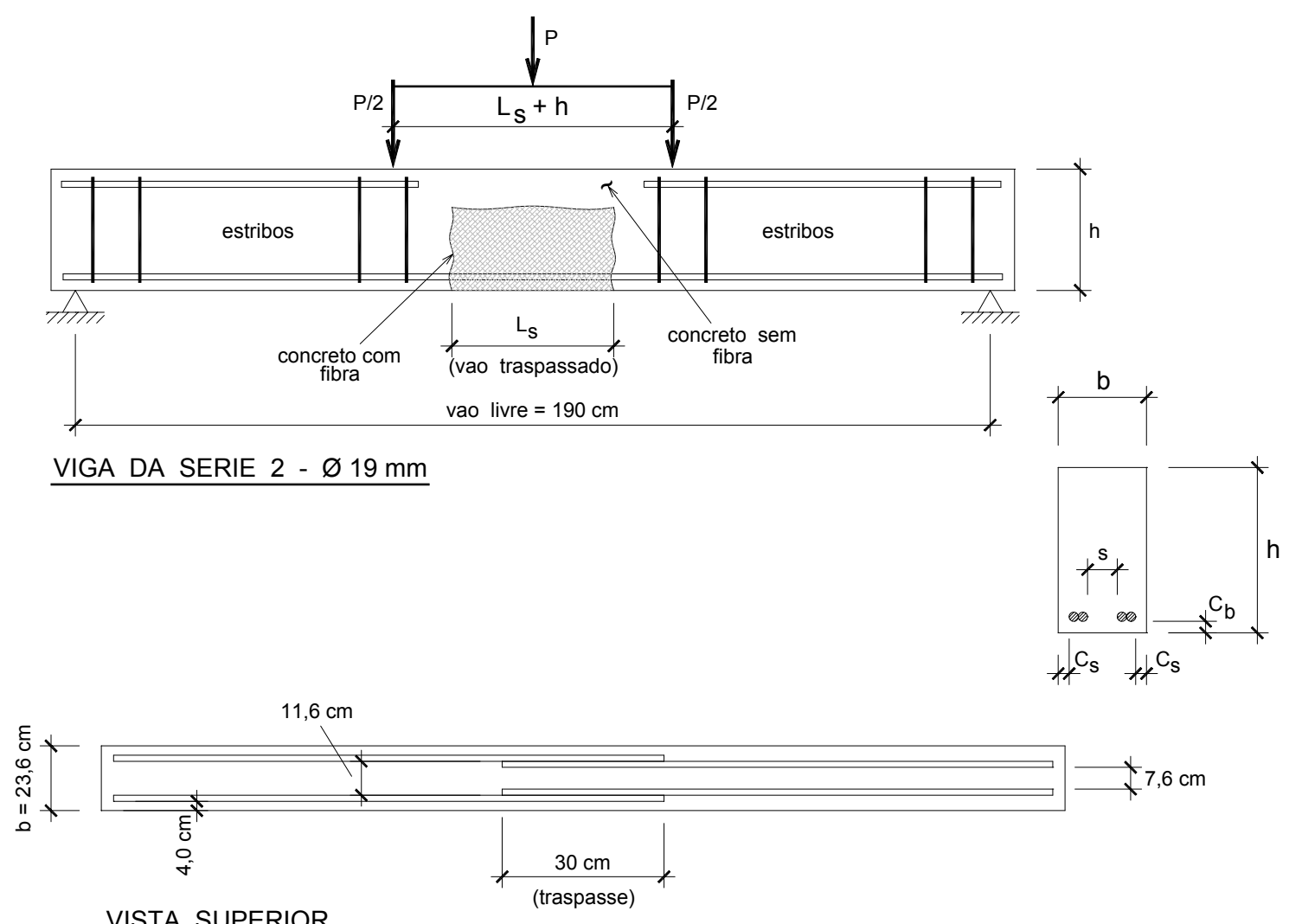

Figura 2.34 - Modelo e arranjo de ensaio das vigas (HARAJLI \& SALLOUKH, 1997).

Os parâmetros de ensaio foram: diâmetro das barras (\#5, \#6 e \#8 - 16, 19 e $25 \mathrm{~mm}$, aproximadamente), tipo das fibras (aço e polipropileno), volume de fibras [zero, $35 \mathrm{~kg} / \mathrm{m}^{3}(0,45 \%), 94 \mathrm{~kg} / \mathrm{m}^{3}(1,2 \%)$ e $157 \mathrm{~kg} / \mathrm{m}^{3}(2 \%)$ para as de aço; e zero e $0,6 \%$ para as de polipropileno] e índice $\left.\mid \mathrm{V}_{\mathrm{f}} \ell / \mathrm{d}\right\rfloor(0,45,0,72$ e 1,2 para as de aço; e 0,9 para as de polipropileno).

Os pesquisadores chegaram às seguintes conclusões:

- A presença de fibras de aço com ganchos nas extremidades aumentou consideravelmente a aderência das armaduras sob tração;

- As fibras de aço são mais efetivas no aumento da aderência do que as armaduras transversais convencionais; 
- O uso de fibras de aço com ganchos nas extremidades aumenta o número de fissuras que se formam em torno das barras traspassadas, restringe o crescimento das fissuras de fendilhamento, e leva efetivamente a uma melhoria substancial na ductilidade da ruptura por aderência;

- As fibras de polipropileno, no volume de $0,6 \%$, melhoraram a ductilidade da ruptura por aderência, porém elas não são tão eficientes como as de aço no aumento da aderência das armaduras;

- Com as demais variáveis mantidas constantes, a razão entre a aderência do compósito com fibras e a aderência do compósito sem fibras aumenta com o aumento do volume e do índice de fibras;

- Os ensaios de aderência com modelos de arrancamento subestimam, e muito, o efeito das fibras na resistência ao fendilhamento das armaduras.

\section{g) HOTA \& NAAMAN (1997)}

HOTA \& NAAMAN (1997) estudaram a relação entre a tensão de aderência e o escorregamento de barras embutidas em matrizes de concreto reforçado com fibras, sob carregamento monotônicos e cíclicos. Foram ensaiados 24 modelos ao arrancamento. Foram utilizadas apenas fibras de aço com ganchos nas extremidades e fator de forma $\ell / \mathrm{d}=60$. As armaduras utilizadas foram barras \#8 $(\phi 25 \mathrm{~mm})$. Os parâmetros de ensaio foram: composição do compósito [SIFCON com $\mathrm{V}_{\mathrm{f}}=754 \mathrm{~kg} / \mathrm{m}^{3}$ (9,6\%); CRF com $V_{\mathrm{f}}=157 \mathrm{~kg} / \mathrm{m}^{3}$ (2\%); concreto confinado sem fibras; e concreto sem fibras], resistência do concreto à compressão (5 e $9 \mathrm{ksi}-35$ e $63 \mathrm{MPa})$, e tipo de carregamento (monotônico, cíclico unidirecional, e cíclico reversível). Os pesquisadores chegaram às seguintes conclusões:

- A adição de fibras de aço em quantidade suficiente, à matriz de cimento, melhora as propriedades de aderência de uma barra sob arrancamento;

- Quanto ao modo de ruptura, os modelos de SIFCON apresentaram ruptura por arrancamento, os de concreto sem fibras romperam por fendilhamento, os de concreto confinado sem fibras tiveram uma ruptura por arrancamento de forma cônica, e os de CRF apresentaram tanto ruptura por fendilhamento como por arrancamento; 
- A adição de fibras de aço melhora a ductilidade do comportamento Tensão de aderência versus Escorregamento;

- Um aumento na resistência do concreto à compressão leva a um aumento da carga máxima de arrancamento e da tensão de aderência;

- Um aumento no volume de fibras leva a um aumento da carga máxima de arrancamento e ao escorregamento correspondente.

\subsubsection{Conclusões sobre a influência das fibras na aderência}

A utilização das fibras no concreto armado, em especial as de aço, melhoram o comportamento das peças em relação à aderência. Com base nos artigos estudados, pôde-se concluir o seguinte:

- As fibras melhoram o comportamento Tensão de aderência versus Escorregamento;

- As fibras possuem um efeito significativo quando da ruptura por fendilhamento. Já para a ruptura por arrancamento, a sua contribuição, especialmente em baixos teores, é bem menor;

- Os ensaios de arrancamento subestimam a influência das fibras na melhora da aderência, sendo recomendado o uso de ensaios de flexão.

\subsection{A Aderência no Concreto Protendido}

A aderência no concreto protendido pode ser interpretada sob vários aspectos, entre eles: a aderência de peças pós-tracionadas (aderência posterior), os aparelhos de ancoragem externos, ou, ainda, a ancoragem de peças pré-tracionadas. Neste item será tratada a aderência de cordoalhas pré-aderentes de sete fios.

Como já foi visto, o estudo da aderência no concreto pré-tracionado é baseado num comportamento duplo: um durante a transferência dos esforços (devido ao efeito Hoyer), e outro quando a peça é colocada em serviço, submetida a esforços de flexão.

Segundo LIN \& BURNS (1981), para se determinarem as tensões de aderência existentes entre o concreto e os cabos, devem-se considerar dois estágios: antes e depois da fissuração do concreto. $\mathrm{Na}$ fase pré-fissuração, pode-se usar a análise elástica para o cálculo da tensão de aderência. Porém, em termos práticos, se a peça não fissurar, as tensões de aderência são muito pequenas e não constituem um 
problema. A maioria das peças pré-tracionadas, em serviço, não apresenta fissuras. Nesses casos, é suficiente que se tenham garantido os comprimentos de transferência e de ancoragem necessário.

Após a fissuração do concreto, o cálculo da tensão de aderência torna-se mais complexo, pois vão aparecer picos de tensão nos pontos de fissuras, impossibilitando a análise elástica. Em serviço, mesmo as vigas parcialmente protendidas apresentam uma fissuração muito pequena, e mesmo que ocorram rupturas localizadas em pontos da cordoalha, na grande maioria dos casos, a integridade da peça não é comprometida, desde que se tenham garantido os comprimentos de transferência e de ancoragem necessário.

Portanto, para as peças pré-tracionadas, o cálculo da aderência pode ser baseado na determinação dos comprimentos de ancoragem. Essa é a filosofia utilizada pelo ACI. Na realidade, para a tensão de aderência admitem-se valores constantes, e a favor da segurança, que são embutidos nos cálculos dos comprimentos de ancoragem. Já a Norma Brasileira e a FIB apresentam o cálculo da tensão de aderência, que é função da resistência do concreto à tração, e a partir dela são calculados os comprimentos de ancoragem. O Capítulo 3 aborda este assunto com mais detalhes.

Desde a década de 40 vários pesquisadores vêm estudando o comportamento das cordoalhas e dos fios pré-tracionados em relação à aderência, tentando estabelecer expressões confiáveis, e o mais próximo do comportamento real quanto possível, para o cálculo da tensão de aderência ou dos comprimentos de ancoragem.

\subsubsection{Pesquisas sobre a aderência no concreto protendido}

A seguir são relatados alguns dos principais artigos, escritos ao longo dos últimos cinqüenta anos, referentes a este tema. Foi mantida a nomenclatura usada em cada trabalho, não sendo feita uma padronização dos símbolos utilizados.

\section{a) JANNEY (1954)}

Um dos primeiros e mais importante trabalho sobre aderência em concreto prétracionado foi o de JANNEY (1954). O autor apresentou um estudo sobre a natureza da aderência no concreto protendido, pré-tracionado, a partir de ensaios de 
arrancamento e de flexão em vigas. Os primeiros visaram à avaliação da aderência durante a transferência da protensão; e os últimos estudaram a aderência na flexão.

JANNEY (1954) observou que a armadura pré-tracionada exerce dupla função. Parte da tensão da armadura à tração disponível é usada para pré-comprimir o concreto, durante a fase da protensão, antes da peça entrar em serviço. Posteriormente, quando a peça é carregada além da resistência à fissuração, toda ou uma outra parte da tensão do aço à tração é utilizada para ajudar o concreto a resistir aos esforços solicitantes, ou seja, os momentos fletores.

$\mathrm{O}$ autor separou o estudo em duas partes: primeiro analisa a aderência na transferência da protensão; e depois estuda a aderência na flexão.

$\mathrm{Na}$ primeira parte, após a análise dos resultados dos ensaios de arrancamento, JANNEY (1954) observou que o diâmetro e as condições superficiais das armaduras têm uma grande influência na determinação do comprimento de transferência e na forma da distribuição das tensões de aderência. Ele concluiu, também, que a transferência de esforços do aço para o concreto se dá, basicamente, devido à aderência por atrito entre os dois materiais. Para os diâmetros estudados $\left(2,5 \mathrm{~mm} \leq \phi_{\mathrm{p}}\right.$ $\leq 8 \mathrm{~mm}$ ), o comprimento de transferência variou de $30 \mathrm{~cm}$ a $90 \mathrm{~cm}$, aproximadamente.

$\mathrm{Na}$ segunda parte da pesquisa foram realizados 11 ensaios de flexão em vigas biapoiadas, com carga concentrada no meio do vão. A partir da análise do comportamento dessas vigas, JANNEY (1954) concluiu que a tensão máxima de aderência na flexão atua como uma onda ao longo da viga, partindo do ponto de momento máximo (ponto de introdução da carga), e se deslocando em direção às extremidades da peça. A Figura 2.35 representa esquematicamente este comportamento.

Para a viga da Figura 2.35, antes da peça ser carregada, as únicas tensões de aderência atuantes são as provenientes da transferência da protensão, nas extremidades da viga (esquema A). A peça então começa a ser carregada. Quando se ultrapassa a resistência à fissuração, surge a primeira fissura, e passa a atuar a tensão de aderência na flexão, até que esta atinja o seu valor máximo (esquema B). Quando isso ocorre, a cordoalha sofre um escorregamento local em relação ao concreto, e a tensão de aderência cai nesse ponto, e se desloca em direção à extremidade (esquema C). Esse fenômeno se repete até que a onda de pico de tensão de aderência atinja a 
zona de transferência de esforços (esquema D). Quando isso ocorre, há uma redução brusca da capacidade de aderência na flexão na região da extremidade, pois a tensão na armadura tende a aumentar com o aumento do momento fletor. Isso faz com que haja a tendência de diminuição do diâmetro da cordoalha (efeito de Poisson), reduzindo assim a pressão transversal que a armadura exercia sobre o concreto (redução do efeito Hoyer). Portanto, é de se esperar que ocorra uma ruptura por aderência, quando a onda de pico de tensão atinge a zona de transferência de esforços, antes mesmo de atingir a extremidade da armadura, ou a capacidade resistente da peça.

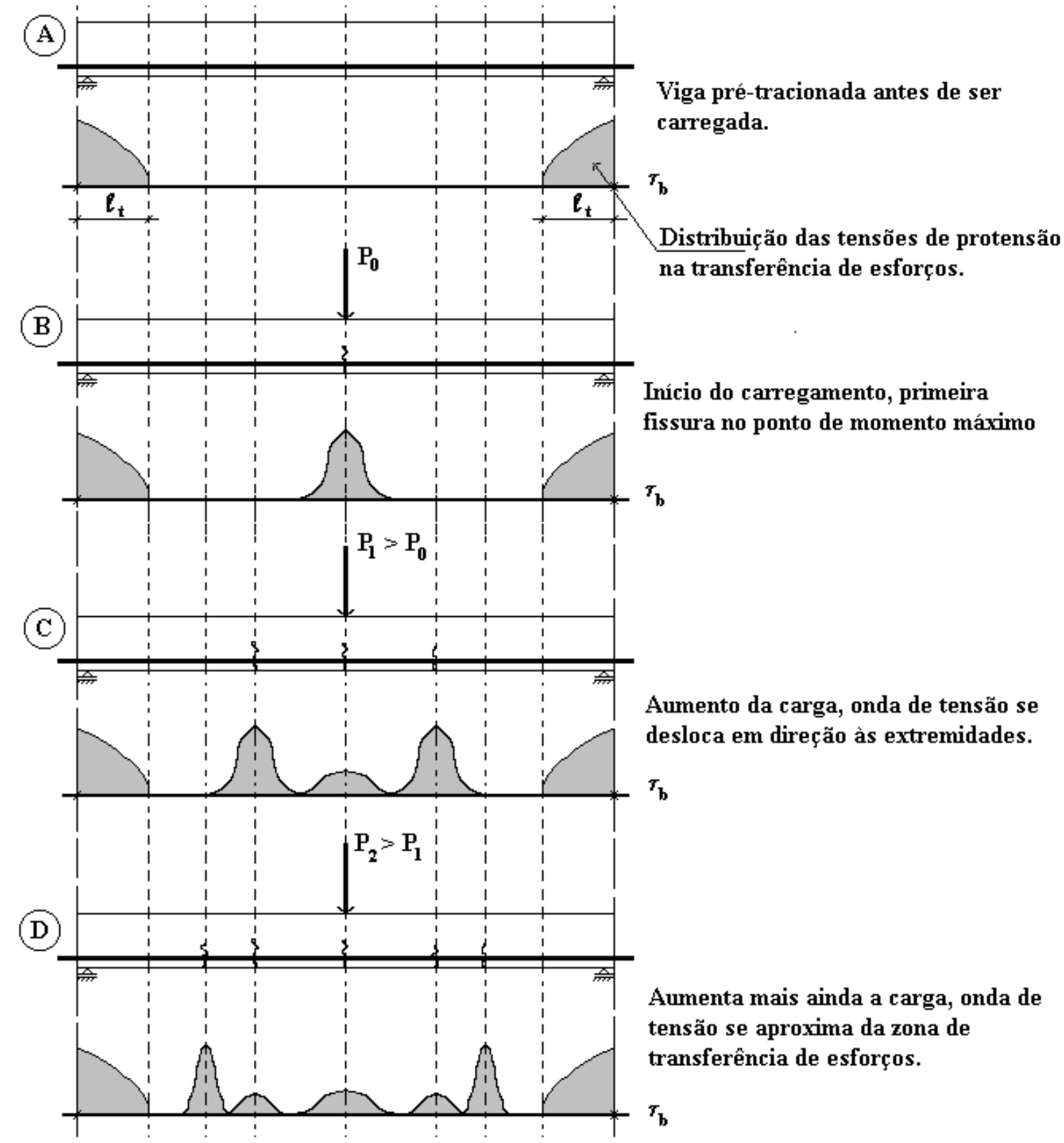

Figura 2.35 - Representação esquemática da onda da tensão de aderência (JANNEY, 1954). 
Segundo JANNEY (1954), os ensaios nas vigas levaram à conclusão de que o comprimento efetivo disponível do aço para a aderência na flexão é, aproximadamente, igual à diferença entre o comprimento total e o comprimento necessário para transmitir a força de pré-tração ao concreto. E continua, dizendo que a distribuição da aderência por transferência da protensão é significativa, pois ela limita a região onde as tensões de aderência na flexão podem ser acomodadas.

É importante notar que, como já foi citado, o aumento da tensão na armadura, devido a atuação do momento fletor, nas peças pré-tracionadas, não é importante para as peças em serviço, quando estas não estão fissuradas. Porém, após a fissuração, a aderência entre o aço e o concreto nas regiões fletidas desempenham um papel importante na garantia do bom comportamento das peças.

\section{b) HANSON \& KAAR (1959)}

Os autores apresentam um estudo sobre ensaios de aderência na flexão de vigas pré-tracionadas, que tinha, entre outros, o intuito de verificar as conclusões de JANNEY (1954).

Segundo HANSON \& KAAR (1959), os resultados de ensaios em 47 vigas reforçaram a teoria proposta por JANNEY (1954) da 'onda de aderência na flexão', e confirmaram que um escorregamento generalizado ocorre numa viga pré-tracionada quando o pico da onda alcança a zona de transferência de tensões.

\section{c) KAAR \& MAGURA (1965)}

KAAR \& MAGURA (1965) estudaram o efeito da retirada da aderência de cordoalhas perto dos apoios, no desempenho de vigas pré-tracionadas.

Segundo os autores, sob carregamento de serviço, as tensões na armadura prétracionada normalmente permanecem em torno da tensão efetiva de protensão; a integridade estrutural da peça continua a depender essencialmente da aderência na região de transferência de tensões, e as tensões de aderência na flexão são desprezíveis.

Os autores observaram que devido à retirada da aderência próxima às extremidades, os comprimentos de transferência e de ancoragem necessário podem acontecer numa zona tracionada, e fissurar antes de atingir a carga última. Se não 
houver comprimento de ancoragem suficiente, a capacidade última da peça passa a ser governada pela aderência, e não por flexão.

Em relação ao modo de ruptura das peças por aderência, os autores observaram que o escorregamento das cordoalhas ocorre em três etapas:

- O escorregamento progressivo começa na fissura de flexão;

- Depois, começa a ocorrer o escorregamento generalizado ao longo de todo o comprimento de ancoragem;

- Por fim, a aderência mecânica entre a superfície helicoidal da cordoalha e o concreto é destruída.

\section{d) STOCKER \& SOZEN (1970)}

Os autores relatam e interpretam os resultados de 486 ensaios de arrancamento e cinco ensaios de viga, com o objetivo de obter uma compreensão básica sobre a natureza da aderência entre concreto e cordoalha. Eles desenvolveram, também, uma expressão para a determinação do comprimento de ancoragem para a cordoalha protendida. Os parâmetros de ensaio foram: tipo (fio e cordoalha) e diâmetro da armadura, resistência do concreto à compressão, retração, lançamento e adensamento do concreto, pressão de confinamento e idade do modelo. Para a grande maioria dos modelos de arrancamento foi utilizado um comprimento aderente de ensaio de 1 " $(2,54 \mathrm{~cm})$.

As principais conclusões foram:

- A aderência entre a cordoalha e o concreto é garantida por dois mecanismos: (1) um engrenamento físico entre a microscópica superfície rugosa do aço e o concreto que a envolve (aderência mecânica); e (2) o atrito entre as duas superfícies de contato, que escorregam após a perda da aderência mecânica. Não há escorregamento significativo $(\mathrm{S}<0,0001 "=0,00254 \mathrm{~mm})$ durante a fase da aderência mecânica;

- Durante a fase onde a aderência se dá por atrito, ocorre o escorregamento da cordoalha. Devido à forma helicoidal do arranjo dos fios externos, a cordoalha gira à medida que vai escorregando dentro do concreto. Porém, o momento torçor máximo causado por esta rotação não produz pressões de contato grandes o suficiente para aumentar significativamente a aderência; 
- Idealmente, as propriedades aderentes de uma cordoalha perfeita (em que todas as seções transversais ao longo do seu eixo são iguais) deveriam ser semelhantes às dos fios. Porém, as pequenas imperfeições devidas ao arranjo dos fios causam um certo efeito-de-cunha. Esse efeito de barra nervurada atua apenas na fase da aderência por atrito, e aumenta com o escorregamento;

- Para os ensaios de arrancamento, e parâmetros de ensaio utilizados, verificouse o seguinte: a aderência aumenta com o diâmetro; a aderência aumenta com a resistência do concreto à compressão; as pressões transversais devidas à retração do concreto aumentam consideravelmente a aderência; a aderência da cordoalha, posicionada horizontalmente (perpendicular ao lançamento do concreto), diminui com o aumento do cobrimento sob a armadura, até um valor limite de $\mathrm{c}=10$ " $(25,4 \mathrm{~cm})$; a aderência aumenta com o aumento da pressão lateral.

Baseado nos ensaios de arrancamento e de viga, foi proposta a seguinte equação para o cálculo do comprimento de ancoragem necessário (L) para as cordoalhas:

$$
L=70 . A \cdot B \cdot D \frac{f_{s e}}{175}
$$

onde: $\mathrm{A}=$ coeficiente que leva em conta o adensamento do concreto (varia entre $1 \mathrm{e}$ 1,4, dependendo do cobrimento de concreto sob a armadura);

$\mathrm{B}=$ coeficiente que leva em conta o tipo de alívio da protensão (varia entre $1 \mathrm{e}$ $1,3)$;

$\mathrm{D}=$ diâmetro nominal da cordoalha;

$\mathrm{f}_{\mathrm{se}}=$ tensão de protensão imediatamente após a desprotensão (ksi).

\section{e) KAAR \& HANSON (1975)}

Os autores fizeram um estudo sobre ensaios de fadiga em vigas pré-tracionadas que simulavam dormentes de concreto, e observaram que a aderência entre o concreto e a cordoalha pré-tracionada é adequada para peças não-fissuradas, mesmo sob carregamento repetitivo. Entretanto, para dormentes de concreto pré-tracionados e para vigas curtas em balanço, sujeitos a cargas repetidas que causem grandes momentos fletores próximos às extremidades, um grande comprimento de 
transferência pode reduzir a protensão desenvolvida no ponto de momento máximo, reduzindo, portanto, o momento de fissuração.

\section{f) ANDERSON \& ANDERSON (1976)}

Eles estudaram o desempenho de lajes alveolares pré-tracionadas em relação à aderência.

Os autores observaram que quando peças curtas são submetidas a sobrecargas excessivas, a onda da aderência na flexão pode invadir a região de transferência de esforços, precipitando a perda de ancoragem dos cabos, nas extremidades das peças.

Os autores concluíram, também, que uma má consolidação do concreto na zona de transferência pode ser a causa principal de escorregamento excessivo da cordoalha na extremidade, levando a uma ruptura prematura por perda de aderência.

\section{g) ZIA \& MOSTAFA (1977)}

ZIA \& MOSTAFA (1977) publicaram um artigo propondo uma expressão para o cálculo do comprimento de ancoragem de cordoalhas pré-tracionadas. Eles se basearam em resultados de alguns ensaios citados na literatura técnica, entre eles os obtidos por HANSON \& KAAR (1959), e, através de uma análise por regressão linear, sugeriram uma equação para o cálculo do comprimento de transferência de esforços $\left(\ell_{\mathrm{t}}\right)$. O valor do comprimento de ancoragem necessário da cordoalha $\left(\ell_{\mathrm{d}}\right)$ é a soma desse comprimento $\ell_{\mathrm{t}}$ com o comprimento de aderência na flexão $\left(\ell_{\mathrm{b}}\right)$, ou seja:

$$
\ell_{\mathrm{d}}=\ell_{\mathrm{t}}+\ell_{\mathrm{b}}
$$

Esse conceito está presente no ACI 318 (1971), e está representado na Figura 2.36, na qual: $d_{b}=$ diâmetro da barra;

$\mathrm{f}_{\mathrm{se}}=$ tensão efetiva na cordoalha após todas as perdas;

$\mathrm{f}_{\mathrm{su}}=$ resistência última da cordoalha à tração.

A equação para o cálculo do comprimento de transferência de esforços, proposta pelos autores, é a seguinte:

$$
\ell_{\mathrm{t}}=1,5 \cdot \frac{\mathrm{f}_{\mathrm{si}}}{\mathrm{f}_{\mathrm{ci}}^{\prime}} \cdot \mathrm{d}_{\mathrm{b}}-4,6
$$

onde: $\mathrm{f}_{\mathrm{si}}=$ tensão inicial de protensão; 
$\mathrm{f}_{\mathrm{ci}}{ }^{\prime}=$ resistência do concreto à compressão no momento da transferência de esforços.

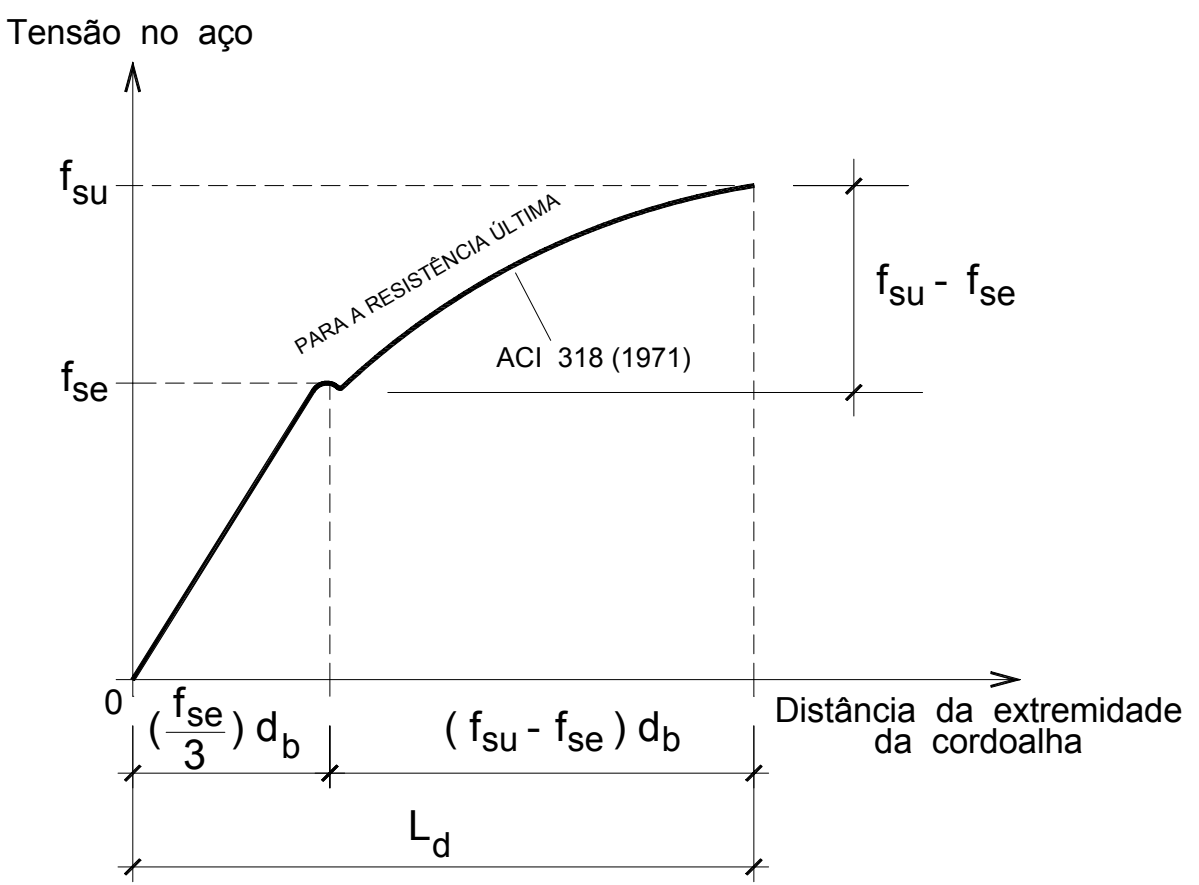

Figura 2.36 - Variação da tensão na armadura ao longo da extremidade da viga, segundo o ACI 318 (1971) (ZIA \& MOSTAFA, 1977).

A partir desta equação, os autores sugeriram a seguinte expressão para o cálculo do comprimento de ancoragem necessário $\left(\ell_{\mathrm{d}}\right)$ :

$$
\ell_{d}=\ell_{t}+\ell_{b}=1,5 \cdot \frac{f_{s i}}{f_{c i}^{\prime}} \cdot d_{b}-4,6+1,25 \cdot\left(f_{s u}-f_{s e}\right) \cdot d_{b}
$$

Esta expressão é válida para concretos com resistências à compressão variando entre 2000 e 8000 psi (14 e 55MPa), e leva em consideração os efeitos do diâmetro das cordoalhas, a tensão inicial de protensão e a resistência do concreto à compressão no momento da transferência de esforços. Os valores obtidos por meio desta equação foram considerados conservadores e um pouco abaixo dos valores resultantes da formulação do ACI 318 (1971), porém, para cordoalhas de até 12,7mm de diâmetro, as diferenças foram pequenas, sendo significativas apenas para diâmetros maiores, especialmente se o concreto apresentasse baixa resistência à compressão, no momento da transferência de esforços. Essa expressão também foi utilizada na análise teórica deste trabalho. 


\section{h) RABBAT et al (1979)}

Os autores apresentaram um estudo sobre ensaios de fadiga em vigas prétracionadas, com cordoalhas de traçado não-linear, e com retirada de aderência nas extremidades.

Eles concluíram que o uso de cordoalhas com a retirada da aderência nas extremidades é uma técnica não só plausível, como também que leva a uma produção mais segura e econômica de vigas pré-tracionadas de pontes.

\section{i) JOKELA \& TEPFERS (1982)}

Os autores apresentaram o resultado de um estudo experimental sobre a aderência de feixes de cordoalhas pré-tracionadas. Foram realizados 62 ensaios de arrancamento, 30 peças sem protensão, e 32 pré-tracionadas. A Figura 2.37 apresenta os modelos utilizados nos ensaios. Os tipos A, B, C, D e E foram confeccionados sem protensão, e os tipos D e E foram, também, pré-tracionados.

Para os modelos pré-tracionados, estudaram-se dois tipos de alívio de protensão: súbito e gradual. $\mathrm{O}$ concreto utilizado apresentou resistências à compressão entre $37,5 \mathrm{MPa}$ e 53,5MPa. A cordoalha foi de sete fios e diâmetro de 12,5mm, com aço equivalente ao CP $190 \mathrm{RB}$.

Para os modelos sem protensão, as principais conclusões do trabalho foram:

- A utilização de feixes com duas ou três cordoalhas não aumenta a tendência de fendilhamento na zona de ancoragem;

- Não se deve posicionar as cordoalhas em camadas em que atuam as forças de fendilhamento, que geram fissuração;

- A utilização de feixes não diminui a capacidade aderente das peças, e o aumento do escorregamento é muito pequeno.

Para os modelos pré-tracionados:

- A pré-tração aumenta, um pouco, a capacidade aderente dos modelos;

- A utilização de feixes não diminui a aderência das peças;

- O alívio súbito da protensão aumenta o escorregamento para os feixes, mas não para as cordoalhas isoladas, porém, em nenhum dos casos, afeta a aderência da peça. 

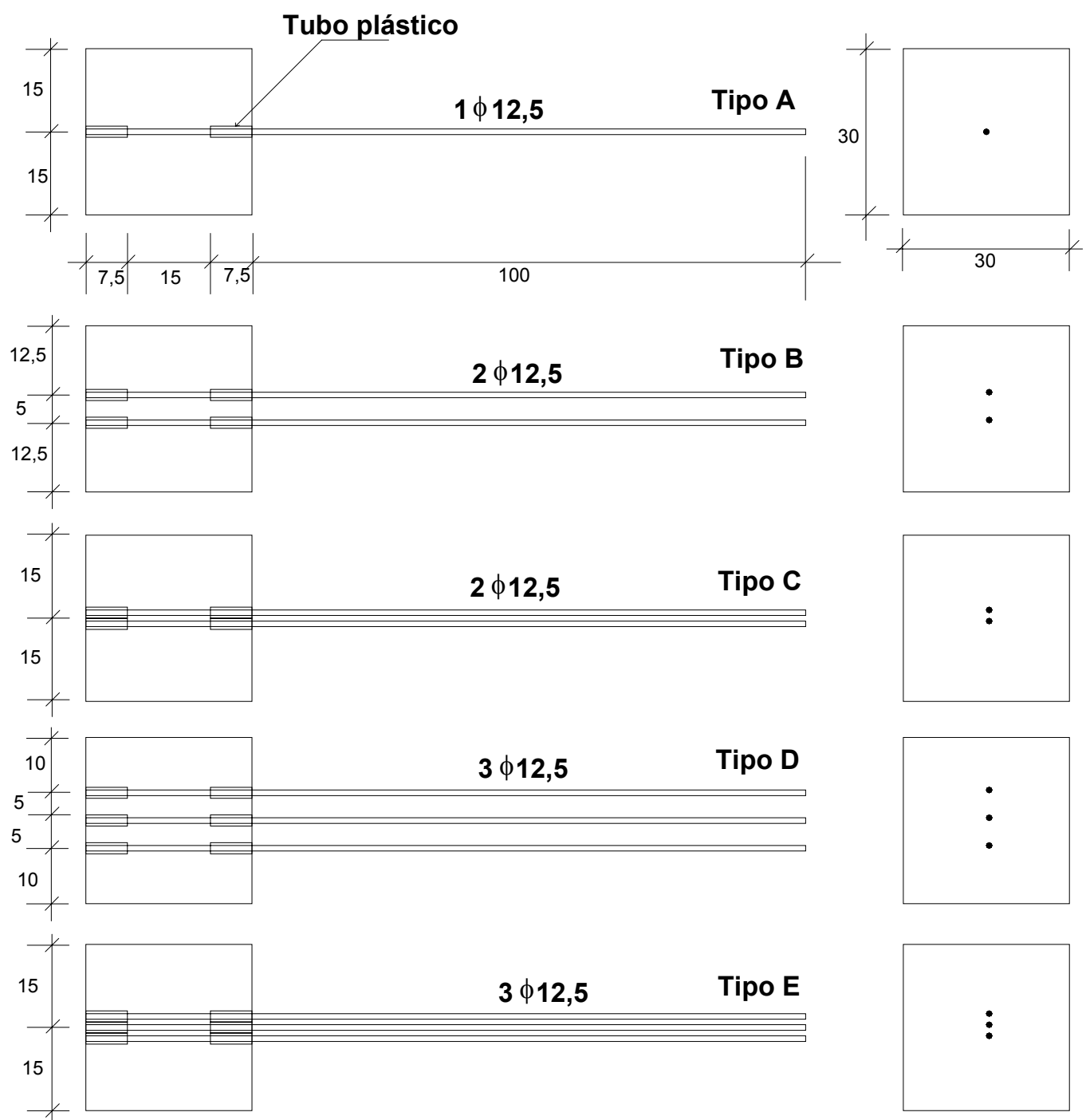

Figura 2.37 - Modelos de arrancamento com comprimento de ancoragem de $15 \mathrm{~cm}$ no centro dos cubos - dimensões em centímetros (JOKELA \& TEPFERS, 1982).

\section{j) CASTRODALE, BURNS \& KREGER (1988)}

Os autores apresentam uma pesquisa sobre a utilização de concretos de alta resistência (CAR) em vigas pré-tracionadas para pontes. Eles dividem o relatório em duas partes: (1) um estudo comparativo entre o comprimento de transferência de cordoalhas de sete fios e $0,5^{\prime \prime}(12,7 \mathrm{~mm})$ de diâmetro, no concreto de resistência normal e no de alta resistência, visando verificar a validade das expressões de cálculo das prescrições normativas para o CAR; e (2) ensaio de duas vigas pré-tracionadas de CAR, na escala 1:3, para verificar se as prescrições normativas valem para o CAR. Foram feitos, também, vários ensaios de caracterização para o CAR, em que se 
avaliaram as seguintes propriedades: a resistência à compressão $\left(f_{c}\right)$, a resistência à tração $\left(f_{\mathrm{ct}}\right)$, o módulo de elasticidade $\left(\mathrm{E}_{\mathrm{c}}\right)$, a fluência, a retração e o peso específico. Foi utilizado um concreto de $12.000 \mathrm{psi}(83 \mathrm{MPa})$.

Para a análise do comprimento de transferência, foram ensaiados 22 corpos-deprova, cujos parâmetros estudados foram: a resistência à compressão (5 e 10ksi - 34 e 69MPa); tipo de alívio da protensão (súbito e gradual); e o nível de tensão de compressão no concreto. A seção transversal dos modelos variou entre $4 \times 4$ " e $6 \times 6$ " $(10 \times 10 \mathrm{~cm}$ e $15 \times 15 \mathrm{~cm})$.

Para as vigas, os principais aspectos que se queria estudar eram: a capacidade última na flexão; o comportamento força versus deslocamento (que dá uma indicação da ductilidade); as deformações do concreto e da cordoalha em serviço e na ruptura; e a fluência. A Figura 2.38 apresenta a forma das vigas.

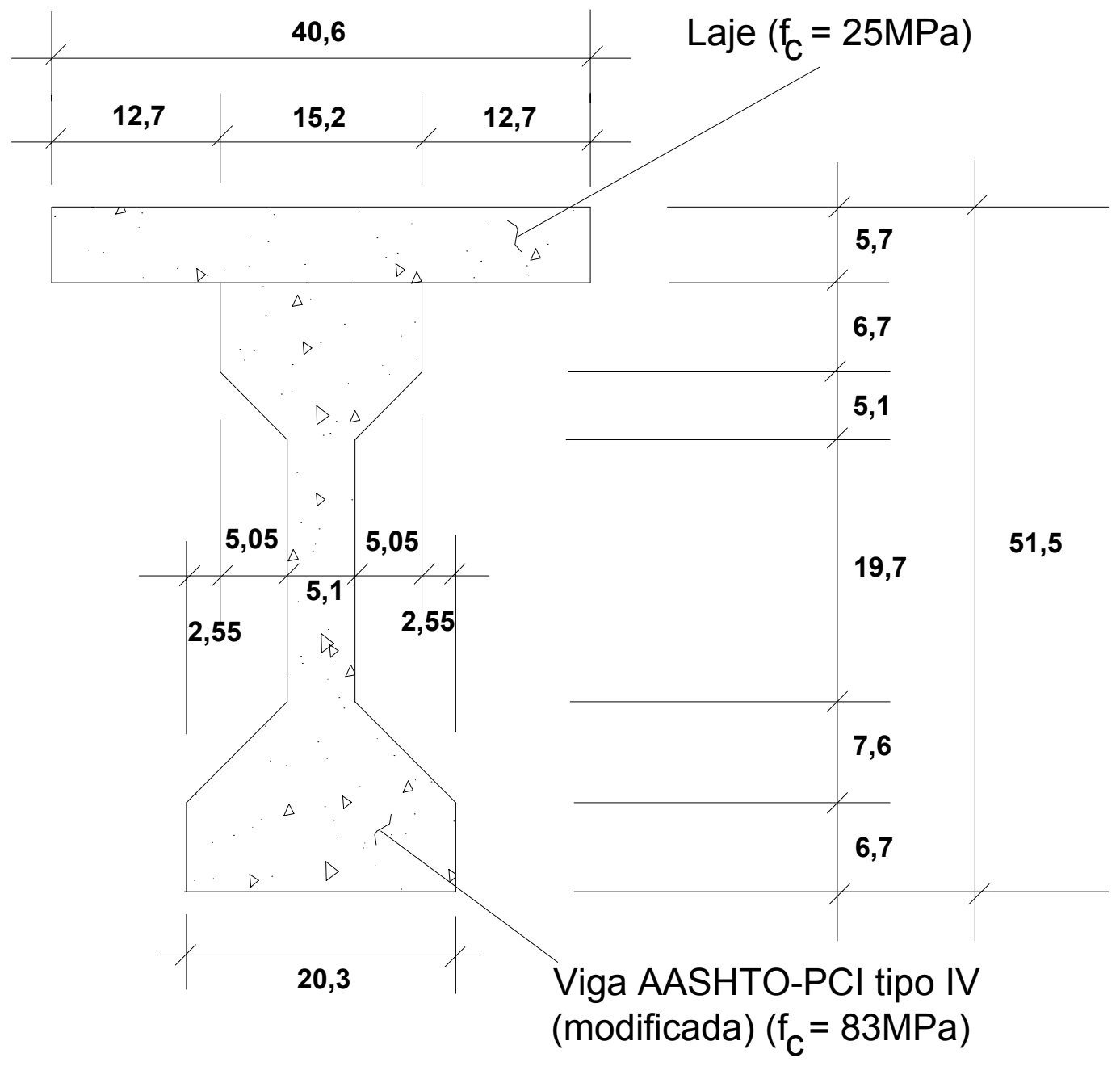

Figura 2.38 - Seção transversal das vigas, dimensões em cm. 


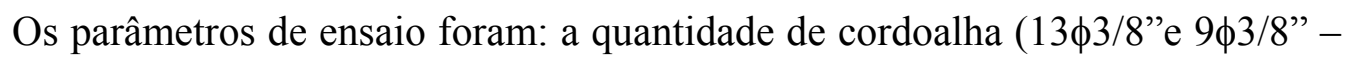
$\phi 9,5 \mathrm{~mm})$ e a armadura de cisalhamento $\left(\mathrm{V}_{\mathrm{s} 1}=\left[8 \sqrt{\mathrm{f}_{\mathrm{c}}} \cdot \mathrm{b}_{\mathrm{w}} \cdot \mathrm{d}\right]\right.$ - valor máximo, e $\left.\mathrm{V}_{\mathrm{s} 2}=\mathrm{V}_{\mathrm{s} 1} / 2\right)$.

As principais conclusões do trabalho foram:

- O comprimento de transferência no CAR é aproximadamente 30\% menor do que no concreto de resistência normal;

- O tipo de alívio da protensão, súbito ou gradual, não apresentou diferença significativa no comprimento de transferência do CAR;

- As prescrições da AASHTO fornecem valores conservadores, mas razoáveis, para a estimativa do comprimento de transferência;

- A deformação última de compressão do CAR é menor do que a do concreto de resistência normal, e ambas apresentaram valores menores do que o valor de $3 \%$;

- $\mathrm{O}$ valor de $\mathrm{f}_{\mathrm{c}}=80 \mathrm{MPa}$ é o limite máximo que se deve utilizar para o CAR, no que diz respeito a sua produção comercial; a relação custo-benefício para valores maiores que 80MPa não é satisfatória.

\section{1) COUSINS, JOHNSTON \& ZIA (1990a), (1990b), (1990c)}

Os autores apresentaram três estudos sobre a aderência de cordoalhas prétracionadas, com diâmetros de 9,5mm, 12,7mm e 15,2mm, com e sem revestimento epóxi. No primeiro são apresentados os resultados experimentais para o comprimento de transferência. No segundo, os resultados experimentais para o comprimento de ancoragem necessário. E no terceiro, eles apresentam o desenvolvimento de equações analíticas para o cálculo dos comprimentos de transferência, de aderência na flexão, e de ancoragem necessário, para as cordoalhas com e sem revestimento epóxi. Os resultados obtidos são comparados com os resultados experimentais.

As cordoalhas com revestimento epóxi foram utilizadas como uma alternativa para se resolver o problema da oxidação dessas armaduras. Os ensaios mostraram que a sua utilização é viável, e que o revestimento epóxi não só protege a armadura da oxidação e garante uma boa aderência entre o concreto e a armadura, como também reduz os comprimentos de transferência e de ancoragem necessário. 
As Tabelas 2.3 e 2.4 apresentam os resultados para os dois primeiros trabalhos, respectivamente, para as cordoalhas de $\phi_{\mathrm{p}} 12,7 \mathrm{~mm}$.

Tabela 2.3 - Resultados para os comprimentos médios de transferência, $\ell_{\text {t,médio }}$ (COUSINS,

JOHNSTON \& ZIA, 1990a).

\begin{tabular}{|c|c|c|c|}
\hline $\begin{array}{l}\text { Resistência do concreto à } \\
\text { compressão, na transferência } \\
\left(\mathrm{f}_{\mathrm{ci}}\right)(\mathrm{MPa})\end{array}$ & Tipo de revestimento & $\begin{array}{c}\ell_{\mathrm{t}, \text { médio }} \\
(\mathrm{cm})\end{array}$ & $\begin{array}{l}\text { Número de } \\
\text { medidas }\end{array}$ \\
\hline \multirow{4}{*}{30} & Sem revestimento & 127 & 20 \\
\hline & epóxi baixa-densidade & 71 & 8 \\
\hline & epóxi média-densidade & 48 & 16 \\
\hline & epóxi alta-densidade & 43 & 8 \\
\hline
\end{tabular}

O arranjo de ensaio está apresentado na Figura 2.39. O comprimento de ancoragem disponível $\left(\ell_{\mathrm{E}}\right)$ é a distância do ponto de aplicação da carga à extremidade da viga. A determinação do comprimento de ancoragem necessário foi feita da seguinte maneira: escolhia-se um comprimento de ancoragem disponível $\left(\ell_{\mathrm{E}}\right)$ e ensaiava-se a viga à flexão; se a viga rompesse por flexão, significava que o comprimento de ancoragem disponível era maior do que o necessário; adotava-se um comprimento disponível menor que o anterior e ensaiava-se outra viga, ou a outra extremidade da mesma viga, e verificava-se o novo modo de ruptura; ia-se diminuindo o comprimento disponível até que o modo de ruptura mudasse para ruptura por perda de aderência. Portanto, o comprimento de ancoragem necessário era o menor comprimento que fornecia uma ruptura por flexão. Esse mesmo procedimento foi utilizado nesta pesquisa.

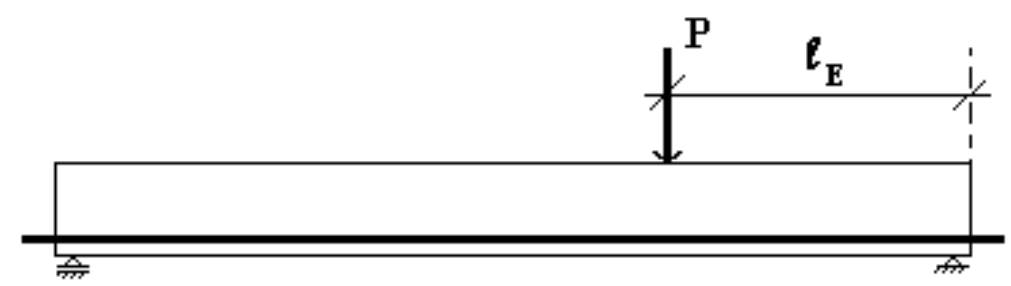

Figura 2.39 - Arranjo de ensaio (COUSINS, JOHNSTON \& ZIA, 1990b). 
Tabela 2.4 - Resultados para os comprimentos de ancoragem necessários, $\ell_{\mathrm{d}}$,min (COUSINS,

JOHNSTON \& ZIA, 1990b).

\begin{tabular}{|c|c|c|c|c|}
\hline $\begin{array}{c}\text { Comprimento de } \\
\text { ancoragem } \\
\text { disponível }\left(\ell_{\mathrm{E}}\right)(\mathrm{cm})\end{array}$ & $\begin{array}{c}\text { Tipo de } \\
\text { revestimento }\end{array}$ & $\begin{array}{c}\text { Momento de } \\
\text { fissuração }\left(\mathrm{M}_{\mathrm{cr}}\right) \\
(\mathrm{kN.m})\end{array}$ & Tipo de ruptura & $\begin{array}{l}\ell_{\mathrm{d}, \min } \\
(\mathrm{cm})\end{array}$ \\
\hline 302,26 & \multirow{6}{*}{$\begin{array}{c}\text { Sem } \\
\text { revestimento }\end{array}$} & 16,05 & \multirow{6}{*}{ Aderência } & \multirow{6}{*}{302,26} \\
\hline 266,70 & & 13,20 & & \\
\hline 266,70 & & 13,31 & & \\
\hline 182,88 & & 15,93 & & \\
\hline 182,88 & & 13,20 & & \\
\hline 121,92 & & 14,11 & & \\
\hline 121,92 & \multirow{5}{*}{$\begin{array}{c}\text { epóxi média- } \\
\text { densidade }\end{array}$} & 13,43 & \multirow{3}{*}{ Flexão } & \multirow{5}{*}{76,20} \\
\hline 91,44 & & 14,00 & & \\
\hline 83,82 & & 13,77 & & \\
\hline 76,20 & & 13,88 & Flexão/ Aderência & \\
\hline 68,58 & & 12,63 & Aderência & \\
\hline 162,56 & \multirow{4}{*}{$\begin{array}{c}\text { epóxi baixa- } \\
\text { densidade }\end{array}$} & 14,79 & Flexão & \multirow{4}{*}{162,56} \\
\hline 121,92 & & 13,54 & \multirow{3}{*}{ Aderência } & \\
\hline 106,68 & & 13,77 & & \\
\hline 91,44 & & 12,97 & & \\
\hline 83,82 & \multirow{4}{*}{$\begin{array}{l}\text { epóxi alta- } \\
\text { densidade }\end{array}$} & 14,11 & Flexão/ Cortante & \multirow{4}{*}{76,20} \\
\hline 76,20 & & 13,31 & Flexão & \\
\hline 68,58 & & 13,43 & Aderência/ Flexão & \\
\hline 60,96 & & 12,97 & Cortante & \\
\hline
\end{tabular}

No terceiro trabalho apresentado pelos autores, foram desenvolvidas as equações apresentadas na Tabela 2.5. 
Tabela 2.5 - Equações para o cálculo dos comprimentos de ancoragem (COUSINS, JOHNSTON \& ZIA, 1990c).

\begin{tabular}{c|c|c}
\hline $\begin{array}{c}\text { Comprimento de transferência } \\
\left(\ell_{\mathrm{t}}\right)\end{array}$ & $\begin{array}{c}\text { Comprimento de ancoragem na } \\
\text { flexão }\left(\ell_{\mathrm{b}}\right)\end{array}$ & $\begin{array}{c}\text { Comprimento de } \\
\text { ancoragem } \\
\text { necessário }\left(\ell_{\mathrm{d}}\right)\end{array}$ \\
\hline $0,5\left(\frac{\mathrm{U}_{\mathrm{t}}^{\prime} \sqrt{\mathrm{f}_{\mathrm{ci}}^{\prime}}}{\mathrm{B}}\right)+\frac{\mathrm{f}_{\mathrm{se}} \cdot \mathrm{A}_{\mathrm{p}}}{\pi \cdot \mathrm{d}_{\mathrm{b}} \cdot \mathrm{U}_{\mathrm{t}}^{\prime} \sqrt{\mathrm{f}_{\mathrm{ci}}^{\prime}}}$ & $\left(\mathrm{f}_{\mathrm{ps}}-\mathrm{f}_{\mathrm{se}}\right)\left(\frac{\mathrm{A}_{\mathrm{p}} /\left(\pi \cdot \mathrm{d}_{\mathrm{b}}\right)}{\mathrm{U}_{\mathrm{d}}^{\prime} \sqrt{\mathrm{f}_{\mathrm{c}}^{\prime}}}\right)$ & $\ell_{\mathrm{t}}+\ell_{\mathrm{b}}$ \\
\hline
\end{tabular}

Na Tabela 2.5, tem-se:

$\mathrm{U}_{\mathrm{t}}^{\prime}=6,7$ (para cordoalhas sem revestimento);

$\mathrm{U}_{\mathrm{d}}^{\prime}=1,32$ (para cordoalhas sem revestimento);

$\mathrm{f}_{\mathrm{ci}}=$ resistência do concreto à compressão, na transferência;

$\mathrm{f}_{\mathrm{c}}=$ resistência característica do concreto à compressão, na data de ensaio;

$\mathrm{B}=$ Módulo da aderência (inclinação da curva de tensão de aderência na zona elástica $(\mathrm{kPa} / \mathrm{mm})$; adota-se um valor médio de $81,5 \mathrm{kPa} / \mathrm{mm}$.

\section{m) RUSSEL \& BURNS (1993)}

Os autores apresentaram um vasto estudo sobre a aderência de cordoalhas de sete fios com diâmetros de $0,6 "(15,2 \mathrm{~mm})$ e de $0,5 "(12,7 \mathrm{~mm})$, para uso em vigas de concreto pré-tracionadas.

Uma das razões para a pesquisa foi a publicação de um memorando pela Federal Highway Administration (FHWA), órgão que regulamenta a construção de rodovias e pontes nos Estados Unidos, que proibia a utilização de cordoalhas com diâmetro de 0,6" $(15,2 \mathrm{~mm})$ em aplicações de concreto pré-tracionado, e que aumentava os valores de cálculo para os comprimentos de ancoragem das cordoalhas de diâmetros menores. Essas restrições haviam sido baseadas nos resultados obtidos por COUSINS et al (1986), e foram adotadas interinamente até que novas pesquisas comprovassem ou mudassem os resultados adotados. Portanto, um dos objetivos da pesquisa era determinar os comprimentos de transferência e de ancoragem necessário para as cordoalhas com diâmetros de 0,5 "'(12,7mm) e 0,6"(15,2mm).

O programa experimental englobou ensaios para: 
- A medição do comprimento de transferência (65 modelos), cujos parâmetros de ensaio foram o número de cordoalhas, diâmetro da cordoalha, tipo da retirada de aderência, armadura de confinamento, e tamanho e tipo da seção transversal;

- A medição do comprimento de ancoragem necessário (19 modelos com vigas de seção I e nove modelos com vigas de seção retangular), cujos parâmetros de ensaio foram diâmetro da cordoalha, e tamanho e tipo da seção transversal;

- A avaliação do comportamento e da performance de vigas com cordoalhas cuja aderência era retirada nas extremidades (seis modelos com vigas de seção I), cujos parâmetros de ensaio foram o comprimento onde foi retirada a aderência $\left(\mathrm{L}_{\mathrm{b}}\right)$, tipo de retirada da aderência, e o comprimento aderente disponível de ensaio $\left(\mathrm{L}_{\mathrm{e}}\right)$. Foram feitos ensaios estáticos e dinâmicos.

Baseado nos resultados experimentais, observou-se que a ruptura por aderência pode ser evitada se não ocorrer fissuração na zona de ancoragem das cordoalhas prétracionadas. No final do trabalho são apresentadas recomendações e procedimentos de cálculo para os comprimentos de ancoragem e para a retirada da aderência das cordoalhas, nas extremidades das peças.

Para o cálculo do comprimento de transferência $\left(\mathrm{L}_{\mathrm{t}}\right)$, em vigas onde não há a retirada da aderência, os autores sugerem a seguinte expressão:

$$
\mathrm{L}_{\mathrm{t}}=\frac{\mathrm{f}_{\mathrm{se}}}{2} \mathrm{~d}_{\mathrm{b}}
$$

onde: $\mathrm{f}_{\mathrm{se}}=$ tensão de protensão imediatamente após a desprotensão;

$\mathrm{d}_{\mathrm{b}}=$ diâmetro da cordoalha.

As duas principais conclusões do trabalho são:

- Pode-se usar as cordoalhas de 0,6" $(15,2 \mathrm{~mm})$ de diâmetro, com toda a segurança, nas aplicações com concreto pré-tracionado;

- É seguro o uso de cordoalhas com retirada de aderência nas extremidades, desde que sejam seguidas as recomendações de cálculo apresentadas no trabalho. 


\section{n) VARGAS (2001)}

O autor apresenta um estudo sobre a aderência de cordoalhas pré-tracionadas em concretos de altas resistências iniciais. O trabalho compreende uma ampla revisão bibliográfica sobre o tema e apresenta um novo método de ensaio, intitulado de ensaio ECADA, para a determinação das propriedades aderentes de peças prétracionadas. Segundo VARGAS (2001), a principal característica do ensaio é que ele permite que se determine o comprimento de ancoragem de uma armadura após a transferência da protensão. Com este método de ensaio, as operações de desprotensão e de arrancamento se realizam sobre a mesma peça de concreto, uma operação seguida da outra, sendo esta situação a que reflete mais fielmente o estado real dos elementos de concreto protendido com armaduras pré-tracionadas. A Figura 2.40 apresenta um esquema do método de ensaio proposto.

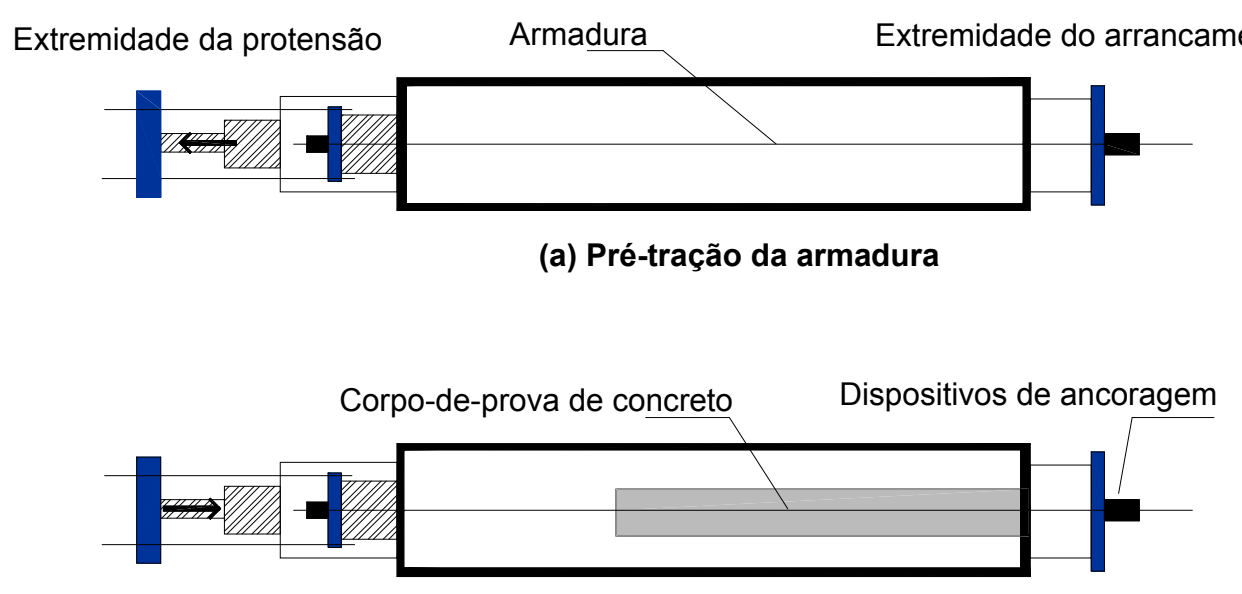

(b) Concretagem do CP e desprotensão

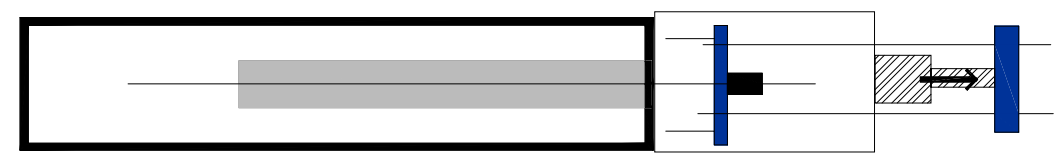

(c) Ensaio de arrancamento

Figura 2.40 - Método de ensaio proposto por VARGAS (2001).

Inicialmente, faz-se a protensão da armadura dentro do pórtico de ensaio (Figura 2.40a), pela extremidade da esquerda. Em seguida, concreta-se o corpo-deprova (CP), e libera-se a protensão (Figura 2.40b). Por último, faz-se o ensaio de arrancamento na extremidade oposta à de protensão (Figura 2.40c). A peça de concreto é metade da peça teórica, e a outra metade é simulada pela rigidez da placa 
de apoio da extremidade de arrancamento. A grande dificuldade, e limitação, deste ensaio está na obtenção da rigidez adequada para simular várias peças de concreto de diversas dimensões. Para uma única placa de apoio, o número de peças de concreto diferentes que podem ser representadas é pequeno.

VARGAS (2001) realizou 51 ensaios, divididos em 11 séries, nas quais variou os seguintes parâmetros: tipo de concreto (três traços distintos); comprimento aderente disponível $\left(25 \mathrm{~cm} \leq \ell_{\mathrm{ef}} \leq 100 \mathrm{~cm}\right)$; grau de protensão (zero; $0,13 \mathrm{f}_{\mathrm{ptk}} ; 0,25 \mathrm{f}_{\text {ptk }}$; $0,5 \mathrm{f}_{\text {ptk }} ; 0,75 \mathrm{f}_{\text {ptk }}$ ); idade de desprotensão (6 horas $\leq$ idade $\leq 24$ horas); idade de arrancamento (10 horas $\leq$ idade $\leq 15$ dias); e dimensões dos corpos-de-prova de concreto (10x10x112cm; 10x10x152cm; 8x8x115cm; 6x6x115cm).

Entre as conclusões do trabalho, destacaram-se as seguintes:

- O ensaio é viável, desde que tomadas as devidas precauções para simular a rigidez do trecho de concreto substituído;

- A determinação do comprimento de transferência pelo escorregamento da cordoalha nas extremidades das peças não é confiável;

- A influência do concreto na aderência não deve ser levada em conta apenas com relação à resistência; a compactação do concreto também influi na aderência;

- O comprimento de transferência estabiliza-se muito rapidamente, não variando ao longo do tempo;

- O cobrimento mínimo de concreto para que não haja fendilhamento, e conseqüentemente a força de protensão possa ser transmitida por completo, é de 2,5 vezes o diâmetro da armadura;

- O comprimento de transferência obtido com um alívio súbito da protensão é maior do que o obtido com um alívio gradual;

- Nos ensaios de arrancamento, a velocidade de carga não influi muito (o autor utilizou controle de força, e não de deslocamento);

- A aderência depende do grau de protensão;

- Os efeitos Hoyer e de Poisson influenciam no escorregamento, mas não influenciam no valor da tensão máxima de aderência; 
- Ensaios de arrancamento com armadura pré-tracionada e comprimento aderente menor do que o comprimento de transferência não fornecem resultados confiáveis, não sendo indicado o seu uso.

\subsubsection{Comentários gerais}

A grande maioria das pesquisas adota como parâmetros básicos, para a determinação dos comprimentos de ancoragem, o diâmetro das cordoalhas (ou fios), a tensão na armadura, o cobrimento e a resistência do concreto à compressão. Mesmo assim, as pesquisas apresentam grandes diferenças nos seus resultados, não sendo possível fazer uma grande generalização para as equações e as conclusões. Segundo STOCKER \& SOZER (1970), é virtualmente impossível conceber um único tipo de ensaio e realizá-lo sob as mais variadas condições, de tal forma que os resultados possam ser representativos de todas as condições de aderência encontradas na prática. Da mesma forma, FERGUSON et al (1988) dizem que como o desenvolvimento das tensões de aderência pode ocorrer nos mais diversos ambientes, com grandes variações de espaçamento entre as armaduras, de cobrimentos inferior e lateral, e de estribos de confinamento, não é possível estabelecer valores para a tensão de aderência, ou para os comprimentos de ancoragem, que cubram um universo muito vasto. Percebe-se que não só os resultados obtidos, como também as condições e os parâmetros de ensaio adotados pelos diversos pesquisadores, têm um papel importante no estudo da aderência, especialmente para as peças protendidas. Baseado nesta observação, optou-se por ensaios os mais simples possíveis, tanto para o estudo da tensão de aderência, como para a medição dos comprimentos de ancoragem. Esses ensaios estão descritos em detalhes nos capítulos 4, 5 e 6 .

Além dos tipos de ensaio já citados, se encontram na literatura vários artigos sobre a determinação do comprimento de transferência a partir da medição da penetração da armadura no concreto, nas extremidades das peças, na desprotensão. Vários autores sugerem expressões relacionando o comprimento de transferência e a penetração da armadura. Entre eles destacam-se Guyon ${ }^{7}$ apud VARGAS (2001), BALÁZS (1993) e ROSE \& RUSSEL (1997). A grande dificuldade nesses casos

\footnotetext{
${ }^{7}$ GUYON, Y. (1953) - Béton précontrainte. Étude théorique et experiméntale. Ed. Eyrolles, Paris, apud VARGAS (2001).
} 
reside na medição da penetração na retirada da protensão, já que vários fatores influenciam nessa leitura: a deformação da armadura, o encurtamento do concreto, a rigidez do pórtico ou da pista de protensão, e a sensibilidade e a precisão da instrumentação utilizada. Devido a essas dificuldades, não se utilizou este método de cálculo neste trabalho. Este problema está descrito em mais detalhes no capítulo 6 .

Alguns dos resultados apresentados na literatura foram usados em comparação com os resultados desta pesquisa. Também para a análise teórica, foram utilizadas equações encontradas na revisão bibliográfica, algumas já citadas neste capítulo, para a caracterização do problema. Este estudo está apresentado no Capítulo 3.

\subsubsection{As fibras e a aderência no concreto protendido}

Segundo FURLAN (1995) "O comportamento das vigas de concreto armado e protendido é qualitativamente o mesmo, alterando-se a extensão das zonas fissuradas e o instante da fissuração, em função do grau de protensão". Quando se analisa uma peça de concreto protendido, além dos fenômenos básicos que se referem tanto às peças armadas como às protendidas, deve-se levar em conta também as características específicas do concreto protendido, como o cálculo do comprimento de transferência de esforços de protensão do aço para o concreto, a influência da protensão no cálculo das resistências à flexão e ao cisalhamento, e a determinação das flechas e contraflechas das peças. O uso de fibras nas peças de concreto protendido tem influência, em maior ou menor grau, nas três características citadas. Nas vigas de concreto protendido com protensão parcial, as fibras também influem no controle da fissuração, seja no padrão de fissuração (a peça apresenta fissuras menores e mais uniformemente distribuídas com um menor espaçamento entre elas), seja no aumento do momento de físsuração da peça, quando utilizadas em altos teores $\left(\mathrm{V}_{\mathrm{f}}>\mathrm{V}_{\mathrm{fcr}}\right)$. A Figura 2.41 apresenta um gráfico que relaciona o volume de fibras com o espaçamento das fissuras.

Segundo Balaguru \& Ezeldin ${ }^{8}$, apud BALAGURU \& SHAH (1992), ensaios em vigas de concreto protendido reforçado com fibras mostraram que há um

8 BALAGURU, P.; EZELDIN, A. (1987). Behavior of partially prestressed beams made with high strength fiber reinforced concrete. In Fiber Reinforced Concrete Properties and Applications, SP-105 ACI, Detroit, Michigan, pp. 419-434, apud BALAGURU \& SHAH (1992). 
aumento na flecha de ruptura à medida que se aumenta o volume das fibras. A Figura 2.42 mostra este comportamento.

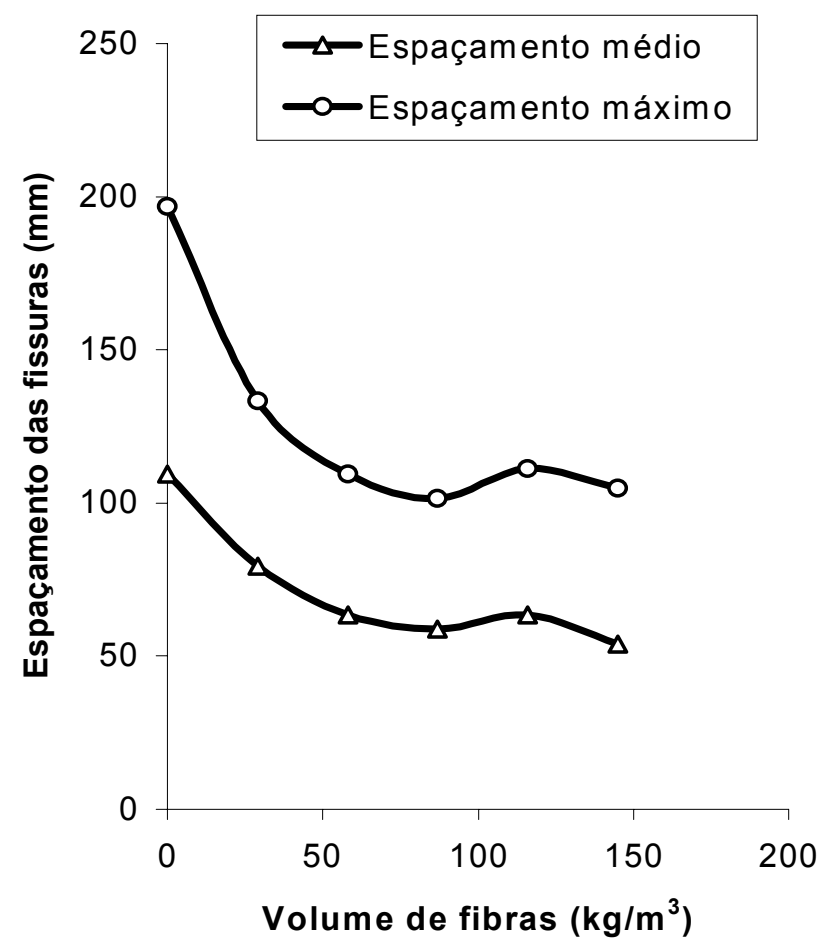

Figura 2.41 - Gráfico Volume de fibras versus Espaçamento das fissuras (BALAGURU \& SHAH, 1992).

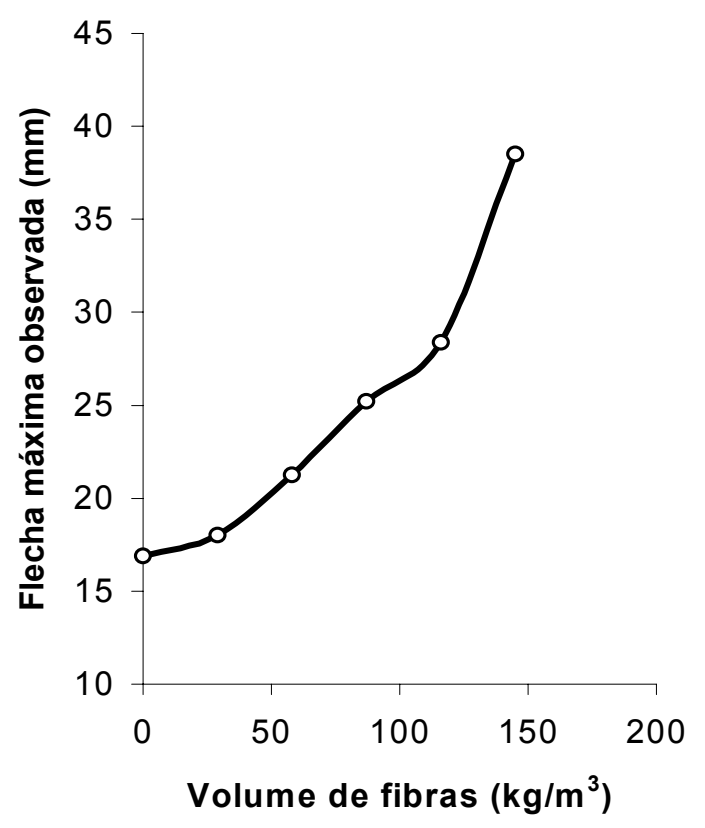

Figura 2.42 - Gráfico Volume de fibras versus Flecha máxima (BALAGURU \& SHAH, 1992). 
Segundo BALAGURU \& SHAH (1992), estudos mostraram que o uso de

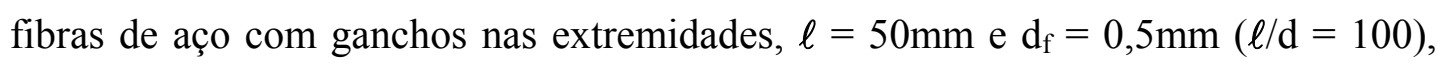
tanto fornece uma melhora significativa na ductilidade como no aumento do momento de fissuração das peças de concreto protendido, à medida que se aumenta o volume de fibras. As fibras também desempenham um papel importante no controle da fissuração de peças pré-moldadas no estado em vazio (estocadas no pátio da fábrica, e no transporte e no içamento das peças), quando podem estar sujeitas a tensões de tração um pouco elevadas, nas suas faces superiores.

Além das já citadas, uma das maiores contribuições das fibras ao concreto protendido é na redução do comprimento de transferência dos esforços de protensão do aço para o concreto nas peças pré-tracionadas, pois quanto maior for este comprimento menores serão as resistências à flexão e ao cisalhamento das peças. Nas extremidades dessas peças surgem tensões de tração elevadas, o que pode levar ao fendilhamento. Além disso, se a transferência de esforços ocorrer de forma brusca ou imediata (corte das cordoalhas sem um alívio gradual de tensão, por exemplo), a peça sofre um impacto. Nessas duas situações a presença das fibras melhora o comportamento do concreto, seja no controle das fissuras de fendilhamento, seja na ajuda à absorção das cargas de impacto.

Não existem, ainda, muitas pesquisas com o uso de concreto protendido reforçado com fibras de aço, porém BALAGURU et al (1996) acreditam que o uso do CRFA em peças pré-tracionadas deve: 1) melhorar a qualidade do concreto; 2) ajudar a resistir aos impactos devidos a um alívio súbito da protensão; e 3) reduzir ou substituir a armadura de fretagem ao prevenir a fissuração das extremidades das peças.

O concreto protendido reforçado com fibras tem sido utilizado, principalmente, em pavimentos, dormentes de concreto, vigas pré-moldadas e em alguns reparos.

Neste trabalho, foi estudada a influência das fibras no comprimento de transferência dos esforços de protensão, do aço para o concreto, de vigas prétracionadas, com alívio gradual da protensão (sem impacto), e no comportamento em relação à aderência. Segundo FURLAN (1995) "O comprimento do trecho da zona de transferência pode ser calculado a partir da tensão de aderência ou pode ser estimado experimentalmente". Nesta pesquisa, foram efetuados os dois processos e 
depois comparados um com o outro. Os capítulos referentes ao programa experimental (Capítulos 4, 5 e 6) apresentam mais detalhadamente os procedimentos de ensaio que foram realizados para a obtenção dos dados desejados.

\subsection{Comentários Finais sobre a Revisão Bibliográfica}

A revisão bibliográfica respondeu a algumas dúvidas, e levantou outras. Alguns desses novos questionamentos foram solucionados com as análises teórica e experimental, outros não. Para tentar entender alguns desses questionamentos que ficaram sem resposta, são sugeridas, no Capítulo 7, novas pesquisas sobre o tema.

A partir da revisão bibliográfica, constatou-se o seguinte:

- Para o concreto armado, principalmente o de resistência normal, existe um vasto número de pesquisas que estudaram, e estudam, a influência das fibras, em especial as de aço, no comportamento da aderência. Existem, inclusive, modelos numéricos e analíticos que tentam representar esse comportamento;

- De acordo com a grande maioria das pesquisas na área da aderência em peças de concreto armado reforçado com fibras de aço, pode-se, como já foi dito, concluir o seguinte: as fibras melhoram o comportamento Tensão de aderência versus Escorregamento; as fibras possuem um efeito significativo quando da ruptura por fendilhamento, mas para a ruptura por arrancamento, a sua contribuição, especialmente a baixos teores, é bem menor; e, os ensaios de arrancamento subestimam a influência das fibras na melhora da aderência, sendo recomendado o uso de ensaios de flexão. Essas conclusões não foram confirmadas nesta pesquisa, visto que aqui foram utilizadas cordoalhas e não barras nervuradas;

- O modo de ruptura por aderência é influenciado pelas tensões de tração, radiais ou tangenciais, e pela resistência do concreto à tração;

- Os resultados e conclusões obtidos para o concreto armado não podem ser estendidos, ou generalizados, para as peças de concreto pré-tracionado, já que estas últimas apresentam dois comportamentos distintos, um na transferência e outro na flexão, o que o torna mais complexo, em relação à aderência. Além disso, a conformação superficial das cordoalhas é 
diferente da das barras nervuradas e da dos fios lisos, e o seu comportamento como mais próximo do de uma barra ou do de um fio depende do impedimento do giro da cordoalha dentro do concreto, durante o escorregamento;

- O comportamento da aderência em concretos de alta resistência (CAR), especialmente os de altas resistências iniciais, difere do comportamento da aderência em concretos de resistências normais, não se tendo ainda uma quantidade grande de dados experimentais, que pudesse fornecer equações confiáveis para o dimensionamento de peças com a utilização de CAR;

- A grande maioria das peças pré-tracionadas, inclusive com protensão parcial, não apresentam problemas em relação à aderência na fase em serviço, já que ou não há fissuração, ou esta é muito pequena, não comprometendo a integridade das peças;

- A aderência pode vir a ser um problema, nas peças pré-tracionadas, quando existe a possibilidade da onda de aderência atingir a zona de transferência, e então iniciar uma ruptura prematura da peça, por perda de aderência. Isso pode ocorrer em peças curtas (consolos, painéis de lajes alveolares, dormentes de concreto, entre outras), ou em peças em que se tem um ponto de momento alto próximo aos apoios (algumas vigas de pontes, por exemplo), ou ainda, se submetidas a carregamentos cíclicos;

- O estudo da aderência em peças pré-tracionadas se baseia mais na determinação de comprimentos de ancoragem satisfatórios, do que na determinação da tensão de aderência em si;

- Existe uma variabilidade muito grande nos resultados de ensaios de arrancamento e na determinação dos comprimentos de aderência por expressões empíricas, já que o desenvolvimento das tensões de aderência pode ocorrer sob os mais variados ambientes;

- Existem vários trabalhos sobre a aderência em peças pré-tracionadas, porém muito poucos com a utilização de concreto reforçado com fibras de aço.

Ao fim da Revisão Bibliográfica, algumas questões ainda permaneceram sem respostas. As fibras usadas em baixos teores influenciam, de algum modo, na 
aderência das cordoalhas pré-tracionadas? E se influenciam, de que maneira? Aumentam a tensão de aderência, diminuem os comprimentos de transferência e de ancoragem necessário, melhoram o comportamento em relação à aderência (na préfissuração ou na pós-fissuração)? As fibras influenciam no modo de ruptura? Por arrancamento ou por fendilhamento?

Estas são algumas das perguntas que se pretende responder com este trabalho. 


\section{ANÁLISE TEÓRICA}

$\mathrm{Na}$ análise teórica foram utilizadas algumas formulações encontradas na literatura técnica internacional, tanto para a caracterização da tensão de aderência e do respectivo comportamento Tensão de aderência versus Escorregamento, como para os cálculos dos comprimentos de ancoragem. Os valores obtidos com essas formulações foram comparados com os resultados experimentais. Essas comparações são apresentadas nos Capítulos 5 e 6 .

Neste capítulo foram utilizadas equações teóricas retiradas da literatura. A maioria desses estudos foi feita por pesquisadores nos Estados Unidos, Europa e Japão, e publicada em periódicos técnicos como as revistas do ACI e do PCI. Por esse motivo, as equações se apresentavam no sistema de unidades norte-americano, que utiliza polegadas e libras. Para este trabalho, foram feitas as transformações de unidades baseadas nas seguintes relações:

- $\quad \operatorname{lin}=2,54 \mathrm{~cm}$

- $1 \mathrm{kip}=4,45 \mathrm{kN}$

- $\quad$ 1kip.in $=0,113 \mathrm{kN} . \mathrm{m}$

- $\quad 1 \mathrm{ksi}=6,895 \mathrm{MPa}$

Nos cálculos para o ACI 318 (2002), e outros trabalhos no sistema de unidades norte-americano, o valor utilizado da resistência do concreto à compressão foi o próprio valor do $f_{c}$, fazendo-se apenas a conversão de um sistema de unidades para o outro. Sabe-se que o critério considerado pelo ACI 318 (2002) para a determinação 
do $\hat{f}_{\mathrm{c}}$ é diferente do adotado pela Norma Brasileira para o cálculo do $\mathrm{f}_{\mathrm{ck}}$. Enquanto o ACI admite um valor característico definido pelo quantil de 1\%, a NBR 6118 (1978) admite um quantil de 5\% (VASCONCELOS \& GIAMMUSSO, 1993). Porém, isso leva a uma diferença de aproximadamente $3 \%$ entre os valores de $f_{c k}$ e $f_{c}$ (para valores pequenos do desvio padrão), que para o estudo teórico não é significativa.

\subsection{Formulações Empíricas}

Como já foi dito, não existe um modelo único que represente o comportamento da aderência para o concreto pré-tracionado. Neste estudo foram utilizados modelos analíticos para a tensão de aderência, para armaduras não-protendidas, e expressões para os cálculos dos comprimentos de ancoragem para as cordoalhas pré-tracionadas.

Os valores de cálculo adotados para a análise teórica são:

\section{Armaduras ativas:}

$$
\begin{aligned}
& \mathrm{f}_{\mathrm{ptk}}=\mathrm{f}_{\mathrm{pu}}=1900 \mathrm{MPa} \\
& \mathrm{f}_{\mathrm{pyk}}=0,9 \mathrm{f}_{\mathrm{ptk}}=1710 \mathrm{MPa} \\
& \mathrm{f}_{\mathrm{ptd}}=\mathrm{f}_{\mathrm{ptk}} / 1,15=1652 \mathrm{MPa} \\
& \mathrm{f}_{\mathrm{pyd}}=0,9 \mathrm{f}_{\mathrm{ptd}}=1487 \mathrm{MPa} \\
& \sigma_{\mathrm{pi}}=\mathrm{f}_{\mathrm{si}}=1496 \mathrm{MPa} \quad \Delta \sigma_{\mathrm{p}}=25 \% \quad\left(\mathrm{P}_{\mathrm{i}}=150 \mathrm{kN}\right) \\
& \sigma_{\mathrm{p} \infty}=\sigma_{\mathrm{pcs}}=\mathrm{f}_{\mathrm{se}}=1201 \mathrm{MPa} \\
& \mathrm{A}_{\mathrm{p}}=100,3 \mathrm{~mm}^{2}(\text { valor fornecido pelo fabricante) } \\
& \phi_{\mathrm{p}}=\mathrm{d}_{\mathrm{b}}=12,7 \mathrm{~mm}(\text { valor teórico) } \\
& \phi_{\mathrm{p}, \text { medido }}=12,88 \mathrm{~mm} \text { (valor fornecido pelo fabricante) } \\
& \left.\phi_{\mathrm{p}, \text { equiv }}=11,30 \mathrm{~mm} \text { (referente à } \mathrm{A}_{\mathrm{p}}: \phi_{\mathrm{p}, \text { equiv }}=\sqrt{\frac{4 . \mathrm{A}_{\mathrm{p}}}{\pi}}\right) \\
& \mathrm{E}_{\mathrm{p}}=204.000 \mathrm{MPa} \text { (valor fornecido pelo fabricante) }
\end{aligned}
$$

Concreto: $\quad \mathrm{f}_{\mathrm{c}, \text { transf,prismas }}=\mathrm{f}_{\text {ci,prismas }}=45 \mathrm{MPa}$ (valor médio adotado, baseado nos ensaios de compressão axial de corpos-de-prova cilíndricos, na data de transferência da protensão)

$\mathrm{f}_{\mathrm{c} \text {, transf,vigas }}=\mathrm{f}_{\text {ci,vigas }}=50 \mathrm{MPa}$ (valor médio adotado, baseado nos ensaios de compressão axial de corpos-de-prova cilíndricos, na data de transferência da protensão) 
$\mathrm{f}_{\mathrm{c} \text {,ensaio,prismas }}=\mathrm{f}_{\mathrm{c} \text {,prismas }}^{\prime}=68 \mathrm{MPa}$ (valor médio adotado, baseado nos ensaios de compressão axial de corpos-de-prova cilíndricos, na data de ensaio)

$\mathrm{f}_{\mathrm{c} \text {, ensaio,vigas }}=\mathrm{f}_{\mathrm{c} \text {,vigas }}=65 \mathrm{MPa}$ (valor médio adotado, baseado nos ensaios de compressão axial de corpos-de-prova cilíndricos, na data de ensaio)

$\mathrm{f}_{\mathrm{ct}, 0}=4,1 \mathrm{MPa}$ (valor médio obtido em ensaios de caracterização para $\left.\mathrm{V}_{\mathrm{f}}=0\right)$

$\mathrm{f}_{\mathrm{ct}, 40}=4,5 \mathrm{MPa}$ (valor médio obtido em ensaios de caracterização para $\mathrm{V}_{\mathrm{f}}=40 \mathrm{~kg} / \mathrm{m}^{3}$ )

$\mathrm{f}_{\mathrm{ct}, 60}=5,1 \mathrm{MPa}$ (valor médio obtido em ensaios de caracterização $\operatorname{para} \mathrm{V}_{\mathrm{f}}=60 \mathrm{~kg} / \mathrm{m}^{3}$ )

$\mathrm{E}_{\mathrm{c}, 28}=39.000 \mathrm{MPa}$ (valor médio obtido de ensaios em compressão axial de corpos-de-prova cilíndricos, aos 28 dias)

$\bar{\sigma}_{\mathrm{b}, 40}=2,22 \mathrm{MPa}$ (valor médio obtido em ensaios de caracterização $\operatorname{para} \mathrm{V}_{\mathrm{f}}=40 \mathrm{~kg} / \mathrm{m}^{3}$ )

$\bar{\sigma}_{b, 60}=3,10 \mathrm{MPa}$ (valor médio obtido em ensaios de caracterização para $\mathrm{V}_{\mathrm{f}}=60 \mathrm{~kg} / \mathrm{m}^{3}$ )

\section{Armaduras passivas das vigas:}

$\phi_{\text {long }}=8 \mathrm{~mm}$

$\mathrm{A}_{\mathrm{s}, 8 \mathrm{~mm}}=0,503 \mathrm{~cm}^{2}$

$\phi_{\text {transv }}=6,3 \mathrm{~mm}$

$\mathrm{A}_{\mathrm{s}, 6,3 \mathrm{~mm}}=0,315 \mathrm{~cm}^{2} \quad \mathrm{~s}=15 \mathrm{~cm}$

$\mathrm{f}_{\mathrm{yk}, 6,3 \mathrm{~mm}}=600 \mathrm{MPa}$ (valor médio obtido em ensaio de tração axial)

$\mathrm{f}_{\mathrm{yk}, 8 \mathrm{~mm}}=530 \mathrm{MPa}$ (valor médio obtido em ensaio de tração axial)

$\mathrm{E}_{\mathrm{s}}=210.000 \mathrm{MPa}$ (valor teórico)

\section{Dados geométricos dos prismas da Série 1:}

$\mathrm{c}_{\mathrm{p}}=2,9 \mathrm{~cm}$ (cobrimento da cordoalha)

$\mathrm{b}_{\mathrm{w}}=7 \mathrm{~cm}$ 


$$
\begin{aligned}
& \mathrm{h}=7 \mathrm{~cm} \\
& \mathrm{~L}=40 \mathrm{~cm} \\
& \ell_{\mathrm{ef} 2}=9 \mathrm{~cm}\left(7 \phi_{\mathrm{p}}\right) \\
& \ell_{\mathrm{ef} 3}=19 \mathrm{~cm}\left(15 \phi_{\mathrm{p}}\right)
\end{aligned}
$$

\section{Dados geométricos dos prismas da Série 2:}

$$
\begin{aligned}
& \mathrm{c}_{\mathrm{p}}=9,4 \mathrm{~cm} \text { (cobrimento da cordoalha) } \\
& \mathrm{b}_{\mathrm{w}}=20 \mathrm{~cm} \\
& \mathrm{~h}=20 \mathrm{~cm} \\
& \mathrm{~L}=12,7 \mathrm{~cm} \\
& \ell_{\mathrm{efl}}=6,35 \mathrm{~cm}\left(5 \phi_{\mathrm{p}}\right)
\end{aligned}
$$

\section{Dados geométricos das vigas:}

$\mathrm{c}_{\mathrm{p}}=4,0 \mathrm{~cm}$ (cobrimento da armadura ativa)

$\mathrm{c}=2,5 \mathrm{~cm}$ (cobrimento da armadura passiva)

$\mathrm{b}=15 \mathrm{~cm}$

$\mathrm{h}=30 \mathrm{~cm}$

$\mathrm{d}_{\mathrm{p}}=25,4 \mathrm{~cm}$ (altura útil da armadura ativa)

$\mathrm{d}=26,5 \mathrm{~cm}$ (altura útil da armadura passiva)

$\mathrm{L}=240 \mathrm{~cm}$ (vão livre)

\section{Dados das fibras:}

$$
\begin{aligned}
& \ell=30 \mathrm{~mm} \text { (valor fornecido pelo fabricante) } \\
& \mathrm{d}_{\mathrm{f}}=0,62 \mathrm{~mm} \text { (valor fornecido pelo fabricante) } \\
& \ell / \mathrm{d}=45 \\
& \mathrm{f}_{\mathrm{ft}}=1100 \mathrm{MPa} \text { (valor fornecido pelo fabricante) }
\end{aligned}
$$

Os valores fornecidos pelos fabricantes foram obtidos em ensaios de caracterização feitos por eles. Os valores para o concreto e para as armaduras passivas foram obtidos de estudo de dosagem e de ensaios de caracterização realizados no Laboratório de Estruturas do Departamento de Engenharia de 
Estruturas da EESC/USP. Esses ensaios estão descritos no Capítulo 4. No Anexo A encontram-se os resultados fornecidos pelos fabricantes dos materiais.

Para este estudo teórico, foi adotado um único valor médio para as resistências do concreto à compressão, levando em conta os compósitos com e sem fibras de aço. O mesmo ocorreu para o módulo de elasticidade do concreto. Na realidade, houve diferenças entre os valores para os três compósitos estudados. Porém, para a análise teórica, as diferenças não foram significativas, sendo razoável adotar-se um único valor para todos. Já para a resistência do concreto à tração, essas diferenças foram maiores, optando-se então por adotar os respectivos valores para os compósitos com e sem fibras de aço.

\subsubsection{Tensão de aderência}

$\mathrm{Na}$ análise experimental, para os ensaios de arrancamento, foram feitos ensaios em prismas de concreto com a cordoalha pré-tracionada e com a cordoalha sem protensão. Para a análise da tensão de aderência, foram usados como referência os ensaios de arrancamento com cordoalhas não-protendidas.

$\mathrm{Na}$ literatura encontram-se vários modelos analíticos e numéricos que tentam descrever o comportamento Tensão de aderência versus Escorregamento de armaduras passivas, principalmente de barras nervuradas. Para o concreto sem fibras, destacam-se os modelos propostos por ELIGEHAUSEN et al (1983), ALSIWAT \& SAATCIOGLU (1992), LUNDGREN \& GYLLTOFT (2000) e ELMORSI et al (2000). Os dois últimos já foram direcionados para a modelagem numérica, usando de iterações para chegar aos valores desejados. O modelo de LUNDGREN \& GYLLTOFT (2000) foi especialmente desenvolvido para a análise tridimensional da aderência.

Para analisar o comportamento da cordoalha não-protendida, em concreto com e sem fibras de aço, foi utilizado, como base de comparação, o modelo analítico proposto por HARAJLI et al (1995), já descrito no Capítulo 2.

A escolha deste modelo analítico baseou-se em dois fatores: (1) é um modelo de fácil aplicação e entendimento, abrange o concreto com e sem fibras, e leva em conta os dois modos de ruptura (arrancamento e fendilhamento); e (2) os limites do modelo estão de acordo com os parâmetros adotados nesta pesquisa.

O estudo de HARAJLI et al (1995) é válido para os seguintes limites: 
- $8 \mathrm{~mm} \leq \phi \leq 25 \mathrm{~mm}$;

- $36 \mathrm{MPa} \leq \mathrm{f}_{\mathrm{c}} \leq 81 \mathrm{MPa}$;

- $0,23 \leq \mathrm{V}_{\mathrm{f}} \cdot \frac{l}{\mathrm{~d}} \leq 0,75$;

- Ensaios de arrancamento com carga monotônica;

- Comprimento médio de ancoragem disponível de $\ell_{\text {ef,m }} \approx 7 \phi$.

Os parâmetros desta pesquisa são:

- $\phi_{\mathrm{p}}=12,7 \mathrm{~mm}$;

- $\mathrm{f}_{\mathrm{cm}}=68 \mathrm{MPa}$;

- Foram utilizados dois volumes de fibra: $\left\{\begin{array}{l}\mathrm{V}_{\mathrm{f}}=40 \mathrm{~kg} / \mathrm{m}^{3} \Rightarrow \mathrm{V}_{\mathrm{f}} \cdot \frac{l}{\mathrm{~d}}=0,23 \\ \mathrm{~V}_{\mathrm{f}}=60 \mathrm{~kg} / \mathrm{m}^{3} \Rightarrow \mathrm{V}_{\mathrm{f}} \cdot \frac{l}{\mathrm{~d}}=0,34\end{array}\right.$

- Ensaios de arrancamento com carga monotônica;

- Foram utilizados três comprimentos de ancoragem: $\left\{\begin{array}{l}\ell_{\mathrm{ef} 1}=5 \phi_{\mathrm{p}} ; \\ \ell_{\mathrm{ef} 2}=7 \phi_{\mathrm{p}} ; \\ \ell_{\mathrm{ef} 3}=15 \phi_{\mathrm{p}}\end{array}\right.$

O modelo de HARAJLI et al (1995) utiliza, entre outras, as seguintes variáveis:

- $\quad \mathrm{c}_{0}=$ distância entre as nervuras da barra;

- $\sigma_{\mathrm{s}}=$ resistência à tração da matriz reforçada com fibra, imediatamente antes do fendilhamento;

- $\sigma_{\mathrm{ps}}=$ resistência à tração da matriz reforçada com fibra, imediatamente após o fendilhamento.

A cordoalha não possui nervuras, logo a escolha, ou determinação, de $c_{0}$ não é uma relação direta. Nas barras nervuradas, a distância entre as nervuras está relacionada com a aderência mecânica, devido ao efeito-de-cunha que as irregularidades fornecem. Como já foi dito, a cordoalha de fios lisos nem apresenta um comportamento de barra lisa, nem de barra nervurada, mas sim, um comportamento entre os dois citados acima. A forma helicoidal do arranjo dos fios introduz irregularidades na superfície da armadura, logo o valor de $\mathrm{c}_{0}$ pode ser relacionado com este arranjo. Na literatura encontraram-se dois valores extremos para esta caracterização: (1) a distância entre os pontos mais externos dos fios que 
compõem a cordoalha; e (2) o comprimento que um fio leva para dar a volta completa no diâmetro.

Para a distância entre os pontos mais externos dos fios que compõem a cordoalha, foi tomado o valor $\mathrm{c}_{0}=3 \mathrm{~mm}$, que foi o valor médio obtido, como mostra a Figura 3.1.

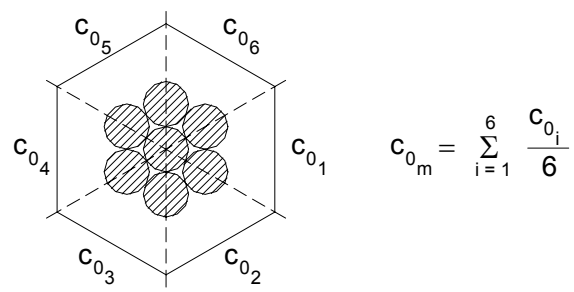

Figura 3.1 - Determinação de $c_{0}$ para as cordoalhas, levando em conta a distância entre os fios.

Já para o comprimento que um fio leva para dar a volta completa no contorno, o valor médio foi de $\mathrm{c}_{0}=17 \mathrm{~cm}$, como mostra a Figura 3.2 .

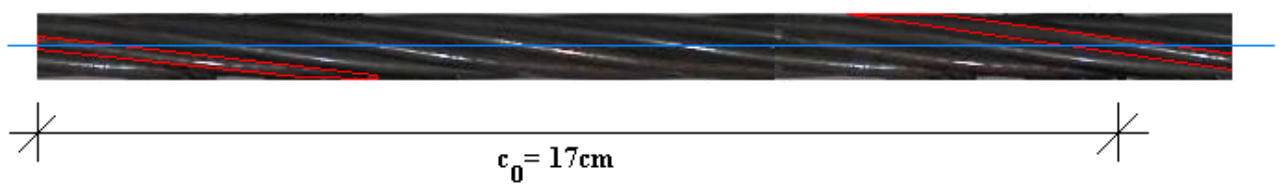

Figura 3.2 - Determinação de $\mathrm{c}_{0}$ para as cordoalhas, levando em conta o comprimento para dar a volta no contorno.

Para a determinação de $\sigma_{\mathrm{s}}$ e $\sigma_{\mathrm{ps}}$, foram utilizados os resultados dos ensaios de caracterização de tração na flexão. $\mathrm{O}$ valor de $\sigma_{\mathrm{s}}$ foi o valor médio obtido para a resistência do concreto à tração $\left(\mathrm{f}_{\mathrm{ct}}\right)$ aos 28 dias. Para $\sigma_{\mathrm{ps}}$, utilizou-se o gráfico Força versus Deslocamento, obtido do ensaio de tração na flexão para os compósitos com fibras de aço, para estabelecer a relação $\sigma_{\mathrm{s}} / \sigma_{\mathrm{ps}}$. Observou-se, nesses gráficos, uma queda brusca logo após o aparecimento da primeira fissura, e depois a curva passa a ter um comportamento mais suave. A carga máxima $\left(\mathrm{P}_{\mathrm{u}}\right)$ cai para aproximadamente $71 \%$ do seu valor, antes da suavização da curva (Figura 3.3), para os compósitos com $\mathrm{V}_{\mathrm{f}}=40 \mathrm{~kg} / \mathrm{m}^{3}$, e para aproximadamente $61 \%$ do seu valor para os compósitos com $\mathrm{V}_{\mathrm{f}}=60 \mathrm{~kg} / \mathrm{m}^{3}$.

Baseado neste comportamento, adotou-se, então, para o valor de $\sigma_{\mathrm{ps}}$ as seguintes relações: $\sigma_{\mathrm{ps}, 40}=0,71 \sigma_{\mathrm{s}, 40}$ e $\sigma_{\mathrm{ps}, 60}=0,61 \sigma_{\mathrm{s}, 60}$. Os valores obtidos foram:

- $\sigma_{\mathrm{s}}=4,5 \mathrm{MPa}$ e $\sigma_{\mathrm{ps}}=3,2 \mathrm{MPa}\left(\right.$ para $\left.\mathrm{V}_{\mathrm{f}}=40 \mathrm{~kg} / \mathrm{m}^{3}\right)$;

- $\sigma_{\mathrm{s}}=5,1 \mathrm{MPa}$ e $\sigma_{\mathrm{ps}}=3,1 \mathrm{MPa}\left(\right.$ para $\left.\mathrm{V}_{\mathrm{f}}=60 \mathrm{~kg} / \mathrm{m}^{3}\right)$. 


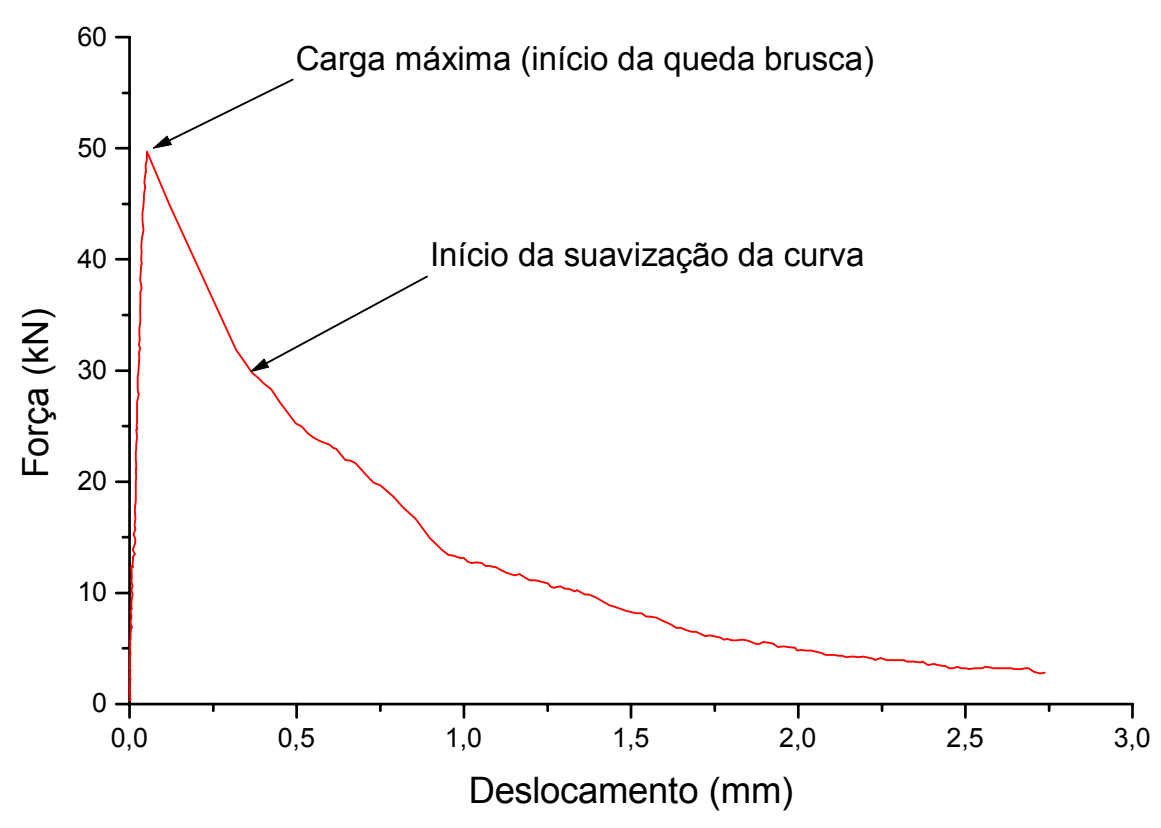

Figura 3.3 - Gráfico Força versus Deslocamento do CRFA.

A seguir são apresentados os valores calculados para os pontos característicos do modelo, cujo cálculo completo se encontra no Apêndice D, para um valor de $\mathrm{c}_{0}=3 \mathrm{~mm}$. A Figura 3.4 mostra o modelo para esta pesquisa.

$$
\begin{array}{ll}
\tau_{\mathrm{b} 1}=21,23 \mathrm{MPa} & \tau_{\mathrm{bf}}=7,43 \mathrm{MPa} \\
\tau_{\mathrm{bs}, 40}=6,46 \mathrm{MPa} & \tau_{\mathrm{bps}, 40}=4,60 \mathrm{MPa} \\
\tau_{\mathrm{bs}, 60}=7,32 \mathrm{MPa} & \tau_{\mathrm{bps}, 60}=4,47 \mathrm{MPa} \\
\tau_{\mathrm{bfr}, 40}=1,38 \mathrm{MPa} & \tau_{\mathrm{bfr}, 60}=1,34 \mathrm{MPa} \\
\mathrm{S}_{\text {máx }}=0,60 \mathrm{~mm} & \mathrm{~S}_{3}=3,00 \mathrm{~mm} \\
\mathrm{~S}_{2}=1,05 \mathrm{~mm} & \mathrm{~S}_{1}=0,45 \mathrm{~mm} \\
\mathrm{~S}_{\mathrm{s}, 40}=0,009 \mathrm{~mm} & \mathrm{~S}_{\mathrm{s}, 60}=0,013 \mathrm{~mm}
\end{array}
$$

A seguir são apresentados os valores calculados para os pontos característicos do modelo, para um valor de $c_{0}=170 \mathrm{~mm}$. A Figura 3.5 mostra o modelo para esta pesquisa.

$$
\begin{array}{ll}
\tau_{\mathrm{b} 1}=21,23 \mathrm{MPa} & \tau_{\mathrm{bf}}=7,43 \mathrm{MPa} \\
\tau_{\mathrm{bs}, 40}=6,46 \mathrm{MPa} & \tau_{\mathrm{bps}, 40}=4,59 \mathrm{MPa} \\
\tau_{\mathrm{bs}, 60}=7,32 \mathrm{MPa} & \tau_{\mathrm{bps}, 60}=4,47 \mathrm{MPa} \\
\tau_{\mathrm{bfr}, 40}=1,38 \mathrm{MPa} & \tau_{\mathrm{bfr}, 60}=1,34 \mathrm{MPa} \\
\mathrm{S}_{\text {máx }}=34,00 \mathrm{~mm} & \mathrm{~S}_{3}=170,00 \mathrm{~mm}
\end{array}
$$




$$
\begin{array}{ll}
\mathrm{S}_{2}=59,50 \mathrm{~mm} & \mathrm{~S}_{1}=25,50 \mathrm{~mm} \\
\mathrm{~S}_{\mathrm{s}, 40}=0,46 \mathrm{~mm} & \mathrm{~S}_{\mathrm{s}, 60}=0,70 \mathrm{~mm}
\end{array}
$$

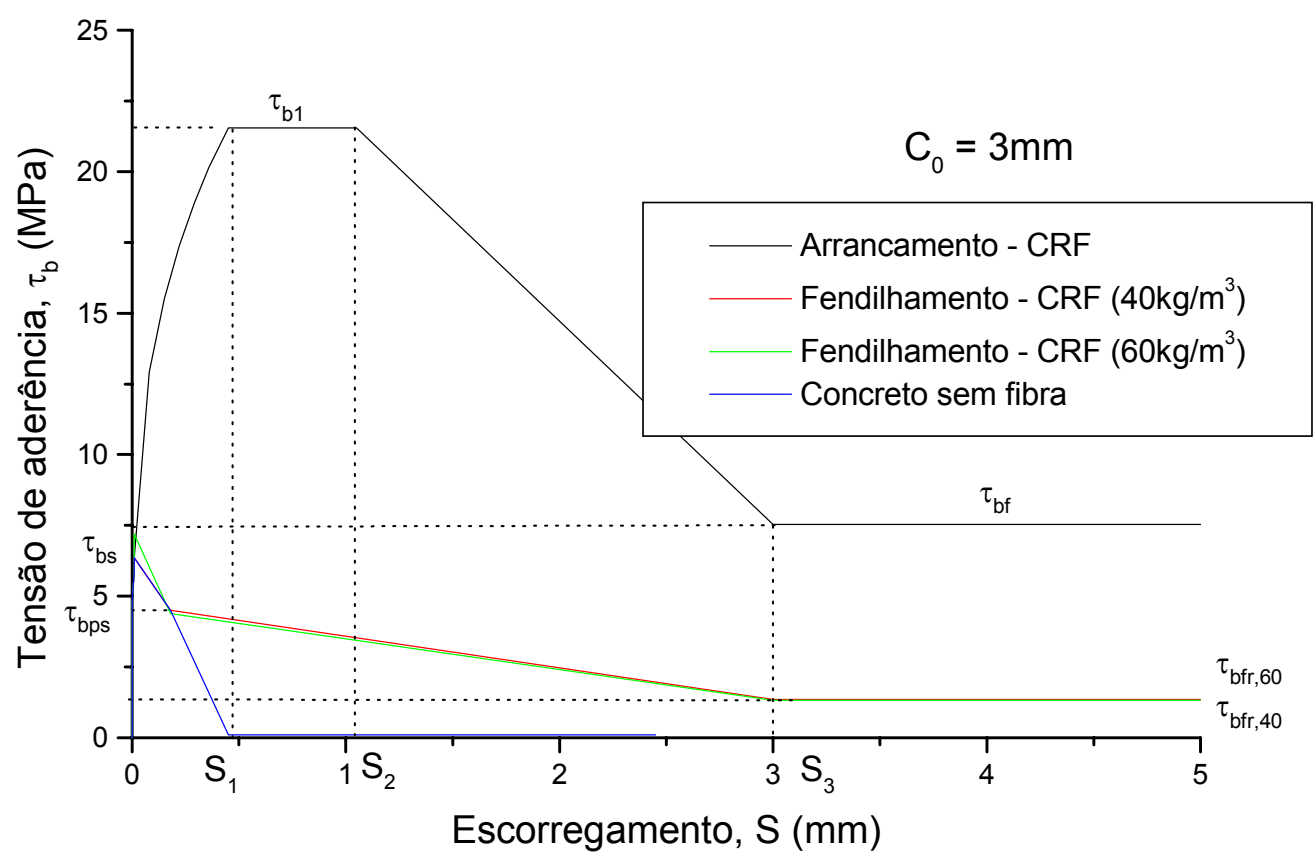

Figura 3.4 - Modelo proposto por HARAJLI et al (1995), para $\mathrm{c}_{0}=3 \mathrm{~mm}$.

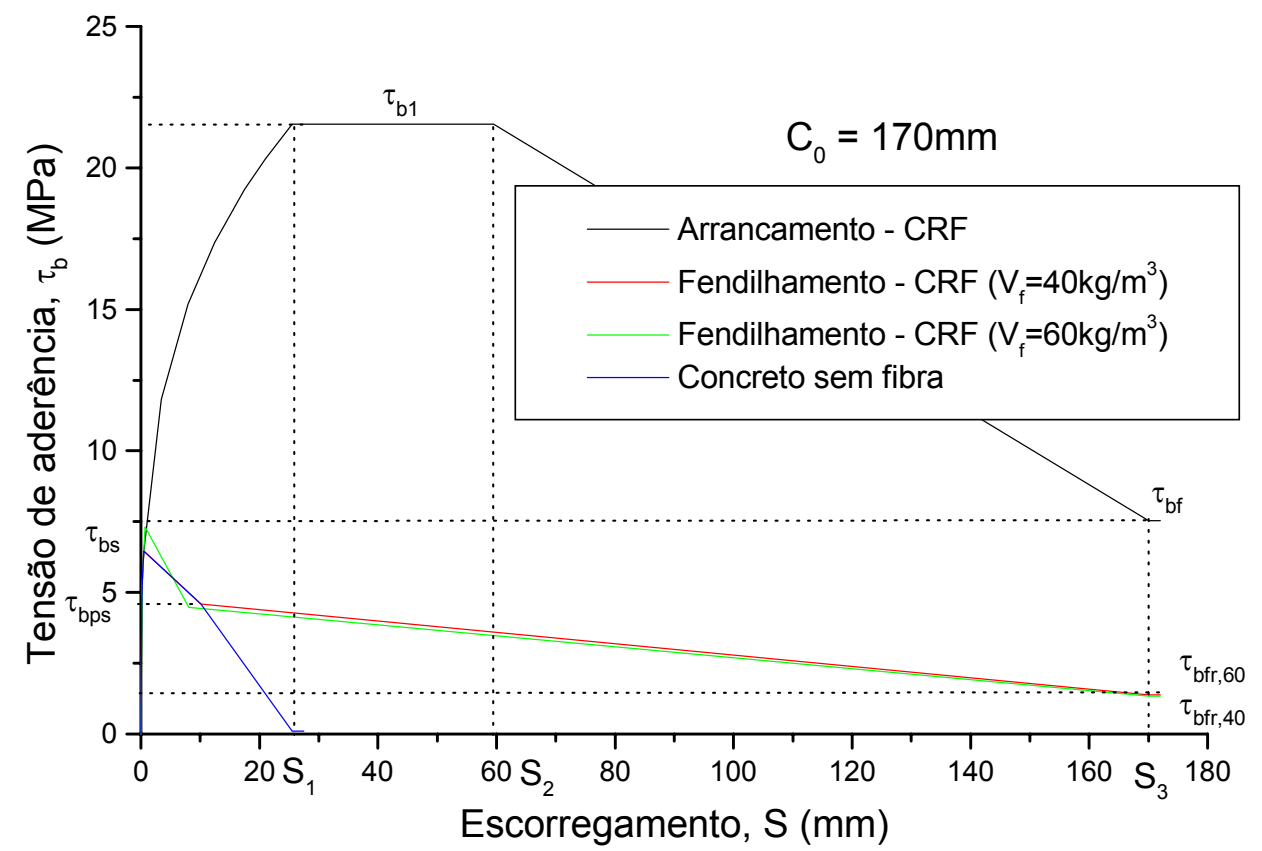

Figura 3.5 - Modelo proposto por HARAJLI et al (1995), para $\mathrm{c}_{0}=170 \mathrm{~mm}$.

Nota-se que, com os parâmetros desta pesquisa, para o CRFA, para os dois métodos de determinação de $\mathrm{c}_{0}$, a diferença entre as tensões de aderência máximas 
para as rupturas por arrancamento e por fendilhamento é muito grande. A tensão máxima de aderência para uma ruptura por arrancamento é função apenas da resistência do concreto à compressão. A tensão máxima de aderência para uma ruptura por fendilhamento é função da resistência do concreto à tração (que pode ser relacionada à resistência à compressão), e da razão entre o cobrimento, ou o espaçamento entre as barras, e o diâmetro da armadura.

A diferença entre os modelos, para os valores extremos de $\mathrm{c}_{0}$, está, principalmente, nos valores do escorregamento. Os valores da tensão de aderência são praticamente os mesmos para os dois modelos. Ou seja, a consideração de maior ou menor rugosidade da superfície da armadura (maior ou menor aderência mecânica) influi significativamente apenas no escorregamento: quanto maior a rugosidade considerada, menor o escorregamento da cordoalha, para valores semelhantes da tensão de aderência.

A Figura 3.6 apresenta a comparação dos dois modelos para as rupturas por fendilhamento. O gráfico foi interrompido para $S=20 \mathrm{~mm}$, para que os valores entre $\mathrm{S}_{\mathrm{S}}$ e $\mathrm{S}_{1}$ pudessem ser melhor vistos. Se o gráfico mostrasse a escala até o valor último de $\mathrm{S}_{3}=170 \mathrm{~mm}$, para $\mathrm{c}_{0}=170 \mathrm{~mm}$, a visualização da parte inicial ficaria comprometida.

Percebe-se que para os valores iniciais, as diferenças de escorregamento não são muito grandes. Também, para o concreto sem fibra, as diferenças são pequenas. Já a diferença entre o escorregamento último para os dois modelos é muito grande, tanto para os compósitos com fibras como os sem fibras. Acredita-se que os valores de ensaio devam ficar entre esses dois valores extremos dos dois modelos adotados. Essa comparação está apresentada no capítulo 5.

É importante lembrar, que essas considerações são referentes ao modelo proposto por HARAJLI et al (1995).

Além do modelo proposto por HARAJLI et al (1995), foram escolhidas algumas expressões para a determinação da tensão de aderência de armaduras passivas. 


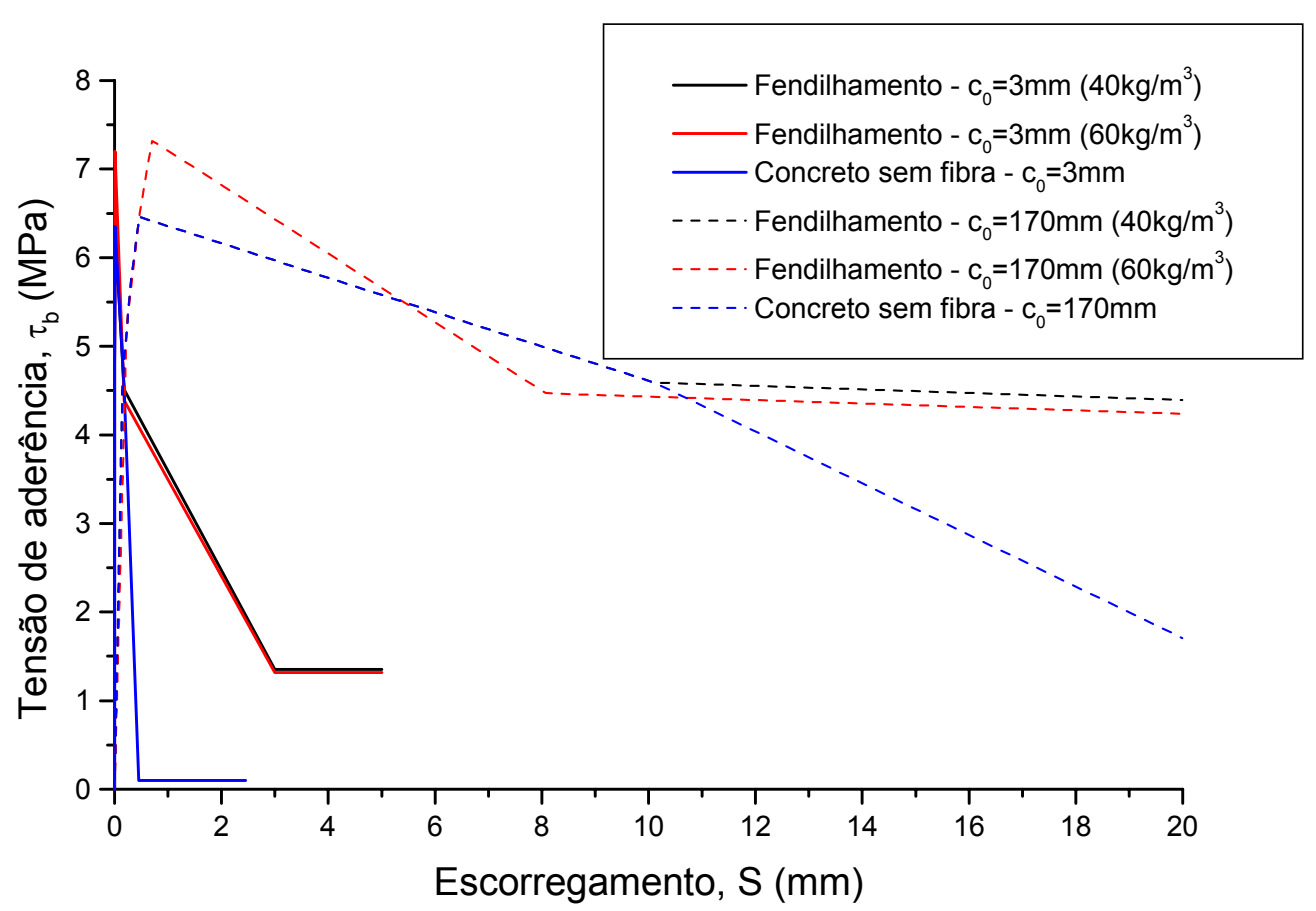

Figura 3.6 - Modelo proposto por HARAJLI et al (1995), para $\mathrm{c}_{0}=3 \mathrm{~mm} \mathrm{e} \mathrm{c}_{0}=170 \mathrm{~mm}$.

Vários pesquisadores têm tentado desenvolver expressões que abranjam o maior número possível de variáveis, englobando, então, um universo maior no cálculo da tensão de aderência. A Tabela 3.1 apresenta as expressões sugeridas por ORANGUN et al (1977), Eligehausen ${ }^{1}$ apud HARAJLI et al (1995), KEMP \& WILHELM (1979), DARWIN et al (1992), HARAJLI (1994), e KRSTULOVICOPARA et al (1994), utilizando as respectivas simbologias. Foi utilizada também a expressão presente no ACI 318 (1963). Entre elas, apenas as expressões de HARAJLI (1994) e KRSTULOVIC-OPARA et al (1994) levam em conta a influência das fibras na aderência.

As expressões foram desenvolvidas a partir de análise por regressão não-linear de resultados de ensaios.

$\mathrm{Na}$ realidade, todas as expressões aqui apresentadas, exceto a de Eligehausen (1979), foram derivadas da expressão de ORANGUN et al (1977), que já foi descrita

1 ELIGEHAUSEN, R. (1979). Lapped splices of tensioned deformed bars with straight ends. Schriften-reihe des Deutschen Ausschusses fur Stahlbeton, Berlim, 1979 (Alemanha), apud HARAJLI et al (1995). 
no Capítulo 2, mudando-se os coeficientes para levar em conta as condições de ensaio e parâmetros diferentes.

A expressão proposta por KRSTULOVIC-OPARA et al (1994) teve a intenção de mostrar a importância da resistência do concreto à tração e da tenacidade da matriz de concreto no cálculo da tensão de aderência. Os autores ressaltaram que foi desenvolvido um modelo simples, cujo objetivo foi apenas indicar a importância das propriedades citadas, e que a expressão não deveria ser usada como uma alternativa de dimensionamento.

Tabela 3.1 - Expressões para o cálculo da tensão de aderência.

\begin{tabular}{|c|c|}
\hline Autor(es) & Expressão \\
\hline $\begin{array}{l}\text { ORANGUN et al } \\
\text { (1977) }\end{array}$ & $\begin{array}{l}\mathrm{u}=\left[1,2+3 \frac{\mathrm{c}}{\mathrm{d}_{\mathrm{b}}}+50 \cdot \frac{\mathrm{d}_{\mathrm{b}}}{\ell_{\mathrm{d}}}+\mathrm{K}_{\mathrm{tr}}\right] \cdot \sqrt{\mathrm{f}_{\mathrm{c}}^{\prime}} \\
\mathrm{K}_{\mathrm{tr}}=\frac{\mathrm{A}_{\mathrm{tr}} \cdot \mathrm{f}_{\mathrm{yt}}}{500 \cdot \mathrm{s} \cdot \mathrm{d}_{\mathrm{b}}} \leq 3\end{array}$ \\
\hline Eligehausen (1979) & $\mathrm{u}_{\mathrm{s}}=1,5 \cdot \sqrt{\frac{\mathrm{c}}{\mathrm{d}_{\mathrm{b}}}} \cdot \mathrm{f}_{\mathrm{ct}}$ \\
\hline $\begin{array}{c}\text { KEMP \& } \\
\text { WILHELM (1979) }\end{array}$ & $u_{v}=\left[1,64+2,9 \cdot \frac{c}{d_{b}}\right] \cdot \sqrt{f_{c}^{\prime}}+95,5 \cdot K_{t r}$ \\
\hline $\begin{array}{l}\text { DARWIN et al } \\
\qquad(1992)\end{array}$ & $\mathrm{u}=\left[2,12 \cdot\left(\frac{\mathrm{c}}{\mathrm{d}_{\mathrm{b}}}+0,5\right) \cdot\left(0,92+0,08 \cdot \frac{\mathrm{c}_{\text {máx }}}{\mathrm{c}_{\text {mín }}}\right)+75 \cdot \frac{\mathrm{d}_{\mathrm{b}}}{\ell_{\mathrm{d}}}\right] \cdot \sqrt{\mathrm{f}_{\mathrm{c}}^{\prime}}$ \\
\hline HARAJLI (1994) & $\begin{array}{l}\mathrm{u}=\left[1,2+3 \cdot \frac{\mathrm{c}}{\mathrm{d}_{\mathrm{b}}}+50 \cdot \frac{\mathrm{d}_{\mathrm{b}}}{\ell_{\mathrm{d}}}+\mathrm{K}_{\mathrm{tr}}+\frac{1}{25} \cdot\left(\mathrm{K}_{\mathrm{f}}-50\right)\right] \cdot \sqrt{\mathrm{f}_{\mathrm{c}}^{\prime}} \\
\mathrm{K}_{\mathrm{f}}=\left(\mathrm{V}_{\mathrm{f}} \cdot l / \mathrm{d}\right) \cdot\left(\frac{\mathrm{c}}{\mathrm{d}_{\mathrm{b}}}\right) \cdot\left(\frac{l_{\mathrm{d}}}{\mathrm{d}_{\mathrm{b}}}\right) \geq 50\end{array}$ \\
\hline $\begin{array}{c}\text { KRSTULOVIC- } \\
\text { OPARA et al (1994) }\end{array}$ & $u=\left(0,5+0,89 \cdot \frac{c}{d_{b}}\right) \cdot f_{t}+\left(1,2+0,83 \cdot \frac{c}{d_{b}}\right) \cdot \sqrt[3]{T_{t}}$ \\
\hline $\begin{array}{c}\text { ACI } 318(1963 \mathrm{a} \\
1983)\end{array}$ & $\mathrm{u}=\frac{9,5}{\mathrm{~d}_{\mathrm{b}}} \cdot \sqrt{\mathrm{f}_{\mathrm{c}}^{\prime}} \leq 800 \mathrm{psi} \quad(5,5 \mathrm{MPa})$ \\
\hline
\end{tabular}

onde: $\mathrm{f}_{\mathrm{ct}}=\mathrm{f}_{\mathrm{t}}=$ resistência do concreto à tração;

$\mathrm{c}_{\text {máx }}=$ cobrimento máximo;

$\mathrm{c}_{\text {mín }}=$ cobrimento mínimo; 
$\mathrm{T}_{\mathrm{t}}=$ coeficiente de tenacidade da matriz reforçada com fibras (MPa).

Foi escolhida, também, a equação para a tensão última de aderência presente em versões mais antigas do ACI 318. Essa expressão apareceu pela primeira vez no ACI 318 (1963). Porém, no ACI 318 (1989) ela foi retirada, e o dimensionamento da aderência passou a se basear, apenas, no cálculo do comprimento de ancoragem necessário, que supunha uma tensão de aderência média, constante, e a favor da segurança. Essa é a filosofia vigente no ACI 318 até os dias atuais, tanto para o concreto armado, como para o concreto protendido.

Nota-se que o cobrimento, o espaçamento entre as barras, o diâmetro da barra, o comprimento aderente, a presença ou não de armadura transversal, e a resistência do concreto à compressão são os principais parâmetros adotados.

O cálculo da tensão de aderência, pela equação proposta por HARAJLI (1994), só leva em consideração a influência das fibras, quando o valor de $\mathrm{K}_{\mathrm{f}}$ é superior a 50 . Para valores de $\mathrm{K}_{\mathrm{f}}<50$, a equação recai na proposta por ORANGUN et al (1977). Usando os parâmetros adotados nesta pesquisa, tem-se:

- $3,62 \leq \mathrm{K}_{\mathrm{f}} \leq 11,29$.

Logo, teoricamente, segundo HARAJLI (1994), as fibras não influenciariam na aderência, e as sete expressões apresentadas se resumiriam a seis. Nesta pesquisa, mantendo-se os demais parâmetros constantes, para um fator de forma $\ell / \mathrm{d}=45, \mathrm{~K}_{\mathrm{f}}$ só ultrapassaria 50 para um consumo de fibras de $V_{\mathrm{f}} \geq 267 \mathrm{~kg} / \mathrm{m}^{3}(3,4 \%)$ para $\ell_{\mathrm{ef}}=$ $15 \phi_{\mathrm{p}}$, ou $\mathrm{V}_{\mathrm{f}} \geq 557 \mathrm{~kg} / \mathrm{m}^{3}(7,1 \%)$ para $\ell_{\mathrm{ef}}=7 \phi_{\mathrm{p}}$.

Já a expressão de KRSTULOVIC-OPARA et al (1994), que leva em conta a tenacidade, apresenta valores maiores para a tensão de aderência, em comparação à matriz sem fibras, mesmo para teores pequenos de fibra. Os autores, para o cálculo da tenacidade, levam em conta toda a área sob o diagrama Carga versus Deslocamento, até a ruptura. Neste trabalho foi adotado o processo de cálculo sugerido pela norma japonesa JSCE-SF4 (1984), que leva em conta a área sob o diagrama até um valor do deslocamento equivalente a $1 / 3$ do vão. Isso porém, neste caso, não levou a diferenças muito grandes na determinação do coeficiente de tenacidade. Para o concreto sem fibras, desprezando-se o valor da tenacidade $\left(T_{t}=0\right)$, a equação de KRSTULOVIC-OPARA et al (1994) recai numa expressão muito 
parecida com a de KEMP \& WILHELM (1979), para esta última sem a consideração da armadura transversal.

Nos ensaios de arrancamento realizados nesta pesquisa, os prismas não possuíam armadura transversal, portanto $K_{\text {tr }}$ foi tomado como zero para as equações onde aparece esta variável $\left(\mathrm{K}_{\mathrm{tr}}=0\right)$. Para os parâmetros desta pesquisa, $\mathrm{c}_{\text {máx }}=\mathrm{c}_{\text {mín }}$ na expressão de DARWIN et al (1992).

A Tabela 3.2 apresenta os resultados do cálculo da tensão de aderência pelas diversas expressões listadas na Tabela 3.1. Para este estudo, foram considerados os dados dos prismas da Série 1.

Tabela 3.2 - Valores da tensão de aderência para as expressões analisadas.

\begin{tabular}{|c|c|c|c|}
\hline Autor(es) & $\ell_{\mathrm{d}}\left(\mathrm{ou} \ell_{\mathrm{ef}}\right)$ & $V_{f}\left(k g / m^{3}\right)$ & $\begin{array}{c}\mathbf{u}\left(\mathrm{ou} \tau_{\mathrm{b}}\right) \\
(\mathrm{MPa})\end{array}$ \\
\hline \multirow{2}{*}{ ORANGUN et al (1977) } & $7 \phi_{\mathrm{p}}$ & \multirow{2}{*}{--- } & 10,35 \\
\hline & $15 \phi_{\mathrm{p}}$ & & 7,77 \\
\hline \multirow{3}{*}{ Eligehausen (1979) } & \multirow{3}{*}{--- } & 0 & 9,23 \\
\hline & & 40 & 10,13 \\
\hline & & 60 & 11,48 \\
\hline KEMP \& WILHELM (1979) & --- & --- & 5,59 \\
\hline \multirow{2}{*}{ DARWIN et al (1992) } & $7 \phi_{\mathrm{p}}$ & \multirow{2}{*}{---} & 11,34 \\
\hline & $15 \phi_{\mathrm{p}}$ & & 7,48 \\
\hline \multirow{6}{*}{ HARAJLI (1994) } & \multirow{3}{*}{$7 \phi_{\mathrm{p}}$} & 0 & \multirow{3}{*}{10,35} \\
\hline & & 40 & \\
\hline & & 60 & \\
\hline & \multirow{3}{*}{$15 \phi_{\mathrm{p}}$} & 0 & \multirow{3}{*}{7,77} \\
\hline & & 40 & \\
\hline & & 60 & \\
\hline \multirow{3}{*}{$\begin{array}{l}\text { KRSTULOVIC-OPARA et al } \\
\text { (1994) }\end{array}$} & \multirow{3}{*}{--- } & 0 & 11,27 \\
\hline & & 40 & 13,54 \\
\hline & & 60 & 15,94 \\
\hline ACI 318 (1963 a 1983) & --- & --- & 5,50 \\
\hline
\end{tabular}


Esses valores para a tensão de aderência foram comparados aos valores fornecidos pelas NBR 6118 (2001) e FIB Bulletin 1 (1999), que também foram resultantes de ensaios de arrancamento com cordoalhas não-protendidas. Essa análise encontra-se no item 3.3 deste capítulo.

Percebe-se que há uma variação muito grande nos valores encontrados, $\tau_{\text {bmín }}=5,50 \mathrm{MPa}(\mathrm{ACI} 318)$ e $\tau_{\text {bmáx }}=11,34 \mathrm{MPa}$ (DARWIN et al, 1992) para os concretos sem fibras, e $\tau_{\text {bmáx }}=15,94 \mathrm{MPa}$ (KRSTULOVIC-OPARA et al, 1994) para os CRFA. Isso se deve ao fato de que os diversos pesquisadores utilizaram condições e parâmetros de ensaio diferentes, para obterem as equações, como já foi citado anteriormente. Uma das diferenças principais está no arranjo de ensaio, já que alguns pesquisadores utilizaram o modelo tradicional de arrancamento, com o concreto comprimido (Figura 2.15), e outros utilizaram o modelo baseado no da Norma Dinamarquesa, que trabalha com o concreto tracionado (Figura 2.17). O valor mínimo dado pelo ACI 318 é, na verdade, um limite máximo de projeto imposto pelo código. Caso fossem calculados os valores pela fórmula apresentada, para $\mathrm{f}_{\mathrm{c}}>20 \mathrm{MPa}$ os valores da tensão de aderência ultrapassariam o limite de 5,5MPa.

Rearrumando as expressões da Tabela 3.1 para levar em conta os parâmetros desta pesquisa, e utilizando a simbologia adotada neste trabalho, chega-se às expressões listadas na Tabela 3.3.

Os gráficos seguintes apresentam uma comparação entre as expressões analisadas, para os diversos parâmetros (Figuras 3.7 a 3.10). Para cada gráfico, variou-se o parâmetro escolhido, e manteve-se todos os demais constantes, utilizando os valores adotados nesta pesquisa.

Pelo gráfico da Figura 3.7, à medida que vai aumentando o valor da resistência do concreto à compressão, vão aumentando as diferenças entre o maior e o menor valor, dados pelas expressões. Excluindo-se a equação de KRSTULOVIC-OPARA et al (1994) que leva em conta as fibras, a equação de DARWIN et al (1992) para $\ell_{\mathrm{ef}}=7 \phi_{\mathrm{p}}$ fornece os maiores valores para a tensão de aderência entre, aproximadamente, $15 \mathrm{MPa} \leq \mathrm{f}_{\mathrm{c}} \leq 40 \mathrm{MPa}$, a partir desse ponto, a equação proposta por KRSTULOVIC-OPARA et al (1994), sem levar em conta as fibras, passa a fornecer os maiores valores. As equações propostas por KEMP \& WILHELM (1979) e ACI 318 (1963), para $f_{c} \geqslant 35 \mathrm{MPa}$, fornecem os menores valores para a tensão de 
aderência. Isso é uma constante para todos os gráficos. De maneira geral, as equações com mesmos comprimentos de ancoragem disponíveis $\left(\ell_{\mathrm{ef}}\right)$ apresentam valores mais próximos. Isso não vale, obviamente, para as expressões onde o comprimento aderente não é levado em conta no cálculo da tensão de aderência.

Tabela 3.3 - Expressões adaptadas para esta pesquisa.

\begin{tabular}{|c|c|c|}
\hline & Autor(es) & Expressões adaptadas \\
\hline \multirow{6}{*}{$\begin{array}{l}\text { Concreto } \\
\text { sem } \\
\text { fibras }\end{array}$} & $\begin{array}{c}\text { ORANGUN et al } \\
\text { (1977) e HARAJLI } \\
\text { (1994) }\end{array}$ & $\tau_{\mathrm{b}}=\left[1,2+3 \frac{\mathrm{c}}{\phi}+50 \cdot \frac{\phi}{\ell_{\mathrm{ef}}}\right] \cdot \sqrt{\mathrm{f}_{\mathrm{c}}}$ \\
\hline & Eligehausen (1979) & $\tau_{\mathrm{bs}}=1,5 \cdot \sqrt{\frac{\mathrm{c}}{\tau}} \cdot \mathrm{f}_{\mathrm{ct}}$ \\
\hline & $\begin{array}{l}\text { KEMP \& WILHELM } \\
\qquad(1979)\end{array}$ & $\tau_{\mathrm{bv}}=\left[1,64+2,9 \cdot \frac{\mathrm{c}}{\phi}\right] \cdot \sqrt{\mathrm{f}_{\mathrm{c}}}$ \\
\hline & DARWIN et al (1992) & $\tau_{\mathrm{b}}=\left[1,06+2,12 \cdot \frac{\mathrm{c}}{\phi}+75 \cdot \frac{\phi}{\ell_{\mathrm{ef}}}\right] \cdot \sqrt{\mathrm{f}_{\mathrm{c}}}$ \\
\hline & $\begin{array}{c}\text { KRSTULOVIC- } \\
\text { OPARA et al (1994) }\end{array}$ & $\tau_{\mathrm{b}}=\left(0,5+0,89 \cdot \frac{\mathrm{c}}{\phi}\right) \cdot \mathrm{f}_{\mathrm{ct}}$ \\
\hline & ACI 318 (1963 a 1983) & $\tau_{\mathrm{b}}=\frac{9,5}{\phi} \cdot \sqrt{\mathrm{f}_{\mathrm{c}}} \leq 800 \mathrm{psi} \quad(5,5 \mathrm{MPa})$ \\
\hline \multirow{2}{*}{ CRFA } & HARAJLI (1994) & $\tau_{\mathrm{b}}=\left[1,2+3 \cdot \frac{\mathrm{c}}{\phi}+50 \cdot \frac{\phi}{\ell_{\mathrm{ef}}}+\frac{1}{25} \cdot\left(\mathrm{K}_{\mathrm{f}}-50\right)\right] \cdot \sqrt{\mathrm{f}_{\mathrm{c}}}$ \\
\hline & $\begin{array}{c}\text { KRSTULOVIC- } \\
\text { OPARA et al (1994) }\end{array}$ & $\tau_{\mathrm{b}}=\left(0,5+0,89 \cdot \frac{\mathrm{c}}{\phi}\right) \cdot \mathrm{f}_{\mathrm{ct}}+\left(1,2+0,83 \cdot \frac{\mathrm{c}}{\phi}\right) \cdot \sqrt[3]{\overline{\sigma_{\mathrm{b}}}}$ \\
\hline
\end{tabular}

Pelo gráfico da Figura 3.8, observa-se que apenas a equação proposta por Eligehausen (1979) não apresenta uma resposta linear em relação ao parâmetro (c/ $\phi)$, e sim uma variação em relação à raiz quadrada deste valor $(\sqrt{(\mathrm{c} / \phi)})$. Para as demais, não há muita variação na diferença entre os maiores e os menores resultados, com a variação da razão (c/ $\phi)$, exceto para as expressões de KRSTULOVIC-OPARA et al (1994) com fibra. 


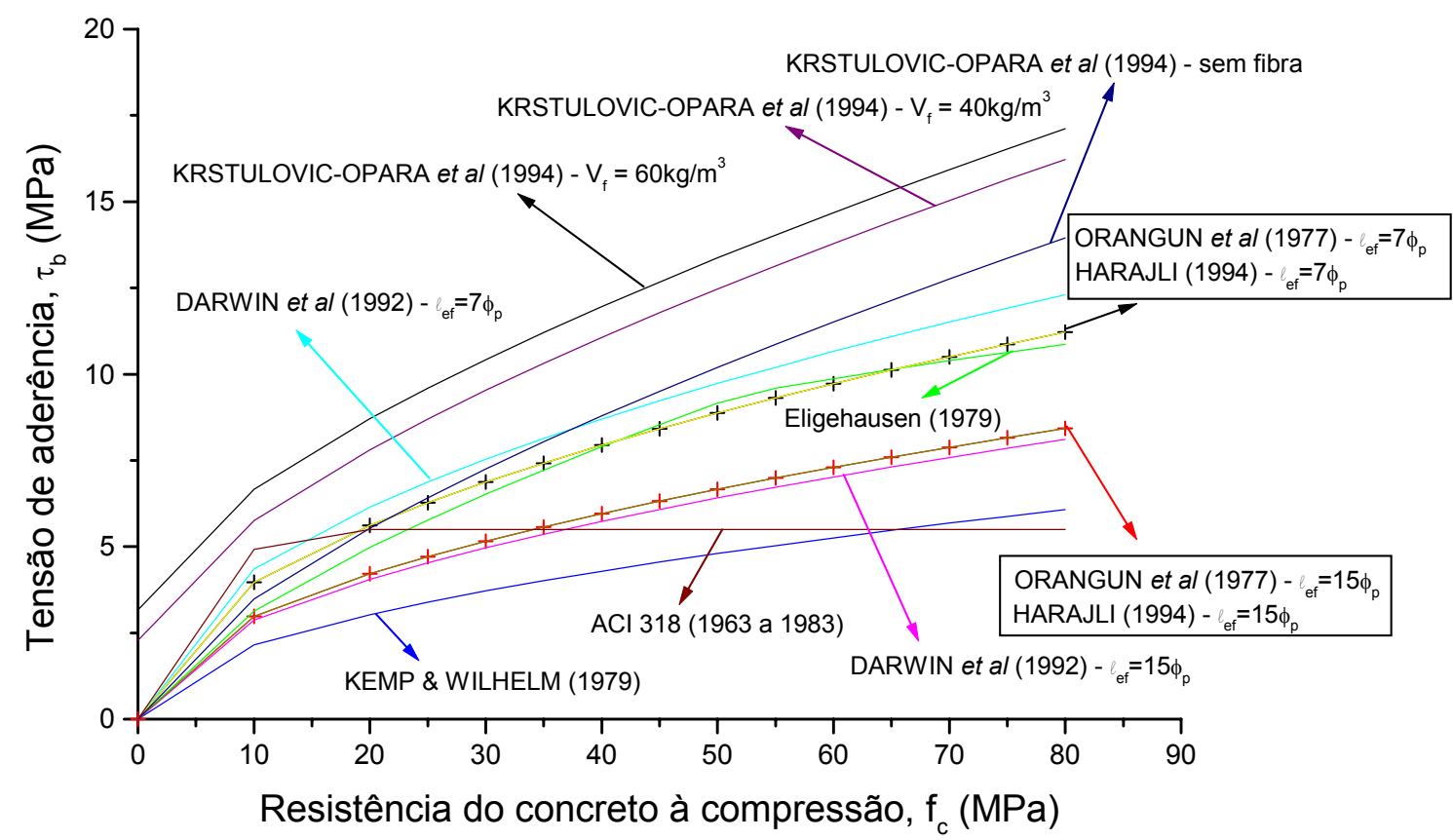

Figura 3.7 - Gráfico Tensão de aderência versus Resistência do concreto à compressão.

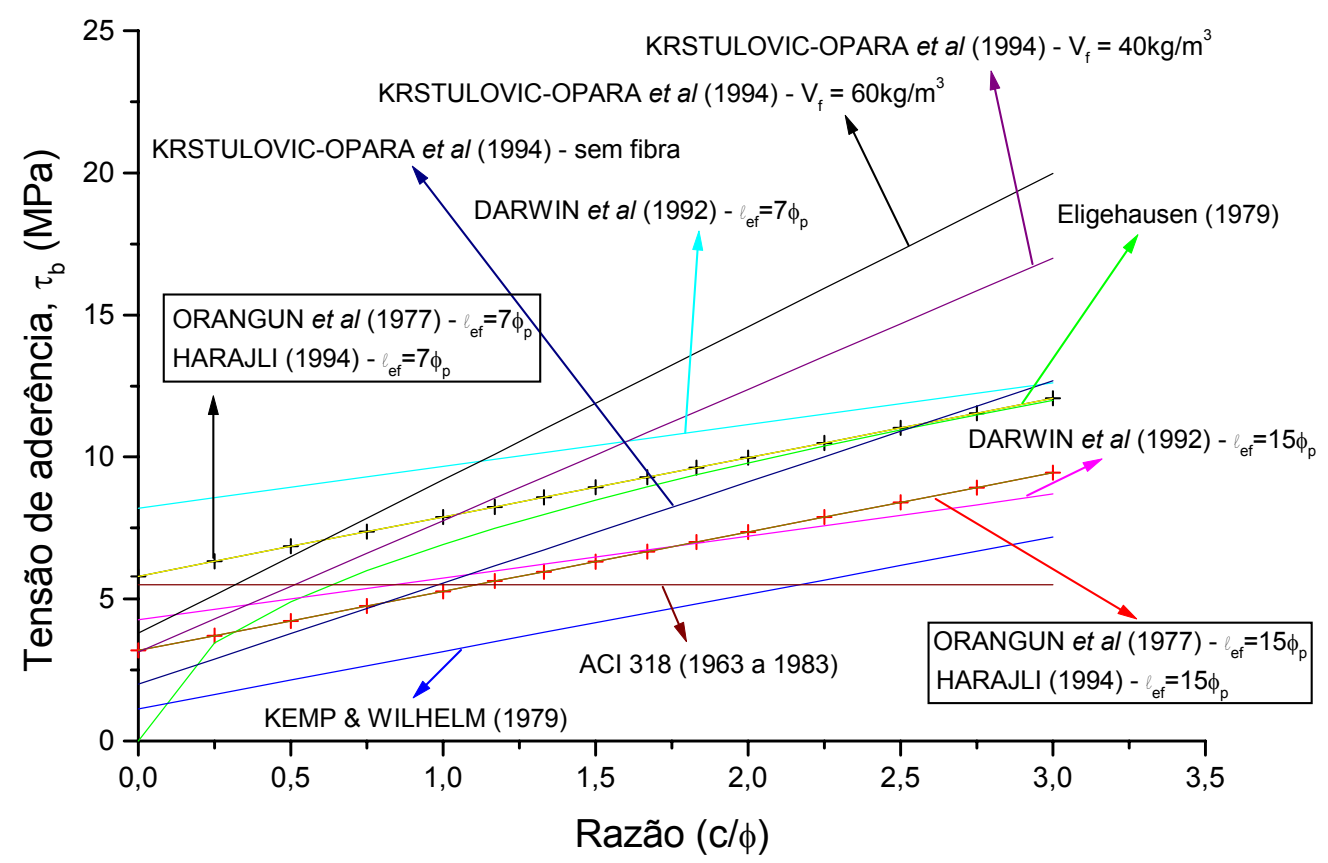

Figura 3.8 - Gráfico Tensão de aderência versus Razão entre o cobrimento e o diâmetro da barra.

Pelo gráfico da Figura 3.9, nota-se que apenas nas expressões propostas por ORANGUN et al (1977), DARWIN et al (1992), e HARAJLI (1994) o comprimento de ancoragem disponível $\ell_{\text {ef }}$ interfere no cálculo da tensão de aderência, o que é refletido nas expressões. A diferença entre as expressões de ORANGUN et al (1977) 
e HARAJLI (1994) em relação à de DARWIN et al (1992) aumenta com o aumento da razão $\left(\phi / \ell_{\mathrm{ef}}\right)$. Percebe-se, também, que quanto menor o comprimento aderente para um mesmo diâmetro, ou seja, quanto maior a razão $\left(\phi / \ell_{\mathrm{ef}}\right)$, maior será a tensão de aderência, o que já foi observado anteriormente.

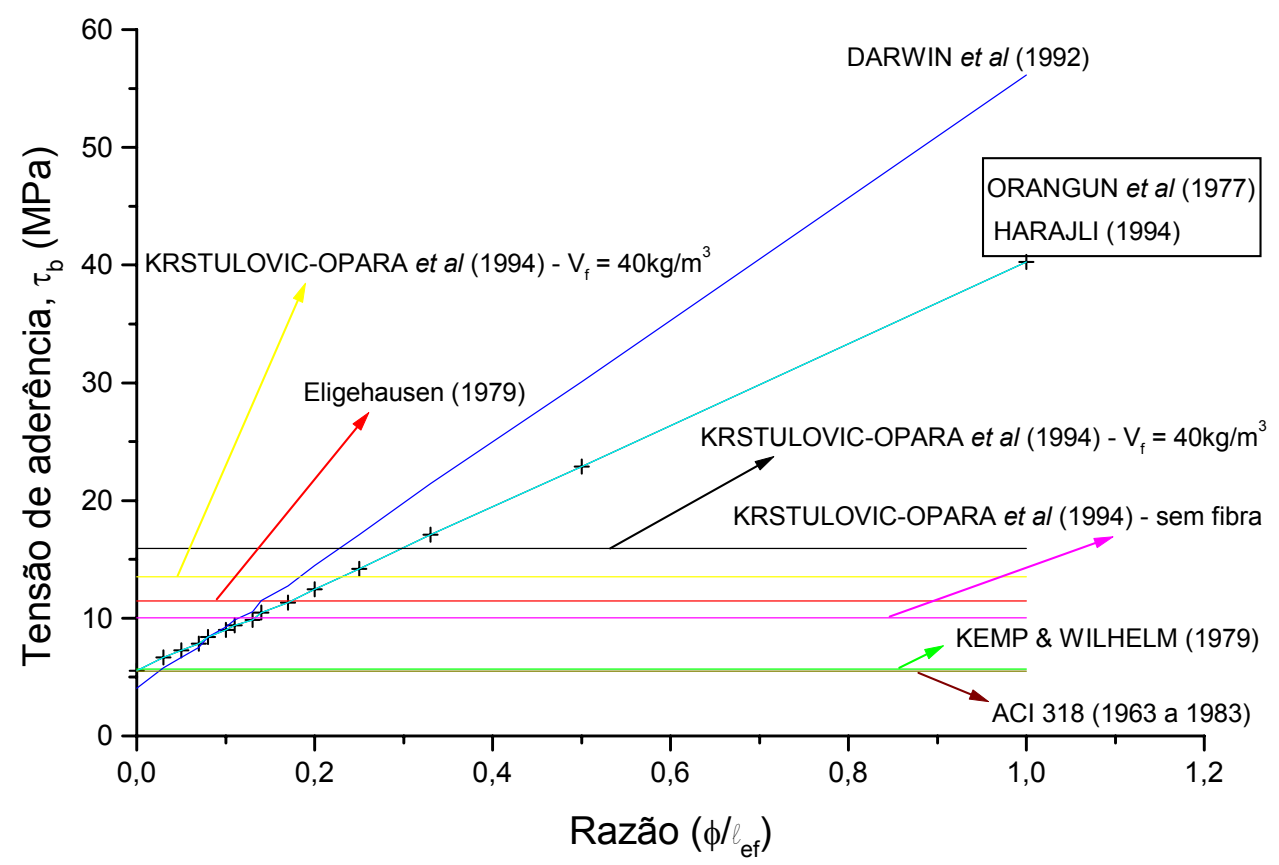

Figura 3.9 - Gráfico Tensão de aderência versus Razão entre o diâmetro da barra e o comprimento aderente.

Por fim, pelo gráfico da Figura 3.10, pode-se dizer que a tensão de aderência aumenta, com o aumento do coeficiente $K_{\mathrm{f}}$, proposto por HARAJLI (1994). Esse aumento de $\mathrm{K}_{\mathrm{f}}$ tanto pode representar um aumento no volume de fibras, como um aumento no fator de forma. Apenas para este último gráfico, há diferença entre as expressões de ORANGUN et al (1977) e de HARAJLI (1994), para valores de $\mathrm{K}_{\mathrm{f}}>50$. Os valores obtidos da expressão de KRSTULOVIC-OPARA et al (1994), levando em conta as fibras, apesar de não serem afetados diretamente pelo coeficiente $\mathrm{K}_{\mathrm{f}}$, são superiores aos valores sugeridos por HARAJLI (1994), principalmente para um consumo de fibra de $\mathrm{V}_{\mathrm{f}}=60 \mathrm{~kg} / \mathrm{m}^{3}$. Para $\mathrm{V}_{\mathrm{f}}=40 \mathrm{~kg} / \mathrm{m}^{3}$, a partir de $\mathrm{K}_{\mathrm{f}} \cong 90$ a expressão de HARAJLI (1994) para $\ell_{\mathrm{ef}}=5 \phi_{\mathrm{p}}$ passa a apresentar valores maiores. 


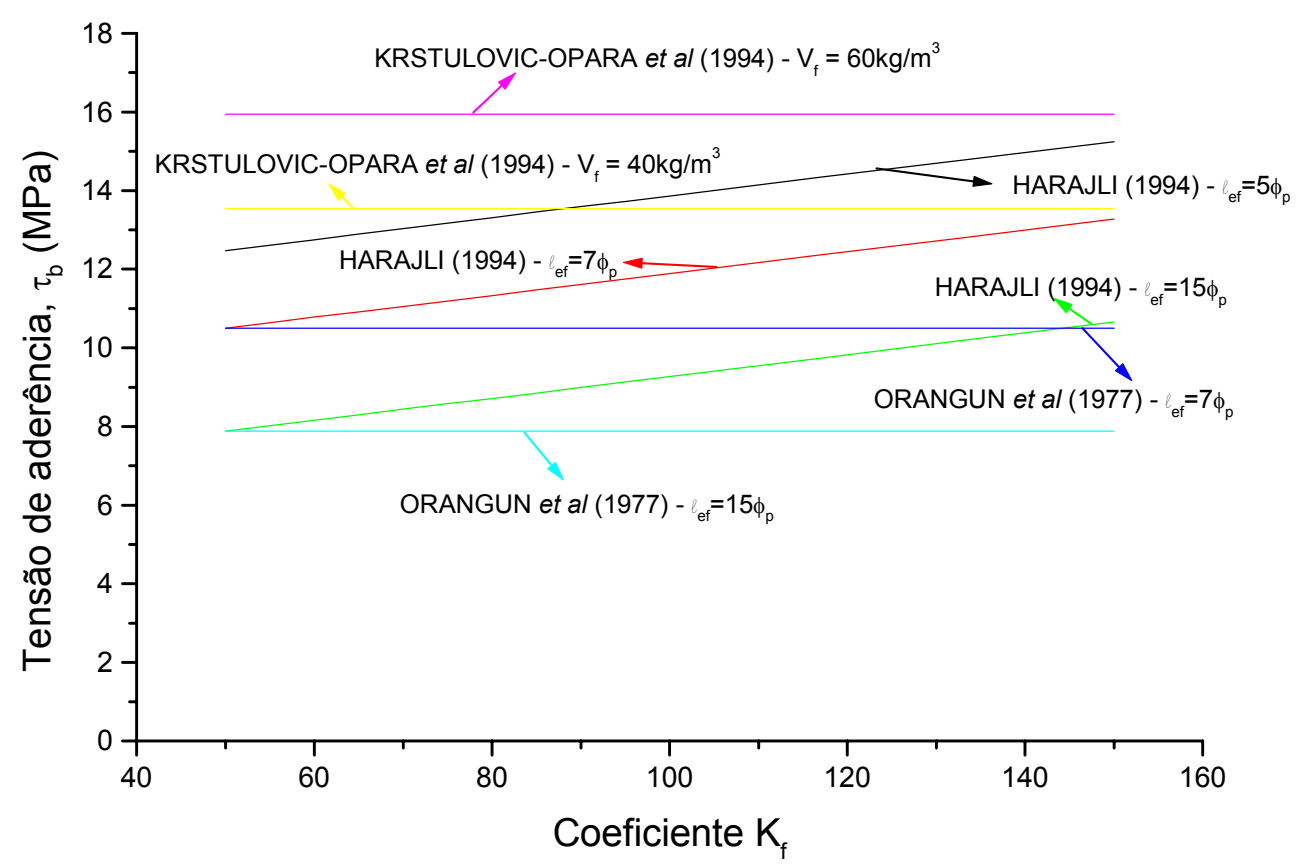

Figura 3.10 - Gráfico Tensão de aderência versus Coeficiente $\mathrm{K}_{\mathrm{f}}$, que leva em conta a influência das fibras.

De maneira geral, pode-se dizer que, para todas as expressões, a tensão de aderência cresce com o aumento da resistência do concreto à compressão, das razões $(\mathrm{c} / \phi)$ e $\left(\phi / \ell_{\mathrm{ef}}\right)$, e com a presença de fibras de aço, especialmente para valores de $\mathrm{K}_{\mathrm{f}}>50$. Percebe-se, também, que quanto menor o comprimento aderente utilizado, para cada expressão, maior será a tensão de aderência resultante. A expressão proposta por KRSTULOVIC-OPARA et al (1994), que leva em conta a tenacidade fornecida pelas fibras para $\mathrm{V}_{\mathrm{f}}=60 \mathrm{~kg} / \mathrm{m}^{3}$, apresenta-se acima de todas as outras. Isso se deve ao fato de que esta equação tem a intenção de caracterizar materiais que apresentem encruamento, ou seja, um ganho de resistência após a primeira fissura, como os concretos de alto desempenho reforçados com fibras de aço. Nestes materiais o volume de fibras usado é bem superior aos volumes críticos. KRSTULOVIC-OPARA et al (1994) utilizaram quatro volumes de fibras: zero, 1\%, $3 \%$ e $7 \%$.

Não só para os valores de tensão de aderência apresentados na Tabela 3.2, como também para as expressões representadas nos gráficos das Figuras 3.7 a 3.10, há uma variação muito grande para a tensão de aderência, mesmo levando-se em conta que a maioria das expressões tem uma origem comum, na expressão de 
ORANGUN et al (1977). Isso, mais uma vez, reforça a idéia da variabilidade dos resultados obtidos nos ensaios de arrancamento.

Os valores fornecidos pela expressão de KEMP \& WILHELM (1979) são, claramente, os mais conservadores.

No capítulo 5, essas expressões são comparadas aos resultados experimentais desta pesquisa.

\subsubsection{Comprimentos de ancoragem}

Para a análise dos comprimentos de ancoragem, foram usados como referência os valores obtidos na retirada da protensão (comprimento de transferência), e nos ensaios de flexão (comprimento de ancoragem necessário), das vigas pré-tracionadas.

Para o cálculo dos comprimentos de ancoragem foram utilizadas, também, algumas expressões obtidas por diversos pesquisadores. São eles: ZIA \& MOSTAFA (1977), COUSINS et al (1990c), SHAHAWY et al (1992), RUSSEL \& BURNS (1993) e DEATHERAGE et al (1994). A Tabela 3.4 apresenta as expressões de cálculo, com as respectivas simbologias, onde:

$\mathrm{f}_{\mathrm{su}}=$ resistência última da armadura ativa à tração;

$\mathrm{f}_{\mathrm{ps}}=$ resistência atuante da armadura ativa à tração;

$\mathrm{d}=$ diâmetro nominal da armadura ativa;

$\mathrm{A}_{\mathrm{s}}=$ área da armadura ativa.

Percebe-se claramente que todas as formulações apresentadas seguem o mesmo tipo de equacionamento, que é proveniente da expressão básica para a tensão de aderência da armadura ativa $\left(\tau_{\mathrm{bp}}\right)$ :

$$
\tau_{\mathrm{bp}}=\frac{\mathrm{A}_{\mathrm{p}} \cdot \Delta \mathrm{f}_{\mathrm{p}}}{\mathrm{u} \cdot \ell_{\mathrm{bp}}}
$$

Rearrumando a equação anterior em função do comprimento de ancoragem $\left(\ell_{\mathrm{bp}}\right)$, tem-se:

$$
\ell_{\mathrm{bp}}=\frac{\mathrm{A}_{\mathrm{p}} \cdot \Delta \mathrm{f}_{\mathrm{p}}}{\mathrm{u} \cdot \tau_{\mathrm{bp}}}=\frac{\mathrm{A}_{\mathrm{p}}\left(\mathrm{f}_{\mathrm{p}, \text { final }}-\mathrm{f}_{\mathrm{p}, \text { inicial }}\right)}{\mathrm{u} \cdot \tau_{\mathrm{bp}}}
$$

$\mathrm{f}_{\mathrm{p}, \text { final }}=$ tensão na armadura ativa no final do período que se está considerando;

$\mathrm{f}_{\mathrm{p}, \text { inicial }}=$ tensão na armadura ativa no início do período que se está considerando; $\mathrm{u}=$ perímetro da seção transversal da armadura ativa. 
Tabela 3.4 - Expressões para o cálculo dos comprimentos de ancoragem.

\begin{tabular}{|c|c|c|}
\hline Autor(es) & Comprimento de transferência & $\begin{array}{c}\text { Comprimento de ancoragem } \\
\text { necessário }\end{array}$ \\
\hline $\begin{array}{c}\text { ZIA \& } \\
\text { MOSTAFA } \\
(1977)\end{array}$ & $\mathrm{L}_{\mathrm{t}}=1,5 \frac{\mathrm{f}_{\mathrm{si}}}{\mathrm{f}_{\mathrm{ci}}^{\prime}} \mathrm{d}_{\mathrm{b}}-4,6$ & $\mathrm{~L}_{\mathrm{d}}=1,5 \frac{\mathrm{f}_{\mathrm{si}}}{\mathrm{f}_{\mathrm{ci}}^{\prime}} \mathrm{d}_{\mathrm{b}}-4,6+1,25\left(\mathrm{f}_{\mathrm{su}}-\mathrm{f}_{\mathrm{se}}\right) \mathrm{d}_{\mathrm{b}}$ \\
\hline $\begin{array}{l}\text { COUSINS et al } \\
\qquad \begin{array}{l}(1990 \mathrm{c}) \\
(\mathrm{em} \text { psi })\end{array}\end{array}$ & $\mathrm{L}_{\mathrm{t}}=0,5\left(\frac{6,7 \sqrt{\mathrm{f}_{\mathrm{ci}}^{\prime}}}{300}\right)+\frac{\mathrm{f}_{\mathrm{se}} \cdot \mathrm{A}_{\mathrm{s}}}{\pi \cdot \mathrm{d} \cdot 6,7 \sqrt{\mathrm{f}_{\mathrm{ci}}^{\prime}}}$ & $\begin{aligned} \mathrm{L}_{\mathrm{d}}= & 0,5\left(\frac{6,7 \sqrt{\mathrm{f}_{\mathrm{ci}}^{\prime}}}{300}\right)+\frac{\mathrm{f}_{\mathrm{se}} \cdot \mathrm{A}_{\mathrm{s}}}{\pi \cdot \mathrm{d} \cdot 6,7 \sqrt{\mathrm{f}_{\mathrm{ci}}^{\prime}}}+ \\
& +\left(\mathrm{f}_{\mathrm{ps}}-\mathrm{f}_{\mathrm{se}}\right)\left(\frac{\mathrm{A}_{\mathrm{s}}}{\pi \cdot \mathrm{d} \cdot 1,32 \sqrt{\mathrm{f}_{\mathrm{c}}^{\prime}}}\right)\end{aligned}$ \\
\hline $\begin{array}{c}\text { SHAHAWY et } \\
\text { al (1992) }\end{array}$ & $\ell_{\mathrm{t}}=\frac{\mathrm{f}_{\mathrm{si}}}{3} \mathrm{~d}_{\mathrm{b}}$ & ----- \\
\hline $\begin{array}{c}\text { RUSSEL \& } \\
\text { BURNS (1993) }\end{array}$ & $\mathrm{L}_{\mathrm{t}}=\frac{\mathrm{f}_{\mathrm{se}}}{2} \mathrm{~d}_{\mathrm{b}}$ & ----- \\
\hline $\begin{array}{l}\text { DEATHERAGE } \\
\text { et al (1994) }\end{array}$ & $\mathrm{L}_{\mathrm{t}}=\frac{\mathrm{f}_{\mathrm{si}}}{3} \mathrm{~d}_{\mathrm{b}}$ & $\mathrm{L}_{\mathrm{d}}=\frac{\mathrm{f}_{\mathrm{si}}}{3} \mathrm{~d}_{\mathrm{b}}+1,5\left(\mathrm{f}_{\mathrm{ps}}-\mathrm{f}_{\mathrm{se}}\right) \mathrm{d}_{\mathrm{b}}$ \\
\hline
\end{tabular}

Pode-se dizer, então, que, o comprimento de ancoragem que se quer é função da variação de tensão na armadura, das propriedades geométricas da armadura e da tensão de aderência. Para as cordoalhas de três e sete fios, devido a sua forma helicoidal, a determinação das suas propriedades geométricas (diâmetro e área da seção transversal) não é direta, ou seja, tem que se fazer algumas correções, tanto no valor obtido pela fórmula da área circular, como no valor nominal do diâmetro. Por causa disso, a relação $\left(\mathrm{A}_{\mathrm{p}} / \mathrm{u}\right)$ é diferente do valor simplificado para as barras lisas, que vale $\left(\phi_{\mathrm{p}} / 4\right)$. As expressões de ZIA \& MOSTAFA (1977) e COUSINS et al (1990c), que trabalham, também, em função da resistência do concreto à compressão, ou seja, admitem uma variação na tensão da aderência em função da resistência do concreto à compressão, apresentam as correções das propriedades geométricas na suas formulações. As outras três expressões apresentadas admitem a relação $\left(\phi_{\mathrm{p}} / 4\right)$, e consideram um valor médio e constante para a tensão de aderência. As correções 
por conta das propriedades geométricas das armaduras ficam embutidas no valor da tensão de aderência.

Para os comprimentos de transferência, admite-se uma tensão inicial na armadura de $\mathrm{f}_{\mathrm{p} \text {,inicial }}=0$. Para a tensão final, não há um consenso, pode-se trabalhar com a tensão de protensão inicial $\left(\mathrm{f}_{\mathrm{si}}\right)$, antes das perdas, com a tensão após todas as perdas $\left(f_{s e}\right)$, ou ainda levar-se em conta o valor da resistência do concreto à compressão na transferência $\left(\hat{\mathrm{f}}_{\mathrm{ci}}\right)$. Cada pesquisador procurou o valor que melhor se adequava aos seus resultados experimentais. A norma norte-americana, o ACI 318 (2002), trabalha com o valor da tensão após todas as perdas.

Para os comprimentos de ancoragem necessários, a variação da tensão na armadura é, sempre, entre a tensão após todas as perdas e a tensão última admitida. Esta última pode variar um pouco, mas isso não traz diferenças significativas na sua consideração.

A Tabela 3.5 apresenta os valores para os comprimentos de ancoragem, calculados com os parâmetros desta pesquisa.

Tabela 3.5 - Valores para os comprimentos de ancoragem (em metros).

\begin{tabular}{c|c|c}
\hline Autor(es) & $\begin{array}{c}\text { Comprimento de } \\
\text { transferência }\left(\ell_{\text {bpt}}\right)\end{array}$ & $\begin{array}{c}\text { Comprimento de } \\
\text { ancoragem necessário } \\
\left(\ell_{\text {bpd}}\right)\end{array}$ \\
\hline ZIA \& MOSTAFA (1977) & 0,45 & 2,06 \\
\hline COUSINS et al (1990c) & 0,79 & 2,81 \\
\hline SHAHAWY et al $(1992)$ & 0,92 & ----- \\
\hline RUSSEL \& BURNS (1993) & 1,11 & ----- \\
\hline DEATHERAGE et al $(1994)$ & 0,92 & 2,64 \\
\hline
\end{tabular}

Percebe-se que a variação entre os resultados é grande, assim como para a tensão de aderência. Os valores fornecidos por ZIA \& MOSTAFA (1977) são bem inferiores aos demais, o que pode ser função dos parâmetros adotados por eles. Os autores trabalharam com concretos com resistências à compressão entre 2000psi e 8000 psi (14MPa e 55MPa), que são inferiores aos valores desta pesquisa. De qualquer forma, a expressão proposta por esses autores tem sido a base para o dimensionamento apresentado no ACI 318 desde a década de 70. 
Rearrumando as expressões da Tabela 3.4 para levar em conta os parâmetros desta pesquisa, e utilizando a simbologia adotada neste trabalho, chega-se às expressões listadas na Tabela 3.6.

Tabela 3.6 - Expressões adaptadas para esta pesquisa, para os comprimentos de ancoragem.

\begin{tabular}{|c|c|c|}
\hline Autor(es) & Comprimento de transferência $\left(\ell_{\text {bpt }}\right)$ & $\begin{array}{c}\text { Comprimento de ancoragem } \\
\text { necessário }\left(\ell_{\text {bpd }}\right)\end{array}$ \\
\hline $\begin{array}{c}\text { ZIA \& } \\
\text { MOSTAFA } \\
(1977)\end{array}$ & $1,5 \frac{\sigma_{\mathrm{pi}}}{\mathrm{f}_{\mathrm{c}, \text { transf }}} \phi_{\mathrm{p}}-4,6$ & $1,5 \frac{\sigma_{\mathrm{pi}}}{\mathrm{f}_{\mathrm{c}, \text { transf }}} \phi_{\mathrm{p}}-4,6+1,25\left(\mathrm{f}_{\mathrm{ptk}}-\sigma_{\mathrm{p} \infty}\right) \phi_{\mathrm{p}}$ \\
\hline $\begin{array}{l}\text { COUSINS et al } \\
\qquad \begin{array}{l}(1990 \mathrm{c}) \\
(\mathrm{em} \mathrm{psi})\end{array}\end{array}$ & $0,5\left(\frac{6,7 \sqrt{f_{c, \text { transf }}}}{300}\right)+\frac{\sigma_{p \infty} \cdot A_{p}}{\pi \cdot \phi_{p} \cdot 6,7 \sqrt{f_{c, \text { transf }}}}$ & $\ell_{\mathrm{bpt}}+\left(\mathrm{f}_{\mathrm{ps}}-\sigma_{\mathrm{p} \infty}\right)\left(\frac{\mathrm{A}_{\mathrm{p}}}{\pi \cdot \phi_{\mathrm{p}} \cdot 1,32 \sqrt{\mathrm{f}_{\mathrm{c}}}}\right)$ \\
\hline $\begin{array}{l}\text { SHAHAWY et } \\
\text { al (1992) }\end{array}$ & $\frac{\sigma_{\mathrm{pi}}}{3} \phi_{\mathrm{p}}$ & ----- \\
\hline $\begin{array}{c}\text { RUSSEL \& } \\
\text { BURNS (1993) }\end{array}$ & $\frac{\sigma_{\mathrm{p} \infty}}{2} \phi_{\mathrm{p}}$ & ----- \\
\hline $\begin{array}{l}\text { DEATHERAGE } \\
\text { et al (1994) }\end{array}$ & $\frac{\sigma_{\mathrm{pi}}}{3} \phi_{\mathrm{p}}$ & $\frac{\sigma_{\mathrm{pi}}}{3} \phi_{\mathrm{p}}+1,5\left(\mathrm{f}_{\mathrm{ps}}-\sigma_{\mathrm{p} \infty}\right) \phi_{\mathrm{p}}$ \\
\hline
\end{tabular}

Como já citado, os principais parâmetros levados em conta para o cálculo dos comprimentos de ancoragem são: o diâmetro da armadura, a tensão na armadura ativa após todas as perdas, e a tensão última admitida para a armadura ativa.

Os gráficos seguintes apresentam uma comparação entre as expressões analisadas, para os diversos parâmetros (Figuras 3.11 a 3.13). Para cada gráfico, variou-se o parâmetro escolhido, e mantiveram-se todos os demais constantes, utilizando os valores adotados nesta pesquisa.

Para o gráfico da Figura 3.12, nas fórmulas onde aparece como variável a tensão na armadura após todas as perdas $\left(\sigma_{\mathrm{p} \infty}\right)$, ao invés da tensão inicial de protensão $\left(\sigma_{\mathrm{pi}}\right)$, foi adotada a seguinte relação: $\sigma_{\mathrm{p} \infty}=0,75 . \sigma_{\mathrm{pi}}$.

Para o gráfico da Figura 3.13, admitiu-se que a tensão última na armadura $\left(\mathrm{f}_{\mathrm{pu}}\right)$ era o valor da resistência característica da armadura ativa à tração $\left(f_{\text {ptk }}\right)$, e nas fórmulas onde aparece como variável a resistência atuante da armadura ativa à tração $\left(f_{p s}\right)$, foi adotada a seguinte relação: $f_{p s}=0,95 . f_{p u}$. 


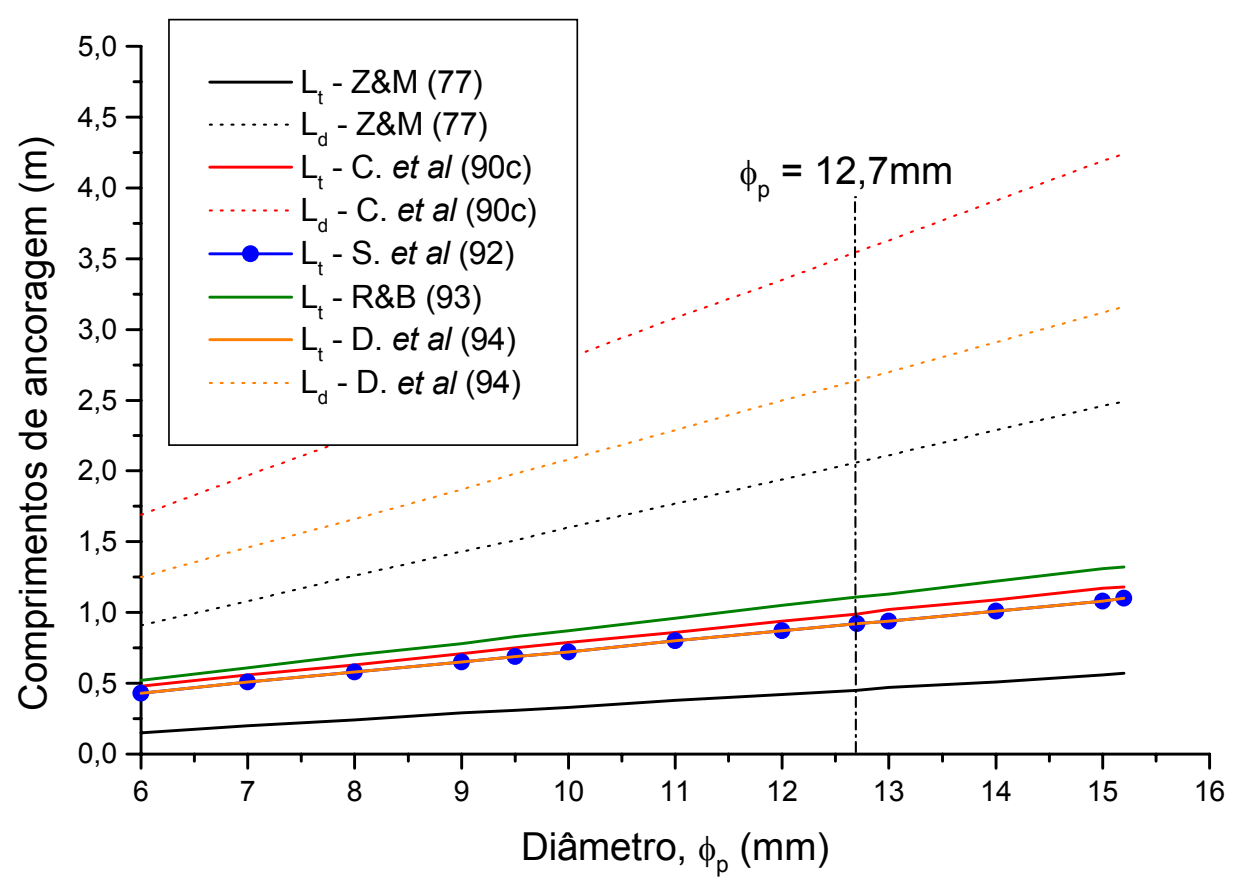

Figura 3.11 - Gráfico Comprimentos de ancoragem versus Diâmetro da armadura.

Para o gráfico da Figura 3.11, os comprimentos de transferência estão indicados com linhas cheias, e os comprimentos de ancoragem necessários com linhas tracejadas. Não foram plotados valores para o diâmetro inferiores a $6 \mathrm{~mm}$ nem superiores a 15,2mm, já que esses são valores limites inferior e superior, respectivamente, para as cordoalhas de três e sete fios encontradas no mercado. Observa-se que as expressões propostas por COUSINS et al (1990c) apresentam os maiores valores, exceto para o comprimento de transferência calculado pela expressão de RUSSEL \& BURNS (1993), pois apesar desses autores terem trabalhado com a tensão após todas as perdas $\left(\sigma_{\mathrm{p} \infty}\right)$, adotaram uma tensão de aderência bem menor $\left(\tau_{\mathrm{bp}}=3,45 \mathrm{MPa}\right)$. Existem duas ressalvas a serem feitas para as expressões de COUSINS et al (1990c): (1) o número da dados utilizados para a obtenção das expressões era pequeno, e os próprios autores sugeriram que mais ensaios deveriam ser feitos e analisados para a obtenção de expressões mais confiáveis; e (2) os coeficientes desenvolvidos para as expressões (os valores de 300, 6,7 e 1,32) foram valores médios que apresentaram um desvio padrão muito elevado. Para as demais formulações, as diferenças se resumem a que tensão de protensão deve ser adotada como parâmetro, se a tensão inicial ou se a tensão final após todas as perdas. Como será visto adiante, as prescrições normativas adotam o valor da 
tensão de protensão após todas as perdas, como o valor de cálculo, o que leva a comprimentos de transferência menores.

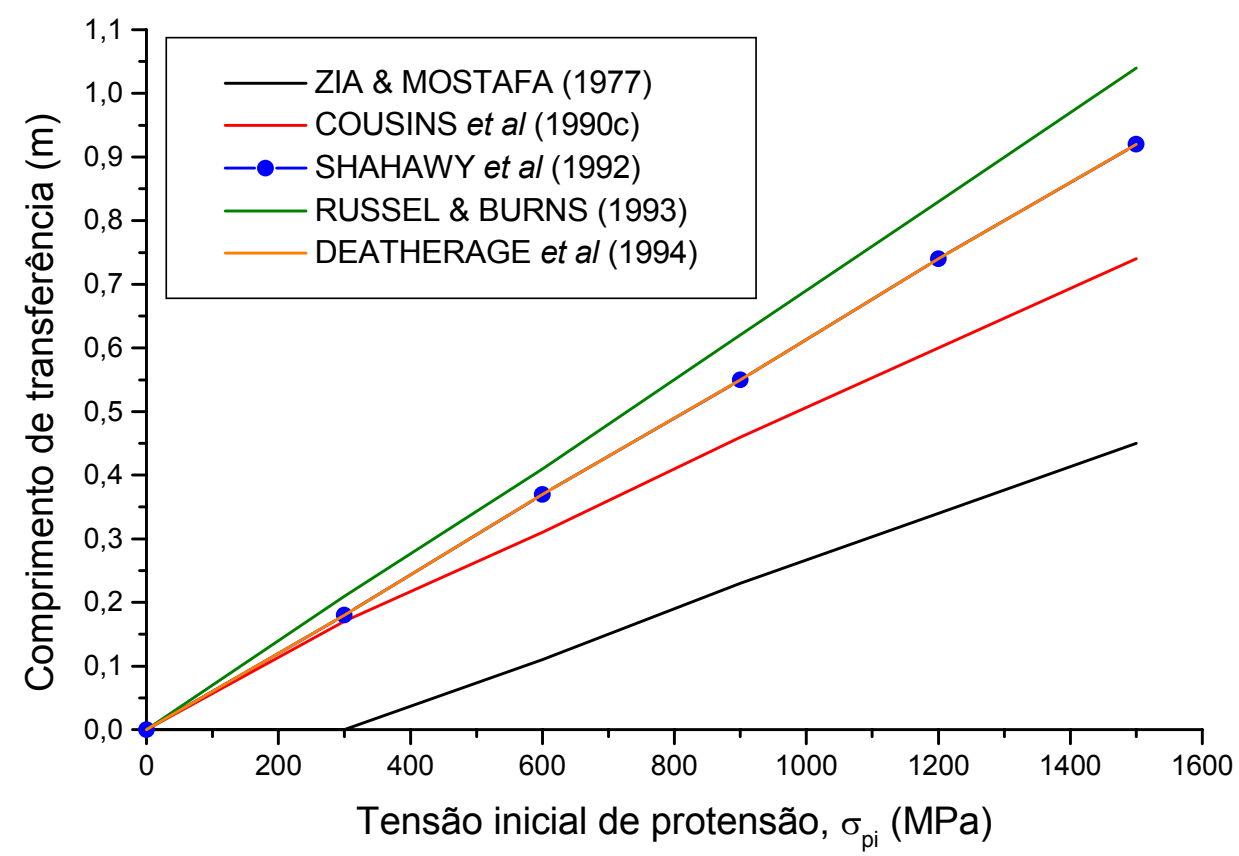

Figura 3.12 - Gráfico Comprimento de transferência versus Tensão inicial de protensão na armadura ativa.

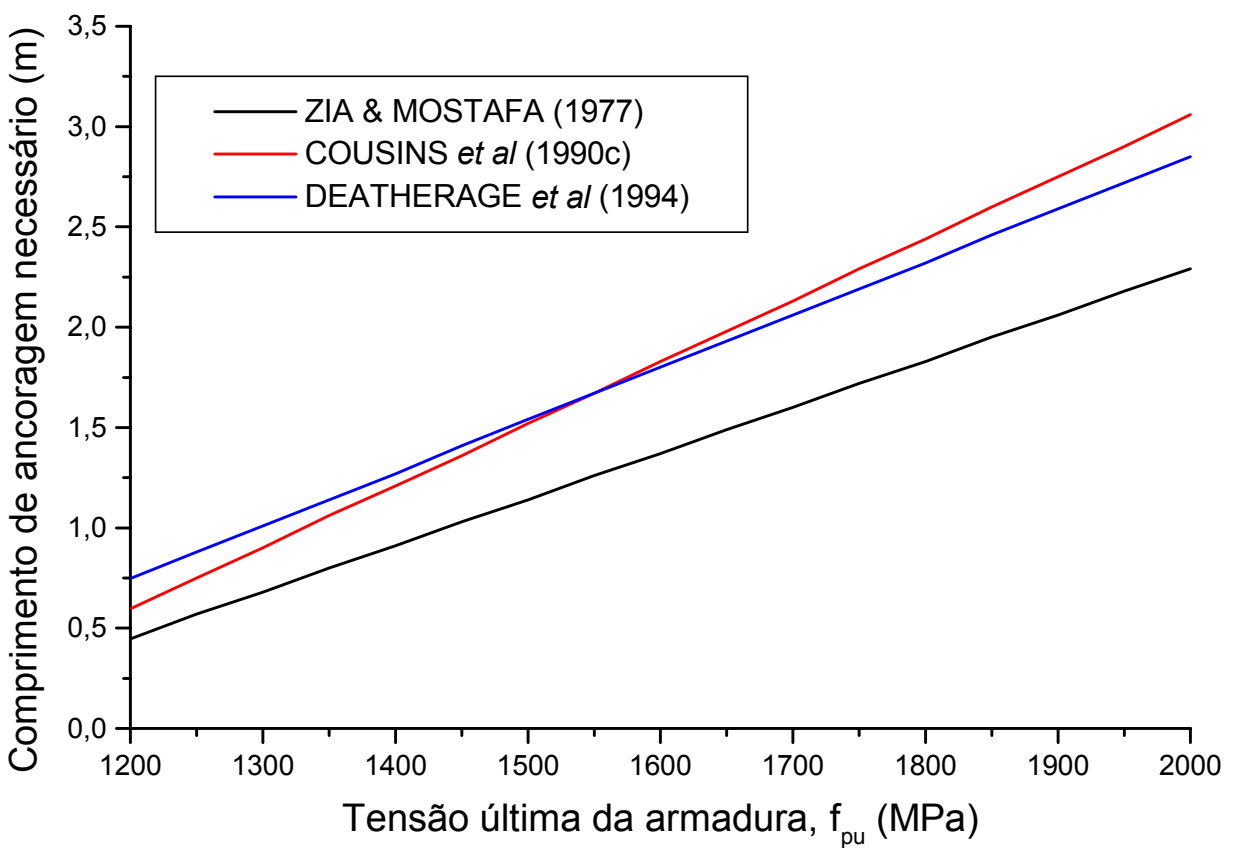

Figura 3.13 - Gráfico Comprimento de ancoragem necessário versus Tensão última admitida para a armadura ativa. 
Para o gráfico da Figura 3.12, observa-se que as diferenças entre as expressões aumentam, com o aumento da tensão inicial de protensão. O valor máximo admitido de $1600 \mathrm{MPa}$ foi tomado como, aproximadamente, $0,85 \mathrm{f}_{\mathrm{ptk}}$, que é um limite superior, a favor da segurança, encontrado na prática para os aços CP 190.

Para o gráfico da Figura 3.13, observa-se, também, que as diferenças entre as expressões aumentam com o aumento da tensão última admitida. Essa variação, porém, é menor que no caso do gráfico anterior. $O$ valor máximo admitido de 2000MPa foi tomado como, aproximadamente, o valor de $f_{\text {ptk }}$, para os aços CP 190.

Confirmando os resultados apresentados na Tabela 3.5, os menores valores são os fornecidos pelas expressões de ZIA \& MOSTAFA (1977).

Percebe-se que quase todas as formulações se baseiam apenas no diâmetro da armadura e nas tensões da armadura ativa, para a determinação dos comprimentos de ancoragem, com exceção das expressões propostas por ZIA \& MOSTAFA (1977) e por COUSINS et al (1990c). Isso se justifica, pois a maioria dos artigos publicados nas revistas do ACI e PCI refletem a abordagem de dimensionamento adotada pelo ACI 318, que não leva em conta, diretamente, nem a resistência do concreto à compressão, e nem, conseqüentemente, a tensão de aderência.

\subsection{Prescrições Normativas}

Foram escolhidos os seguintes códigos e normas, nacionais e internacionais, para serem avaliados: NBR 6118 (2001), ACI 318 (2002), e FIB Bulletin 1 (1999).

As normas brasileiras em vigor não fazem menção ao cálculo dos comprimentos de ancoragem de peças pré-tracionadas. A NBR 6118 (1978) não faz nenhuma referência a esses cálculos, e nem deveria fazer, pois trata apenas de concreto armado, citando apenas a ancoragem das barras passivas. As NBR 7197 (1989) e NBR 9062 (1985), normas de protendido e de pré-moldados respectivamente, também não fazem referência ao assunto, restringindo-se a falar da aderência de peças pós-tracionadas, e, em especial, dos aparelhos e blocos de ancoragem.

A seguir são apresentados os cálculos para a determinação dos comprimentos de transferência e de ancoragem necessário, segundo a NBR 6118 (2001), o ACI 318 (2002), e a FIB Bulletin 1 (1999). Os valores recomendados por eles foram comparados aos obtidos da análise teórica e da experimental (Capítulos 5 e 6). Os 
cálculos completos dos comprimentos de ancoragem pelos diversos códigos e normas citados se encontram no Apêndice C.

\subsubsection{NBR 6118 (2001)}

A NBR 6118 (2001), sem valor normativo e em processo de Consulta Pública, adota as recomendações da FIB Bulletin 1 (1999) para a determinação dos comprimentos de ancoragem. Ela estabelece que o comprimento de ancoragem básico $\left(\ell_{\mathrm{bp}}\right)$ para cordoalhas de três ou sete fios pré-tracionadas e pré-aderentes será dado pela seguinte expressão:

$$
\begin{aligned}
& \ell_{\mathrm{bp}}=\frac{7 \cdot \phi_{\mathrm{p}}}{36} \cdot \frac{\mathrm{f}_{\mathrm{pyd}}}{\mathrm{f}_{\mathrm{bpd}}} \\
& \mathrm{f}_{\mathrm{bpd}}=\eta_{\mathrm{p} 1} \cdot \eta_{\mathrm{p} 2} \cdot \mathrm{f}_{\mathrm{ctd}} \quad \mathrm{f}_{\mathrm{ctd}}=\frac{\mathrm{f}_{\mathrm{ctk}, \text { inf }}}{\gamma_{\mathrm{c}}} \quad \mathrm{f}_{\mathrm{ctk}, \text { inf }}=0,7 \mathrm{f}_{\mathrm{ctm}}=0,7\left(0,3 \sqrt[3]{\mathrm{f}_{\mathrm{ck}}^{2}}\right) \\
& \phi_{\mathrm{p}}=\text { diâmetro nominal da cordoalha; } \\
& \mathrm{f}_{\mathrm{pyd}}=\text { limite de escoamento de cálculo da armadura de protensão; } \\
& \mathrm{f}_{\mathrm{bpd}}=\text { tensão de aderência de cálculo da armadura ativa; } \\
& \eta_{\mathrm{p} 1}=1,2 \text { para cordoalhas de } 7 \text { fios; } \\
& \eta_{\mathrm{p} 2}=\left\{\begin{array}{l}
1 \text { para situações de boa aderência; } \\
0,7 \text { para situações de má aderência; }
\end{array}\right.
\end{aligned}
$$

$\mathrm{f}_{\mathrm{ctd}}=$ valor de cálculo da resistência do concreto à tração, obtido na idade de aplicação da protensão, para a determinação do comprimento de transferência; e na idade de 28 dias, para a determinação do comprimento de ancoragem;

$\mathrm{f}_{\text {ctk,inf }}=$ resistência característica inferior do concreto à tração;

$\gamma_{\mathrm{c}}=$ coeficiente de ponderação da resistência do concreto;

$\mathrm{f}_{\mathrm{ctm}}=$ resistência média do concreto à tração direta.

Para o cálculo do comprimento de transferência $\left(\ell_{\text {bpt }}\right)$ de cordoalhas de sete fios pré-tracionadas, com liberação gradual da protensão, a NBR 6118 (2001) fornece a seguinte equação:

$$
\ell_{\mathrm{bpt}}=0,5 \ell_{\mathrm{bp}} \cdot \frac{\sigma_{\mathrm{pi}}}{\mathrm{f}_{\mathrm{pyd}}}
$$

$\sigma_{\mathrm{pi}}=$ tensão na armadura ativa imediatamente após a aplicação da protensão. 
Para o cálculo do comprimento de ancoragem necessário $\left(\ell_{\mathrm{bpd}}\right)$, para as cordoalhas de sete fios pré-tracionadas, tem-se:

$$
\ell_{\mathrm{bpd}}=\ell_{\mathrm{bpt}}+\ell_{\mathrm{bp}}\left(\frac{\mathrm{f}_{\mathrm{pyd}}-\sigma_{\mathrm{p} \infty}}{\mathrm{f}_{\mathrm{pyd}}}\right)
$$

$\sigma_{\mathrm{p} \infty}=$ tensão na armadura ativa, após todas as perdas ao longo do tempo.

A NBR 6118 (2001) se baseia no gráfico da Figura 3.14, que mostra a relação entre os comprimentos de ancoragem e as tensões na armadura ativa.

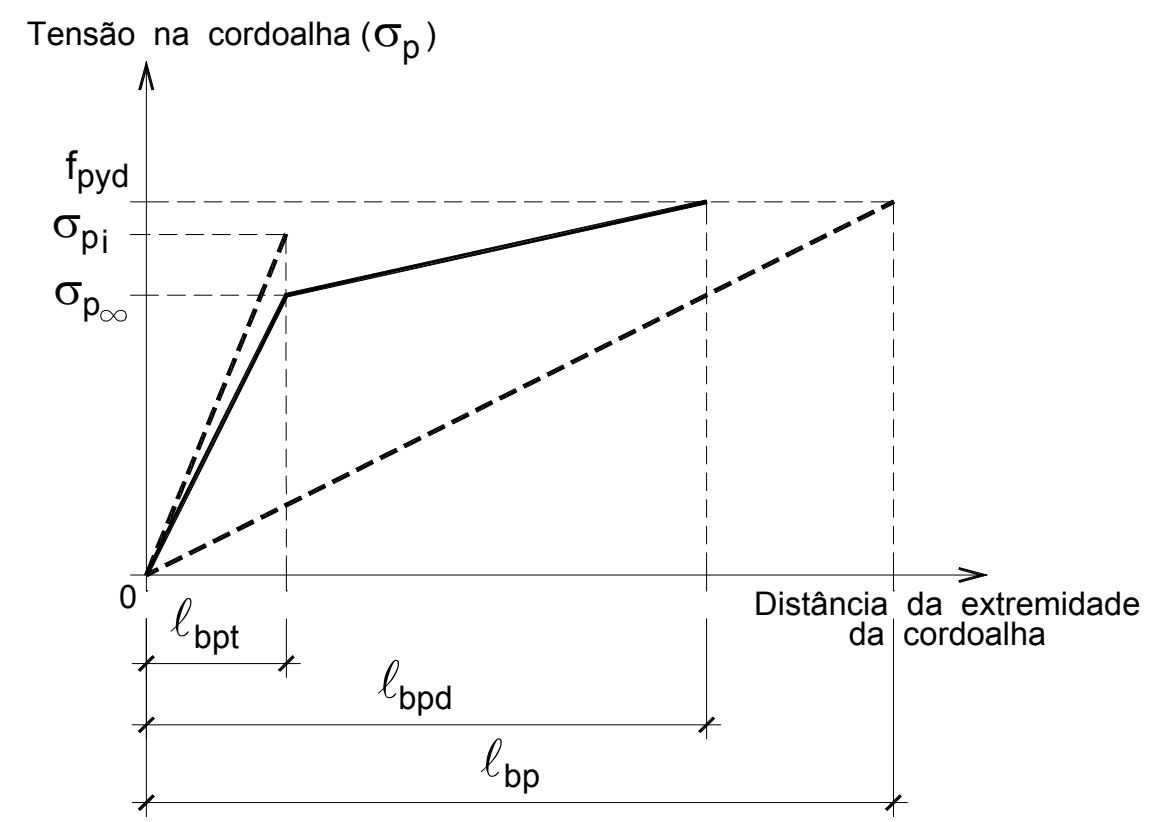

Figura 3.14 - Ancoragem de armaduras pré-tracionadas (NBR 6118, 2001).

\subsubsection{ACI 318 (2002)}

O ACI 318 (2002) estabelece que para cordoalhas de sete fios pré-tracionadas o comprimento de ancoragem necessário $\left(\ell_{\mathrm{d}}\right)$ vale:

$$
l_{\mathrm{d}}=l_{\mathrm{t}}+\ell_{\mathrm{b}}=\overbrace{\frac{\mathrm{f}_{\mathrm{se}}}{3} \cdot \mathrm{d}_{\mathrm{b}}}^{\ell_{\mathrm{t}}}+\overbrace{\left.\mathrm{f}_{\mathrm{ps}}-\mathrm{f}_{\mathrm{se}}\right) \cdot \mathrm{d}_{\mathrm{b}}}^{\ell_{\mathrm{b}}}=\left(\mathrm{f}_{\mathrm{ps}}-\frac{2}{3} \mathrm{f}_{\mathrm{se}}\right) \cdot \mathrm{d}_{\mathrm{b}}
$$

$\ell_{\mathrm{t}}=$ comprimento de transferência de esforços;

$\ell_{\mathrm{b}}=$ comprimento de aderência na flexão;

$\mathrm{f}_{\mathrm{se}}=$ tensão na armadura ativa, após todas as perdas;

$\mathrm{f}_{\mathrm{ps}}=$ resistência atuante da armadura ativa à tração;

$\mathrm{d}_{\mathrm{b}}=$ diâmetro nominal da cordoalha. 
O ACI 318 (2002) apresenta o gráfico da Figura 3.15, que indica a variação de tensão na armadura ativa ao longo da zona de ancoragem da peça.

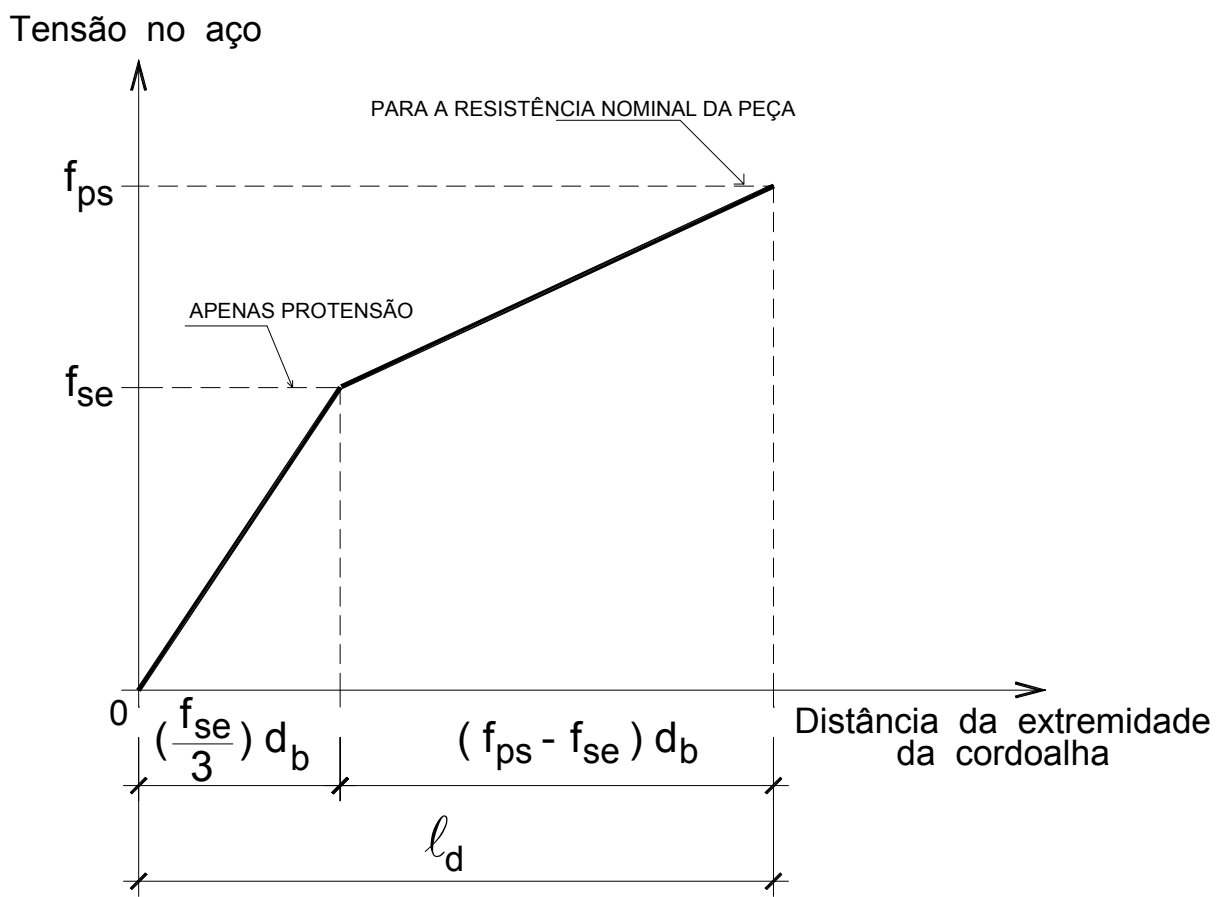

Figura 3.15 - Ancoragem das armaduras ativas (ACI 318, 2002).

$\mathrm{Na}$ ausência de um valor mais realista de $\mathrm{f}_{\mathrm{ps}}$, baseado na relação Tensão versus Deformação, o Código admite seu cálculo através da seguinte expressão:

$$
\begin{array}{r}
f_{p s}=f_{p u}\left\{1-\frac{\gamma_{p}}{\beta_{1}}\left[\rho_{p} \frac{f_{p u}}{f_{c}^{\prime}}+\frac{d}{d_{p}}\left(\omega-\omega^{\prime}\right)\right]\right\} \\
\omega=\frac{\rho \cdot f_{y}}{f_{c}^{\prime}} \quad \omega^{\prime}=\frac{\rho^{\prime} \cdot f_{y}}{f_{c}^{\prime}}
\end{array}
$$

$\mathrm{f}_{\mathrm{pu}}=$ resistência característica do aço da armadura ativa à tração;

$\gamma_{\mathrm{p}}=0,28$ para $\left(\mathrm{f}_{\mathrm{py}} / \mathrm{f}_{\mathrm{pu}}\right) \geq 0,9$;

$\beta_{1}=0,65$ (coeficiente definido no item 10.2.7.3 do ACI 318, 2002);

$\rho_{\mathrm{p}}=\mathrm{A}_{\mathrm{ps}} /$ (b.d)

$\mathrm{f}_{\mathrm{c}}=$ resistência característica do concreto à compressão;

$\mathrm{d}=$ altura útil da armadura passiva;

$\mathrm{d}_{\mathrm{p}}=$ altura útil da armadura ativa;

$\omega=\rho \cdot f_{y} / f_{c}^{\prime}$;

$\omega^{\prime}=\rho \cdot f_{\mathrm{y}} / \mathrm{f}_{\mathrm{c}}^{\prime}$; 
$\mathrm{A}_{\mathrm{ps}}=$ área da armadura ativa;

$\mathrm{b}=$ largura da seção transversal;

$\mathrm{f}_{\mathrm{y}}=$ resistência característica de escoamento do aço da armadura passiva;

$\rho=\mathrm{A}_{\mathrm{s}} /(\mathrm{b} . \mathrm{d})$;

$\rho^{\prime}=\mathrm{A}_{\mathrm{s}}^{\prime} /(\mathrm{b} . \mathrm{d})$, (presença de armadura comprimida);

$\mathrm{A}_{\mathrm{s}}=$ área da armadura passiva tracionada;

$\mathrm{A}_{\mathrm{s}}=$ área da armadura passiva comprimida.

\subsubsection{FIB Bulletin 1 (1999)}

A FIB Bulletin 1 (1999), que é mais uma complementação do que uma atualização do CEB-FIP (1990), faz apenas uma alteração no cálculo dos comprimentos de transferência e de ancoragem necessário, em relação ao apresentado no CEB-FIP (1990). A diferença está no cálculo de $\mathrm{f}_{\mathrm{bpd}}$. Há uma mudança no valor de $\eta_{\mathrm{p} 1}$ e no cálculo do $f_{\mathrm{ctd}}$. A FIB Bulletin 1 (1999) estabelece que para cordoalhas de sete fios pré-aderentes, pré-tracionadas, o comprimento básico de ancoragem $\left(\ell_{\mathrm{bp}}\right)$ deve ser:

$$
\begin{aligned}
\ell_{\mathrm{bp}}=\frac{7 \cdot \phi}{36} \cdot \frac{\mathrm{f}_{\mathrm{ptd}}}{\mathrm{f}_{\mathrm{bpd}}} & \mathrm{f}_{\mathrm{bpd}}=\eta_{\mathrm{p} 1} \cdot \eta_{\mathrm{p} 2} \cdot \mathrm{f}_{\mathrm{ctd}} \quad \mathrm{f}_{\mathrm{ctd}}=\frac{\mathrm{f}_{\mathrm{ctk}}}{1,5} \quad \mathrm{f}_{\mathrm{ctk}}=0,7 \mathrm{f}_{\mathrm{ctm}} \\
\mathrm{f}_{\mathrm{ctm}} & =\left\{\begin{array}{lll}
0,3 \sqrt[3]{\mathrm{f}_{\mathrm{ck}}^{2}} & \text { para } & \mathrm{f}_{\mathrm{ck}} \leq 50 \mathrm{MPa} \\
1,12 \sqrt[3]{\mathrm{f}_{\mathrm{ck}}} & \text { para } & \mathrm{f}_{\mathrm{ck}}>50 \mathrm{MPa}
\end{array}\right.
\end{aligned}
$$

$\phi=$ diâmetro da cordoalha;

$\mathrm{f}_{\mathrm{ptd}}=$ resistência de cálculo do aço da armadura ativa à tração;

$\mathrm{f}_{\mathrm{bpd}}=$ tensão de aderência de cálculo da cordoalha;

$\eta_{\mathrm{p} 1}=1,3$ para cordoalhas de 7 fios (diferente do valor de 1,2 do CEB-FIP, 1990);

$\eta_{\mathrm{p} 2}=\left\{\begin{array}{l}1 \text { para situações de boa aderência; } \\ 0,7 \text { para situações de má aderência; }\end{array}\right.$

$\mathrm{f}_{\text {ctd }}=$ valor de cálculo da resistência do concreto à tração, obtido na idade de aplicação da protensão, para a determinação do comprimento de transferência; e na idade de 28 dias, para a determinação do comprimento de ancoragem;

$\mathrm{f}_{\mathrm{ctk}}=$ menor resistência característica do concreto à tração; 
$\mathrm{f}_{\mathrm{ctm}}=$ resistência média do concreto à tração direta.

Para o cálculo do comprimento de transferência $\left(\ell_{\mathrm{bpt}}\right)$ de cordoalhas prétracionadas com alívio gradual da protensão, a FIB Bulletin 1 (1999) estabelece que:

$$
\ell_{\mathrm{bpt}}=1 \cdot 1 \cdot 0,5 \ell_{\mathrm{bp}} \cdot \frac{\sigma_{\mathrm{pi}}}{\mathrm{f}_{\mathrm{pd}}}=0,5 \ell_{\mathrm{bp}} \cdot \frac{\sigma_{\mathrm{pi}}}{\mathrm{f}_{\mathrm{pd}}}
$$

$\sigma_{\mathrm{pi}}=$ tensão na armadura ativa imediatamente após a aplicação da protensão;

$\mathrm{f}_{\mathrm{pd}}=$ resistência de cálculo da cordoalha.

Para o cálculo do comprimento de ancoragem de projeto $\left(\ell_{\mathrm{bpd}}\right)$ de cordoalhas pré-tracionadas, a FIB Bulletin 1 (1999) estabelece que:

$$
\ell_{\mathrm{bpd}}=\ell_{\mathrm{bpt}}+\ell_{\mathrm{bp}}\left(\frac{\sigma_{\mathrm{pd}}-\sigma_{\mathrm{pcs}}}{\mathrm{f}_{\mathrm{pd}}}\right)
$$

$\sigma_{\mathrm{pd}}=$ tensão na cordoalha sob a carga de projeto atuante $\left(\sigma_{\mathrm{pd}} \leq \mathrm{f}_{\mathrm{pd}}\right)$;

$\sigma_{\mathrm{pcs}}=\sigma_{\mathrm{p} \infty}=$ tensão na armadura ativa após todas as perdas ao longo do tempo.

O Código Modelo 90, e conseqüentemente a FIB Bulletin 1 (1999), apresentam o gráfico da Figura 3.16, que indica o desenvolvimento das tensões da cordoalha ao longo da zona de ancoragem das peças.

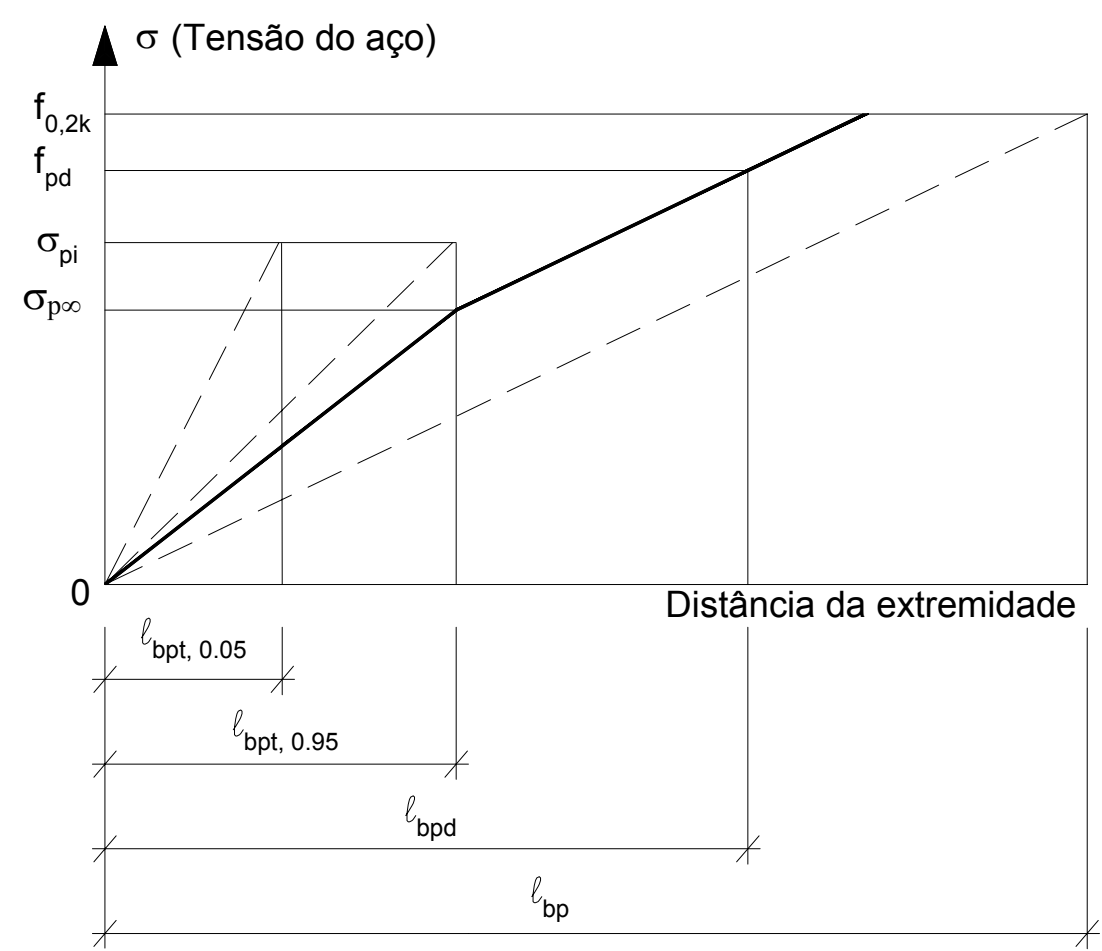

Figura 3.16 - Ancoragem das armaduras ativas (CEB-FIP, 1990) 


\subsubsection{Comentários sobre as prescrições normativas}

As normas apresentam dois tipos de abordagem: uma baseada na capacidade de cálculo e outra baseada no desempenho.

O ACI 318 (2002) baseia-se no primeiro tipo, ou seja, ele se preocupa apenas em garantir que a peça tenha capacidade resistente, que não entrará em colapso, o que acontece depois da ruptura não interessa. Esta abordagem leva a um dimensionamento um pouco mais conservador, principalmente para os concretos de alta resistência, mas por outro lado, apresenta uma formulação mais simples.

Já a FIB Bulletin 1 (1999), e conseqüentemente a NBR 6118 (2001), se interessam pelo desempenho do material, ou seja, as considerações sobre as deformações são de grande importância, pois não só a garantia da capacidade resistente deve ser satisfeita, mas também deve ser conhecido o nível de deformação a que a peça estará sujeita. Nesta abordagem o comportamento pós-ruptura deve ser conhecido (a curva descendente do gráfico Tensão de aderência versus Escorregamento).

Tanto para a NBR 6118 (2001) como para a FIB Bulletin 1 (1999), que são atualizações, ou complementações, da NBR 6118 (1978) e do CEB-FIP (1990), respectivamente, houve um pequeno ganho na consideração da tensão de aderência, ou seja, admite-se uma tensão um pouco maior e conseqüentemente um comprimento de ancoragem um pouco menor. Como o cálculo pela NBR 6118 (2001) é baseado nas sugestões da FIB Bulletin 1 (1999), ambas apresentam a mesma formulação para o cálculo dos comprimentos de transferência e de ancoragem, com pequenas diferenças em alguns coeficientes. Portanto, seus resultados são bem próximos. Já o ACI 318 (2002) apresenta uma formulação baseada apenas nas tensões das armaduras, não se referindo, diretamente, à tensão de aderência, e sim admitindo para ela um valor constante médio, e a favor da segurança.

Os resultados obtidos segundo a NBR 6118 (2001), a FIB Bulletin 1 (1999) e o ACI 318 (2002), para os dados desta pesquisa, são apresentados na Tabela 3.7. Como já foi dito, os cálculos completos dos comprimentos de ancoragem se encontram no Apêndice C.

No cálculo desses comprimentos admitiu-se o escoamento da armadura ativa. Caso a armadura não entre em escoamento, todas as prescrições, com exceção da 
NBR 6118 (2001), permitem que se utilize o valor da tensão atuante na cordoalha para o cálculo dos comprimentos, o que pode levar a valores menores.

Tabela 3.7 - Valores dos comprimentos de transferência e de ancoragem.

\begin{tabular}{|l|c|c|c|}
\hline \multicolumn{1}{|c|}{ Variável } & $\begin{array}{c}\text { NBR 6118 } \\
\mathbf{( 2 0 0 1 )}\end{array}$ & $\begin{array}{c}\text { FIB Bulletin 1 } \\
\mathbf{( 1 9 9 9 )}\end{array}$ & $\begin{array}{c}\text { ACI 318 } \\
\mathbf{( 2 0 0 2})\end{array}$ \\
\hline $\begin{array}{l}\text { Tensão de aderência na transferência } \\
\left(\mathrm{f}_{\text {bpd,transf }}\right)(\mathrm{MPa})\end{array}$ & 2,44 & 2,47 & 5,17 \\
\hline $\begin{array}{l}\text { Tensão de aderência aos 28 dias }\left(\mathrm{f}_{\mathrm{bpd}, 28 \mathrm{~d}}\right) \\
(\mathrm{MPa})\end{array}$ & 2,91 & 2,73 & 1,72 \\
\hline $\begin{array}{l}\left.\text { Comprimento de transferência ( } \ell_{\text {bpt }}\right) \\
(\text { metros })\end{array}$ & 0,76 & 0,75 & 0,74 \\
\hline $\begin{array}{l}\text { Comprimento de ancoragem necessário } \\
\left(\ell_{\text {bpd }}\right)(\text { metros })\end{array}$ & 1,00 & 1,16 & 1,89 \\
\hline
\end{tabular}

Como se pode observar, para os resultados apresentados na Tabela 3.7, os valores para os comprimentos de transferência, para o concreto estudado, são praticamente os mesmos, independente da norma ou do código, porém esse fato foi uma mera coincidência de resultados, o que pode ser observado no gráfico da Figura 3.18. Os valores das tensões de aderência do ACI 318 (2002) são valores médios, a favor da segurança, que estão embutidos nas formulações para os cálculos dos comprimentos de ancoragem. O valor para a tensão de aderência na transferência $(5,17 \mathrm{MPa})$ é bem superior ao valor adotado para a tensão de aderência na flexão $(1,72 \mathrm{MPa})$, o que é devido à consideração da influência favorável do efeito Hoyer durante a transferência de esforços, como descrito no Capítulo 2. Apesar de admitir uma tensão de aderência na transferência maior do que a NBR e a FIB, o resultado para o comprimento de transferência obtido pelo ACI, neste caso, foi o mesmo que para as outras prescrições, o que poderia indicar que a sua determinação admitiria um cálculo mais conservador. Entretanto, pelo gráfico da Figura 3.18, percebe-se que para concretos de resistência normal, o cálculo do ACI 318 (2002) é menos conservador que as outras prescrições, e para CAR é o contrário.

Para os valores dos comprimentos de ancoragem necessários, há uma variação bem maior entre os valores das NBR 6118 (2001) e FIB Bulletin 1 (1999) com o 
valor do ACI 318 (2002), já que se baseiam em abordagens diferentes, como já citado. A diferença entre os valores da NBR 6118 (2001) e da FIB Bulletin 1 (1999) pode ser atribuída às diferenças nos coeficientes de segurança, e no fato de que a NBR 6118 (2001) só vale para concretos até $\mathrm{f}_{\mathrm{ck}} \leq 50 \mathrm{MPa}$, e o concreto utilizado apresentou um $\mathrm{f}_{\mathrm{cm}}=68 \mathrm{MPa}$ nas datas de ensaio. É importante dizer que o cálculo pela NBR 6118 (2001) só deve ser utilizado dentro dos limites da norma, ou seja, para um concreto com $\mathrm{f}_{\mathrm{ck}}=68 \mathrm{MPa}$, o dimensionamento deve seguir outra recomendação, como a da FIB Bulletin 1 (1999), por exemplo, que vale para resistências à compressão de até $80 \mathrm{MPa}$. O cálculo aqui apresentado teve intenção de apenas comparar e alertar para o uso incorreto das prescrições normativas.

O resultado final para o comprimento de ancoragem necessário mostra que, neste caso, a formulação do ACI é, também, mais conservadora do que a das outras prescrições avaliadas.

Essas conclusões, porém, não podem ser estendidas para outras peças com distintas resistências do concreto à compressão. São considerações, apenas, para os resultados aqui apresentados. Para uma análise mais abrangente, foram elaborados três gráficos relacionando a tensão de aderência, o comprimento de transferência e o comprimento de ancoragem necessário, com a resistência do concreto à compressão, levando em conta o cálculo pelas três prescrições normativas avaliadas. As Figuras 3.17 a 3.19 apresentam os respectivos gráficos. Vale lembrar também que, para os gráficos a seguir, admitiu-se que as armaduras ativas entraram em escoamento. Caso contrário, a análise comparativa das formulações normativas fica mais complexa, já que seriam, então, dois parâmetros a serem avaliados: a resistência do concreto à compressão e a tensão atuante na armadura ativa. Outro aspecto importante é que as recomendações da FIB Bulletin 1 (1999), e conseqüentemente da NBR 6118 (2001), não levam em conta nem as dimensões da peça nem a existência de armaduras passivas. Porém, esses fatores são levados em conta pelo ACI 318 (2002) na determinação da tensão atuante da armadura ativa $\left(f_{\mathrm{ps}}\right)$, que é utilizada no cálculo do comprimento de ancoragem necessário. Os gráficos apresentam valores da resistência do concreto à compressão entre $15 \mathrm{MPa}$ e $80 \mathrm{MPa}$, que são os mais encontrados usualmente. Porém, sabe-se que para o concreto protendido não se usa, normalmente, resistências à compressão inferiores a 30MPa. 


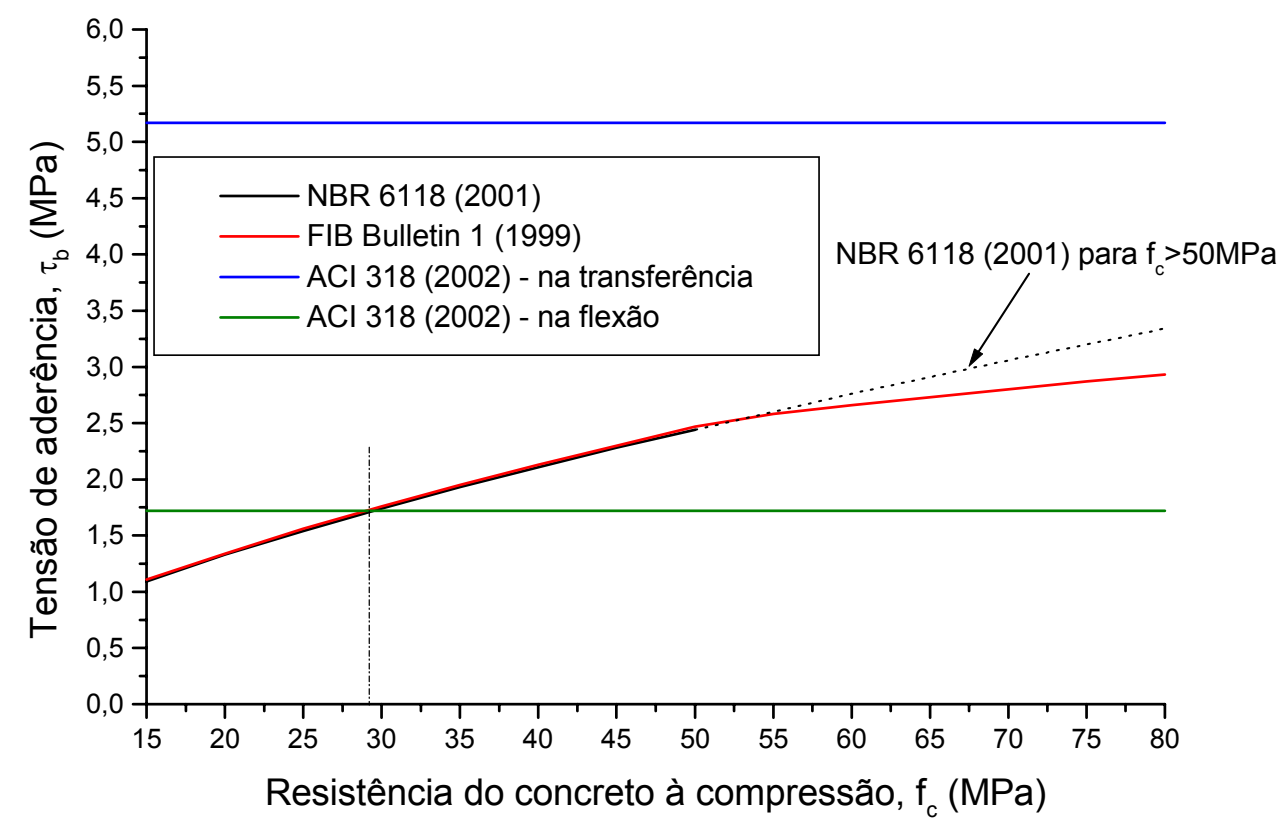

Figura 3.17 - Desenvolvimento da tensão de aderência em função da resistência do concreto à compressão.

Pelo gráfico da Figura 3.17, nota-se que o valor para a tensão de aderência na flexão adotado pelo ACI 318 (2002) é inferior aos da FIB Bulletin 1 (1999) e da NBR 6118 (2001), para valores de $\mathrm{f}_{\mathrm{c}}>30 \mathrm{MPa}$. Para as estruturas protendidas, esse é, praticamente, um valor limite inferior, no que diz respeito à resistência do concreto à compressão. Logo, pode-se dizer que, na prática, os valores fornecidos pelo ACI 318 (2002) são mais conservadores do que os fornecidos pelas FIB Bulletin 1 (1999) e NBR 6118 (2001). E que a diferença entre eles aumenta, com o aumento da resistência do concreto à compressão. Observa-se também que, para valores de $\mathrm{f}_{\mathrm{c}}>50 \mathrm{MPa}$ (linha pontilhada no gráfico), a formulação da NBR 6118 (2001) fornece valores cada vez maiores em relação aos valores da FIB Bulletin 1 (1999). Isso poderia levar a uma subestimação dos comprimentos de ancoragem.

Segundo o gráfico da Figura 3.18, a formulação do ACI 318 (2002) fornece valores menores dos que as outras prescrições para resistências do concreto à compressão de até, aproximadamente, 50MPa. A partir daí as recomendações da FIB Bulletin 1 (1999) e da NBR 6118 (2001) passam a apresentar valores menores. A diferença, porém, não é muito grande. Para valores de $\mathrm{f}_{\mathrm{c}}>50 \mathrm{MPa}$ (linha pontilhada no gráfico), a formulação da NBR 6118 (2001) fornece valores cada vez menores em relação aos valores da FIB Bulletin 1 (1999). 


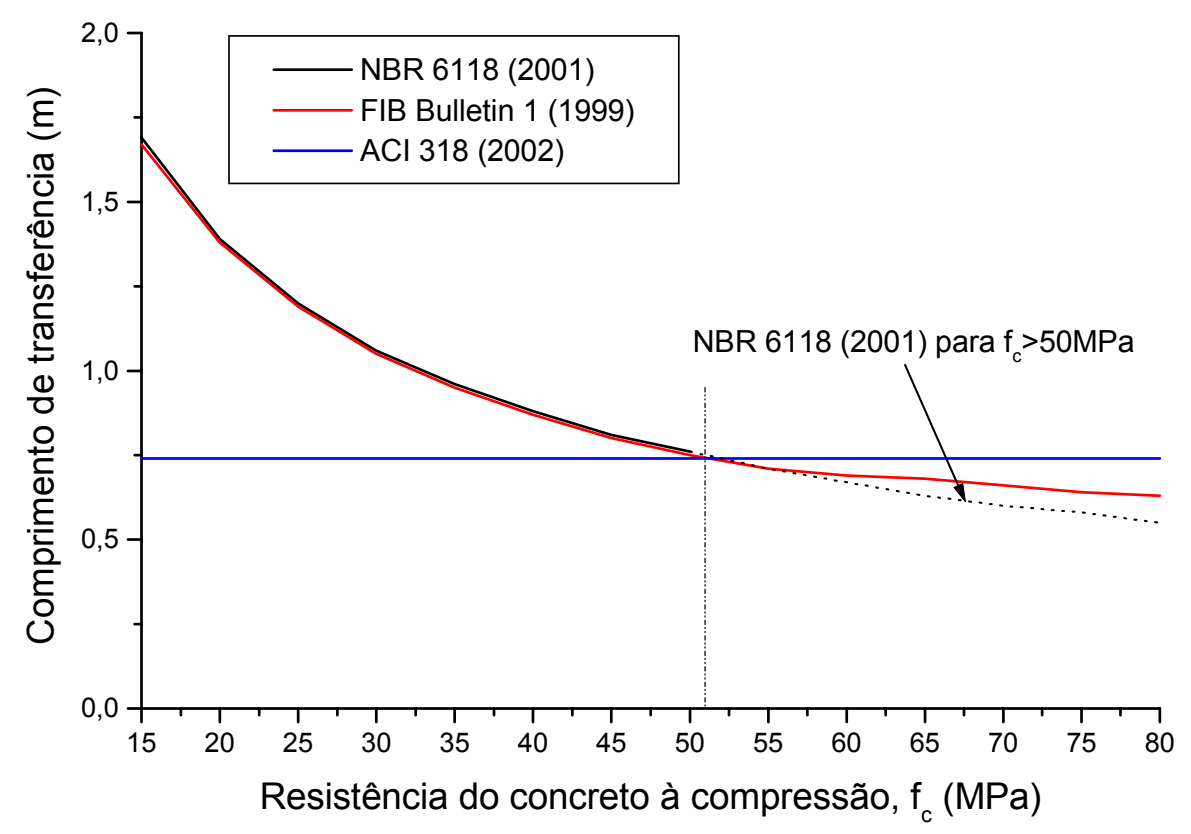

Figura 3.18 - Desenvolvimento do comprimento de transferência em função da resistência do concreto à compressão.

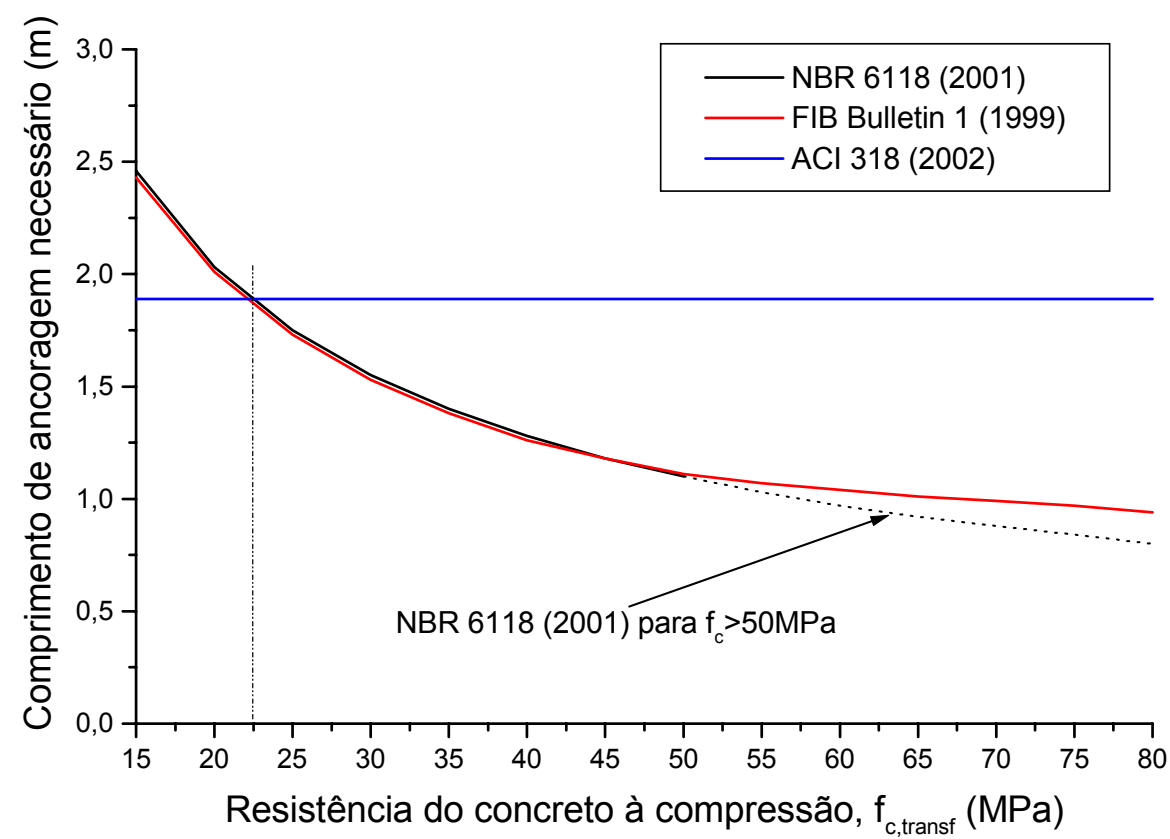

Figura 3.19 - Desenvolvimento do comprimento de ancoragem necessário em função da resistência do concreto à compressão, na transferência.

Para o gráfico da Figura 3.19, foi admitida a seguinte relação: $f_{c}=1,3 f_{c}$,transf. Isso foi feito para levar em conta a diferença da resistência do concreto à compressão, entre a transferência da protensão e o carregamento de serviço das peças, para o cálculo dos comprimentos de ancoragem necessários pela NBR 6118 
(2001) e pela FIB Bulletin 1 (1999). Foi escolhida a razão de 1,3 porque foi a obtida nesta pesquisa. Segundo o gráfico, a formulação do ACI 318 (2002) fornece valores menores do que as outras prescrições, para resistências do concreto à compressão de até, aproximadamente, 22,5MPa. A partir daí as recomendações da FIB Bulletin 1 (1999) e da NBR 6118 (2001) passam a apresentar valores menores. A diferença, neste caso, não é pequena, e aumenta com o aumento da resistência do concreto à compressão. Para valores de $\mathrm{f}_{\mathrm{c}}>50 \mathrm{MPa}$ (linha pontilhada no gráfico), a formulação da NBR 6118 (2001) fornece valores cada vez menores em relação aos da FIB Bulletin 1 (1999).

Logo, pode-se concluir que, para os concretos de alta resistência $\left(\mathrm{f}_{\mathrm{c}}>40 \mathrm{MPa}\right), \mathrm{o}$ ACI 318 (2002) fornece valores mais conservadores, tanto para a tensão de aderência, como para o comprimento de ancoragem necessário. Para o comprimento de transferência as diferenças são pequenas, apesar do ACI 318 (2002) fornecer valores um pouco maiores que as outras prescrições.

\subsection{Análise Comparativa das Formulações Teóricas}

A análise comparativa das formulações teóricas visa, principalmente, verificar a margem de segurança das prescrições normativas em relação às expressões empíricas avaliadas, as quais se basearam em resultados de ensaios experimentais.

Foram elaborados cinco gráficos (Figuras 3.20 a 3.24) para a análise comparativa, levando em conta alguns dos parâmetros estudados anteriormente neste capítulo. A Tabela 3.8 apresenta os dados que foram utilizados e mantidos constantes durante as comparações, exceto quando ele próprio era o parâmetro avaliado. Esses dados já foram listados no início deste capítulo, mas foram repetidos aqui para facilitar a análise dos gráficos.

Tabela 3.8 - Dados utilizados na análise comparativa.

\begin{tabular}{l|l|l}
\hline $\mathrm{c}=2,9 \mathrm{~cm}$ & $\phi_{\mathrm{p}}=12,7 \mathrm{~mm}$ & $\mathrm{~A}_{\mathrm{p}}=100,3 \mathrm{~mm}^{2}$ \\
\hline $\mathrm{V}_{\mathrm{f}}=0$ & $\mathrm{f}_{\mathrm{c}, \text { transf }}=50 \mathrm{MPa}$ & $\mathrm{f}_{\mathrm{c}}=65 \mathrm{MPa}$ \\
\hline $\mathrm{f}_{\mathrm{ptk}}=\mathrm{f}_{\mathrm{su}}=1900 \mathrm{MPa}$ & $\mathrm{f}_{\mathrm{ps}}=1824 \mathrm{MPa}$ & $\mathrm{f}_{\mathrm{ptd}}=1652 \mathrm{MPa}$ \\
\hline $\mathrm{f}_{\mathrm{pyd}}=1607 \mathrm{MPa}$ & $\sigma_{\mathrm{pi}}=1496 \mathrm{MPa}$ & $\sigma_{\mathrm{p} \infty}=1201 \mathrm{MPa}$ \\
\hline
\end{tabular}




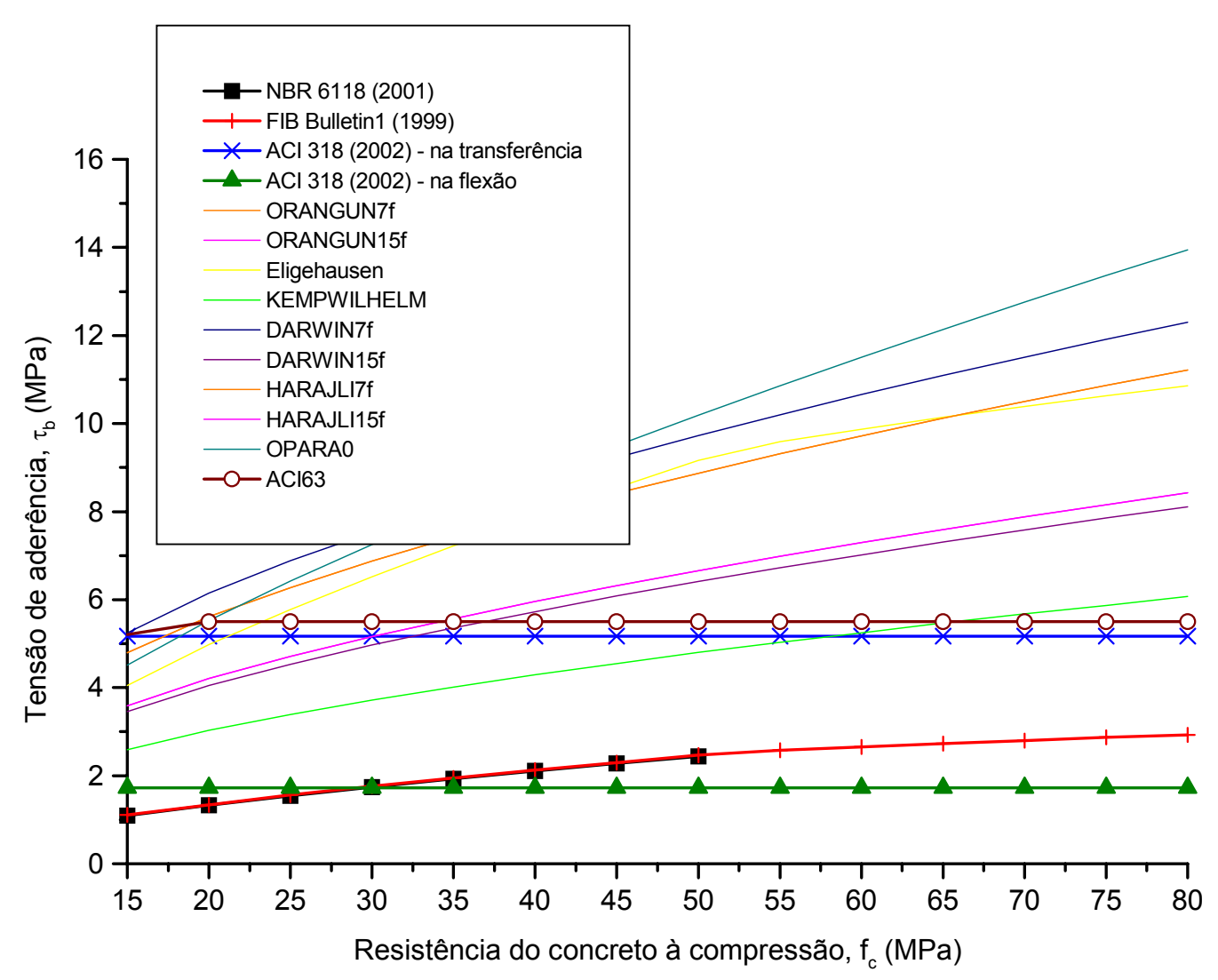

Figura 3.20 - Gráfico Tensão de aderência versus Resistência do concreto à compressão, para a análise teórica.

O gráfico da Figura 3.20 apresenta a comparação para o cálculo da tensão de aderência. Percebe-se que os valores fornecidos pelas prescrições normativas estão a favor da segurança, o que era de se esperar. $O$ valor para a tensão de aderência na transferência dado pelo ACI 318 (2002) é bem próximo do valor limite dado pelo ACI 318 (1963), que ainda trabalhava levando em conta no cálculo o valor da referida tensão.

O gráfico da Figura 3.21 apresenta a variação dos comprimentos de ancoragem em função do diâmetro da armadura ativa. Para este gráfico, os comprimentos de transferência estão plotados em linha cheia, e os comprimentos de ancoragem necessários com linha tracejada. Os valores fornecidos pelas prescrições normativas foram plotados com linhas com símbolos, sendo: linha cheia com triângulo para os comprimentos de transferência; e linha tracejada com $x$ para os comprimentos de ancoragem necessários. De maneira geral, percebe-se que os valores normativos estão próximos entre si, e contra a segurança, quando comparados com as expressões empíricas utilizadas. Observa-se também que, as expressões empíricas para os 
comprimentos de ancoragem necessários fornecem valores muito superiores aos das normas.

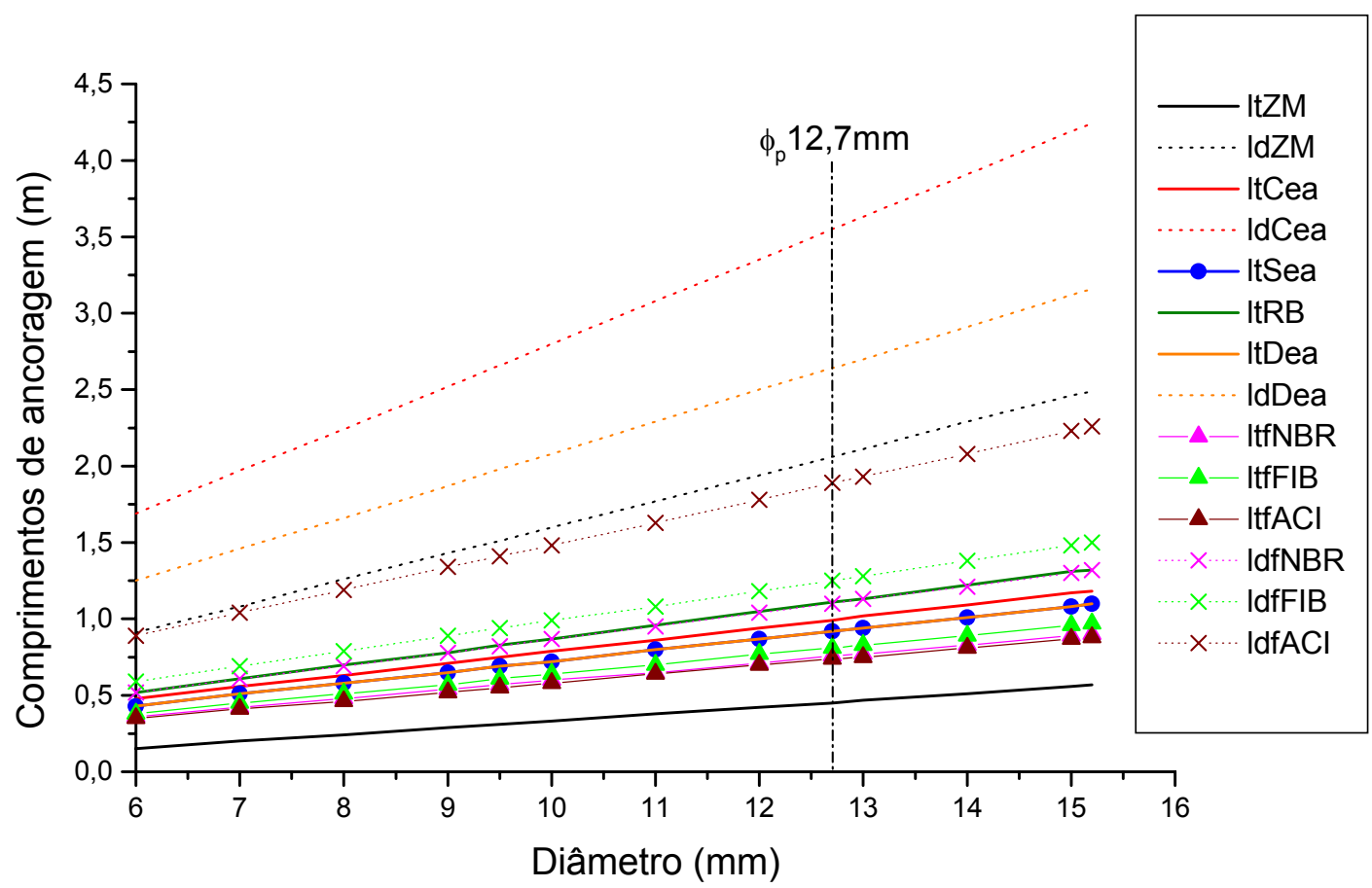

Figura 3.21 - Gráfico Comprimentos de ancoragem versus Diâmetro, para a análise teórica.

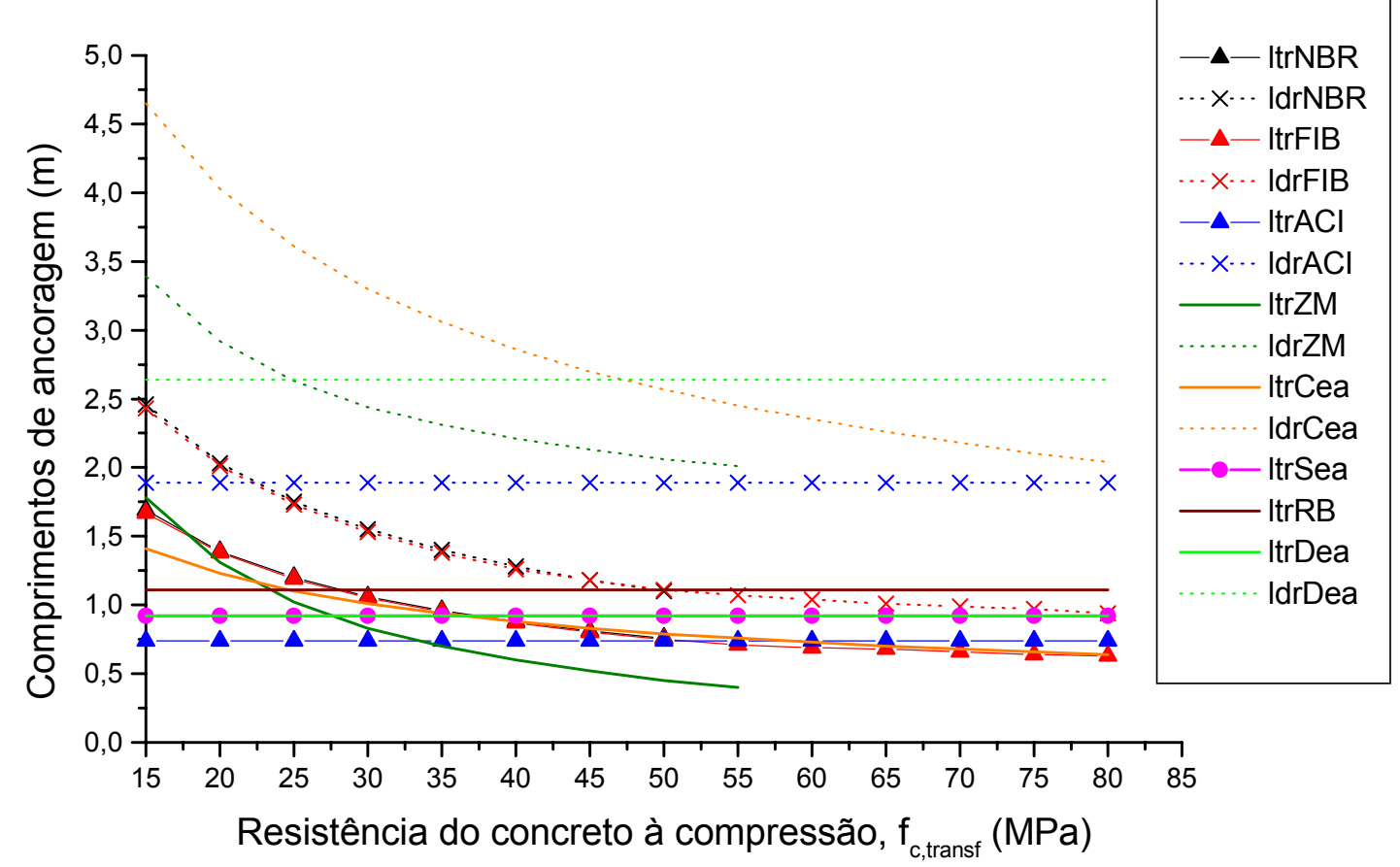

Figura 3.22 - Gráfico Comprimentos de ancoragem versus Resistência do concreto à compressão, para a análise teórica. 
Para o gráfico da Figura 3.22, vale o mesmo padrão para a simbologia, que foi utilizado no anterior. Também, em função da resistência do concreto à compressão, os valores normativos estão próximos entre si, e contra a segurança, quando comparados com as expressões empíricas utilizadas, da mesma forma que as expressões empíricas para os comprimentos de ancoragem necessários fornecem valores muito superiores aos das normas.

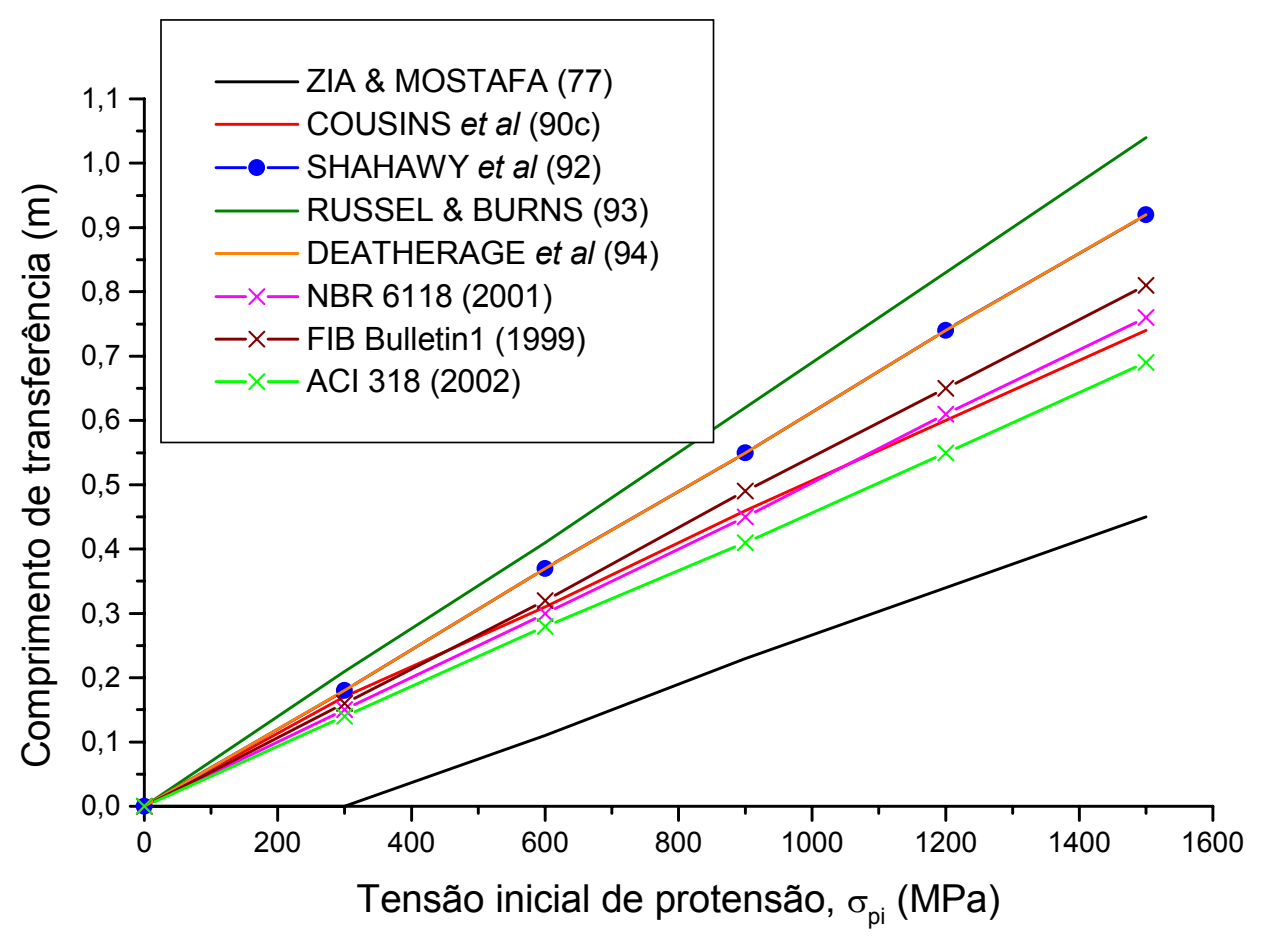

Figura 3.23 - Gráfico Comprimento de transferência versus Tensão inicial de protensão, para a análise teórica.

Para o gráfico da Figura 3.23, observa-se que as prescrições normativas fornecem valores menores que as expressões empíricas, exceto em relação à expressão de ZIA \& MOSTAFA (1977), que se encontra bem afastadas das outras. As diferenças aumentam com o aumento da tensão inicial de protensão, ou seja, quanto mais solicitada a armadura durante a protensão, maior a diferença em relação às formulações analisadas, para o concreto avaliado.

O mesmo se observa no gráfico 3.24, que compara os valores para o comprimento de ancoragem necessário, em função da tensão última admitida para a armadura ativa. Para os valores de tensão última entre 1500MPa e 1900MPa, que são os mais usuais para os aços CP $190\left(f_{p y d}=1496 \leq f_{p u} \leq f_{p t k}=1900 M P a\right)$, os valores normativos são inferiores aos das equações avaliadas. 


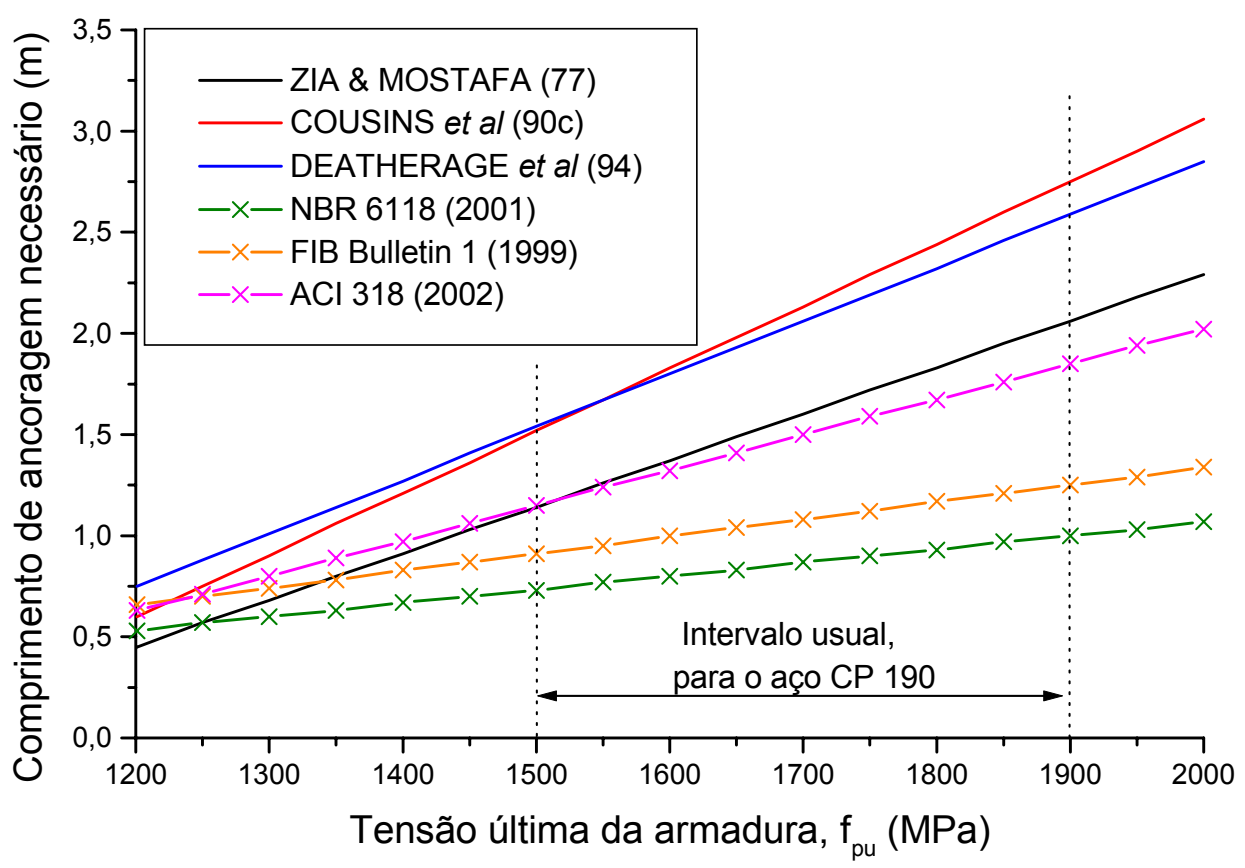

Figura 3.24 - Gráfico Comprimento de ancoragem necessário versus Tensão última admitida da armadura, para a análise teórica.

Mais uma vez, vale lembrar que para os gráficos apresentados admitiu-se que as armaduras ativas entraram em escoamento. Caso contrário essa análise comparativa ficaria mais complexa, já que seriam, então, dois parâmetros a serem avaliados ao mesmo tempo: a resistência do concreto à compressão e a tensão atuante da armadura ativa. Outro aspecto importante é que algumas formulações não levam em conta nem as dimensões da peça nem a existência de armaduras passivas, e outras levam. Portanto, as considerações feitas valem para os parâmetros aqui estabelecidos, e se referem mais aos concretos de alta resistência $\left(f_{c}=65 \mathrm{MPa}\right)$ do que aos concretos de resistências normais $\left(\mathrm{f}_{\mathrm{c}}<40 \mathrm{MPa}\right)$.

Outro aspecto muito importante se refere à armadura analisada. Para todas as expressões citadas (normativas e empíricas) foi admitido o uso de cordoalhas de sete fios e diâmetro de $12,7 \mathrm{~mm}$ (exceto quando o diâmetro foi o parâmetro analisado). $\mathrm{Ou}$ seja, todos os coeficientes utilizados nas fórmulas se referiam a esta armadura.

De maneira geral, pode-se dizer que, para os resultados obtidos da análise teórica, as prescrições normativas apresentaram formulações menos conservativas do que as empíricas aqui avaliadas. 


\section{PROGRAMA EXPERIMENTAL}

Neste trabalho, foram realizados ensaios estáticos (monotônicos) de arrancamento e de viga pré-tracionada submetida à flexão, para a obtenção da tensão de aderência e dos comprimentos de ancoragem das cordoalhas analisadas, respectivamente. Este estudo foi dividido em duas partes: (1) nos ensaios de arrancamento foram medidas as tensões de aderência para os diversos modelos com parâmetros de ensaio diferentes; e (2) nos ensaios de vigas foram medidos os comprimentos de transferência e de ancoragem necessário, para os diferentes compósitos.

Todos os ensaios aqui citados foram feitos no Laboratório de Estruturas da EESC-USP.

Este capítulo descreve o programa experimental desta pesquisa, os ensaios piloto de viga, e os ensaios de caracterização do concreto e das armaduras ativas e passivas.

\subsection{Programa de Ensaio}

A pesquisa experimental foi composta das seguintes etapas:

- Projeto dos modelos (para os ensaios de arrancamento e de flexão);

- Plano de execução dos ensaios;

- Ensaios pilotos;

- Ensaios de caracterização dos materiais;

- Ensaios de arrancamento;

- Ensaios de flexão;

- Análise e comparação dos resultados. 
A definição do programa de ensaios foi baseada no estudo de diversos artigos sobre ensaios de arrancamento e de flexão em vigas pré-tracionadas. Alguns desses artigos já foram citados na Revisão Bibliográfica, apresentada no Capítulo 2.

Foram feitos, no total, 108 ensaios de arrancamento, divididos em duas séries, e 14 ensaios de flexão em vigas pré-tracionadas, além dos ensaios de caracterização dos materiais.

A escolha por realização de ensaios de flexão teve dois motivos: (1) a possibilidade de medir os comprimentos de transferência e de ancoragem necessário; e (2) a sugestão de alguns pesquisadores, como HARAJLI et al (1995), que verificaram que este tipo de ensaio fornece valores mais próximos da realidade do que os ensaios de arrancamento, para concretos com fibras de aço, visto que nestes últimos a influência da fibra fica subestimada devido ao efeito de confinamento que o cobrimento exagerado de concreto e as características do ensaio fornecem às armaduras.

A definição do tema desta pesquisa, como já foi dito, seguiu uma das sugestões de BASTOS (1999), que estudou dormentes de concreto pré-tracionados. Por este motivo, seguiu-se usando alguns parâmetros por ele adotados: traço do concreto, tipo de fibra e volumes de fibra.

Para a pré-tração dos modelos, foi utilizado o pórtico de protensão elaborado por BASTOS (1999). As Figuras 4.1 a 4.6 mostram algumas etapas e detalhes da protensão das vigas e dos prismas de arrancamento, e as dimensões do pórtico de protensão.

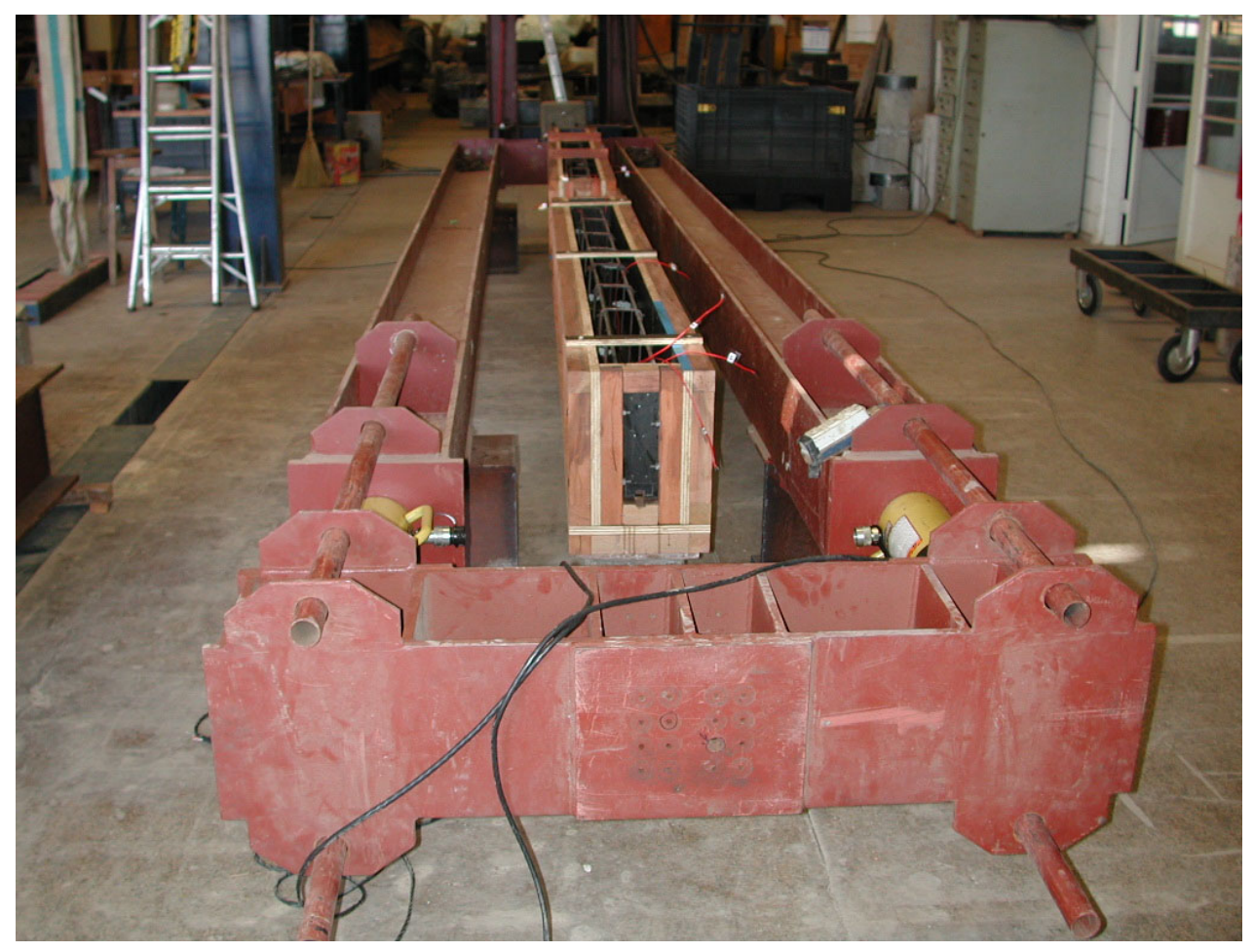

Figura 4.1 - Detalhe do pórtico durante a protensão de vigas 


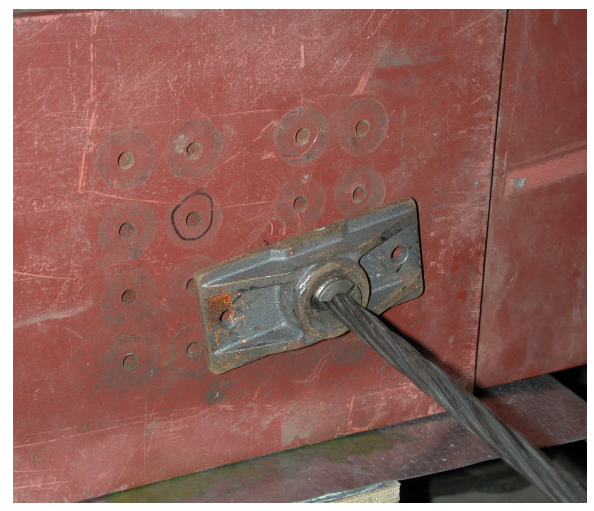

Figura 4.2 - Detalhe do encunhamento da cordoalha

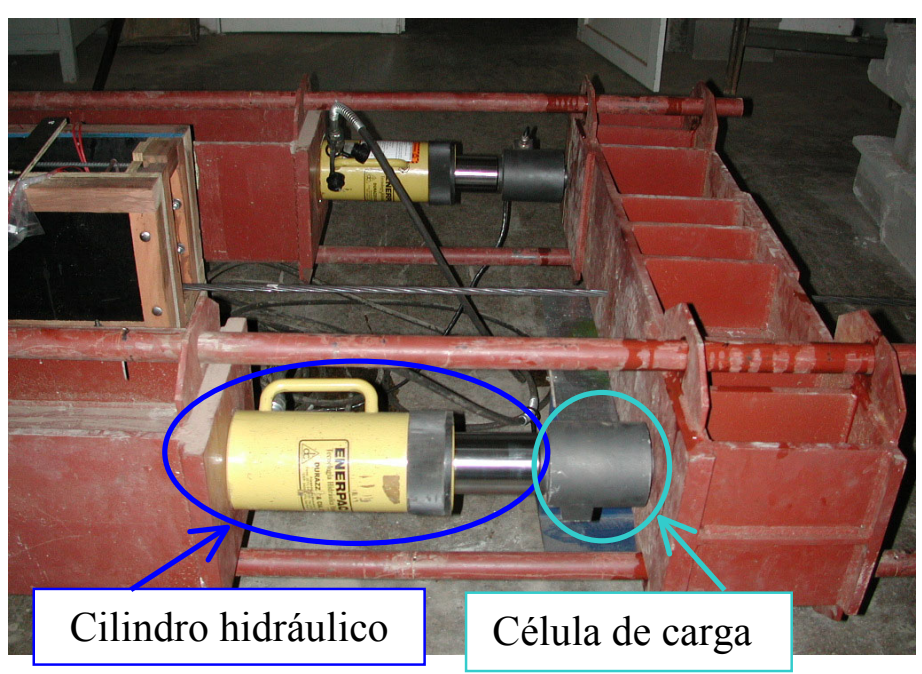

Figura 4.3 - Detalhe da posição dos cilíndricos hidráulicos de protensão e das células de carga.

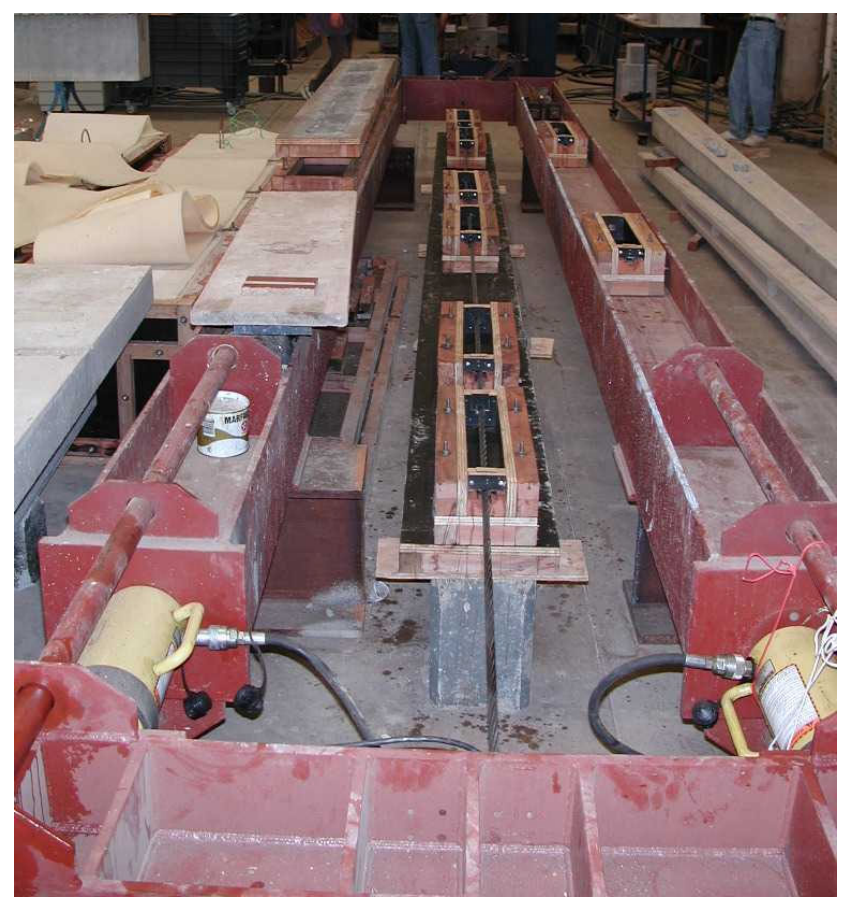

Figura 4.4 - Protensão dos prismas de arrancamento da Série 1.

Como se pode notar, a protensão era dada por dois cilindros hidráulicos (ENERPAC $500 \mathrm{kN}$ cada), que deslocavam o perfil transversal móvel (Figura 4.3). O restante do pórtico ficava fixo. A cordoalha era presa por duas cunhas, uma em cada extremidade do pórtico (Figura 4.2). A leitura da carga era feita por duas células de carga (SENSORTEC TRK 50ton) colocadas entre os cilindros hidráulicos e o perfil transversal móvel (Figura 4.3). Esse sistema mostrou-se bastante eficiente, não apresentando nenhum tipo de problema, nem durante a protensão das peças, nem durante a retirada da protensão, que foi feita de maneira gradual, aliviando-se lentamente a carga dos cilindros hidráulicos. 


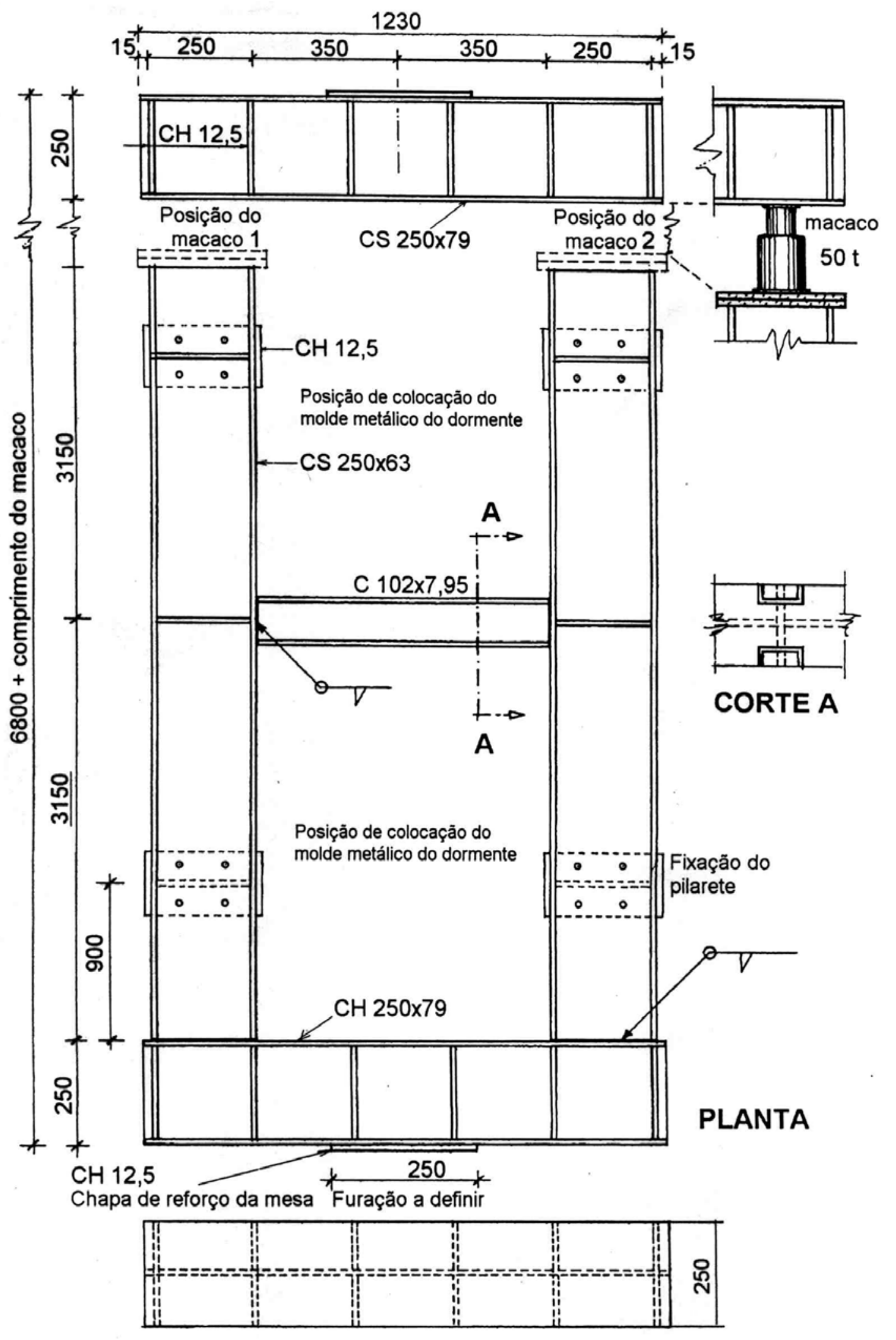

ELEVAÇÃO

Figura 4.5 - Planta e elevação do pórtico de protensão (medidas em mm) (BASTOS, 1999). 

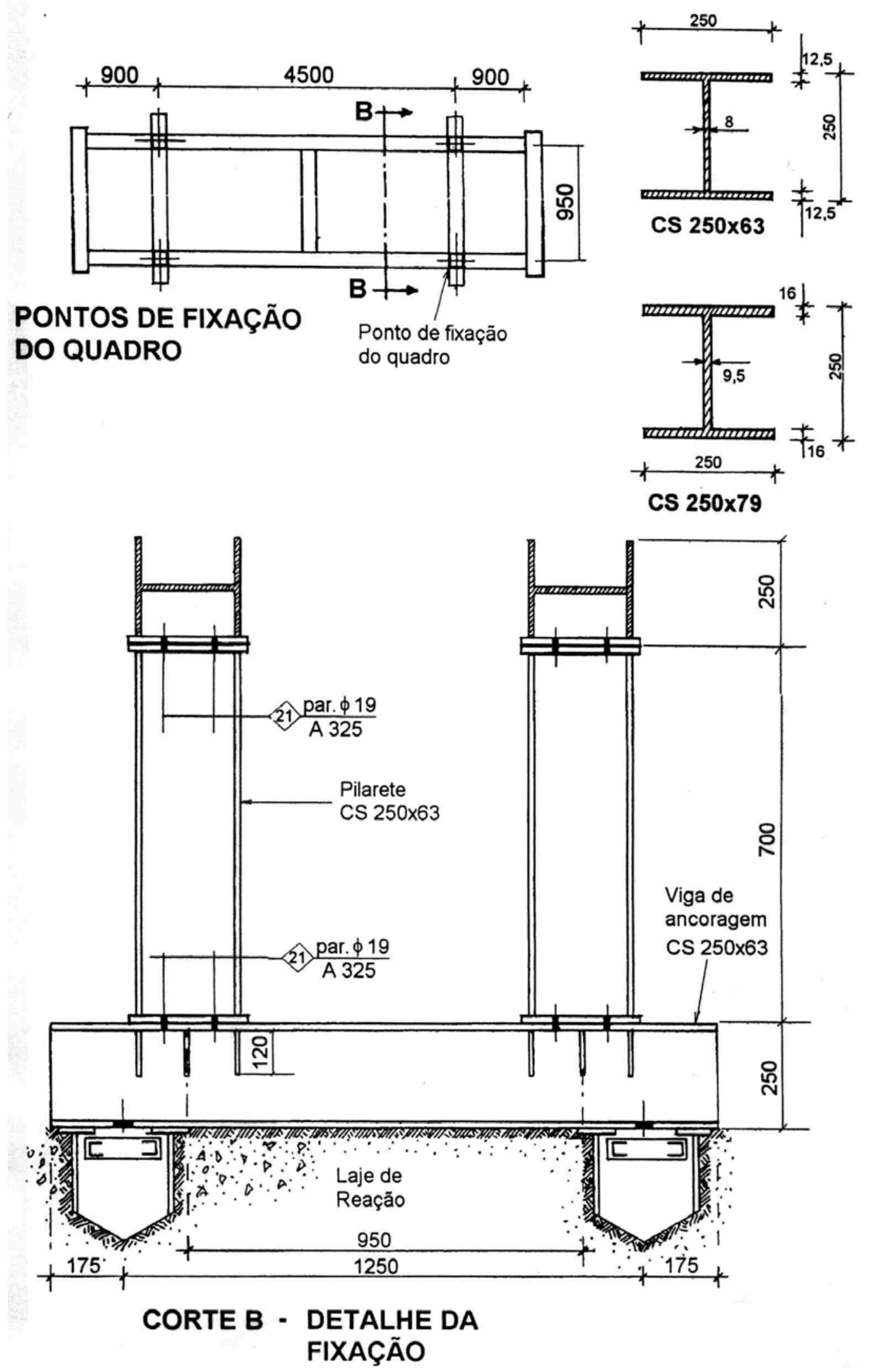

Figura 4.6 - Pontos de fixação e detalhes do pórtico de protensão (medidas em mm) (BASTOS, 1999). 
Para a cordoalha, procurou-se trabalhar com a tensão máxima permitida pela FIB Bulletin 1 (1999) de $\sigma_{\mathrm{pi}}=0,80 \mathrm{f}_{\mathrm{ptk}}$, o que fornece uma força de protensão de $\mathrm{P}_{\mathrm{i}}=150 \mathrm{kN}$. O Apêndice B apresenta os cálculos completos para a força de protensão. A Tabela 4.1 apresenta os valores das forças de protensão para todos os modelos, e as respectivas deformações das cordoalhas.

Tabela 4.1 - Força de protensão e alongamento da cordoalha dos modelos.

\begin{tabular}{|c|c|c|c|}
\hline Concretagem & Modelos & $\mathbf{P}_{\mathbf{i}}(\mathbf{k N})$ & $\varepsilon_{p, \text { lido }}(\% o)$ \\
\hline $\mathrm{C} 1$ & Viga-piloto 1 & 147 & 5,97 \\
\hline $\mathrm{C} 2$ & Viga-piloto 2 & 147 & 5,97 \\
\hline $\mathrm{C} 3$ & Prisma & 140 & ----- \\
\hline $\mathrm{C} 4$ & Prisma & 140 & ----- \\
\hline $\mathrm{C} 5$ & Prisma & 132 & ----- \\
\hline C6 & Prisma & 132 & ----- \\
\hline $\mathrm{C} 7$ & Prisma & 150 & ----- \\
\hline $\mathrm{C} 8$ & Prisma & 145 & ----- \\
\hline $\mathrm{C} 10$ & Prisma & 150 & ----- \\
\hline C11 & Prisma & 149 & ----- \\
\hline C12 & Prisma & 149 & ----- \\
\hline C13 & Prisma & 151 & ----- \\
\hline C14 & Prisma & 149 & ----- \\
\hline C19 & V_0_L/3 e V_0_L/6 & 146 & 6,29 \\
\hline $\mathrm{C} 20$ & V_40_L/3 e V_40_L/6 & 151 & 6,56 \\
\hline $\mathrm{C} 21$ & V_60_L/3 e V_60_L/6 & 140 & 6,45 \\
\hline $\mathrm{C} 22$ & V_0_L/3b e V_0_L/4 & 148 & 6,30 \\
\hline $\mathrm{C} 23$ & V_40_L/4 e V_40_L/6u & 148 & 6,44 \\
\hline $\mathrm{C} 24$ & V_60_L/4 e V_60_L/6u & 147 & 6,37 \\
\hline
\end{tabular}

Percebe-se que houve uma pequena variação da carga, devido às perdas que ocorrem durante as operações de concretagem e desprotensão. $O$ alongamento da cordoalha $\left(\varepsilon_{\mathrm{p}, \text { lido }}\right)$ medido foi referente ao final da protensão e corresponde ao valor médio do alongamento dos fios que foram instrumentados. 


\subsubsection{Projeto dos modelos}

O projeto dos modelos consistiu na escolha da forma e no detalhamento das peças a serem ensaiadas.

Para os ensaios de arrancamento, foram feitos dois tipos de modelo: (1) para a Série 1 foram elaborados modelos prismáticos de dimensões $7 \times 7 \times 40 \mathrm{~cm}$ (Figura 4.7), cujos parâmetros de ensaio que variaram foram o compósito e o comprimento de ancoragem da armadura de protensão; (2) para a Série 2 foi utilizado o modelo padrão para ensaios de arrancamento sugerido pela RILEM/CEB/FIP (1970) (Figura 4.8), cujo parâmetro de ensaio que variou foi o compósito. A cordoalha foi concretada no centro da seção transversal, para os modelos das duas séries.

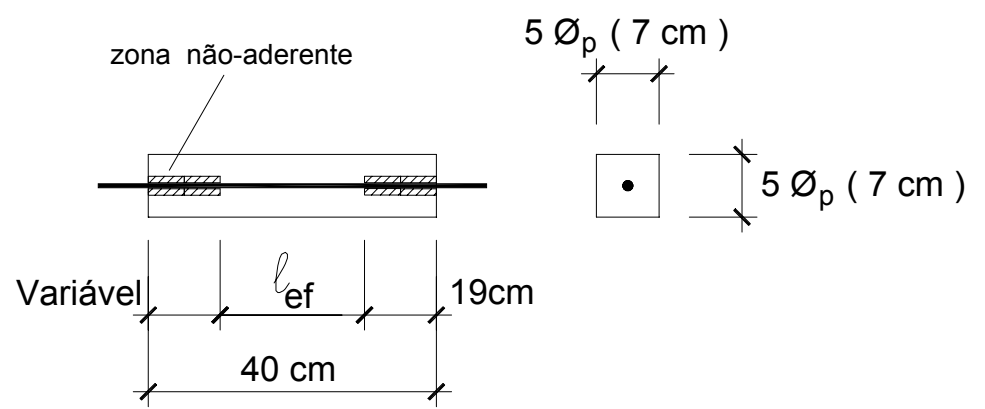

Figura 4.7 - Dimensões dos modelos da Série 1 para os ensaios de arrancamento.

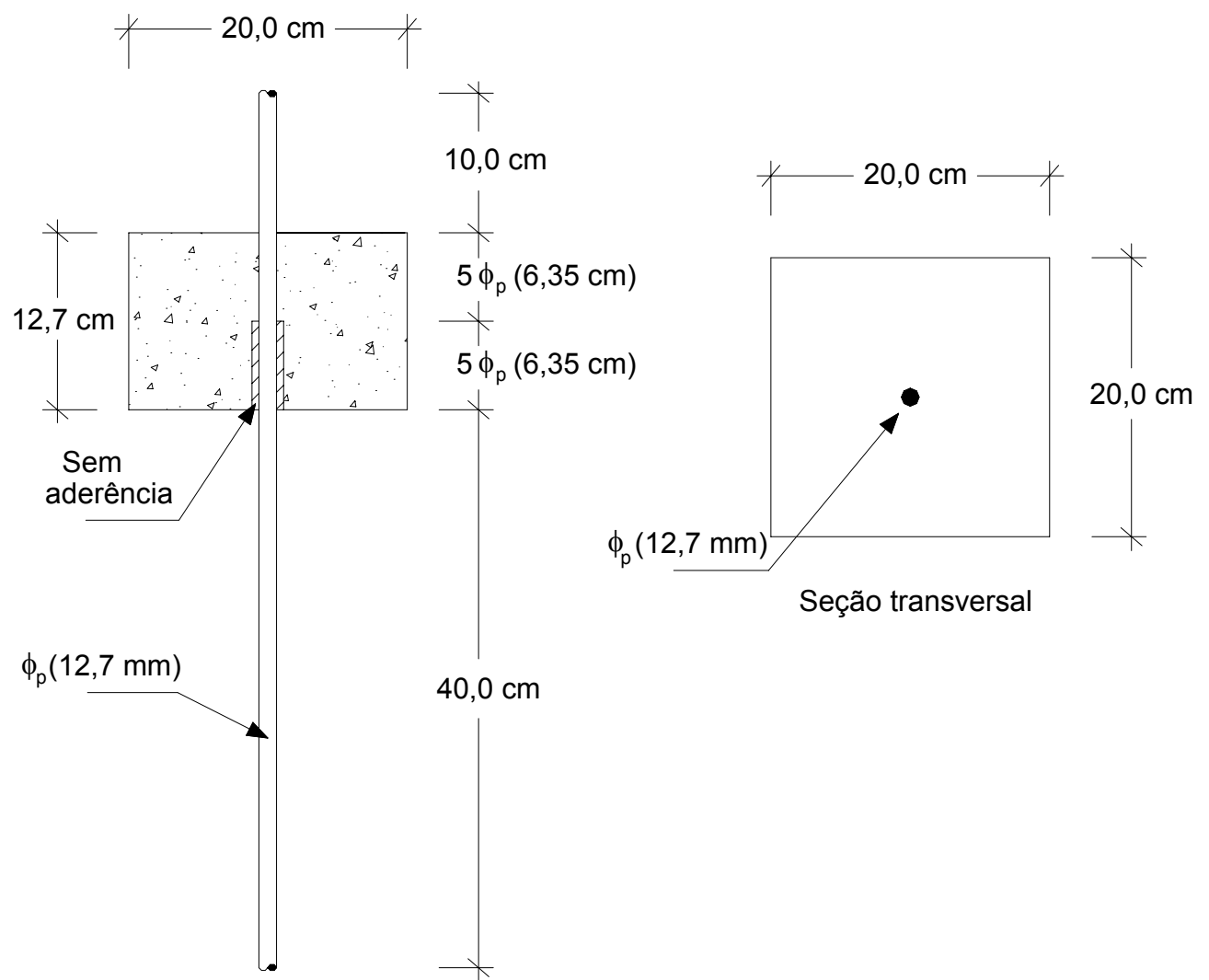

Figura 4.8 - Dimensões dos modelos da Série 2 (RILEM/CEB/FIP, 1970) para os ensaios de arrancamento. 
A escolha das dimensões da seção transversal para a Série 1 foi uma tentativa para eliminar, ou minimizar, a influência do cobrimento exagerado do concreto na aderência das peças. Optou-se por utilizar um cobrimento de $2 \phi_{\mathrm{p}}$ (duas vezes o diâmetro da cordoalha), que é um valor sugerido na literatura, resultando numa seção transversal de $5 \phi_{\mathrm{p}} \times 5 \phi_{\mathrm{p}}(7 \mathrm{x} 7 \mathrm{~cm})$.

Sabe-se que, nas peças reforçadas com fibras de aço, as dimensões transversais mínimas das mesmas devem ser $\left(3 \ell_{\mathrm{f}}\right)$, ou seja, pelo menos três vezes o comprimento das fibras. Neste trabalho foram utilizadas fibras de aço com $\ell_{\mathrm{f}}=30 \mathrm{~mm}$, logo, as peças deveriam ter, no mínimo, seções transversais com $9 \mathrm{cmx} 9 \mathrm{~cm}$. Porém, optou-se por fazer uma primeira concretagem com as dimensões de $7 \times 7 \mathrm{~cm}$, e verificar se havia um alinhamento das fibras, ou vazios de concretagem. A Figura 4.9 apresenta os cortes transversais e longitudinais feitos nos prismas, para os compósitos com $40 \mathrm{~kg} / \mathrm{m}^{3}$ e $60 \mathrm{~kg} / \mathrm{m}^{3}$, para a avaliação da distribuição das fibras.
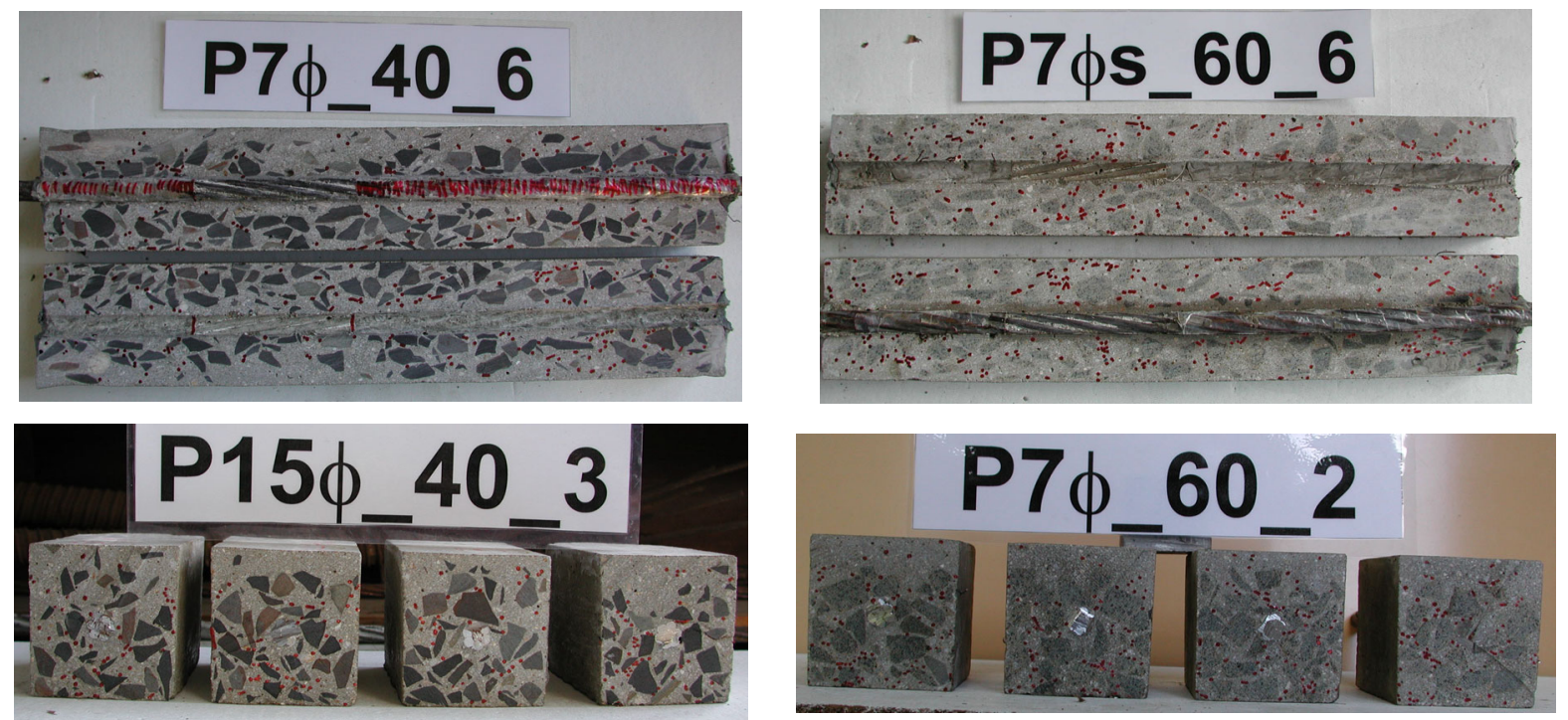

(a)

(b)

Figura 4.9 - Cortes transversais e longitudinais nos prismas da Série 1: (a) $V_{\mathrm{f}}=40 \mathrm{~kg} / \mathrm{m}^{3}$; (b) $\mathrm{V}_{\mathrm{f}}=60 \mathrm{~kg} / \mathrm{m}^{3}$.

Após o corte dos prismas, as fibras foram pintadas, ou melhor, realçadas, de vermelho para facilitar a sua visualização na fotografia. Como se pode observar, as fibras se encontram bem distribuídas ao longo de toda a peça, tanto longitudinalmente como transversalmente. Nota-se também, que os compósitos com $\mathrm{V}_{\mathrm{f}}=60 \mathrm{~kg} / \mathrm{m}^{3}$ apresentam uma concentração maior de fibras de aço do que os compósitos com $\mathrm{V}_{\mathrm{f}}=40 \mathrm{~kg} / \mathrm{m}^{3}$, o que era de se esperar. Não foi observada tendência de alinhamento das fibras. Portanto, optou-se por continuar com a seção de $7 \times 7 \times 40 \mathrm{~cm}$. 
A determinação do comprimento da peça foi baseada no comprimento aderente $\left(\ell_{\mathrm{ef}}\right)$ máximo que se pretendia utilizar, que foi de $15 \phi_{\mathrm{p}}(19 \mathrm{~cm})$. Esse é o comprimento máximo que se deve adotar para que se possa admitir uma tensão de aderência constante ao longo de toda a sua extensão. Comprimentos aderentes maiores que 15ф, além de não permitirem a hipótese de tensão de aderência constante, já começam a exigir cargas de ruptura mais elevadas, o que poderia levar ao escoamento da armadura. Na literatura, recomenda-se retirar a aderência das extremidades dos modelos de arrancamento, especialmente no lado de introdução de carga, não só para fugir de zonas de perturbações de tensões, como também para evitar a ruptura do cone de concreto, principalmente para peças tracionadas, e, ainda, para poder admitir uma tensão de aderência constante ao longo de todo o comprimento aderente. Por este motivo, a aderência foi retirada ao longo do mesmo valor do comprimento aderente máximo, $19 \mathrm{~cm}$, resultando num prisma de $40 \mathrm{~cm}(19+19=38 \mathrm{~cm}$, arredondou-se para $40 \mathrm{~cm})$. Com esse comprimento foi possível concretar seis modelos pré-tracionados por vez. Para os modelos com $\ell_{\mathrm{ef}}=7 \phi_{\mathrm{p}}(9 \mathrm{~cm})$, o comprimento variável (Figura 4.7) foi, aproximadamente, $12 \mathrm{~cm}$. Para as peças com $\ell_{\mathrm{ef}}=15 \phi_{\mathrm{p}}(19 \mathrm{~cm})$, o comprimento variável foi zero, ou seja, não foi retirada a aderência da extremidade livre.

A Série 2 utilizou o modelo sugerido pela RILEM. Essa série teve o objetivo de servir como padrão de comparação para os modelos da Série 1. Foram concretados seis modelos pré-tracionados por vez.

Nos ensaios de arrancamento, o comprimento de ancoragem $\left(\ell_{\mathrm{ef}}\right)$ adotado foi sempre menor do que o admitido nos ensaios de flexão. Isso se deve a alguns fatores: (1) para facilitar o arrancamento da barra; (2) para garantir que a barra não entre em escoamento; (3) para garantir que a seção de concreto resista às tensões de compressão e de tração; e (4) para que a tensão de aderência ao longo do comprimento de ancoragem possa ser admitida constante.

A Figura 4.10 apresenta algumas fotos das formas e dos modelos de arrancamento das Séries 1 e 2 .

O tipo de modelo ensaiado à flexão foi escolhido com base em ensaios já realizados. Procurou-se elaborar um modelo simples, de fácil manuseio no laboratório, mas que fornecesse resultados satisfatórios, optando-se então por viga de seção transversal retangular, com dimensões $15 \times 30 \mathrm{~cm}$, que foi uma seção utilizada em vários ensaios citados na literatura, e que permitiu, para a cordoalha de $\phi_{\mathrm{p}} 12,7 \mathrm{~mm}$ e o vão adotado, obter-se uma viga subarmada. Essa escolha teve a intenção de que a armadura pudesse ser solicitada ao extremo, 
antes da ruptura do concreto, para que se pudesse observar melhor o comportamento das peças ensaiadas em relação à aderência.

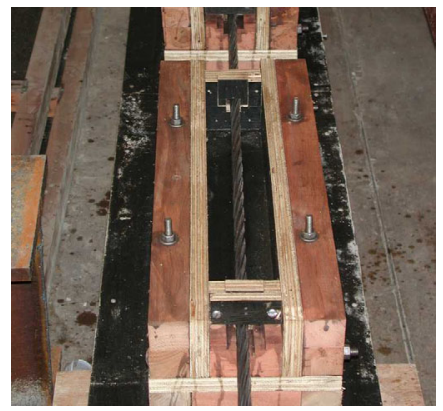

(a)

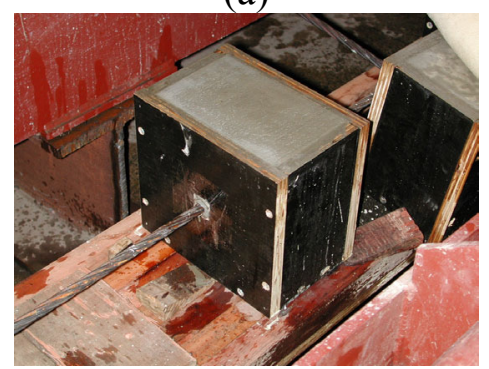

(c)

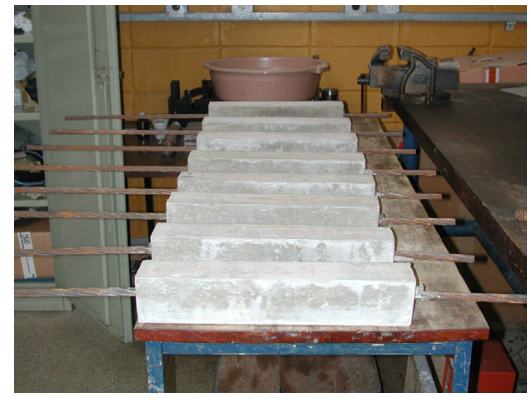

(b)

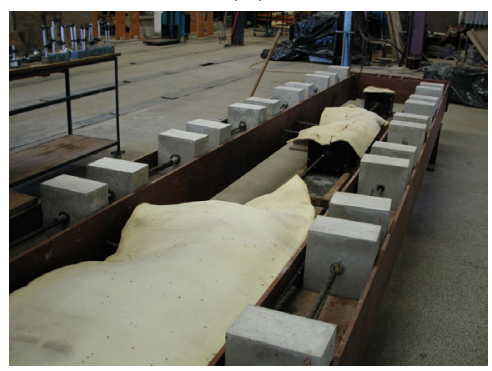

(d)

Figura 4.10 - Modelos de arrancamento: (a) formas da Série 1; (b) modelos da Série 1; (c) forma da Série 2; (d) modelos da Série 2.

Outro aspecto importante foi a otimização das concretagens, o que influenciou na determinação do vão da viga. Para a seção transversal e a cordoalha adotadas, a dimensão mínima para o vão da viga era em torno de $200 \mathrm{~cm}$, para que fosse possível medir com segurança os comprimentos de transferência e de ancoragem necessário, nas duas extremidades da peça, ou seja, o vão da viga deveria ser, pelo menos, duas vezes maior do que o comprimento de ancoragem necessário máximo $\left(\mathrm{L}>2 . \ell_{\mathrm{bpd} \text {,máx }}\right)$. Apesar do pórtico apresentar um vão disponível de aproximadamente $600 \mathrm{~cm}$, não seria possível concretar três vigas ao mesmo tempo, já que é necessário um espaço entre as peças, não só para o corte posterior das cordoalhas, como também para a colocação de transdutores de deslocamento, durante a retirada da protensão. Por esse motivo, o vão total das vigas foi de $250 \mathrm{~cm}$, sendo possível a concretagem de duas peças por vez (Figura 4.1). Além disso, o vão livre foi de $240 \mathrm{~cm}$, o que permitia utilizar valores inteiros para L/3 $(80 \mathrm{~cm}), \mathrm{L} / 4(60 \mathrm{~cm})$ e L/6 $(40 \mathrm{~cm})$. Esses valores foram utilizados para os comprimentos de ancoragem disponíveis $\left(\ell_{\mathrm{ef}}\right)$ dos ensaios.

Os modelos de viga foram todos prismáticos e de mesmas dimensões. Os parâmetros de ensaio que variaram foram o compósito e o comprimento de ancoragem disponível de ensaio, 
da armadura de protensão, que era função da distância do ponto de aplicação da carga ao apoio mais próximo. A Figura 4.11 mostra o projeto dos modelos.

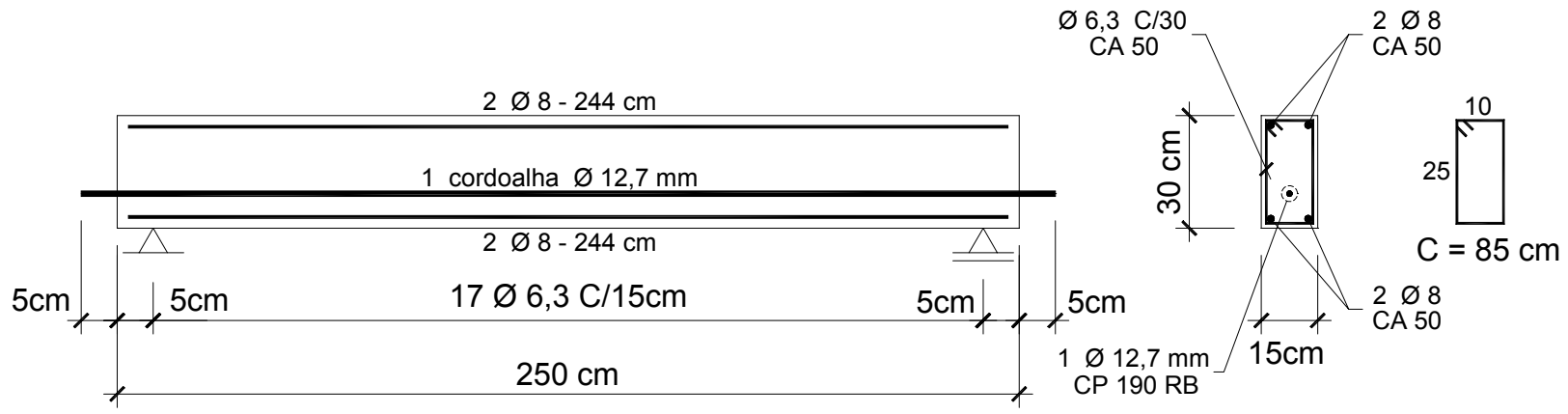

Figura 4.11 - Dimensões e forma das vigas para os ensaios de flexão.

Para as últimas cinco vigas ensaiadas, aumentou-se a armadura transversal no vão de cisalhamento. Esse fato está comentado em detalhes no Capítulo 6.

A Figura 4.12 apresenta algumas fotos da forma, armação e desforma das vigas.

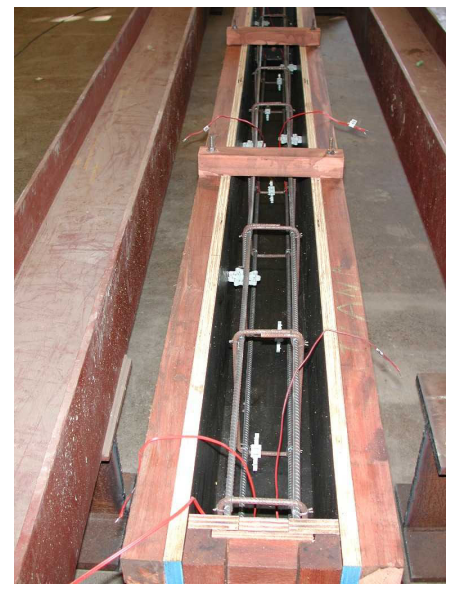

(a)

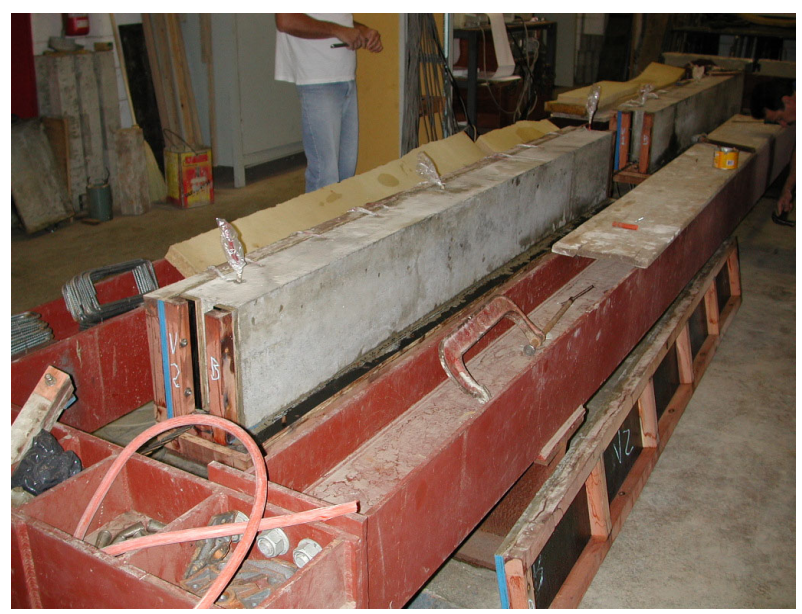

(b)

Figura 4.12 - Modelo para os ensaios de viga: (a) forma e armação das vigas; (b) desforma das vigas.

A Figura 4.13 apresenta a definição do comprimento de ancoragem disponível de ensaio.

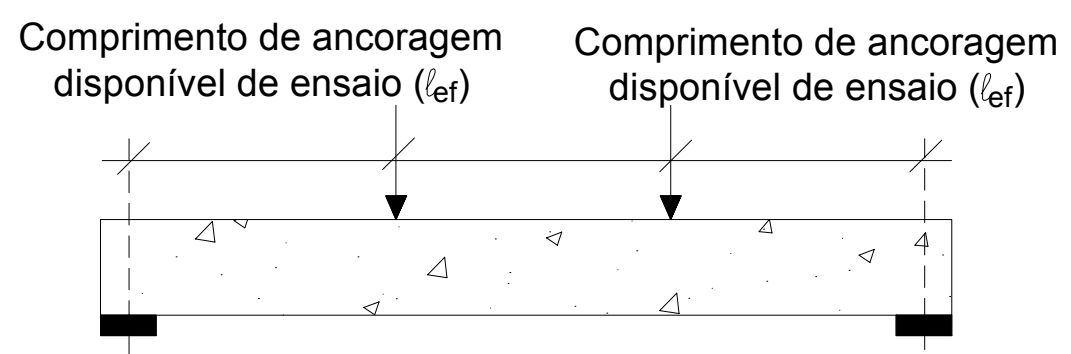

Figura 4.13 - Comprimento de ancoragem disponível de ensaio. 


\subsubsection{Plano de execução dos ensaios}

Uma vez determinado o tipo de modelo, foram estabelecidos o melhor arranjo de ensaio e a instrumentação adequada, necessários para a obtenção dos resultados desejados. Foram definidas, também, as séries de ensaios com seus respectivos parâmetros.

\section{a) Ensaios de arrancamento}

A Figura 4.14 apresenta o esquema de ensaio e da instrumentação para os ensaios de arrancamento.

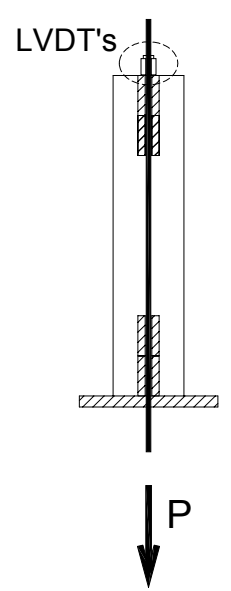

Figura 4.14 - Arranjo de ensaio e instrumentação para os ensaios de arrancamento das Séries 1 e 2.

Nos ensaios de arrancamento, tanto para a Série 1 como para a Série 2, foram feitas apenas duas leituras: (1) do escorregamento da cordoalha na extremidade livre, através de um relógio comparador com curso de $10 \mathrm{~mm}$ (Figura $4.15 \mathrm{~b}$ e $4.16 \mathrm{~b}$ ); e (2) da carga, cuja leitura foi obtida diretamente da máquina de ensaio. Com essas leituras foi possível determinar os gráficos Tensão de aderência versus Escorregamento para os modelos ensaiados. As Figuras 4.15 e 4.16 apresentam algumas fotos dos arranjos de ensaio e da instrumentação dos modelos.

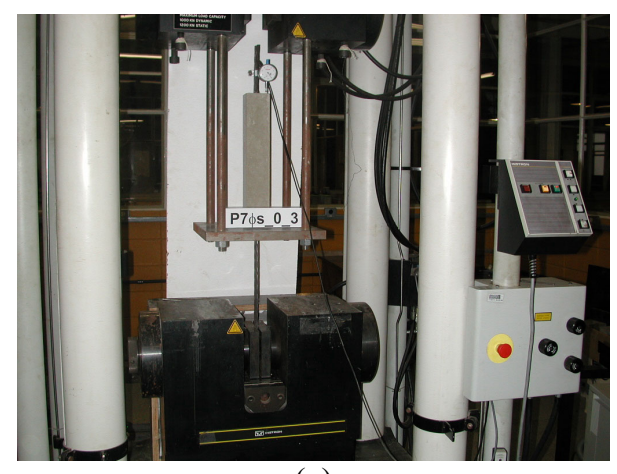

(a)

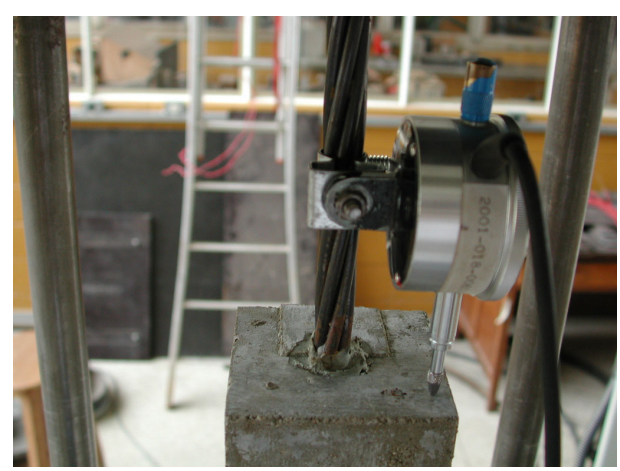

(b)

Figura 4.15 - Arranjo de ensaio e instrumentação para os modelos de arrancamento da Série 1: (a) arranjo de ensaio da Série 1; (b) detalhe do relógio comparador na Série 1. 
Não foram colocados extensômetros elétricos ao longo da cordoalha para estas peças, pois, devido aos pequenos comprimentos de ancoragem adotados $\left[5 \phi_{\mathrm{p}}(6,35 \mathrm{~cm}), 7 \phi_{\mathrm{p}}(9 \mathrm{~cm}) \mathrm{e}\right.$ $\left.15 \phi_{\mathrm{p}}(19 \mathrm{~cm})\right]$, o tamanho do isolamento dos extensômetros, que ficou em torno de $5 \mathrm{~cm}$, foi incompatível com o comprimento aderente disponível. A Figura 4.17 apresenta o detalhe do isolamento do extensômetro elétrico colocado na cordoalha das vigas.

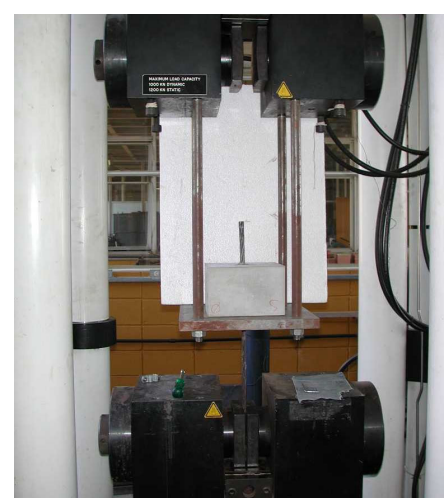

(a)

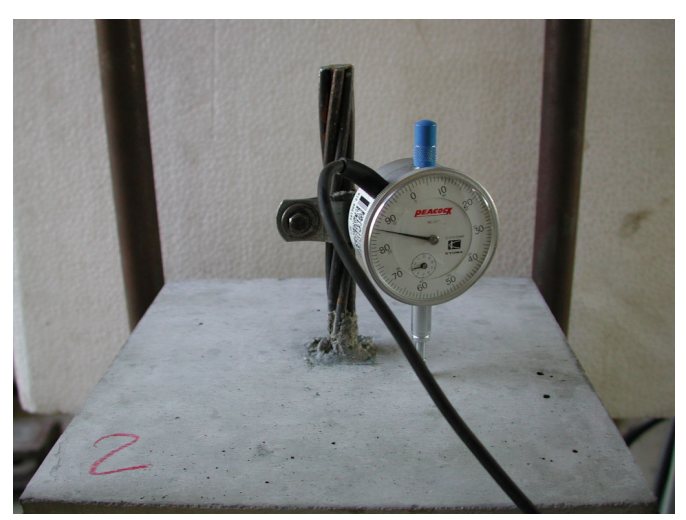

(b)

Figura 4.16 - Arranjo de ensaio e instrumentação para os modelos de arrancamento da Série 2: (a) arranjo de ensaio da Série 2; (b) detalhe do relógio comparador na Série 2.

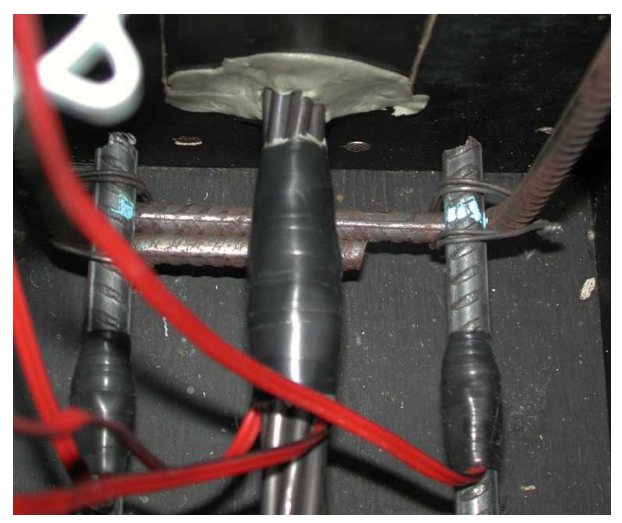

Figura 4.17 - Detalhe do isolamento dos extensômetros elétricos.

\section{b) Ensaios de flexão}

$\mathrm{O}$ arranjo de ensaio, com duas cargas eqüidistantes das extremidades, foi escolhido por três motivos: (1) define o tamanho do comprimento de ancoragem disponível, que é a distância do ponto de aplicação da carga até o apoio externo da viga (comprimentos $\ell_{0}$ na Figura 4.19a); (2) permite um controle maior do padrão de fissuração da viga; e (3) permite o controle do vão de cisalhamento e da região de momento constante. Esse arranjo foi utilizado nas nove primeiras vigas. Verificou-se, então, que para as vigas com comprimentos $\ell_{0}$ menores que L/3 a viga apresentava uma rigidez muito grande, optando-se então por um 
arranjo de ensaio com apenas uma carga aplicada em uma das extremidades da viga, como mostra a Figura 4.18.

Para as vigas, foram feitas diversas leituras. A Figura 4.19 apresenta um esquema de alguns detalhes do arranjo de ensaio e da instrumentação. A Figura 4.20 apresenta os detalhes da seção transversal das vigas, e a legenda para a simbologia da Figura 4.19.

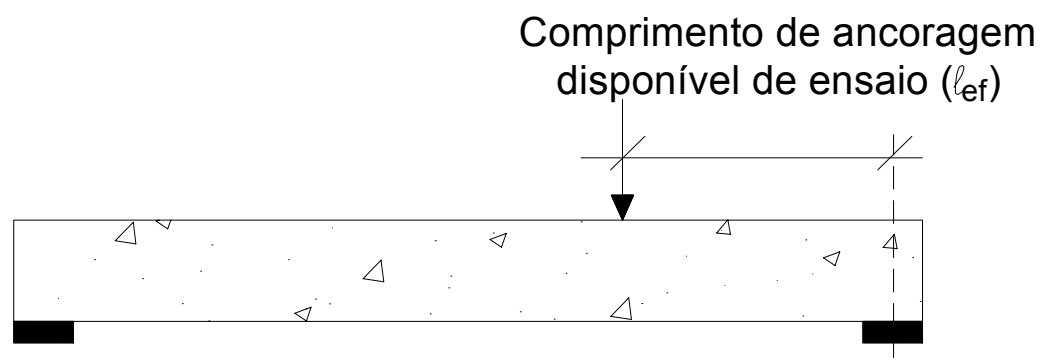

Figura 4.18 - Arranjo de ensaio alternativo.

A instrumentação utilizada nestes ensaios, e esquematizada na Figura 4.19, foi diferente da instrumentação utilizada nos dois ensaios pilotos. A descrição destes últimos encontra-se no item 4.1.3, a seguir. A instrumentação das outras doze vigas seguiu o padrão apresentado na Figura 4.19, porém, cada ensaio apresentou algumas particularidades, que estão descritas, ensaio a ensaio, no Capítulo 6.

As vigas foram instrumentadas com: relógios comparadores da KYOWA com curso de $10 \mathrm{~mm}\left(\mathrm{R}_{1}\right.$ e $\left.\mathrm{R}_{2}\right)$; transdutores de deslocamento da KYOWA com cursos de $50 \mathrm{~mm}$ e $100 \mathrm{~mm}$ $\left(\mathrm{R}_{3}\right.$ a $\left.\mathrm{R}_{7}\right)$; extensômetros elétricos colocados na cordoalha $\left(\mathrm{EA}_{1}\right)$, nas armaduras longitudinais passivas $\left(\mathrm{EA}_{2}\right.$ a $\left.\mathrm{EA}_{7}\right)$, e nas armaduras transversais $\left(\mathrm{EA}_{8}\right.$ e $\left.\mathrm{EA}_{9}\right)$ - tipo KFG-2-C1-11 com base de medida de $2 \mathrm{~mm}$; extensômetros elétricos colocados na face externa da viga $\left(\mathrm{EC}_{1}\right.$ a $\left.\mathrm{EC}_{14}\right)$, sobre o concreto - tipo PA-06-500-BA-120L com base de medida de 12,7mm (0,5"); e, pastilhas de aço coladas na face externa das vigas $\left(\mathrm{T}_{1}\right.$ a $\left.\mathrm{T}_{30}\right)$, sobre o concreto, para a leitura de deslocamento com o TENSOTAST.

Os relógios comparadores $\left(\mathrm{R}_{1}\right.$ e $\left.\mathrm{R}_{2}\right)$ mediram o escorregamento da cordoalha em relação ao concreto (Figura 4.21a).

Os transdutores de deslocamento mediram o deslocamento vertical da viga ao longo de seu eixo (Figura 4.23): no meio do vão $\left(\mathrm{R}_{4}\right)$, e sob os pontos de introdução de carga $\left(\mathrm{R}_{3}\right.$ e $\left.\mathrm{R}_{5}\right)$. Logo, $R_{3}$ e $R_{5}$ variaram a posição em função de $\ell_{0}$. Os transdutores $R_{6}$ e $R_{7}$ mediram o deslocamento sobre os apoios, devido às suas rotações. A partir dessas leituras foram feitas as correções para os deslocamentos verticais de $\mathrm{R}_{3}$ a $\mathrm{R}_{5}$. 

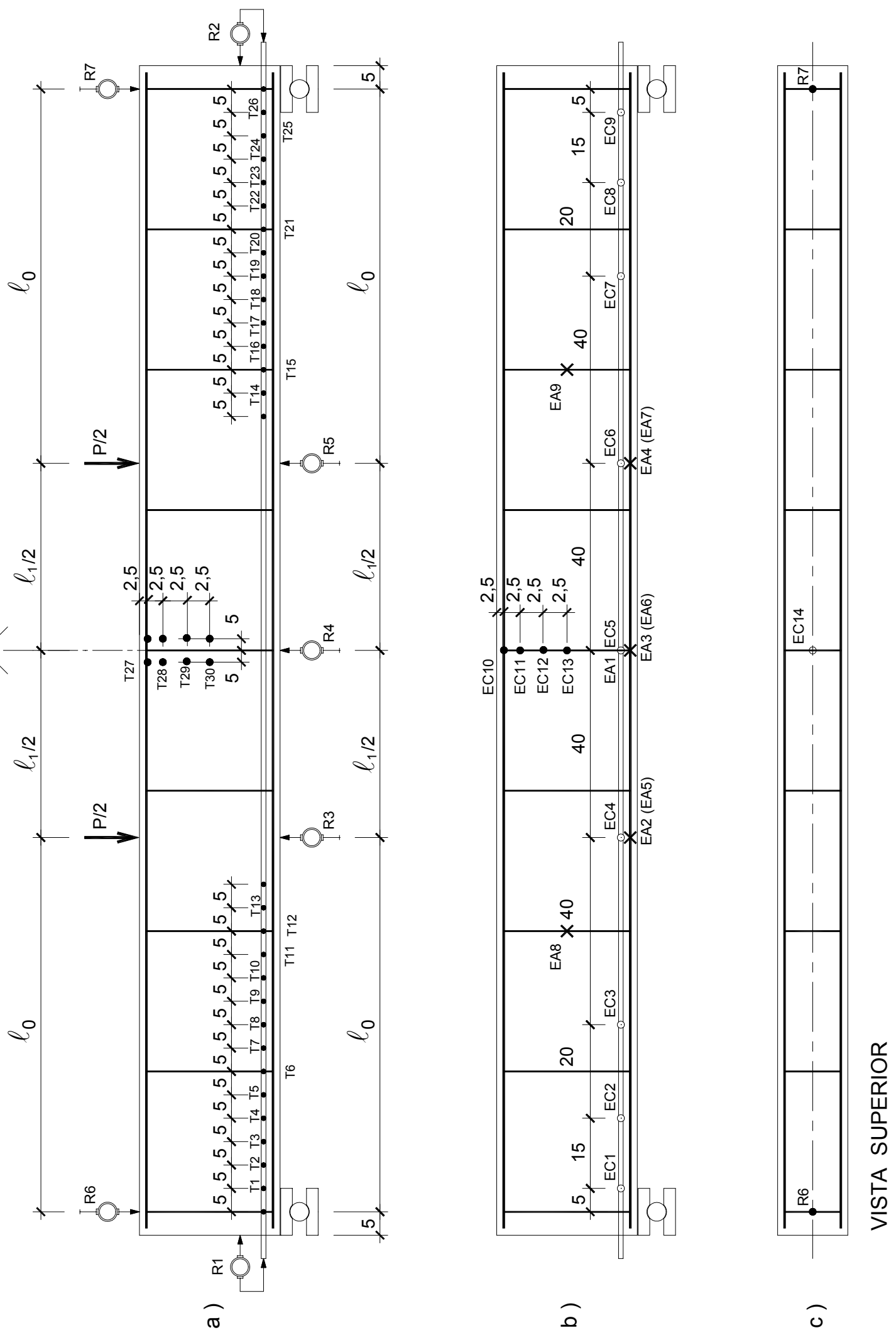

Figura 4.19 - Arranjo de ensaio e instrumentação para os ensaios de flexão (dimensões em cm): (a) arranjo de ensaio, posição da colocação das pastilhas para leitura com o TENSOTAST $\left(\mathrm{T}_{\mathrm{i}}\right)$, posição dos transdutores de deslocamento e dos relógios comparadores nas extremidades $\left(\mathrm{R}_{\mathrm{i}}\right)$; (b) posição dos extensômetros elétricos na face externa do concreto $\left(\mathrm{EC}_{\mathrm{i}}\right)$ e posição dos extensômetros elétricos nas armaduras passivas e ativas $\left(\mathrm{EA}_{\mathrm{i}}\right)$; (c) vista superior da peça, com posição de extensômetros e transdutores de deslocamento. 


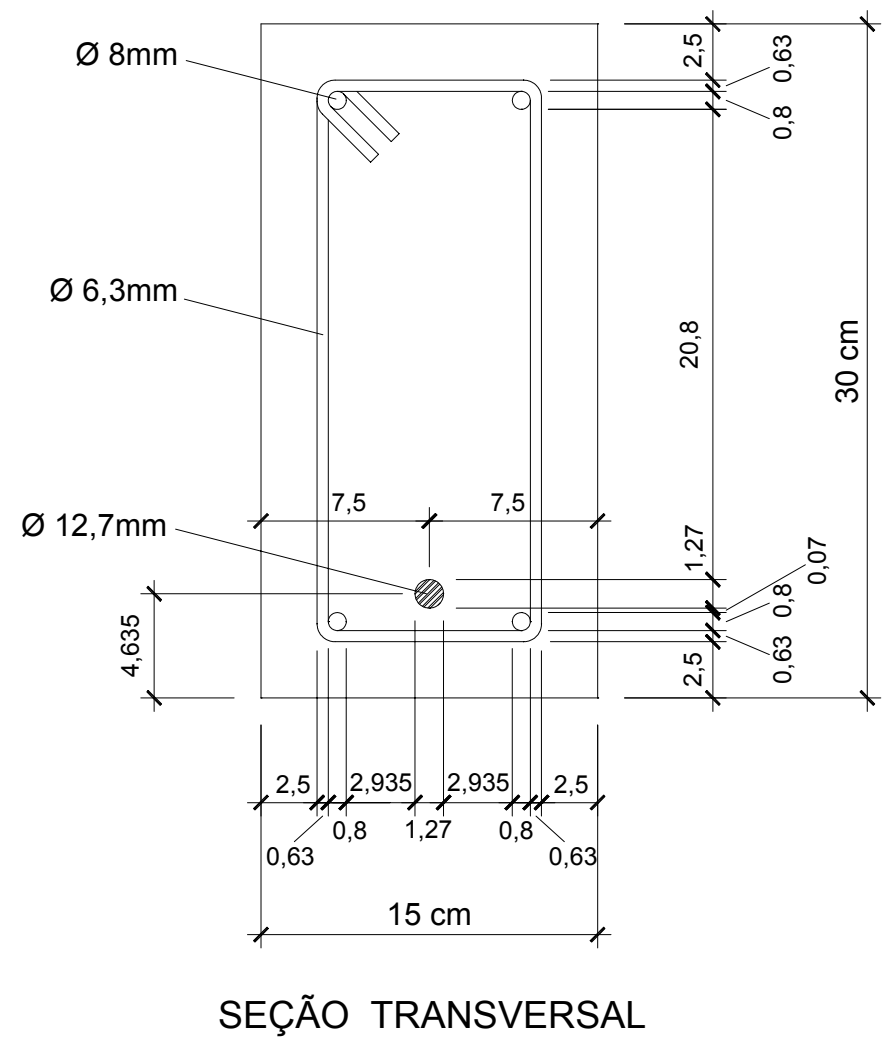

LEGENDA :

Armadura transversal (estribo) : $\varnothing 6,3 \mathrm{~mm} \mathrm{c} / 15 \mathrm{~cm}$

Armadura longitudinal : $\varnothing 8 \mathrm{~mm}$

armaduras passivas CA-50

Cordoalha de 7 fios : $\varnothing 12,7 \mathrm{~mm}\}$ armadura ativa CP-190 RB

- Pontos de colocação das pastilhas p/ leitura com TENSOTAST (face externa)

$\times \quad$ Pontos de colocação dos extensômetros elétricos no aço

Pontos de colocação dos extensômetros elétricos no concreto (face externa)

- Pontos de colocação dos transdutores de deslocamento

Figura 4.20 - Seção transversal detalhada das vigas e legenda para a Figura 4.19 (dimensões em cm).

O extensômetro elétrico colocado na cordoalha $\left(E_{1}\right)$ mediu a deformação no meio do vão, e, conseqüentemente, a tensão máxima no aço. Para isso, foram colados dois extensômetros em fios diametralmente opostos da cordoalha, e calculado o valor médio entre eles. A utilização de apenas um ponto de leitura na armadura ativa foi para evitar a retirada da aderência ao longo da peça, principalmente na zona de ancoragem, já que o isolamento dos extensômetros tinha um comprimento exagerado (Figura 4.17).

Apesar do extensômetro medir apenas $5 \mathrm{~mm}$, é necessário isolar um comprimento bem maior para impedir que entre água, pelas reentrâncias da cordoalha, durante a concretagem, o que inutilizaria o extensômetro. Porém, ao longo dos ensaios, o número de pontos de 
extensômetros na cordoalha aumentou para três, colocados nas mesmas posições que os extensômetros da armadura passiva longitudinal.

Os extensômetros elétricos colocados na armadura longitudinal passiva mediram a deformação no meio do vão $\left.\left(\mathrm{EA}_{3} \text { e EA }\right)_{6}\right)$ e nos pontos de introdução de carga $\left(\mathrm{EA}_{2}, \mathrm{EA}_{4}, \mathrm{EA}_{5}\right.$ e $\mathrm{EA}_{7}$ ). A posição destes últimos variou de acordo com $\ell_{0}$. A deformação, e conseqüentemente a tensão, das armaduras passivas deu uma boa indicação da deformação, e conseqüentemente da tensão, das cordoalhas. Esse fato foi verificado nos ensaios pilotos.

Os extensômetros elétricos colocados nas armaduras transversais (EA 8 e EA9) mediram as suas deformações, e serviram para verificar a que tensão de cisalhamento a peça estava submetida. Esses extensômetros foram colocados ou nos estribos sob os pontos de introdução de carga, ou nos estribos mais próximos desses pontos, na região de cisalhamento, ou seja, entre a carga e o apoio mais próximo.

$\mathrm{Na}$ face externa da viga, sobre o concreto, foram utilizados dois tipos de instrumentação, um de cada lado da peça. De um lado foram colocados os extensômetros elétricos (Figura 4.22), e do outro as pastilhas de aço para leitura com o TENSOTAST (Figura 4.21b). Essa redundância na instrumentação serviu para validação dos resultados, já que um tipo de instrumentação verificava o outro, e vice-versa. Os extensômetros $\mathrm{EC}_{1}$ a $\mathrm{EC}_{9}$, assim como as leituras de TENSOTAST $\mathrm{T}_{1}$ a $\mathrm{T}_{26}$, foram colocados na altura da cordoalha, e mediram a deformação ao longo de toda a extensão da peça. As leituras de $\mathrm{EC}_{10} \mathrm{a} \mathrm{EC}_{13}$ e de $\mathrm{T}_{27}$ a $\mathrm{T}_{30}$ serviram para verificar a extensão da zona comprimida do concreto. Foi feita ainda uma leitura com extensômetro elétrico $\left(\mathrm{EC}_{14}\right)$ na face superior da viga, no meio do vão, para medir a tensão máxima de compressão da peça. A quantidade e a posição desses dois tipos de leitura (extensômetros elétricos e TENSOTAST) sofreram algumas variações no transcorrer dos ensaios, o que está relatado no Capítulo 6.

Com todas essas leituras, foi possível avaliar e acompanhar o comportamento das vigas durante os ensaios de flexão, e também avaliar os comprimentos de transferência e de ancoragem necessário.

As Figuras 4.21 a 4.23 apresentam algumas fotos dos arranjos de ensaio e da instrumentação dos modelos. 


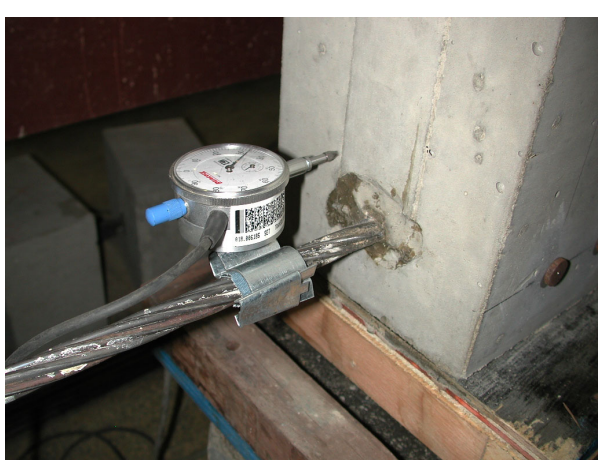

(a)

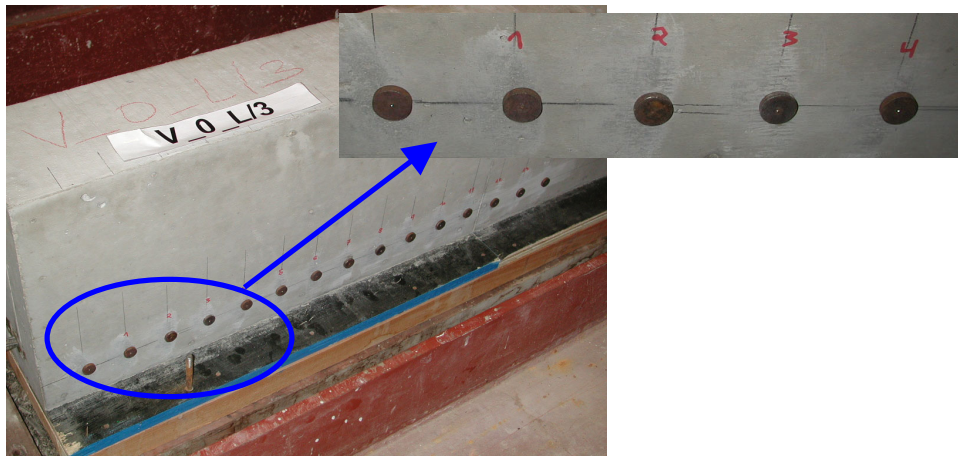

(b)

Figura 4.21 - Detalhes da instrumentação das vigas: (a) detalhe do relógio comparador para leitura do escorregamento; (b) detalhe da posição das pastilhas para leitura com o TENSOTAST.

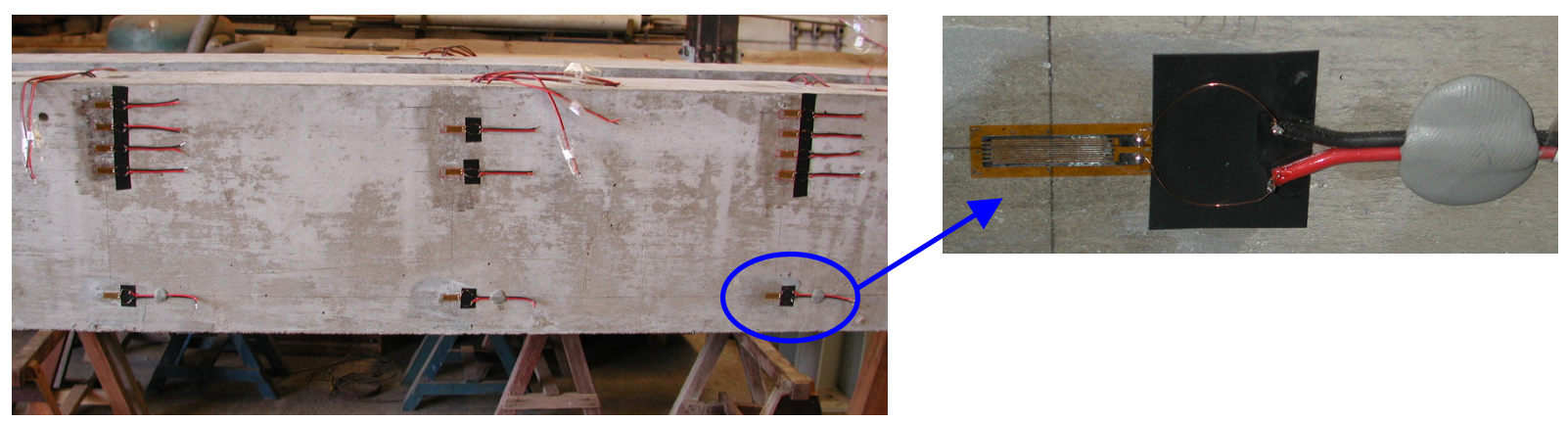

Figura 4.22 - Vista e detalhe dos extensômetros elétricos na face externa do concreto.

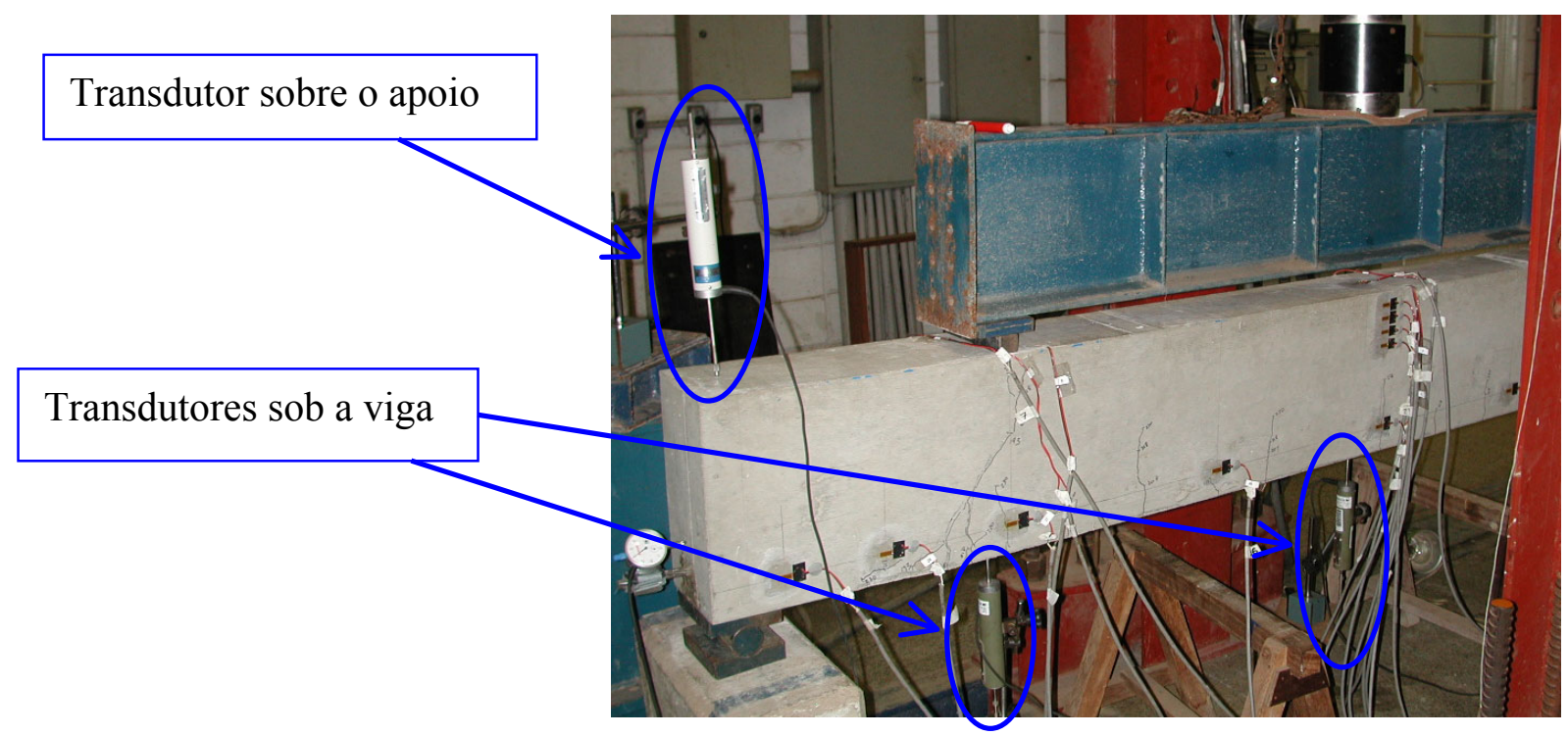

Figura 4.23 - Vista dos transdutores colocados sob a viga e sobre o apoio, e do perfil de distribuição de carga.

\section{c) Parâmetros dos ensaios}

Com base no tipo do modelo, no arranjo de ensaio e na instrumentação, foi estabelecido um cronograma de fabricação dos modelos e de realização dos ensaios. 
Os planos de ensaios, divididos em três séries, discriminando os parâmetros e os modelos de cada série, estão apresentados nas Tabelas 4.2, 4.3 e 4.4.

Tabela 4.2 - Plano dos ensaios estáticos de arrancamento da Série 1 (72 modelos).

\begin{tabular}{|c|c|c|c|c|c|c|c|}
\hline \multicolumn{2}{|c|}{ SÉRIE } & \multicolumn{6}{|c|}{1} \\
\hline $\begin{array}{l}\text { Aço } \\
\text { CP } 190\end{array}$ & $\begin{array}{l}\text { Volum } \\
\text { de fibra }\end{array}$ & \multirow{2}{*}{\multicolumn{2}{|c|}{$0 \%$}} & \multirow{2}{*}{\multicolumn{2}{|c|}{$\begin{array}{l}40 \mathrm{~kg} / \mathrm{m}^{3} \\
(0,51 \%)\end{array}$}} & \multirow{2}{*}{\multicolumn{2}{|c|}{$\begin{array}{l}60 \mathrm{~kg} / \mathrm{m}^{3} \\
(0,76 \%)\end{array}$}} \\
\hline Tipo & Protensão & & & & & & \\
\hline \multirow{4}{*}{$\begin{array}{l}7 \text { fios } \\
\phi 12,7\end{array}$} & \multirow[b]{2}{*}{ Com } & $\ell_{\mathrm{ef}}=7 \phi_{\mathrm{p}}$ & $\ell_{\mathbf{e f}}=15 \phi_{\mathrm{p}}$ & $\ell_{\mathbf{e f}}=7 \phi_{\mathrm{p}}$ & $\ell_{\mathbf{e f}}=15 \phi_{\mathrm{p}}$ & $\ell_{\mathrm{ef}}=7 \phi_{\mathrm{p}}$ & $\ell_{\mathbf{e f}}=15 \phi_{\mathrm{p}}$ \\
\hline & & 6 modelos & 6 modelos & 6 modelos & 6 modelos & 6 modelos & 6 modelos \\
\hline & \multirow[b]{2}{*}{ Sem } & $\ell_{\mathrm{ef}}=7 \phi_{\mathrm{p}}$ & $\ell_{\mathbf{e f}}=15 \phi_{\mathrm{p}}$ & $\ell_{\mathrm{ef}}=7 \phi_{\mathrm{p}}$ & $\ell_{\mathrm{ef}}=15 \phi_{\mathrm{p}}$ & $\ell_{\mathrm{ef}}=7 \phi_{\mathrm{p}}$ & $\ell_{\mathbf{e f}}=15 \phi_{\mathrm{p}}$ \\
\hline & & 6 modelos & 6 modelos & 6 modelos & 6 modelos & 6 modelos & 6 modelos \\
\hline
\end{tabular}

Tabela 4.3 - Plano dos ensaios estáticos de arrancamento da Série 2 (36 modelos).

\begin{tabular}{|c|c|c|c|c|}
\hline \multicolumn{2}{|c|}{ SÉRIE } & \multicolumn{3}{|c|}{2} \\
\hline $\begin{array}{l}\text { Aço } \\
\text { CP } 190\end{array}$ & de fibra & \multirow[t]{2}{*}{$0 \%$} & \multirow[t]{2}{*}{$\begin{array}{l}40 \mathrm{~kg} / \mathrm{m}^{3} \\
(0,51 \%)\end{array}$} & \multirow[t]{2}{*}{$\begin{array}{l}60 \mathrm{~kg} / \mathrm{m}^{3} \\
(0,76 \%)\end{array}$} \\
\hline Tipo & Protensão & & & \\
\hline \multirow{2}{*}{$\begin{array}{l}7 \text { fios } \\
\phi 12,7\end{array}$} & Com & $\begin{array}{l}6 \text { modelos } \\
\left(\ell_{\mathrm{ef}}=5 \phi_{\mathrm{p}}\right)\end{array}$ & $\begin{array}{l}6 \text { modelos } \\
\left(\ell_{\mathrm{ef}}=5 \phi_{\mathrm{p}}\right)\end{array}$ & $\begin{array}{l}6 \text { modelos } \\
\left(\ell_{\mathrm{ef}}=5 \phi_{\mathrm{p}}\right)\end{array}$ \\
\hline & Sem & $\begin{array}{l}6 \text { modelos } \\
\left(\ell_{\mathrm{ef}}=5 \phi_{\mathrm{p}}\right)\end{array}$ & $\begin{array}{l}6 \text { modelos } \\
\left(\ell_{\mathrm{ef}}=5 \phi_{\mathrm{p}}\right)\end{array}$ & $\begin{array}{l}6 \text { modelos } \\
\left(\ell_{\mathrm{ef}}=5 \phi_{\mathrm{p}}\right)\end{array}$ \\
\hline
\end{tabular}

Tabela 4.4 - Plano dos ensaios estáticos de flexão (14 modelos).

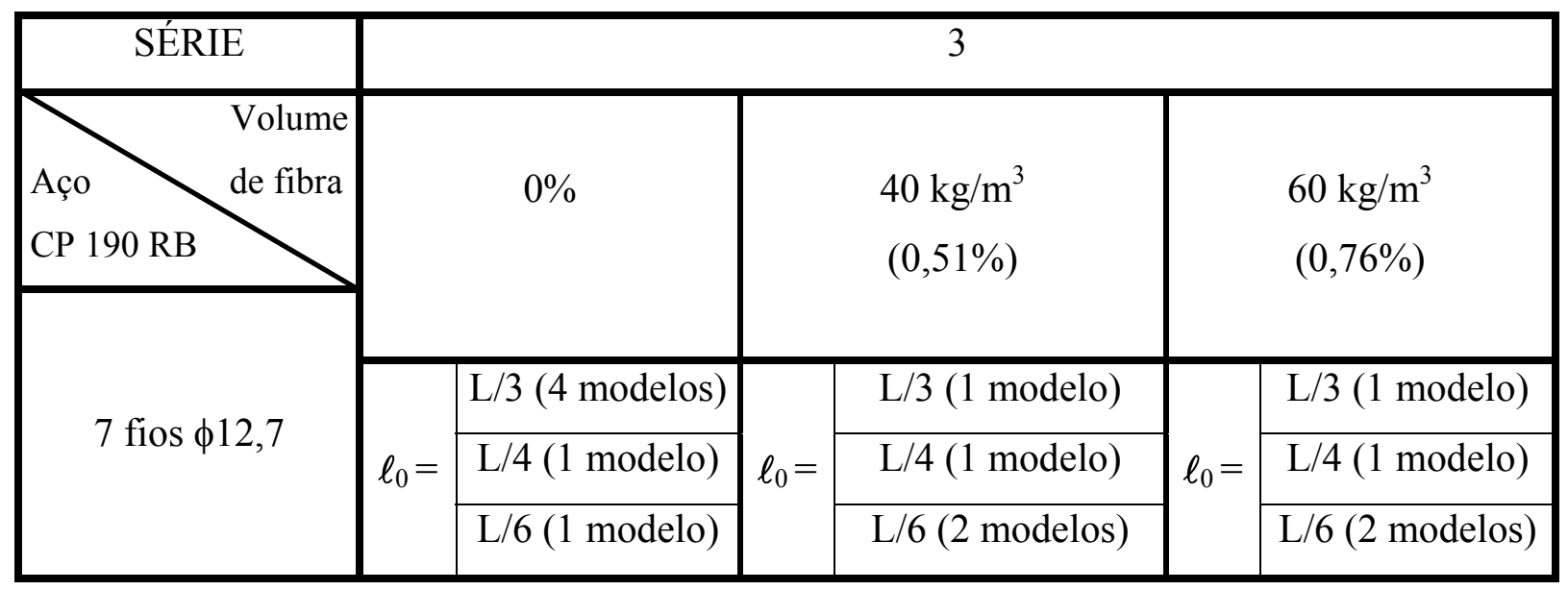


Como se pode notar, foi utilizado apenas um tipo de fibra (DRAMIX RL-45/30BN, $\ell / \mathrm{d}=45, \ell=30 \mathrm{~mm}$ ), com três consumos diferentes: zero, $40 \mathrm{~kg} / \mathrm{m}^{3}$ e $60 \mathrm{~kg} / \mathrm{m}^{3}$. Também, apenas um tipo de armadura de protensão foi analisada: cordoalhas de sete fios, com diâmetro de 12,7mm, e aço CP190 RB. Esta cordoalha foi escolhida por ser uma das mais usadas nas construções de concreto protendido.

Optou-se por se fazer mais ensaios de arrancamento, que descrevem qualitativamente o comportamento da aderência e apresentam um coeficiente de variação (CV) grande, e menos ensaios de viga, que não apresentam variação significativa nos resultados de peças idênticas. Esses últimos foram usados como comprovação do comportamento à flexão e determinação dos comprimentos de transferência e de ancoragem necessário das cordoalhas. Procurou-se usar poucos parâmetros de ensaio, para que se tivesse um controle maior dos resultados obtidos.

\subsubsection{Ensaios pilotos}

Foram feitos, apenas, dois ensaios pilotos para os modelos de viga à flexão. Para os ensaios de arrancamento, devido à simplicidade do ensaio e à utilização de modelos padrão, não houve necessidade de se fazer ensaio piloto. Os ensaios pilotos de flexão serviram para a verificação dos parâmetros de ensaio adotados e para a validação do tipo de ensaio que se pretendia fazer. Após a realização desses ensaios, foram feitos os ajustes necessários para a obtenção dos dados desejados.

O modelo de viga para os ensaios pilotos foi o mesmo já apresentado na Figura 4.11, cuja única diferença foi o espaçamento da armadura transversal, que foi de $\mathrm{s}=30 \mathrm{~cm}$, duas vezes o espaçamento dos outros ensaios. Foram confeccionadas duas vigas gêmeas, sem fibras de aço $\left(\mathrm{V}_{\mathrm{f}}=0\right)$. $\mathrm{O}$ arranjo de ensaio e a instrumentação dessas vigas estão apresentados na Figura 4.24.

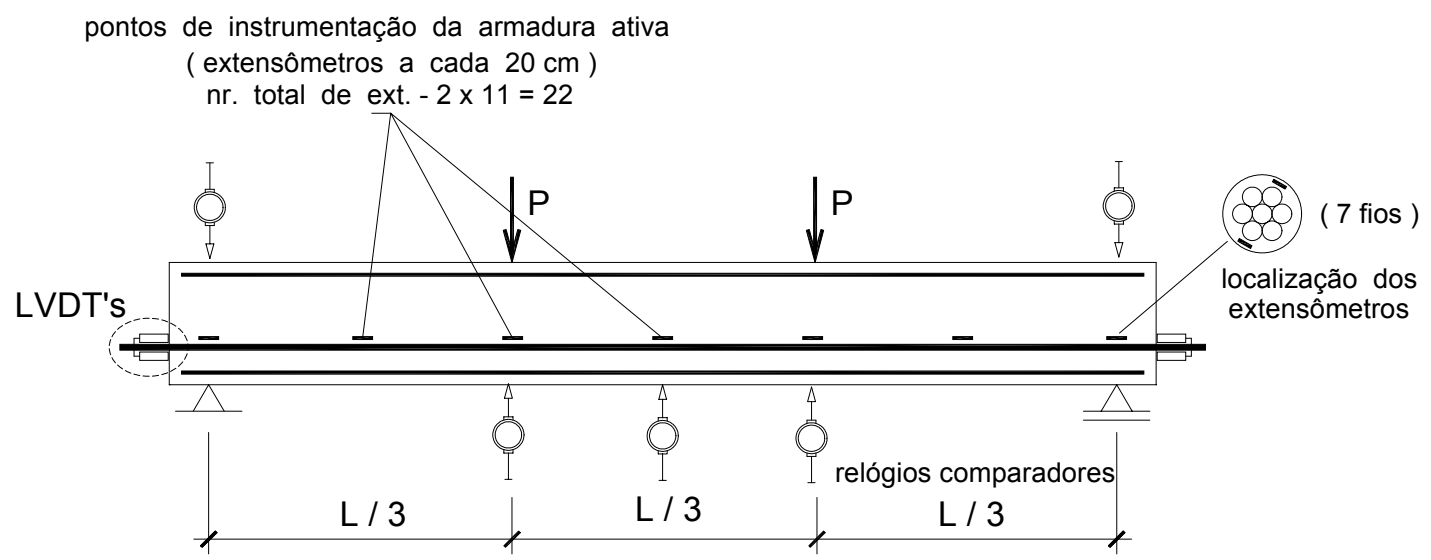


Figura 4.24 - Arranjo de ensaio e instrumentação das vigas para os ensaios pilotos.

Além da cordoalha, foram instrumentadas as armaduras passivas. A instrumentação destas últimas foi a mesma já descrita anteriormente, no item 4.1.2. A posição dos transdutores de deslocamento e dos relógios comparadores também foi a mesma do item 4.1.2. Nos ensaios pilotos não foram utilizados os extensômetros elétricos na face externa da viga, sobre o concreto, e foi utilizado um número reduzido de leituras com o TENSOTAST. Isso ocorreu porque a cordoalha já se encontrava bem instrumentada. As leituras do TENSOTAST foram feitas, apenas, na altura da cordoalha, e de um dos lados das peças. No arranjo de ensaio, para viga biapoiada, foi utilizado um apoio móvel e um apoio fixo (Figura $4.25 \mathrm{a}$ e b, respectivamente).

O procedimento de ensaio foi o seguinte:

1) A cordoalha foi pré-tracionada no pórtico de protensão, no dia anterior à concretagem, e foi feita a leitura inicial de todos os pontos de instrumentação das armaduras ativas e passivas;

2) As duas vigas foram concretadas e vibradas no pórtico;

3) As formas foram retiradas com 24 horas, e as pastilhas para leitura com o TENSOTAST foram coladas às faces externas das vigas;

4) A protensão foi sendo retirada lentamente após 48 horas (dois dias) da concretagem, com leitura passo a passo de toda a instrumentação.

5) Em torno dos 28 dias, as vigas foram colocadas na máquina de ensaio, e submetidas ao ensaio de flexão, com deformação controlada. O final dos ensaios foi determinado por um estado limite último de fissuração excessiva, após a viga apresentar ruptura por cisalhamento, o que ocorreu devido à falta de armadura transversal suficiente.

A Figura 4.25 apresenta detalhes da concretagem e do arranjo de ensaio das vigas.

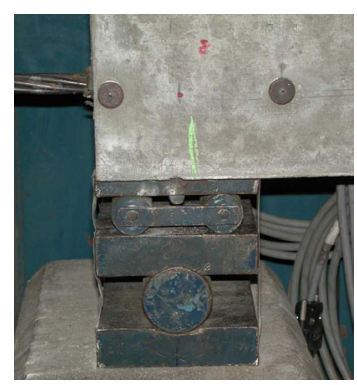

(a)

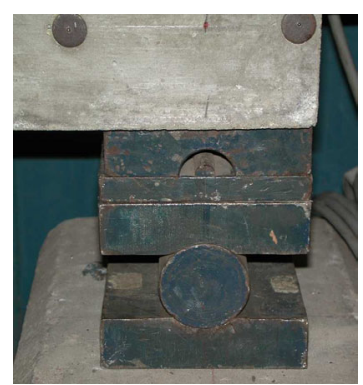

(b)

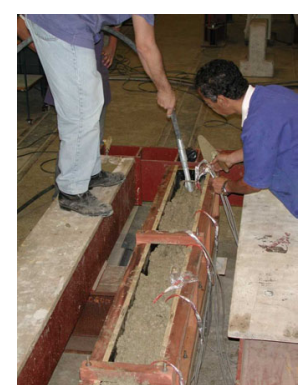

(c)

Figura 4.25 - Detalhes do arranjo de ensaio das vigas: (a) apoio móvel; (b) apoio fixo; (c) adensamento das vigas, com vibrador de agulha. 
As armaduras passivas e ativas das vigas foram montadas no próprio Laboratório de Estruturas. A Figura 4.26 apresenta detalhes das armaduras das vigas.

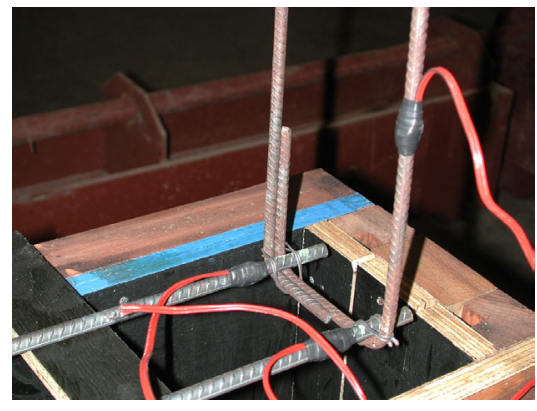

(a)

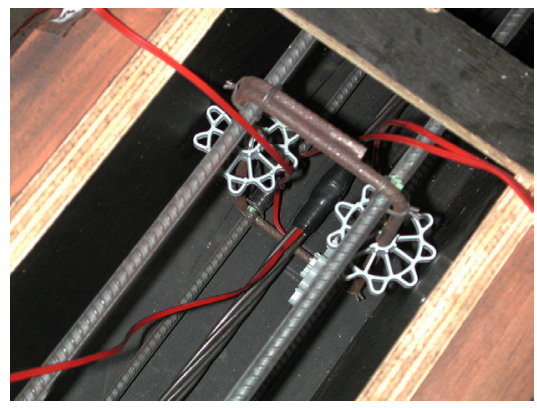

(b)

Figura 4.26 - Detalhes da armação das vigas: (a) ligação do estribo e das armaduras passivas na extremidade da peça; (b) vista superior das armaduras passivas e ativa, e espaçadores, já colocados no interior da forma.

Não houve grandes problemas na instrumentação, montagem e concretagem das vigas. O único ajuste necessário a ser feito nesta etapa foi referente à leitura da deformação do concreto, com o TENSOTAST, na face externa da viga. Após o primeiro ensaio, verificou-se que esses dados possuíam uma variabilidade enorme e não eram confiáveis, visto que foi utilizada uma base de medida muito pequena, $5 \mathrm{~cm}$, e algumas das leituras coincidiam com os pontos de isolamento da cordoalha, o que causava perturbações.

Durante a retirada da protensão foi possível determinar experimentalmente os valores do comprimento de transferência $\left(\ell_{\mathrm{bpt}}\right)$. O gráfico da Figura 4.27 apresenta o andamento das leituras feitas nos extensômetros elétricos da cordoalha, durante a aplicação e a retirada da protensão na viga V1. Os dois gráficos, um para cada viga, foram bem similares. Esses gráficos representam a deformação na cordoalha ao longo do eixo da viga, que vai de zero a 2,5m. De acordo com os gráficos, os valores para o comprimento de transferência, que é a distância da extremidade da viga até o ponto de deformação constante, ficaram em torno de 0,65m. O gráfico da Figura 4.28 apresenta a deformação após a retirada da protensão, nas duas vigas.

Os valores obtidos destes gráficos sofreram uma correção para levar em conta o trecho de aderência que é perdido devido ao isolamento dos extensômetros. A Tabela 4.5 apresenta os resultados finais obtidos.

É interessante notar que o comprimento na extremidade com ancoragem ativa (introdução da protensão) é menor do que o da extremidade com ancoragem morta.

Após a retirada da protensão, as vigas aguardaram até os 28 dias, mais ou menos, para serem levadas aos ensaios de flexão. 


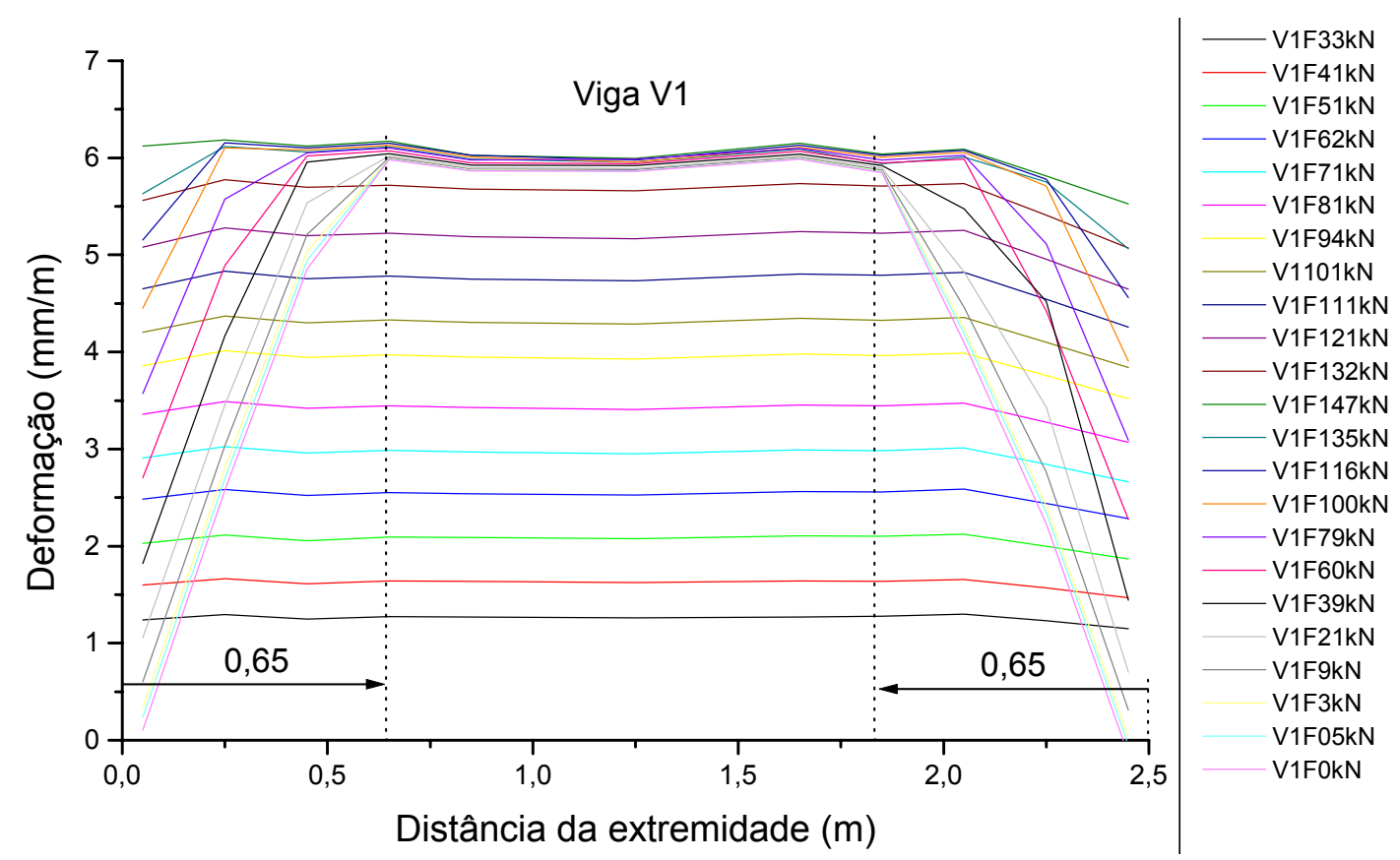

Figura 4.27 - Gráfico Deformação versus Distância para a viga piloto V1.

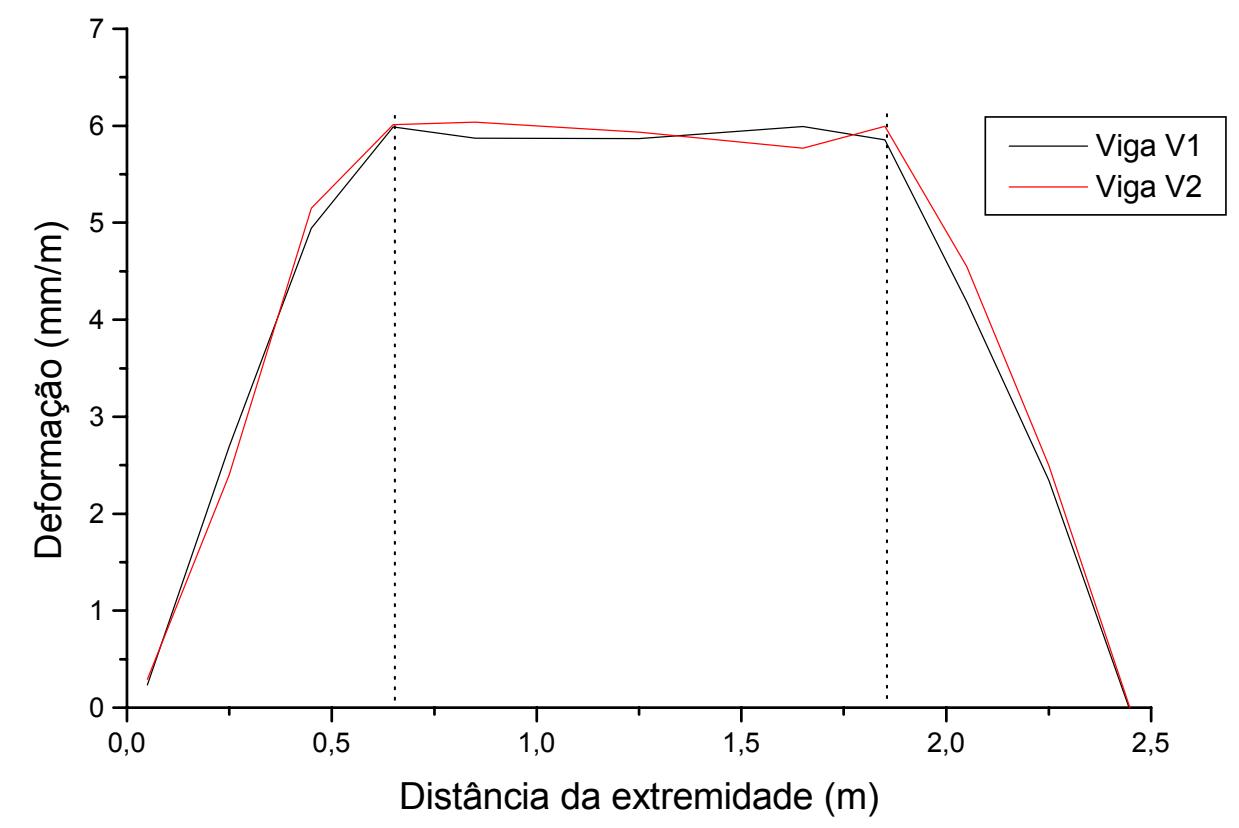

Figura 4.28 - Gráfico Deformação final versus Distância para as vigas V1 e V2.

Tabela 4.5 - Comprimentos de transferência $\left(\ell_{\text {bpt }}\right.$, em metros) para as vigas piloto.

\begin{tabular}{|c|c|c|c|}
\hline Viga & Extremidade 1 (ativa) & Extremidade 2 (morta) & Média \\
\hline V1 & 0,35 & 0,45 & 0,40 \\
\hline V2 & 0,35 & 0,45 & 0,40 \\
\hline
\end{tabular}


No primeiro ensaio à flexão, que foi na viga $V 2$, foram encontradas algumas dificuldades, principalmente na montagem do arranjo de ensaio, devido à grande quantidade de instrumentação. O maior problema nesta etapa acabou sendo a escolha do perfil que seria colocado para distribuir a carga nos terços (Figura 4.23). Os dois primeiros perfis utilizados começaram a deformar antes da viga dar sinais de colapso, ou até mesmo de apresentar fissuração visível a olho nu. Isso ocorreu porque a carga de ruptura estimada foi muito aquém da carga de ruptura real. Esse, também, foi o motivo da obtenção de uma armadura transversal inferior, em relação aos outros ensaios de vigas. Devido a este problema, a viga acabou sendo carregada e descarregada duas vezes antes de ser levada à ruptura, sendo que, na primeira vez, a peça ainda se encontrava na fase elástica, mas na segunda vez houve uma certa plastificação. O gráfico da Figura 4.29 mostra o que ocorreu no ensaio.

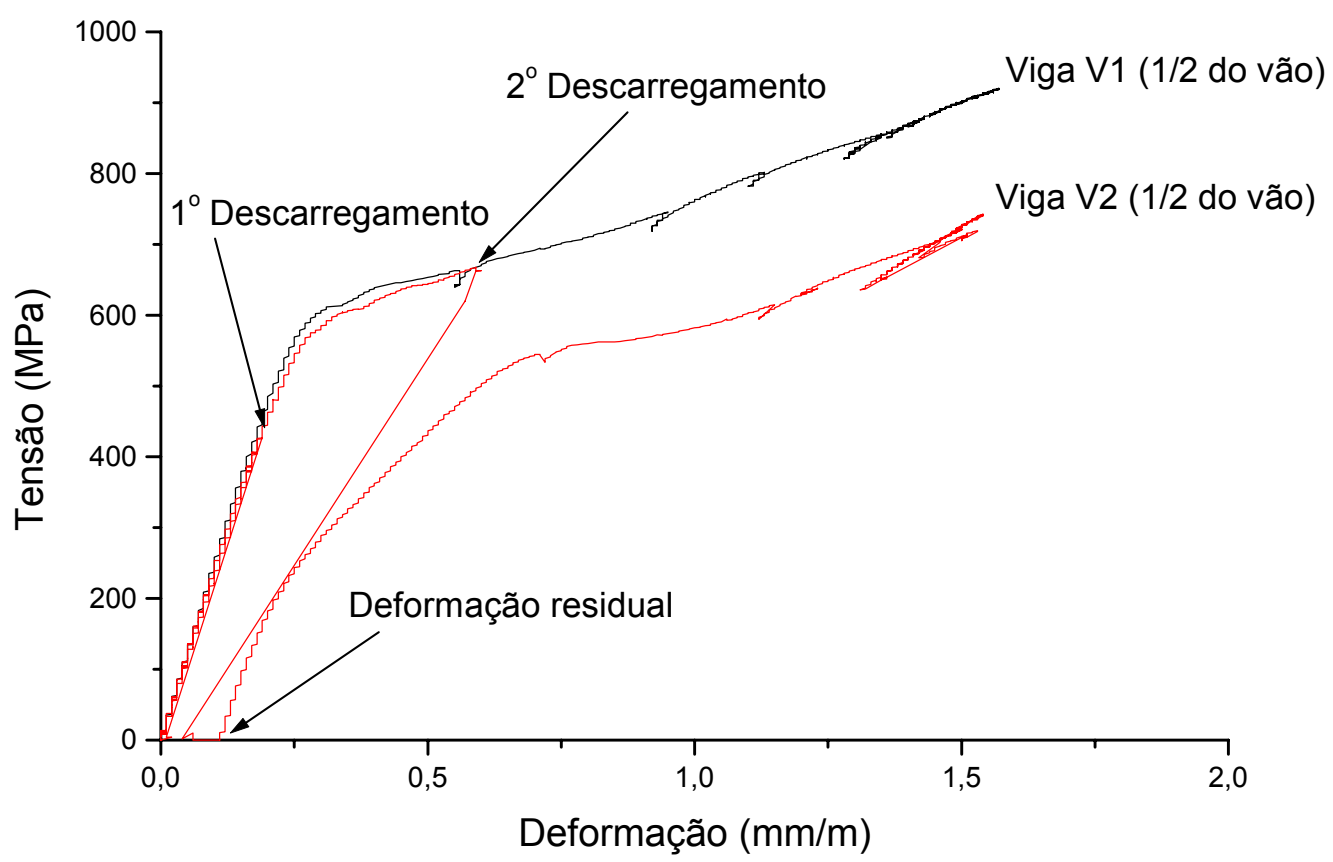

Figura 4.29 - Gráfico Tensão versus Deformação no meio do vão, para as vigas piloto.

Como se pode notar, para a viga V2, o primeiro descarregamento ocorreu ainda na fase elástica, não comprometendo a integridade da viga. Já o segundo descarregamento ocorreu após a fissuração da viga, e percebe-se que ficou uma deformação residual, ou seja, ocorreu uma plastificação da peça. Por conta disso, observa-se que a inclinação para o terceiro carregamento é menor, indicando que a peça realmente já havia perdido um pouco de rigidez. A viga foi carregada até que se atingiu um estado limite último por fissuração excessiva, devido à ruptura por cisalhamento, apesar da peça ainda ter capacidade de carga, como mostra o gráfico. 
Para a viga V1, não houve descarregamento, como mostra a Figura 4.29. O ensaio foi encerrado quando a peça já apresentava um estado último por fissuração excessiva, assim como para a viga anterior, apesar de ainda apresentar capacidade de carga. Outro fator que determinou o término do ensaio foi a movimentação excessiva do apoio móvel, que já se encontrava praticamente no seu limite.

Os pontos de descontinuidade do gráfico coincidem com o aparecimento das fissuras principais (maiores), e representam uma perda de aderência localizada das cordoalhas, por escorregamento da armadura. As duas vigas ensaiadas apresentaram um estado limite último por fissuração excessiva, especialmente de cisalhamento, nos pontos de introdução de carga. Para essas peças não foi possível determinar o comprimento de ancoragem necessário, que pode ser definido como o menor comprimento para o qual a peça apresenta ruptura por flexão, e não por perda de aderência. Logo, pôde-se concluir, apenas, que o comprimento de ancoragem necessário para essas vigas é menor do que $80 \mathrm{~cm}\left(\ell_{0}=\mathrm{L} / 3\right)$. As Figuras 4.30 e 4.31 apresentam detalhes da fissuração das vigas, ao final dos ensaios.

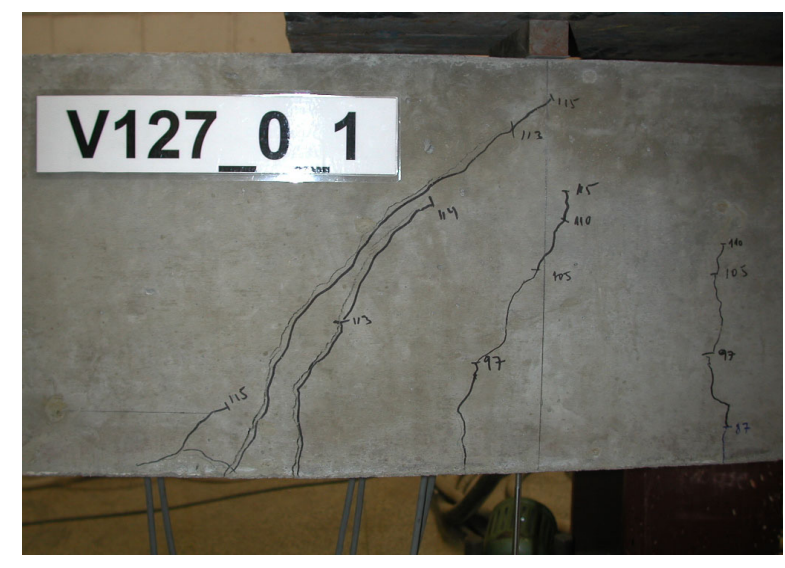

Figura 4.30 - Detalhe da fissuração da viga V1.

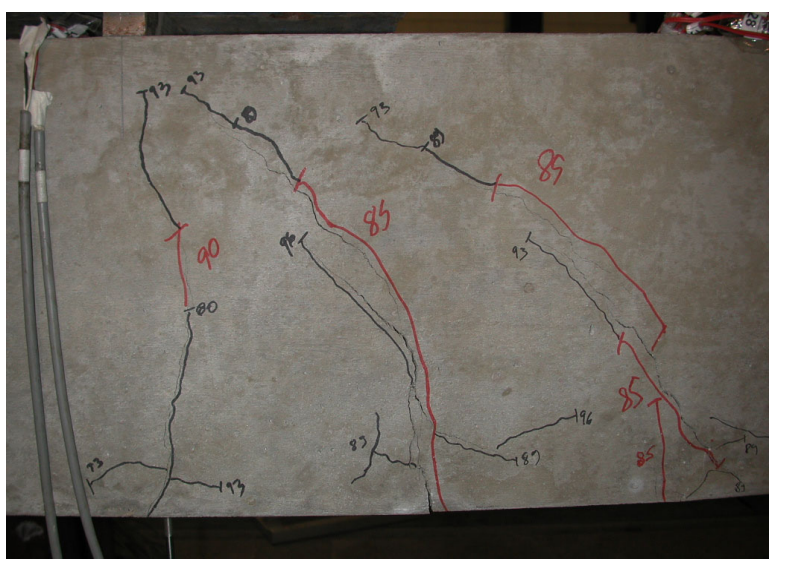

Figura 4.31 - Detalhe da fissuração da viga V2.

O panorama de fissuração completo das vigas V1 e V2, ao longo dos ensaios de flexão, se encontra no Apêndice G.

Após a análise desses resultados, verificou-se que as deformações medidas na cordoalha e nas armaduras longitudinais passivas, nos pontos de leitura equivalentes, forneciam resultados, também, equivalentes, como mostra a Figura 4.32. Logo, a deformação, e conseqüentemente a tensão, das armaduras passivas davam uma boa indicação da deformação, e conseqüentemente da tensão, das cordoalhas.

Observou-se que o comportamento das vigas em relação à aderência segue a onda de pico de tensão proposta por JANNEY (1954). Esse fenômeno pode ser visualizado nos gráficos da Figura 4.33. Inicialmente, ao longo de toda a região central com momento 
constante, entre os pontos de introdução de carga, a cordoalha vai-se deformando lentamente até perder a aderência em um determinado ponto, onde aparece um pico de deformação, logo, um pico de tensão, como indica a Figura 4.33b. À medida que se aumenta a carga esta deformação vai aumentando até atingir um valor limite, onde esta deformação se estabiliza. Aparece então, um pico de deformação em outro ponto da cordoalha, Figura $4.33 \mathrm{c}$, e o processo se repete até que a cordoalha perca toda a aderência. Esse processo ocorreu nas duas vigas piloto. Como a ruptura se deu por cisalhamento, e não por aderência, a onda de tensão não chegou a atingir a zona de transferência. Porém, nos estágios finais do carregamento apareceram algumas fissuras longitudinais na altura da cordoalha (Figura 4.31), que são características da perda de aderência.

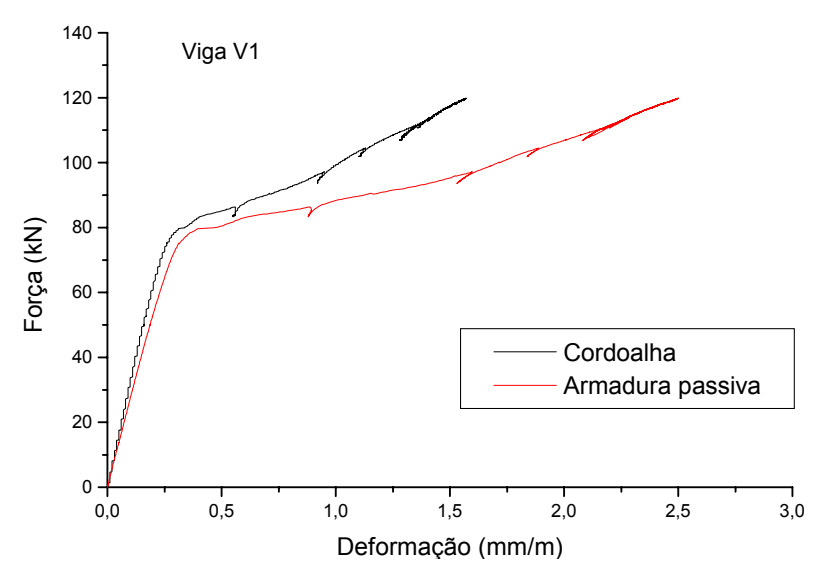

(a)

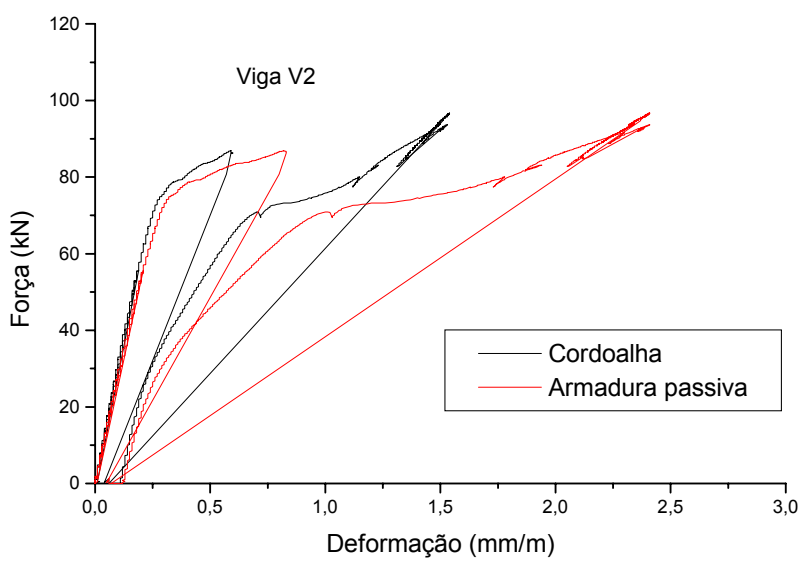

(b)

Figura 4.32 - Gráfico Força versus Deformação para a cordoalha e para as armaduras passivas longitudinais no meio do vão: (a) viga V1; (b) viga V2.

Baseando-se nos resultados dos ensaios pilotos, concluiu-se que:

- As dimensões escolhidas para as vigas apresentaram resultados muito bons, tanto no comportamento à flexão, como em relação à aderência;

- A instrumentação da cordoalha, com extensômetros elétricos, fornece uma excelente visão do comportamento da viga à flexão, porém, modifica os resultados em relação à aderência, já que a peça perde muita área de contato;

- Durante o ensaio, como a viga apresenta um deslocamento horizontal que não pode ser desprezado, a utilização de um apoio móvel pode ser determinante na sua interrupção, independentemente das condições de carregamento e de utilização da viga, ou seja, mesmo antes da peça apresentar um estado limite que caracterizasse o término do ensaio, ele teria que ser encerrado. 


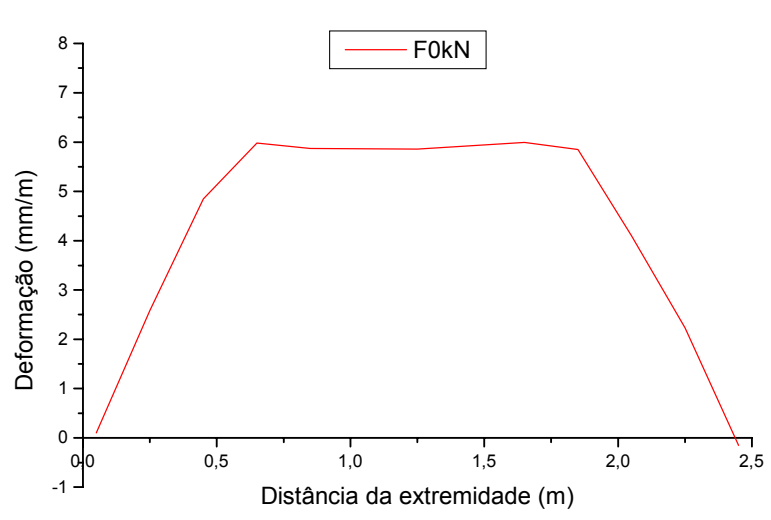

(a) $\mathrm{P}=0 \mathrm{kN}$

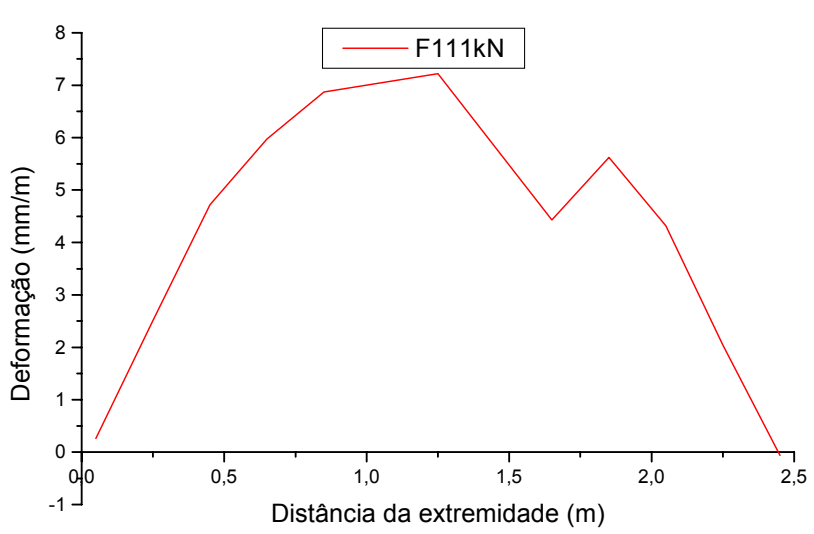

(c) $\mathrm{P}=111 \mathrm{kN}$

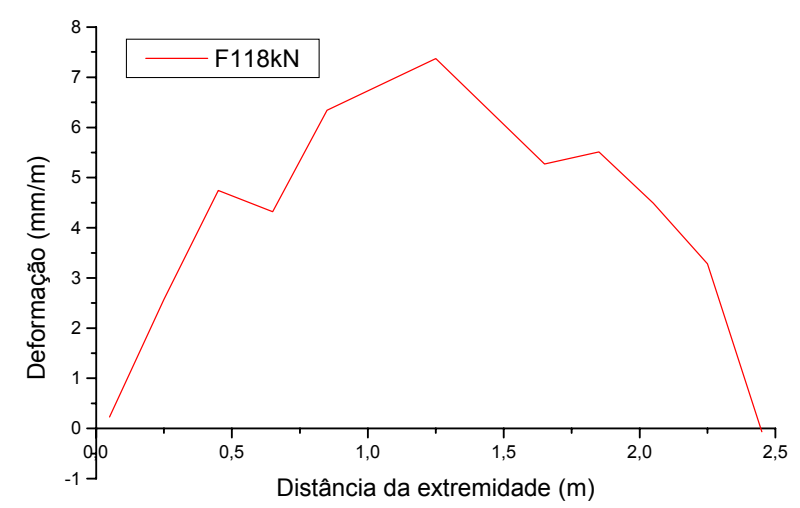

(e) $\mathrm{P}=118 \mathrm{kN}$

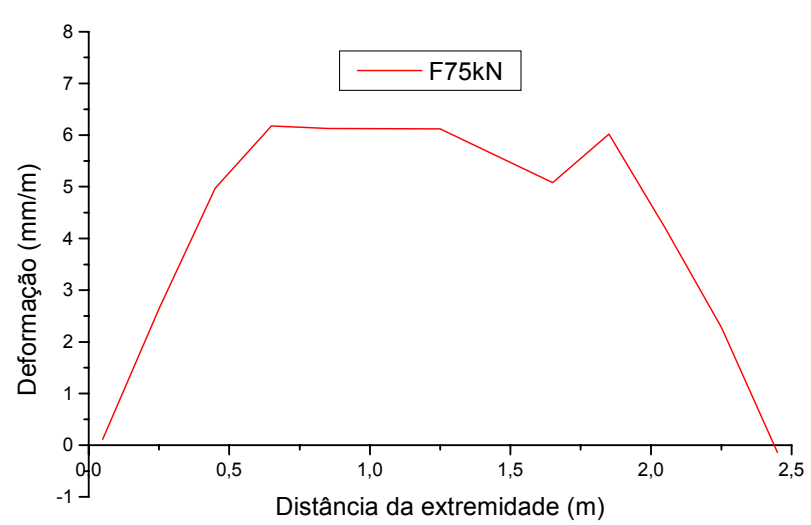

(b) $\mathrm{P}=75 \mathrm{kN}$

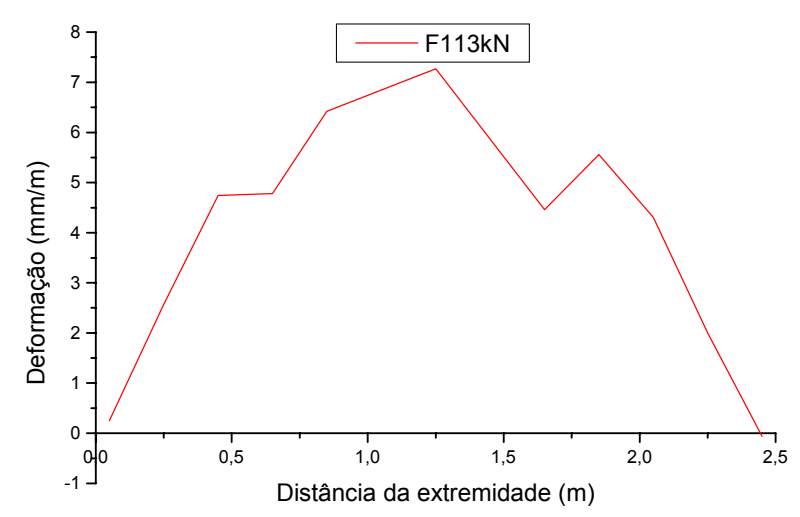

(d) $\mathrm{P}=113 \mathrm{kN}$

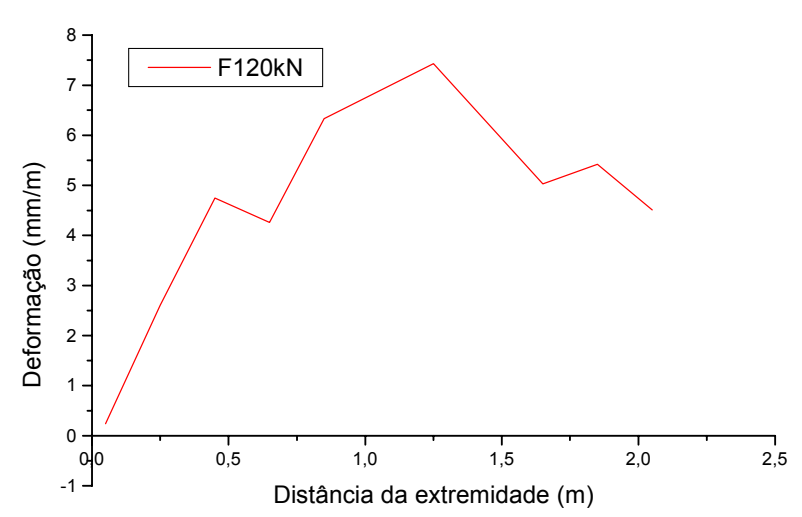

(f) $\mathrm{P}=120 \mathrm{kN}$

Figura 4.33 - Deformações ao longo da cordoalha da viga V1, para diversas etapas do carregamento, no ensaio de flexão.

A partir dos ensaios pilotos e de suas indicações, foram feitas as seguintes modificações para os ensaios de flexão:

- O número de pontos de leitura com extensômetros na cordoalha foi reduzido para apenas 1, posicionado no meio do vão, com a função de medir a deformação, e, conseqüentemente, determinar a tensão atuante da armadura; 
- Fazer leituras com extensômetros elétricos na face externa da viga, na altura da cordoalha;

- Utilizar uma base de medida maior para as leituras com o TENSOTAST. Optouse por uma base de $10 \mathrm{~cm}$, que era a maior disponível do laboratório;

- Utilizar dois apoios fixos, deixando livre apenas o giro nas duas extremidades;

- Medir a região comprimida das peças, com extensômetros elétricos e TENSOTAST, para caracterizar melhor a ruptura por flexão.

\subsubsection{Ensaios de caracterização dos materiais}

Foram feitos ensaios de caracterização das armaduras passivas e ativas, e do concreto, para obtenção das principais propriedades dos materiais e dos compósitos, tais como: resistência à tração, resistência à compressão, módulo de elasticidade e tenacidade. Os ensaios foram os seguintes:

- Ensaios de compressão axial: 33 corpos-de-prova (CP) de $15 \times 30 \mathrm{~cm}$ (cilíndricos), em que se obteve, para os diversos compósitos, o módulo de elasticidade $\left(\mathrm{E}_{\mathrm{c}}\right)$, com, aproximadamente, 28 dias; e $205 \mathrm{CP}$ de $10 \times 20 \mathrm{~cm}$ (cilíndricos), em que se obteve a resistência do concreto à compressão $\left(\mathrm{f}_{\mathrm{cj}}\right)$, com 1, 2, 3, 4, 7, 14, 21, 28 dias e no dia do respectivo ensaio, caso este não tenha sido realizado aos 28 dias.

- Ensaios de compressão diametral: $32 \mathrm{CP}$ de 10x20 cm (cilíndricos); nestes ensaios obteve-se a resistência do concreto à tração na compressão diametral $\left(\mathrm{f}_{\mathrm{ct}, \mathrm{sp}}\right)$, aos 28 dias, aproximadamente, para os diversos compósitos.

- Ensaios de flexão: $38 \mathrm{CP}$ de $15 \times 15 \times 50 \mathrm{~cm}$ (prismáticos); nestes ensaios obteve-se a resistência do concreto à tração na flexão $\left(f_{\mathrm{ct}, \mathrm{fl}}\right)$ e sua tenacidade (para os concretos com fibra, no total de 18), aos 28 dias, aproximadamente, para os diversos compósitos.

- Ensaios de tração da cordoalha: $3 \mathrm{CP}$; estes ensaios tiveram o objetivo de corelacionar as deformações lidas pelos extensômetros elétricos colados nos fios da cordoalha, com a deformação da cordoalha como um todo, e para isso as peças foram instrumentadas com extensômetros elétricos nos fios e um extensômetro removível (clip-gage) da INSTRON ao redor da cordoalha.

- Ensaios de tração da armadura passiva: $4 \mathrm{CP}$, dois para cada tipo de armadura $(\phi 6,3 \mathrm{~mm}$ e $\phi 8 \mathrm{~mm})$; nestes ensaios obteve-se a resistência à tração das armaduras passivas $\left(f_{s}\right)$. 
Não foram feitos ensaios de caracterização das fibras, visto que na literatura corrente e nos manuais de especificações este material já se encontrava bem caracterizado. As principais propriedades das fibras e das armaduras ativas, como resistência à tração, módulo de elasticidade, deformações últimas, etc., foram fornecidas pelos fabricantes. Esses resultados se encontram no Anexo A.

\subsubsection{Ensaios de arrancamento}

Para se determinar a tensão de aderência das peças protendidas, ou não, com e sem fibras de aço, foram realizados cento e oito ensaios estáticos de arrancamento. Os resultados destes ensaios foram comparados entre si, e com os resultados da análise teórica. Esses ensaios tiveram o objetivo de comparar qualitativamente o comportamento dos diversos compósitos, para os diferentes parâmetros de ensaio (comprimento aderente e dimensões dos modelos).

\subsubsection{Ensaios de flexão}

Para se determinar os comprimentos de transferência e de ancoragem necessário das peças pré-tracionadas com e sem fibras de aço, foram realizados catorze ensaios estáticos de flexão (dois foram ensaios pilotos). Os resultados foram comparados entre si, e com os resultados da análise teórica.

\subsubsection{Análise dos resultados}

Os resultados dos ensaios sofreram um tratamento estatístico, para se fazer uma triagem dos dados compatíveis, e em seguida foram realizadas as comparações entre estes dados e os resultados das análises teóricas.

Os resultados foram apresentados na forma de gráficos e tabelas.

\subsection{Ensaios de Caracterização dos Materiais}

Os ensaios descritos a seguir serviram para a caracterização dos materiais utilizados nos ensaios de flexão e de arrancamento.

\subsubsection{Concreto}

Foram utilizados três traços para os compósitos, um para cada teor de fibra utilizado. Foram eles:

- Traço $1=1: 1,66: 1,84: 0,40: 0,6 \%+0 \mathrm{~kg} / \mathrm{m}^{3}$ de fibras;

- Traço $2=1: 1,66: 1,84: 0,40: 1,5 \%+40 \mathrm{~kg} / \mathrm{m}^{3}$ de fibras;

- Traço $3=1: 1,66: 1,84: 0,40: 1,5 \%+60 \mathrm{~kg} / \mathrm{m}^{3}$ de fibras; 
Para os traços indicados anteriormente, os valores em percentagem indicam a quantidade de aditivo superplastificante. Foi utilizado o cimento CP V-ARI-PLUS, doado pela Holcim Brasil S. A., num consumo de $500 \mathrm{~kg} / \mathrm{m}^{3}$. Foi utilizada areia fina como agregado miúdo e brita 1 como agregado graúdo. O superplastificante utilizado foi o Reax 3000, doado pela Fosroc Brasil. Os traços utilizados foram os mesmos adotados por BASTOS (1999), porém os resultados encontrados foram um pouco superiores, principalmente no que diz respeito às resistências à compressão. Esse fato pode ser justificado, entre outras, por duas razões: (1) os agregados utilizados, apesar de apresentarem granulometria semelhantes, e compradas do mesmo fornecedor, não foram da mesma procedência (região ou pedreira de onde foi retirado o material); e, (2) o cimento também apresentava algumas modificações, apesar de ser do mesmo tipo e fornecedor. Entre os três traços utilizados, o Traço 2 apresentou a melhor trabalhabilidade, e o Traço 3 a pior. Porém, nenhum dos três traços apresentou problemas para concretagem das peças.

No total, foram feitas 24 concretagens. De cada uma foram retirados corpos-de-prova para a caracterização dos compósitos. A Tabela 4.6 apresenta os compósitos e corpos-deprova de cada concretagem, das quais foram retirados: corpos-de-prova cilíndricos de 10x20cm para ensaios de compressão axial e diametral (baseados na NBR 5739 (1994) e na NBR 7222 (1994), respectivamente), corpos-de-prova cilíndricos de $15 \times 30 \mathrm{~cm}$ para ensaios de compressão axial (baseado na NBR 8522, 1984), e corpos-de-prova prismáticos de $15 \times 15 \times 50 \mathrm{~cm}$ para ensaios de flexão (baseado na NBR 12142, 1992). A moldagem e a cura dos corpos-de-prova seguiram recomendações da NBR 5738 (1994). O cálculo da tenacidade dos compósitos com fibras foi feito pela norma japonesa JSCE-SF4 (1984). A retirada da forma dos $\mathrm{CP}$ prismáticos se deu às 24horas, diferentemente do que recomenda a NBR 5738 (1994), que estabelece a idade mínima de desforma de 48horas. Esse fato, porém, não causou problemas nos corpos-de-prova, pois o concreto utilizou cimento com alta resistência inicial, o que já garantia uma boa resistência mesmo com apenas 24horas. A Tabela 4.7 apresenta a relação dos corpos-de-prova, ensaios e dados obtidos.

Para as concretagens dos prismas, o volume de concreto utilizado foi menor do que para as das vigas. Houve uma variação no volume das concretagens dos prismas, pois o número deles concretados por vez era diferente, e, também, a quantidade e tipo de corpos-de-prova retirados sofreram variações. Porém, o volume máximo de concreto utilizado por vez foi de 127 $\ell$. Para as concretagens das vigas, foi necessário um volume de $250 \ell$ por vez, referentes a duas vigas e mais os corpos-de-prova. Por conta desse fato, utilizaram-se duas betoneiras diferentes, com capacidades volumétricas máximas distintas: (1) os prismas foram 
concretados com uma betoneira de eixo inclinado (Figura 4.34b), com capacidade de 150 $\ell$; e (2) as vigas foram concretadas com uma misturadora planetária CIBI - P250 (betoneira) de eixo vertical (Figura 4.34a), com capacidade de $250 \ell$.

Tabela 4.6 - Relação das concretagens realizadas.

\begin{tabular}{|c|c|c|c|}
\hline Concretagem & $V_{f}\left(\mathbf{k g} / \mathbf{m}^{3}\right)$ & Modelo referente & Corpos-de-prova retirados \\
\hline $\mathrm{C} 1$ & 0 & Viga & CP10x20cm, CP15x30cm e CP15x15x50cm \\
\hline $\mathrm{C} 2$ & 0 & Viga & CP10x20cm, CP15x30cm e CP15x15x50cm \\
\hline $\mathrm{C} 3$ & 0 & Prisma Série 1 & CP10x20cm, CP15x30cm e CP15x15x50cm \\
\hline $\mathrm{C} 4$ & 40 & Prisma S.1 & CP10x20cm, CP15x30cm e CP15x15x50cm \\
\hline $\mathrm{C} 5$ & 0 & Prisma S.1 & CP10x20cm, CP15x30cm e CP15x15x50cm \\
\hline C6 & 40 & Prisma S.1 & CP10x20cm, CP15x30cm e CP15x15x50cm \\
\hline $\mathrm{C} 7$ & 0 & Prisma S.1 & CP10x20cm \\
\hline $\mathrm{C} 8$ & 40 & Prisma S.1 & CP10x20cm \\
\hline C9 & 0 & Prisma S.1 & CP10x20cm \\
\hline $\mathrm{C} 10$ & 60 & Prisma S.1 & $\mathrm{CP} 10 \times 20 \mathrm{~cm}$ \\
\hline C11 & 60 & Prisma S.1 & CP10x20cm, CP15x30cm e CP15x15x50cm \\
\hline $\mathrm{C} 12$ & 0 & Prisma S.2 & CP10x20cm \\
\hline $\mathrm{C} 13$ & 40 & Prisma S.2 & CP10x20cm \\
\hline $\mathrm{C} 14$ & 60 & Prisma S.2 & CP10x20cm \\
\hline $\mathrm{C} 15$ & 60 & Prisma S.1 e 2 & CP10x20cm, CP15x30cm e CP15x15x50cm \\
\hline $\mathrm{C} 16$ & 0 & Viga & CP10x20cm, CP15x30cm e CP15x15x50cm \\
\hline $\mathrm{C} 17$ & 40 & Viga & CP10x20cm, CP15x30cm e CP15x15x50cm \\
\hline $\mathrm{C} 18$ & 60 & Viga & CP10x20cm, CP15x30cm e CP15x15x50cm \\
\hline C19 & 0 & Viga & CP10x20cm \\
\hline $\mathrm{C} 20$ & 40 & Viga & $\mathrm{CP} 10 \times 20 \mathrm{~cm}$ \\
\hline $\mathrm{C} 21$ & 60 & Viga & $\mathrm{CP} 10 \mathrm{x} 20 \mathrm{~cm}$ \\
\hline $\mathrm{C} 22$ & 0 & Viga & $\mathrm{CP} 10 \times 20 \mathrm{~cm}$ \\
\hline $\mathrm{C} 23$ & 40 & Viga & CP10x20cm \\
\hline $\mathrm{C} 24$ & 60 & Viga & CP10x20cm \\
\hline
\end{tabular}

Todas as concretagens ocorreram na parte inicial da manhã. A ordem de colocação dos materiais foi a seguinte: brita 1, areia, cimento, ligava a betoneira e deixava misturar um pouco, depois acrescentava, com a betoneira girando, água, superplastificante e, por fim, as fibras. Estas últimas eram jogadas aos poucos, para evitar o empelotamento das mesmas. 
Após a colocação de todos os materiais, a betoneira misturava-os por mais 3 minutos, quando então começava-se a concretagem das peças. As Figuras 4.34 a 4.37 apresentam detalhes das concretagens e da confecção dos corpos-de-prova. A cura das vigas e dos prismas de arrancamento foi feita com a colocação de espuma molhada sobre as peças.

Tabela 4.7 - Ensaios de caracterização do concreto.

\begin{tabular}{l|c|c|c|c|c}
\hline Corpo-de-prova & \multicolumn{2}{|c|}{ Cilíndrico $10 \times 20 \mathrm{~cm}$} & $\begin{array}{c}\text { Cilíndrico } \\
15 \times 30 \mathrm{~cm}\end{array}$ & \multicolumn{2}{c}{ Prismático $15 \times 15 \times 50 \mathrm{~cm}$} \\
\hline Ensaio & $\begin{array}{c}\text { Compressão } \\
\text { axial }\end{array}$ & $\begin{array}{c}\text { Compressão } \\
\text { diametral }\end{array}$ & $\begin{array}{c}\text { Compressão } \\
\text { axial }\end{array}$ & \multicolumn{2}{c}{ Flexão } \\
\hline Propriedade & $\begin{array}{c}\text { Resistência à } \\
\text { compressão } \\
\left(\mathrm{f}_{\mathrm{cj}}\right)\end{array}$ & $\begin{array}{c}\text { Resistência à } \\
\text { tração } \\
\left(\mathrm{f}_{\mathrm{ct}}\right)\end{array}$ & $\begin{array}{c}\text { Módulo de } \\
\text { elasticidade } \\
\left(\mathrm{E}_{\mathrm{c}}\right)\end{array}$ & $\begin{array}{c}\text { Resistência } \\
\text { à tração } \\
\left(\mathrm{V}_{\mathrm{f}}=0 \%\right)\end{array}$ & $\begin{array}{c}\text { Tenacidade e } \\
\text { resistência à } \\
\text { tração }\left(\mathrm{V}_{\mathrm{f}} \neq 0 \%\right)\end{array}$ \\
\hline
\end{tabular}

Foram feitos testes de abatimento de tronco de cone normal, segundo a NBR 7223 (1992), para as concretagens iniciais sem fibras de aço, e testes de abatimento de tronco de cone invertido, recomendado pelo ACI 544 2R (1989), para as com fibras de aço. Todos os resultados deram dentro dos limites esperados. A partir daí, não foram feitos mais os testes de abatimento de tronco de cone, apenas verificava-se visualmente a trabalhabilidade do concreto.

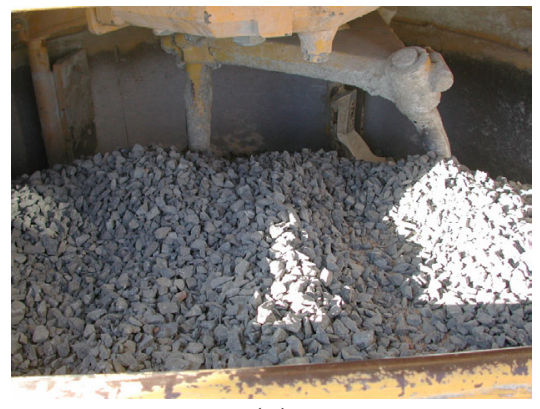

(a)

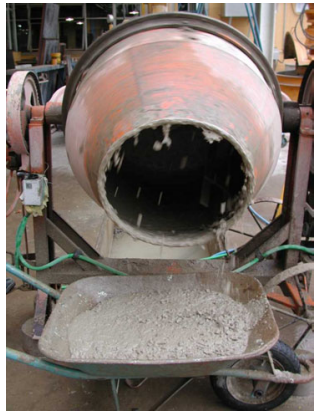

(b)

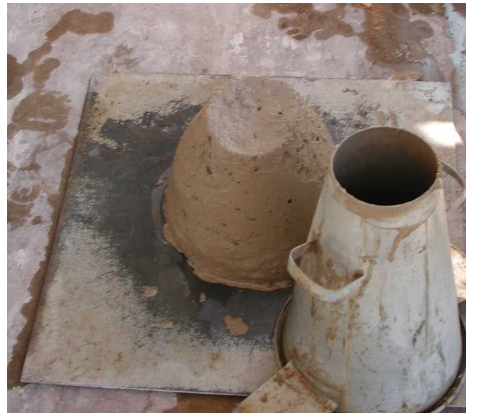

(c)

Figura 4.34 - Detalhes das concretagens: (a) concreto seco na betoneira, antes da adição da água; (b) retirada do concreto; (c) teste para o abatimento de tronco de cone do concreto sem fibras.

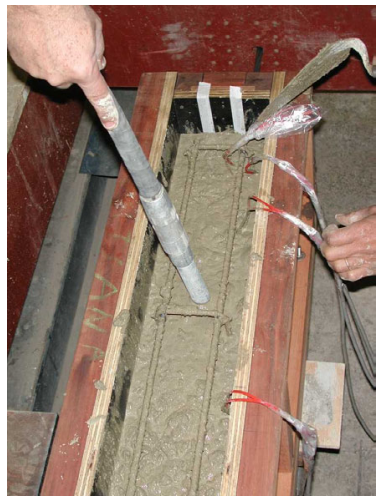

(a)

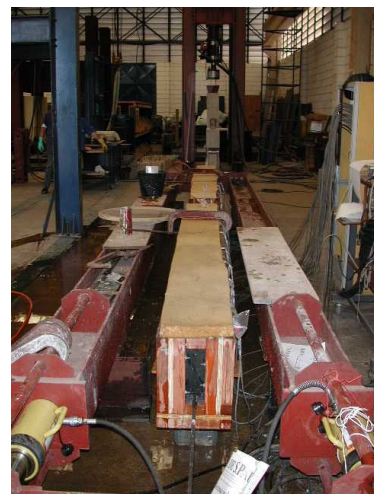

(b)

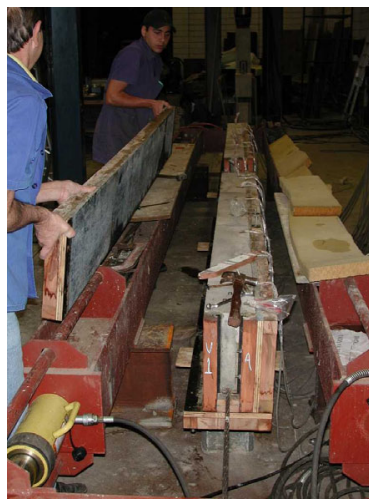

(c)

Figura 4.35 - Detalhes das concretagens: (a) vibração do concreto; (b) cura das vigas; (c) desforma das vigas. 


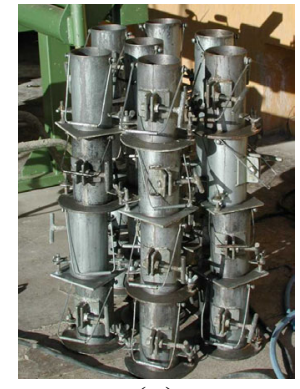

(a)

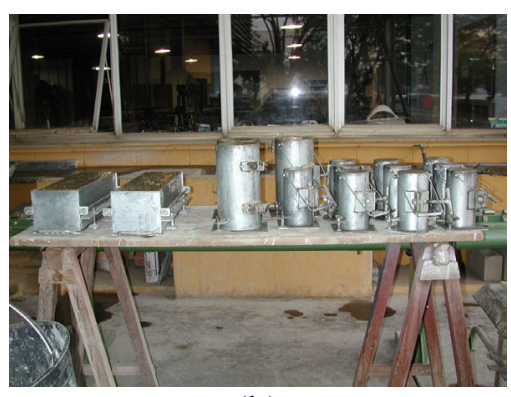

(b)

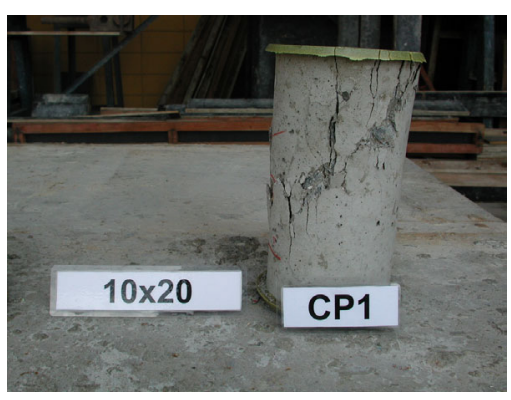

(c)

Figura 4.36 - Confecção dos corpos-de-prova cilíndricos de 10x20cm: (a) formas metálicas para os corpos-deprova; (b) corpos-de-prova concretados; (c) CP1, compósito com fibra de aço, após ensaio de compressão axial

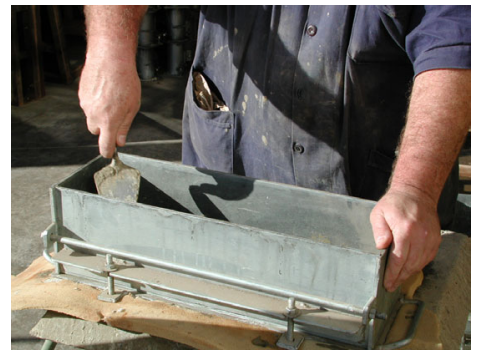

(a)

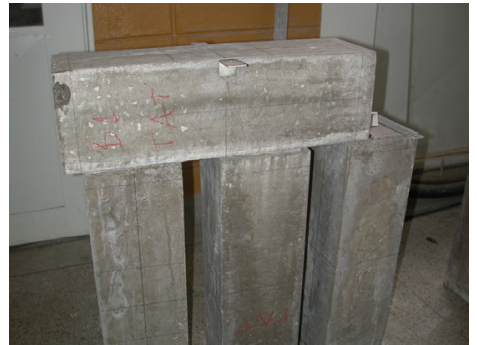

(b)

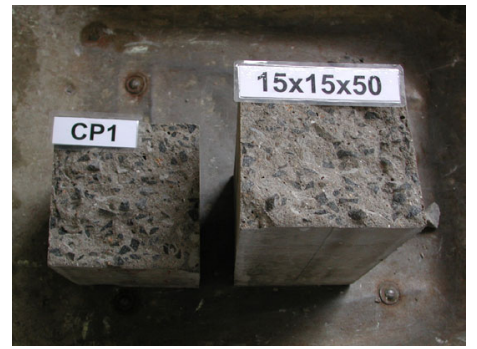

(c)

Figura 4.37 - Confecção dos corpos-de-prova prismáticos de 15x15x50cm: (a) concretagem do CP; (b) corposde-prova concretados; (c) CP1, compósito sem fibra de aço, após ensaio de tração na flexão.

A concretagem dos corpos-de-prova e dos prismas sem protensão foi feita sobre mesa vibratória CSN (Figura 4.37a). O adensamento dos prismas pré-tracionados e das vigas foi feito com vibrador de imersão DYNAPAC AF 14M com diâmetro de 25mm (Figura 4.35a). Não houve problemas nem na confecção dos corpos-de-prova, nem na realização dos ensaios de caracterização do concreto. Apenas uma quantidade mínima (três) dos corpos-de-prova cilíndricos de $10 \times 20 \mathrm{~cm}$ apresentaram nichos de concretagem, os quais tiveram seus resultados descartados.

Os ensaios para determinação da tenacidade dos compósitos com fibras foram realizados na máquina de ensaio hidráulica servo-contralada INSTRON 8506, com capacidade de carga de compressão de $2500 \mathrm{kN}$. Os demais ensaios de caracterização do concreto foram feitos na máquina de ensaio de corpo-de-prova de concreto ELE Autotest 2000, com capacidade na compressão de $2000 \mathrm{kN}$.

A seguir são descritos os ensaios de caracterização, os cálculos e os resultados obtidos para as propriedades do concreto. Os dados de todos os ensaios de caracterização do concreto se encontram no Apêndice F.

Para os dados dos ensaios foram determinados os coeficientes de variação, que indicam a dispersão dos resultados em função do valor médio. O coeficiente de variação $(\mathrm{CV})$ foi calculado pela seguinte expressão: 


$$
\mathrm{CV}=\frac{\mathrm{SD}}{\overline{\mathrm{X}}} \cdot 100
$$

onde: $\mathrm{SD}=$ desvio padrão;

$\overline{\mathrm{X}}=$ valor médio dos dados.

\section{a) Resistência à compressão $\left(f_{c}\right)$}

Foram feitos ensaios de compressão axial para os corpos-de-prova das diferentes betonadas, num total de 205 ensaios, dos quais 127 foram nas datas de retirada da protensão e de ensaio. Essas datas variaram em função da disponibilidade para a retirada da protensão (entre 1 e 5 dias) e para a realização dos ensaios de flexão (entre 22 e 30 dias) e de arrancamento (entre 15 e 122 dias) dos modelos estudados. A taxa de carregamento para o ensaio foi de $\mathrm{v}_{\text {ensaio,fc }}=2,4 \mathrm{kN} / \mathrm{s}$.

Os resultados foram submetidos a um tratamento estatístico para a validação dos mesmos. De acordo com essas verificações, pôde-se assegurar que os dados são válidos, e que as interpretações resultantes da sua análise serão legítimas. A análise estatística completa desses dados se encontra no Apêndice E.

$\mathrm{O}$ valor da resistência à compressão de cada corpo-de-prova $\left(\mathrm{f}_{\mathrm{ci}}\right)$ foi calculado dividindo-se a carga máxima obtida no ensaio pela área da seção transversal do $\mathrm{CP}$, da seguinte forma:

$$
\mathrm{f}_{\mathrm{ci}}=\frac{\mathrm{F}_{\text {máx }}}{\mathrm{A}_{\mathrm{c}}}=\frac{\mathrm{F}_{\text {máx }}}{\left(\pi \cdot \mathrm{d}_{\mathrm{CP} / 4}^{2} /\right)}=\frac{4 \cdot \mathrm{F}_{\text {máx }}}{\pi \cdot 0,10^{2}}
$$

A Tabela 4.8 apresenta as médias obtidas, e os respectivos desvios padrão, para as operações de transferência da protensão, ensaios de arrancamento e ensaios de flexão. Tanto para cada teor de fibra separadamente, como para todo o universo ensaiado.

Percebe-se que há um pequeno ganho de resistência para os concretos reforçados com fibras de aço, não superior a 10\%, tanto para os modelos dos prismas de arrancamento como para os das vigas. Para os primeiros, a diferença é mais significativa do que para os últimos. Isso ocorreu devido a um erro em uma das concretagens (Concretagem 7), onde o concreto resultante apresentou resistências à compressão de $\mathrm{f}_{\mathrm{cm} \text {,tranf }}=32,19 \mathrm{MPa}$ e de $\mathrm{f}_{\mathrm{cm} \text {,ensaio }}=$ $39,60 \mathrm{MPa}$, que foram valores bem abaixo dos esperados, o que fez com que a média para o compósito caísse um pouco mais do que as outras. Apesar dessas diferenças, optou-se por desprezá-las, já que os coeficientes de variação (CV) para cada grupo (prismas na 
transferência, prismas no ensaio, vigas na transferência e vigas no ensaio) ficaram entre $7 \% \mathrm{e}$ $15 \%$ dos valores médios obtidos, o que foi considerado satisfatório.

Tabela 4.8 - Médias para as resistências do concreto à compressão.

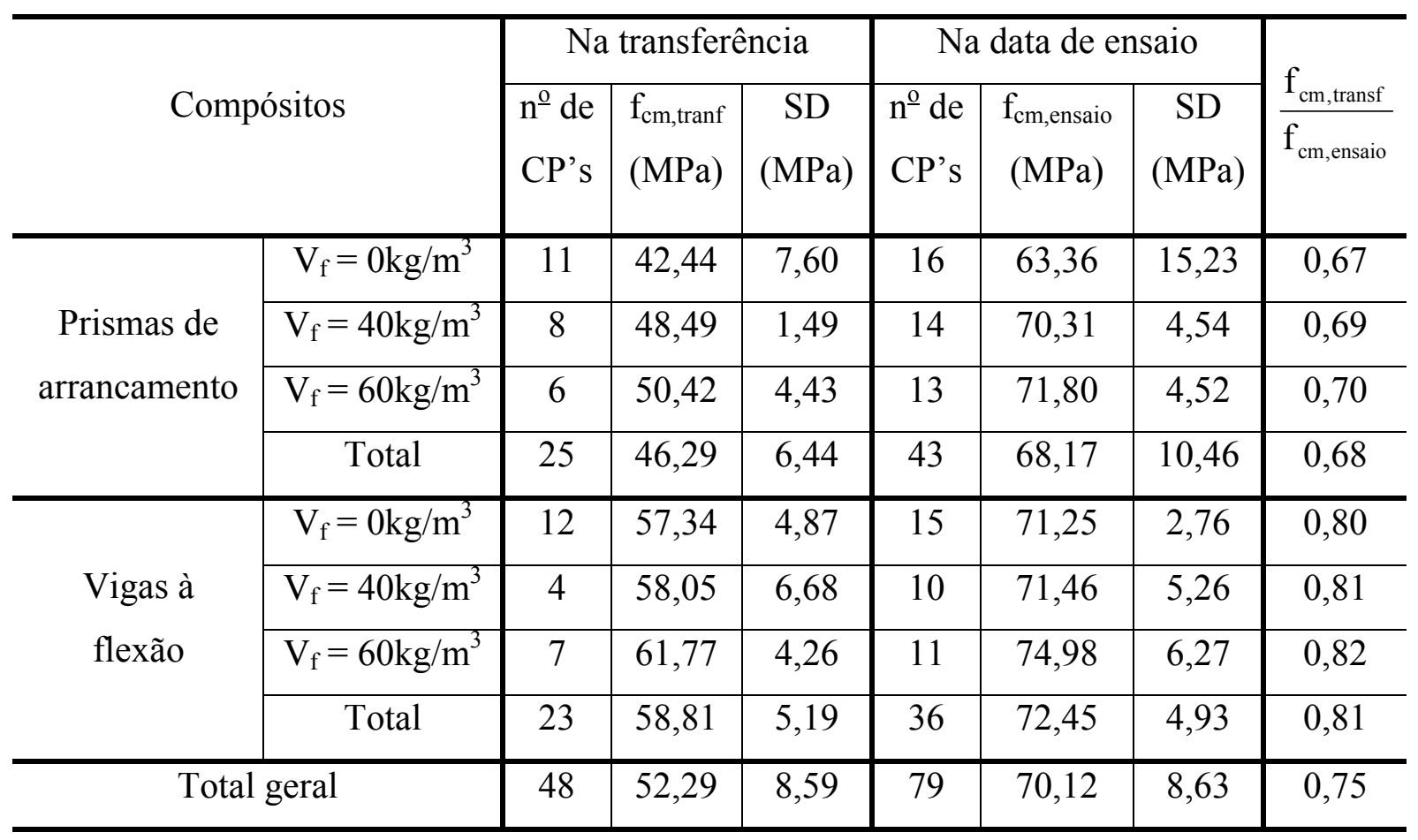

Nota-se, também, que os valores obtidos para os modelos de viga foram um pouco superiores aos dos prismas. Isso ocorreu porque a betoneira utilizada para a concretagem dos prismas foi diferente da utilizada para a das vigas. A primeira foi uma betoneira de eixo inclinado e a segunda uma de eixo vertical, que fornecia resistências maiores. A utilização de duas betoneiras diferentes foi em função dos volumes de concreto de cada elemento, já que para os prismas o volume de concreto por betonada foi bem menor do que para as vigas.

Também na relação entre as resistências à compressão na transferência e no ensaio, há diferenças entre os resultados para os prismas e para as vigas. Isso ocorreu porque a idade da retirada da protensão para os prismas foi menor (a grande maioria se deu aos 2 dias) do que para as vigas (de 3 a 5 dias). Logo, como foi utilizado um cimento de alta resistência inicial (ARI), o ganho de resistência do compósito nos primeiros dias foi muito grande, sendo significativa a diferença de 1 ou 2 dias de idade na resistência à compressão.

Baseado nos resultados dos ensaios, optou-se por trabalhar com quatro valores distintos, desprezando-se as diferenças entre os compósitos com e sem fibras de aço. São eles:

- Para os prismas. $\left\{\begin{array}{l}\mathrm{f}_{\mathrm{cm}, \text { transf }}=46,29 \mathrm{MPa} \text {; } \\ \mathrm{f}_{\mathrm{cm}, \text { ensaio }}=68,17 \mathrm{MPa} \text {. }\end{array}\right.$

- Para as vigas: $\left\{\mathrm{f}_{\mathrm{cm}, \text { transf }}=58,81 \mathrm{MPa}\right.$;

$$
\mathrm{f}_{\mathrm{cm} \text {,ensaio }}=72,45 \mathrm{MPa} \text {. }
$$


Para os prismas não foi feita nenhuma correção nos valores médios obtidos, pois os modelos ensaiados não eram muito maiores do que os corpos-de-prova, e, também, porque os ensaios de arrancamento são ensaios de curta duração.

Já para as vigas, foi feita uma única correção para levar em conta a diferença de tamanho entre o corpo-de-prova e o modelo ensaiado. Como os corpos-de-prova eram cilíndricos de $10 \times 20 \mathrm{~cm}$, foi utilizada a seguinte correlação:

$$
\mathrm{f}_{\mathrm{c}, \text { mod elo }}=0,9 \cdot \mathrm{f}_{\mathrm{c}, \text { corpo-de-prova }}
$$

Logo, os valores médios reduzidos de $10 \%$ para a resistência à compressão que foram utilizados são:

- Para as vigas: $\left\{\begin{array}{l}\mathrm{f}_{\mathrm{cm}, \text { transf }}=0,9 * 58,81=52,93 \mathrm{MPa} ; \\ \mathrm{f}_{\mathrm{cm}, \text { ensaio }}=0,9 * 72,45=65,21 \mathrm{MPa} .\end{array}\right.$

Esse coeficiente de 0,9 para a correção da resistência do concreto à compressão é um valor utilizado e aceito na prática, porém não foi encontrada uma explicação científica para ele. A Tabela 4.9 apresenta os valores arredondados a serem utilizados nesta pesquisa.

A Figura 4.38 apresenta detalhes dos ensaios de compressão axial.

Tabela 4.9 - Valores médios da resistência do concreto à compressão para a pesquisa.

\begin{tabular}{l|c|c}
\hline Idade & Na transferência & Na data de ensaio \\
Modelo & & \\
\hline Prismas de arrancamento & $45 \mathrm{MPa}$ & $68 \mathrm{MPa}$ \\
\hline Vigas à flexão & $50 \mathrm{MPa}$ & $65 \mathrm{MPa}$ \\
\hline
\end{tabular}

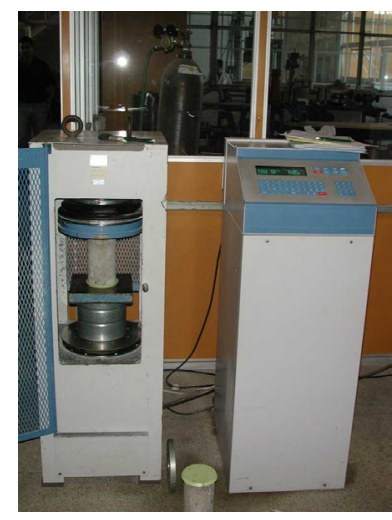

(a)

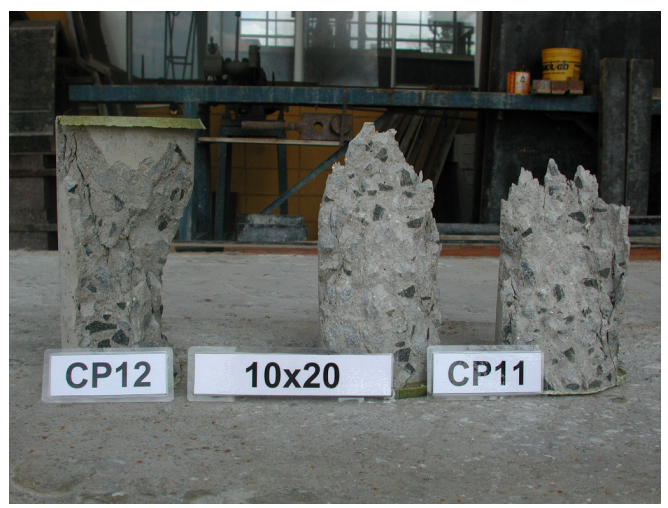

(b)

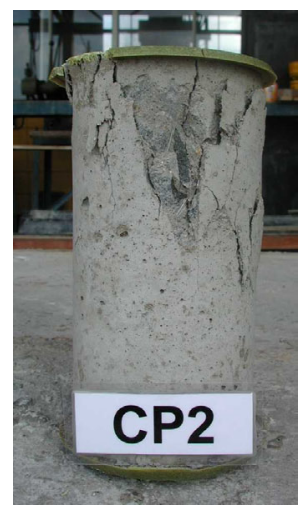

(c)

Figura 4.38 - Detalhes dos ensaios de compressão axial: (a) CP na máquina de ensaio ELE; (b) CP11 e CP12 (compósito sem fibra) após o ensaio; CP2 (compósito com fibra) após o ensaio. 


\section{b) Resistência à tração $\left(\mathrm{f}_{\mathrm{ct}}\right)$}

Foram realizados ensaios de compressão diametral e de tração na flexão para os corposde-prova das diferentes betonadas, num total de 32 ensaios de compressão diametral, onde obteve-se a $\mathrm{f}_{\mathrm{ct}, \mathrm{sp}}$, e 38 ensaios de tração na flexão, onde obteve-se a $\mathrm{f}_{\mathrm{ct}, \mathrm{fl} \text {. }}$ Ocorreu uma pequena variação na idade de ensaio em função da disponibilidade de data para a realização dos mesmos. Por outro lado, essa variação não apresentou nenhum problema, pois, devido à utilização do cimento ARI (alta resistência inicial) na confecção do concreto, a resistência à compressão já estava praticamente constante (desde a idade de 10 dias, aproximadamente). As taxas de carregamento para os ensaios foram de $v_{\text {ensaio,sp }}=0,94 \mathrm{kN} / \mathrm{s}$ e $v_{\text {ensaio,fl }}=0,45 \mathrm{kN} / \mathrm{s}$.

Esses dados também sofreram uma avaliação estatística. De acordo com essas verificações, pôde-se assegurar que os dados são válidos, e que as interpretações resultantes da sua análise serão legítimas. A análise estatística completa desses dados se encontra no Apêndice E.

O valor da resistência à tração de cada corpo-de-prova, foi calculado da seguinte forma:

$$
\mathrm{f}_{\mathrm{ct}, \mathrm{sp}}=\frac{2 \cdot \mathrm{F}_{\text {máx }}}{\pi \cdot \mathrm{d}_{\mathrm{CP}} \cdot \mathrm{h}_{\mathrm{CP}}} \quad \text { e } \quad \mathrm{f}_{\mathrm{ct}, \mathrm{fl}}=\frac{\mathrm{L}_{\mathrm{CP}} \cdot \mathrm{F}_{\text {máx }}}{\mathrm{b}_{\mathrm{CP}} \cdot \mathrm{h}_{\mathrm{CP}}^{2}}
$$

Para o cálculo da resistência à tração direta dos compósitos, tem-se que:

$$
\mathrm{f}_{\mathrm{ct}}=0,9 \mathrm{f}_{\mathrm{ct}, \mathrm{sp}} \quad \text { e } \quad \mathrm{f}_{\mathrm{ct}}=0,7 \mathrm{f}_{\mathrm{ct}, \mathrm{fl}}
$$

A Tabela 4.10 apresenta os resultados obtidos dos ensaios, e as resistências médias do concreto à tração, calculadas para o material em estudo.

Como se pode perceber, quando se analisa a última coluna da Tabela 4.10, que dá a média levando em conta todos os teores de fibras, as diferenças obtidas nos resultados são desprezíveis, pois os valores para $\mathrm{f}_{\mathrm{ct}}$ ficam entre $4,45 \mathrm{MPa}$ e $4,55 \mathrm{MPa}$. Porém, quando se analisam os valores para cada teor de fibra individualmente, que se encontram na última linha da Tabela 4.10, percebe-se que as diferenças não podem ser desprezadas, pois há ganho de até $20 \%$, aproximadamente, quando se compara o concreto sem fibra e o compósito com $60 \mathrm{~kg} / \mathrm{m}^{3}$ de fibras de aço.

Nota-se, também que, tanto para os modelos dos prismas como para os das vigas, a diferença entre os resultados obtidos nos ensaios de compressão diametral e de tração na flexão não diferem em mais do que $10 \%$. Observa-se, também, que, assim como para os resultados de resistência à compressão, os valores aqui obtidos para os modelos de viga foram um pouco superiores aos dos prismas. Isso ocorreu porque a betoneira utilizada para a concretagem dos prismas foi diferente da utilizada para a das vigas. Essa diferença foi em 
média de $8 \%$ para os ensaios de compressão diametral e de $5 \%$ para os ensaios de tração na flexão.

Baseado nos resultados dos ensaios, optou-se por trabalhar com três valores distintos, um para cada teor de fibra, fazendo-se uma média dos resultados obtidos nos dois tipos de ensaio (compressão diametral e tração na flexão). A Tabela 4.11 apresenta os valores adotados.

Tabela 4.10 - Resultados médios dos ensaios para determinação da resistência do concreto à tração (em MPa).

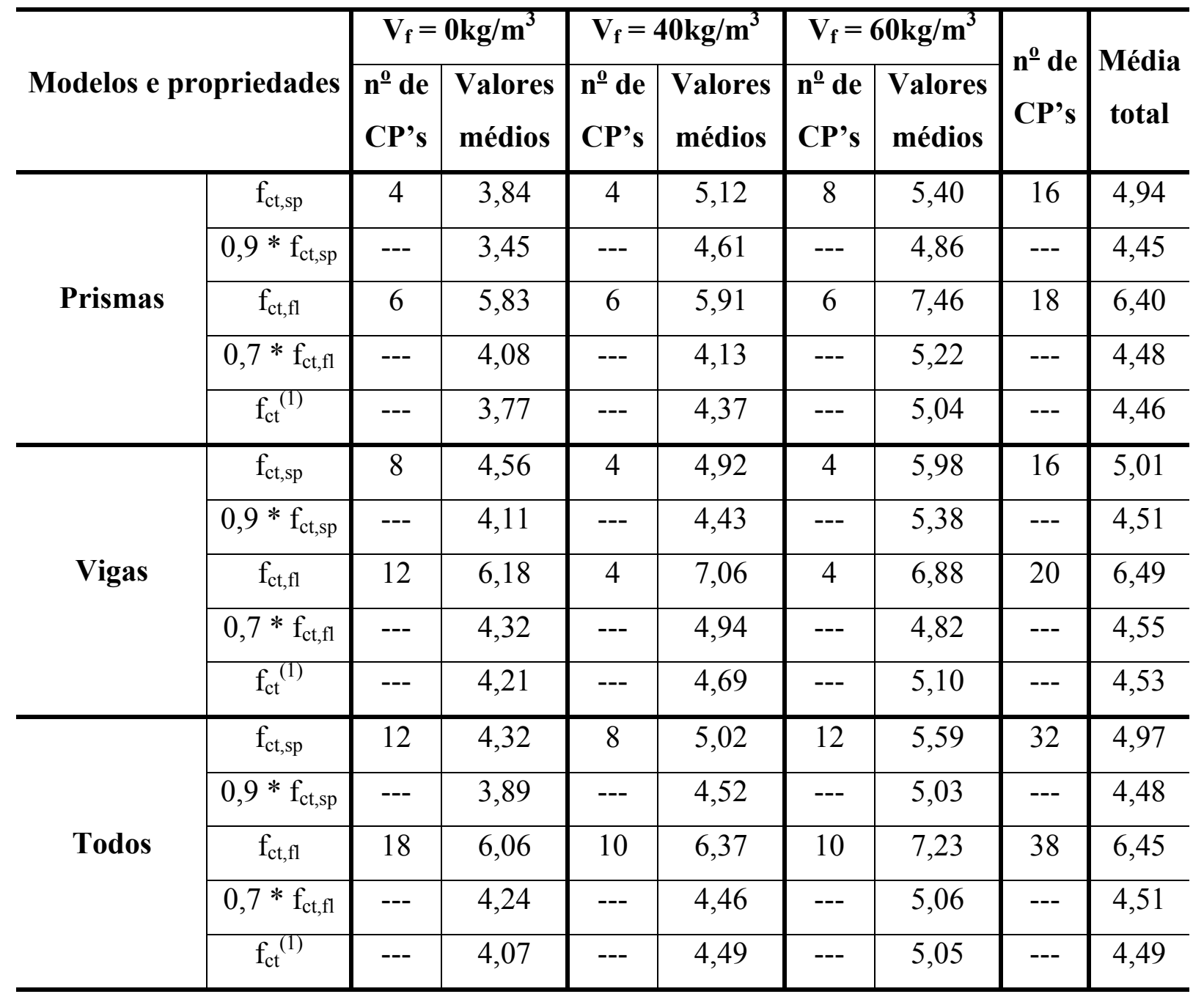

(1) $\mathrm{f}_{\mathrm{ct}}=\left(\frac{0,9 \cdot \mathrm{f}_{\mathrm{ct}, \mathrm{sp}}+0,7 \cdot \mathrm{f}_{\mathrm{ct}, \mathrm{fl}}}{2}\right)$

Tabela 4.11 - Valores de cálculo para a resistência à tração dos compósitos.

\begin{tabular}{c|c|c|c}
\hline Teor de fibra de aço & $\mathrm{V}_{\mathrm{f}}=0 \mathrm{~kg} / \mathrm{m}^{3}$ & $\mathrm{~V}_{\mathrm{f}}=40 \mathrm{~kg} / \mathrm{m}^{3}$ & $\mathrm{~V}_{\mathrm{f}}=60 \mathrm{~kg} / \mathrm{m}^{3}$ \\
\hline $\mathrm{f}_{\mathrm{ct}}(\mathrm{MPa})$ & 4,1 & 4,5 & 5,1 \\
\hline
\end{tabular}


$\mathrm{Na}$ falta de resultados de ensaios, as normas e os códigos apresentam algumas expressões para o cálculo da resistência do concreto à tração, em função da resistência do concreto à compressão. São elas:

- $\quad \operatorname{NBR} 6118$ (1978): $\mathrm{f}_{\mathrm{ctk}}=0,06 \mathrm{f}_{\mathrm{ck}}+0,7 \mathrm{MPa} \quad\left(\mathrm{f}_{\mathrm{ck}}>18 \mathrm{MPa}\right)$

- $\quad \operatorname{NBR} 6118$ (2001): $\mathrm{f}_{\mathrm{ctk}, \text { inf }}=0,7\left[0,3\left(\mathrm{f}_{\mathrm{ck}}\right)^{2 / 3}\right] \quad\left(\mathrm{f}_{\mathrm{ck}} \leq 50 \mathrm{MPa}\right)$

- FIB Bulletin 1 (1999): $\mathrm{f}_{\mathrm{ctk}}= \begin{cases}0,7\left[0,3\left(\mathrm{f}_{\mathrm{ck}}\right)^{2 / 3}\right] & \left(\mathrm{f}_{\mathrm{ck}} \leq 50 \mathrm{MPa}\right) \\ 0,7\left[1,12\left(\mathrm{f}_{\mathrm{ck}}\right)^{1 / 3}\right] & \left(\mathrm{f}_{\mathrm{ck}}>50 \mathrm{MPa}\right)\end{cases}$

Para o cálculo das resistências à tração, para $\mathrm{V}_{\mathrm{f}}=0 \mathrm{~kg} / \mathrm{m}^{3}$, admitiu-se uma resistência à compressão de $\mathrm{f}_{\mathrm{cm}}=68 \mathrm{MPa}$. A Tabela 4.12 apresenta a comparação dos valores obtidos dos ensaios com os valores propostos pela NBR 6118 (1978), pela NBR 6118 (2001) e pela FIB Bulletin 1 (1999).

Tabela 4.12 - Valores da resistência do concreto à tração (valores em $\mathrm{MPa}$ ).

\begin{tabular}{c|c|c|c}
\hline Ensaio & NBR 6118 (1978) & NBR 6118 (2001) & FIB Bulletin 1 (1999) \\
\hline 4,1 & 4,8 & 3,5 & 3,2 \\
\hline
\end{tabular}

Observa-se que os valores da NBR 6118 (2001) e da FIB Bulletin 1 (1999) estão a favor da segurança, o que é de se esperar, enquanto que o valor dado pela NBR 6118 (1978), que não tratava de concretos de alta resistência, está contra a segurança. É importante lembrar que a NBR 6118 (2001) trata de concretos com resistência à compressão de até 50MPa, logo não deve ser usada para concretos com resistências à compressão superiores ao seu valor limite, mas mesmo para um $\mathrm{f}_{\mathrm{cm}}=68 \mathrm{MPa}$, o valor obtido está a favor da segurança.

As Figuras 4.39 e 4.40 apresentam detalhes dos ensaios para a determinação da resistência à tração.

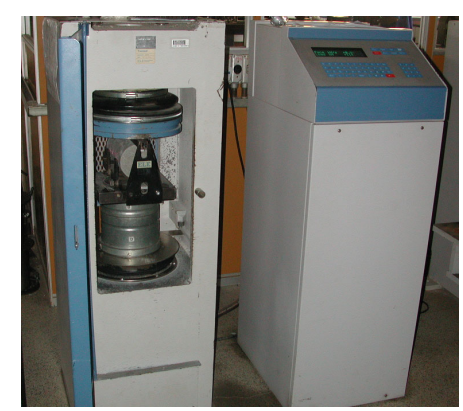

(a)

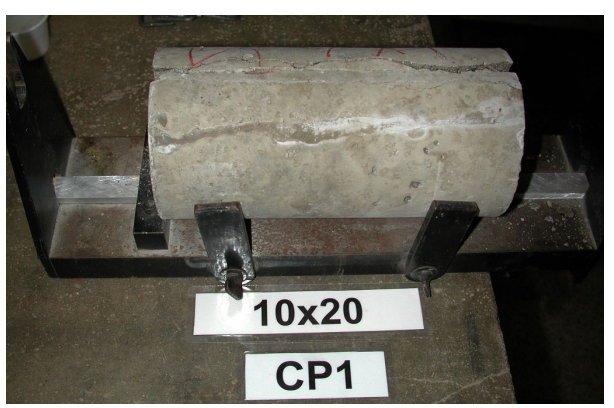

(b)

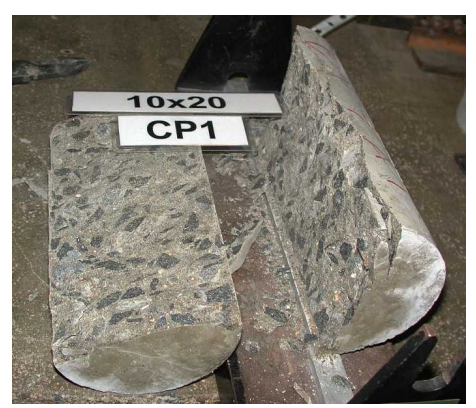

(c)

Figura 4.39 - Ensaios de tração na compressão diametral: (a) CP1 na máquina de ensaio; (b) CP1 no aparelho para o ensaio de compressão diametral; (c) CP1 após o ensaio. 


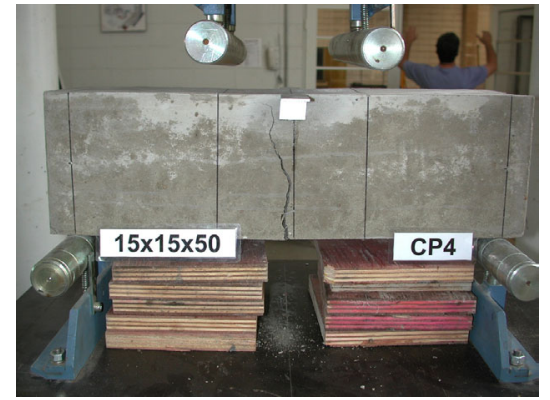

(a)

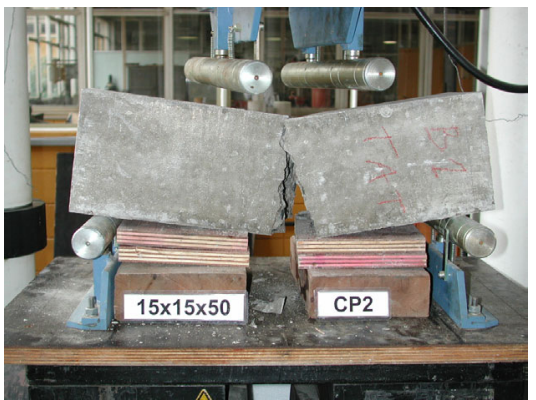

(b)

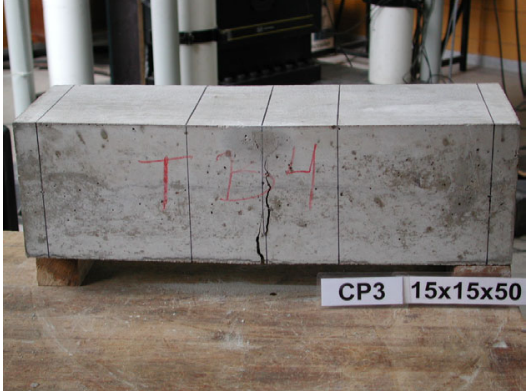

(c)

Figura 4.40 - Ensaios de tração na flexão: (a) arranjo de ensaio; (b) CP2 (compósito sem fibra) após o ensaio; (c) CP3 (compósito com fibra) após o ensaio.

\section{c) Módulo de elasticidade $\left(E_{c}\right)$}

Foram feitos ensaios de compressão axial, entre os 22 e 30 dias, para os corpos-deprova das diferentes betonadas, num total de 33 ensaios. Essa variação na idade de ensaio ocorreu em função da disponibilidade de data para a realização desses ensaios. Por outro lado, essa variação não apresentou nenhum problema, pois, devido à utilização do cimento ARI (alta resistência inicial) na confecção do concreto, a resistência à compressão já estava praticamente constante (desde a idade de 10 dias, aproximadamente). Dos 33 ensaios realizados, perdeu-se a leitura dos dados em dois deles, resultando num total de 31 ensaios a serem analisados. A taxa de carregamento para os ensaios foi de $\mathrm{v}_{\text {ensaio,Ec }}=5,3 \mathrm{kN} / \mathrm{s}$. Em cada ensaio de compressão axial, foram feitas duas leituras de deformação longitudinal, diametralmente opostas, com extensômetros removíveis MSI com base de medida de $20 \mathrm{~cm}$.

Os dados obtidos foram submetidos a um tratamento estatístico para a validação dos mesmos. De acordo com essas verificações, pode-se assegurar que os dados são válidos, e que as interpretações resultantes da sua análise serão legítimas. A análise estatística completa desses dados se encontra no Apêndice E.

$\mathrm{O}$ valor do módulo de elasticidade de cada corpo-de-prova $\left(\mathrm{E}_{\mathrm{ci}}\right)$, foi determinado calculando-se a inclinação da reta do gráfico Tensão versus Deformação longitudinal, que foi plotado apenas até $40 \%$ da carga de ruptura estimada $\left(\mathrm{F}_{\text {máx }}\right)$, ou seja, determinou-se apenas a fase elástica. O gráfico da Figura 4.41 apresenta um exemplo do cálculo do módulo de elasticidade.

A partir dos dados, adicionou-se uma linha de tendência, por regressão linear, e calculou-se a equação da reta, cujo coeficiente indica o valor do módulo de elasticidade que se quer. Para o gráfico da Figura 4.41, o valor do módulo foi de $\mathrm{E}_{\mathrm{c}}=43848 \mathrm{MPa}$. Os pontos de leitura são referentes à média de duas leituras de deformação longitudinal, diametralmente 
opostas, feitas em cada corpo-de-prova por relógios comparadores, como mostra a Figura 4.42 .

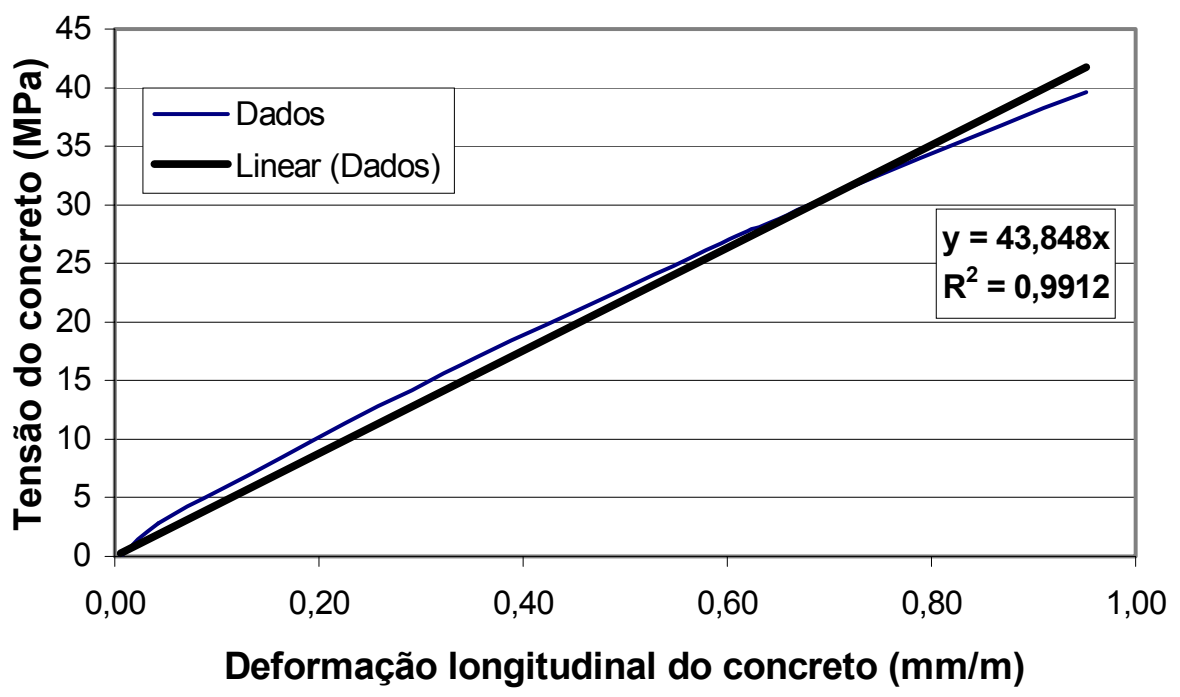

Figura 4.41 - Determinação do módulo de elasticidade do concreto.

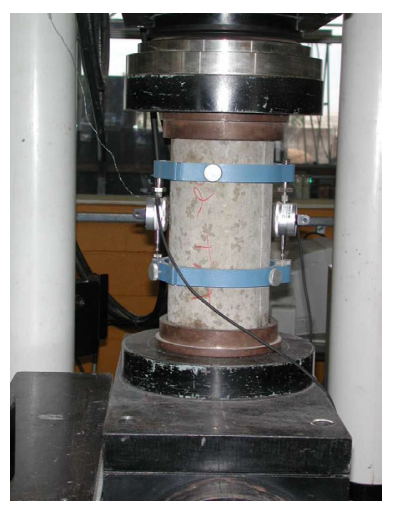

Figura 4.42 - Ensaio de compressão axial para determinação do módulo de elasticidade.

A Tabela 4.13 apresenta as médias obtidas, e os respectivos desvios padrão, tanto para cada teor de fibra separadamente, como para todo o universo ensaiado.

Nota-se claramente que as diferenças entre os resultados entre os três compósitos, e entre os dois tipos de modelo, são desprezíveis. Portanto, como não há grande diferença entre o concreto com e o sem fibras de aço, para esta pesquisa será utilizado o valor de $\mathrm{E}_{\mathrm{cm}}=39 \mathrm{GPa}$, para todos os compósitos.

$\mathrm{Na}$ falta de resultados de ensaio, as normas e os códigos estabelecem equações para o cálculo do módulo de elasticidade secante do concreto. São elas:

- $\quad \operatorname{NBR} 6118$ (1978): $\mathrm{E}_{\mathrm{c}}=0,9.6600\left(\mathrm{f}_{\mathrm{ck}}+3,5\right)^{1 / 2}$

- $\operatorname{NBR} 6118(2001): \mathrm{E}_{\mathrm{c}}=0,85.5600\left(\mathrm{f}_{\mathrm{ck}}\right)^{1 / 2}$

- $\operatorname{CEB}-F I P(1990): \mathrm{E}_{\mathrm{c}}=0,85.2,15 \times 10^{4}\left[\left(\mathrm{f}_{\mathrm{ck}}+8\right) / 10\right]^{1 / 3} \quad(\mathrm{MPa})$ 
- $\quad \mathrm{EC}-2$ (1999): $\mathrm{E}_{\mathrm{c}}=9,5 \times 10^{3}\left(\mathrm{f}_{\mathrm{ck}}+8\right)^{1 / 3}$

$(\mathrm{MPa})$

- $\quad$ FIB Bulletin 1 (1999): $\mathrm{E}_{\mathrm{cm}}=41,75 \mathrm{GPa}$

Tabela 4.13 - Resultados médios dos ensaios para determinação do módulo de elasticidade.

\begin{tabular}{|c|c|c|c|c|c|c|}
\hline \multicolumn{2}{|c|}{ Compósitos } & \multirow{2}{*}{$\frac{\mathrm{n}^{\mathrm{o}} \text { de CP's }}{6}$} & \multirow{2}{*}{$\begin{array}{c}\mathrm{E}_{\mathrm{cm}} \\
(\mathrm{MPa}) \\
37188,83\end{array}$} & \multirow{2}{*}{$\begin{array}{c}\mathrm{SD} \\
(\mathrm{MPa}) \\
304,46\end{array}$} & \multirow{2}{*}{$\frac{\frac{\mathrm{SD}}{\mathrm{E}_{\mathrm{cm}}}}{0,02}$} & \multirow{2}{*}{$\begin{array}{c}\frac{\mathrm{E}_{\mathrm{cm}, \mathrm{i}}}{\mathrm{E}_{\mathrm{cm}, \mathrm{total}}} \\
0,95\end{array}$} \\
\hline \multirow{4}{*}{$\begin{array}{l}\text { Prismas de } \\
\text { arrancamento }\end{array}$} & $\mathrm{V}_{\mathrm{f}}=0 \mathrm{~kg} / \mathrm{m}^{3}$ & & & & & \\
\hline & $\mathrm{V}_{\mathrm{f}}=40 \mathrm{~kg} / \mathrm{m}^{3}$ & 5 & 37664,20 & 304,04 & 0,02 & 0,96 \\
\hline & $\mathrm{V}_{\mathrm{f}}=60 \mathrm{~kg} / \mathrm{m}^{3}$ & 6 & 40978,67 & 750,81 & 0,04 & 1,05 \\
\hline & Total & 17 & 38666,24 & 513,57 & 0,05 & 0,99 \\
\hline \multirow{4}{*}{$\begin{array}{l}\text { Vigas à } \\
\text { flexão }\end{array}$} & $\mathrm{V}_{\mathrm{f}}=0 \mathrm{~kg} / \mathrm{m}^{3}$ & 8 & 39062,00 & 693,7 & 0,05 & 1,00 \\
\hline & $\mathrm{V}_{\mathrm{f}}=40 \mathrm{~kg} / \mathrm{m}^{3}$ & 3 & 41649,33 & 1117,22 & 0,05 & 1,06 \\
\hline & $\mathrm{V}_{\mathrm{f}}=60 \mathrm{~kg} / \mathrm{m}^{3}$ & 3 & 39375,33 & 402,33 & 0,02 & 1,01 \\
\hline & Total & 14 & 39683,57 & 526,12 & 0,05 & 1,01 \\
\hline \multicolumn{2}{|c|}{ Total geral } & 31 & 39125,68 & 373,97 & 0,05 & 1 \\
\hline
\end{tabular}

A Tabela 4.14 apresenta a comparação dos resultados de ensaio com os valores obtidos das normas e dos códigos, para uma resistência à compressão de $65 \mathrm{MPa}$.

Tabela 4.14 - Valores para o módulo de elasticidade do concreto (valores em GPa).

\begin{tabular}{c|c|c|c|c|c}
\hline Ensaio & $\begin{array}{c}\text { NBR 6118 } \\
(1978)\end{array}$ & $\begin{array}{c}\text { NBR 6118 } \\
(2001)\end{array}$ & $\begin{array}{c}\text { CEB-FIP } \\
(1990)\end{array}$ & $\begin{array}{c}\text { EC-2 } \\
(1999)\end{array}$ & $\begin{array}{c}\text { FIB Bulletin 1 } \\
(1999)\end{array}$ \\
\hline 39 & 49,2 & 38,4 & 35,5 & 39,7 & 41,75 \\
\hline
\end{tabular}

Como se pode perceber, os valores dados pela NBR 6118/2001, pelo EC-2/99 e pela FIB Bulletin 1/99 estão próximos dos valores de ensaio. O valor dado pela NBR 6118/78, que não tratava de concretos de alta resistência, está muito acima dos outros resultados, o que leva a uma superestimativa do valor do módulo de elasticidade, o que por sua vez levaria a subestimar-se as deformações. Esses resultados devem ser tratados com bastante cuidado.

\section{d) Tenacidade}

Foram realizados no total 38 ensaios de tração na flexão, dos quais 18 em concretos sem fibra e 20 em concretos com fibras de aço. Para 16 corpos-de-prova entre estes últimos 20, foi medida a tenacidade na flexão. Os ensaios foram realizados entre 23 e 30 dias. Ocorreu uma pequena variação na idade de ensaio em função da disponibilidade de data para a realização 
dos mesmos. Por outro lado, essa variação não apresentou nenhum problema, pois, devido à utilização do cimento ARI (alta resistência inicial) na confecção do concreto, a resistência à compressão já estava praticamente constante (desde a idade de 10 dias, aproximadamente). A taxa de carregamento para os ensaios foi de $v_{\text {ensaio,Tb }}=0,005 \mathrm{~mm} / \mathrm{s}$.

Os dados obtidos foram submetidos a um tratamento estatístico para a validação dos mesmos. Segunda a análise estatística, os dados para um teor de fibra de $V_{\mathrm{f}}=40 \mathrm{~kg} / \mathrm{m}^{3}$ não apresentaram resultados satisfatórios. Já para os compósitos com $\mathrm{V}_{\mathrm{f}}=60 \mathrm{~kg} / \mathrm{m}^{3}$, os dados apresentaram-se aceitáveis. A rigor, deveriam ter sido feitos mais ensaios para os concretos com $40 \mathrm{~kg} / \mathrm{m}^{3}$ de fibras de aço para obter-se uma amostra melhor, entretanto isso não foi possível devido ao cronograma apertado com que se estava trabalhando. Por este motivo, apesar desses dados apresentarem uma dispersão grande, aceitaram-se os mesmos para a determinação da tenacidade dos compósitos. A análise estatística completa desses dados se encontra no Apêndice E.

Segundo AGULLÓ et al (2000), o módulo de ruptura $\left(\mathrm{f}_{\mathrm{r}}\right)$ ou resistência à flexo-tração se determina convencionalmente mediante um ensaio de flexão num corpo-de-prova prismático, no qual se registra a carga máxima e, aplicando a análise elástica, se calcula a tensão máxima. A depender do tipo de material, o módulo de ruptura e a resistência à tração na flexão podem ser o mesmo valor ou não. Para materiais que não apresentam encruamento, $\mathrm{f}_{\mathrm{r}}=\mathrm{f}_{\mathrm{ct} \text { fl }}$, caso contrário, os valores são diferentes, o módulo de ruptura é associado à carga de primeira fissura (que se define, geralmente, como o ponto da curva Carga versus Deslocamento no qual a forma da curva se converte em não linear pela primeira vez), e a resistência à tração é relativa à carga máxima, pós-encruamento. Os gráficos da Figura 4.43 apresentam as duas situações.

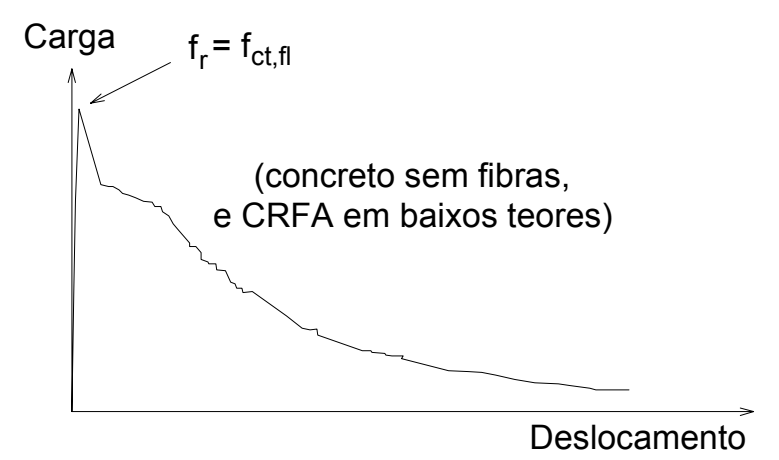

(a) Materiais sem encruamento

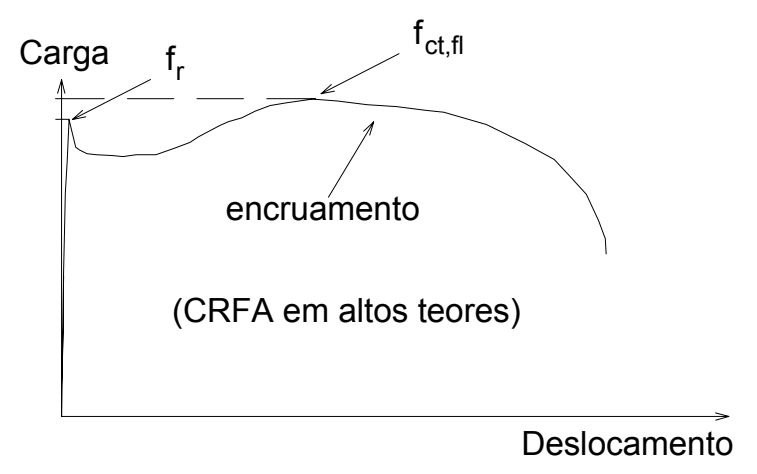

(b) Materiais com encruamento

Figura 4.43 - Gráficos Carga versus Deslocamento, para materiais que apresentam comportamentos distintos em relação ao encruamento. 
Ainda segundo os mesmos autores, a caracterização da tenacidade pode ser feita através de distintos indicadores, são eles: a absorção absoluta de energia (área total sob o diagrama Carga versus Deslocamento), os índices adimensionais relacionados com a capacidade de absorção de energia (método recomendado pela ASTM C1018, 1992), a resistência equivalente à flexo-tração (método recomendado pela JSCE-SF4 (1984)), ou qualquer outro parâmetro que quantifique a resposta do concreto no regime pós-pico. Neste trabalho optou-se por utilizar o método proposto pela JSCE-SF4 (1984), que estabelece um coeficiente de tenacidade na flexão $\left(\overline{\sigma_{\mathrm{b}}}\right)$, calculado pela seguinte expressão:

$$
\overline{\sigma_{\mathrm{b}}}=\frac{\mathrm{T}_{\mathrm{b}} \cdot 150}{\mathrm{~b} \cdot \mathrm{h}^{2}} \quad\left(\mathrm{kN} / \mathrm{mm}^{2}\right)
$$

$\mathrm{T}_{\mathrm{b}}$ representa a área sob o diagrama Carga versus Deslocamento, até um deslocamento limite de $\mathrm{L}_{\mathrm{CP}} / 150$. Para os compósitos estudados, $\mathrm{f}_{\mathrm{r}}=\mathrm{f}_{\mathrm{ct}, \mathrm{fl}}$.

A opção por este método baseou-se em dois fatores: (1) para esta pesquisa, o valor da tenacidade foi utilizado na expressão de KRSTULOVIC-OPARA et al (1994), para o cálculo da tensão de aderência, que está no Capítulo 3, e que utilizou este tipo de indicador para a tenacidade; e (2) o cálculo dos índices adimensionais para concretos com baixos teores de fibras não é muito recomendado, já que a sua determinação se encontra numa zona de instabilidade, pois se baseia no ponto de primeira fissura. Assim que esta ocorre, para esses compósitos, há uma queda brusca da carga neste ponto, gerando a zona de instabilidade.

O gráfico da Figura 4.44 apresenta um exemplo de cálculo para a tenacidade $\left(\mathrm{T}_{\mathrm{b}}\right)$.

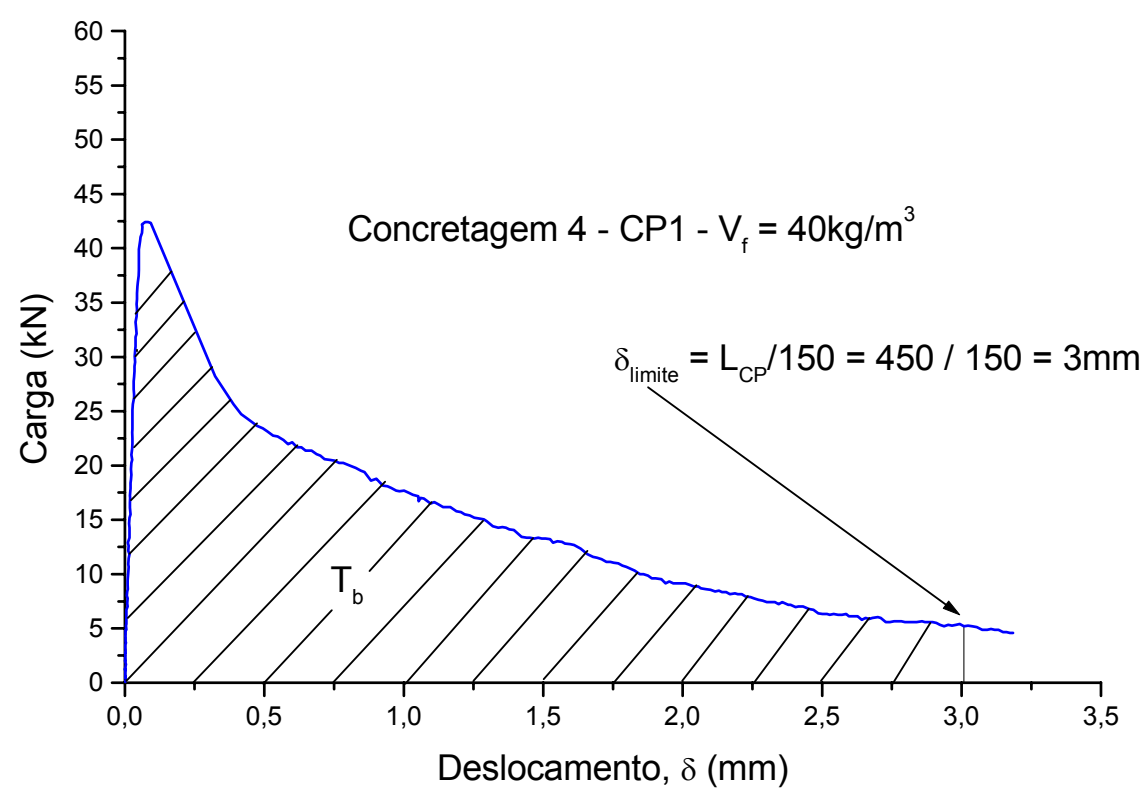

Figura 4.44 - Gráfico Carga versus Deslocamento para um compósito com $\mathrm{V}_{\mathrm{f}}=40 \mathrm{~kg} / \mathrm{m}^{3}$. 
A Tabela 4.15 apresenta as médias obtidas, e os respectivos desvios padrão, tanto para cada teor de fibra separadamente, como para todo o universo ensaiado.

Tabela 4.15 - Resultados médios dos ensaios para determinação da tenacidade na flexão.

\begin{tabular}{|c|c|c|c|c|c|c|}
\hline \multicolumn{2}{|c|}{ Compósitos } & \multirow{2}{*}{$\frac{\mathrm{n}^{\mathrm{o}} \text { de CP's }}{5}$} & \multirow{2}{*}{$\begin{array}{c}\mathrm{T}_{\mathrm{bm}} \\
(\mathrm{kN} . \mathrm{mm}) \\
43,49\end{array}$} & \multirow{2}{*}{$\begin{array}{c}\mathrm{SD} \\
(\mathrm{kN} . \mathrm{mm}) \\
4,83\end{array}$} & \multirow{2}{*}{$\frac{\frac{\mathrm{SD}}{\mathrm{T}_{\mathrm{bm}}}}{0,11}$} & \multirow{2}{*}{$\frac{\frac{\mathrm{T}_{\mathrm{bm}, \mathrm{i}}}{\mathrm{T}_{\mathrm{bm}, \text { total }}}}{0,73}$} \\
\hline \multirow{3}{*}{$\begin{array}{c}\text { Prismas de } \\
\text { arrancamento }\end{array}$} & $\mathrm{V}_{\mathrm{f}}=40 \mathrm{~kg} / \mathrm{m}^{3}$ & & & & & \\
\hline & $\mathrm{V}_{\mathrm{f}}=60 \mathrm{~kg} / \mathrm{m}^{3}$ & 4 & 73,99 & 11,23 & 0,15 & 1,24 \\
\hline & Total & 9 & 57,04 & 17,81 & 0,31 & 0,95 \\
\hline \multirow{3}{*}{$\begin{array}{l}\text { Vigas à } \\
\text { flexão }\end{array}$} & $\mathrm{V}_{\mathrm{f}}=40 \mathrm{~kg} / \mathrm{m}^{3}$ & 3 & 60,94 & 21,99 & 0,36 & 1,02 \\
\hline & $\mathrm{V}_{\mathrm{f}}=60 \mathrm{~kg} / \mathrm{m}^{3}$ & 4 & 65,48 & 12,13 & 0,19 & 1,09 \\
\hline & Total & 7 & 63,53 & 15,52 & 0,24 & 1,06 \\
\hline \multicolumn{2}{|c|}{ Total para $\mathrm{V}_{\mathrm{f}}=40 \mathrm{~kg} / \mathrm{m}^{3}$} & 8 & 50,03 & 15,27 & 0,31 & 0,84 \\
\hline \multicolumn{2}{|c|}{ Total para $\mathrm{V}_{\mathrm{f}}=60 \mathrm{~kg} / \mathrm{m}^{3}$} & 8 & 69,73 & 11,74 & 0,17 & 1,16 \\
\hline \multicolumn{2}{|c|}{ Total geral } & 16 & 59,88 & 16,63 & 0,28 & 1 \\
\hline
\end{tabular}

Baseado nos resultados dos ensaios, optou-se por trabalhar com dois valores distintos, levando-se em conta as diferenças entre os compósitos com $40 \mathrm{~kg} / \mathrm{m}^{3}$ e $60 \mathrm{~kg} / \mathrm{m}^{3}$ de fibras, desprezando-se as diferenças entre os dois tipos de modelo. $\mathrm{O}$ valor do módulo de ruptura $\left(\mathrm{f}_{\mathrm{r}}\right)$, para os compósitos ensaiados, é o mesmo valor calculado para a resistência à tração na flexão, já apresentado anteriormente.

Os valores finais adotados, para a tenacidade dos compósitos, foram:

$$
\overline{\sigma_{\mathrm{b}, 40}}=2,22 \mathrm{MPa} \quad \text { e } \quad \overline{\sigma_{\mathrm{b}, 60}}=3,10 \mathrm{MPa}
$$

A Figura 4.45 apresenta um exemplo do arranjo do ensaio de tenacidade.

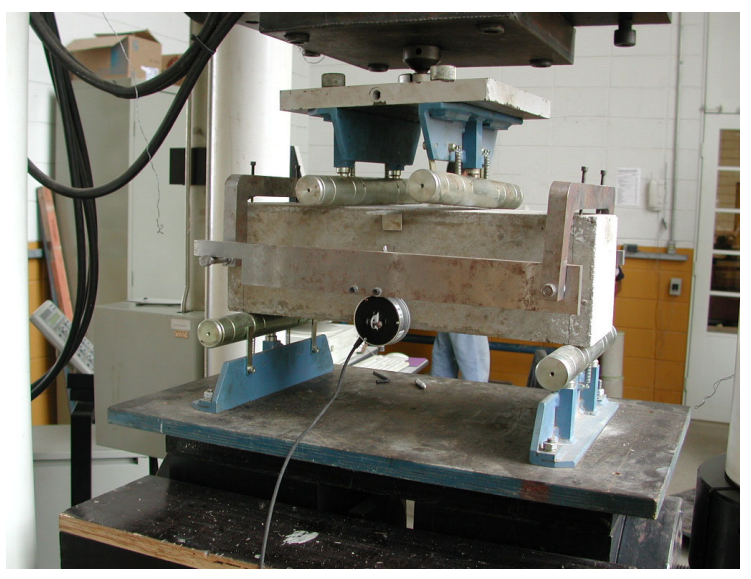

Figura 4.45 - Ensaio de tenacidade. 


\subsubsection{Armaduras passivas}

Nas vigas ensaiadas à flexão, foram utilizadas armaduras longitudinais passivas de $\phi 8 \mathrm{~mm}$ e armaduras transversais passivas, estribos, de $\phi 6,3 \mathrm{~mm}$. Foram realizados 4 ensaios nas armaduras passivas (2 para $\phi 6,3 \mathrm{~mm}$ e 2 para $\phi 8 \mathrm{~mm}$ ) para a verificação da resistências das barras à tração e para obtenção do comportamento Tensão versus Deformação. Os ensaios foram realizados na máquina de ensaio servo-contralada INSTRON. Os gráficos das Figuras 4.46 e 4.47 apresentam os resultados dos ensaios, para as barras de $\phi 6,3 \mathrm{~mm}$ e $\phi 8 \mathrm{~mm}$, respectivamente. Também não houve nenhum problema nestes ensaios. A Figura 4.48 mostra detalhes dos ensaios de tração.

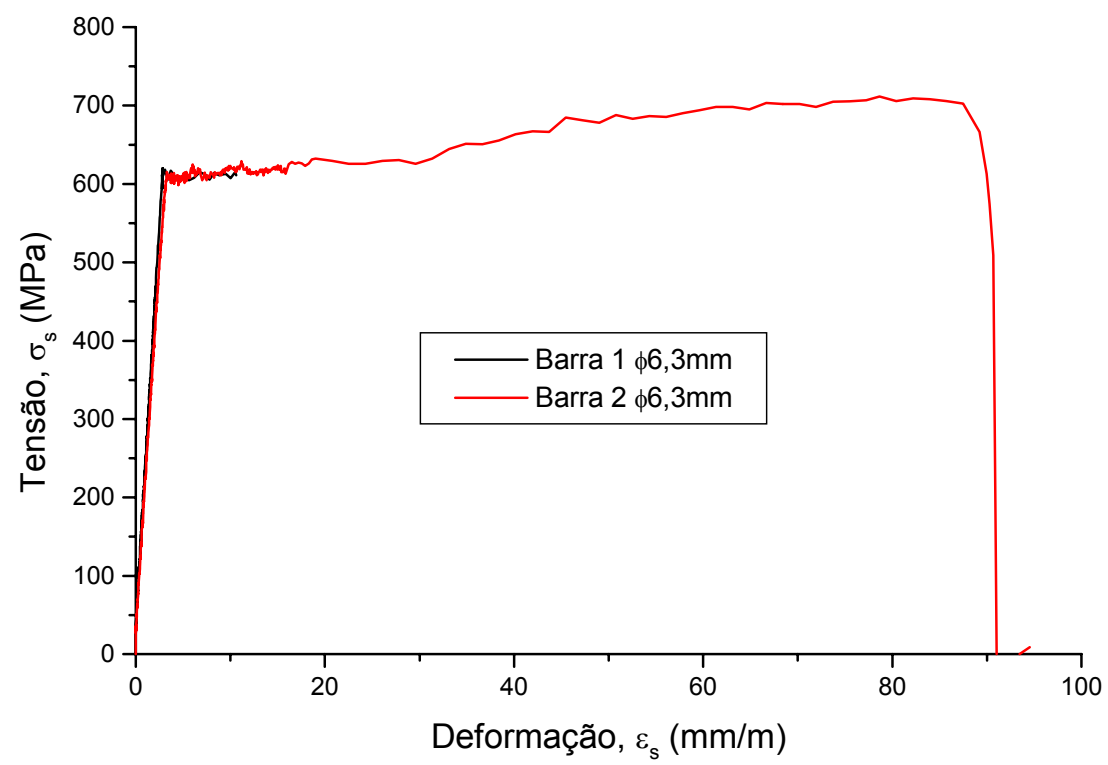

Figura 4.46 - Gráfico Tensão versus Deformação para a barra de $\phi 6,3 \mathrm{~mm}$.

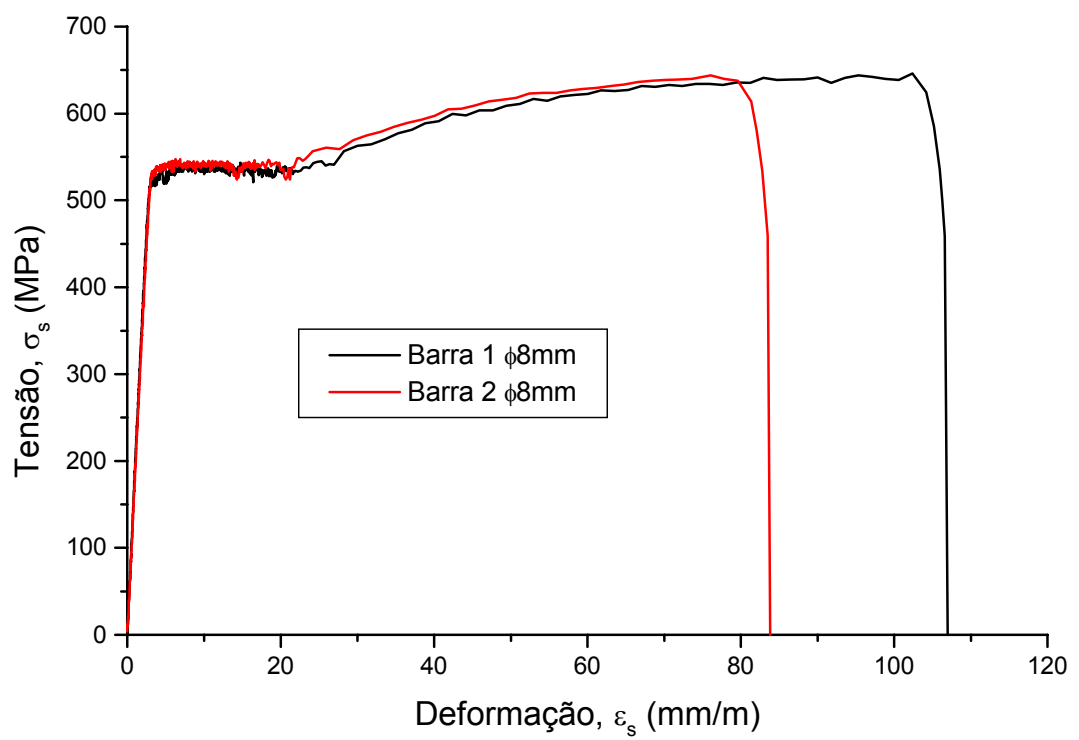

Figura 4.47 - Gráfico Tensão versus Deformação para a barra de $\phi 8 \mathrm{~mm}$. 
Como pode-se observar pelos gráficos, a tensão última de ruptura das armaduras foram acima do valor teórico de cálculo de 500MPa.
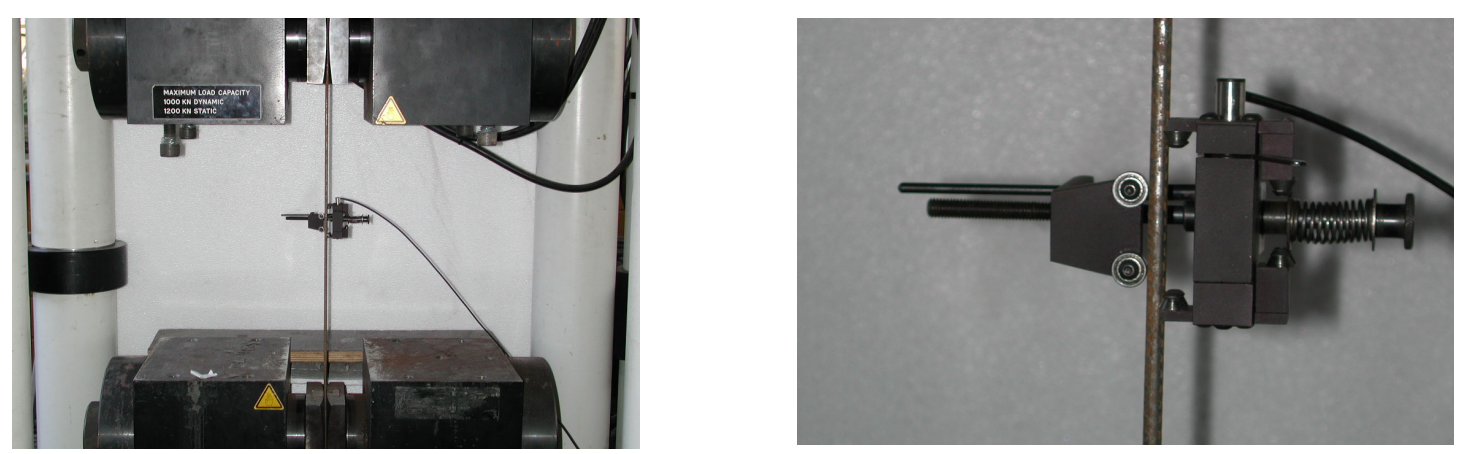

Figura 4.48 - Ensaios de tração das armaduras passivas, com detalhe do clip-gage.

\subsubsection{Armaduras ativas}

Foram utilizadas cordoalhas de sete fios com diâmetro 12,7mm e CP 190 RB, doadas pela Belgo Bekaert Arames S. A. Não foram feitos ensaios de caracterização dessas armaduras, pois estes foram enviados pela Belgo, e se encontram no Anexo A.

Porém, foram feitos ensaios para determinar a relação entre a deformação e a tensão nessas armaduras. Foram realizados três ensaios de tração na cordoalha, e foram feitos dois tipos de leitura de deformação, durante esses ensaios. Nos dois primeiros ensaios instrumentaram-se três fios da cordoalha com extensômetros elétricos, para verificar o caminhamento das deformações. Nestes ensaios observou-se que tanto a deformação de cada fio como a média dos três eram praticamente coincidentes, indicando que os fios externos da cordoalha se deformavam igualmente. A partir daí, decidiu-se instrumentar apenas dois fios diametralmente opostos, e trabalhar com o valor médio entre eles, já que os resultados foram bastante confiáveis.

No terceiro ensaio à tração da cordoalha, além de intrumentar os seis fios da cordoalha com extensômetros elétricos, utilizou-se, também, um clip-gage, que é um extensômetro indutivo removível que abraça a armadura e mede a deformação da cordoalha como um todo. O gráfico da Figura 4.49 apresenta as deformações médias dos três ensaios, medidas com os extensômetros elétricos, e a deformação medida com o clip-gage.

Como se pode observar, a deformação medida com clip-gage fornece tensões menores do que as medidas com os extensômetros elétricos. Para a análise dos resultados de ensaio das vigas, onde as cordoalhas foram instrumentadas com extensômetros elétricos, foi usada a correlação acima para determinar o nível de tensão em que as armaduras ativas se encontravam. Não se tem o gráfico completo, além do escoamento da armadura, porque o 
clip-gage foi retirado antes para evitar danos ao equipamento, pois uma ruptura prematura de um dos fios da cordoalha poderia inutilizar o transdutor.

Tensão média da cordoalha

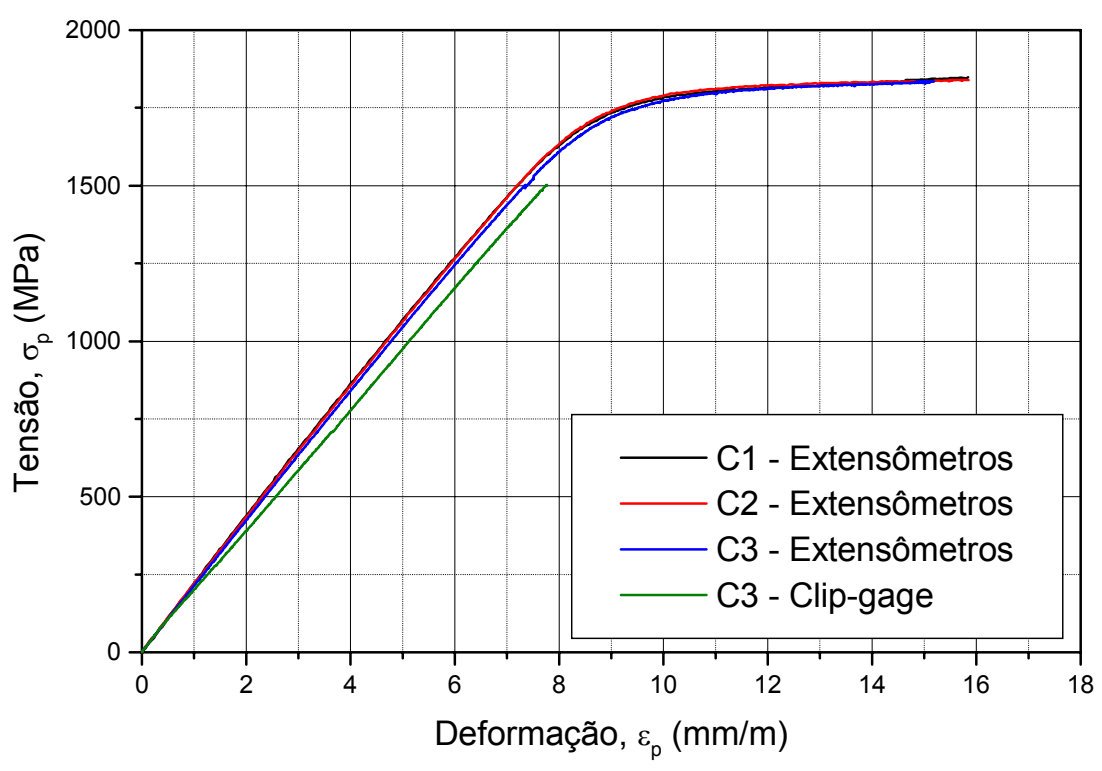

Figura 4.49 - Gráfico Tensão versus Deformações medidas na cordoalha.

A Figura 4.50 apresenta detalhes da instrumentação da cordoalha com os extensômetros elétricos e o clip-gage.

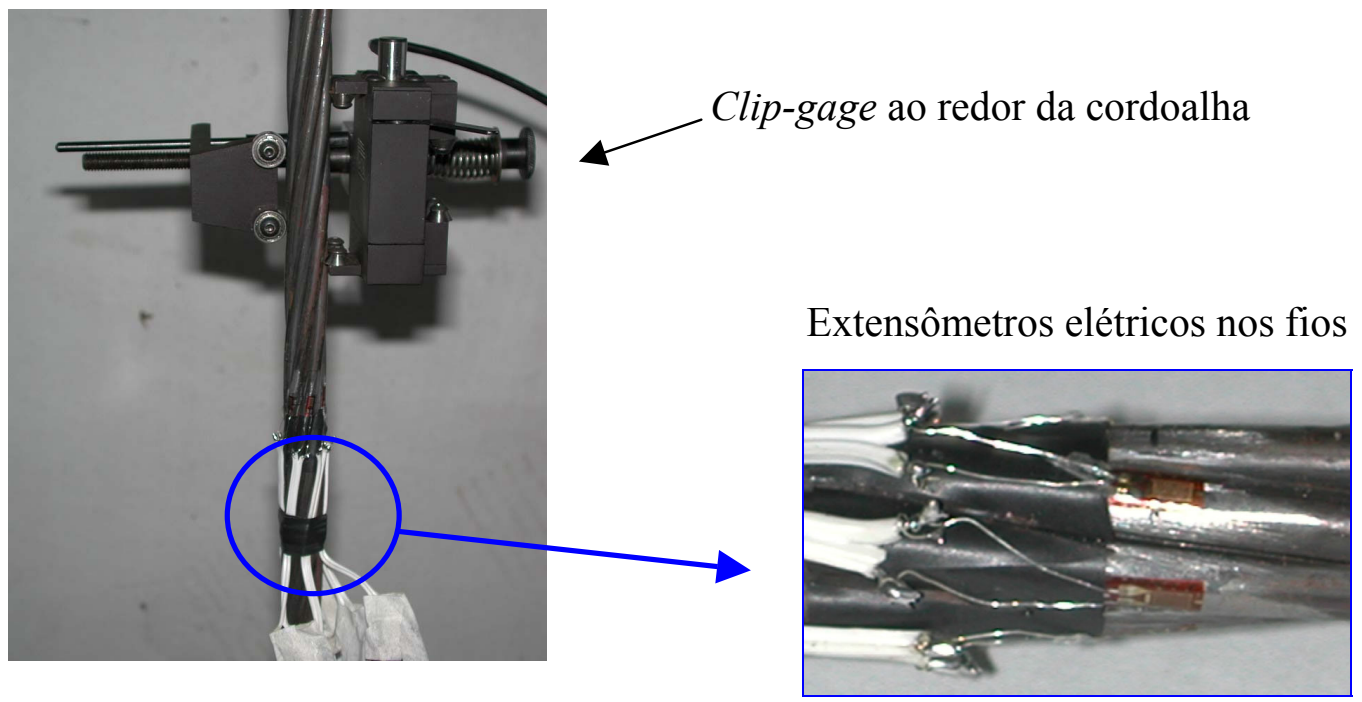

Figura 4.50 - Detalhes da instrumentação da cordoalha.

\subsubsection{Fibras de aço}

Foram utilizadas fibras de aço DRAMIX RL 45/30 BN, com gancho nas extremidades, doadas pela Belgo Bekaert Arames S.A. Não foram feitos ensaios de caracterização das fibras, pois estes foram enviados pela Belgo. As características das fibras fornecidas pelo fabricante se encontram no Anexo A. 


\section{ENSAIOS DE ARRANCAMENTO}

Este capítulo apresenta os ensaios estáticos (monotônicos) de arrancamento, que foram realizados para a obtenção da tensão de aderência da cordoalha analisada e do comportamento Tensão de aderência versus Escorregamento, para os diversos modelos e parâmetros de ensaio diferentes.

Todos os ensaios aqui citados foram feitos no Laboratório de Estruturas da EESC-USP.

O capítulo descreve o programa e a análise experimental dos ensaios de arrancamento.

\subsection{Descrição dos Ensaios}

Para esta pesquisa, foram realizados 108 ensaios de arrancamento em modelos prismáticos, cujo objetivo principal foi avaliar a influência das fibras de aço na aderência entre a armadura e o concreto. A armadura utilizada foi a cordoalha de sete fios com $12,7 \mathrm{~mm}$ de diâmetro e aço CP 190 RB. O concreto apresentou resistência média à compressão de, aproximadamente, $68 \mathrm{MPa}$, na data de ensaio, sendo, então, um concreto de alta resistência (CAR).

Os parâmetros de ensaio escolhidos foram: o comprimento aderente disponível $\left(\ell_{\mathrm{ef}}\right)$, o volume de fibras de aço $\left(\mathrm{V}_{\mathrm{f}}\right)$, e o grau de protensão da armadura $\left(\sigma_{\mathrm{p}}\right)$.

O principal resultado de ensaio que se buscava foi a tensão máxima de aderência $\left(\tau_{b, \text { máx }}\right)$. O valor da tensão máxima de aderência foi calculado da seguinte forma:

$$
\tau_{\mathrm{b}, \text { máx }}=\frac{\mathrm{P}_{\text {máx }}}{\mathrm{u}_{\mathrm{p}} \cdot \ell_{\mathrm{ef}}}=\frac{\mathrm{P}_{\text {máx }}}{\pi \cdot \phi_{\mathrm{p}, \text { equivalente }} \cdot \ell_{\mathrm{ef}}}
$$

onde: $\mathrm{P}_{\operatorname{máx}}=$ força máxima de arrancamento registrada; 
$\mathrm{u}_{\mathrm{p}}=$ perímetro da seção transversal da cordoalha;

$\ell_{\mathrm{ef}}=$ comprimento aderente disponível;

$\phi_{\mathrm{p}, \text { equivalente }}=\sqrt{\frac{4 \cdot \mathrm{A}_{\mathrm{p}}}{\pi}}$.

No cálculo da tensão de aderência, foi levado em conta o diâmetro equivalente das cordoalhas $\left(\phi_{\mathrm{p} \text {,equivalente }}=11,3 \mathrm{~mm}\right)$, e não o seu valor nominal $\left(\phi_{\mathrm{p}}=12,7 \mathrm{~mm}\right)$. O diâmetro equivalente foi determinado a partir do valor da área da seção transversal da cordoalha fornecido pelo fabricante $\left(A_{p}=100,3 \mathrm{~mm}^{2}\right)$, ou seja, utilizou-se o valor real, ou existente, para o diâmetro. Isso levou a uma tensão de aderência maior.

Para a utilização da cordoalha não foi feito nenhum processo de limpeza profunda da mesma. Ela foi recebida em forma de rolo, e ficou armazenada no Laboratório de Estruturas (LE) durante o período dos trabalhos experimentais. Para as concretagens, as peças eram cortadas, limpas superficialmente com um pano seco, e posicionadas nas formas. A limpeza da armadura com um pano seco visou, apenas, retirar a ferrugem superficial da cordoalha, que foi se formando enquanto a peça ficava guardada. Por conta disso, as condições superficiais da cordoalha eram semelhantes às condições de utilização nos canteiros de obra. Ou seja, a armadura apresentava pequenas irregularidades devidas à sujeira e à oxidação.

A Figura 5.1 apresenta um esquema do arranjo de ensaio, das características dos modelos, e detalhes da vedação e do modo de retirada da aderência dos prismas.

O modelo ficava preso à máquina de ensaio pela cordoalha, e o prisma de concreto era puxado para cima, procedendo-se assim o arrancamento da armadura. Optou-se pelo ensaio de arrancamento com o concreto comprimido para que se pudesse comparar os resultados com a cordoalha sem protensão e com ela pré-tracionada. O método de ensaio com o concreto tracionado, sugerido pela norma dinamarquesa (Figura 2.17, Capítulo 2), apesar de fornecer resultados mais próximos da realidade, não permitiria essa comparação direta entre os resultados, pois não seria possível realizar o ensaio, com tal arranjo, para a peça prétracionada.

Para a retirada da aderência foram utilizados dois métodos diferentes: (1) para os modelos da Série 1, a cordoalha foi envolvida por um filme plástico nas regiões das extremidades (Figura 5.1d); e (2) para os modelos da Série 2, um tubo de PVC foi colocado em volta da cordoalha, na região sem aderência (Figura 5.1b). A diferença foi devida às dimensões reduzidas dos modelos da Série 1, que não permitiram a colocação do tubo de PVC. Antes da concretagem das peças, a vedação das formas foi feita com a colocação de 
cera de abelha (Figura 5.1c) ou de massa de vedação (Figura 5.1b), ao redor da cordoalha ou do tubo de isolamento. Isso foi válido para as duas séries. O uso de um ou outro material foi em função da disponibilidade deles no momento da concretagem.

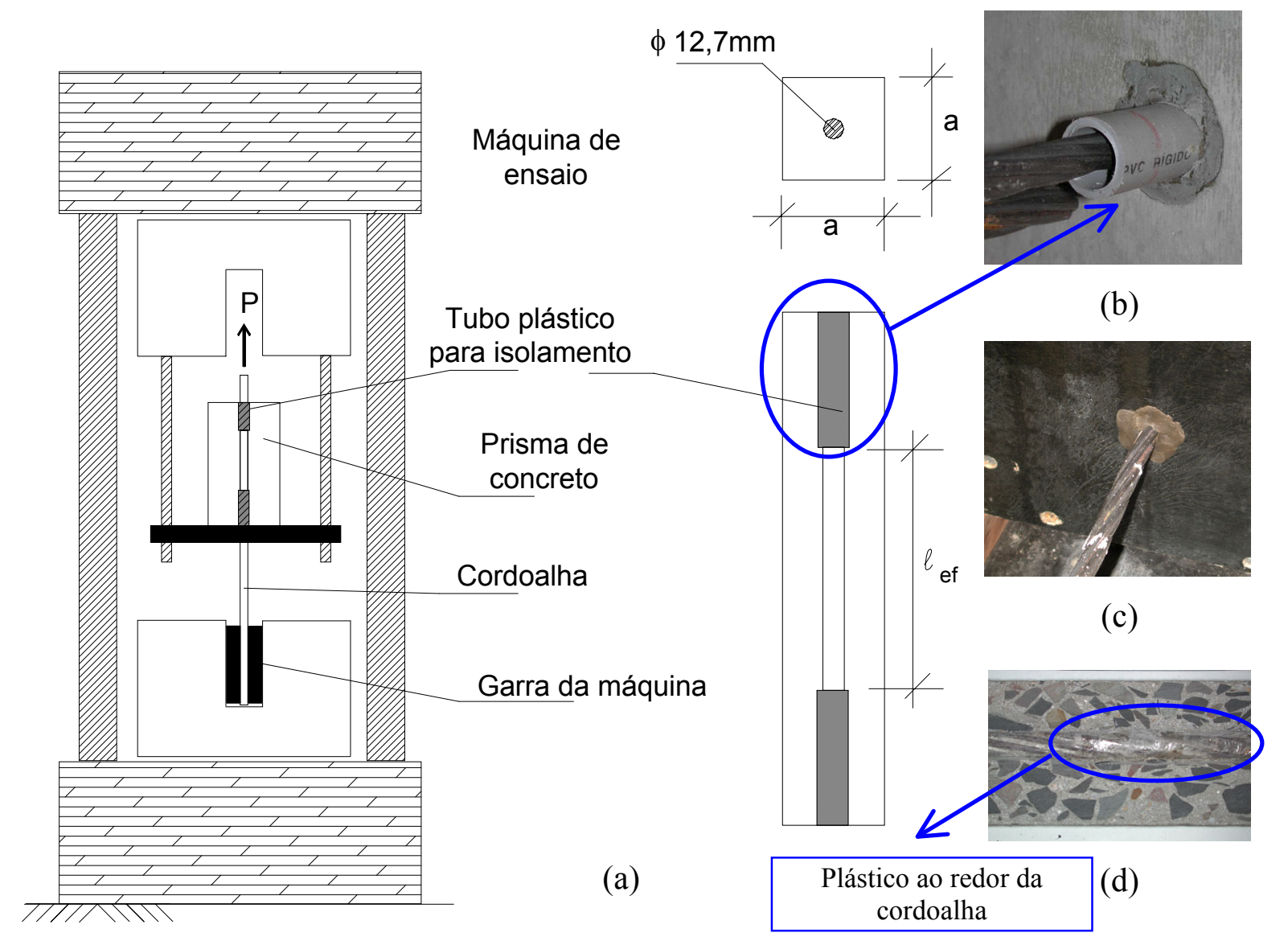

Figura 5.1 - Detalhes do ensaio de arrancamento dos prismas das Séries 1 e 2: (a) arranjo para os ensaios de arrancamento e forma dos modelos; (b) detalhe da vedação com massa de vedação e do tubo de PVC utilizado para a retirada da aderência dos prismas da Série 2; (c) detalhe da vedação com cera de abelha; (d) detalhe do filme plástico ao redor da cordoalha (após corte do prisma), para a retirada da aderência dos prismas da Série 1.

Para os parâmetros de ensaio utilizados, os valores escolhidos foram:

- $\ell_{\mathrm{ef}}=\left\{\begin{array}{l}5 \phi_{\mathrm{p}}=6,35 \mathrm{~cm} \\ 7 \phi_{\mathrm{p}}=9 \mathrm{~cm} \\ 15 \phi_{\mathrm{p}}=19 \mathrm{~cm}\end{array}\right.$

- $\mathrm{V}_{\mathrm{f}}=\left\{\begin{array}{l}0 \mathrm{~kg} / \mathrm{m}^{3} \\ 40 \mathrm{~kg} / \mathrm{m}^{3} \\ 60 \mathrm{~kg} / \mathrm{m}^{3}\end{array}\right.$

- $\sigma_{\mathrm{p}}=\left\{\begin{array}{l}\text { zero }(\text { armadura sem protensão }) \\ 0,8 \mathrm{f}_{\mathrm{ptk}}(\text { armadura pré }- \text { tracionada })\end{array}\right.$ 
Fazendo-se o cruzamento de todos os parâmetros, e seus respectivos valores, obteve-se um total de 18 combinações diferentes. Para cada combinação, confeccionaram-se 6 modelos idênticos, o que resultou no total de 108 ensaios, ou seja:

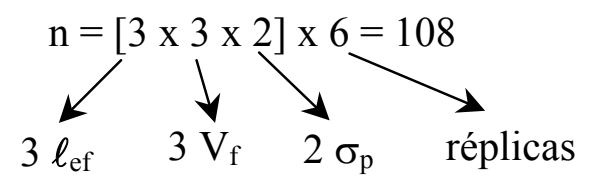

Como já descrito no Capítulo 4, os ensaios de arrancamento foram divididos em duas séries: (1) prismas de $7 \mathrm{~cm} \times 7 \mathrm{~cm} \times 40 \mathrm{~cm}$; e (2) prismas de $20 \mathrm{~cm} \times 20 \mathrm{~cm} \times 12,7 \mathrm{~cm}$. As Tabela 5.1 e 5.2 apresentam os parâmetros de ensaio de cada série. Essas tabelas se encontram, também no capítulo 4, mas foram repetidas aqui para melhor visualização do programa para os ensaios de arrancamento.

Tabela 5.1 - Plano dos ensaios estáticos de arrancamento da Série 1 (72 modelos).

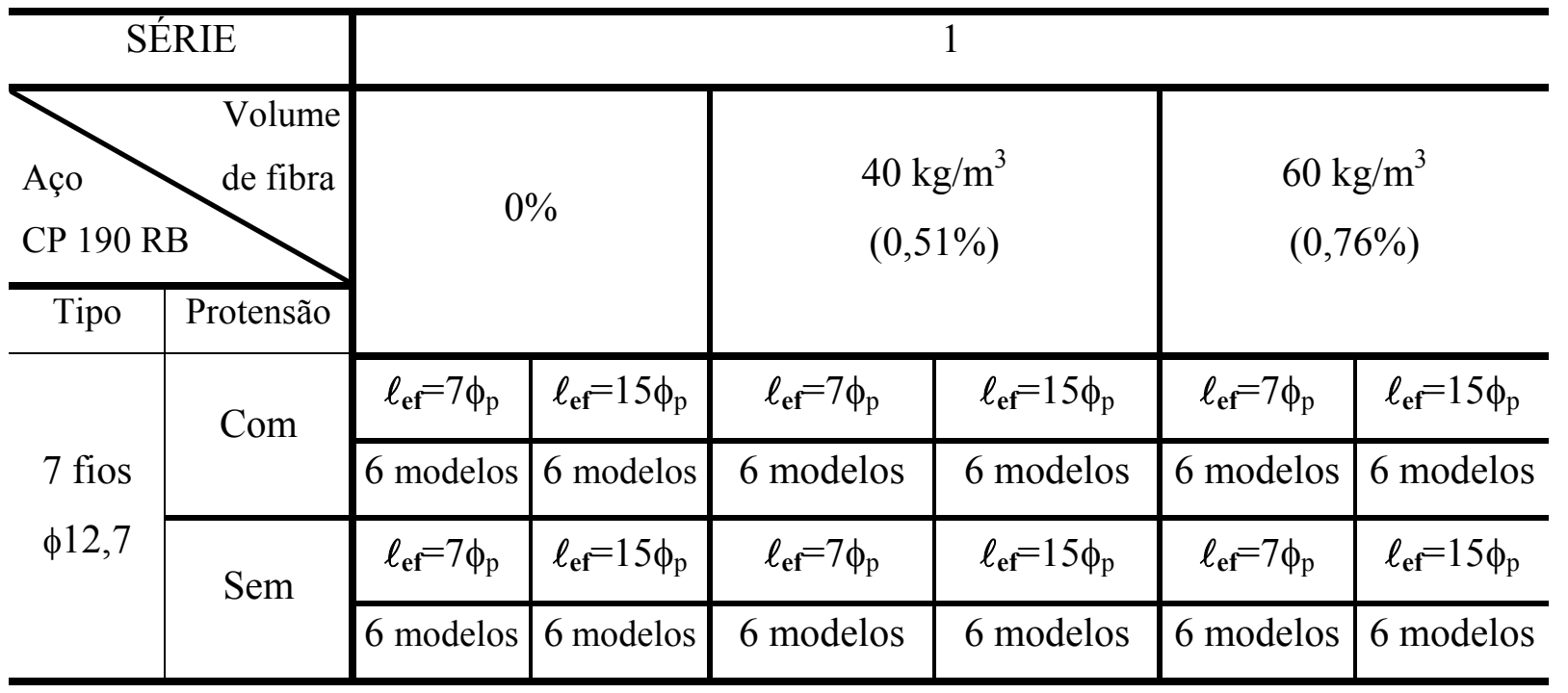

Tabela 5.2 - Plano dos ensaios estáticos de arrancamento da Série 2 (36 modelos).

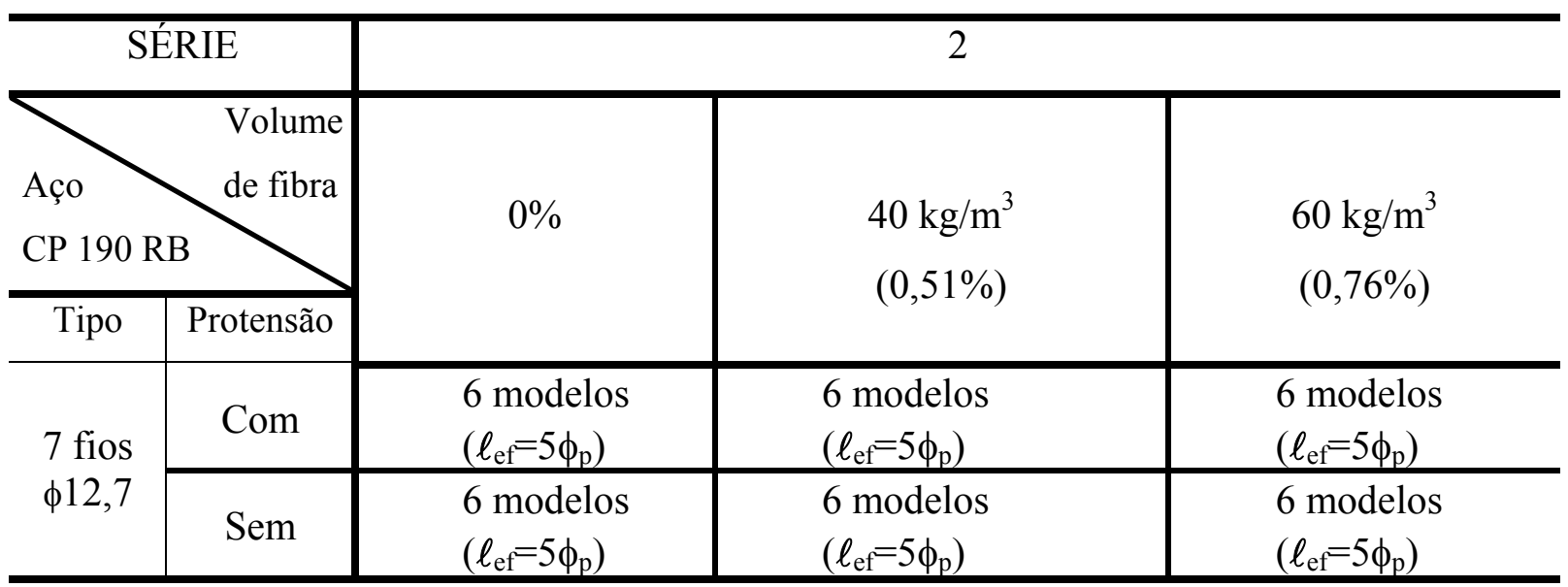


Nos ensaios de arrancamento, o comprimento de ancoragem $\left(\ell_{\mathbf{e f}}\right)$ adotado foi menor do que o calculado pelas prescrições normativas e do que o admitido nos ensaios de flexão. Isso teve três motivos: (1) facilitar o arrancamento da barra; (2) garantir que ela não entrasse em escoamento; e (3) garantir que a seção de concreto resistiria às tensões de compressão e tração. Os cálculos para verificação das seções de concreto, para os prismas das Séries 1 e 2, se encontram no Apêndice A.

A nomenclatura dos prismas foi determinada de modo a fornecer as seguintes informações: tipo do modelo, comprimento de ancoragem disponível (em função do diâmetro da cordoalha), grau de protensão, teor de fibra $\left(\mathrm{em} \mathrm{kg} / \mathrm{m}^{3}\right)$ e número do modelo. Por exemplo:

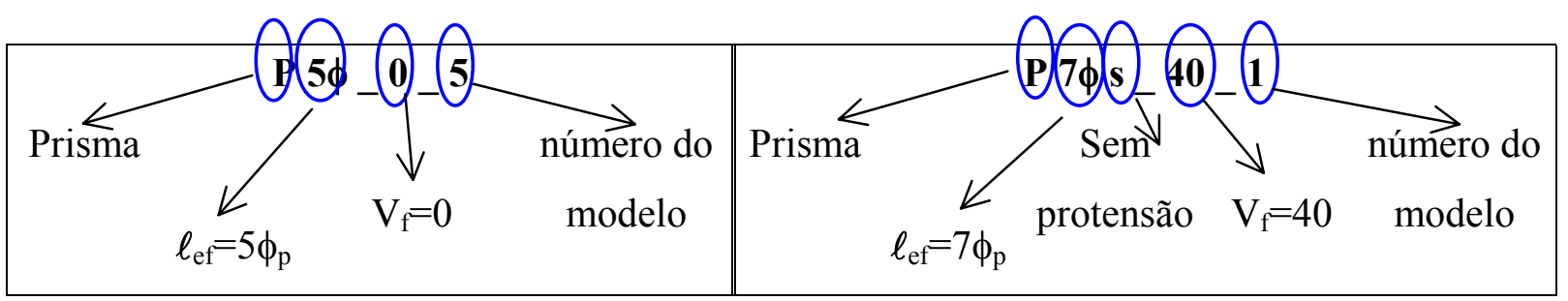

O procedimento de ensaio padrão, para as duas séries, foi o seguinte:

1) Colocação das formas no pórtico de protensão, seis por vez, para posicionamento da cordoalha (Figura 5.2a);

2) Fixação da cordoalha no pórtico, e pré-tracionamento da mesma;

3) No dia seguinte à protensão, ocorria a concretagem dos prismas pré-tracionados (Figura 5.2b) no pórtico, e, quando era o caso, a concretagem, também, dos prismas sem protensão na mesa vibratória;

4) Após 48 horas, efetuava-se a retirada gradual da protensão;

5) Em seguida, dava-se o corte da cordoalha entre os prismas pré-tracionados, e a retirada das formas (Figura 5.2c) de todos os prismas concretados;

6) Após 21 dias, aproximadamente, os prismas eram colocados, um a um, na máquina para o ensaio de arrancamento (Figura 5.2d).

A Figura 5.2 apresenta alguns detalhes dos procedimentos de ensaio para os prismas da Série 1.

Após a concretagem, a cura dos prismas era feita com a colocação de espumas molhadas sobre as peças, tanto as pré-tracionadas como as sem protensão. A cura durava 48horas, até o momento da retirada da protensão. Esta era feita de maneira gradual, com o alívio lento da carga nos cilindros hidráulicos. A leitura da carga foi feita através de um indicador analógico para extensometria TRANSDUTEC T832, tanto durante a protensão 
como na sua retirada. Essa foi a única leitura feita nessas duas etapas, pois nem a cordoalha, nem os prismas possuíam instrumentação. Após a retirada das formas, os prismas ficavam armazenados no Laboratório de Estruturas (LE), à temperatura ambiente, sem procedimentos de cura, até a data de ensaio (Figura 5.2c). Cada jogo de forma foi reutilizado três vezes.

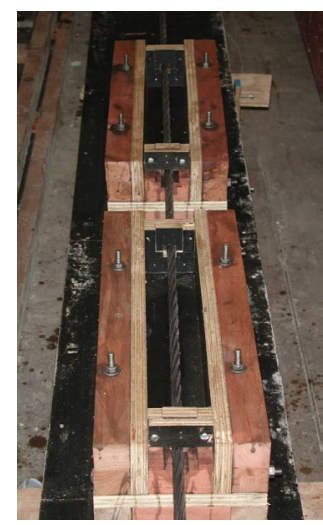

(a)

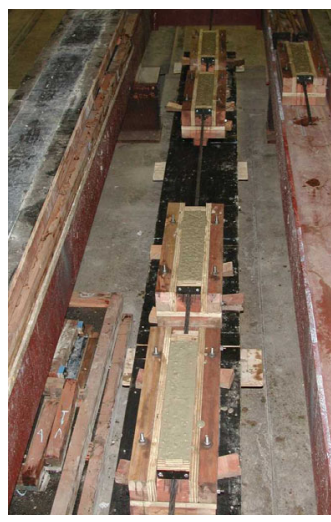

(b)

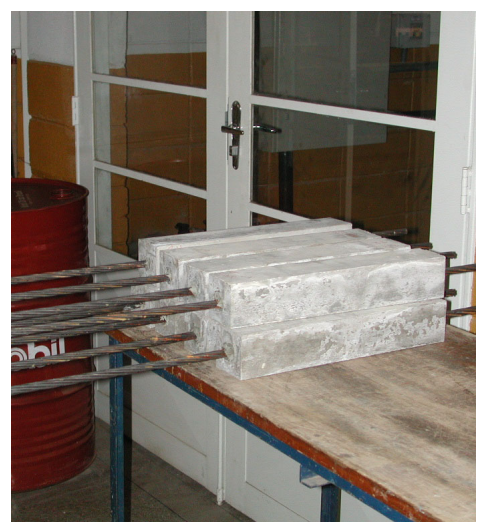

(c)

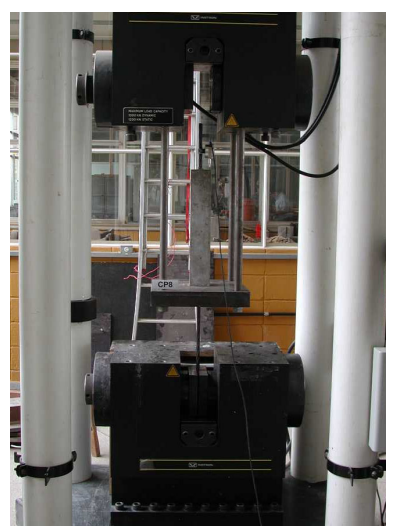

(d)

Figura 5.2 - Detalhes da forma e concretagem dos prismas da Série 1: (a) formas dos prismas no pórtico de protensão; (b) prismas após a concretagem; (c) prismas após a desforma; (d) vista geral do ensaio de arrancamento na máquina universal de ensaio.

De modo geral, não foram encontradas grandes dificuldades, nem na montagem e na concretagem dos prismas, nem nos ensaios de arrancamento. $\mathrm{O}$ único problema para esses ensaios ocorreu devido à reutilização das formas de madeira. Devido ao procedimento de cura utilizado, as formas sofreram com os ciclos de umidade e secagem, que as iam deformando aos poucos. Com isso, os prismas concretados por último apresentavam, também, algumas deformações: os topos não estavam tão retos e lisos, e algumas arestas ficaram inclinadas. Por conta disso, a colocação destes prismas na máquina de ensaio exigiu um pouco mais de cuidado, para que os modelos ficassem centrados e bem apoiados.

Foram feitos, em média, de 8 a 12 ensaios de arrancamento por dia, pois cada ensaio durava, aproximadamente, 30 minutos. Com esses ensaios foi possível determinar experimentalmente os valores da tensão de aderência, e o comportamento Tensão de aderência versus Escorregamento, dos modelos estudados. Os ensaios foram realizados com controle de deformação, e utilizaram uma velocidade baixa: $v_{\text {ensaio }}=0,005 \mathrm{~mm} / \mathrm{s}$. A leitura da carga e a do escorregamento, medido pelo relógio comparador colocado na extremidade livre da cordoalha, foram feitas automaticamente de 2 em 2 segundos.

Os dados obtidos, para a elaboração dos gráficos Tensão de aderência versus Escorregamento, sofreram uma correção para levar em conta a dispersão dos valores da resistência do concreto à compressão, para as diversas concretagens. Vários autores sugerem 
essa correção, baseados no fato de que a tensão de aderência varia com a raiz quadrada da resistência à compressão, tanto para o concreto armado como para o protendido. Ou seja, os valores da tensão de aderência foram normalizados da seguinte forma:

$$
\overline{\tau_{\mathrm{b}}}=\tau_{\mathrm{b} \text {,ensaio }} \sqrt{\frac{\mathrm{f}_{\mathrm{cm}}}{\mathrm{f}_{\mathrm{c} \text {,ensaio }}}}
$$

$\mathrm{Na}$ realidade, isso não alterou significativamente os resultados, pois a dispersão de valores para a resistência do concreto à compressão foi pequena, o que já foi comentado no Capítulo 4.

A seguir são apresentados os ensaios de arrancamento para os prismas das Séries 1 e 2.

\subsubsection{Ensaios dos prismas da Série 1}

Foram realizados 72 ensaios nesta série, divididos em 12 grupos, e cada grupo com seis modelos teoricamente idênticos. A Tabela 5.3 apresenta os dados para a Série 1.

Tabela 5.3 - Características dos prismas da Série 1.

\begin{tabular}{|c|c|c|c|c|}
\hline Grupo & Modelos & $\sigma_{\mathbf{p}}$ & $\mathbf{V}_{\mathbf{f}}\left(\mathrm{kg} / \mathrm{m}^{3}\right)$ & $\ell_{\text {ef }}(\mathrm{cm})$ \\
\hline$\overline{1}$ & P7 $\phi \_0 \_1,2,3,4,5,6$ & $\overline{0,8 \mathrm{f}_{\mathrm{ptk}}}$ & \multirow{2}{*}{0} & \multirow{6}{*}{$7 \phi_{\mathrm{p}}=9 \mathrm{~cm}$} \\
\hline 2 & P7 $\phi s \_0 \_1,2,3,4,5,6$ & Zero (sem protensão) & & \\
\hline 3 & P7申_40_1,2,3,4,5,6 & $0,8 \mathrm{f}_{\mathrm{ptk}}$ & \multirow{2}{*}{40} & \\
\hline 4 & P7 $\phi$ s $40 \quad 1,2,3,4,5,6$ & Zero (sem protensão) & & \\
\hline 5 & P7 $\phi \_60 \_1,2,3,4,5,6$ & $0,8 \mathrm{f}_{\mathrm{ptk}}$ & \multirow{2}{*}{60} & \\
\hline 6 & P7 $\phi s \_60 \_1,2,3,4,5,6$ & Zero (sem protensão) & & \\
\hline 7 & P15ф_0_1,2,3,4,5,6 & $0,8 \mathrm{f}_{\mathrm{ptk}}$ & \multirow{2}{*}{0} & \multirow{6}{*}{$15 \phi_{\mathrm{p}}=19 \mathrm{~cm}$} \\
\hline 8 & P15 $\phi s \_0 \_1,2,3,4,5,6$ & Zero (sem protensão) & & \\
\hline 9 & P15ф_40_1,2,3,4,5,6 & $0,8 \mathrm{f}_{\mathrm{ptk}}$ & \multirow{2}{*}{40} & \\
\hline 10 & P15 $\phi s \_40 \_1,2,3,4,5,6$ & Zero (sem protensão) & & \\
\hline 11 & P15ф_60_1,2,3,4,5,6 & $0,8 \mathrm{f}_{\text {ptk }}$ & \multirow{2}{*}{60} & \\
\hline 12 & 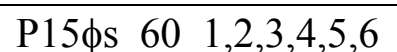 & Zero (sem protensão) & & \\
\hline
\end{tabular}

Os gráficos a seguir (Figuras 5.3, 5.7, 5.9, 5.10, 5.12, 5.13, 5.14, 5.16, 5.17, 5.18, 5.19 e 5.20) apresentam o comportamento Tensão de aderência versus Escorregamento, para os grupos da Tabela 5.3. Cada gráfico contém o resultado de ensaio dos seis modelos de cada grupo. 
O término dos ensaios foi determinado ou pela queda acentuada da carga, ou quando a peça atingia um escorregamento de, pelo menos, $3 \mathrm{~mm}$ com a carga já apresentado uma leve queda, o que ocorresse primeiro. Alguns ensaios foram levados além desses limites, quando não ocorria, claramente, nenhum dos dois fatores. Alguns ensaios, onde a carga não apresentou tendência de queda, tiveram o seu término determinado pelo alcance do final do curso do relógio comparador, que fazia a leitura do escorregamento.

Para todos esses modelos, observou-se que há o giro da cordoalha à medida que vai ocorrendo o escorregamento da mesma em relação ao concreto. Isso pôde ser observado devido à movimentação do relógio comparador sobre a face superior da peça.

Apesar de teoricamente idênticos, os seis modelos de cada grupo apresentaram comportamentos Tensão de aderência versus Escorregamento diferentes, o que pode ser claramente observado nos gráficos a seguir. Alguns grupos apresentam diferenças maiores do que outros. Para cada grupo, foram feitos os comentários que se julgaram relevantes.

Procurou-se manter a mesma escala para todos os gráficos, tanto para a tensão de aderência como para o escorregamento, visando uma melhor comparação visual entre os diversos grupos.

\section{a) Grupo 1}

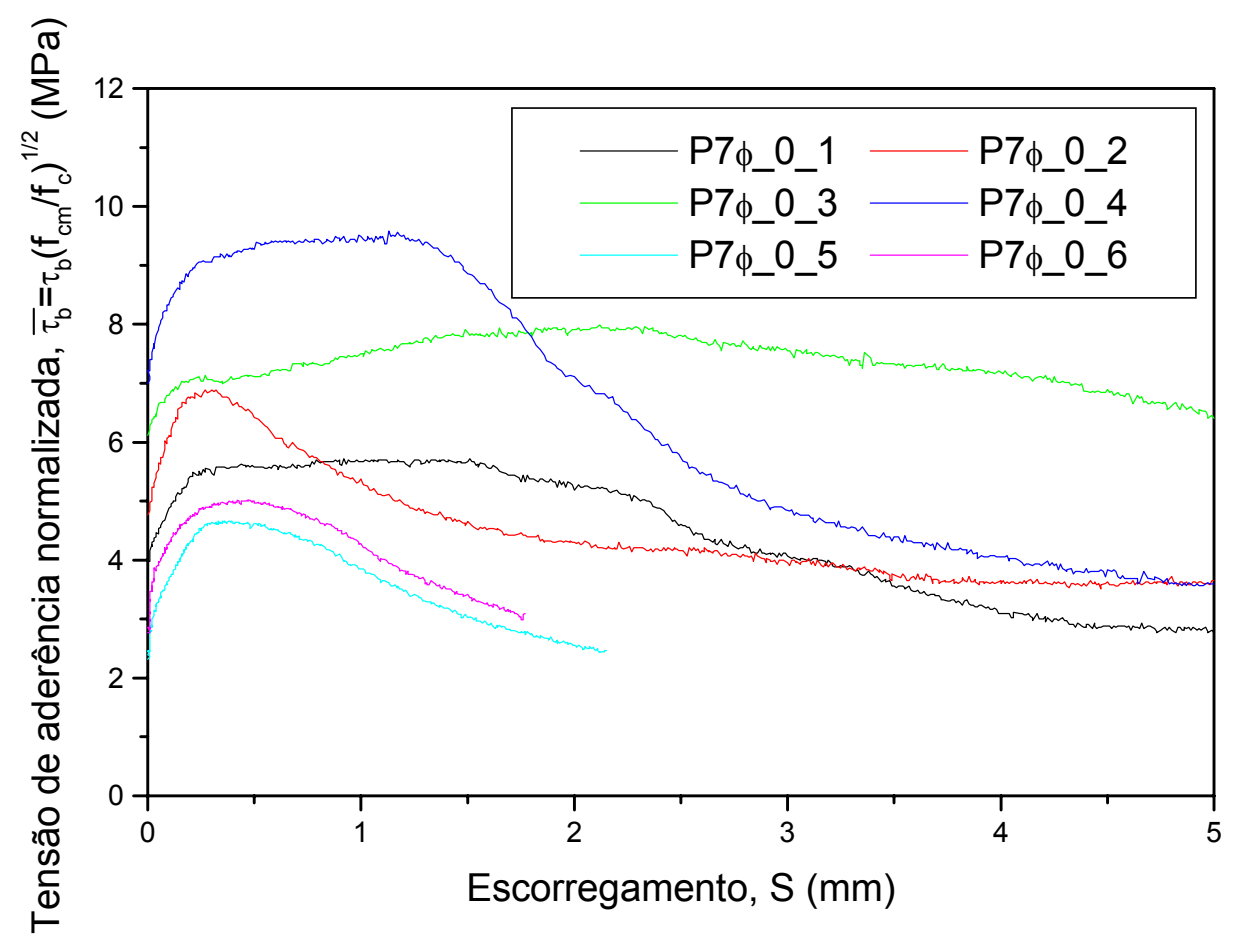

Figura 5.3 - Diagramas Tensão de aderência versus Escorregamento para os prismas do Grupo 1. 
Para este primeiro grupo, os seis modelos foram confeccionados em três concretagens distintas: os modelos 1 e 2 na concretagem C3; os modelos 3 e 4 na C5; e os modelos 5 e 6 na C7.

O primeiro prisma ensaiado, o P7ф_0_1, após ter atingido o patamar de carga constante e aumento do escorregamento, começou a fissurar longitudinalmente em uma das faces do prisma (Figura 5.4b), na altura onde havia aderência entre a cordoalha e o concreto, e depois a fissura foi aumentando até atingir a extremidade superior, que era a extremidade livre. $\mathrm{Na}$ outra face, onde apareceu fissura longitudinal, esta não chegou a atingir a extremidade livre (Figura 5.4a). Vale lembrar que para os prismas com $\ell_{\mathrm{ef}}=7 \phi_{\mathrm{p}}$, foi retirada a aderência nas duas extremidades da cordoalha (ver Figura 4.7 no Capítulo 4). A fissura transversal, ligando as duas fissuras longitudinais, apareceu quando a carga já estava caindo, e indica um estado limite último. Segundo KRSTULOVIC-OPARA et al (1994), o desenvolvimento de fissura transversal é resultado do esgotamento da capacidade da matriz de concreto de resistir às tensões de tração, ao longo da seção transversal da peça, no ponto de maior concentração de tensão na extremidade da armadura, quando esta já perdeu quase toda a aderência. A Figura 5.4 apresenta o padrão de fissuração do prisma. Este padrão de fissuração longitudinal, e transversal, foi típico para os prismas com comprimento aderente disponível de $7 \phi_{\mathrm{p}}(9 \mathrm{~cm})$, que fissuraram.

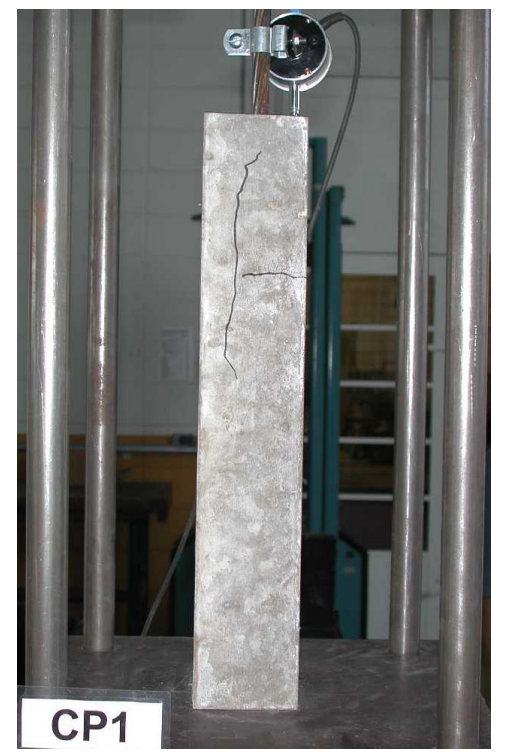

(a)

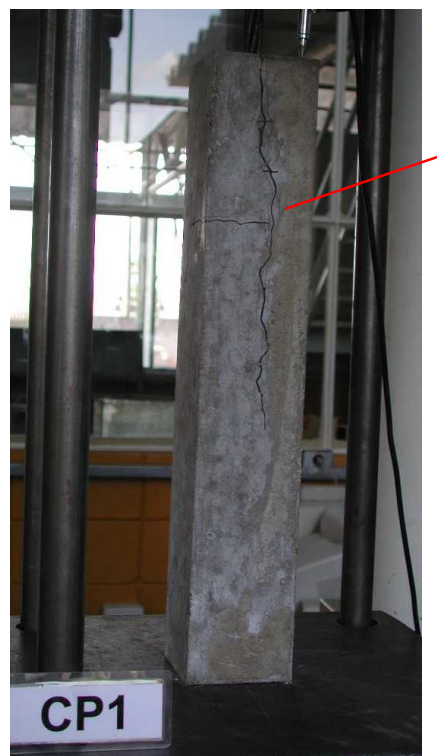

(b)

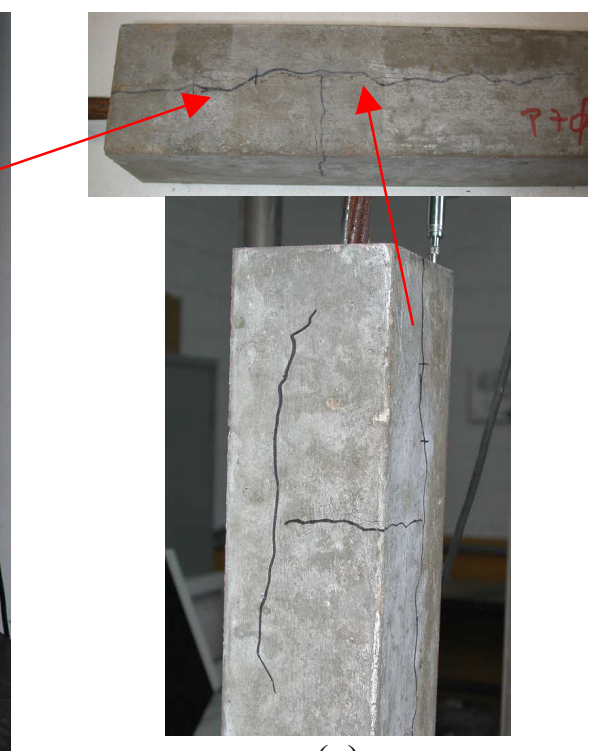

(c)

Figura 5.4 - Fissuração de P7ф_0_1.

Para este primeiro grupo, todos os prismas apresentaram fissuração longitudinal, e apenas o P7ф_0_2 não apresentou fissuração transversal. A Figura 5.5 apresenta exemplos da fissuração dos modelos. 


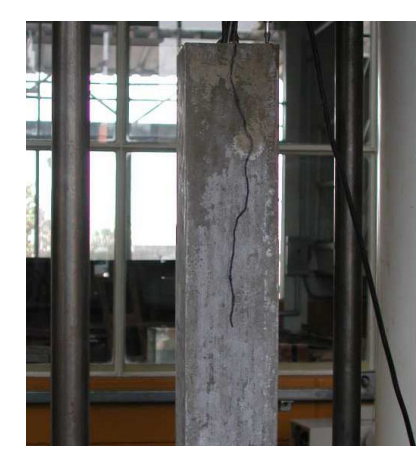

(a)

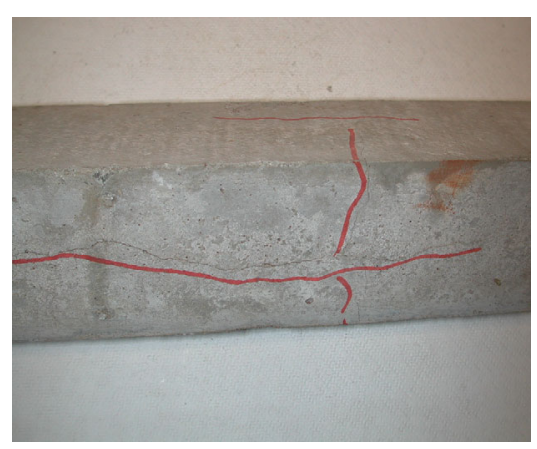

(b)

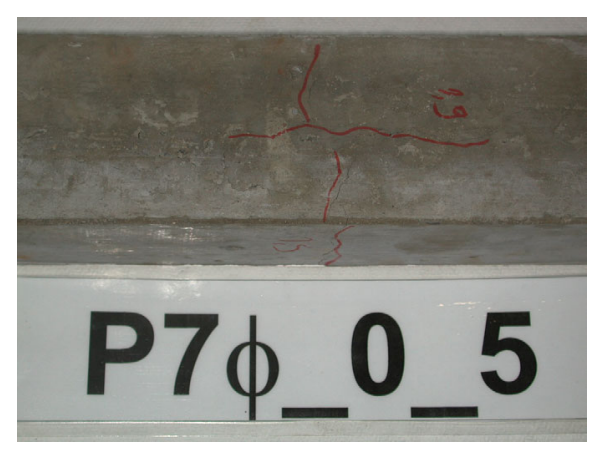

(c)

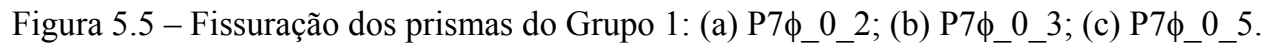

Devido a um problema na bomba do Laboratório de Estruturas (LE), que ficou parada

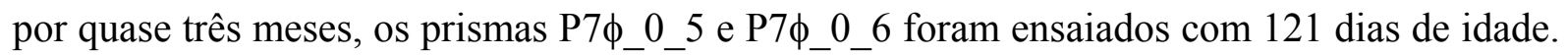
Além desses, outros modelos tiveram o mesmo problema, pois a bomba quebrou depois que já haviam sido feitas as concretagens de várias peças. Devido ao tempo excessivo de armazenamento, essas peças apresentaram uma elevada fissuração de retração, principalmente nas suas faces laterais. A Figura 5.6 apresenta um exemplo da fissuração de retração dos prismas, e a posição das faces laterais onde ela ocorreu, em relação à direção da concretagem.
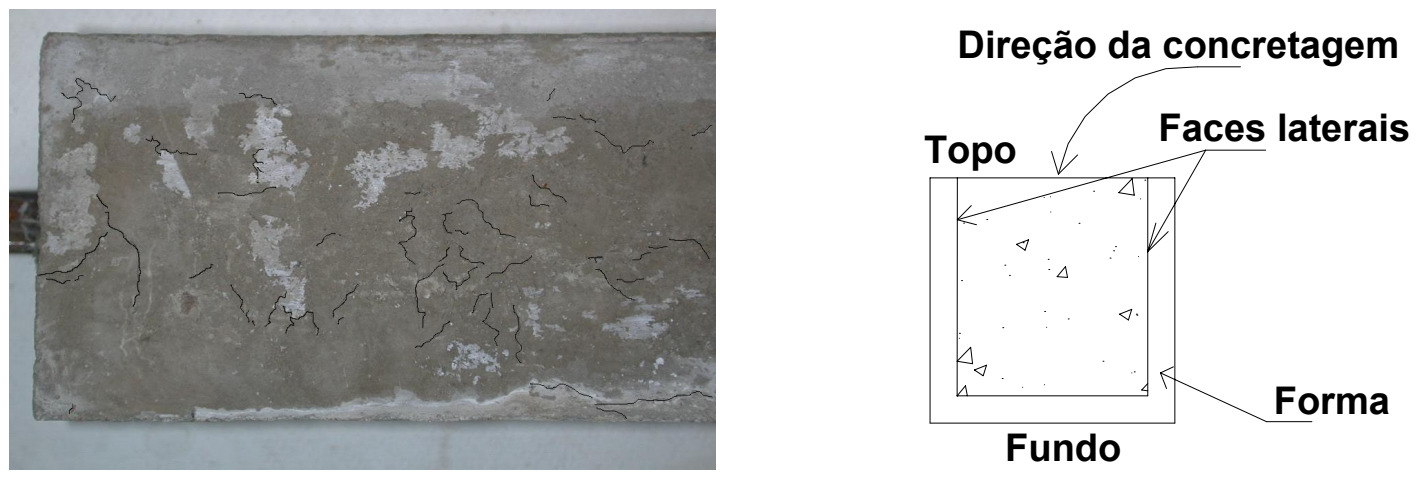

Figura 5.6 - Fissuração de retração.

Pelo gráfico da Figura 5.3, percebe-se que os prismas 5 e 6 apresentaram os menores valores para a tensão de aderência. Isso tanto pode ter sido por causa da fissuração de retração, como também, por conta da reduzida resistência à compressão do concreto, que a concretagem C7 apresentou. A resistência média foi $\mathrm{f}_{\mathrm{cm}}=39,6 \mathrm{MPa}$ para a $\mathrm{C}$, enquanto que para as outras foram $\mathrm{f}_{\mathrm{cm}}=66,2 \mathrm{MPa}$ para a $\mathrm{C} 3$ e $\mathrm{f}_{\mathrm{cm}}=72,1 \mathrm{MPa}$ para a C5. Porém, como a dispersão de valores para os ensaios de arrancamento é muito grande, as diferenças apresentadas entre os prismas podem não ter relação com os dois fatores citados. Essas considerações serão retomadas no item 5.3 deste capítulo.

De maneira geral, pode-se dizer que no que se refere à forma da curva, exceto pelo P7ф_0_3, os modelos apresentaram um comportamento Tensão de aderência versus 
Escorregamento dentro do esperado. Apesar de apresentarem fissuras de fendilhamento, o que ocorreu num estágio mais avançado do carregamento, os modelos apresentaram curvas típicas de ruptura por arrancamento, e não por fendilhamento. Para este grupo, nenhum dos modelos apresentou encruamento.

Além do gráfico Tensão de aderência versus Escorregamento, foram registrados, na forma de tabela, outros dados importantes para a caracterização do comportamento das peças em relação à aderência. São eles: tensão de aderência para a primeira físsura $\left(\tau_{\mathrm{b}, 1} \mathrm{a}_{\mathrm{a} i s s}\right)$, tensão de aderência para um escorregamento de $S=0,1 \mathrm{~mm}\left(\tau_{\mathrm{b}, 0.1}\right)$, tensão de aderência para um escorregamento de $S=1 \mathrm{~mm}\left(\tau_{\mathrm{b}, 1}\right)$, tensão de aderência para um escorregamento de $S=3 \mathrm{~mm}$ $\left(\tau_{\mathrm{b}, 3}\right)$, tensão máxima de aderência $\left(\tau_{\mathrm{b}, \text { máx }}\right)$ e escorregamento referente à tensão máxima $\left(\mathrm{S}_{\tau_{\mathrm{b}, \text { máx }}}\right)$. A tensão de aderência para a primeira fissura $\left(\tau_{\mathrm{b}, 1{ }^{\mathrm{a}} \text { fiss }}\right)$ é a tensão equivalente ao ponto onde, pela primeira vez, a curva deixa de ser linear, ou seja, é a tensão para a qual a curva começa a se afastar do eixo vertical, quando começa a haver escorregamento.

A Tabela 5.4 apresenta os dados para os modelos do Grupo 1 e as respectivas resistências do concreto à compressão na data de ensaio. Também para os resultados da Tabela 5.4, observa-se que a dispersão de valores é grande.

Tabela 5.4 - Dados característicos do comportamento aderente dos prismas do Grupo 1, Série 1.

\begin{tabular}{|c|c|c|c|c|c|c|c|c|}
\hline Modelo & $\begin{array}{l}\mathbf{f}_{\mathrm{c}, \text { ensaio }} \\
\text { (MPa) }\end{array}$ & $\begin{array}{l}\text { Idade } \\
\text { (dias) }\end{array}$ & $\begin{array}{l}\tau_{\mathbf{b}, \mathbf{1} \mathbf{a}_{\text {fiss }}} \\
\text { (MPa) }\end{array}$ & $\begin{array}{c}\tau_{\mathrm{b}, 0.1} \\
(\mathrm{MPa})\end{array}$ & $\begin{array}{c}\tau_{\mathrm{b}, 1} \\
(\mathbf{M P a})\end{array}$ & $\begin{array}{c}\tau_{\mathrm{b}, 3} \\
(\mathbf{M P a})\end{array}$ & $\begin{array}{c}\tau_{\mathrm{b}, \text { máx }} \\
(\mathrm{MPa})\end{array}$ & $\begin{array}{r}\mathbf{S}_{\tau}{ }_{\text {b,máx }} \\
(\mathrm{mm})\end{array}$ \\
\hline 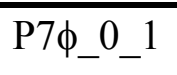 & 66,20 & 28 & 4,19 & 5,15 & 5,98 & 4,24 & 6,00 & 1,10 \\
\hline P7申_0_2 & 66,20 & 28 & 5,10 & 6,43 & 5,67 & 4,17 & 7,26 & 0,27 \\
\hline P7 & 72,10 & 23 & 6,01 & 6,58 & 7,26 & 7,31 & 7,68 & 1,90 \\
\hline P7申_0_4 & 72,10 & 23 & 6,98 & 8,06 & 9,19 & 4,70 & 9,29 & 1,13 \\
\hline P7 $\phi \_0 \_5$ & 39,60 & 121 & 4,89 & 6,46 & 6,78 & --- & 8,22 & 0,35 \\
\hline P7ф_0_6 & 39,60 & 121 & 6,02 & 7,52 & 7,55 & $\begin{array}{l}-- \\
\end{array}$ & 8,55 & 0,48 \\
\hline
\end{tabular}

A escolha desses pontos característicos foi baseada no estudo de alguns artigos sobre o tema. A tensão de aderência para a primeira fissura, a tensão máxima de aderência e o escorregamento relativo a esta última são valores padrão que caracterizam a aderência das peças. A tensão para um escorregamento de $S=0,1 \mathrm{~mm}$ é a tensão teórica de ruptura por aderência, ou seja, o ponto a partir do qual se considera, convencionalmente, que a peça perdeu a aderência. A tensão para um escorregamento de $S=3 \mathrm{~mm}$, admitido como um valor 
último, seria a tensão residual para o modelo de aderência de HARAJLI et al (1995). E, por último, a tensão para um escorregamento de $S=1 \mathrm{~mm}$ foi escolhida para ser um valor intermediário entre $\mathrm{S}=0,1 \mathrm{~mm}$ e $\mathrm{S}=3 \mathrm{~mm}$.

\section{b) Grupo 2}

Para o Grupo 2, todos os modelos foram confeccionados de uma só vez, na concretagem C9. Esses modelos foram ensaiados com 113 e 114 dias de idade, devido ao problema com a bomba do LE. Todos os seis modelos apresentaram fissuração de retração nas suas faces laterais, sendo que os modelos 4 e 5 foram os que tiveram mais fissuras.

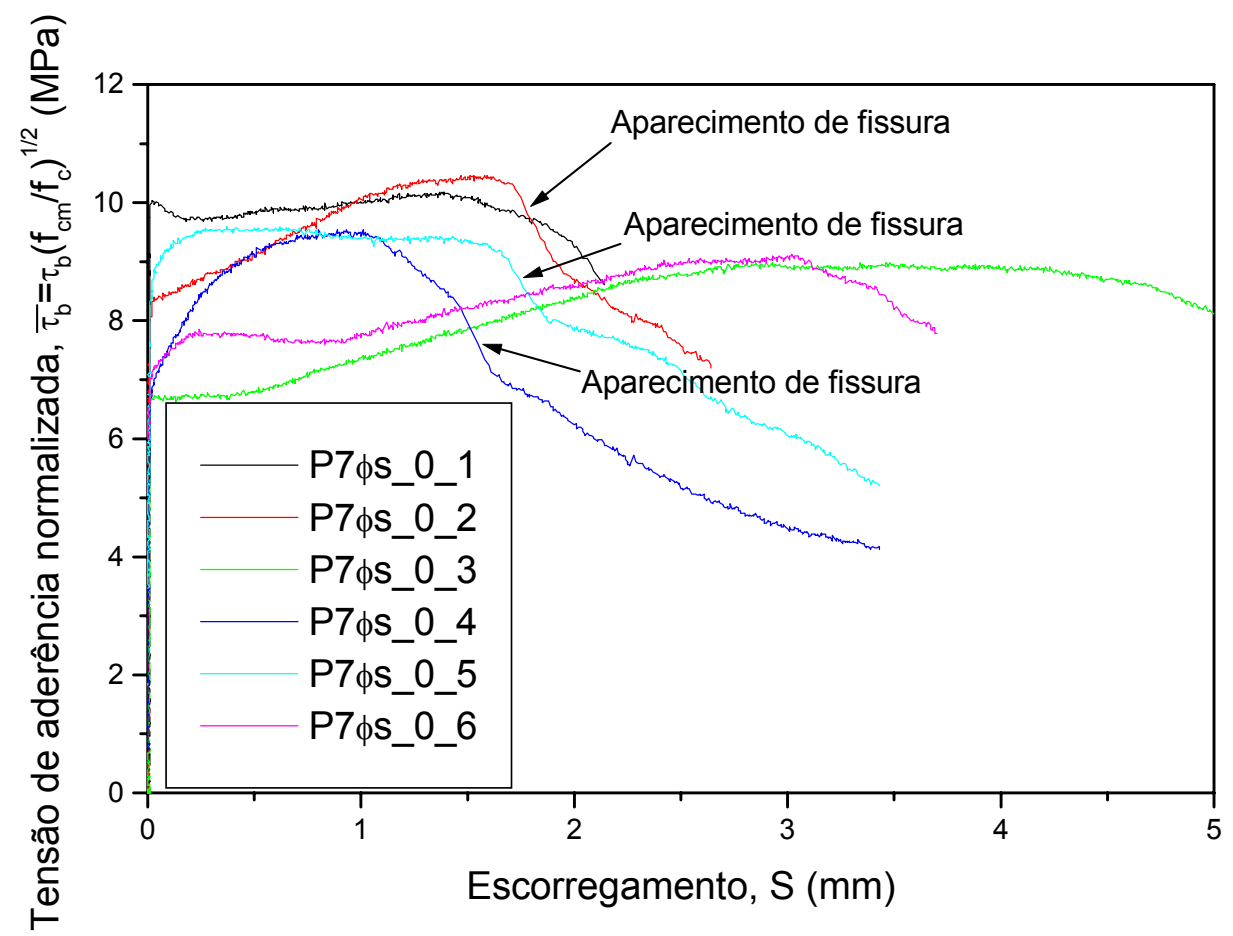

Figura 5.7 - Diagramas Tensão de aderência versus Escorregamento para os prismas do Grupo 2.

Nos ensaios, os modelos 1, 2, 3, 4 e 5 apresentaram fendilhamento longitudinal, e os modelos 1 e 4 apresentaram fissuração transversal, num estágio mais avançado de carregamento. Observa-se, no gráfico, uma queda brusca na tensão de aderência, para os modelos 2, 4 e 5, que coincide com o aparecimento das fissuras longitudinais de fendilhamento. Também, para este grupo, todas as curvas são características de ruptura por arrancamento, apesar das fissuras longitudinais. O modelo P7 $\phi$ s_0_6 apresentou encruamento. O modelo P7申s_0_3 apresentou um comportamento estranho, que não pode ser caracterizado nem como ruptura por arrancamento nem por fendilhamento. E, também, não se pode dizer que apresentou encruamento. Após o ensaio, este modelo foi cortado longitudinalmente, para 
verificar-se se havia algo diferente que justificasse o seu comportamento, mas a peça não apresentou nada de anormal. A Figura 5.8 apresenta a fissuração de alguns dos modelos.
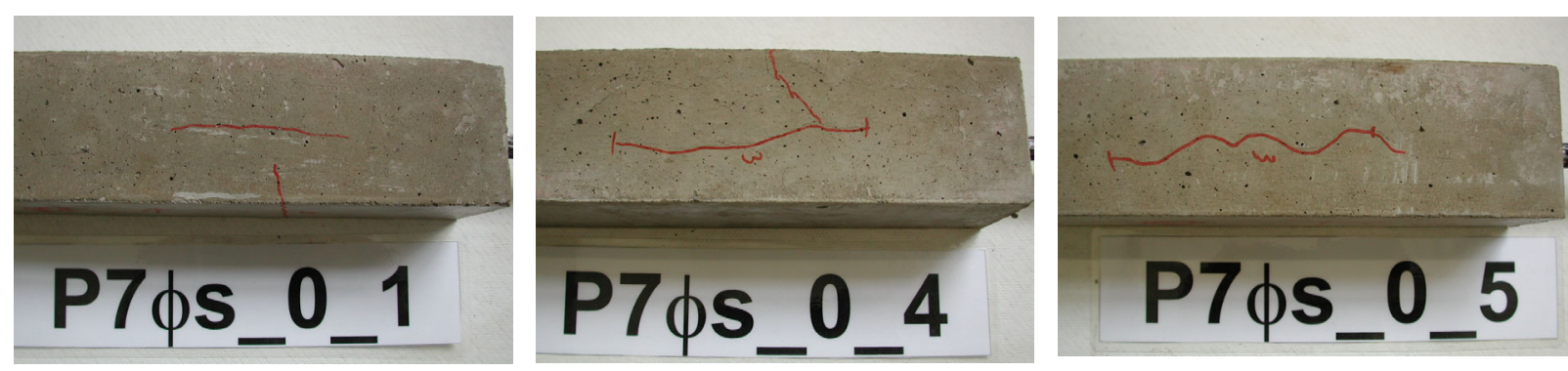

Figura 5.8 - Fissuração dos modelos do Grupo 2.

A Tabela 5.5 apresenta os dados característicos para os modelos do Grupo 2.

Percebe-se, tanto pelo gráfico como pela tabela, que há uma dispersão não desprezível dos resultados, porém, menor que a dispersão do Grupo 1. É interessante notar que o grau de dispersão dos resultados varia de um valor característico para o outro. Por exemplo, a variação dos valores da tensão máxima de aderência $\left(\tau_{b, \text { máx }}\right)$ é bem menor do que a variação dos valores do escorregamento para a tensão máxima $\left(\mathrm{S}_{\tau_{\mathrm{b}, \text { máx }}}\right)$. Vale lembrar que, neste caso, todos os prismas foram confeccionados de uma só vez, o que eliminaria as dispersões por conta da variação do compósito, e foram ensaiados praticamente na mesma data, ou seja, com a mesma idade, o que eliminaria a dispersão por conta do tempo.

Tabela 5.5 - Dados característicos do comportamento aderente dos prismas do Grupo 2, Série 1.

\begin{tabular}{|c|c|c|c|c|c|c|c|c|}
\hline Modelo & $\begin{array}{l}\mathbf{f}_{\mathrm{c}, \text { ensaio }} \\
\text { (MPa) }\end{array}$ & $\begin{array}{l}\text { Idade } \\
\text { (dias) }\end{array}$ & $\begin{array}{l}\tau_{\mathrm{b}, \mathbf{1}_{\mathrm{f}} \text { fiss }} \\
(\mathbf{M P a})\end{array}$ & $\begin{array}{c}\tau_{\mathrm{b}, 0.1} \\
(\mathbf{M P a})\end{array}$ & $\begin{array}{c}\tau_{\mathbf{b}, 1} \\
(\mathbf{M P a})\end{array}$ & $\begin{array}{c}\tau_{\mathbf{b}, 3} \\
(\mathbf{M P a})\end{array}$ & $\begin{array}{l}\tau_{\mathrm{b}, \text { máx }} \\
(\mathbf{M P a})\end{array}$ & $\begin{array}{l}\mathbf{S}_{\tau_{\mathrm{b}, \mathrm{máx}}} \\
(\mathrm{mm})\end{array}$ \\
\hline 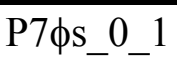 & 67,32 & 113 & 10,02 & 10,19 & 10,37 & --- & 10,55 & 1,38 \\
\hline P7 $\phi s \_0 \_2$ & 67,32 & 113 & 8,37 & 8,75 & 10,43 & --- & 10,82 & 1,53 \\
\hline P7 $\phi$ s_0_3 & 67,32 & 113 & 6,88 & 6,91 & 7,64 & 9,26 & 9,29 & 2,76 \\
\hline 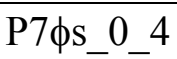 & 67,32 & 114 & 6,91 & 7,86 & 9,90 & 4,64 & 9,90 & 0,89 \\
\hline P7 $\phi s \_0 \_5$ & 67,32 & 114 & 8,26 & 9,55 & 9,75 & 6,24 & 9,95 & 0,37 \\
\hline P7申s_0_6 & 67,32 & 114 & 6,86 & 7,73 & 8,06 & 9,44 & 9,44 & 2,93 \\
\hline
\end{tabular}

\section{c) Grupo 3}

Para o Grupo 3, as peças foram confeccionadas em três concretagens distintas: modelos 1 e 2 na C4, modelos 3 e 4 na C6, e modelos 5 e 6 na C8. Estes últimos foram ensaiados com 115 dias de idade, também devido ao problema com a bomba de ensaios do LE. Porém, 


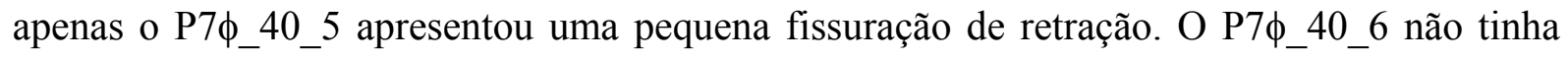
fissuras de retração, mas apresentou uma fissura transversal antes de ser ensaiado. É importante notar que, apesar da fissuração de retração do modelo 5, este apresenta um valor elevado para a tensão de aderência, próximo dos outros modelos. O modelo 6 apresenta a maior tensão de aderência para este grupo, e bem acima dos demais valores. Isso vai de encontro com a observação feita para o Grupo 1 em relação aos baixos valores da tensão de aderência para os modelos que apresentaram retração. Na realidade, segundo STOCKER \& SOZER (1970), as deformações do concreto devidas à retração levam a tensões laterais adicionais que agem sobre a armadura, na direção radial. Isso resulta em tensões de aderência maiores. Esses autores concluíram que a tensão de aderência cresce com a idade do concreto, e que isso é devido, principalmente, à retração, o que foi verificado nesta pesquisa.

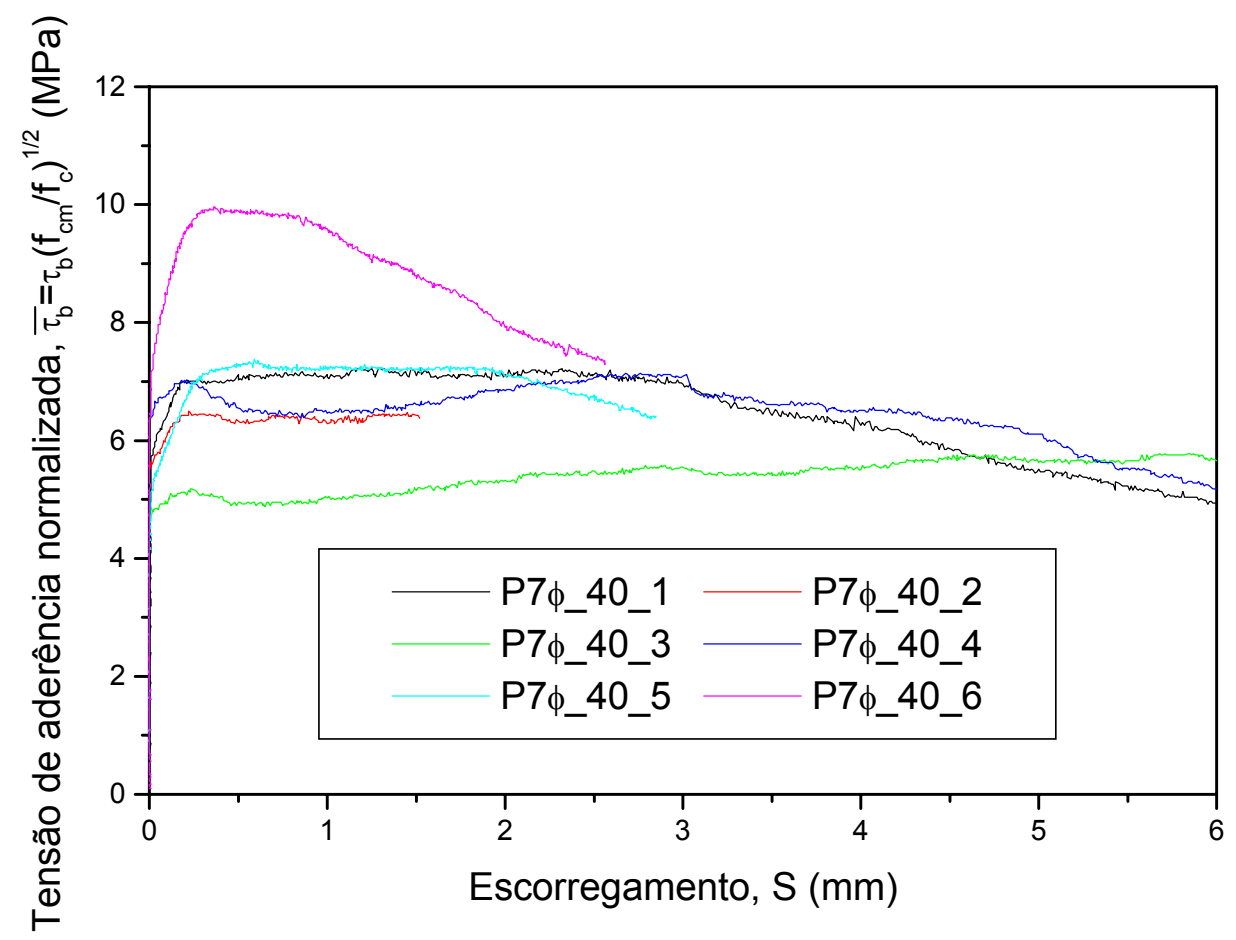

Figura 5.9 - Diagramas Tensão de aderência versus Escorregamento para os prismas do Grupo 3.

Para o modelo P7 $\phi \_40 \_1$, no ramo descendente do carregamento, o prisma fissurou nas quatro faces, e no final a peça apresentou um certo empenamento. O P7ф_40_3, aparentemente, apresentou um certo encruamento. Exceto pelo P7申_40_6, os modelos apresentaram um comportamento bem próximo um do outro, com um patamar de carga constante e aumento do escorregamento bem acentuado. Esse tipo de patamar é típico quando há confinamento da armadura. Neste caso, a presença das fibras pode ter ajudado a fornecer algum confinamento à cordoalha. Para este grupo, os modelos 1, 3, 4 e 6 apresentaram fissuras longitudinais, e os modelos 1, 3, 4 e 5 fissuras transversais. 
A Tabela 5.6 apresenta os dados característicos para os modelos do Grupo 3. Percebese, tanto pelo gráfico como pela tabela, que há uma dispersão dos resultados. Entretanto, pelo gráfico, os modelos 1, 2, 4 e 5 apresentam comportamentos bem próximos, e quando analisamos os valores característicos da tabela, percebe-se que, para o escorregamento referente à tensão máxima, a dispersão de valores é muito grande. Logo, não só a forma da curva é importante, mas, também, a análise dos pontos característicos é fundamental para que se possa ter uma noção mais exata do comportamento dos modelos. Neste caso, apesar de curvas aparentemente semelhantes, os modelos atingiram a tensão máxima de aderência para valores diferentes do escorregamento, ou seja, há diferenças significativas na aderência dos modelos.

Tabela 5.6 - Dados característicos do comportamento aderente dos prismas do Grupo 3, Série 1.

\begin{tabular}{|c|c|c|c|c|c|c|c|c|}
\hline Modelo & $\begin{array}{l}\mathbf{f}_{\mathrm{c}, \text { ensaio }} \\
\text { (MPa) }\end{array}$ & $\begin{array}{l}\text { Idade } \\
\text { (dias) }\end{array}$ & $\begin{array}{l}\tau_{b, 1} \mathbf{a}_{\text {fiss }} \\
(\mathbf{M P a})\end{array}$ & $\begin{array}{c}\tau_{\mathrm{b}, \mathbf{0 . 1}} \\
(\mathbf{M P a})\end{array}$ & $\begin{array}{c}\tau_{\mathrm{b}, 1} \\
(\mathbf{M P a})\end{array}$ & $\begin{array}{c}\tau_{\mathrm{b}, 3} \\
(\mathbf{M P a})\end{array}$ & $\begin{array}{c}\tau_{\mathrm{b}, \mathbf{m a ́ x}} \\
(\mathbf{M P a})\end{array}$ & $\begin{array}{r}\mathbf{S}_{\tau_{\mathbf{b}, \mathbf{m a ́ x}}} \\
(\mathrm{mm})\end{array}$ \\
\hline P7申_40_1 & 70,40 & 28 & 5,69 & 6,38 & 7,06 & 6,90 & 7,18 & 1,53 \\
\hline P7申_40_2 & 70,40 & 28 & 5,58 & 6,04 & 6,23 & --- & 6,45 & 0,22 \\
\hline $\mathrm{P} 7 \phi \_40 \_3$ & 78,00 & 23 & 4,21 & 4,41 & 4,52 & 4,97 & 5,15 & 4,52 \\
\hline P7申_40_4 & 78,00 & 23 & 5,72 & 6,08 & 5,78 & 6,35 & 6,39 & 2,68 \\
\hline P7 ${ }_{2} 40 \_5$ & 72,21 & 115 & 4,86 & 5,73 & 6,99 & --- & 7,14 & 0,59 \\
\hline P7 & 72,21 & 115 & 6,88 & 8,24 & 9,25 & --- & 9,60 & 0,40 \\
\hline
\end{tabular}

\section{d) Grupo 4}

Para o Grupo 4, todos os prismas foram confeccionados de uma só vez, na concretagem C8. Esses modelos foram ensaiados com 118 dias de idade, devido ao problema com a bomba do LE. Porém, apenas o P7申s_40_6 apresentou fissuração de retração, mas seu comportamento, em relação à aderência, se encontra semelhante aos demais modelos deste grupo.

Quanto à fissuração no ensaio, apenas o P7申s_40_1 apresentou fissuras longitudinais e transversais. E os modelos 2 e 4 apresentaram, apenas, fissuras longitudinais.

A Tabela 5.7 apresenta os dados característicos para os modelos do Grupo 4.

Percebe-se pelo gráfico que os prismas apresentaram um comportamento bem semelhante, onde parece ter havido o confinamento da armadura, exceto para o P7申s_40_4. Nenhum deles apresentou encruamento. Pela Tabela 5.7, nota-se que há uma certa dispersão 
de valores, principalmente no que diz respeito ao escorregamento referente à tensão máxima de aderência. Os prismas P7申s_40_5 e P7申s_40_6, devido a reutilização das fôrmas, ficaram com as extremidades inclinadas, o que os levou a ficarem meio tortos durante o ensaio. Isso, entretanto, não parece ter afetado o comportamento dos mesmos. A Figura 5.11 apresenta fotos dos modelos.

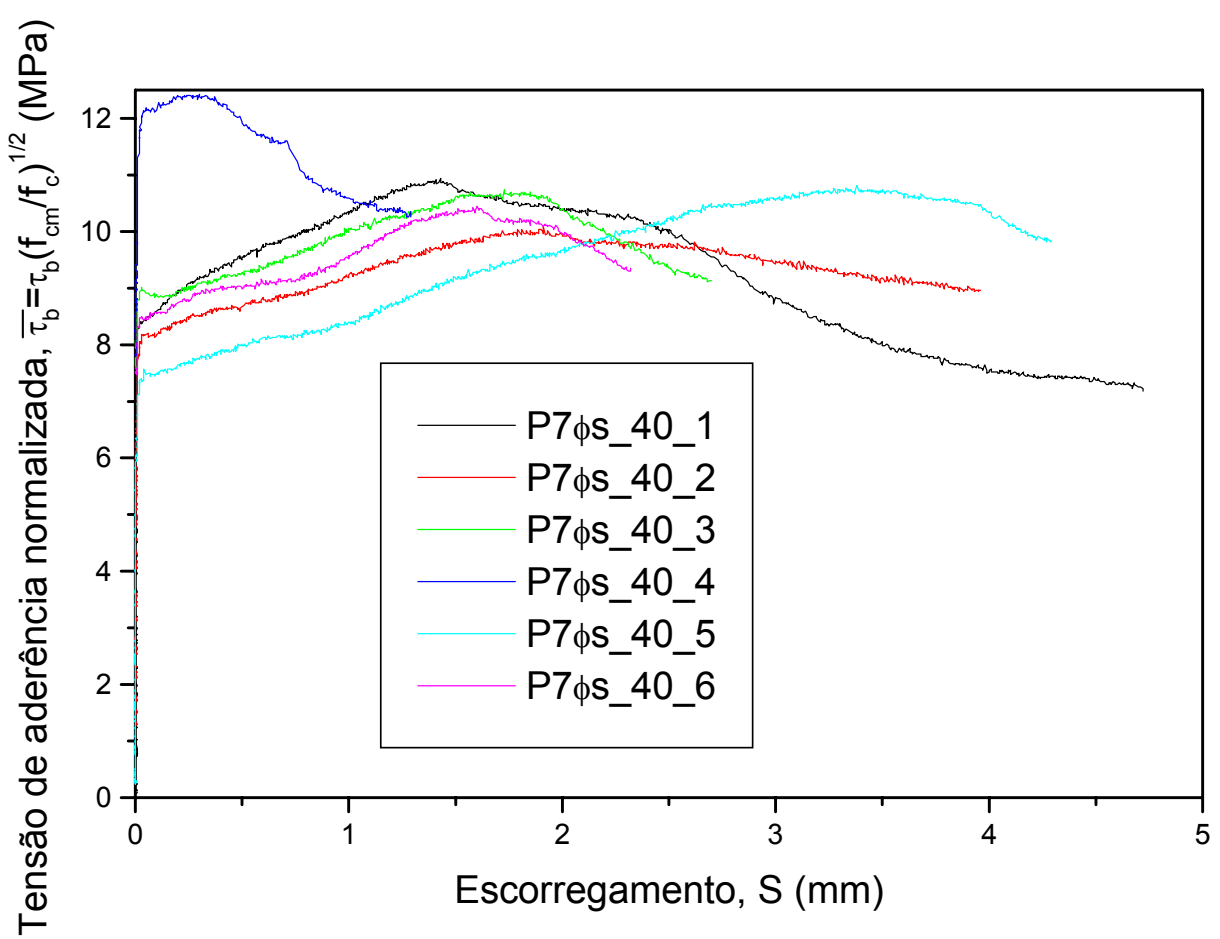

Figura 5.10 - Diagramas Tensão de aderência versus Escorregamento para os prismas do Grupo 4.

Tabela 5.7 - Dados característicos do comportamento aderente dos prismas do Grupo 4, Série 1.

\begin{tabular}{|c|c|c|c|c|c|c|c|c|}
\hline Modelo & $\begin{array}{l}\mathbf{f}_{\mathrm{c}, \text { ensaio }} \\
\text { (MPa) }\end{array}$ & $\begin{array}{l}\text { Idade } \\
\text { (dias) }\end{array}$ & $\begin{array}{l}\tau_{\mathrm{b}, \mathbf{1}^{\mathrm{a}} \text { fiss }} \\
(\mathbf{M P a})\end{array}$ & $\begin{array}{c}\tau_{\mathrm{b}, 0.1} \\
(\mathbf{M P a})\end{array}$ & $\begin{array}{c}\tau_{\mathrm{b}, 1} \\
(\mathbf{M P a})\end{array}$ & $\begin{array}{c}\tau_{b, 3} \\
(\mathbf{M P a})\end{array}$ & $\begin{array}{c}\tau_{\mathrm{b}, \text { máx }} \\
(\mathbf{M P a})\end{array}$ & $\begin{array}{r}S_{\tau_{\text {b,máx }}} \\
(\mathrm{mm})\end{array}$ \\
\hline P7 $\phi s \_40 \_1$ & 72,98 & 118 & 7,64 & 8,23 & 9,98 & 8,43 & 10,47 & 1,43 \\
\hline P7 $\phi s \_40 \_2$ & 72,98 & 118 & 7,47 & 7,80 & 8,81 & 9,06 & 9,64 & 1,91 \\
\hline P7 $\phi s \_40 \_3$ & 72,98 & 118 & 7,92 & 8,48 & 9,60 & --- & 10,28 & 1,73 \\
\hline P7 $\phi$ s_40_4 & 72,98 & 118 & 9,28 & 11,60 & 10,13 & --- & 11,86 & 0,25 \\
\hline P7 $\phi s \_40 \_5$ & 72,98 & 118 & 6,80 & 7,15 & 8,02 & 10,11 & 10,35 & 3,38 \\
\hline P7 $\phi s \_40 \_6$ & 72,98 & 118 & 7,45 & 8,17 & 9,15 & --- & 10,00 & 1,60 \\
\hline
\end{tabular}



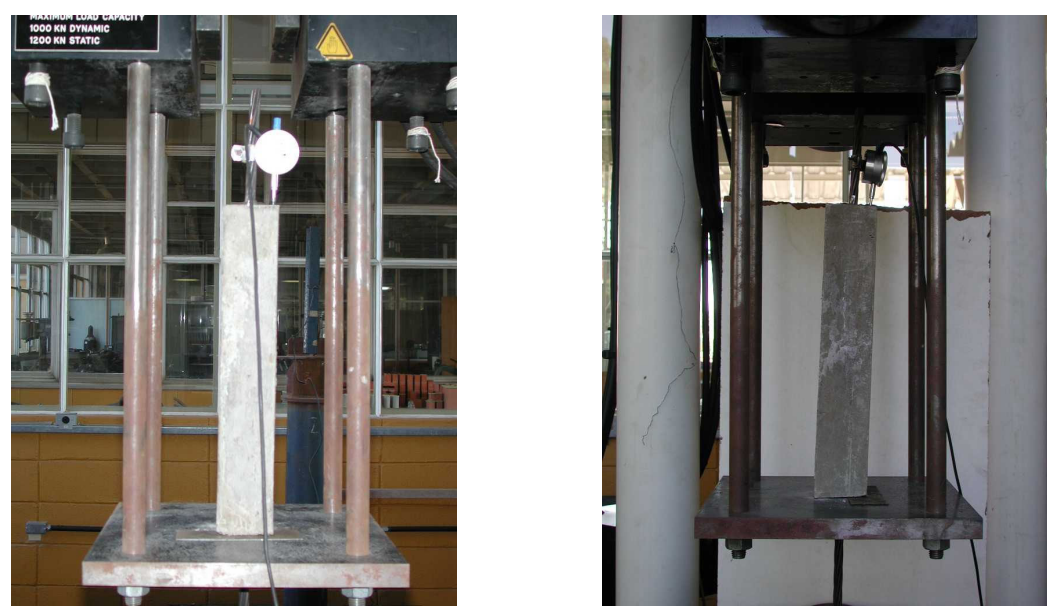

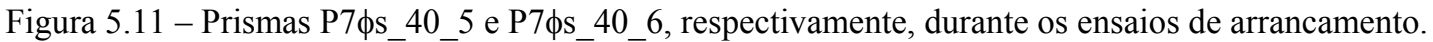

\section{e) Grupo 5}

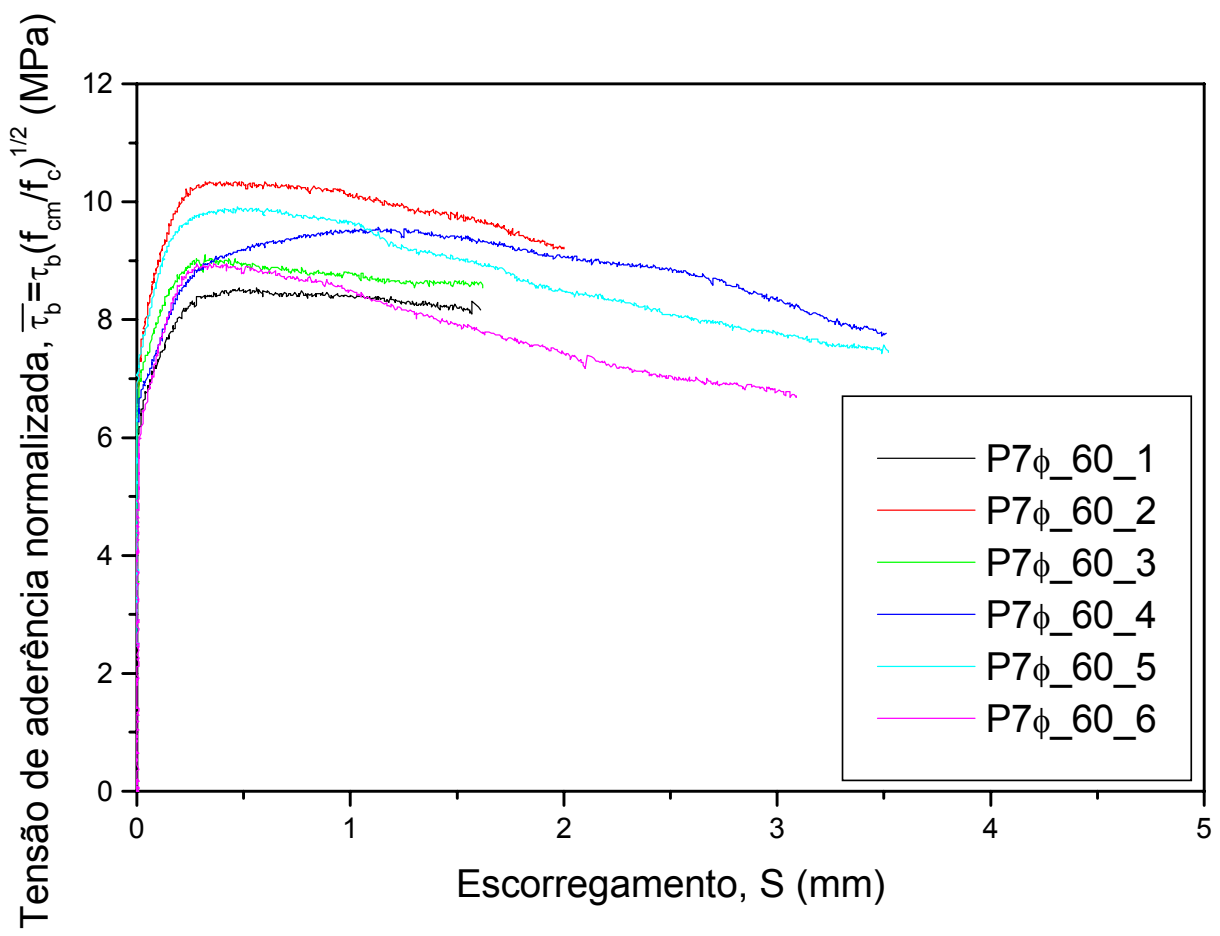

Figura 5.12 - Diagramas Tensão de aderência versus Escorregamento para os prismas do Grupo 5.

Para os prismas desse grupo, os três primeiros foram confeccionados na concretagem C10 e ensaiados com 97 dias de idade, e os três últimos na C11, e ensaiados com 86 dias de idade. Nenhum dos modelos apresentou fissuração de retração.

Os prismas 3, 4, 5 e 6 apresentaram fissuras longitudinais no ensaio. E os modelos 2, 3 e 5 apresentaram fissuras transversais. Este grupo apresentou um comportamento bem uniforme. Nenhum dos modelos apresentou encruamento.

A Tabela 5.8 apresenta os dados característicos para os modelos do Grupo 5. 
Tabela 5.8 - Dados característicos do comportamento aderente dos prismas do Grupo 5, Série 1.

\begin{tabular}{|c|c|c|c|c|c|c|c|c|}
\hline Modelo & $\begin{array}{l}\mathbf{f}_{\mathrm{c}, \text { ensaio }} \\
\text { (MPa) }\end{array}$ & $\begin{array}{l}\text { Idade } \\
\text { (dias) }\end{array}$ & $\begin{array}{l}\tau_{\mathrm{b}, \mathbf{1}_{\mathrm{a}} \text { fiss }} \\
(\mathbf{M P a})\end{array}$ & $\begin{array}{c}\tau_{\mathrm{b}, 0.1} \\
(\mathbf{M P a})\end{array}$ & $\begin{array}{c}\tau_{\mathbf{b}, 1} \\
(\mathbf{M P a})\end{array}$ & $\begin{array}{c}\tau_{\mathbf{b}, 3} \\
(\mathbf{M P a})\end{array}$ & $\begin{array}{c}\tau_{b, \text { máx }} \\
(\mathbf{M P a})\end{array}$ & $\begin{array}{r}\mathbf{S}_{\tau_{\text {b,máx }}} \\
(\mathbf{m m})\end{array}$ \\
\hline P7ф_60_1 & 74,94 & 97 & 5,76 & 6,80 & 7,81 & --- & 7,95 & 0,56 \\
\hline P7申_60_2 & 74,94 & 97 & 6,78 & 8,29 & 9,45 & --- & 9,64 & 0,32 \\
\hline P7 $\phi \_60 \_3$ & 74,94 & 97 & 6,20 & 7,40 & 8,18 & --- & 8,48 & 0,32 \\
\hline P7ф_60_4 & 74,43 & 86 & 5,97 & 7,03 & 8,89 & 7,86 & 8,93 & 0,98 \\
\hline P7申_60_5 & 74,43 & 86 & 6,82 & 8,19 & 9,06 & 7,31 & 9,27 & 0,45 \\
\hline P7 & 74,43 & 86 & 5,60 & 6,97 & 7,79 & 6,36 & 8,40 & 0,36 \\
\hline
\end{tabular}

f) Grupo 6

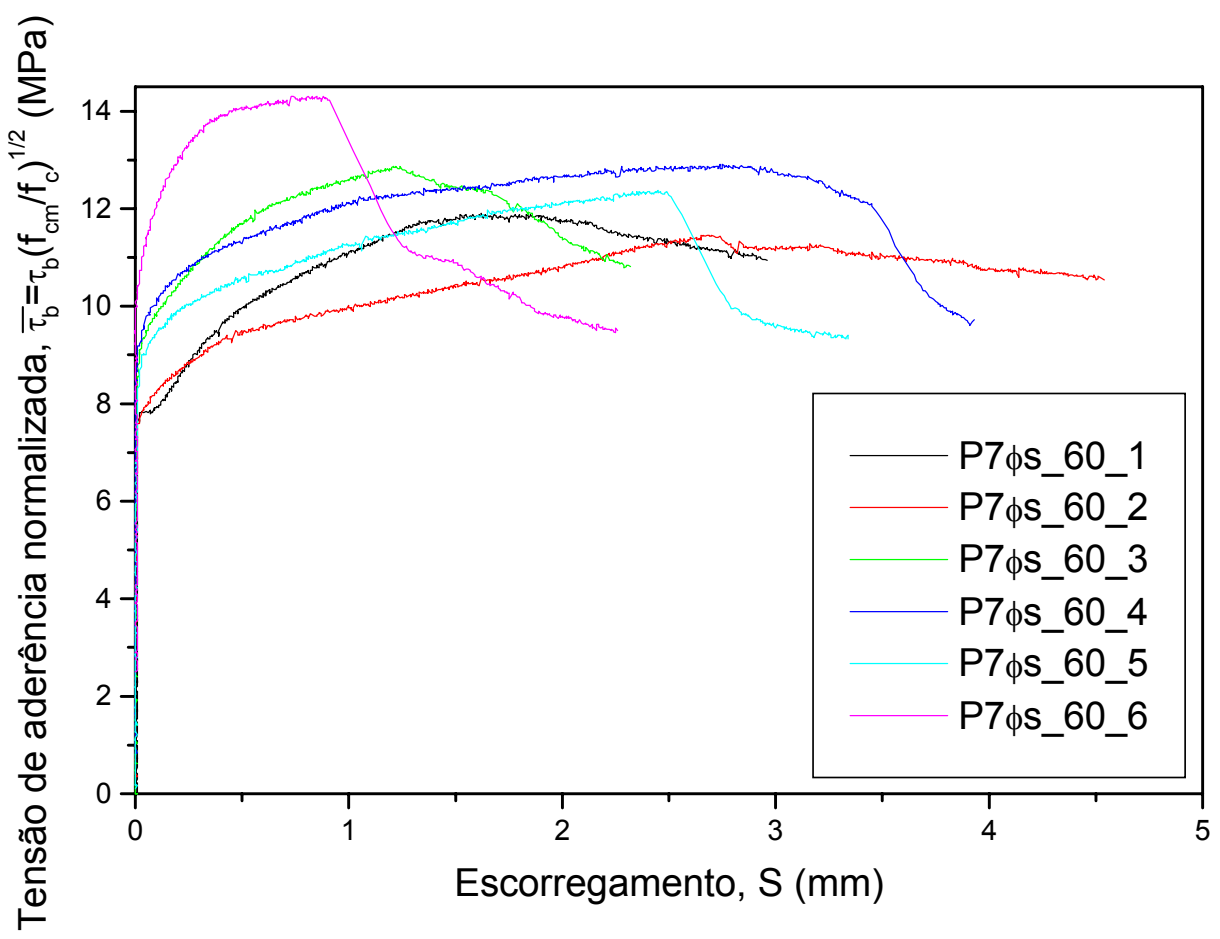

Figura 5.13 - Diagramas Tensão de aderência versus Escorregamento para os prismas do Grupo 6.

Para o Grupo 6, todos os prismas foram confeccionados na concretagem $\mathrm{C} 10$, e ensaiados aos 98 dias de idade. Nenhum dos modelos apresentou fissuração de retração.

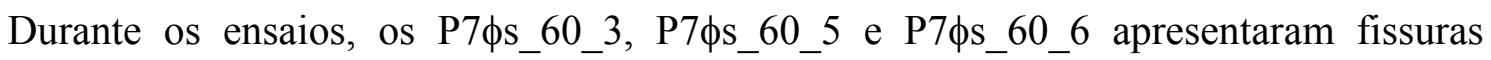
longitudinais, que coincidiram com a queda brusca da carga no gráfico, e apenas o P7申s_60_3 apresentou fissura transversal. Apesar do P7фs_60_4 não apresentar fissura longitudinal visível, a sua curva indica que deve ter ocorrido fendilhamento interno. 
Os prismas apresentaram comportamento semelhante, porém com variação dos valores característicos. A Tabela 5.9 apresenta os dados característicos para os modelos do Grupo 6.

Tabela 5.9 - Dados característicos do comportamento aderente dos prismas do Grupo 6, Série 1.

\begin{tabular}{|c|c|c|c|c|c|c|c|c|}
\hline Modelo & $\begin{array}{l}\mathbf{f}_{\mathrm{c}, \text { ensaio }} \\
\text { (MPa) }\end{array}$ & $\begin{array}{l}\text { Idade } \\
\text { (dias) }\end{array}$ & $\begin{array}{l}\tau_{\mathrm{b}, \mathbf{1}^{\mathrm{a}} \text { fiss }} \\
(\mathbf{M P a})\end{array}$ & $\begin{array}{c}\tau_{\mathbf{b}, 0.1} \\
(\mathbf{M P a})\end{array}$ & $\begin{array}{c}\tau_{\mathrm{b}, 1} \\
(\mathbf{M P a})\end{array}$ & $\begin{array}{c}\tau_{\mathbf{b}, 3} \\
(\mathbf{M P a})\end{array}$ & $\begin{array}{c}\tau_{\mathrm{b}, \text { máx }} \\
(\mathbf{M P a})\end{array}$ & $\begin{array}{r}\mathbf{S}_{\tau_{\mathrm{b}, \mathrm{máx}}} \\
(\mathrm{mm})\end{array}$ \\
\hline P7申s_60_1 & 74,94 & 98 & 7,05 & 7,40 & 10,35 & 10,19 & 11,09 & 1,62 \\
\hline P7 $\phi s \_60 \_2$ & 74,94 & 98 & 7,03 & 7,70 & 9,28 & 10,42 & 10,67 & 2,69 \\
\hline P7 $\phi s \_60 \_3$ & 74,94 & 98 & 7,95 & 9,20 & 11,76 & - & 11,99 & 1,22 \\
\hline P7申s_60_4 & 74,94 & 98 & 8,04 & 9,47 & 11,28 & 11,83 & 12,01 & 2,78 \\
\hline P7申s_60_5 & 74,94 & 98 & 7,07 & 8,80 & 10,48 & 8,94 & 11,51 & 2,49 \\
\hline P7申s_60_6 & 74,94 & 98 & 9,41 & 11,39 & 12,29 & --- & 13,52 & 0,74 \\
\hline
\end{tabular}

\section{g) Grupo 7}

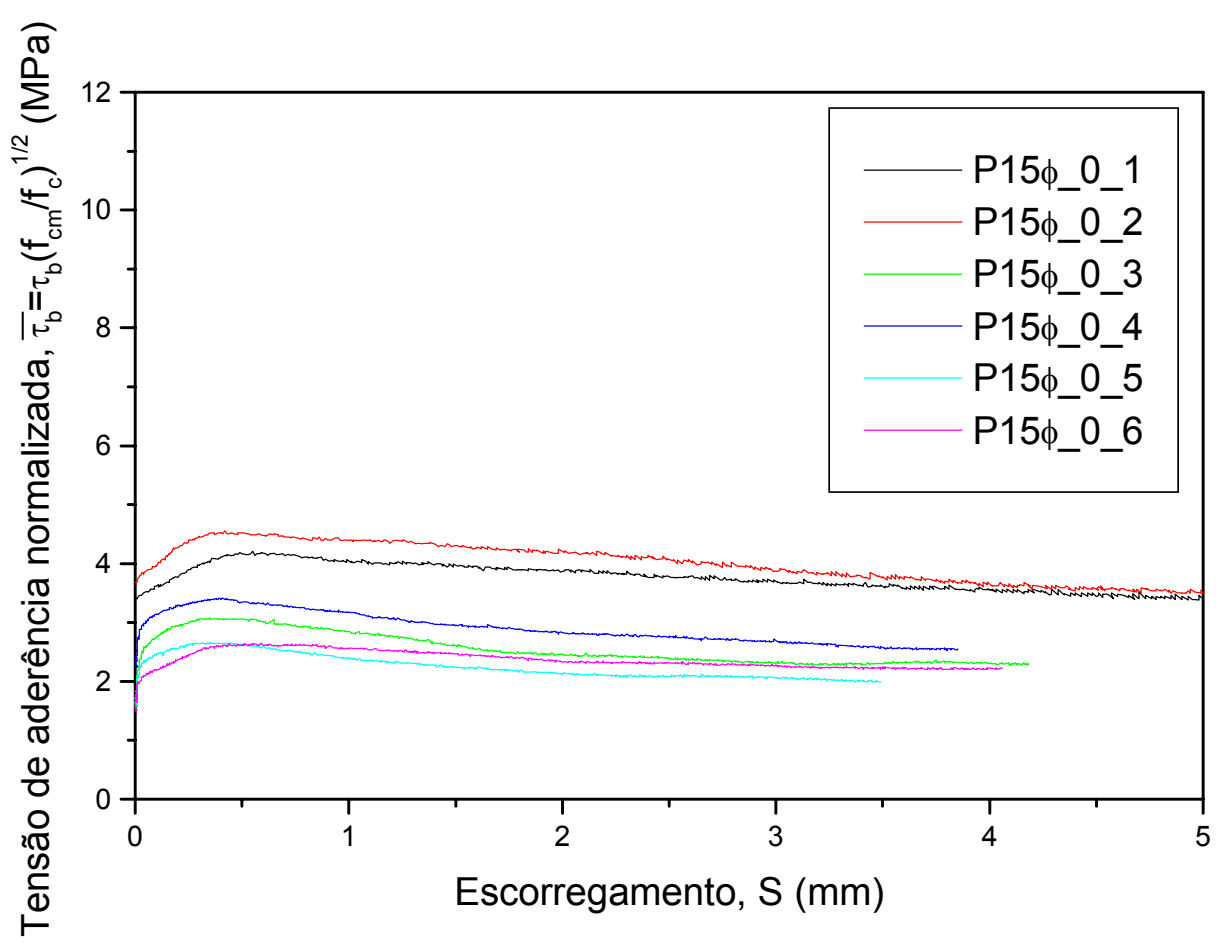

Figura 5.14 - Diagramas Tensão de aderência versus Escorregamento para os prismas do Grupo 7.

Para o Grupo 7, os prismas foram confeccionados em três concretagens diferentes: o

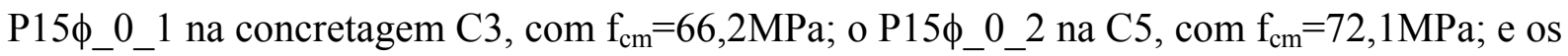

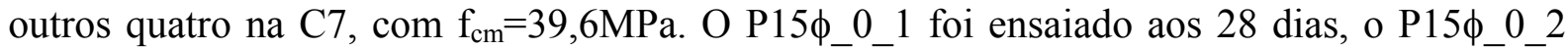
aos 23 dias, e o restante aos 121 dias. Estes últimos quatro apresentaram elevada fissuração de retração, principalmente os modelos 3 e 4. O P15ф_0_5 apresentou uma fissura longitudinal 
antes do início do ensaio (fissura marcada em preto na Figura 5.15), o que pode ter sido causada por uma queda do modelo, enquanto ele estava armazenado. Isso, porém, é apenas uma suposição.

Durante os ensaios, todos os modelos apresentaram fissuras longitudinais, e nenhum deles apresentou fissura transversal. O P15ф_0_2 fissurou todo desde o início do ensaio, e não quando a peça já se encontrava num estágio de carga mais avançado. A Figura 5.15 apresenta o padrão de fissuração para os prismas com comprimento aderente de ensaio de $\ell_{\mathrm{ef}}=15 \phi_{\mathrm{p}}$.

Apesar de todos os contratempos, os prismas apresentaram comportamentos semelhantes, com pequena variação dos valores característicos. Nenhum dos modelos apresentou encruamento. A Tabela 5.10 apresenta os dados característicos para os modelos do Grupo 7.
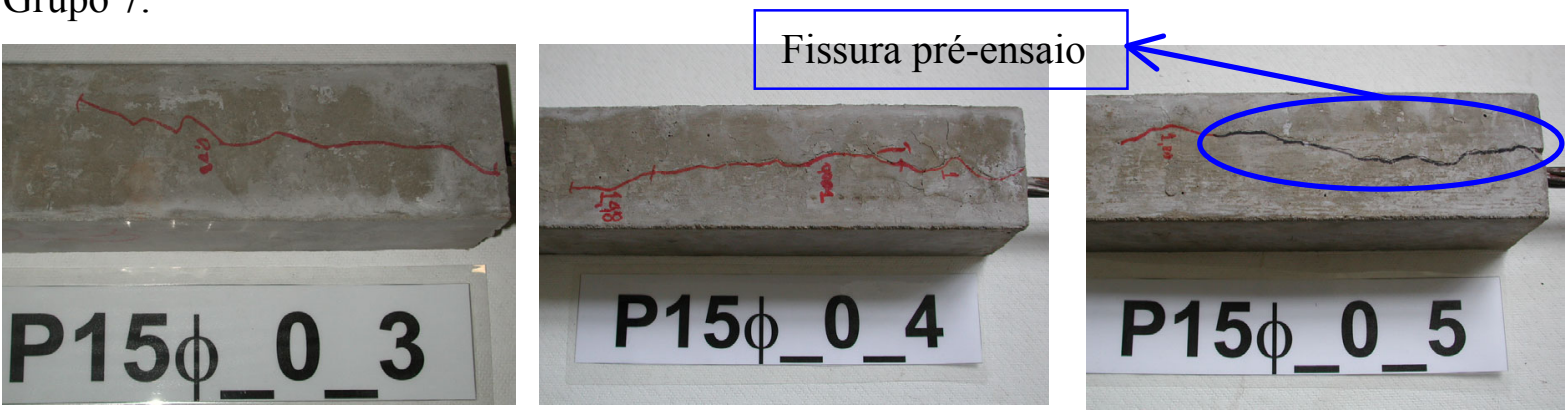

Figura 5.15 - Fissuração dos prismas do Grupo 7.

Tabela 5.10 - Dados característicos do comportamento aderente dos prismas do Grupo 7, Série 1.

\begin{tabular}{|c|c|c|c|c|c|c|c|c|}
\hline Modelo & $\begin{array}{l}\mathbf{f}_{\mathrm{c}, \text { ensaio }} \\
\text { (MPa) }\end{array}$ & $\begin{array}{l}\text { Idade } \\
\text { (dias) }\end{array}$ & $\begin{array}{l}\tau_{\mathbf{b}, \mathbf{1}} \mathbf{a}_{\text {fiss }} \\
(\mathbf{M P a})\end{array}$ & $\begin{array}{c}\tau_{\mathrm{b}, 0.1} \\
(\mathbf{M P a})\end{array}$ & $\begin{array}{c}\tau_{\mathrm{b}, \mathbf{1}} \\
(\mathbf{M P a})\end{array}$ & $\begin{array}{c}\tau_{\mathrm{b}, 3} \\
(\mathbf{M P a})\end{array}$ & $\begin{array}{c}\tau_{\text {b,máx }} \\
(\mathbf{M P a})\end{array}$ & $\begin{array}{r}S_{\tau_{\text {b,máx }}} \\
(\mathrm{mm})\end{array}$ \\
\hline P15ф_0_1 & 66,20 & 28 & 3,59 & 3,82 & 4,27 & 3,91 & 4,44 & 0,55 \\
\hline P15ф_0_2 & 72,10 & 23 & 3,58 & 3,84 & 4,26 & 3,75 & 4,41 & 0,42 \\
\hline P15ф_0_3 & 39,60 & 121 & 3,45 & 4,86 & 5,01 & 4,12 & 5,42 & 0,34 \\
\hline P15ф_0_4 & 39,60 & 121 & 4,34 & 5,54 & 5,60 & 4,75 & 6,02 & 0,41 \\
\hline P15ф_0_5 & 67,32 & 114 & 3,68 & 4,34 & 4,21 & 3,63 & 4,68 & 0,32 \\
\hline P15ф_0_6 & 67,32 & 114 & 3,45 & 3,87 & 4,53 & 4,00 & 4,68 & 0,59 \\
\hline
\end{tabular}

\section{h) Grupo 8}

Para este grupo, os prismas foram confeccionados em quatro concretagens distintas: o

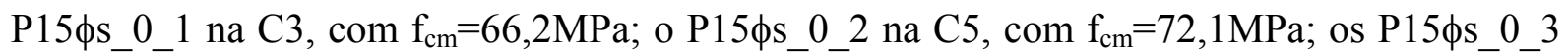

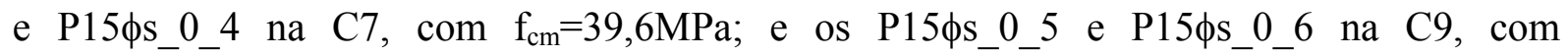




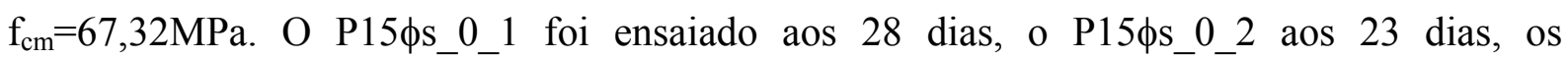

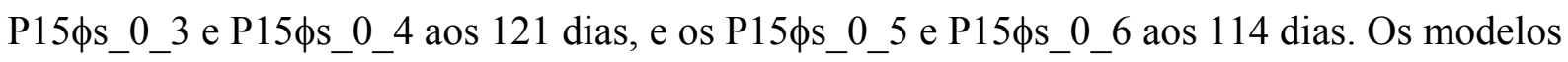
3 e 4 apresentaram elevada fissuras de retração. O modelo 5 apresentou alguma fissuração de retração, enquanto que o modelo 6 apresentou uma retração muita pequena. Vale lembrar que apenas as faces laterais dos modelos apresentaram esse padrão de fissuras de retração.

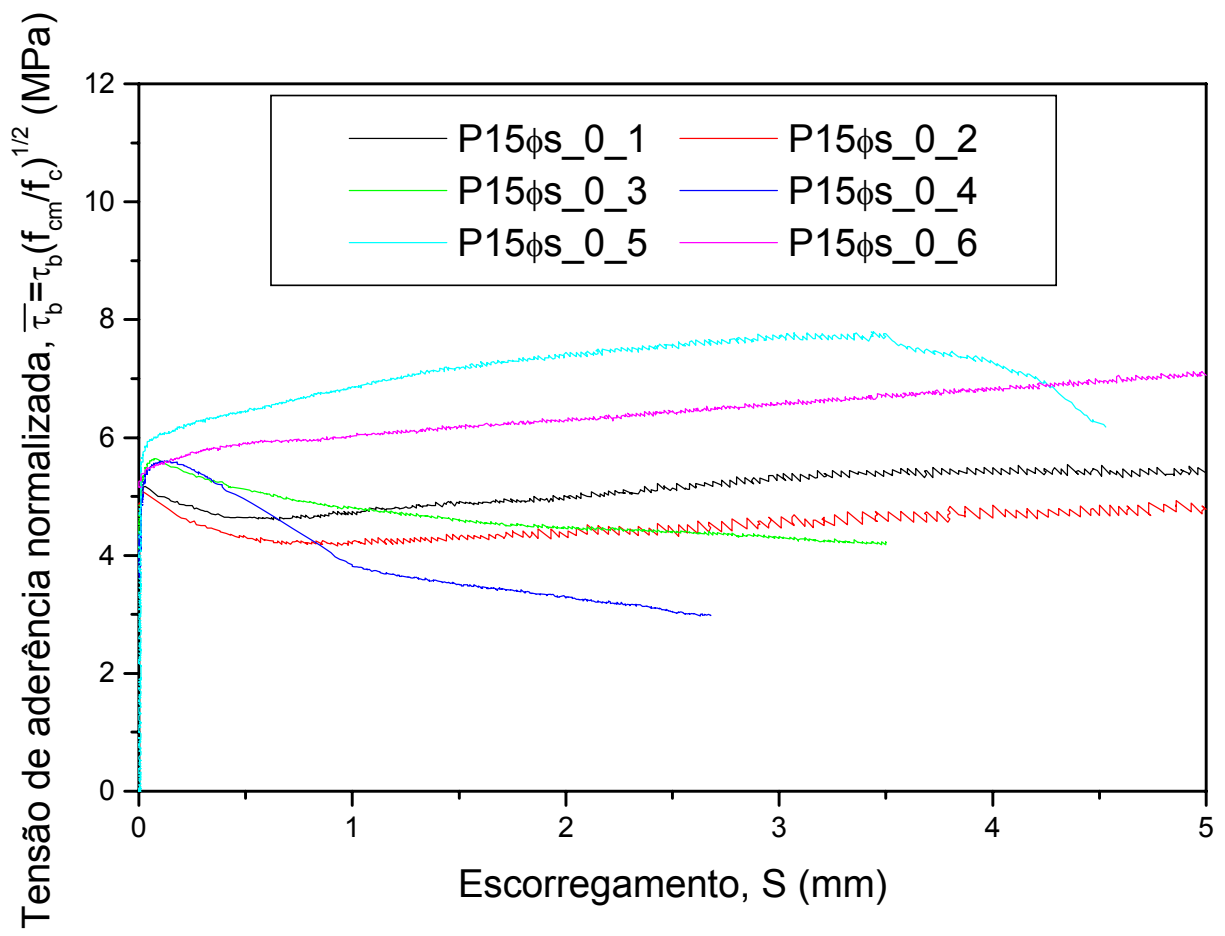

Figura 5.16 - Diagramas Tensão de aderência versus Escorregamento para os prismas do Grupo 8.

Os prismas 2, 4 e 5 apresentaram fissuras longitudinais durante os ensaios de arrancamento. Nenhum dos prismas apresentou fissura transversal.

Pelo gráfico, nota-se que houve uma grande dispersão dos resultados, principalmente no que diz respeito ao comportamento em relação à aderência dos modelos deste grupo. Apenas os prismas 1 e 2 apresentam comportamento semelhante, e também, encruamento. $\mathrm{O}$

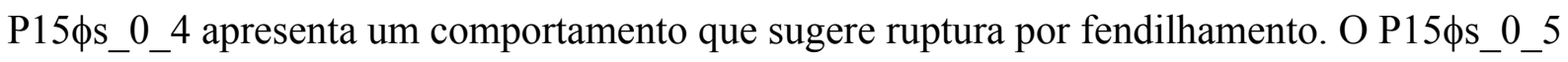
apresenta um comportamento de confinamento, com grande ductilidade, representada pelo crescimento da tensão de aderência até um valor elevado do escorregamento. O P15 $\phi$ s_0_3 apresenta um comportamento intermediário entre os comportamentos de 1 e 2 e de 4 . E, por último, o P15 $\phi$ s_0_6 apresenta um comportamento próximo ao do modelo 5, porém, sem a tendência de queda da tensão.

A Tabela 5.11 apresenta os dados característicos para os modelos do Grupo 8. É importante notar que o modelo 6 apresentava crescimento de carga quando o ensaio foi interrompido, o que significa que os valores de tensão máxima de aderência e de 
escorregamento para a tensão máxima seriam maiores do que os listados na Tabela 5.11. A dispersão de valores para este grupo foi bem elevada.

Tabela 5.11 - Dados característicos do comportamento aderente dos prismas do Grupo 8, Série 1.

\begin{tabular}{|c|c|c|c|c|c|c|c|c|}
\hline Modelo & $\begin{array}{l}\mathbf{f}_{\mathrm{c}, \text { ensaio }} \\
\text { (MPa) }\end{array}$ & $\begin{array}{l}\text { Idade } \\
\text { (dias) }\end{array}$ & $\begin{array}{l}\tau_{\mathrm{b}, 1 \mathbf{1}_{\text {fiss }}} \\
(\mathbf{M P a})\end{array}$ & $\begin{array}{c}\tau_{\mathrm{b}, \mathbf{0 . 1}} \\
(\mathbf{M P a})\end{array}$ & $\begin{array}{c}\tau_{\mathrm{b}, 1} \\
(\mathbf{M P a})\end{array}$ & $\begin{array}{c}\tau_{\mathrm{b}, 3} \\
(\mathbf{M P a})\end{array}$ & $\begin{array}{c}\tau_{\mathrm{b}, \mathrm{máx}} \\
(\mathbf{M P a})\end{array}$ & $\begin{array}{r}S_{\tau_{\text {b,máx }}} \\
(\mathrm{mm})\end{array}$ \\
\hline P15 ss_0_1 & 66,20 & 28 & 4,94 & 5,28 & 5,01 & 5,67 & 5,98 & 6,80 \\
\hline P15 & 72,10 & 23 & 4,86 & 4,77 & 4,09 & 4,42 & 4,90 & 0,03 \\
\hline 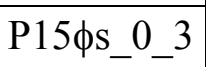 & 39,60 & 121 & 8,52 & 9,88 & 8,51 & 7,61 & 9,94 & 0,08 \\
\hline P15 & 39,60 & 121 & 7,82 & 9,85 & 6,73 & --- & 9,88 & 0,12 \\
\hline P15 & 67,32 & 114 & 5,56 & 5,26 & 7,12 & 8,03 & 8,09 & 3,44 \\
\hline 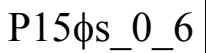 & 67,32 & 114 & 5,47 & 5,75 & 6,24 & 6,82 & 7,39 & 5,03 \\
\hline
\end{tabular}

\section{i) Grupo 9}

Para o Grupo 9, os prismas foram confeccionados em três concretagens diferentes: o

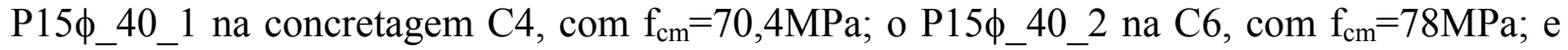
os outros quatro na $\mathrm{C} 8$, com $\mathrm{f}_{\mathrm{cm}}=72,21 \mathrm{MPa}$. O P15ф_40_1 foi ensaiado aos 28 dias, o P15ф_40_2 aos 23 dias, e o restante aos 115 dias. Nenhuma das peças apresentou fissuras de retração.

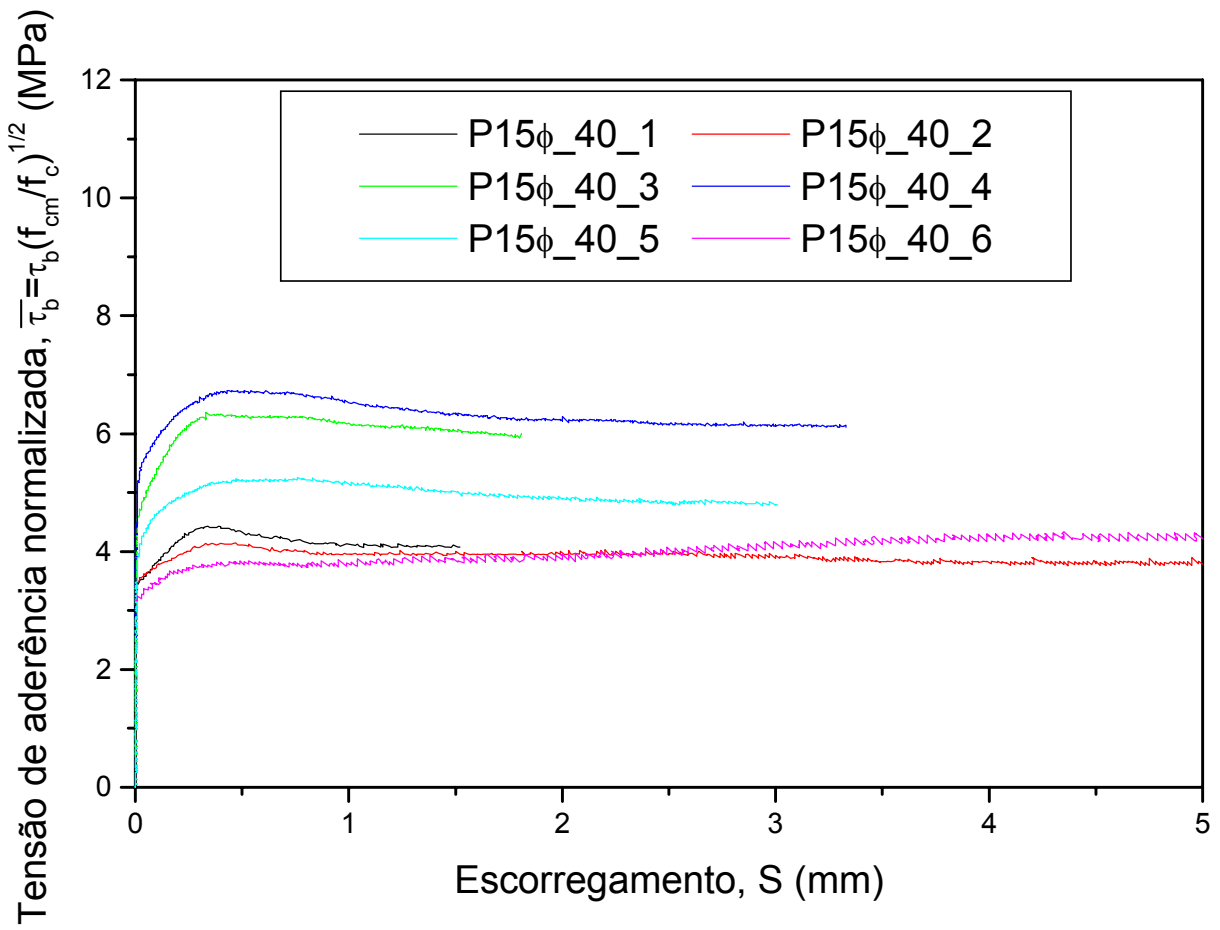

Figura 5.17 - Diagramas Tensão de aderência versus Escorregamento para os prismas do Grupo 9. 
Durante os ensaios, os prismas 3, 4, 5 e 6 fissuraram longitudinalmente, e os prismas 4 e 5 fissuraram transversalmente. Pelo gráfico, pode-se dizer que os modelos apresentaram comportamentos aderentes semelhantes, mas com dispersão de valores, principalmente no que diz respeito às tensões máximas de aderência.

A Tabela 5.12 apresenta os dados característicos para os modelos do Grupo 9.

Vale lembrar que, o modelo 6 apresentava crescimento de carga quando o ensaio foi interrompido.

Tabela 5.12 - Dados característicos do comportamento aderente dos prismas do Grupo 9, Série 1.

\begin{tabular}{|c|c|c|c|c|c|c|c|c|}
\hline Modelo & $\begin{array}{l}\mathbf{f}_{\mathrm{c}, \text { ensaio }} \\
\text { (MPa) }\end{array}$ & $\begin{array}{l}\text { Idade } \\
\text { (dias) }\end{array}$ & $\begin{array}{l}\tau_{\mathrm{b}, 1 \mathbf{1}^{\mathbf{a}} \text { iss }} \\
\text { (MPa) }\end{array}$ & $\begin{array}{c}\tau_{\mathrm{b}, 0.1} \\
(\mathbf{M P a})\end{array}$ & $\begin{array}{c}\tau_{b, 1} \\
(\mathbf{M P a})\end{array}$ & $\begin{array}{c}\tau_{\mathrm{b}, 3} \\
(\mathbf{M P a})\end{array}$ & $\begin{array}{c}\tau_{\mathrm{b}, \text { máx }} \\
(\mathbf{M P a})\end{array}$ & $\begin{array}{r}\mathbf{S}_{\tau}{ }_{\text {b,máx }} \\
(\mathrm{mm})\end{array}$ \\
\hline P15ф_40_1 & 70,40 & 28 & 3,48 & 3,77 & 4,09 & -- & 4,39 & 0,34 \\
\hline P15ф_40_2 & 78,00 & 23 & 3,08 & 3,34 & 3,55 & 3,53 & 3,70 & 0,36 \\
\hline P15ф_40_3 & 72,21 & 115 & 4,43 & 5,17 & 5,97 & -- & 6,15 & 0,33 \\
\hline P15ф_40_4 & 72,21 & 115 & 4,91 & 5,70 & 6,33 & 5,93 & 6,51 & 0,44 \\
\hline P15ф_40_5 & 72,21 & 115 & 3,63 & 4,46 & 5,00 & 4,64 & 5,09 & 0,74 \\
\hline P15ф_40_6 & 72,21 & 115 & 3,13 & 3,36 & 3,69 & 4,02 & 4,20 & 5,09 \\
\hline
\end{tabular}

\section{j) Grupo 10}

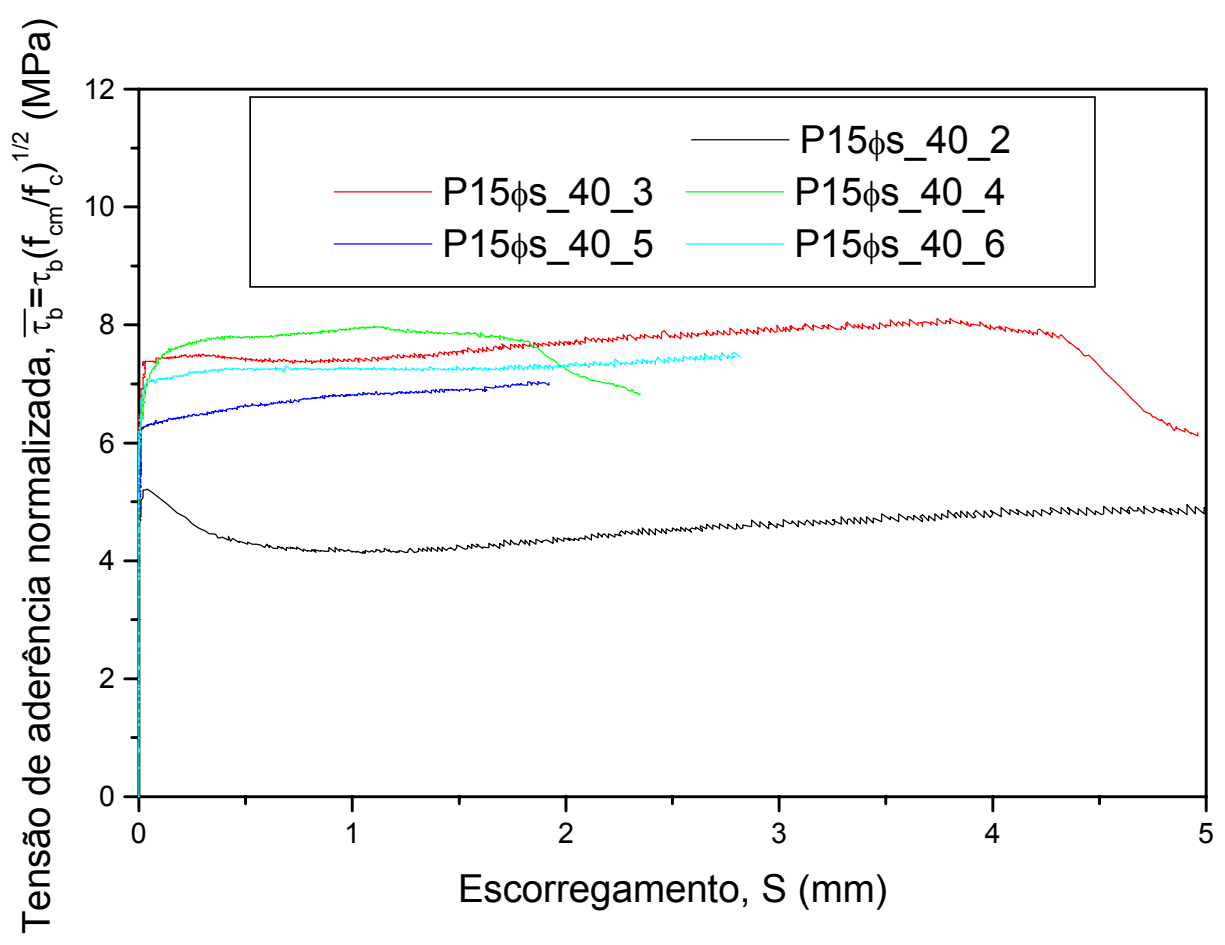

Figura 5.18 - Diagramas Tensão de aderência versus Escorregamento para os prismas do Grupo 10. 
Para o Grupo 10, os prismas foram confeccionados em três concretagens diferentes: o

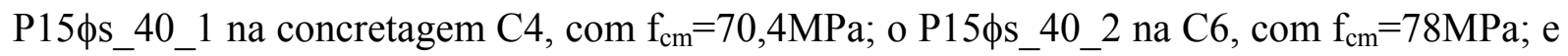
os outros quatro na $\mathrm{C} 8$, com $\mathrm{f}_{\mathrm{cm}}=72,98 \mathrm{MPa}$. O P15фs_40_1 foi ensaiado aos 28 dias, o P15фs_40_2 aos 23 dias, e o restante aos 118 dias. Os modelos 3, 4, 5 e 6 apresentaram fissuras de retração.

No ensaio do prisma P15申s_40_1 perderam-se os dados para a elaboração do gráfico Tensão de aderência versus Escorregamento, só tendo sido feito o registro da carga máxima, que foi utilizado para o cálculo da tensão máxima de aderência $\left(\tau_{b, \text { máx }}\right)$. Durante os ensaios, apenas o prisma 3 fissurou longitudinalmente, e nenhum dos prismas apresentou fissuras transversais.

Pelo gráfico, pode-se dizer que os modelos apresentaram comportamentos aderentes um pouco distintos, e grande dispersão de valores, principalmente no que diz respeito às tensões máximas de aderência. Aparentemente, os modelos 3, 4, 5 e 6 comportaram-se de maneira semelhante, porém para níveis de escorregamento diferentes. Já o P15фs_40_2 apresentou um comportamento de encruamento, bastante diferente dos demais.

A Tabela 5.13 apresenta os dados característicos para os modelos do Grupo 10.

Tabela 5.13 - Dados característicos do comportamento aderente dos prismas do Grupo 10, Série 1.

\begin{tabular}{|c|c|c|c|c|c|c|c|c|}
\hline Modelo & $\begin{array}{l}\mathbf{f}_{\mathrm{c}, \text { ensaio }} \\
\text { (MPa) }\end{array}$ & $\begin{array}{l}\text { Idade } \\
\text { (dias) }\end{array}$ & $\begin{array}{l}\tau_{\mathrm{b}, \mathbf{1}_{\mathrm{a}}^{\mathrm{fiss}}} \\
(\mathbf{M P a})\end{array}$ & $\begin{array}{c}\tau_{\mathrm{b}, \mathbf{0 . 1}} \\
(\mathbf{M P a})\end{array}$ & $\begin{array}{c}\tau_{\mathrm{b}, 1} \\
(\mathbf{M P a})\end{array}$ & $\begin{array}{c}\tau_{\mathrm{b}, 3} \\
(\mathbf{M P a})\end{array}$ & $\begin{array}{l}\tau_{\mathrm{b}, \mathbf{m a ́ x}} \\
(\mathbf{M P a})\end{array}$ & $\begin{array}{r}S_{\tau_{\text {b,máx }}} \\
(\mathrm{mm})\end{array}$ \\
\hline 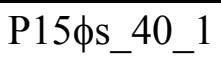 & 70,40 & 28 & --- & --- & --- & --- & 4,31 & --- \\
\hline P15 15 s_40_2 & 78,00 & 23 & 4,45 & 4,54 & 3,72 & 4,12 & 4,67 & 0,04 \\
\hline P15 $\phi s \_40 \_3$ & 72,98 & 118 & 6,25 & 7,11 & 7,07 & 7,64 & 7,76 & 3,80 \\
\hline 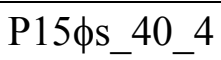 & 72,98 & 118 & 5,99 & 7,09 & 7,59 & --- & 7,63 & 1,07 \\
\hline P15фs_40_5 & 72,98 & 118 & 5,98 & 6,08 & 6,52 & --- & 6,73 & 1,87 \\
\hline P15фs_40_6 & 72,98 & 118 & 6,12 & 6,78 & 6,93 & --- & 7,20 & 2,73 \\
\hline
\end{tabular}

Vale lembrar que, os modelos 5 e 6 apresentavam crescimento de carga quando o ensaio foi interrompido.

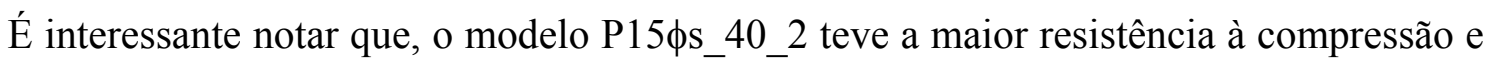
a menor tensão de aderência máxima, antes do encruamento. Os outros modelos, apesar de resistências à compressão menores, apresentaram tensões de aderência maiores, o que pode indicar que a idade influencia na aderência. Essa consideração será retomada no item 5.3. 


\section{1) Grupo 11}

Para os prismas desse grupo, os três primeiros foram confeccionados na concretagem $\mathrm{C} 10$, com $\mathrm{f}_{\mathrm{cm}}=74,94 \mathrm{MPa}$, e ensaiados com 97 e 98 dias de idade, e os três últimos na C11, com $\mathrm{f}_{\mathrm{cm}}=74,43 \mathrm{MPa}$, e ensaiados com 86 dias de idade. Apenas o P15 fissuração de retração. Porém, diferentemente de todos os demais prismas que sofreram fissuras de retração, este modelo apresentou fissuras na face superior, e não nas suas faces laterais. A face superior foi a que ficava exposta, coberta com espuma, durante o período de cura.

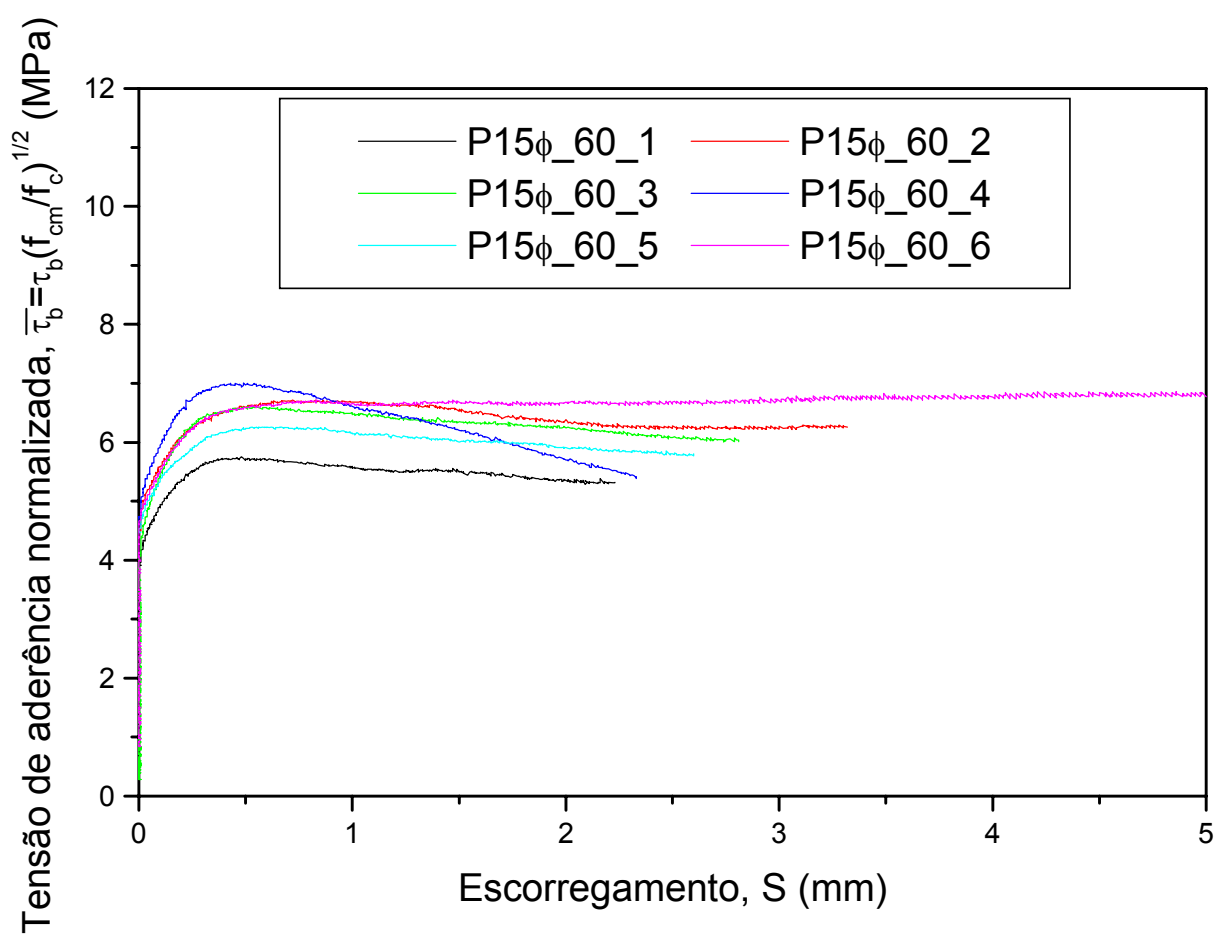

Figura 5.19 - Diagramas Tensão de aderência versus Escorregamento para os prismas do Grupo 11.

Todos os prismas apresentaram fissuras longitudinais no ensaio. E os modelos 1 e 2 apresentaram fissuras transversais. Essas últimas, porém, apareceram muito cedo, para um escorregamento em torno de $0,003 \mathrm{~mm}$, talvez por causa da retração.

Este grupo apresentou um comportamento bem uniforme. Nenhum dos modelos apresentou encruamento. Exceto para P15ф_60_4, que apresentou uma queda acentuada na curva, os demais prismas apresentam um patamar de tensão constante e aumento do escorregamento, bem grande e bem definido. Isso pode ser devido ao tamanho do comprimento aderente disponível, de $15 \phi_{\mathrm{p}}=19 \mathrm{~cm}$, que demanda mais energia para vencer a aderência da peça. 
A Tabela 5.14 apresenta os dados característicos para os modelos do Grupo 11. A dispersão dos valores é pequena.

Tabela 5.14 - Dados característicos do comportamento aderente dos prismas do Grupo 11, Série 1.

\begin{tabular}{|c|c|c|c|c|c|c|c|c|}
\hline Modelo & $\begin{array}{l}\mathbf{f}_{\mathrm{c}, \text { ensaio }} \\
\text { (MPa) }\end{array}$ & $\begin{array}{l}\text { Idade } \\
\text { (dias) }\end{array}$ & $\begin{array}{l}\tau_{\mathrm{b}, 1^{\mathrm{a}} \text { fiss }} \\
(\mathbf{M P a})\end{array}$ & $\begin{array}{c}\tau_{\mathbf{b}, \mathbf{0 . 1}} \\
(\mathbf{M P a})\end{array}$ & $\begin{array}{c}\tau_{\mathbf{b}, 1} \\
(\mathbf{M P a})\end{array}$ & $\begin{array}{c}\tau_{\mathbf{b}, 3} \\
(\mathbf{M P a})\end{array}$ & $\begin{array}{c}\tau_{\mathrm{b}, \text { máx }} \\
(\mathbf{M P a})\end{array}$ & $\begin{array}{r}S_{\tau_{\text {b,máx }}} \\
(\mathrm{mm})\end{array}$ \\
\hline P15ф_60_1 & 74,94 & 97 & 3,71 & 4,55 & 5,17 & --- & 5,36 & 0,48 \\
\hline P15ф_60_2 & 74,94 & 98 & 4,48 & 5,19 & 6,23 & 5,84 & 6,25 & 0,63 \\
\hline P15ф_60_3 & 74,94 & 98 & 3,91 & 5,05 & 6,03 & --- & 6,15 & 0,51 \\
\hline P15ф_60_4 & 74,43 & 86 & 4,61 & 5,54 & 6,20 & --- & 6,56 & 0,40 \\
\hline P15ф_60_5 & 74,43 & 86 & 4,26 & 5,00 & 5,77 & --- & 5,87 & 0,53 \\
\hline P15ф_60_6 & 74,43 & 86 & 4,45 & 5,13 & 6,25 & 6,31 & 6,44 & 4,21 \\
\hline
\end{tabular}

m) Grupo 12

Para este grupo, todos os modelos foram confeccionados de uma só vez, na concretagem $\mathrm{C} 10$, com $\mathrm{f}_{\mathrm{cm}}=74,94 \mathrm{MPa}$, e foram ensaiados aos 98 e 99 dias. Nenhum dos prismas apresentou fissuração de retração.

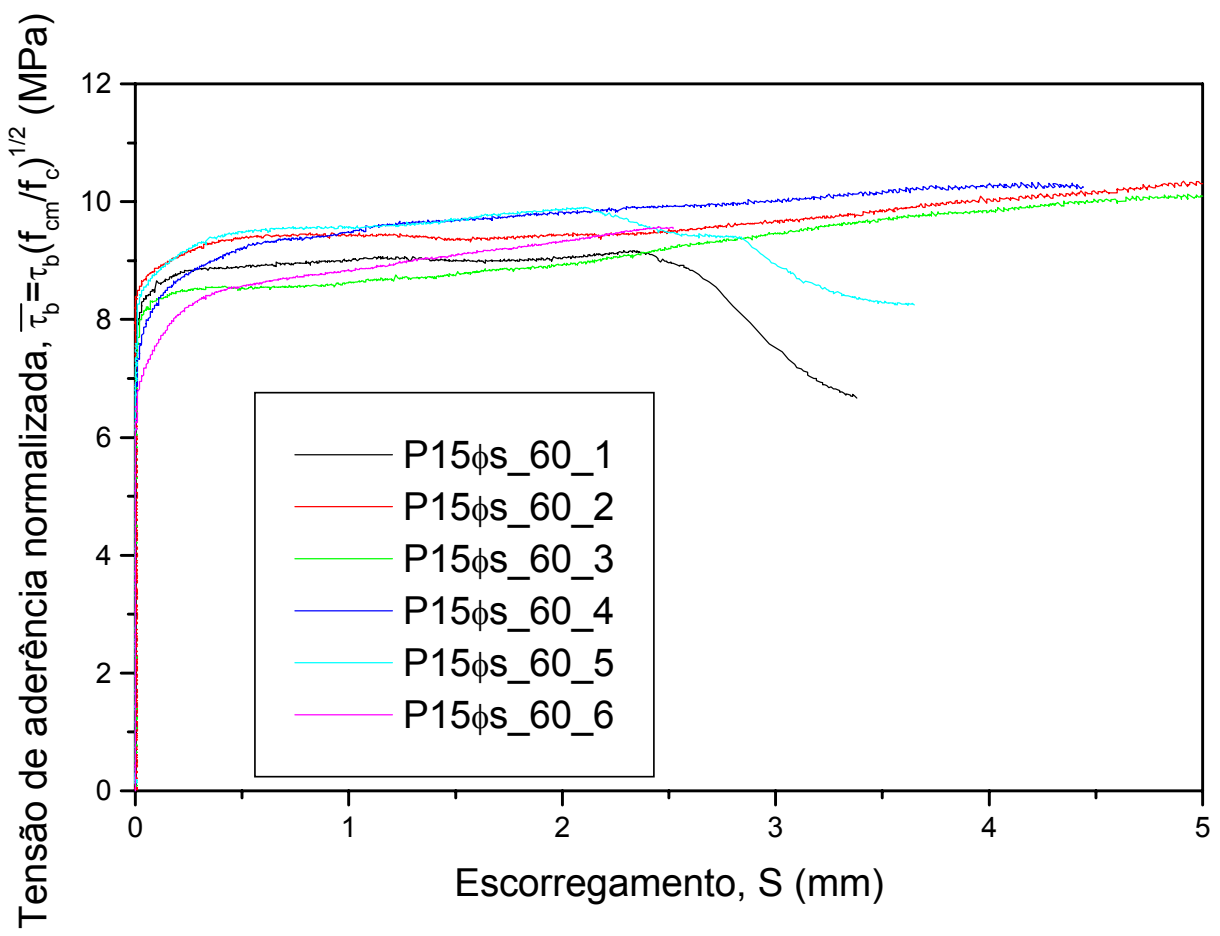

Figura 5.20 - Diagramas Tensão de aderência versus Escorregamento para os prismas do Grupo 12.

Durante os ensaios, apenas os modelos 1, 5 e 6 apresentaram fissuras longitudinais. Nenhum dos prismas fissurou transversalmente. Pelo gráfico, percebe-se o momento da 
fissura longitudinal dos modelos 1 e 5, pela queda brusca da tensão de aderência representada nas curvas. De maneira geral, os prismas apresentaram comportamentos aderentes bem semelhantes, sendo que os modelos 1 e 5 atingiram a tensão máxima de aderência imediatamente antes do aparecimento da fissura longitudinal. Provavelmente, imagina-se que, se os ensaios dos outros modelos fossem levados adiante, o mesmo aconteceria com eles.

A Tabela 5.15 apresenta os dados característicos para os modelos do Grupo 12. Percebe-se que há alguma dispersão dos valores.

Tabela 5.15 - Dados característicos do comportamento aderente dos prismas do Grupo 12, Série 1.

\begin{tabular}{|c|c|c|c|c|c|c|c|c|}
\hline Modelo & $\begin{array}{l}\mathbf{f}_{\mathrm{c}, \text { ensaio }} \\
\text { (MPa) }\end{array}$ & $\begin{array}{l}\text { Idade } \\
\text { (dias) }\end{array}$ & $\begin{array}{l}\tau_{\mathrm{b}, \mathbf{1}_{\mathrm{a}}^{\mathrm{fiss}}} \\
(\mathbf{M P a})\end{array}$ & $\begin{array}{c}\tau_{\mathrm{b}, 0.1} \\
(\mathbf{M P a})\end{array}$ & $\begin{array}{c}\tau_{\mathrm{b}, 1} \\
(\mathbf{M P a})\end{array}$ & $\begin{array}{c}\tau_{\mathbf{b}, 3} \\
(\mathbf{M P a})\end{array}$ & $\begin{array}{c}\tau_{\mathrm{b}, \mathrm{máx}} \\
(\mathbf{M P a})\end{array}$ & $\begin{array}{r}\mathbf{S}_{\tau_{\text {b,máx }}} \\
(\mathrm{mm})\end{array}$ \\
\hline P15 $\phi s \_60 \_1$ & 74,94 & 98 & 6,91 & 8,06 & 8,39 & 7,00 & 8,54 & 2,32 \\
\hline P15 15 s_60_2 & 74,94 & 98 & 7,89 & 8,26 & 8,79 & 9,02 & 9,64 & 4,91 \\
\hline P15 $\phi s \_60 \_3$ & 74,94 & 98 & 7,16 & 7,76 & 8,04 & 8,82 & 9,41 & 5,10 \\
\hline 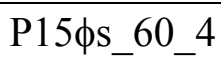 & 74,94 & 98 & 6,70 & 7,70 & 8,84 & 9,32 & 9,62 & 4,23 \\
\hline P15 $\phi s \_60 \_5$ & 74,94 & 98 & 7,57 & 8,21 & 8,92 & 8,33 & 9,22 & 2,12 \\
\hline P15 $\phi s \_60 \_6$ & 74,94 & 99 & 6,23 & 7,03 & 8,22 & --- & 8,91 & 2,52 \\
\hline
\end{tabular}

\subsubsection{Ensaios dos prismas da Série 2}

Foram realizados 36 ensaios nesta série, divididos em seis grupos, e cada grupo com seis modelos teoricamente idênticos. A Tabela 5.16 apresenta os dados para a Série 2.

Tabela 5.16 - Características dos prismas da Série 2.

\begin{tabular}{|c|c|c|c|c|}
\hline Grupo & Modelos & $\sigma_{p}$ & $\mathbf{V}_{\mathbf{f}}\left(\mathrm{kg} / \mathrm{m}^{3}\right)$ & $\ell_{\text {ef }}(\mathrm{cm})$ \\
\hline 1 & P5 $\phi \_0 \_1,2,3,4,5,6$ & $0,8 \mathrm{f}_{\mathrm{ptk}}$ & \multirow{2}{*}{0} & \multirow{6}{*}{$5 \phi_{\mathrm{p}}=6,35 \mathrm{~cm}$} \\
\hline 2 & P5 $\phi s \_0 \_1,2,3,4,5,6$ & Zero (sem protensão) & & \\
\hline 3 & P5 $\phi \_40 \_1,2,3,4,5,6$ & $0,8 \mathrm{f}_{\mathrm{ptk}}$ & \multirow{2}{*}{40} & \\
\hline 4 & P5 $\phi s \_40 \_1,2,3,4,5,6$ & Zero (sem protensão) & & \\
\hline 5 & P5 ${ }_{-} 60 \_1,2,3,4,5,6$ & $0,8 \mathrm{f}_{\mathrm{ptk}}$ & \multirow{2}{*}{60} & \\
\hline 6 & P5 $\phi \mathrm{s} \quad 60 \quad 1,2,3,4,5,6$ & Zero (sem protensão) & & \\
\hline
\end{tabular}

O término dos ensaios foi determinado pela abertura da hélice dos fios. Porém, o término das leituras do escorregamento foi determinado ou pela queda acentuada da carga, ou 
quando a peça atingia um escorregamento de, pelo menos, $3 \mathrm{~mm}$ com a carga já apresentado uma leve queda, o que ocorresse primeiro. Algumas leituras foram levadas além desses limites, quando não ocorria, claramente, nenhum dos dois fatores. Para alguns ensaios, onde a carga não apresentou tendência de queda, o término da leitura do escorregamento foi determinado pelo alcance do final do curso do relógio comparador. Isso ocorreu nos dois últimos grupos (Grupos 5 e 6) dessa série. Após a retirada do relógio comparador, aumentavase a taxa de deformação do ensaio, passava-se para $\mathrm{v}_{\text {ensaio }}=0,5 \mathrm{~mm} / \mathrm{s}$, e procedia-se com o arrancamento até a hélice dos fios da cordoalha se abrirem, como mostra a Figura 5.21.

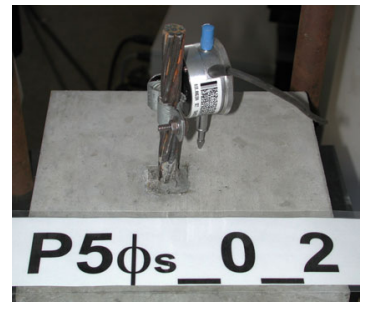

(a)

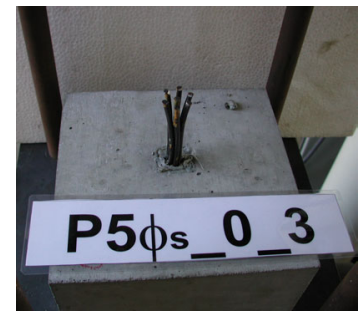

(b)

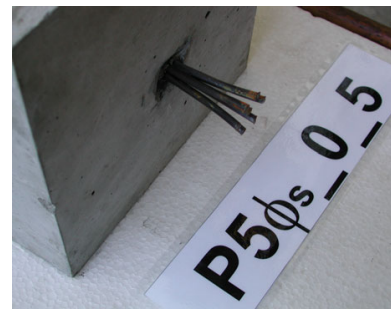

(c)

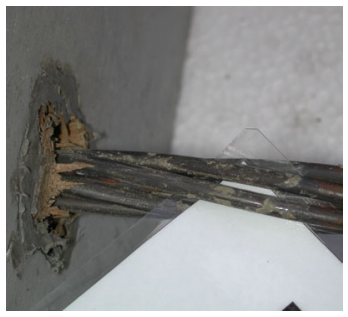

(d)

Figura 5.21 - Detalhes dos ensaios de arrancamento dos prismas da Série 2: (a) cordoalha com o relógio comparador; (b) abertura da hélice dos fios; (c) detalhe da hélice; (d) detalhe do desligamento dos fios na extremidade inferior, que ficava presa à máquina de ensaio.

Após o aumento da taxa de carregamento, havia um aumento da carga máxima, porém, este valor foi descartado. Esse padrão de ensaio foi o mesmo para todos os prismas desta série. A partir do momento que se aumentava a velocidade do carregamento, era visível o giro da cordoalha, à medida que ela ia escorregando dentro do concreto, e culminava com a abertura da hélice. Na extremidade inferior (Figura 5.21d), que ficava presa à garra da máquina, ocorria o desligamento dos fios, porém estes não se abriam, pois o comprimento inferior era muito grande (maior do que $40 \mathrm{~cm}$ ). De maneira geral, essa abertura dos fios ocorreu após um escorregamento de $50 \mathrm{~mm}$. Esse comportamento está de acordo com o que foi observado por vários pesquisadores em relação ao arrancamento das cordoalhas de sete fios.

Em relação à fissuração, nenhum dos prismas apresentou qualquer tipo de fissura, nem de retração, nem durante os ensaios, mesmo para escorregamentos da ordem de $50 \mathrm{~mm}$. Esse fato reforça a idéia de que o cobrimento exagerado de concreto influi significativamente no modo de ruptura das peças.

Os prismas desta série foram ensaiados entre 14 e 29 dias, dependendo da disponibilidade de data do Laboratório de Estruturas (LE). 
Os gráficos a seguir (Figuras 5.22, 5.24, 5.25, 5.26, 5.27 e 5.29), apresentam o comportamento Tensão de aderência versus Escorregamento para os grupos da Tabela 5.16. Cada gráfico contém o resultado de ensaio dos seis modelos de cada grupo. Apesar de teoricamente idênticos, os seis modelos de cada grupo apresentaram comportamentos Tensão de aderência versus Escorregamento diferentes, o que pode ser claramente observado nos gráficos a seguir. Alguns grupos apresentam diferenças maiores do que outros. Para cada grupo, foram feitos os comentários que se julgaram relevantes. Procurou-se manter a mesma escala para todos os gráficos, tanto para a tensão de aderência como para o escorregamento, visando uma melhor comparação visual entre os diversos grupos.

\section{a) Grupo 1}

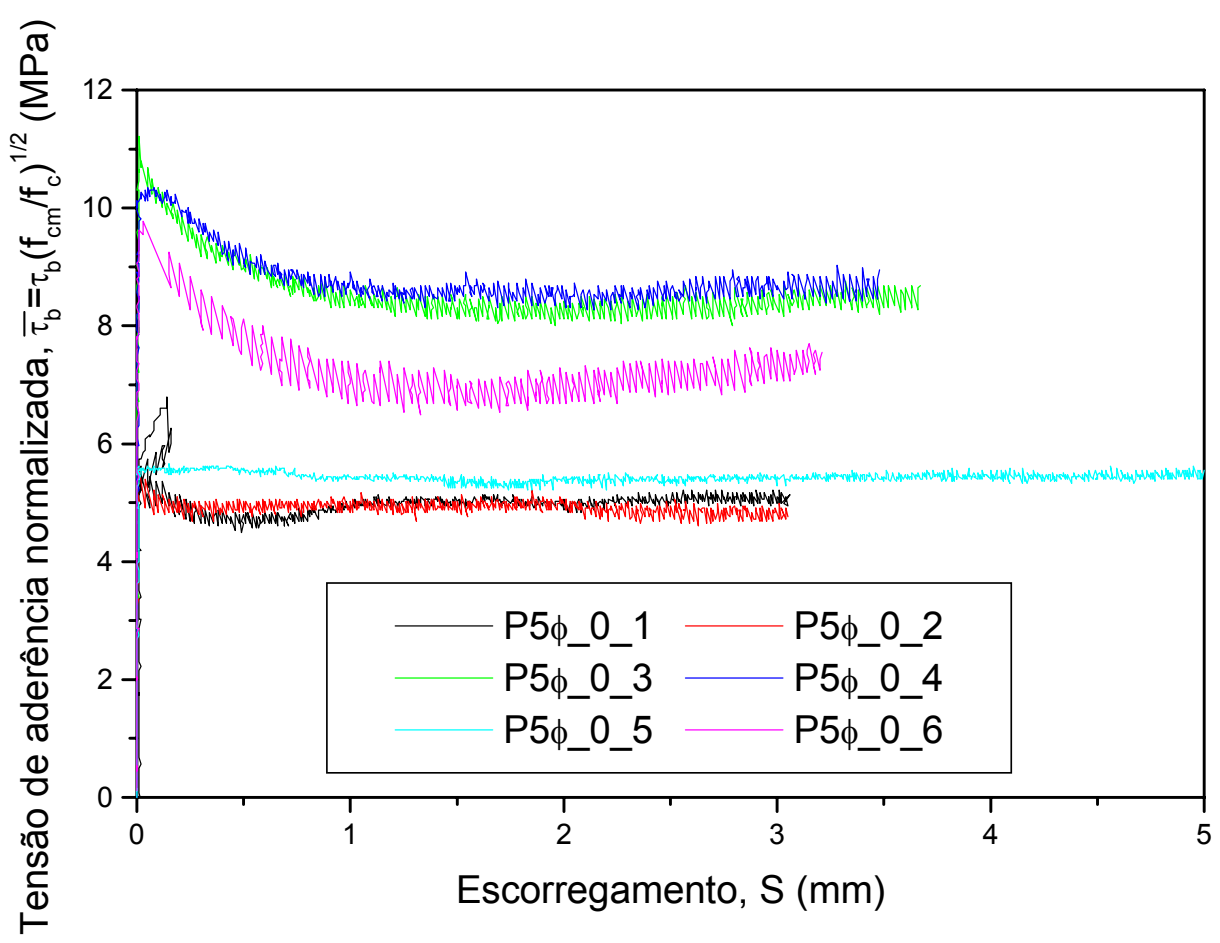

Figura 5.22 - Diagramas Tensão de aderência versus Escorregamento para os prismas do Grupo 1.

Para este primeiro grupo, todos os prismas foram confeccionados na concretagem $\mathrm{C} 12$, que apresentou $\mathrm{f}_{\mathrm{cm}}=77,54 \mathrm{MPa}$, e foram ensaiados aos 28 e 29 dias de idade.

Pelo gráfico, percebe-se que há, basicamente, dois tipos de comportamento. Para os modelos 3, 4 e 6 pode-se dizer que a curva segue o padrão de ruptura por arrancamento para concreto não-confinado. Esses modelos não apresentaram nenhuma fissura aparente, nem externamente nem internamente, pois eles foram cortados longitudinalmente para verificar o estado interno dos mesmos (Figura 5.23). E os modelos 2 e 5 que apresentam um comportamento que não se enquadra nem no padrão de ruptura por arrancamento nem no por 
fendilhamento. O modelo 1, apesar de apresentar uma perturbação inicial na curva, pode-se dizer que esta se aproxima do comportamento de ruptura por arrancamento, como os modelos 3, 4 e 6. Apesar da forma das curvas sugerir um fendilhamento interno, devido à queda brusca da carga, as cordoalhas foram arrancadas do concreto sem que nenhum tipo de fissura aparecesse, talvez devido ao volume exagerado de concreto ao redor da armadura.
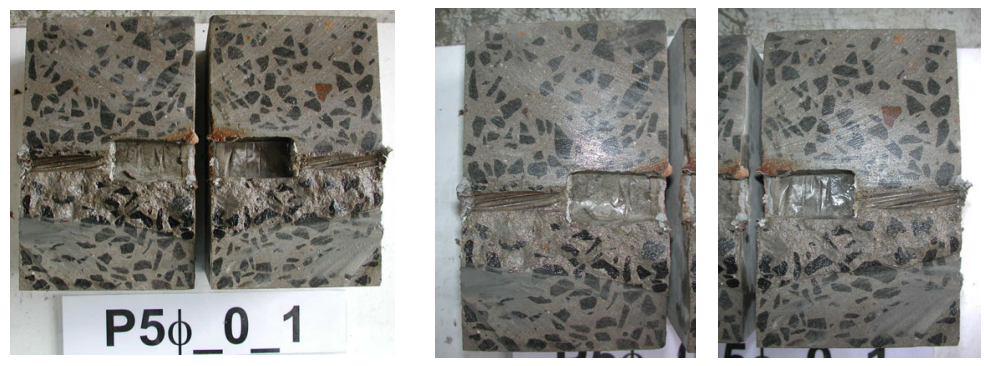

Figura 5.23 - Detalhes dos prismas P5ф_0_1.

Observa-se no gráfico que as curvas apresentam perturbações, após o início do escorregamento, indicando que o arrancamento da armadura segue um movimento de vai-evem, diferentemente das curvas para os prismas da Série 1, que eram muito mais suaves. Isso ocorreu em todos os grupos da Série 2, possivelmente devido ao comprimento de ancoragem reduzido.

A Tabela 5.17 apresenta os dados característicos para os modelos do Grupo 1. Observase, tanto pela tabela como pelo gráfico, que há uma grande dispersão dos valores, principalmente para as tensões de aderência.

Tabela 5.17 - Dados característicos do comportamento aderente dos prismas do Grupo 1, da Série 2.

\begin{tabular}{|c|c|c|c|c|c|c|c|c|}
\hline Modelo & $\begin{array}{l}\mathbf{f}_{\mathrm{c}, \text { ensaio }} \\
\text { (MPa) }\end{array}$ & $\begin{array}{l}\text { Idade } \\
\text { (dias) }\end{array}$ & $\begin{array}{l}\tau_{\mathrm{b}, 1^{\mathbf{a}} \text { fiss }} \\
(\mathbf{M P a})\end{array}$ & $\begin{array}{c}\tau_{\mathrm{b}, 0.1} \\
(\mathbf{M P a})\end{array}$ & $\begin{array}{c}\tau_{\mathrm{b}, 1} \\
(\mathbf{M P a})\end{array}$ & $\begin{array}{c}\tau_{\mathrm{b}, 3} \\
(\mathbf{M P a})\end{array}$ & $\begin{array}{c}\tau_{\mathrm{b}, \mathrm{máx}} \\
(\mathbf{M P a})\end{array}$ & $\begin{array}{l}\mathbf{S}_{\tau_{\mathrm{b}, \mathbf{m a ́ x}}} \\
(\mathrm{mm})\end{array}$ \\
\hline P5 $\phi \_0 \_1$ & 77,54 & 28 & 5,00 & 4,82 & 4,38 & 4,59 & 6,12 & 0,14 \\
\hline P5 $\phi \_0 \_2$ & 77,54 & 28 & 5,03 & 4,35 & 4,52 & 4,35 & 5,03 & 0,01 \\
\hline P5 $\phi \_0 \_3$ & 77,54 & 28 & 10,09 & 9,31 & 7,75 & 7,57 & 10,09 & 0,01 \\
\hline P5 $\phi_{-} 0 \_4$ & 77,54 & 29 & 9,11 & 9,25 & 8,02 & 7,82 & 9,31 & 0,05 \\
\hline P5 $\phi \_0 \_5$ & 77,54 & 29 & 5,00 & 5,00 & 4,90 & 4,92 & 7,71 & 4,84 \\
\hline P5 $\phi \_0 \_6$ & 77,54 & 29 & 8,66 & 8,30 & 6,39 & 6,73 & 8,80 & 0,03 \\
\hline
\end{tabular}

\section{b) Grupo 2}

Para este grupo, todos os prismas foram confeccionados na concretagem $\mathrm{C} 12$, que apresentou $\mathrm{f}_{\mathrm{cm}}=77,54 \mathrm{MPa}$, e foram ensaiados aos 28 dias de idade. 
Os modelos apresentam comportamentos semelhantes, menos o P5 $\phi$ s_0_5. Exceto para o P5申s_0_1, todos os demais apresentam tendência de subida de carga até para valores do escorregamento maiores que $3 \mathrm{~mm}$, ou seja, apesar de já ter, convencionalmente, atingido a ruptura, os modelos continuam com capacidade resistente crescente.

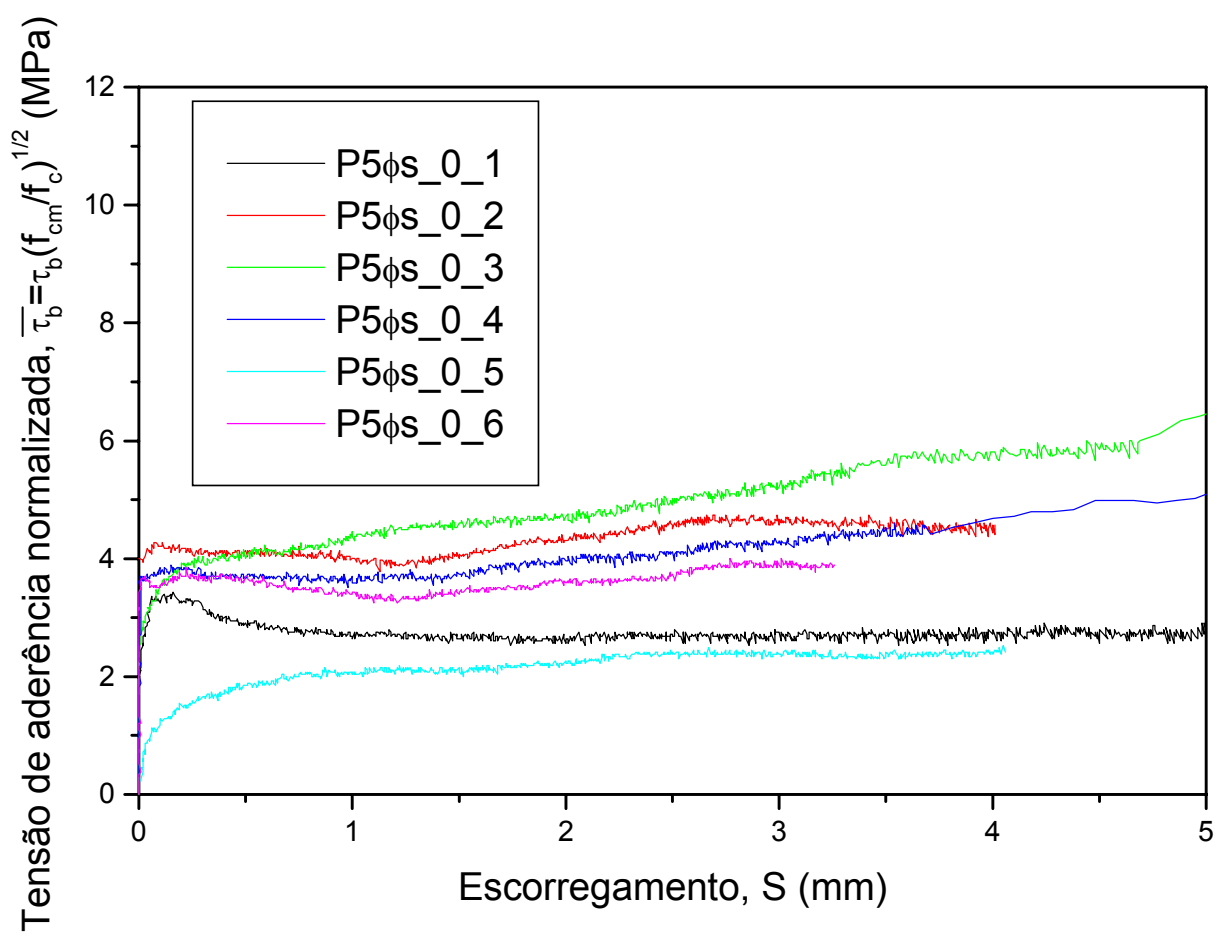

Figura 5.24 - Diagramas Tensão de aderência versus Escorregamento para os prismas do Grupo 2.

A Tabela 5.18 apresenta os dados característicos para os modelos do Grupo 2. A dispersão dos valores característicos é significativa.

Tabela 5.18 - Dados característicos do comportamento aderente dos prismas do Grupo 2, da Série 2.

\begin{tabular}{|c|c|c|c|c|c|c|c|c|}
\hline Modelo & $\begin{array}{l}\mathbf{f}_{\mathrm{c}, \text { ensaio }} \\
\text { (MPa) }\end{array}$ & $\begin{array}{l}\text { Idade } \\
\text { (dias) }\end{array}$ & $\begin{array}{l}\tau_{\mathrm{b}, \mathbf{1}_{\mathrm{a}}^{\mathrm{fiss}}} \\
(\mathbf{M P a})\end{array}$ & $\begin{array}{c}\tau_{\mathrm{b}, 0.1} \\
(\mathbf{M P a})\end{array}$ & $\begin{array}{c}\tau_{\mathrm{b}, 1} \\
(\mathbf{M P a})\end{array}$ & $\begin{array}{c}\tau_{\mathrm{b}, 3} \\
(\mathbf{M P a})\end{array}$ & $\begin{array}{c}\tau_{\mathrm{b}, \text { máx }} \\
(\mathbf{M P a})\end{array}$ & $\begin{array}{l}\mathbf{S}_{\tau_{\mathrm{b}, \mathbf{m a ́ x}}} \\
(\mathrm{mm})\end{array}$ \\
\hline P5 $\phi s \_0 \_1$ & 77,54 & 28 & 1,87 & 2,92 & 2,48 & 2,48 & 3,09 & 0,16 \\
\hline P5 $\phi s \_0 \_2$ & 77,54 & 28 & 4,11 & 4,32 & 4,11 & 4,19 & 4,86 & 2,66 \\
\hline P5 $\phi s \_0 \_3$ & 77,54 & 28 & 2,28 & 3,19 & 3,95 & 4,69 & 5,50 & 4,78 \\
\hline P5 $\phi s \_0 \_4$ & 77,54 & 28 & 3,30 & 3,47 & 3,33 & 3,84 & 4,14 & 3,54 \\
\hline P5 $\phi s \_0 \_5$ & 77,54 & 28 & 0,71 & 1,05 & 1,87 & 2,14 & 2,28 & 4,05 \\
\hline P5 $\phi s \_0 \_6$ & 77,54 & 28 & 3,19 & 3,16 & 3,09 & 3,50 & 3,60 & 2,77 \\
\hline
\end{tabular}




\section{c) Grupo 3}

Para o grupo 3 , todos os prismas foram confeccionados na concretagem $\mathrm{C} 13$, que apresentou $\mathrm{f}_{\mathrm{cm}}=66,14 \mathrm{MPa}$, e foram ensaiados aos 14 dias de idade.

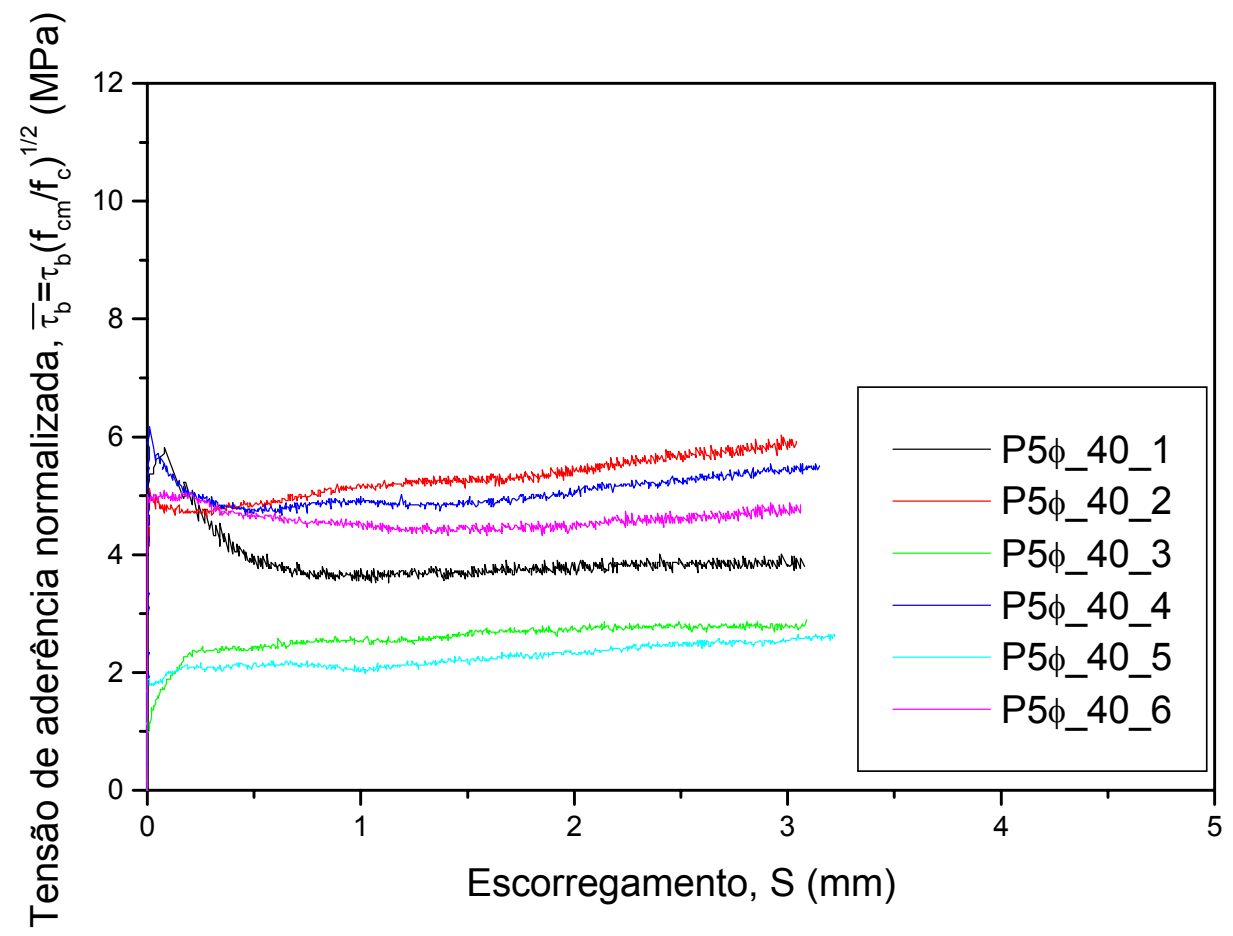

Figura 5.25 - Diagramas Tensão de aderência versus Escorregamento para os prismas do Grupo 3.

A Tabela 5.19 apresenta os dados característicos para os modelos do Grupo 3.

Tabela 5.19 - Dados característicos do comportamento aderente dos prismas do Grupo 3, da Série 2.

\begin{tabular}{|c|c|c|c|c|c|c|c|c|}
\hline Modelo & $\begin{array}{l}\mathbf{f}_{\mathrm{c}, \text { ensaio }} \\
\text { (MPa) }\end{array}$ & $\begin{array}{l}\text { Idade } \\
\text { (dias) }\end{array}$ & $\begin{array}{l}\tau_{\mathrm{b}, 1^{\mathrm{a}} \text { fiss }} \\
(\mathrm{MPa})\end{array}$ & $\begin{array}{c}\tau_{\mathrm{b}, 0.1} \\
(\mathbf{M P a})\end{array}$ & $\begin{array}{c}\tau_{\mathrm{b}, 1} \\
(\mathbf{M P a})\end{array}$ & $\begin{array}{c}\tau_{\mathrm{b}, 3} \\
(\mathbf{M P a})\end{array}$ & $\begin{array}{c}\tau_{\mathrm{b}, \text { máx }} \\
(\mathbf{M P a})\end{array}$ & $\begin{array}{r}\mathbf{S}_{\tau_{\mathrm{b}, \mathrm{máx}}} \\
(\mathrm{mm})\end{array}$ \\
\hline P5ф_40_1 & 66,14 & 14 & 5,67 & 5,34 & 3,97 & 4,05 & 6,15 & 0,08 \\
\hline P5 $\phi \_40 \_2$ & 66,14 & 14 & 5,12 & 5,05 & 5,45 & 6,25 & 6,37 & 2,97 \\
\hline P5 $\phi_{-} 40 \_3$ & 66,14 & 14 & 1,14 & 1,99 & 2,68 & 2,94 & 3,06 & 3,09 \\
\hline P5ф_40_4 & 66,14 & 14 & 6,51 & 5,63 & 5,21 & 5,70 & 6,51 & 0,01 \\
\hline P5 $\phi \_40 \_5$ & 66,14 & 14 & 1,99 & 2,13 & 2,17 & 2,68 & 2,80 & 3,05 \\
\hline P5ф_40_6 & 66,14 & 14 & 5,30 & 5,22 & 4,79 & 5,02 & 5,37 & 0,08 \\
\hline
\end{tabular}

Da mesma forma que para o Grupo 1, percebe-se pelo gráfico que há, basicamente, três tipos de comportamento. Para os modelos 1, 2 e 4 pode-se dizer que a curva segue o padrão de ruptura por arrancamento para concreto não-confinado, e eles não apresentaram nenhuma fissura aparente, nem externamente nem internamente. O modelo 6 apresenta um 
comportamento que não se enquadra nem no padrão de ruptura por arrancamento nem no por fendilhamento. E para os modelos 3 e 5, pode-se dizer que as curvas se aproximam do comportamento de ruptura por arrancamento, com confinamento da armadura.

\section{d) Grupo 4}

Para o grupo 4, todos os prismas foram confeccionados na concretagem $\mathrm{C} 13$, que apresentou $\mathrm{f}_{\mathrm{cm}}=66,14 \mathrm{MPa}$, e foram ensaiados aos 15 dias de idade.

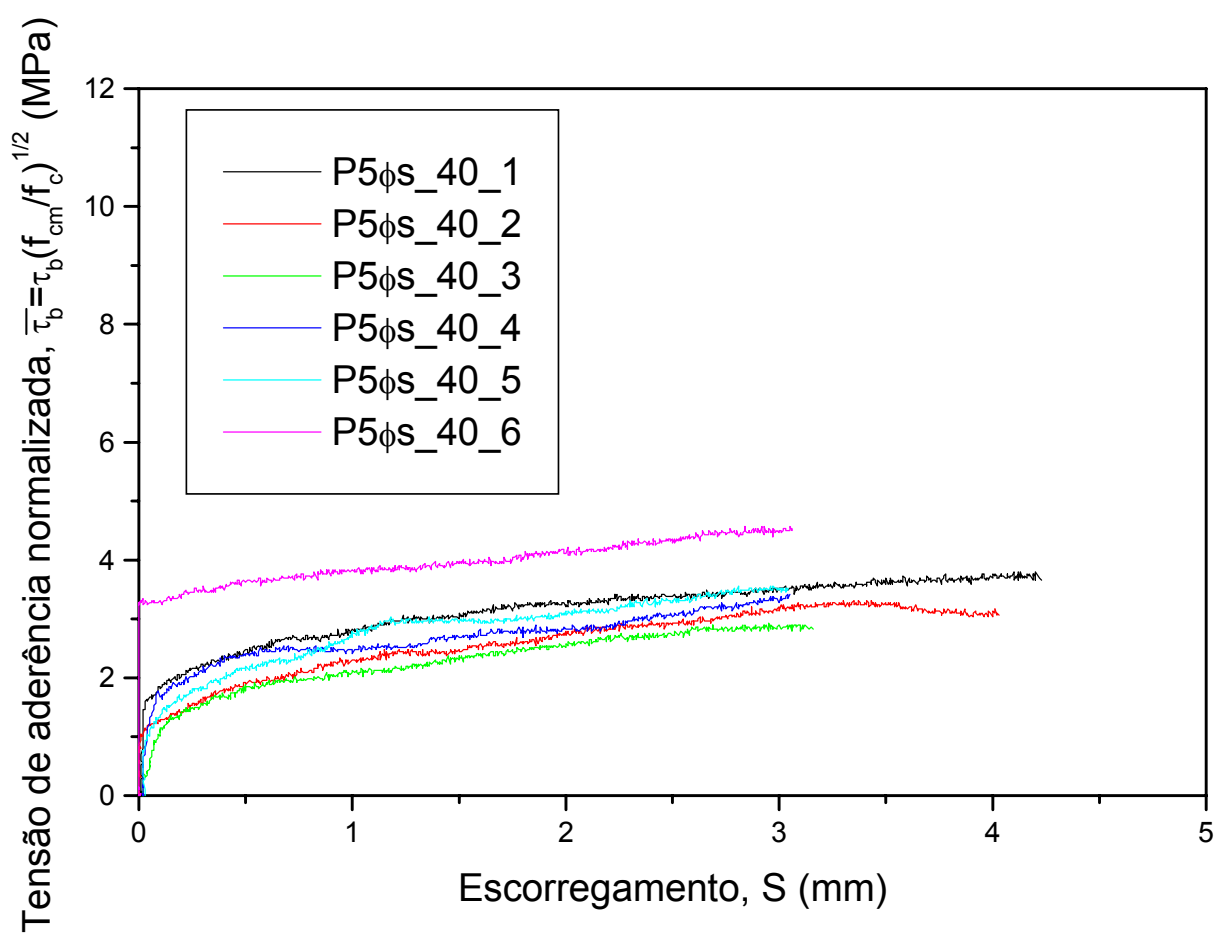

Figura 5.26 - Diagramas Tensão de aderência versus Escorregamento para os prismas do Grupo 4.

A Tabela 5.20 apresenta os dados característicos para os modelos do Grupo 4.

Tabela 5.20 - Dados característicos do comportamento aderente dos prismas do Grupo 4, da Série 2.

\begin{tabular}{|c|c|c|c|c|c|c|c|c|}
\hline Modelo & $\begin{array}{l}\mathbf{f}_{\mathrm{c}, \text { ensaio }} \\
\text { (MPa) }\end{array}$ & $\begin{array}{l}\text { Idade } \\
\text { (dias) }\end{array}$ & $\begin{array}{l}\tau_{\mathrm{b}, 1^{\mathrm{a}} \text { fiss }} \\
(\mathbf{M P a})\end{array}$ & $\begin{array}{c}\tau_{\mathrm{b}, 0.1} \\
(\mathbf{M P a})\end{array}$ & $\begin{array}{c}\tau_{\mathrm{b}, 1} \\
(\mathbf{M P a})\end{array}$ & $\begin{array}{c}\tau_{\mathrm{b}, 3} \\
(\mathbf{M P a})\end{array}$ & $\begin{array}{l}\tau_{b, \text { máx }} \\
\text { (MPa) }\end{array}$ & $\begin{array}{r}S_{\tau_{\text {b,máx }}} \\
(\mathrm{mm})\end{array}$ \\
\hline P5 $\phi s \_40 \_1$ & 66,14 & 15 & 1,70 & 1,96 & 2,99 & 3,71 & 4,02 & 4,10 \\
\hline P5 $\phi s \_40 \_2$ & 66,14 & 15 & 0,93 & 1,32 & 2,42 & 3,31 & 3,50 & 3,30 \\
\hline P5 $\phi s \_40 \_3$ & 66,14 & 15 & 0,44 & 1,07 & 2,21 & 3,06 & 3,09 & 2,95 \\
\hline P5 $\phi s \_40 \_4$ & 66,14 & 15 & 0,84 & 1,77 & 2,58 & 3,55 & 3,61 & 3,04 \\
\hline P5申s_40_5 & 66,14 & 15 & 0,84 & 1,44 & 2,83 & 3,68 & 3,76 & 2,81 \\
\hline P5фs_40_6 & 66,14 & 15 & 3,45 & 3,50 & 4,05 & 4,74 & 4,82 & 2,84 \\
\hline
\end{tabular}


Este grupo apresenta um comportamento aderente praticamente uniforme, para todos os modelos, com o crescimento da carga até valores do escorregamento superiores a $3 \mathrm{~mm}$. Também, pela tabela percebe-se que a dispersão de valores é pequena, exceto para o modelo 6, que está um pouco acima dos demais.

Vale ressaltar que os modelos 2, 3, 5 e 6 ficaram com a cordoalha um pouco inclinada em relação ao eixo central dos prismas, o que, aparentemente, não influiu nos resultados.

\section{e) Grupo 5}

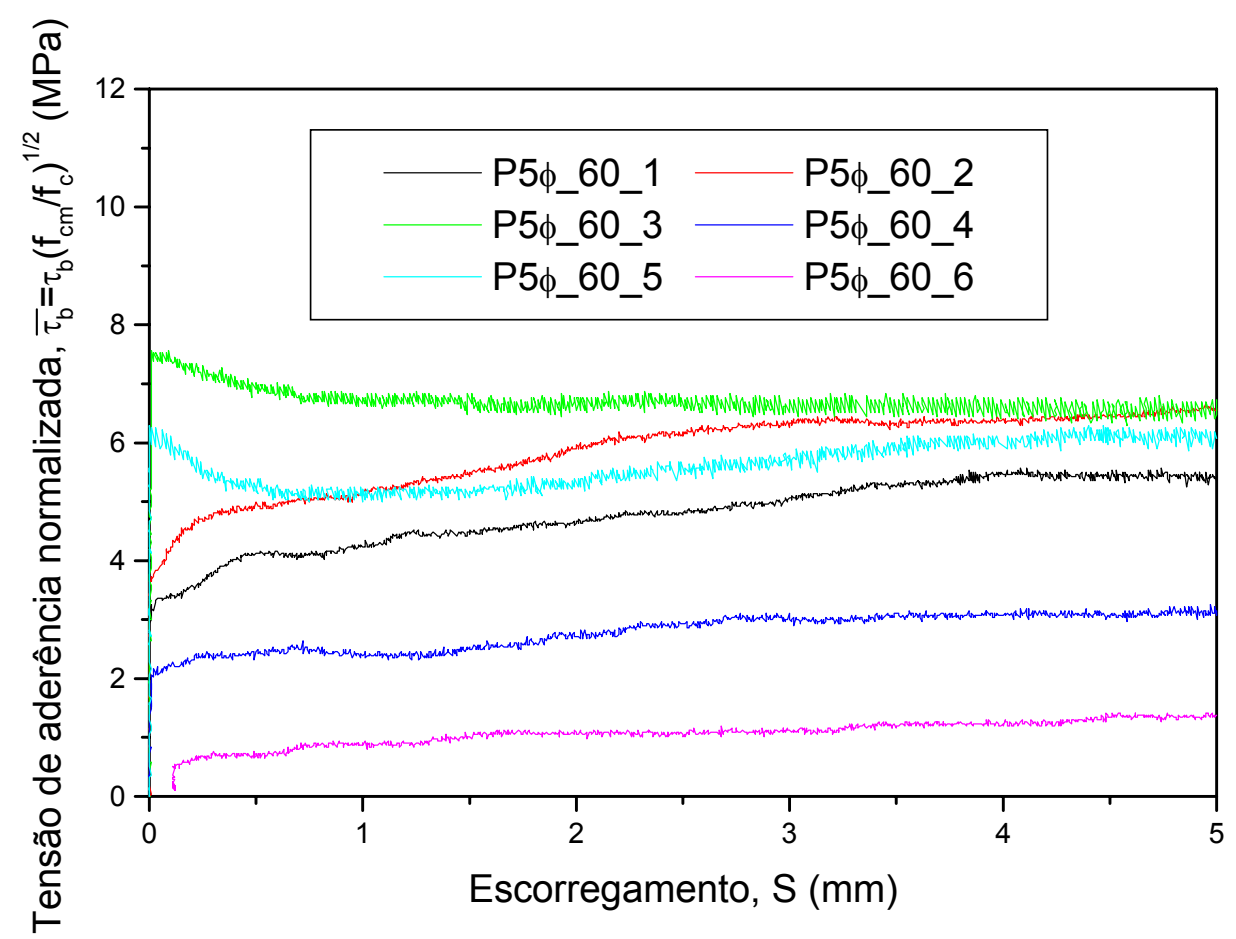

Figura 5.27 - Diagramas Tensão de aderência versus Escorregamento para os prismas do Grupo 5.

Para este grupo, todos os prismas foram confeccionados na concretagem $\mathrm{C} 14$, que apresentou $\mathrm{f}_{\mathrm{cm}}=71,21 \mathrm{MPa}$, e foram ensaiados aos 15 e 16 dias de idade.

Durante a concretagem dos modelos, o tubo de PVC do P5 $\phi$ 60_6 entrou no prisma além do tamanho correto, o que fez com que o comprimento aderente disponível da peça ficasse menor que o desejado. Por conta disso, os resultados desse modelo ficaram bem abaixo dos resultados dos demais prismas do grupo. Isso pode ser verificado tanto no gráfico como nos valores da Tabela. 5.21, que apresenta os dados característicos para os modelos do Grupo 5. Depois do ensaio o prisma foi cortado, e verificou-se que o comprimento aderente efetivo ficou em torno dos $4 \mathrm{~cm}$, ou $\ell_{\mathrm{ef}} \approx 3,5 \phi_{\mathrm{p}}$. A Figura 5.28 apresenta detalhes do prisma cortado. Quanto menor o comprimento aderente, mais sensível é o modelo às pequenas diferenças construtivas, ou seja, um erro de $5 \mathrm{~mm}$ é significativo num comprimento aderente 
de $6 \mathrm{~cm}$, ao passo que para um comprimento aderente de $19 \mathrm{~cm}\left(15 \phi_{\mathrm{p}}\right)$ ele passa desapercebido. Portanto, quanto menor o comprimento, maior deve ser o cuidado na confecção dos modelos, para tentar evitar, ao máximo, essas pequenas diferenças.

Este grupo apresentou os piores resultados, no que diz respeito à dispersão dos valores. Os modelos apresentaram dois tipos de comportamento: um para os prismas 1, 2, 4 e 6; e outro para os prismas 3 e 5 . Entretanto as diferenças entre eles são muito grandes.

Tabela 5.21 - Dados característicos do comportamento aderente dos prismas do Grupo 5, da Série 2.

\begin{tabular}{|c|c|c|c|c|c|c|c|c|}
\hline Modelo & $\begin{array}{l}\mathbf{f}_{\mathrm{c}, \text { ensaio }} \\
\text { (MPa) }\end{array}$ & $\begin{array}{l}\text { Idade } \\
\text { (dias) }\end{array}$ & $\begin{array}{l}\tau_{\mathbf{b}, 1_{\text {fiss }}} \\
(\mathbf{M P a})\end{array}$ & $\begin{array}{c}\tau_{\mathrm{b}, \mathbf{0 . 1}} \\
(\mathbf{M P a})\end{array}$ & $\begin{array}{c}\tau_{\mathrm{b}, 1} \\
(\mathbf{M P a})\end{array}$ & $\begin{array}{c}\tau_{\mathbf{b}, 3} \\
(\mathbf{M P a})\end{array}$ & $\begin{array}{c}\tau_{\mathrm{b}, \text { máx }} \\
(\mathbf{M P a})\end{array}$ & $\begin{array}{r}\mathbf{S}_{\tau_{\mathrm{b}, \mathrm{máx}}} \\
(\mathrm{mm})\end{array}$ \\
\hline P5ф_60_1 & 71,21 & 15 & 2,88 & 3,30 & 4,15 & 4,97 & 5,46 & 4,11 \\
\hline P5ф_60_2 & 71,21 & 15 & 3,58 & 4,07 & 5,07 & 6,14 & 6,64 & 5,34 \\
\hline P5ф_60_3 & 71,21 & 15 & 7,39 & 7,27 & 6,64 & 6,60 & 7,41 & 0,01 \\
\hline P5ф_60_4 & 71,21 & 15 & 1,99 & 2,17 & 2,34 & 3,05 & 3,62 & 7,22 \\
\hline P5ф_60_5 & 71,21 & 16 & 6,14 & 5,68 & 5,11 & 5,68 & 6,42 & 8,92 \\
\hline P5ф_60_6 & 71,21 & 16 & 0,53 & 0,53 & 0,85 & 1,09 & 1,46 & 5,81 \\
\hline
\end{tabular}
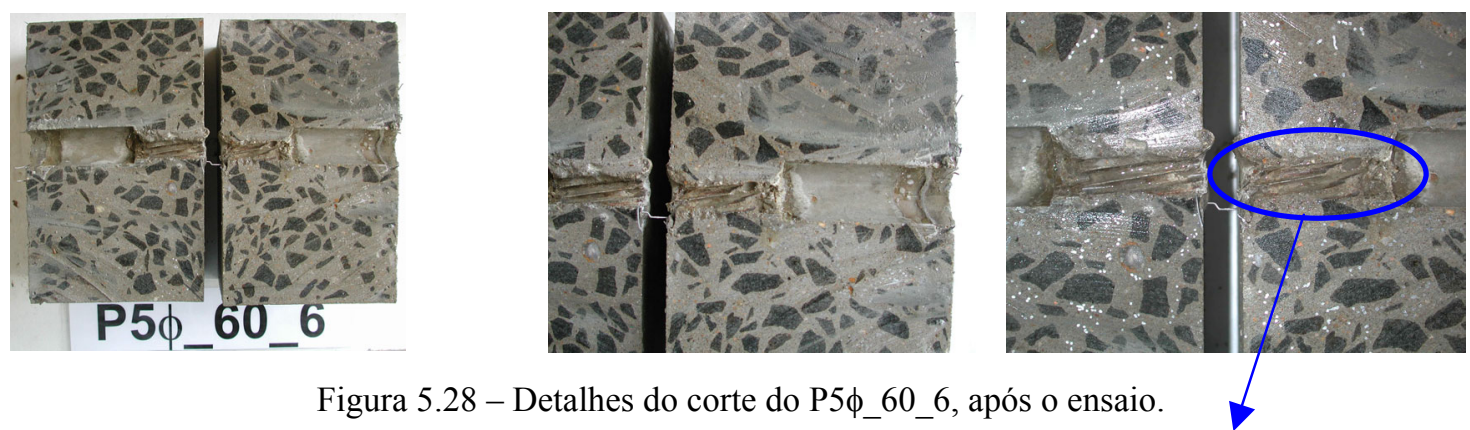

Figura 5.28 - Detalhes do corte do P5ф_60_6, após o ensaio.

Comprimento aderente resultante

\section{f) Grupo 6}

Para o último grupo, todos os prismas foram confeccionados na concretagem $\mathrm{C} 14$, que apresentou $\mathrm{f}_{\mathrm{cm}}=71,21 \mathrm{MPa}$, e foram ensaiados aos 16 dias de idade.

A Tabela 5.22 apresenta os dados característicos para os modelos do Grupo 6.

Os prismas apresentam comportamento Tensão de aderência versus Escorregamento semelhantes. Entretanto, o P5фs_60_1 mostra uma tendência de queda de carga, enquanto que os outros não. 
Percebe-se que há uma certa dispersão de valores, principalmente em relação ao escorregamento referente à tensão máxima de aderência.

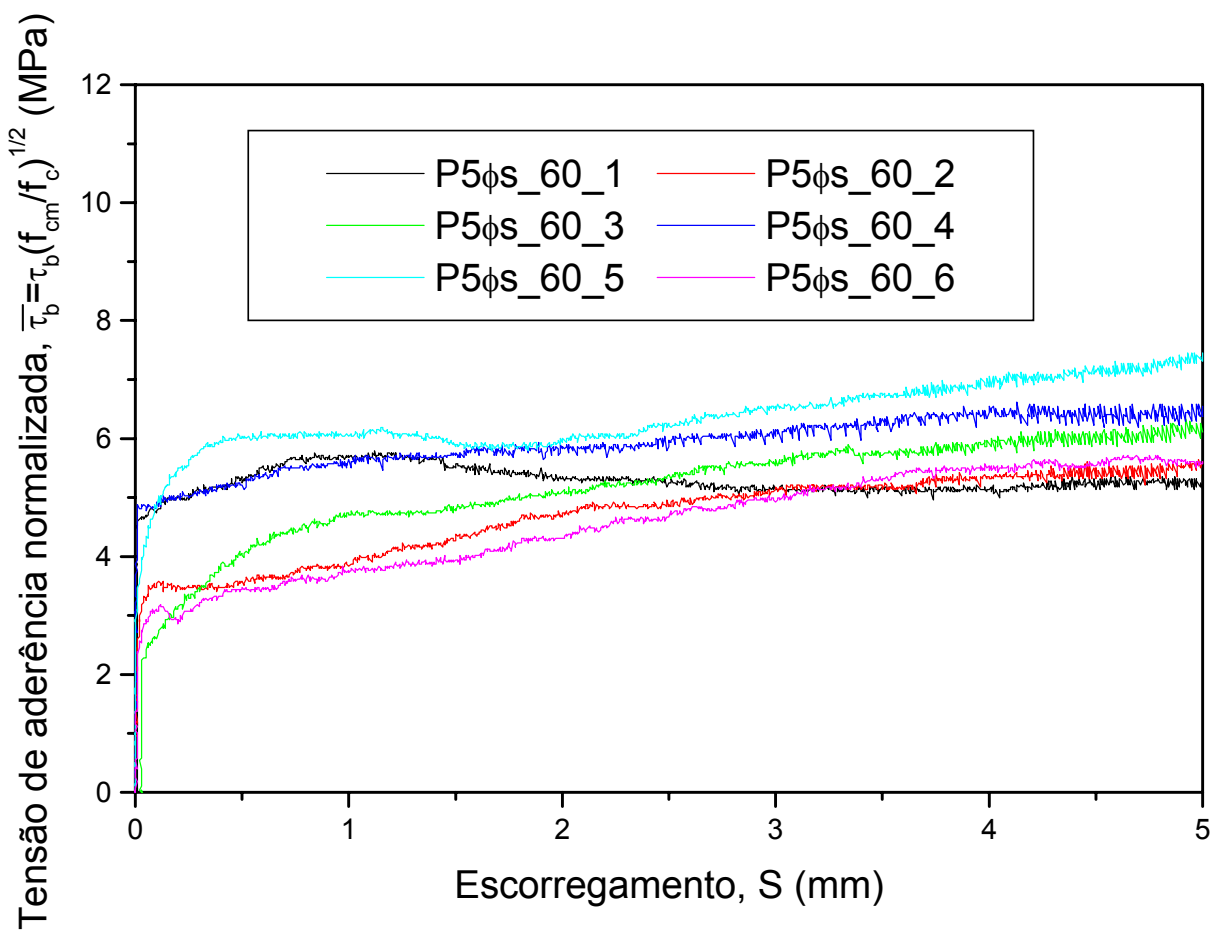

Figura 5.29 - Diagramas Tensão de aderência versus Escorregamento para os prismas do Grupo 6.

Tabela 5.22 - Dados característicos do comportamento aderente dos prismas do Grupo 6, da Série 2.

\begin{tabular}{|c|c|c|c|c|c|c|c|c|}
\hline Modelo & $\begin{array}{l}\mathbf{f}_{\mathrm{c}, \text { ensaio }} \\
(\mathrm{MPa})\end{array}$ & $\begin{array}{l}\text { Idade } \\
\text { (dias) }\end{array}$ & $\begin{array}{l}\tau_{\mathrm{b}, \mathbf{1}^{\mathrm{a}} \mathrm{fiss}} \\
(\mathbf{M P a})\end{array}$ & $\begin{array}{c}\tau_{\mathrm{b}, 0.1} \\
(\mathbf{M P a})\end{array}$ & $\begin{array}{c}\tau_{\mathrm{b}, 1} \\
(\mathbf{M P a})\end{array}$ & $\begin{array}{c}\tau_{\mathrm{b}, 3} \\
(\mathbf{M P a})\end{array}$ & $\begin{array}{l}\tau_{\text {b,máx }} \\
(\mathbf{M P a})\end{array}$ & $\begin{array}{c}\mathbf{S}_{\tau_{\text {b,máx }}} \\
(\mathrm{mm})\end{array}$ \\
\hline P5 $\phi s \_60 \_1$ & 71,21 & 16 & 4,44 & 4,65 & 5,61 & 5,03 & 5,68 & 1,12 \\
\hline P5 $\phi s \_60 \_2$ & 71,21 & 16 & 3,23 & 3,48 & 3,76 & 5,03 & 6,27 & 8,95 \\
\hline P5 $\phi s \_60 \_3$ & 71,21 & 16 & 2,38 & 2,55 & 4,62 & 5,53 & 6,88 & 9,11 \\
\hline P5 $\phi s \_60 \_4$ & 71,21 & 16 & 4,72 & 4,82 & 5,53 & 5,92 & 6,81 & 8,99 \\
\hline P5 $\phi s \_60 \_5$ & 71,21 & 16 & 3,41 & 4,72 & 5,92 & 6,42 & 8,51 & 8,56 \\
\hline $\mathrm{P} 5 \phi \mathrm{s} \quad 606$ & 71,21 & 16 & 2,55 & 3,05 & 3,69 & 4,86 & 5,74 & 5,85 \\
\hline
\end{tabular}

\subsection{Análise Estatística dos Ensaios de Arrancamento}

Antes de proceder-se com a análise comparativa entre os diversos grupos dos ensaios de arrancamento, foi feita uma análise estatística nos dados experimentais para verificar se os mesmos eram confiáveis, ou seja, se esses dados eram representativos do problema que se estava estudando. 
A análise de resultados experimentais e, conseqüentemente, as conclusões nela baseadas dependem do conhecimento do pesquisador sobre o tema e da qualidade dos dados obtidos. Esses dois fatores são fundamentais e complementares. É necessário conhecimento para interpretar os dados obtidos, e é preciso garantir a confiabilidade dos dados para que as conclusões sejam legítimas. O Apêndice E apresenta noções gerais sobre a análise estatística de dados experimentais, visando um melhor entendimento das análises feitas nos dados desta pesquisa, e, também, a análise estatística completa a que os dados foram submetidos.

A análise estatística dos resultados experimentais de arrancamento foi dividida em duas partes:

1) Verificação da normalidade dos dados, através de teste de normalidade e da plotagem dos resíduos;

2) Montagem de uma Tabela de Análise de Variância (ANOVA) com a comparação de médias pelo processo de Tukey, para quantificar a variabilidade dos dados.

Para uma melhor caracterização do problema em termos estatísticos, admitiram-se as seguintes definições:

- Variável resposta principal $(\mathrm{Y})=$ tensão de aderência máxima $\left(\tau_{\mathrm{b}, \text { máx }}\right)$;

- Fatores ou variáveis independentes $\left(\mathrm{X}_{\mathrm{i}}\right)$ :

○ $\mathrm{X}_{1}=$ comprimento aderente disponível $\left(\ell_{\mathrm{ef}}\right)$;

○ $\mathrm{X}_{2}=$ volume de fibras de aço $\left(\mathrm{V}_{\mathrm{f}}\right)$;

$\circ \mathrm{X}_{3}=$ grau de protensão da armadura $\left(\sigma_{\mathrm{p}}\right)$.

Além da variável resposta principal (tensão de aderência máxima, $\tau_{b \text {,máx }}$ ), foram analisados, também, os dados para outras variáveis resposta. São elas:

- $\mathrm{Y}_{1}=$ tensão de aderência para a primeira fissura $\left(\tau_{\mathrm{b}, 1 \text { a } \mathrm{a} \text { iss }}\right)$;

- $\mathrm{Y}_{2}=$ tensão de aderência para um escorregamento de $\mathrm{S}=0,1 \mathrm{~mm}\left(\tau_{\mathrm{b}, 0.1}\right)$;

- $\mathrm{Y}_{3}=$ tensão de aderência para um escorregamento de $\mathrm{S}=1 \mathrm{~mm}\left(\tau_{\mathrm{b}, 1}\right)$;

- $\mathrm{Y}_{4}=$ escorregamento referente à tensão máxima $\left(\mathrm{S}_{\tau_{\mathrm{b}, \text { máx }}}\right)$.

Para a análise estatística, esses dados foram divididos em quatro blocos:

- Bloco 1 - as cinco variáveis resposta $\left(Y=\tau_{b, \operatorname{máx}}, Y_{1}=\tau_{b, 1} a_{\text {fiss }}, Y_{2}=\tau_{b, 0.1}, Y_{3}=\tau_{b, 1}\right.$ e $Y_{4}=$ $\left.\mathrm{S}_{\tau_{\mathrm{b} \text {,máx }}}\right)$ foram analisadas levando em conta as três variáveis independentes $\left(\mathrm{X}_{1}=\ell_{\mathrm{ef}}\right.$, $\mathrm{X}_{2}=\mathrm{V}_{\mathrm{f}}$ e $\mathrm{X}_{3}=\sigma_{\mathrm{p}}$ ). Todos os dados, de todos os grupos, foram avaliados três vezes: (1) para a variável $\mathrm{X}_{1}$, onde os 108 modelos foram divididos em três sub-grupos de 36, 
levando-se em conta os comprimentos aderentes; (2) para $\mathrm{X}_{2}$, onde os 108 modelos foram divididos em três sub-grupos de 36 , levando-se em conta os volumes de fibra; e (3) para $\mathrm{X}_{3}$, onde os 108 modelos foram divididos em dois sub-grupos de 54, levandose em conta o grau de protensão. Ou seja, foram construídas três Tabelas de Análise de Variância para cada variável resposta, cada tabela levando em conta uma variável independente. Para cada sub-grupo também foi feita a plotagem dos resíduos e a avaliação de Tukey, para um intervalo de confiança (CI) de 95\%.

- Bloco 2 - as cinco variáveis respostas foram divididas em três grupos, um para cada comprimento aderente disponível $\left(\mathrm{X}_{1}\right)$, e analisadas para as outras duas variáveis independentes $\left(\mathrm{X}_{2}\right.$ e $\left.\mathrm{X}_{3}\right)$. Todos os dados foram avaliados duas vezes: (1) para $\mathrm{X}_{2}$, onde os 36 modelos de cada grupo foram divididos em três sub-grupos de 12, levandose em conta os volumes de fibra; e (2) para $\mathrm{X}_{3}$, onde os 36 modelos de cada grupo foram divididos em dois sub-grupos de 18, levando-se em conta o grau de protensão. Ou seja, foram construídas duas Tabelas de Análise de Variância para cada variável resposta, cada tabela levando em conta uma variável independente. Para cada subgrupo também foi feita a plotagem dos resíduos e a avaliação de Tukey, para um intervalo de confiança (CI) de 95\%.

- Bloco 3 - as cinco variáveis respostas foram divididas em três grupos, um para cada volume de fibra $\left(\mathrm{X}_{2}\right)$, e analisadas para as outras duas variáveis independentes $\left(\mathrm{X}_{1} \mathrm{e}\right.$ $\mathrm{X}_{3}$ ). Todos os dados foram avaliados duas vezes: (1) para $\mathrm{X}_{1}$, onde os 36 modelos de cada grupo foram divididos em três sub-grupos de 12, levando-se em conta os volumes de fibra; e (2) para $\mathrm{X}_{3}$, onde os 36 modelos de cada grupo foram divididos em dois sub-grupos de 18, levando-se em conta o grau de protensão. Ou seja, foram construídas duas Tabelas de Análise de Variância para cada variável resposta, cada tabela levando em conta uma variável independente. Para cada sub-grupo também foi feita a plotagem dos resíduos e a avaliação de Tukey, para um intervalo de confiança (CI) de $95 \%$.

- Bloco 4 - as cinco variáveis respostas foram divididas em dois grupos, um para cada grau de protensão $\left(\mathrm{X}_{3}\right)$, e analisadas para as outras duas variáveis independentes $\left(\mathrm{X}_{1} \mathrm{e}\right.$ $\mathrm{X}_{2}$ ). Todos os dados foram avaliados duas vezes: (1) para $\mathrm{X}_{1}$, onde os 36 modelos de cada grupo foram divididos em três sub-grupos de 12, levando-se em conta os comprimentos aderentes; e (2) para $\mathrm{X}_{2}$, onde os 36 modelos de cada grupo foram divididos em três sub-grupos de 12, levando-se em conta o volume de fibras. Ou seja, foram construídas duas Tabelas de Análise de Variância para cada variável resposta, 
cada tabela levando em conta uma variável independente. Para cada sub-grupo também foi feita a plotagem dos resíduos e a avaliação de Tukey, para um intervalo de confiança (CI) de $95 \%$.

Para essas análises, foi utilizado o programa estatístico MINITAB version 13.52.

Após a análise dos dados, concluiu-se que, para um intervalo de confiança de $95 \%$, a maioria dos dados é representativa do problema em estudo, apesar das dispersões de valores apresentadas, exceto para os valores do escorregamento referente à tensão máxima de aderência. Verificou-se, também, que os dados para a tensão de aderência máxima se enquadram numa distribuição amostral normal, e, portanto, as conclusões para essa variável, que é a principal variável em estudo, são confiáveis. A análise completa desses dados se encontra no Apêndice E. A seguir estão listadas as principais conclusões obtidas da análise estatística. Vale lembrar que essas observações têm um caráter estatístico, e objetivaram avaliar a qualidade dos dados obtidos, e não a interpretação física dos mesmos.

- Para o Bloco 1 (todos os dados), analisando-se em função da variável independente $\mathrm{X}_{1}$ (comprimento aderente), exceto para a variável resposta $\mathrm{Y}_{4}=\mathrm{S}_{\tau_{\mathrm{b} \text {,máx }}}$, pode-se dizer que:

○ Os modelos com $\ell_{\mathrm{ef}}=5 \phi_{\mathrm{p}}$ apresentaram os menores valores e as maiores variabilidades;

○ Os modelos com $\ell_{\mathrm{ef}}=7 \phi_{\mathrm{p}}$ e $\ell_{\mathrm{ef}}=15 \phi_{\mathrm{p}}$ apresentaram, praticamente, a mesma variabilidade;

O Os modelos com $\ell_{\mathrm{ef}}=7 \phi_{\mathrm{p}}$ apresentaram os maiores valores;

○ Os modelos para $\mathrm{Y}=\tau_{\mathrm{b} \text {,máx }}$ apresentaram os dados de melhor qualidade;

- Para $Y=\tau_{b, \text { máx }}$, foram significativas as diferenças entre as médias dos três comprimentos aderentes utilizados.

- Para o Bloco 1, analisando-se em função da variável independente $\mathrm{X}_{2}$ (volume de fibras), exceto para a variável resposta $\mathrm{Y}_{4}=\mathrm{S}_{\tau_{\mathrm{b} \text {,máx }}}$, pode-se dizer que:

○ Os modelos com $\mathrm{V}_{\mathrm{f}}=40 \mathrm{~kg} / \mathrm{m}^{3}$ apresentaram os menores valores;

○ Os modelos com $\mathrm{V}_{\mathrm{f}}=60 \mathrm{~kg} / \mathrm{m}^{3}$ apresentaram os maiores valores, exceto para $Y_{1}=\tau_{b, 1}{ }^{a}$ fiss, em que o maior valor foi para $V_{f}=0$, porém a diferença entre eles foi desprezível;

- A variabilidade foi praticamente a mesma para os três volumes de fibras; 


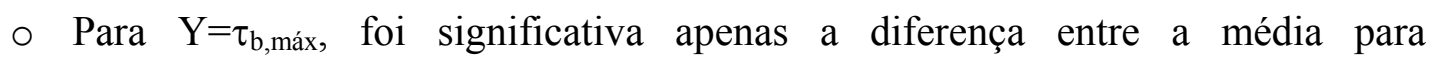
$\mathrm{V}_{\mathrm{f}}=40 \mathrm{~kg} / \mathrm{m}^{3}$ e para $\mathrm{V}_{\mathrm{f}}=60 \mathrm{~kg} / \mathrm{m}^{3}$;

- Para $Y_{1}=\tau_{b, 1} a_{\text {fiss, }}$, verificou-se que as médias para os três volumes de fibras não foram significativamente diferentes, o que indica que, para os volumes utilizados, as fibras de aço não influem na fissuração inicial dos modelos.

- Para o Bloco 1, analisando-se em função da variável independente $\mathrm{X}_{3}$ (grau de protensão), pode-se dizer que:

○ Os modelos sem protensão apresentaram valores significativamente bem maiores do que os pré-tracionados;

- Os modelos pré-tracionados apresentaram uma variabilidade menor, porém a diferença em relação às peças sem protensão foi pequena;

- Para $Y=\tau_{b, \text { máx }}$, foi bastante significativa a diferença entre as médias para as peças sem e com protensão.

- Para o Bloco 1, os resultados da variável $\mathrm{Y}_{4}=\mathrm{S}_{\tau_{\mathrm{b} \text {,máx }}}$ não foram levados em conta, pois esses dados nem apresentaram distribuição amostral normal, nem variabilidade constante, logo não são confiáveis. Isso valeu, na realidade, não apenas para o Bloco 1, mas, também, para todos os outros blocos (2, 3 e 4);

- Para o Bloco 2, para cada comprimento aderente utilizado, observaram-se, de maneira geral, as mesmas tendências do Bloco 1, porém com uma qualidade pior dos dados, ou seja, eles apresentaram variabilidade maior e menos constante e também algumas amostras foram descartadas devido, não só à variabilidade, mas também à não normalidade da distribuição. No geral, observou-se que:

- Para $\ell_{\mathrm{ef}}=7 \phi_{\mathrm{p}}$ e $\ell_{\mathrm{ef}}=15 \phi_{\mathrm{p}}$, os modelos com $\mathrm{V}_{\mathrm{f}}=40 \mathrm{~kg} / \mathrm{m}^{3}$ apresentaram os menores valores e os com $\mathrm{V}_{\mathrm{f}}=60 \mathrm{~kg} / \mathrm{m}^{3}$ os maiores;

○ Para $\ell_{\mathrm{ef}}=5 \phi_{\mathrm{p}}$, os modelos com $\mathrm{V}_{\mathrm{f}}=40 \mathrm{~kg} / \mathrm{m}^{3}$ também apresentaram os menores valores, porém, os modelos com $\mathrm{V}_{\mathrm{f}}=0$ apresentaram os maiores valores, exceto para $\mathrm{Y}=\tau_{\mathrm{b} \text {,máx }}$, em que os valores com $\mathrm{V}_{\mathrm{f}}=0$ e $\mathrm{V}_{\mathrm{f}}=60 \mathrm{~kg} / \mathrm{m}^{3}$ foram praticamente idênticos;

○ Para $\ell_{\mathrm{ef}}=7 \phi_{\mathrm{p}}$ e $\ell_{\mathrm{ef}}=15 \phi_{\mathrm{p}}$, os modelos sem protensão apresentaram os maiores valores, com diferenças significativas em relação aos modelos pré-tracionados;

- Para $\ell_{\mathrm{ef}}=5 \phi_{\mathrm{p}}$, ocorreu o contrário, os modelos pré-tracionados apresentaram valores significativamente maiores do que os modelos sem protensão. 
- Para o Bloco 3, para cada volume de fibra utilizado, observaram-se as mesmas tendências do Bloco 1, porém com uma qualidade pior dos dados, o mesmo que ocorreu para o Bloco 2. De maneira geral, para os três volumes de fibra separadamente, pode-se dizer que:

O Os modelos com $\ell_{\mathrm{ef}}=5 \phi_{\mathrm{p}}$ apresentaram os menores resultados e os com $\ell_{\mathrm{ef}}=7 \phi_{\mathrm{p}}$ os maiores;

O Os modelos com $\ell_{\mathrm{ef}}=15 \phi_{\mathrm{p}}$ apresentaram a menor variabilidade e os com $\ell_{\mathrm{ef}}=5 \phi_{\mathrm{p}}$ a maior;

- Os modelos sem protensão apresentaram os maiores valores, ao passo que os modelos pré-tracionados apresentaram uma variabilidade menor;

- Para $Y=\tau_{b \text {,máx }}$, foi significativa a diferença entre as médias dos modelos com $\ell_{\mathrm{ef}}=5 \phi_{\mathrm{p}}$ e $\ell_{\mathrm{ef}}=15 \phi_{\mathrm{p}}$ em relação à média dos modelos com $\ell_{\mathrm{ef}}=7 \phi_{\mathrm{p}}$.

- Para o Bloco 4, para cada grau de protensão utilizado, observaram-se tendências diferentes: para as peças sem protensão observaram-se as mesmas tendências do Bloco 1, porém com uma qualidade pior dos dados, o mesmo que ocorreu para os Blocos $2 \mathrm{e}$ 3; para as peças pré-tracionadas observaram-se tendências um pouco diferentes das dos blocos anteriores. Na verdade, os dados desse bloco foram os piores, no que se refere à sua qualidade. Eles apresentaram os piores testes de normalidade e de constância da variabilidade. De maneira geral, pode-se dizer que:

- Para as peças sem protensão, os modelos com $\ell_{\mathrm{ef}}=5 \phi_{\mathrm{p}}$ apresentaram os menores valores e os com $\ell_{\mathrm{ef}}=7 \phi_{\mathrm{p}}$ apresentaram não só os maiores valores como também a menor variabilidade;

- Para as peças pré-tracionadas, os modelos com $\ell_{\mathrm{ef}}=15 \phi_{\mathrm{p}}$ apresentaram os menores valores e a menor variabilidade, os com $\ell_{\mathrm{ef}}=7 \phi_{\mathrm{p}}$ apresentaram os maiores valores, e os com $\ell_{\mathrm{ef}}=5 \phi_{\mathrm{p}}$ apresentaram maior variabilidade;

- Para as peças sem protensão, os modelos com $V_{\mathrm{f}}=40 \mathrm{~kg} / \mathrm{m}^{3}$ apresentaram os menores valores e os com $\mathrm{V}_{\mathrm{f}}=60 \mathrm{~kg} / \mathrm{m}^{3}$ os maiores;

○ Para as peças pré-tracionadas, os modelos com $V_{\mathrm{f}}=40 \mathrm{~kg} / \mathrm{m}^{3}$ também apresentaram os menores valores, porém, os modelos com $\mathrm{V}_{\mathrm{f}}=0$ apresentaram os maiores; 
○ Para $Y=\tau_{b \text {,máx }}$ e $\sigma_{\mathrm{p}}=0$, as diferenças entre as médias para os três comprimentos aderentes foram significativas, já para os três volumes de fibras, foi significativa, apenas, a diferença entre as médias de $\mathrm{V}_{\mathrm{f}}=40 \mathrm{~kg} / \mathrm{m}^{3}$ e de $\mathrm{V}_{\mathrm{f}}=60 \mathrm{~kg} / \mathrm{m}^{3}$.

- Em relação à qualidade geral dos dados obtidos, pode-se dizer que:

- Os dados referentes a $\mathrm{Y}_{4}=\mathrm{S}_{\tau}$ b,máx (escorregamento) foram os piores, não sendo possível fazer qualquer tipo de análise de variância para eles;

○ Os dados referentes a $Y=\tau_{b \text {,máx }}$ e a $Y_{1}=\tau_{b, 1} a_{\text {fiss }}$ foram os melhores, para os quais se perderam muito poucos resultados;

- Os dados do Bloco 1 foram os melhores e os do Bloco 4 os piores, tanto em relação à normalidade como à variabilidade;

○ O comprimento aderente e o grau de protensão tiveram muito mais influência na qualidade dos dados do que o volume de fibras, ou seja, entre os três comprimentos, os modelos com $\ell_{\mathrm{ef}}=15 \phi_{\mathrm{p}}$ apresentaram, claramente, os dados de melhor qualidade, e entre os dois graus de protensão, ocorreu o mesmo para os modelos pré-tracionados. Para os três volumes de fibra, não houve variação significativa na qualidade dos dados; não foi possível observar que conjunto de dados apresentou um melhor ou pior desempenho qualitativo.

\subsection{Análise Comparativa dos Resultados Experimentais}

Após a verificação da legitimidade dos dados experimentais, foi feita a análise comparativa entre os diversos grupos das duas séries de prismas. Essa análise foi dividida em quatro partes: (1) análise da fissuração dos modelos; (2) análise do corte dos prismas; (3) análise do comportamento Tensão de aderência versus Escorregamento; e (4) análise dos valores característicos.

\subsubsection{Análise da fissuração dos modelos}

Como já foi comentado, os modelos da Série 2 não apresentaram qualquer tipo de fissuração. A Tabela 5.23 apresenta as características de todos os modelos da Série 1, em relação à fissuração.

A Tabela 5.24 apresenta o resumo da fissuração desses modelos, dividido em blocos de acordo com os parâmetros de ensaio. 
Tabela 5.23 - Características da fissuração dos modelos de arrancamento da Série 1.

\begin{tabular}{|c|c|c|c|c|}
\hline Grupo & Modelo & $\begin{array}{c}\text { Fissuras } \\
\text { Longitudinais }\end{array}$ & $\begin{array}{c}\text { Fissuras } \\
\text { Transversais }\end{array}$ & Fissuras de Retração \\
\hline \multirow{6}{*}{1} & $\mathrm{P} 7 \phi \quad 0 \quad 1$ & $\mathrm{OK}$ & $\mathrm{OK}$ & $\overline{---}$ \\
\hline & P7申_0_2 & OK & 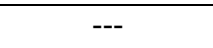 & --- \\
\hline & P7 $\phi \_0 \_3$ & OK & OK & --- \\
\hline & P7 & OK & OK & --- \\
\hline & P7 & OK & OK & Algumas nas faces laterais \\
\hline & P7ф_0_6 & OK & OK & Algumas nas faces laterais \\
\hline \multirow{6}{*}{2} & $\mathrm{P} 7 \phi \mathrm{s} \quad 0 \quad 1$ & $\overline{\mathrm{OK}}$ & $\mathrm{OK}$ & Muito poucas nas laterais \\
\hline & P7 & OK & $\begin{array}{ll}-- \\
\end{array}$ & Muito poucas nas laterais \\
\hline & P7 $\phi$ s_0_3 & OK & --- & Muito poucas nas laterais \\
\hline & P7申s_0_4 & OK & $\mathrm{OK}$ & Algumas nas faces laterais \\
\hline & P7 $\phi s \_0 \_5$ & OK & --- & Algumas nas faces laterais \\
\hline & P7 $\phi$ s_0_6 & --- & --- & Poucas nas faces laterais \\
\hline \multirow{6}{*}{3} & $\mathrm{P} 7 \phi 401$ & $\mathrm{OK}$ & $\mathrm{OK}$ & --- \\
\hline & P7申_40_2 & --- & --- & --- \\
\hline & P7 $1 \_40 \_3$ & OK & $\mathrm{OK}$ & --- \\
\hline & P7ф_40_4 & OK & $\mathrm{OK}$ & --- \\
\hline & P7ф_40_5 & --- & $\mathrm{OK}$ & Poucas nas faces laterais \\
\hline & P7申_40_6 & OK & $\mathrm{OK}$ & --- \\
\hline \multirow{6}{*}{4} & $\mathrm{P} 7 \phi \mathrm{s} \quad 401$ & $\mathrm{OK}$ & $\mathrm{OK}$ & --- \\
\hline & P7申s_40_2 & OK & --- & --- \\
\hline & P7申s_40_3 & --- & --- & --- \\
\hline & P7申s_40_4 & OK & --- & --- \\
\hline & P7申s_40_5 & --- & --- & --- \\
\hline & P7申s_40_6 & --- & --- & Poucas nas faces laterais \\
\hline \multirow{6}{*}{5} & $\mathrm{P} 7 \phi \quad 60 \quad 1$ & $\overline{---}$ & --- & --- \\
\hline & $\mathrm{P} 7 \phi \_60 \_2$ & --- & OK & --- \\
\hline & P7ф_60_3 & OK & $\mathrm{OK}$ & --- \\
\hline & P7ф_60_4 & OK & --- & --- \\
\hline & P7ф_60_5 & OK & $\mathrm{OK}$ & --- \\
\hline & P7ф_60_6 & $\mathrm{OK}$ & --- & --- \\
\hline \multirow{6}{*}{6} & $\mathrm{P} 7 \phi \mathrm{s} \quad 60 \quad 1$ & $-\overline{--}$ & --- & --- \\
\hline & P7 & --- & --- & --- \\
\hline & P7 $\phi s \_60 \_3$ & OK & $\mathrm{OK}$ & --- \\
\hline & P7申s_60_4 & --- & --- & --- \\
\hline & P7申s_60_5 & OK & $\begin{array}{l}-- \\
\end{array}$ & --- \\
\hline & P7 $9 \mathrm{~s} \_60 \_6$ & $\mathrm{OK}$ & --- & --- \\
\hline \multirow{6}{*}{7} & $\mathrm{P} 15 \phi \quad 0 \quad 1$ & $\mathrm{OK}$ & --- & --- \\
\hline & P15ф_0_2 & OK & --- & --- \\
\hline & P15ф_0_3 & OK & --- & Muitas nas faces laterais \\
\hline & P15ф_0_4 & OK & --- & Muitas nas faces laterais \\
\hline & P15ф_0_5 & OK & --- & --- \\
\hline & P15ф_0_6 & OK & --- & Poucas nas faces laterais \\
\hline \multirow{6}{*}{8} & $\begin{array}{lllll}\mathrm{P} 15 \phi \mathrm{s} & 0 & 1\end{array}$ & $\overline{---}$ & --- & --- \\
\hline & P15 $\phi s \_0 \_2$ & $\mathrm{OK}$ & $\begin{array}{ll}-- \\
\end{array}$ & --- \\
\hline & P15фs_0_3 & --- & --- & Muitas nas faces laterais \\
\hline & P15申s_0_4 & OK & --- & Muitas nas faces laterais \\
\hline & P15фs_0_5 & OK & --- & Algumas nas faces laterais \\
\hline & P15фs_0_6 & --- & --- & Muito poucas nas laterais \\
\hline
\end{tabular}


Tabela 5.23 - Continuação

\begin{tabular}{|c|c|c|c|c|}
\hline Grupo & Modelo & $\begin{array}{c}\text { Fissuras } \\
\text { Longitudinais }\end{array}$ & $\begin{array}{c}\text { Fissuras } \\
\text { Transversais }\end{array}$ & Fissuras de Retração \\
\hline \multirow{6}{*}{9} & $\begin{array}{llll}\mathrm{P} 15 \phi & 40 & 1\end{array}$ & $\overline{---}$ & $\overline{---}$ & $\overline{---}$ \\
\hline & 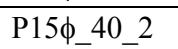 & --- & --- & --- \\
\hline & $\mathrm{P} 15 \phi \_40 \_3$ & OK & $\begin{array}{l}-- \\
\end{array}$ & --- \\
\hline & P15ф_40_4 & OK & OK & --- \\
\hline & P15ф_40_5 & OK & $\mathrm{OK}$ & --- \\
\hline & P15ф_40_6 & $\mathrm{OK}$ & --- & --- \\
\hline \multirow{6}{*}{10} & $\begin{array}{llll}\mathrm{P} 15 \phi \mathrm{s} & 40 & 1\end{array}$ & $\overline{---}$ & --- & --- \\
\hline & P15 $\phi$ s_40_2 & --- & --- & --- \\
\hline & P15 15 s_40_3 & OK & --- & Algumas nas faces laterais \\
\hline & 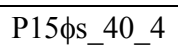 & OK & --- & Muito poucas nas laterais \\
\hline & P15 $\phi$ s_40_5 & $\mathrm{OK}$ & $\begin{array}{ll}-- \\
\end{array}$ & Muito poucas nas laterais \\
\hline & P15 $\$$ s_40_6 & --- & --- & Muito poucas nas laterais \\
\hline \multirow{6}{*}{11} & $\begin{array}{lllll}\mathrm{P} 15 \phi & 60 & 1\end{array}$ & $\overline{\mathrm{OK}}$ & $\overline{\mathrm{OK}}$ & --- \\
\hline & P15ф_60_2 & OK & OK & Algumas na face exposta \\
\hline & P15ф_60_3 & $\mathrm{OK}$ & $\begin{array}{ll}-- \\
\end{array}$ & --- \\
\hline & P15ф_60_4 & $\mathrm{OK}$ & --- & --- \\
\hline & P15ф_60_5 & $\mathrm{OK}$ & --- & --- \\
\hline & P15ф_60_6 & $\mathrm{OK}$ & --- & --- \\
\hline \multirow{6}{*}{12} & $\begin{array}{llll}\mathrm{P} 15 \phi \mathrm{s} & 60 & 1\end{array}$ & $\overline{\mathrm{OK}}$ & $\overline{---}$ & -- \\
\hline & P15 15 s_60_2 & --- & --- & --- \\
\hline & P15 1 s_60_3 & --- & --- & --- \\
\hline & P15 15s_60_4 & --- & --- & --- \\
\hline & P15фs_60_5 & $\mathrm{OK}$ & --- & --- \\
\hline & 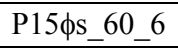 & $\mathrm{OK}$ & --- & --- \\
\hline
\end{tabular}

Tabela 5.24 - Resumo da fissuração dos modelos de arrancamento da Série 1.

\begin{tabular}{|c|c|c|c|c|c|c|}
\hline \multirow[b]{2}{*}{ Bloco } & \multicolumn{3}{|c|}{ Fissuração Longitudinal } & \multicolumn{3}{|c|}{ Fissuração Transversal } \\
\hline & $\begin{array}{c}\mathbf{N} \\
\left(\mathrm{n}^{\mathrm{o}} \text { total de }\right. \\
\text { modelos })\end{array}$ & $\begin{array}{c}\mathbf{n} \\
\left(\mathrm{n}^{\mathrm{o}} \text { de modelos }\right. \\
\text { com fissura })\end{array}$ & $\begin{array}{l}\frac{\mathbf{n}}{\mathbf{N}} \\
(\%)\end{array}$ & $\begin{array}{c}\mathbf{N} \\
\left(\mathrm{n}^{\mathrm{o}} \text { total de }\right. \\
\text { modelos })\end{array}$ & $\begin{array}{c}\mathbf{n} \\
\left(\mathrm{n}^{\mathrm{o}} \text { de modelos }\right. \\
\text { com fissura })\end{array}$ & $\begin{array}{l}\frac{\mathbf{n}}{\mathbf{N}} \\
(\%)\end{array}$ \\
\hline $7 \phi$ & 18 & 14 & 78 & 18 & 12 & 67 \\
\hline $7 \phi \mathrm{s}$ & 18 & 10 & 56 & 18 & 4 & 22 \\
\hline $7 \phi+7 \phi s$ & 36 & 24 & 67 & 36 & 16 & 44 \\
\hline $15 \phi$ & 18 & 16 & 89 & 18 & 4 & 22 \\
\hline $15 \phi \mathrm{s}$ & 18 & 5 & 28 & 18 & 0 & 0 \\
\hline $15 \phi+15 \phi \mathrm{s}$ & 36 & 21 & 58 & 36 & 4 & 11 \\
\hline $7 \phi+15 \phi$ & 36 & 30 & 83 & 36 & 16 & 44 \\
\hline $7 \phi s+15 \phi s$ & 36 & 15 & 42 & 36 & 4 & 11 \\
\hline $0 \mathrm{~kg} / \mathrm{m}^{3}$ & 24 & 17 & 71 & 24 & 7 & 29 \\
\hline $40 \mathrm{~kg} / \mathrm{m}^{3}$ & 24 & 12 & 50 & 24 & 7 & 29 \\
\hline $60 \mathrm{~kg} / \mathrm{m}^{3}$ & 24 & 16 & 67 & 24 & 6 & 25 \\
\hline Todos & 72 & 45 & 63 & 72 & 20 & 28 \\
\hline
\end{tabular}


A primeira observação a ser feita é em relação às diferenças entre os modelos das Séries 1 e 2. Os modelos da Série 2, apesar de terem comprimentos aderentes menores, não apresentaram nenhum tipo de fissura, o que confirma o resultado de várias pesquisas, de que quanto maior o cobrimento das armaduras, menor é a possibilidade da ruptura por fendilhamento. Segundo COLLINS \& MITCHELL (1997), o comprimento de ancoragem necessário para evitar o fendilhamento diminui com o aumento do cobrimento, o aumento da distância entre as armaduras, e o aumento da armadura de confinamento.

Analisando-se as Tabelas 5.23 e 5.24, para os modelos da Série 1, pode-se dizer que:

- Entre todos os grupos, os modelos pré-tracionados com $\ell_{\mathrm{ef}}=7 \phi_{\mathrm{p}}$ (Grupo 1) foram os que mais apresentaram fissuras, longitudinais e transversais;

- Desconsiderando-se o grau de protensão, os modelos com comprimentos aderentes menores $\left(7 \phi_{\mathrm{p}}=9 \mathrm{~cm}\right)$ apresentaram mais fissuração do que os modelos com comprimentos aderentes maiores $\left(15 \phi_{\mathrm{p}}=19 \mathrm{~cm}\right)$, tanto longitudinal como transversal, porém as diferenças para a fissuração transversal foram bem mais significativas;

- Levando-se em conta o grau de protensão e o comprimento aderente, os modelos prétracionados com $\ell_{\mathrm{ef}}=15 \phi_{\mathrm{p}}$ apresentaram a maior fissuração longitudinal, e os modelos pré-tracionados com $\ell_{\mathrm{ef}}=7 \phi_{\mathrm{p}}$ apresentaram a maior fissuração transversal;

- Independentemente do comprimento aderente, os modelos pré-tracionados apresentaram uma fissuração muito maior do que as peças sem protensão, tanto longitudinal como transversal;

- O volume de fibras não afetou significativamente a fissuração dos modelos.

\subsubsection{Análise do corte dos prismas}

Após os ensaios, alguns prismas foram cortados, e observou-se o seguinte:

- As fibras ficaram bem distribuídas em todo o prisma, tanto para os modelos da Série 1 como para os da Série 2, como mostra a Figura 5.30.
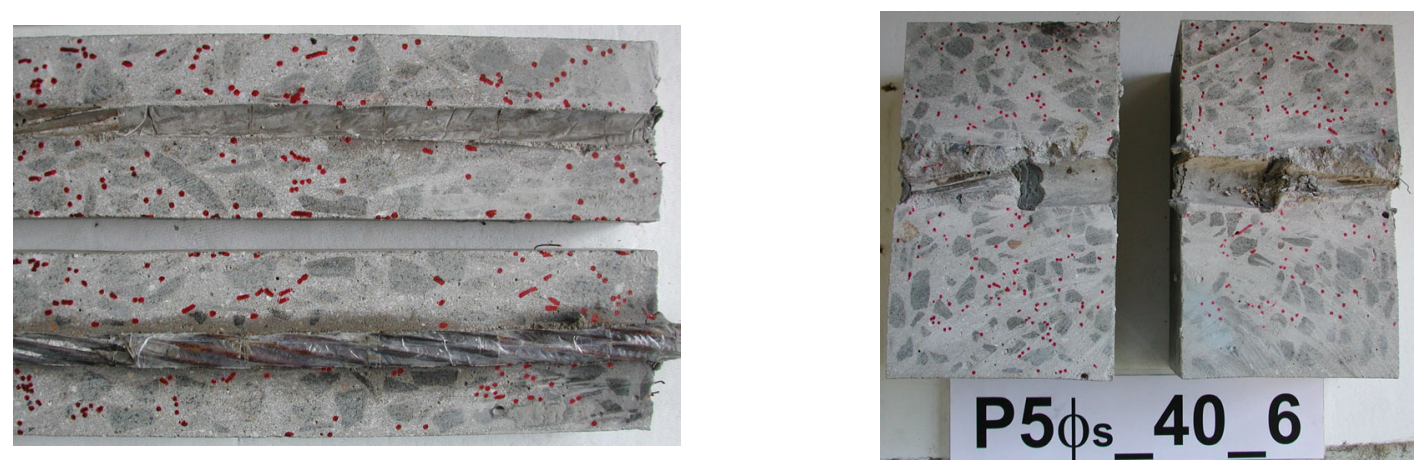

Figura 5.30 - Distribuição das fibras no interior dos prismas das Séries 1 e 2 , respectivamente. 
- Houve uma maior concentração do agregado graúdo (brita 1) na parte inferior dos prismas da Série 1, como mostra a Figura 5.31.
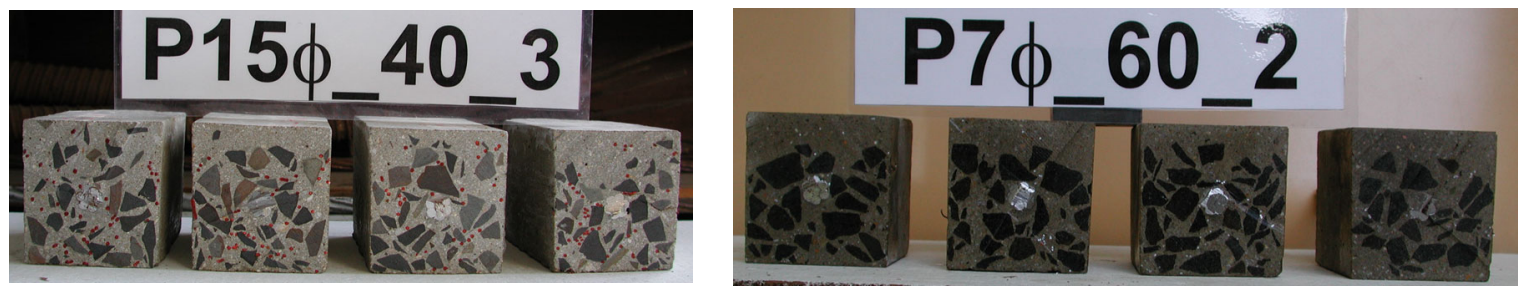

Figura 5.31 - Corte transversal dos prismas da Série 1, concentração maior de brita 1 na parte inferior.

- Os dois modos de retirada da aderência funcionaram muito bem. Tanto o uso de filme plástico como o uso de tubo de PVC, como indica a Figura 5.32.
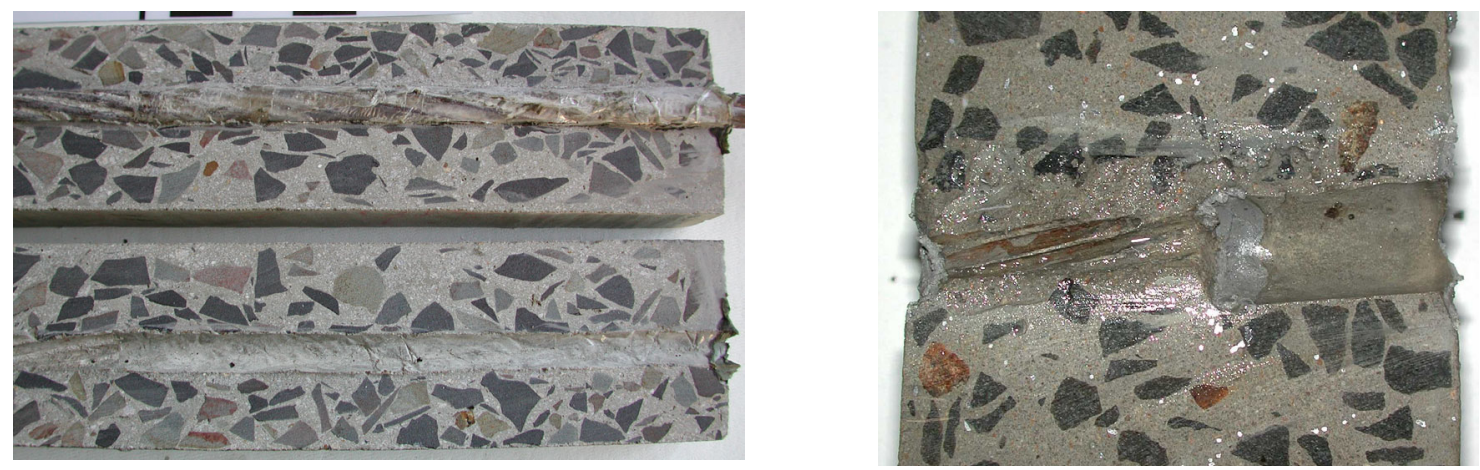

Figura 5.23 - Retirada da aderência dos prismas das Séries 1 e 2, respectivamente.

- Alguns poucos prismas apresentaram vazios pequenos no seu interior.

- Apesar da menor concentração de brita 1 na face superior dos prismas da Série 1 , as fissuras não ocorreram, preferencialmente, nessa face, como ilustra a Figura 5.33. Isso pode ser explicado pelo uso do CAR, em que a matriz de cimento apresenta resistência elevada, em alguns casos até superior à do agregado graúdo.

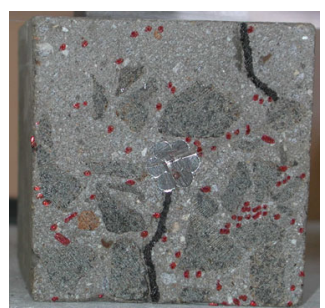

P7ф_60_2

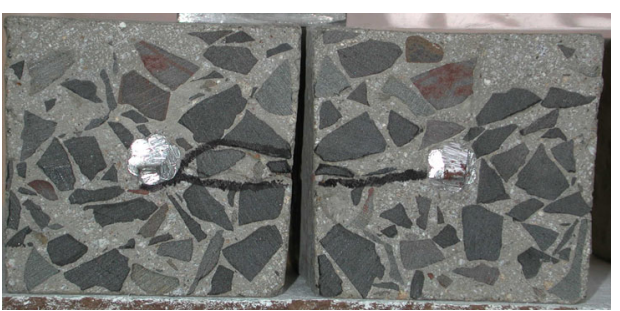

P15ф_0_4

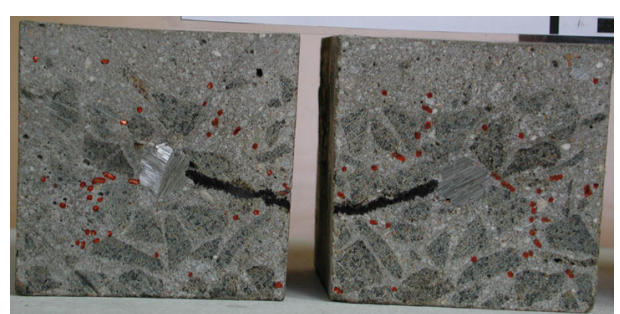

P15ф_40_2

Figura 5.33 - Detalhe interno das fissuras dos prismas da Série 1.

\subsubsection{Análise do comportamento Tensão de aderência versus Escorregamento}

Os prismas apresentaram, basicamente, cinco comportamentos distintos, todos eles apresentando ruptura por arrancamento, que são descritos a seguir. 
- Tipo 1: comportamento de concreto confinado, com ruptura por arrancamento, cujo gráfico Tensão de aderência versus Escorregamento típico se encontra na Figura 5.34.

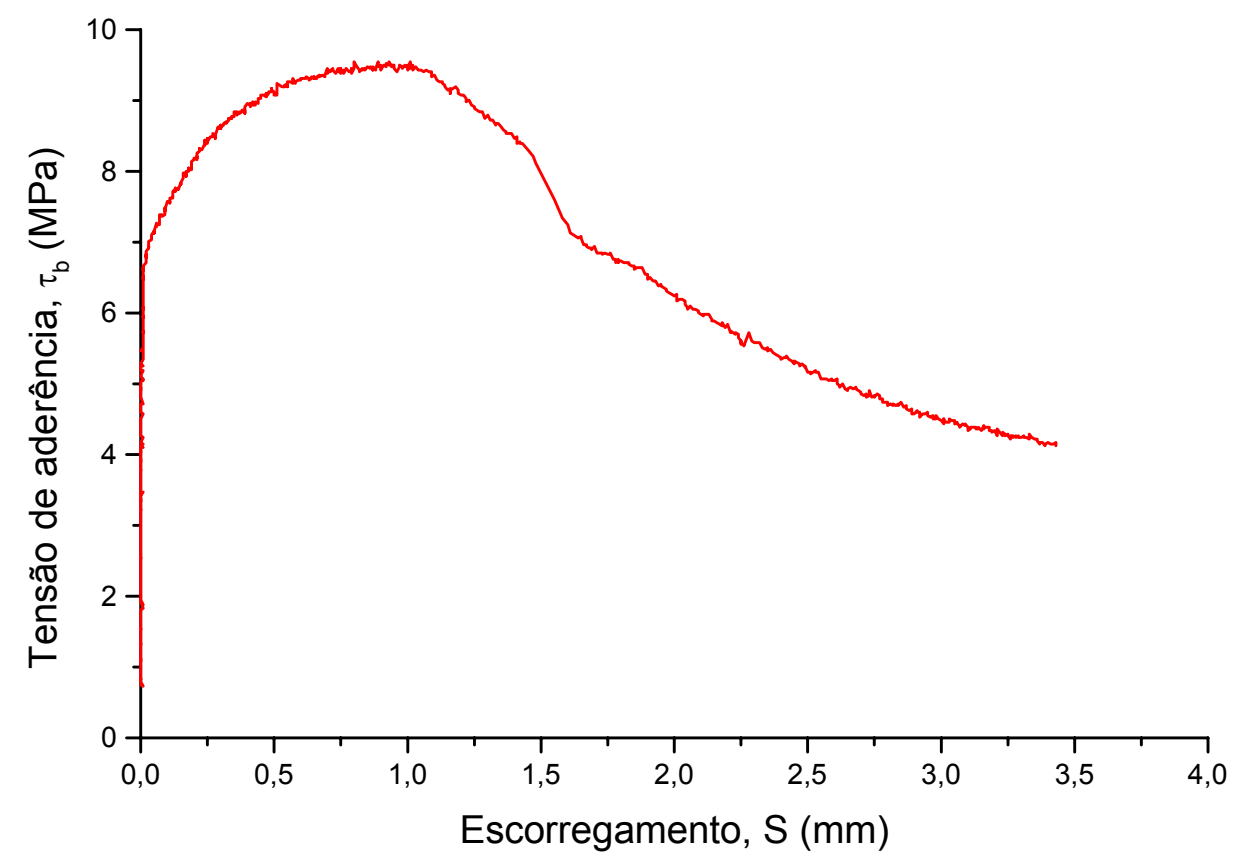

Figura 5.34 - Comportamento aderente típico para concreto confinado (P7фs_0_4).

- Tipo 2: comportamento de concreto não-confinado, com ruptura por arrancamento (Figura 5.35).

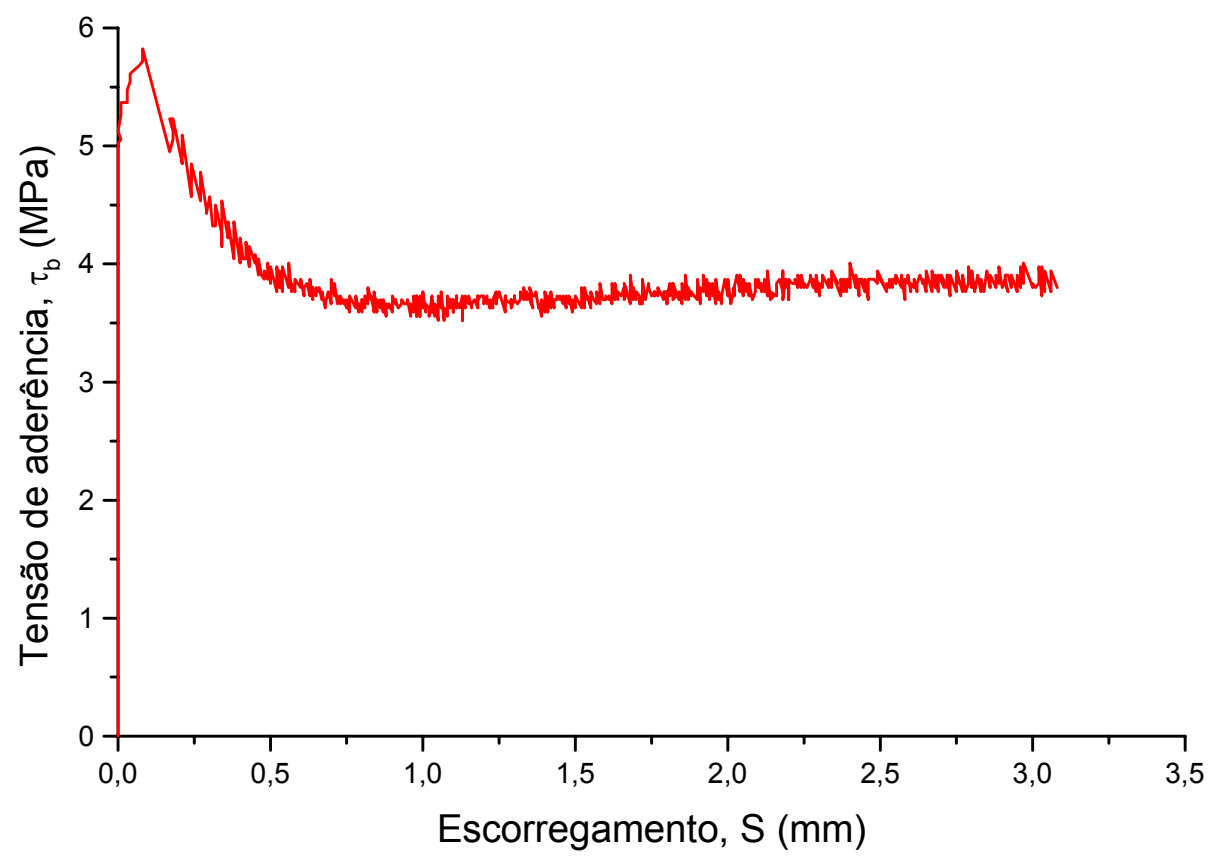

Figura 5.35 - Comportamento aderente típico para concreto não-confinado (P5ф_40_1). 
- Tipo 3: comportamento inicial de concreto confinado, porém com perda de aderência ocorrendo para um escorregamento maior, indicando maior ductilidade (Figura 5.36).

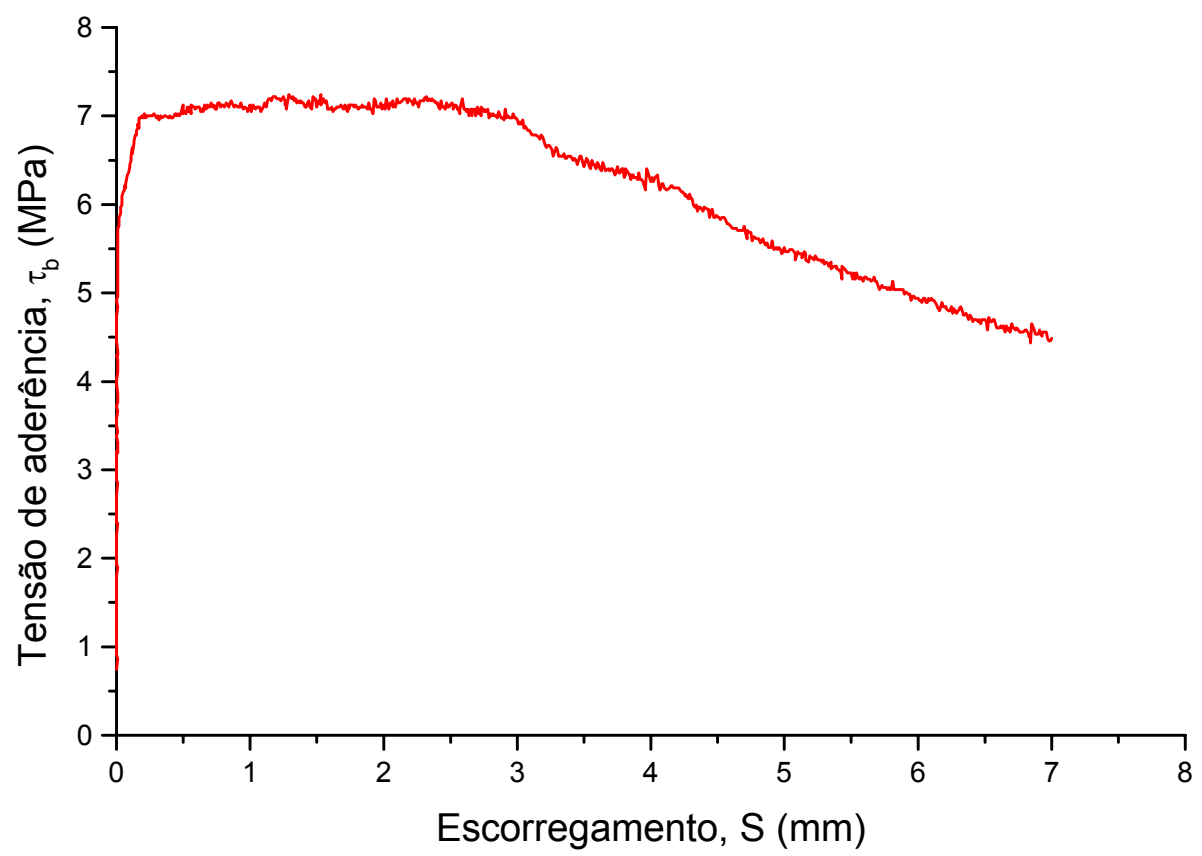

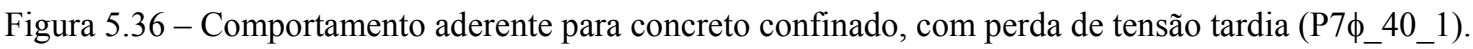

- Tipo 4: comportamento de concreto confinado, com ruptura por arrancamento, com queda de carga bem suave, ou sem queda, até o final da leitura do relógio, cujo gráfico Tensão de aderência versus Escorregamento típico se encontra na Figura 5.37.

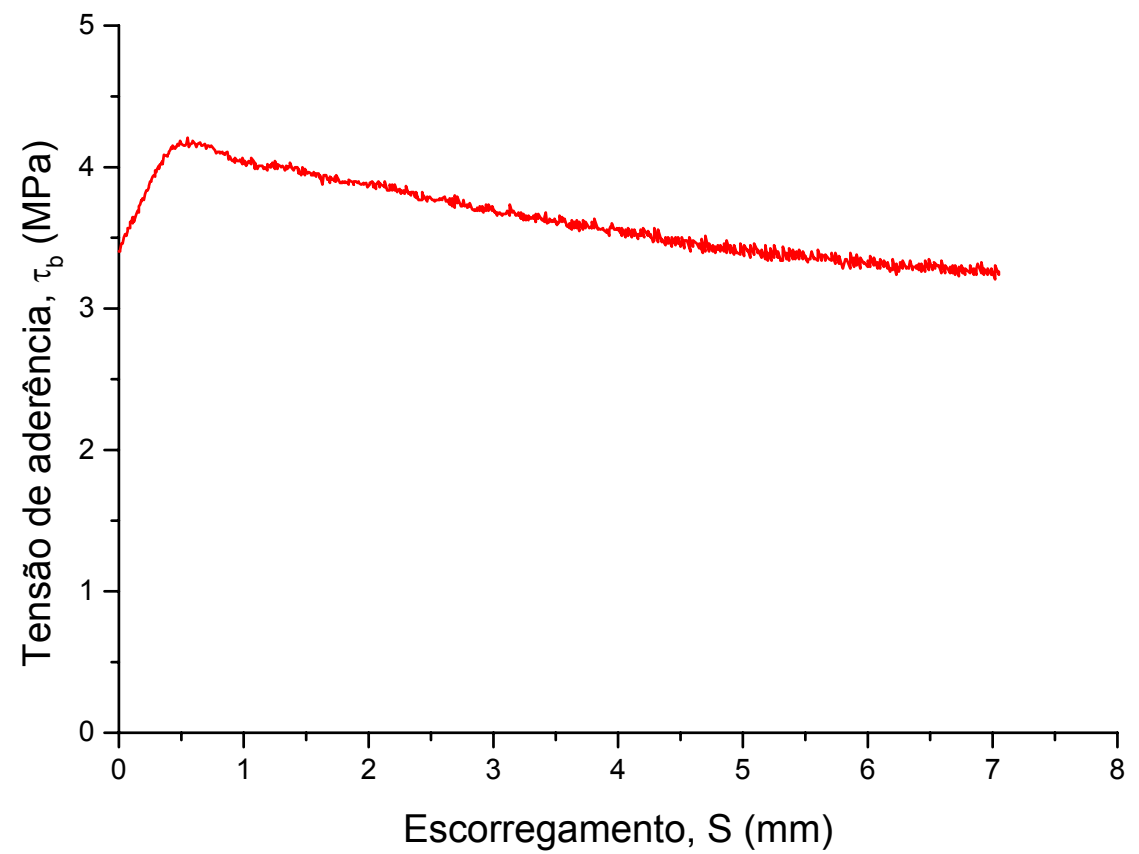

Figura 5.37 - Comportamento aderente para concreto confinado, sem perda brusca de tensão (P15 _ $\left._{0} \_1\right)$. 
- Tipo 5: comportamento atípico, com um patamar de tensão constante e aumento de escorregamento, após a perda da linearidade (Figura 5.38).

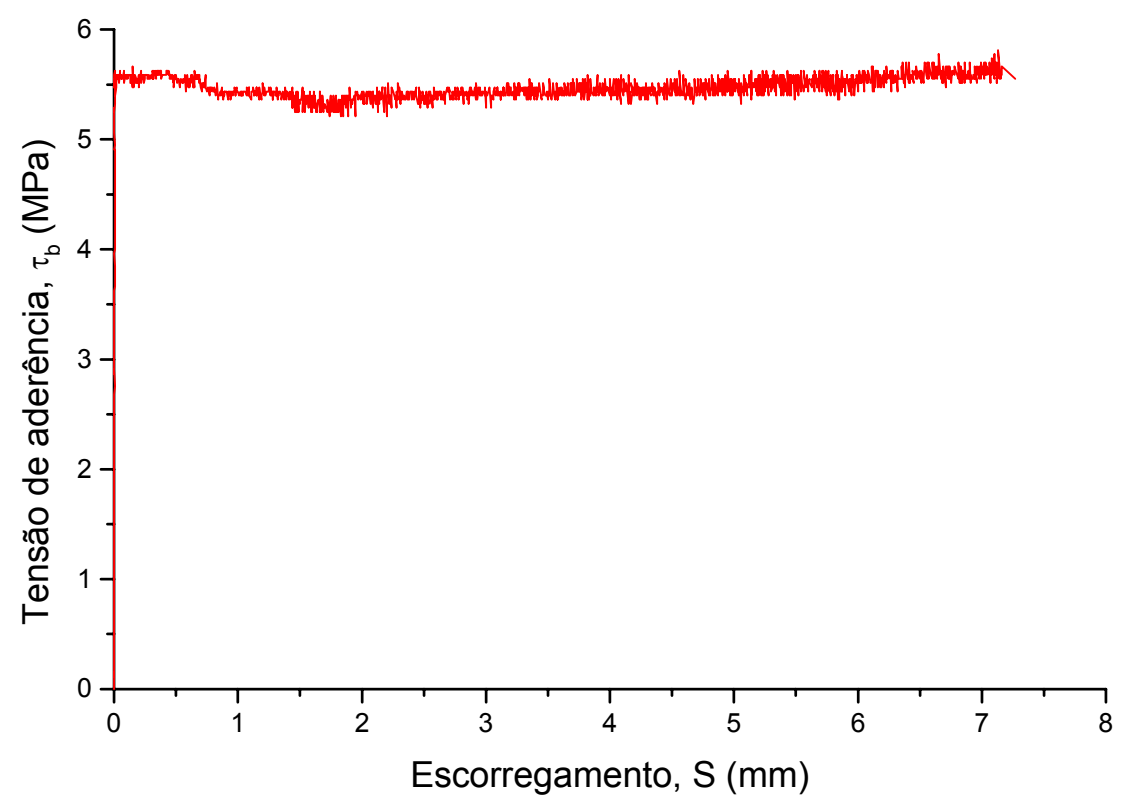

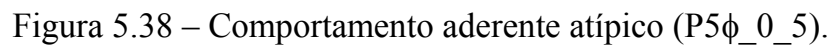

A Tabela 5.25 apresenta as características de todos os modelos em relação ao tipo de comportamento aderente. A Tabela 5.26 apresenta o resumo do tipo de comportamento aderente desses modelos, dividido em blocos de acordo com os parâmetros de ensaio.

Tabela 5.25 - Modelos de arrancamento e o tipo de comportamento aderente.

\begin{tabular}{|c|c|c|c|c|c|c|}
\hline Série & Grupo & Modelo & $\begin{array}{c}\text { Tipo de Comportamento } \\
\text { Aderente }\end{array}$ & $\begin{array}{c}\text { Grau de } \\
\text { Protensão }\end{array}$ & $\begin{array}{c}\text { Consumo de } \\
\text { Fibras }\left(\mathrm{kg} / \mathrm{m}^{3}\right)\end{array}$ & $\begin{array}{c}\text { Comprimento } \\
\text { Aderente }\end{array}$ \\
\hline \multirow{24}{*}{1} & \multirow{6}{*}{1} & $\mathrm{P} 7 \phi \quad 0 \quad 1$ & 3 & \multirow{6}{*}{$0,8 \mathrm{f}_{\mathrm{ptk}}$} & \multirow{12}{*}{0} & \multirow{24}{*}{$7 \phi_{\mathrm{p}}=9 \mathrm{~cm}$} \\
\hline & & $\mathrm{P} 7 \phi \quad 0 \quad 2$ & 1 & & & \\
\hline & & P7 $1 \_0 \_3$ & 3 & & & \\
\hline & & $\mathrm{P} 7 \phi \_0 \_4$ & 1 & & & \\
\hline & & $\mathrm{P} 7 \phi \_0 \_5$ & 1 & & & \\
\hline & & $\mathrm{P} 7 \phi \_0 \_6$ & 1 & & & \\
\hline & \multirow{6}{*}{2} & P7 $\phi \mathrm{s} \_0 \_1$ & 3 & \multirow{6}{*}{0} & & \\
\hline & & \begin{tabular}{|lllll}
$\mathrm{P} 7 \phi \mathrm{s}$ & 0 & 2
\end{tabular} & 1 & & & \\
\hline & & P7 7 s_0_3 & 5 (com encruamento) & & & \\
\hline & & P7 $\phi s \_0 \_4$ & 1 & & & \\
\hline & & $\mathrm{P} 7 \phi \mathrm{s} \quad 0 \quad 5$ & 1 & & & \\
\hline & & $\mathrm{P} 7 \phi \mathrm{s} \quad 06$ & 5 (com encruamento) & & & \\
\hline & \multirow{6}{*}{3} & $\mathrm{P} 7 \phi 401$ & 3 & \multirow{6}{*}{$0,8 \mathrm{f}_{\text {ptk }}$} & \multirow{12}{*}{40} & \\
\hline & & $\mathrm{P} 7 \phi \quad 40 \_2$ & 3 & & & \\
\hline & & $\mathrm{P} 7 \phi \quad 40 \_3$ & 5 & & & \\
\hline & & P7 $7 \_40 \_4$ & 3 & & & \\
\hline & & $\mathrm{P} 7 \phi \_40 \_5$ & 3 & & & \\
\hline & & $\mathrm{P} 7 \phi \quad 40 \_6$ & 1 & & & \\
\hline & \multirow{6}{*}{4} & $\mathrm{P} 7 \phi \mathrm{s} \_40 \_1$ & 3 & \multirow{6}{*}{0} & & \\
\hline & & P7 $\phi$ s_40_2 & 3 & & & \\
\hline & & P7 $\phi \mathrm{s} \_40 \_3$ & 3 & & & \\
\hline & & \begin{tabular}{|l|l|} 
P7_ $40 \_4$ \\
\end{tabular} & 1 & & & \\
\hline & & P7 $\phi \mathrm{s} \_40 \_5$ & 3 & & & \\
\hline & & P7 $\phi \mathrm{s} \_40 \_6$ & 3 & & & \\
\hline
\end{tabular}


Tabela 5.25 - Continuação

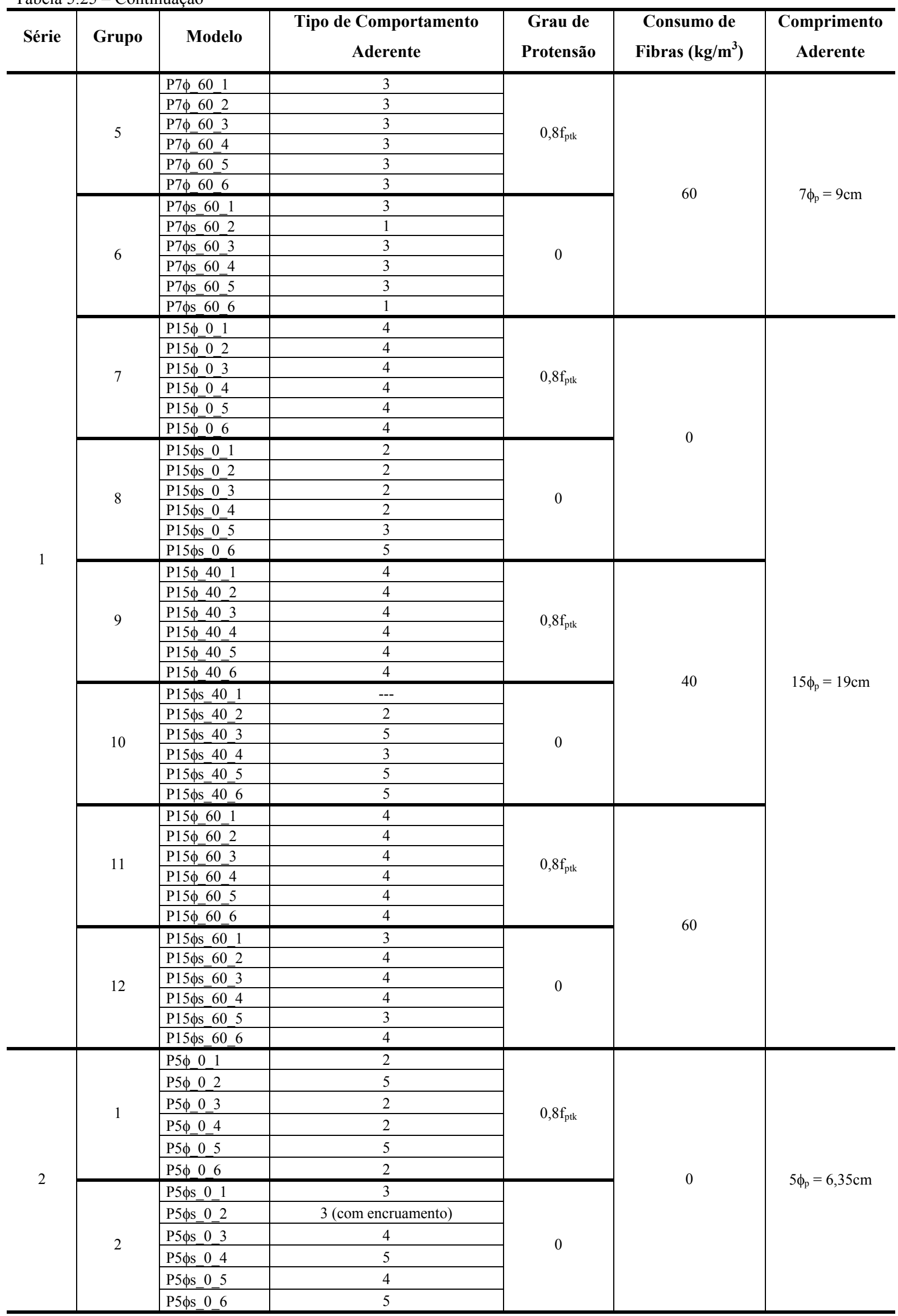


Tabela 5.25 - Continuação

\begin{tabular}{|c|c|c|c|c|c|c|}
\hline Série & Grupo & Modelo & $\begin{array}{c}\text { Tipo de Comportamento } \\
\text { Aderente }\end{array}$ & $\begin{array}{c}\text { Grau de } \\
\text { Protensão }\end{array}$ & $\begin{array}{c}\text { Consumo de } \\
\text { Fibras }\left(\mathrm{kg} / \mathrm{m}^{3}\right)\end{array}$ & $\begin{array}{c}\text { Comprimento } \\
\text { Aderente }\end{array}$ \\
\hline \multirow{24}{*}{2} & \multirow{6}{*}{3} & P5 4401 & 2 & \multirow{6}{*}{$0,8 \mathrm{f}_{\mathrm{ptk}}$} & \multirow{12}{*}{40} & \multirow{24}{*}{$5 \phi_{\mathrm{p}}=6,35 \mathrm{~cm}$} \\
\hline & & Р5ф 402 & 5 (com encruamento) & & & \\
\hline & & P5ф 403 & 4 & & & \\
\hline & & $\mathrm{P} 5 \phi 40 \_4$ & 2 & & & \\
\hline & & $\mathrm{P} 5 \phi_{-} 40 \_5$ & 5 & & & \\
\hline & & $\mathrm{P} 5 \phi \_40 \_6$ & 5 & & & \\
\hline & \multirow{6}{*}{4} & P5 $\phi s \_40 \_1$ & 5 & \multirow{6}{*}{0} & & \\
\hline & & P5 $\phi \mathrm{s} 402$ & 4 & & & \\
\hline & & P5 $\phi \mathrm{s} 403$ & 4 & & & \\
\hline & & P5 $\phi \mathrm{s} 40 \quad 4$ & 4 & & & \\
\hline & & P5 $\phi \mathrm{s} 405$ & 4 & & & \\
\hline & & P5 $\phi$ s_40_6 & 4 & & & \\
\hline & & $\mathrm{P} 5 \phi \_60 \_1$ & 4 & & & \\
\hline & & $\mathrm{P} 5 \phi \quad 60 \_2$ & 4 & & & \\
\hline & 5 & P5 $6 \_60 \_3$ & 5 & $08 \mathrm{f}$ & & \\
\hline & & P5 & 5 & $0, \mathrm{~d}_{\mathrm{ptk}}$ & & \\
\hline & & P5ф_60_5 & 2 & & & \\
\hline & & P5ф_60_6 & 5 & & 60 & \\
\hline & & P5 $\phi s \_60 \_1$ & 4 & & 80 & \\
\hline & & P5 $\phi s \_60 \_2$ & 4 & & & \\
\hline & 6 & P5 5 s_60_3 & 4 & 0 & & \\
\hline & 0 & P5 $\phi s \_60 \_4$ & 4 & 0 & & \\
\hline & & P5 & 1 (com encruamento) & & & \\
\hline & & P5 $\phi \mathrm{s} 606$ & 4 & & & \\
\hline
\end{tabular}

Tabela 5.26 - Resumo dos tipos de comportamento aderente dos modelos das Séries 1 e 2.

\begin{tabular}{|c|c|c|c|c|c|c|c|c|c|c|c|}
\hline \multirow[b]{3}{*}{ Bloco } & \multirow[b]{3}{*}{$\mathbf{N}$} & \multicolumn{10}{|c|}{ Tipo do Comportamento Aderente } \\
\hline & & \multicolumn{2}{|c|}{ Tipo 1} & \multicolumn{2}{|c|}{ Tipo 2} & \multicolumn{2}{|c|}{ Tipo 3} & \multicolumn{2}{|c|}{ Tipo 4} & \multicolumn{2}{|c|}{ Tipo 5} \\
\hline & & $\mathbf{n}_{1}$ & $\begin{array}{c}\frac{\mathrm{n}}{\mathrm{N}} \\
(\%)\end{array}$ & $\mathbf{n}_{2}$ & $\begin{array}{l}\frac{\mathrm{n}}{\mathrm{N}} \\
(\%)\end{array}$ & $\mathbf{n}_{3}$ & $\begin{array}{c}\frac{\mathrm{n}}{\mathrm{N}} \\
(\%)\end{array}$ & $\mathbf{n}_{4}$ & $\begin{array}{l}\frac{\mathrm{n}}{\mathrm{N}} \\
(\%)\end{array}$ & $\mathbf{n}_{5}$ & $\begin{array}{l}\frac{n}{N} \\
(\%)\end{array}$ \\
\hline $5 \phi$ & 18 & --- & 0 & 7 & 39 & $\overline{---}$ & 0 & 3 & 17 & 8 & 44 \\
\hline $5 \phi \mathrm{s}$ & 18 & 1 & 6 & --- & 0 & 2 & 11 & 12 & 67 & 3 & 17 \\
\hline $5 \phi+5 \phi \mathrm{s}$ & 36 & 1 & 3 & 7 & 19 & 2 & 6 & 15 & 42 & 11 & 31 \\
\hline $7 \phi$ & 18 & 5 & 28 & --- & 0 & 12 & 67 & --- & 0 & 1 & 6 \\
\hline $7 \phi \mathrm{s}$ & 18 & 6 & 33 & --- & 0 & 10 & 56 & --- & 0 & 2 & 11 \\
\hline $7 \phi+7 \phi s$ & 36 & 11 & 31 & --- & 0 & 22 & 61 & --- & 0 & 3 & 8 \\
\hline $15 \phi$ & 18 & --- & 0 & --- & 0 & --- & 0 & 18 & 100 & --- & 0 \\
\hline $15 \phi \mathrm{s}$ & 18 & --- & 0 & 5 & 29 & 4 & 24 & 4 & 24 & 4 & 24 \\
\hline $15 \phi+15 \phi \mathrm{s}$ & 36 & --- & 0 & 5 & 14 & 4 & 11 & 22 & 63 & 4 & 11 \\
\hline $7 \phi+15 \phi+5 \phi$ & 54 & 5 & 9 & 7 & 13 & 12 & 22 & 21 & 39 & 9 & 17 \\
\hline $7 \phi s+15 \phi s+5 \phi s$ & 54 & 7 & 13 & 5 & 9 & 16 & 30 & 16 & 30 & 9 & 17 \\
\hline 0 & 36 & 7 & 19 & 8 & 22 & 6 & 17 & 8 & 22 & 7 & 19 \\
\hline $40 \mathrm{~kg} / \mathrm{m}^{3}$ & 36 & 2 & 6 & 3 & 9 & 10 & 29 & 12 & 34 & 8 & 23 \\
\hline $60 \mathrm{~kg} / \mathrm{m}^{3}$ & 36 & 3 & 8 & 1 & 3 & 12 & 33 & 17 & 47 & 3 & 8 \\
\hline Todos & 108 & 12 & 11 & 12 & 11 & 28 & 26 & 37 & 35 & 18 & 17 \\
\hline
\end{tabular}


A primeira observação a ser feita é em relação à variabilidade dos resultados. Em alguns casos, mesmo dentro de um grupo, composto de seis modelos teoricamente idênticos, há uma grande variação do comportamento aderente das peças. Analisando-se as Tabelas 5.25 e 5.26 pode-se dizer que:

- Os modelos com $\ell_{\mathrm{ef}}=5 \phi_{\mathrm{p}}$ apresentaram, na sua maioria, comportamento Tensão de aderência versus Escorregamento do Tipo 4, típico de concreto confinado, com elevada ductilidade, sem indicação de ruptura para escorregamentos de até, aproximadamente, $\mathrm{S}=8 \mathrm{~mm}$;

- Os modelos com $\ell_{\mathrm{ef}}=7 \phi_{\mathrm{p}}$ apresentaram, na sua maioria, comportamento Tensão de aderência versus Escorregamento do Tipo 3, típico de concreto confinado, também com elevada ductilidade, porém com ruptura por arrancamento tardia, ou seja, para um escorregamento grande;

- Os modelos com $\ell_{\mathrm{ef}}=15 \phi_{\mathrm{p}}$ apresentaram, na sua maioria, comportamento Tensão de aderência versus Escorregamento do Tipo 4, da mesma forma que os modelos com $\ell_{\mathrm{ef}}=5 \phi_{\mathrm{p}}$;

- Os modelos pré-tracionados apresentaram, na sua maioria, comportamento Tensão de aderência versus Escorregamento do Tipo 4;

- Os modelos sem protensão apresentaram, na sua maioria, comportamento Tensão de aderência versus Escorregamento dos Tipos 3 e 4;

- Os modelos sem fibras de aço, com $V_{\mathrm{f}}=0$, apresentaram os cinco tipos de comportamento, de maneira mais ou menos uniforme, com uma pequena tendência para os Tipos 2 e 4 . O Tipo 2 é típico de concreto não-confinado, com ruptura por arrancamento;

- Os modelos com $\mathrm{V}_{\mathrm{f}}=40 \mathrm{~kg} / \mathrm{m}^{3}$ e $\mathrm{V}_{\mathrm{f}}=60 \mathrm{~kg} / \mathrm{m}^{3}$ apresentaram, na sua maioria, comportamento Tensão de aderência versus Escorregamento dos Tipos 3 e 4, com uma tendência levemente maior para o do Tipo 4;

- Os modelos com $\ell_{\mathrm{ef}}=5 \phi_{\mathrm{p}}$ foram os que mais apresentaram o comportamento Tensão de aderência versus Escorregamento do Tipo 5, que foi considerado um comportamento atípico, pois não se enquadra em nenhum modelo, nem analítico nem numérico, representativo da aderência encontrado na literatura técnica sobre o tema;

- Os modelos com $\ell_{\mathrm{ef}}=7 \phi_{\mathrm{p}}$ foram os que mais apresentaram o comportamento Tensão de aderência versus Escorregamento do Tipo 1, que é típico de concreto confinado, com ruptura por arrancamento, e é o modelo analítico mais encontrado na literatura. 


\subsubsection{Análise dos valores característicos}

A partir dos valores característicos de cada grupo de prisma, foram elaboradas três tabelas, de acordo com os parâmetros que se pretendia avaliar. A Tabela 5.27 mostra os resultados agrupados em função do comprimento aderente. A Tabela 5.28 mostra os resultados agrupados em função do volume de fibras. E a Tabela 5.29 mostra os resultados agrupados em função do grau de protensão. Nessas tabelas, cada linha indica a média dos seis modelos do grupo a que ela se refere. Por exemplo, na Tabela 5.27 a primeira linha depois da dos títulos representa a média dos seis modelos do Grupo 1, da Série 2 (de P5ф_0_1 a P5ф_0_6) e a sexta linha representa a média dos seis modelos do Grupo 6, da Série 2 (de

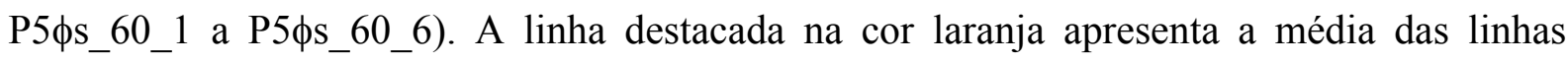
anteriores. Logo, a primeira linha em laranja representa a média das seis médias para os modelos com $\ell_{\mathrm{ef}}=5 \phi_{\mathrm{p}}$. Na décima coluna das tabelas, logo após a coluna para $\mathrm{S}_{\tau_{\mathrm{b} \text {,máx }}}$, é fornecido o valor da tensão de aderência $\left(\tau_{\mathrm{b}, \mathrm{FIB}}\right)$ segundo a FIB Bulletin 1 (1999), cujo cálculo já foi descrito no Capítulo 3. Essas considerações valem para as três tabelas a seguir.

Tabela 5.27 - Médias dos resultados em função do comprimento aderente disponível $\left(\ell_{\mathrm{ef}}\right)$.

\begin{tabular}{|c|c|c|c|c|c|c|c|c|c|c|c|}
\hline $\begin{array}{c}\text { Médias } \\
\text { dos } \\
\text { Modelo }\end{array}$ & $\begin{array}{c}\ell_{\text {ef }} \\
(\mathrm{cm})\end{array}$ & $\begin{array}{c}\mathbf{f}_{\mathbf{c}} \\
(\mathrm{MPa})\end{array}$ & $\begin{array}{l}\tau_{\mathrm{b}, 1^{\mathrm{a}} \text { fiss }} \\
(\mathrm{MPa})\end{array}$ & $\begin{array}{c}\tau_{\mathrm{b}, 0.1 \mathrm{~mm}} \\
(\mathrm{MPa})\end{array}$ & $\begin{array}{l}\tau_{\mathrm{b}, 1 \mathrm{~mm}} \\
(\mathrm{MPa})\end{array}$ & $\begin{array}{l}\tau_{\mathrm{b}, 3 \mathrm{~mm}} \\
(\mathrm{MPa})\end{array}$ & $\begin{array}{c}\tau_{\mathrm{b}, \text { máx }} \\
(\mathrm{MPa})\end{array}$ & $\begin{array}{c}\mathbf{S}_{\tau \mathbf{b}, \mathbf{m a x}} \\
(\mathrm{mm})\end{array}$ & $\begin{array}{c}\tau_{\mathrm{b}, \mathrm{FIB}} \\
(\mathrm{MPa})\end{array}$ & $\begin{array}{l}\tau_{b, 1^{\text {afiss }}} \\
I \tau_{\mathrm{b} \text {,máx }}\end{array}$ & $\begin{array}{c}\tau_{\mathrm{b}, \mathrm{FIB}} / \tau_{\mathrm{b}} \\
\text { máx }\end{array}$ \\
\hline $\mathrm{P} 5 \phi \_0$ & \multirow{6}{*}{6,35} & 77,54 & 7,15 & 6,84 & 6,00 & 6,00 & 7,84 & 0,85 & 4,35 & 0,90 & 0,59 \\
\hline P5 $\phi s \_0$ & & 77,54 & 2,58 & 3,02 & 3,14 & 3,57 & 3,91 & 2,99 & 4,35 & 0,64 & 1,21 \\
\hline $\begin{array}{l}\text { P5 } \phi \_40 \\
\end{array}$ & & 66,14 & 4,29 & 4,23 & 4,04 & 4,44 & 5,04 & 1,55 & 4,12 & 0,80 & 0,92 \\
\hline P5 $\phi s \_40$ & & 66,14 & 1,37 & 1,84 & 2,85 & 3,68 & 3,80 & 3,17 & 4,12 & 0,33 & 1,11 \\
\hline P5 $\phi \_60$ & & 71,21 & 4,39 & 4,50 & 4,66 & 5,29 & 5,91 & 5,12 & 4,22 & 0,71 & 0,76 \\
\hline P5 $\phi s \_60$ & & 71,21 & 3,45 & 3,88 & 4,85 & 5,47 & 6,65 & 7,10 & 4,22 & 0,53 & 0,65 \\
\hline Médias & & 71,63 & 3,87 & 4,05 & 4,26 & 4,74 & 5,53 & 3,46 & 4,23 & 0,65 & 0,87 \\
\hline P7 $\phi \_0$ & \multirow{6}{*}{9,00} & 59,30 & 5,51 & 6,63 & 7,02 & 3,69 & 7,78 & 0,87 & 3,95 & 0,70 & 0,51 \\
\hline P7 $\phi$ s_0 & & 67,32 & 7,88 & 8,50 & 9,36 & 4,93 & 9,99 & 1,64 & 4,15 & 0,79 & 0,42 \\
\hline P7ф_40 & & 73,54 & 5,48 & 6,13 & 6,62 & 3,07 & 6,97 & 1,66 & 4,27 & 0,79 & 0,63 \\
\hline P7 $\phi$ s_40 & & 72,98 & 7,76 & 8,57 & 9,28 & 4,60 & 10,43 & 1,72 & 4,26 & 0,74 & 0,41 \\
\hline $\mathrm{P} 7 \phi \_60$ & & 74,69 & 6,19 & 7,45 & 8,53 & 3,58 & 8,78 & 0,50 & 4,29 & 0,71 & 0,49 \\
\hline $\mathrm{P} 7 \phi \mathrm{s} \_60$ & & 74,94 & 7,76 & 8,99 & 10,91 & 6,90 & 11,77 & 1,92 & 4,30 & 0,66 & 0,37 \\
\hline Médias & & 70,46 & 6,76 & 7,71 & 8,62 & 4,46 & 9,29 & 1,39 & 4,20 & 0,73 & 0,47 \\
\hline P15 $\phi \_0$ & \multirow{6}{*}{19,00} & 49,45 & 3,64 & 4,28 & 4,57 & 3,97 & 4,84 & 0,44 & 3,71 & 0,75 & 0,77 \\
\hline P15 $\phi$ s_0 & & 58,69 & 6,03 & 6,48 & 6,11 & 5,51 & 7,44 & 2,58 & 3,93 & 0,82 & 0,55 \\
\hline $\mathrm{P} 15 \phi_{-} 40$ & & 72,87 & 3,77 & 4,30 & 4,76 & 3,03 & 5,00 & 1,22 & 4,26 & 0,76 & 0,89 \\
\hline P15 $\phi s \_40$ & & 73,98 & 5,75 & 6,31 & 6,35 & 2,36 & 6,78 & 1,90 & 4,28 & 0,86 & 0,65 \\
\hline P15 $\phi \_60$ & & 74,69 & 4,24 & 5,08 & 5,94 & 2,03 & 6,10 & 1,13 & 4,29 & 0,69 & 0,71 \\
\hline P15 $\phi$ s_60 & & 74,94 & 7,08 & 7,84 & 8,54 & 7,08 & 9,22 & 3,53 & 4,30 & 0,77 & 0,47 \\
\hline Médias & & 67,44 & 5,08 & 5,71 & 6,04 & 4,00 & 6,57 & 1,80 & 4,13 & 0,77 & 0,67 \\
\hline
\end{tabular}


Tabela 5.28 - Médias dos resultados em função do volume de fibras $\left(\mathrm{V}_{\mathrm{f}}\right)$.

\begin{tabular}{|c|c|c|c|c|c|c|c|c|c|c|c|}
\hline $\begin{array}{c}\text { Médias } \\
\text { dos } \\
\text { Modelo }\end{array}$ & $\begin{array}{c}\ell_{\text {ef }} \\
(\mathrm{cm})\end{array}$ & $\begin{array}{c}\mathbf{f}_{\mathrm{c}} \\
(\mathrm{MPa})\end{array}$ & $\begin{array}{l}\tau_{\mathrm{b}, 1^{\mathrm{a} f i s s}} \\
(\mathrm{MPa})\end{array}$ & $\begin{array}{c}\tau_{\mathrm{b}, 0.1 \mathrm{~mm}} \\
(\mathrm{MPa})\end{array}$ & $\begin{array}{l}\tau_{\mathrm{b}, 1 \mathrm{~mm}} \\
(\mathrm{MPa})\end{array}$ & $\begin{array}{l}\tau_{\mathrm{b}, 3 \mathrm{~mm}} \\
(\mathrm{MPa})\end{array}$ & $\begin{array}{l}\tau_{\mathrm{b} \text {,máx }} \\
(\mathrm{MPa})\end{array}$ & $\begin{array}{c}\mathbf{S}_{\tau \mathbf{b}, \max } \\
(\mathrm{mm})\end{array}$ & $\begin{array}{c}\tau_{\mathrm{b}, \mathrm{FIB}} \\
(\mathrm{MPa})\end{array}$ & $\begin{array}{l}\tau_{b, 1^{\text {afiss }}} \\
I \tau_{\mathrm{b}, \text { máx }}\end{array}$ & $\begin{array}{c}\tau_{\mathrm{b}, \mathrm{FlB}} / \tau_{\mathrm{b}}, \\
\text { máx }\end{array}$ \\
\hline $\mathrm{P} 5 \phi$ & \multirow[t]{2}{*}{6,35} & 77,54 & 7,15 & 6,84 & 6,00 & 6,00 & 7,84 & 0,85 & 4,35 & 0,90 & 0,56 \\
\hline P5 $\phi s \_0$ & & 77,54 & 2,58 & 3,02 & 3,14 & 3,57 & 3,91 & 2,99 & 4,35 & 0,64 & 1,15 \\
\hline P7申_0 & \multirow[t]{2}{*}{9,00} & 59,30 & 5,51 & 6,63 & 7,02 & 3,69 & 7,78 & 0,87 & 3,95 & 0,70 & 0,56 \\
\hline P7 7 s_0 & & 67,32 & 7,88 & 8,50 & 9,36 & 4,93 & 9,99 & 1,64 & 4,15 & 0,79 & 0,42 \\
\hline $\mathrm{P} 15 \phi_{-} 0$ & \multirow[t]{2}{*}{19,00} & 49,45 & 3,64 & 4,28 & 4,57 & 3,97 & 4,84 & 0,44 & 3,71 & 0,75 & 0,92 \\
\hline $\mathrm{P} 15 \phi \mathrm{s} \_0$ & & 58,69 & 6,03 & 6,48 & 6,11 & 5,51 & 7,44 & 2,58 & 3,93 & 0,82 & 0,60 \\
\hline \multicolumn{2}{|l|}{ Médias } & 64,97 & 5,46 & 5,96 & 6,03 & 4,61 & 6,97 & 1,56 & 4,07 & 0,77 & 0,70 \\
\hline $\mathrm{P} 5 \phi \_40$ & \multirow[t]{2}{*}{6,35} & 66,14 & 4,29 & 4,23 & 4,04 & 4,44 & 5,04 & 1,55 & 4,12 & 0,80 & 0,95 \\
\hline P5 $\phi$ s_40 & & 66,14 & 1,37 & 1,84 & 2,85 & 3,68 & 3,80 & 3,17 & 4,12 & 0,33 & 1,14 \\
\hline $\mathrm{P} 7 \phi_{-} 40$ & \multirow[t]{2}{*}{9,00} & 73,54 & 5,48 & 6,13 & 6,62 & 3,07 & 6,97 & 1,66 & 4,27 & 0,79 & 0,62 \\
\hline P7 $\phi$ s_40 & & $\begin{array}{l}72,98 \\
\end{array}$ & 7,76 & 8,57 & 9,28 & 4,60 & 10,43 & 1,72 & 4,26 & 0,74 & 0,40 \\
\hline$\overline{\mathrm{P} 15 \phi \_40}$ & \multirow[t]{2}{*}{19,00} & 72,87 & 3,77 & 4,30 & 4,76 & 3,03 & 5,00 & 1,22 & 4,26 & 0,76 & 0,87 \\
\hline P15 $\phi s \_40$ & & 73,98 & 5,75 & 6,31 & 6,35 & 2,36 & 6,78 & 1,90 & 4,28 & 0,86 & 0,63 \\
\hline \multicolumn{2}{|l|}{ Médias } & 70,94 & 4,74 & 5,23 & 5,65 & 3,53 & 6,34 & 1,87 & 4,22 & 0,71 & 0,77 \\
\hline $\mathrm{P} 5 \phi \_60$ & \multirow[t]{2}{*}{6,35} & 71,21 & 4,39 & 4,50 & 4,66 & 5,29 & 5,91 & 5,12 & 4,22 & 0,71 & 0,75 \\
\hline P5 $\phi$ s_60 & & 71,21 & 3,45 & 3,88 & 4,85 & 5,47 & 6,65 & 7,10 & 4,22 & 0,53 & 0,64 \\
\hline$P 7 \phi_{-} 60$ & \multirow[t]{2}{*}{9,00} & 74,69 & 6,19 & 7,45 & 8,53 & 3,58 & 8,78 & 0,50 & 4,29 & 0,71 & 0,47 \\
\hline P7 $\phi$ s_60 & & 74,94 & 7,76 & 8,99 & 10,91 & 6,90 & 11,77 & 1,92 & 4,30 & 0,66 & 0,35 \\
\hline $\mathrm{P} 15 \phi \_60$ & \multirow[t]{2}{*}{19,00} & 74,69 & 4,24 & 5,08 & 5,94 & 2,03 & 6,10 & 1,13 & 4,29 & 0,69 & 0,68 \\
\hline P15 $\phi s \_60$ & & 74,94 & 7,08 & 7,84 & 8,54 & 7,08 & 9,22 & 3,53 & 4,30 & 0,77 & 0,45 \\
\hline Médias & & 73,61 & 5,52 & 6,29 & 7,24 & 5,06 & 8,07 & 3,22 & 4,27 & 0,68 & 0,56 \\
\hline
\end{tabular}

Tabela 5.29 - Médias dos resultados em função do grau de protensão $\left(\sigma_{p}\right)$

\begin{tabular}{|c|c|c|c|c|c|c|c|c|c|c|c|}
\hline $\begin{array}{c}\text { Médias } \\
\text { dos } \\
\text { Modelo }\end{array}$ & $\begin{array}{c}\ell_{\text {ef }} \\
(\mathrm{cm})\end{array}$ & $\begin{array}{c}\mathbf{f}_{\mathbf{c}} \\
(\mathrm{MPa})\end{array}$ & $\begin{array}{c}\tau_{b, 1^{\text {afiss }}} \\
(\mathrm{MPa})\end{array}$ & $\begin{array}{c}\tau_{\mathrm{b}, 0.1 \mathrm{~mm}} \\
(\mathrm{MPa})\end{array}$ & $\begin{array}{r}\tau_{\mathrm{b}, 1 \mathrm{~mm}} \\
(\mathrm{MPa})\end{array}$ & $\begin{array}{r}\tau_{\mathrm{b}, 3 \mathrm{~mm}} \\
(\mathrm{MPa})\end{array}$ & $\begin{array}{c}\tau_{\mathrm{b} \text {,máx }} \\
(\mathrm{MPa})\end{array}$ & $\begin{array}{c}\mathbf{S}_{\tau \mathbf{b}, \max } \\
(\mathrm{mm})\end{array}$ & $\begin{array}{c}\tau_{\mathrm{b}, \mathrm{FIB}} \\
(\mathrm{MPa})\end{array}$ & $\begin{array}{l}\tau_{b, 1^{\text {afiss }}} \\
\tau_{\tau_{\text {b,máx }}}\end{array}$ & $\begin{array}{c}\tau_{\mathrm{b}, \mathrm{FIB}} / \tau_{\mathrm{b}} \\
\text { máx }\end{array}$ \\
\hline P5 $\phi \_0$ & & 77,54 & 7,15 & 6,84 & 6,00 & 6,00 & 7,84 & 0,85 & 4,35 & 0,90 & 0,56 \\
\hline $\begin{array}{l}\mathrm{P} 15 \phi \_0 \\
\end{array}$ & & 49,45 & 3,64 & 4,28 & 4,57 & 3,97 & 4,84 & 0,44 & 3,71 & 0,75 & 0,92 \\
\hline P5 $\phi \_40$ & & 66,14 & 4,29 & 4,23 & 4,04 & 4,44 & 5,04 & 1,55 & 4,12 & 0,80 & 0,95 \\
\hline P5 $\phi \_60$ & & 71,21 & 4,39 & 4,50 & 4,66 & 5,29 & 5,91 & 5,12 & 4,22 & 0,71 & 0,75 \\
\hline $\mathrm{P} 7 \phi \_60$ & & 74,69 & 6,19 & 7,45 & 8,53 & 3,58 & 8,78 & 0,50 & 4,29 & 0,71 & 0,47 \\
\hline P15 $\phi \_60$ & & 74,69 & 4,24 & 5,08 & 5,94 & 2,03 & 6,10 & 1,13 & 4,29 & 0,69 & 0,68 \\
\hline Médias & & 68,82 & 4,96 & 5,49 & 5,79 & 3,90 & 6,47 & 1,48 & 4,16 & 0,76 & 0,71 \\
\hline P5 $\phi$ s_0 & & 77,54 & 2,58 & 3,02 & 3,14 & 3,57 & 3,91 & 2,99 & 4,35 & 0,64 & 1,15 \\
\hline P7 $\phi$ s_40 & & 72,98 & 7,76 & 8,57 & 9,28 & 4,60 & 10,43 & 1,72 & 4,26 & 0,74 & 0,40 \\
\hline P15 $\phi s \_40$ & & 73,98 & 5,75 & 6,31 & 6,35 & 2,36 & 6,78 & 1,90 & 4,28 & 0,86 & 0,63 \\
\hline P5 $\phi$ s_60 & & 71,21 & 3,45 & 3,88 & 4,85 & 5,47 & 6,65 & 7,10 & 4,22 & 0,53 & 0,64 \\
\hline P7 $\phi$ s_60 & & 74,94 & 7,76 & 8,99 & 10,91 & 6,90 & 11,77 & 1,92 & 4,30 & 0,66 & 0,35 \\
\hline P15 $\phi s \_60$ & & 74,94 & 7,08 & 7,84 & 8,54 & 7,08 & 9,22 & 3,53 & 4,30 & 0,77 & 0,45 \\
\hline Médias & & 70,86 & 5,52 & 6,16 & 6,82 & 4,90 & 7,78 & 2,95 & 4,21 & 0,68 & 0,64 \\
\hline
\end{tabular}

A partir da análise das Tabelas 5.27 a 5.29, observa-se que:

- Para a tensão de aderência máxima, os modelos com $\ell_{\mathrm{ef}}=7 \phi_{\mathrm{p}}$ apresentam os maiores valores, e os modelos com $\ell_{\mathrm{ef}}=5 \phi_{\mathrm{p}}$ os menores;

- Os modelos com $\mathrm{V}_{\mathrm{f}}=60 \mathrm{~kg} / \mathrm{m}^{3}$ apresentam resultados bem superiores aos demais. Isso indica que para $\mathrm{V}_{\mathrm{f}}=40 \mathrm{~kg} / \mathrm{m}^{3}$ não há ganho de aderência em relação a $\mathrm{V}_{\mathrm{f}}=0 \mathrm{~kg} / \mathrm{m}^{3}$; 
- Os resultados obtidos com um comprimento de ancoragem $\ell_{\mathrm{b}}=15 \phi_{\mathrm{p}} \quad(19 \mathrm{~cm})$ apresentam não só um comportamento mais uniforme, como também valores mais próximos das prescrições normativas;

- A aderência melhora com o tempo, apesar da fissuração de retração e de resistências do concreto à compressão menores;

- Independentemente da variação da resistência do concreto à compressão, o coeficiente de variação da tensão de aderência ficou acima de $20 \%$ para os três compósitos;

- Quando se avaliam vários parâmetros ao mesmo tempo, independentemente de pequenas variações individuais, o coeficiente de variação geral é em torno de $25 \%$;

- Os modelos sem protensão apresentaram um desempenho superior aos modelos prétracionados;

- Em relação ao comprimento aderente, os modelos com $\ell_{\mathrm{ef}}=5 \phi_{\mathrm{p}}$ apresentaram os valores mais próximos aos da FIB Bulletin1 (1999);

- Em relação ao volume de fibras, os modelos com $V_{\mathrm{f}}=40 \mathrm{~kg} / \mathrm{m}^{3}$ apresentaram os valores mais próximos aos da FIB Bulletin1 (1999);

- Em relação ao grau de protensão, os modelos pré-tracionados apresentaram os valores mais próximos aos da FIB Bulletin1 (1999);

- Independentemente do parâmetro analisado, a relação entre a tensão de aderência para a primeira fissura $\left(\tau_{b, 1^{a} \text { fiss }}\right)$ e a tensão máxima de aderência $\left(\tau_{b \text {,máx }}\right)$ fica em torno de $72 \%$.

\subsection{Confrontação dos Resultados Teóricos e Experimentais}

Após a análise dos resultados experimentais, obtiveram-se os valores representativos para a tensão de aderência para os parâmetros de ensaio utilizados. Foram levados em conta, apenas, os resultados dos modelos sem protensão, para que se pudesse fazer a comparação com os valores teóricos. Foram utilizados os valores para a tensão máxima de aderência. A Tabela 5.30 apresenta os resultados obtidos.

As diferenças são significativas entre os valores da tensão de aderência para os três comprimentos aderentes. Já para os três volumes de fibra, é significativa apenas a diferença entre as tensões de aderência para $\mathrm{V}_{\mathrm{f}}=40 \mathrm{~kg} / \mathrm{m}^{3}$ e para $\mathrm{V}_{\mathrm{f}}=60 \mathrm{~kg} / \mathrm{m}^{3}$. Isso já foi constatado anteriormente.

Os valores teóricos não-normalizados e admitindo uma resistência do concreto à compressão de $\mathrm{f}_{\mathrm{c}}=68 \mathrm{MPa}$, obtidos no Capítulo 3 , variaram de $\tau_{\mathrm{b}}=5,5 \mathrm{MPa}$ a $\tau_{\mathrm{b}}=15,94 \mathrm{MPa}$, 
dependendo da equação e parâmetro utilizados. A Tabela 5.31 apresenta os valores teóricos e experimentais, normalizados, obtidos para a tensão de aderência, e, também, os valores fornecidos pelas prescrições normativas FIB Bulletin 1 (1999) e ACI 318 (2002), para as armaduras pré-tracionadas. Percebe-se que houve um aumento de $28 \%$ na tensão de aderência para o compósito com $\mathrm{V}_{\mathrm{f}}=60 \mathrm{~kg} / \mathrm{m}^{3}$ em relação ao com $\mathrm{V}_{\mathrm{f}}=0$.

Tabela 5.30 - Valores médios experimentais normalizados para a tensão máxima de aderência.

\begin{tabular}{|c|c|c|c|c|c|c|}
\hline \multirow[t]{2}{*}{ Parâmetros de ensaio } & \multicolumn{3}{|c|}{ Comprimentos aderentes } & \multicolumn{3}{|c|}{$\begin{array}{c}\text { Consumos de fibra } \\
\left(\mathrm{kg} / \mathrm{m}^{3}\right)\end{array}$} \\
\hline & $5 \phi_{p}$ & $7 \phi_{p}$ & $15 \phi_{p}$ & $\mathbf{0}$ & 40 & 60 \\
\hline $\begin{array}{l}\text { Tensão máxima de aderência } \\
\text { normalizada, } \bar{\tau}_{b, \text { máx }}(\mathrm{MPa})\end{array}$ & 4,8 & 10,7 & 7,8 & 7,2 & 6,9 & 9,2 \\
\hline
\end{tabular}

Tabela 5.31 - Valores teóricos e experimentais para a tensão de aderência.

\begin{tabular}{|c|c|c|c|c|}
\hline Fonte & $\ell_{\text {ef }}$ & $V_{f}\left(\mathrm{~kg} / \mathrm{m}^{3}\right)$ & $\tau_{b}(\mathbf{M P a})$ & $\overline{\tau_{\mathrm{b}}}(\mathbf{M P a})$ \\
\hline \multirow{2}{*}{ ORANGUN et al (1977) } & $7 \phi_{\mathfrak{p}}$ & \multirow{2}{*}{---} & 10,35 & 10,49 \\
\hline & $15 \phi_{\mathrm{p}}$ & & 7,77 & 7,87 \\
\hline \multirow{3}{*}{ Eligehausen (1979) } & \multirow{3}{*}{---} & 0 & 9,23 & 9,35 \\
\hline & & 40 & 10,13 & 10,26 \\
\hline & & 60 & 11,48 & 11,63 \\
\hline KEMP \& WILHELM (1979) & $\overline{---}$ & $\overline{---}$ & 5,59 & 5,66 \\
\hline \multirow{2}{*}{ DARWIN et al (1992) } & $7 \phi_{\mathfrak{p}}$ & \multirow[t]{2}{*}{--- } & 11,34 & 11,49 \\
\hline & $15 \phi_{\mathrm{p}}$ & & 7,48 & 7,58 \\
\hline \multirow{6}{*}{ HARAJLI (1994) } & \multirow{3}{*}{$7 \phi_{\mathrm{p}}$} & 0 & \multirow{3}{*}{10,35} & \multirow{3}{*}{10,49} \\
\hline & & 40 & & \\
\hline & & 60 & & \\
\hline & \multirow{3}{*}{$15 \phi_{\mathrm{p}}$} & 0 & \multirow{3}{*}{7,77} & \multirow{3}{*}{7,87} \\
\hline & & 40 & & \\
\hline & & 60 & & \\
\hline \multirow{3}{*}{$\begin{array}{l}\text { KRSTULOVIC-OPARA et al } \\
\qquad(1994)\end{array}$} & \multirow{3}{*}{---} & 0 & 11,27 & 11,42 \\
\hline & & 40 & 13,54 & 13,72 \\
\hline & & 60 & 15,94 & 16,15 \\
\hline ACI 318 (1963 a 1983) & --- & --- & 5,50 & 5,57 \\
\hline FIB Bulletin 1 (1999) & --- & --- & --- & 2,77 \\
\hline ACI 318 (2002) & --- & --- & --- & 1,72 \\
\hline \multirow{6}{*}{ Experimentais } & $5 \phi_{\mathfrak{p}}$ & \multirow{3}{*}{---} & \multirow{3}{*}{---} & 4,8 \\
\hline & $7 \phi_{\mathrm{p}}$ & & & 10,7 \\
\hline & $15 \phi_{\mathrm{p}}$ & & & 7,8 \\
\hline & \multirow{3}{*}{---} & 0 & \multirow{3}{*}{---} & 7,2 \\
\hline & & 40 & & 6,9 \\
\hline & & 60 & & 9,2 \\
\hline
\end{tabular}


O gráfico da Figura 5.39 apresenta a comparação entre os valores teóricos e os experimentais.

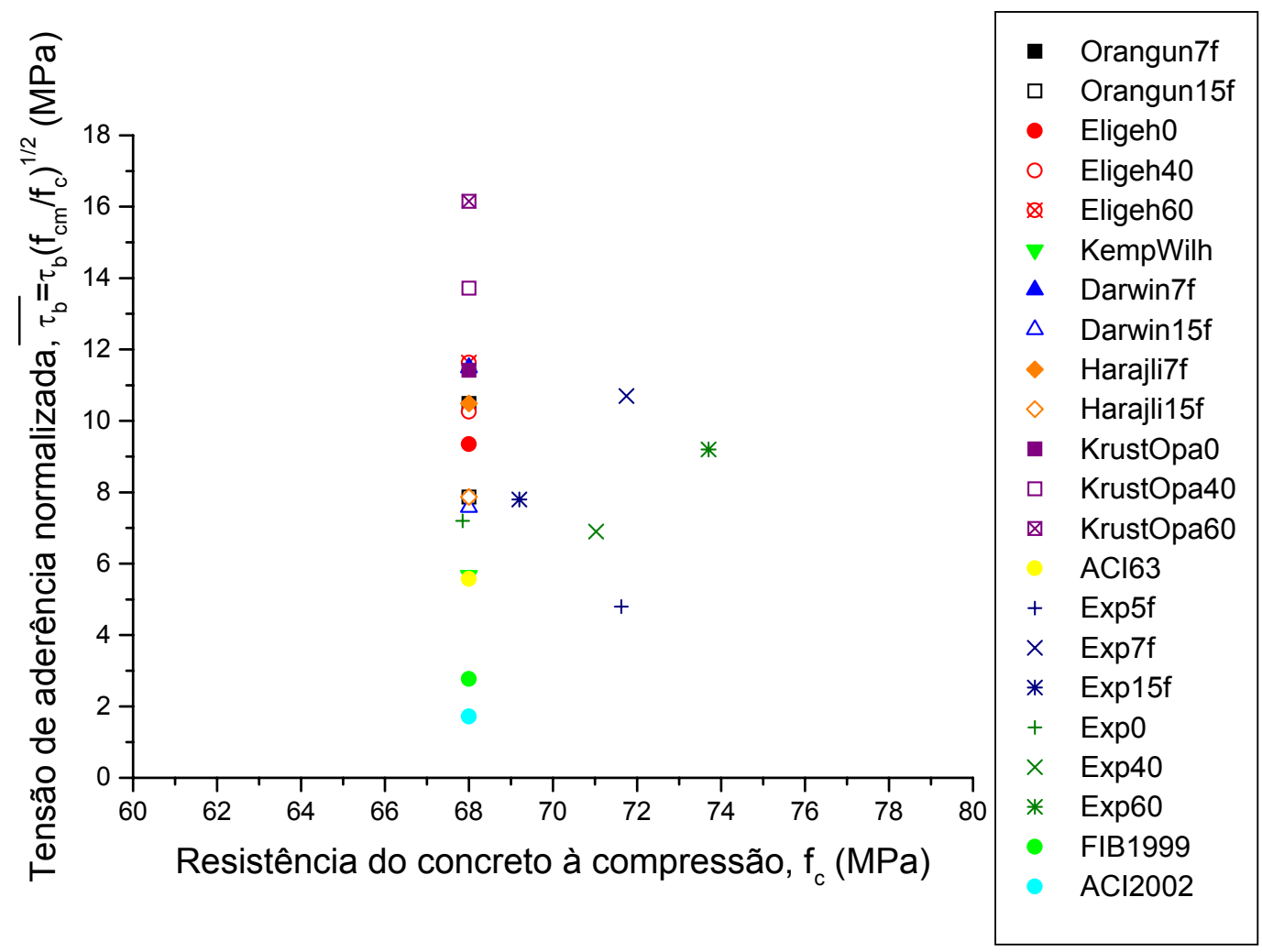

Figura 5.39 - Comparação entre os valores teóricos e experimentais, normalizados, para a tensão de aderência.

Como se pode observar, os valores experimentais se encontram dentro da faixa dos valores teóricos, exceto para as equações de KRSTULOVIC-OPARA et al (1994), que levam em conta a contribuição das fibras de aço, mesmo a baixos teores, o que não foi confirmado pelos resultados experimentais. Os valores fornecidos por esses autores estão acima dos demais. Por outro lado, os valores experimentais estão bem acima dos valores fornecidos pela FIB Bulletin 1 (1999) e pelo ACI 318 (2002), para as armaduras pré-tracionadas. Esses últimos se encontram muito abaixo de todos os outros, o que se justifica pela grande dispersão de resultados, que é característica dos ensaios de arrancamento. As prescrições normativas procuram, sempre, estar a favor da segurança. Além da grande dispersão de resultados, para as armaduras pré-tracionadas, há também muita dúvida e incertezas em como representar a tensão de aderência nesses casos.

Vale lembrar que a tensão de aderência experimental para as peças pré-tracionadas foi menor que para as peças sem protensão. Porém, não se pode fazer a comparação direta com os resultados das prescrições normativas, visto que estas admitem a transferência completa da força de protensão do aço para o concreto, o que não ocorreu nos ensaios. Foram utilizados 
comprimentos aderentes inferiores ao comprimento de transferência mínimo necessário, o que influenciou negativamente nos resultados. Como o comprimento aderente disponível era menor do que o necessário, não ocorreu a transferência de esforços. Após o alívio da protensão, a cordoalha retornava à posição original, perdendo as características da protensão e, também, piorando a aderência da peça, pois ocorria uma movimentação entre a armadura e o concreto nesse retorno da cordoalha ao tamanho original. Isso confirma as conclusões de VARGAS (2001) em relação ao comprimento mínimo de aderência para os ensaios de arrancamento de peças pré-tracionadas. Ele concluiu que, para essas peças, não devem ser feitos ensaios de arrancamento com comprimentos aderentes menores que o comprimento de transferência.

Além dos valores característicos, foram comparados os comportamentos aderentes experimentais com o do modelo analítico proposto por HARAJLI et al (1995). O gráfico da Figura 5.40 apresenta a comparação dos comportamentos, levando em conta uma distância fictícia entre nervuras de $\mathrm{C}_{0}=3 \mathrm{~mm}$. $\mathrm{O}$ modelo para $\mathrm{C}_{0}=170 \mathrm{~mm}$ apresentou intervalos de escorregamento muito diferentes dos experimentais.

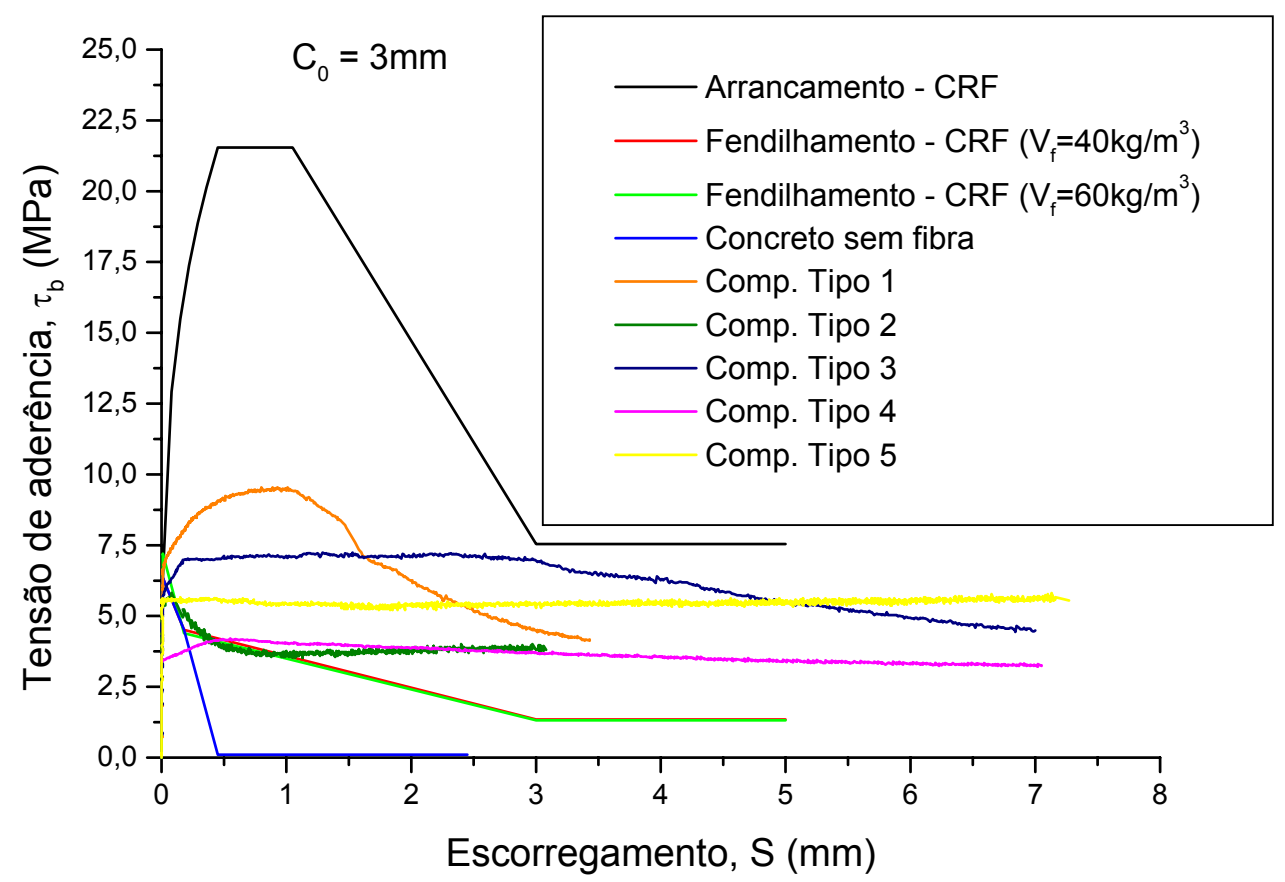

Figura 5.40 - Comparação entre o modelo de HARAJLI et al (1995) e os comportamentos experimentais.

Como se pode observar, os comportamentos aderentes experimentais ficaram entre os comportamentos teóricos de arrancamento para CRF e fendilhamento para CRF, porém, os valores para a tensão máxima de aderência ficaram mais próximos dos valores para a ruptura por fendilhamento. Os resultados experimentais, entretanto, mostraram que as rupturas se 
deram por arrancamento das cordoalhas, e não por fendilhamento. Os valores para a tensão residual de aderência ficaram entre os dois limites citados anteriormente. O gráfico da Figura 5.41 apresenta a comparação sem o modelo de HARAJLI et al (1995) para ruptura por arrancamento de CRF, para uma melhor visualização da comparação.

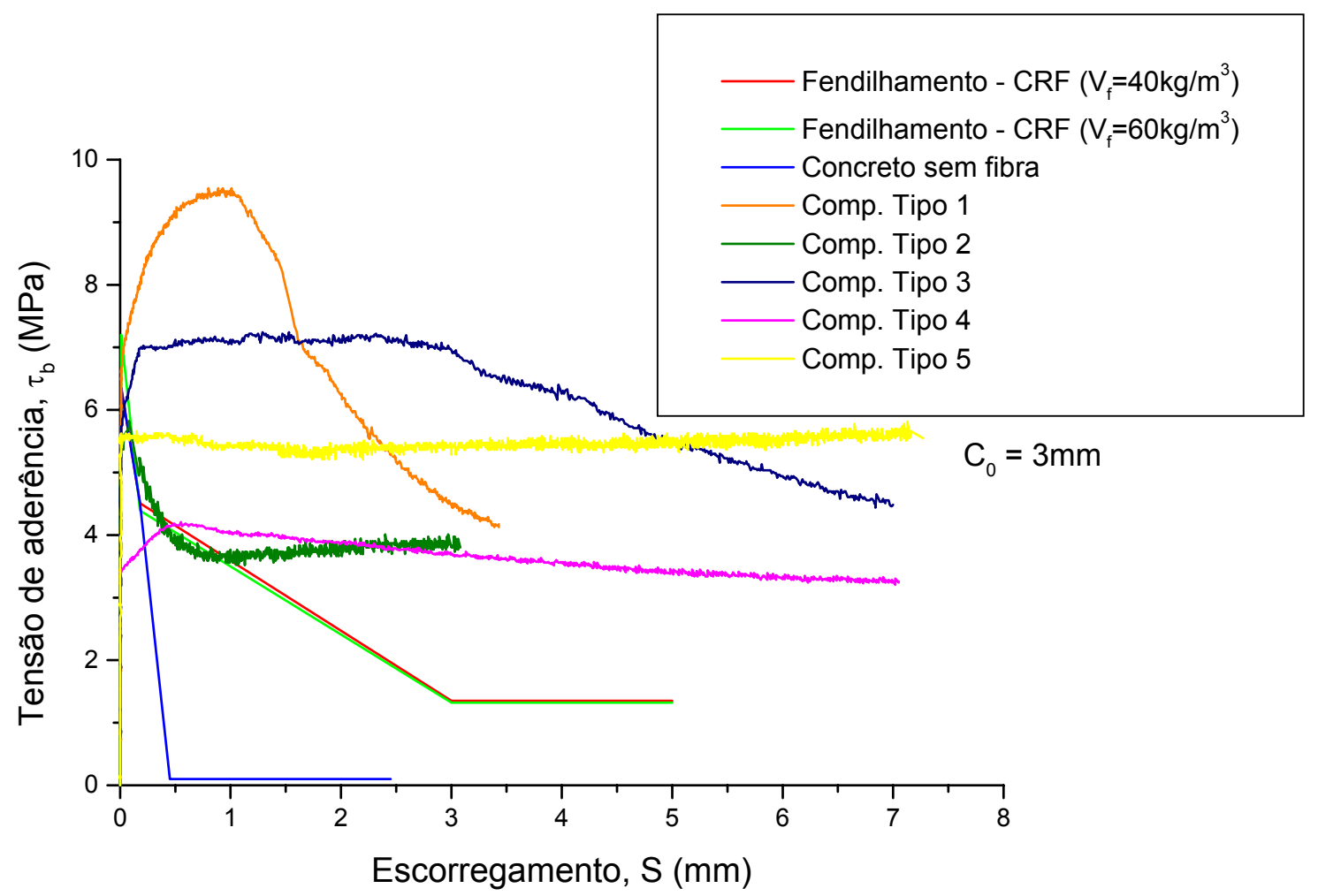

Figura 5.41 - Comparação dos comportamentos aderentes, sem levar em conta a ruptura por arrancamento do concreto reforçado com fibras (CRF).

Percebe-se que o comportamento do Tipo 2, concreto não-confinado, se assemelha bastante ao comportamento com ruptura por fendilhamento para o CRF. Para os demais, Tipos 1, 3, 4 e 5, a ruptura se dá de maneira mais dúctil, sem apresentar queda brusca da carga, que é característica da ruptura por fendilhamento. Apesar de algumas semelhanças, não é recomendável que se utilize o modelo de HARAJLI et al (1995) para representar a aderência de cordoalhas sem protensão. Percebe-se que a presença ou não de nervuras nas armaduras tem um papel fundamental nas propriedades aderentes das peças. Para as cordoalhas, a ruptura se dá, basicamente, por arrancamento, e o patamar de carga constante e aumento do escorregamento é bem mais acentuado do que para as barras nervuradas. A fissura de fendilhamento nas cordoalhas, quando ocorre, é para valores bem mais elevados do escorregamento do que para os das barras nervuradas.

De maneira geral, pode-se dizer que o comportamento das cordoalhas de sete fios se aproxima mais do comportamento do Tipo 4, sem queda brusca da carga, pois o arrancamento 
se dá de maneira lenta, já que a forma helicoidal do arranjo dos fios favorece o escorregamento, o que não ocorre para as nervuras, que impedem o escorregamento até o esmagamento do concreto entre elas, quando se dá, então, a ruptura por fendilhamento com queda brusca de carga. É importante que se busque um modelo analítico para as cordoalhas sem protensão, que melhor caracterize o seu comportamento aderente.

\subsection{Conclusões}

As principais conclusões obtidas dos ensaios de arrancamento são:

- O modelo proposto pela RILEM/CEB/FIP (1970) foi o que apresentou os piores resultados no que diz respeito à qualidade dos dados, com uma variabilidade bastante elevada, o que é explicado pelo comprimento de ancoragem reduzido, que o torna mais sensível às pequenas imperfeições que ocorrem nos ensaios; uma diferença de $5 \mathrm{~mm}$ no comprimento aderente, a mais ou a menos, influi muito mais nesses resultados, do que nos modelos com $\ell_{\mathrm{ef}}=15 \phi_{\mathrm{p}}$, por exemplo, nos quais as pequenas imperfeições são bem menos significativos;

- Os modelos com $\ell_{\mathrm{ef}}=7 \phi_{\mathrm{p}}$ apresentaram os melhores resultados, no que se refere à tensão de aderência;

- As fibras, utilizadas em volumes baixos, não influem na qualidade dos dados experimentais;

- As fibras, nos volumes utilizados, não influem na tensão de aderência relativa à primeira fissura, ou seja, a presença das fibras de aço não influi na fissuração inicial dos modelos;

- Os modelos com $\mathrm{V}_{\mathrm{f}}=40 \mathrm{~kg} / \mathrm{m}^{3}$ não apresentam diferença significativa para a tensão máxima de aderência em comparação com os compósitos sem fibras;

- Os modelos com $\mathrm{V}_{\mathrm{f}}=60 \mathrm{~kg} / \mathrm{m}^{3}$ apresentam um aumento significativo, de aproximadamente $28 \%$, para a tensão máxima de aderência, em comparação com os compósitos sem fibras;

- As fibras, em qualquer teor, melhoram a ductilidade do comportamento Tensão de aderência versus Escorregamento, e fornecem um certo confinamento à armadura, o que é refletido pelo aumento do patamar de escoamento de carga no gráfico;

- Os modelos com $\mathrm{V}_{\mathrm{f}}=40 \mathrm{~kg} / \mathrm{m}^{3}$ apresentaram os piores resultados, o que pode estar relacionado com a qualidade do concreto, já que o compósito com esse teor de fibra 
foi o que se apresentou mais plástico, com a melhor trabalhabilidade durante a concretagem; porém, apresentou os menores valores para a tensão de aderência;

- O comportamento aderente das cordoalhas de sete fios, em ensaios de arrancamento com a armadura não-protendida, não se enquadra nem nos modelos analíticos para barras nervuradas nem nos para fios lisos; é importante que se busque um modelo mais adequado para essas armaduras, para que se obtenha um dimensionamento mais econômico;

- Devido ao tipo de comportamento aderente dos modelos, com um longo patamar de escoamento, o valor do escorregamento referente à tensão máxima de aderência não se mostrou significativo nem confiável, já que para uma diferença quase imperceptível da tensão máxima, o escorregamento apresentava uma variação muito grande;

- Para o CAR, as tensões de aderência fornecidas pelas prescrições normativas avaliadas são bem inferiores às experimentais, indicando que o cálculo dos comprimentos de ancoragem está a favor da segurança;

- Não se deve usar modelos pré-tracionados para ensaios de arrancamento com comprimento de ancoragem inferior ao comprimento de transferência; quando isso ocorre, há uma diminuição da aderência;

- O modo de ruptura das cordoalhas de sete fios é por arrancamento da armadura e não por fendilhamento, motivo pelo qual as fibras não têm uma maior influência;

- Devido à grande dispersão de resultados $(\mathrm{CV}>25 \%)$, é importante que se tenha um grande número de modelos, pois quanto maior a amostra em estudo, melhor o resultado, e menor a influência da dispersão. 


\section{ENSAIOS DE FLEXÃO}

Este capítulo apresenta as operações de protensão e desprotensão de vigas prétracionadas e os ensaios estáticos de flexão, que foram realizados para a obtenção dos comprimentos de transferência e de ancoragem necessário, para os diversos modelos e parâmetros de ensaio diferentes.

Todos os ensaios aqui citados foram feitos no Laboratório de Estruturas da EESC-USP.

O capítulo descreve o programa e a análise experimental das operações de retirada de protensão e dos ensaios de flexão.

Para esta pesquisa, além dos ensaios-piloto já descritos no Capítulo 4, foram realizados mais doze ensaios de flexão em vigas pré-tracionadas biapoiadas, cujo objetivo principal foi avaliar a influência das fibras de aço nos comprimentos de ancoragem das peças. A armadura utilizada foi a cordoalha de sete fios com 12,7mm de diâmetro e aço CP 190 RB. O concreto apresentou resistência média à compressão de, aproximadamente, $65 \mathrm{MPa}$, na data de ensaio, sendo, então, um concreto de alta resistência (CAR). Foram monitoradas, também, as operações de protensão e desprotensão das vigas para o estudo da influência das fibras de aço no comprimento de transferência.

Os parâmetros de ensaio escolhidos foram: o comprimento aderente disponível $\left(\lambda_{\text {ef }}\right)$ e o volume de fibras de aço $\left(\mathrm{V}_{\mathrm{f}}\right)$.

A nomenclatura das vigas foi determinada de modo a fornecer as seguintes informações: tipo do modelo, consumo de fibra $\left(\mathrm{em} \mathrm{kg} / \mathrm{m}^{3}\right.$ ), comprimento de ancoragem disponível (em função da distância do ponto de aplicação de carga à extremidade da peça) e tipo de carregamento (duas cargas eqüidistantes, em relação ao meio do vão, ou uma carga deslocada 
para a extremidade). Quando esta última informação é omitida, significa que a peça foi carregada com duas cargas eqüidistantes. A seguir são apresentados dois exemplos da nomenclatura.

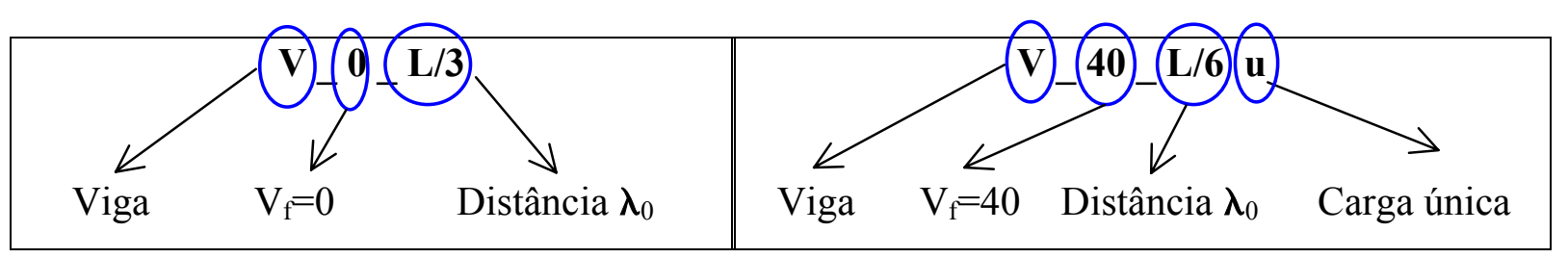

A Tabela 6.1 apresenta a relação das vigas por concretagem.

Tabela 6.1 - Relação das vigas por concretagem.

\begin{tabular}{l|c}
\hline \multicolumn{1}{c|}{ Vigas } & Concretagem \\
\hline V_0_L/3 e V_0_L/6 & C19 \\
\hline V_40_L/3 e V_40_L/6 & C20 \\
\hline V_60_L/3 e V_60_L/6 & C21 \\
\hline V_0_L/3b e V_0_L/4u & C22 \\
\hline V_40_L/4u e V_40_L/6u & C23 \\
\hline V_60_L/4u e V_60_L/6u & C24 \\
\hline
\end{tabular}

As vigas com carga a L/4 da extremidade foram todas com uma única carga, daí eliminar-se a letra $\mathbf{u}$ do final da nomenclatura. Durante o ensaio da V_0_L/3 houve um problema com o atuador hidráulico, que esmagou a viga de uma vez (esse assunto será tratado em mais detalhes posteriormente). Por isso, foi feita uma nova viga idêntica à primeira, que recebeu o nome de V_0_L/3b.

Os principais valores que se pretendia obter foram: o comprimento de transferência e o comprimento de ancoragem necessário. O primeiro foi medido durante as operações de retirada da protensão, e o segundo foi verificado nos ensaios de flexão. A seguir, são descritos, separadamente, os dois processos.

\subsection{Comprimento de Transferência}

\subsubsection{Descrição dos ensaios}

A determinação experimental do comprimento de transferência de peças pré-tracionadas pode ser feita de duas maneiras: pela leitura direta das deformações na zona de transferência, seja na armadura seja no concreto; e através de expressões empíricas baseadas na penetração 
da cordoalha, que é medida na desprotensão. Nesta pesquisa, tentou-se analisar os dois processos.

Para as seis primeiras vigas $\left(V_{-} 0 \_L / 3, V_{-} 0_{-} L / 6, V_{-} 40 \_L / 3, V \_40 \_L / 6, V \_60 \_L / 3\right.$ e V_60_L/6), o procedimento para a retirada da protensão foi praticamente o mesmo que para as vigas-pilotos, e está descrito a seguir:

1) A cordoalha foi pré-tracionada no pórtico de protensão, com uma força de, aproximadamente, $150 \mathrm{kN}$, no dia anterior à concretagem, e foi feita a leitura inicial da carga e dos extensômetros da armadura (dois para cada viga, ambos no meio do vão em fios diametralmente opostos, no total de quatro extensômetros por cordoalha);

2) As duas vigas foram concretadas e vibradas no pórtico;

3) As formas foram retiradas com 24 horas, os extensômetros elétricos foram colados na face externa da viga na altura da cordoalha (sobre o concreto, Figura 6.1a), e os relógios comparadores foram posicionados nas extremidades das vigas (Figura 6.1b), para medição da penetração da cordoalha no concreto durante a retirada da protensão. Esses procedimentos levaram 2 dias;

4) A protensão foi sendo retirada lentamente após 72 horas (três dias) da concretagem, com leitura de toda a instrumentação a cada $50 \mathrm{kN}$ de descarga (descarregamento em quatro etapas: $150 \mathrm{kN}, 100 \mathrm{kN}, 50 \mathrm{kN}$ e zero).

Esse procedimento foi mantido, também, para as outras operações, porém, com algumas mudanças na quantidade e posicionamento da instrumentação, o que está descrito ao longo deste item.

A Figura 6.1 apresenta alguns detalhes da instrumentação durante as três primeiras operações de retirada da protensão.

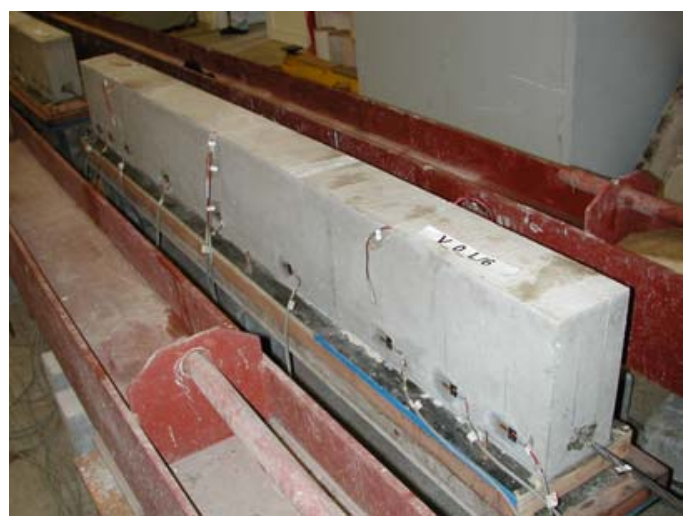

(a)

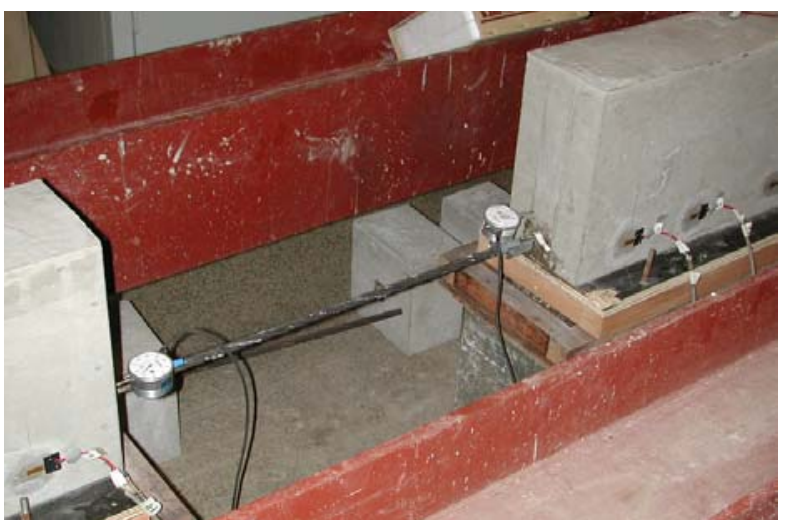

(b)

Figura 6.1 - Detalhes da retirada da protensão das vigas: (a) vigas no pórtico de protensão e vista dos extensômetros no concreto; (b) vista da posição dos relógios para leitura da penetração da cordoalha. 
Para as seis primeiras vigas, foram colados nove extensômetros, em cada uma, de acordo com o esquema da Figura 6.2, perfazendo um total de dezoito extensômetros em cada operação de desprotensão.

Note-se que há uma concentração maior de extensômetros perto das extremidades da viga, para que se pudesse acompanhar melhor a variação de deformação nessas regiões. Teoricamente, após o comprimento de transferência, as tensões e, conseqüentemente, as deformações permanecem constantes até que a viga seja posta em serviço. Portanto, não foi necessária uma instrumentação maior na região central das peças.

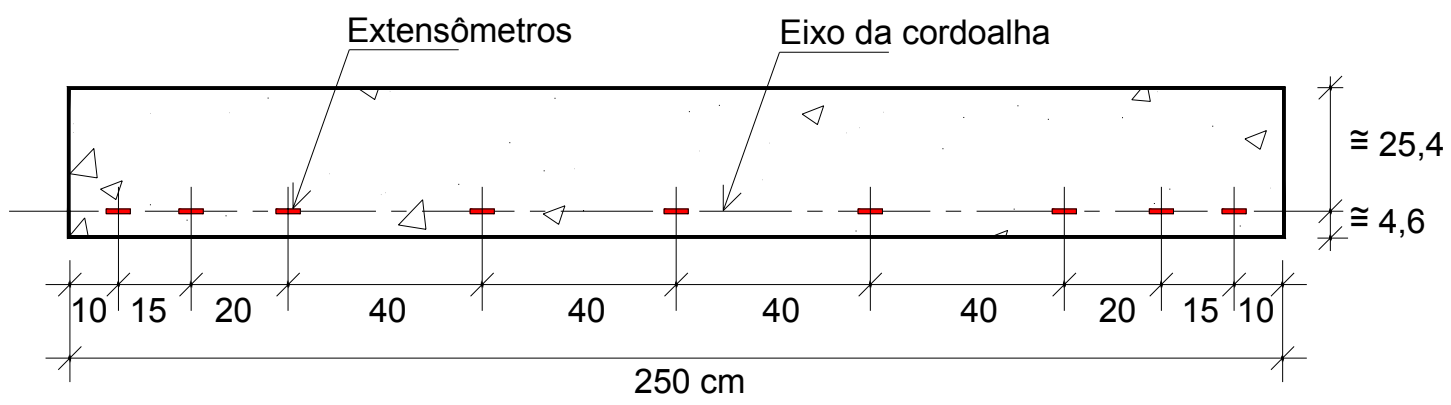

Figura 6.2 - Posicionamento dos extensômetros elétricos sobre o concreto (dimensões em $\mathrm{cm}$ ).

No total, em cada uma das três operações de desprotensão das seis primeiras vigas, a instrumentação utilizada foi a seguinte:

- Quatro relógios comparadores, um em cada extremidade das duas vigas;

- Quatro extensômetros elétricos na cordoalha, dois em cada viga;

- Dezoito extensômetros elétricos no concreto, nove em cada viga;

- Duas células de carga para leitura dos cilindros hidráulicos.

A Figura 6.3 apresenta o esquema do posicionamento dos relógios de leitura da penetração.

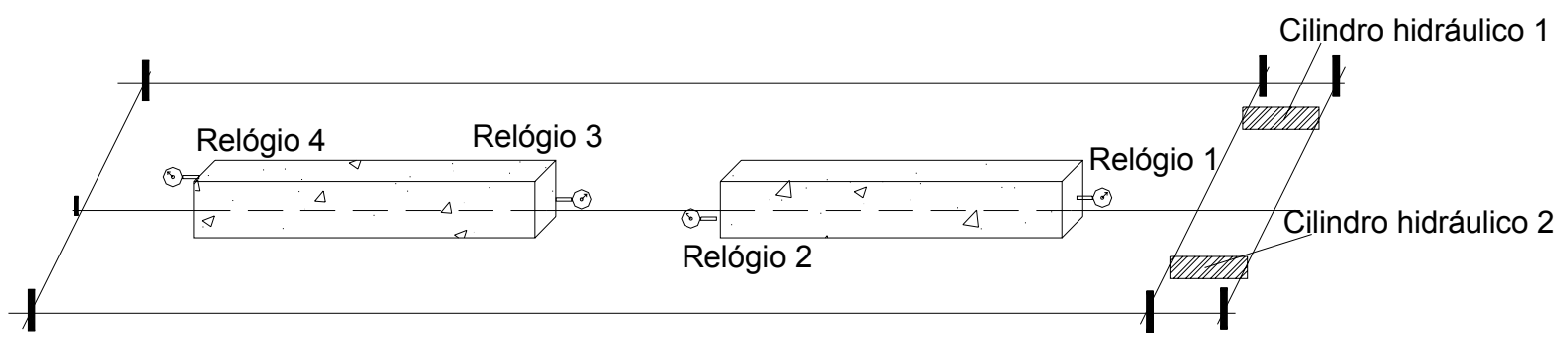

Figura 6.3 - Esquema da instrumentação das extremidades das vigas durante a desprotensão.

Para as seis últimas vigas, foram acrescentados quatro extensômetros elétricos por viga, de acordo com o esquema da Figura 6.4, perfazendo um total de 26 extensômetros em cada operação de desprotensão. 


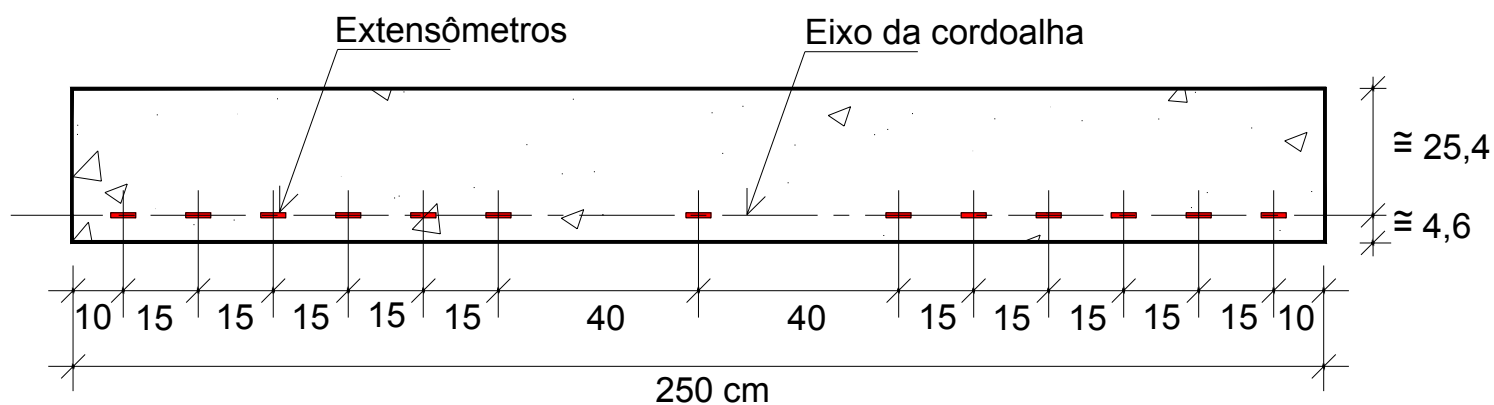

Figura 6.4 - Novo posicionamento dos extensômetros elétricos sobre o concreto (dimensões em $\mathrm{cm}$ ).

Foram acrescentados, também, mais quatro extensômetros elétricos na cordoalha de cada viga, posicionados, dois a dois, na direção dos pontos de aplicação de carga dos ensaios de flexão. No total, em cada uma das três operações de desprotensão das seis últimas vigas, a instrumentação utilizada foi a seguinte:

- Quatro relógios comparadores, um em cada extremidade das duas vigas;

- Doze extensômetros elétricos na cordoalha, seis em cada viga;

- Vinte e seis extensômetros elétricos no concreto, treze em cada viga;

- Duas células de carga para leitura dos cilindros hidráulicos.

Esse aumento de instrumentação teve como objetivo um melhor acompanhamento das deformações nas zonas de transferência.

A partir das leituras dos extensômetros do concreto, montou-se o gráfico Deformação (longitudinal) versus Distância da extremidade da viga. As Figuras 6.5 a 6.10 apresentam os gráficos para os modelos. A extremidade ativa (introdução da protensão) corresponde à distância zero, e a passiva à distância de 2,5m. As Figuras 6.11 a 6.13 apresentam os gráficos para a penetração da cordoalha para as três primeiras concretagens. Vale notar que todos esses gráficos representam a leitura direta dos dados, sem nenhum tratamento ou correção de valores. Isso será feito mais adiante. Todos esses resultados sofreram ajustes e correções para que se obtivessem os valores corretos para os comprimentos de transferência e para a penetração da cordoalha.

Vale notar, também, que tanto para os gráficos dos comprimentos de transferência (Figuras 6.5 a 6.10) como para os referentes à medição da penetração, os valores de deformação e deslocamento, para facilitar a visualização, estão com sinal positivo, apesar de representarem encurtamentos.

Para a determinação do valor da penetração da cordoalha no concreto, durante a retirada da protensão, deve-se levar em conta os seguintes fatores:

- Encurtamento da cordoalha; 
- Encurtamento do concreto;

- Movimentação do pórtico de protensão.

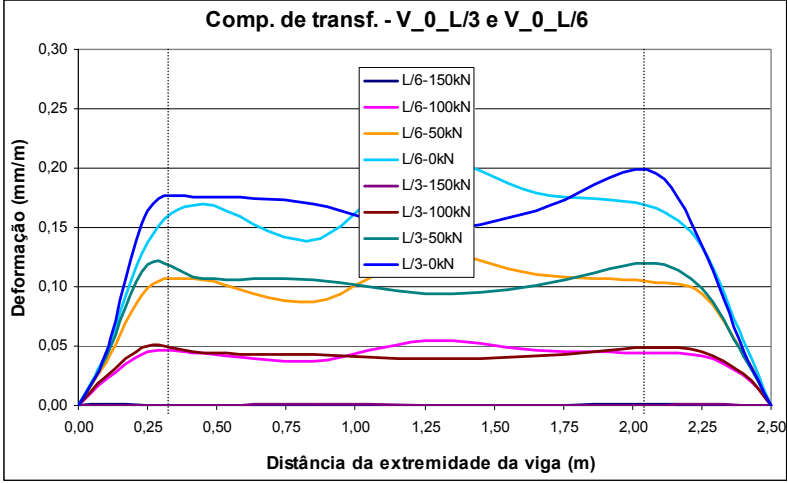

Figura 6.5 - Gráfico Deformação longitudinal versus

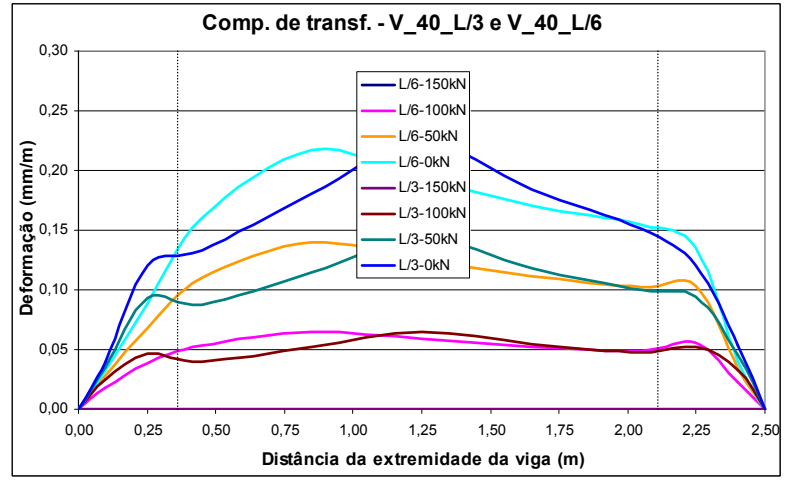

Figura 6.6 - Gráfico Deformação longitudinal versus

Distância à extremidade da peça para as vigas V_0_L/3 e Distância à extremidade da peça para as vigas V_40_L/3

V 0 L $/ 6$.

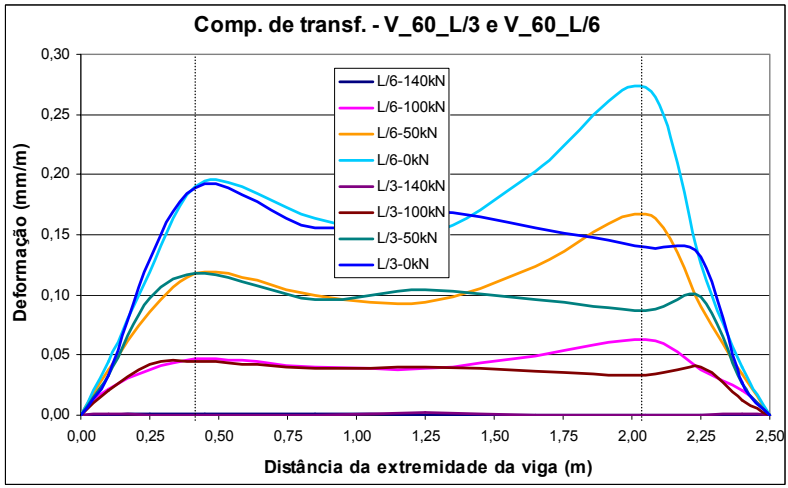

Figura 6.7 - Gráfico Deformação longitudinal versus

Distância à extremidade da peça para as vigas V 60 L/3

$$
\text { e V_60_L/6. }
$$

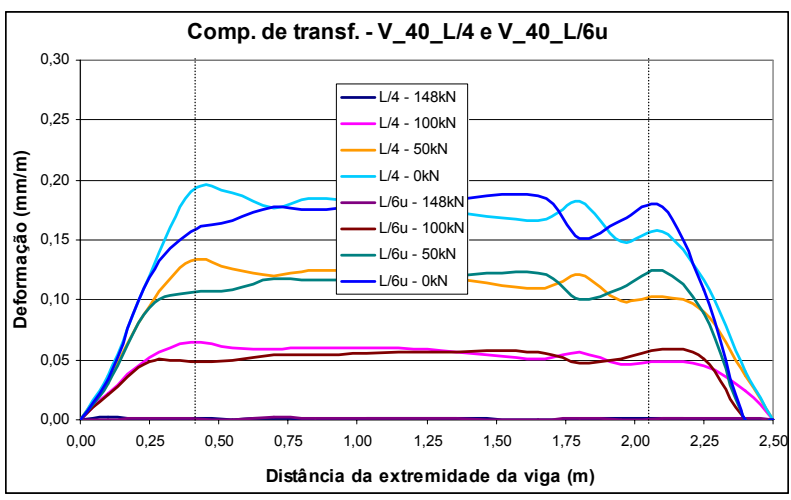

Figura 6.9 - Gráfico Deformação longitudinal versus

Distância à extremidade da peça para as vigas V_40_L/4 e V_40_L/6u. e V_40_L/6.

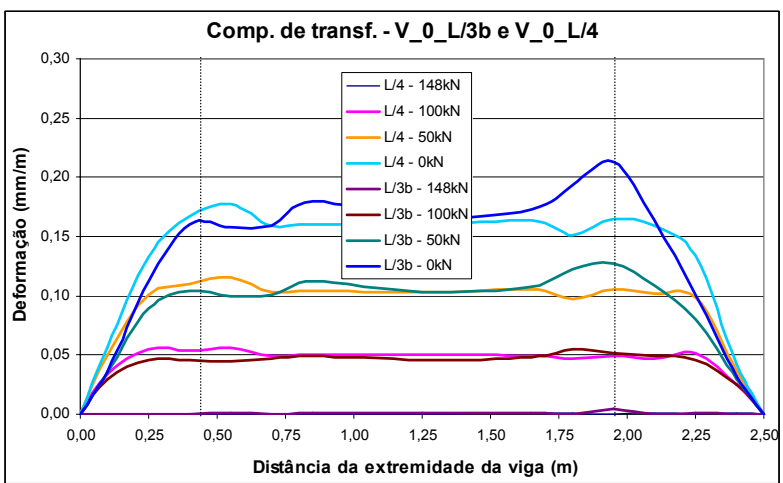

Figura 6.8 - Gráfico Deformação longitudinal versus

Distância à extremidade da peça para as vigas $\mathrm{V} \_0 \_\mathrm{L} / 3 \mathrm{~b}$

$$
\text { e V_0_L/4. }
$$

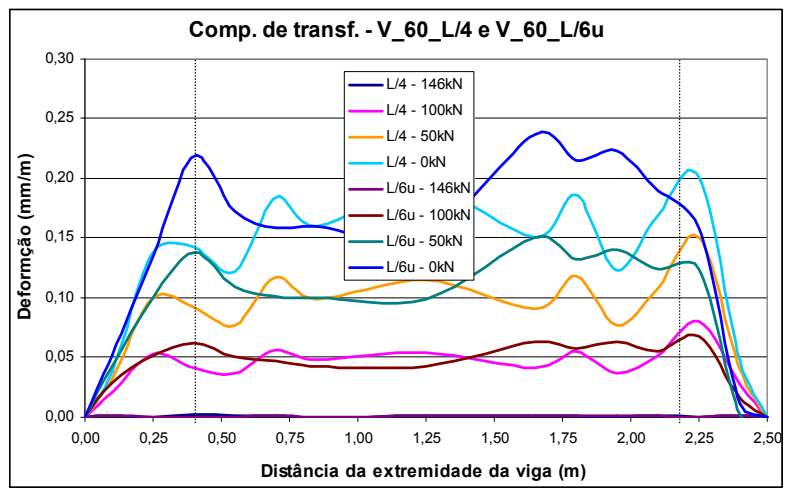

Figura 6.10 - Gráfico Deformação longitudinal versus Distância à extremidade da peça para as vigas V_60_L/4 e V_60_L/6u. 


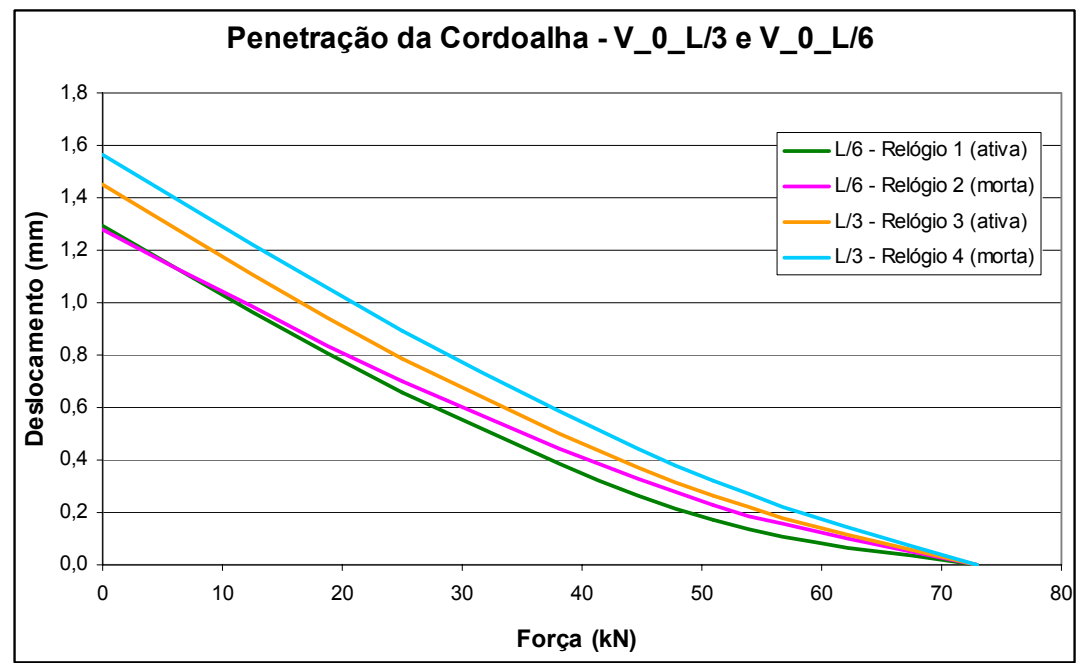

Figura 6.11 - Gráfico Força versus Deslocamento para as vigas V_0_L/3 e V_0_L/6.

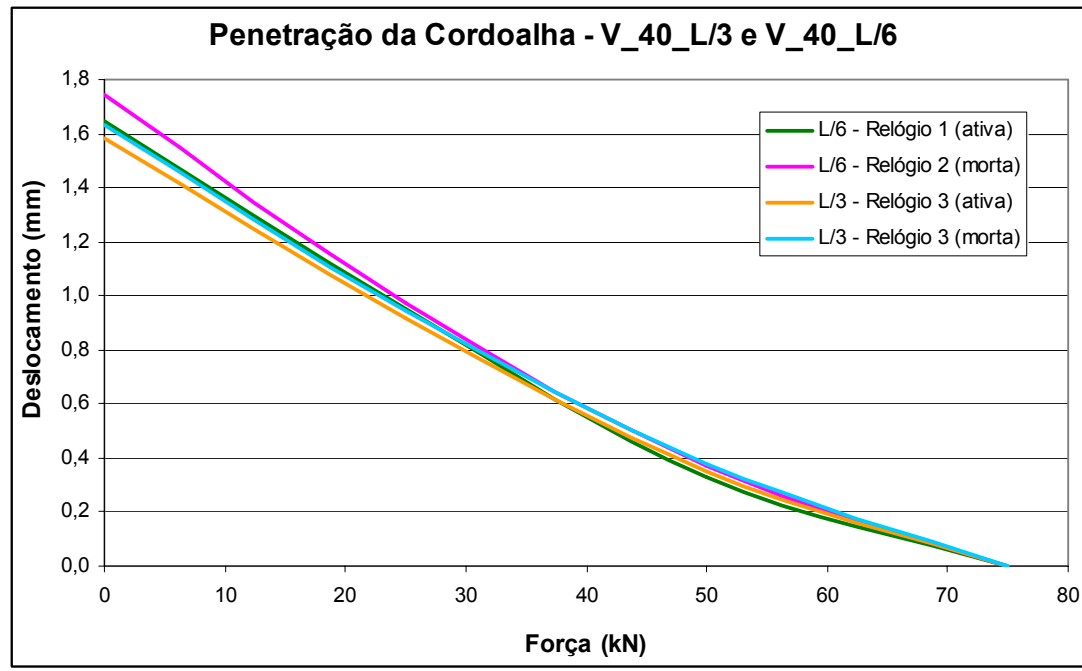

Figura 6.12 - Gráfico Força versus Deslocamento para as vigas V_40_L/3 e V_40_L/6.

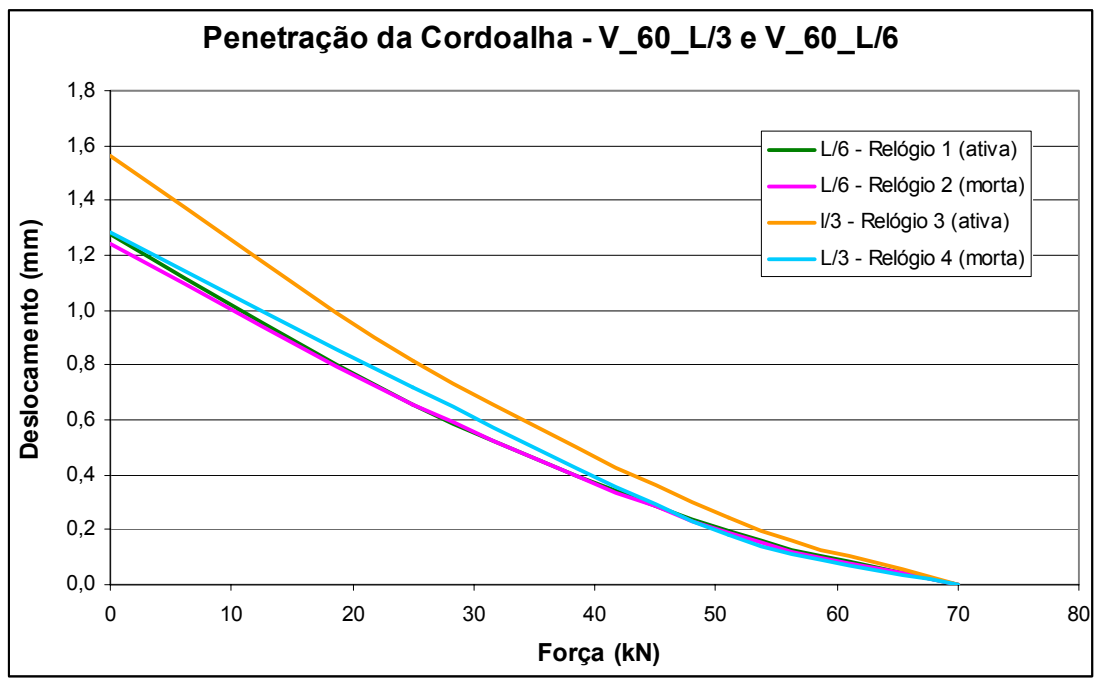

Figura 6.13 - Gráfico Força versus Deslocamento para as vigas V_60_L/3 e V_60_L/6. 
Quando se libera a protensão, todos esses fatores ocorrem ao mesmo tempo, e a leitura feita pelo relógio comparador recebe essas influências. É fundamental que se isolem todos esses fatores para que se obtenha o real valor da penetração. A partir dele, vários pesquisadores têm desenvolvido expressões empíricas para o cálculo, ou estimativa, do comprimento de transferência. Dentre os citados, a movimentação do pórtico, e a sua contribuição na leitura da penetração, é o valor mais difícil de ser determinado. Essa movimentação ocorre quando a rigidez do pórtico não é suficiente para garantir a sua indeslocabilidade. Nesta pesquisa, esse fato só foi percebido após as primeiras operações de retirada da protensão, por isso essa correção não foi possível para as oito primeiras vigas.

Após a concretagem das seis primeiras, sentiu-se a necessidade de instrumentar o deslocamento das vigas, para tentar medir com mais precisão a penetração da cordoalha. Observou-se que durante a desprotensão ocorre um movimento relativo entre a cordoalha e o concreto, pois à medida que a protensão vai sendo retirada, vai havendo deformações em ambos, que tendem a voltar para suas posições originais. A partir daí, foram posicionados, também, transdutores de deslocamento ao longo do pórtico, para medir o encurtamento das vigas de concreto, como indicado no esquema da Figura 6.14. As Figuras 6.15 a 6.17 apresentam fotos da nova instrumentação.

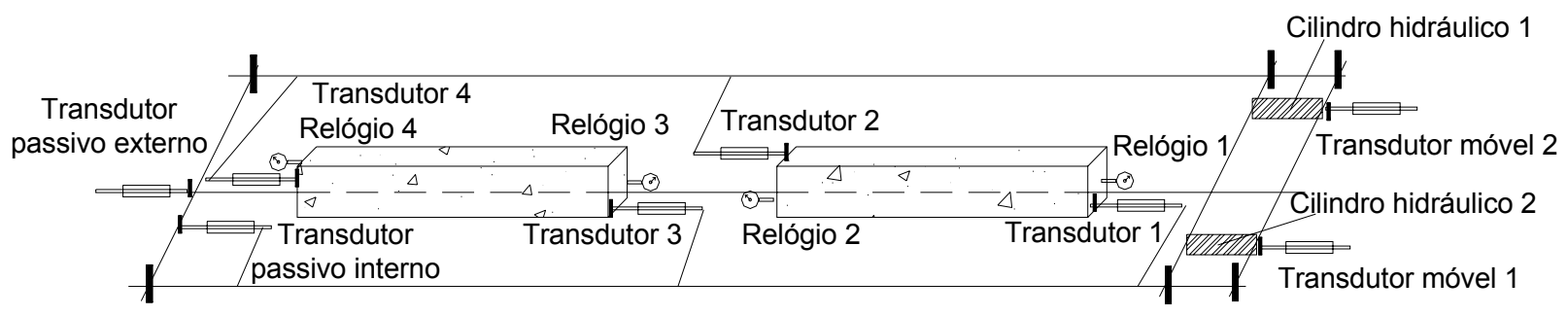

Figura 6.14 - Esquema da instrumentação do pórtico de protensão.

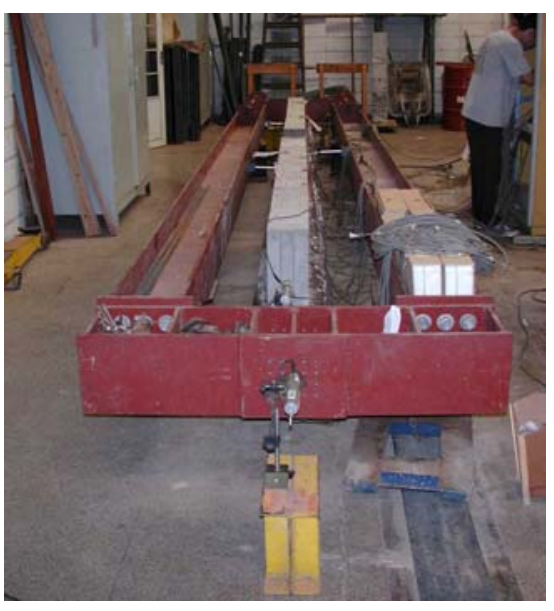

(a)

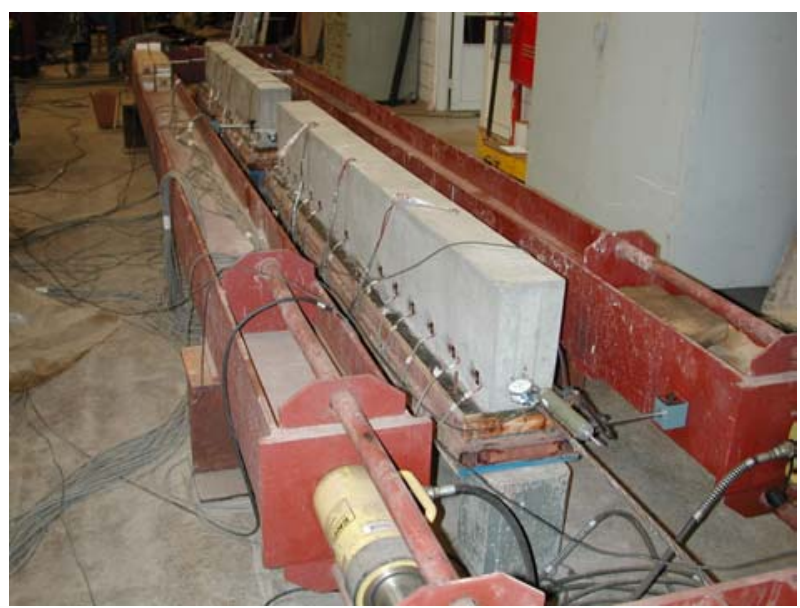

(b)

Figura 6.15 - Detalhes da instrumentação: (a) vista geral; (b) vista lateral. 


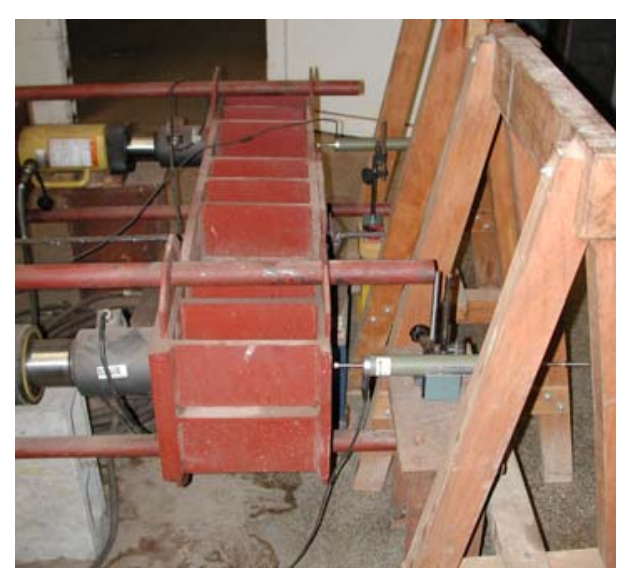

(a)

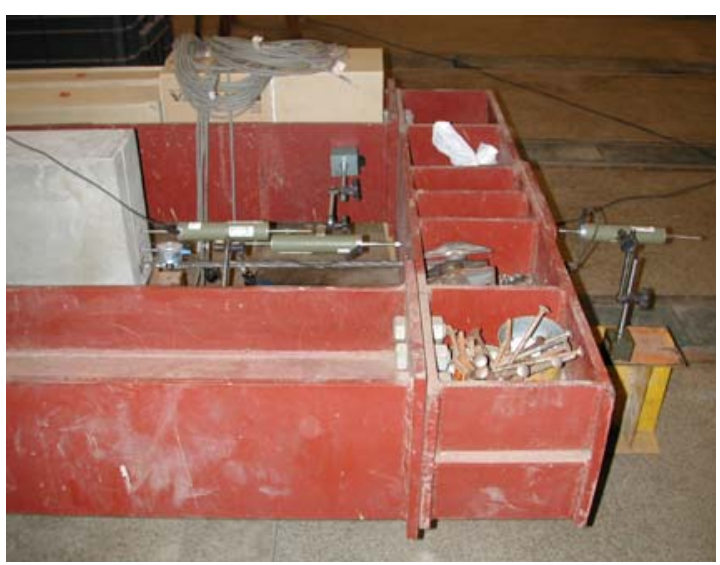

(b)

Figura 6.16 - Detalhes da instrumentação: (a) transdutores no perfil móvel; (b) transdutores no perfil fixo (ou passivo).

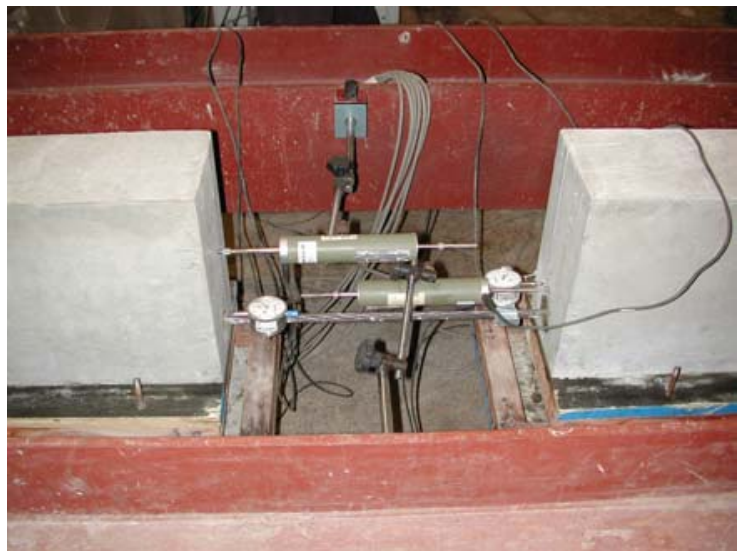

(a)

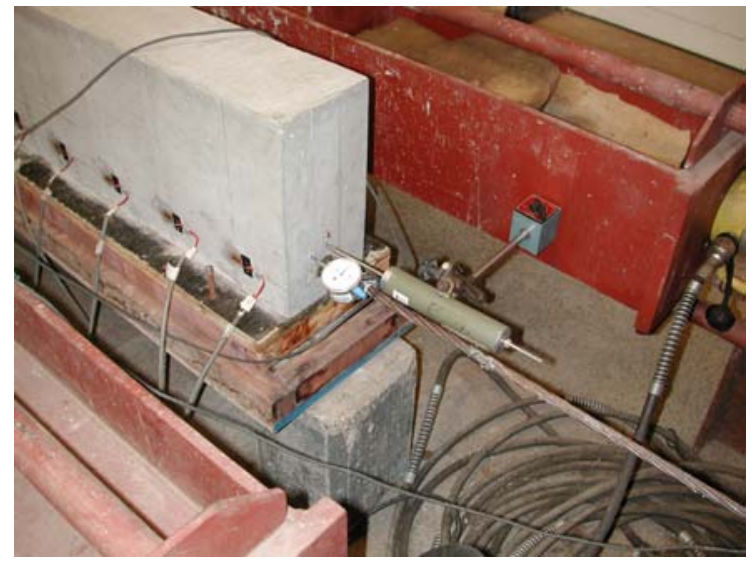

(b)

Figura 6.17 - Detalhes da instrumentação: (a) transdutores entre as vigas; (b) transdutor na extremidade.

Porém, após a desprotensão das sétima e oitava vigas, V_0_L/3b e V_0_L/4, observouse que o pórtico de protensão movimentava-se durante a desprotensão, o que influenciava nos valores medidos para a penetração, pois à medida que se aliviava a carga, ia ocorrendo um encurtamento tanto do concreto e da cordoalha como, também, do pórtico, e os transdutores para a leitura da movimentação das extremidades das vigas foram fixados nele (Figura 6.17), ou seja, as suas leituras levavam em conta essa movimentação. Percebido isto, para a retirada da protensão das últimas quatro vigas (V_40_L/4, V_40_L/6u, V_60_L/4 e V_60_L/6u), os transdutores foram posicionados em perfis metálicos fora do pórtico, o que mostrou-se bem melhor. Isso pode ser verificado nos gráficos de deslocamento dos transdutores das Figuras 6.21 a 6.23. Percebe-se que para as vigas com $\mathrm{V}_{\mathrm{f}}=0$, não há simetria nos deslocamentos, pois os transdutores levaram em conta, também, a deformação do pórtico, que não foi uniforme. Já 
para as vigas com $\mathrm{V}_{\mathrm{f}}=40 \mathrm{~kg} / \mathrm{m}^{3}$ e $\mathrm{V}_{\mathrm{f}}=60 \mathrm{~kg} / \mathrm{m}^{3}$, os deslocamentos foram simétricos, pois os transdutores mediram apenas o deslocamento das vigas.

As Figuras 6.18 a 6.20 apresentam os gráficos para a penetração da cordoalha para as três últimas concretagens.

As Figuras 6.21 a 6.23 apresentam os gráficos das medições dos deslocamentos do pórtico de protensão e dos transdutores das extremidades das vigas.

Nota-se que há uma movimentação do pórtico de protensão, em relação às leituras da penetração, que não pode ser desprezada.

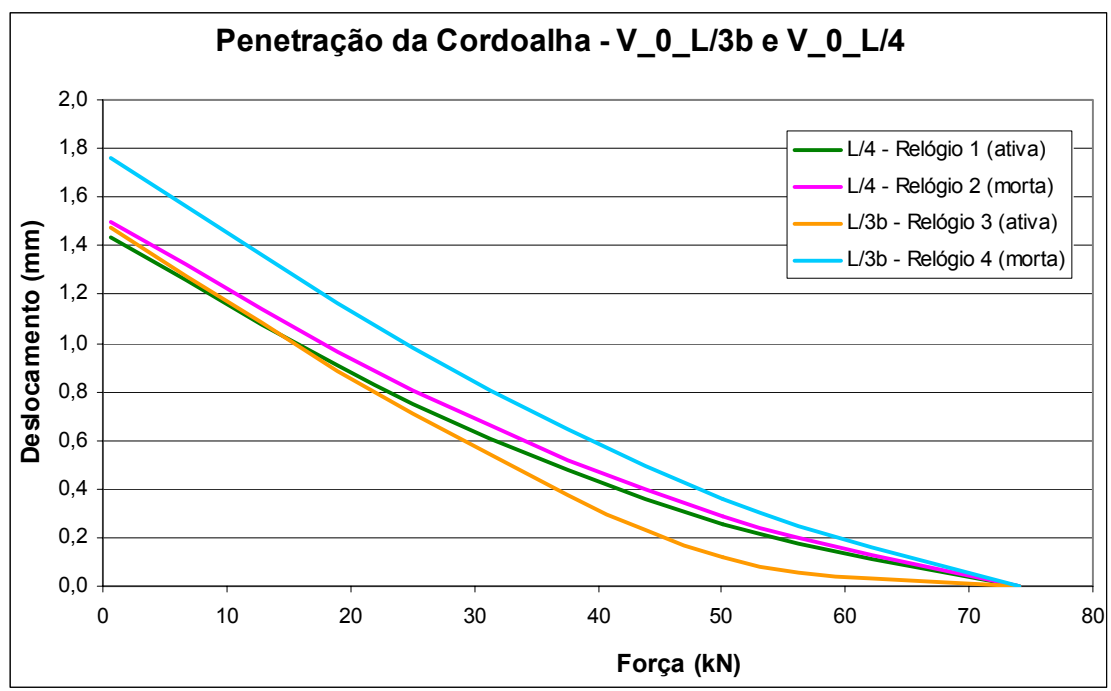

Figura 6.18 - Gráfico Força versus Deslocamento para as vigas V_0_L/3b e V_0_L/4.

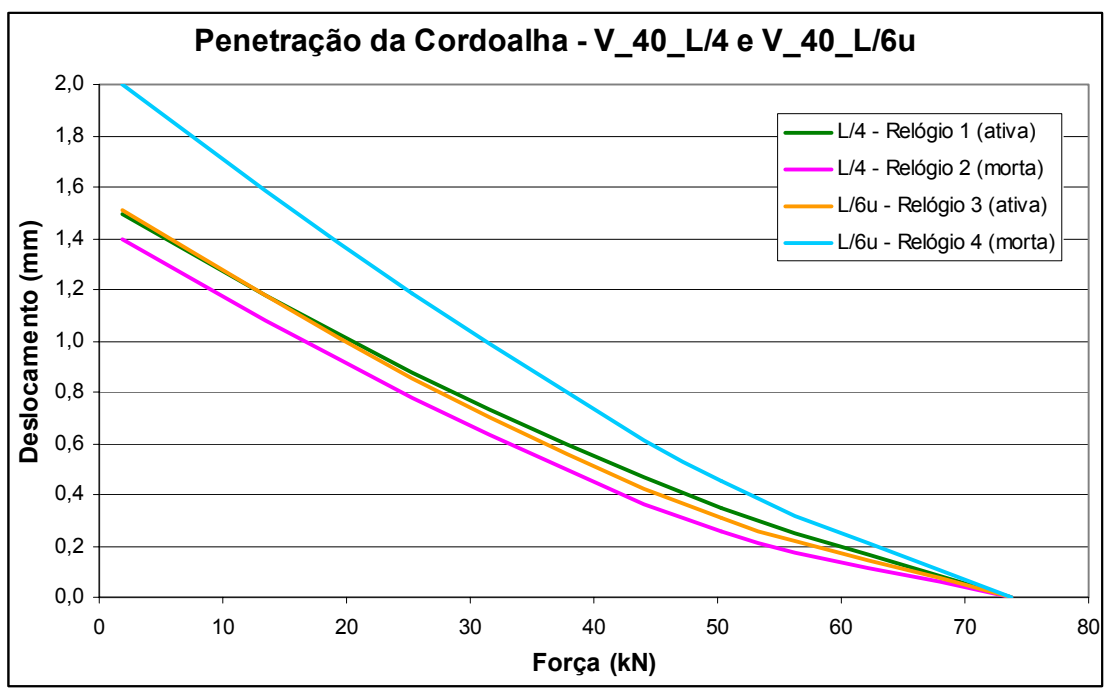

Figura 6.19 - Gráfico Força versus Deslocamento para as vigas V_40_L/4 e V_40_L/6u. 


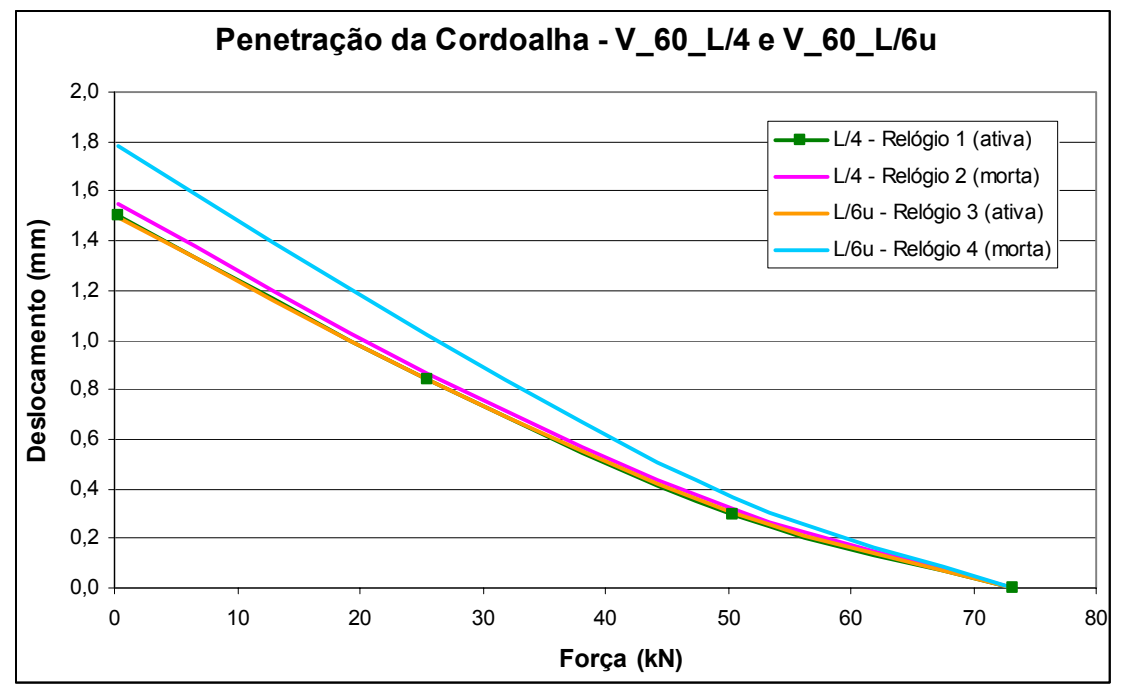

Figura 6.20 - Gráfico Força versus Deslocamento para as vigas V_60_L/4 e V_60_L/6u.
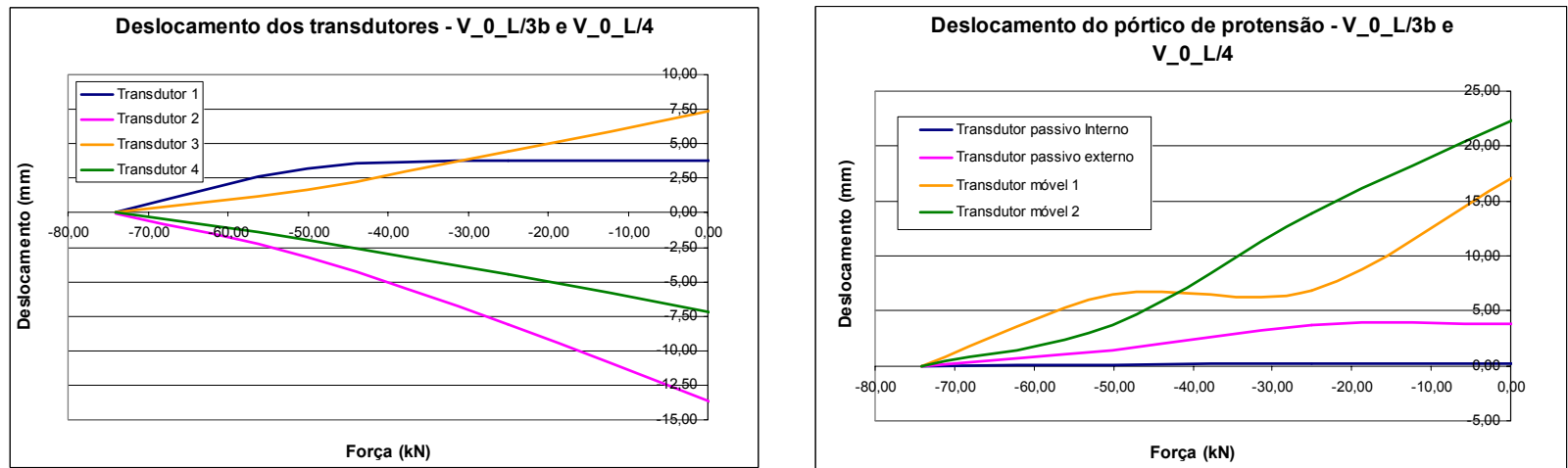

Figura 6.21 - Gráfico Força versus Deslocamento para os transdutores do pórtico, na concretagem das vigas

$$
\text { V_0_L/3b e V_0_L/4. }
$$
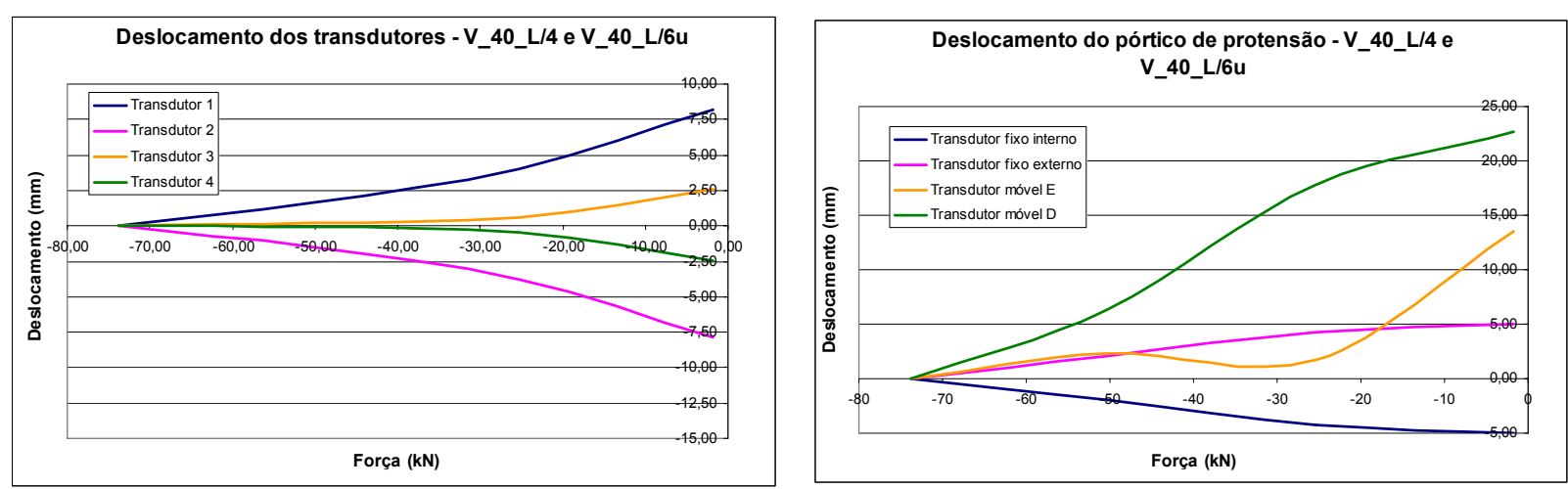

Figura 6.22 - Gráfico Força versus Deslocamento para os transdutores do pórtico, na concretagem das vigas

$$
\text { V_40_L/4 e V_40_L/6u. }
$$

Para a retirada da protensão das vigas $V_{-}$__L $/ 3 b$ e $V \_0 \_L / 4$, o transdutor passivo interno mediu o deslocamento relativo entre o perfil transversal fixo e os perfis longitudinais fixos do pórtico (Figura 6.24), e verificou-se que essa movimentação é desprezível. Então, para a operação de desprotensão seguinte, o transdutor passivo interno mediu o deslocamento 
do perfil transversal fixo pela parte de dentro do pórtico, e verificou-se que ambos os deslocamentos, interno e externo, apresentaram, praticamente, o mesmo valor. Para a última desprotensão, essa leitura (transdutor passivo interno) foi eliminada.
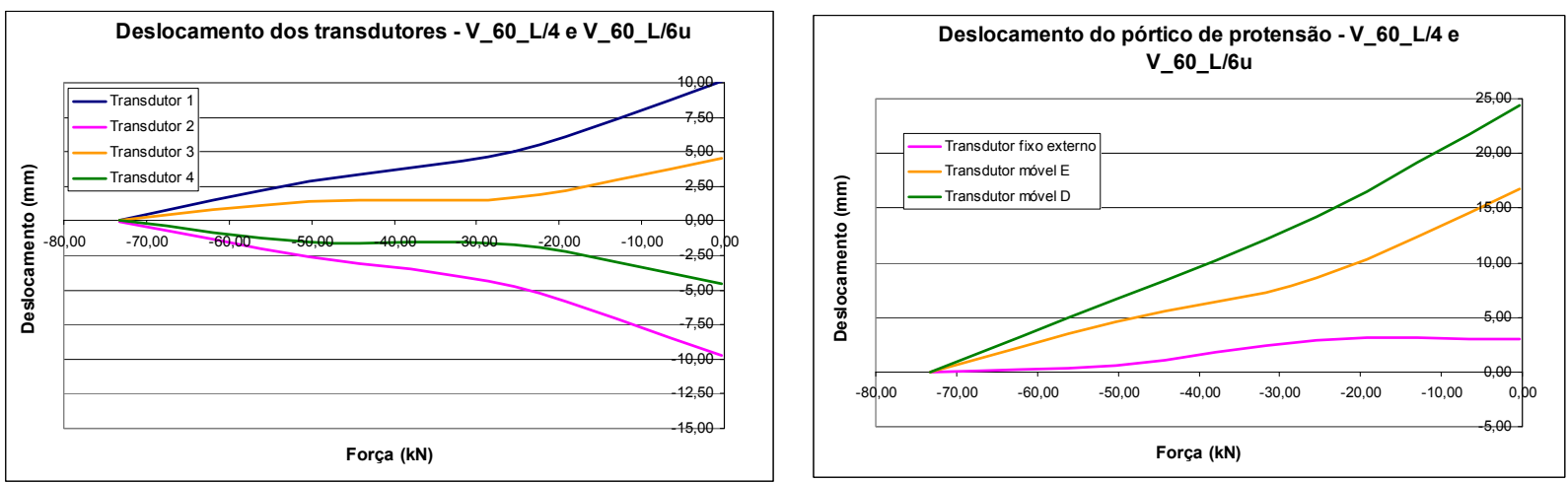

Figura 6.23 - Gráfico Força versus Deslocamento para os transdutores do pórtico, na concretagem das vigas V_60_L/4 e V_60_L/6u.

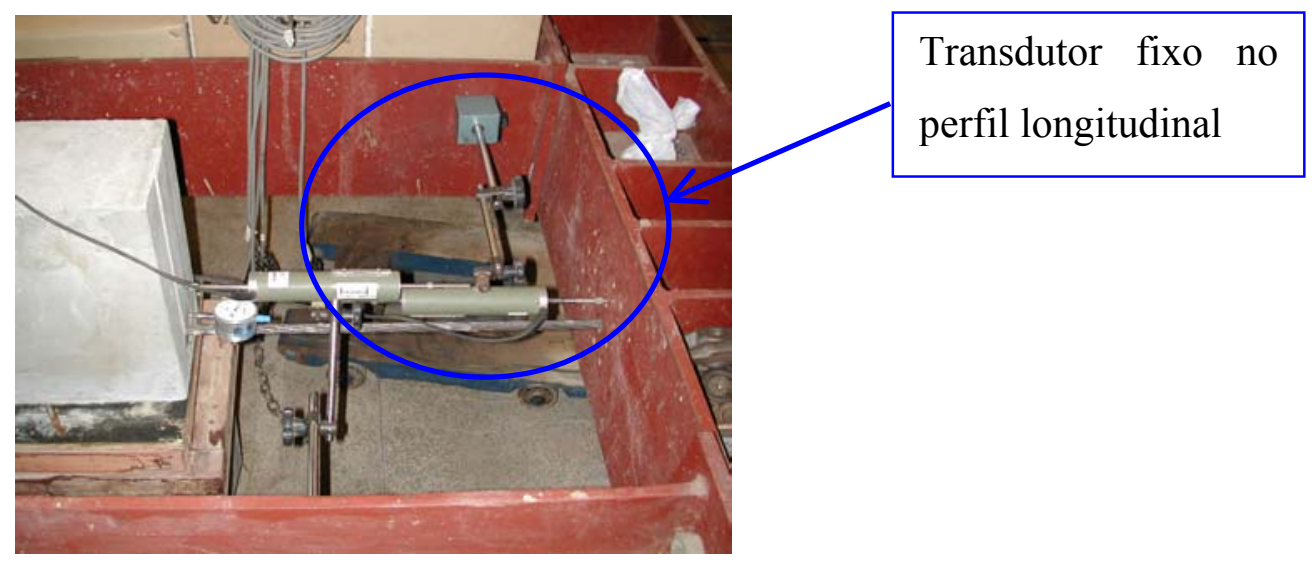

Figura 6.24 - Detalhe do posicionamento do transdutor passivo interno na desprotensão das vigas V___L/3b e

$$
\text { V_0_L/4. }
$$

Para a determinação da penetração, percebeu-se que a posição das vigas no pórtico de protensão também tinha influência nos resultados, pois as deformações não foram uniformes. As vigas mais próximas dos cilindros hidráulicos (lado do perfil transversal móvel) apresentaram deslocamentos maiores que as vigas posicionadas mais próximas do perfil transversal fixo. A Figura 6.25 apresenta o posicionamento das doze vigas nas seis últimas concretagens desta pesquisa. Foi percebido também que as leituras feitas nas extremidades ativas apresentaram-se mais uniformes que as feitas nas extremidades mortas. Essas observações ficam mais claras na análise das Tabelas 6.2 e 6.3 apresentadas mais adiante. Acredita-se que todos esses problemas foram decorrentes da falta de rigidez apropriada do 
pórtico de protensão, e da falta de uma instrumentação mais adequada para medir os deslocamentos separadamente.

Perfil Transversal Fixo

2a Viga

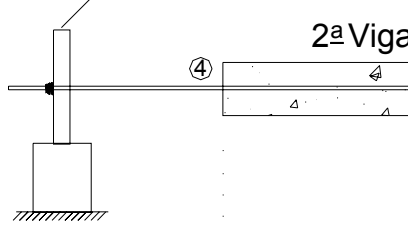

1a Viga

Cilindro hidráulico

Perfil Transversal

Móvel

$\begin{array}{lll}\text { Concretagem C19 } & \text { V_0_L/3 } & \text { V_0_L/6 } \\ \text { Concretagem C20 } & \text { V_40_L/3 } & \text { V_40_L/6 } \\ \text { Concretagem C21 } & \text { V_60_L/3 } & \text { V_60_L/6 } \\ \text { Concretagem C22 } & \text { V_0_L/3b } & \text { V_0_L/4 } \\ \text { Concretagem C23 } & \text { V_40_L/6u } & \text { V_40_L/4 } \\ \text { Concretagem C24 } & \text { V_60_L/6u } & \text { V_60_L/4 }\end{array}$

Figura 6.25 - Posicionamento das vigas na concretagem e desprotensão.

A Tabela 6.2 apresenta os valores finais dos deslocamentos do pórtico e das vigas.

Tabela 6.2 - Valores para os deslocamentos durante as operações de desprotensão (valores em mm).

\begin{tabular}{|c|c|c|c|c|c|c|c|c|}
\hline \multirow[b]{2}{*}{ Viga } & \multicolumn{2}{|c|}{ Relógios } & \multicolumn{2}{|c|}{ Transdutores } & \multirow{2}{*}{$\begin{array}{l}\text { Transd. } \\
\text { passivo } \\
\text { interno }\end{array}$} & \multirow{2}{*}{$\begin{array}{l}\text { Transd. } \\
\text { passivo } \\
\text { externo }\end{array}$} & \multirow{2}{*}{$\begin{array}{l}\text { Transd. } \\
\text { móvel } 1\end{array}$} & \multirow{2}{*}{$\begin{array}{l}\text { Transd. } \\
\text { móvel } 2\end{array}$} \\
\hline & $\begin{array}{l}\text { Ext. } \\
\text { ativa }\end{array}$ & $\begin{array}{c}\text { Ext. } \\
\text { morta }\end{array}$ & $\begin{array}{l}\text { Ext. } \\
\text { ativa }\end{array}$ & $\begin{array}{c}\text { Ext. } \\
\text { morta }\end{array}$ & & & & \\
\hline $\mathrm{V} \_0 \_\mathrm{L} / 3$ & $-1,45$ & $-1,57$ & $\begin{array}{l}---- \\
\end{array}$ & $\begin{array}{l}---- \\
\end{array}$ & \multirow{2}{*}{----- } & \multirow{2}{*}{----- } & \multirow{2}{*}{----- } & \multirow{2}{*}{----- } \\
\hline $\bar{V}{ }_{-} 0 \_L / 6$ & $-1,29$ & $-1,28$ & ----- & ----- & & & & \\
\hline V_40_L/3 & $-1,58$ & $-1,64$ & ----- & ----- & \multirow{2}{*}{----- } & \multirow{2}{*}{----- } & \multirow{2}{*}{----- } & \multirow{2}{*}{----- } \\
\hline V_40_L/6 & $-1,64$ & $-1,75$ & ----- & ----- & & & & \\
\hline V_60_L/3 & $-1,56$ & $-1,28$ & ----- & ----- & \multirow{2}{*}{-----} & \multirow{2}{*}{----- } & \multirow{2}{*}{----- } & \multirow{2}{*}{----- } \\
\hline V_60_L/6 & $-1,27$ & $-1,24$ & ----- & ----- & & & & \\
\hline V_0_L/3b & $-1,48$ & $-1,76$ & 7,39 & $-7,28$ & \multirow{2}{*}{0,21} & \multirow{2}{*}{3,82} & \multirow{2}{*}{17,22} & \multirow{2}{*}{22,45} \\
\hline V_0_L/4 & $-1,43$ & $-1,50$ & 3,80 & $-13,73$ & & & & \\
\hline V_40_L/4 & $-1,50$ & $-1,40$ & 8,15 & $-7,85$ & \multirow{2}{*}{$-5,02$} & \multirow{2}{*}{5,05} & \multirow{2}{*}{13,48} & \multirow{2}{*}{22,65} \\
\hline V_40_L/6u & $-1,51$ & $-2,00$ & 2,58 & $-2,46$ & & & & \\
\hline V_60_L/4 & $-1,50$ & $-1,55$ & 10,12 & $-9,75$ & \multirow{2}{*}{----- } & \multirow{2}{*}{2,98} & \multirow{2}{*}{16,79} & \multirow{2}{*}{24,35} \\
\hline V_60_L/6u & $-1,50$ & $-1,79$ & 4,57 & $-4,55$ & & & & \\
\hline
\end{tabular}


Os valores da Tabela 6.2 correspondem aos que foram medidos após a retirada completa da protensão. A partir desses valores, pôde-se determinar o encurtamento das vigas de concreto e a penetração da cordoalha. Essa última só foi calculada para as duas últimas operações de desprotensão, nas quais foi possível estimar os encurtamentos da viga e da cordoalha. $\mathrm{O}$ valor do alongamento da cordoalha foi obtido dos extensômetros elétricos, que mediam a sua deformação.

O cálculo da penetração baseou-se no esquema apresentado na Figura 6.26.

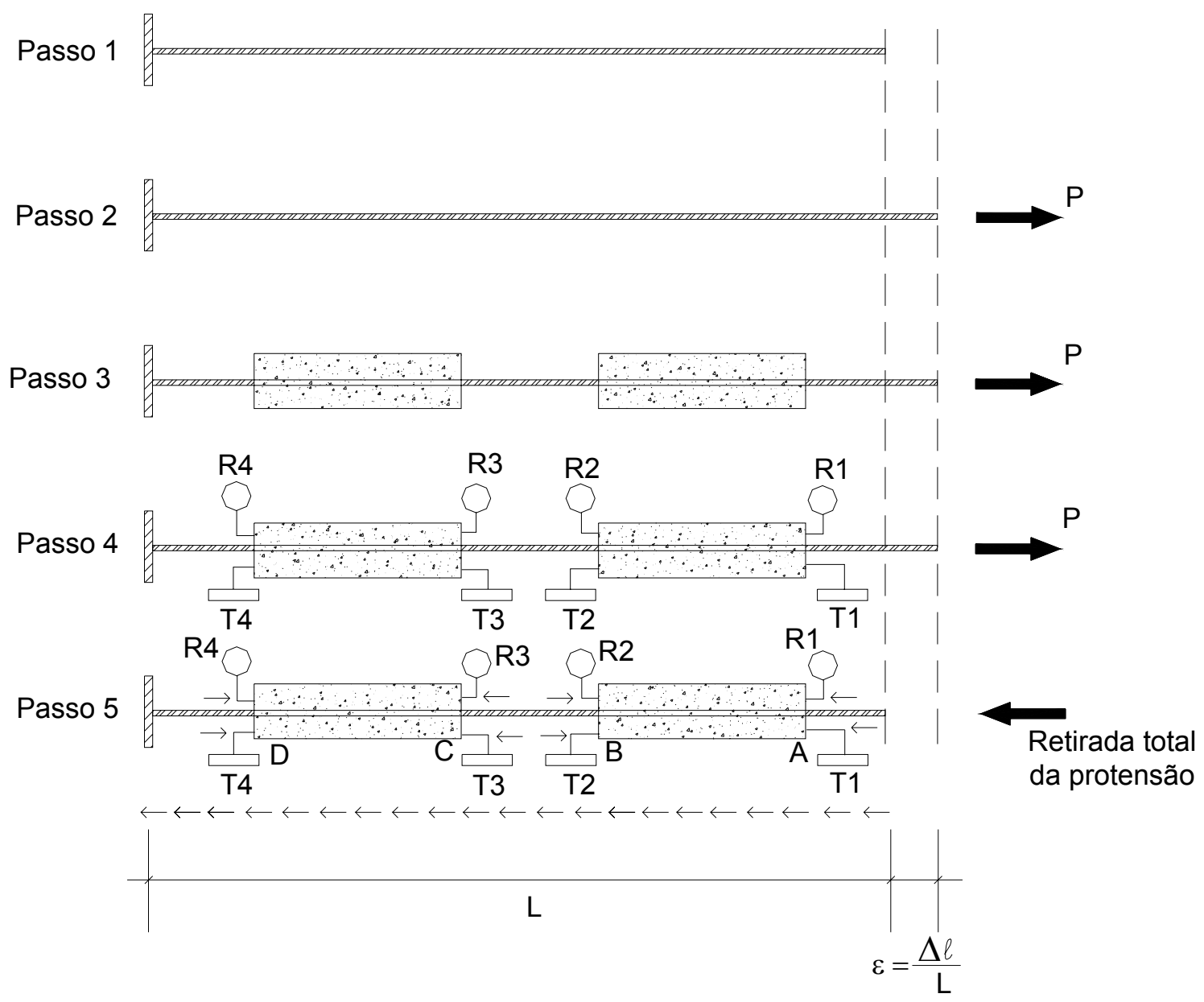

Figura 6.26 - Movimentação dos elementos durante a desprotensão.

Como já foi explicado anteriormente, inicialmente posiciona-se a cordoalha no pórtico (Passo 1), aplica-se uma força de pré-tração de valor $\mathbf{P}$ (Passo 2), que implica num alongamento da cordoalha ( $\varepsilon$ ), e depois as vigas são concretadas no pórtico (Passo 3). Depois que as formas são retiradas, são posicionados, além dos extensômetros elétricos, os relógios comparadores $\left(\mathrm{R}_{\mathrm{i}}\right)$ e os transdutores de deslocamento $\left(\mathrm{T}_{\mathrm{i}}\right)$ (Passo 4). Por fim, a protensão é retirada (Passo 5). Observa-se que há o retorno da cordoalha e, também, da viga no sentido contrário ao que foi aplicada a força de protensão. Como a leitura da instrumentação é feita 
nas extremidades das vigas, nas ativas os valores do encurtamento do aço e da leitura dos relógios têm o mesmo sentido, e são contrários ao sentido do valor do deslocamento da viga de concreto. Nas extremidades mortas os valores do encurtamento do aço e do deslocamento da viga de concreto têm o mesmo sentido, e são contrários ao sentido da leitura dos relógios.

Portanto, foram feitas duas correções diferentes, uma para as extremidades ativas (A e C) e outra para as extremidades mortas (B e D).

1) Para as extremidades ativas, tem-se o esquema da Figura 6.27, e o valor final da penetração é dado pela expressão:

$$
\delta=\Delta \ell_{\mathrm{c}}-\mathrm{L}_{\mathrm{r}, \mathrm{final}}-\Delta \mathrm{L}_{\mathrm{p}}
$$

2) Para as extremidades mortas, analogamente ao item anterior, porém com o sentido contrário para a leitura do relógio, o valor final da penetração vale:

$$
\delta=\Delta \ell_{\mathrm{c}}-\mathrm{L}_{\mathrm{r}, \text { final }}+\Delta \mathrm{L}_{\mathrm{p}}
$$

Para o cálculo do encurtamento da cordoalha, foi levada em conta a distância entre o ponto de fixação do relógio comparador e a face da viga $\left(\mathrm{L}_{\mathrm{p}}\right)$ e a deformação máxima medida na cordoalha para a força total de protensão $\left(\varepsilon_{\mathrm{p}}\right)$, ou seja:

$$
\Delta \mathrm{L}_{\mathrm{p}}=\varepsilon_{\mathrm{p}} \cdot \mathrm{L}_{\mathrm{p}}
$$

Para o encurtamento do concreto, admitiu-se uma deformação constante ao longo de toda a viga, o que foi uma aproximação, e não o que realmente ocorre. Calculou-se a diferença entre as leituras das extremidades das vigas e a dividiu pelo comprimento total $(250 \mathrm{~cm})$. Admitindo-se que houve simetria, metade de cada deformação foi distribuída para as duas extremidades. Por fim, multiplicou-se a deformação pelo comprimento de transferência calculado, chegando-se à seguinte expressão de cálculo:

$$
\Delta \ell_{\mathrm{c}}=\frac{\left(\mathrm{L}_{\mathrm{r}, \text { ativa }}+\mathrm{L}_{\mathrm{r}, \text { passiva }}\right)}{\mathrm{L}_{\mathrm{viga}}} \frac{1}{2} \cdot \ell_{\mathrm{bpt}}
$$

Vale notar que o encurtamento do concreto é teoricamente nulo na região central da viga, e vai aumentando à medida que vai se aproximando da extremidade da peça, já que a força de protensão instalada vai diminuindo.

Sabe-se que a leitura do encurtamento da viga levou em conta o deslocamento da cordoalha, pois os perfis metálicos usados como apoio dos transdutores ficaram imóveis em relação a todo o sistema de desprotensão, logo, eles mediram não só o encurtamento do 
concreto das vigas, como também o retorno de toda a peça (aço + concreto), decorrente da movimentação de volta da cordoalha. Essa interação foi desprezada.

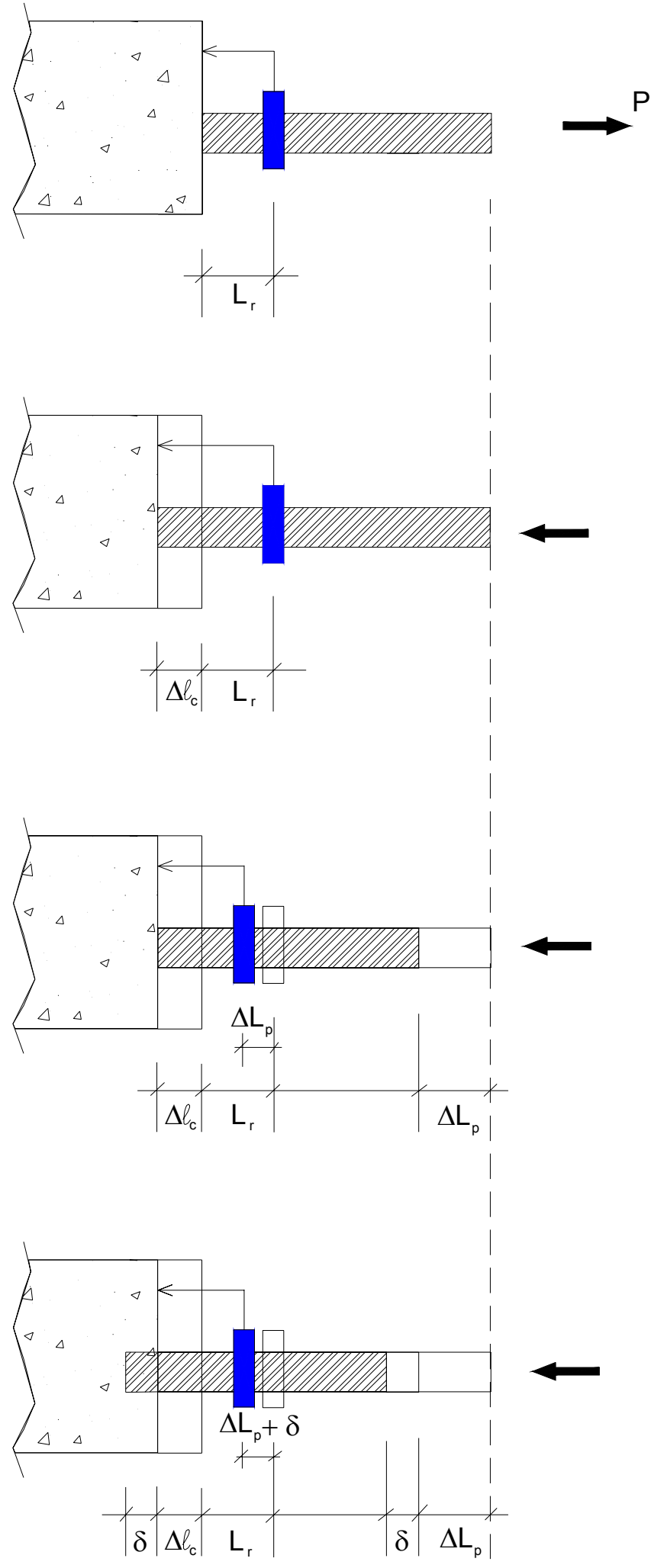

Inicialmente a peça está prétracionada com a força $\mathrm{P}$, e $\mathrm{O}$ relógio comparador indica a leitura inicial $\mathrm{L}_{\mathrm{r}}$, que normalmente é zerada.

Quando a protensão é retirada, ocorrem algumas deformações, entre elas, o encurtamento do concreto $\left(\Delta \lambda_{c}\right) . \quad \mathrm{O}$ relógio comparador passa a medir $\left(\Delta \lambda_{\mathrm{c}}+\right.$ $\left.\mathrm{L}_{\mathrm{r}}\right)$.

Ocorre também, simultaneamente, o encurtamento da cordoalha $\left(\Delta \mathrm{L}_{\mathrm{p}}\right) . \quad \mathrm{O}$ relógio comparador passa a medir $\left(\Delta \lambda_{c}+L_{r}-\Delta L_{p}\right)$.

Finalmente, ocorre um movimento relativo entre a cordoalha e o concreto, que é chamado de "penetração". O relógio comparador passa a medir $\left(\Delta \lambda_{\mathrm{c}}+\mathrm{L}_{\mathrm{r}}-\Delta \mathrm{L}_{\mathrm{p}}-\delta\right)$.

Figura 6.27 - Deslocamentos nas extremidades ativas das vigas.

A Tabela 6.3 apresenta os resultados dos cálculos dos deslocamentos e da penetração. 
Tabela 6.3 - Valores finais para os deslocamentos e a penetração das vigas (dimensões em mm).

\begin{tabular}{|c|c|c|c|c|c|c|c|c|c|}
\hline \multirow{3}{*}{\multicolumn{2}{|c|}{ Deslocamentos }} & \multicolumn{8}{|c|}{ Vigas } \\
\hline & & \multicolumn{2}{|c|}{ V_40_L/4 } & \multicolumn{2}{|c|}{ V_40_L/6u } & \multicolumn{2}{|c|}{ V_60_L/4 } & \multicolumn{2}{|c|}{ V_60_L/6u } \\
\hline & & ativa & morta & ativa & morta & ativa & morta & ativa & morta \\
\hline $\begin{array}{c}\text { Leitura final do } \\
\text { relógio }\end{array}$ & $\mathrm{L}_{\mathrm{r}, \mathrm{final}}$ & 1,50 & 1,40 & 1,51 & 2,00 & 1,50 & 1,55 & 1,50 & 1,97 \\
\hline \multirow{3}{*}{$\begin{array}{c}\text { Encurtamento da } \\
\text { cordoalha }\end{array}$} & $\varepsilon_{\mathrm{p}}$ & \multicolumn{2}{|c|}{$6,44 \%$ о } & \multicolumn{2}{|c|}{$6,44 \%$ o } & \multicolumn{2}{|c|}{$6,37 \%$} & \multicolumn{2}{|c|}{$6,37 \%$} \\
\hline & $\mathrm{L}_{\mathrm{p}}$ & \multicolumn{2}{|c|}{60} & \multicolumn{2}{|c|}{60} & \multicolumn{2}{|c|}{60} & \multicolumn{2}{|c|}{60} \\
\hline & $\Delta \mathrm{L}_{\mathrm{p}}$ & \multicolumn{2}{|c|}{0,39} & \multicolumn{2}{|c|}{0,39} & \multicolumn{2}{|c|}{0,38} & \multicolumn{2}{|c|}{0,38} \\
\hline \multirow{4}{*}{$\begin{array}{c}\text { Encurtamento do } \\
\text { concreto }\end{array}$} & $\mathrm{L}_{\mathrm{r} \text {,ativa }}$ & \multicolumn{2}{|c|}{8,15} & \multicolumn{2}{|c|}{2,58} & \multicolumn{2}{|c|}{10,12} & \multicolumn{2}{|c|}{4,57} \\
\hline & $\mathrm{L}_{\mathrm{r}, \text { morta }}$ & \multicolumn{2}{|c|}{$-7,85$} & \multicolumn{2}{|c|}{$-2,46$} & \multicolumn{2}{|c|}{$-9,75$} & \multicolumn{2}{|c|}{$-4,55$} \\
\hline & $\lambda_{\mathrm{bpt}}$ & 350 & 610 & 500 & 370 & 610 & 200 & 330 & 350 \\
\hline & $\Delta \lambda_{\mathrm{c}}$ & 0,021 & 0,037 & 0,012 & 0,009 & 0,045 & 0,015 & 0,001 & 0,001 \\
\hline Penetração & $\delta$ & $-1,87$ & $-0,98$ & $-1,88$ & $-1,60$ & $-1,84$ & $-1,15$ & $-1,88$ & $-1,59$ \\
\hline
\end{tabular}

Percebe-se que para as extremidades ativas o valor da penetração é praticamente uniforme, já para as extremidades mortas a variação é bem grande. A contribuição do encurtamento do concreto é muito pequena, ao contrário da do encurtamento da cordoalha. Nota-se também que há diferenças entre a penetração nas duas extremidades da mesma viga. Devido a todas as incertezas na medição e determinação da penetração nas vigas ensaiadas, optou-se por não levar adiante o estudo do comprimento de transferência baseado nesse valor.

\subsubsection{Análise comparativa dos resultados experimentais}

Para a determinação dos comprimentos de transferência a partir das deformações medidas na altura da cordoalha foi utilizado o método sugerido por RUSSEL \& BURNS (1993), intitulado de "Método de 95\% da Média das Deformações Máximas". Seu procedimento é o seguinte:

1) Plotam-se as deformações máximas medidas pelos extensômetros (deformações para $\mathrm{P}=0 \mathrm{kN}$ nos gráficos das Figuras 6.5 a 6.10 );

2) Determinam-se as médias das deformações máximas, que são as médias dos valores medidos no patamar correspondente à atuação da força total de protensão;

3) Determina-se $95 \%$ do valor da média das deformações máximas, e traça-se uma linha, paralela ao eixo das distâncias, correspondente a esse valor; 
4) Determina-se o comprimento de transferência pela interseção da linha de $95 \%$ com a linha das deformações medidas.

A Figura 6.28 apresenta a comparação da linha de 95\% da média geral da deformação máxima, ou seja, levando-se em conta todos os modelos, com as deformações máximas de todas as vigas.

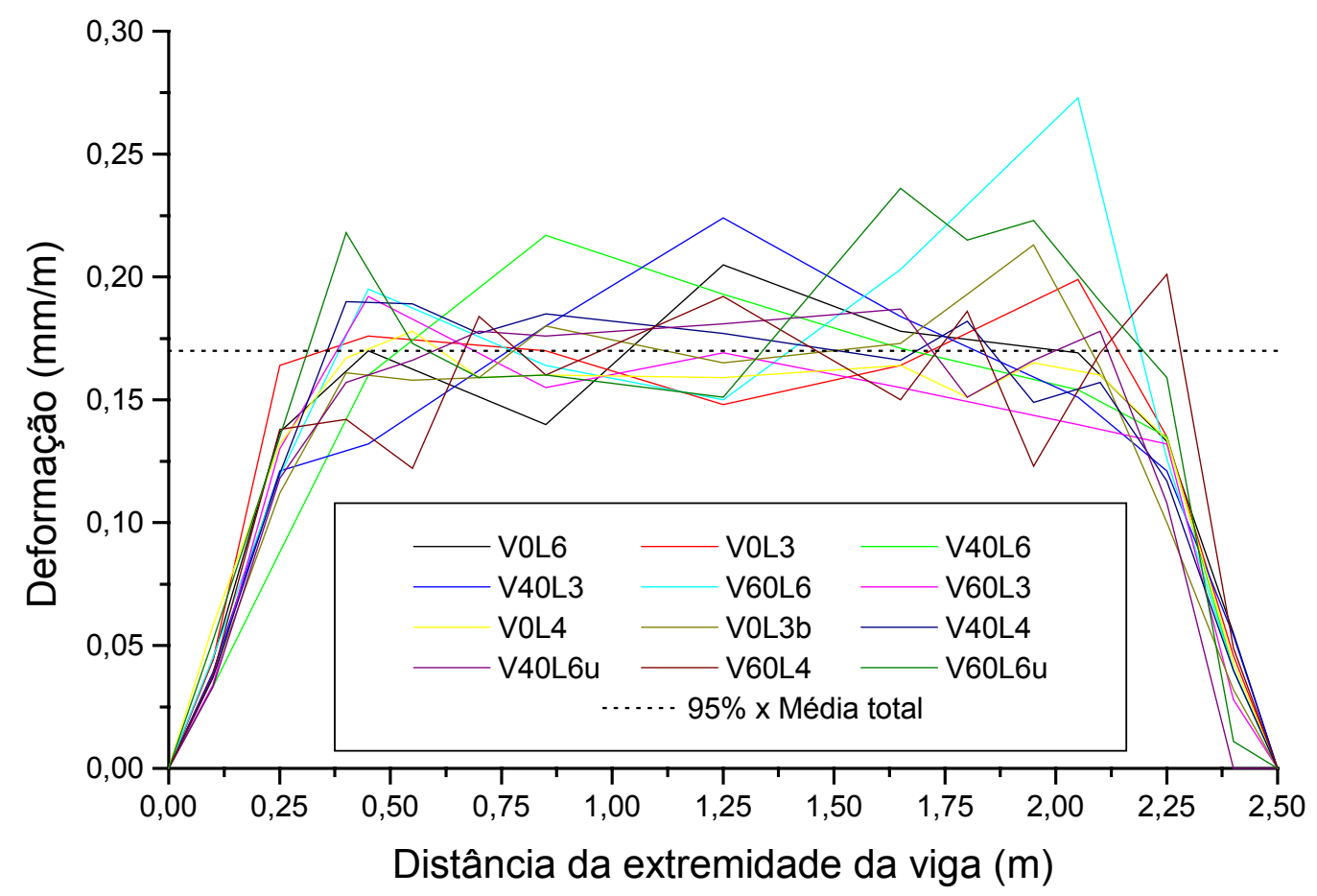

Figura 6.28 - Gráfico Deformação versus Distância da extremidade da viga, para as deformações máximas.

Percebe-se que os modelos, de maneira geral, apresentam o mesmo comportamento e que a dispersão em torno do valor médio total não é muito grande. Os gráficos das Figuras 6.29 a 6.40 apresentam a determinação, individualmente, dos comprimentos de transferência para as vigas ensaiadas.

A Tabela 6.4 apresenta os valores dos comprimentos de transferência para as vigas.

Percebe-se que, assim como para os ensaios de arrancamento, os modelos com $\mathrm{V}_{\mathrm{f}}=40 \mathrm{~kg} / \mathrm{m}^{3}$ apresentaram os piores resultados, o que mais uma vez vem a confirmar que a qualidade do concreto, e não apenas a sua resistência à compressão, tem influência na aderência das peças. A presença das fibras não melhorou o comprimento de transferência, pelo contrário, as peças sem fibras de aço foram as que apresentaram os melhores resultados, e os mais uniformes. Logo, a utilização das fibras de aço em teores baixos não influiu positivamente na determinação do comprimento de transferência das peças pré-tracionadas. 


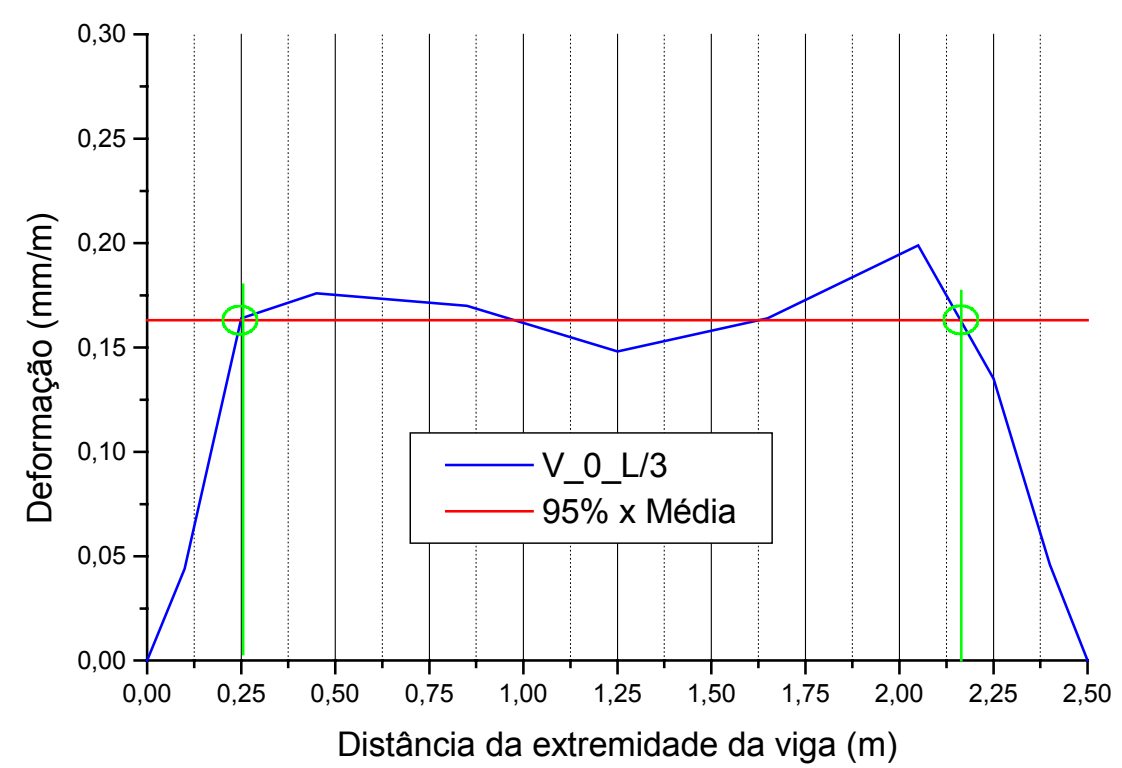

Figura 6.29 - Determinação dos comprimentos de transferência para a V_0_L/3.

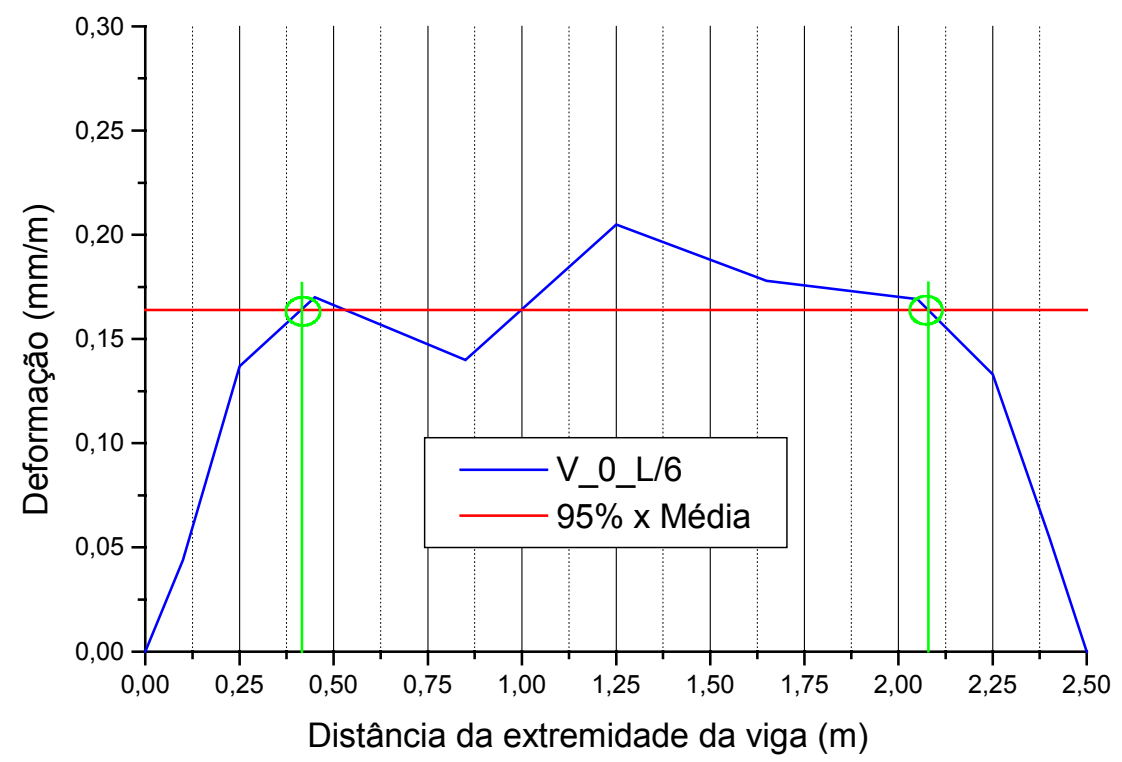

Figura 6.30 - Determinação dos comprimentos de transferência para a V_0_L/6.

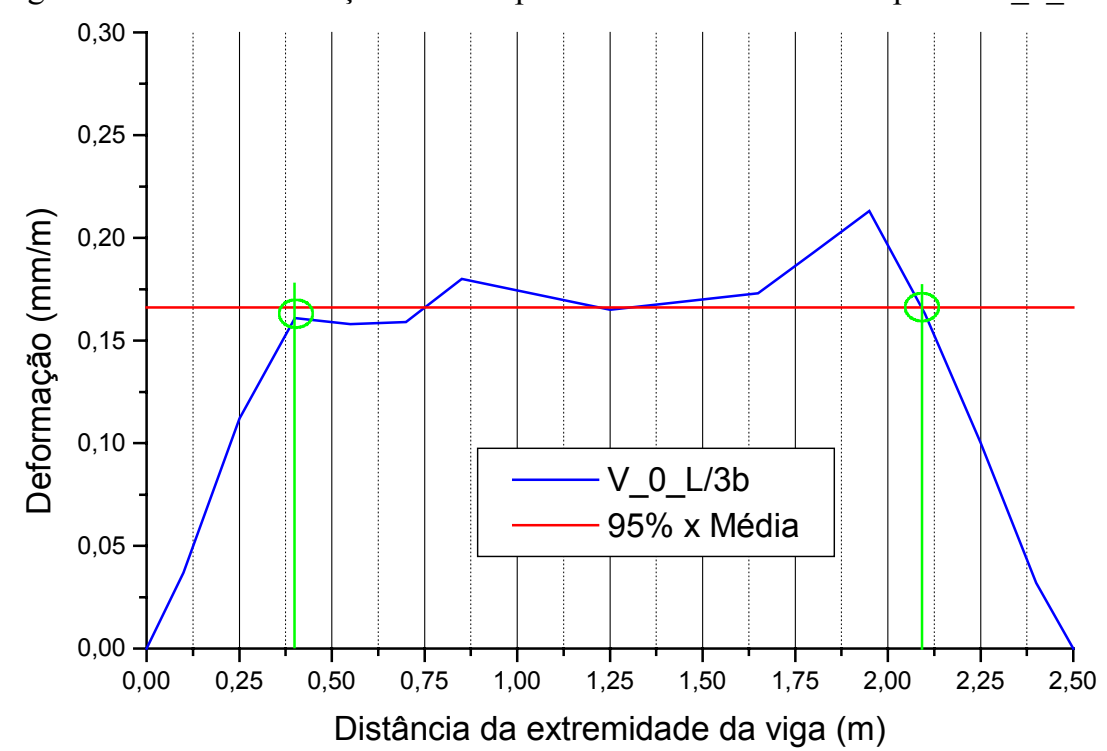

Figura 6.31 - Determinação dos comprimentos de transferência para a V_0_L/3b. 


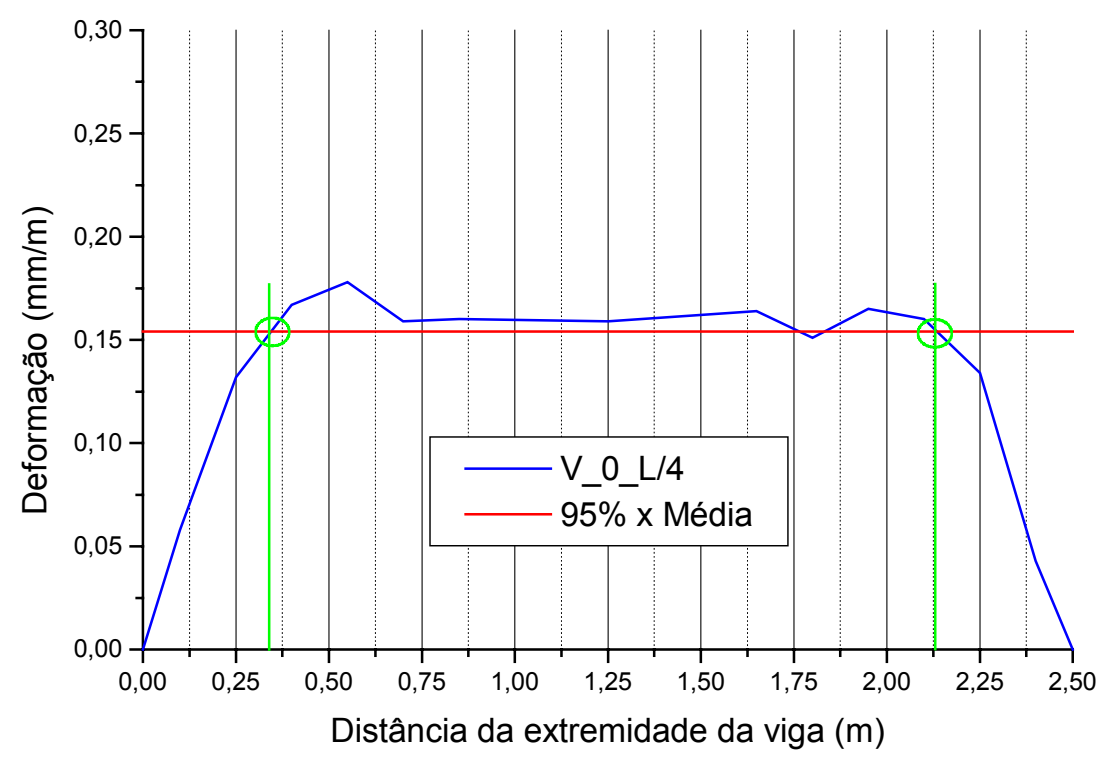

Figura 6.32 - Determinação dos comprimentos de transferência para a V_0_L/4.

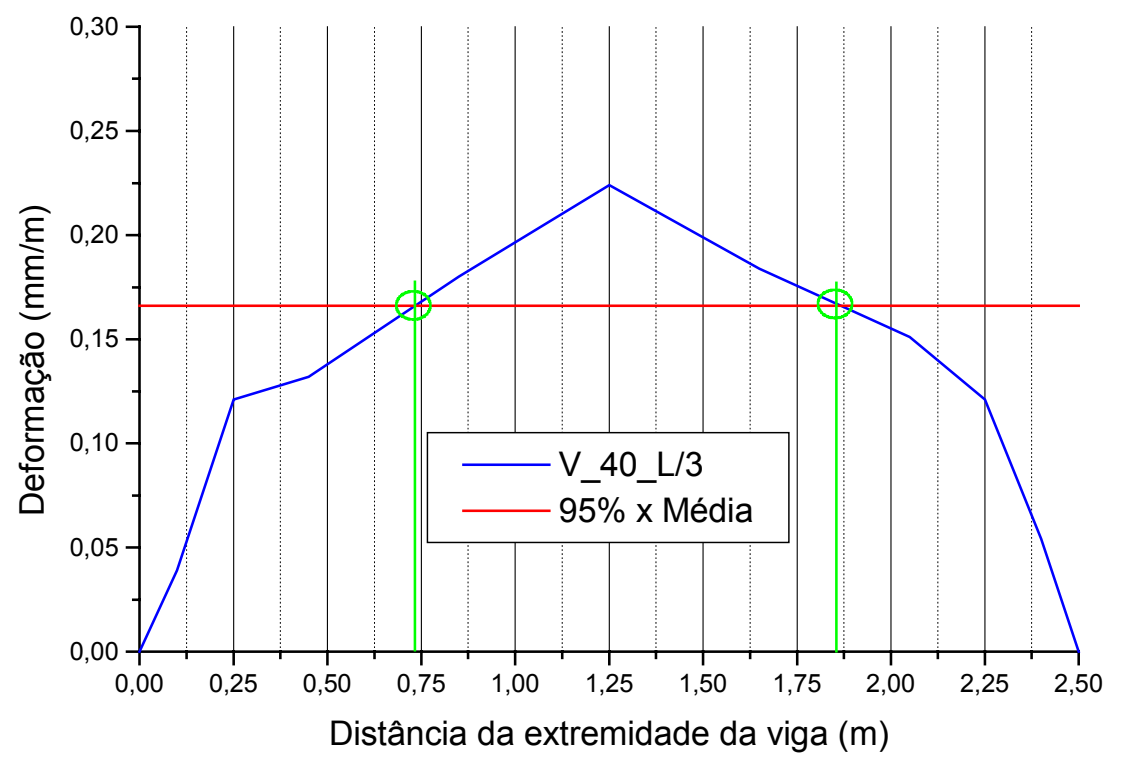

Figura 6.33 - Determinação dos comprimentos de transferência para a $V_{-} 40 \_L / 3$.

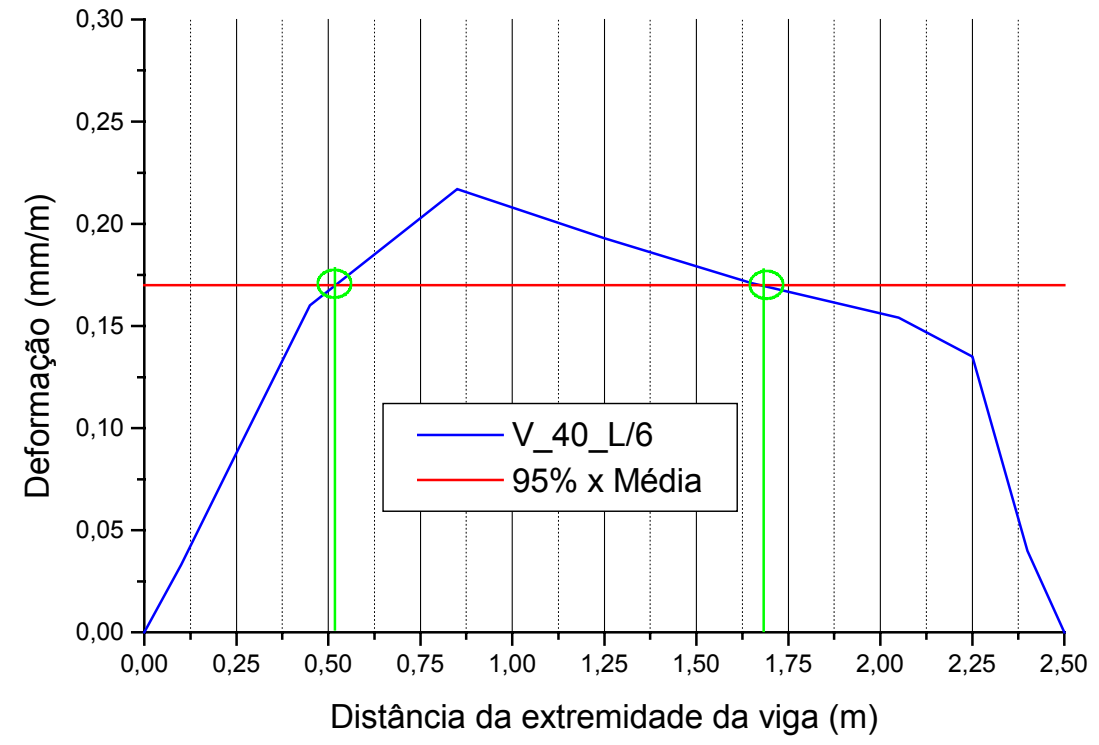

Figura 6.34 - Determinação dos comprimentos de transferência para a V_40_L/6. 


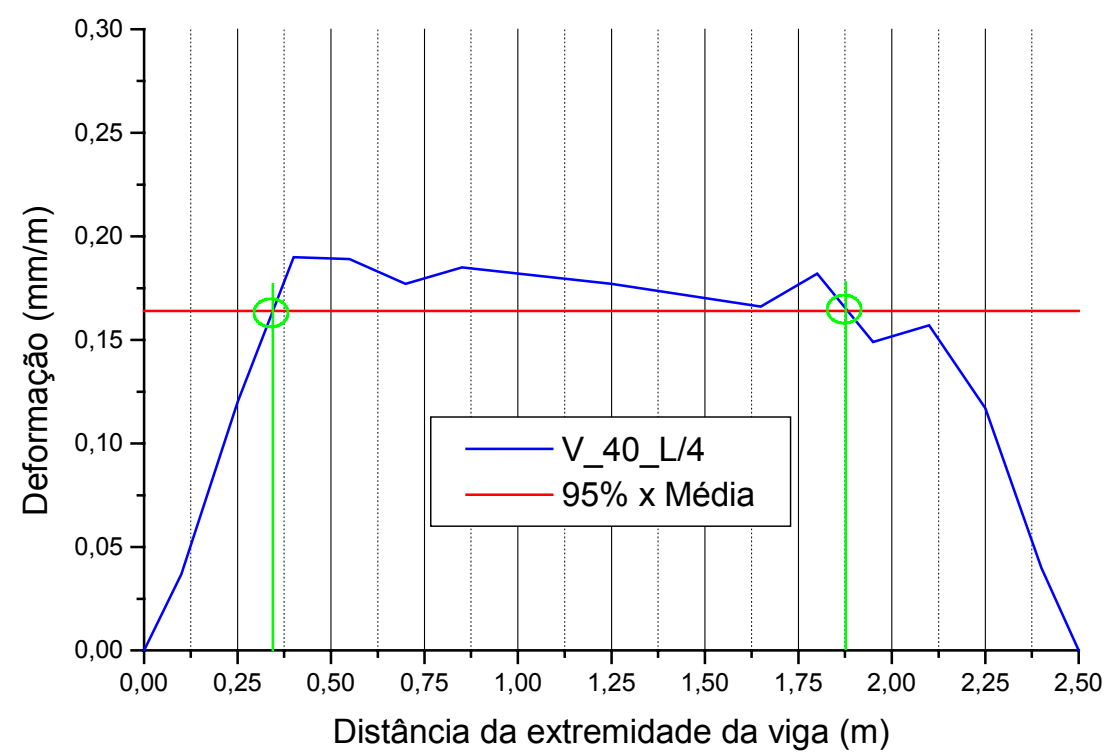

Figura 6.35 - Determinação dos comprimentos de transferência para a V_40_L/4.

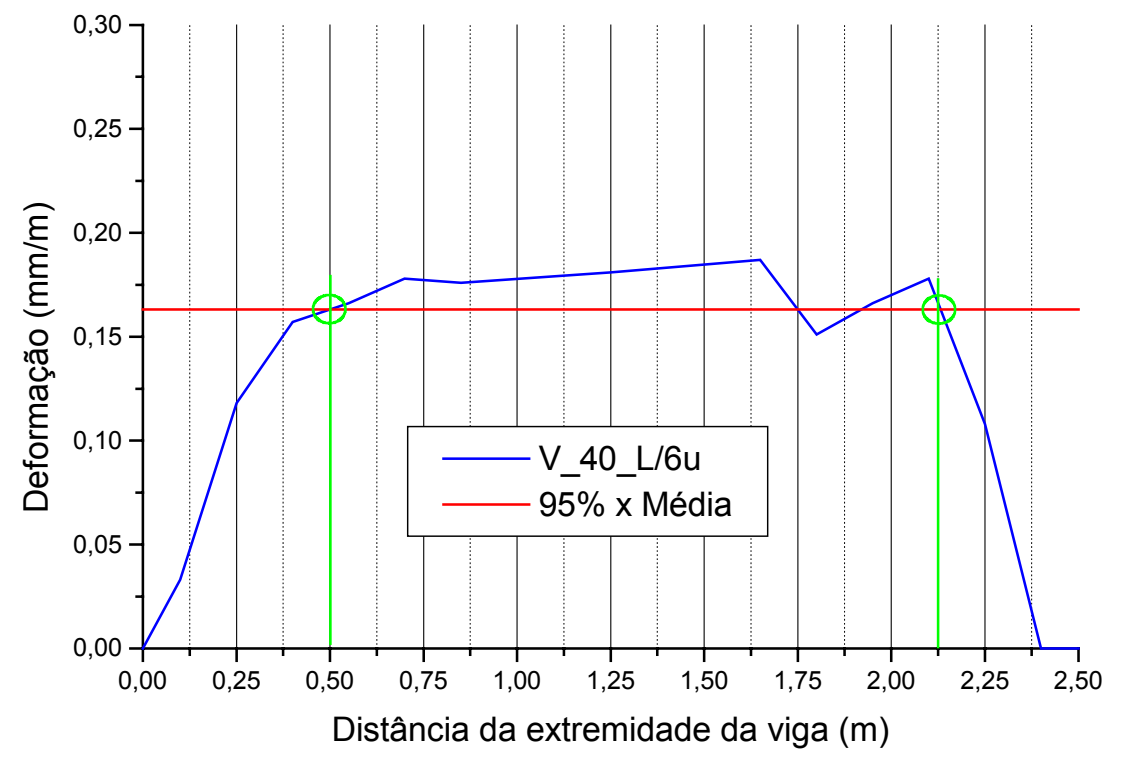

Figura 6.36 - Determinação dos comprimentos de transferência para a V_40_L/6u.

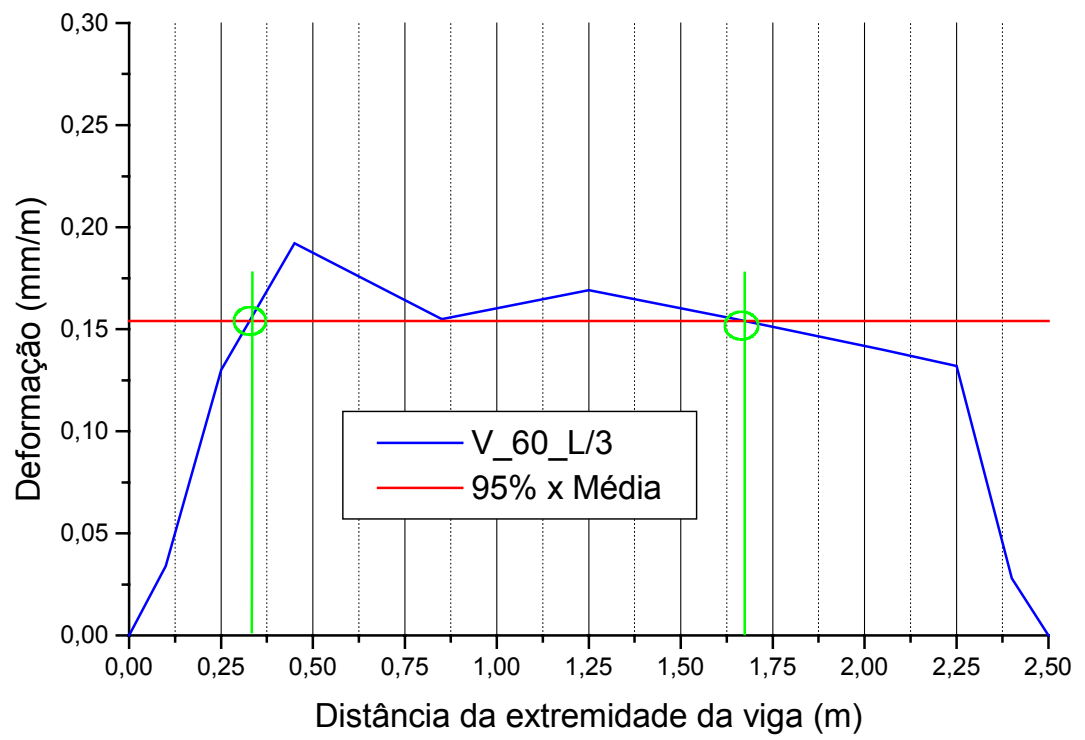

Figura 6.37 - Determinação dos comprimentos de transferência para a V_60_L/3. 


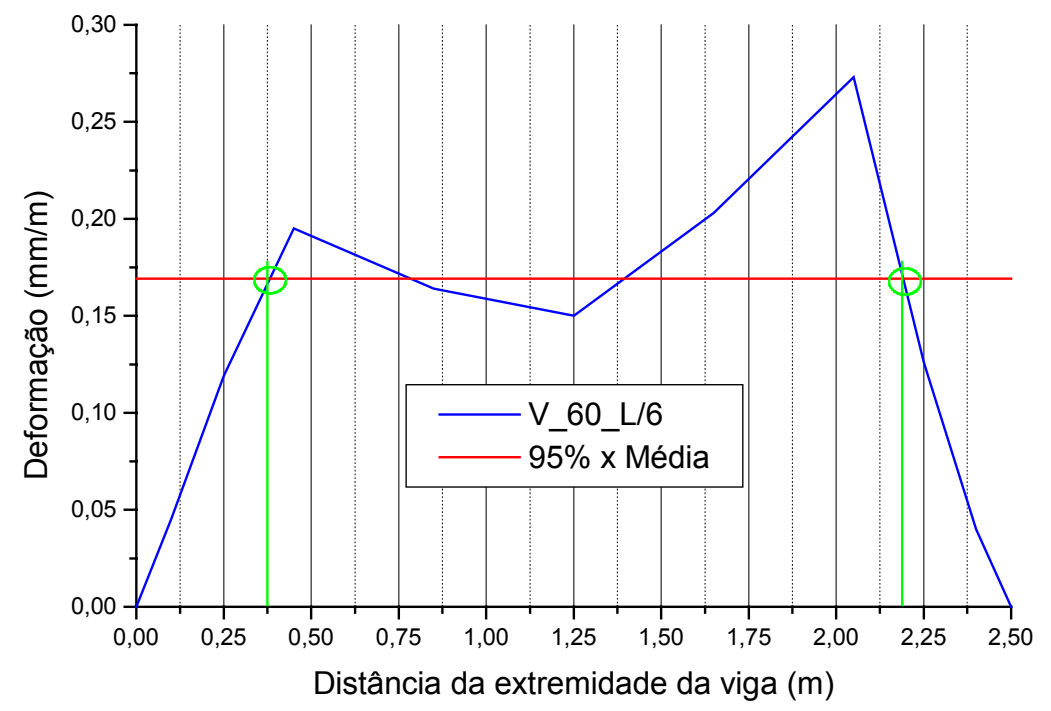

Figura 6.38 - Determinação dos comprimentos de transferência para a V_60_L/6.

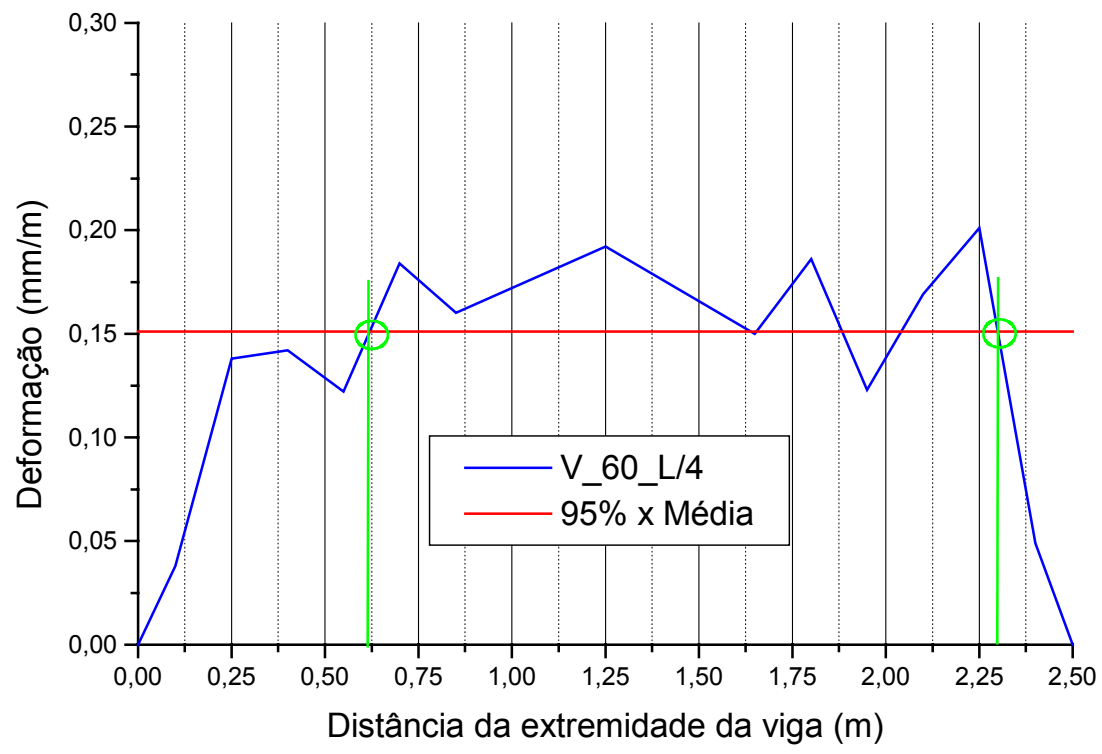

Figura 6.39 - Determinação dos comprimentos de transferência para a V_60_L/4.

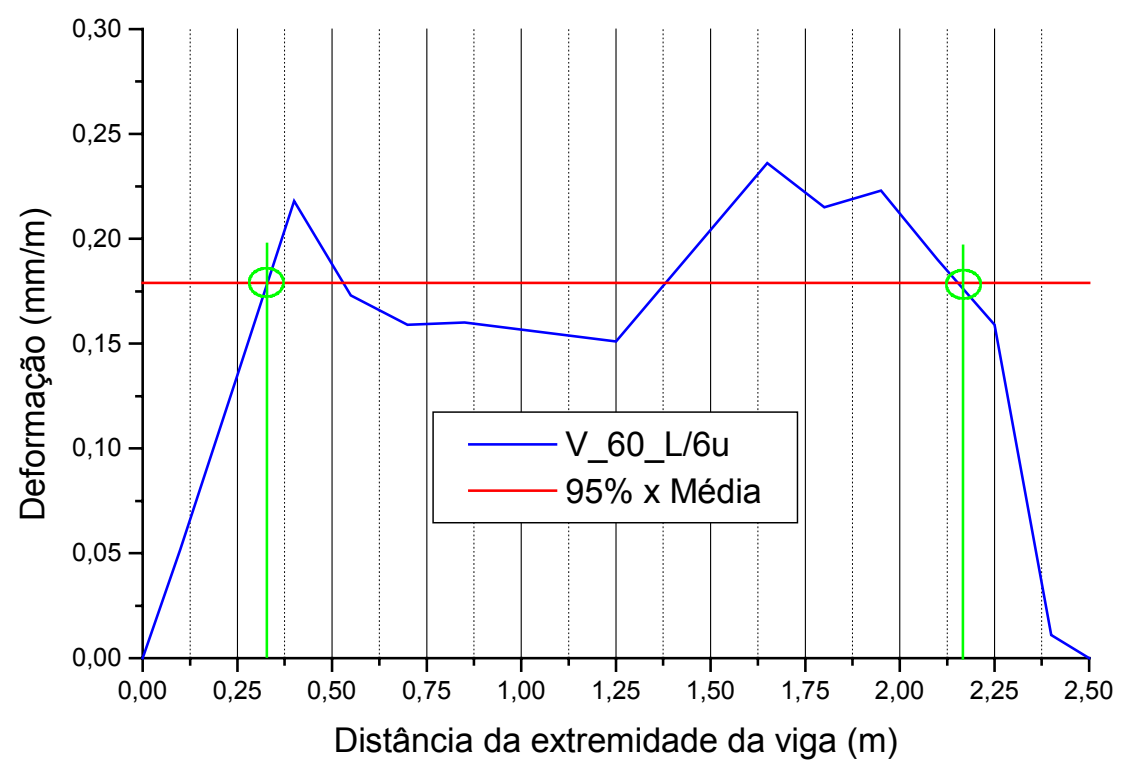

Figura 6.40 - Determinação dos comprimentos de transferência para a V_60_L/6u. 
Ao contrário do que foi observado para os valores da penetração, não há grandes diferenças entre os comprimentos de transferência das duas extremidades das peças, apesar de haver uma leve tendência indicando que os valores da extremidade morta foram um pouco maiores que os da extremidade ativa.

Tabela 6.4 - Valores corrigidos para os comprimentos de transferência das vigas.

\begin{tabular}{|c|c|c|c|c|c|}
\hline \multirow{2}{*}{ Viga } & \multirow{2}{*}{$\begin{array}{c}\lambda_{\mathrm{bpt}, 1} \\
\text { (extremidade } \\
\text { ativa) }(\mathrm{cm})\end{array}$} & \multirow{2}{*}{$\begin{array}{c}\lambda_{\text {bpt }, 2} \\
\text { (extremidade } \\
\text { morta) }(\mathrm{cm})\end{array}$} & \multicolumn{3}{|c|}{ Médias } \\
\hline & & & $\lambda_{\text {bpt }, 1}$ & $\lambda_{\mathrm{bpt}, 2}$ & Geral \\
\hline V_0_L/3 & 25 & 33 & \multirow{4}{*}{35,25} & \multirow{4}{*}{36,25} & \multirow{4}{*}{35,75} \\
\hline V_0_L/6 & 41 & 36 & & & \\
\hline V_0_L/3b & 40 & 40 & & & \\
\hline V_0_L/4 & 35 & 36 & & & \\
\hline V_40_L/3 & 74 & 62 & \multirow{4}{*}{52,75} & \multirow{4}{*}{60,50} & \multirow{4}{*}{56,63} \\
\hline V_40_L/6 & 52 & 82 & & & \\
\hline V_40_L/4 & 35 & 61 & & & \\
\hline V_40_L/6u & 50 & 37 & & & \\
\hline V_60_L/3 & 33 & 82 & \multirow{4}{*}{41,25} & \multirow{4}{*}{42,00} & \multirow{4}{*}{41,63} \\
\hline V_60_L/6 & 38 & 31 & & & \\
\hline V_60_L/4 & 61 & 20 & & & \\
\hline V_60_L/6u & 33 & 35 & & & \\
\hline Médias & 43,08 & 46,25 & & 44,67 & \\
\hline
\end{tabular}

\subsubsection{Confrontação dos resultados teóricos e experimentais}

Após a análise dos resultados experimentais, obtiveram-se os valores representativos para o comprimento de transferência para os parâmetros de ensaio utilizados. A Tabela 6.5 apresenta a comparação dos valores experimentais com os valores teóricos descritos no Capítulo 3.

Percebe-se que os valores encontrados nesta pesquisa foram menores que os de outros pesquisadores, exceto para os de ZIA \& MOSTAFA (1977). Porém, foram coerentes com os valores sugeridos pelas prescrições normativas, que fornecem uma boa margem de segurança, o que é de se esperar. 
Tabela 6.5 - Valores experimentais e teóricos para os comprimentos de transferência (comprimentos em m).

\begin{tabular}{|c|c|c|c|}
\hline Fonte & $V_{f}\left(\mathbf{k g} / \mathrm{m}^{3}\right)$ & $\begin{array}{l}\text { Comprimento de } \\
\text { transferência, } \lambda_{\text {bpt }}\end{array}$ & $\frac{\ell_{\mathrm{bpt}, \mathrm{i}}}{\ell_{\mathrm{bpt}, \mathrm{FIB}}}$ \\
\hline \multirow{3}{*}{ Experimental } & 0 & 0,36 & 0,48 \\
\hline & 40 & 0,57 & 0,76 \\
\hline & 60 & 0,42 & 0,56 \\
\hline ZIA \& MOSTAFA (1977) & \multirow{5}{*}{0} & 0,45 & 0,60 \\
\hline COUSINS et al (1990c) & & 0,79 & 1,05 \\
\hline SHAHAWY et al (1992) & & 0,92 & 1,23 \\
\hline RUSSEL \& BURNS (1993) & & 1,11 & 1,48 \\
\hline DEATHERAGE et al (1994) & & 0,92 & 1,23 \\
\hline FIB Bulletin 1 (1999) & \multirow{2}{*}{0} & 0,75 & 1 \\
\hline ACI 318 (2002) & & 0,74 & 0,99 \\
\hline
\end{tabular}

Entretanto, alguns pesquisadores como BUCKNER (1995) afirmam que as prescrições normativas do ACI 318 se basearam em ensaios feitos nas décadas de 50 e 60, quando se utilizavam aços de relaxação normal e tensões atuantes menores, de aproximadamente $\sigma_{\mathrm{pi}}=1000 \mathrm{MPa}$. Por conta disso, os valores para os comprimentos de transferência e ancoragem necessário estariam menores do que o ideal. Além disso, ele constata que há uma grande variação nos valores de ensaios relatados por diferentes pesquisadores. Essa é uma área que ainda merece bastante estudo.

\subsection{Comprimento de Ancoragem Necessário}

\subsubsection{Descrição dos ensaios}

A determinação do comprimento de ancoragem das vigas se baseia na mudança do modo de ruptura da peça durante os ensaios de flexão, como já explicado no Capítulo 2. Para as vigas utilizadas, foram escolhidos três comprimentos aderentes disponíveis: L/3, L/4 e L/6, como indica a Figura 6.41.

Para cada volume de fibra utilizado, variou-se o comprimento de ancoragem disponível dos ensaios. A Tabela 6.6 apresenta a relação entre os volumes de fibra e os comprimentos aderentes. Vale lembrar que para $\lambda_{0}=\mathrm{L} / 3$ todos os ensaios tiveram duas cargas eqüidistantes, e para $\lambda_{0}=\mathrm{L} / 4$ todos os ensaios foram com uma carga deslocada para a extremidade. 
Comprimento de ancoragem de ensaio, com duas cargas eqüidistantes

$\ell_{0}$

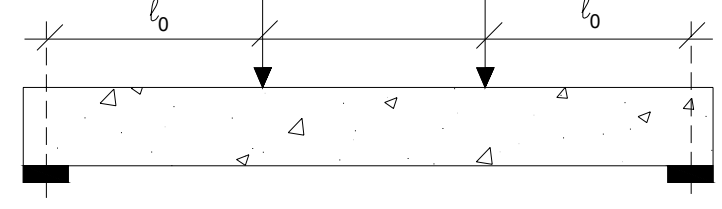

(a)
Comprimento de ancoragem de ensaio, com uma carga deslocada para a extremidade

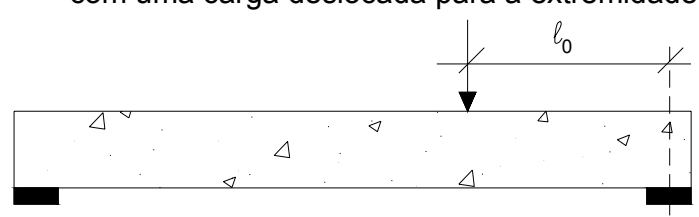

(b)

Figura 6.41 - Comprimentos aderentes disponíveis de ensaio: (a) com duas cargas eqüidistantes; (b) com uma carga deslocada para a extremidade.

Tabela 6.6 - Relação entre os volumes de fibras de aço e comprimentos aderentes de ensaio.

\begin{tabular}{|c|c|c|}
\hline Consumo de fibra $\left(V_{f}\right)$ & Viga & $\begin{array}{c}\text { Comprimento aderente } \\
\text { de ensaio }\left(\lambda_{0}\right)\end{array}$ \\
\hline \multirow{3}{*}{0} & $\mathrm{~V} \_0 \_\mathrm{L} / 3$ e V_0_L/3b & $\mathrm{L} / 3$ \\
\hline & V_0_L/4 & $\mathrm{L} / 4$ \\
\hline & V_0_L/6 & $\mathrm{L} / 6$ \\
\hline \multirow{3}{*}{$40 \mathrm{~kg} / \mathrm{m}^{3}$} & V_40_L/3 & $\mathrm{L} / 3$ \\
\hline & V_40_L/4 & $\mathrm{L} / 4$ \\
\hline & V_40_L/6 e V_40_L/6u & $\mathrm{L} / 6$ \\
\hline \multirow{3}{*}{$60 \mathrm{~kg} / \mathrm{m}^{3}$} & V_40_L/4 & $\mathrm{L} / 3$ \\
\hline & V_40_L/4 & $\mathrm{L} / 4$ \\
\hline & V_60_L/6 e V_60_L/6u & $\mathrm{L} / 6$ \\
\hline
\end{tabular}

O procedimento de ensaio para as vigas, após a retirada da protensão, foi o seguinte:

1) Eram colados os extensômetros elétricos da zona comprimida do concreto (Figura 6.42), pelo menos 48 horas antes do ensaio;

2) Após, aproximadamente, 28 dias da concretagem da viga, ela era colocada no pórtico de reação, de acordo com o arranjo de ensaio estabelecido (Figura 6.42);

3) Todos os pontos da instrumentação eram ligados ao sistema de aquisição de dados (SYSTEM 5000);

4) Os pontos de instrumentação eram testados, corrigidos quando necessário, e iniciavase o ensaio;

5) Os dados eram lidos automaticamente a cada 2 segundos;

6) As fissuras iam sendo marcadas à medida que iam aparecendo, com as respectivas cargas; 
7) Quando se atingia um ponto limite, o ensaio era interrompido, a peça descarregada, a instrumentação retirada, e a viga era colocada em cavaletes para que se tirassem as fotos e se anotasse o seu padrão de fissuração completo.

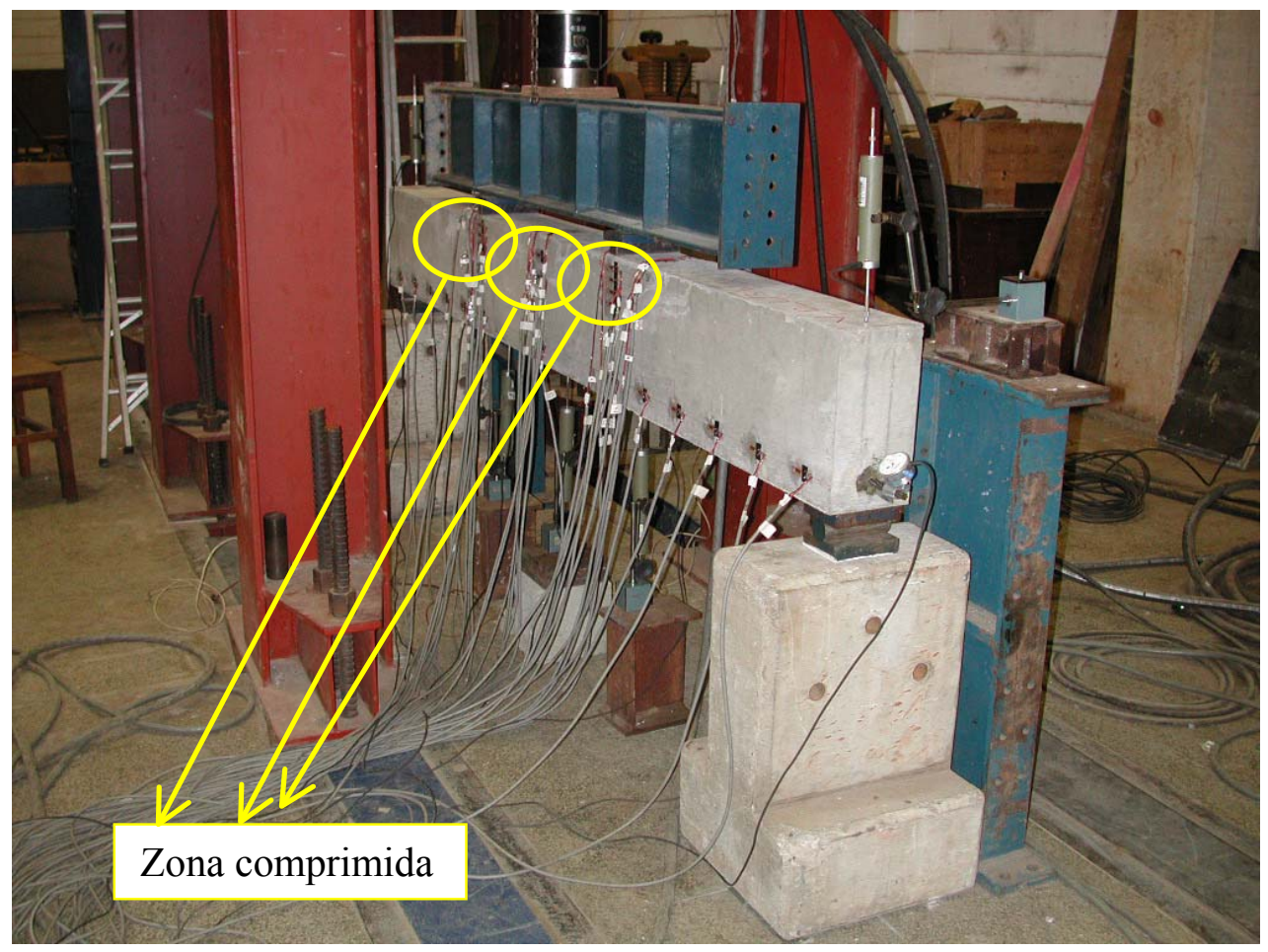

Figura 6.42 - Detalhes dos ensaios de flexão.

Para os ensaios de flexão, a taxa de carregamento foi de $\mathrm{v}_{\text {ensaio }}=0,005 \mathrm{~mm} / \mathrm{seg}$. Os ensaios duraram entre 1:30hs e 2:00hs, dependendo do arranjo de carregamento.

Os valores das forças inicial $\left(\mathrm{P}_{\mathrm{i}}\right)$ e após as perdas imediatas $\left(\mathrm{P}_{0}\right)$, assim como os dos encurtamentos das armaduras foram medidos nas operações de protensão e desprotensão. A Figura 6.43 apresenta os gráficos Tensão versus Deformação para as cordoalhas das vigas. Percebe-se que a variação dos valores é muito pequena. Nota-se, também, que a tensão na cordoalha após as perdas imediatas $\left(\sigma_{\mathrm{p} 0 \text {,ensaio }} \approx 1350 \mathrm{MPa}\right)$ ficou bem próxima à calculada, que foi da ordem de $\sigma_{\mathrm{p} 0}=1275 \mathrm{MPa}$, cujo cálculo está apresentado no Apêndice B. Isso indica que as perdas calculadas foram maiores que as que ocorreram nos ensaios, pois as forças de protensão eram sempre corrigidas no momento da concretagem, o que diminuiu as perdas por encunhamento da ancoragem e relaxação inicial da armadura.

Os valores de deformação obtidos, medidos nos fios isolados, foram corrigidos através do gráfico apresentado na Figura 4.49, no final do Capítulo 4, para levar em conta a deformação da cordoalha como um todo. O valor da tensão na cordoalha após as perdas imediatas $\left(\sigma_{\mathrm{p} 0 \text {,ensaio }}\right)$ foi obtida, também, a partir do gráfico da Figura 4.49. 


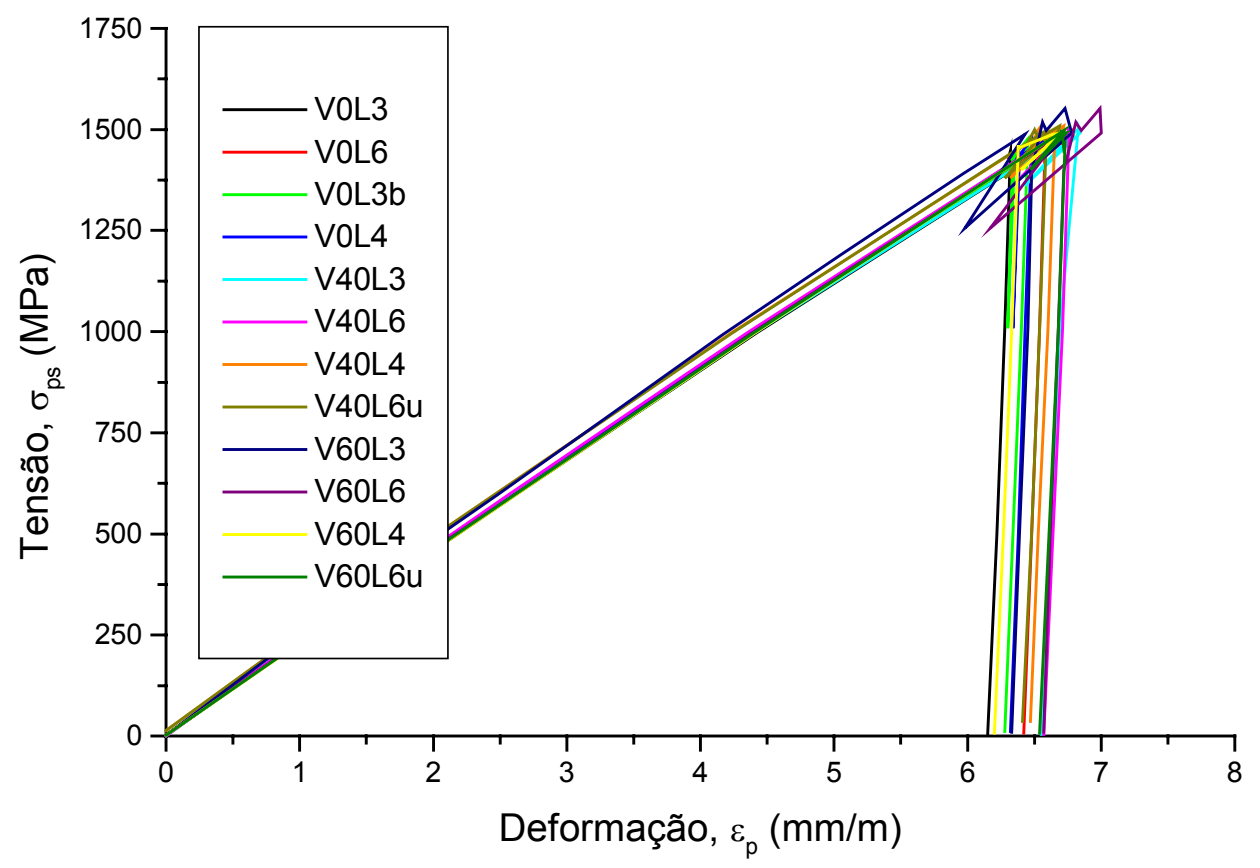

Figura 6.43 - Gráfico Tensão versus Deformação para as cordoalhas, durante a protensão e desprotensão.

A Tabela 6.7 apresenta os resultados para as forças de protensão e as deformações médias e corrigidas das cordoalhas.

Tabela 6.7 - Forças de protensão e deformações médias da cordoalha para as vigas.

\begin{tabular}{|c|c|c|c|c|c|c|c|c|c|}
\hline Viga & Concretagem & $\begin{array}{c}\mathrm{P}_{\mathrm{i}} \\
(\mathrm{kN})\end{array}$ & $\begin{array}{l}\varepsilon_{\mathrm{p}, \mathrm{i}, \mathrm{m}} \\
(\% \mathrm{o})\end{array}$ & $\begin{array}{c}\varepsilon_{\mathrm{p}, \mathrm{final}, \mathrm{m}} \\
(\% \mathrm{o})\end{array}$ & $\begin{array}{l}\Delta \varepsilon_{\mathrm{m}} \\
(\%)\end{array}$ & $\begin{array}{c}\varepsilon_{\mathrm{p}, \mathrm{corr}} \\
(\% \mathrm{o})\end{array}$ & $\begin{array}{c}\sigma_{\mathrm{p} 0 \text {,ensaio }} \\
(\mathrm{MPa})\end{array}$ & $\begin{array}{c}\mathrm{P}_{0} \\
(\mathrm{kN})\end{array}$ & $\begin{array}{l}\Delta \mathrm{P} \\
(\%)\end{array}$ \\
\hline V_0_L/3 & \multirow{2}{*}{ C19 } & \multirow{2}{*}{146} & 6,32 & 6,15 & 3 & 6,66 & 1300 & 130 & 11 \\
\hline V_0_L/6 & & & 6,58 & 6,42 & 2 & 6,93 & 1350 & 135 & 7 \\
\hline V_40_L/3 & \multirow{2}{*}{$\mathrm{C} 20$} & \multirow{2}{*}{151} & 6,83 & 6,55 & 4 & 7,06 & 1375 & 138 & 9 \\
\hline V_40_L/6 & & & 6,76 & 6,57 & 3 & 7,10 & 1381 & 139 & 8 \\
\hline V_60_L/3 & \multirow{2}{*}{$\mathrm{C} 21$} & \multirow{2}{*}{140} & 6,48 & 6,33 & 2 & 6,83 & 1331 & 134 & 5 \\
\hline V_60_L/6 & & & 6,72 & 6,57 & 2 & 7,10 & 1381 & 139 & 1 \\
\hline V_0_L/3b & \multirow{2}{*}{$\mathrm{C} 22$} & \multirow{2}{*}{148} & 6,45 & 6,28 & 3 & 6,80 & 1325 & 133 & 10 \\
\hline V_0_L/4 & & & 6,48 & 6,32 & 2 & 6,83 & 1331 & 134 & 10 \\
\hline V_40_L/4 & \multirow{2}{*}{$\mathrm{C} 23$} & \multirow{2}{*}{148} & 6,65 & 6,47 & 3 & 6,99 & 1363 & 137 & 8 \\
\hline V_40_L/6u & & & 6,59 & 6,41 & 3 & 6,90 & 1344 & 135 & 9 \\
\hline V_60_L/4 & \multirow{2}{*}{$\mathrm{C} 24$} & \multirow{2}{*}{147} & 6,38 & 6,20 & 3 & 6,70 & 1313 & 132 & 10 \\
\hline V_60_L/6u & & & 6,73 & 6,54 & 3 & 7,06 & 1375 & 138 & 6 \\
\hline
\end{tabular}


A Tabela 6.8 apresenta a relação das datas de concretagem e ensaio, a idade e as resistências do concreto à compressão dos corpos-de-prova e corrigidas, para todas as vigas.

Tabela 6.8 - Dados das idades e resistências do concreto à compressão para as vigas.

\begin{tabular}{|c|c|c|c|c|c|}
\hline $\begin{array}{c}\text { Concretagem } \\
\text { e data } \\
\end{array}$ & Viga & $\begin{array}{c}\text { Data do } \\
\text { ensaio }\end{array}$ & $\begin{array}{l}\text { Idade } \\
\text { (dias) } \\
\end{array}$ & $\begin{array}{c}\mathbf{f}_{\mathrm{c}, \mathrm{CP} 10 \times 20} \\
(\mathrm{MPa})\end{array}$ & $\begin{aligned} \mathbf{f}_{\mathrm{c}, \mathrm{corr}}= & 0,9 * \mathbf{f}_{\mathrm{c}, \mathrm{CP} 10 \times 20} \\
& (\mathrm{MPa})\end{aligned}$ \\
\hline \multirow{2}{*}{ C19 $(26 / 8)$} & $\mathrm{V} \_0 \_\mathrm{L} / 3$ & $23 / 9$ & 28 & \multirow{2}{*}{72,39} & \multirow{2}{*}{65,2} \\
\hline & V_0_L/6 & $24 / 9$ & 29 & & \\
\hline \multirow{2}{*}{ C20 (9/9) } & V_40_L/3 & $8 / 10$ & 29 & \multirow{2}{*}{65,77} & \multirow{2}{*}{59,2} \\
\hline & $\mathrm{V} \_40 \_\mathrm{L} / 6$ & $9 / 10$ & 30 & & \\
\hline \multirow{2}{*}{ C21 (16/9) } & $\mathrm{V} \_60 \_\mathrm{L} / 3$ & $10 / 10$ & 24 & \multirow{2}{*}{71,67} & \multirow{2}{*}{64,5} \\
\hline & V_60_L/6 & $11 / 10$ & 25 & & \\
\hline \multirow{2}{*}{ C22 (21/10) } & V_0_L/3b & $13 / 11$ & 23 & \multirow{2}{*}{70,19} & \multirow{2}{*}{63,2} \\
\hline & V_0_L/4 & $14 / 11$ & 24 & & \\
\hline \multirow{2}{*}{$\mathrm{C} 23(7 / 11)$} & V_40_L/4 & $4 / 12$ & 27 & \multirow{2}{*}{74,52} & \multirow{2}{*}{67,1} \\
\hline & V_40_L/6u & $6 / 12$ & 29 & & \\
\hline \multirow{2}{*}{ C24 (14/11) } & V_60_L/4 & $5 / 12$ & 21 & \multirow{2}{*}{71,24} & \multirow{2}{*}{64,1} \\
\hline & V_60_L/6u & $9 / 12$ & 25 & & \\
\hline
\end{tabular}

A seguir estão descritos na ordem cronológica dos ensaios, um a um, os doze ensaios de vigas pré-tracionadas que foram realizados. Vale lembrar que as vigas foram todas idênticas no que disse respeito às suas dimensões e armaduras, exceto para as cinco últimas (V_0_L/4, V_40_L/4, V_40_L/6u, V_60_L/4 e V_60_L/6u), em que se aumentou a armadura transversal (estribos) na região de cortante máximo. A diferença básica entre as vigas, além do volume de fibras de aço, está nos pontos de instrumentação, tanto do concreto como das armaduras passivas e ativas, que foram relativos aos pontos de carregamento. Esses detalhes estão mostrados a seguir.

\section{a) Viga V_o_L/3}

A Figura 6.44 apresenta o esquema de ensaio da viga V_0_L/3, em que: TAE representa o transdutor do apoio à esquerda, TAD o transdutor do apoio à direita, TL/3E o transdutor sob o ponto de carga à esquerda, TL/3D o transdutor sob o ponto de carga à direita, TL/2 o transdutor sob o meio do vão, RE o relógio na cordoalha à esquerda, $\mathrm{RD}$ o relógio na cordoalha à direita e $\mathrm{P}_{\mathrm{k}}$ a carga vertical aplicada. Na figura, também, estão indicados os pontos dos extensômetros elétricos das armaduras e do concreto. Essa simbologia é válida para todas as vigas, com as respectivas referências aos pontos de aplicação da carga (L/3, L/4 e L/6). Todas as dimensões estão em centímetros. 


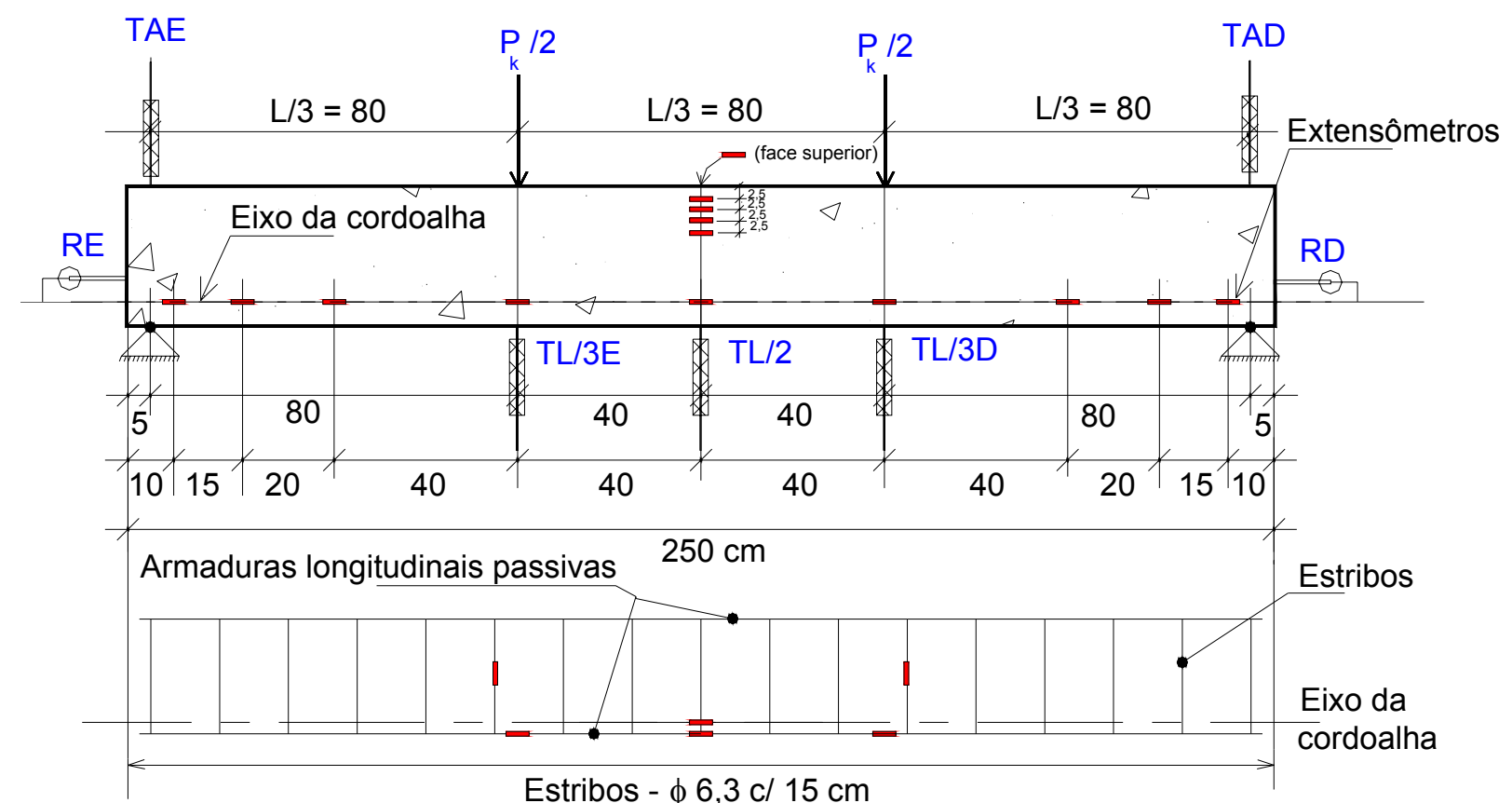

Figura 6.44 - Esquema de ensaio e instrumentação da viga V_0_L/3.

Vale lembrar que os extensômetros da armadura longitudinal passiva foram colocados nas duas barras, num total de seis extensômetros por viga, e que cada ponto de instrumentação da cordoalha representa dois extensômetros posicionados em dois fios diametralmente opostos, como indicado no Capítulo 4. O extensômetro que está indicado acima da viga com a nota "(face superior)" foi colado no meio da face superior da peça.

Como já foi dito, essa viga não pôde ser ensaiada, pois sofreu um acidente. Após a realização de todos os procedimentos preparatórios, ligou-se o atuador hidráulico para dar início ao ensaio. Porém, na passagem da pressão baixa para a pressão alta, o atuador desceu de uma só vez esmagando a viga. Posteriormente verificou-se que isso ocorreu devido a um curto-circuito nos fios de controle do deslocamento do atuador. A Figura 6.45 apresenta fotos da viga após o acidente.
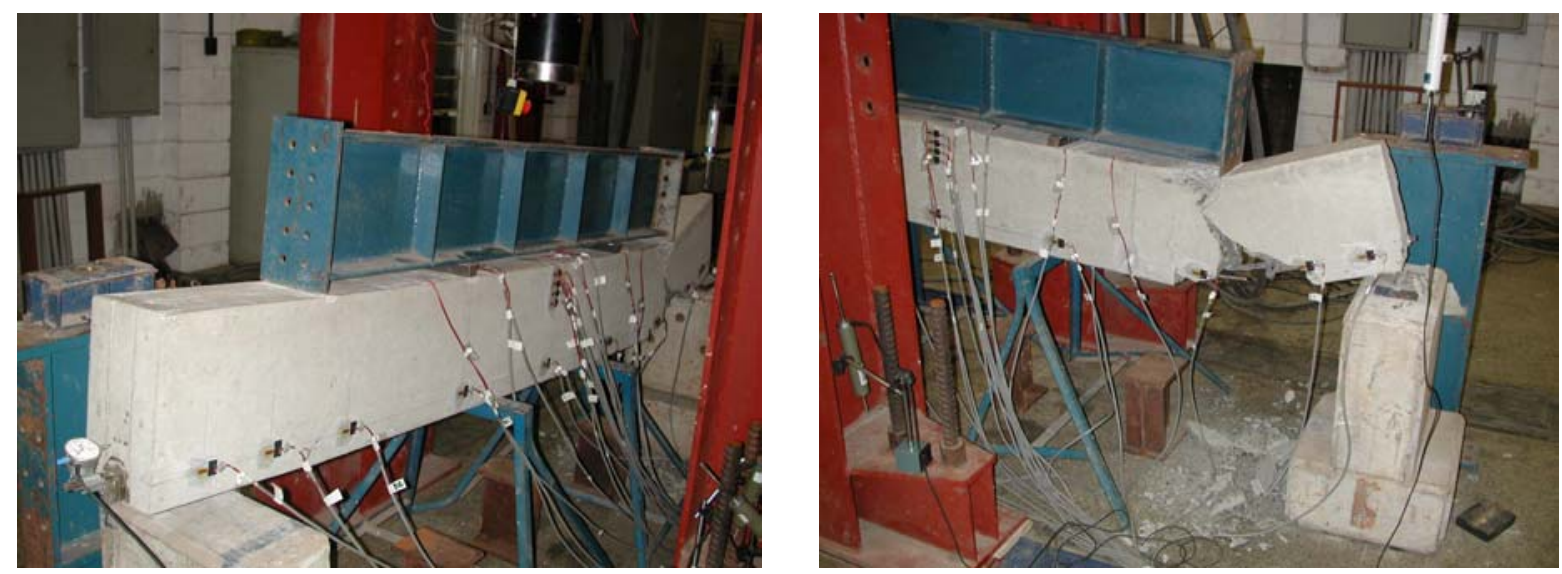

Figura 6.45 - Fotos da viga V_0_L/3 após o acidente. 


\section{b) Viga V_0_L/6}

Sanado o problema do curto-circuito nos fios do atuador, seguiram-se com os ensaios. A Figura 6.46 apresenta o esquema de ensaio da viga V_0_L/6.

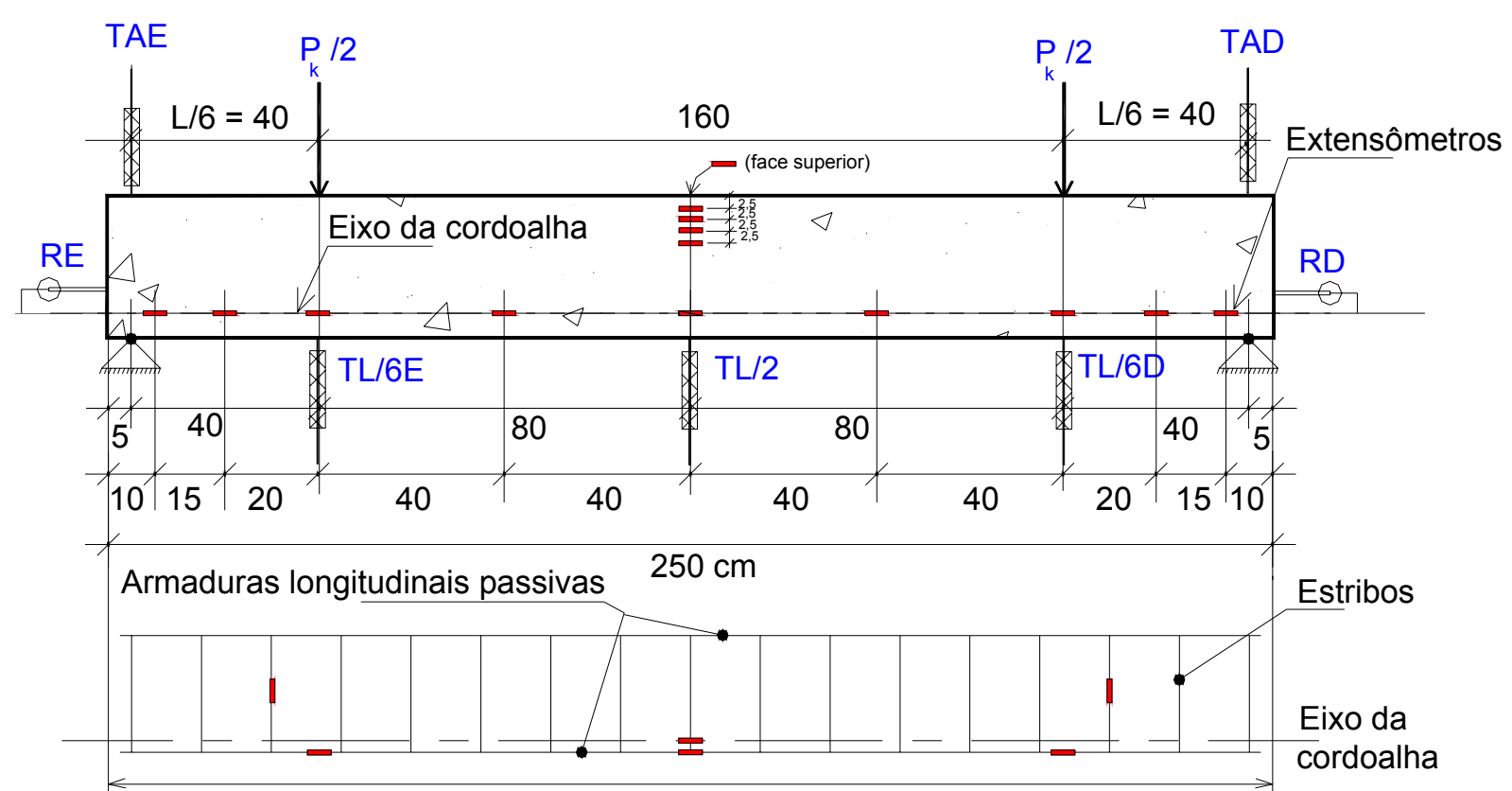

Estribos - $\phi 6,3 \mathrm{c} / 15 \mathrm{~cm}$

Figura 6.46 - Esquema de ensaio e instrumentação da viga V_0_L/6.

A carga teórica de início da fissuração era de $\mathrm{P}_{\text {fiss }}=157,65 \mathrm{kN}$ e a última de $P_{u ́ l t}=172,1 \mathrm{kN}$. Esses cálculos se encontram no Apêndice B. A peça, porém, começou a fisssurar para uma carga de $\mathrm{P}_{\text {fiss,ensaio }}=193 \mathrm{kN}$. Quando apareceu a primeira fissura, já foi uma de cisalhamento, bem inclinada. Com o aumento da carga, aumentaram-se as aberturas e os tamanhos das fissuras existentes, e, também, apareceram mais algumas fissuras, porém, poucas. A viga esgotou, primeiro, a capacidade de carga do seu lado esquerdo onde surgiram as primeiras fissuras, o que foi verificado pelos aumentos excessivos da deformação no estribo do lado esquerdo e do escorregamento da cordoalha no lado esquerdo (Figura 6.52). A partir daí, o lado direito da viga passou a absorver mais a carga, abrindo mais fissuras desse lado e solicitando o estribo da direita. A Figura 6.47 apresenta detalhes da fissuração dos dois lados da viga. O escorregamento da cordoalha pela direita, também, foi aumentando, assim como as deformações e o deslocamento da viga, o que levou à formação do efeito de pino na região mais solicitada, que pode ser observado na Figura 6.48a. O ensaio foi interrompido quando rompeu uma das armaduras longitudinais passivas, na zona de cortante máximo à direita, como mostra a Figura 6.48b. A carga já se encontrava em queda quando o ensaio foi interrompido para $\mathrm{P} \approx 230 \mathrm{kN}$. A carga máxima registrada foi de $\mathrm{P}_{\text {últ,ensaio }}=240 \mathrm{kN}$. 


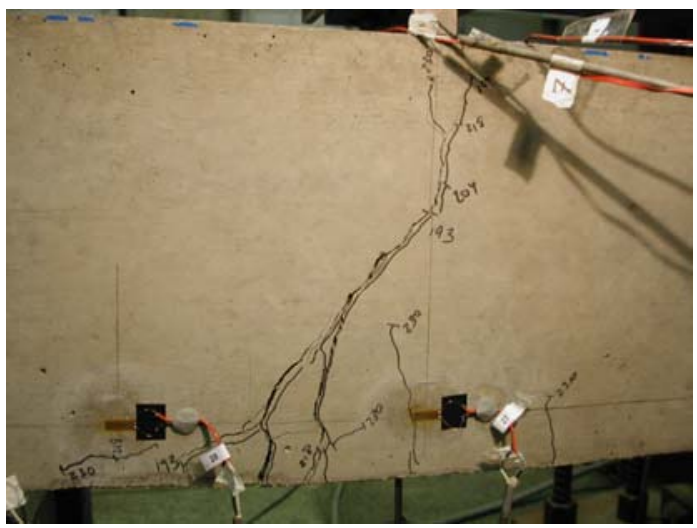

(a)

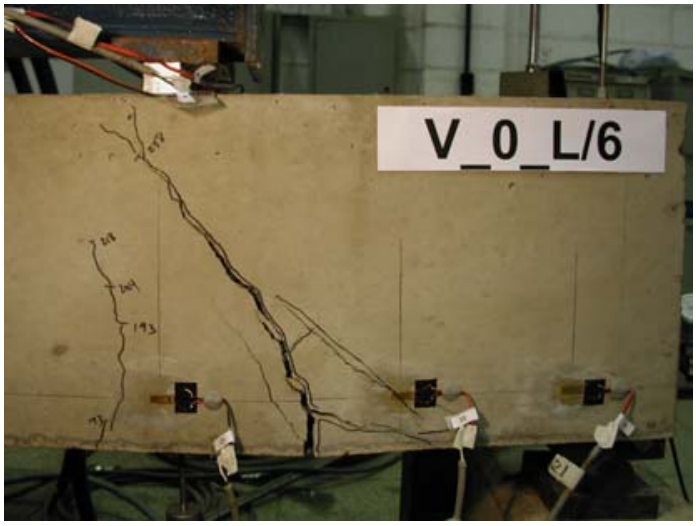

(b)

Figura 6.47 - Detalhes da fissuração da V_0_L/6: (a) lado esquerdo; (b) lado direito.

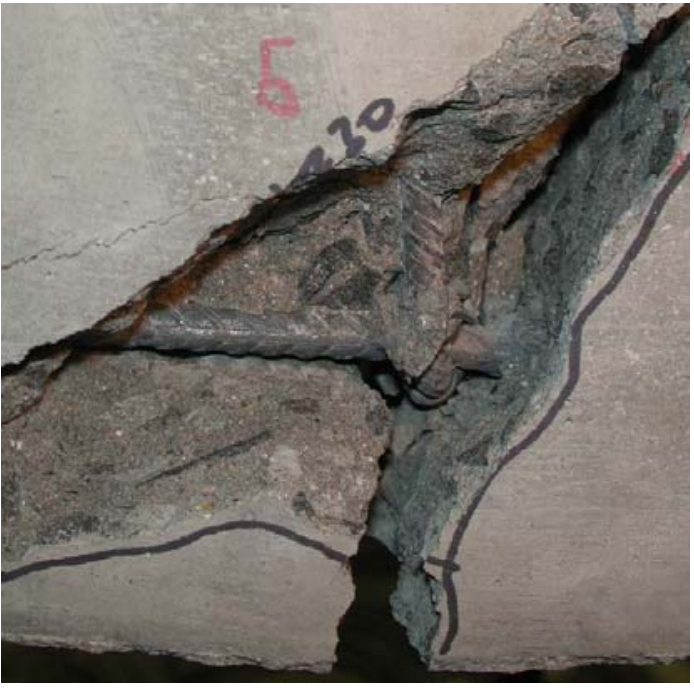

(a)

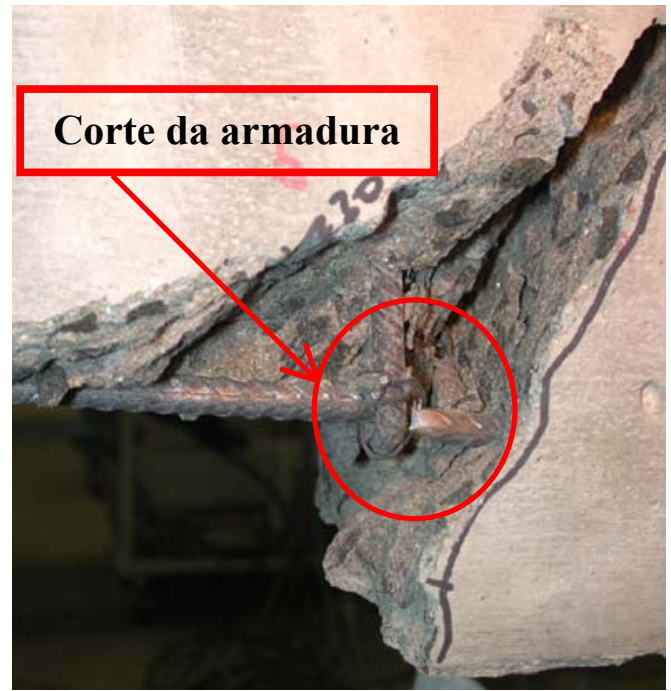

(b)

Figura 6.48 - Detalhes da V_0_L/6 durante o ensaio de flexão: (a) efeito de pino; (b) ruptura da armadura longitudinal passiva.

O panorama completo da fissuração da viga $V_{-} 0 \_L / 6$ se encontra no Apêndice G. As Figuras 6.49 a 6.52 apresentam os gráficos representativos do ensaio de flexão.

Percebe-se pelo gráfico da Figura 6.50 que não houve escoamento das armaduras. Já pelo gráfico da Figura 6.52, nota-se que a ruptura se deu por escorregamento. Para essa viga não ocorreu esmagamento do concreto na zona comprimida, indicado pelo gráfico de ZC que estava posicionado na face superior da viga, nem escoamento das armaduras. Observa-se que quando começam os escorregamentos da cordoalha nas extremidades da viga, as deformações não mais se alteram. A partir desse ponto só há aumento do escorregamento, que ultrapassou muito o valor teórico limite admitido para ruptura por aderência de vigas, que é de $\mathrm{S}_{\text {máx }}=0,25 \mathrm{~mm}$. 


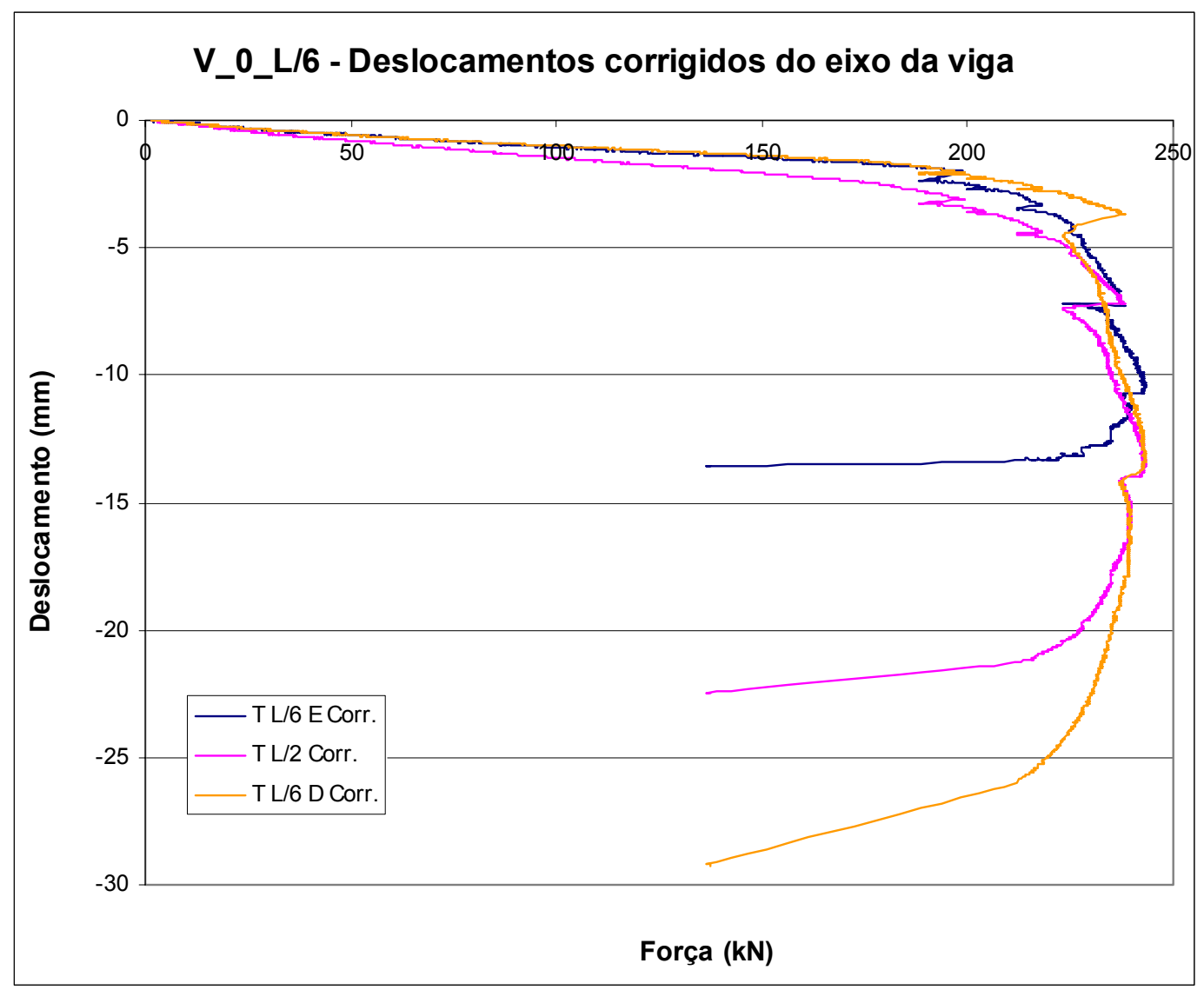

Figura 6.49 - Gráfico Força versus Deslocamento para a V_0_L/6.

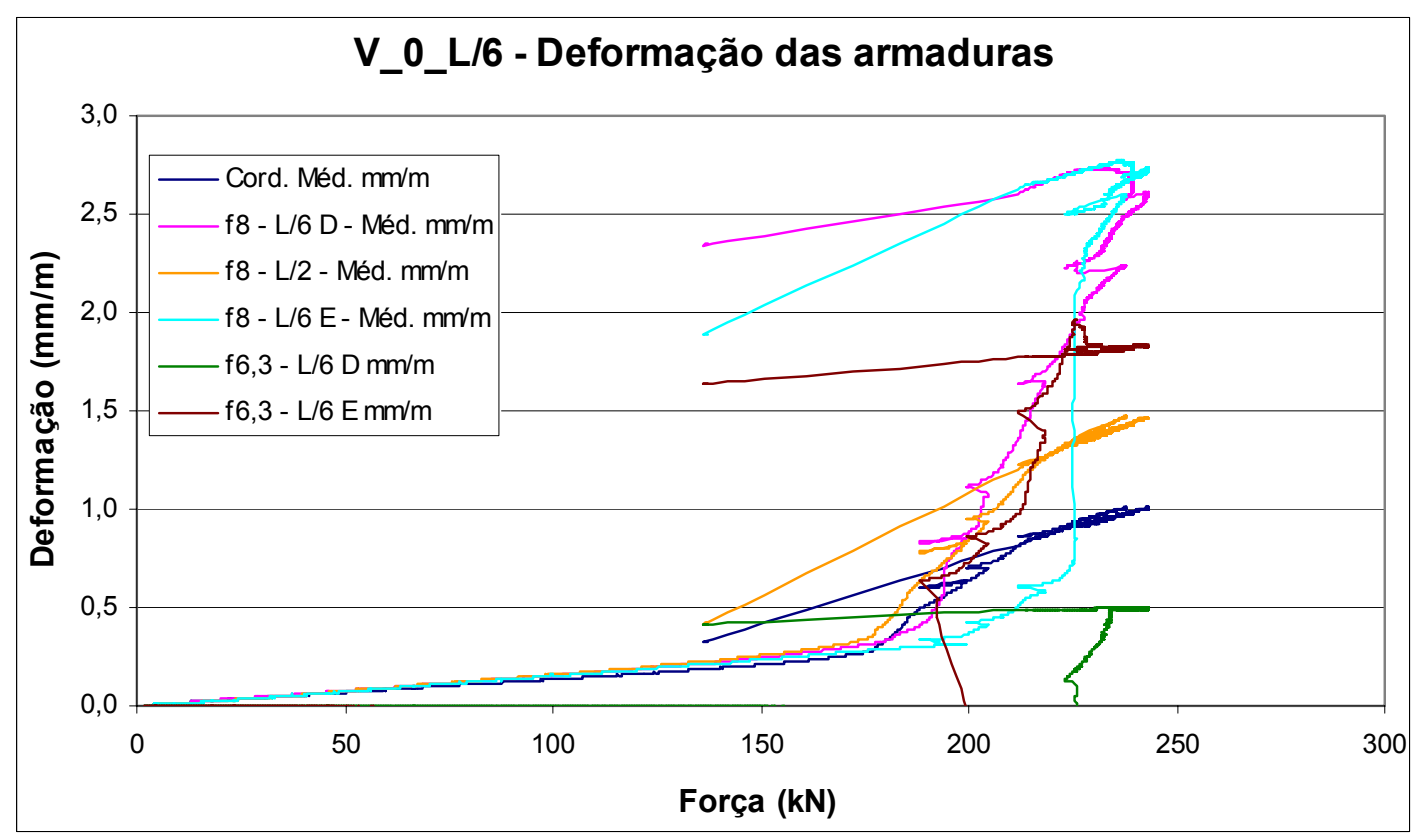

Figura 6.50 - Gráfico Força versus Deformação para a V_0_L/6. 


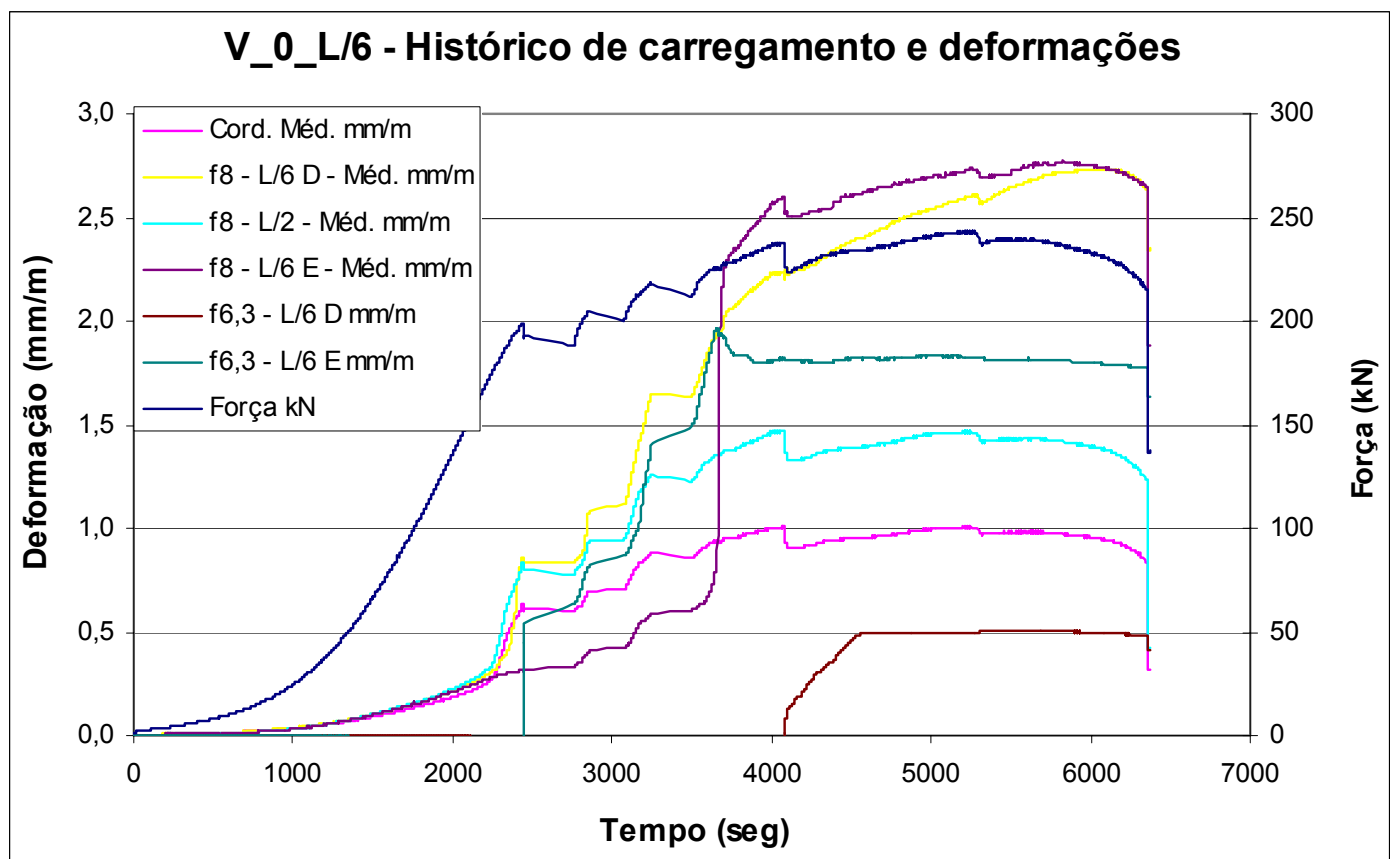

Figura 6.51 - Gráfico das deformações e forças em função do tempo, para a V_0_L/6.

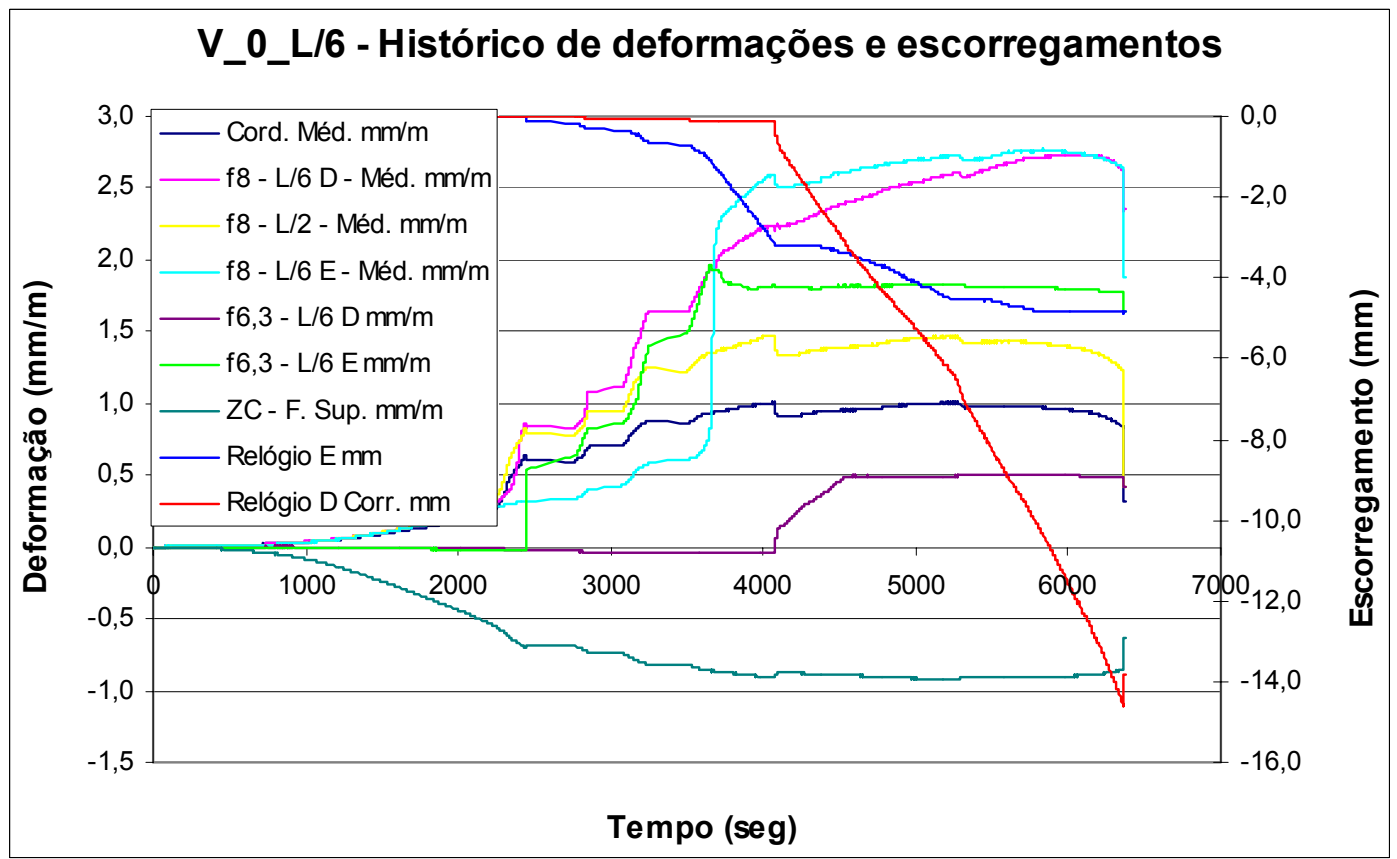

Figura 6.52 - Gráfico das deformações e escorregamentos em função do tempo, para a V_0_L/6.

\section{c) Viga V_40_L/3}

A Figura 6.53 apresenta o esquema de ensaio da viga V_40_L/3.

A carga teórica de início da fissuração era de $P_{\text {fiss }}=82,2 \mathrm{kN}$ e a última de $P_{\text {últ }}=85,3 \mathrm{kN}$. A viga começou a fissurar com uma carga de $\mathrm{P}_{\text {fiss,ensaio }}=89 \mathrm{kN}$ e a carga máxima alcançada foi de $P_{\text {últtensaio }}=157 \mathrm{kN}$. A peça seguiu o padrão de fissuração esperado para vigas sob flexão. 
Primeiro apareceram as fissuras de flexão localizadas na região de momento máximo e constante (terço central), e, depois, à medida que se aumentava a carga, aumentavam-se as fissuras e a quantidade delas em direção às extremidades, culminando com o surgimento de fissuras de cisalhamento, como mostra a Figura 6.54. O panorama completo da fissuração se encontra no Apêndice G.

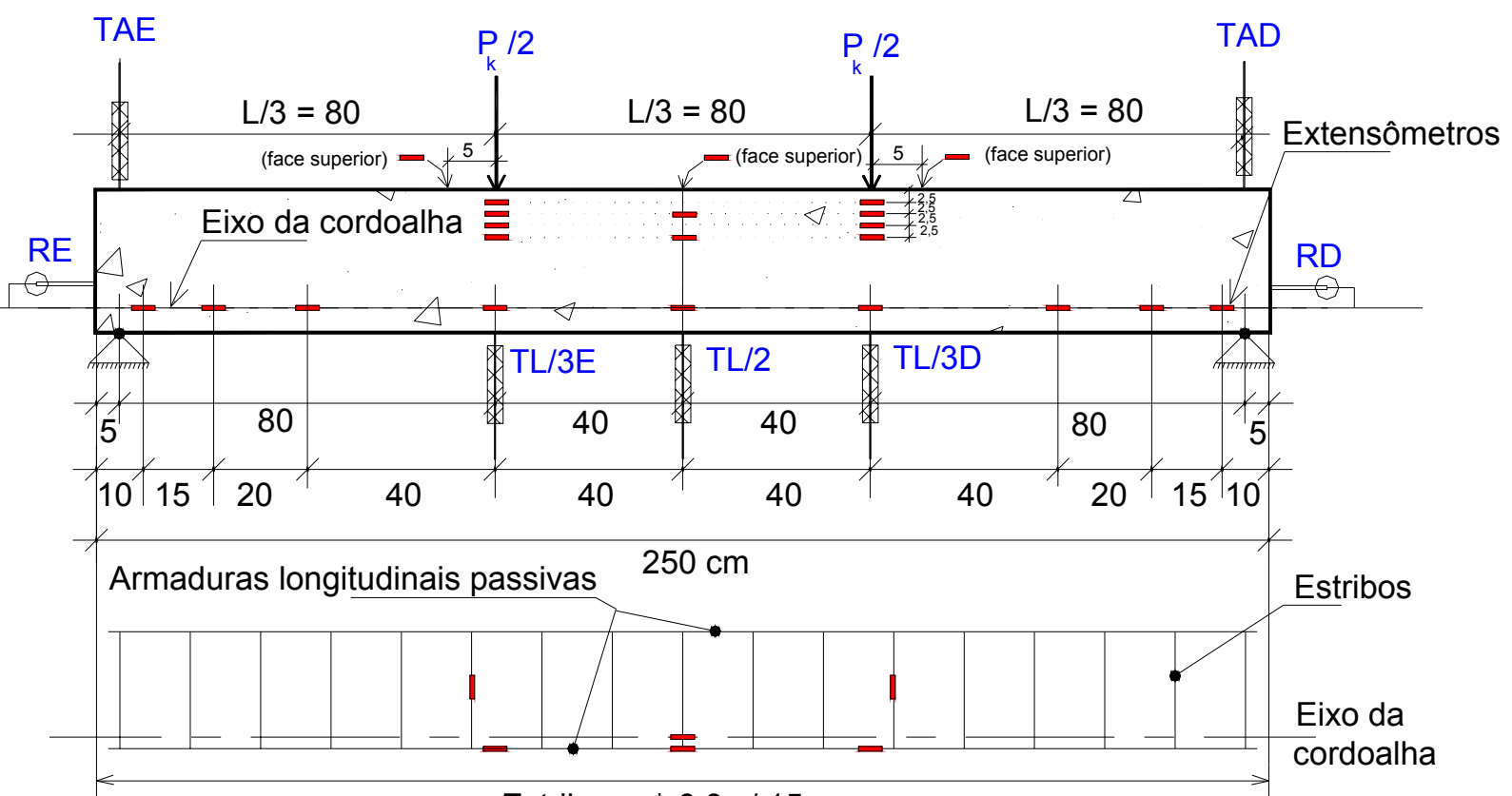

Estribos - $\phi 6,3 \mathrm{c} / 15 \mathrm{~cm}$

Figura 6.53 - Esquema de ensaio e instrumentação da viga V_40_L/3.

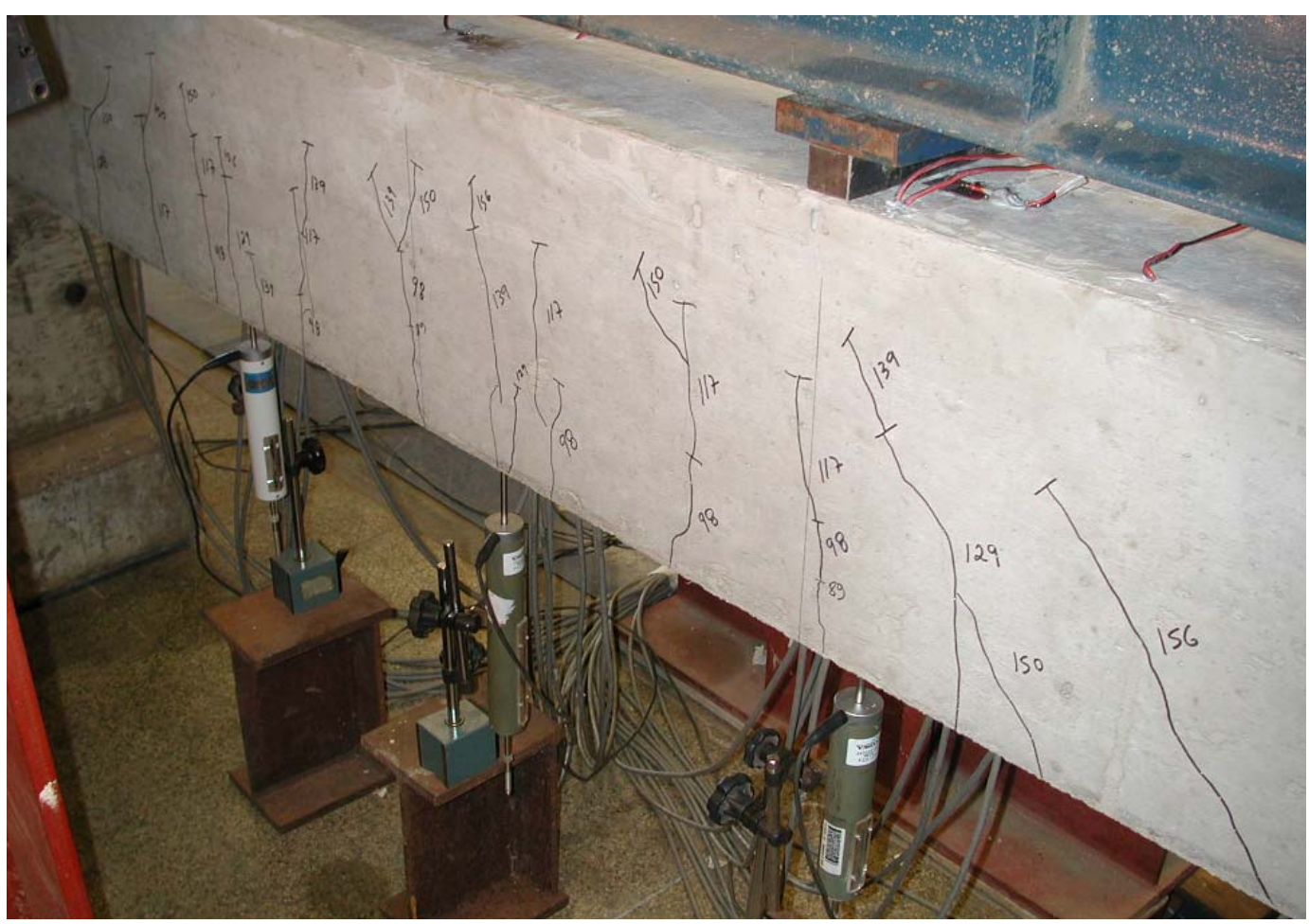

Figura 6.54 - Detalhes da fissuração da V_40_L/3. 
As Figuras 6.55 a 6.58 apresentam os gráficos representativos do ensaio.

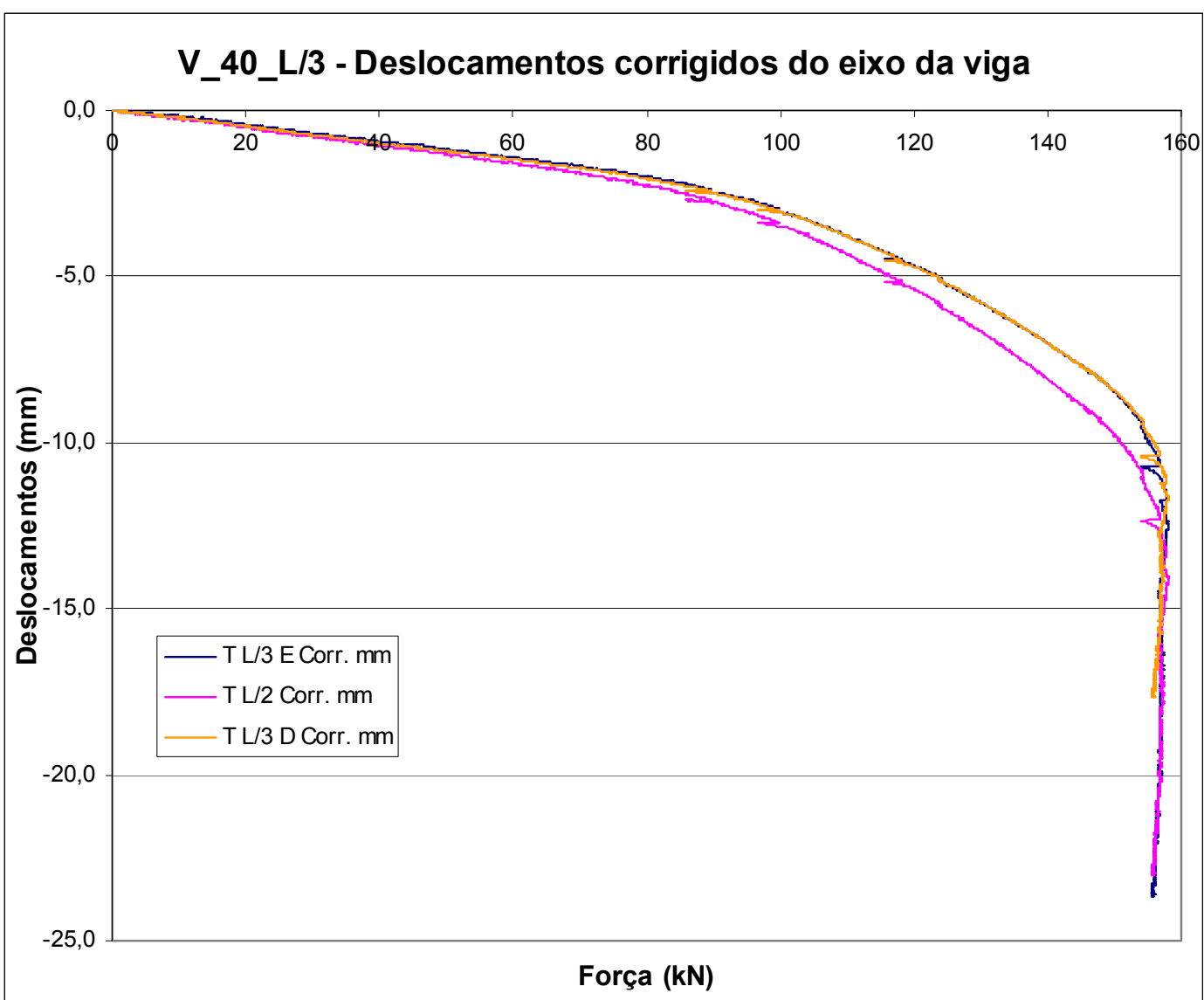

Figura 6.55 - Gráfico Força versus Deslocamento para a V_40_L/3.

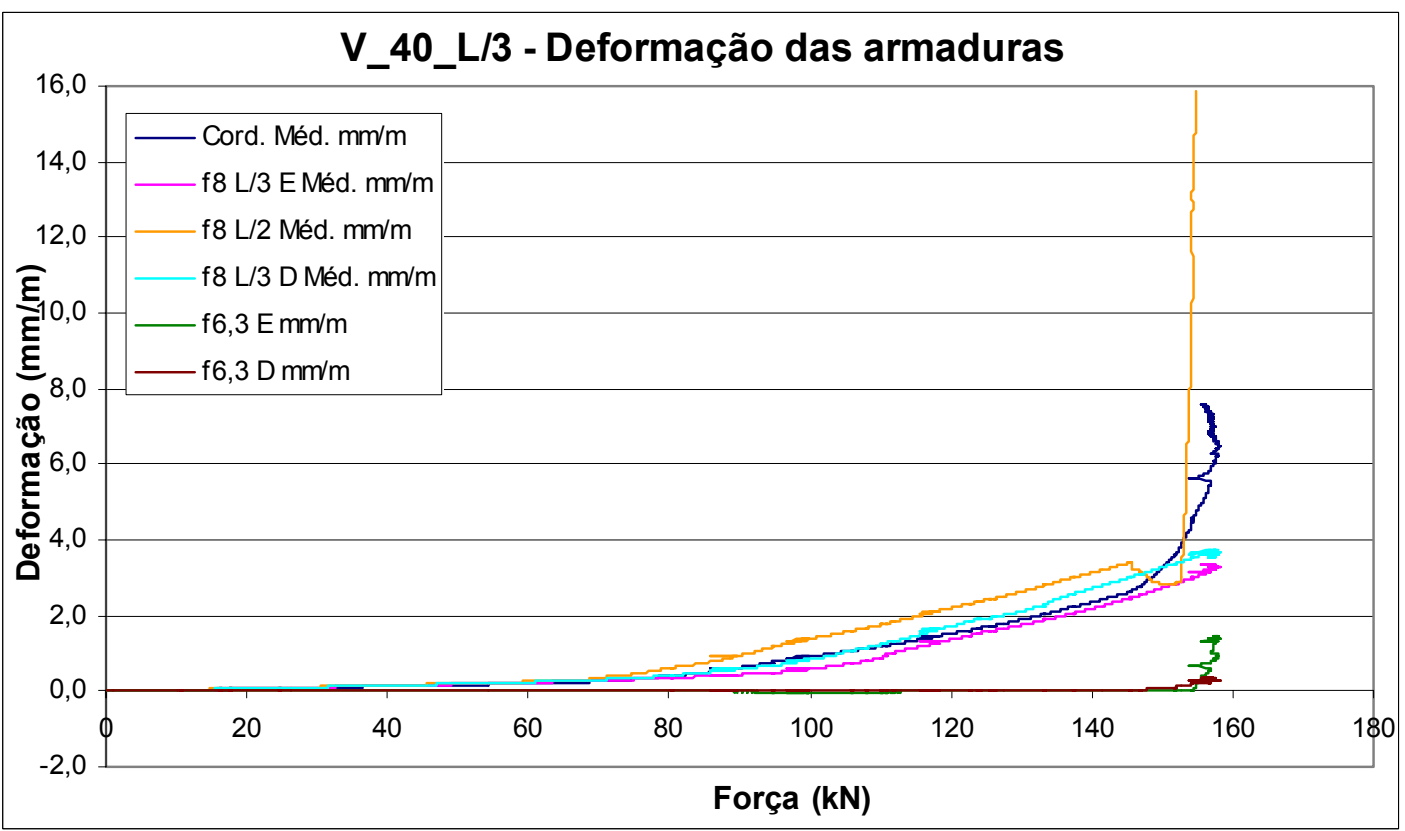

Figura 6.56 - Gráfico Força versus Deformação para a V_40_L/3. 


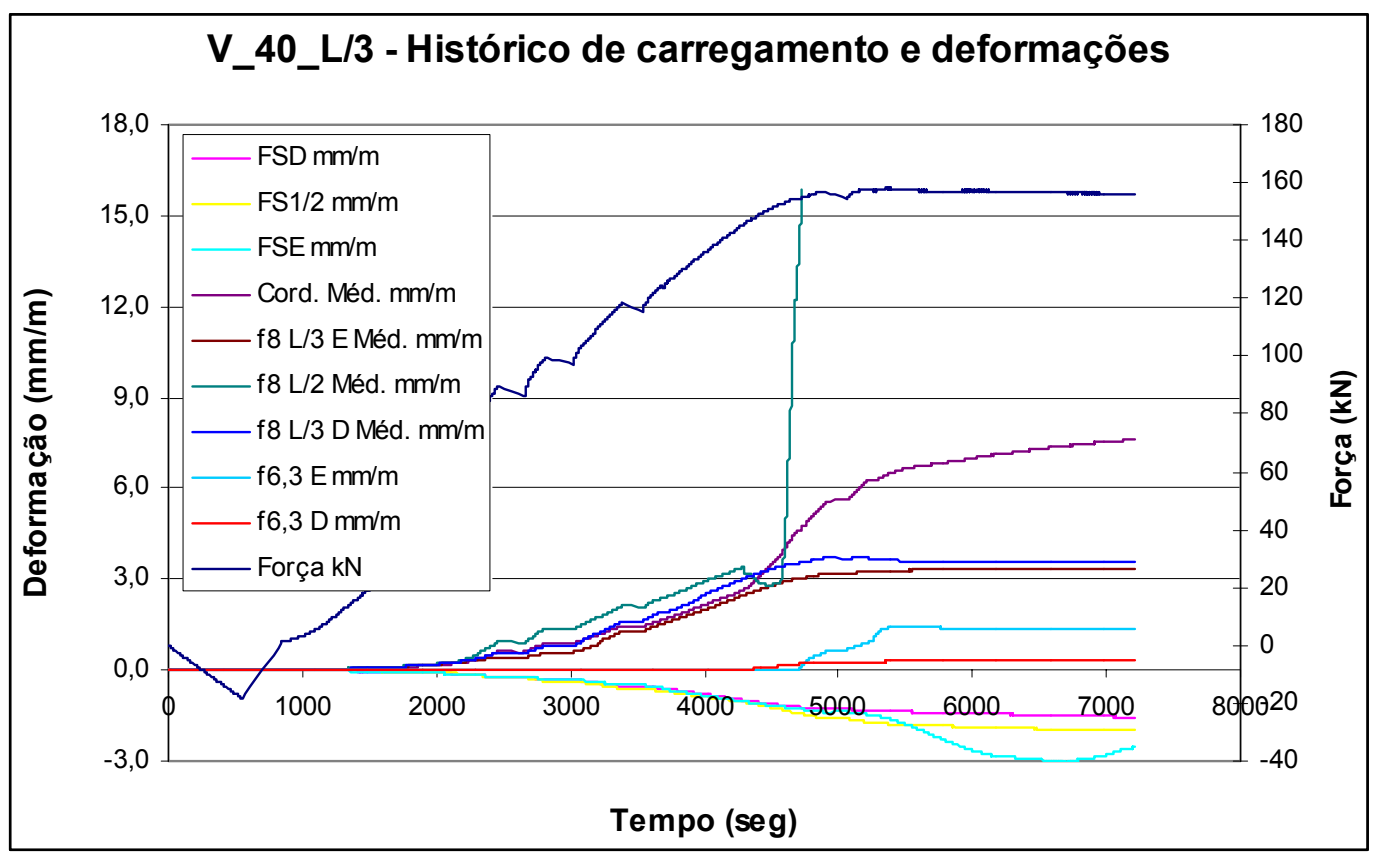

Figura 6.57 - Gráfico das deformações e forças em função do tempo, para a V_40_L/3.

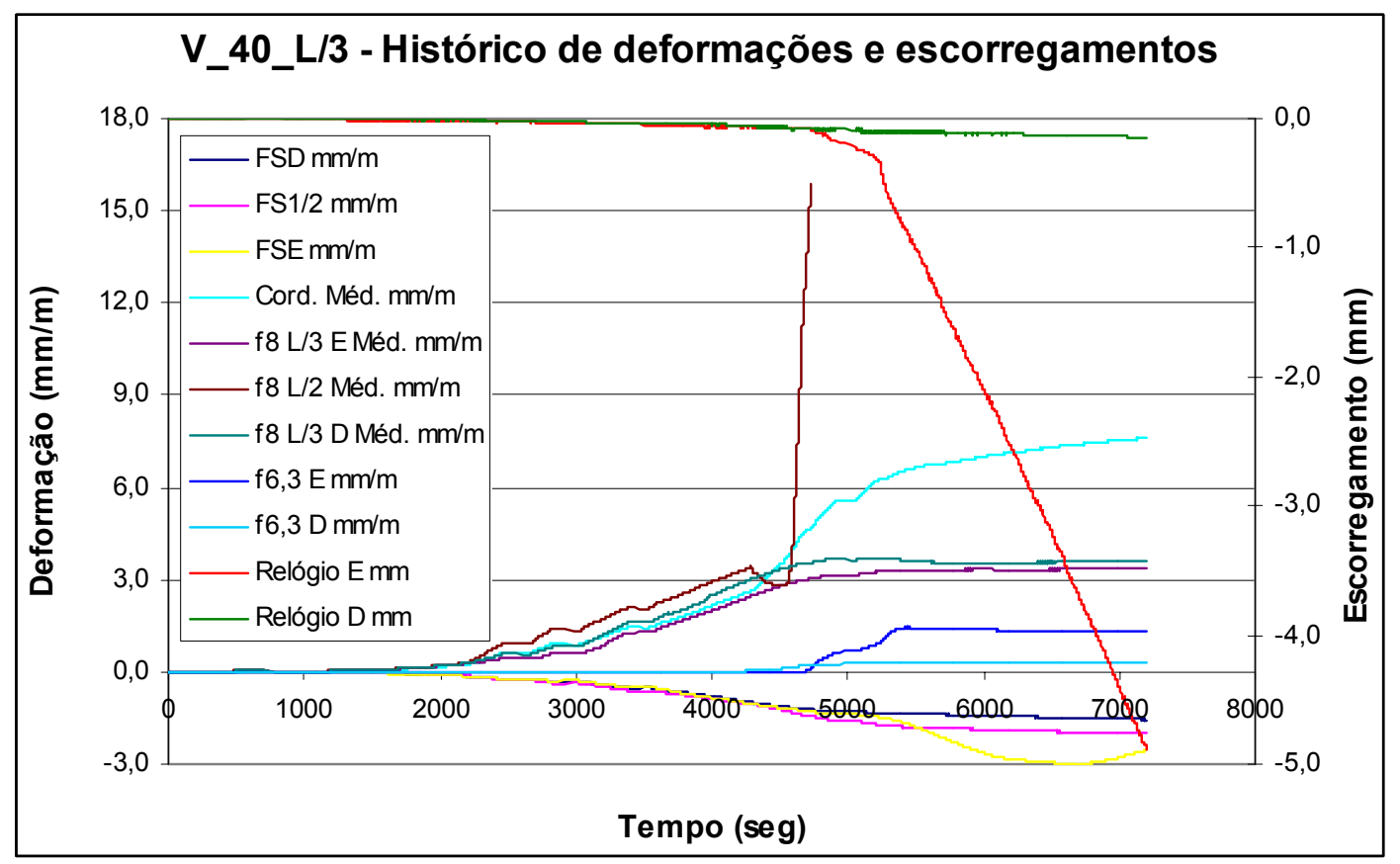

Figura 6.58 - Gráfico das deformações e escorregamentos em função do tempo, para a V_40_L/3.

O ensaio foi interrompido quando a carga já se apresentava em queda, e o relógio da esquerda já apresentava elevado escorregamento, caracterizando perda de aderência. Pelo gráfico da Figura 6.58, percebe-se que a viga rompeu por flexão, seguida de perda de aderência do lado esquerdo. Após o escoamento da cordoalha, que já tinha um préalongamento de $7,06 \%$ o $\left(\varepsilon_{\mathrm{p}, \text { total }} \approx 13 \%\right.$ o), e da armadura longitudinal passiva de $\phi 8 \mathrm{~mm}$, também do lado esquerdo, ocorreu o escorregamento da cordoalha do lado esquerdo, indicado pelo 
relógio cuja leitura marcava $S \approx 5 \mathrm{~mm}$, o que ocorreu próximo ao esmagamento do concreto na face superior esquerda (leitura FSE). Praticamente não houve escorregamento do lado direito da viga.

Essa viga se comportou de maneira mais dúctil do que a anterior, e fissurou muito mais.

\section{d) Viga V_40_L/6}

A Figura 6.59 apresenta o esquema de ensaio da viga V_40_L/6.

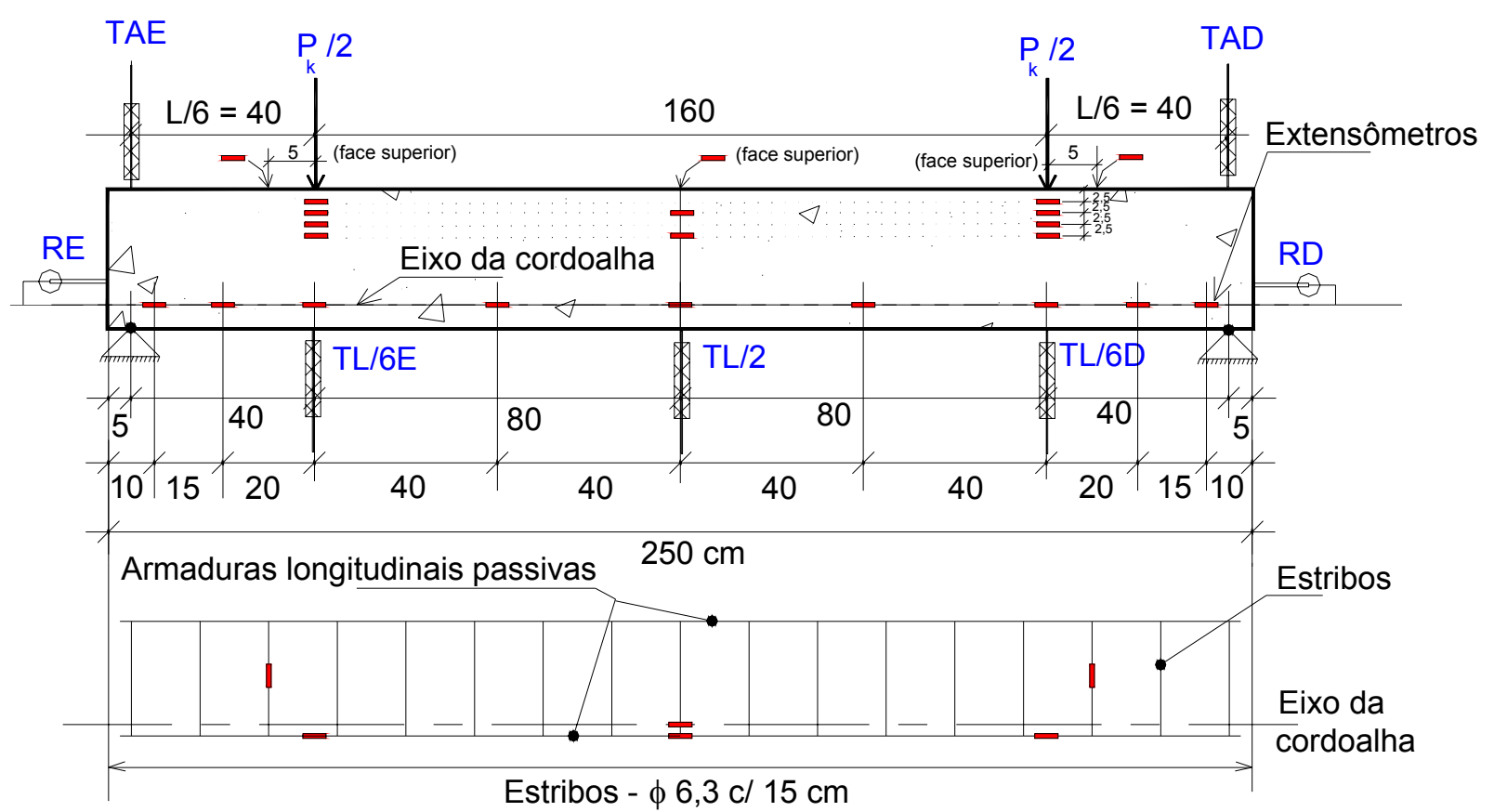

Figura 6.59 - Esquema de ensaio e instrumentação da viga V_40_L/6.

A carga teórica de início da fissuração era de $\mathrm{P}_{\text {fiss }}=164,41 \mathrm{kN}$ e a última de $\mathrm{P}_{\text {últ }}=172,1 \mathrm{kN}$. A viga começou a fissurar com uma carga de $\mathrm{P}_{\text {fiss,ensaio }}=182 \mathrm{kN}$ e a carga máxima alcançada foi de $P_{\text {últ,ensaio }}=231,87 \mathrm{kN}$. Não houve diferenças significativas entre as cargas máximas dessa viga e a da $\mathrm{V} \_0 \_L / 6$, apesar da diferença nas resistências do concreto à compressão $\left(\mathrm{f}_{\mathrm{c}, 0} \approx 65 \mathrm{MPa}\right.$ e $\left.\mathrm{f}_{\mathrm{c}, 40} \approx 59 \mathrm{MPa}\right)$. Entretanto, a V_40_L/6 apresentou-se mais dúctil, rompendo apenas de um lado, e não havendo a ruptura da armadura longitudinal passiva, já que a presença das fibras de aço controlou a deformação da peça. A Figura 6.60 apresenta uma foto do final do ensaio no lado mais solicitado (lado esquerdo). O panorama completo da fissuração se encontra no Apêndice G.

O ensaio foi interrompido quando a carga já apresentava tendência de queda, e o relógio da esquerda já apresentava elevado escorregamento, caracterizando perda de aderência. Pelo gráfico da Figura 6.62, nota-se que não houve escoamento das armaduras, exceto para a barra de $8 \mathrm{~mm}$ no lado esquerdo, o que deve ter sido um problema localizado, como o descolamento 
do extensômetro, por exemplo. Pelo gráfico da Figura 6.64, percebe-se que a viga rompeu por perda de aderência do lado esquerdo.

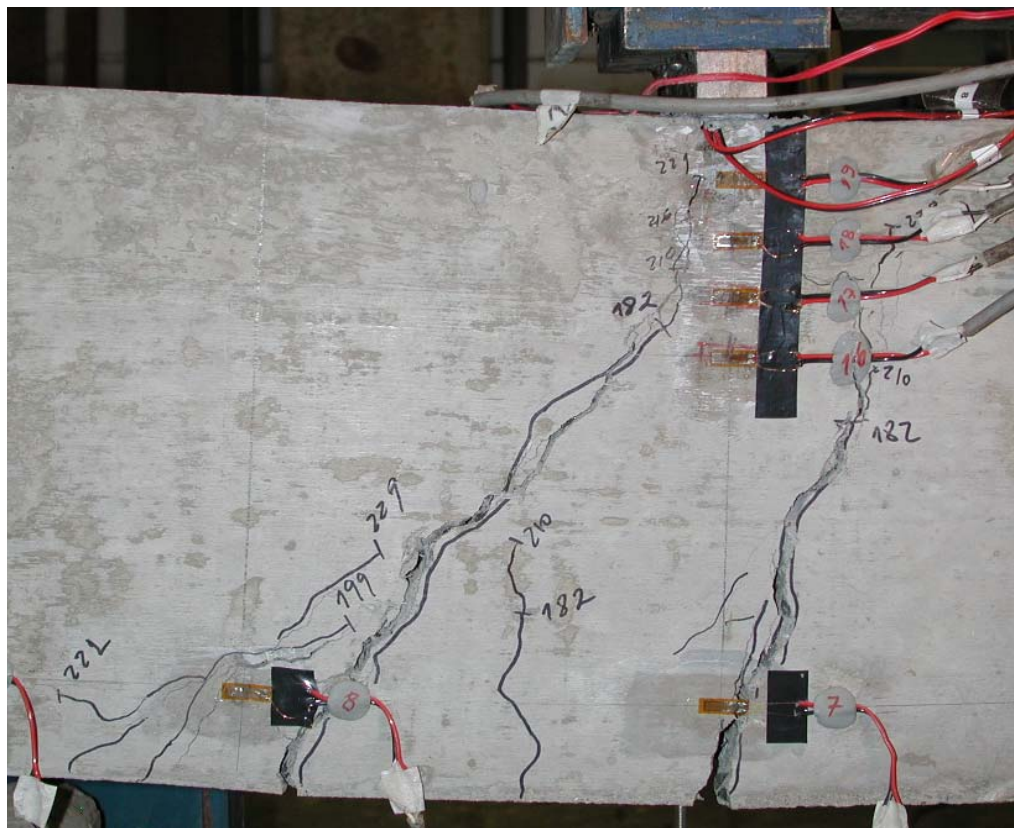

Figura 6.60 - Detalhes da fissuração da V_40_L/6.

As Figuras 6.61 a 6.64 apresentam os gráficos representativos do ensaio.

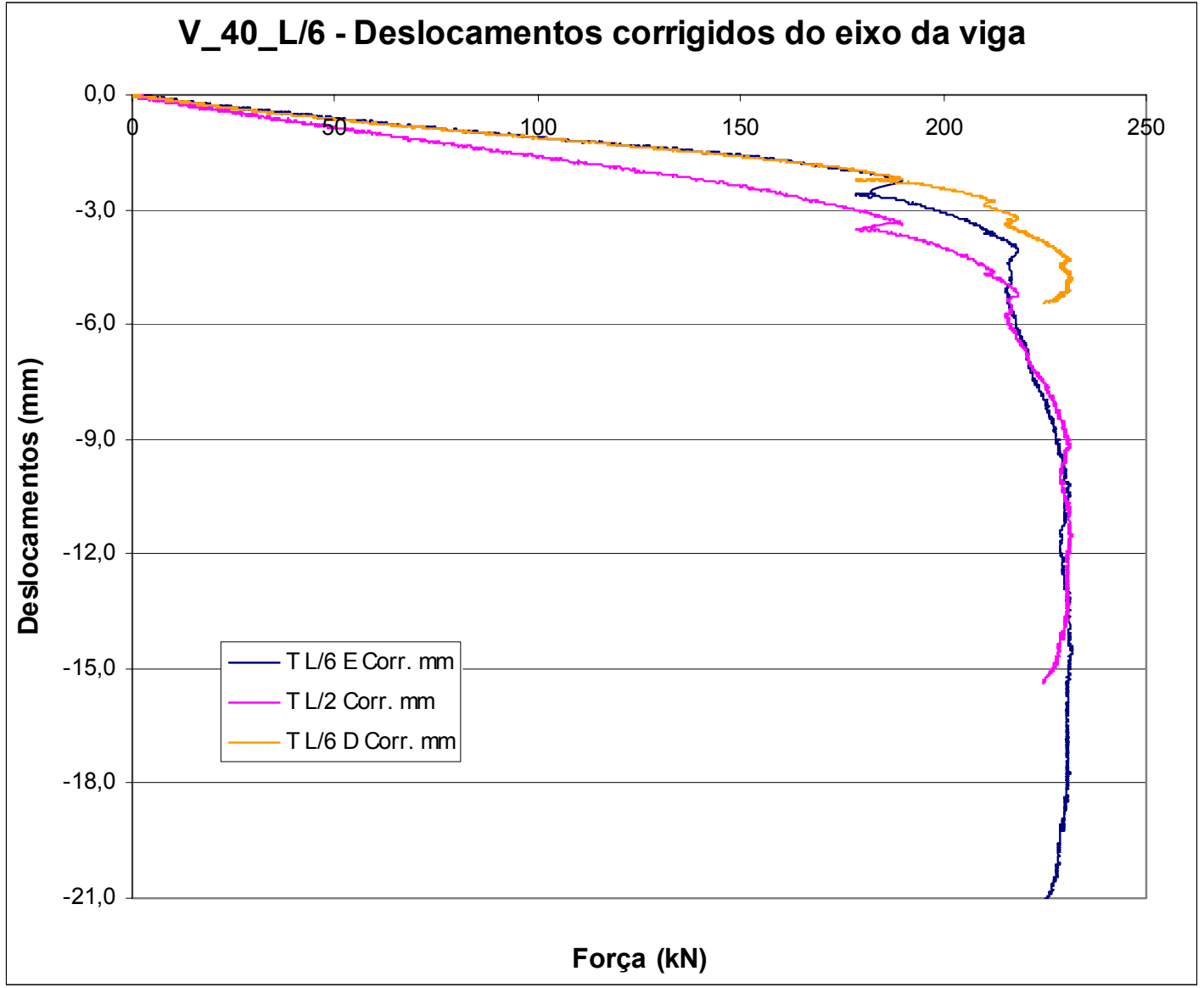

Figura 6.61 - Gráfico Força versus Deslocamento para a V_40_L/6. 


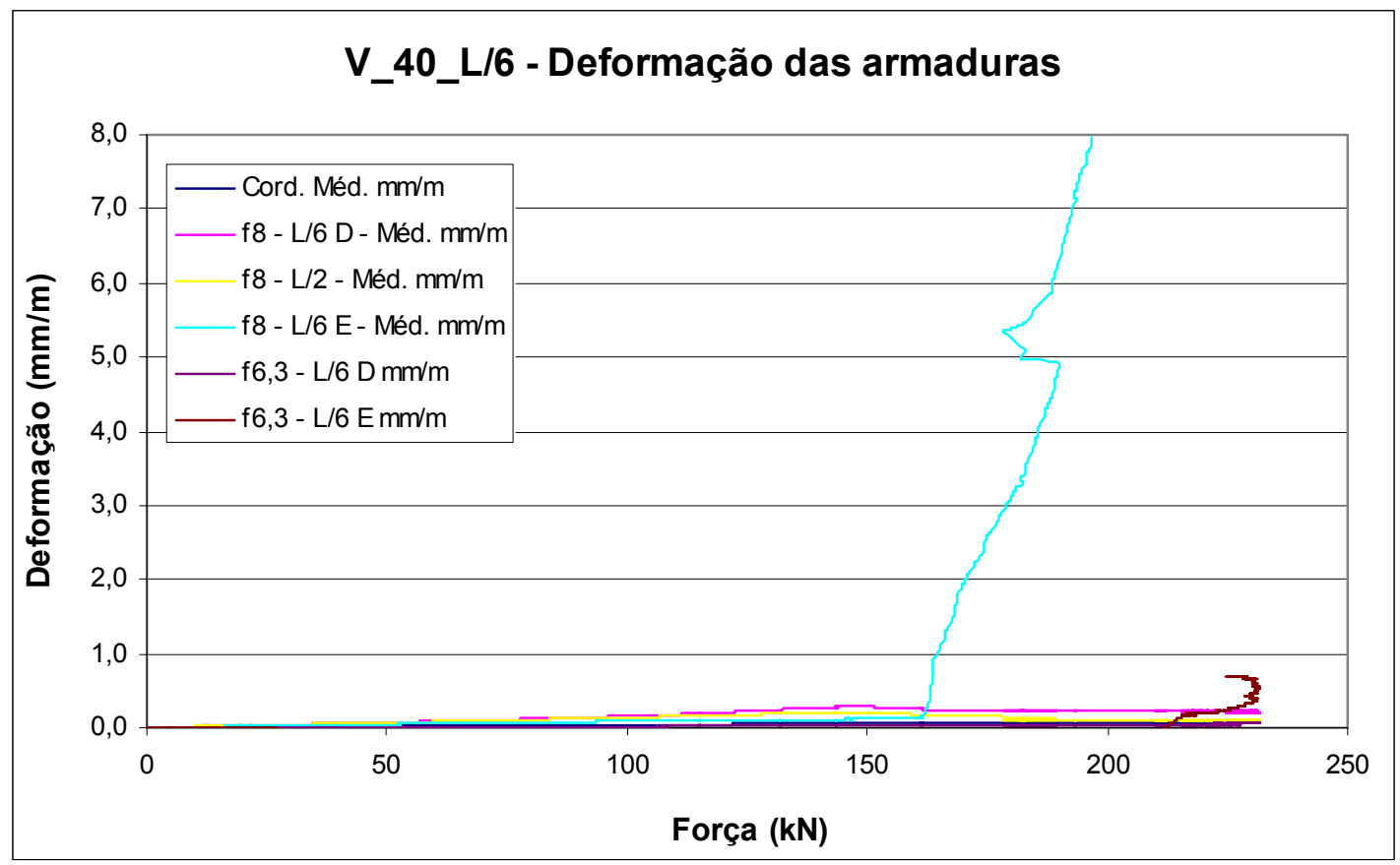

Figura 6.62 - Gráfico Força versus Deformação para a V_40_L/6.

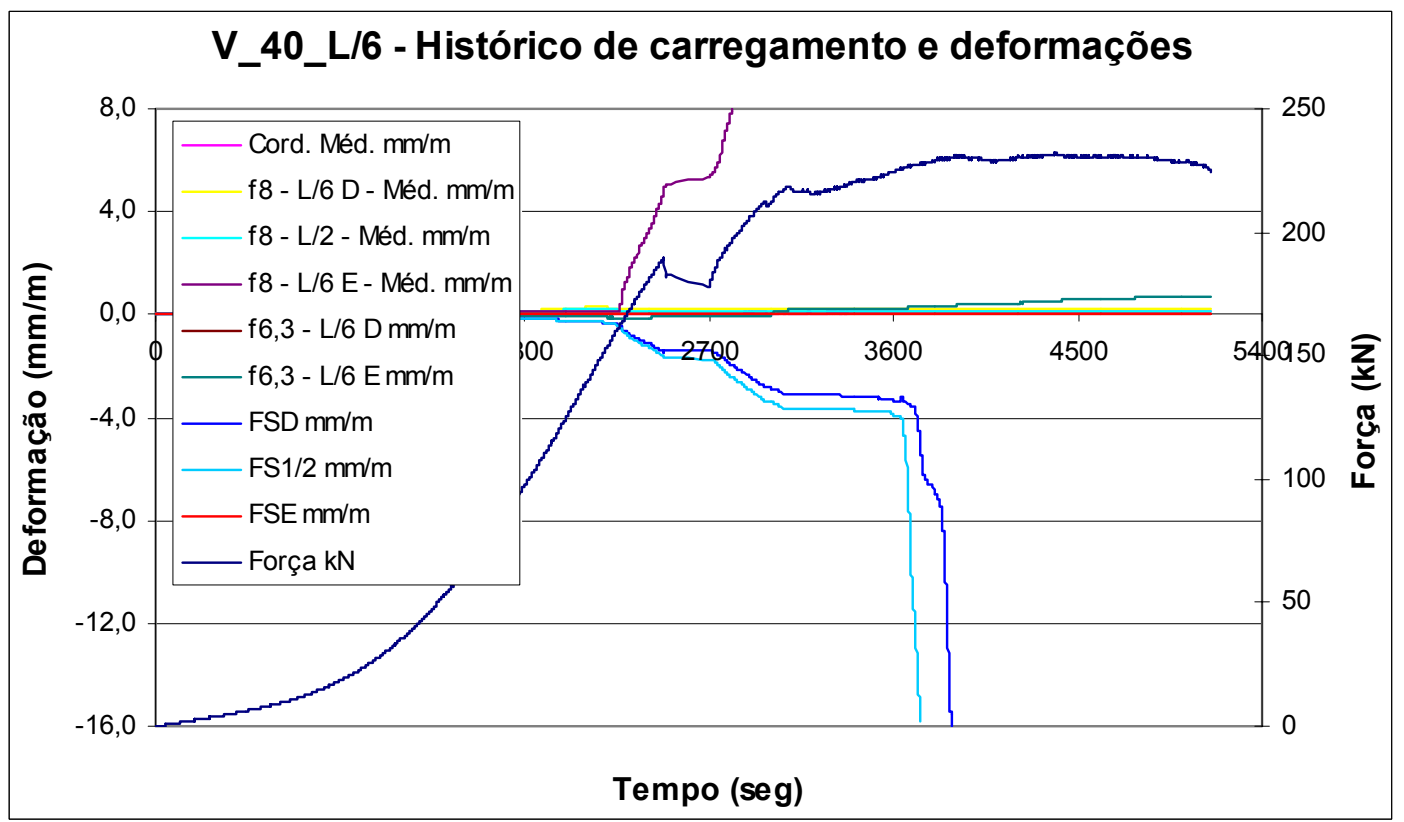

Figura 6.63 - Gráfico das deformações e forças em função do tempo, para a V_40_L/6.

Observa-se, para o gráfico da Figura 6.63, que as leituras da zona comprimida de concreto (FSD e FS1/2), na face superior da peça, apresentaram uma deformação de compressão muito grande, o que ocorreu após o início da perda de aderência, como indica o gráfico da Figura 6.64. Isso o correu porque a peça formou uma espécie de alavanca, pois, como o arranjo fornecia uma rigidez muito grande, quando a cordoalha começou a escorregar, houve a tendência de quebra da peça, como ocorreu para a V_0_L/6, porém, devido a 
presença das fibras isso não se concretizou, havendo apenas o esmagamento do concreto na face superior. A ruptura, entretanto, foi por escorregamento e não por esmagamento do concreto, o que foi uma conseqüência. Pelo gráfico da Figura 6.64 percebe-se que não houve escorregamento significativo do lado direito da peça.

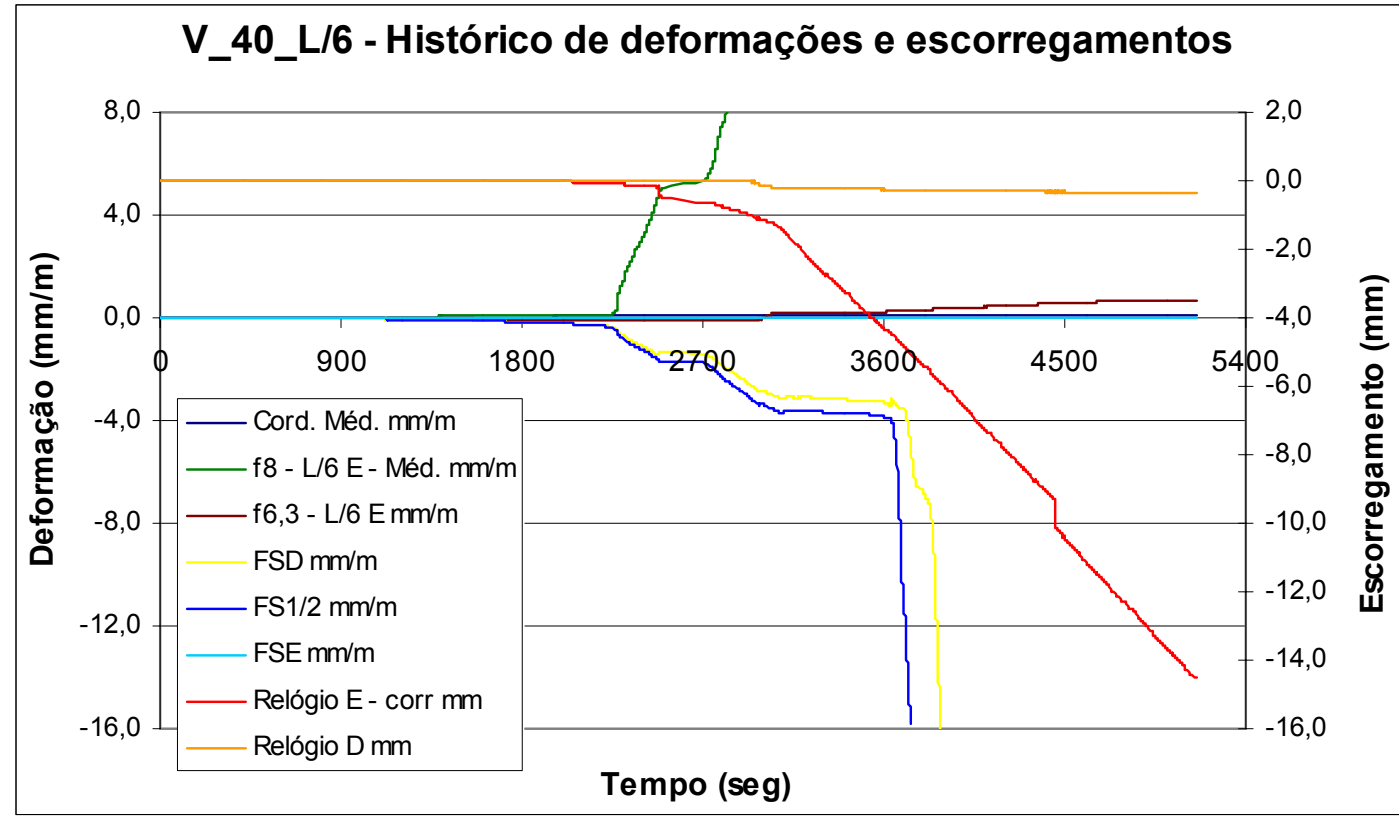

Figura 6.64 - Gráfico das deformações e escorregamentos em função do tempo, para a V_40_L/6.

\section{e) Viga V_60_L/3}

A Figura 6.65 apresenta o esquema de ensaio da viga V_60_L/3.

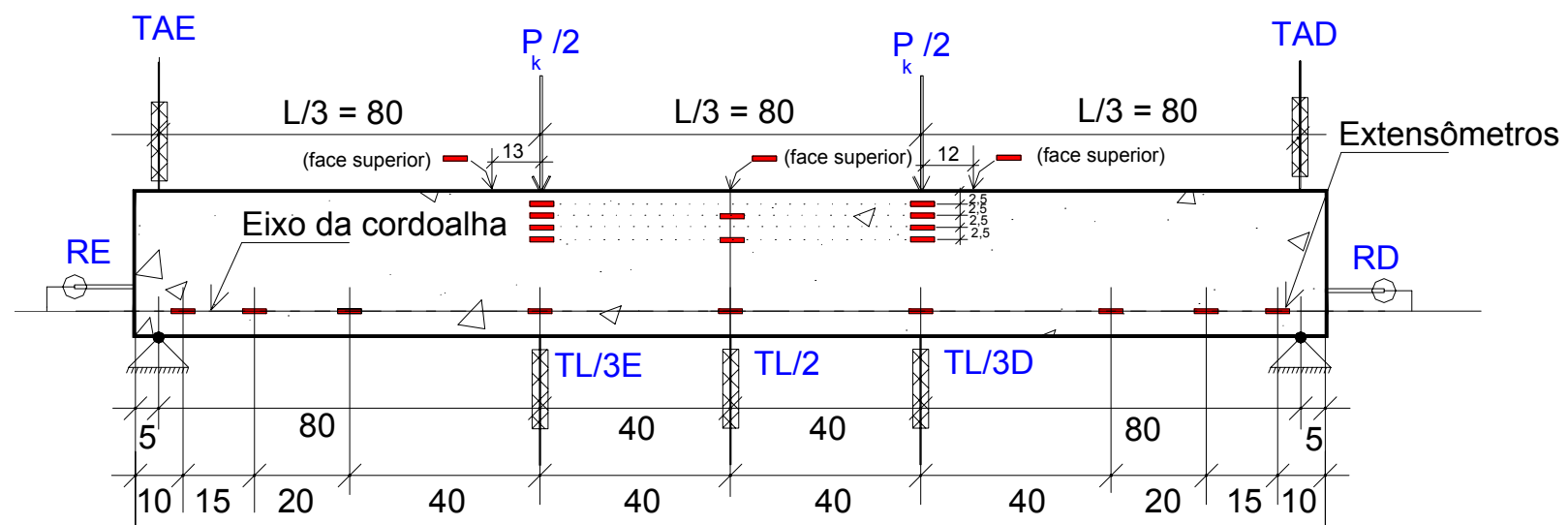

Armaduras longitudinais passivas

$250 \mathrm{~cm}$

Estribos

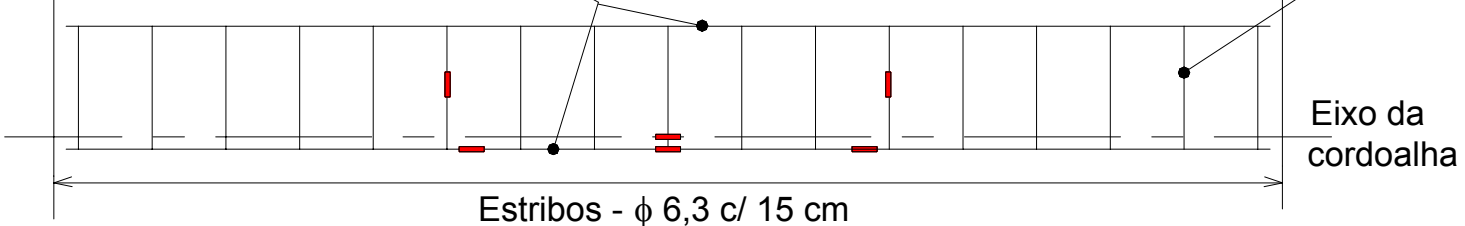

Figura 6.65 - Esquema de ensaio e instrumentação da viga V_60_L/3. 
A carga teórica de início da fissuração era de $P_{\text {fiss }}=87,27 \mathrm{kN}$ e a última de $P_{\text {últ }}=85,3 \mathrm{kN}$. A viga começou a fissurar com uma carga de $\mathrm{P}_{\text {fiss,ensaio }}=90 \mathrm{kN}$ e a carga máxima alcançada foi de $\mathrm{P}_{\text {últ,ensaio }}=155,4 \mathrm{kN}$. O padrão de fissuração da viga foi muito parecido com o da V_40_L/3. A Figura 6.66 apresenta uma foto da viga após o ensaio. O panorama completo da fissuração se encontra no Apêndice G. O ensaio foi interrompido quando ocorreu o esmagamento do concreto na face superior, o que pode ser verificado pelo gráfico da Figura 6.69 (leituras FSD e F1/2).

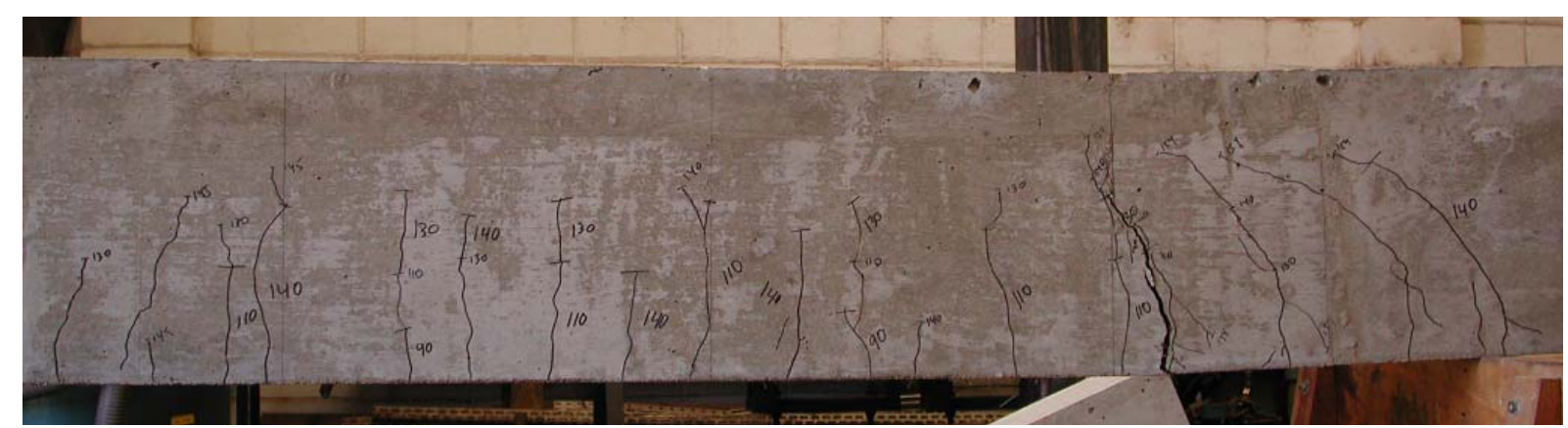

Figura 6.66 - Detalhes da fissuração da V_60_L/3.

As Figuras 6.67 a 6.70 apresentam os gráficos representativos do ensaio.

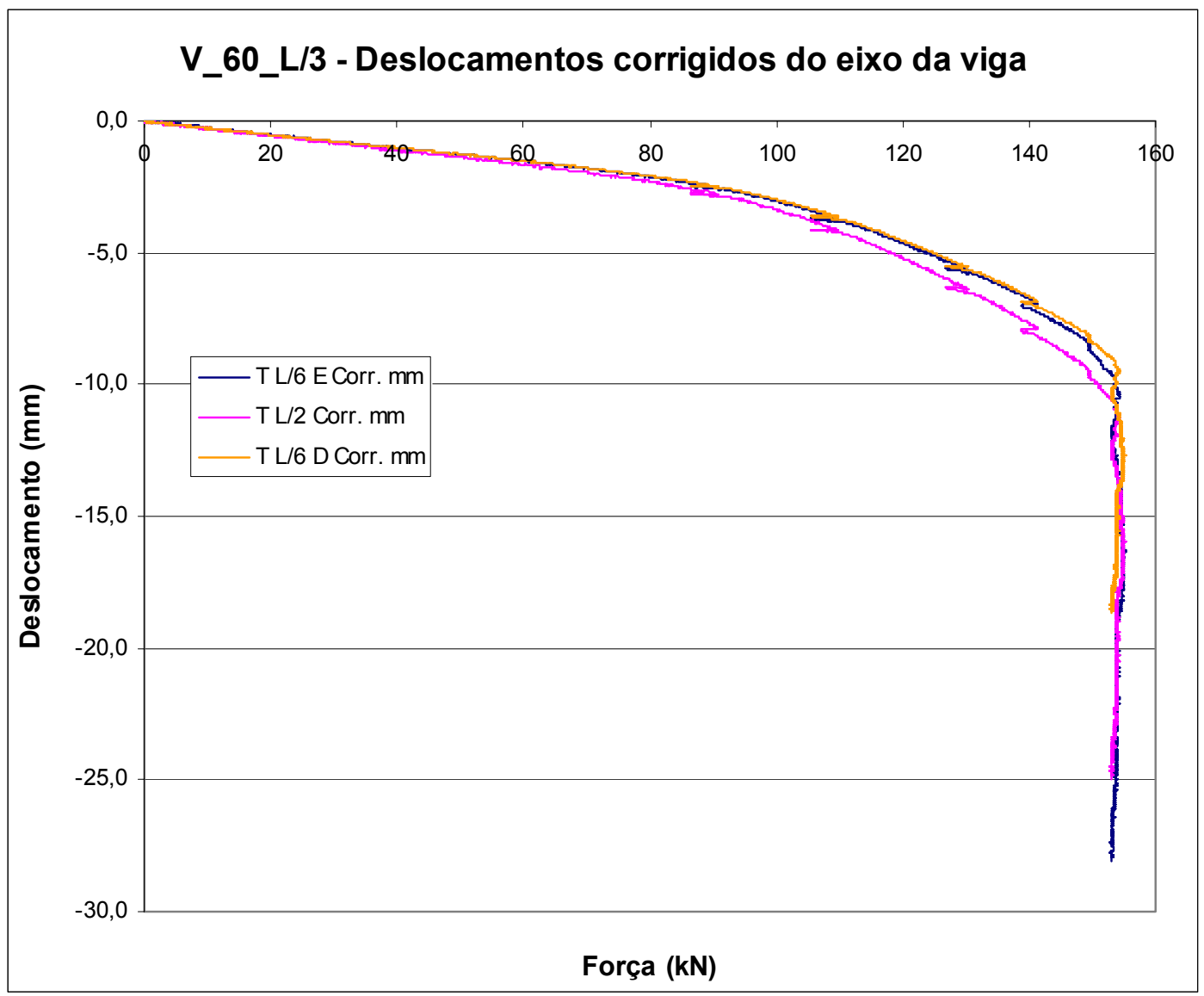

Figura 6.67 - Gráfico Força versus Deslocamento para a V_60_L/3. 


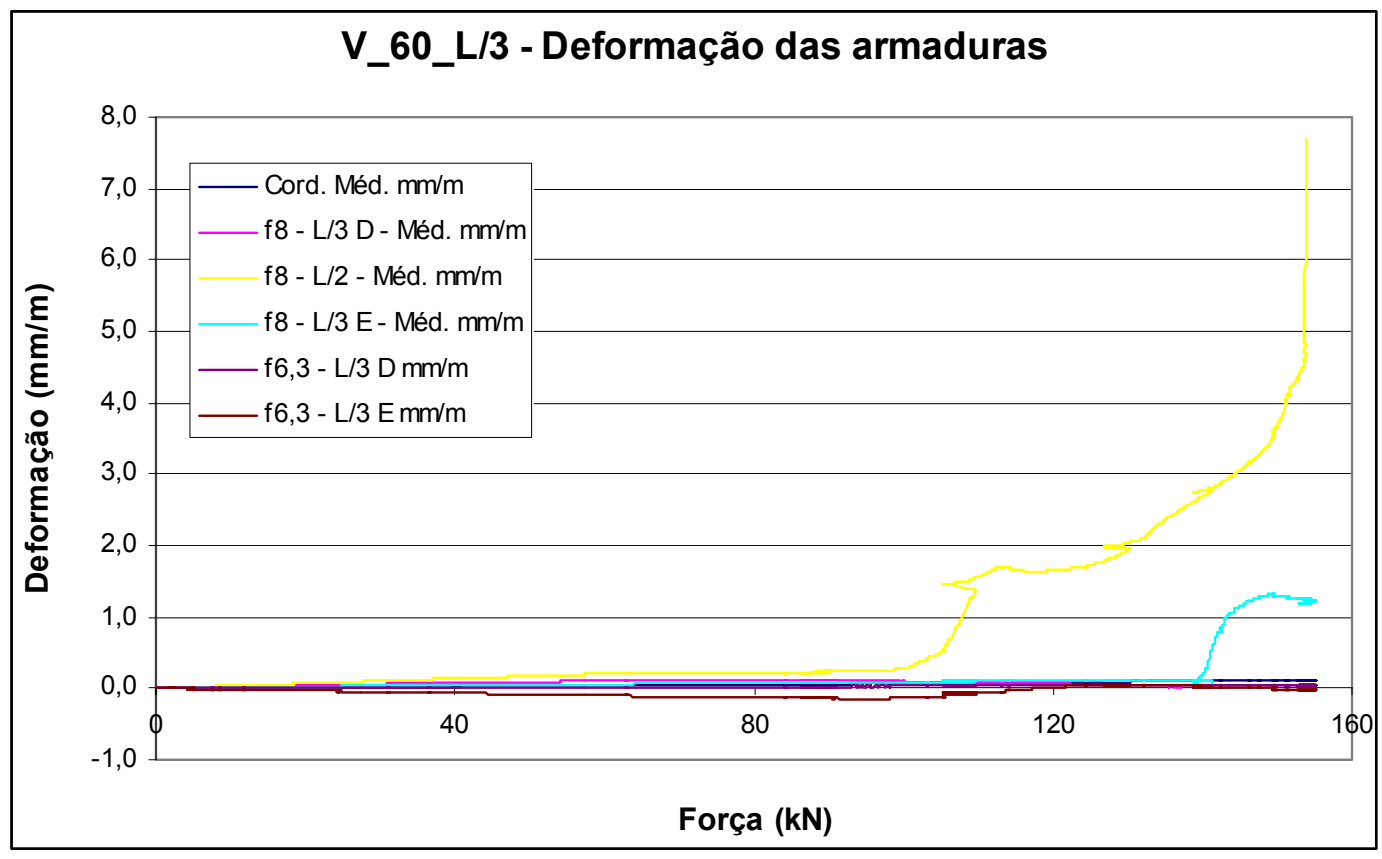

Figura 6.68 - Gráfico Força versus Deformação para a V_60_L/3.

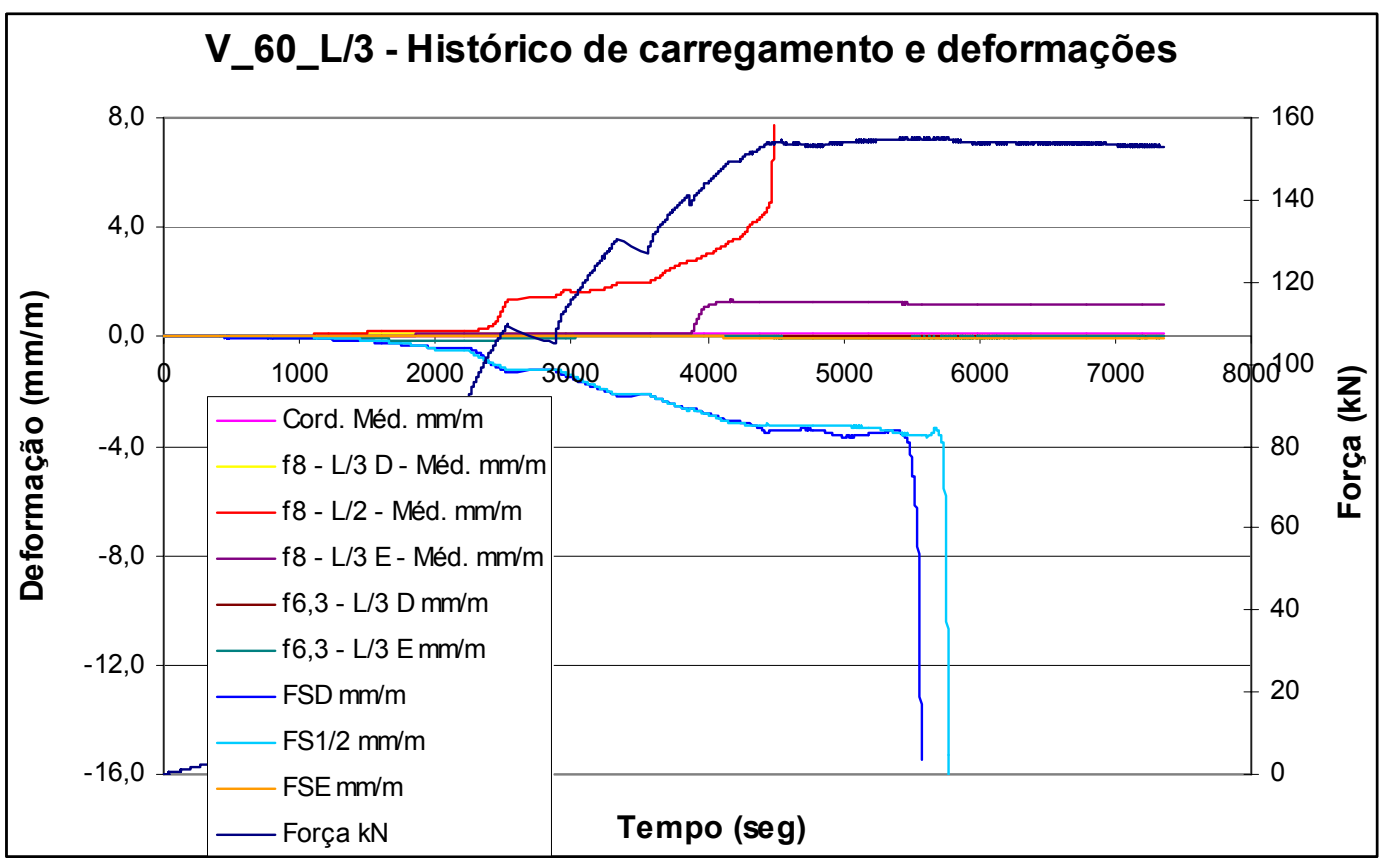

Figura 6.69 - Gráfico das deformações e forças em função do tempo, para a V_60_L/3.

Vale notar, tanto na Figura 6.69 como na 6.70, que não houve escoamento da cordoalha e que os estribos foram muito pouco solicitados. Isso pode ter ocorrido por duas razões: 1) pelo posicionamento do estribo instrumentado, que estava praticamente embaixo do ponto de aplicação de carga, e, portanto, não ter registrado os esforços caso esses tenham ocorrido um pouco mais próximos do apoio; e 2) pela presença das fibras de aço, que ajudaram a absorver os esforços de tração. 


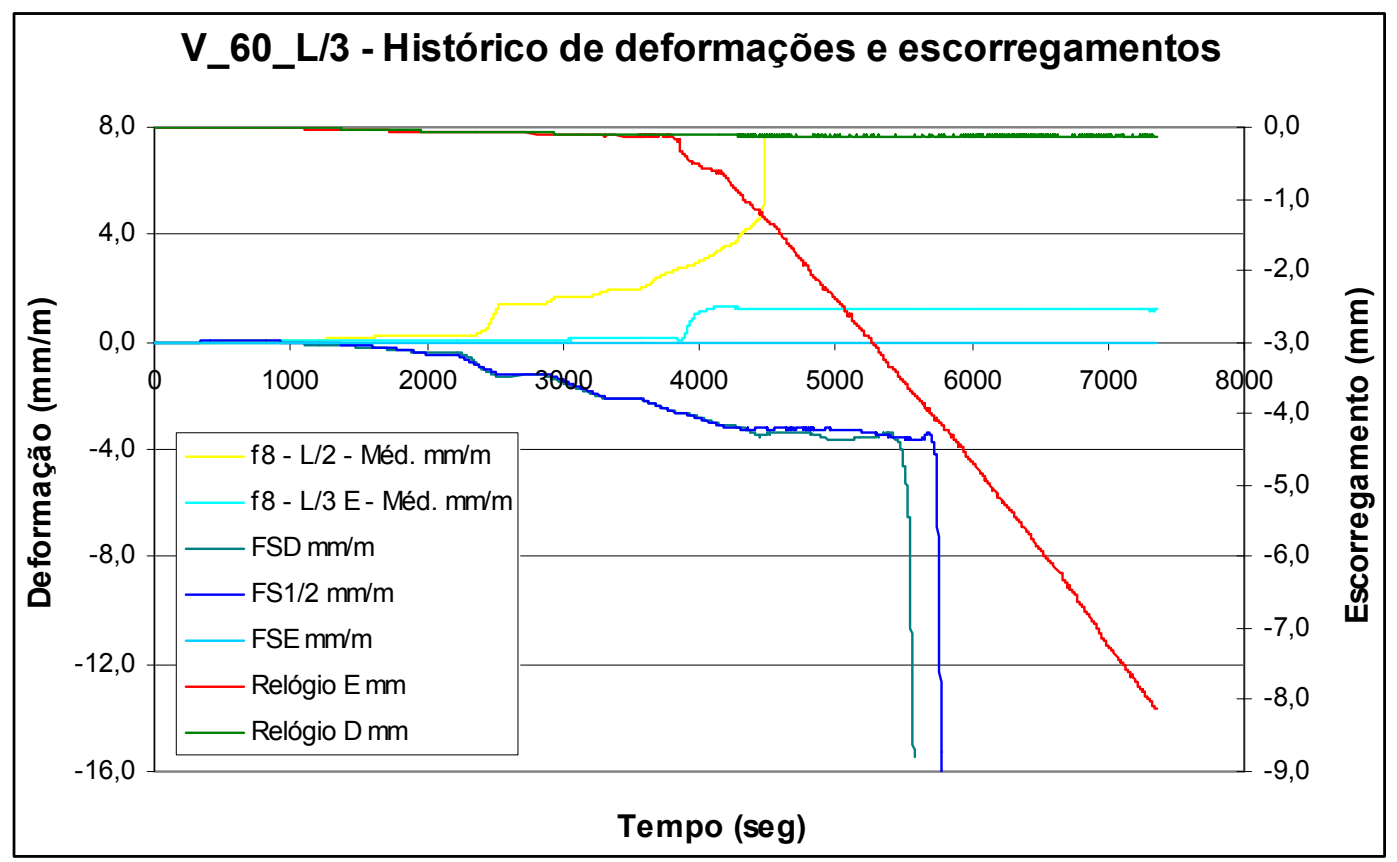

Figura 6.70 - Gráfico das deformações e escorregamentos em função do tempo, para a V_60_L/3.

Percebe-se que a viga rompeu por esmagamento do concreto, devido à flexão, na zona comprimida, seguido da perda de aderência (escorregamento da cordoalha no lado direito), como mostra a Figura 6.70.

\section{f) Viga V_60_L/6}

A Figura 6.71 apresenta o esquema de ensaio da viga V_60_L/6.

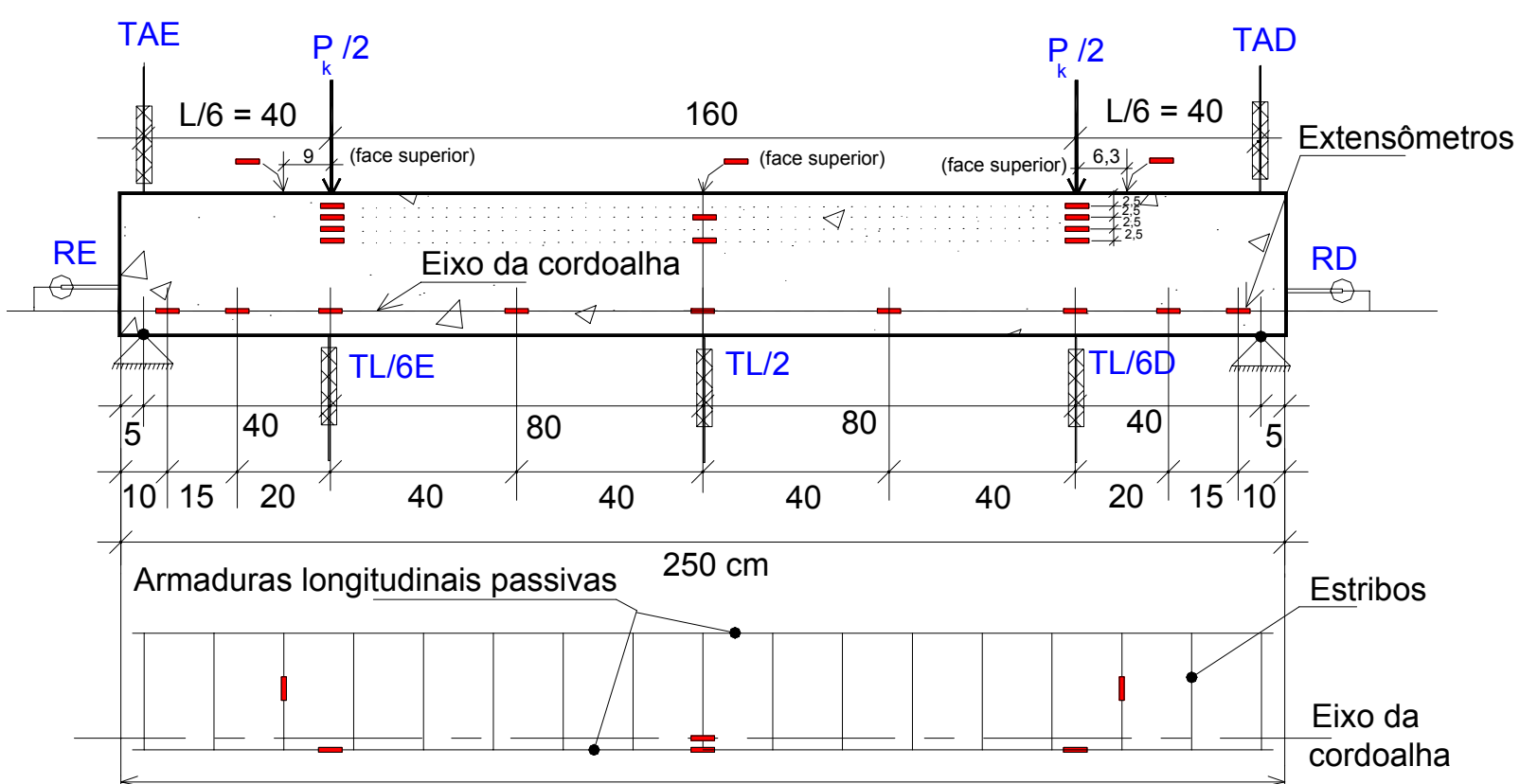

Estribos - $\phi 6,3 \mathrm{c} / 15 \mathrm{~cm}$

Figura 6.71 - Esquema de ensaio e instrumentação da viga V_60_L/6. 
A carga teórica de início da fissuração era de $\mathrm{P}_{\text {fiss }}=174,53 \mathrm{kN}$ e a última de $\mathrm{P}_{\text {últ }}=172,1 \mathrm{kN}$. A viga começou a fissurar com uma carga de $\mathrm{P}_{\text {fiss,ensaio }}=190 \mathrm{kN}$ e a carga máxima alcançada foi de $P_{\text {últ,ensaio }}=241,54 \mathrm{kN}$. O padrão de fissuração da viga foi muito parecido com o da V_40_L/6. A Figura 6.72 apresenta uma foto da metade esquerda da viga, onde se deu a ruptura, após o ensaio. O panorama completo da fissuração se encontra no Apêndice G.

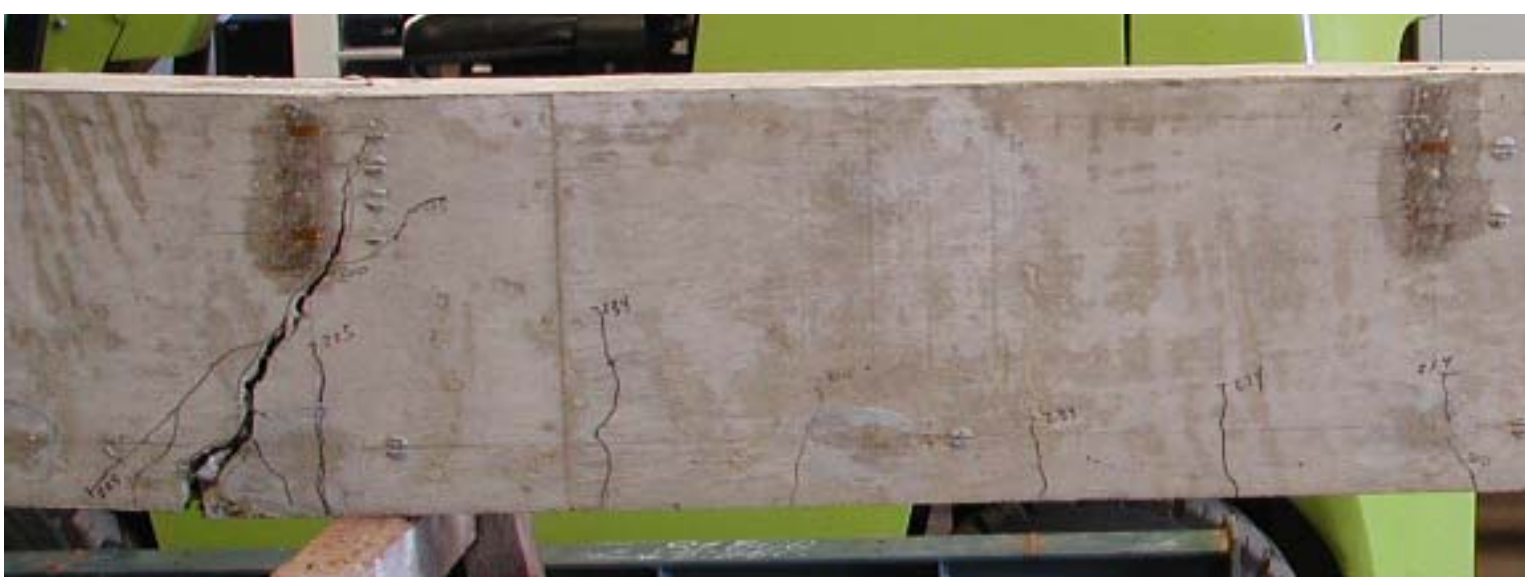

Figura 6.72 - Detalhes da fissuração da V_60_L/6, do lado esquerdo.

As Figuras 6.73 a 6.76 apresentam os gráficos representativos do ensaio.

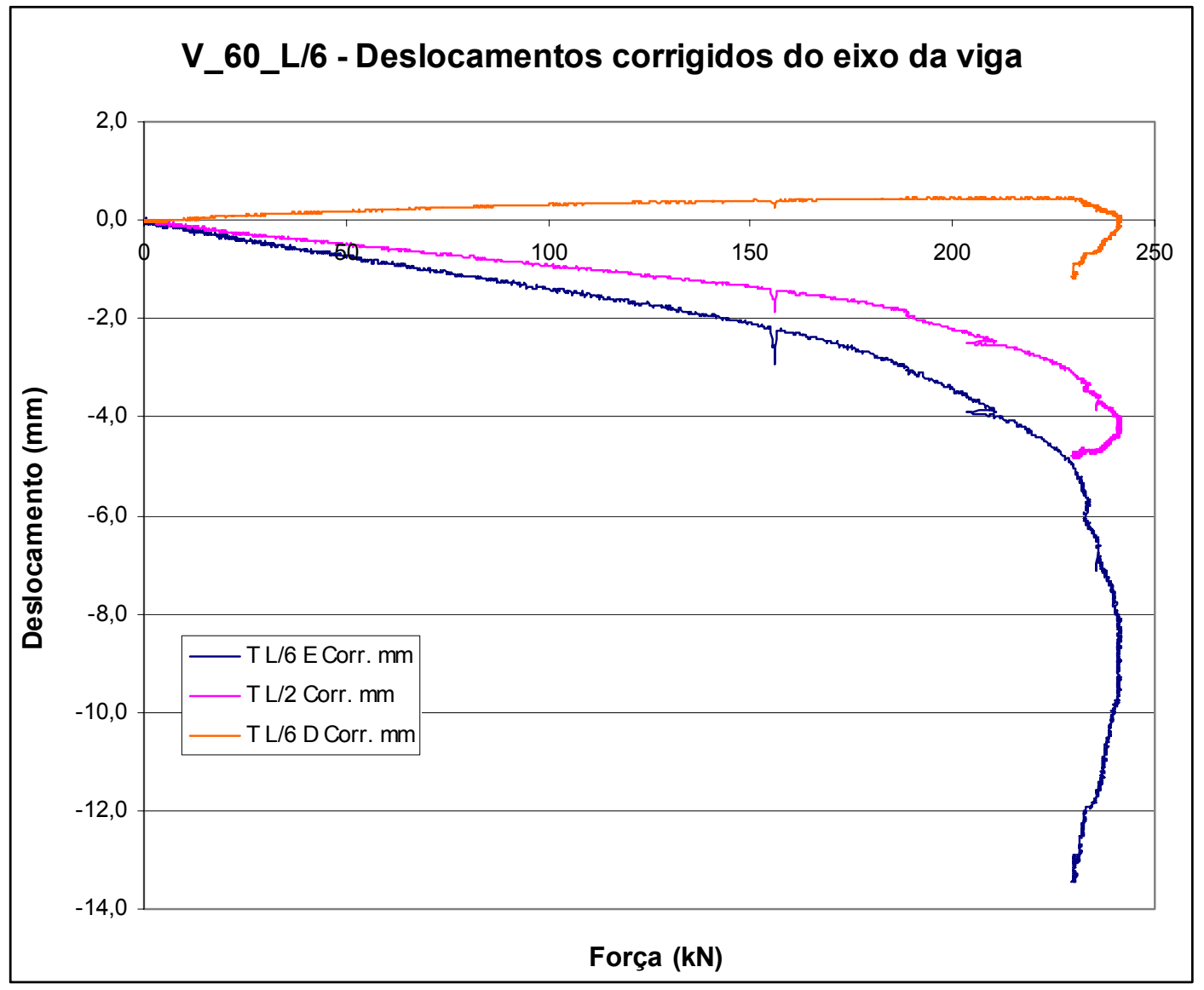

Figura 6.73 - Gráfico Força versus Deslocamento para a V_60_L/6. 


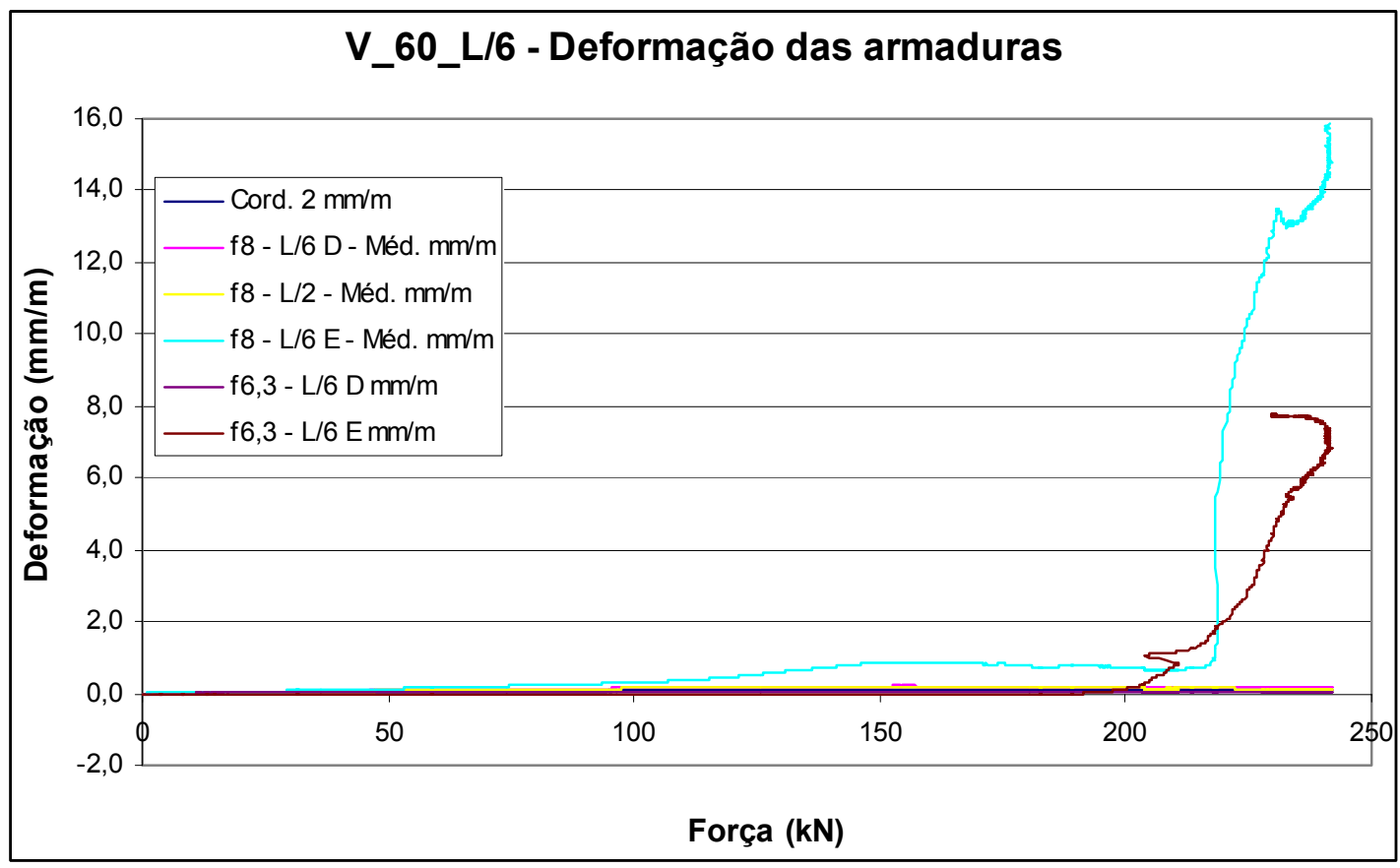

Figura 6.74 - Gráfico Força versus Deformação para a V_60_L/6.

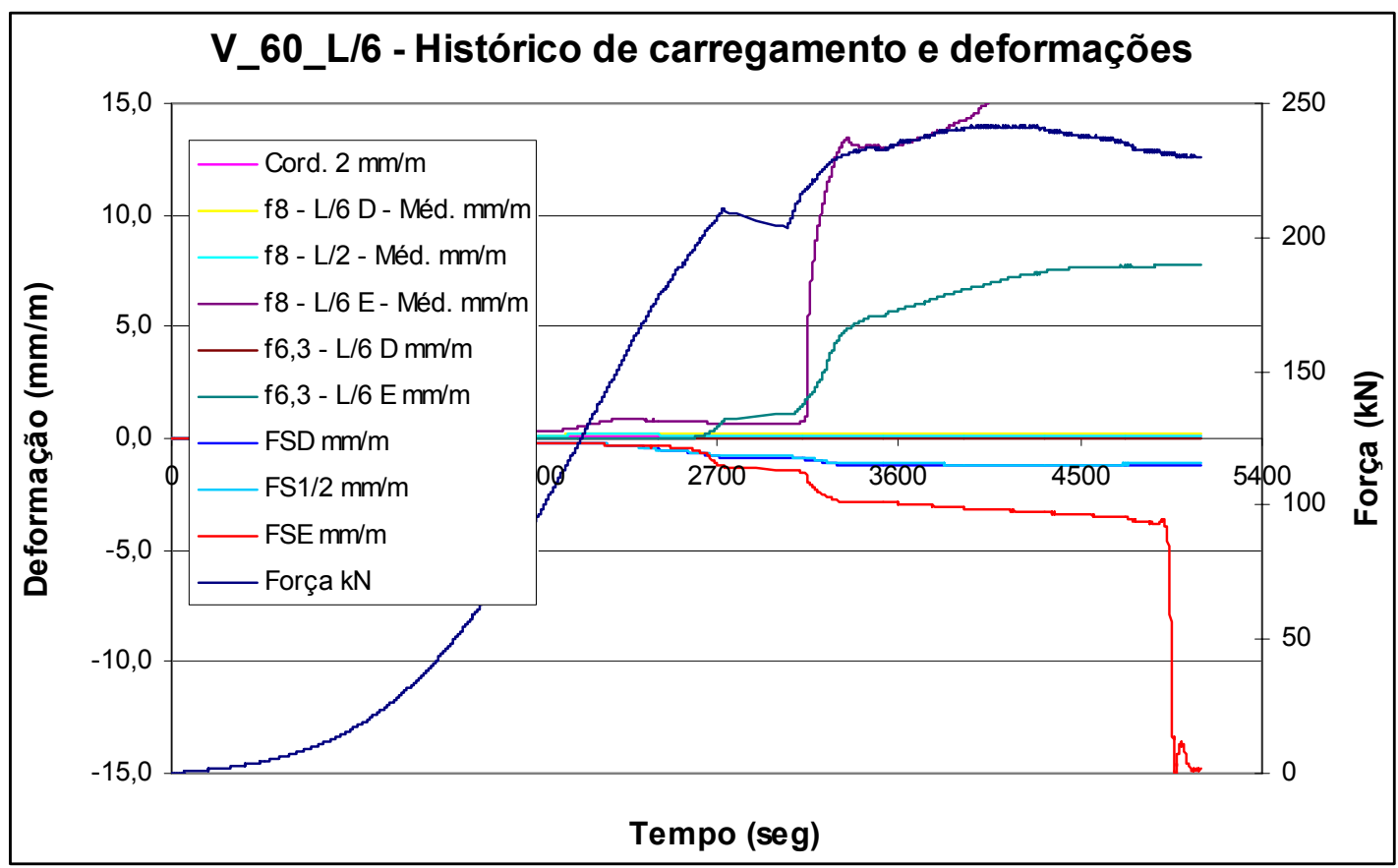

Figura 6.75 - Gráfico das deformações e forças em função do tempo, para a V_60_L/6.

O ensaio foi interrompido quando a carga já se apresentava em queda e o escorregamento do lado esquerdo já indicava ruptura por perda de aderência. Observa-se, pela Figura 6.76, que a viga rompeu primeiro por escorregamento e em seguida houve o escoamento do estribo da esquerda e da barra longitudinal passiva de $\phi 8 \mathrm{~mm}$, assim como o esmagamento do concreto na face superior da peça. 


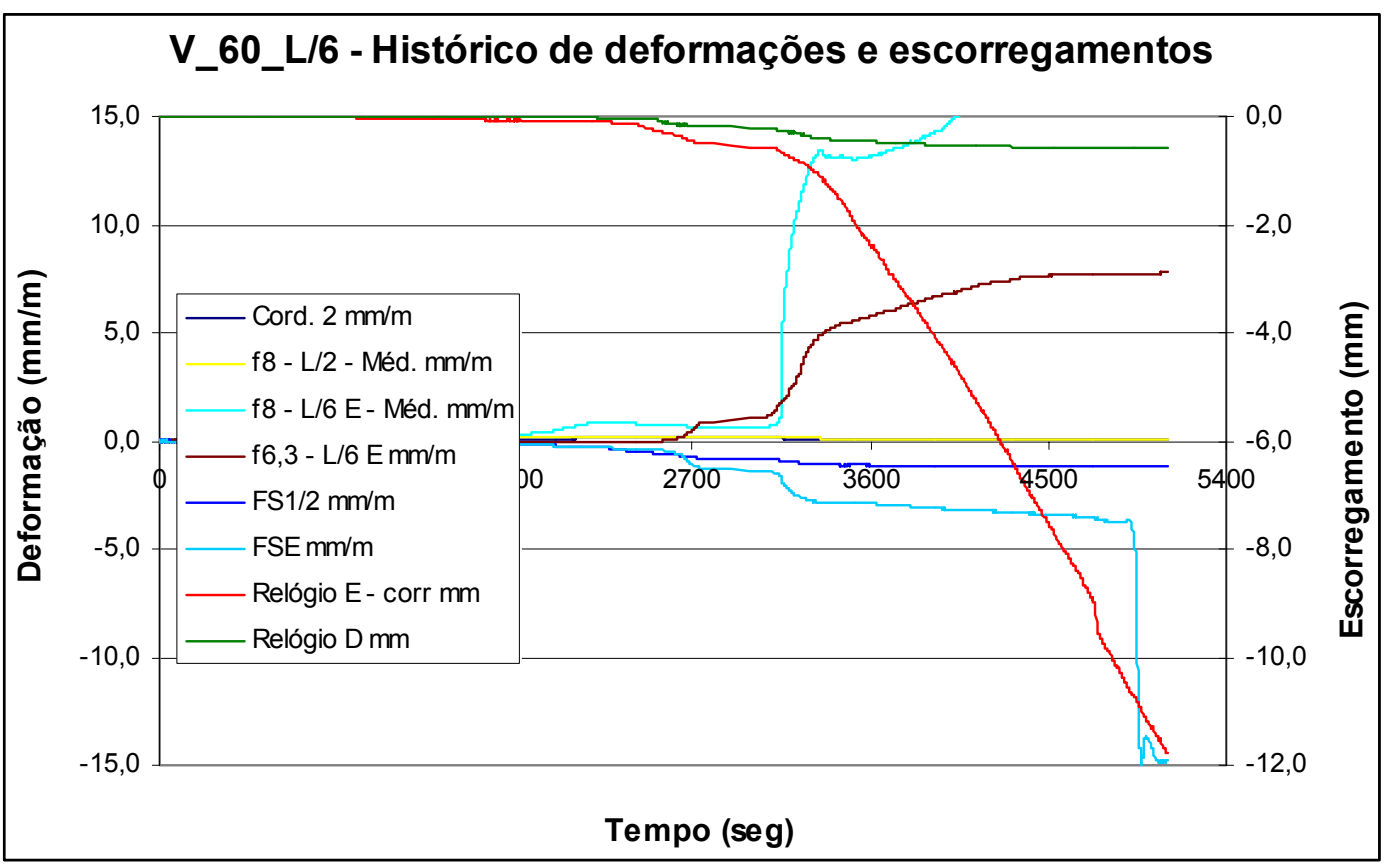

Figura 6.76 - Gráfico das deformações e escorregamentos em função do tempo, para a V_60_L/6.

\section{g) Conclusões parciais}

Após os ensaios das seis primeiras vigas, observou-se que o arranjo com duas cargas eqüidistantes a L/6 dos apoios enrijecia muito o sistema, e, além disso, a armadura transversal de cisalhamento seguiu as recomendações da FIB Bulletin 1 (1999) que permitia uma grande contribuição do concreto na resistência ao cortante, o que foi levado em conta no cálculo, ou seja, o concreto estava resistindo a quase metade do valor do cortante máximo de cálculo. Esses dois fatores em conjunto, faziam com que a ruptura por cisalhamento das peças com $\lambda_{0}=\mathrm{L} / 6$ fosse frágil, sem praticamente nenhum aviso prévio. Quando apareciam as primeiras fissuras, já eram fissuras de cisalhamento com aberturas bem significativas, mesmo sem o escoamento dos estribos.

Optou-se, então, por duas mudanças para os ensaios seguintes: 1) mudar o arranjo de ensaio para uma carga concentrada deslocada para a extremidade; e 2) desprezar a contribuição do concreto no cálculo do cisalhamento, o que aumentou a armadura transversal, que passou a ser $\phi 6,3$ a cada $7,5 \mathrm{~cm}$, na região de cisalhamento.

Essas mudanças foram realizadas nas cinco últimas vigas, pois a viga $V_{-}$__L/3b seguiu o mesmo arranjo da V_0_L/3.

\section{h) Viga V_o_L/3b}

A Figura 6.77 apresenta o esquema de ensaio da viga $V \_0 \_L / 3 b$. 


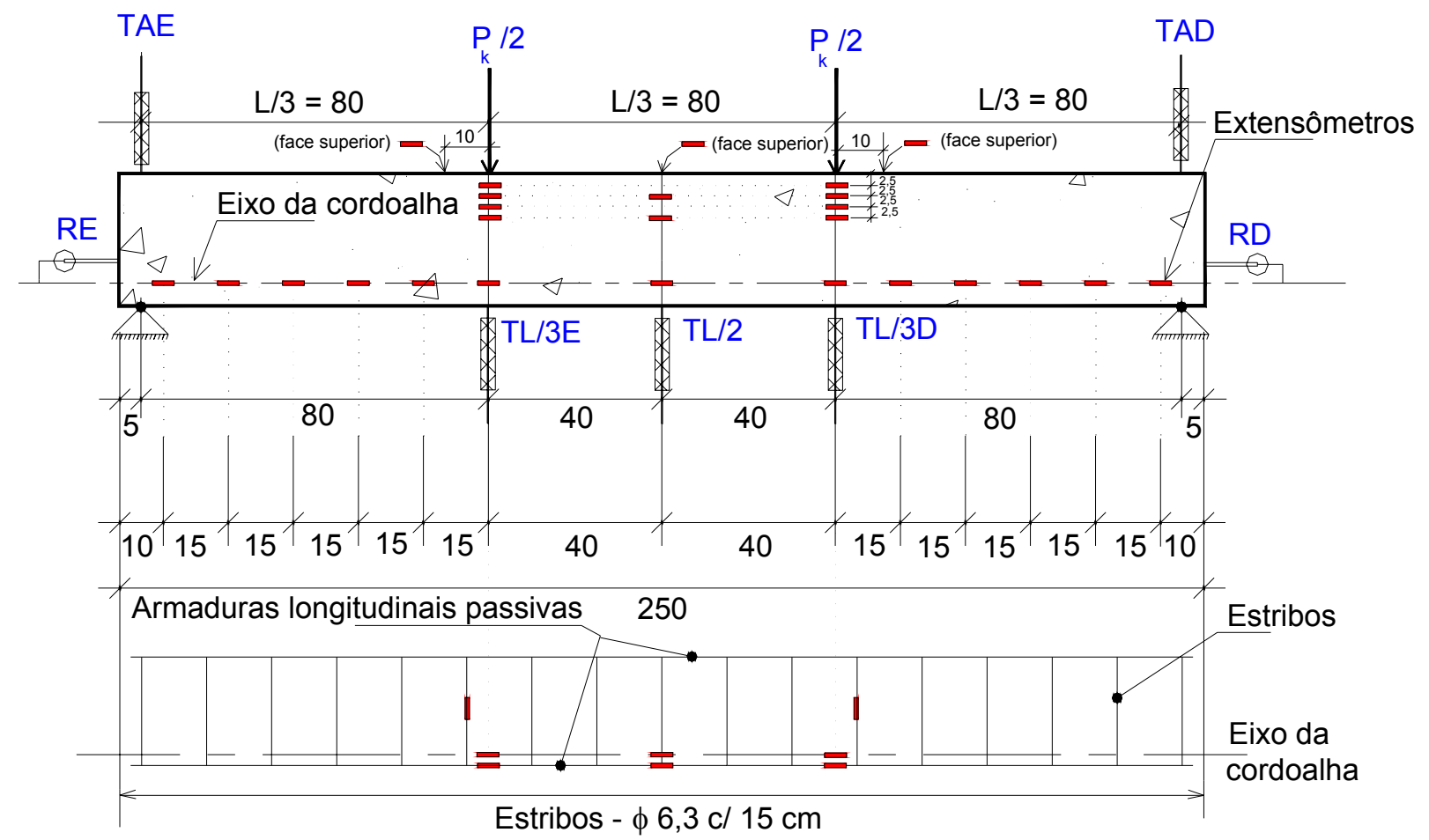

Figura 6.77 - Esquema de ensaio e instrumentação da viga V_0_L/3b.

A carga teórica de início da fissuração era de $P_{\text {fiss }}=78,83 \mathrm{kN}$ e a última de $P_{\text {últ }}=85,3 \mathrm{kN}$. A viga começou a fissurar com uma carga de $\mathrm{P}_{\text {fiss,ensaio }}=95 \mathrm{kN}$ e a carga máxima alcançada foi de $P_{\text {últ,ensaio }}=171,64 \mathrm{kN}$. A Figura 6.78 apresenta uma foto da fissuração da viga após o ensaio.

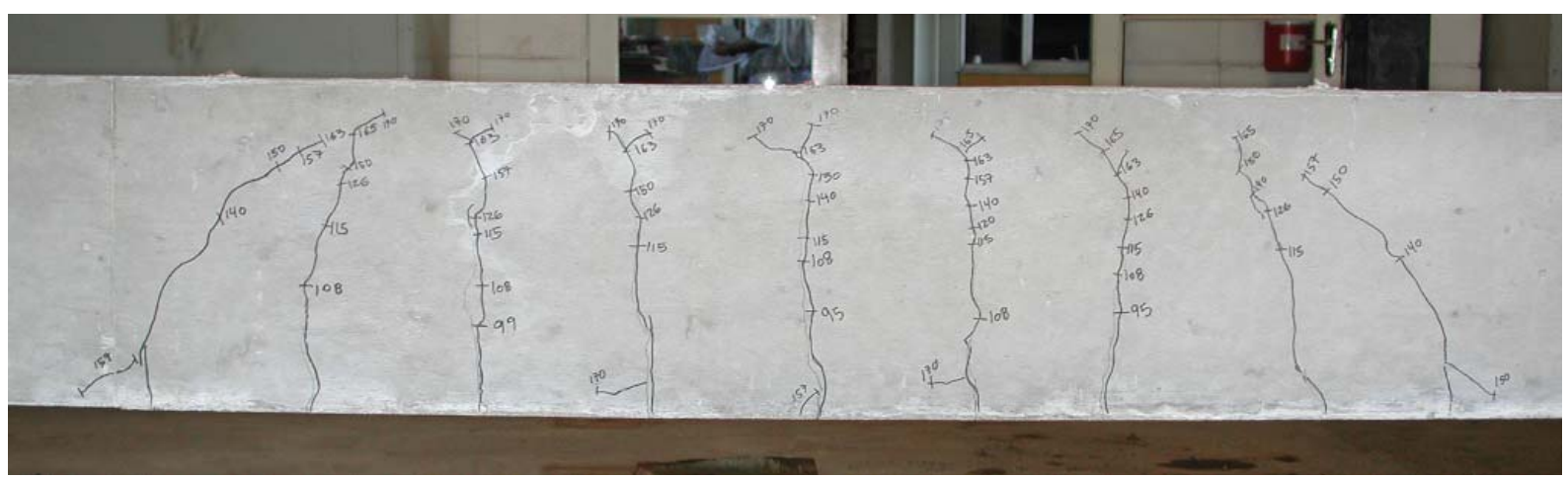

Figura 6.78 - Detalhes da fissuração da V_0_L/3b, após o ensaio.

As Figuras 6.78 a 6.81 apresentam os gráficos representativos do ensaio.

O ensaio foi interrompido após o escoamento da cordoalha, apesar da carga ainda não ter apresentado tendência de queda, como mostra a Figura 6.79. A partir do momento que as armaduras começaram a escoar, não havia mais ganho de carga, apenas o aumento das deformações. Não houve escoamento dos estribos, mas ocorreu o esmagamento do concreto na face superior, como mostra a Figura 6.81. A cordoalha não perdeu a aderência, como indica a Figura 6.81, cuja leitura para o escorregamento máximo foi de $\mathrm{S} \approx 0,1 \mathrm{~mm}$. 


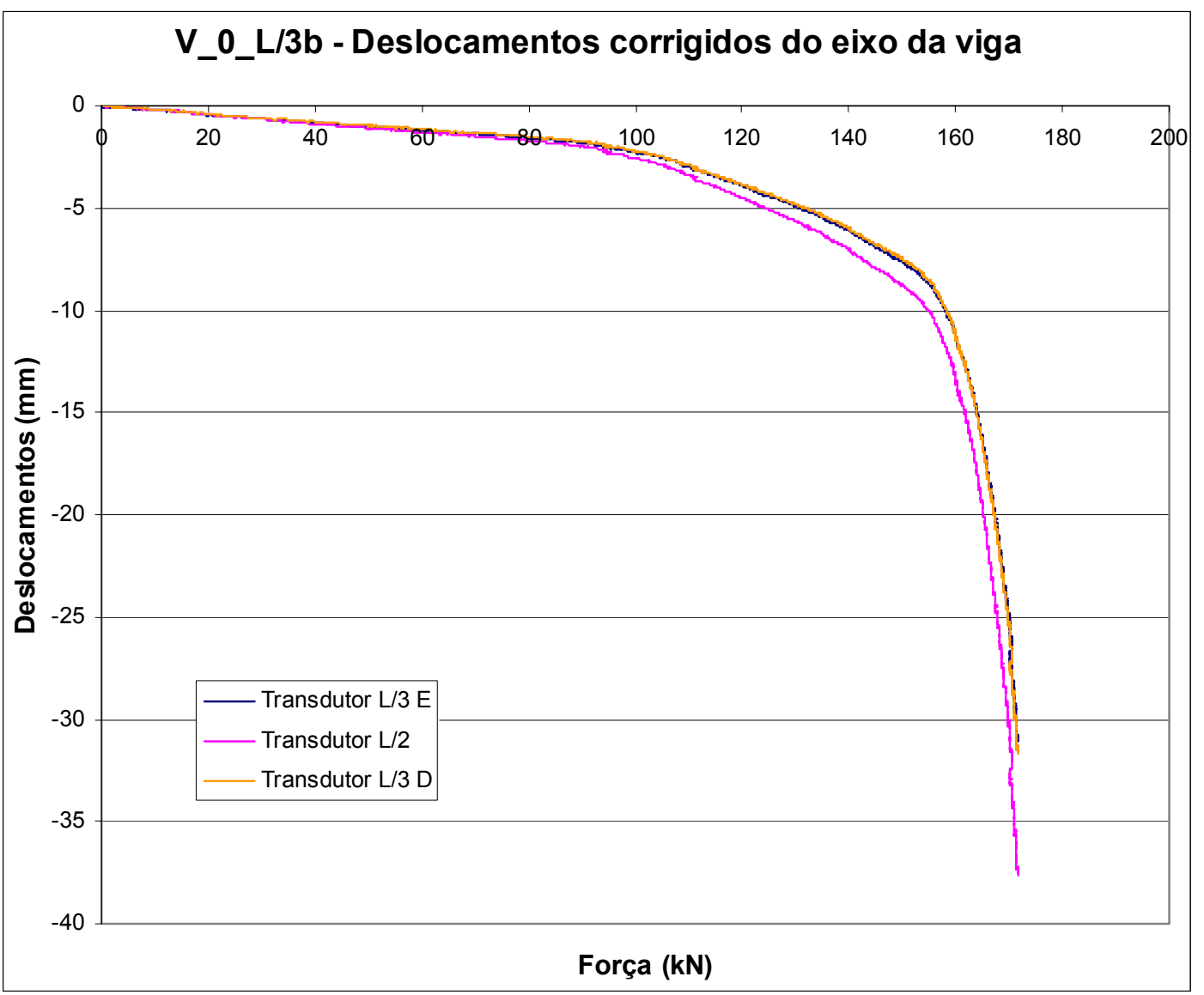

Figura 6.78 - Gráfico Força versus Deslocamento para a V_0_L/3b.

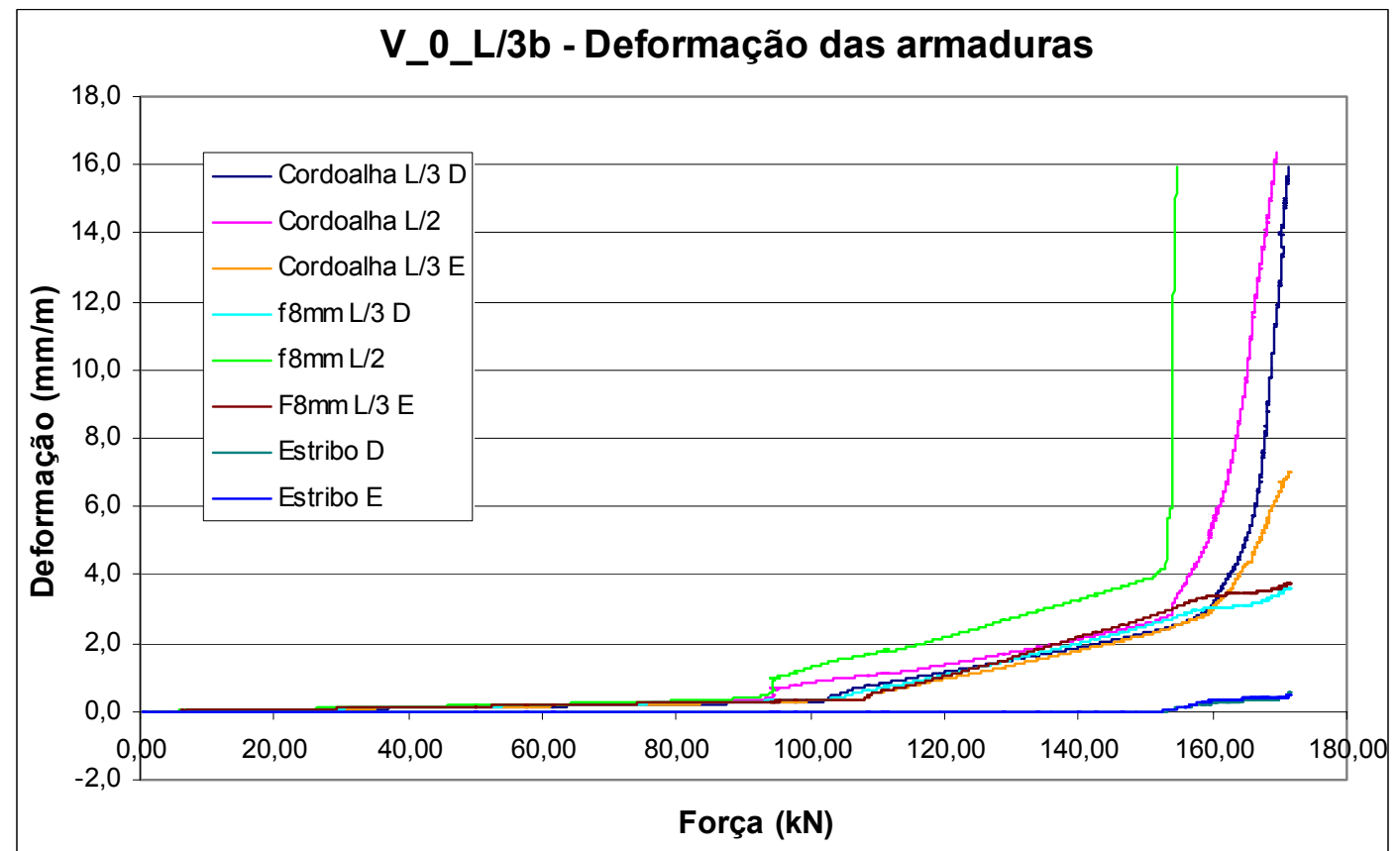

Figura 6.79 - Gráfico Força versus Deformação para a V_0_L/3b. 


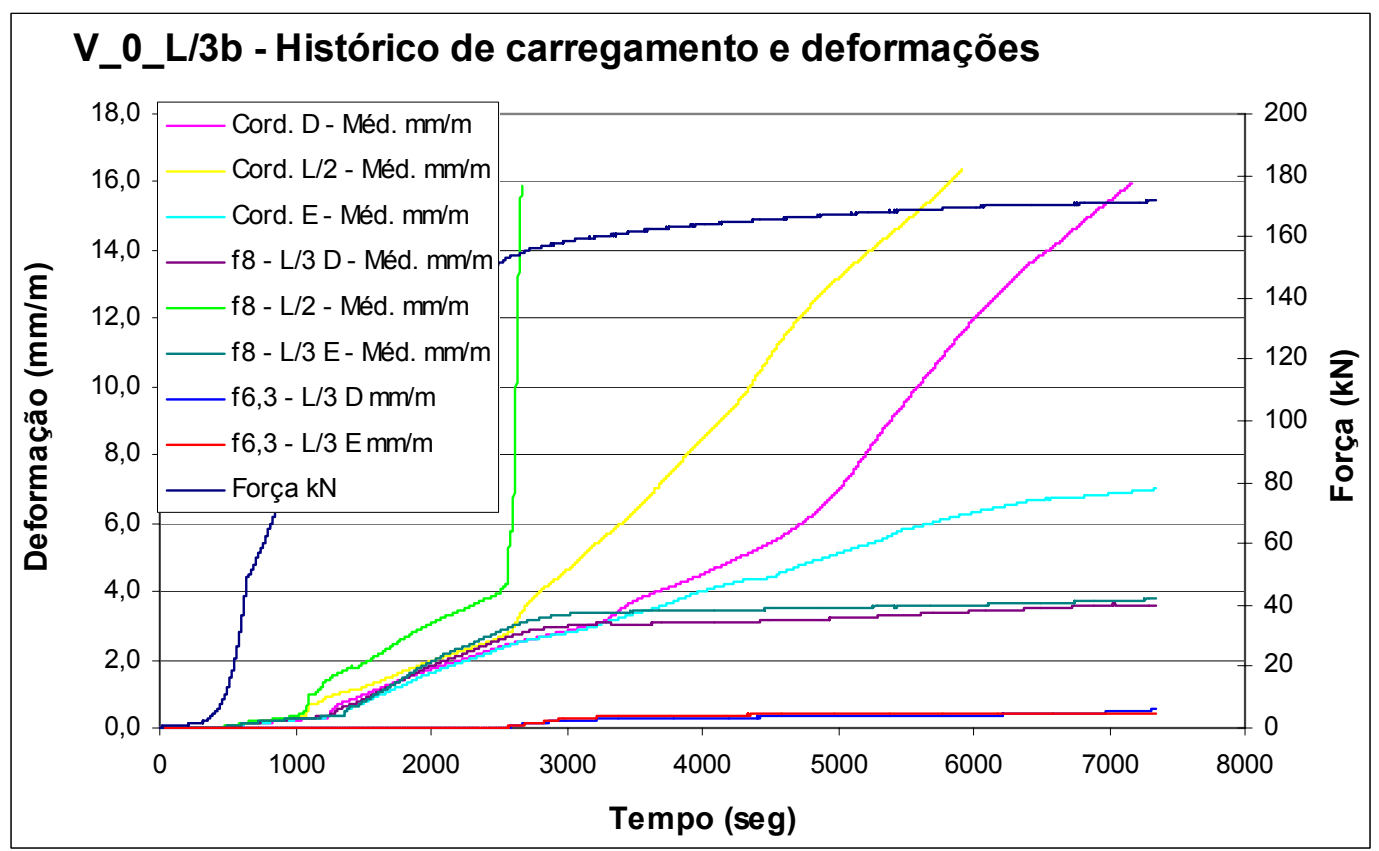

Figura 6.80 - Gráfico das deformações e forças em função do tempo, para a V_0_L/3b.

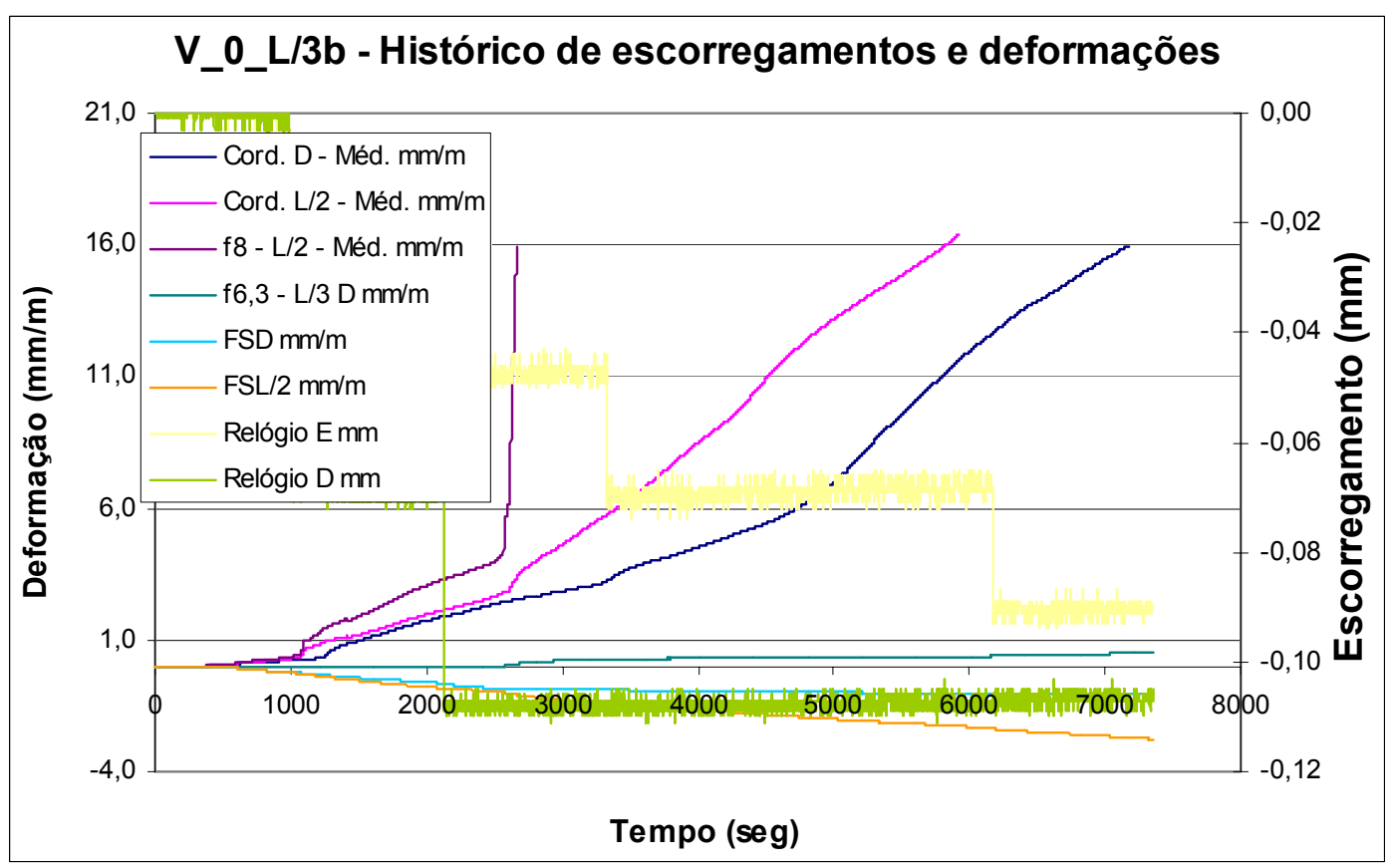

Figura 6.81 - Gráfico das deformações e escorregamentos em função do tempo, para a V_0_L/3b.

\section{i) Viga V_0_L/4}

A Figura 6.82 apresenta o esquema de ensaio da viga V_0_L/4.

A carga teórica de início da fissuração era de $P_{\text {fiss }}=70,29 \mathrm{kN}$ e a última de $P_{\text {últ }}=76,69 \mathrm{kN}$. A viga começou a fissurar com uma carga de $P_{\text {fiss,ensaio }}=91 \mathrm{kN}$ e a carga máxima alcançada foi de $P_{\text {últ,ensaio }}=141,07 \mathrm{kN}$. A Figura 6.83 apresenta uma foto da fissuração da viga após o ensaio. 


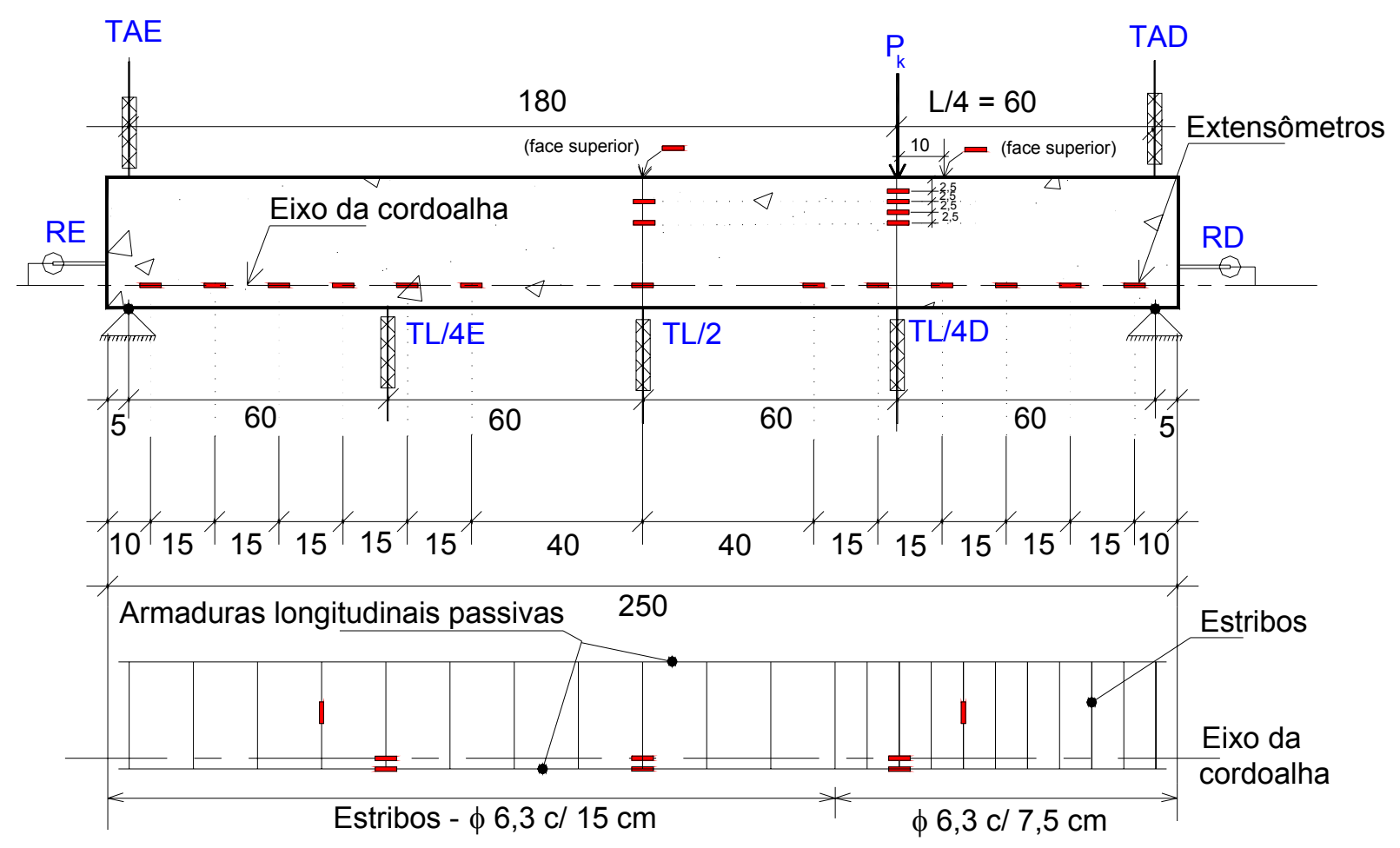

Figura 6.82 - Esquema de ensaio e instrumentação da viga V_0_L/4.

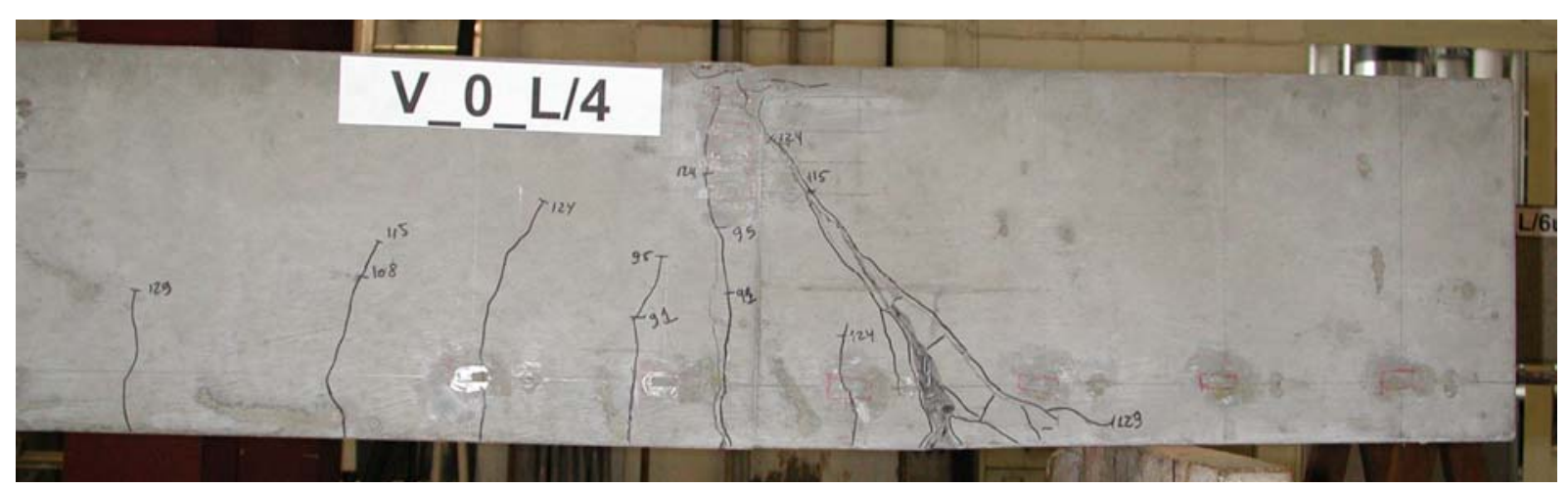

Figura 6.83 - Detalhes da fissuração da V_0_L/4, após o ensaio.

Pela Figura 6.83 percebe-se que as fissuras ficaram concentradas próximas ao ponto de introdução de carga, e que elas não foram muitas. Quando apareceu a primeira já era de cisalhamento, e já surgiu com uma dimensão elevada. A partir daí, com o aumento da carga, aumentava a fissura existente e surgiram mais algumas.

O ensaio foi interrompido quando a carga já estava caindo, e o escorregamento da cordoalha à esquerda, lado de introdução de carga, já ultrapassava os 10mm. Isso foi verificado visualmente, pois a leitura do transdutor apresentou problemas, não sendo possível registrá-la.

As Figuras 6.84 a 6.87 apresentam os gráficos representativos do ensaio. Pelos gráficos percebe-se que não houve escoamento das cordoalhas nem dos estribos, e que o esmagamento 
do concreto ficou em torno de $\varepsilon_{\mathrm{c}}=2 \%$. Logo, a viga não rompeu por flexão, e sim por perda de aderência, apesar de não se ter o registro do escorregamento.

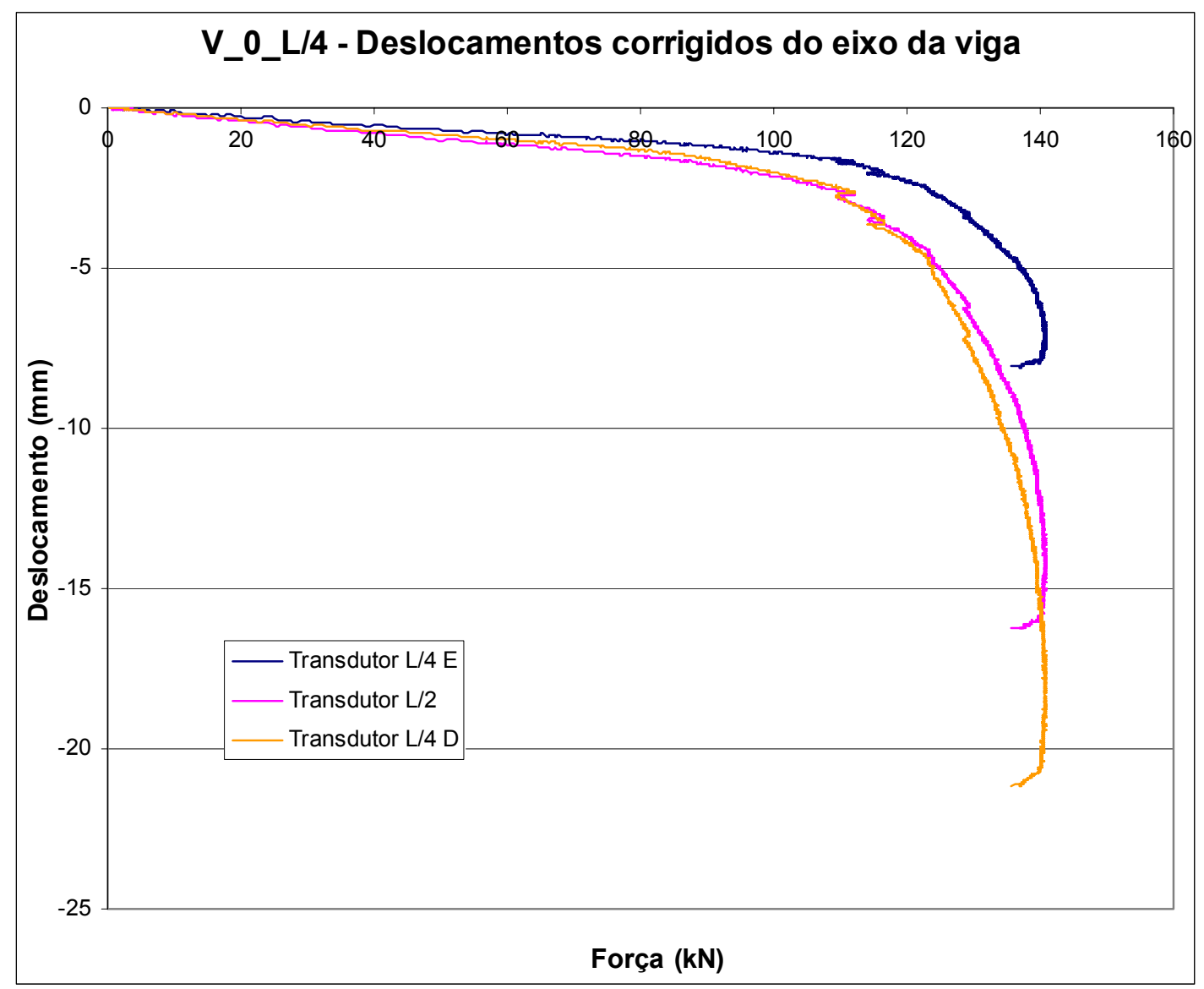

Figura 6.84 - Gráfico Força versus Deslocamento para a V_0_L/4.

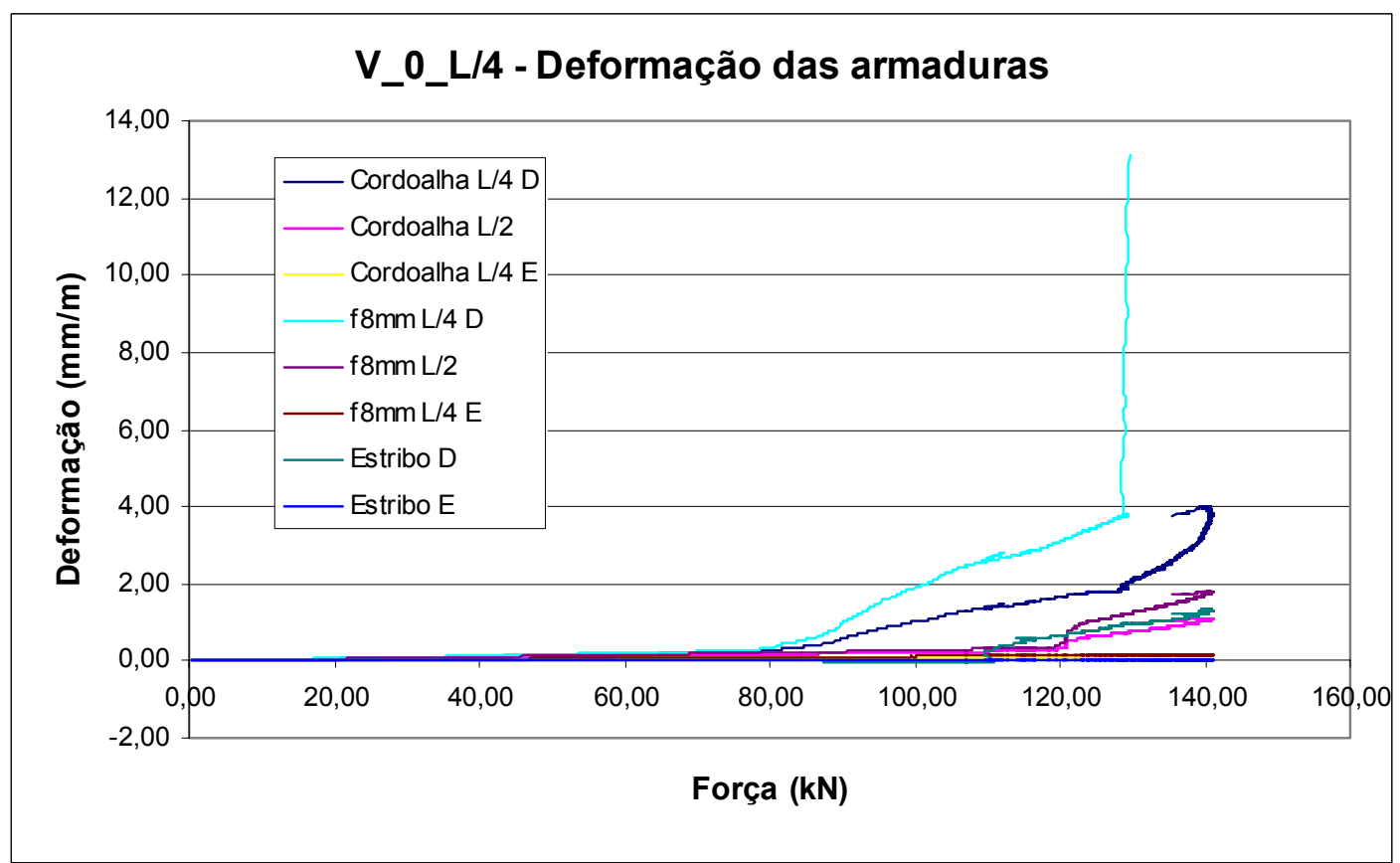

Figura 6.85 - Gráfico Força versus Deformação para a V_0_L/4. 


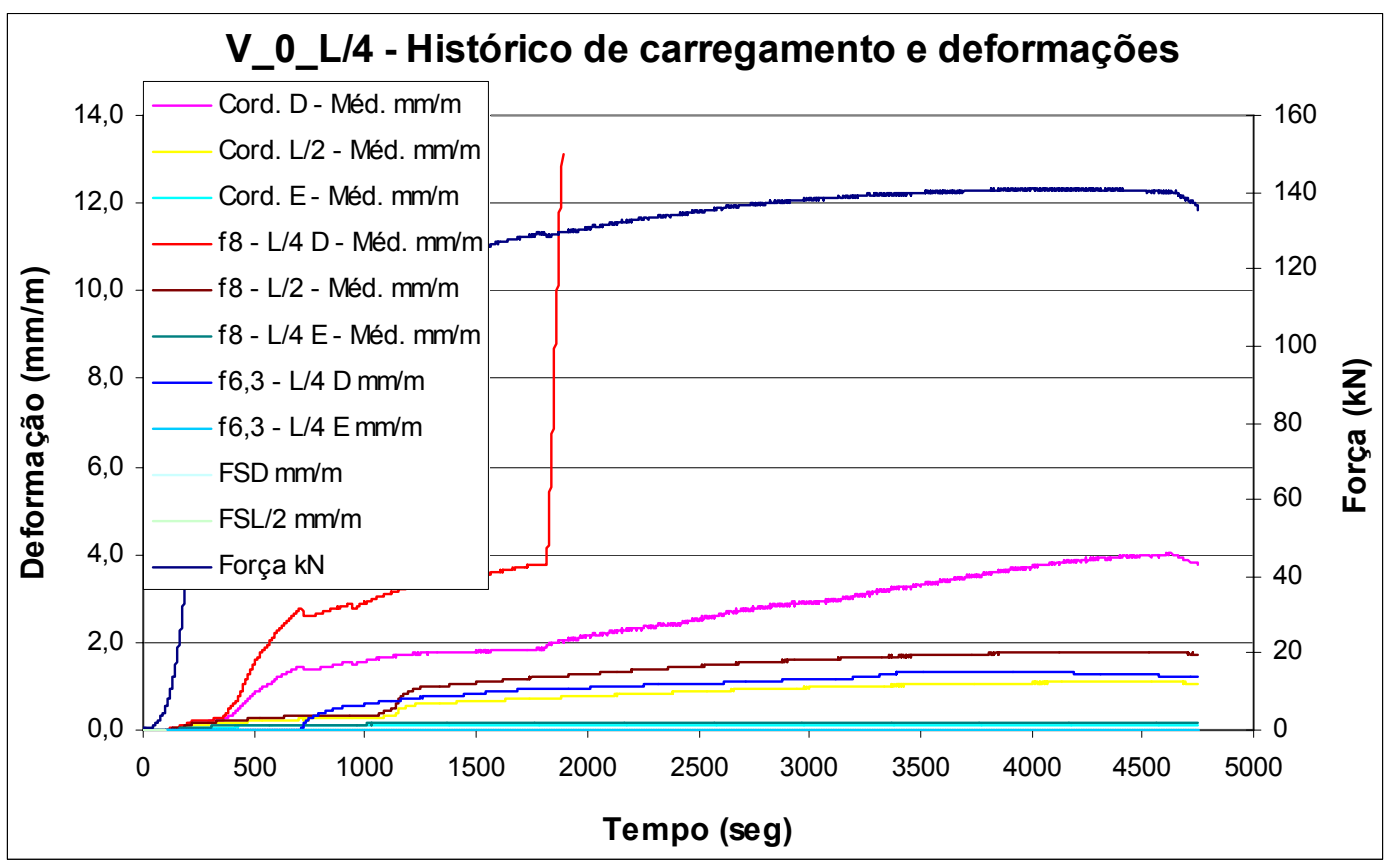

Figura 6.86 - Gráfico das deformações e forças em função do tempo, para a V_0_L/4.

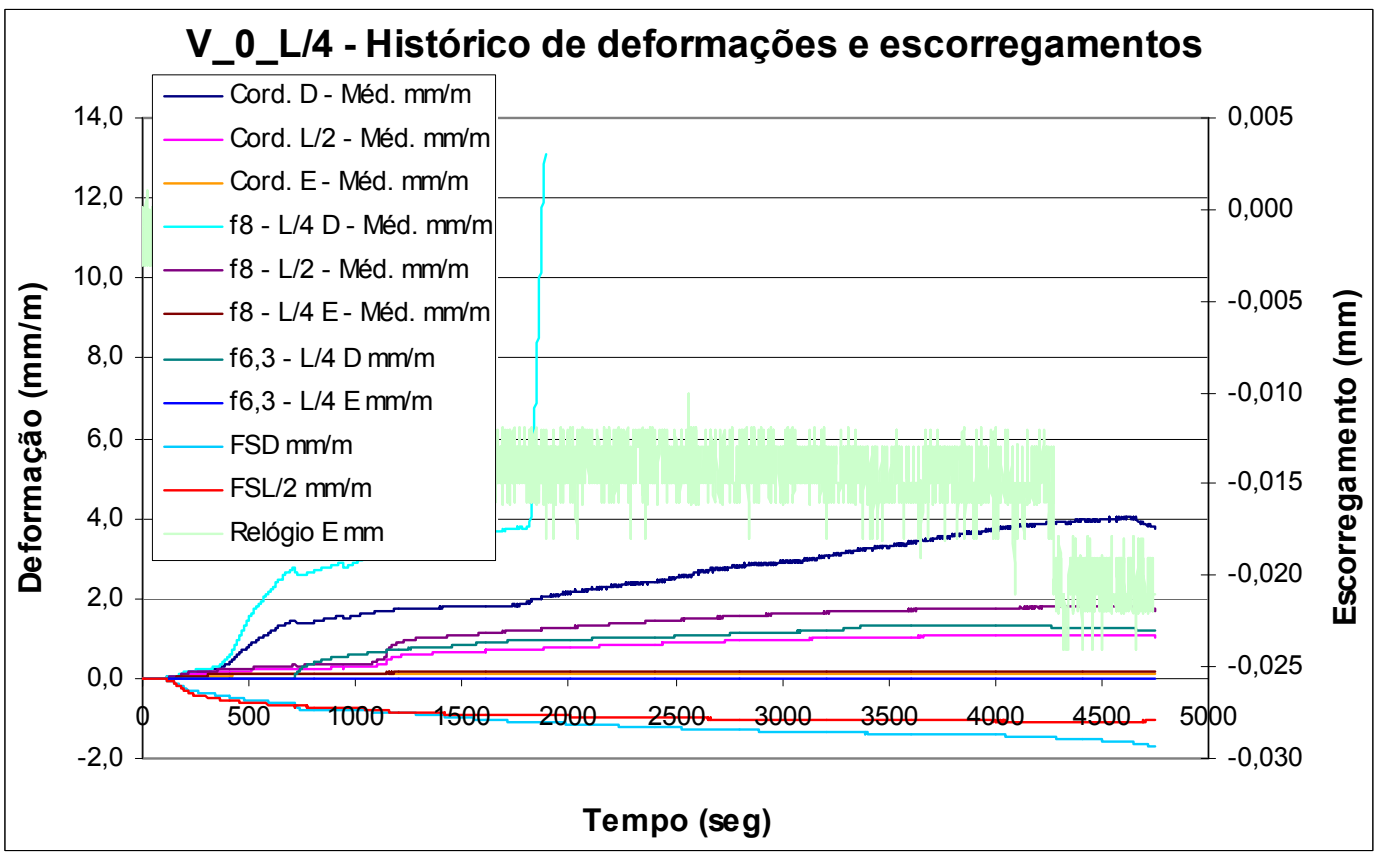

Figura 6.87 - Gráfico das deformações e escorregamentos em função do tempo, para a V_0_L/4.

\section{j) Viga V_40_L/4}

$\mathrm{O}$ esquema de ensaio e instrumentação foi o mesmo da viga V_0_L/4, que está apresentado na Figura 6.82. A carga teórica de início da fissuração era de $\mathrm{P}_{\text {fiss }}=73,29 \mathrm{kN}$ e a última de $\mathrm{P}_{\text {últ }}=76,69 \mathrm{kN}$. A viga começou a fissurar com uma carga de $\mathrm{P}_{\text {fiss,ensaio }}=82 \mathrm{kN}$ e a 
carga máxima alcançada foi de $P_{\text {últ,ensaio }}=137,94 \mathrm{kN}$. A Figura 6.88 apresenta uma foto da fissuração da viga após o ensaio.

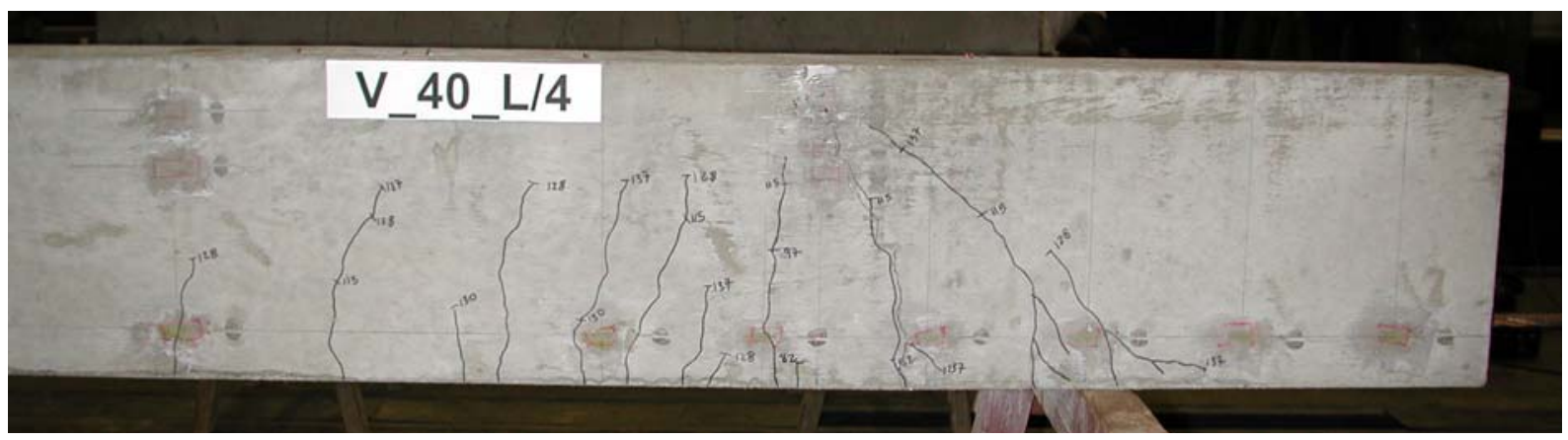

Figura 6.88 - Detalhes da fissuração da V_40_L/4, após o ensaio.

As Figuras 6.89 a 6.92 apresentam os gráficos representativos do ensaio.

O ensaio foi interrompido quando a carga já estava em queda, e a cordoalha já apresentava um escorregamento de $\mathrm{S} \approx 4,5 \mathrm{~mm}$.

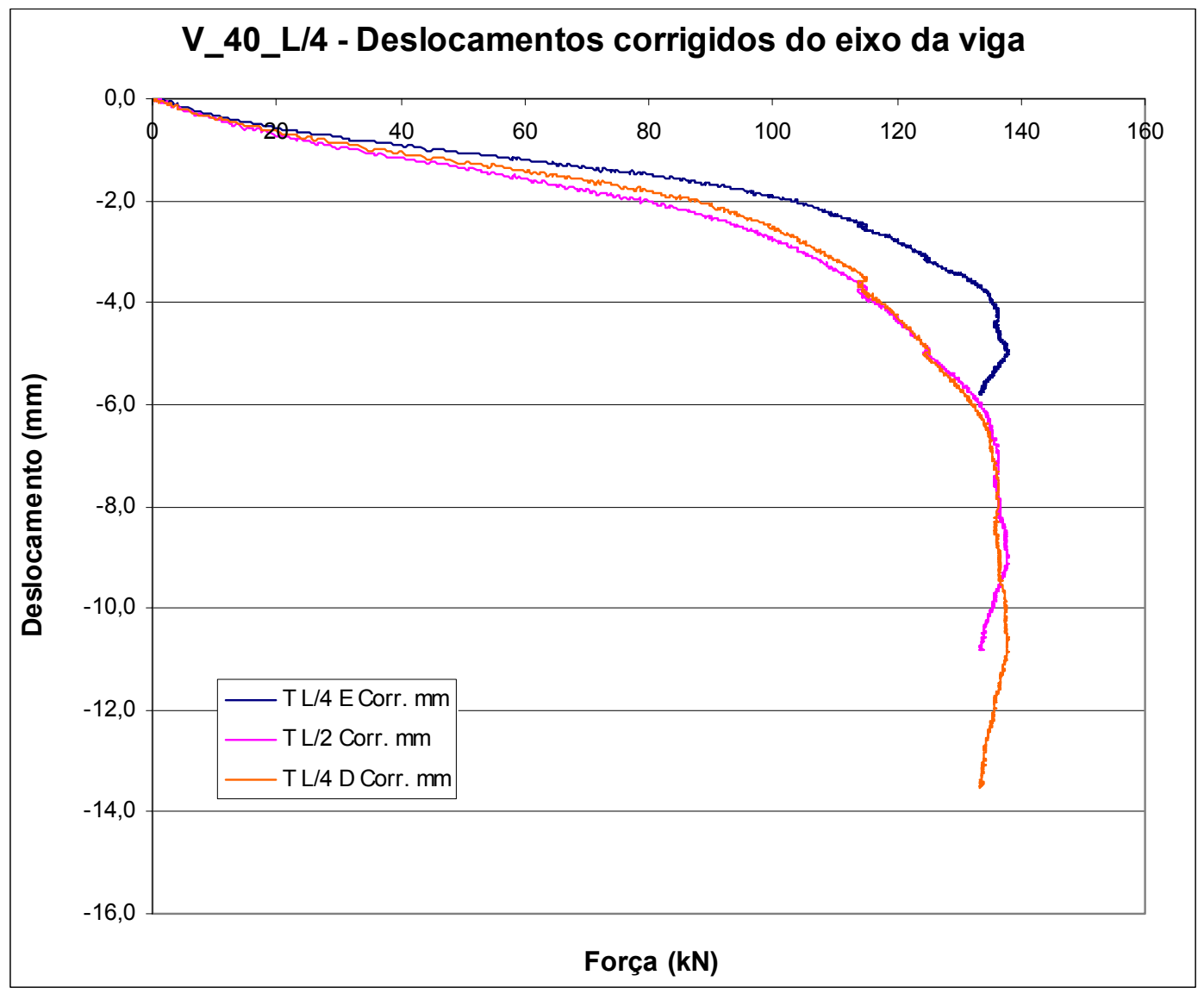

Figura 6.89 - Gráfico Força versus Deslocamento para a V_40_L/4.

Percebe-se pelo gráfico da Figura 6.90 que não houve escoamento das armaduras. Já pelo gráfico da Figura 6.92, nota-se que a ruptura se deu por escorregamento. Para essa viga não ocorreu esmagamento do concreto na zona comprimida, indicado pelo gráfico de FSD 
que estava posicionado na face superior da viga. Observa-se que quando começa o escorregamento da cordoalha na extremidade da viga, as deformações não mais se alteram. A partir desse ponto só há aumento do escorregamento, que ultrapassou muito o valor teórico limite admitido para ruptura por aderência de vigas, que é de $\mathrm{S}_{\operatorname{máx}}=0,25 \mathrm{~mm}$.

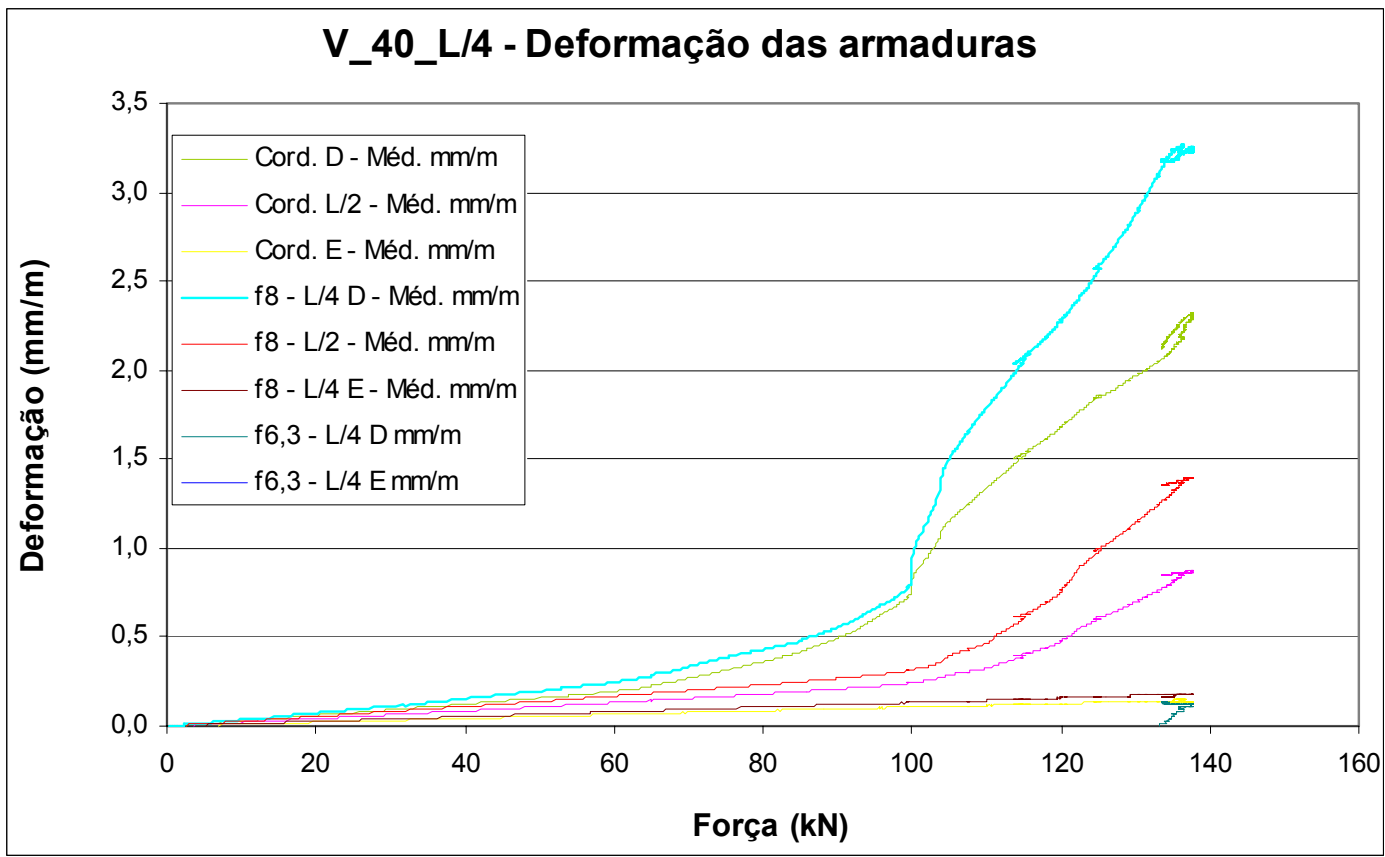

Figura 6.90 - Gráfico Força versus Deformação para a V_40_L/4.

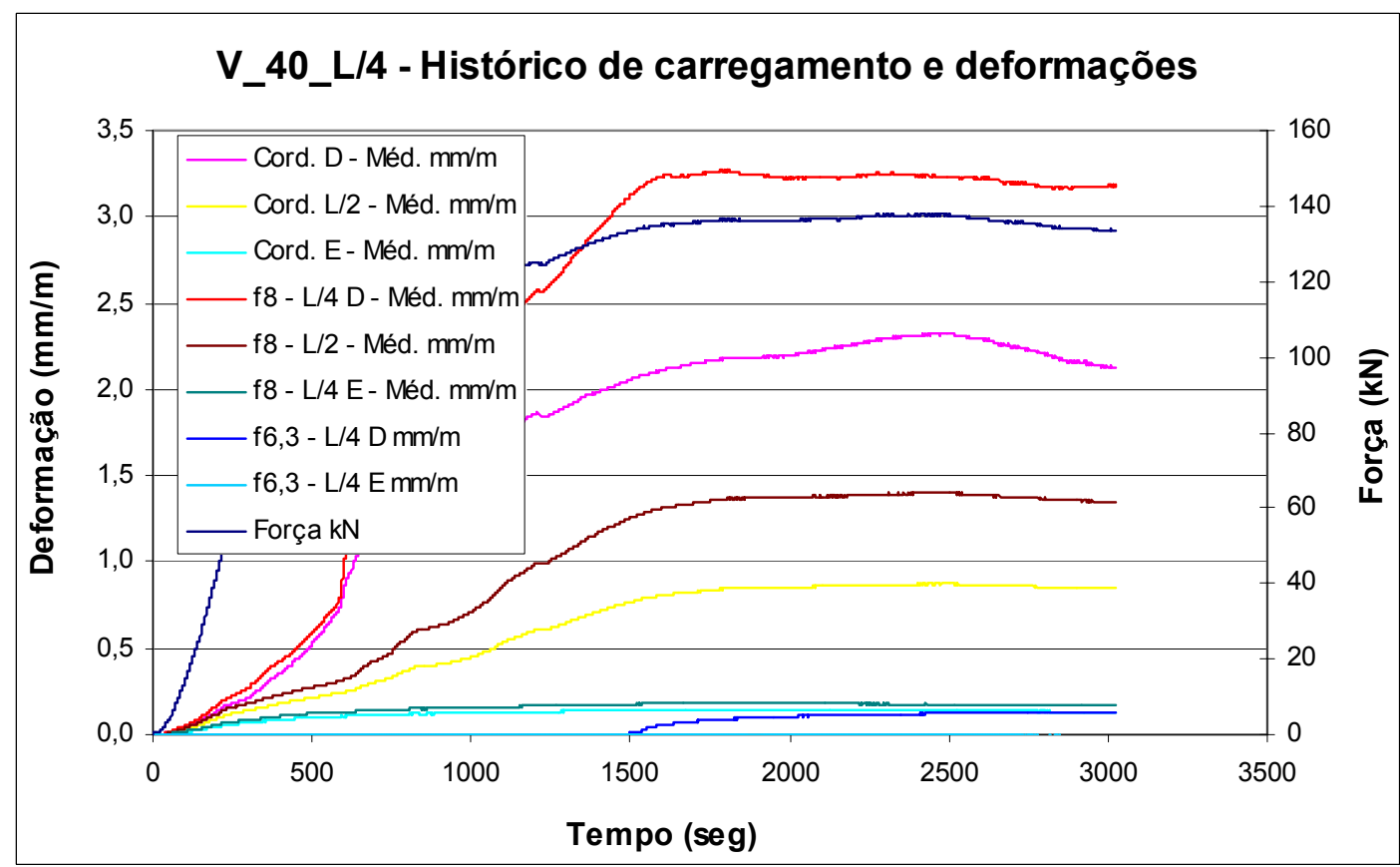

Figura 6.91 - Gráfico das deformações e forças em função do tempo, para a V_40_L/4. 


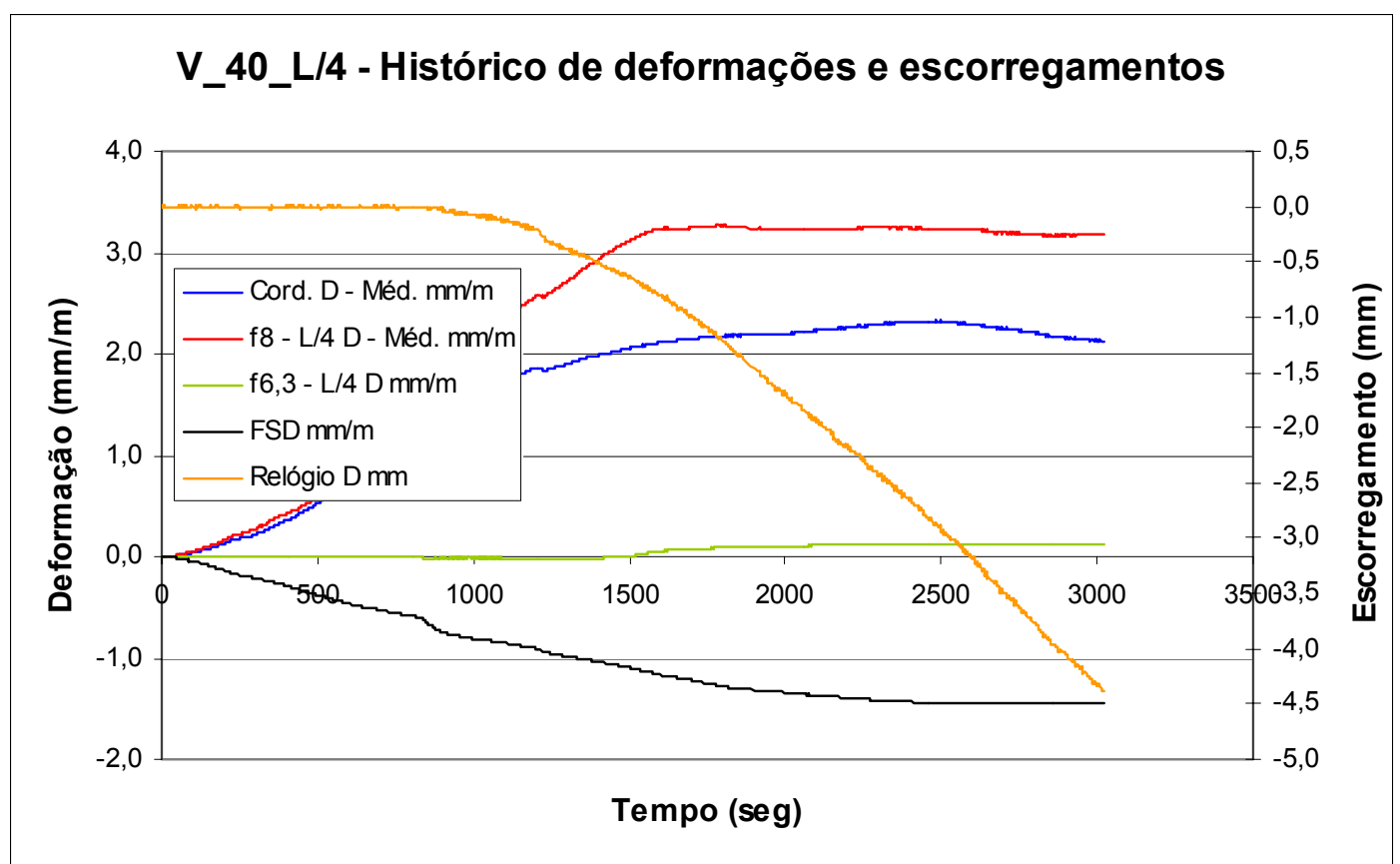

Figura 6.92 - Gráfico das deformações e escorregamentos em função do tempo, para a V_40_L/4.

k) Viga V_60_L/4

$\mathrm{O}$ esquema de ensaio e instrumentação foi o mesmo da viga V_0_L/4, que está apresentado na Figura 6.82.

A carga teórica de início da fissuração era de $\mathrm{P}_{\text {fiss }}=77,8$ e a última de $\mathrm{P}_{\text {últt }}=76,69 \mathrm{kN}$. A viga começou a fissurar com uma carga de $\mathrm{P}_{\text {fiss,ensaio }}=90 \mathrm{kN}$ e a carga máxima alcançada foi de $\mathrm{P}_{\text {últ,ensaio }}=138,7 \mathrm{kN}$. A Figura 6.93 apresenta uma foto da fissuração da viga após o ensaio.

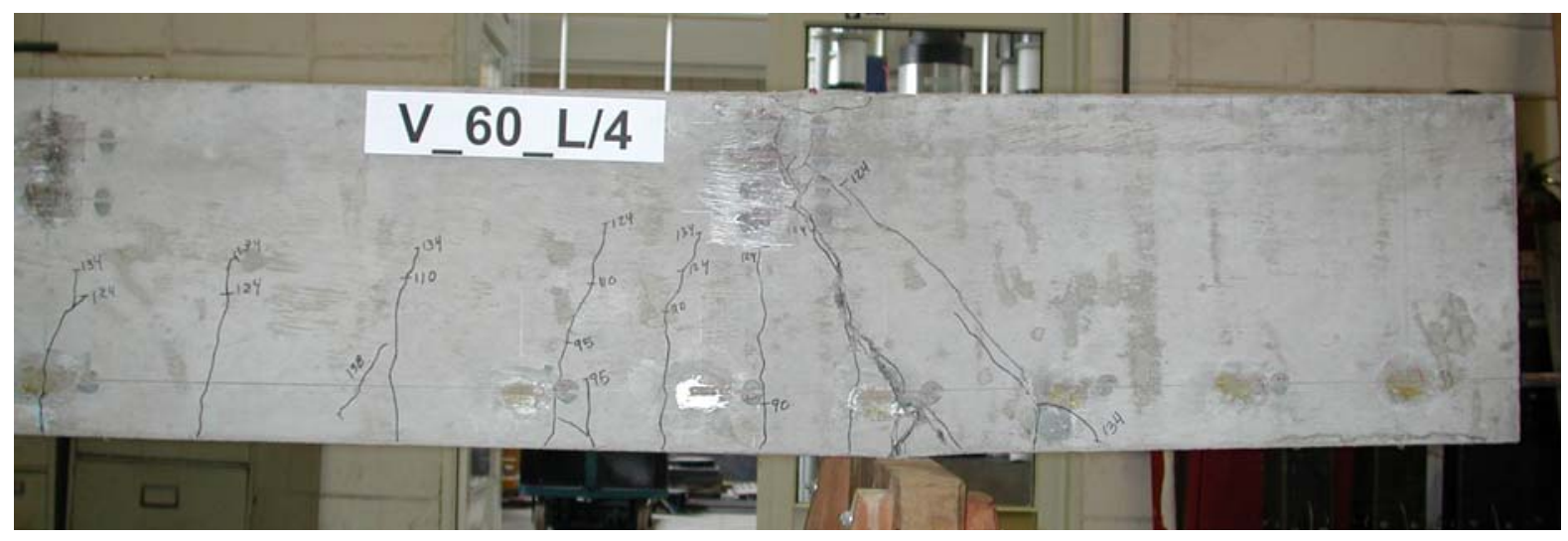

Figura 6.93 - Detalhes da fissuração da V_60_L/4.

As Figuras 6.94 a 6.97 apresentam os gráficos representativos do ensaio.

De maneira geral, o comportamento e o modo de ruptura dessa viga foram os mesmos que para a viga $V_{-} 40 \_L / 4$. 


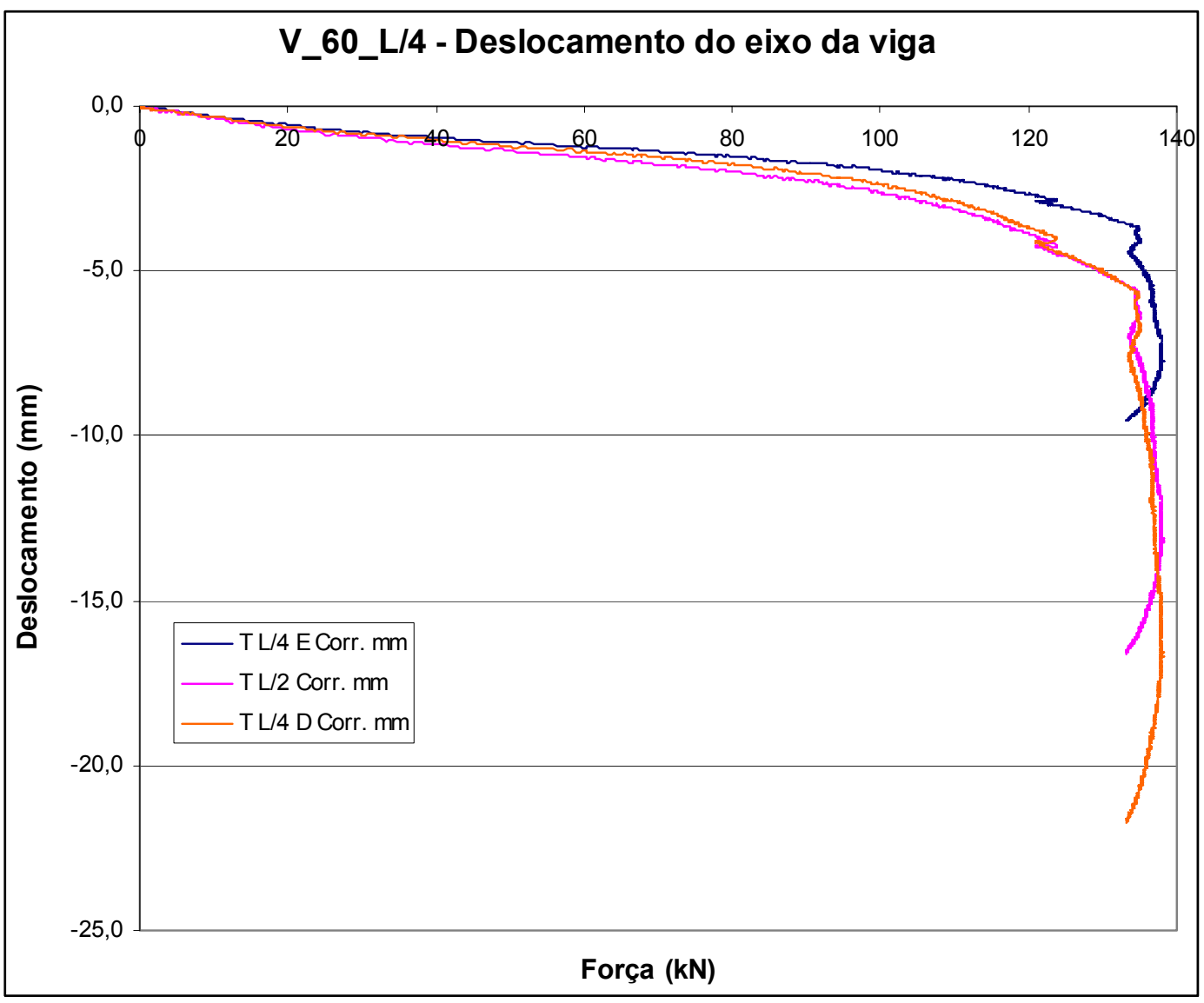

Figura 6.94 - Gráfico Força versus Deslocamento para a V_60_L/4.

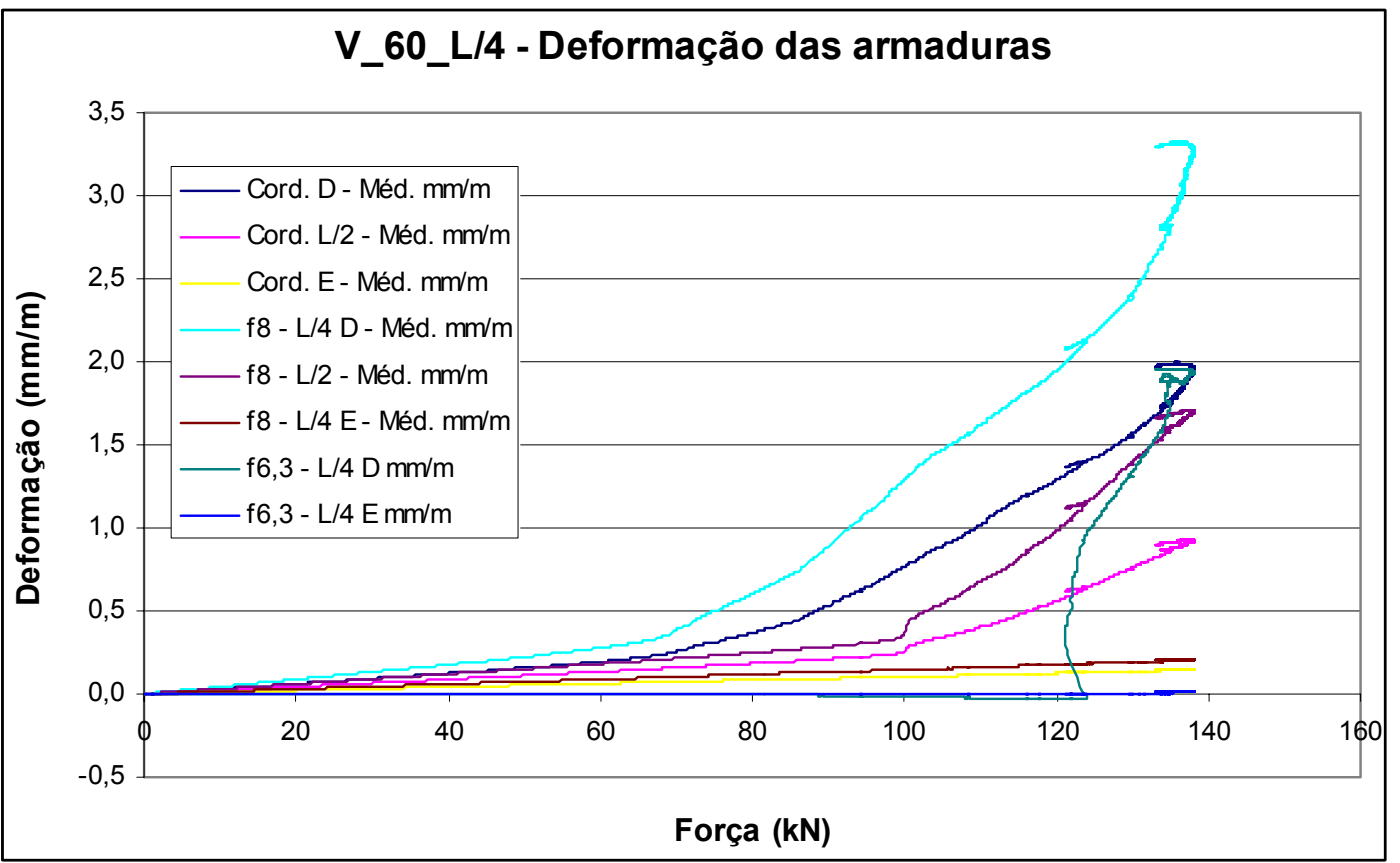

Figura 6.95 - Gráfico Força versus Deformação para a V_60_L/4. 


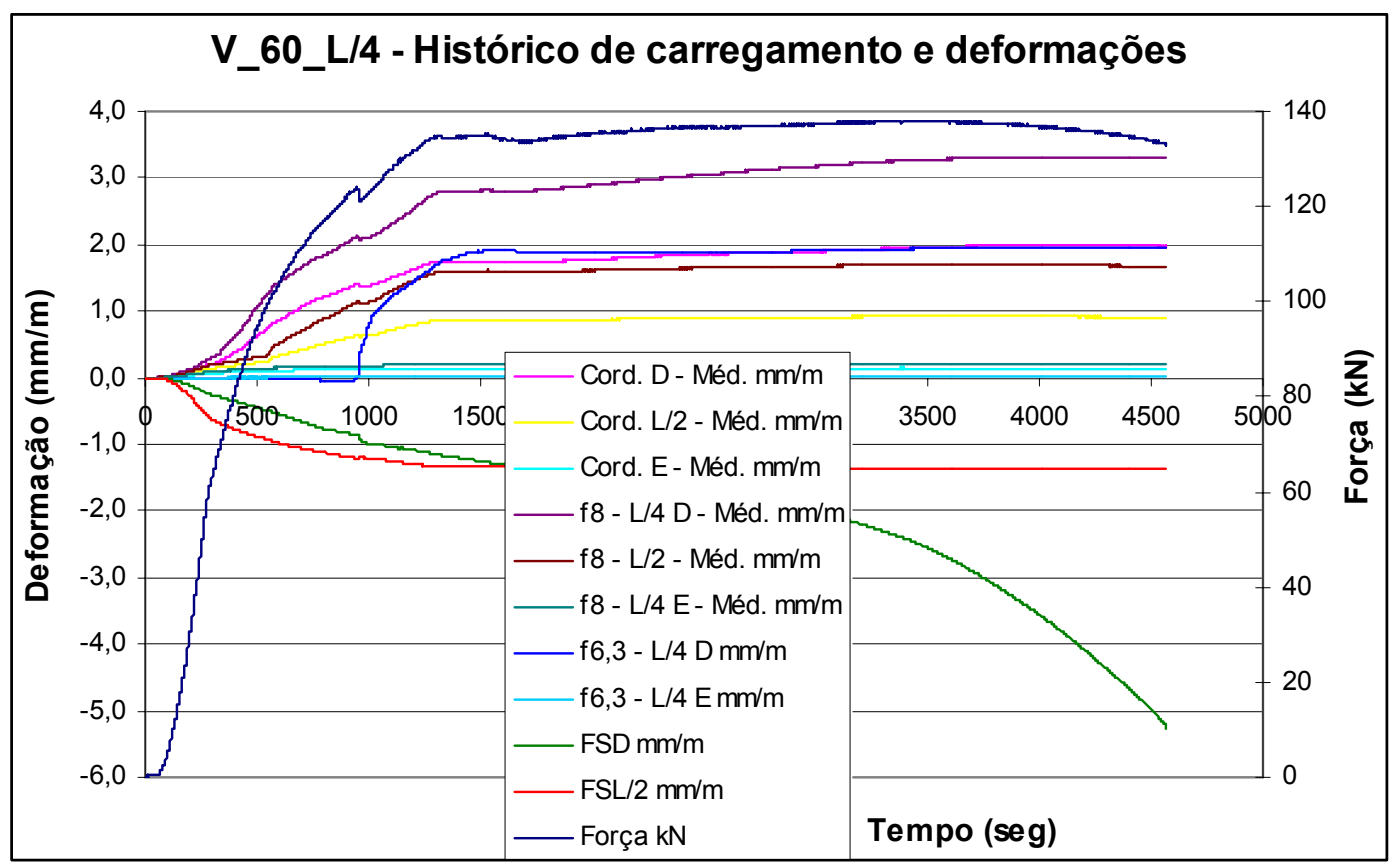

Figura 6.96 - Gráfico das deformações e forças em função do tempo, para a V_60_L/4.

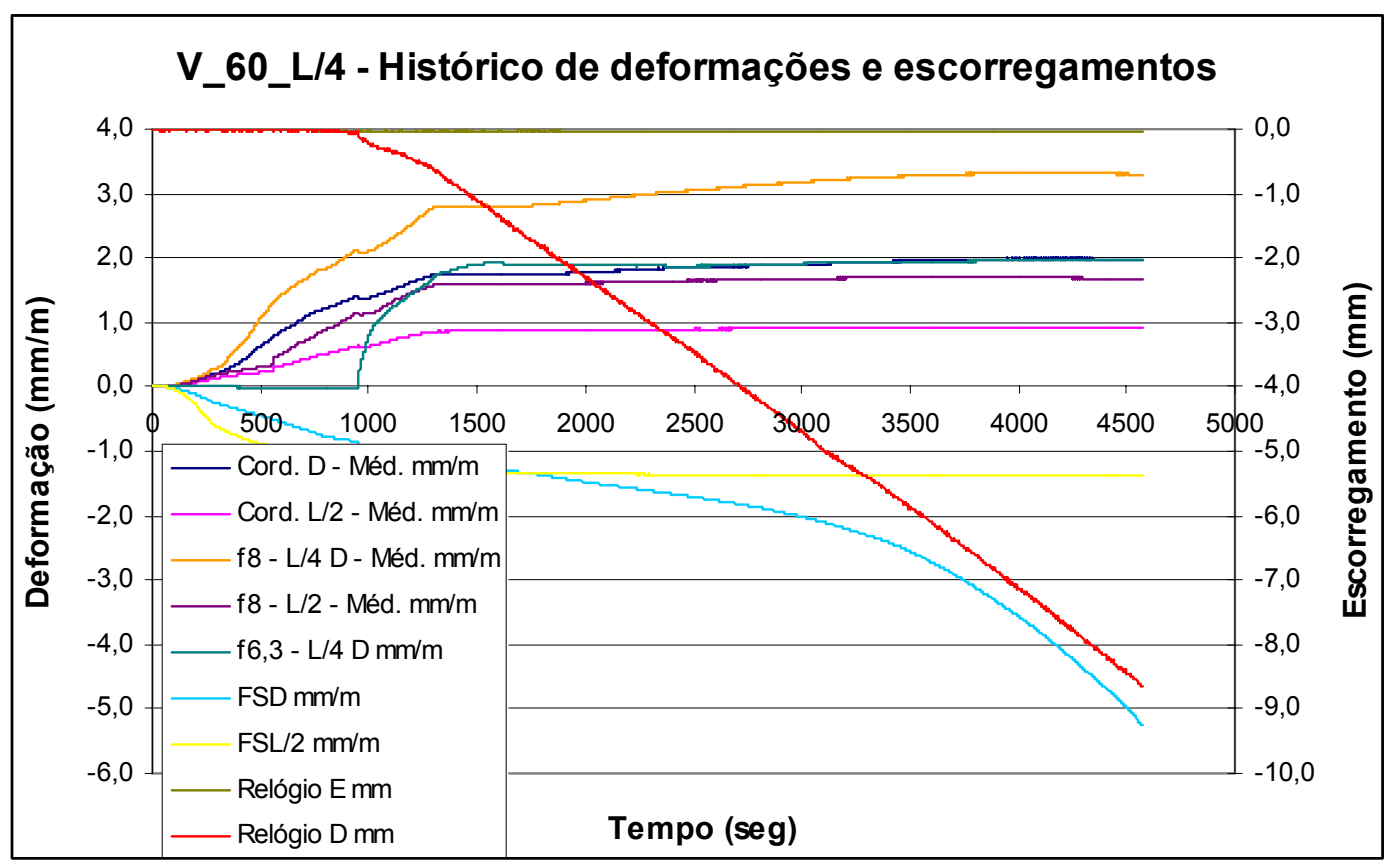

Figura 6.97 - Gráfico das deformações e escorregamentos em função do tempo, para a V_60_L/4.

\section{l) Viga V_40_L/6u}

A Figura 6.98 apresenta o esquema de ensaio da viga V_40_L/6u. A carga teórica de início da fissuração era de $P_{\text {fiss }}=99,39 \mathrm{kN}$ e a última de $P_{\text {últ }}=103,97 \mathrm{kN}$. A viga começou a fissurar com uma carga de $\mathrm{P}_{\text {fiss,ensaio }}=114 \mathrm{kN}$ e a carga máxima alcançada foi de $P_{\text {últ,ensaio }}=143,3 \mathrm{kN}$. A Figura 6.99 apresenta uma foto da fissuração da viga após o ensaio. 


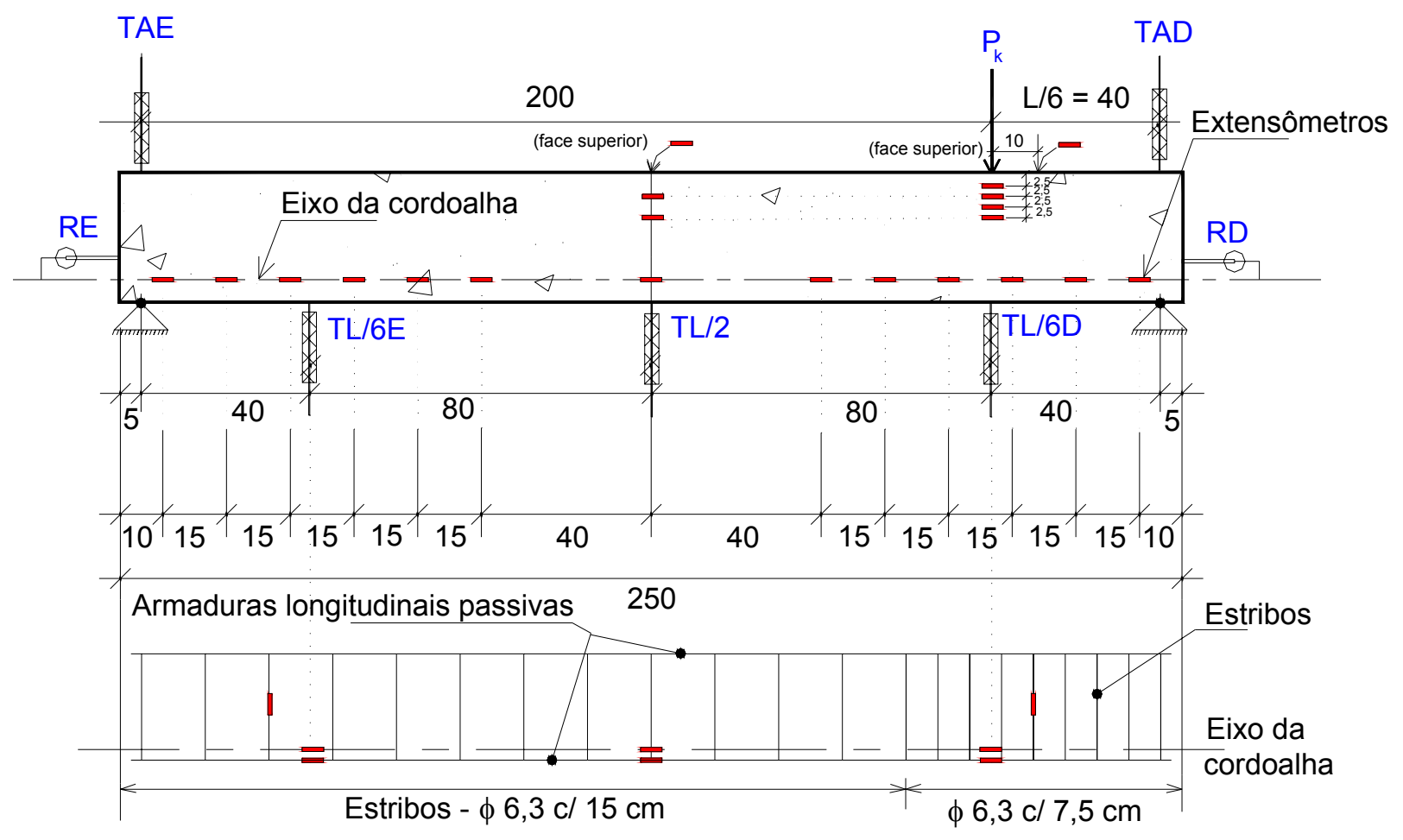

Figura 6.98 - Esquema de ensaio e instrumentação da viga V_40_L/6u.

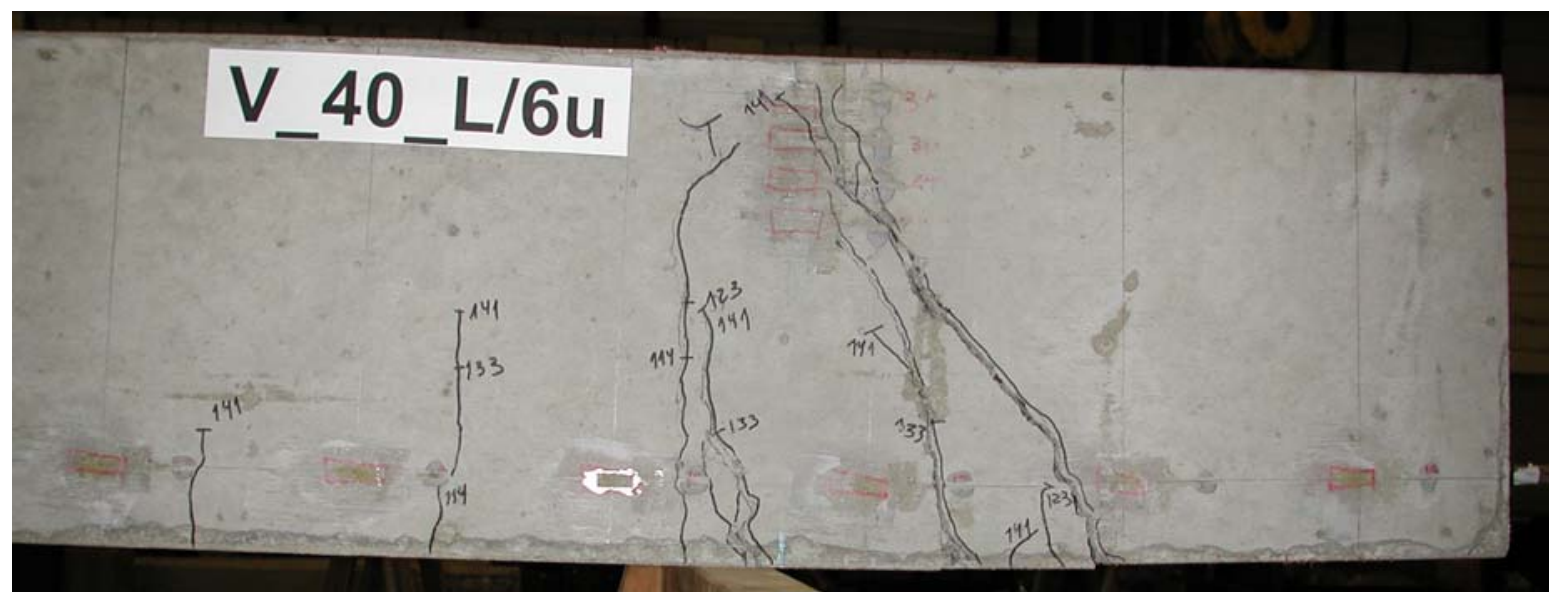

Figura 6.99 - Detalhes da fissuração da V_40_L/6u.

As Figuras 6.100 a 6.103 apresentam os gráficos representativos do ensaio.

O ensaio foi interrompido quando a carga já estava caindo e a cordoalha já apresentava um escorregamento de aproximadamente $\mathrm{S} \approx 9 \mathrm{~mm}$, no lado de introdução de carga. Não houve escoamento das armaduras, apesar das fissuras de cisalhamento, nem esmagamento do concreto. A ruptura se deu por perda de aderência por escorregamento, como indica o gráfico da Figura 103. 


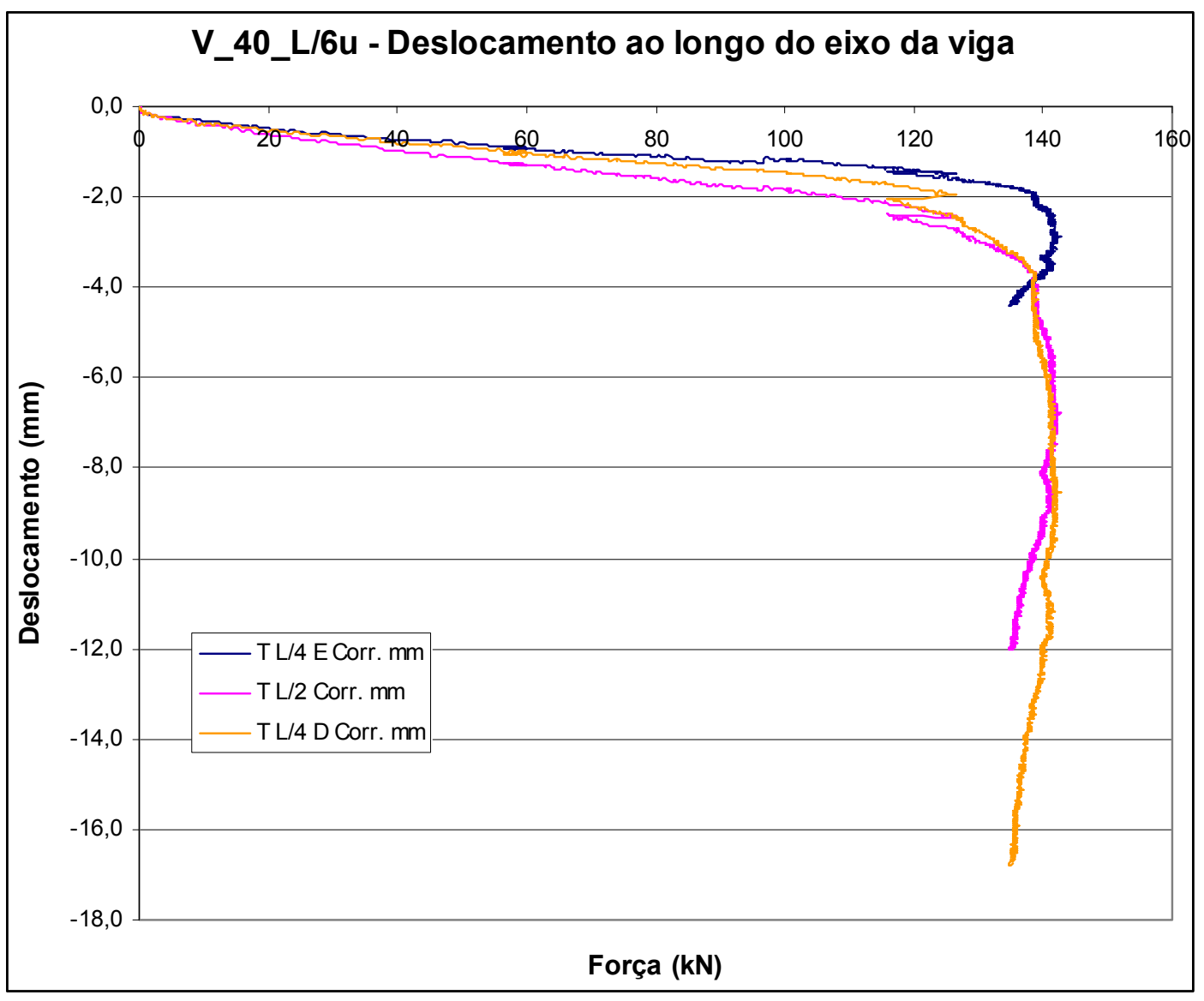

Figura 6.100 - Gráfico Força versus Deslocamento para a V_40_L/6u.

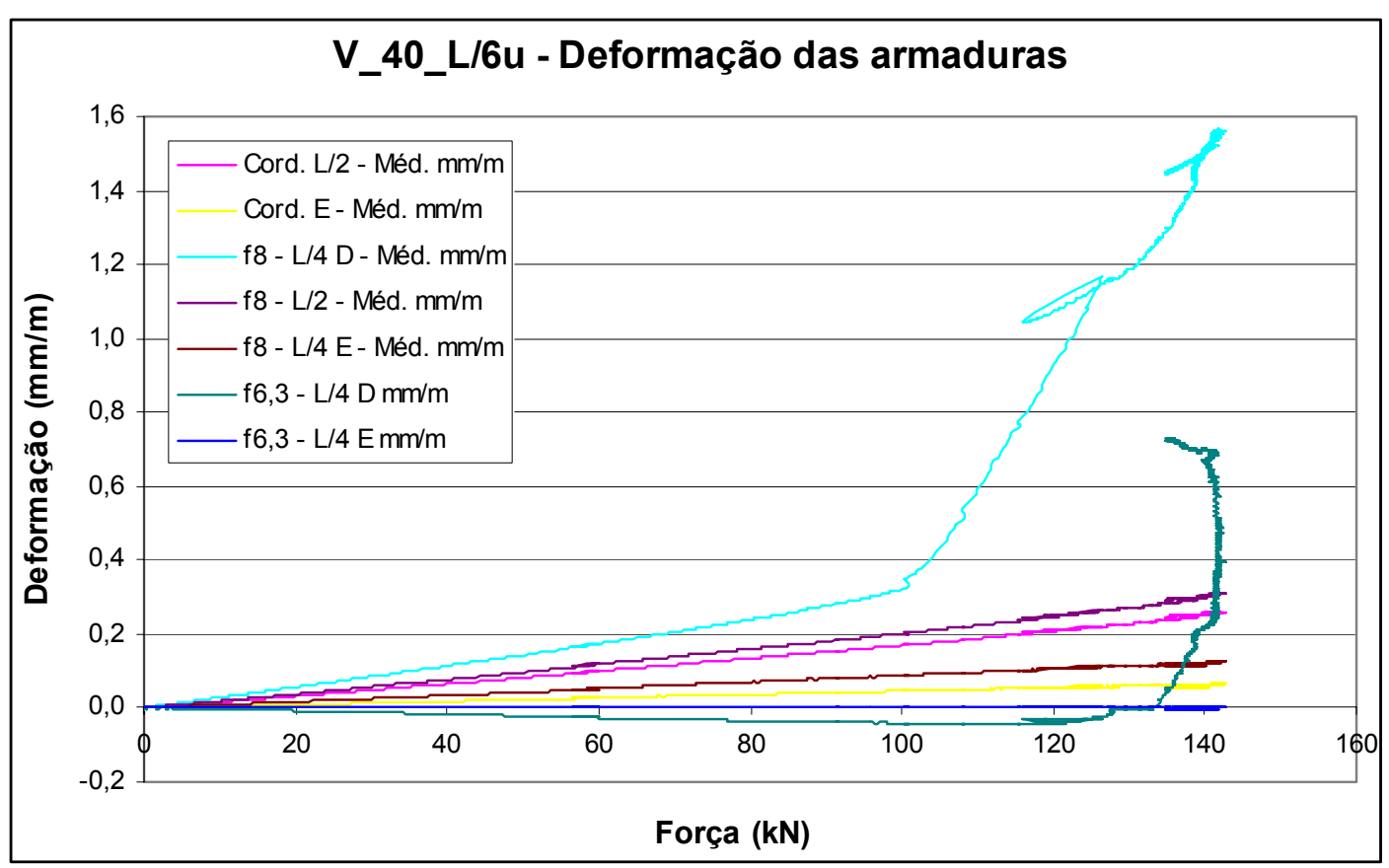

Figura 6.101 - Gráfico Força versus Deformação para a V_40_L/6u. 


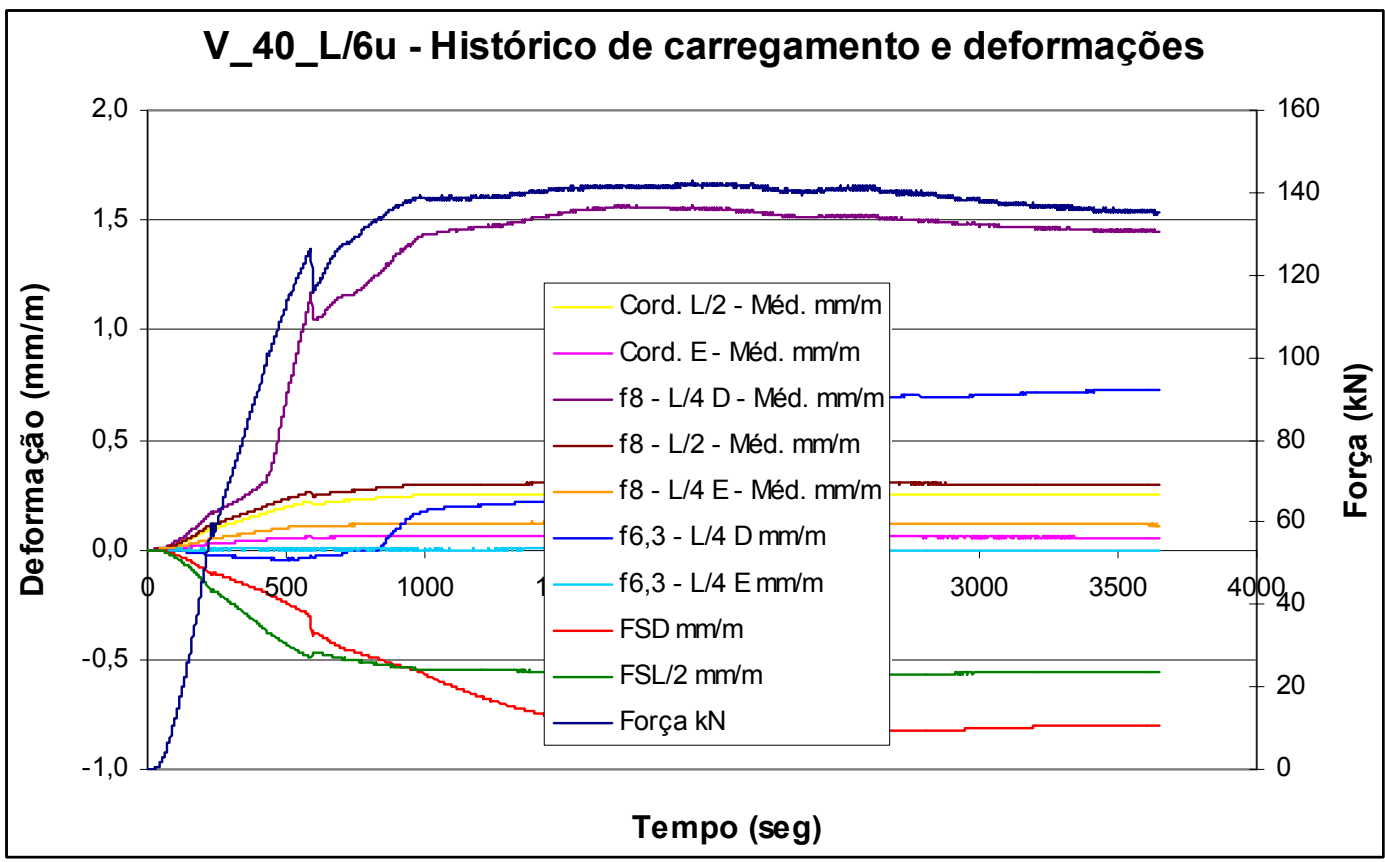

Figura 6.102 - Gráfico das deformações e forças em função do tempo, para a V_40_L/6u.

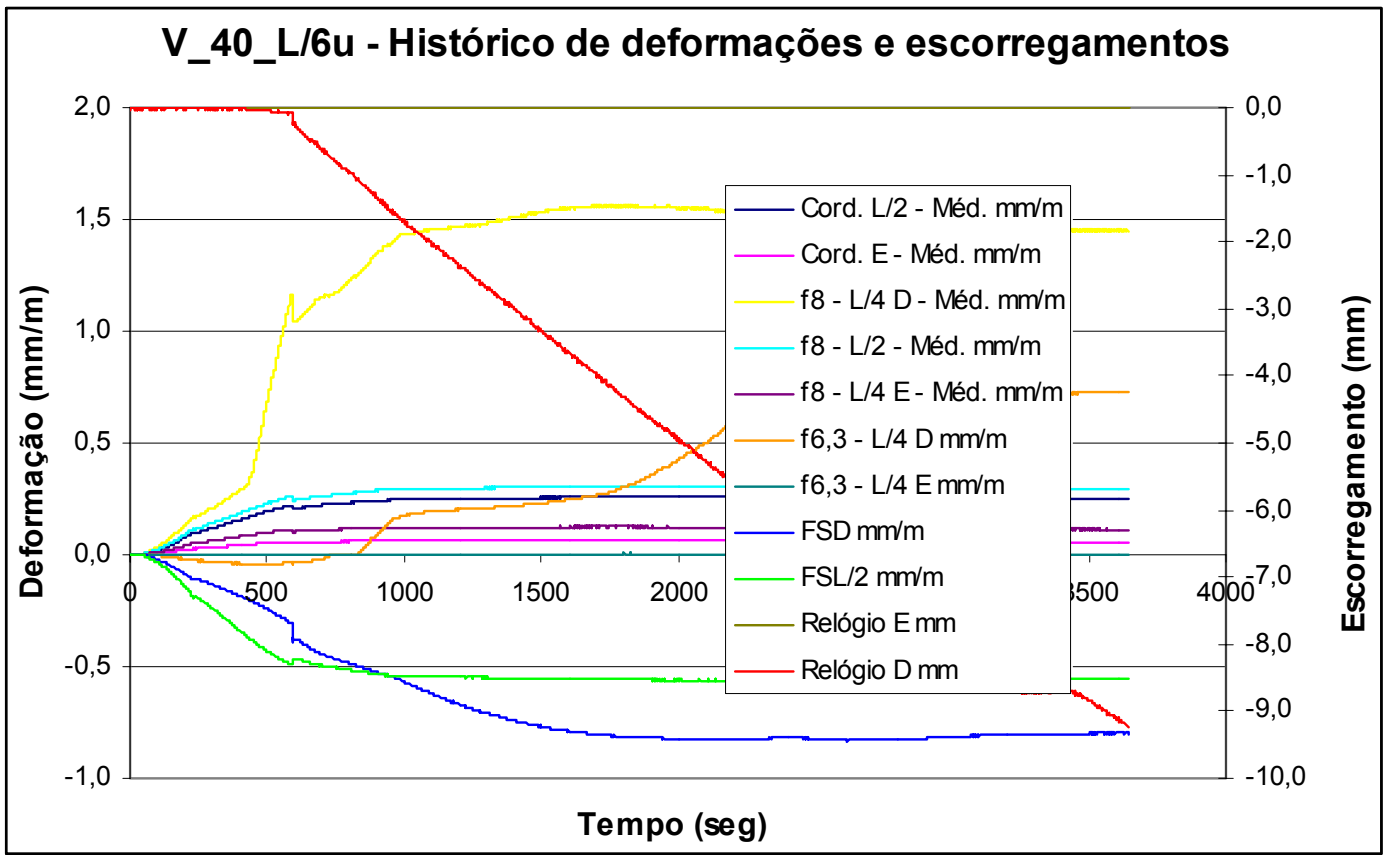

Figura 6.103 - Gráfico das deformações e escorregamentos em função do tempo, para a V_40_L/6u.

\section{m) Viga V_60_L/6u}

$\mathrm{O}$ esquema de ensaio e instrumentação foi o mesmo da viga $\mathrm{V}_{-} 40 \_\mathrm{L} / 6 \mathrm{u}$, que está apresentado na Figura 6.98.

A carga teórica de início da fissuração era de $\mathrm{P}_{\text {fiss }}=105,45 \mathrm{kN}$ e a última de $P_{\text {últ }}=103,97 \mathrm{kN}$. A viga começou a fissurar com uma carga de $P_{\text {fiss,ensaio }}=100 \mathrm{kN}$ e a carga 
máxima alcançada foi de $P_{\text {últ,ensaio }}=130,1 \mathrm{kN}$. A Figura 6.104 apresenta uma foto da fissuração da viga após o ensaio.

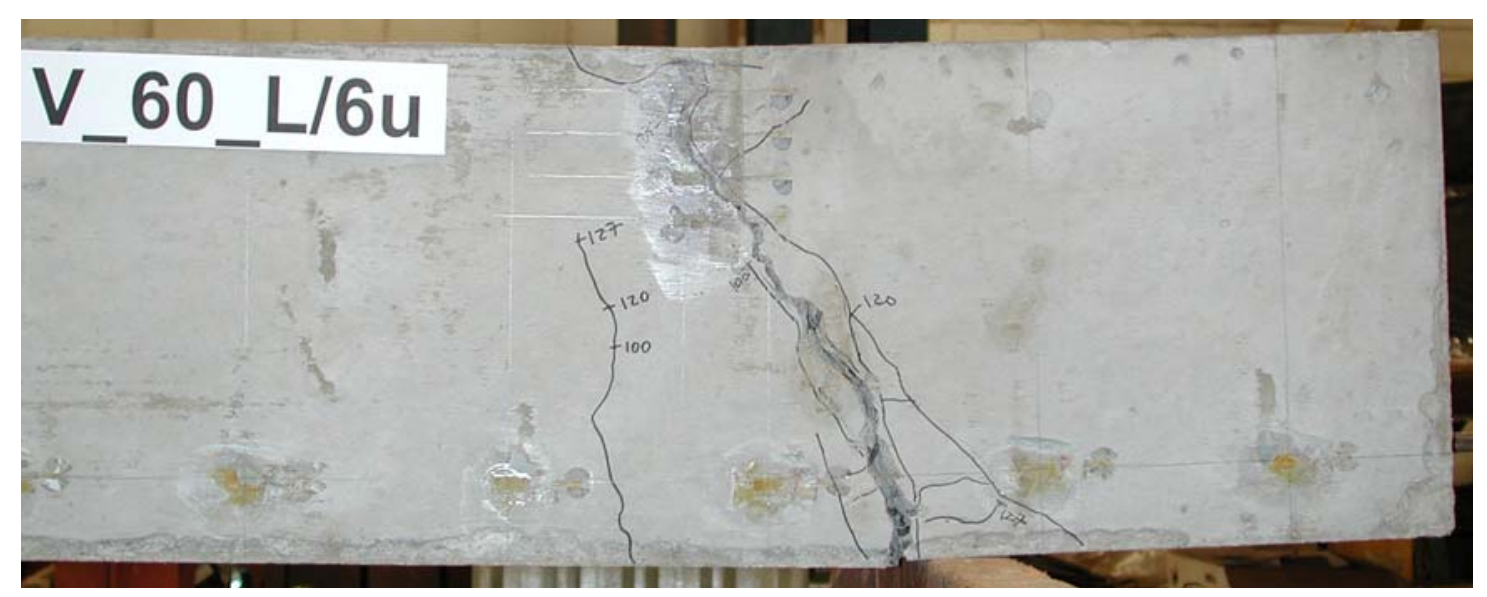

Figura 6.104 - Detalhes da fissuração da V_60_L/6u.

As Figuras 6.105 a 6.108 apresentam os gráficos representativos do ensaio.

De maneira geral, o comportamento e o modo de ruptura dessa viga foram os mesmos que para a viga V_40_L/6u.

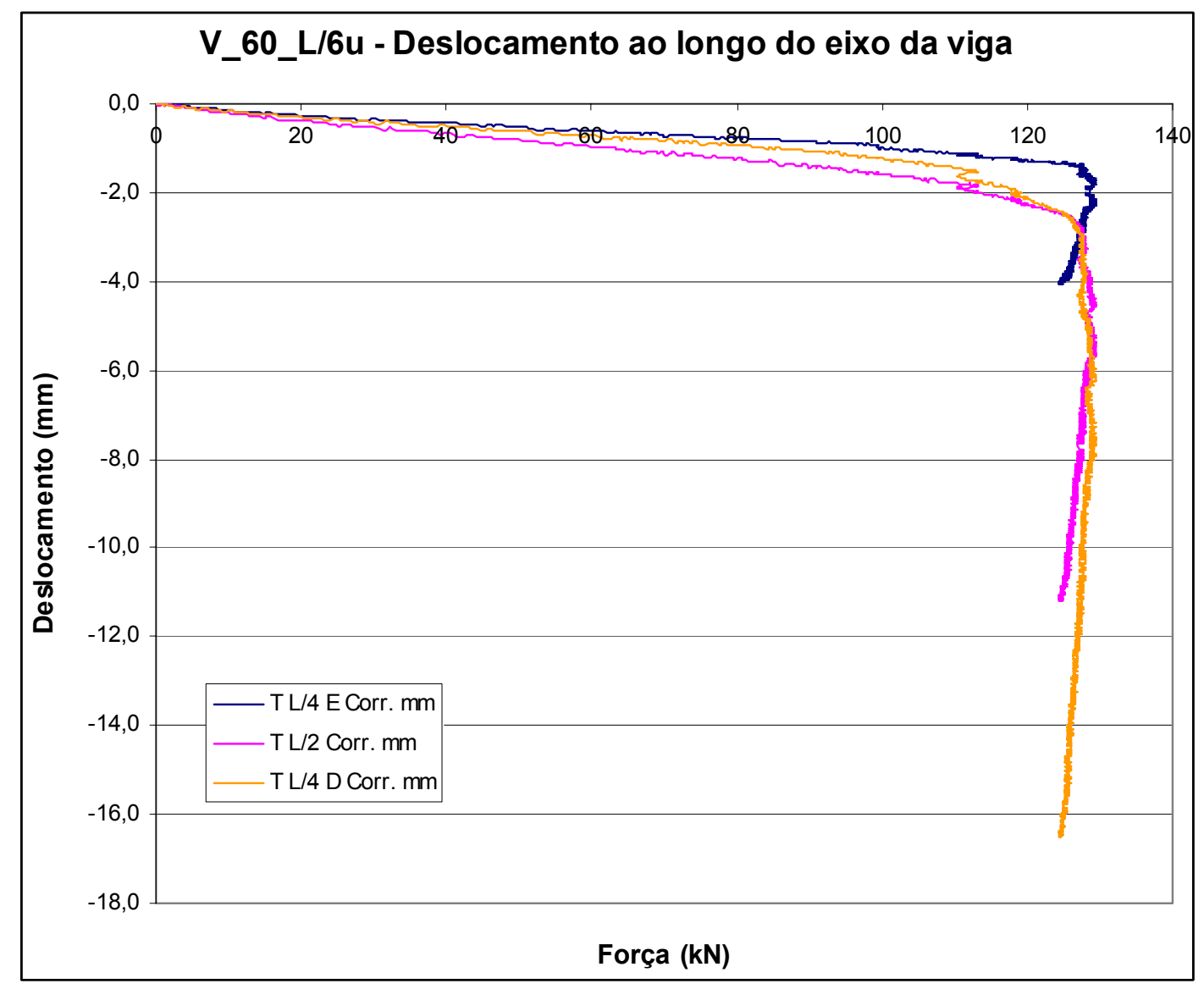

Figura 6.105 - Gráfico Força versus Deslocamento para a V_60_L/6u. 


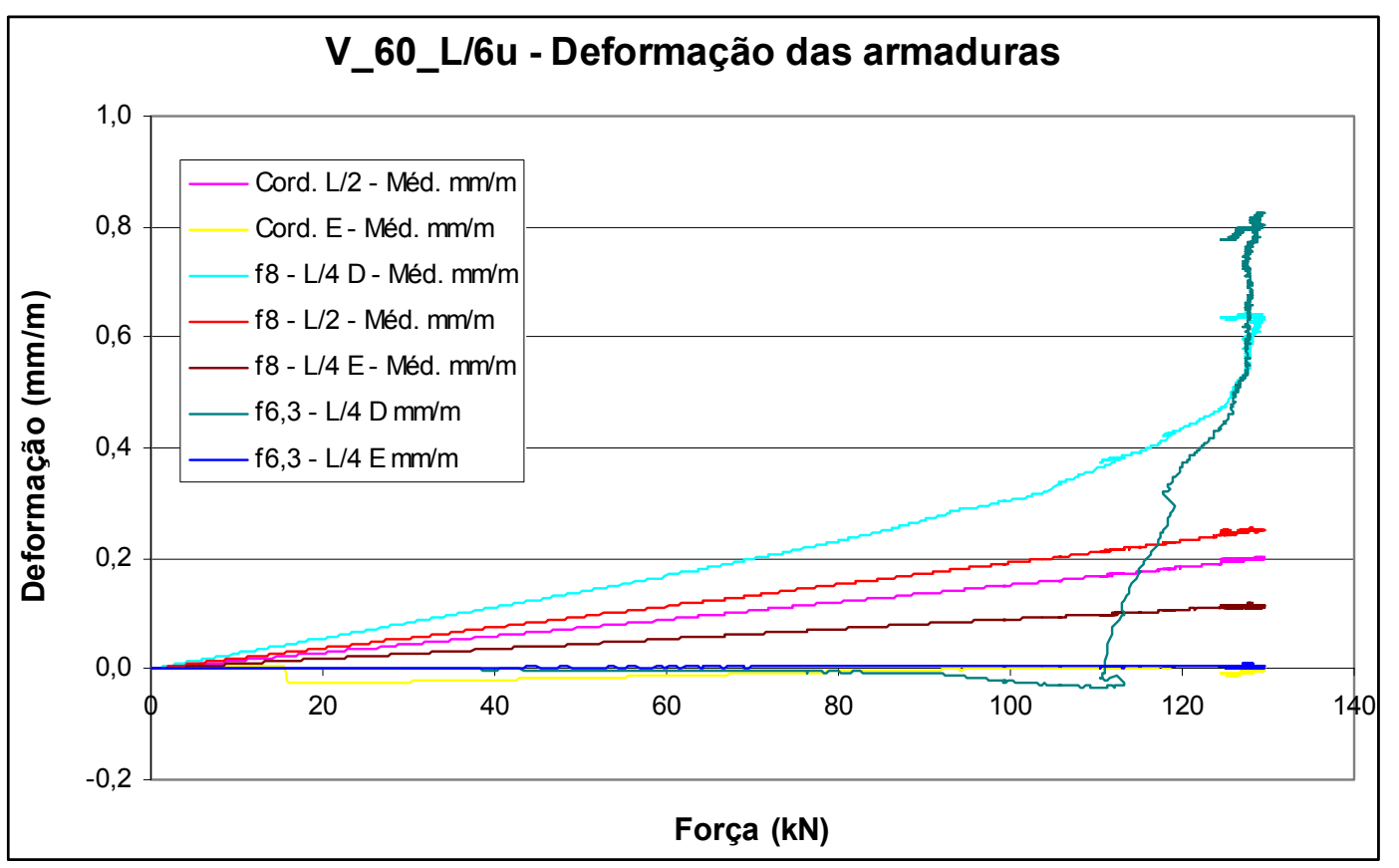

Figura 6.106 - Gráfico Força versus Deformação para a V_60_L/6u.

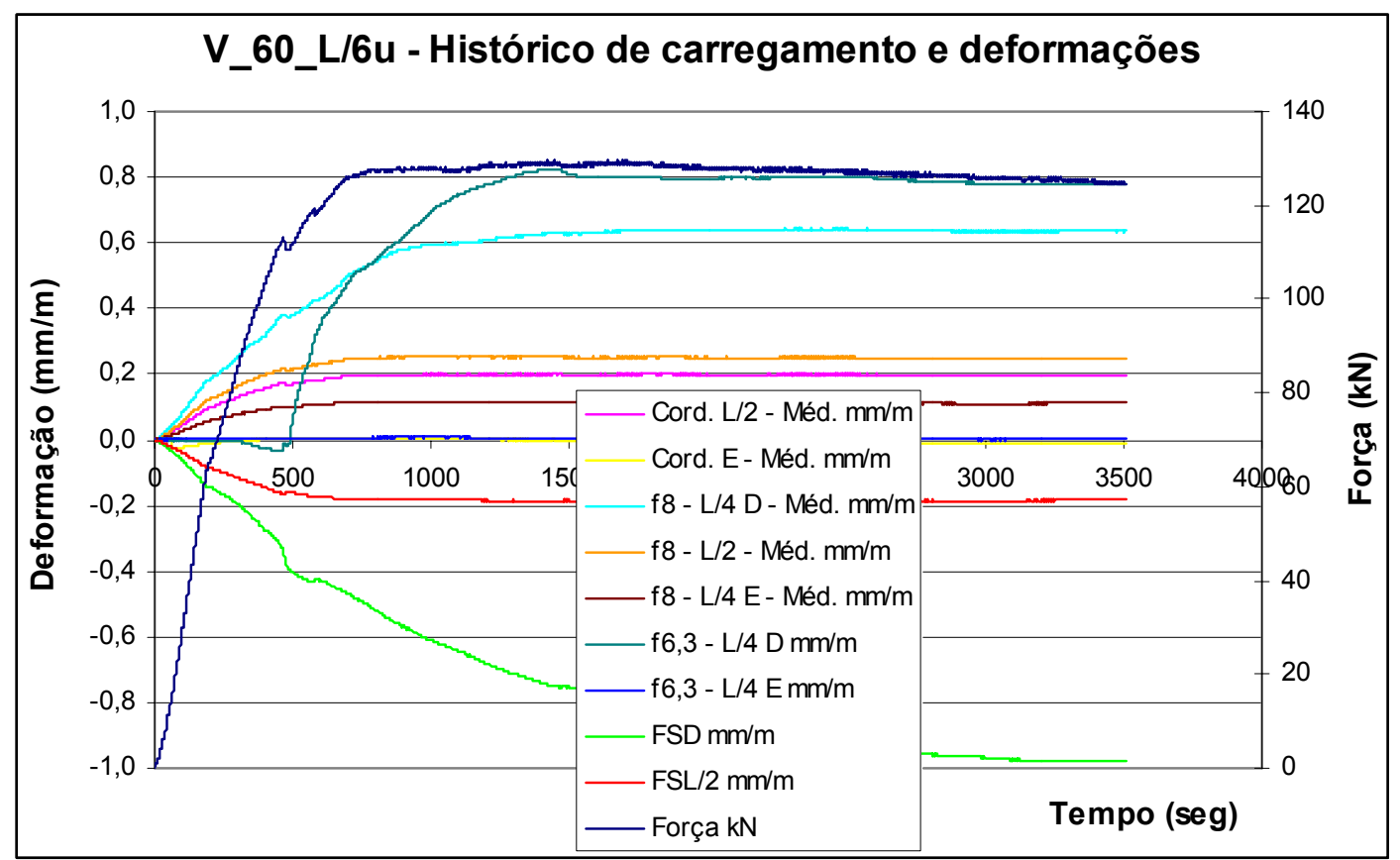

Figura 6.107 - Gráfico das deformações e forças em função do tempo, para a V_60_L/6u. 


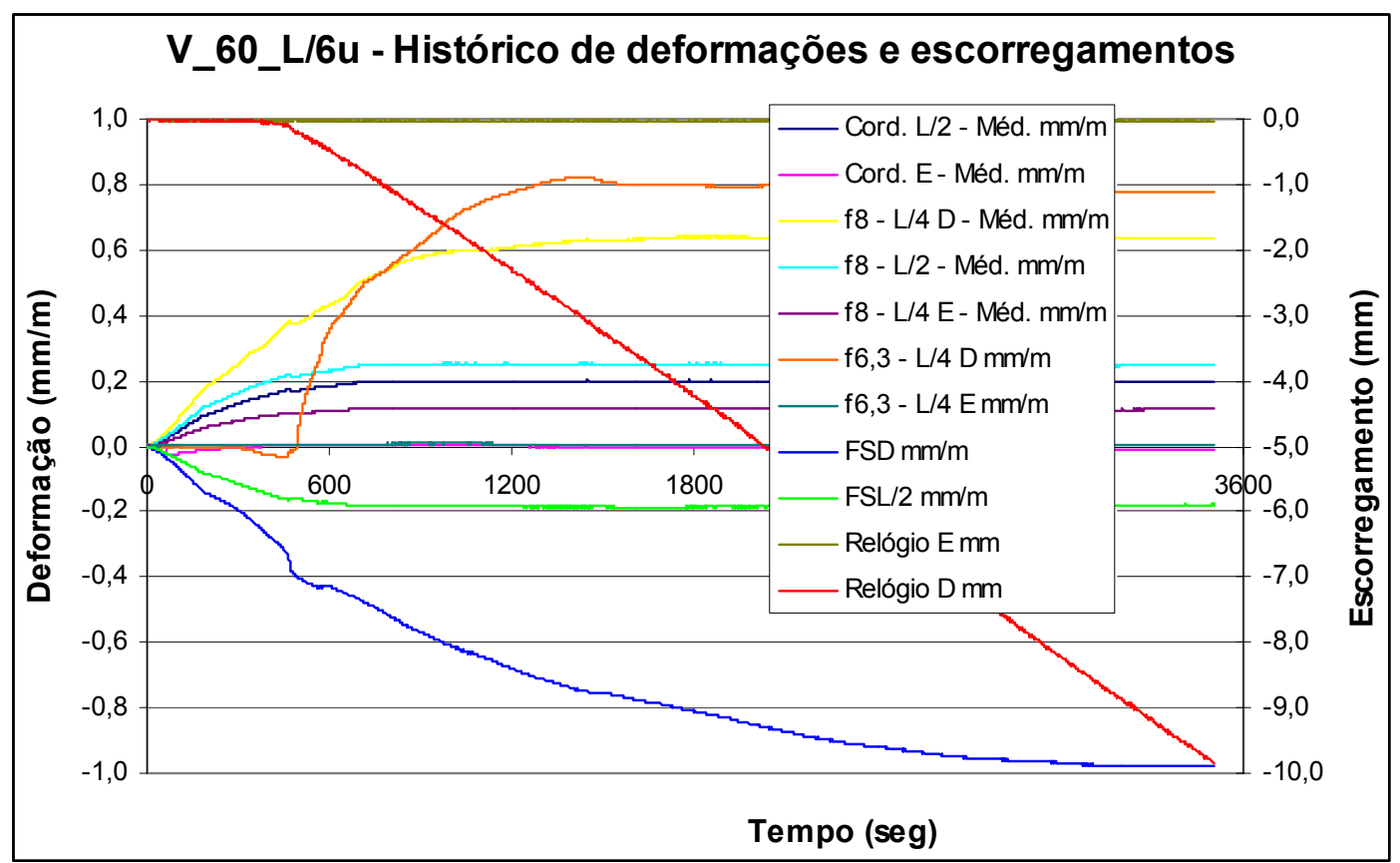

Figura 6.108 - Gráfico das deformações e escorregamentos em função do tempo, para a V_60_L/6u.

\subsubsection{Análise comparativa dos resultados experimentais}

A análise comparativa entre os grupos de vigas foi dividida em duas partes: (1) análise da fissuração dos modelos; e (2) análise do modo de ruptura.

\section{a) Análise da fissuração das vigas}

Foram feitas duas análises comparativas, uma fixando o comprimento de ancoragem e variando o volume de fibras, e outro fixando o volume de fibras e variando o comprimento de ancoragem. As Figuras 6.109 a 6.114 apresentam as comparações.

Para as vigas com $\lambda_{0}=\mathrm{L} / 3$, Figura 6.109 , percebe-se que a diferença entre os modelos está na quantidade de fissuras e no espaçamento entre elas, quanto maior o volume de fibras, maior o número de fissuras e menor o espaçamento.

Para as vigas com $\lambda_{0}=\mathrm{L} / 6$, Figura 6.110 , percebe-se que a diferença entre os modelos está, basicamente, na abertura da fissura principal de cisalhamento. Quanto maior o volume de fibras, menor a abertura da fissura.

Para as vigas com $\lambda_{0}=\mathrm{L} / 4$, Figura 6.111, percebe-se que a diferença entre os modelos está na abertura da fissura principal de cisalhamento, na quantidade de fissuras e no espaçamento entre elas. Quanto maior o consumo de fibras, menor a abertura da fissura, maior o número de fissuras e menor o espaçamento. Porém, as diferenças entre as vigas com $\mathrm{V}_{\mathrm{f}}=40 \mathrm{~kg} / \mathrm{m}^{3}$ e $\mathrm{V}_{\mathrm{f}}=60 \mathrm{~kg} / \mathrm{m}^{3}$ são muito pequenas. 


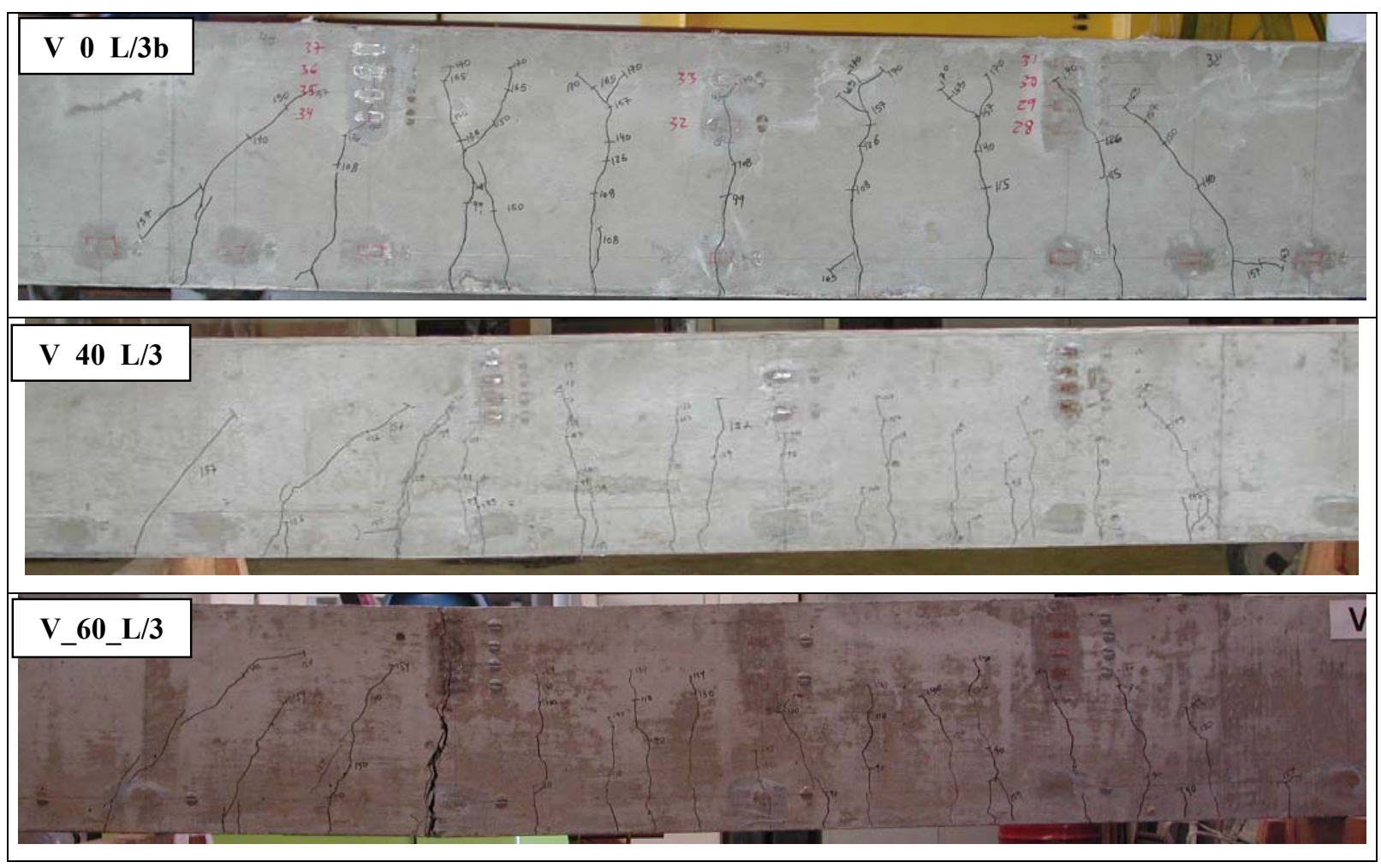

Figura 6.109 - Padrão de fissuração das vigas com comprimento de ancoragem de $\lambda_{0}=\mathrm{L} / 3$.

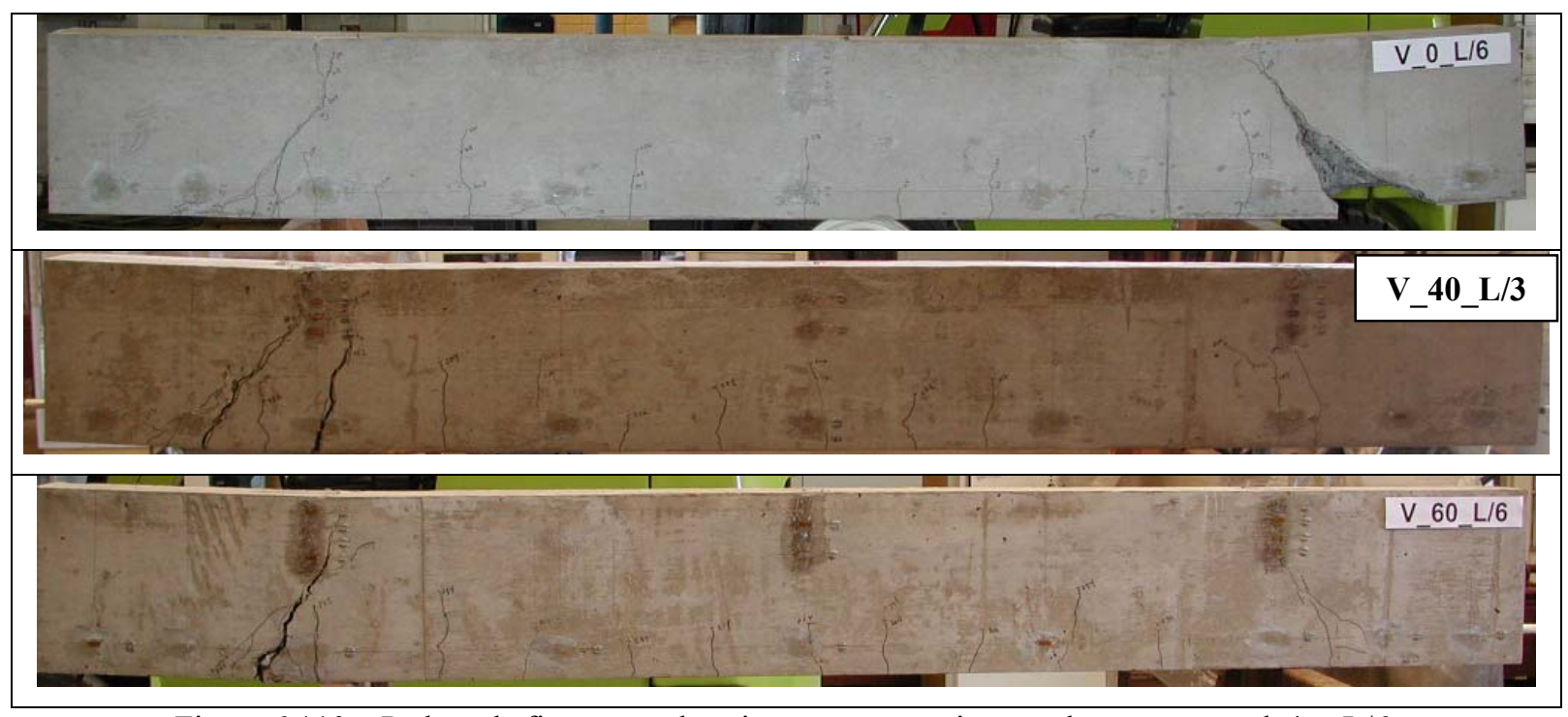

Figura 6.110 - Padrão de fissuração das vigas com comprimento de ancoragem de $\lambda_{0}=\mathrm{L} / 6$.

Para as vigas com mesmos volumes de fibras de aço, Figuras 6.112 a 6.114, percebe-se que a diferença entre os comprimentos de ancoragem é bem grande. Quanto menor o comprimento aderente, ou seja, quanto mais perto da extremidade é o ponto de aplicação de carga, menos fissuras aparecem nas peças, e essas se concentram mais próximas ao ponto de carga. 


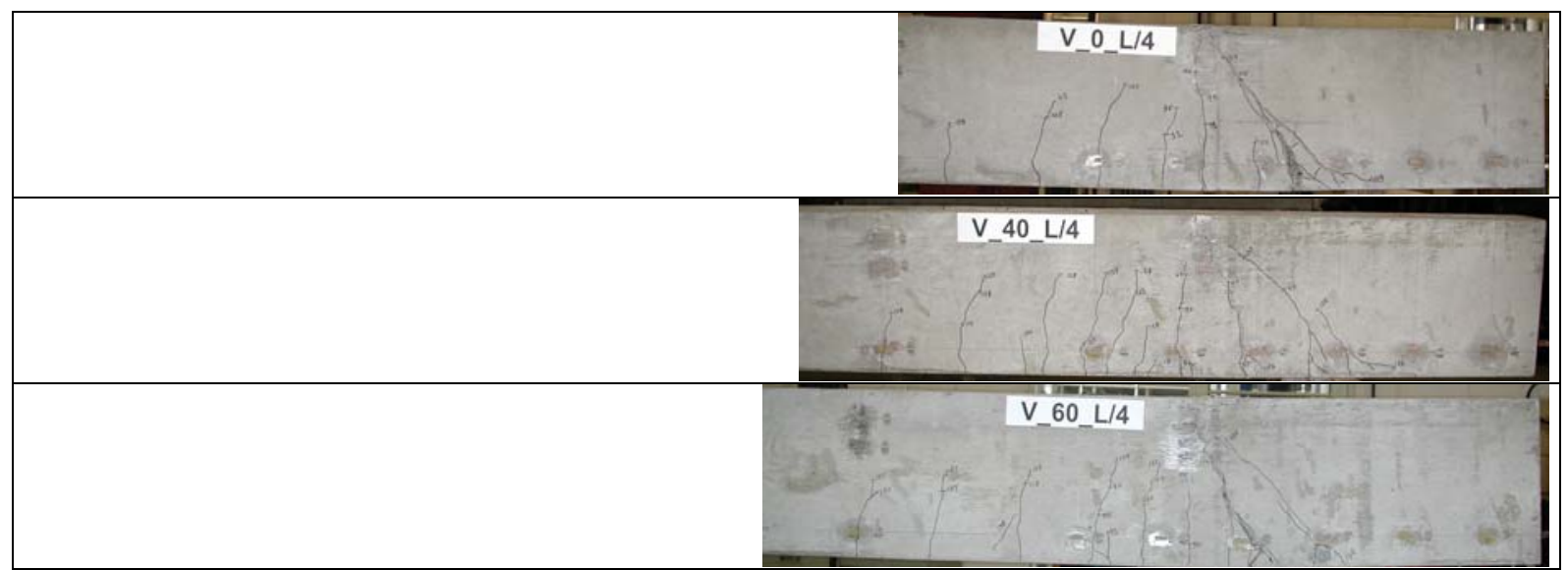

Figura 6.111 - Padrão de fissuração das vigas com comprimento de ancoragem de $\ell_{0}=\mathrm{L} / 4$.

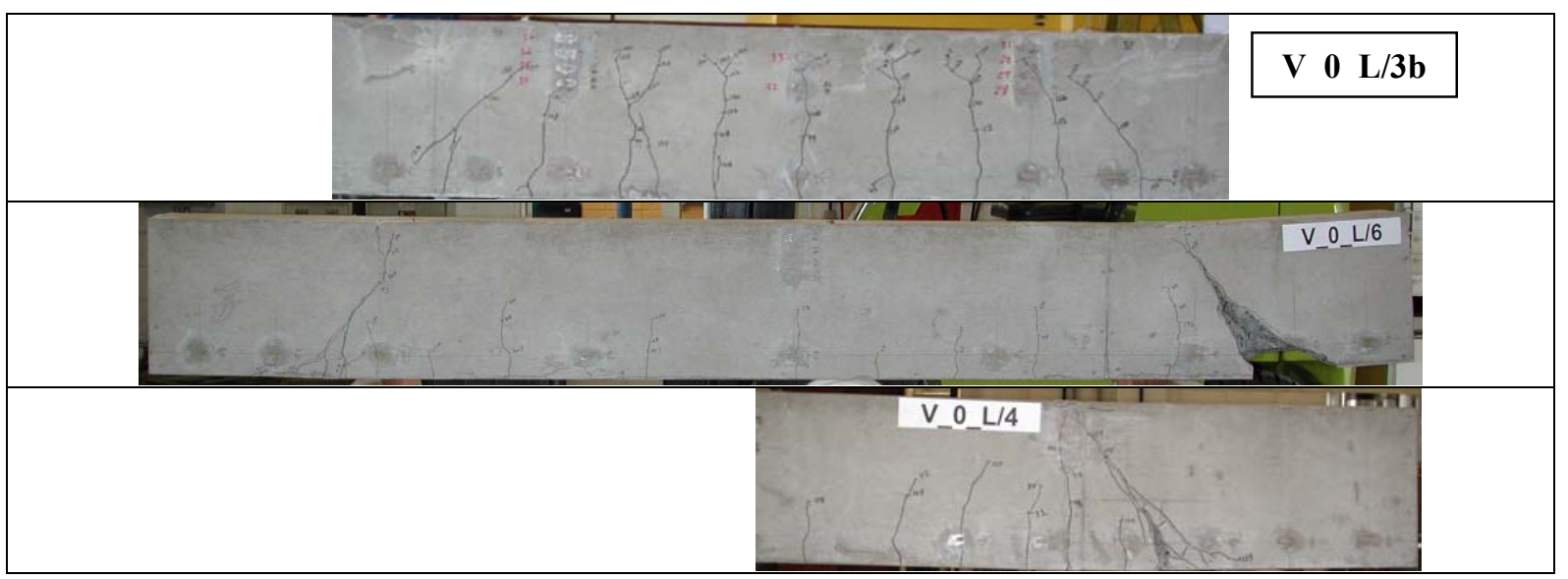

Figura 6.112 - Padrão de fissuração das vigas com consumo de fibra de $\mathrm{V}_{\mathrm{f}}=0$.

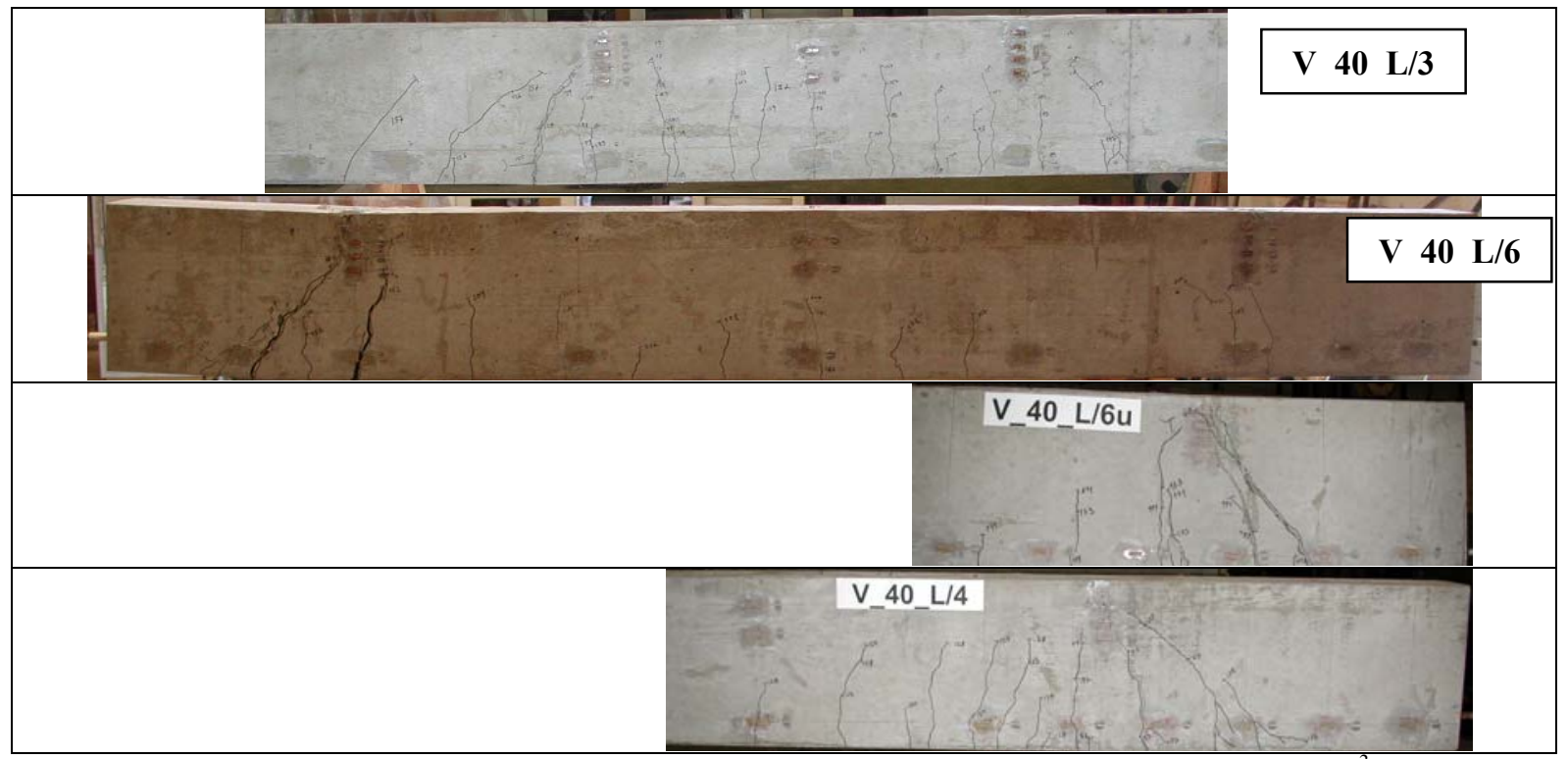

Figura 6.113 - Padrão de fissuração das vigas com consumo de fibra de $\mathrm{V}_{\mathrm{f}}=40 \mathrm{~kg} / \mathrm{m}^{3}$. 


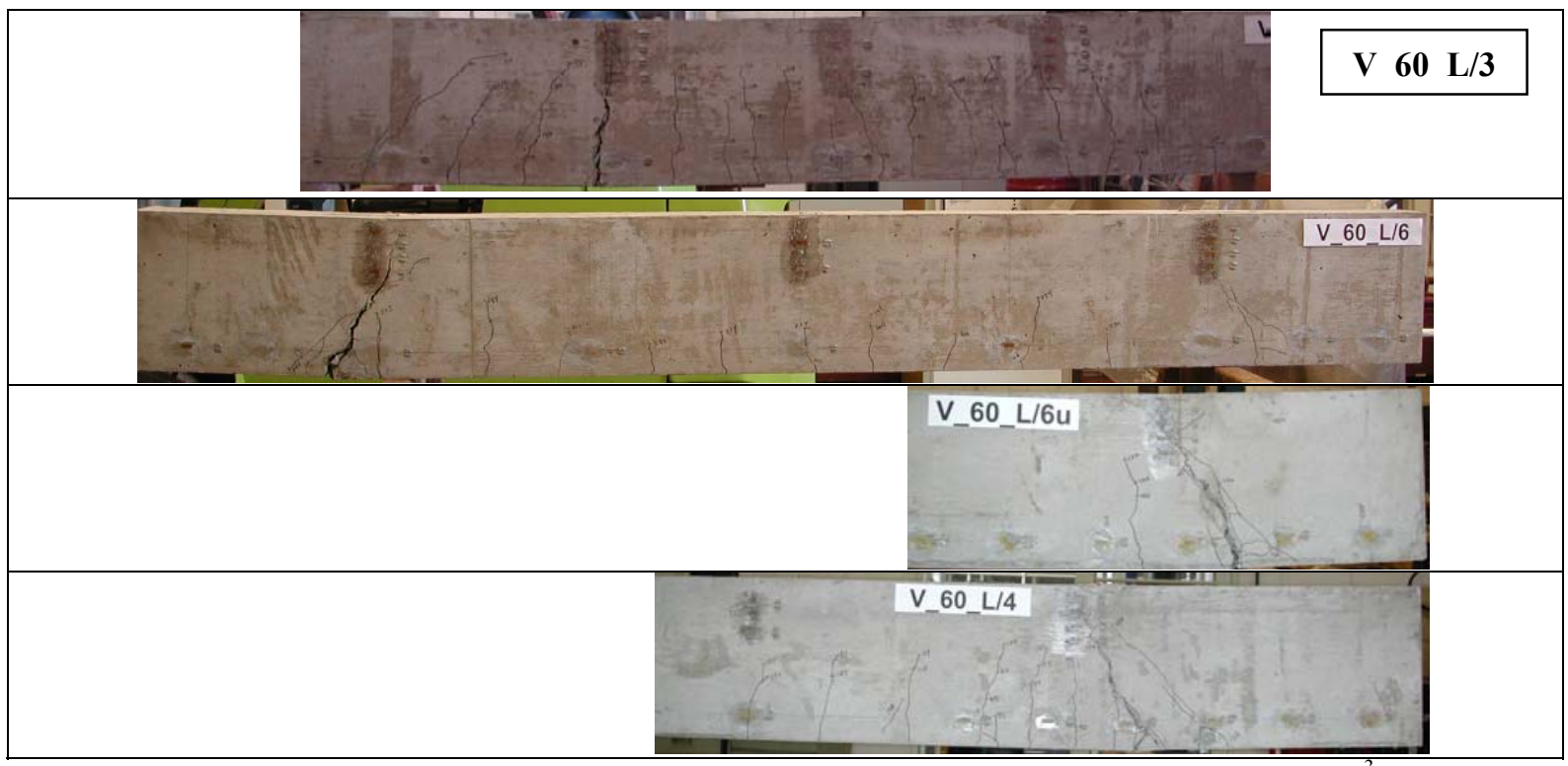

Figura 6.114 - Padrão de fissuração das vigas com consumo de fibra de $\mathrm{V}_{\mathrm{f}}=60 \mathrm{~kg} / \mathrm{m}^{3}$.

De maneira geral nota-se que o espaçamento inicial das fissuras segue o espaçamento dos estribos. À medida que a peça se aproxima da ruptura aparecem, então, fissuras menos espaçadas do que a distância entre eles.

Não há diferença no padrão de fissuração entre as vigas com duas cargas eqüidistantes e apenas uma carga a L/6 do apoio, no lado onde ocorre a ruptura. Para as vigas com apenas uma carga, as fissuras se concentram unicamente do lado carregado. Para as vigas com duas cargas, além da fissuração do lado onde ocorre a ruptura, as vigas apresentam algumas fissuras ao longo do trecho de momento constante.

\section{b) Análise do modo de ruptura}

A determinação do comprimento de ancoragem necessário das vigas se baseia na mudança do modo de ruptura das peças, como já explicado anteriormente. A Tabela 6.9 apresenta os resultados dos ensaios. Para os cálculos teóricos das cargas de fissuração foram levadas em conta as respectivas resistências do concreto à tração dos três compósitos, ou seja, adotou-se $\mathrm{f}_{\mathrm{ct}}=4,1 \mathrm{MPa}$ para $\mathrm{V}_{\mathrm{f}}=0, \mathrm{f}_{\mathrm{ct}}=4,5 \mathrm{MPa}$ para $\mathrm{V}_{\mathrm{f}}=40 \mathrm{~kg} / \mathrm{m}^{3}$, e $\mathrm{f}_{\mathrm{ct}}=5,1 \mathrm{MPa}$ para $\mathrm{V}_{\mathrm{f}}=60 \mathrm{~kg} / \mathrm{m}^{3}$. O Apêndice B apresenta os cálculos para o compósito sem fibras.

Percebe-se que para todas as vigas com $\lambda_{0}=\mathrm{L} / 6$ e $\lambda_{0}=\mathrm{L} / 4$, o modo de ruptura foi perda de aderência pelo escorregamento excessivo da cordoalha na extremidade da peça. Para algumas vigas, após o início do escorregamento excessivo, havia o esmagamento do concreto ou o escoamento de alguma armadura. Logo, o comprimento de aderência necessário para a cordoalha é superior a $\lambda_{0}=\mathrm{L} / 4=60 \mathrm{~cm}$. 
Tabela 6.9 - Resultado de ensaio e modo de ruptura das vigas.

\begin{tabular}{|c|c|c|c|c|c|c|c|c|}
\hline \multirow[b]{2}{*}{ Viga } & \multicolumn{2}{|c|}{ Valores teóricos } & \multicolumn{3}{|c|}{ Valores experimentais } & \multirow{2}{*}{$\frac{\mathbf{P}_{\text {fiss }}}{\mathbf{P}_{\text {fiss,ens }}}$} & \multirow{2}{*}{$\frac{\mathbf{P}_{\text {máx }}}{\mathbf{P}_{\text {máx,ens }}}$} & \multirow{2}{*}{$\begin{array}{l}\text { Modo de } \\
\text { ruptura }\end{array}$} \\
\hline & $\begin{array}{l}P_{\text {fiss }} \\
(k N)\end{array}$ & $\begin{array}{l}P_{\text {máx }} \\
(k N)\end{array}$ & $\begin{array}{c}P_{\text {fiss,ens }} \\
(\mathrm{kN})\end{array}$ & $\begin{array}{c}P_{\text {máx,ens }} \\
(\mathrm{kN})\end{array}$ & $\frac{\mathbf{P}_{\text {fiss,ens }}}{\mathbf{P}_{\text {máx,ens }}}$ & & & \\
\hline $\bar{V}{ }_{-} 0 \_L / 3$ & 78,83 & 85,30 & --- & --- & --- & --- & --- & --- \\
\hline V_0_L/6 & 157,65 & 172,10 & 193,00 & 240,00 & 0,80 & 0,82 & 0,72 & Aderência \\
\hline V_40_L/3 & 82,20 & 85,30 & 89,00 & 157,00 & 0,57 & 0,92 & 0,54 & Flexão \\
\hline V_40_L/6 & 164,41 & 172,10 & 182,00 & 231,87 & 0,78 & 0,90 & 0,74 & Aderência \\
\hline V_60_L/3 & 87,27 & 85,30 & 90,00 & 155,40 & 0,58 & 0,97 & 0,55 & Ader./ Flex. \\
\hline V_60_L/6 & 174,53 & 172,10 & 190,00 & 241,54 & 0,79 & 0,92 & 0,71 & Aderência \\
\hline V_0_L/3b & 78,83 & 85,30 & 95,00 & 171,64 & 0,55 & 0,83 & 0,50 & Flexão \\
\hline V_0_L/4 & 70,29 & 76,69 & 91,00 & 141,07 & 0,65 & 0,77 & 0,54 & Aderência \\
\hline V_40_L/4 & 73,29 & 76,69 & 82,00 & 137,94 & 0,59 & 0,89 & 0,56 & Aderência \\
\hline V_60_L/4 & 77,80 & 76,69 & 90,00 & 138,70 & 0,65 & 0,86 & 0,55 & Aderência \\
\hline V_40_L/6u & 99,39 & 103,97 & 114,00 & 143,30 & 0,80 & 0,87 & 0,73 & Aderência \\
\hline V_60_L/6u & 105,45 & 103,97 & 100,00 & 130,10 & 0,77 & 1,05 & 0,80 & Aderência \\
\hline
\end{tabular}

Para as vigas com $\lambda_{0}=\mathrm{L} / 3$ o modo de ruptura foi por flexão. Em nenhuma das três houve escoamento da armadura transversal. Para as três houve esmagamento do concreto. Para as peças com $\mathrm{V}_{\mathrm{f}}=0$ e $\mathrm{V}_{\mathrm{f}}=40 \mathrm{~kg} / \mathrm{m}^{3}$ não houve escorregamento significativo da cordoalha, e houve o escoamento tanto da cordoalha como da armadura longitudinal passiva. Para a viga com $\mathrm{V}_{\mathrm{f}}=60 \mathrm{~kg} / \mathrm{m}^{3}$, quando começou o esmagamento do concreto, ocorreu o escorregamento da cordoalha, que por sua vez não chegou ao escoamento. Isso pode ter acontecido devido à presença das fibras de aço, que ajudam na resistência à tração. Logo, o comprimento de ancoragem necessário é entre $80 \mathrm{~cm}$ e $60 \mathrm{~cm}$, independentemente do volume de fibra de aço.

Pela Tabela 6.9 percebe-se, também, que para um mesmo arranjo de ensaio não há diferença significativa entre as cargas máximas para os três volumes de fibras de aço utilizados.

\subsubsection{Confrontação dos resultados teóricos e experimentais}

De maneira geral, ainda pela Tabela 6.9, quanto menor o comprimento aderente $\left(\lambda_{0}\right)$, maior a razão entre a carga para a primeira fissura e a carga máxima e menos dúctil é a ruptura. A razão entre a carga para a primeira fissura teórica e a de ensaio ficou em torno de 
90\%. A razão entre a carga máxima teórica e a de ensaio ficou em torno de 70\%. Isso indica que o dimensionamento teórico está a favor da segurança, como é de se esperar.

Após a análise dos resultados experimentais, obtiveram-se os valores representativos para o comprimento de ancoragem necessário para os parâmetros de ensaio utilizados. A Tabela 6.10 apresenta a comparação dos valores experimentais com os valores teóricos descritos no Capítulo 3.

Tabela 6.10 - Valores experimentais e teóricos para os comprimentos de ancoragem necessários (comprimentos em $\mathrm{m})$.

\begin{tabular}{|c|c|c|c|}
\hline Fonte & $V_{f}\left(\mathbf{k g} / \mathbf{m}^{3}\right)$ & $\begin{array}{c}\text { Comprimento de } \\
\text { ancoragem necessário, } \\
\lambda_{\text {bpd }}\end{array}$ & $\frac{\ell_{\mathrm{bpd}, \mathrm{i}}}{\ell_{\mathrm{bpd}, \mathrm{FIB}}}$ \\
\hline \multirow{3}{*}{ Experimental } & 0 & \multirow{3}{*}{$0,60 \leq \lambda_{\text {bpd }} \leq 0,80$} & \multirow{3}{*}{$0,52 \leq \frac{\ell_{\mathrm{bpd}, \mathrm{i}}}{\ell_{\mathrm{bpd}, \mathrm{FIB}}} \leq 0,69$} \\
\hline & 40 & & \\
\hline & 60 & & \\
\hline ZIA \& MOSTAFA (1977) & \multirow{3}{*}{0} & 2,06 & 1,78 \\
\hline COUSINS et al (1990c) & & 2,81 & 2,42 \\
\hline DEATHERAGE et al (1994) & & 2,64 & 2,28 \\
\hline FIB Bulletin 1 (1999) & \multirow{2}{*}{0} & 1,16 & 1,00 \\
\hline ACI 318 (2002) & & 1,89 & 1,63 \\
\hline
\end{tabular}

Percebe-se que os valores encontrados nesta pesquisa foram bem menores que os de outros pesquisadores. Foram, também, menores que os valores sugeridos pelas prescrições normativas, o que indica que fornecem uma boa margem de segurança, o que é de se esperar. Assim como para os comprimentos de transferência, há uma grande variação nos valores de ensaios relatados por diferentes pesquisadores para os comprimentos de ancoragem necessário. Realmente, essa é uma área que ainda merece bastante estudo.

Baseando-se nesses resultados, a presença de fibras em baixos teores não influencia na no comprimento de ancoragem necessário. Ela tem influência no comportamento da peça à flexão, aumentando a ductilidade das vigas e ajudando na resistência à tração, principalmente quando as peças se aproximam de estados limites últimos. Isso confirma as conclusões de vários outros pesquisadores. 


\subsection{Conclusões}

\subsubsection{Comprimento de transferência}

As principais conclusões para os comprimentos de transferência são:

- As fibras utilizadas em baixos teores não influem no comprimento de transferência das peças;

- Os valores das prescrições normativas, para concretos de alta resistência, estão a favor da segurança em comparação com os valores desta pesquisa;

- A qualidade do concreto, e não apenas a sua resistência à compressão, influi no comprimento de transferência das peças;

- Para a medição da penetração da cordoalha no concreto, é muito importante estabelecer valores mínimos para a rigidez do sistema de sustentação da protensão, para que ele não influa nos resultados;

- A medição das deformações por extensômetros elétricos colocados sobre a face externa das peças, no concreto, mostrou-se uma excelente opção. A colocação de extensômetros na armadura influi no comprimento de transferência, e a medição com o TENSOTAST, principalmente o de leitura analógica e manual, depende muito de fatores externos como a temperatura das peças e do ambiente, e a destreza, experiência e humor do pesquisador que está fazendo a leitura. Isso pode levar a resultados duvidosos. Por esses motivos, eliminaram-se as leituras com o TENSOTAST para esta pesquisa, já que os resultados obtidos não foram confiáveis;

- Para o estudo, apenas, do comprimento de transferência, a utilização de modelos prismáticos, de preferência com seção transversal quadrada, com a armadura centrada deve fornecer resultados mais uniformes, já que apresentam tensão e deformação constantes ao longo de toda a seção, além de serem de execução mais simples, pois se pode eliminar as armaduras passivas.

\subsubsection{Comprimento de ancoragem necessário}

As principais conclusões para os comprimentos de ancoragem necessários são:

- As fibras utilizadas em baixos teores não influem no comprimento de ancoragem necessário das peças;

- Os valores das prescrições normativas, para concretos de alta resistência, estão a favor da segurança em comparação com os valores desta pesquisa; 
- A instrumentação utilizada mostrou-se adequada para determinar o modo de ruptura das peças, e verificar o comprimento de ancoragem;

- Para os comprimentos aderentes de L/4 e L/6, o ensaio com apenas uma carga deslocada para a extremidade mostrou-se mais eficiente do que o com duas cargas eqüidistantes, já que não enrijecia muito o sistema e levava menos tempo.

\subsubsection{Gerais}

São três, as principais conclusões advindas destes ensaios:

- As fibras, utilizadas em baixos teores, não influenciam na aderência de peças de concreto de alta resistência;

- Os valores das prescrições normativas para a aderência, para concretos de alta resistência, estão a favor da segurança em comparação com os valores desta pesquisa;

- A qualidade do concreto tem uma importância muito grande na aderência das peças. Por qualidade entende-se não só a resistência do concreto à compressão, mas também suas propriedades em relação à trabalhabilidade no estado fresco, porosidade e quantidade de aditivos, entre outras. 


\section{CONSIDERAÇÕES FINAIS}

Este capítulo apresenta as conclusões do trabalho e algumas sugestões para pesquisas futuras, que podem tanto complementar este estudo, como se constituírem em trabalhos isolados.

\subsection{Conclusões Principais}

As principais conclusões resultantes desta pesquisa são:

- As fibras, nos volumes utilizados, não influíram na tensão de aderência relativa à primeira fissura, ou seja, a presença das fibras de aço não influiu na fissuração inicial dos modelos, nem para os ensaios de arrancamento, nem para os de flexão;

- Os modelos com $\mathrm{V}_{\mathrm{f}}=40 \mathrm{~kg} / \mathrm{m}^{3}$ não apresentaram ganho de aderência em comparação com os compósitos sem fibras, nem para os ensaios de arrancamento, na determinação da tensão máxima de aderência, nem para os de flexão, na determinação dos comprimentos de transferência e de ancoragem necessário;

- Nos ensaios de arrancamento, os modelos com $\mathrm{V}_{\mathrm{f}}=60 \mathrm{~kg} / \mathrm{m}^{3}$ apresentaram um aumento significativo, de aproximadamente $28 \%$, para a tensão máxima de aderência, em comparação com os compósitos sem fibras;

- Nos ensaios de flexão, os modelos com $\mathrm{V}_{\mathrm{f}}=60 \mathrm{~kg} / \mathrm{m}^{3}$ não apresentaram um aumento significativo na determinação dos comprimentos de transferência e de ancoragem necessário, em comparação com os compósitos sem fibras; 
- O comportamento aderente das cordoalhas de sete fios, em ensaios de arrancamento com a armadura não-protendida, não se enquadra nem nos modelos analíticos para barras nervuradas nem nos para fios lisos;

- Para o CAR, as tensões de aderência fornecidas pelas prescrições normativas avaliadas são bem inferiores às experimentais, assim como os comprimentos de ancoragem, indicando que o cálculo está a favor da segurança;

- Não se deve usar modelos pré-tracionados para ensaios de arrancamento com comprimento de ancoragem inferior ao comprimento de transferência; quando isso ocorre, há uma diminuição da aderência;

- O modo de ruptura das cordoalhas de sete fios é por arrancamento da armadura e não por fendilhamento, motivo pelo qual as fibras não têm uma maior influência;

- A qualidade do concreto, e não apenas a sua resistência à compressão, tem uma importância muito grande na aderência das peças, tanto na determinação da tensão de aderência, nos ensaios de arrancamento, como na determinação do comprimento de transferência, na desprotensão das vigas. Por qualidade entende-se não só a resistência do concreto à compressão, mas também suas propriedades em relação à trabalhabilidade no estado fresco, porosidade e quantidade de aditivos, entre outras.

\subsection{Sugestões para Pesquisas Futuras}

A seguir são apresentados alguns dos temas para pesquisas futuras.

\subsubsection{Ensaios de arrancamento variando a armadura ativa}

Pode-se ensaiar várias séries de prismas variando-se a armadura de protensão: fio de $7 \mathrm{~mm}$; cordoalhas de 3 fios; cordoalhas de 7 fios com diâmetros de 9,5mm e 15,2mm, entre outras. Podem ser feitos ensaios apenas com as armaduras não-protendidas, se forem utilizados comprimentos aderentes menores que o comprimento de transferência dos fios e cordoalhas.

\subsubsection{Ensaios de arrancamento variando-se a relação $c / \phi_{p}$}

Pode-se ensaiar várias séries, para um mesmo tipo de armadura, ou mais, variando-se a relação entre o cobrimento e o diâmetro do fio ou cordoalha. Este estudo é muito importante para que se tenha uma idéia da influência do cobrimento de concreto na aderência. 


\subsubsection{Ensaios de arrancamento variando-se o grau de protensão}

Pode-se ensaiar várias séries, para um mesmo tipo de armadura ou mais, variando-se o grau de protensão da cordoalha, como por exemplo: $0,5 \mathrm{f}_{\mathrm{ptk}}, 0,7 \mathrm{f}_{\mathrm{ptk}}, 0,8 \mathrm{f}_{\mathrm{ptk}}$ e $0,9 \mathrm{f}_{\mathrm{ptk}}$. Para esse tipo de ensaio, deve-se estudar séries de prismas com comprimentos aderentes maiores que o comprimento de transferência das armaduras escolhidas. Esse estudo visa avaliar a influência do grau de protensão na aderência das peças.

\subsubsection{Ensaios de arrancamento variando-se o tipo e o consumo de fibra de aço}

Nesta pesquisa foi utilizado apenas um tipo de fibra. Pode-se repetir as séries de ensaio, excluindo-se as peças pré-tracionadas, para outros tipos de fibras de aço, variando-se o fator de forma, o comprimento, usando fibras menores, e os consumos a serem utilizados.

\subsubsection{Estudo da influência do tipo de alívio da protensão}

Pode-se estudar, para os tipos de fibras de aço e armaduras escolhidas, a influência do tipo de alívio da protensão, se súbito ou gradual, na aderência das peças.

\subsubsection{Estudo da utilização de fibras de aço em vigas sem armaduras passivas}

Pode-se avaliar o comportamento de vigas pré-tracionadas sem armaduras passivas, sendo estas substituídas por fibras de aço. Já existem alguns estudos nessa área, principalmente com consumos de fibra mais elevados, de até $\mathrm{V}_{\mathrm{f}}=640 \mathrm{~kg} / \mathrm{m}^{3}(\approx 8 \%)$.

\subsubsection{Determinação de um modelo analítico para as cordoalhas}

Pode-se elaborar um estudo estatístico com ensaios de arrancamento em peças não protendidas, com um grande número de modelos, já que são ensaios fáceis de fazer, para se determinar um modelo analítico para o comportamento Tensão de aderência versus Escorregamento das cordoalhas. A pesquisa pode abranger uma única armadura, ou uma série delas. Pode ser feita em conjunto com uma modelagem numérica.

\subsubsection{Determinação do comprimento de ancoragem necessário}

Pode-se ensaiar mais vigas, seguindo os modelos desta pesquisa, com valores do comprimento aderente disponível entre $\ell_{0}=\mathrm{L} / 3$ e $\ell_{0}=\mathrm{L} / 4$, para se determinar com mais precisão o valor do comprimento de ancoragem necessário. 


\section{REFERÊNCIAS BIBLIOGRÁFICAS}

AGUllÓ, L.; GETTU, R.; AGUADO, A.; SALDIVAR, H. (2000) - La tenacidade de hormigones reforzados con fibras de acero. Monografia CIMNE n. 54, Barcelona, Mayo, 2000.

ALSIWAT, J. M.; SAATCIOGLU, M. (1992) - Reinforcement anchorage slip under monotonic loading. Journal of Structural Engineering, Vol. 118, n. 9, September, 1992.

AMERICAN CONCRETE INSTITUTE (2002). Committee 318 - Building code requirements for structural concrete and commentary (ACI 318 R-02). Farmington Hills, 2002.

AMERICAN CONCRETE INSTITUTE (1986). Committee 544 - State-of-the-art report on fiber reinforced concrete (ACI 544 1R-82). Detroit. 22p.

AMERICAN CONCRETE INSTITUTE (1989). Committee 544 - Measurement of properties of fiber reinforced concrete (ACI 544 2R-89). Detroit. 11p.

AMERICAN CONCRETE INSTITUTE (1993). Committee 544 - Guide for specifying, proportioning, mixing, placing and finishing steel fiber reinforced concrete (ACI 544 3R-93). Detroit. 10p.

AMERICAN CONCRETE INSTITUTE (1988). Committee 544 - Design considerations for steel fiber reinforced concrete (ACI 544 4R-88). Detroit. 18p.

AMERICAN SOCIETY FOR TESTING AND MATERIALS (1994) - Standard test method for flexural strength of concrete (using simple beam with third-point loading) (ASTM C 78-94). Philadelphia. 3p.

AMERICAN SOCIETY FOR TESTING AND MATERIALS (1994) - Standard test method for flexural toughness and first-crack strength of fiber-reinforced concrete (using beam with third-point loading) (ASTM C 1018-94b). Philadelphia. 8p.

ANDERSON, A. R.; ANDERSON, R. G. (1976) - An assurance criterion for flexural bond in pretensioned hollow core units. ACI Journal, August 1976.

ASSOCIAÇÃO BRASILEIRA DE NORMAS TÉCNICAS (1994). NBR 5738 - "Moldagem e cura de corpos-de-prova cilíndricos ou prismáticos de concreto" - Método de ensaio. Rio de Janeiro, 1994.

ASSOCIAÇÃO BRASILEIRA DE NORMAS TÉCNICAS (1994). NBR 5739 - "Concreto Ensaio de compressão de corpos-de-prova cilíndricos" - Método de ensaio. Rio de Janeiro, 1994. 
ASSOCIAÇÃO BRASILEIRA DE NORMAS TÉCNICAS (1978). NBR 6118 - Projeto e execução de obras de concreto armado. Rio de Janeiro, 1978

ASSOCIAÇÃO BRASILEIRA DE NORMAS TÉCNICAS (1989). NBR 7197 - Projeto de estruturas de concreto protendido. Rio de Janeiro, 1989.

ASSOCIAÇÃO BRASILEIRA DE NORMAS TÉCNICAS (1994). NBR 7222 - “Argamassa e concreto - Determinação da resistência à tração por compressão diametral de corposde-prova cilíndricos" - Método de ensaio. Rio de Janeiro, 1994.

ASSOCIAÇÃO BRASILEIRA DE NORMAS TÉCNICAS (1992). NBR 7223 - "Concreto Determinação da consistência pelo abatimento do tronco de cone" - Método de ensaio. Rio de Janeiro, 1992.

ASSOCIAÇÃO BRASILEIRA DE NORMAS TÉCNICAS (1984). NBR 8522 - "Concreto Determinação do módulo de deformação estática e diagrama - Tensão-deformação" Método de ensaio. Rio de Janeiro, 1984.

ASSOCIAÇÃO BRASILEIRA DE NORMAS TÉCNICAS (1985). NBR 9062 - Projeto e execução de estruturas de concreto pré-moldado - Procedimento. Rio de Janeiro, 1985.

ASSOCIAÇÃO BRASILEIRA DE NORMAS TÉCNICAS (1992). NBR 12142 - "Concreto - Determinação da resistência à tração na flexão em corpos-de-prova prismáticos" Método de ensaio. Rio de Janeiro, 1992.

ASSOCIAÇÃO BRASILEIRA DE NORMAS TÉCNICAS (2001). Revisão da NBR 6118 Projeto de concreto estrutural - procedimentos. Rio de Janeiro, 2001.

BALAGURU, P.; GAMBAROVA, P. G.; ROSATI, G. P.; SCHUMM, C. E. (1996) - Bond of reinforcing bars and prestressing tendons in HPFRCC matrices. Proceedings of the Second International Workshop, High Performance Fiber Reinforced Cement Composites (HPFRCC2). June 11-14, 1995, University of Michigan. NAAMAN, A. E. and REINHARDT, H. W. editors, pp. 1-24.

BALAGURU, P. N.; SHAH, S. P. (1992) - Fiber-reinforced cement composites. Singapura. McGraw-Hill Book Co.

BALÁZS, G. L. (1993) - Transfer length of prestressing strand as a function of draw-in and initial prestress. PCI Journal, March-April 1993.

BASTOS, P. S. S. (1999) - Análise experimental de dormentes de concreto protendido reforçado com fibras de aço. São Carlos. Tese (Doutorado) - Escola de Engenharia de São Carlos, Universidade de São Paulo.

BENTUR, A.; MINDESS, S. (1990) - Fibre reinforced cementitious composites. Essex, Inglaterra. Elsevier Science Publishers LTD.

BOX, G. E. P.; HUNTER, W. G.; HUNTER, J. S. (1978) - Statistics for experimenters: an introduction to design, data analysis, and model building. John Wiley \& Sons, New York, 1978.

BUCKNER, C. DALE. (1995) - A review of strand development length for pretensioned concrete members. PCI Journal, March - April, 1995.

CASTRODALE, R. W.; BURNS, N. H.; KREGER, M. E. (1988) - A study of pretensioned high strength concrete girders in composite highway bridges - Laboratory tests. Research Report 381-3, Center for Transportation Reasearch - Bureau of Engineering Reasearch, The University of Texas at Austin. January 1988.

COLlinS, M. P.; MITCHELL, D. (1997) - Prestressed concrete structures. Response Publications, Canada.

COMITÉ EURO-INTERNATIONAL DU BÉTON (1993). CEB-FIP Model Code 1990. Bulletin d'Information, $n^{\circ}$ 203-205, 1993.

COUSINS, T. E. ; BADEUX, M.H. ; MOUSTAFA, S. (1992) - Proposed test for determining bond characteristics of prestressing strand. PCI Journal, January-February 1992. 
COUSINS, T. E. ; JOHNSTON, D. W. ; ZIA, P. (1986) - Bond of epoxy coated prestressing strand. Center for Transportation Engineering Studies, Department of Civil Engineering, North Carolina State University, December 1986.

COUSINS, T. E. ; JOHNSTON, D. W. ; ZIA, P. (1990a) - Transfer length of epoxy-coated prestressing strand. ACI Materials Journal, V. 87, n. 3, May-June 1990.

COUSINS, T. E. ; JOHNSTON, D. W. ; ZIA, P. (1990b) - Development length of epoxycoated prestressing strand. ACI Materials Journal, V. 87, n. 3, May-June 1990.

COUSINS, T. E. ; JOHNSTON, D. W. ; ZIA, P. (1990c) - Transfer and development length of epoxy coated and uncoated prestressing strand. PCI Journal, July-August 1990.

DARWIN, D. ; McCABE, S. L. ; IDUN, E. K. ; SCHOENEKASE, S. P. (1992) Development length criteria: bars not confined by transverse reinforcement. ACI Structural Journal, V. 89, n. 6, November- December 1992.

DEATHERAGE, J. H.; BURDETTE, E.; CHEW, Ch. K. (1994) - Development length and lateral spacing requirements of prestressing strand for prestressed concrete bridge girders. PCI Journal, Vol. 39, n. 1, 1994.

DUCATTI, V. A. (1993) - Concreto de elevado desempenho: estudo da aderência com a armadura. São Paulo. Tese (Doutorado) - Escola Politécnica de São Paulo, Universidade de São Paulo.

ELIGEHAUSEN, R.; POPOV, E. P.; BERTERO, V. V. (1983) - Local bond stress-slip relationships of deformed bars under generalized excitations. Report $\mathrm{n}^{\mathrm{o}} \mathrm{UCB} / \mathrm{EERC}-$ 83/23, University of California, Berkeley. 162 p.

ELMORSI, M.; KIANOUSH, M. R.; TSO, W. K. (2000) - Modeling bond-slip deformations in reinforced concrete beam-column joints. Canadian Journal of Civil Engineering, Vol. 27, Iss. 3, Jun/ 2000.

EUROPEAN STANDARD (1999). prEN 1992-1 ( $1^{\text {st }}$ draft). Eurocode 2: Design of concrete structures - Part 1: General rules and rules for buildings. December, 1999.

EZELDIN, A. S.; BALAGURU, P. N. (1989) - Bond behavior of normal and high-strength fiber reinforced-concrete. ACI Materials Journal, Vol. 86, n. 5, September-October 1989.

FÉDÉRATION INTERNATIONALE DU BÉTON (1999). Fib - Structural concrete: textbook on behaviour, design and performance. Vols. 1, 2 and 3. Sprint-Druck, Stuttgart, 1999.

FÉDÉRATION INTERNATIONALE DE LA PRÉCONTRAINTE (1999). FIP Recommendations: Practical design of structural concrete. FIP Commission 3 on Practical Design Working Group on Recommendations for Practical Design of Structural Concrete. September, 1999.

FERGUSON, P. M; BREEN, J. E; JIRSA, J. O. (1988) - Reinforced concrete fundamentals. John Wiley \& Sons, $5^{\text {th }}$ edition, 1988.

FURLAN JR., S. (1995) - Vigas de concreto com taxas reduzidas de armadura de cisalhamento: influência do emprego de fibras curtas e de protensão. São Carlos. Tese (Doutorado) - Escola de Engenharia de São Carlos, Universidade de São Paulo.

FUSCO, P. B. (1995) - Técnica de armar as estruturas de concreto. São Paulo: PINI.

GOTO, Y. (1971) - Cracks formed in concrete around deformed tension bars. ACI journal, April 1971.

HANSON, N. W.; KAAR, P. H. (1959) - Flexural bond tests of pretensioned prestressed beams. Journal of the ACI, January 1959.

HARAJLI, M. H. (1994) - Development/splice strength of reinforcing bars embedded in plain and fiber reinforced concrete. ACI Structural Journal, V. 91, n. 5, SeptemberOctober 1994. 
HARAJLI, M. H.; HOUT, M.; JALKH, W. (1995) - Local bond stress-slip behavior of reinforcing bars embedded in plain and fiber concrete. ACI Materials Journal, V. 92, n. 4, July-August 1995.

HARAJLI, M. H.; SALLOUKH, K. A. (1997) - Effect of fibers on development/splice strength of reinforcing bars in tension. ACI Materials Journal, V. 94, n. 4, July-August 1997.

HOTA, S.; NAAMAN, A. E. (1997) - Bond stress-slip response of reinforcing bars embedded in FRC matrices under monotonic and cyclic loading. ACI Structural Journal, V. 94, n. 5, September-October 1997.

JANNEY, J. R. (1954) - Nature of bond in pre-tensioned prestressed concrete. Journal of the ACI, May 1954.

JAPAN SOCIETY OF CIVIL ENGINEERS (1984). JSCE-SF4 - Method of tests for flexural toughness of steel fiber reinforced concrete. Concrete Library of JSCE, Part III-2 Method of tests for steel fiber reinforced concrete, n.3, June. P.58-61.

JOKELA,J.; TEPFERS, R. (1982) - Bond of bundled prestressing steel strands. Nordic Concrete Research - Technical Research Centre of Finland, n.1, December 1982.

KAAR, P. H; HANSON, N, W. (1975) - Bond fatigue tests of beams simulating pretensioned concrete crossties. PCI Journal, September-October 1975.

KAAR, P. H.; MAGURA, D. D. (1965) - Effect of strand blanketing on performance of pretensioned girders. Journal of the Prestressed Concrete Institute, Vol. 10, n. 6, December, 1965.

KEMP, E. L.; WILHELM, W. J. (1979) - Investigation of the parameters influencing bond cracking. ACI Journal, January 1979.

KRSTULOVIC-OPARA, N.; WATSON, K. A.; LAFAVE, J. M. (1994) - Effect of increased tensile strength and toughness on reinforcing-bar bond behavior. Cement \& Concrete Composites, Vol. 16, 1994.

LIN,T. Y.; BURNS, N. H. (1981) - Design of prestressed concrete structures. John Wiley \& Sons, Inc.

LUNDGREN, K.; GYLLTOFT, K. (2000) - A model for the bond between concrete and reinforcement. Magazine of Concrete Research, Vol. 52, Iss. 1, Feb./ 2000.

MACGREGOR, J. G. (1988) - Reinforced concrete: mechanics and design. Englewood Cliffs, New Jersey, Prentice-Hall.

MAGALHÃES, M. N.; LIMA, A. C. P. (2002) - Noções de probabilidade e estatística. 4 ed. - São Paulo: Editora da Universidade de São Paulo, 2002.

NAAMAN, A. E.; REINHARDT, H. W. (1996) - Characterization of high performance fiber reinforced cement composites HPFRCC. Proceedings of the Second International Workshop, High Performance Fiber Reinforced Cement Composites (HPFRCC2). June 11-14, 1995, University of Michigan. NAAMAN, A. E. and REINHARDT, H. W. editors, pp. 1-24.

NEVILLE, A. M. (1997) - Concreto de alto desempenho: visão atual. 39º Congresso Brasileiro do Concreto, São Paulo.

ORANGUN, C. O.; JIRSA, J. O.; BREEN, J. E. (1977) - A reevaluation of test data on development length and splices. ACI Journal, March 1977.

RABBAT, B. G.; KAAR, P. H.; RUSSELL, H. G.; BRUCE Jr., R. N. (1979) - Fatigue tests of pretensioned girders with blanketed and draped strands. PCA Research and Development Bulletin RD062.01D. PCI Journal, July-August 1979.

REINHARDT, H. W. et al (1996) - Future research needs in the field of HPFRCC. Proceedings of the Second International Workshop, High Performance Fiber Reinforced Cement Composites (HPFRCC2). June 11-14, 1995, University of Michigan. NAAMAN, A. E. and REINHARDT, H. W. editors, pp. 461-467. 
RILEM/CEB/FIP (1970) - Test and Specifications of reinforcements for reinforced and prestressed concrete. Four recommendations of the RILEM/CEB/FIP Committee 2: Pull-out test, Materials and Structures, RILEM, vol. 3, n. 15.

ROMUALDI, J. P.; MANDEL, J. A. (1964) - Tensile strength of concrete affected by uniformly distributed and closely spaced short lengths of wire reinforcement. Journal of the ACI, June 1964.

ROSE, D. R.; RUSSEL, B. W. (1997) - Investigation of standardized tests to measure the bond performance of prestressing strand. PCI Journal, July-August 1997.

RUSSEL, B. W.; BURNS, N. H. (1993) - Design guidelines for transfer, development and debonding of large diameter seven wire strands in pretensioned concrete girders. Research Report 1210-5F, Center for Transportation Reasearch - Bureau of Engineering Reasearch, The University of Texas at Austin. January 1993.

SHAHAWY, M. A.; ISSA, M.; BATCHELOR, B. (1992) - Strand transfer lengths in full scale AASHTO prestressed concrete girders. PCI Journal, May-June, 1992.

SHAH, S. P.; WANG, K.; WEISS, W. J. (1999) - Is high strength concrete durable? Simpósio Tendência da Engenharia Estrutural Empregando Concreto de Alto Desempenho e Concreto Reforçado com Fibras, ENECE 99. São Paulo.

SILVA, N. N. (2001) - Amostragem probabilística. 2. ed. ver. - São Paulo: Editora da Universidade de São Paulo, 2001.

SOROUSHIAN, P.; MIRZA, F.; ALHOZAIMY, A. (1994) - Bonding of confined steel fiber reinforced concrete to deformed bars. ACI Materials Journal, V. 91, n. 2, March-April 1994.

STOCKER, M. F.; SOZEN, M. A. (1970) - Investigation of prestressed reinforced concrete for highway bridges, part $V$ : bond characteristics of prestressing strand. Engineering Experiment Station, Bulletin 503. University of Illinois. August 1970.

SWAMY, R. N.; AL-NOORI, K. (1974) - Bond strength of steel fibre reinforced concrete. Concrete, August 1974.

VALLE, A. (1994) - Estudo da aderência entre concreto e armadura sob carregamento cíclico. São Paulo. Dissertação (Mestrado) - Escola Politécnica de São Paulo, Universidade de São Paulo.

VAN MIER, J. G. M.; STANG, H.; RAMAKRISHNAN, V. (1996) - Practical structural applications of FRC and HPFRCC. Proceedings of the Second International Workshop, High Performance Fiber Reinforced Cement Composites (HPFRCC2). June 11-14, 1995, University of Michigan. NAAMAN, A. E. and REINHARDT, H. W. editors, pp. 443-459.

VARGAS, J. R. M. (2001) - Estudio experimental de la adherencia de cordones pretesos en hormigones de altas prestaciones iniciales. Valencia. Tese (Doutorado) - E. T. S. de Ingenieiros de Caminos, Canales y Puertos, Universidad Politécnica de Valencia.

VASCONCELOS, A. C.; GIAMMUSSO, S. E. (1993) - Qual a diferença entre a $f_{c k}$ e a f' ${ }_{c} d o$ ACI? Revista Engenharia, n. 498, 1993.

YERLICI, V. A.; ÖZTURAN, T. (2000) - Factors affecting anchorage bond strength in highperformance concrete. ACI Structural Journal, Vol. 97, n. 3, May-June 2000.

ZIA, P.; MOSTAFA, T. (1977). Development length of prestressing strands. PCI Journal, Sept./ Oct. 1977. 


\section{BIBLIOGRAFIA COMPLEMENTAR}

AÏTCIN, P-C (1999) - Concretes of yesterday, today and tomorrow. $41^{\circ}$ Congresso Brasileiro do Concreto, Salvador.

ALVAREZ, E. R. (1991) - Ensayo de transferencia de pretensado y adherencia em traviesas de desvio. Symposium Internacional de Traviesas Ferroviarias Prefabricadas de Hormignon - Colégio de Ingenieros de Caminos, Canales y Puertos. Madrid, 1991.

AMERICAN CONCRETE INSTITUTE (1992). Committee 408 - State-of-the-art report: bond under cyclic loads (ACI 408.2R-92). Detroit. 5p.

ASSOCIAÇÃO BRASILEIRA DE NORMAS TÉCNICAS (1992). NBR 6152 - "Materiais metálicos - Determinação das propriedades mecânicas à tração" - Método de ensaio. Rio de Janeiro, 1992.

BENTUR, A. et al (1996) - Fiber-matrix interfaces. Proceedings of the Second International Workshop, High Performance Fiber Reinforced Cement Composites (HPFRCC2). June 11-14, 1995, University of Michigan. NAAMAN, A. E. and REINHARDT, H. W. editors, pp. 149-191.

COMITÉ EURO-INTERNATIONAL DU BÉTON (1991). Bulletin d'Information, $n^{-} 151$. Bond action and bond behaviour of reinforcement (State-of-the-art report). Paris.

DAL MOLIN, D.; VIEIRA, F. P.; KULAKOWSKI, M. P.; VILELA, A. C. F. (1998) Concreto de alto desempenho com adição de sílica ativa. Seminário Sobre o Uso do Concreto de Alto Desempenho e a Durabilidade das Estruturas de Concreto. Feira de Santana.

EHSANI, M. R.; SAADATMANESH, H.; NELSON, C. T. (1997) - Transfer and flexural bond performance of aramid and carbon FRP tendons. PCI Journal, January February, 1997.

HANAI, J. B. (1995) - Fundamentos do concreto protendido: notas de aula para o curso de engenharia civil. São Carlos, EESC.

INTERNATIONAL CONFERENCE (1992) - Bond in concrete: from research to practice. CEB, Riga Technical University, Riga, Latvia. October 15-17, 1992.

KANNEL, J.; FRENCH, C.; STOLARSKI, H. (1997) - Release methodology of strands to reduce end cracking in pretensioned concrete girders. PCI Journal, January - February, 1997.

LEONHARDT, F. (1983) - Construções de concreto: concreto protendido. Trad. por João Luís Escosteguy Merino. Rio de Janeiro, Interciência. v.5. 
LORRAIN, M. - Progress on high strength concrete research and application. Toulouse, France (199?).

MEHTA, P. K.; MONTEIRO, P. J. M. (1994) - Concreto: estrutura, propriedades e materiais. São Paulo: PINI.

NAAMAN, A. E. et al (1996) - Reinforced and prestressed concrete using HPFRCC matrices. Proceedings of the Second International Workshop, High Performance Fiber Reinforced Cement Composites (HPFRCC2). June 11-14, 1995, University of Michigan. NAAMAN, A. E. and REINHARDT, H. W. editors, pp. 291-347.

NANNI, A.; TANIGAKI, M. (1992) - Prestressed concrete members with bonded fiber reinforced plastic tendons: development and flexural bond lengths (static). ACI Structural Journal, V. 89, n. 4, July-August 1992.

NANNI, A.; UTSUNOMIYA, T.;YONEKURA, H.; TANIGAKI, M. (1992) - Transmission of prestressing force to concrete by bonded fiber reinforced plastic tendons. ACI Structural Journal, V. 89, n. 3, May-June 1992.

PETRUCCI, E. G. R. (1983) - Concreto de cimento portland. 10 ed. atualizada e revisada por VLADIMIR A. PAULON - Porto Alegre - Rio de Janeiro: Globo, 1983.

PFEIL, W. (1988) - Concreto protendido: introdução. 2.ed. Rio de Janeiro, LTC Livros Técnicos. v.1 e v. 2.

RUSSEL, B. W.; BURNS, N. H.; ZUMBRUNNEN, L. G. (1994) - Predicting the bond behavior of prestressed concrete beams containing debonded strands. PCI Journal, September - October, 1994.

SHAHAWY, M. A.; ISSA, M. (1992) - Effect of pile embedment on the development length of prestressing strands. PCI Journal, November - December, 1992.

TABATABAI, H.; DICKSON, T. J. (1993) - The history of the prestressing strand development length equation. PCI Journal, November - December, 1993. 


\section{APÊNDICE A}

CÁLCULO DOS PRISMAS DE ARRANCAMENTO 
Foram ensaiadas duas séries de prismas, com dimensões diferentes. A simbologia utilizada neste apêndice está listada a seguir.

$f_{\mathrm{bp}}=\quad$ Tensão de aderência [simbologia usada pela FIB Bulletin 1 (1999)]

$\mathrm{f}_{\mathrm{c}}=\quad$ Resistência do concreto à compressão

$\mathrm{f}_{\mathrm{ctk}}=\quad$ Resistência característica do concreto à tração

$\mathrm{f}_{\mathrm{ctm}}=\quad$ Resistência média do concreto à tração direta

$\mathrm{f}_{\mathrm{p}}=\quad$ Tensão da armadura

$\mathrm{f}_{\text {pyk }}=\quad$ Resistência característica da armadura de protensão ao escoamento

$\ell_{\text {ef }}=\quad$ Comprimento de ancoragem disponível

$\mathrm{A}_{\mathrm{c}}=\quad$ Área da seção transversal de concreto

$\mathrm{A}_{\mathrm{p}}=\quad$ Área da cordoalha

$\mathrm{F}_{\text {arranc }}=\quad$ Força de arrancamento

$\mathrm{V}_{\mathrm{f}}=\quad$ Volume de fibras

$\phi_{\mathrm{p}}=\quad$ Diâmetro da cordoalha

$\phi_{\mathrm{p}, \text { equivalente }}=$ Diâmetro equivalente da cordoalha $\left(\phi_{\mathrm{p}_{\text {equivalente }}}=\sqrt{\frac{4 . \mathrm{A}_{\mathrm{p}}}{\pi}}\right)$

$\eta_{\mathrm{p} 1}=\quad$ Coeficiente para cálculo da tensão de aderência para o tipo de armadura

$\eta_{\mathrm{p} 2}=\quad$ Coeficiente para cálculo da tensão de aderência para a situação da aderência

$\sigma_{\mathrm{c}}=\quad$ Tensão no concreto

$\tau_{\mathrm{b}}=\quad$ Tensão de aderência

A seguir são apresentados os cálculos para cada série separadamente.

\section{A.1. Prismas da Série 1}

A Figura A.1 apresenta as dimensões do modelo, e a Tabela A.1 apresenta os dados utilizados no cálculo.

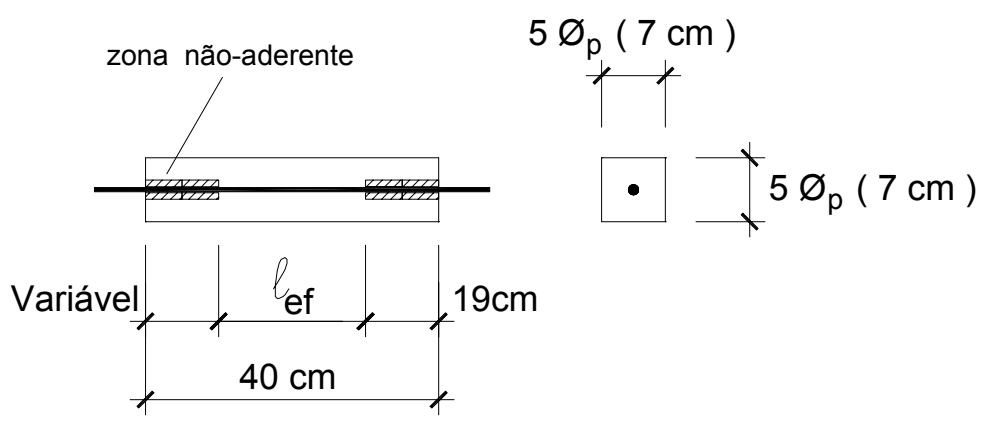

Figura A.1 - Modelo dos prismas da Série 1. 
Tabela A.1 - Dados para o cálculo dos prismas da Série 1.

\begin{tabular}{l|l}
\hline $\mathrm{f}_{\mathrm{c}}=68 \mathrm{MPa}$ & AÇO CP $190 \mathrm{RB}$ \\
\hline $\mathrm{V}_{\mathrm{f}}=0 \mathrm{~kg} / \mathrm{m}^{3}$ & $\phi_{\mathrm{p}}=12,7 \mathrm{~mm}$ \\
\hline$\ell_{\mathrm{ef}, 1}=9 \mathrm{~cm}\left(7 \phi_{\mathrm{p}}\right)$ & $\mathrm{A}_{\mathrm{p}}=100,3 \mathrm{~mm}^{2}$ \\
\hline$\ell_{\mathrm{ef}, 2}=19 \mathrm{~cm}\left(15 \phi_{\mathrm{p}}\right)$ & $\phi_{\mathrm{p}, \text { equivalente }}=11,3 \mathrm{~mm}$ \\
\hline
\end{tabular}

Para a determinação da força de arrancamento, foi adotada a equação básica para o cálculo da aderência:

$$
\begin{gathered}
\tau_{\mathrm{b}_{\text {max }}}=\frac{\phi_{\mathrm{p}, \text { equivalente }} \cdot \mathrm{f}_{\mathrm{p}, \text { máx }}}{4 \cdot \ell_{\mathrm{ef}}} \quad \mathrm{f}_{\mathrm{p}, \text { máx }}=\frac{\tau_{\mathrm{b}_{\text {max }}} \cdot 4 \cdot \ell_{\mathrm{ef}}}{\phi_{\mathrm{p}, \text { equivalente }}} \\
\mathrm{F}_{\text {arranc }}=\mathrm{f}_{\mathrm{p} \text {, máx }} \cdot \mathrm{A}_{\mathrm{p}}
\end{gathered}
$$

Para o cálculo da tensão de aderência máxima, foi utilizada a formulação sugerida pela FIB Bulletin 1 (1999), que cobre concretos com resistências à compressão superiores a 50MPa. A NBR 6118 (2001) só vale para $\mathrm{f}_{\mathrm{c}}$ menores ou iguais a $50 \mathrm{MPa}$.

$$
\begin{aligned}
& \tau_{\mathrm{b}_{\text {max }}}=\mathrm{f}_{\mathrm{bp}}=\eta_{1} \cdot \eta_{2} \cdot \mathrm{f}_{\mathrm{ctk}} \\
& \mathrm{f}_{\mathrm{ctk}}=0,7 \cdot \mathrm{f}_{\mathrm{ctm}}=0,7\left[1,12 \sqrt[3]{\mathrm{f}_{\mathrm{c}}}\right] \\
& \eta_{1}=1,3 \text { e } \eta_{2}=1,0 \quad \text { (para esta pesquisa) } \\
& \tau_{\mathrm{b}_{\max }}=1,3 \cdot 1,0 \cdot 0,7 \cdot 1,12 \cdot \sqrt[3]{68}=4,2 \mathrm{MPa}
\end{aligned}
$$

Logo, para a força de arrancamento, tem-se:

$$
\begin{aligned}
& \mathrm{F}_{\text {arranc }_{7 \phi_{\mathrm{p}}}}=\left[\frac{\tau_{\mathrm{b}_{\text {max }}} \cdot 4 \cdot \ell_{\mathrm{ef}, 1}}{\phi_{\mathrm{p}, \text { equivalente }}}\right] \mathrm{A}_{\mathrm{p}}=\frac{4,2 \cdot 4 \cdot 9}{1,13} \cdot 100,3 \times 10^{-3}=13,42 \mathrm{MPa} \\
& \mathrm{F}_{\text {arranc }_{15 \phi_{\mathrm{p}}}}=\left[\frac{\tau_{\mathrm{b}_{\text {max }}} \cdot 4 \cdot \ell_{\mathrm{ef}, 2}}{\phi_{\mathrm{p}, \text { equivalente }}}\right] \mathrm{A}_{\mathrm{p}}=\frac{4,2 \cdot 4 \cdot 19}{1,13} \cdot 100,3 \times 10^{-3}=28,33 \mathrm{MPa}
\end{aligned}
$$

Para a verificação do escoamento da armadura, tem-se:

$$
\mathrm{f}_{\mathrm{p}, \text { máx }}=282,5 \mathrm{MPa}<<\mathrm{f}_{\text {pyk }}=0,9.1900=1710 \mathrm{MPa} \text { OK }
$$

Para a verificação da seção de concreto, tem-se:

$$
\begin{aligned}
& \mathrm{A}_{\mathrm{c}}=0,07^{2}=0,0049 \mathrm{~m}^{2} \quad \sigma_{\mathrm{c}, \text { máx }}=0,7 . \mathrm{f}_{\mathrm{c}}=0,7.68=47,6 \mathrm{MPa} \\
& \sigma_{\mathrm{c}}=\frac{\mathrm{F}_{\text {arranc,máx }}}{\mathrm{A}_{\mathrm{c}}}=\frac{28,33}{0,0049}=5781,6 \mathrm{kN} / \mathrm{m}^{2}=5,8 \mathrm{MPa} \quad \sigma_{\mathrm{c}}<<\sigma_{\mathrm{c}, \text { máx }} \quad \text { OK }
\end{aligned}
$$

As dimensões escolhidas para os modelos da Série 1 estão de acordo com as hipóteses desejadas, que são: (1) o não escoamento da armadura; e (2) a garantia da capacidade resistente da seção transversal de concreto contra o esmagamento por compressão. 


\section{A.2. Prismas da Série 2}

A Figura A.2 apresenta as dimensões do modelo, e a Tabela A.2 apresenta os dados utilizados no cálculo.

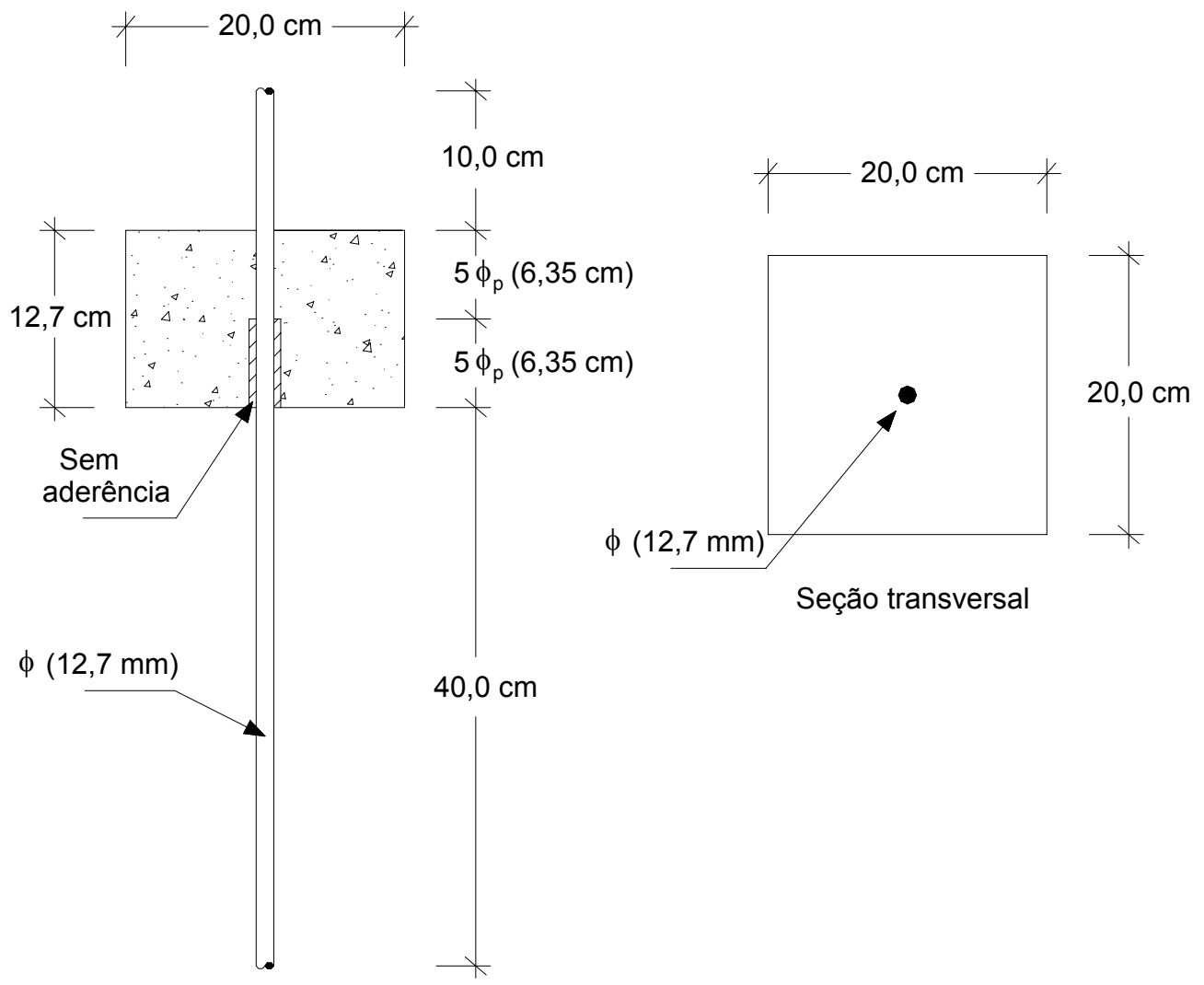

Figura A.2 - Modelo dos prismas da Série 2.

Tabela A.2 - Dados para o cálculo dos prismas da Série 2.

\begin{tabular}{l|l}
\hline $\mathrm{f}_{\mathrm{c}}=68 \mathrm{MPa}$ & AÇO CP 190 RB \\
\hline $\mathrm{V}_{\mathrm{f}}=0 \mathrm{~kg} / \mathrm{m}^{3}$ & $\phi_{\mathrm{p}}=12,7 \mathrm{~mm} \mathrm{e} \phi_{\mathrm{p}, \text { equivalente }}=11,3 \mathrm{~mm}$ \\
\hline$l_{\mathrm{ef}}=6,35 \mathrm{~cm}\left(5 \phi_{\mathrm{p}}\right)$ & $\mathrm{A}_{\mathrm{p}}=100,3 \mathrm{~mm}^{2}$ \\
\hline
\end{tabular}

Da mesma forma que para a Série 1, tem-se:

$$
\begin{aligned}
& \tau_{\mathrm{b}_{\text {max }}}=4,2 \mathrm{MPa} \quad \mathrm{F}_{\text {arranc }}=\frac{4,2 \cdot 4 \cdot 6,35}{1,13} \cdot 100,3 \times 10^{-3}=9,5 \mathrm{kN} \\
& \mathrm{f}_{\mathrm{p} \text {,máx }}=94,4 \mathrm{MPa}<<\mathrm{f}_{\text {pyk }} \quad \text { OK } \\
& \sigma_{\mathrm{c}}=\frac{9,5}{0,2^{2}}=237,5 \mathrm{kN} / \mathrm{m}^{2}=0,24 \mathrm{MPa}<<\sigma_{\mathrm{c}, \text { máx }} \quad \text { OK }
\end{aligned}
$$

Os prismas da Série 2 também satisfazem as hipóteses desejadas para os ensaios.

A Tabela A.3 apresenta o resumo dos resultados. 
Tabela A.3 - Resultados teóricos para os prismas das Séries 1 e 2.

\begin{tabular}{c|c|c|c|c}
\hline \multirow{2}{*}{ Série } & $\ell_{\mathbf{e f}}(\mathbf{c m})$ & $\mathbf{F}_{\text {arranc }}(\mathbf{k N})$ & $\mathbf{f}_{\mathbf{p}}(\mathbf{M P a})$ & $\sigma_{\mathbf{c}}(\mathbf{M P a})$ \\
\hline \multirow{2}{*}{1} & $9,00\left(7 \phi_{\mathrm{p}}\right)$ & 13,42 & 133,80 & 2,74 \\
\cline { 2 - 5 } & $19,00\left(15 \phi_{\mathrm{p}}\right)$ & 28,33 & 282,50 & 5,80 \\
\hline 2 & $6,35\left(5 \phi_{\mathrm{p}}\right)$ & 9,50 & 94,40 & 0,24 \\
\hline
\end{tabular}




\section{APÊNDICE B}

CÁLCULO DAS VIGAS PRÉ-TRACIONADAS 
O dimensionamento das vigas foi feito baseado nas recomendações da FIB Bulletin 1 (1999) e do Código Modelo CEB-FIP (1990). Isso ocorreu porque o concreto utilizado foi de alta resistência, $\mathrm{f}_{\mathrm{c}}=65 \mathrm{MPa}$. A NBR 6118 (2001) só cobre concretos com resistências à compressão de até $\mathrm{f}_{\mathrm{c}}=50 \mathrm{MPa}$, enquanto que a FIB e o Código Modelo valem para valores até $\mathrm{f}_{\mathrm{c}}=80 \mathrm{MPa}$. Isso é válido para os cálculos aqui apresentados.

No dimensionamento não foi levada em conta a presença das fibras de aço. As vigas foram dimensionadas para o concreto sem fibras.

A simbologia utilizada neste apêndice está listada a seguir.

\section{Letras romanas minúsculas}

$\mathrm{b}_{\mathrm{w}}=$ Largura da alma da viga

$\mathrm{d}_{\mathrm{p}}=\quad$ Altura útil em relação à armadura ativa

$\mathrm{e}_{\mathrm{p}}=$ Excentricidade da armadura ativa

$\mathrm{e}_{\mathrm{p}, \mathrm{h}}=$ Excentricidade da armadura ativa para a seção homogeneizada de concreto

$\mathrm{f}_{\mathrm{c}}=$ Resistência do concreto à compressão

$\mathrm{f}_{\mathrm{cd}}=$ Resistência de cálculo do concreto à compressão

$\mathrm{f}_{\mathrm{cd} 1}=$ Resistência uniaxial de cálculo do concreto

$\mathrm{f}_{\mathrm{cd} 2}=$ Resistência biaxial de cálculo do concreto

$\mathrm{f}_{\mathrm{ck}}=$ Resistência característica do concreto à compressão

$\mathrm{f}_{\mathrm{cm}}=$ Resistência média do concreto à compressão

$\mathrm{f}_{\mathrm{ct}}=$ Resistência do concreto à tração

$\mathrm{f}_{\mathrm{cwd}}=$ Resistência da biela inclinada à compressão

$\mathrm{f}_{\text {ptk }}=$ Resistência característica da armadura ativa à tração

$\mathrm{f}_{\mathrm{pyd}}=$ Resistência de cálculo da armadura ativa à tração

$\mathrm{f}_{\text {pyk }}=$ Resistência característica da armadura ativa ao escoamento

$\mathrm{f}_{\mathrm{yd}}=$ Resistência de cálculo da armadura passiva à tração

$\mathrm{f}_{\mathrm{yk}}=$ Resistência característica da armadura passiva ao escoamento

$\mathrm{f}_{\mathrm{ywk}}=$ Resistência característica da armadura passiva transversal ao escoamento

$\mathrm{g}=\quad$ Carga permanente

$\mathrm{g}_{\mathrm{pp}}=$ Carga permanente devida ao peso próprio da viga

$\mathrm{h}=\quad$ (1) altura da seção transversal da viga

(2)espessura equivalente para o cálculo da fluência e da retração do concreto

$\mathrm{s}=\quad$ Espaçamento da armadura transversal

$\mathrm{t}=\quad$ Idade do concreto

$\mathrm{t}_{\mathrm{s}}=\quad$ Idade do concreto no início da secagem

$\mathrm{u}=\quad$ Perímetro da seção transversal da viga

$\mathrm{x}=\quad$ Altura da zona comprimida da seção transversal da viga 
$\mathrm{y}=\quad$ Distância do centro de gravidade da viga à fibra mais externa

$\mathrm{y}_{\mathrm{h}}=$ Distância do centro de gravidade da seção homogeneizada da viga à fibra mais externa

$\mathrm{y}_{\mathrm{p}}=$ Distância do centro da armadura ativa ao centro de gravidade da viga

$z_{p}=\quad$ Braço de alavanca em relação à armadura ativa

\section{Letras romanas maiúsculas}

$\mathrm{A}_{\mathrm{c}}=\quad$ Área da seção transversal de concreto

$\mathrm{A}_{\mathrm{cc}}=\quad$ Área do bloco comprimido de concreto

$\mathrm{A}_{\mathrm{h}}=\quad$ Área da seção homogeneizada de concreto

$\mathrm{A}_{\mathrm{p}}=\quad$ Área da armadura ativa

$\mathrm{A}_{\mathrm{sw}}=\quad$ Área da armadura passiva transversal

$\mathrm{E}_{\mathrm{c}}=\quad$ Módulo de elasticidade do concreto

$\mathrm{E}_{\mathrm{p}}=\quad$ Módulo de elasticidade da armadura ativa

$\mathrm{I}=\mathrm{I}_{\mathrm{c}}=\quad$ Momento de inércia da seção de concreto

$\mathrm{I}_{\mathrm{h}}=\quad$ Momento de inércia da seção homogeneizada de concreto

$\mathrm{L}=\quad$ Vão livre da viga

$\mathrm{L}_{\text {pista }}=\quad$ Comprimento da pista de protensão

$\mathrm{M}_{\mathrm{d}}=\quad$ Momento fletor de cálculo

$\mathrm{M}_{\mathrm{g}}=\quad$ Momento fletor devido às cargas permanentes

$\mathrm{M}_{\mathrm{Q}}=\quad$ Momento fletor devido às cargas variáveis

$\mathrm{M}_{\mathrm{u}}=\quad$ Momento fletor último resistente da seção

$\mathrm{N}_{\mathrm{sd}}=\quad$ Força axial de cálculo

$\mathrm{P}=\quad$ Força externa variável aplicada

$\mathrm{P}_{0}=\quad$ Força de protensão após as perdas imediatas

$\mathrm{P}_{\infty}=\quad$ Força de protensão após todas as perdas

$\mathrm{P}_{\mathrm{a}}=\quad$ Força de protensão ancorada

$\mathrm{P}_{\mathrm{i}}=\quad$ Força de protensão máxima inicial

$\mathrm{Q}=\quad$ Carga variável

$\mathrm{R}_{\mathrm{ccd}}=\quad$ Força resultante de compressão

$\mathrm{R}_{\mathrm{g}}=\quad$ Reação nos apoios devida às cargas permanentes

$\mathrm{RH}=\mathrm{U}=$ Umidade ambiente

$\mathrm{R}_{\mathrm{Q}}=\quad$ Reação nos apoios devida às cargas variáveis

$\mathrm{R}_{\mathrm{ptd}}=\quad$ Força resultante de tração

$\mathrm{T}=\quad$ Temperatura

$\mathrm{V}_{\mathrm{ccd}}=\quad$ Componente vertical da força da biela comprimida

$\mathrm{V}_{\mathrm{f}}=\quad$ Volume de fibras

$\mathrm{V}_{\mathrm{fd}}=\quad$ Componente vertical da força de atrito numa fissura 
$\mathrm{V}_{\mathrm{k}}=\quad$ Força cortante característica

$\mathrm{V}_{\mathrm{pd}}=\quad$ Componente vertical da força da armadura ativa

$\mathrm{V}_{\mathrm{Rd}}=\quad$ Força de cálculo resistente ao cisalhamento

$\mathrm{V}_{\mathrm{sd}}=\quad$ Força de cálculo solicitante de cisalhamento

$\mathrm{V}_{\mathrm{sw}}=\quad$ Força cortante resistida pela armadura passiva transversal

$\mathrm{V}_{\text {swd }}=\quad$ Força cortante de cálculo resistida pela armadura passiva transversal

\section{Letras gregas minúsculas}

$\alpha_{p}=\quad$ Relação entre $E_{p}$ e $E_{c}$

$\delta=\quad$ Valor do escorregamento da armadura ativa na ancoragem

$\varepsilon=\quad$ Deformação específica

$\varepsilon_{\mathrm{cs}}\left(\mathrm{t}, \mathrm{t}_{\mathrm{s}}\right)=$ Deformação específica de retração do concreto

$\varepsilon_{\mathrm{cu}}=\quad$ Deformação última de compressão do concreto

$\varepsilon_{\mathrm{pd}}=\quad$ Alongamento total de cálculo da armadura ativa

$\varepsilon_{\text {pnd }}=\quad$ Pré-alongamento de cálculo da armadura ativa

$\gamma_{\mathrm{c}}=\quad$ Massa específica do concreto

$\phi=\quad$ Diâmetro da armadura passiva

$\phi_{\mathrm{p}}=\quad$ Diâmetro da armadura ativa

$\phi\left(t, t_{0}\right)=$ Coeficiente de fluência do concreto

$\Psi_{1000}=\quad$ Coeficiente de relaxação da armadura ativa após 1000 horas

$\Psi\left(\mathrm{t}-\mathrm{t}_{0}\right)=$ Coeficiente de relaxação da armadura ativa

$\rho_{\mathrm{w}}=\quad$ Taxa geométrica de armadura transversal

$\sigma_{\mathrm{c}}=\quad$ Tensão no concreto

$\sigma_{\mathrm{cw}}=\quad$ Tensão de compressão na alma da viga

$\sigma_{\mathrm{g}}=\quad$ Tensão normal devido às cargas permanentes

$\sigma_{\mathrm{p}}=\quad$ Tensão na armadura ativa

$\sigma_{\mathrm{p} 0}=\quad$ Tensão na armadura ativa correspondente a $\mathrm{P}_{0}$

$\sigma_{\mathrm{p} \infty}=\quad$ Tensão na armadura ativa após todas as perdas

$\sigma_{\mathrm{pd}}=\quad$ Tensão de cálculo na armadura ativa

$\sigma_{\mathrm{pi}}=\quad$ Tensão na armadura ativa imediatamente após a aplicação da protensão

$\sigma_{\mathrm{Q}}=\quad$ Tensão normal devido às cargas variáveis

$\sigma_{\mathrm{xd}}=\quad$ Tensão axial de cálculo

\section{Letras gregas maiúsculas}

$\Delta \mathrm{P}=\quad$ Perdas de protensão relativas às forças

$\Delta \mathrm{P}_{\mathrm{anc}}=$ Perda de protensão por escorregamento dos fios na ancoragem

$\Delta \mathrm{P}_{\mathrm{csi}}=$ Perda de protensão por retração inicial do concreto 
$\Delta \mathrm{P}_{\mathrm{e}}=$ Perda de protensão por encurtamento imediato do concreto

$\Delta \mathrm{P}_{\mathrm{ri}}=$ Perda de protensão por relaxação inicial da armadura ativa

$\Delta \sigma_{\mathrm{p}}=$ Perdas de protensão relativas às tensões

$\Delta \sigma_{\mathrm{pr}}=$ Perda de protensão por relaxação da armadura ativa

$\Theta=\quad$ Ângulo da biela de compressão em relação ao eixo da viga

A Figura B.1 apresenta o modelo para as vigas, e a Tabela B.1 apresenta os dados adotados para o cálculo.

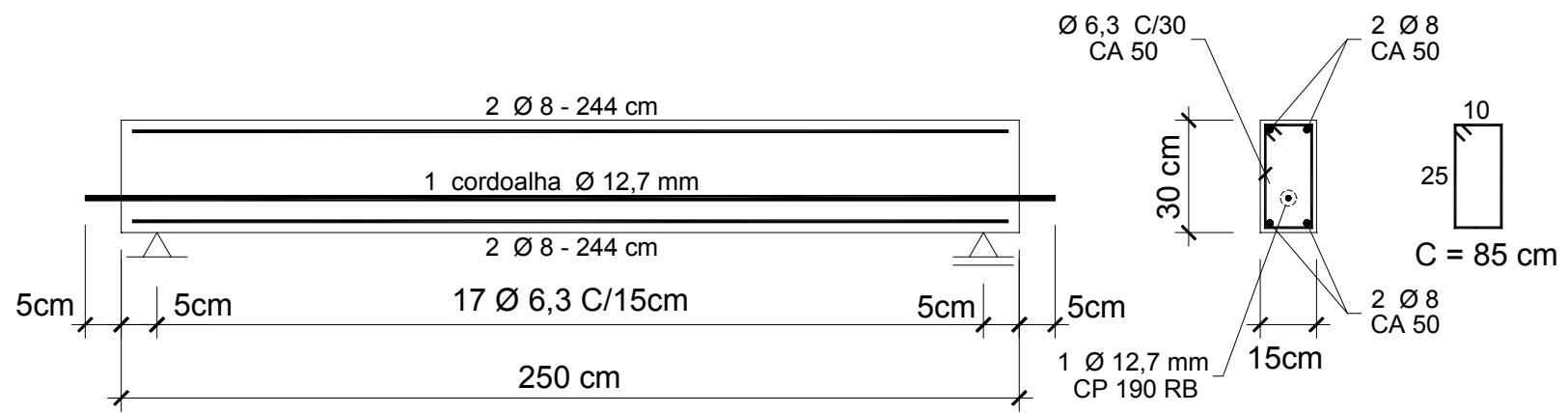

Figura B.1 - Modelo das vigas pré-tracionadas.

Tabela B.1 - Dados para o cálculo das vigas pré-tracionadas.

\begin{tabular}{l|l|l}
\hline $\mathrm{f}_{\mathrm{c}, \text { transf }}=50 \mathrm{MPa}$ & CA 50A (armaduras passivas) & $\mathrm{f}_{\mathrm{pyk}}=1710 \mathrm{MPa}$ \\
\hline $\mathrm{f}_{\mathrm{c}}=65 \mathrm{MPa}$ & $\mathrm{f}_{\mathrm{ywk}}=500 \mathrm{MPa}$ & $\mathrm{E}_{\mathrm{p}}=204.000 \mathrm{MPa}$ \\
\hline$\gamma_{\mathrm{c}}=25 \mathrm{kN} / \mathrm{m}^{3}$ & AÇO CP 190 RB (cordoalhas) & $\mathrm{A}_{\mathrm{p}}=100,3 \mathrm{~mm}^{2}$ \\
\hline $\mathrm{V}_{\mathrm{f}}=0 \mathrm{~kg} / \mathrm{m}^{3}$ & $\mathrm{f}_{\mathrm{ptk}}=1900 \mathrm{MPa}$ & $\phi_{\mathrm{p}}=12,7 \mathrm{~mm}$ \\
\hline $\mathrm{f}_{\mathrm{ct}}=4,1 \mathrm{MPa}$ & $\mathrm{E}_{\mathrm{c}}=39.000 \mathrm{MPa}$ \\
\hline
\end{tabular}

A Figura B.2 apresenta o sistema estático para as vigas.

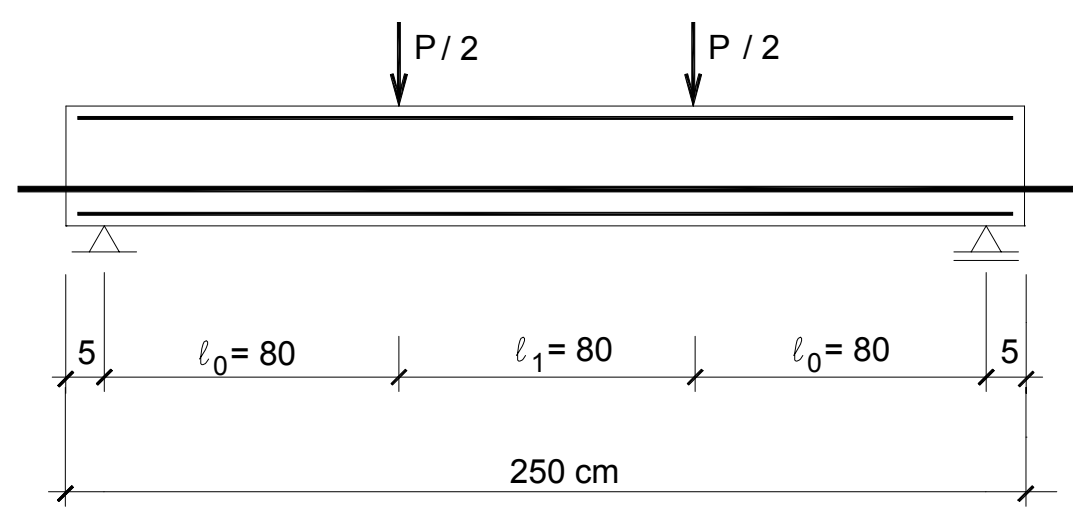

SEÇÃO TRANSVERSAL

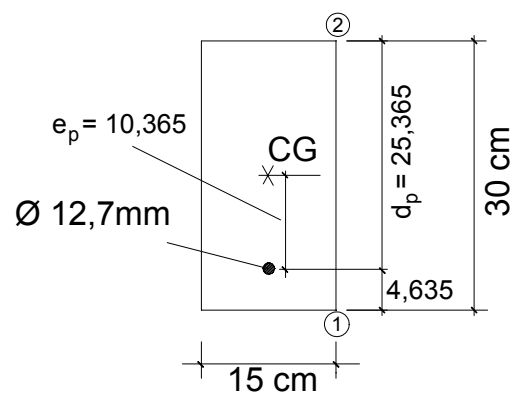

Figura B.2 - Sistema estático para as vigas pré-tracionadas.

A seguir são apresentados os cálculos para as propriedades geométricas das vigas. 


$$
\begin{array}{lr}
\mathrm{A}_{\mathrm{c}}=0,15 \cdot 0,30=0,045 \mathrm{~m}^{2} & \mathrm{I}=\frac{0,15 \cdot 0,30^{3}}{12}=0,0003375 \mathrm{~m}^{4} \\
\mathrm{y}_{1}=\mathrm{y}_{2}=0,15 \mathrm{~m} & \mathrm{w}_{1}=\mathrm{w}_{2}=\frac{0,0003375}{0,15}=0,00225 \mathrm{~m}^{3}
\end{array}
$$

Peso próprio da viga $=\mathrm{g}_{\mathrm{pp}}=0,15 \cdot 0,30.25=1,125 \mathrm{kN} / \mathrm{m}$

Admitindo uma tensão máxima na cordoalha de $\sigma_{\mathrm{pi}}=0,80 \mathrm{f}_{\mathrm{ptk}}$, segundo recomendação da FIB Bulletin 1 (1999), tem-se que:

$$
\begin{aligned}
& \sigma_{\mathrm{pi}}=0,80.1900=1520 \mathrm{MPa} \\
& \mathrm{P}_{\mathrm{i}}=\sigma_{\mathrm{pi}} \cdot \mathrm{A}_{\mathrm{p}}=1520.100,3 \times 10^{-3}=152,5 \mathrm{kN}
\end{aligned}
$$

Será adotado $\mathrm{P}_{\mathrm{i}}=150 \mathrm{kN}$. Tem-se, portanto:

$$
\sigma_{p i}=\frac{P_{i}}{A_{p}}=\frac{150}{100,3} \times 10^{3}=1495,5 \mathrm{MPa}
$$

A seguir são apresentados os cálculos para as perdas de protensão. Para o cálculo das perdas imediatas, tem-se que:

$$
\mathrm{P}_{0}=\mathrm{P}_{\mathrm{i}}-\Delta \mathrm{P}_{\mathrm{anc}}-\Delta \mathrm{P}_{\mathrm{ri}}-\Delta \mathrm{P}_{\mathrm{csi}}-\Delta \mathrm{P}_{\mathrm{e}}
$$

\section{Cálculo da perda por escorregamento dos fios na ancoragem $\left(\Delta \mathbf{P}_{\text {anc }}\right)$}

Adotando-se $\delta=5 \mathrm{~mm}$ para o deslizamento da armadura, segundo informação do fabricante.

$$
\begin{aligned}
& \varepsilon_{\text {anc }}=\frac{\delta}{L_{\text {pista }}}=\frac{5}{7250}=0,00069=0,069 \% \\
& \Delta \sigma_{\mathrm{P}_{\text {anc }}}=\mathrm{E}_{\mathrm{p}} \cdot \varepsilon_{\text {anc }}=204000.0 .00069=140,7 \mathrm{MPa} \\
& \frac{\Delta \mathrm{P}_{\text {anc }}}{\mathrm{P}_{\mathrm{i}}}=\frac{\Delta \sigma_{\mathrm{P}_{\text {anc }}}}{\sigma_{\mathrm{P}_{\mathrm{i}}}}=\frac{140,7}{1495,5}=0,094=9,4 \% \\
& \Delta \mathrm{P}_{\mathrm{anc}}=0,094.150=14,11 \mathrm{kN}
\end{aligned}
$$

\section{Cálculo da perda por relaxação inicial da armadura $\left(\Delta \mathbf{P}_{\mathrm{ri}}\right)$}

$$
\Psi_{\left(\mathrm{t}-\mathrm{t}_{0}\right)}=\frac{\Delta \sigma_{\mathrm{P}_{\mathrm{r}}}\left(\mathrm{t}, \mathrm{t}_{0}\right)}{\sigma_{\mathrm{P}_{\mathrm{i}}}} \quad \frac{\sigma_{\mathrm{P}_{\mathrm{i}}}}{\mathrm{f}_{\mathrm{ptk}}}=\frac{1495,5}{1900}=0,787
$$

Pelo gráfico da Figura 2.3.3 do Código Modelo (1990), tem-se que:

$$
\begin{aligned}
\sigma_{\mathrm{P}_{\mathrm{i}}}=0,8 \mathrm{f}_{\mathrm{ptk}} & \mapsto \Psi_{1000}=5,0 \% \\
\sigma_{\mathrm{P}_{\mathrm{i}}}=0,7 \mathrm{f}_{\mathrm{ptk}} & \mapsto \Psi_{1000}=2,0 \%
\end{aligned}
$$

Interpolando-se para os valores de cálculo:

$$
\frac{0,8-0,7}{5-2}=\frac{0,8-0,787}{5-\Psi_{1000}} \quad \therefore \quad \Psi_{1000}=4,61 \%
$$


Substituindo-se na equação para a relaxação, e adotando-se $\left(\mathrm{t}-\mathrm{t}_{0}\right)=72$ horas, tem-se:

$$
\begin{gathered}
\Psi_{\left(\mathrm{t}, \mathrm{t}_{0}\right)}=\Psi_{1000}\left(\frac{\mathrm{t}-\mathrm{t}_{0}}{1000}\right)^{0,19}=4,61\left(\frac{72}{1000}\right)^{0,19}=2,80 \% \\
\frac{\Delta \sigma_{\mathrm{P}_{\mathrm{ri}}}}{\sigma_{\mathrm{P}_{\mathrm{i}}}}=\frac{\Delta \mathrm{P}_{\mathrm{ri}}}{\mathrm{P}_{\mathrm{i}}}=2,80 \%
\end{gathered}
$$

\section{Cálculo da perda por retração inicial do concreto $\left(\Delta \mathbf{P}_{\text {csi }}\right)$}

Adotar-se-á $\Delta \mathrm{P}_{\text {csi }}=0$, pois o procedimento de cura das vigas começou pouco tempo após a concretagem, e foi mantido até a data de retirada da protensão, que ocorreu 72 horas depois.

\section{Cálculo da perda por encurtamento imediato do concreto $\left(\Delta \mathbf{P}_{\mathbf{e}}\right)$}

A Figura B.3 apresenta a seção homogeneizada de concreto. Da Tabela 2.1 da FIP Recommendations (1999), tem-se que para $\mathrm{f}_{\mathrm{c}, \text { transf }}=50 \mathrm{MPa}$ o módulo de elasticidade vale $\mathrm{E}_{\mathrm{c}, \text { transf }}=38,5 \mathrm{GPa}$.

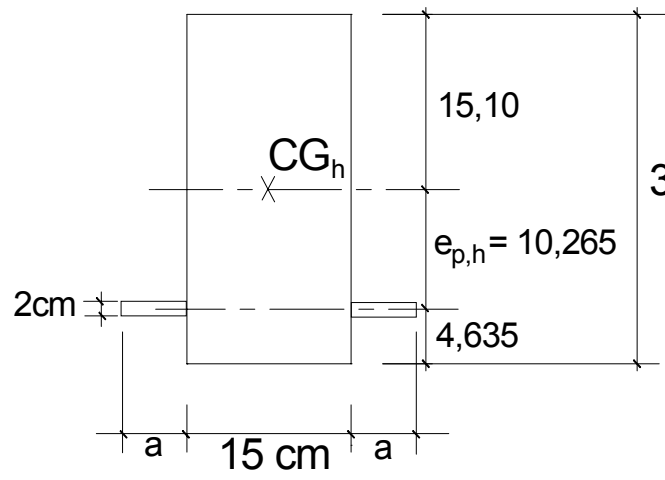

Figura B.3 - Seção homogeneizada de concreto.

$$
\mathrm{E}_{\mathrm{c}_{\text {transf }}}=38,5 \mathrm{GPa}
$$

$30 \mathrm{~cm} \quad \alpha_{p_{\text {transf }}}=\frac{E_{p}}{E_{c_{\text {transf }}}}=\frac{204000}{38500}=5,30$

$$
\mathrm{A}_{\mathrm{c}, \text { equivalente }}=\mathrm{A}_{\mathrm{p}} \cdot \alpha_{\mathrm{p}_{\text {trans }}}=100,3 \cdot 5,30
$$

$\mathrm{A}_{\mathrm{c}, \text { equivalente }}=531,5 \mathrm{~mm}^{2}$

$$
\mathrm{A}_{\mathrm{c}, \mathrm{extra}}=531,5-100,3=431,2 \mathrm{~mm}^{2}
$$

$\mathrm{a}=\frac{431,2}{2} \cdot \frac{1}{20}=10,78 \mathrm{~mm}=0,01078 \mathrm{~m}$

$$
\begin{aligned}
& \mathrm{A}_{\mathrm{h}}=0,15 \cdot 0,30+2 \cdot 0,02 \cdot 0,01078=0,04543 \mathrm{~m}^{2} \\
& \mathrm{y}_{\mathrm{h}_{1}}=\frac{0,15 \cdot 0,30 \cdot 0,15+2 \cdot 0,02 \cdot 0,01078 \cdot 0,04635}{0,04543}=0,1490 \mathrm{~m} \quad \mathrm{y}_{\mathrm{h}_{2}}=0,1510 \mathrm{~m} \\
& \mathrm{I}_{\mathrm{h}}=\frac{0,15 \cdot 0,3^{3}}{12}+0,15 \cdot 0,3 \cdot 0,001^{2}+2\left[\frac{0,01078 \cdot 0,02^{3}}{12}+0,01078 \cdot 0,02 \cdot 0,10265^{2}\right] \\
& \mathrm{I}_{\mathrm{h}}=0,0003421 \mathrm{~m}^{4} \\
& \mathrm{P}_{\mathrm{a}}=\mathrm{P}_{\mathrm{i}}-\Delta \mathrm{P}_{\mathrm{anc}}-\Delta \mathrm{P}_{\mathrm{ri}}=150-14,11-4,20=131,69 \mathrm{kN} \\
& \sigma_{\mathrm{c}, \mathrm{P}_{\mathrm{a}}}=\frac{\mathrm{P}_{\mathrm{a}}}{\mathrm{A}_{\mathrm{h}}}+\frac{\mathrm{P}_{\mathrm{a}} \cdot \mathrm{e}_{\mathrm{p}, \mathrm{h}}^{2}}{\mathrm{I}_{\mathrm{h}}}=\frac{131,69}{0,04543}+\frac{131,69 \cdot 0,10265^{2}}{0,0003421}=6954,9 \mathrm{kN} / \mathrm{m}^{2} \\
& \Delta \sigma_{\mathrm{P}_{\mathrm{e}}}=\varepsilon_{\mathrm{c}, \mathrm{P}_{\mathrm{a}}} \cdot \mathrm{E}_{\mathrm{p}}=\frac{\sigma_{\mathrm{c}, \mathrm{P}_{\mathrm{a}}}}{\mathrm{E}_{\mathrm{c}}} \cdot \mathrm{E}_{\mathrm{p}}=\sigma_{\mathrm{c}, \mathrm{P}_{\mathrm{a}}} \cdot \alpha_{\mathrm{p}_{\text {transf }}}=6954,9 \cdot 5,30=36,86 \mathrm{MPa}
\end{aligned}
$$




$$
\frac{\Delta \mathrm{P}_{\mathrm{e}}}{\mathrm{P}_{\mathrm{i}}}=\frac{\Delta \sigma_{\mathrm{P}_{\mathrm{e}}}}{\sigma_{\mathrm{p}_{\mathrm{i}}}}=\frac{36,86}{1495,5}=0,025=2,5 \% \quad \Delta \mathrm{P}_{\mathrm{e}}=3,79 \mathrm{MPa}
$$

\section{Cálculo de $\mathbf{P}_{0}$}

$$
\begin{aligned}
& \mathrm{P}_{0}=150-14,11-4,20-0-3,79=127,90 \mathrm{kN} \\
& \Delta \mathrm{P}_{0}=14,70 \% \quad \sigma_{\mathrm{P}_{0}}=\frac{\mathrm{P}_{0}}{\mathrm{~A}_{\mathrm{p}}}=\frac{127,9}{100,3} \times 10^{3}=1275,17 \mathrm{MPa}
\end{aligned}
$$

\section{Verificação da tensão na armadura, ao término da protensão}

$$
\sigma_{\mathrm{P}_{0}}=1276 \mathrm{MPa} \leq 0,75 \mathrm{f}_{\mathrm{ptk}}=1425 \mathrm{MPa} \text { OK }
$$

\section{Cálculo da fluência e da retração do concreto}

Admitiu-se uma umidade relativa do ar de $\mathrm{U}=75 \%$, uma temperatura média de $22^{\circ} \mathrm{C}$ e um tempo de $\mathrm{t}=28$ dias. O cálculo pelo Código Modelo (1990) admite umidades relativas do ar entre $40 \%$ e $100 \%$, temperaturas médias entre $5^{\circ} \mathrm{C}$ e $30^{\circ} \mathrm{C}$, e resistências do concreto à compressão entre $12 \mathrm{MPa}$ e $80 \mathrm{MPa}$. Logo, os parâmetros desta pesquisa se enquadram dentro dos limites admitidos pelo Código. A seguir são apresentados alguns valores característicos dados pelo Código, para o cálculo dos coeficientes de fluência e retração.

$$
\begin{aligned}
& \mathrm{h}=\frac{2 \mathrm{~A}_{\mathrm{c}}}{\mathrm{u}}=\frac{2.15 .30}{2(15+30)}=10 \mathrm{~cm}=100 \mathrm{~mm} \quad \mathrm{f}_{\mathrm{cm}}=65 \mathrm{MPa} \quad \mathrm{f}_{\mathrm{cm} 0}=10 \mathrm{MPa} \\
& \begin{array}{llll}
\mathrm{RH}=75 \% & \mathrm{RH}_{0}=100 \% & \mathrm{~h}_{0}=100 \mathrm{~mm} & \mathrm{t}_{1}=\mathrm{t}_{1, \mathrm{~T}}=1 \text { dia } \\
\mathrm{t}=28 \text { dias } & \Delta \mathrm{t}_{\mathrm{i}}=25 \text { dias } & \mathrm{t}_{\mathrm{s}}=3 \text { dias } & \alpha=1 \text { (cimento ARI) } \\
\mathrm{T}\left(\Delta \mathrm{t}_{\mathrm{i}}\right)=22^{\circ} \mathrm{C} & \mathrm{T}_{0}=1{ }^{\circ} \mathrm{C} & \beta_{\mathrm{sc}}=8 \text { (cimento ARI) } &
\end{array}
\end{aligned}
$$

Admitindo-se os valores apresentados acima, para o cálculo do coeficiente de fluência tem-se:

$$
\begin{aligned}
& \phi\left(\mathrm{t}, \mathrm{t}_{0}\right)=\phi_{0} \cdot \beta_{\mathrm{c}}\left(\mathrm{t}-\mathrm{t}_{0}\right)=2,274 \cdot 0,417=0,948 \\
& \phi_{0}=\phi_{\mathrm{RH}} \cdot \beta\left(\mathrm{f}_{\mathrm{cm}}\right) \cdot \beta\left(\mathrm{t}_{0}\right)=1,543 \cdot 2,079 \cdot 0,709=2,274 \\
& \phi_{\mathrm{RH}}=1+\frac{1-\mathrm{RH} / \mathrm{RH}_{0}}{0,46\left(\mathrm{~h} / \mathrm{h}_{0}\right)^{1 / 3}}=1+\frac{1-75 / 100}{0,46(100 / 100)^{1 / 3}}=1,543 \\
& \beta\left(\mathrm{f}_{\mathrm{cm}}\right)=\frac{5,3}{\left(\mathrm{f}_{\mathrm{cm}} / \mathrm{f}_{\mathrm{cmo}}\right)^{1 / 2}}=\frac{5,3}{(65 / 10)^{1 / 2}}=2,079 \\
& \beta\left(\mathrm{t}_{0}\right)=\frac{1}{0,1+\left(\mathrm{t}_{0} / \mathrm{t}_{1}\right)^{0,2}}=\frac{1}{0,1+(3,87 / 1)^{0,2}}=0,709 \\
& \mathrm{t}_{0}=\mathrm{t}_{0, \mathrm{~T}}\left[\frac{9}{2+\left(\mathrm{t}_{0, \mathrm{~T}}+\mathrm{t}_{1, \mathrm{~T}}\right)^{1,2}}+1\right]^{\alpha}=1,34\left[\frac{9}{2+(1,34+1)^{1,2}}+1\right]^{1}=3,87 \text { dias } \geq 0,5 \text { dias }
\end{aligned}
$$




$$
\begin{gathered}
\mathrm{t}_{0, \mathrm{~T}}=\Delta \mathrm{t}_{\mathrm{i}}\left[13,65-\frac{4000}{273+\mathrm{T}\left(\Delta \mathrm{t}_{\mathrm{i}}\right) / \mathrm{T}_{0}}\right]=25^{\left[13,65-\frac{4000}{273+(22 / 1)}\right]}=1,34 \\
\beta_{\mathrm{c}}\left(\mathrm{t}-\mathrm{t}_{0}\right)=\left[\frac{\left(\mathrm{t}-\mathrm{t}_{0}\right) / \mathrm{t}_{1}}{\beta_{\mathrm{H}}+\left(\mathrm{t}-\mathrm{t}_{0}\right) / \mathrm{t}_{1}}\right]^{0,3}=\left[\frac{(28-3,87) / 1}{422,5+(28-3,87) / 1}\right]^{0,3}=0,417 \\
\beta_{\mathrm{H}}=150\left\{1+\left(1,2 \frac{\mathrm{RH}}{\mathrm{RH}}\right)^{18}\right\} \frac{\mathrm{h}}{\mathrm{h}_{0}}+250=150\left\{1+\left(1,2 \frac{75}{100}\right)^{18}\right\} \frac{100}{100}+250=422,5 \leq 1500
\end{gathered}
$$

Admitindo-se os valores apresentados anteriormente, para o cálculo da retração tem-se:

$$
\begin{aligned}
& \varepsilon_{\mathrm{cs}}\left(\mathrm{t}, \mathrm{t}_{\mathrm{s}}\right)=\varepsilon_{\mathrm{cs} 0} \cdot \beta_{\mathrm{s}}\left(\mathrm{t}-\mathrm{t}_{\mathrm{s}}\right)=-0,000323 \cdot 0,258=-0,000083 \\
& \varepsilon_{\mathrm{cs} 0}=\varepsilon_{\mathrm{s}}\left(\mathrm{f}_{\mathrm{cm}}\right) \cdot \beta_{\mathrm{RH}}=0,00036 \cdot(-0,896)=-0,000323 \\
& \varepsilon_{\mathrm{s}}\left(\mathrm{f}_{\mathrm{cm}}\right)=\left[160+10 \beta_{\mathrm{sc}}\left(9-\mathrm{f}_{\mathrm{cm}} / \mathrm{f}_{\mathrm{cm} 0}\right)\right] \times 10^{-6}=[160+10.8(9-65 / 10)] \times 10^{-6}=0,00036 \\
& \beta_{\mathrm{RH}}=-1,55 \beta_{\mathrm{sRH}}=-1,55 \cdot 0,578=-0,896 \quad(40 \% \leq \mathrm{RH} \leq 99 \%) \\
& \beta_{\mathrm{sRH}}=1-\left(\frac{\mathrm{RH}}{\mathrm{RH}}\right)^{3}=1-\left(\frac{75}{100}\right)^{3}=0,578 \\
& \beta_{\mathrm{s}}\left(\mathrm{t}-\mathrm{t}_{\mathrm{s}}\right)=\left[\frac{\left(\mathrm{t}-\mathrm{t}_{\mathrm{s}}\right) / \mathrm{t}_{1}}{350\left(\mathrm{~h} / \mathrm{h}_{0}\right)^{2}+\left(\mathrm{t}-\mathrm{t}_{\mathrm{s}}\right) / \mathrm{t}_{1}}\right]^{0,5}=\left[\frac{(28-3) / 1}{350(100 / 100)^{2}+(28-3) / 1}\right]^{0,5}=0,258
\end{aligned}
$$

\section{Cálculo da relaxação da armadura}

Segundo a FIB Recommendations (1999), na ausência de informações mais precisas, o valor final da perda por relaxação da armadura para uma tensão de $\sigma_{\mathrm{p} 0}=0,7 \mathrm{f}_{\mathrm{ptk}}$ pode ser adotada como $\left(\Delta \sigma_{\mathrm{Pr}, \text { total }} / \sigma_{\mathrm{Pi}}\right)=6 \%$, para os aços de baixa relaxação $(\mathrm{RB})$. Tem-se, então:

$$
\begin{aligned}
& \sigma_{\mathrm{P} 0}=1275 \mathrm{MPa} \quad \therefore \quad \frac{\sigma_{\mathrm{P} 0}}{\mathrm{f}_{\mathrm{ptk}}}=\frac{1275}{1900}=0,67 \quad \text { OK } \\
& \frac{\Delta \sigma_{\mathrm{Pr}, \text { total }}}{\sigma_{\mathrm{Pi}}}=6 \% \quad \therefore \quad \Delta \sigma_{\mathrm{Pr}, \text { total }}=\frac{6}{100} 1495,5=89,73 \mathrm{MPa} \\
& \Delta \sigma_{\mathrm{Pr}}=\Delta \sigma_{\mathrm{Pr}, \text { total }}-\Delta \sigma_{\mathrm{Pri}}=\frac{(6-2,8)}{100} 1495,5=47,86 \mathrm{MPa}
\end{aligned}
$$

\section{Cálculo das perdas progressivas}

$$
\begin{aligned}
& \mathrm{E}_{\mathrm{c}}=39000 \mathrm{MPa} \quad \alpha_{\mathrm{p}}=\frac{204000}{39000}=5,2 \quad \chi=0,8 \text { (perdas progressivas) } \\
& \left(\sigma_{\mathrm{cg}}+\sigma_{\mathrm{cP} 0}\right)=\sigma_{\mathrm{c}, \mathrm{P}_{\mathrm{og}}}=\frac{\mathrm{P}_{0}}{\mathrm{~A}_{\mathrm{h}}}+\frac{\mathrm{P}_{0} \mathrm{e}_{\mathrm{p}, \mathrm{h}}^{2}}{\mathrm{I}_{\mathrm{h}}}-\frac{\mathrm{M}_{\mathrm{g}} \mathrm{e}_{\mathrm{p}, \mathrm{h}}}{\mathrm{I}_{\mathrm{h}}} \quad \mathrm{M}_{\mathrm{g}}=\frac{1,125.2,4^{2}}{8}=0,81 \mathrm{kN} \cdot \mathrm{m} \\
& \sigma_{\mathrm{c}, \mathrm{P}_{\mathrm{og}}}=\frac{127,9}{0,04543}+\frac{127,9 \cdot 0,10265^{2}}{0,0003421}-\frac{0,81.0,10265}{0,0003421}=6511,7 \mathrm{kN} / \mathrm{m}^{2}=6,51 \mathrm{MPa}
\end{aligned}
$$




$$
\begin{aligned}
& \Delta \sigma_{\mathrm{p}}=\frac{\alpha_{\mathrm{p}} \cdot \phi\left(\mathrm{t}, \mathrm{t}_{0}\right)\left(\sigma_{\mathrm{cg}}+\sigma_{\mathrm{cP} 0}\right)+\mathrm{E}_{\mathrm{p}} \cdot \varepsilon_{\mathrm{cs}}+0,8 \Delta \sigma_{\mathrm{pr}}}{1+\alpha_{\mathrm{p}} \frac{\mathrm{A}_{\mathrm{p}}}{\mathrm{A}_{\mathrm{c}}}\left(1+\alpha_{\mathrm{p}} \frac{\mathrm{A}_{\mathrm{c}} \cdot \mathrm{y}_{\mathrm{p}}^{2}}{\mathrm{I}_{\mathrm{c}}}\right)\left(1+\chi \cdot \phi\left(\mathrm{t}, \mathrm{t}_{0}\right)\right)} \\
& \Delta \sigma_{\mathrm{p}}=\frac{5,2 \cdot 0,948 \cdot(-6,51)+204000 \cdot(-0,000083)+0,8 \cdot(-47,86)}{1+5,2\left(\frac{100,3}{45000}\right)\left(1+5,2 \frac{0,045 \cdot 0,10365^{2}}{0,0003375}\right)(1+0,8 \cdot 0,948)}=-74,49 \mathrm{MPa} \\
& \frac{\Delta \sigma_{\mathrm{p}}}{\sigma_{\mathrm{pi}}}=\frac{74,49}{1495,5}=5,0 \% \\
& \sigma_{\mathrm{P}_{\infty}}=\sigma_{\mathrm{P}_{0}}-\Delta \sigma_{\mathrm{P}}\left(\mathrm{t}, \mathrm{t}_{0}\right)=1275,17-74,49=1200,68 \mathrm{MPa} \\
& \mathrm{P}_{\infty}=\sigma_{\mathrm{P}_{\infty}} \cdot \mathrm{A}_{\mathrm{p}}=1200,68 \cdot 100,3 \times 10^{-3}=120,43 \mathrm{kN}
\end{aligned}
$$

\section{Verificação das tensões normais no concreto, para o estado em vazio}

A seguir são apresentados os cálculos para as tensões devido às forças de protensão nas faces inferior (1) e superior (2) da seção transversal da viga.

$$
\begin{aligned}
& \sigma_{1 \mathrm{P}_{0}}=\frac{127,9}{0,045}+\frac{127,9 \cdot 0,10365}{0,00225}=8734,1 \mathrm{kN} / \mathrm{m}^{2} \\
& \sigma_{2 \mathrm{P}_{0}}=\frac{127,9}{0,045}-\frac{127,9 \cdot 0,10365}{0,00225}=-3049,7 \mathrm{kN} / \mathrm{m}^{2} \\
& \sigma_{1 \mathrm{P}_{\infty}}=\frac{120,43}{0,045}+\frac{120,43 \cdot 0,10365}{0,00225}=8224,0 \mathrm{kN} / \mathrm{m}^{2} \\
& \sigma_{2 \mathrm{P}_{\infty}}=\frac{120,43}{0,045}-\frac{120,43 \cdot 0,10365}{0,00225}=-2871,6 \mathrm{kN} / \mathrm{m}^{2}
\end{aligned}
$$

Os valores para as tensões limites, de compressão e de tração, no concreto, são apresentados a seguir.

$$
\begin{aligned}
& 0,7 \mathrm{f}_{\mathrm{c}, \text { transf }}=0,7 \cdot 50=35 \mathrm{MPa}=35000 \mathrm{kN} / \mathrm{m}^{2} \\
& 0,7 \mathrm{f}_{\mathrm{c}}=0,7 \cdot 65=45,5 \mathrm{MPa}=45500 \mathrm{kN} / \mathrm{m}^{2} \\
& \mathrm{f}_{\mathrm{ct} \text {,transf }}=0,7 \cdot 0,3 \sqrt[3]{50^{2}}=2,85 \mathrm{MPa}=2850 \mathrm{kN} / \mathrm{m}^{2} \\
& \mathrm{f}_{\mathrm{ct}}=4,1 \mathrm{MPa}=4100 \mathrm{kN} / \mathrm{m}^{2} \\
& 1,5 \mathrm{f}_{\mathrm{ct} \text { transf }}=1,5 \cdot 2,85=4,28 \mathrm{MPa}=4280 \mathrm{kN} / \mathrm{m}^{2} \quad \text { [Seção re tan gular] } \\
& 1,5 \mathrm{f}_{\mathrm{ct}}=1,5 \cdot 4,1=6,15 \mathrm{MPa}=6150 \mathrm{kN} / \mathrm{m}^{2}
\end{aligned}
$$

a)Verificação no meio do vão para $\left(g+P_{0}\right)$

$$
\sigma_{1 \mathrm{~g}}=\sigma_{2 \mathrm{~g}}=\frac{\mathrm{M}_{\mathrm{g}}}{\mathrm{w}}=\frac{0,81}{0,00225}=360 \mathrm{kN} / \mathrm{m}^{2}=0,36 \mathrm{MPa}
$$




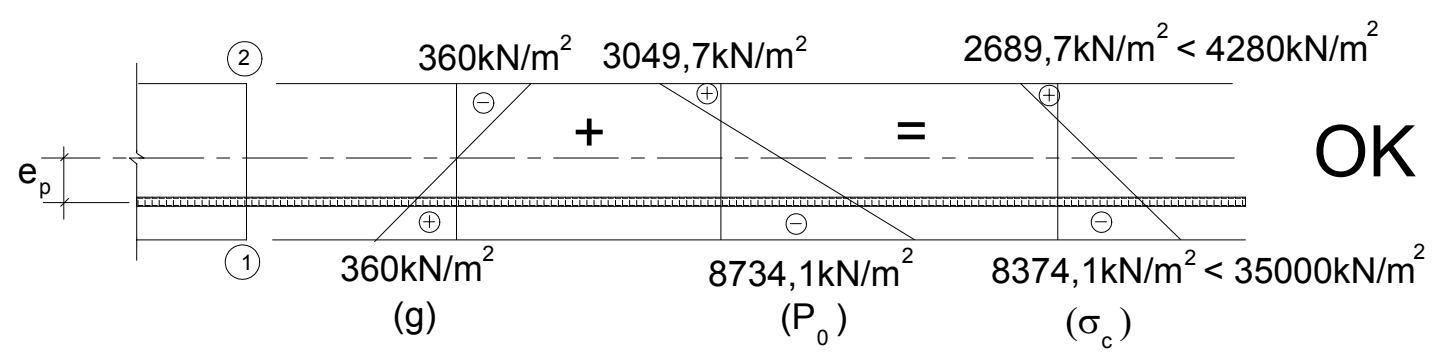

b) Verificação sobre os apoios para $\left(\mathrm{g}+\mathrm{P}_{0}\right)$

Nos apoios g=0, o que não faz muita diferença nos resultados. OK

c)Verificação no meio do vão para $\left(\mathrm{g}+\mathrm{P}_{\infty}\right)$

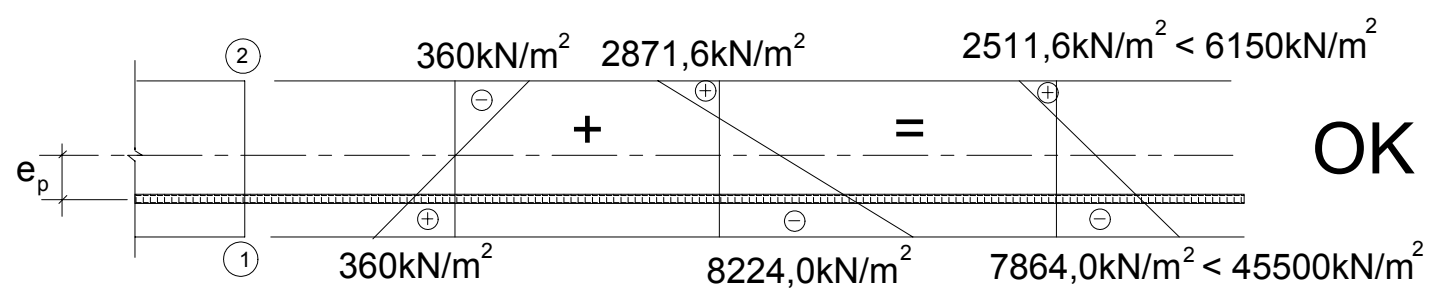

$(\mathrm{g}) \quad\left(\mathrm{P}_{\infty}\right) \quad\left(\sigma_{\mathrm{c}}\right)$

d) Verificação sobre os apoios para $\left(g+P_{\infty}\right)$

Nos apoios g=0, o que não faz muita diferença nos resultados. OK

\section{Cálculo para o Estado Limite Último - solicitações normais}

No cálculo da capacidade resistente da viga, não será levado em conta a contribuição das armaduras passivas longitudinais. Para o cálculo do pré-alongamento da armadura, temse:

$$
\begin{aligned}
& \sigma_{\text {cp }}=\frac{\mathrm{P}_{\infty}}{\mathrm{A}_{\mathrm{c}}}+\frac{\mathrm{P}_{\infty} \cdot \mathrm{e}_{\mathrm{p}}^{2}}{\mathrm{I}}=\frac{120,43}{0,045}+\frac{120,43 \cdot 0,10365^{2}}{0,0003375}=6509,8 \mathrm{kN} / \mathrm{m}^{2} \\
& \mathrm{P}_{\mathrm{nd}}=0,9\left[\mathrm{P}_{\infty}+\alpha_{\mathrm{p}} \cdot \mathrm{A}_{\mathrm{p}} \cdot \sigma_{\mathrm{cp}}\right]=0,9\left[120,43+5,2 \cdot 100,3 \cdot 6509,8 \times 10^{-6}\right]=111,4 \mathrm{kN} \\
& \varepsilon_{\text {Pnd }}=\frac{\mathrm{P}_{\mathrm{nd}}}{\mathrm{A}_{\mathrm{p}} \cdot \mathrm{E}_{\mathrm{p}}}=\frac{111,4}{100,3 \cdot 204}=0,0054=5,4 \%
\end{aligned}
$$

A FIB Bulletin 1 (1999) admite os seguintes valores para as tensão de compressão e deformação última do concreto, para um diagrama de compressão retangular:

$$
\begin{aligned}
& \mathrm{f}_{\mathrm{cd} 1}=0,85\left[1-\frac{\mathrm{f}_{\mathrm{ck}}}{250}\right] \mathrm{f}_{\mathrm{cd}}=0,85\left[1-\frac{65}{250}\right] \frac{65}{1,5}=27,26 \mathrm{MPa} \\
& \varepsilon_{\mathrm{cu}}=0,004-0,002 \frac{\mathrm{f}_{\mathrm{ck}}}{100}=0,004-0,002 \frac{65}{100}=2,7 \% 0
\end{aligned}
$$

Admitindo-se uma tensão na armadura de $\sigma_{\mathrm{Pd}, \text { arb }}=\mathrm{f}_{\text {pyd }}=1710 / 1,15=1487 \mathrm{MPa}$, montamse as seguintes equações de equilíbrio e compatibilidade: 


$$
\begin{aligned}
& \mathrm{R}_{\mathrm{ccd}}=\mathrm{R}_{\mathrm{ptd}} \\
& \mathrm{R}_{\mathrm{ptd}}=\mathrm{A}_{\mathrm{p}} \cdot \sigma_{\mathrm{pd}, \mathrm{arb}}=100,3.1487 \times 10^{-3}=149,15 \mathrm{kN} \\
& \mathrm{R}_{\mathrm{ccd}}=\mathrm{f}_{\mathrm{cd} 1} \cdot \mathrm{A}_{\mathrm{cc}}=149,15 \quad \therefore \quad \mathrm{A}_{\mathrm{cc}}=0,0052 \mathrm{~m}^{2}
\end{aligned}
$$

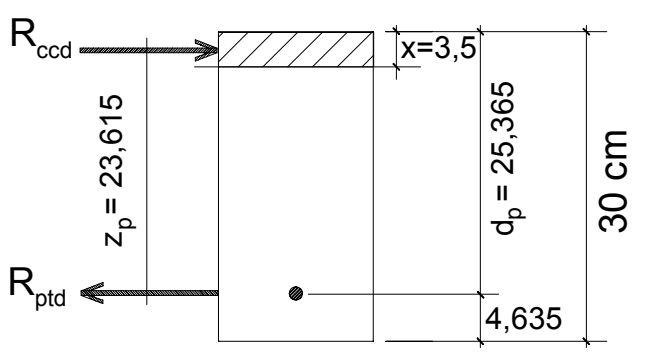

$15 \mathrm{~cm}$
$\mathrm{A}_{\mathrm{cc}}=\mathrm{b}_{\mathrm{w}} \cdot \mathrm{x}$

$\mathrm{x}=\frac{0,0052}{0,15}=0,035 \mathrm{~m}$

$\varepsilon_{\mathrm{pld}}=\frac{\varepsilon_{\mathrm{cu}}\left(\mathrm{d}_{\mathrm{p}}-\mathrm{x}\right)}{\mathrm{x}}=\frac{2,7(25,365-3,5)}{3,5}$

$\varepsilon_{\mathrm{pld}}=16,87 \%$

$\varepsilon_{\mathrm{pd}}=\varepsilon_{\mathrm{pld}}+\varepsilon_{\mathrm{pnd}}=5,4+16,87=22,27 \%$

Logo, a armadura se encontra em escoamento. OK

Para o cálculo do momento máximo da viga, tem-se:

$$
\begin{aligned}
& M_{u}=R_{c c d} \cdot z_{p}=149,15 \cdot 0,23615=35,22 k N . m \\
& M_{u} \geq M_{d}=M_{g}+M_{Q} \\
& M_{Q, \text { máx }}=M_{u}-M_{g, \text { máx }}=35,22-0,81=34,41 k N . m
\end{aligned}
$$

A Figura B.4 apresenta o sistema estático e diagrama de momento para o carregamento variável da viga.

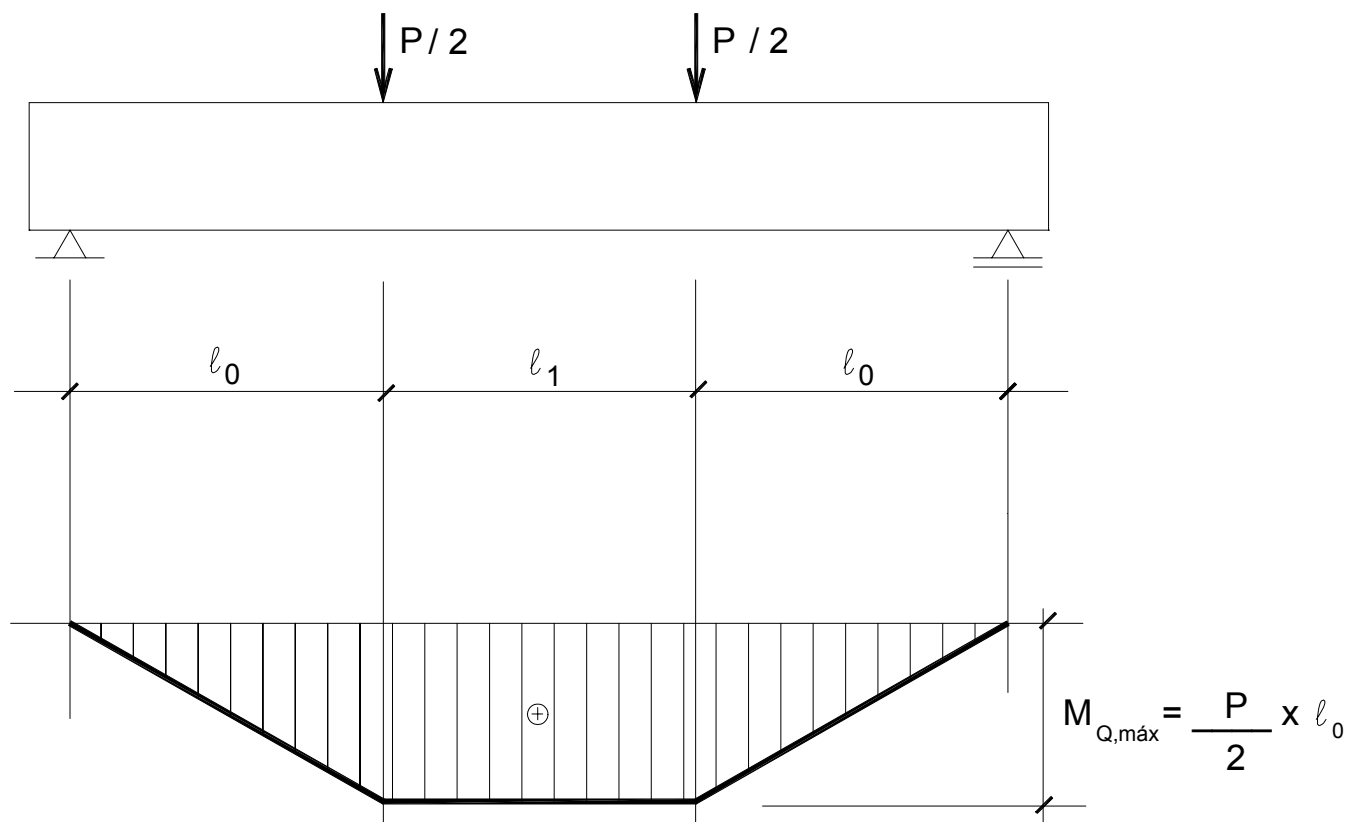

Figura B.4 - Sistema estático e diagrama de momento para o carregamento variável.

Para $\ell_{0}=\mathrm{L} / 3=0,80 \mathrm{~m}$, tem-se:

$$
\frac{\mathrm{P}}{2} \cdot 0,8=34,41 \quad \therefore \quad \mathrm{P}_{\text {máx }}=\frac{34,41 \cdot 2}{0,8}=85,3 \mathrm{kN}
$$


Da mesma forma, para $l_{0}=\mathrm{L} / 4=0,60 \mathrm{~m}$, tem-se $\mathrm{P}_{\text {máx }}=114,7 \mathrm{kN}$, para $l_{0}=\mathrm{L} / 5=0,48 \mathrm{~m}$, temse $\mathrm{P}_{\text {máx }}=143,4 \mathrm{kN}$ e, para $l_{0}=\mathrm{L} / 6=0,40 \mathrm{~m}$, tem-se $\mathrm{P}_{\text {máx }}=172,1 \mathrm{kN}$.

Verificação das tensões normais no concreto, levando em conta o carregamento variável

a) No meio do vão para $\left(g+Q+P_{\infty}\right)$

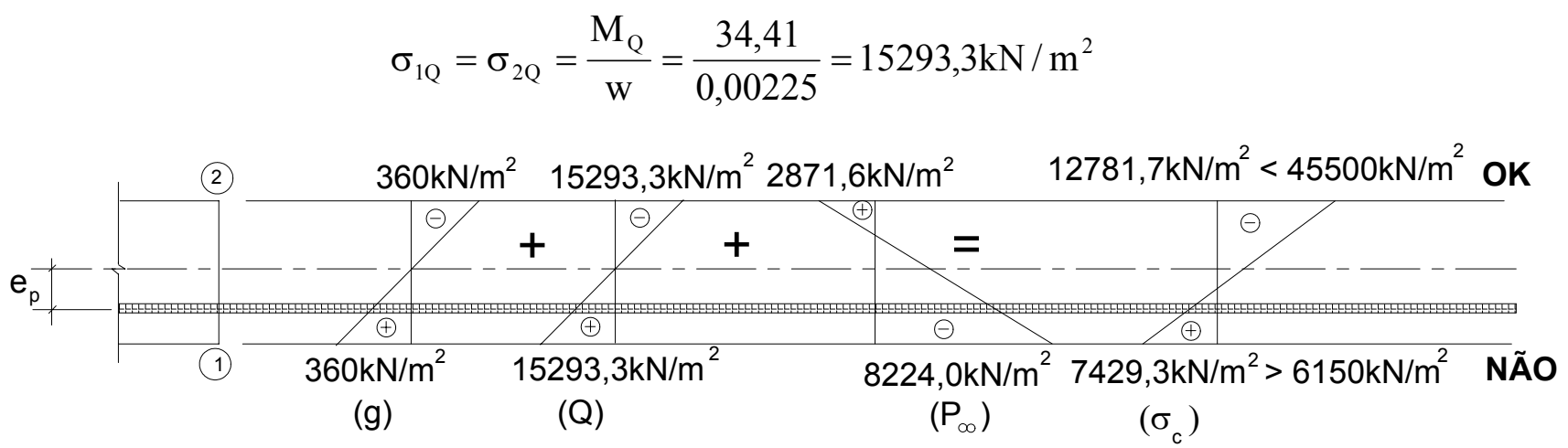

A carga estimada de início de fissuração será:

$$
\begin{aligned}
& \sigma_{2 \mathrm{~g}}+\sigma_{2 \mathrm{Q}, \mathrm{fiss}}-\sigma_{2 \mathrm{P}_{\infty}}=1,5 \mathrm{f}_{\mathrm{ct}} \\
& \sigma_{2 \mathrm{Q} \text {,fiss }}=6150+8224,0-360=14014 \mathrm{kN} / \mathrm{m}^{2} \\
& \mathrm{M}_{\mathrm{Q}, \mathrm{fiss}}=14014.0,00225=31,53 \mathrm{kN} \cdot \mathrm{m}
\end{aligned}
$$

Para os diversos $l_{0}$, tem-se:

$$
\begin{aligned}
& \mathrm{P}_{\text {fiss }, \mathrm{L} / 3}=\frac{31,53 \cdot 2}{0,8}=78,83 \mathrm{kN} \\
& \mathrm{P}_{\text {fiss } \mathrm{L} / 4}=\frac{31,53 \cdot 2}{0,6}=105,10 \mathrm{kN} \\
& \mathrm{P}_{\text {fiss }, \mathrm{L} / 5}=\frac{31,53 \cdot 2}{0,48}=131,38 \mathrm{kN} \\
& \mathrm{P}_{\text {fiss }, \mathrm{L} / 6}=\frac{31,53 \cdot 2}{0,4}=157,65 \mathrm{kN}
\end{aligned}
$$

b) Sobre os apoios para $\left(\mathrm{g}+\mathrm{Q}+\mathrm{P}_{\infty}\right)$

Sobre os apoios $\sigma_{\mathrm{g}}=\sigma_{\mathrm{Q}}=0$, logo, as seções estão dentro dos limites de segurança.

\section{Cálculo para o Estado Limite Último - solicitações tangenciais pela FIB Bulletin 1} (1999)

Para o cálculo, admitiu-se a hipótese de que o cortante foi resistido apenas pela armadura transversal e pelo concreto. Para o valor máximo encontrado de $\mathrm{P}=172,1 \mathrm{kN}$ ( $\left.l_{0}=\mathrm{L} / 6=0,40 \mathrm{~m}\right)$, a uma distância $\mathrm{h} / 2$ do apoio, o valor do esforço cortante de cálculo é: 


$$
\begin{aligned}
& \mathrm{R}_{\mathrm{g}}=\frac{1,125 \cdot 2,5}{2}=1,41 \mathrm{kN} \quad \mathrm{R}_{\mathrm{Q}}=\frac{172,1}{2}=86,05 \mathrm{kN} \\
& \mathrm{V}_{\mathrm{k}}=[1,41-1,125 \cdot 0,15]+86,05=87,29 \mathrm{kN} \\
& \mathrm{V}_{\mathrm{sd}}=1,4 \cdot 87,29=122,2 \mathrm{kN}
\end{aligned}
$$

Segundo o Código, tem-se que:

$$
\begin{aligned}
& \mathrm{V}_{\mathrm{Rd}} \geq \mathrm{V}_{\mathrm{sd}} \\
& \mathrm{V}_{\mathrm{Rd} \text {,web }}=\mathrm{V}_{\text {swd }}+\mathrm{V}_{\mathrm{fd}} \geq \mathrm{V}_{\text {sd,web }}=\mathrm{V}_{\mathrm{sd}}-\mathrm{V}_{\mathrm{Pd}}-\mathrm{V}_{\mathrm{ccd}} \\
& \mathrm{V}_{\mathrm{Pd}}=\mathrm{V}_{\text {ccd }}=0 \quad \therefore \quad \mathrm{V}_{\mathrm{swd}}=\mathrm{V}_{\mathrm{sd}}-\mathrm{V}_{\mathrm{fd}}
\end{aligned}
$$

$\mathrm{V}_{\mathrm{fd}}=0,1\left(1-\frac{\cot \beta_{\mathrm{r}}}{4}\right) \cdot\left(\mathrm{b}_{\mathrm{w}} \cdot \mathrm{z}_{\mathrm{p}} \cdot \mathrm{f}_{\mathrm{cwd}}\right) \geq 0$

$\mathrm{f}_{\mathrm{cwd}}=0,8 \cdot \mathrm{f}_{\mathrm{cd} 1}=0,8\left[0,85\left(1-\frac{\mathrm{f}_{\mathrm{ck}}}{250}\right) \mathrm{f}_{\mathrm{cd}}\right]=0,8 \cdot 0,85\left(1-\frac{65}{250}\right) \frac{65}{1,5}=21,81 \mathrm{MPa}$

$\cot \beta_{\mathrm{r}}=1,2+0,2 \frac{\sigma_{\mathrm{xd}}}{\mathrm{f}_{\mathrm{ctm}}}=1,2+0,2\left[\frac{\mathrm{N}_{\mathrm{sd}}}{\mathrm{A}_{\mathrm{c}}} \cdot \frac{1}{\mathrm{f}_{\mathrm{ctm}}}\right]=1,2+0,2\left[\frac{120,43 \cdot 1,4}{0,045} \cdot \frac{1}{4,1.10^{3}}\right]=1,383$

$\mathrm{V}_{\mathrm{fd}}=0,1\left(1-\frac{1,383}{4}\right)\left(0,15.0,23615.21,81 \times 10^{3}\right)=50,55 \mathrm{kN} \quad \therefore \quad \mathrm{V}_{\mathrm{swd}}=122,2-50,55=71,65 \mathrm{kN}$

A verificação da compressão diagonal do concreto, é feita pela determinação do ângulo $(\Theta)$ da biela de compressão, que pode variar entre $18,4^{\circ}$ e $45^{\circ}$, e pela verificação da tensão de compressão na biela, como se segue:

$$
\cot \Theta=\frac{\cot \beta_{\mathrm{r}}}{1-\frac{\mathrm{V}_{\mathrm{fd}}}{\mathrm{V}_{\mathrm{sd}, \mathrm{web}}}}=\frac{1,383}{1-\frac{50,55}{122,2}}=2,36 \quad \therefore \quad \Theta=23,0^{\circ} \quad \text { OK }
$$

Como, $\Theta_{\min }=18,4^{\circ} \leq \Theta=23,0^{\circ} \leq \Theta_{\operatorname{máx}}=45^{\circ}$, a verificação em relação ao ângulo da biela comprimida está satisfeita. A tensão na biela é dada por:

$$
\begin{aligned}
& \sigma_{\mathrm{cw}}=\frac{\mathrm{V}_{\text {sd,web }}}{\mathrm{b}_{\mathrm{w}} \cdot \mathrm{z}_{\mathrm{p}}} \cdot \frac{1}{\cos \Theta \cdot \operatorname{sen} \Theta} \leq \mathrm{f}_{\mathrm{cwd}}=v_{2} \cdot \mathrm{f}_{1 \mathrm{~cd}}=0,45 \cdot\left[0,85\left(1-\frac{\mathrm{f}_{\mathrm{ck}}}{250}\right) \mathrm{f}_{\mathrm{cd}}\right] \\
& \frac{122,2}{0,15 \cdot 0,23615} \cdot \frac{1}{\cos 23,0 \cdot \operatorname{sen} 23,0} \times 10^{-3} \leq 0,45.0,85 \cdot \frac{65}{1,5}\left(1-\frac{65}{250}\right) \\
& 9,59 \mathrm{MPa} \leq 12,27 \mathrm{MPa} \quad \text { OK }
\end{aligned}
$$

Para a determinação da armadura transversal, tem-se:

$$
\begin{aligned}
& \mathrm{V}_{\mathrm{sw}}=\frac{\mathrm{A}_{\mathrm{sw}}}{\mathrm{s}} \mathrm{f}_{\mathrm{ywd}} \cdot \mathrm{z}_{\mathrm{p}} \cdot \cot \beta_{\mathrm{r}} \\
& 71,65=\frac{\mathrm{A}_{\mathrm{sw}}}{\mathrm{s}} \frac{500 \times 10^{3}}{1,15} 0,23615.1,383
\end{aligned}
$$




$$
\begin{aligned}
& \frac{A_{s w}}{s}=0,0005046 \mathrm{~m}^{2} / \mathrm{m}=5,046 \mathrm{~cm}^{2} / \mathrm{m} \\
& \left(\frac{\mathrm{A}_{\mathrm{sw}}}{\mathrm{s}}\right)_{\min }=\rho_{\mathrm{w}, \min } \cdot \mathrm{b}_{\mathrm{w}}=\frac{0,06 \sqrt[3]{\mathrm{f}_{\mathrm{ck}}^{2}}}{\mathrm{f}_{\mathrm{yd}}} \cdot \mathrm{b}_{\mathrm{w}}=\frac{0,06 \sqrt[3]{65^{2}} \cdot 1,15}{500} \cdot 0,15=0,00034 \mathrm{~m}^{2} / \mathrm{m} \\
& \frac{\mathrm{A}_{\mathrm{sw}}}{\mathrm{s}}=5,046 \mathrm{~cm}^{2} / \mathrm{m} \mapsto\left\{\begin{array}{l}
\phi 5 \rightarrow \mathrm{s}=8 \mathrm{~cm} \\
\phi 6,3 \rightarrow \mathrm{s}=12 \mathrm{~cm} \\
\phi 8 \rightarrow \mathrm{s}=20 \mathrm{~cm}
\end{array}\right.
\end{aligned}
$$

Foi escolhida a armadura transversal de $(\phi 6,3 \mathrm{c} .15 \mathrm{~cm})$ para todas as vigas. Para todos os cálculos acima, foram utilizados os coeficientes de majoração das cargas e minoração das resistências. Se, nos cálculos para $l_{0}=\mathrm{L} / 6$, não forem utilizados os coeficientes de segurança, a armadura transversal determinada é, também, $(\phi 6,3$ c. $15 \mathrm{~cm})$.

A Tabela B.2 apresenta os resultados dos cálculos da armadura transversal para os diversos $\ell_{0}$.

Tabela B.2 - Armaduras transversais para os diversos $l_{0}$.

\begin{tabular}{|c|c|c|c|c|}
\hline$l_{0}$ & $\mathrm{~L} / 3(0,80 \mathrm{~m})$ & $\mathrm{L} / 4(0,60 \mathrm{~m})$ & $\mathrm{L} / 5(0,48 \mathrm{~m})$ & $\mathrm{L} / 6(0,40 \mathrm{~m})$ \\
\hline Armadura transversal & $\phi 6,3 \mathrm{c} .18 \mathrm{~cm}$ & $\phi 6,3 \mathrm{c} .18 \mathrm{~cm}$ & $\phi 6,3 \mathrm{c} .15 \mathrm{~cm}$ & $\phi 6,3 \mathrm{c} .12 \mathrm{~cm}$ \\
\hline
\end{tabular}




\section{APÊNDICE C}

CÁLCULO DOS COMPRIMENTOS DE ANCORAGEM SEGUNDO AS

PRESCRIÇÕES NORMATIVAS 
Foram calculados os comprimentos de ancoragem segundo a NBR 6118 (2001), o Código Modelo CEB-FIP (1990) e a FIB Bulletin 1 (1999), e o ACI 318 (2002). A simbologia utilizada neste apêndice está listada a seguir. Note-se que, alguns símbolos diferentes representam a mesma variável, pois as diversas prescrições apresentam simbologia diferente.

\section{Letras romanas minúsculas}

$\mathrm{b}=\quad$ Largura da alma da viga

$\mathrm{d}=\quad$ Altura útil em relação à armadura passiva

$\mathrm{d}_{\mathrm{b}}=\quad$ Diâmetro da armadura

$\mathrm{d}_{\mathrm{p}}=\quad$ Altura útil em relação à armadura ativa

$\mathrm{f}_{\mathrm{bpd}}=\quad$ Tensão de aderência de cálculo da armadura ativa

$\mathrm{f}^{\prime}{ }_{\mathrm{c}}=\quad$ Resistência característica do concreto à compressão

$\mathrm{f}_{\mathrm{ck}}=\quad$ Resistência característica do concreto à compressão

$\mathrm{f}_{\text {ctd }}=\quad$ Valor de cálculo da resistência do concreto à tração, obtido na idade de aplicação da protensão, para a determinação do comprimento de transferência; e na idade de 28 dias, para a determinação do comprimento de ancoragem

$\mathrm{f}_{\text {ctk,inf }}=$ Resistência característica inferior do concreto à tração

$\mathrm{f}_{\mathrm{ctm}}=\quad$ Resistência média do concreto à tração direta

$\mathrm{f}_{\mathrm{pd}}=\quad$ Resistência de cálculo da cordoalha

$\mathrm{f}_{\mathrm{ps}}=\quad$ Resistência atuante da armadura ativa à tração

$\mathrm{f}_{\text {ptd }}=\quad$ Resistência de cálculo do aço da armadura ativa à tração

$\mathrm{f}_{\mathrm{pu}}=\quad$ Resistência característica do aço da armadura ativa à tração

$\mathrm{f}_{\mathrm{pyd}}=\quad$ Limite de escoamento de cálculo da armadura de protensão

$\mathrm{f}_{\mathrm{se}}=\quad$ Tensão na armadura ativa após todas as perdas ao longo do tempo

$\mathrm{f}_{\mathrm{y}}=\quad$ Resistência característica de escoamento do aço da armadura passiva

$\ell_{b}=\quad$ Comprimento de aderência na flexão

$\ell_{\mathrm{bp}}=\quad$ Comprimento de ancoragem básico

$\ell_{\mathrm{bpd}}=\quad$ Comprimento de ancoragem necessário

$\ell_{\mathrm{bpt}}=\quad$ Comprimento de transferência

$\ell_{d}=\quad$ Comprimento de ancoragem necessário

$h_{t}=\quad$ Comprimento de transferência

\section{Letras romanas maiúsculas}

$\mathrm{A}_{\mathrm{ps}}=\quad$ Área da armadura ativa

$\mathrm{A}_{\mathrm{s}}=\quad$ Área da armadura passiva tracionada

$\mathrm{A}_{\mathrm{s}}{ }_{\mathrm{s}}=\quad$ Área da armadura passiva comprimida 


\section{Letras gregas minúsculas}

$\begin{array}{ll}\phi_{\mathrm{p}}= & \text { Diâmetro da armadura ativa } \\ \sigma_{\mathrm{p} \infty}= & \text { Tensão na armadura ativa após todas as perdas ao longo do tempo } \\ \sigma_{\mathrm{pcs}}= & \text { Tensão na armadura ativa após todas as perdas ao longo do tempo } \\ \sigma_{\mathrm{pd}}= & \text { Tensão de cálculo na armadura ativa } \\ \sigma_{\mathrm{pi}}= & \text { Tensão na armadura ativa imediatamente após a aplicação da protensão }\end{array}$

Para este trabalho, foram feitas as transformações de unidades baseadas nas seguintes relações:

- $\quad 1$ in $=2,54 \mathrm{~cm}$

- $\quad 1 \mathrm{kip}=4,45 \mathrm{kN}$

- $\quad 1$ kip.in $=0,113 \mathrm{kN} \cdot \mathrm{m}$

- $1 \mathrm{ksi}=6,895 \mathrm{MPa}$

A seguir são apresentados os cálculos para alguns valores gerais, comuns a todas as prescrições.

$$
\begin{array}{ll}
\mathrm{f}_{\mathrm{ck}}=\mathrm{f}_{\mathrm{c}}^{\prime}=65 \mathrm{MPa}=9.427 \mathrm{psi} & \begin{array}{l}
\text { (na data de ensaio) } \\
\text { (na transferência) }
\end{array} \\
\mathrm{f}_{\mathrm{c}}=50 \mathrm{MPa} & \mathrm{d}_{\mathrm{p}}=25,365 \mathrm{~cm}=9,99 \mathrm{in} \\
\phi_{\mathrm{p}}=12,7 \mathrm{~mm}=0,5 \mathrm{in} & \mathrm{f}_{\mathrm{ptd}}=\frac{\mathrm{f}_{\mathrm{ptk}}}{1,15}=\frac{1900}{1,15}=1.652,2 \mathrm{MPa} \\
\mathrm{f}_{\mathrm{pu}}=\mathrm{f}_{\mathrm{ptk}}=1.900 \mathrm{MPa}=275.562 \mathrm{psi} & \\
\mathrm{f}_{\mathrm{pyd}}=\frac{0,9 . \mathrm{f}_{\mathrm{ptk}}}{1,15}=\frac{0,9.1 .900}{1,15}=1.487 \mathrm{MPa} & \sigma_{\mathrm{pi}}=1.495,5 \mathrm{MPa} \\
\sigma_{\mathrm{p} \infty}=\sigma_{\mathrm{pcs}}=\mathrm{f}_{\mathrm{se}}=1.200,68 \mathrm{MPa}=174.138 \mathrm{psi} & \sigma_{\mathrm{pd}} \leq \mathrm{f}_{\mathrm{pd}}=\mathrm{f}_{\mathrm{ptd}}=1.652,2 \mathrm{MPa}
\end{array}
$$

\section{C.1. NBR 6118 (2001)}

Para a NBR 6118 (2001), tem-se que:

$$
\begin{array}{ll}
\ell_{\mathrm{bp}}=\frac{7 \cdot \phi_{\mathrm{p}}}{36} \cdot \frac{\mathrm{f}_{\mathrm{pyd}}}{\mathrm{f}_{\mathrm{bpd}}} & \mathrm{f}_{\mathrm{bpd}}=\eta_{\mathrm{p} 1} \cdot \eta_{\mathrm{p} 2} \cdot \mathrm{f}_{\mathrm{ctd}} \\
\mathrm{f}_{\mathrm{ctd}}=\frac{\mathrm{f}_{\mathrm{ctk}, \text { inf }}}{1,4} & \mathrm{f}_{\mathrm{ctk}, \text { inf }}=0,7 \mathrm{f}_{\mathrm{ctm}}=0,7\left(0,3 \sqrt[3]{\mathrm{f}_{\mathrm{ck}}^{2}}\right)
\end{array}
$$

onde: $\eta_{\mathrm{p} 1}=1,2$ para cordoalhas de 7 fios

$$
\eta_{\mathrm{p} 2}=\left\{\begin{array}{l}
1 \text { para situações de boa aderência } \\
0,7 \text { para situações de má aderência }
\end{array}\right.
$$


Logo, na transferência de esforços:

$$
\begin{aligned}
& \mathrm{f}_{\text {ctk, inf,transf }}=0,7 \mathrm{f}_{\mathrm{ctm}}=0,7\left(0,3 \sqrt[3]{\mathrm{f}_{\mathrm{ck}}^{2}}\right)=0,7\left(0,3 \sqrt[3]{50^{2}}\right)=2,85 \mathrm{MPa} \\
& \mathrm{f}_{\mathrm{bpd}}=\eta_{\mathrm{p} 1} \cdot \eta_{\mathrm{p} 2} \cdot \mathrm{f}_{\mathrm{ctd}}=1,2 \cdot 1 \cdot\left(\frac{2,85}{1,4}\right)=2,44 \mathrm{MPa} \\
& \ell_{\mathrm{bp}}=\frac{7 \cdot \phi_{\mathrm{p}}}{36} \cdot \frac{\mathrm{f}_{\mathrm{pyd}}}{\mathrm{f}_{\mathrm{bpd}}}=\frac{7 \cdot 0,0127}{36} \cdot \frac{1487}{2,44}=1,50 \mathrm{~m} \\
& \ell_{\mathrm{bpt}}=0,5 \ell_{\mathrm{bp}} \cdot \frac{\sigma_{\mathrm{pi}}}{\mathrm{f}_{\mathrm{pyd}}}=0,5 \cdot 1,50 \cdot \frac{1495,5}{1487}=0,76 \mathrm{~m}
\end{aligned}
$$

$\mathrm{Na}$ data de ensaio, tem-se que:

$$
\begin{aligned}
& \mathrm{f}_{\mathrm{ctk}, \text { inf }}=0,7 \mathrm{f}_{\mathrm{ctm}}=0,7\left(0,3 \sqrt[3]{\mathrm{f}_{\mathrm{ck}}^{2}}\right)=0,7\left(0,3 \sqrt[3]{65^{2}}\right)=3,39 \mathrm{MPa} \\
& \mathrm{f}_{\mathrm{bpd}}=\eta_{\mathrm{p} 1} \cdot \eta_{\mathrm{p} 2} \cdot \mathrm{f}_{\mathrm{ctd}}=1,2 \cdot 1 \cdot\left(\frac{3,39}{1,4}\right)=2,91 \mathrm{MPa} \\
& \ell_{\mathrm{bp}}=\frac{7 \cdot \phi_{\mathrm{p}}}{36} \cdot \frac{\mathrm{f}_{\mathrm{pyd}}}{\mathrm{f}_{\mathrm{bpd}}}=\frac{7 \cdot 0,0127}{36} \cdot \frac{1487}{2,91}=1,26 \mathrm{~m} \\
& \ell_{\mathrm{bpd}}=\ell_{\mathrm{bpt}}+\ell_{\mathrm{bp}}\left(\frac{\mathrm{f}_{\mathrm{pyd}}-\sigma_{\mathrm{p} \infty}}{\mathrm{f}_{\mathrm{pyd}}}\right)=0,76+1,26\left(\frac{1487-1200,68}{1487}\right)=1,00 \mathrm{~m}
\end{aligned}
$$

\section{C.2. CEB-FIP (1990) e FIB Bulletin 1 (1999)}

Para o CM-90 e a Fib, tem-se que:

$$
\begin{aligned}
\ell_{\mathrm{bp}}=\frac{7 \cdot \phi}{36} \cdot \frac{\mathrm{f}_{\mathrm{ptd}}}{\mathrm{f}_{\mathrm{bpd}}} & \mathrm{f}_{\mathrm{bpd}}=\eta_{\mathrm{p} 1} \cdot \eta_{\mathrm{p} 2} \cdot \mathrm{f}_{\mathrm{ctd}} \quad \mathrm{f}_{\mathrm{ctd}}=\frac{\mathrm{f}_{\mathrm{ctk}}}{1,5} \quad \mathrm{f}_{\mathrm{ctk}}=0,7 \mathrm{f}_{\mathrm{ctm}} \\
\mathrm{f}_{\mathrm{ctm}} & =\left\{\begin{array}{lll}
0,3 \sqrt[3]{\mathrm{f}_{\mathrm{ck}}^{2}} & \text { para } & \mathrm{f}_{\mathrm{ck}} \leq 50 \mathrm{MPa} \\
1,12 \sqrt[3]{\mathrm{f}_{\mathrm{ck}}} & \text { para } & \mathrm{f}_{\mathrm{ck}}>50 \mathrm{MPa}
\end{array}\right.
\end{aligned}
$$

onde: $\eta_{\mathrm{p} 1}=1,3$ para cordoalhas de 7 fios (diferente do valor de 1,2 do CEB-FIP, 1990)

$$
\eta_{\mathrm{p} 2}=\left\{\begin{array}{l}
1 \text { para situações de boa aderência } \\
0,7 \text { para situações de má aderência }
\end{array}\right.
$$

Logo, na transferência de esforços:

$$
\begin{aligned}
& \mathrm{f}_{\text {ctk,transf }}=0,7 \mathrm{f}_{\text {ctm }}=0,7\left(0,3 \sqrt[3]{\mathrm{f}_{c k}^{2}}\right)=0,7\left(0,3 \sqrt[3]{50^{2}}\right)=2,85 \mathrm{MPa} \\
& \mathrm{f}_{\mathrm{bpd}}=\eta_{\mathrm{p} 1} \cdot \eta_{\mathrm{p} 2} \cdot \mathrm{f}_{\mathrm{ctd}}=1,3 \cdot 1 \cdot\left(\frac{2,85}{1,5}\right)=2,47 \mathrm{MPa} \\
& \ell_{\mathrm{bp}}=\frac{7 \cdot \phi_{\mathrm{p}}}{36} \cdot \frac{\mathrm{f}_{\mathrm{ptd}}}{\mathrm{f}_{\mathrm{bpd}}}=\frac{7 \cdot 0,0127}{36} \cdot \frac{1652,2}{2,47}=1,65 \mathrm{~m}
\end{aligned}
$$


$\ell_{\mathrm{bpt}}=0,5 \ell_{\mathrm{bp}} \cdot \frac{\sigma_{\mathrm{pi}}}{\mathrm{f}_{\mathrm{pd}}}=0,5 \cdot 1,65 \cdot \frac{1495,5}{1652,2}=0,75 \mathrm{~m}$

$\mathrm{Na}$ data de ensaio, tem-se que:

$$
\begin{aligned}
& \mathrm{f}_{\mathrm{ctk}, \text { inf }}=0,7 \mathrm{f}_{\mathrm{ctm}}=0,7\left(1,12 \sqrt[3]{\mathrm{f}_{\mathrm{ck}}}\right)=0,7(1,12 \sqrt[3]{65})=3,15 \mathrm{MPa} \\
& \mathrm{f}_{\mathrm{bpd}}=\eta_{\mathrm{p} 1} \cdot \eta_{\mathrm{p} 2} \cdot \mathrm{f}_{\mathrm{ctd}}=1,3 \cdot 1 \cdot\left(\frac{3,15}{1,5}\right)=2,73 \mathrm{MPa} \\
& \ell_{\mathrm{bp}}=\frac{7 \cdot \phi_{\mathrm{p}}}{36} \cdot \frac{\mathrm{f}_{\mathrm{ptd}}}{\mathrm{f}_{\mathrm{bpd}}}=\frac{7 \cdot 0,0127}{36} \cdot \frac{1652,2}{2,73}=1,49 \mathrm{~m} \\
& \ell_{\mathrm{bpd}}=\ell_{\mathrm{bpt}}+\ell_{\mathrm{bp}}\left(\frac{\sigma_{\mathrm{pd}}-\sigma_{\mathrm{pcs}}}{\mathrm{f}_{\mathrm{pd}}}\right)=0,75+1,49\left(\frac{1652,2-1200,68}{1652,2}\right)=1,16 \mathrm{~m}
\end{aligned}
$$

\section{C.3. ACI 318 (2002)}

Para o ACI 318, tem-se que:

$$
\begin{gathered}
l_{\mathrm{d}}=l_{\mathrm{t}}+\ell_{\mathrm{b}}=\overbrace{\frac{\mathrm{f}_{\mathrm{se}}}{3} \cdot \mathrm{d}_{\mathrm{b}}}^{\ell_{\mathrm{t}}}+\overbrace{\left.\mathrm{f}_{\mathrm{ps}}-\mathrm{f}_{\mathrm{se}}\right) \cdot \mathrm{d}_{\mathrm{b}}}^{l_{\mathrm{b}}}=\left(\mathrm{f}_{\mathrm{ps}}-\frac{2}{3} \mathrm{f}_{\mathrm{se}}\right) \cdot \mathrm{d}_{\mathrm{b}} \\
\mathrm{f}_{\mathrm{ps}}=\mathrm{f}_{\mathrm{pu}}\left\{1-\frac{\gamma_{\mathrm{p}}}{\beta_{1}}\left[\rho_{\mathrm{p}} \frac{\mathrm{f}_{\mathrm{pu}}}{\mathrm{f}_{\mathrm{c}}^{\prime}}+\frac{\mathrm{d}}{\mathrm{d}_{\mathrm{p}}}\left(\omega-\omega^{\prime}\right)\right]\right\} \\
\omega=\frac{\rho \cdot \mathrm{f}_{\mathrm{y}}}{\mathrm{f}_{\mathrm{c}}^{\prime}} \quad \omega^{\prime}=\frac{\rho^{\prime} \cdot \mathrm{f}_{\mathrm{y}}}{\mathrm{f}_{\mathrm{c}}^{\prime}}
\end{gathered}
$$

onde: $\gamma_{\mathrm{p}}=0,28$ para $\left(\mathrm{f}_{\mathrm{py}} / \mathrm{f}_{\mathrm{pu}}\right) \geq 0,9$

$\beta_{1}=0,65$ (coeficiente definido no item 10.2.7.3 do ACI 318, 2002)

$\rho_{\mathrm{p}}=\mathrm{A}_{\mathrm{ps}} /$ (b.d)

$\rho=A_{\mathrm{s}} /(b \cdot d)$

$\rho^{\prime}=\mathrm{A}_{\mathrm{s}}^{\prime} /(\mathrm{b} . \mathrm{d})$, (presença de armadura comprimida)

Os valores aqui utilizados são:

$$
\begin{array}{ll}
\mathrm{A}_{\mathrm{ps}}=100,3 \mathrm{~mm}^{2}=0,16 \mathrm{in}^{2} & \mathrm{~A}_{\mathrm{s}}=1,01 \mathrm{~cm}^{2}=0,16 \mathrm{in}^{2} \\
\mathrm{~b}=15 \mathrm{~cm}=5,91 \mathrm{in} & \mathrm{d}=27,1 \mathrm{~cm}=10,67 \mathrm{in}
\end{array} \quad \mathrm{f}_{\mathrm{y}}=\frac{500}{1,15} \cdot \frac{1}{0,006895}=63.058 \mathrm{psi}
$$


Logo, tem-se que:

$$
\begin{aligned}
& \omega=\frac{\rho \cdot f_{y}}{f_{c}^{\prime}}=\frac{(0,16 /(5,91 \cdot 10,67)) \cdot 63058}{9427}=0,01697 \\
& \omega^{\prime}=\frac{\rho^{\prime} \cdot f_{y}}{f_{c}^{\prime}}=0 \quad(\text { sem armadura comprimida }) \\
& f_{p s}=f_{p u}\left\{1-\frac{\gamma_{p}}{\beta_{1}}\left[\rho_{p} \frac{f_{p u}}{f_{c}^{\prime}}+\frac{d}{d_{p}}\left(\omega-\omega^{\prime}\right)\right]\right\}= \\
& f_{p s}=275562\left\{1-\frac{0,28}{0,65}\left[0,00254 \frac{275562}{9427}+\frac{10,67}{9,99}(0,01697-0)\right]\right\}= \\
& f_{p s}=275562 \cdot\{0,960\}=264597 p s i \\
& \ell_{d}=\ell_{t}+\ell_{b}=\frac{f_{s e}}{3} \cdot d_{b}+\left(f_{p s}-f_{s e}\right) \cdot d_{b}=\left(f_{p s}-\frac{2}{3} f_{s e}\right) \cdot d_{b} \\
& \ell_{t}=\frac{f_{s e}}{3} \cdot d_{b}=\frac{174,138}{3} \cdot 0,5=29,023 i n=0,74 m \\
& \ell_{d}=\left(f_{p s}-\frac{2}{3} f_{s e}\right) \cdot d_{b}=\left(264,597-\frac{2}{3} 174,138\right) \cdot 0,5=74,31 \text { in }=1,89 m
\end{aligned}
$$

O ACI 318 (2002) não calcula um valor para a tensão de aderência, mas considera um valor constante e a favor da segurança, e utiliza a equação básica para a determinação dos comprimentos de ancoragem, como está apresentada a seguir:

$$
\ell_{\mathrm{t}}=\frac{\mathrm{d}_{\mathrm{b}} \cdot \mathrm{f}_{\mathrm{se}}}{4 \cdot \mathrm{f}_{\mathrm{bpd}}} \quad \text { e } \quad \ell_{\mathrm{b}}=\frac{\mathrm{d}_{\mathrm{b}} \cdot\left(\mathrm{f}_{\mathrm{ps}}-\mathrm{f}_{\mathrm{se}}\right)}{4 \cdot \mathrm{f}_{\mathrm{bpd}}}
$$

No cálculo do comprimento de transferência, o valor da tensão de aderência é:

$$
\ell_{\mathrm{t}}=\frac{\mathrm{d}_{\mathrm{b}} \cdot \mathrm{f}_{\mathrm{se}}}{4 \cdot \mathrm{f}_{\mathrm{bpd}}}=\frac{\mathrm{f}_{\mathrm{se}}}{3} \cdot \mathrm{d}_{\mathrm{b}} \quad \therefore \quad 4 . \mathrm{f}_{\mathrm{bpd}}=3 \quad \therefore \quad \mathrm{f}_{\mathrm{bpd}}=0,75 \mathrm{ksi}=5,17 \mathrm{MPa}
$$

No cálculo do comprimento de ancoragem na flexão, o valor da tensão de aderência é:

$$
\ell_{\mathrm{b}}=\frac{\mathrm{d}_{\mathrm{b}} \cdot\left(\mathrm{f}_{\mathrm{ps}}-\mathrm{f}_{\mathrm{se}}\right)}{4 \cdot \mathrm{f}_{\mathrm{bpd}}}=\frac{\left(\mathrm{f}_{\mathrm{ps}}-\mathrm{f}_{\mathrm{se}}\right) \cdot \mathrm{d}_{\mathrm{b}}}{1} \quad \therefore \quad 4 . \mathrm{f}_{\mathrm{bpd}}=1 \quad \therefore \quad \mathrm{f}_{\mathrm{bpd}}=0,25 \mathrm{ksi}=1,72 \mathrm{MPa}
$$

\section{C.4. Resumo dos Resultados}

A Tabela C.1 apresenta o resumo dos resultados. 
Tabela C.1 - Resultados teóricos para os comprimentos de ancoragem segundo as prescrições normativas.

\begin{tabular}{|c|c|c|c|}
\hline Variável & $\begin{array}{c}\text { NBR } 6118 \\
\text { (2001) }\end{array}$ & $\begin{array}{c}\text { FIB Bulletin } \\
1 \text { (1999) }\end{array}$ & $\begin{array}{c}\text { ACI } 318 \\
\text { (2002) }\end{array}$ \\
\hline $\begin{array}{l}\text { Tensão de aderência na transferência } \\
\left(\mathrm{f}_{\mathrm{bpd}, \text { trans }}\right)(\mathrm{MPa})\end{array}$ & 2,44 & 2,47 & 5,17 \\
\hline $\begin{array}{l}\text { Tensão de aderência aos } 28 \text { dias }\left(\mathrm{f}_{\mathrm{bpd}, 28 \mathrm{~d}}\right) \\
(\mathrm{MPa})\end{array}$ & 2,91 & 2,73 & 1,72 \\
\hline Comprimento de transferência $\left(l_{\mathrm{bpt}}\right)$ (metros) & 0,76 & 0,75 & 0,74 \\
\hline $\begin{array}{l}\text { Comprimento de ancoragem necessário }\left(l_{\mathrm{bpd}}\right) \\
\text { (metros) }\end{array}$ & 1,00 & 1,16 & 1,89 \\
\hline
\end{tabular}


APÊNDICE D

CÁLCULO DO MODELO DE HARAJLI ET AL (1995) 
Este apêndice apresenta os cálculos para a determinação do modelo analítico escolhido para o estudo da tensão de aderência. A simbologia utilizada neste apêndice está listada a seguir.

\section{Letras romanas minúsculas}

$\mathrm{c}=$ Cobrimento

$\mathrm{c}_{0}=$ Distância entre as nervuras das barras

$\mathrm{d}_{\mathrm{b}}=$ Diâmetro da armadura

$\mathrm{f}_{\mathrm{c}}{ }_{\mathrm{c}}=$ Resistência característica do concreto à compressão

$\mathrm{u}=$ Tensão de aderência

$\mathrm{u}_{\mathrm{f}}=$ Tensão de aderência resistente de atrito

$\mathrm{u}_{\mathrm{fr}}=$ Tensão de aderência reduzida resistente de atrito

$\mathrm{u}_{\mathrm{ps}}=$ Tensão de aderência resistente no pós-fendilhamento

$\mathrm{u}_{\mathrm{s}}=$ Tensão de aderência resistente ao fendilhamento

\section{Letras romanas maiúsculas}

$\mathrm{S}=$ Escorregamento

\section{Letras gregas minúsculas}

$\sigma_{\mathrm{ps}}=$ Resistência à tração da matriz reforçada com fibra imediatamente após o fendilhamento $\sigma_{\mathrm{s}}=$ Resistência à tração da matriz reforçada com fibra imediatamente antes do fendilhamento

A seguir são apresentados os cálculos para a determinação do modelo de HARAJLI et al (1995).

\section{Cálculo do modelo de HARAJLI et al (1995)}

A Tabela D.1 apresenta os dados utilizados no cálculo, e a Figura D.1 apresenta o modelo.

Tabela D.1 - Dados para o cálculo do modelo de HARAJLI et al (1995).

\begin{tabular}{l|l}
\hline $\mathrm{f}_{\mathrm{c}}=68 \mathrm{MPa}=9.862,2 \mathrm{psi}$ & $\mathrm{c}_{0}=3 \mathrm{~mm}=0,12 \mathrm{in}$ \\
\hline $\mathrm{d}_{\mathrm{b}}=12,7 \mathrm{~mm}=0,5 \mathrm{in}$ & $\mathrm{c}=2,87 \mathrm{~cm}=1,13$ in \\
\hline$\sigma_{\mathrm{s}, 40}=4,50 \mathrm{MPa}=652,65 \mathrm{psi}$ & $\sigma_{\mathrm{s}, 60}=5,10 \mathrm{MPa}=739,67 \mathrm{psi}$ \\
\hline$\sigma_{\mathrm{ps}, 40}=3,20 \mathrm{MPa}=464,10 \mathrm{psi}$ & $\sigma_{\mathrm{ps}, 60}=3,11 \mathrm{MPa}=451,05 \mathrm{psi}$ \\
\hline
\end{tabular}




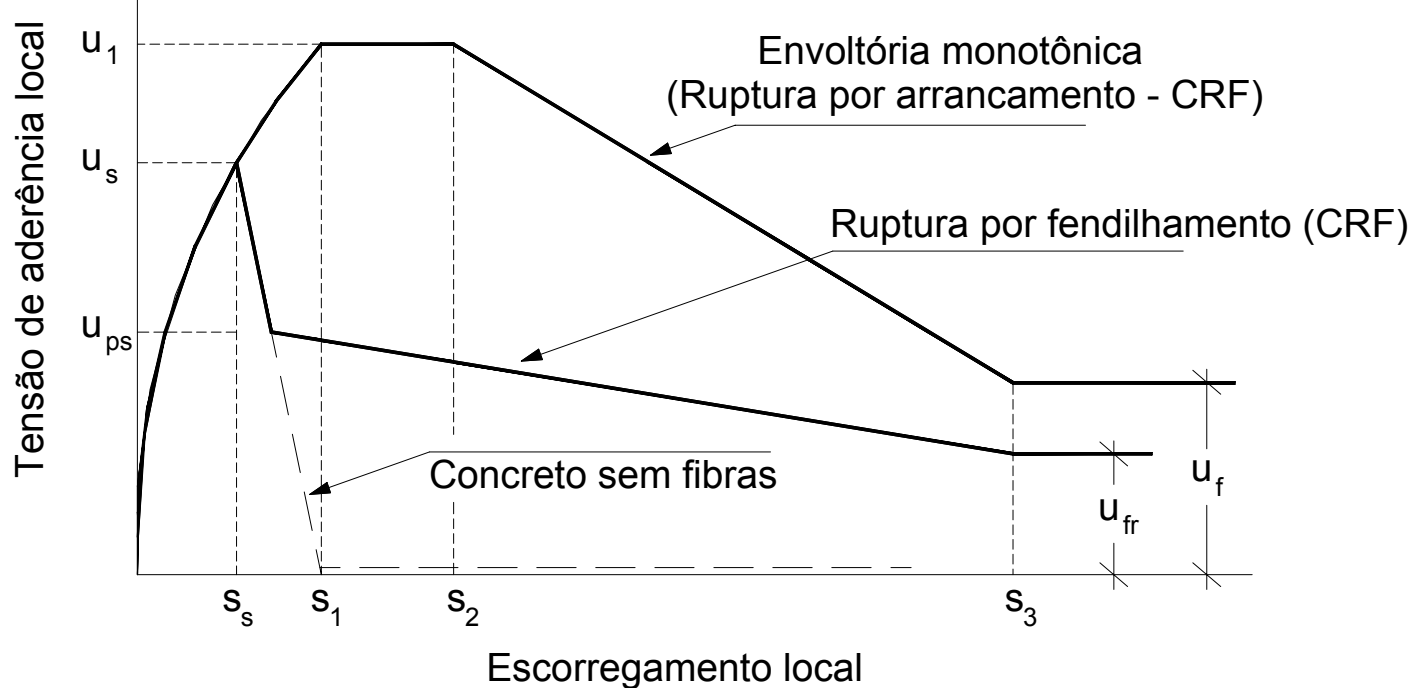

Figura D.1 - Modelo analítico proposto para a representação do comportamento Tensão de aderência local versus Escorregamento local de barras (HARAJLI et al, 1995).

Para os parâmetros de ensaio utilizados foram estabelecidos os valores para os vários pontos característicos do modelo, segundo as expressões a seguir.

$$
\begin{array}{ll}
\mathrm{u}=\mathrm{u}_{1} \cdot\left(\frac{\mathrm{S}}{\mathrm{S}_{1}}\right)^{0,3} & \mathrm{u}_{\mathrm{ps}}=\frac{2 \cdot \sigma_{\mathrm{ps}}}{\pi}\left(\frac{\mathrm{c}}{\mathrm{d}_{\mathrm{b}}}\right) \\
\mathrm{u}_{\mathrm{s}}=\frac{2 \cdot \sigma_{\mathrm{s}}}{\pi}\left(\frac{\mathrm{c}}{\mathrm{d}_{\mathrm{b}}}\right) & \mathrm{u}_{1}=31 \cdot \sqrt{\mathrm{f}_{\mathrm{c}}^{\prime}} \\
\mathrm{u}_{\mathrm{f}}=0,35 \cdot \mathrm{u}_{1}=11 \cdot \sqrt{\mathrm{f}_{\mathrm{c}}^{\prime}} & \mathrm{u}_{\mathrm{fr}}=0,3 \cdot \mathrm{u}_{\mathrm{ps}} \leq 0,35 \cdot \mathrm{u}_{1} \\
\mathrm{~S}_{\mathrm{s}}=\left(\mathrm{S}_{1}\right) \cdot \mathrm{e}^{(1 / 0,3) \cdot \ln \left(\mathrm{u}_{\mathrm{s}} / \mathrm{u}_{1}\right)} & \mathrm{S}_{1}=0,75 \cdot \mathrm{S}_{\text {máx }}=0,15 \cdot \mathrm{c}_{0} \\
\mathrm{~S}_{2}=1,75 \cdot \mathrm{S}_{\text {máx }}=0,35 \cdot \mathrm{c}_{0} & \mathrm{~S}_{3}=\mathrm{c}_{0} \quad \mathrm{~S}_{\text {máx }}=\frac{\mathrm{c}_{0}}{5}
\end{array}
$$

Montando-se o modelo para os valores adotados, tem-se que:

$$
\begin{array}{ll}
\mathrm{u}_{1}=31 \sqrt{9862,2}=3078,6 \mathrm{psi}=21,23 \mathrm{MPa} & \mathrm{u}_{\mathrm{f}}=0,35 \cdot 3078,6=1077,5 \mathrm{psi}=7,43 \mathrm{MPa} \\
\mathrm{u}_{\mathrm{s}, 40}=\frac{2.652,65}{\pi} \frac{1,13}{0,5}=939,01 \mathrm{psi}=6,46 \mathrm{MPa} & \mathrm{u}_{\mathrm{ps}, 40}=\frac{2.464,10}{\pi} \frac{1,13}{0,5}=667,73 \mathrm{psi}=4,60 \mathrm{MPa} \\
\mathrm{u}_{\mathrm{s}, 60}=\frac{2.739,67}{\pi} \frac{1,13}{0,5}=1064,20 \mathrm{psi}=7,32 \mathrm{MPa} & \mathrm{u}_{\mathrm{ps}, 60}=\frac{2.451,05}{\pi} \frac{1,13}{0,5}=648,95 \mathrm{psi}=4,47 \mathrm{MPa} \\
\mathrm{u}_{\mathrm{fr}, 40}=0,3.667,73=200,32 \mathrm{psi}=1,38 \mathrm{MPa} & \mathrm{u}_{\mathrm{fr}, 60}=0,3.648,95=194,69 \mathrm{psi}=1,34 \mathrm{MPa}
\end{array}
$$


Para os escorregamentos característicos, tem-se que:

$$
\begin{aligned}
& \mathrm{S}_{\text {máx }}=\frac{0,12}{5}=0,024 \text { in }=0,6 \mathrm{~mm} \quad \mathrm{~S}_{1}=0,15 \cdot 0,12=0,018 \mathrm{in}=0,45 \mathrm{~mm} \\
& \mathrm{~S}_{2}=0,35 \cdot 0,12=0,042 \text { in }=1,05 \mathrm{~mm} \quad \mathrm{~S}_{3}=0,12 \text { in }=3 \mathrm{~mm} \\
& \mathrm{~S}_{\mathrm{s}, 40}=0,018\left(\mathrm{e}^{(1 / 0,3) \cdot \ln (939,01 / 3078,6)}\right)=0,00034 \text { in }=0,009 \mathrm{~mm} \\
& \mathrm{~S}_{\mathrm{s}, 60}=0,018\left(\mathrm{e}^{(1 / 0,3) \cdot \ln (1064,20 / 3078,6)}\right)=0,00052 \mathrm{in}=0,013 \mathrm{~mm}
\end{aligned}
$$

Para determinar os valores da tensão de aderência ao longo da curva ascendente (entre $0 \leq \mathrm{S} \leq \mathrm{S}_{1}$ ), utiliza-se a seguinte expressão:

$$
\mathrm{u}=\mathrm{u}_{1}\left(\frac{\mathrm{S}}{\mathrm{S}_{1}}\right)^{0,3}=3078,6\left(\frac{\mathrm{S}}{0,018}\right)^{0,3}
$$

Logo, montando-se o modelo com a ajuda de uma planilha Excel, chega-se ao gráfico apresentado na Figura D.2. A Tabela D.2 apresenta a planilha excel desenvolvida.

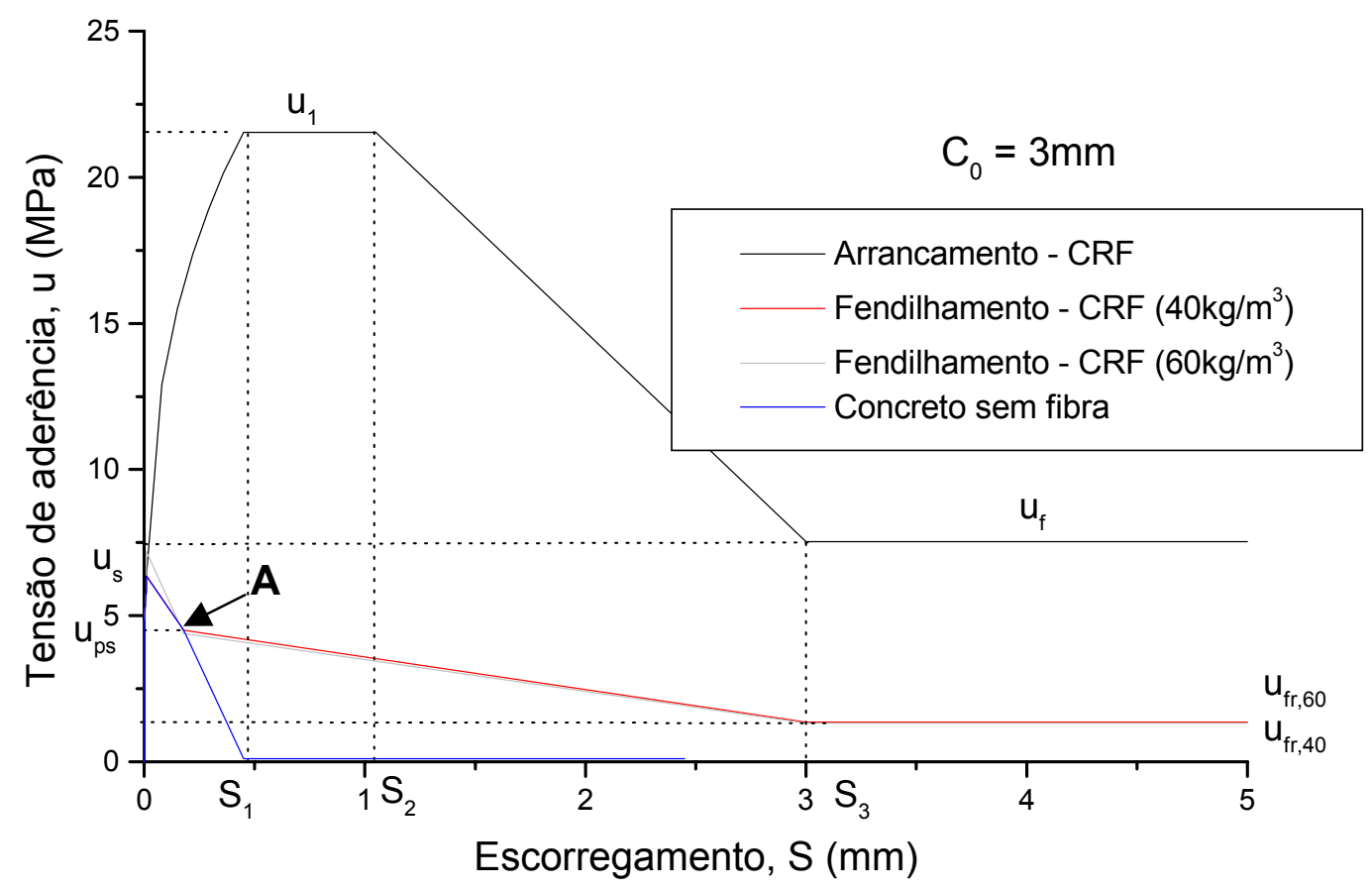

Figura D. 2 - Modelo proposto por HARAJLI et al (1995), para $\mathrm{c}_{0}=3 \mathrm{~mm}$.

A determinação do ponto $\mathbf{A}$ (indicado no gráfico), admitiu a equação de uma reta indo do ponto $\left(\mathrm{S}_{\mathrm{s}} ; \mathrm{u}_{\mathrm{s}}\right)$ até o ponto $\left(\mathrm{S}_{1} ; 0,1\right)$. Após a obtenção da equação da reta, chegava-se ao ponto $\mathbf{A}$, entrando com o valor de $\mathrm{u}_{\mathrm{ps}}$ na equação. Para os dados utilizados, obtiveram-se as seguintes equações, já no Sistema Internacional de unidades (MPa e mm):

$$
\mathrm{u}_{40}=-14,44 \mathrm{~S}+6,60 \quad \text { e } \quad \mathrm{u}_{60}=-16,57 \mathrm{~S}+7,56
$$

Os valores encontrados estão destacados em azul na planilha a seguir. 
Tabela D.2 - Planilha utilizada nos cálculos.

\begin{tabular}{|r|r|r|r|r|r|r|r|}
\hline $\begin{array}{c}\mathbf{S}_{\text {arranc }} \\
(\mathrm{mm})\end{array}$ & $\begin{array}{c}\mathbf{u}_{\text {arranc }} \\
(\mathrm{MPa})\end{array}$ & $\begin{array}{c}\mathbf{S}_{\text {fendilh,40 }} \\
(\mathrm{mm})\end{array}$ & $\begin{array}{c}\mathbf{u}_{\text {fendilh,40 }} \\
(\mathrm{MPa})\end{array}$ & $\begin{array}{c}\mathbf{S}_{\text {fendilh,60 }} \\
(\mathrm{mm})\end{array}$ & $\begin{array}{c}\mathbf{u}_{\text {fendilh,60 }} \\
(\mathrm{MPa})\end{array}$ & $\begin{array}{c}\mathbf{S}_{\mathbf{\%}} \\
(\mathrm{mm})\end{array}$ & $\begin{array}{c}\mathbf{u}_{\mathbf{0}} \\
(\mathrm{MPa})\end{array}$ \\
\hline & & & & & & & \\
\hline 0,00 & 0,00 & 0,00 & 0,00 & 0,00 & 0,00 & 0,00 & 0,00 \\
\hline 0,00 & 4,72 & 0,00 & 4,72 & 0,00 & 4,72 & 0,00 & 4,72 \\
\hline 0,01 & 5,81 & 0,01 & 5,81 & 0,01 & 5,81 & 0,01 & 5,81 \\
\hline 0,01 & 6,46 & 0,01 & 6,46 & 0,01 & 7,32 & 0,01 & 6,46 \\
\hline 0,08 & 12,74 & $\mathbf{0 , 1 4}$ & 4,59 & $\mathbf{0 , 1 9}$ & 4,47 & $\mathbf{0 , 1 4}$ & 4,59 \\
\hline 0,15 & 15,27 & 3,00 & 1,38 & 3,00 & 1,34 & 0,45 & 0,10 \\
\hline 0,22 & 17,13 & 5,00 & 1,38 & 5,00 & 1,34 & 2,45 & 0,10 \\
\hline 0,29 & 18,61 & & & & & & \\
\hline 0,36 & 19,85 & & & & & & \\
\hline 0,45 & 21,23 & & & & & & \\
\hline 1,05 & 21,23 & & & & & & \\
\hline 3,00 & 7,43 & & & & & & \\
\hline 5,00 & 7,43 & & & & & & \\
\hline
\end{tabular}




\section{APÊNDICE E}

NOÇÕES GERAIS SOBRE A ANÁLISE ESTATÍSTICA DE DADOS EXPERIMENTAIS 
Este apêndice apresenta alguns conceitos gerais, para a compreensão da análise estatística, que foi realizada nos dados dos ensaios de caracterização do concreto e de arrancamento, e, também, as análises realizadas.

Parte da simbologia aqui utilizada está listada a seguir.

\section{Letras romanas minúsculas}

$\mathrm{f}_{\mathrm{c}}=\quad$ Resistência do concreto à compressão

$\mathrm{f}_{\mathrm{cj}}=\quad$ Resistência de concreto à compressão na idade $\mathrm{j}$ dias

$\mathrm{f}_{\mathrm{cm}}=\quad$ Resistência média do concreto à compressão

$\mathrm{f}_{\mathrm{ct}}=\quad$ Resistência do concreto à tração direta

\section{Letras romanas maiúsculas}

$\mathrm{CP}=\quad$ Corpo-de-prova

$\mathrm{E}_{\mathrm{c}}=\quad$ Módulo de elasticidade do concreto

$\mathrm{SD}=\quad$ Desvio padrão

$\mathrm{T}_{\mathrm{b}}=\quad$ Tenacidade na flexão

$\mathrm{V}_{\mathrm{f}}=\quad$ Volume de fibras

\section{E.1. Introdução}

A análise de resultados experimentais e, conseqüentemente, as conclusões nela baseadas dependem do conhecimento do pesquisador sobre o tema e da qualidade dos dados obtidos. Esses dois fatores são fundamentais e complementares. É necessário conhecimento para interpretar os dados obtidos, e é preciso garantir a confiabilidade dos dados para que as conclusões sejam legítimas.

Segundo BOX et al (1978), a pesquisa científica é um processo de aprendizado direcionado e iterativo, como está ilustrado na Figura E.1.

Dados (experimentos, fatos, fenômenos)

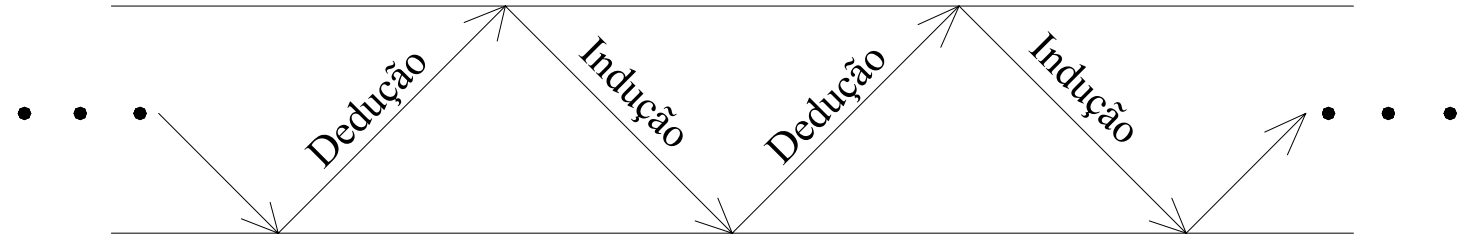

Hipótese (conjectura, modelo, teoria)

Figura E.1 - Processo iterativo de aprendizagem (BOX et al, 1978).

O pesquisador formula uma hipótese, baseado no seu conhecimento prévio sobre o tema, faz algumas deduções, obtém resultados teóricos e os compara com os dados disponíveis. Caso haja discordância entre os resultados da hipótese e os dados, induz-se 
modificações na hipótese, novas deduções, novos resultados e novas comparações, E, assim, sucessivamente, até obter-se correlações satisfatórias.

Percebe-se, então, que tanto a qualidade dos dados como a capacidade do pesquisador são realmente fundamentais para o sucesso da pesquisa científica.

\section{E.2. Noções Gerais}

O objetivo dos métodos estatísticos é tornar o processo de aprendizagem o mais eficiente possível, garantindo, principalmente, a legitimidade dos dados. Admitindo-se que os dados foram coletados de maneira adequada, é necessário verificar se esses dados são representativos do problema que se está estudando, ou, numa linguagem estatística, se a amostra escolhida é capaz de representar toda a população. A estatística fornece ao pesquisador várias ferramentas que permitem verificar a qualidade e confiabilidade dos dados obtidos, entre elas está a Tabela de Análise de Variância (ANOVA). Outra maneira é a utilização de testes de hipótese e intervalos de confiança, como o Processo de Comparação de Pares de Tukey.

Para uma melhor compreensão da Tabela de Análise de Variância, é necessário a definição de alguns conceitos e termos estatísticos, são eles: distribuição amostral, variância e resíduo.

\section{a) Distribuição amostral}

Segundo SILVA (2001), "O levantamento por amostragem permite a obtenção de informações a respeito de valores populacionais desconhecidos, por meio da observação de apenas parte (amostra) do seu universo de estudo (população)". E ainda, "Dentre os vários processos existentes para a obtenção de amostras, a amostragem probabilística caracteriza-se por garantir, a priori, que todo elemento pertencente ao universo de estudo possua probabilidade, conhecida e diferente de zero, de pertencer à amostra sorteada".

Então, o primeiro passo para uma análise estatística de sucesso, é garantir que a amostra é representativa da população. Além disso, é fundamental que a escolha dos elementos seja aleatória, o que evita a contaminação da amostra. Isso poderia levar a conclusões erradas, ou não representativas do universo em estudo.

A Figura E.2 apresenta exemplos de distribuição amostral para um conjunto de dados obtidos de uma amostragem probabilística. A representação tanto pode ser em forma de histograma (Figura E.2a), como em forma de um gráfico com a plotagem dos resíduos (Figura E.2b). Para este último, quanto mais próximo de uma reta se encontra a distribuição dos pontos, melhor. 
Segundo SILVA (2001), “Assumindo-se que os erros de mensuração ou de observação podem ser considerados desprezíveis, o desvio-padrão da distribuição amostral (chamado erro-padrão) indica a precisão do processo adotado, medindo o erro de natureza aleatória inerente ao procedimento de amostragem. Quanto menor o erro-padrão, maior será a precisão e a confiabilidade dos resultados obtidos".

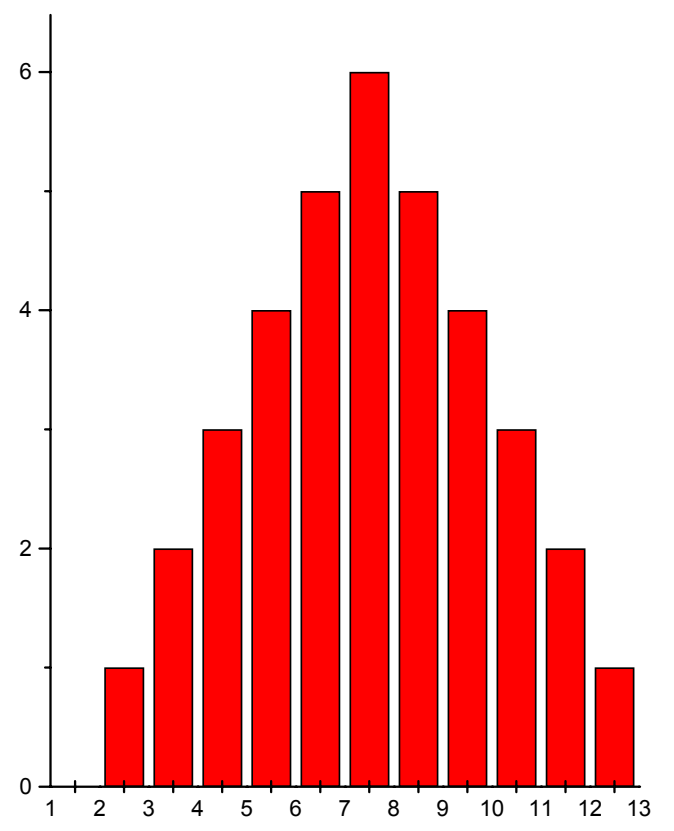

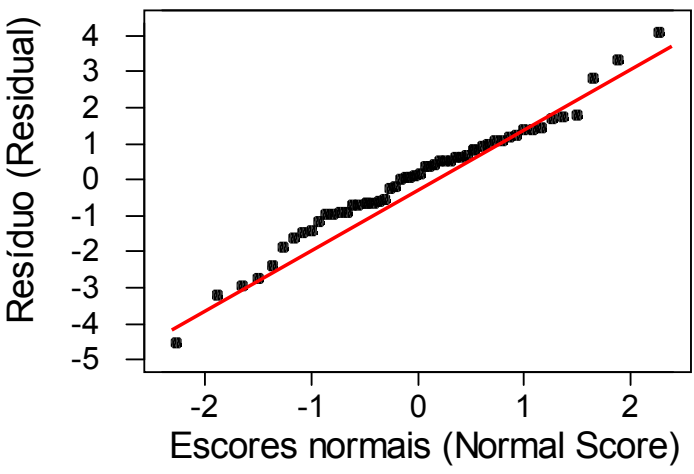

(b)

(a)

Figura E.2 - Distribuição amostral.

Portanto, a primeira análise a ser feita numa amostra é se ela apresenta uma distribuição amostral normal, para que possa ser avaliada pelos estimadores como o desvio-padrão, por exemplo.

\section{b) Variância}

A variância nada mais é do que uma medida da variabilidade. Para uma amostra, define-se variância amostral $\left(\mathrm{S}^{2}\right)$ como:

$$
\mathrm{S}^{2}=\frac{1}{\mathrm{n}-1} \sum_{\mathrm{i}=1}^{\mathrm{n}}\left(\mathrm{X}_{\mathrm{i}}-\overline{\mathrm{X}}\right)^{2}
$$

onde: $\mathrm{n}=$ número de elementos da amostra;

$\mathrm{X}_{\mathrm{i}}=$ valores das variáveis aleatórias;

$\overline{\mathrm{X}}=$ média dos valores.

O desvio-padrão (SD) da amostra é dado pela raiz quadrada da variância, ou seja:

$$
\mathrm{SD}=\sqrt{\mathrm{S}^{2}}=\sqrt{\frac{1}{\mathrm{n}-1} \sum_{\mathrm{i}=1}^{\mathrm{n}}\left(\mathrm{X}_{\mathrm{i}}-\overline{\mathrm{X}}\right)^{2}}
$$


O desvio-padrão mede a dispersão da amostra, e não apenas o comportamento médio da mesma, o que fornece ao pesquisador um intervalo de confiança dos dados.

\section{c) Resíduo}

Segundo MAGALHÃES \& LIMA (2002), quando se quer comparar duas ou mais populações, utiliza-se um modelo estatístico, "em que cada observação Y pode ser decomposta em duas componentes: sistemática e aleatória, esta última representando variações individuais e todos os fatores que não são explicados pela parte sistemática". Matematicamente, tem-se:

$$
\mathrm{Y}=\mu+\varepsilon
$$

Equação (E.1)

onde: $\mathrm{Y}=$ observação associada a uma unidade experimental;

$\mu=$ média populacional, que é fixa (parte sistemática);

$\varepsilon=$ informação referente a outros fatores que podem influir nas observações mas não são incorporadas em $\mu$ (parte aleatória).

Segundo BOX et al (1978), a Equação (E.1) pode ser decomposta em:

$$
\begin{gathered}
\mathrm{Y}=\mathrm{A}+\mathrm{T}+\mathrm{R} \\
\mu=\mathrm{A}+\mathrm{T} \quad \text { e } \quad \varepsilon=\mathrm{R}
\end{gathered}
$$

onde: $\mathrm{A}=$ média geral de todas as populações $(\overline{\mathrm{y}})$;

$\mathrm{T}=$ diferença entre a média de cada população individualmente $\left(\overline{\mathrm{y}}_{\mathrm{t}}\right)$ e à media geral $(\overline{\mathrm{y}})$;

$\mathrm{R}=$ resíduo de cada população.

Os resíduos de uma amostra, ou população, podem ser plotados em relação aos valores médios de cada conjunto, como mostra a Figura E.3.

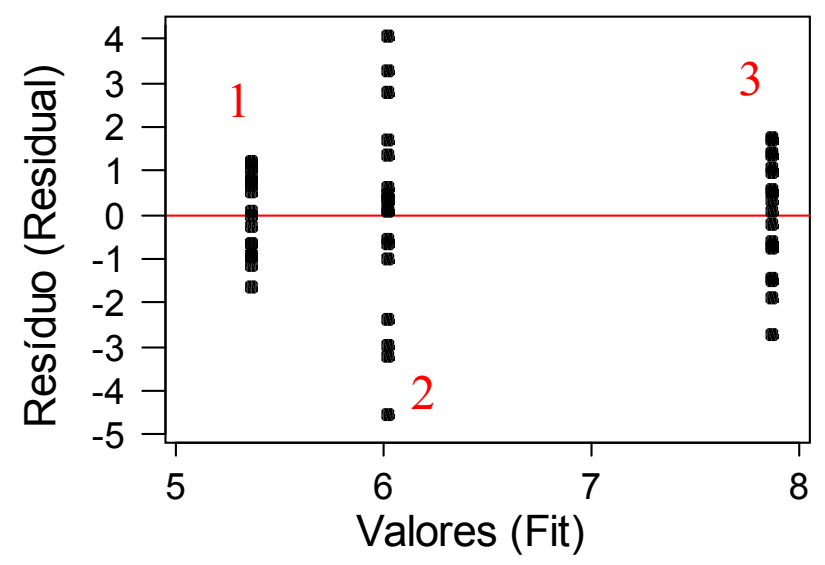

Figura E.3 - Plotagem dos resíduos de um grupo de amostras. 
Para o gráfico da Figura E.3 pode-se dizer que a amostra 1 possui a menor variância (pontos mais próximos do eixo referente ao valor zero) e o menor valor médio, a amostra 2 possui a maior variância, e a amostra 3 possui a maior média.

Para que um conjunto de dados possa ser representado pelo modelo da Equação (E.1), ele deve satisfazer às seguintes hipóteses:

- Os dados devem ter uma distribuição amostral normal;

- Os tratamentos devem ter variância semelhantes;

- A média do erro deve ser zero.

Logo, o conjunto de dados apresentado na Figura E.3 não poderia ser representado pela Equação (E.1), pois as variâncias são diferentes (distâncias diferentes em relação ao eixo zero). Aparentemente, a média do erro é zero, pois todas as amostras possuem simetria em relação ao eixo zero.

Admitindo-se que existam $\boldsymbol{t}$ populações com $\boldsymbol{i}$ elementos em cada uma, que satisfaçam as hipóteses acima, pode-se dizer que:

$$
\begin{aligned}
& \mathrm{A}=\overline{\mathrm{y}} \\
& \mathrm{T}=\left(\overline{\mathrm{y}}_{\mathrm{t}}-\overline{\mathrm{y}}\right) \\
& \mathrm{R}=\left(\mathrm{y}_{\mathrm{ti}}-\overline{\mathrm{y}}_{\mathrm{t}}\right)
\end{aligned}
$$

Logo, pode-se reescrever a Equação (E.1) da seguinte forma:

$$
\mathrm{y}_{\mathrm{ti}}=\overline{\mathrm{y}}+\left(\overline{\mathrm{y}}_{\mathrm{t}}-\overline{\mathrm{y}}\right)+\left(\mathrm{y}_{\mathrm{ti}}-\overline{\mathrm{y}}_{\mathrm{t}}\right)
$$

Segundo BOX et al (1978), os resíduos (R) são as quantidades restantes após a remoção da contribuição sistemática $(\mathrm{A}+\mathrm{T})$ associada ao modelo adotado. A análise dos resíduos permite que se detecte vários tipos de discrepâncias entre a hipótese adotada e os dados experimentais, indicando, assim, a possibilidade ou não de se confiar nos resultados obtidos.

Essa análise pode ser feita para comparação de populações de tamanhos diferentes, sendo feitos os ajustes necessários.

\section{E.3. Tabela de Análise de Variância (ANOVA)}

Admitindo-se que os dados representam populações com amostragem probabilística normal, variâncias iguais e médias diferentes, pode-se representa-los através da Equação (E.1). A partir daí, procede-se com a análise dos resíduos para verificar se o modelo é, ou não, adequado. Feito isto, pode-se estudar a Tabela de Análise de Variância com mais segurança. O resultado dessa análise indica não só o grau de confiança dos resultados, como também ajuda o pesquisador a elaborar e avaliar outras hipóteses para o problema. Segundo BOX et al 
(1978), a Tabela de Análise de Variância fornece uma compreensão imediata e resumida das principais conclusões da investigação.

A Tabela E.1 apresenta um exemplo da Tabela.

Observe-se que os valores da Tabela de Análise de Variância são relacionados com os termos da Equação (E.1), ou seja, pode-se dizer que SQE está relacionado com A (média geral de todas as populações) e com $\mathrm{T}$ (diferença entre a média de cada população individualmente e a média geral), e que SQD está relacionado com $\mathrm{R}$ (resíduo de cada população).

Tabela E.1 - Exemplo de uma Tabela de Análise de Variância.

\begin{tabular}{c|c|c|c}
\hline Fonte de Variação & Soma de Quadrados & Graus de Liberdade & Quadrado Médio \\
\hline Entre populações & $\mathrm{SQE}=\mathrm{m}\left(\sum_{\mathrm{i}=1}^{\mathrm{K}} \overline{\mathrm{Y}}_{\mathrm{i}}^{2}-\mathrm{K} \cdot \overline{\mathrm{Y}}^{2}\right)$ & $\mathrm{K}-1$ & $\mathrm{QME}=\frac{\mathrm{SQE}}{\mathrm{K}-1}$ \\
\hline $\begin{array}{c}\text { Dentro de cada } \\
\text { população }\end{array}$ & $\mathrm{SQD}=\sum_{\mathrm{i}=1}^{\mathrm{K}} \sum_{\mathrm{j}=1}^{\mathrm{m}} \mathrm{Y}_{\mathrm{ij}}^{2}-\mathrm{m} \sum_{\mathrm{i}=1}^{\mathrm{K}} \overline{\mathrm{Y}}_{\mathrm{i}}^{2}$ & $\mathrm{~K}(\mathrm{~m}-1)$ & $\mathrm{QMD}=\frac{\mathrm{SQD}}{\mathrm{K}(\mathrm{m}-1)}$ \\
\hline Total & $\mathrm{SQT}=\sum_{\mathrm{i}=1}^{\mathrm{K}} \sum_{\mathrm{j}=1}^{\mathrm{m}} \mathrm{Y}_{\mathrm{ij}}^{2}-\mathrm{m} \cdot \mathrm{K} \cdot \overline{\mathrm{Y}}^{2}$ & $\mathrm{~K} \mathrm{~m}-1$ & \\
\hline
\end{tabular}

onde: $\mathrm{Y}_{\mathrm{ij}}=$ variáveis aleatórias e independentes (observações);

$\mathrm{K}=$ número de populações;

$\mathrm{m}=$ números de elementos de cada população;

$\mathrm{SQE}=$ soma de quadrados entre;

$\mathrm{SQD}=$ soma de quadrados dentro;

$\mathrm{SQT}=$ soma de quadrados total;

$\mathrm{QME}=$ quadrado médio entre;

$\mathrm{QMD}=$ quadrado médio dentro.

\section{E.4. Processo de Comparação de Pares de Tukey}

Segundo BOX et al (1978), Tukey demonstrou matematicamente como estabelecer intervalos de confiança para uma série de dados. Ou seja, é possível determinar-se previamente qual o grau de confiabilidade que se quer que os dados contenham, e então verificar qual a percentagem dos mesmos que se encontram dentro do intervalo de confiança estabelecido. Costuma-se adotar um intervalo de confiança (CI) de 95\%. 


\section{E.5. Análise Estatística para os Ensaios de Caracterização do Concreto}

Para esta pesquisa, foram feitos ensaios de caracterização dos concretos, para obtenção das principais propriedades dos compósitos. São elas: resistência à compressão, resistência à tração, módulo de elasticidade e tenacidade. No total, foram realizados os seguintes ensaios:

- Ensaios de compressão axial: 33 corpos-de-prova (CP) de $15 \times 30 \mathrm{~cm}$ (cilíndricos), e $205 \mathrm{CP}$ de $10 \times 20 \mathrm{~cm}$ (cilíndricos).

- Ensaios de compressão diametral: $32 \mathrm{CP}$ de 10x20 cm (cilíndricos).

- Ensaios de flexão: $38 \mathrm{CP}$ de $15 \times 15 \times 50 \mathrm{~cm}$ (prismáticos).

A seguir são apresentadas as análises estatísticas para os dados dos valores característicos. Essas análises tiveram dois objetivos:

- Avaliar a legitimidade dos dados, verificando se as amostras apresentavam uma distribuição normal;

- Determinar o coeficiente de variação $(\mathrm{CV})$ dos dados.

O coeficiente de variação $(\mathrm{CV})$ foi calculado pela seguinte expressão:

$$
\mathrm{CV}=\frac{\mathrm{SD}}{\overline{\mathrm{X}}} \cdot 100
$$

Não existe um valor normalizado para um limite de CV geral de ensaios. A American Society for Testing and Materials (ASTM) estabelece, para alguns tipos de ensaio, coeficientes de variação máximos aceitáveis, como por exemplo, para os ensaios de tração na flexão, a ASTM C78 (1994) admite um coeficiente de variação máximo de CV=16\%. As normas brasileiras consultadas, nesta pesquisa, não estabelecem limites de dispersão de resultados. Foi adotado o valor de $\mathrm{CV}=20 \%$ como um limite aceitável para a dispersão dos dados dos ensaios de caracterização.

Foram utilizados os programas ORIGIN version 5 e MINITAB version 13.32 para as análises estatísticas.

\section{a) Resistência à compressão $\left(\mathbf{f}_{\mathrm{cj}}\right)$}

Foram feitos ensaios de compressão axial para os corpos-de-prova das diferentes betonadas, num total de 205 ensaios, dos quais 127 foram nas datas de retirada da protensão e de ensaio. Os dados obtidos foram submetidos a um tratamento estatístico para a validação dos mesmos. As Figuras E.4 a E.7 apresentam os testes de normalidade para os resultados dos corpos-de-prova de concreto, divididos nos seguintes grupos: modelos de prismas na transferência e no ensaio; modelos de vigas na transferência e no ensaio. As Tabelas E.2 a E.7 
apresentam os resultados da análise de variância (ANOVA) dos dados. Foi utilizado um intervalo de confiança (CI) de 95\%.

Pelos gráficos, pode-se considerar que os dados apresentam uma distribuição amostral normal. Os piores resultados foram verificados para os valores da resistência dos prismas na data de ensaio. Isso é verificado pela proximidade, ou não, dos pontos à reta. Quanto mais os pontos estiverem juntos à reta, melhor. Os coeficientes de variação para cada grupo se encontram dentro de valores aceitáveis $(\mathrm{CV} \leq 15 \%)$, como mostra a Tabela E.8.

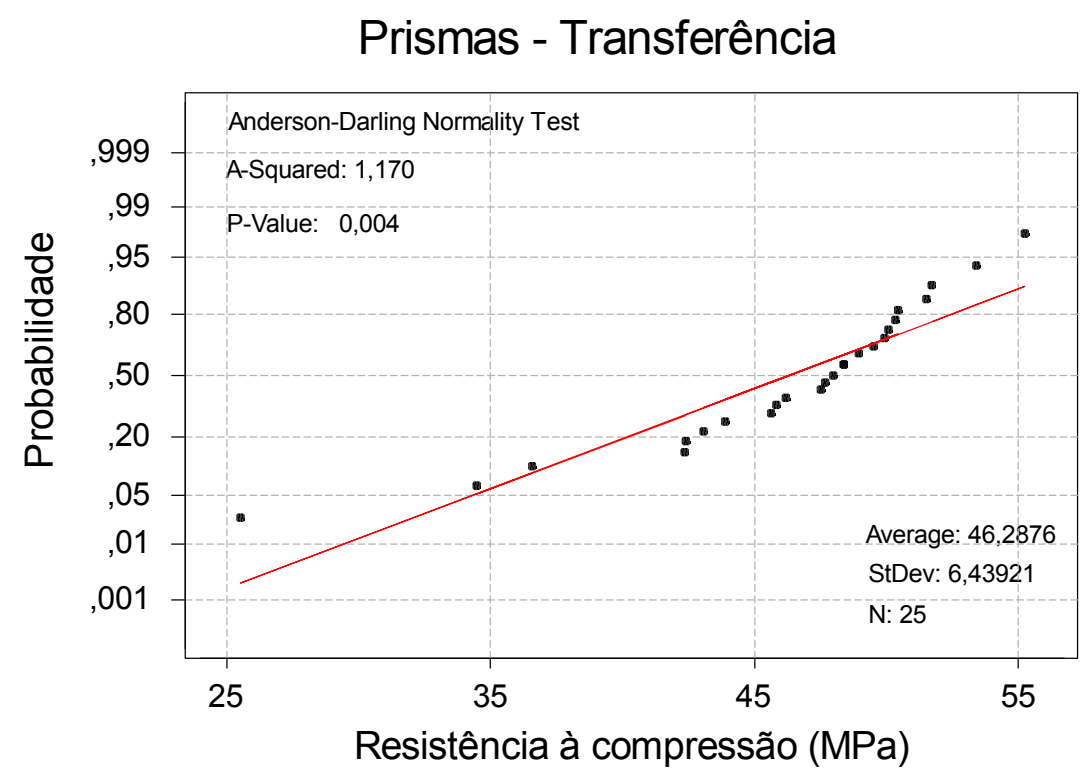

Figura E.4 - Teste de normalidade para os corpos-de-prova dos prismas na retirada da protensão.

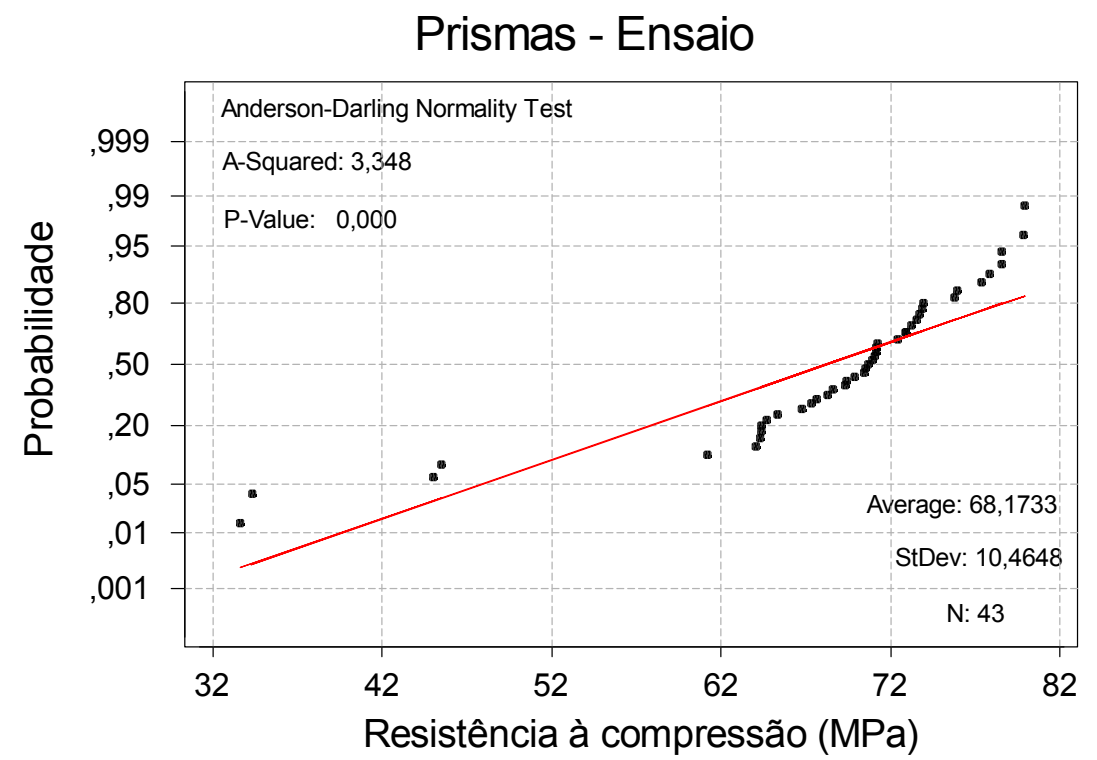

Figura E.5 - Teste de normalidade para os corpos-de-prova dos prismas na data de ensaio. 


\section{Vigas - Transferência}

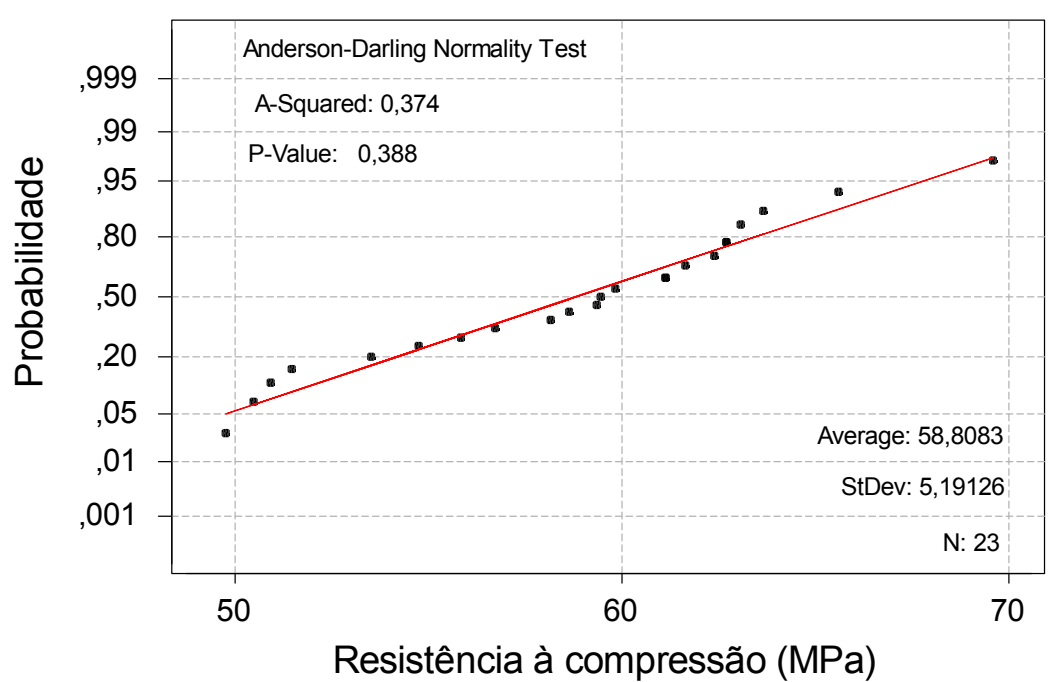

Figura E.6 - Teste de normalidade para os corpos-de-prova das vigas na retirada da protensão.

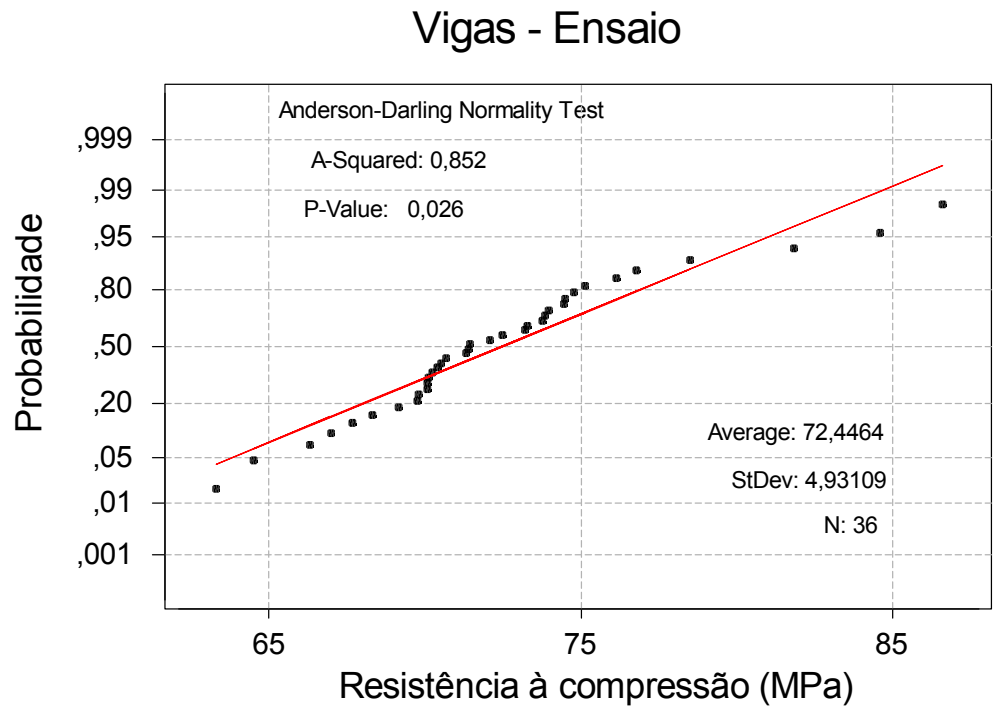

Figura E.7 - Teste de normalidade para os corpos-de-prova das vigas, na data de ensaio.

As Tabela E.2 a E.5 apresentam as comparações dentro de cada grupo estudado, para os três teores de fibras. Apenas para o primeiro grupo, prismas na transferência, as diferenças entre as médias são significativas. Estes valores, porém, não foram utilizados, diretamente, na pesquisa, por isso não foram levados em conta. As Tabelas E.6 e E.7 apresentam as comparações entre os resultados dos prismas e os das vigas, e indicam que as diferenças são significativas, optando-se, então, por não despreza-las. De acordo com essas verificações, pode-se assegurar que os dados são válidos, e que as interpretações resultantes da sua análise serão legítimas.

O valor do erro padrão (se), na Tabela E.8, foi calculado da seguinte forma:

$$
\mathrm{se}=\frac{\mathrm{SD}}{\sqrt{\mathrm{n}}}
$$


Tabela E.2 - Tabela de análise de variância para a resistência à compressão dos prismas na transferência.

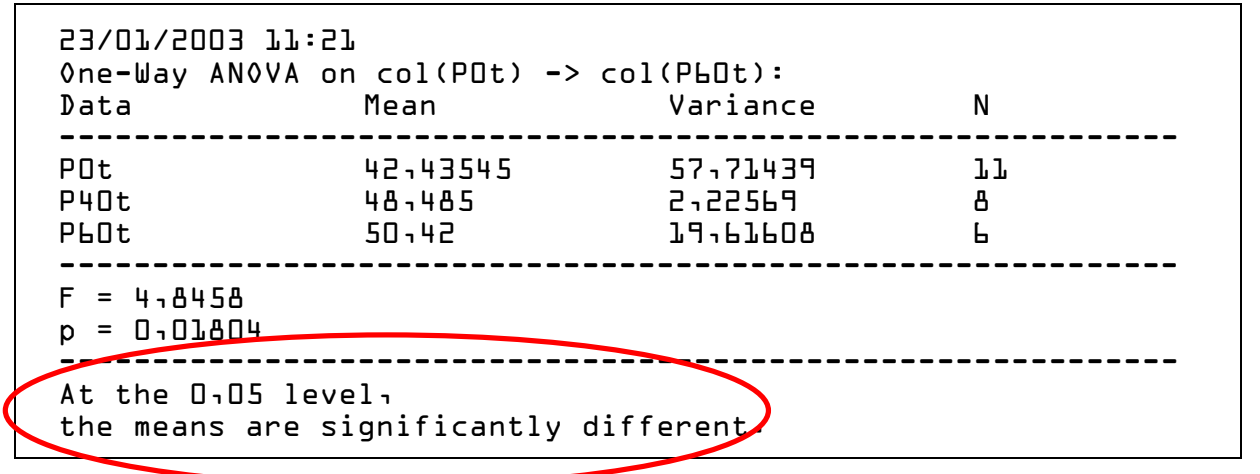

Tabela E.3 - Tabela de análise de variância para a resistência à compressão dos prismas no ensaio.

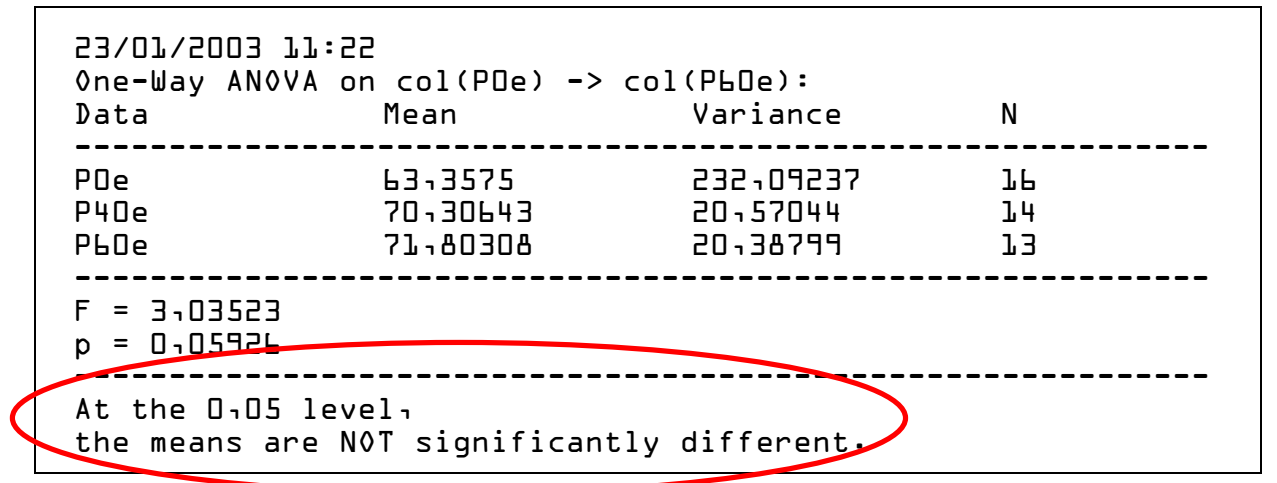

Tabela E.4 - Tabela de análise de variância para a resistência à compressão das vigas na transferência.

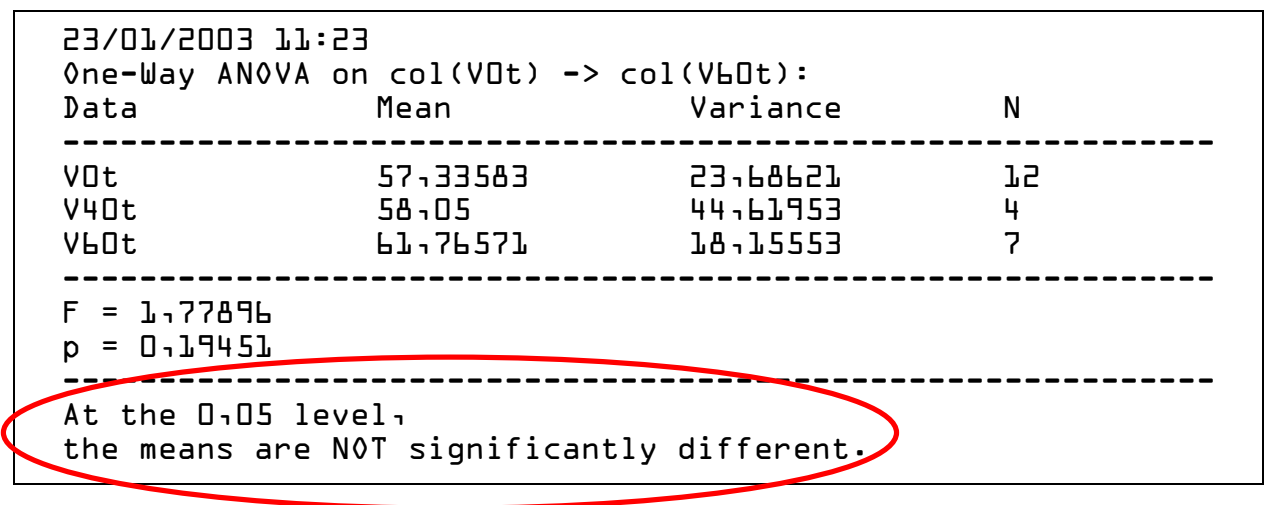

Tabela E.5 - Tabela de análise de variância para a resistência à compressão das vigas no ensaio.

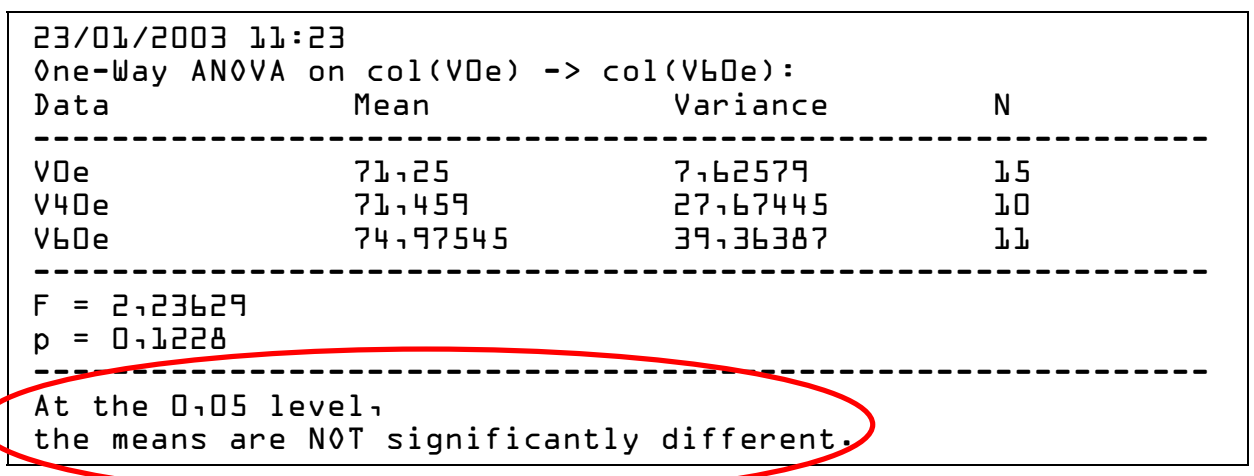


Tabela E.6 - Tabela de análise de variância para a resistência à compressão dos prismas e vigas na transferência.

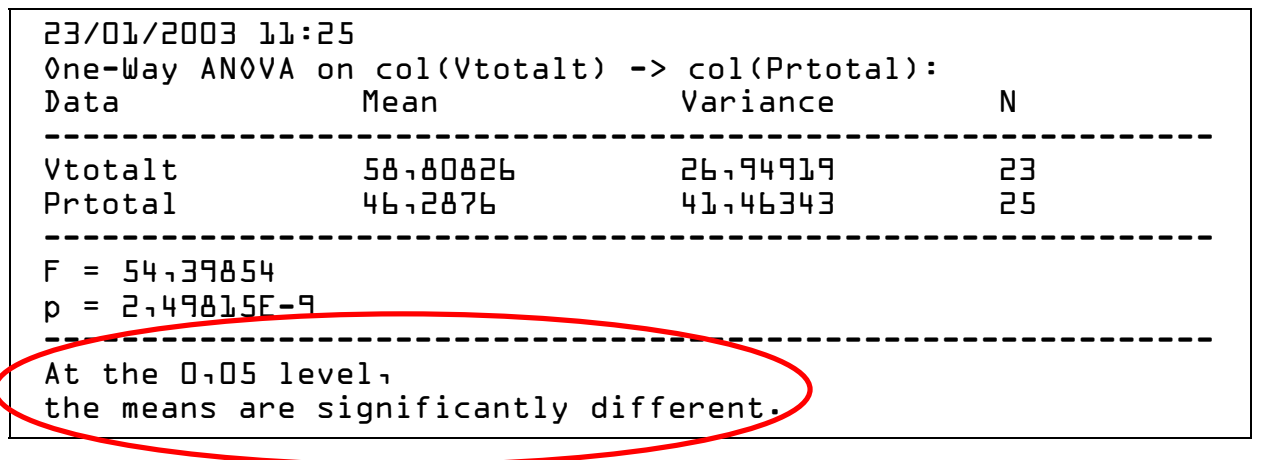

Tabela E.7 - Tabela de análise de variância para a resistência à compressão dos prismas e vigas no ensaio.

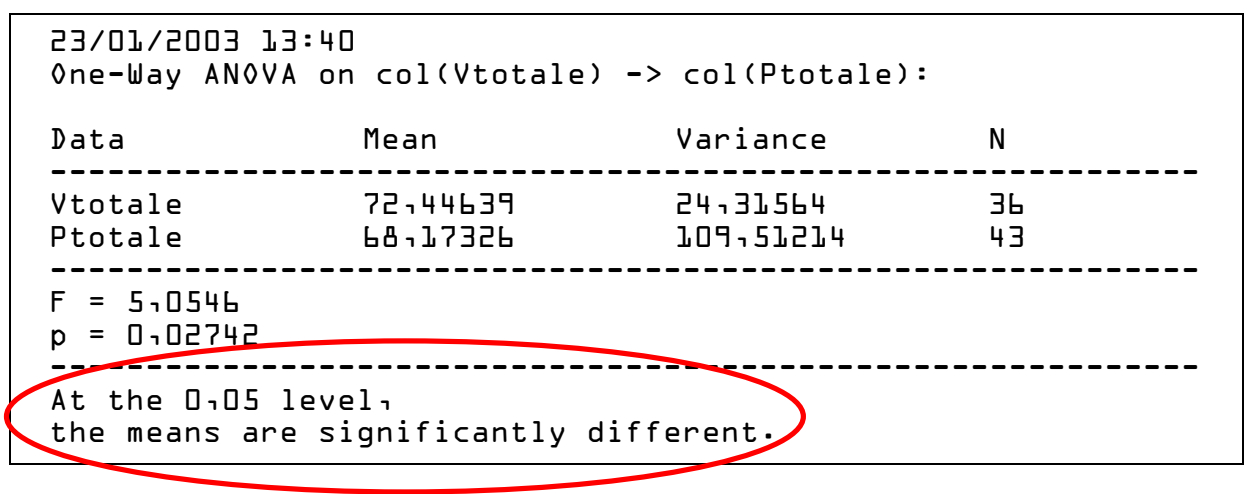

Tabela E.8 - Resultados das médias, desvios e erros padrões, e quantidade de amostras para a resistência à compressão dos prismas e vigas.

\begin{tabular}{|l|r|r|r|r|}
\hline & Médias & Desvio Padrão & Erro Padrão & $\mathbf{n}$ \\
\hline Prismas 0 - trans. & 42,44 & 7,60 & 2,29 & 11 \\
\hline Prismas 40 - trans. & 48,49 & 1,49 & 0,53 & 8 \\
\hline Prismas 60 - trans. & 50,42 & 4,43 & 1,81 & 6 \\
\hline Prismas todos - trans. & 46,29 & 6,44 & 1,29 & 25 \\
\hline Prismas 0 - ensaio & 63,36 & 15,23 & 3,81 & 16 \\
\hline Prismas 40 - ensaio & 70,31 & 4,54 & 1,21 & 14 \\
\hline Prismas 60 - ensaio & 71,80 & 4,52 & 1,25 & 13 \\
\hline Prismas todos - ensaio & 68,17 & 10,46 & 1,60 & 43 \\
\hline Vigas 0 - trans. & 57,34 & 4,87 & 1,40 & 12 \\
\hline Vigas 40 - trans. & 58,05 & 6,68 & 3,34 & 4 \\
\hline Vigas 60 - trans. & 61,77 & 4,26 & 1,61 & 7 \\
\hline Vigas todos - trans. & 58,81 & 5,19 & 1,08 & 23 \\
\hline Vigas 0 - ensaio & 71,25 & 2,76 & 0,71 & 15 \\
\hline Vigas 40 - ensaio & 71,46 & 5,26 & 1,66 & 10 \\
\hline Vigas 60 - ensaio & 74,98 & 6,27 & 1,89 & 11 \\
\hline Vigas todos - ensaio & 72,45 & 4,93 & 0,82 & 36 \\
\hline Total transferência & 52,29 & 8,59 & 1,24 & 48 \\
\hline Total ensaio & 70,12 & 8,63 & 0,97 & 79 \\
\hline
\end{tabular}

\section{b) Resistência à tração $\left(f_{c t}\right)$}

Foram realizados ensaios de compressão diametral e de tração na flexão para os corposde-prova das diferentes betonadas, num total de 32 ensaios de compressão diametral e 38 
ensaios de tração na flexão. Esses dados também sofreram uma avaliação estatística, cujos resultados estão apresentados nas Figuras E.8 a E.13. Os dados foram divididos nos seguintes grupos: resistência à tração indireta para $\mathrm{V}_{\mathrm{f}}=0$, resistência à tração na flexão para $\mathrm{V}_{\mathrm{f}}=0$, resistência à tração indireta para $\mathrm{V}_{\mathrm{f}}=40 \mathrm{~kg} / \mathrm{m}^{3}$, resistência à tração na flexão para $\mathrm{V}_{\mathrm{f}}=$ $40 \mathrm{~kg} / \mathrm{m}^{3}$, resistência à tração indireta para $\mathrm{V}_{\mathrm{f}}=60 \mathrm{~kg} / \mathrm{m}^{3}$, e resistência à tração na flexão para $\mathrm{V}_{\mathrm{f}}=60 \mathrm{~kg} / \mathrm{m}^{3}$. As Tabelas E.9 a E.20 apresentam os resultados da análise de variância (ANOVA) dos dados. Foi utilizado um intervalo de confiança (CI) de 95\%.

Como se pode observar, esses dados também apresentam uma distribuição amostral normal. Os piores resultados são para os dados relativos à resistência à tração na flexão para $\mathrm{V}_{\mathrm{f}}=0$. Isso é verificado pela proximidade dos pontos à reta. Os coeficientes de variação para cada grupo se encontram dentro de valores aceitáveis $(\mathrm{CV} \leq 20 \%)$. Os valores dos desvios padrão se encontram na Tabela E.21.

As Tabelas E.9 a E.12 comparam os valores para as resistências à tração de cada grupo separadamente, variando-se o teor de fibra. Os grupos foram: tração indireta para as concretagens dos prismas; tração na flexão para as concretagens dos prismas; tração indireta para as concretagens das vigas; e tração na flexão para as concretagens das vigas. As Tabelas E.13 e E.14 analisam todos os dados, dos prismas e das vigas, para cada teor de fibra, para a tração indireta e para a tração na flexão, respectivamente. Para todos os casos, as diferenças das médias foram significativas.

As Tabelas E.15 a E.17 apresentam as análises de variância para a resistência à tração indireta, levando em conta as concretagens dos prismas, das vigas, e todos juntos, para $\mathrm{V}_{\mathrm{f}}=0$, $\mathrm{V}_{\mathrm{f}}=40 \mathrm{~kg} / \mathrm{m}^{3}$, e $\mathrm{V}_{\mathrm{f}}=60 \mathrm{~kg} / \mathrm{m}^{3}$, respectivamente. As Tabelas E.18 a E.20 apresentam as análises de variância para a resistência à tração na flexão, levando em conta as concretagens dos prismas, das vigas, e todos juntos, para $\mathrm{V}_{\mathrm{f}}=0, \mathrm{~V}_{\mathrm{f}}=40 \mathrm{~kg} / \mathrm{m}^{3}$, e $\mathrm{V}_{\mathrm{f}}=60 \mathrm{~kg} / \mathrm{m}^{3}$, respectivamente. Para todos os casos, exceto para a Tabela E.19, as diferenças das médias não foram significativas. Apesar dos resultados da Tabela E.19, decidiu-se trabalhar com três valores de resistência à tração, um para cada teor de fibra diferente, desprezando-se as diferenças entre o tipo de ensaio (tração indireta e tração na flexão) e os tipos de peça (concretagem de prisma e de viga). 


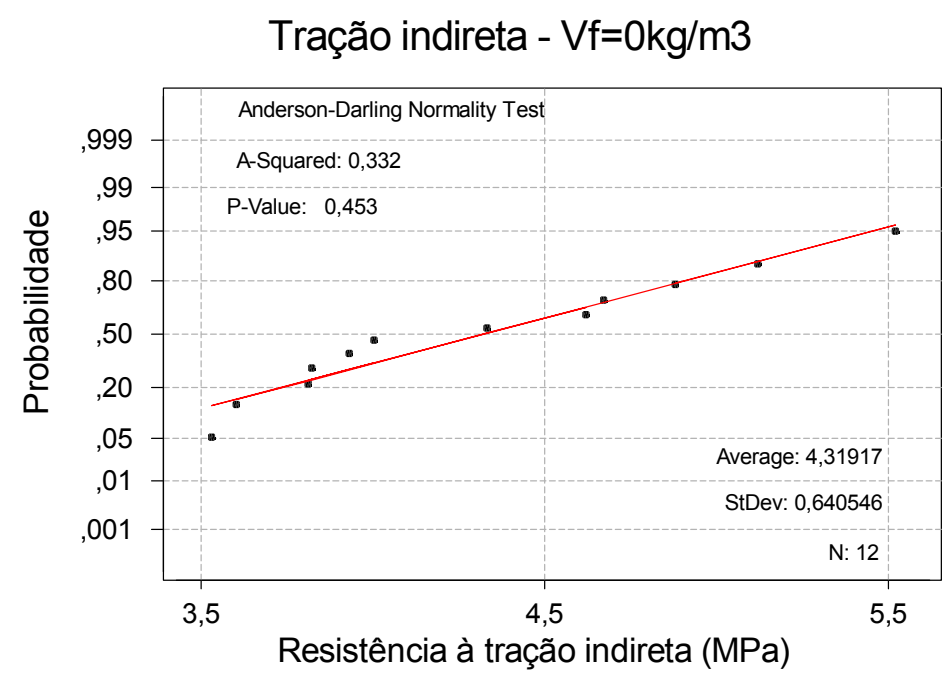

Figura E.8 - Teste de normalidade para os corpos-de-prova para determinação da resistência à tração indireta, $\mathrm{V}_{\mathrm{f}}=0$.

\section{Tração indireta $-\mathrm{Vf}=40 \mathrm{~kg} / \mathrm{m} 3$}

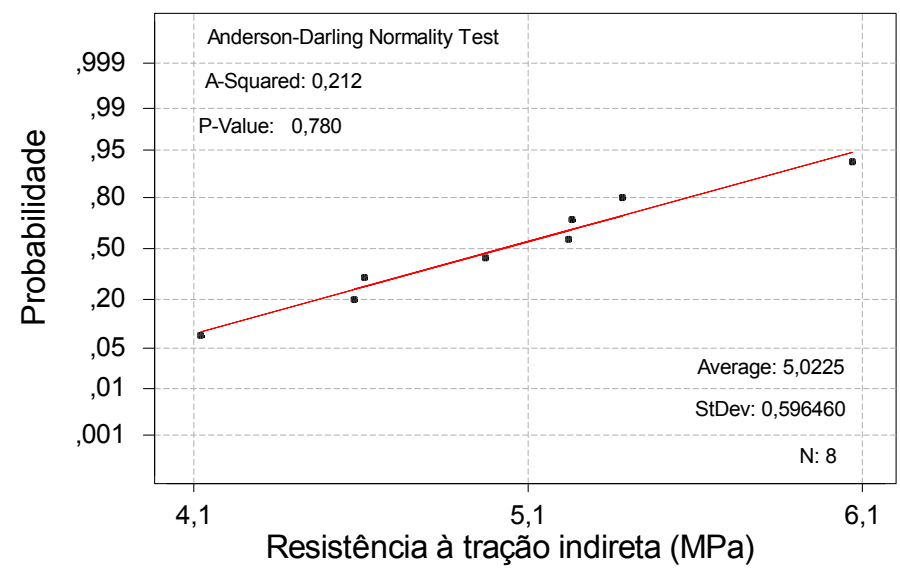

Figura E.9 - Teste de normalidade para os corpos-de-prova para determinação da resistência à tração indireta, $\mathrm{V}_{\mathrm{f}}=40 \mathrm{~kg} / \mathrm{m}^{3}$.

\section{Tração indireta - Vf=60kg/m3}

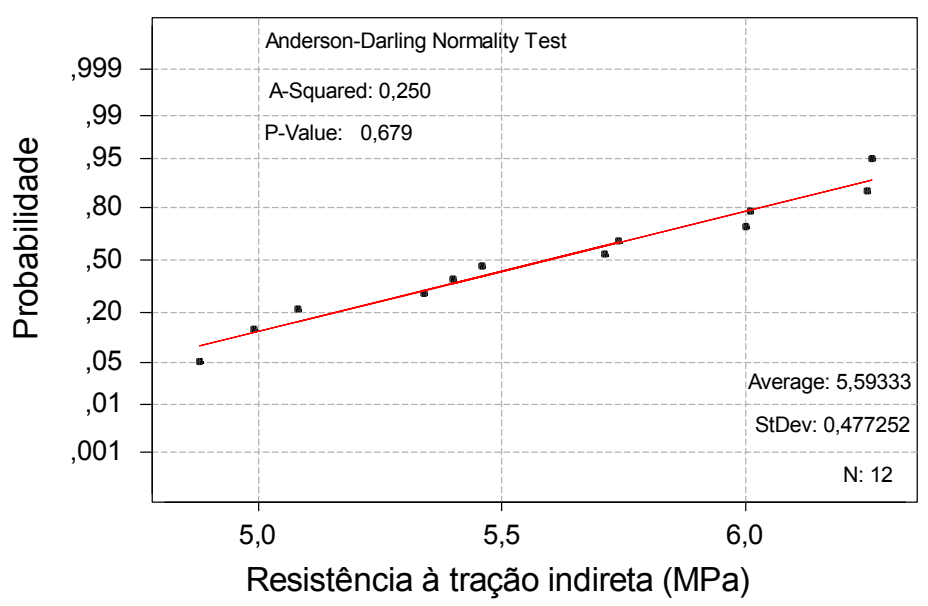

Figura E.10 - Teste de normalidade para os corpos-de-prova para determinação da resistência à tração indireta,

$$
\mathrm{V}_{\mathrm{f}}=60 \mathrm{~kg} / \mathrm{m}^{3} \text {. }
$$




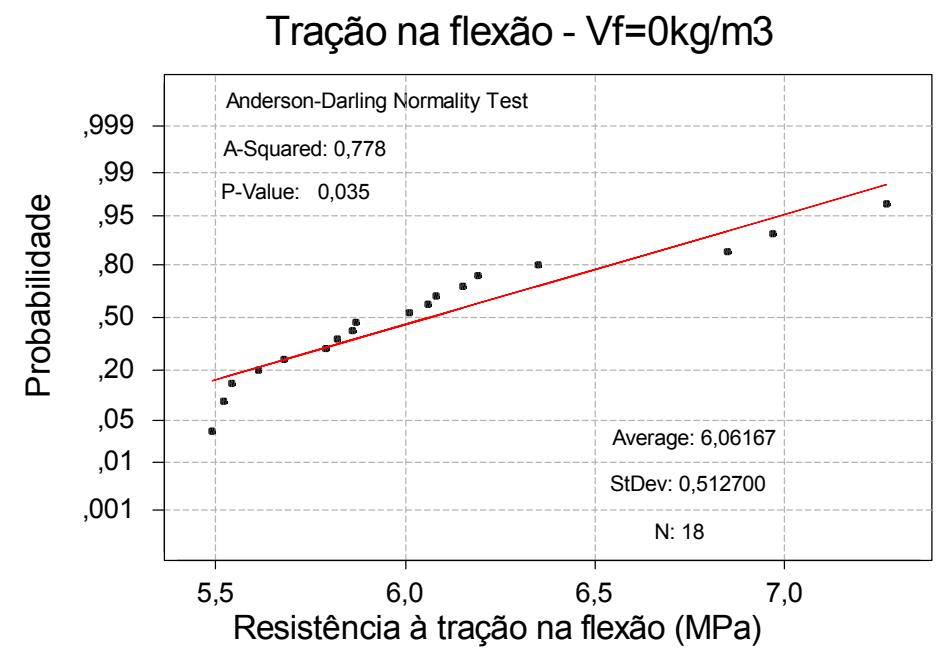

Figura E.11 - Teste de normalidade para os corpos-de-prova para determinação da resistência à tração na flexão, $\mathrm{V}_{\mathrm{f}}=0$.

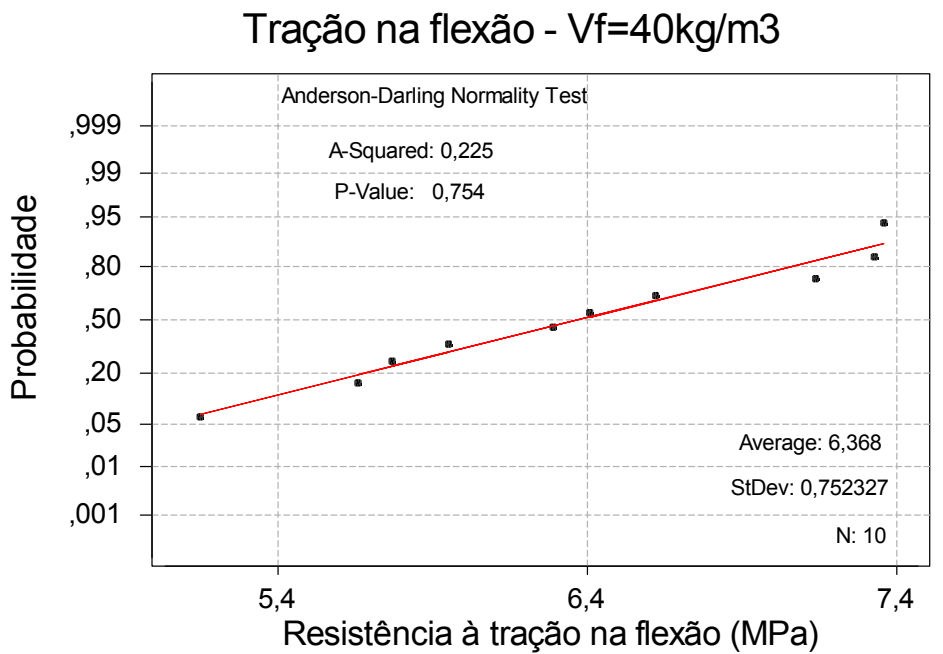

Figura E.12 - Teste de normalidade para os corpos-de-prova para determinação da resistência à tração na flexão, $\mathrm{V}_{\mathrm{f}}=40 \mathrm{~kg} / \mathrm{m}^{3}$.

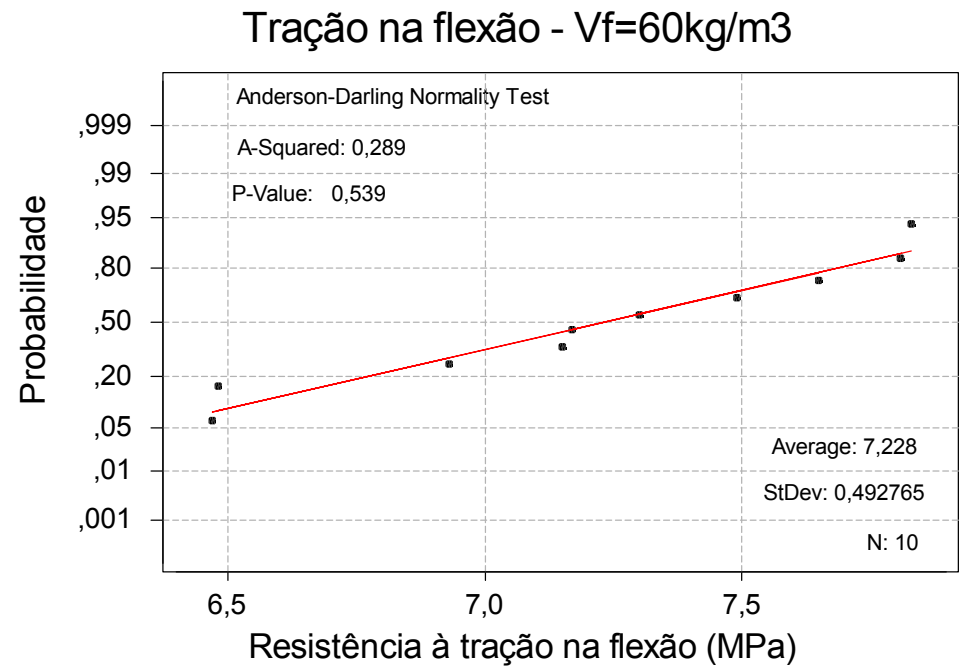

Figura E.13 - Teste de normalidade para os corpos-de-prova para determinação da resistência à tração na flexão,

$$
\mathrm{V}_{\mathrm{f}}=60 \mathrm{~kg} / \mathrm{m}^{3} \text {. }
$$


De acordo com essas verificações, pode-se assegurar que os dados são válidos, e que as interpretações resultantes da sua análise serão legítimas.

Tabela E.9 - Tabela de análise de variância para a resistência à tração indireta dos prismas, para cada teor de fibra separadamente.

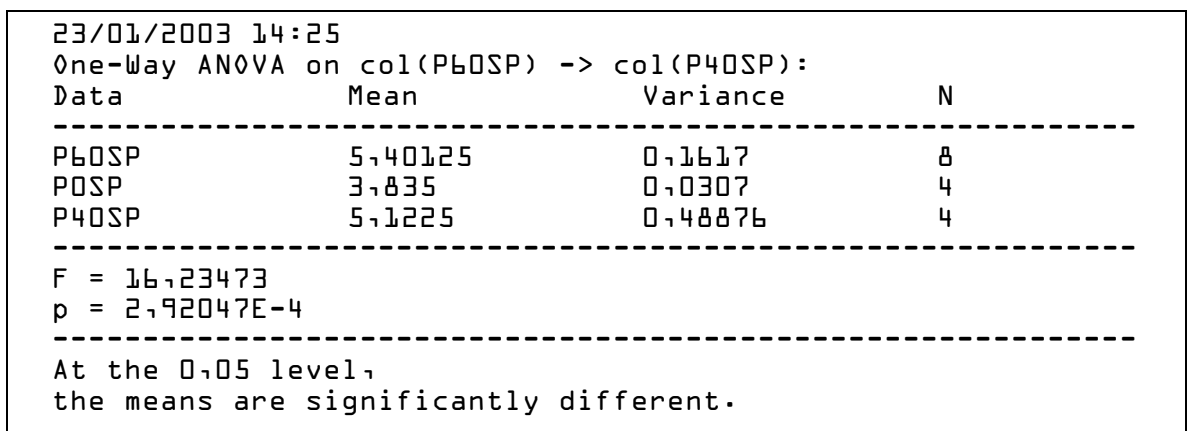

Tabela E.10 - Tabela de análise de variância para a resistência à tração na flexão dos prismas, para cada teor de fibra separadamente.

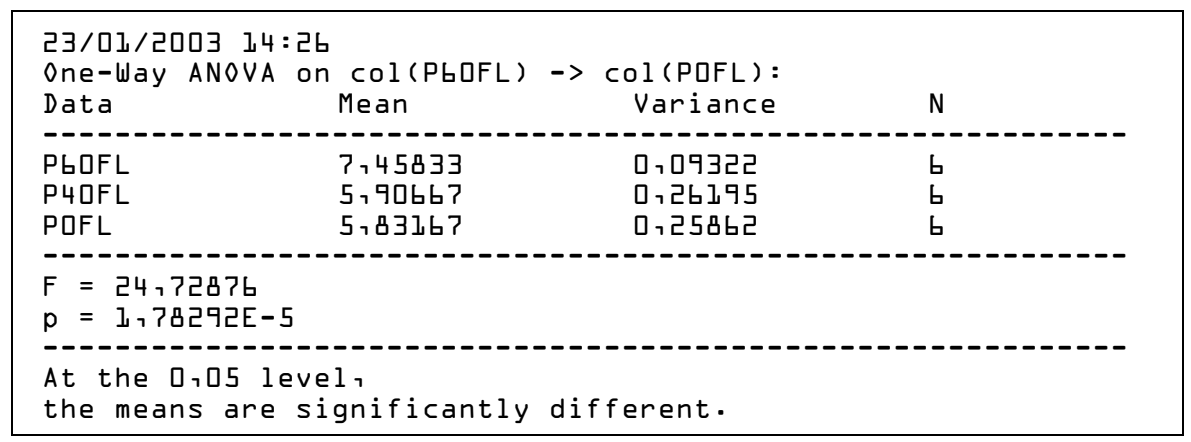

Tabela E.11 - Tabela de análise de variância para a resistência à tração indireta das vigas, para cada teor de fibra separadamente.

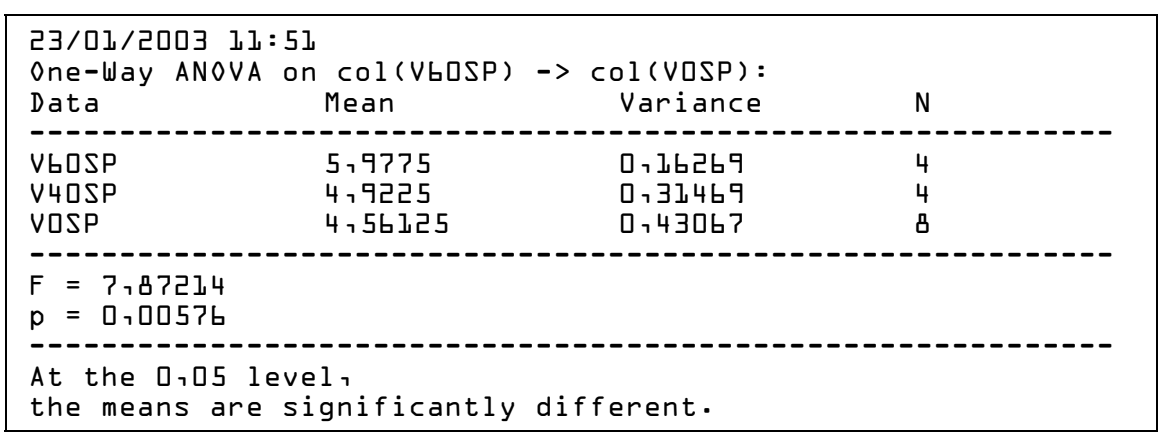


Tabela E.12 - Tabela de análise de variância para a resistência à tração na flexão das vigas, para cada teor de fibra separadamente.

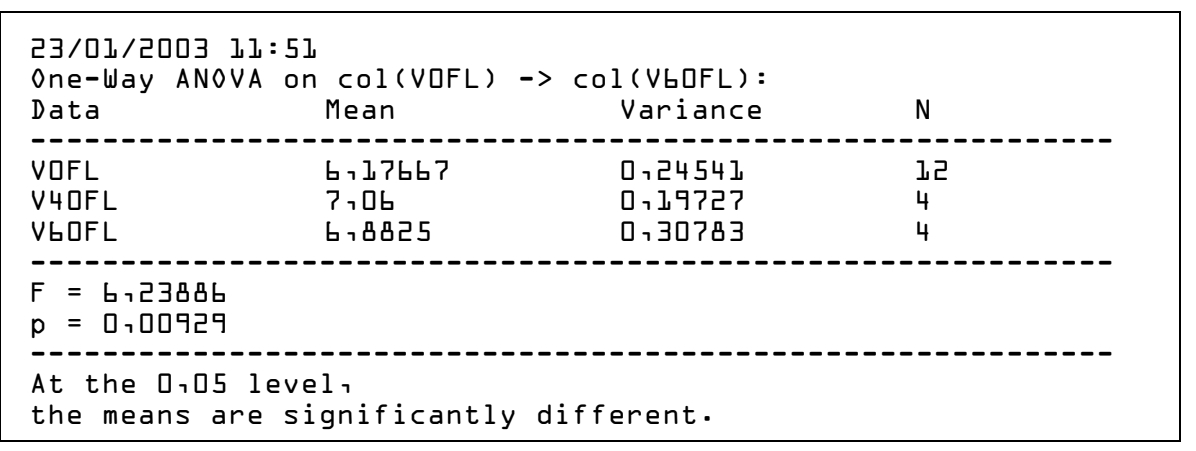

Tabela E.13 - Tabela de análise de variância para a resistência à tração indireta dos prismas e das vigas, para cada teor de fibra separadamente.

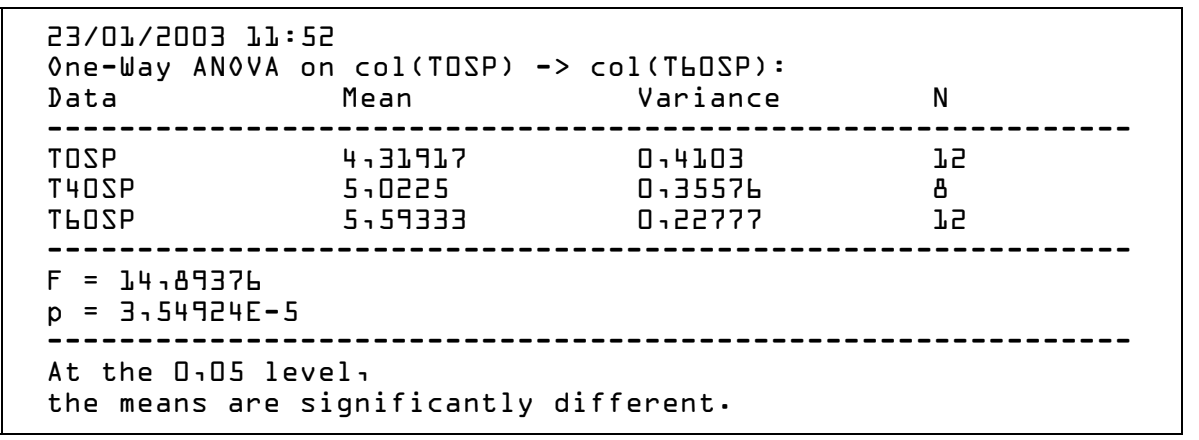

Tabela E.14 - Tabela de análise de variância para a resistência à tração na flexão dos prismas e das vigas, para cada teor de fibra separadamente.

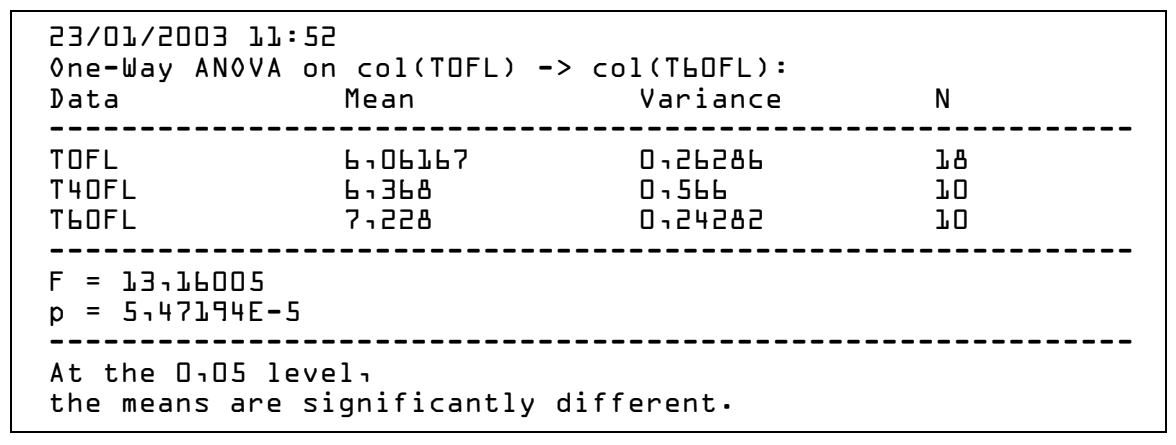

Tabela E.15 - Tabela de análise de variância para a resistência à tração indireta dos prismas, das vigas e de todos os dois, para $\mathrm{V}_{\mathrm{f}}=0$.

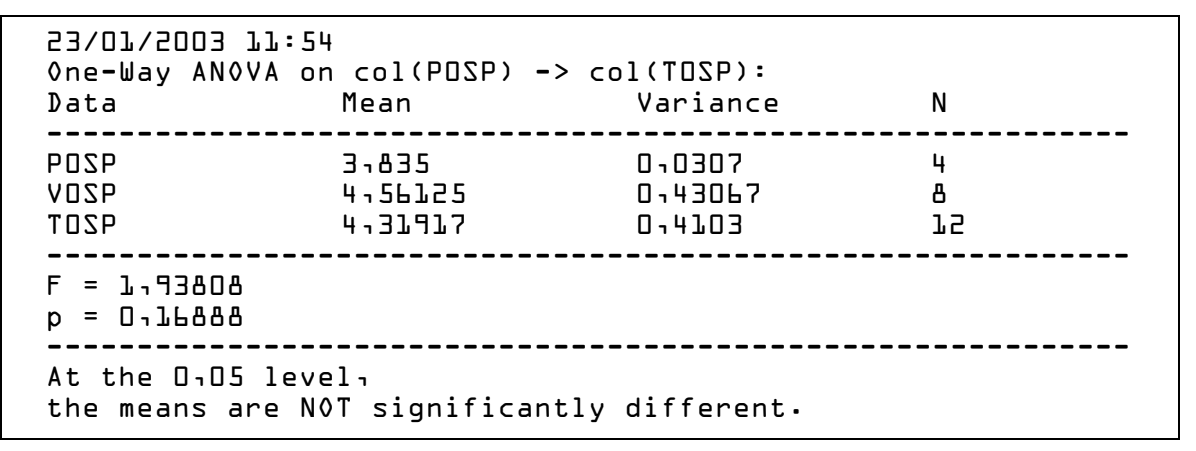


Tabela E.16 - Tabela de análise de variância para a resistência à tração indireta dos prismas, das vigas e de todos os dois, para $\mathrm{V}_{\mathrm{f}}=40 \mathrm{~kg} / \mathrm{m}^{3}$.

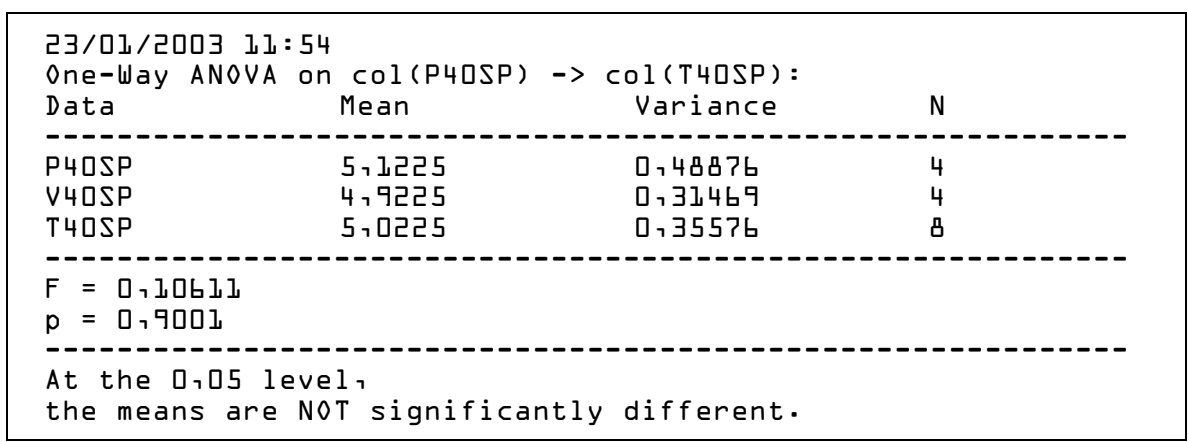

Tabela E.17 - Tabela de análise de variância para a resistência à tração indireta dos prismas, das vigas e de todos os dois, para $\mathrm{V}_{\mathrm{f}}=60 \mathrm{~kg} / \mathrm{m}^{3}$.

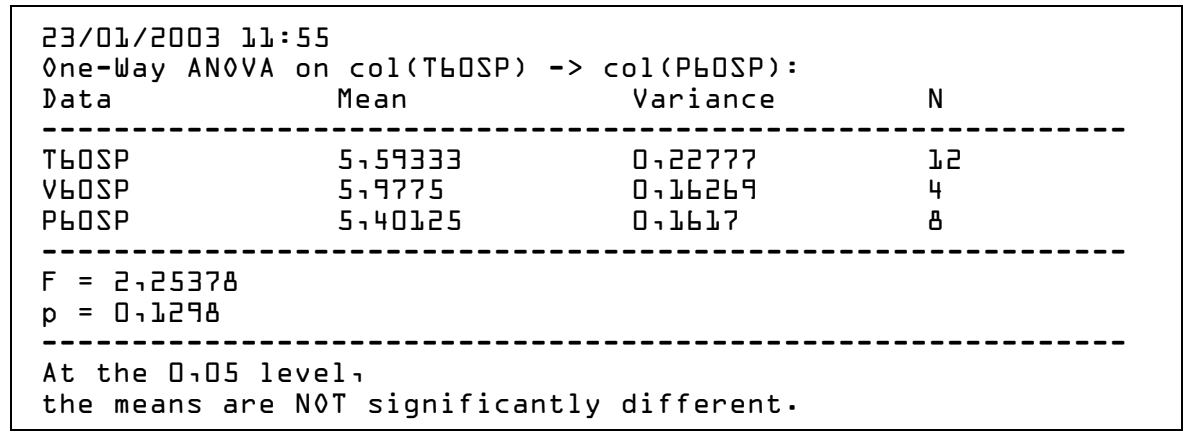

Tabela E.18 - Tabela de análise de variância para a resistência à tração na flexão dos prismas, das vigas e de todos os dois, para $\mathrm{V}_{\mathrm{f}}=0$.

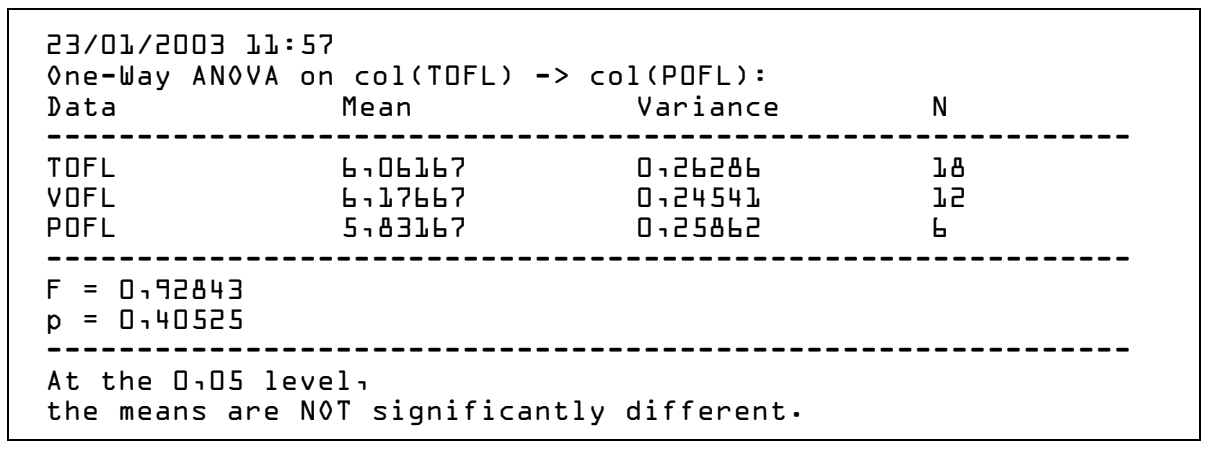

Tabela E.19 - Tabela de análise de variância para a resistência à tração na flexão dos prismas, das vigas e de todos os dois, para $\mathrm{V}_{\mathrm{f}}=40 \mathrm{~kg} / \mathrm{m}^{3}$.

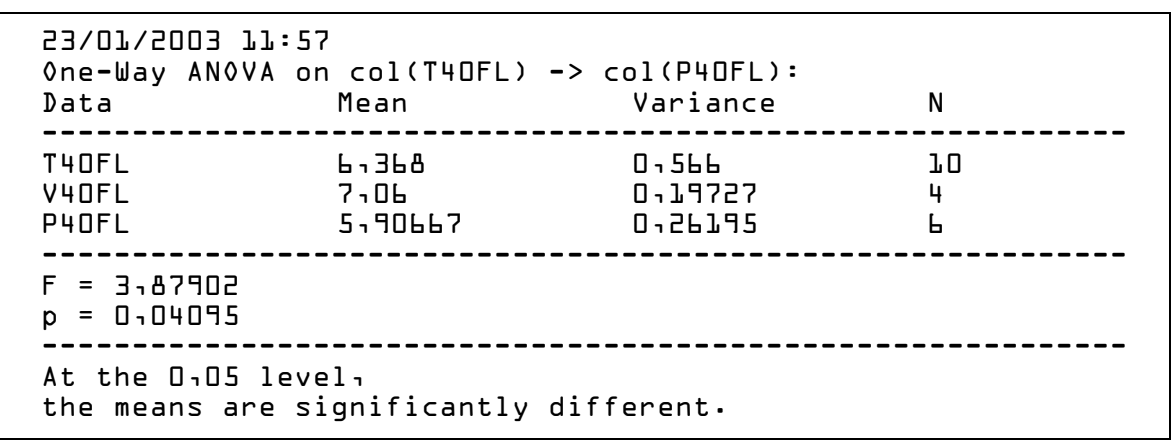


Tabela E.20 - Tabela de análise de variância para a resistência à tração na flexão dos prismas, das vigas e de todos os dois, para $\mathrm{V}_{\mathrm{f}}=60 \mathrm{~kg} / \mathrm{m}^{3}$.

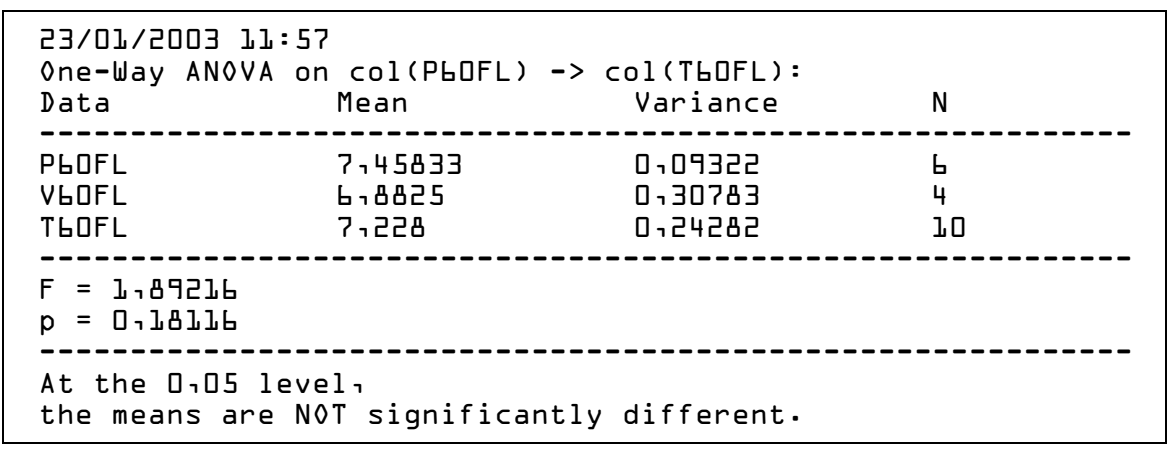

Tabela E.21- Resultados das médias, desvios e erros padrões, e quantidade de amostras para a resistência à tração dos prismas e vigas.

\begin{tabular}{|l|r|r|r|r|}
\hline & Médias & Desvio Padrão & Erro Padrão & \multicolumn{1}{|c|}{$\mathbf{n}$} \\
\hline Prismas 0 - tração indireta & 3,84 & 0,18 & 0,09 & 4 \\
\hline Prismas 0 - tração na flexão & 5,83 & 0,51 & 0,21 & 6 \\
\hline Prismas 40 - tração indireta & 5,12 & 0,70 & 0,35 & 4 \\
\hline Prismas 40 - tração na flexão & 5,91 & 0,51 & 0,21 & 6 \\
\hline Prismas 60 - tração indireta & 5,40 & 0,40 & 0,14 & 8 \\
\hline Prismas 60 - tração na flexão & 7,46 & 0,31 & 0,12 & 6 \\
\hline Vigas 0 - tração indireta & 4,56 & 0,66 & 0,23 & 8 \\
\hline Vigas 0 - tração na flexão & 6,18 & 0,50 & 0,14 & 12 \\
\hline Vigas 40 - tração indireta & 4,92 & 0,56 & 0,28 & 4 \\
\hline Vigas 40 - tração na flexão & 7,06 & 0,44 & 0,22 & 4 \\
\hline Vigas 60 - tração indireta & 5,98 & 0,40 & 0,20 & 4 \\
\hline Vigas 60 - tração na flexão & 6,88 & 0,55 & 0,28 & 4 \\
\hline (Pri + Vig) 0 - tração indireta & 4,32 & 0,64 & 0,18 & 12 \\
\hline (Pri + Vig) 0 - tração na flexão & 6,06 & 0,51 & 0,12 & 18 \\
\hline (Pri + Vig) 40 - tração indireta & 5,02 & 0,60 & 0,21 & 8 \\
\hline (Pri + Vig) 40 - tração na flexã & 6,37 & 0,75 & 0,24 & 10 \\
\hline (Pri + Vig) 60 - tração indireta & 5,59 & 0,48 & 0,14 & 12 \\
\hline (Pri + Vig) 60 - tração na flexãđ & 7,23 & 0,49 & 0,16 & 10 \\
\hline
\end{tabular}

\section{c) Módulo de elasticidade $\left(\mathbf{E}_{\mathrm{c}}\right)$}

Foram feitos ensaios de compressão axial, num total de 33 ensaios. Os dados obtidos foram submetidos a um tratamento estatístico para a validação dos mesmos. A Figura E.14 apresenta o teste de normalidade para os resultados dos corpos-de-prova de concreto. As Tabelas E.22 a E.24 apresentam os resultados da análise de variância (ANOVA) dos dados. Foi utilizado um intervalo de confiança (CI) de 95\%.

Como se pode observar os dados apresentam uma distribuição amostral normal. Isso é verificado pela proximidade dos pontos à reta. Além disso, os coeficientes de variação para cada grupo se encontram dentro de valores excelentes $(\mathrm{CV} \leq 5 \%)$. Os valores dos desvios padrão se encontram na Tabela E.25. 


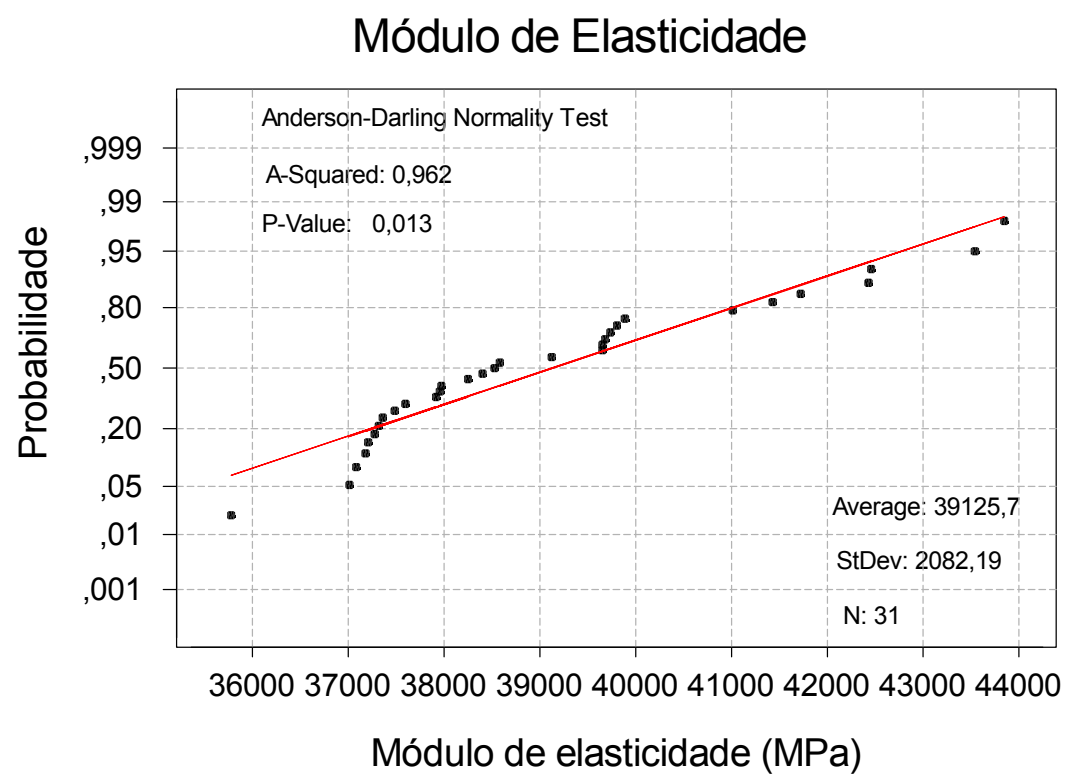

Figura E.14 - Teste de normalidade para os corpos-de-prova para determinação do módulo de elasticidade dos compósitos.

A Tabela E.22 apresenta os resultados para as concretagens dos prismas, para cada teor de fibra separadamente, e a análise indica que a diferença entre as médias é significativa. Isso ocorreu devido aos valores do módulo para $\mathrm{V}_{\mathrm{f}}=60 \mathrm{~kg} / \mathrm{m}^{3}$, que se encontram bem acima dos outros. A Tabela E.23 apresenta os resultados para as concretagens das vigas, para cada teor de fibra separadamente. A Tabela E.24 apresenta os resultados para as concretagens dos prismas, das vigas e de todos juntos, para todos os teores de fibra. Essas análises indicam que a diferença entre as médias não é significativa. Optou-se, então por adotar um valor único para o módulo de elasticidade, englobando todos os parâmetros.

De acordo com essas verificações, pode-se assegurar que os dados são válidos, e que as interpretações resultantes da sua análise serão legítimas.

Tabela E.22 - Tabela de análise de variância para o módulo de elasticidade dos prismas, para cada teor de fibra.

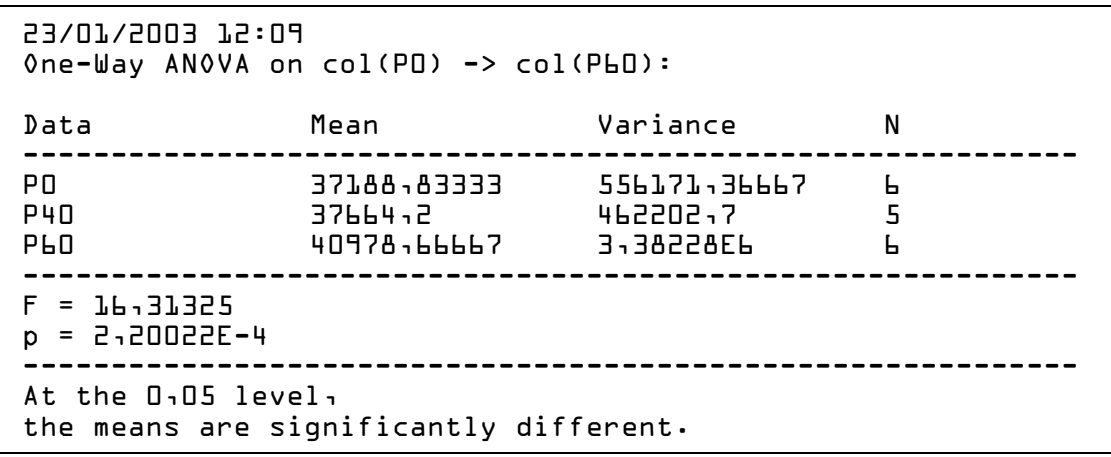


Tabela E.23 - Tabela de análise de variância para o módulo de elasticidade das vigas, para cada teor de fibra.

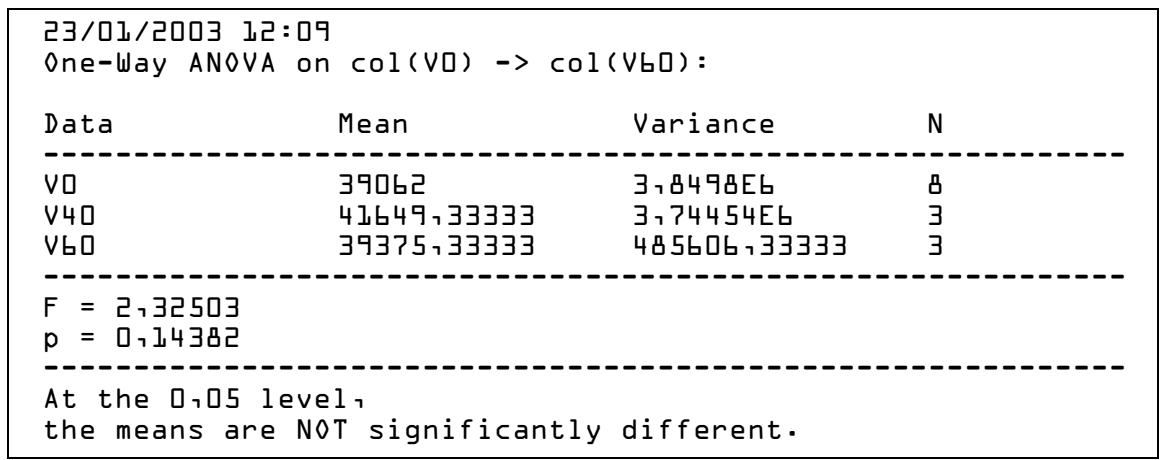

Tabela E.24 - Tabela de análise de variância para o módulo de elasticidade dos prismas e vigas, levando em conta todos os teores de fibra.

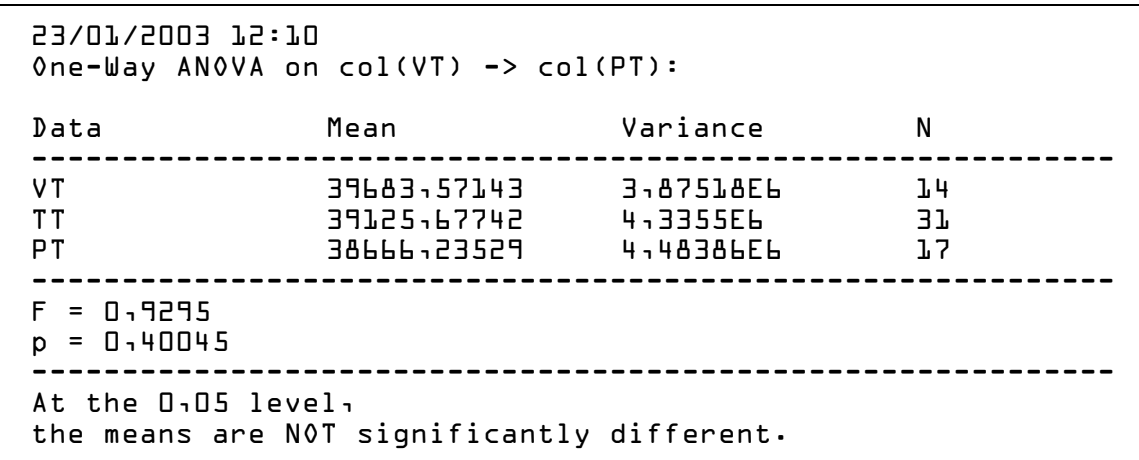

Tabela E.25 - Resultados das médias, desvios e erros padrões, e quantidade de amostras para o módulo de elasticidade dos prismas e vigas.

\begin{tabular}{|l|r|r|r|r|}
\hline & Médias & Desvio Padrão & Erro Padrão & \multicolumn{1}{c|}{$\mathbf{n}$} \\
\hline Prismas 0 & 37188,8 & 745,8 & 304,5 & 6 \\
\hline Prismas 40 & 37664,2 & 679,9 & 304,0 & 5 \\
\hline Prismas 60 & 40978,7 & 1839,1 & 750,8 & 6 \\
\hline Todos os prismas & 38666,2 & 2117,5 & 513,6 & 17 \\
\hline Vigas 0 & 39062,0 & 1962,1 & 693,7 & 8 \\
\hline Vigas 40 & 41649,3 & 1935,1 & 1117,2 & 3 \\
\hline Vigas 60 & 39375,3 & 696,9 & 402,3 & 3 \\
\hline Todas as vigas & 39683,6 & 1968,5 & 526,1 & 14 \\
\hline Todos (Pri + Vig) & 39125,7 & 2082,2 & 374,0 & 31 \\
\hline
\end{tabular}

\section{d) Tenacidade}

Foram realizados no total 38 ensaios de tração na flexão, dos quais 18 em concretos sem fibra e 20 em concretos com fibras de aço. Para 16 corpos-de-prova entre estes últimos 20, foi medida a tenacidade na flexão. Os dados obtidos foram submetidos a um tratamento estatístico para a validação dos mesmos. As Figuras E.15 e E.16 apresentam os testes de normalidade para os resultados dos corpos-de-prova de concreto. As Tabelas E.26 a E.28 apresentam os resultados da análise de variância (ANOVA) dos dados. Foi utilizado um intervalo de confiança (CI) de 95\%. 


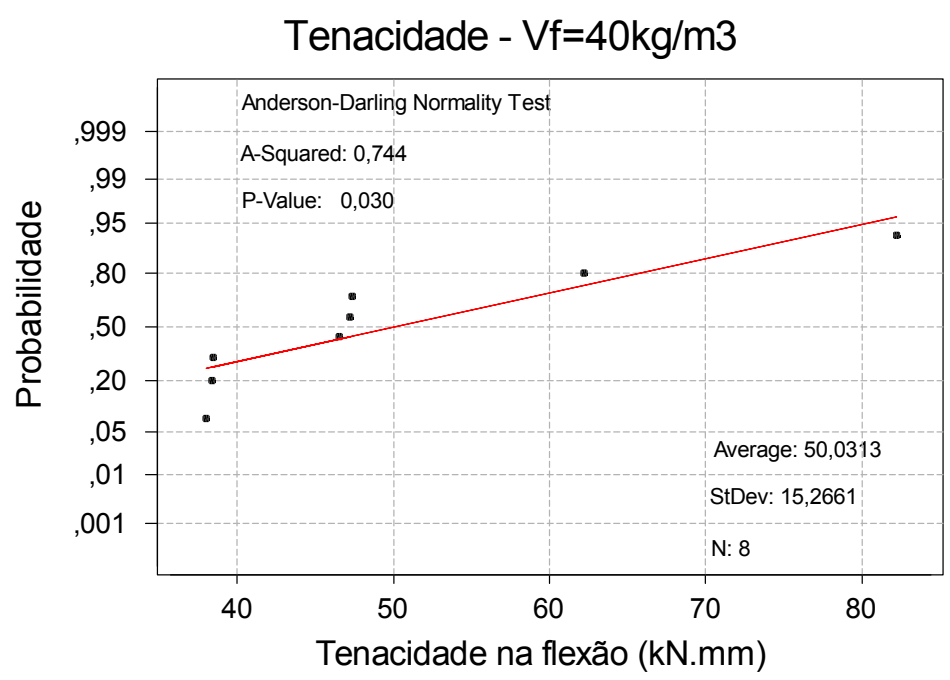

Figura E.15 - Teste de normalidade para os corpos-de-prova para determinação da tenacidade na flexão para os compósitos com $\mathrm{V}_{\mathrm{f}}=40 \mathrm{~kg} / \mathrm{m}^{3}$.

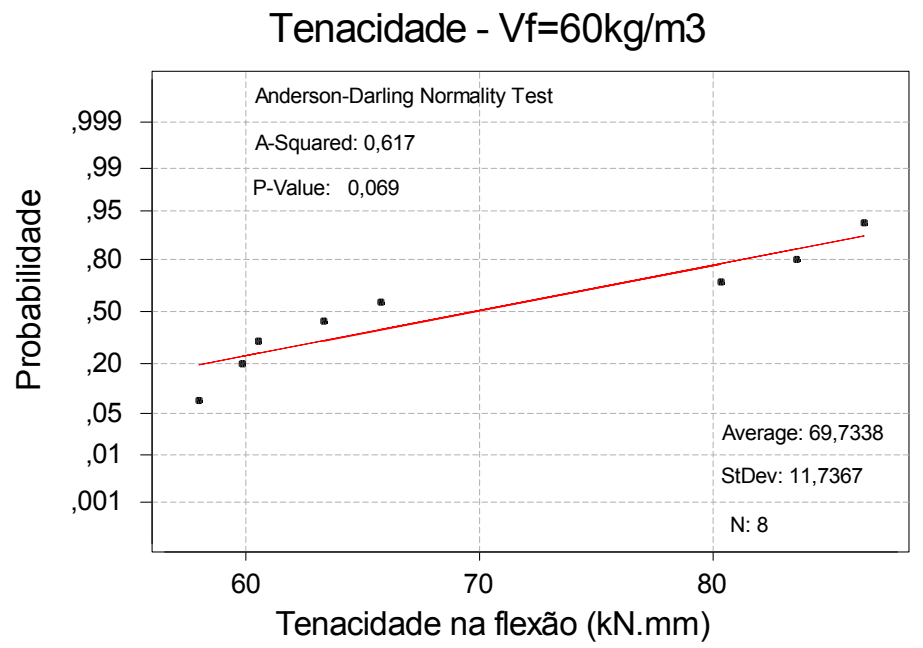

Figura E.16 - Teste de normalidade para os corpos-de-prova para determinação da tenacidade na flexão para os compósitos com $\mathrm{V}_{\mathrm{f}}=60 \mathrm{~kg} / \mathrm{m}^{3}$.

Como se pode observar, os dados para um teor de fibra de $\mathrm{V}_{\mathrm{f}}=40 \mathrm{~kg} / \mathrm{m}^{3}$ não apresentam uma distribuição amostral normal, além de ter um coeficiente de variação elevado ( $C V=31 \%)$. Isso é indicado pela não proximidade dos pontos à reta. Já para os compósitos com $\mathrm{V}_{\mathrm{f}}=60 \mathrm{~kg} / \mathrm{m}^{3}$, os dados apresentam uma distribuição amostral normal. Para este grupo, o coeficiente de variação apresenta um valor aceitável $(\mathrm{CV}=17 \%)$. Os valores dos desvios padrão se encontram na Tabela E.29.

A Tabela E.26 apresenta a análise da variância para os corpos-de-prova da concretagem dos prismas, e conclui que as médias, para os teores de fibra de $40 \mathrm{~kg} / \mathrm{m}^{3}$ e $60 \mathrm{~kg} / \mathrm{m}^{3}$, são significativamente diferentes. A Tabela E.27 apresenta a análise da variância para os corposde-prova da concretagem das vigas, e conclui que as médias, não são significativamente 
diferentes. Para a Tabela E.28, que apresenta os resultados divididos entre os dois teores de fibra de $40 \mathrm{~kg} / \mathrm{m}^{3}$ e $60 \mathrm{~kg} / \mathrm{m}^{3}$, levando em conta todos os modelos, a análise da variância conclui que as médias são significativamente diferentes. Optou-se, então por adotar dois valores para a tenacidade na flexão, um para $\mathrm{V}_{\mathrm{f}}=40 \mathrm{~kg} / \mathrm{m}^{3}$ e outro para $\mathrm{V}_{\mathrm{f}}=60 \mathrm{~kg} / \mathrm{m}^{3}$.

A rigor, deveriam ter sido feitos mais ensaios para os concretos com $40 \mathrm{~kg} / \mathrm{m}^{3}$ de fibras de aço para obter-se uma amostra melhor, entretanto isso não foi possível devido ao cronograma apertado com que se estava trabalhando. Por este motivo, apesar desses dados apresentarem uma dispersão grande, aceitaram-se os mesmos para a determinação da tenacidade dos compósitos.

Tabela E.26 - Tabela de análise de variância para a tenacidade na flexão dos prismas.

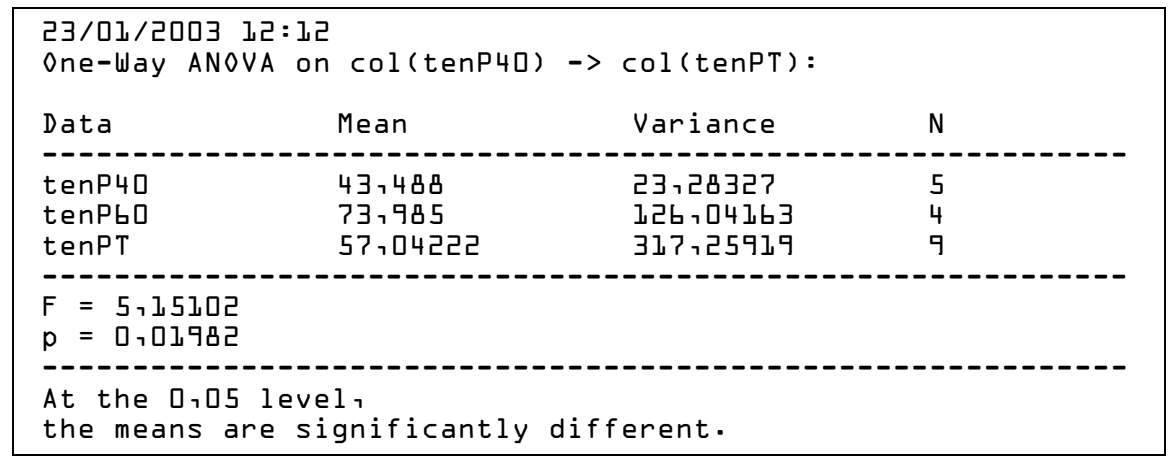

Tabela E.27 - Tabela de análise de variância para a tenacidade na flexão das vigas.

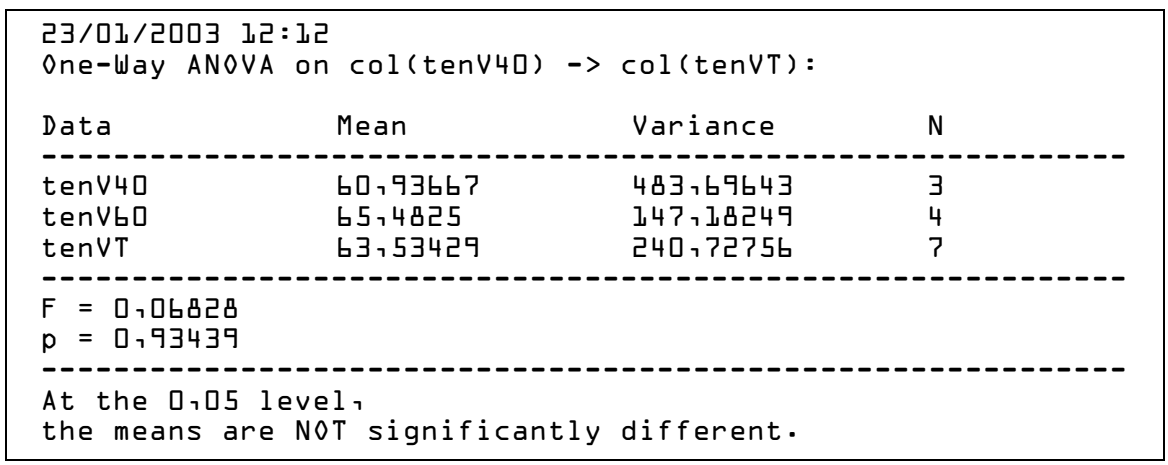

Tabela E.28 - Tabela de análise de variância para a tenacidade na flexão dos prismas e das vigas, para cada teor de fibra.

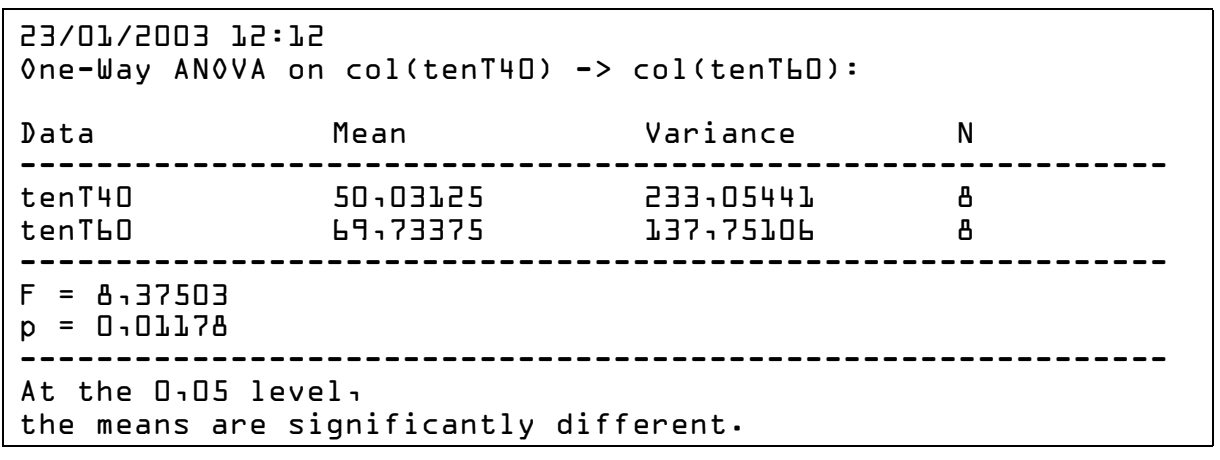


Tabela E.29 - Resultados das médias, desvios e erros padrões, e quantidade de amostras para a tenacidade na flexão dos prismas e vigas.

\begin{tabular}{|l|r|r|r|r|}
\hline & Médias & Desvio Padrão & Erro Padrão & \multicolumn{1}{c|}{ n } \\
\hline Prismas 40 & 43,49 & 4,83 & 2,16 & 5 \\
\hline Prismas 60 & 73,99 & 11,23 & 5,61 & 4 \\
\hline Todos os prismas & 57,04 & 17,81 & 5,94 & 9 \\
\hline Vigas 40 & 60,94 & 21,99 & 12,70 & 3 \\
\hline Vigas 60 & 65,48 & 12,13 & 6,07 & 4 \\
\hline Todas as vigas & 63,53 & 15,52 & 5,86 & 7 \\
\hline Todos 40 & 50,03 & 15,27 & 5,40 & 8 \\
\hline Todos 60 & 69,73 & 11,74 & 4,15 & 8 \\
\hline Todos $(40+60)$ & 59,88 & 16,63 & 4,16 & 16 \\
\hline
\end{tabular}

\section{E.6. Análise Estatística para os Ensaios de Arrancamento}

Para esta pesquisa, foram realizados 108 ensaios de arrancamento em modelos prismáticos, cujo objetivo principal foi avaliar a influência das fibras de aço na aderência entre a armadura e o concreto.

Os parâmetros de ensaio escolhidos foram: o comprimento aderente disponível $\left(\ell_{\mathrm{ef}}\right)$, o volume de fibras de aço $\left(\mathrm{V}_{\mathrm{f}}\right)$, e o grau de protensão da armadura $\left(\sigma_{\mathrm{p}}\right)$.

O resultado de ensaio que se buscava foi a tensão máxima de aderência ( $\left.\tau_{b, \text { máx }}\right)$.

Os valores para os parâmetros de ensaio foram:

$$
\begin{aligned}
& \text { - } \ell_{\mathrm{ef}}=\left\{\begin{array}{l}
5 \phi_{\mathrm{p}}=6,35 \mathrm{~cm} \\
7 \phi_{\mathrm{p}}=9 \mathrm{~cm} \\
15 \phi_{\mathrm{p}}=19 \mathrm{~cm}
\end{array}\right. \\
& \text { - } \mathrm{V}_{\mathrm{f}}=\left\{\begin{array}{l}
0 \mathrm{~kg} / \mathrm{m}^{3} \\
40 \mathrm{~kg} / \mathrm{m}^{3} \\
60 \mathrm{~kg} / \mathrm{m}^{3}
\end{array}\right. \\
& \text { - } \sigma_{\mathrm{p}}=\left\{\begin{array}{l}
\text { zero (armadura sem protensão) } \\
0,8 \mathrm{f}_{\mathrm{ptk}} \text { (armadura pré - tracionada) }
\end{array}\right.
\end{aligned}
$$

Fazendo-se o cruzamento de todos os parâmetros, e seus respectivos valores, obteve-se um total de 18 combinações diferentes. Para cada combinação, confeccionaram-se 6 modelos idênticos, o que resultou no total de 108 ensaios, ou seja:

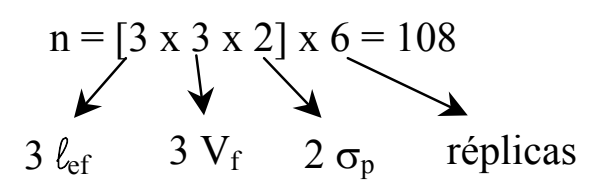

A análise estatística desses resultados foi dividida em duas partes: 
1) Verificação da normalidade dos dados, através do teste de normalidade e da plotagem dos resíduos;

2) Montagem de uma Tabela de Análise de Variância (ANOVA) com a comparação de médias pelo processo de Tukey, para a avaliação comparativa dos dados;

Para uma melhor caracterização do problema em termos estatísticos, admitem-se as seguintes definições:

- $\quad$ Variável resposta principal $(Y)=$ tensão de aderência máxima $\left(\tau_{b, \text { máx }}\right)$;

- Fatores ou variáveis independentes $\left(\mathrm{X}_{\mathrm{i}}\right)$ :

$$
\begin{aligned}
& \checkmark \quad X_{1}=\text { comprimento aderente disponível }\left(\ell_{\mathrm{ef}}\right) \text {; } \\
& \checkmark \quad \mathrm{X}_{2}=\text { volume de fibras de aço }\left(\mathrm{V}_{\mathrm{f}}\right) \text {; } \\
& \checkmark \quad \mathrm{X}_{3}=\text { grau de protensão da armadura }\left(\sigma_{\mathrm{p}}\right) .
\end{aligned}
$$

Cada variável independente foi subdividida em dois ou três valores, chamados de níveis, que foram codificados estatisticamente. Os níveis para as variáveis independentes são

\begin{tabular}{|c|c|c|c|c|c|c|}
\hline Variáveis & \multicolumn{2}{|c|}{$\begin{array}{c}\text { Comprimento aderente } \\
\text { disponível }\left(\ell_{\mathrm{ef}}\right)\end{array}$} & \multicolumn{2}{|c|}{$\begin{array}{l}\text { Volume de fibras de aço } \\
\qquad\left(\mathrm{V}_{\mathrm{f}}\right)\end{array}$} & \multicolumn{2}{|c|}{$\begin{array}{l}\text { Grau de protensão da } \\
\text { armadura }\left(\sigma_{\mathrm{p}}\right)\end{array}$} \\
\hline \multirow{4}{*}{$\begin{array}{l}\text { Níveis e } \\
\text { respectivos } \\
\text { códigos }\end{array}$} & Nível & Código & Nível & Código & Nível & Código \\
\hline & $6,35 \mathrm{~cm}$ & 1 & $0 \mathrm{~kg} / \mathrm{m}^{3}$ & 1 & $0,8 \mathrm{f}_{\mathrm{ptk}}$ & 0 \\
\hline & $9 \mathrm{~cm}$ & 2 & $40 \mathrm{~kg} / \mathrm{m}^{3}$ & 2 & $0 f_{p t k}$ & 1 \\
\hline & $19 \mathrm{~cm}$ & 3 & $60 \mathrm{~kg} / \mathrm{m}^{3}$ & 3 & --- & --- \\
\hline
\end{tabular}
apresentados na Tabela E.30.

Tabela E.30 - Níveis e códigos das variáveis independentes.

Além da variável resposta principal (tensão de aderência máxima, $\tau_{b, \text { máx }}$ ), foram analisados, também, os dados para outras variáveis resposta. São elas:

- $\mathrm{Y}_{1}=$ tensão de aderência para a primeira fissura $\left(\tau_{\mathrm{b}, 1 \text { a } \mathrm{a} \text { iss }}\right)$;

- $\mathrm{Y}_{2}=$ tensão de aderência para um escorregamento de $\mathrm{S}=0,1 \mathrm{~mm}\left(\tau_{\mathrm{b}, 0.1}\right)$;

- $\mathrm{Y}_{3}=$ tensão de aderência para um escorregamento de $\mathrm{S}=1 \mathrm{~mm}\left(\tau_{\mathrm{b}, 1}\right)$;

- $\mathrm{Y}_{4}=$ escorregamento referente à tensão máxima $\left(\mathrm{S}_{\tau_{\mathrm{b}, \text { máx }}}\right)$.

Segundo vários pesquisadores, como ELIGEHAUSEN et al (1983) por exemplo, o valor do coeficiente de variação para os ensaios de arrancamento é em torno de $30 \%$. 


\section{E.6.1. Verificação dos dados}

Para a análise estatística, os dados foram divididos em quatro blocos:

- Bloco 1 - as cinco variáveis resposta $\left(Y=\tau_{b, \text { máx }}, Y_{1}=\tau_{b, 1}\right.$ a fiss, $Y_{2}=\tau_{b, 0.1}, Y_{3}=\tau_{b, 1}$ e $Y_{4}=$ $\left.\mathrm{S}_{\tau_{\mathrm{b} \text {,máx }}}\right)$ foram analisadas levando em conta as três variáveis independentes $\left(\mathrm{X}_{1}=l_{\mathrm{ef}}\right.$, $\mathrm{X}_{2}=\mathrm{V}_{\mathrm{f}}$ e $\left.\mathrm{X}_{3}=\sigma_{\mathrm{p}}\right)$

- Bloco 2 - as cinco variáveis respostas foram divididas em três grupos, um para cada comprimento aderente disponível $\left(\mathrm{X}_{1}\right)$, e analisadas para as outras duas variáveis independentes $\left(\mathrm{X}_{2}\right.$ e $\left.\mathrm{X}_{3}\right)$;

- Bloco 3 - as cinco variáveis respostas foram divididas em três grupos, um para cada volume de fibra $\left(\mathrm{X}_{2}\right)$, e analisadas para as outras duas variáveis independentes $\left(\mathrm{X}_{1} \mathrm{e}\right.$ $\left.\mathrm{X}_{3}\right)$;

- Bloco 4 - as cinco variáveis respostas foram divididas em dois grupos, um para cada grau de protensão $\left(\mathrm{X}_{3}\right)$, e analisadas para as outras duas variáveis independentes $\left(\mathrm{X}_{1} \mathrm{e}\right.$ $\left.\mathrm{X}_{2}\right)$.

Para as análises, foi utilizado o programa estatístico MINITAB version 13.52.

\section{a) Bloco 1}

Todos os dados, de todos os grupos, foram avaliados três vezes: (1) para a variável $\mathrm{X}_{1}$, onde os 108 modelos foram divididos em três sub-grupos de 36, levando-se em conta os comprimentos aderentes; (2) para $\mathrm{X}_{2}$, onde os 108 modelos foram divididos em três subgrupos de 36, levando-se em conta os volumes de fibra; e (3) para $\mathrm{X}_{3}$, onde os 108 modelos foram divididos em dois sub-grupos de 54, levando-se em conta o grau de protensão. Ou seja, foram construídas três Tabelas de Análise de Variância para cada variável resposta, cada tabela levando em conta uma variável independente. Para cada sub-grupo também foi feita a plotagem dos resíduos e a avaliação de Tukey, para um intervalo de confiança (CI) de 95\%.

\section{Variável resposta $Y=\tau_{b, m a ́ x}$}

A primeira análise a ser feita é a dos resíduos, para verificar-se se a amostra tem uma distribuição normal. As Figuras E.17, E.18 e E.19 apresentam os gráficos com plotagem dos resíduos para as variáveis $\mathrm{X}_{1}, \mathrm{X}_{2}$ e $\mathrm{X}_{3}$, respectivamente.

Para a variável $\mathrm{X}_{1}$, percebe-se que a distribuição pode ser considerada normal, o que é verificado pela distribuição quase linear dos pontos no primeiro diagrama. Pelo segundo diagrama, observa-se que a variabilidade dos dados não difere muito, de um nível em relação 
ao outro, e que os dados para o comprimento aderente de $\ell_{\mathrm{ef}}=15 \phi_{\mathrm{p}}$ apresentam a menor variabilidade, o que é verificado pela concentração dos pontos mais próxima do eixo zero.
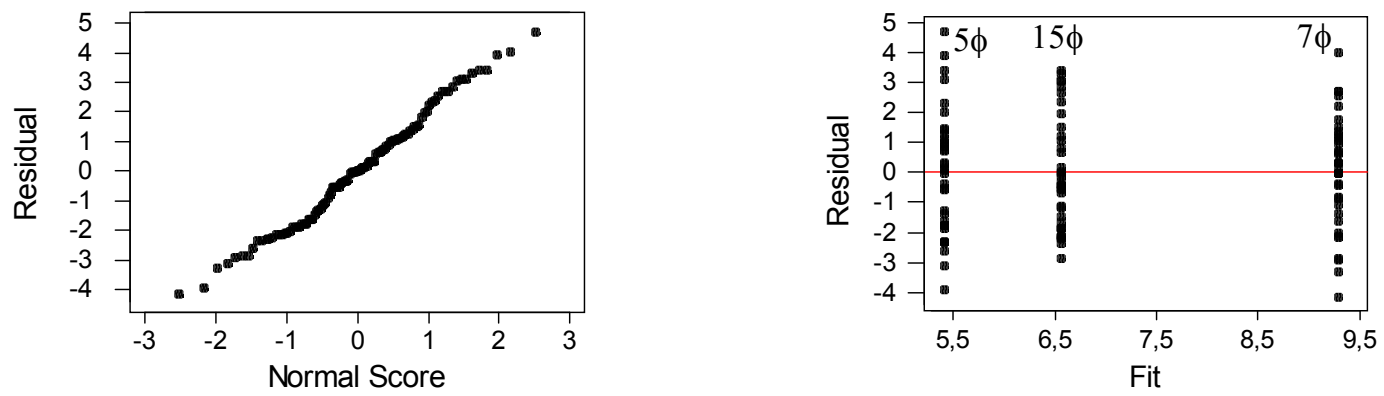

Figura E.17 - Análise de resíduos para $\mathrm{Y}=\tau_{\mathrm{b} \text {,máx }}$ e a variável $\mathrm{X}_{1}$.
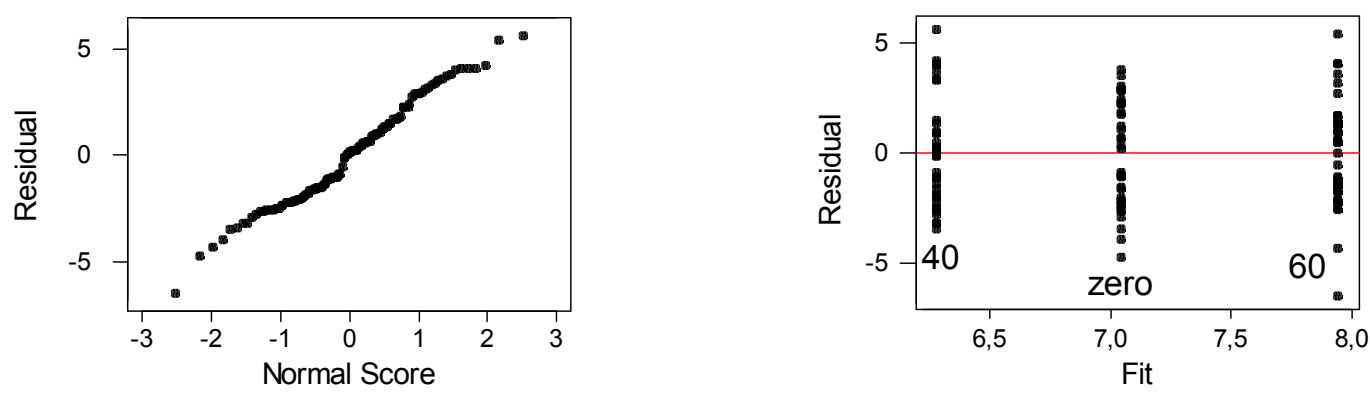

Figura E.18 - Análise de resíduos para $\mathrm{Y}=\tau_{\mathrm{b}, \operatorname{máx}}$ e a variável $\mathrm{X}_{2}$.
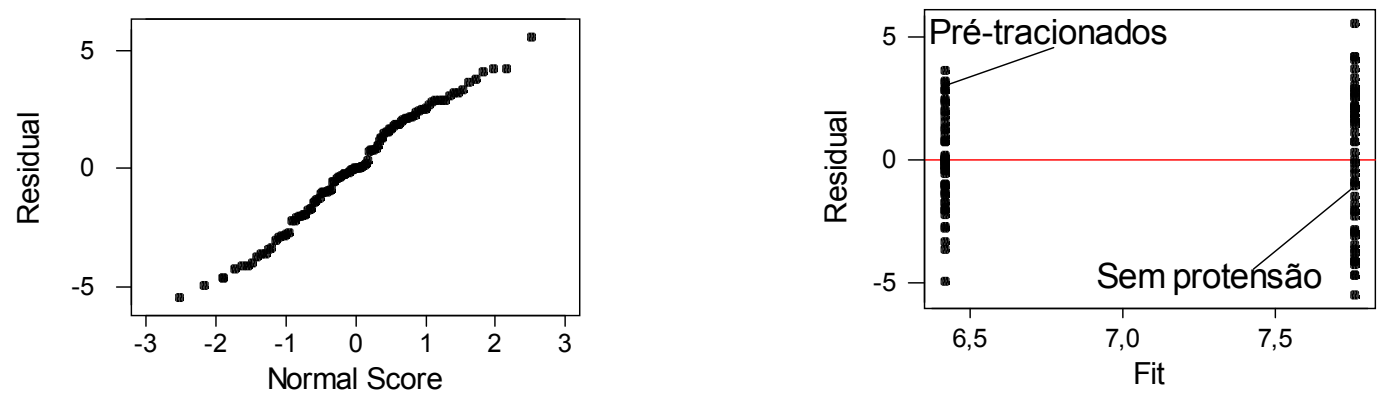

Figura E.19 - Análise de resíduos para $Y=\tau_{b \text {,máx }}$ e a variável $\mathrm{X}_{3}$.

Tanto para a variável $\mathrm{X}_{2}$ como para a variável $\mathrm{X}_{3}$, pode-se dizer que a distribuição amostral é normal e que a variabilidade é boa. Para $\mathrm{X}_{2}$, os dados relativos a $\mathrm{V}_{\mathrm{f}}=0$ e $\mathrm{V}_{\mathrm{f}}=40 \mathrm{~kg} / \mathrm{m}^{3}$ apresentam variabilidades bem próximas, e menores que a dos dados relativos à $\mathrm{V}_{\mathrm{f}}=60 \mathrm{~kg} / \mathrm{m}^{3}$. Para $\mathrm{X}_{3}$, os prismas pré-tracionados apresentam uma variabilidade menor que a dos sem protensão.

Após a verificação dos resíduos, constatado que as amostras apresentam distribuição normal, pôde-se montar a tabela de variância dos resultados. Ela indica a variabilidade dos dados. Juntamente com a tabela de variância, fez-se o teste de Tukey, que indica se há interferência de um conjunto de dado sobre o outro, para o intervalo de confiança estabelecido, que neste caso foi de $\mathrm{CI}=95 \%$. As Figuras E.20 a E.22 apresentam os resultados para as três variáveis independentes analisadas. 
Pela Tabela de Análise da Variância, percebe-se que os melhores resultados são para o nível 2, ou seja, para os modelos com comprimentos aderentes de $9 \mathrm{~cm}\left(7 \phi_{\mathrm{p}}\right)$, que apresentam os maiores valores para a tensão de aderência. Observa-se também, que as médias são diferentes para os três níveis analisados, o que é indicado pelo valor pequeno de $\mathbf{p}(\mathbf{p}<0,05)$.

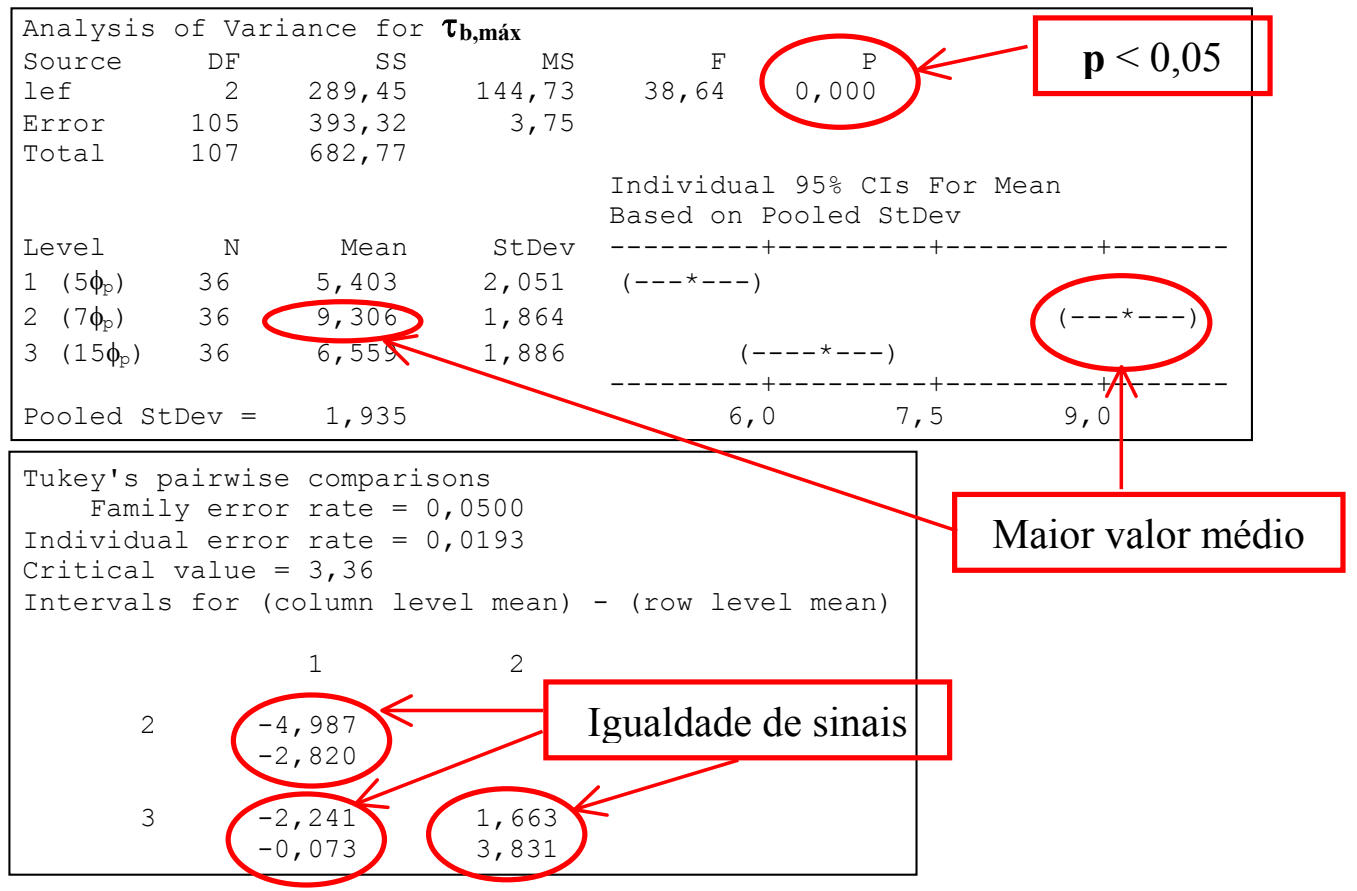

Figura E.20 - Tabela de análise de variância e teste de Tukey para $\mathrm{Y}=\tau_{\mathrm{b}, \operatorname{máx}}$ e $\mathrm{X}_{1}$.

Por fim, pelo teste de Tukey, a análise verifica que não há interferências entre os grupos, o que é indicado pela igualdade de sinais (Figura E.20). Ou seja, as médias são significativamente diferentes umas das outras.

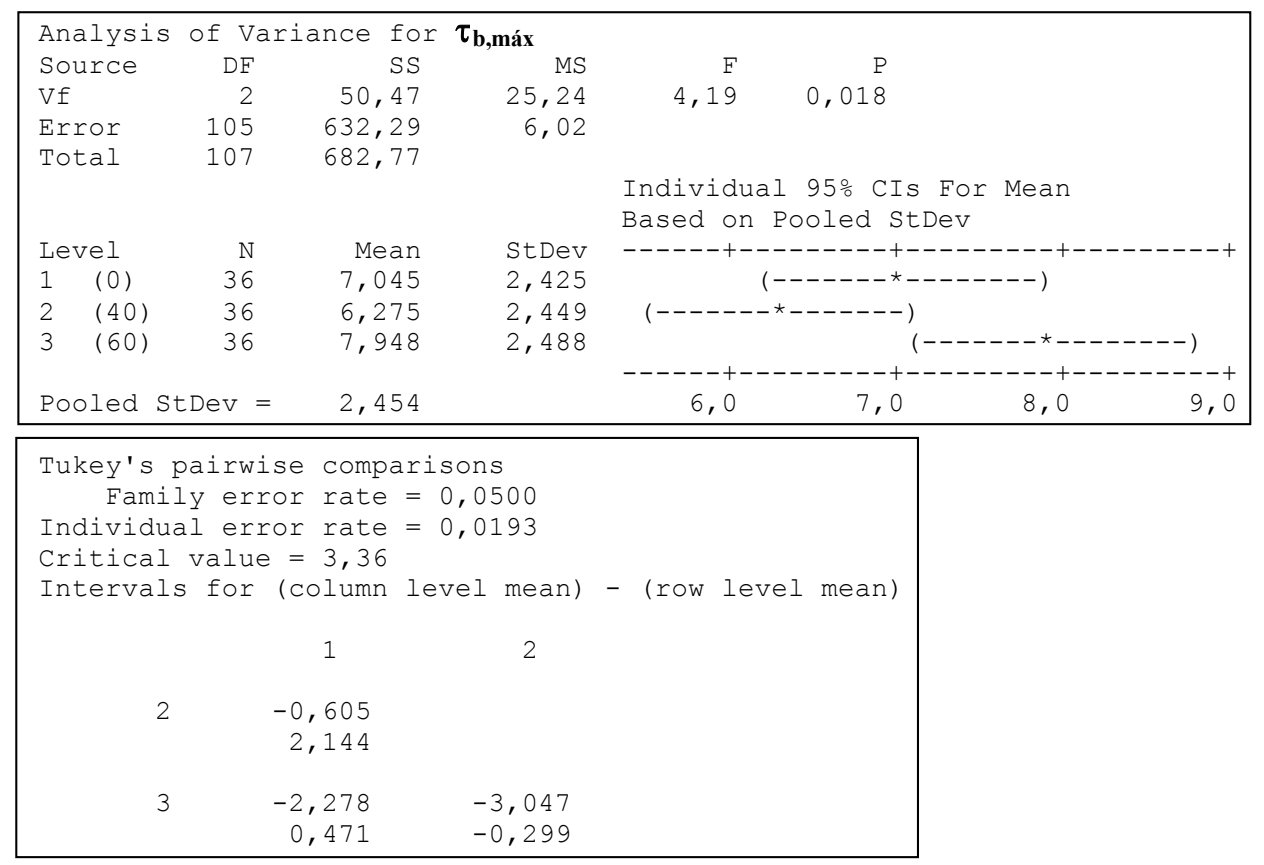

Figura E.21 - Tabela de análise de variância e teste de Tukey para $Y=\tau_{b \text {,máx }}$ e $X_{2}$. 
Percebe-se, para a tabela da Figura E.21, que os melhores resultados são para o nível 3, que representa um volume de fibra de $60 \mathrm{~kg} / \mathrm{m}^{3}$, que apresenta os maiores valores.

Por fim, a análise indica que só não há interferências entre os grupos 2 e 3. Já para os grupos 1 e 2, e 1 e 3 há interferência de um sobre o outro. Ou seja, essas médias não são significativamente diferentes.

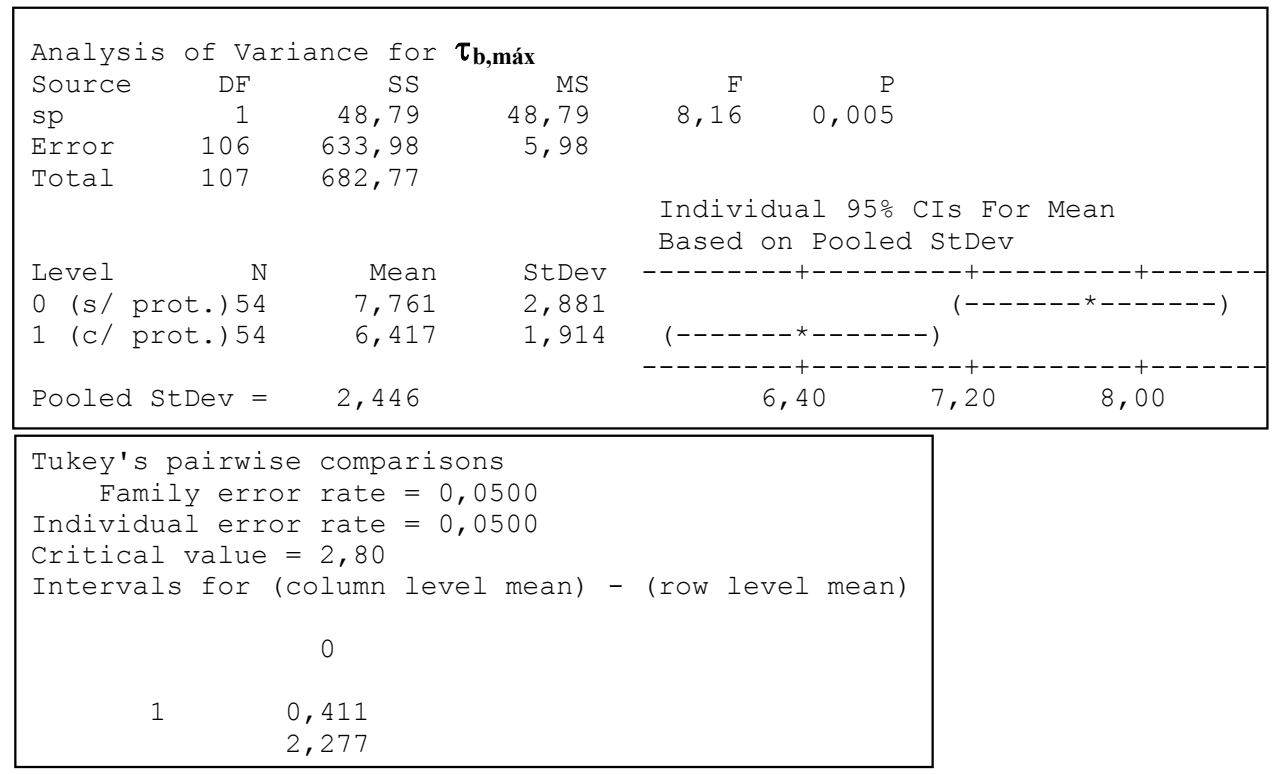

Figura E.22 - Tabela de análise de variância e teste de Tukey para $Y=\tau_{b, \text { máx }}$ e $X_{3}$.

Percebe-se que os melhores resultados são para o nível 2, que representa os modelos sem protensão, que apresenta os maiores valores. Por fim, a análise indica que não há interferências entre os grupos, as médias são significativamente diferentes.

\section{Variável resposta $Y_{1}=\tau_{b, 1^{a}}{ }_{\text {fiss }}$}

A primeira análise a ser feita é a dos resíduos, para verificar-se se a amostra tem uma distribuição normal. As Figura E.23, E.24 e E.25 apresentam os gráficos com plotagem dos resíduos para as variáveis $\mathrm{X}_{1}, \mathrm{X}_{2}$ e $\mathrm{X}_{3}$, respectivamente.
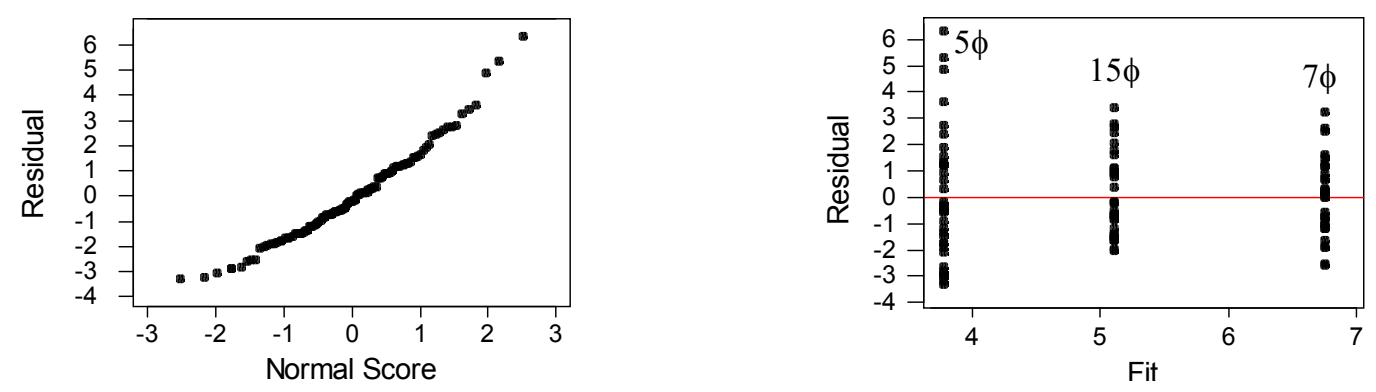

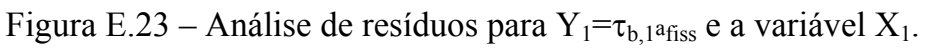



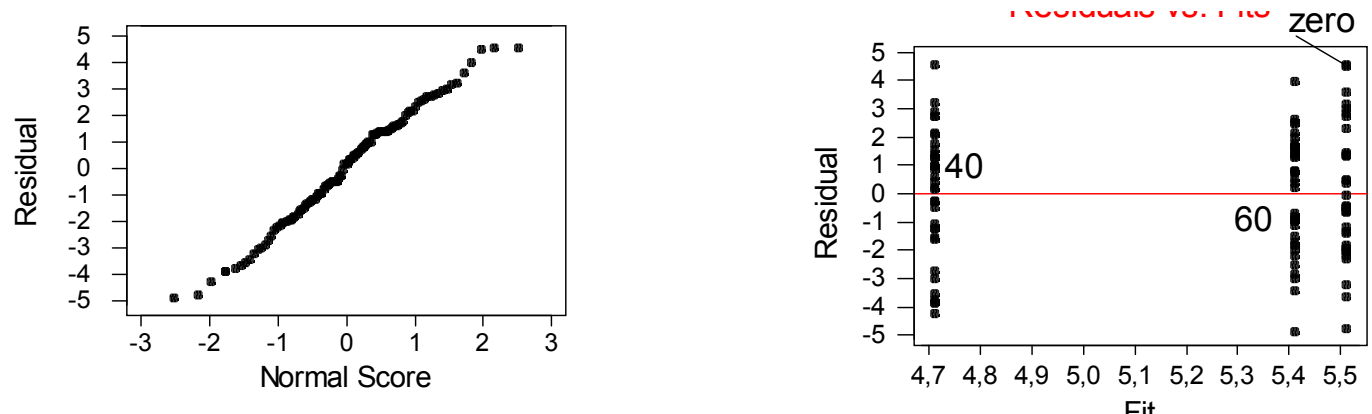

Figura E.24 - Análise de resíduos para $\mathrm{Y}_{1}=\tau_{\mathrm{b}, 1 \mathrm{a}} \mathrm{a}_{\text {fiss }}$ e a variável $\mathrm{X}_{2}$.
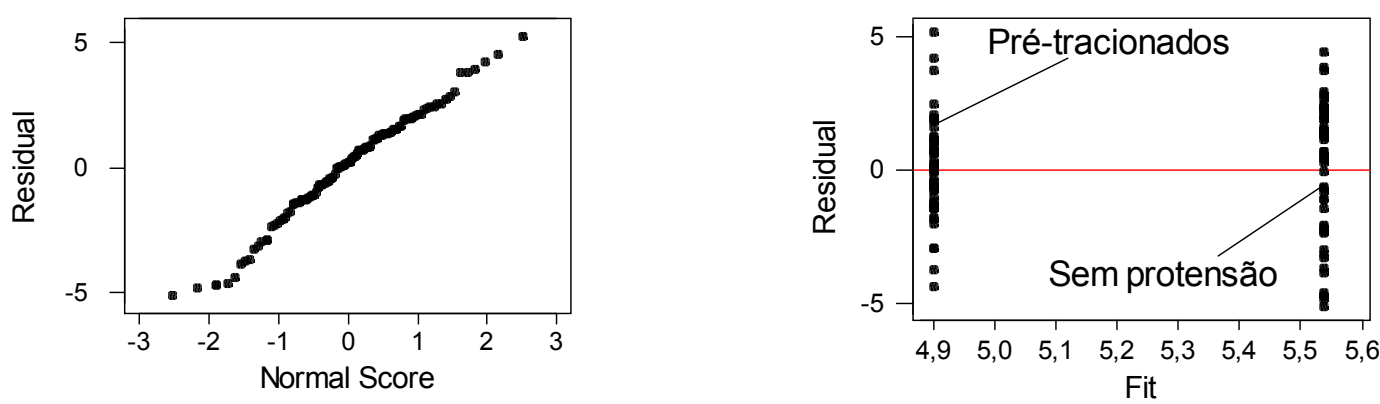

Figura E.25 - Análise de resíduos para $\mathrm{Y}_{1}=\tau_{\mathrm{b}, 1} \mathrm{a}_{\text {fiss }}$ e a variável $\mathrm{X}_{3}$.

Para as três variáveis, a distribuição pode ser considerada normal. Para $X_{1}$, a variabilidade não é constante, há uma tendência de formação do cone (Figura E.23). Ou seja, os resultados podem não ser representativos do problema. Para as outras variáveis a variabilidade é boa.

Após a verificação dos resíduos, constatado que as amostras apresentam distribuição normal, pôde-se montar a tabela de variância dos resultados. Ela indica a variabilidade dos dados. Juntamente com a tabela de variância, fez-se o teste de Tukey, que indica se há interferência de um conjunto de dado sobre o outro, para o intervalo de confiança estabelecido, que neste caso foi de $\mathrm{CI}=95 \%$. As Figuras E.26 a E.28 apresentam os resultados para as três variáveis independentes analisadas.

Para a Figura E.26, percebe-se que os modelos com $\ell_{\mathrm{ef}}=7 \phi_{\mathrm{p}}$ apresentam a maior tensão de aderência na primeira fissura. Observa-se, também, que não há interferência de um nível em relação ao outro, o que significa que as médias são significativamente diferentes.

Para a Figura E.27, tanto pelo valor de p na Tabela de Análise da Variância como para o teste de Tukey, verifica-se que há interferência de um nível sobre o outro, o que significa que as médias não são significativamente diferentes. Ou seja, o teor de fibra não influi na tensão de aderência da primeira fissura.

Percebe-se, nas tabelas de análise de variância, que há interferência de um nível sobre o outro, ou seja, para a tensão de aderência da primeira fissura, não há diferença significativa entre as médias para os modelos com e para os sem protensão. 


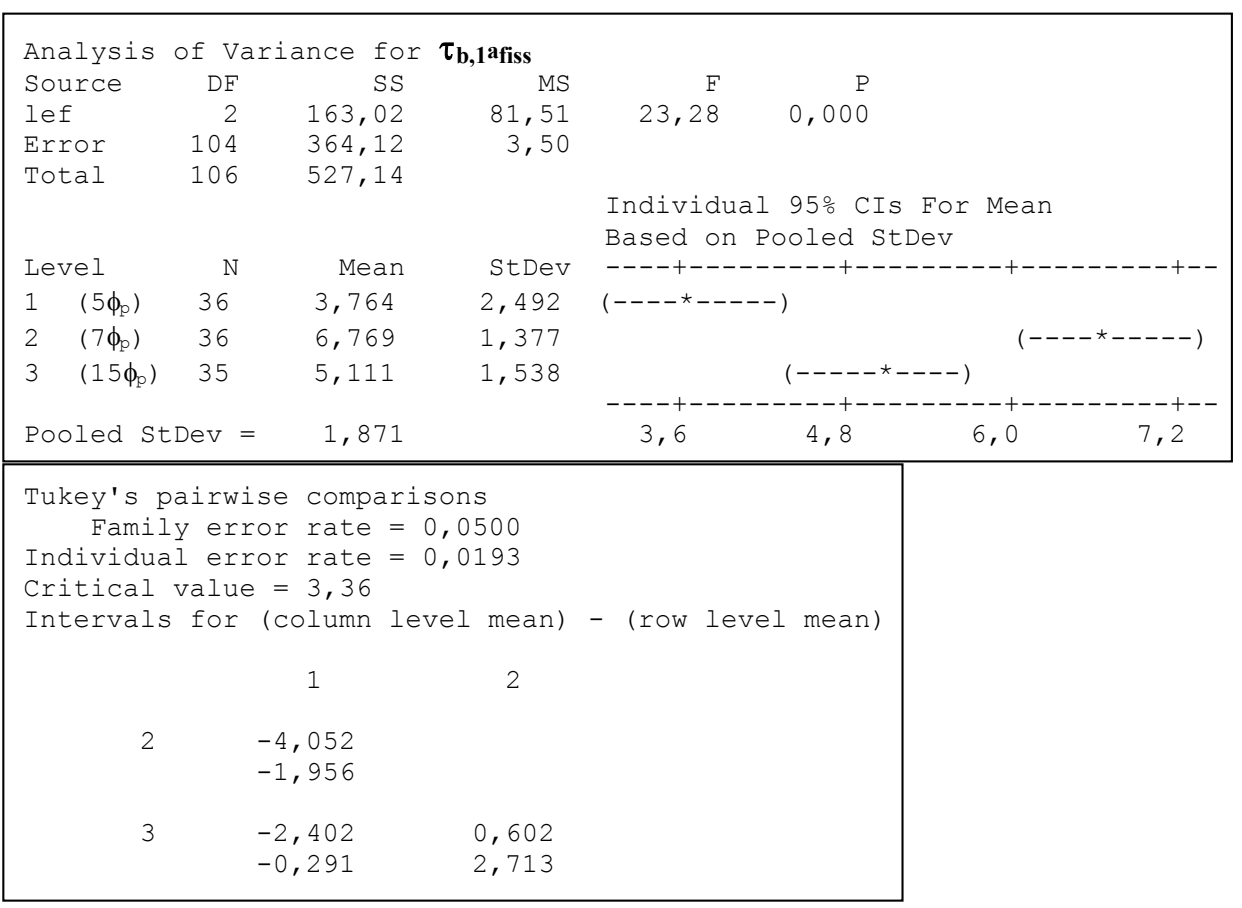

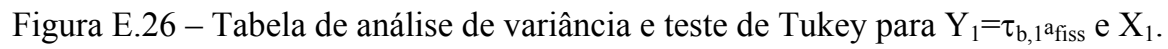

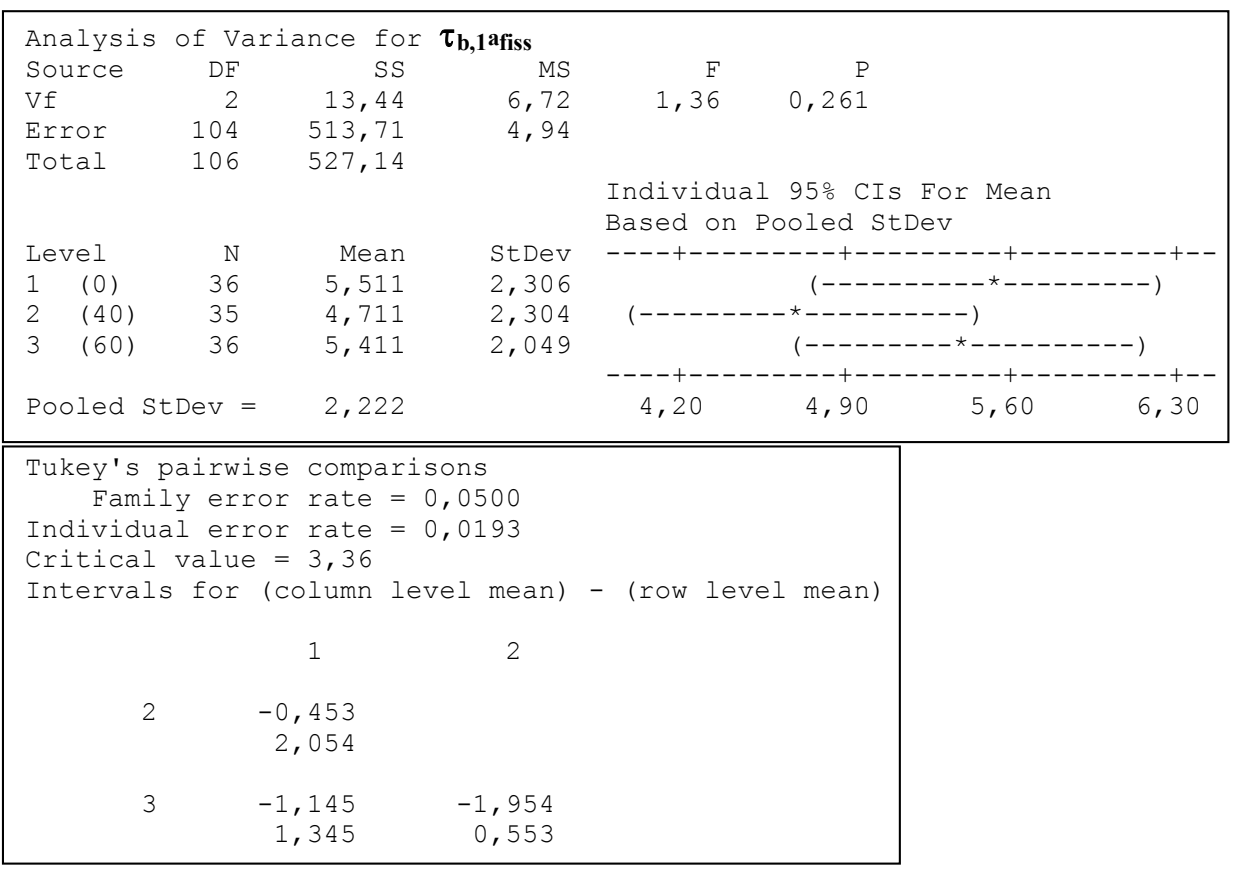

Figura E.27 - Tabela de análise de variância e teste de Tukey para $\mathrm{Y}_{1}=\tau_{\mathrm{b}, 1} \mathrm{a}_{\mathrm{fiss}}$ e $\mathrm{X}_{2}$. 


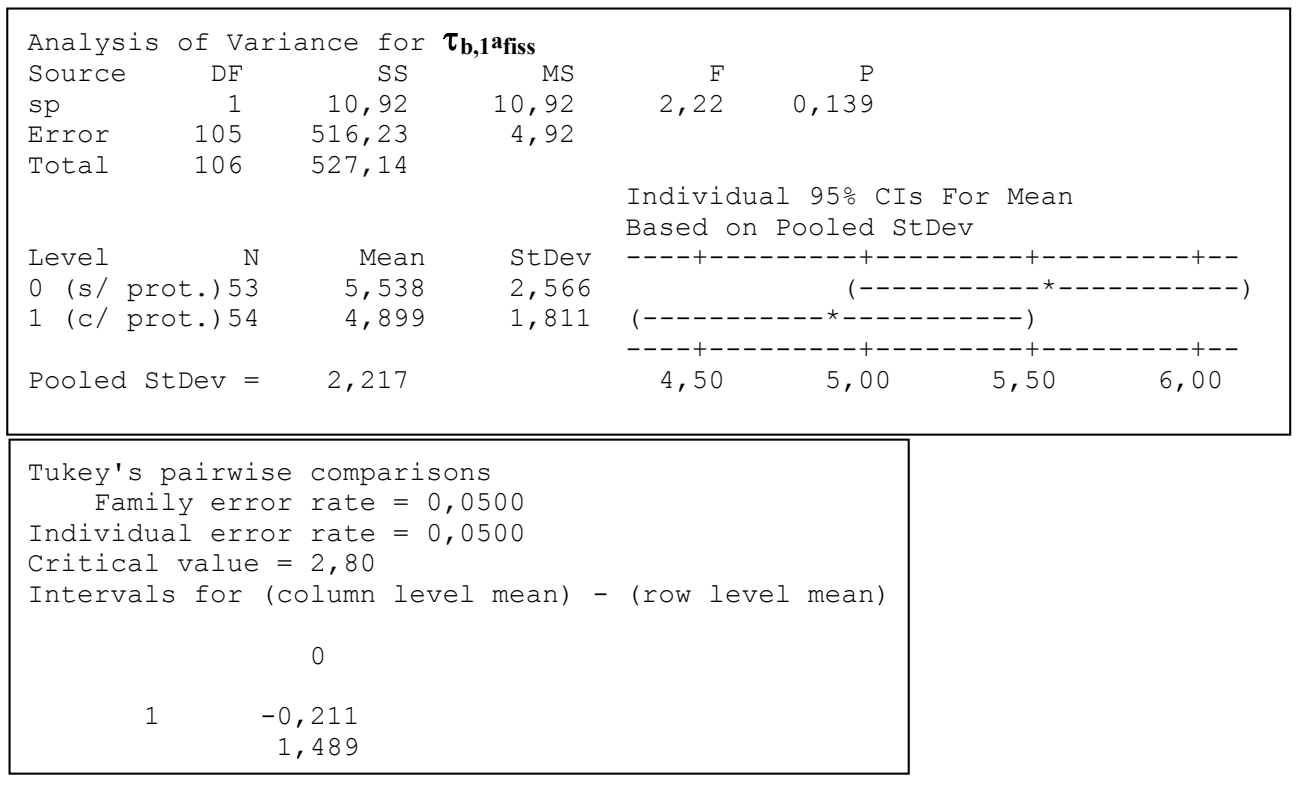

Figura E.28 - Tabela de análise de variância e teste de Tukey para $Y_{1}=\tau_{b, 1}{ }^{\text {fiss }}$ e $X_{3}$.

\section{Variável resposta $Y_{2}=\tau_{b, 0.1}$}

A primeira análise a ser feita é a dos resíduos, para verificar-se se a amostra tem uma distribuição normal. As Figura E.29, E.30 e E.31 apresentam os gráficos com plotagem dos resíduos para as variáveis $\mathrm{X}_{1}, \mathrm{X}_{2}$ e $\mathrm{X}_{3}$, respectivamente.

Para as três variáveis, pode-se dizer que as distribuições amostrais são normais e que as variabilidades são boas.
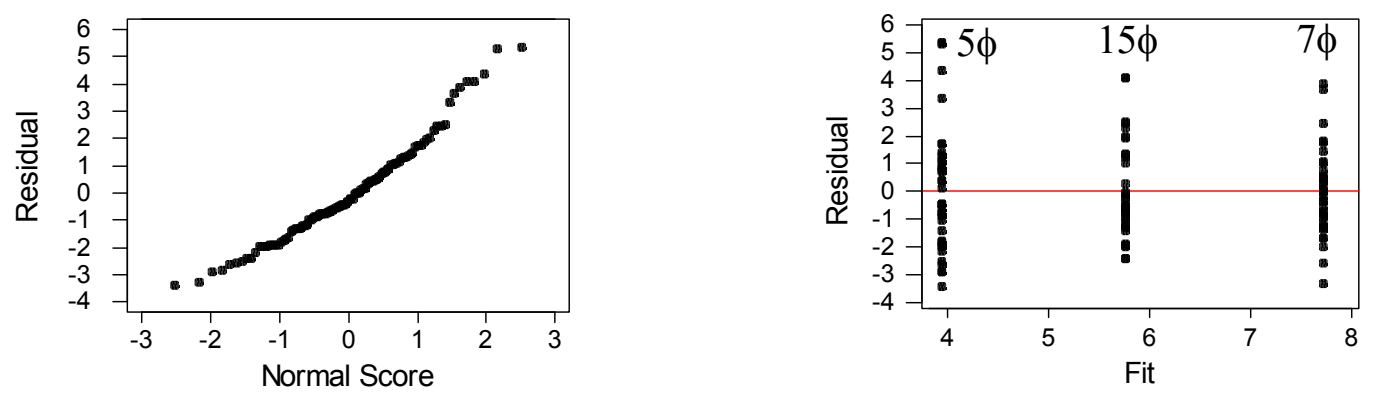

Figura E.29 - Análise de resíduos para $\mathrm{Y}_{2}=\tau_{\mathrm{b}, 0.1}$ e a variável $\mathrm{X}_{1}$.
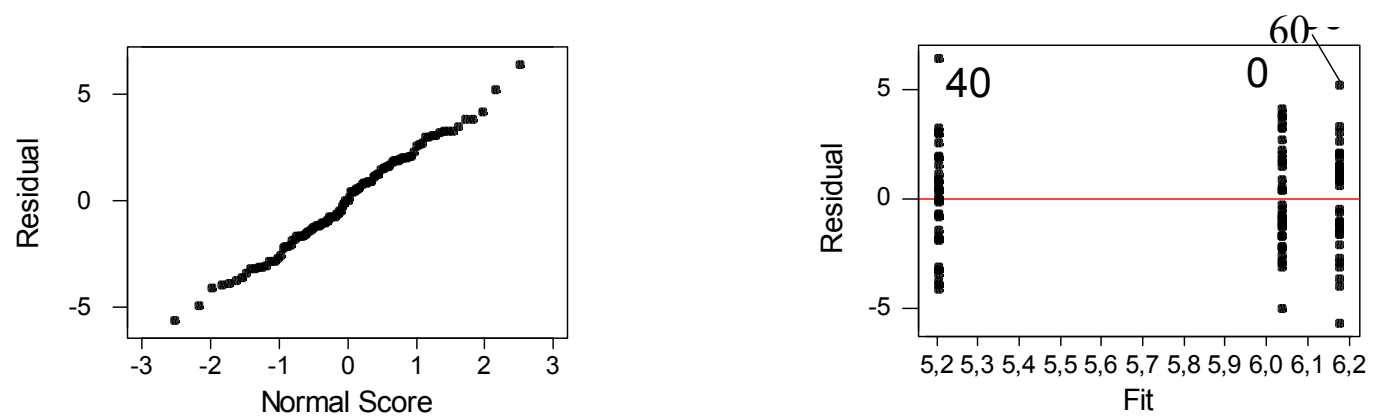

Figura E.30 - Análise de resíduos para $\mathrm{Y}_{2}=\tau_{\mathrm{b}, 0.1} \mathrm{e}$ a variável $\mathrm{X}_{2}$. 

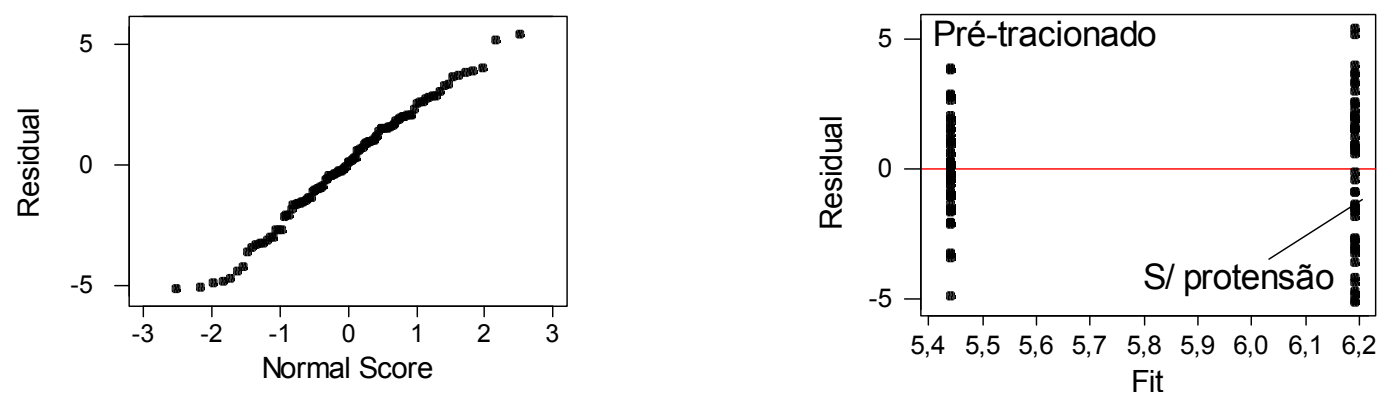

Figura E.31 - Análise de resíduos para $\mathrm{Y}_{2}=\tau_{\mathrm{b}, 0.1}$ e a variável $\mathrm{X}_{3}$.

Após a verificação dos resíduos, constatado que as amostras apresentam distribuição normal, pôde-se montar a tabela de variância dos resultados. Ela indica a variabilidade dos dados. Juntamente com a tabela de variância, fez-se o teste de Tukey, que indica se há interferência de um conjunto de dado sobre o outro, para o intervalo de confiança estabelecido, que neste caso foi de $\mathrm{CI}=95 \%$. As Figuras E.32 a E.34 apresentam os resultados para as três variáveis independentes analisadas.

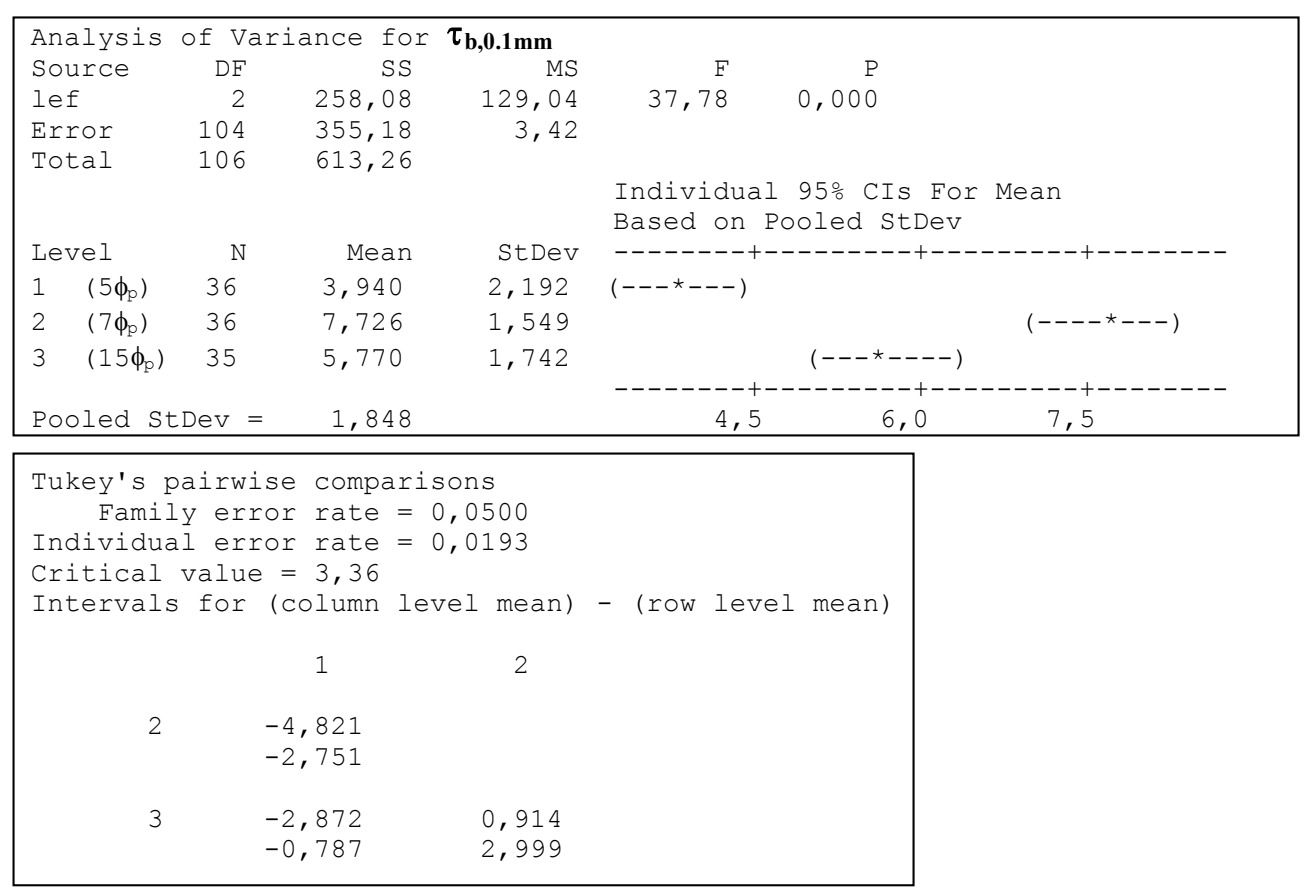

Figura E.32 - Tabela de análise de variância e teste de Tukey para $Y_{2}=\tau_{b, 0.1}$ e $X_{1}$.

Para a Figura E.32, percebe-se que os melhores resultados são para o nível 2, ou seja, para os modelos com comprimentos aderentes de $9 \mathrm{~cm}\left(7 \phi_{\mathrm{p}}\right)$, que apresentam os maiores valores para a tensão de aderência correspondente ao escorregamento de $S=0,1 \mathrm{~mm}$. Observase também, que as médias são diferentes para os três níveis analisados. Pelo teste de Tukey, a análise verifica que não há interferências entre os grupos. Ou seja, as médias são significativamente diferentes umas das outras. 


\begin{tabular}{|c|c|c|c|c|}
\hline Analysi & $\mathrm{s}$ of $\mathrm{Va}$ & ance for & $\tau_{\mathrm{b}, 0.1 \mathrm{~mm}}$ & \\
\hline Source & $\mathrm{DF}$ & SS & MS & $\mathrm{F}$ \\
\hline $\mathrm{Vf}$ & 2 & 19,62 & 9,81 & 0,184 \\
\hline Error & 104 & 593,63 & 5,71 & \\
\hline Total & 106 & 613,26 & & \\
\hline & & & & $\begin{array}{l}\text { Individual 95\% CIs For Mean } \\
\text { Based on Pooled StDev }\end{array}$ \\
\hline Level & $\mathrm{N}$ & Mean & StDev & 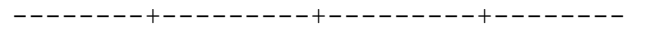 \\
\hline $1 \quad(0)$ & 36 & 6,039 & 2,359 & $(---------\star \star----)$ \\
\hline $2(40)$ & 35 & 5,204 & 2,457 & $(----------\star-----------)$ \\
\hline $3 \quad(60)$ & 36 & 6,178 & 2,352 & $(----------\star------------)$ \\
\hline Pooled & StDev $=$ & 2,389 & & 4,90 \\
\hline
\end{tabular}

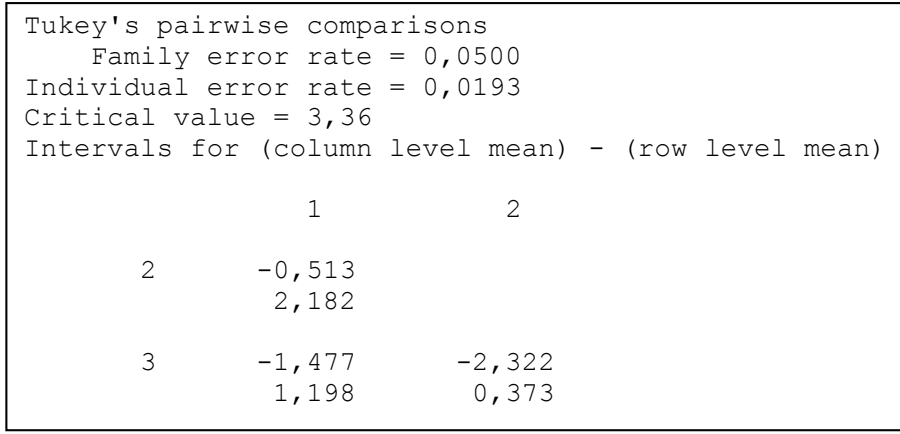

Figura E.33 - Tabela de análise de variância e teste de Tukey para $\mathrm{Y}_{2}=\tau_{\mathrm{b}, 0.1}$ e $\mathrm{X}_{2}$.

Para a Figura E.33, percebe-se que há interferência de um nível sobre o outro, ou seja, para a tensão de aderência correspondente ao escorregamento de $\mathrm{S}=0,1 \mathrm{~mm}$, não há diferença significativa entre as médias para os três volumes de fibra utilizados.

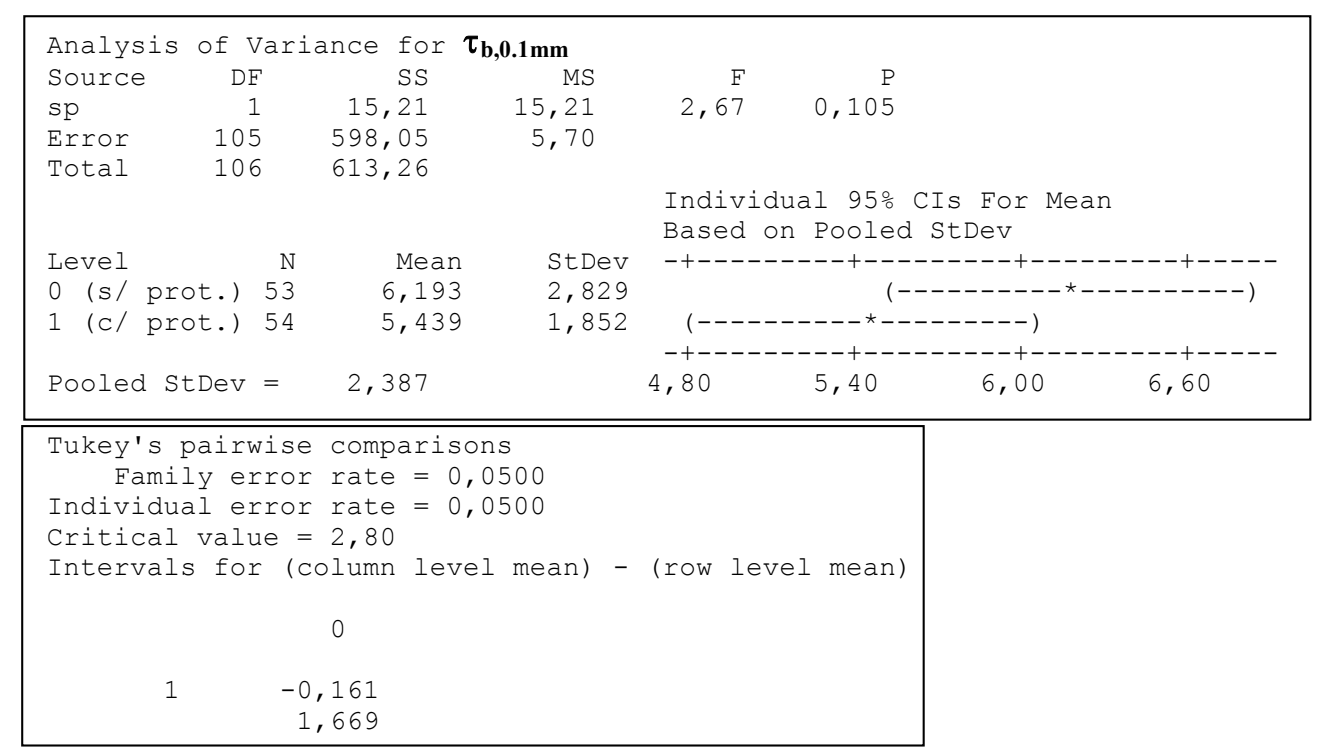

Figura E.34 - Tabela de análise de variância e teste de Tukey para $Y_{2}=\tau_{b, 0.1}$ e $X_{3}$.

Percebe-se que há interferência de um nível sobre o outro, ou seja, não há diferença significativa entre as médias para os modelos com e para os sem protensão. 


\section{Variável resposta $Y_{3}=\tau_{b, 1}$}

A primeira análise a ser feita é a dos resíduos, para verificar-se se a amostra tem uma distribuição normal. As Figuras E.35, E.36 e E.37 apresentam os gráficos com plotagem dos resíduos para as variáveis $\mathrm{X}_{1}, \mathrm{X}_{2}$ e $\mathrm{X}_{3}$, respectivamente.

Para as três variáveis, pode-se dizer que as distribuições amostrais são normais e que as variabilidades são boas.
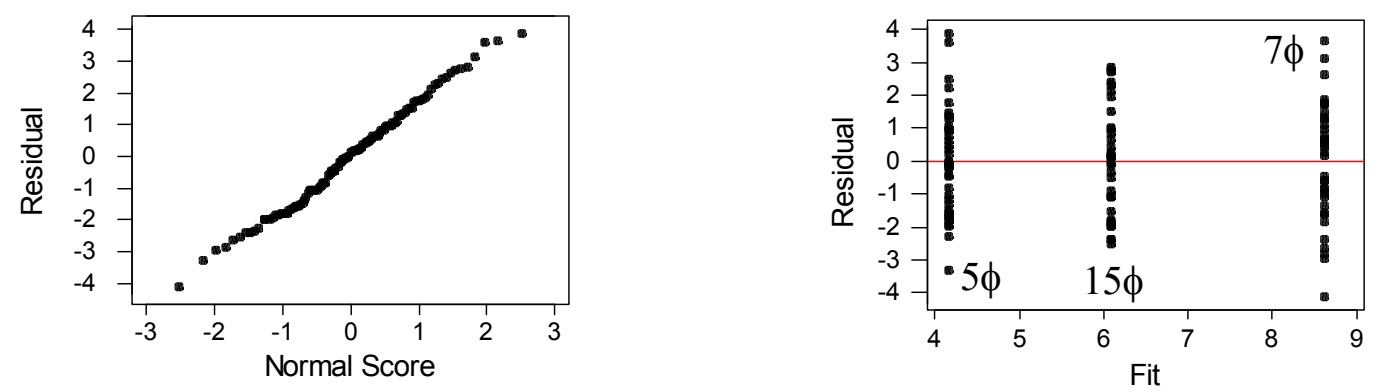

Figura E.35 - Análise de resíduos para $\mathrm{Y}_{3}=\tau_{\mathrm{b}, 1}$ e a variável $\mathrm{X}_{1}$.
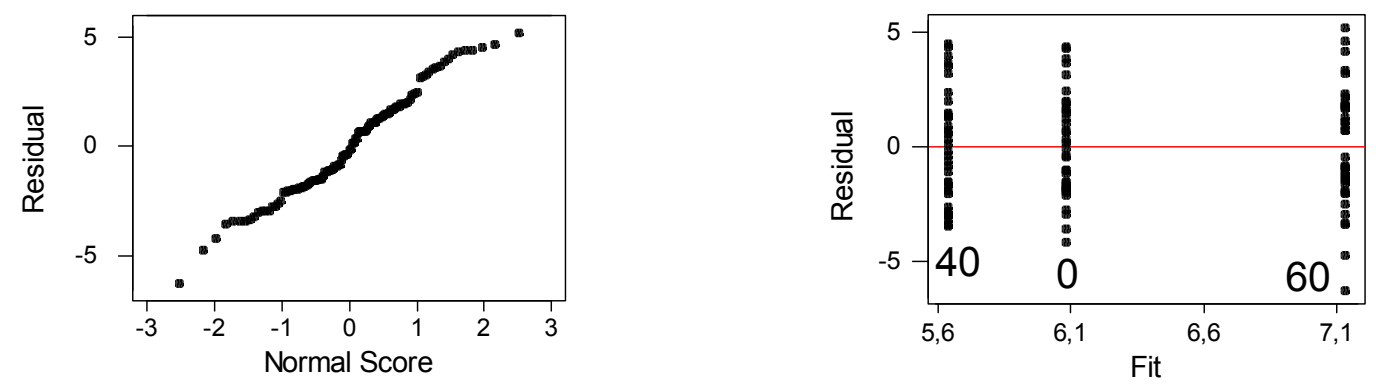

Figura E.36 - Análise de resíduos para $\mathrm{Y}_{3}=\tau_{\mathrm{b}, 1}$ e a variável $\mathrm{X}_{2}$.
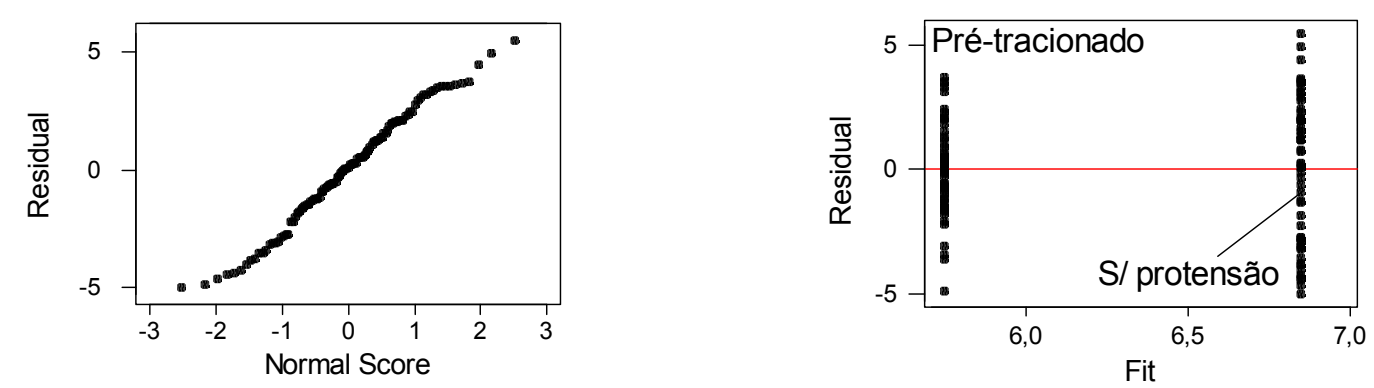

Figura E.37 - Análise de resíduos para $Y_{3}=\tau_{\mathrm{b}, 1}$ e a variável $X_{3}$.

Após a verificação dos resíduos, constatado que as amostras apresentam distribuição normal, pôde-se montar a tabela de variância dos resultados. Ela indica a variabilidade dos dados. Juntamente com a tabela de variância, fez-se o teste de Tukey, que indica se há interferência de um conjunto de dado sobre o outro, para o intervalo de confiança estabelecido, que neste caso foi de $\mathrm{CI}=95 \%$. As Figuras E.38 a E.40 apresentam os resultados para as três variáveis independentes analisadas. 


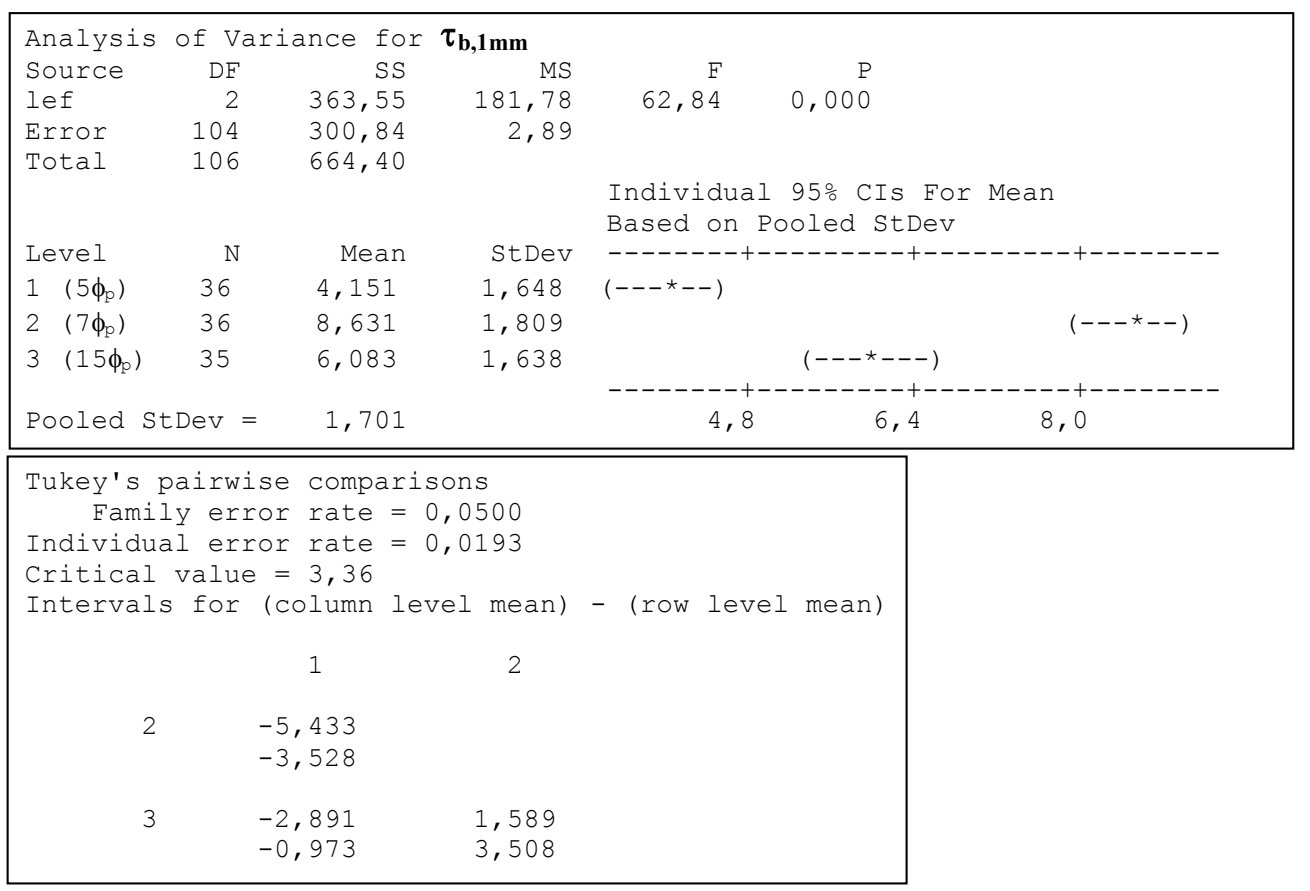

Figura E.38 - Tabela de análise de variância e teste de Tukey para $Y_{3}=\tau_{b, 1}$ e $X_{1}$.

Para a Figura E.38, percebe-se que os melhores resultados são para o nível 2, ou seja, para os modelos com comprimentos aderentes de $9 \mathrm{~cm}\left(7 \phi_{\mathrm{p}}\right)$, que apresentam os maiores valores para a tensão de aderência correspondente ao escorregamento de $S=1 \mathrm{~mm}$. Observa-se também, que as médias são diferentes para os três níveis analisados. Pelo teste de Tukey, a análise verifica que não há interferências entre os grupos. Ou seja, as médias são significativamente diferentes umas das outras.

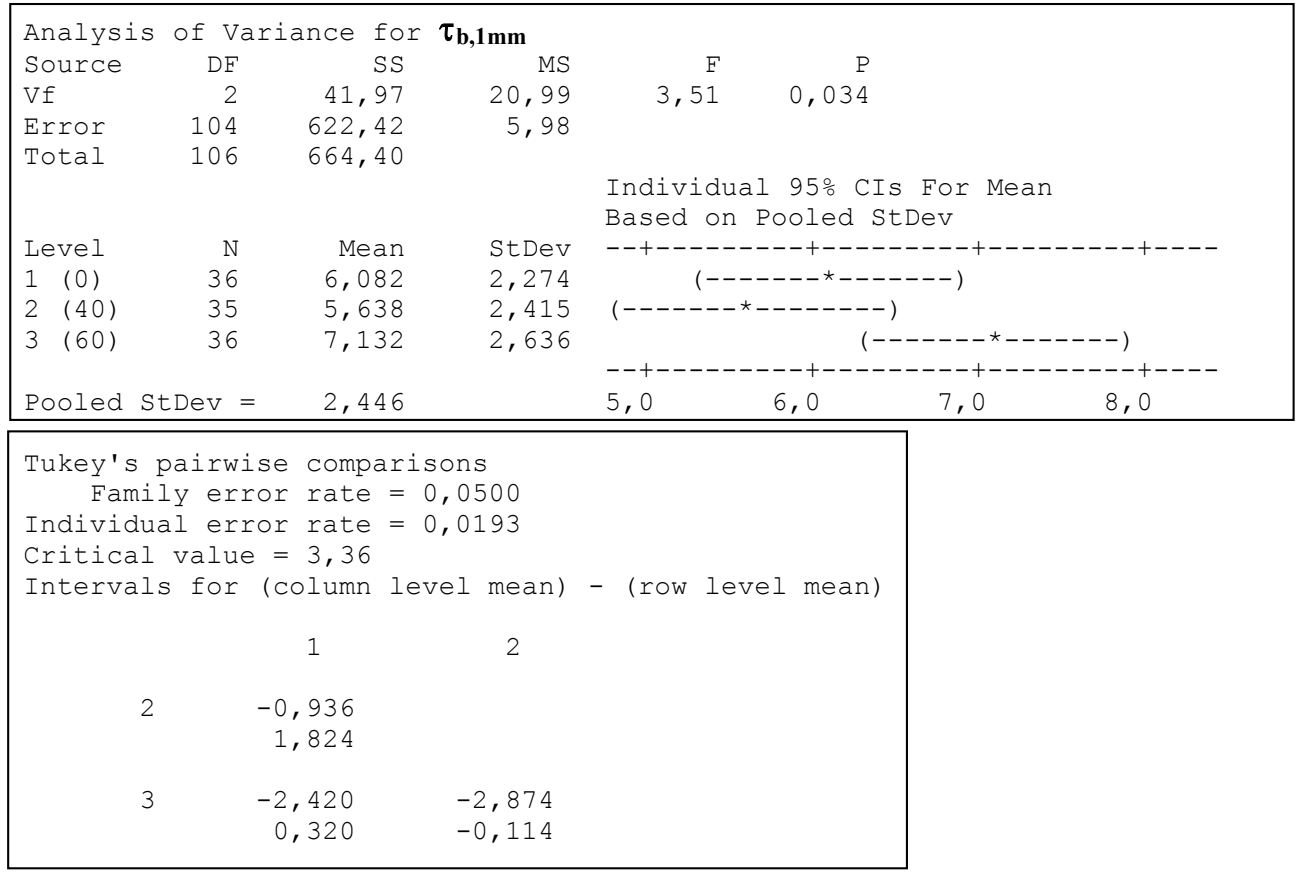

Figura E.39 - Tabela de análise de variância e teste de Tukey para $Y_{3}=\tau_{b, 1}$ e $X_{2}$. 


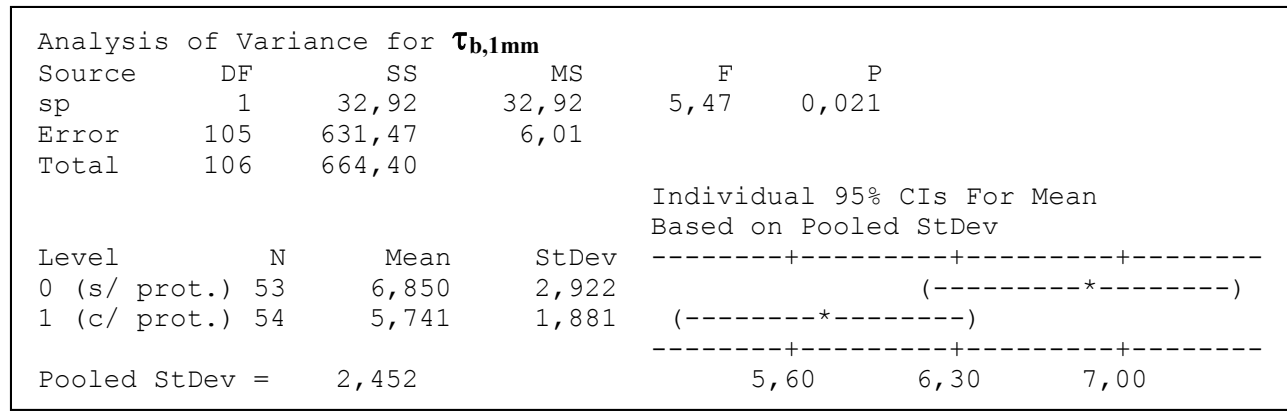

\begin{tabular}{|l|}
\hline Tukey's pairwise comparisons \\
Family error rate $=0,0500$ \\
Individual error rate $=0,0500$ \\
Critical value $=2,80$ \\
Intervals for (column level mean) - (row level mean) \\
0 \\
1 \\
0,169 \\
2,050
\end{tabular}

Figura E.40 - Tabela de análise de variância e teste de Tukey para $\mathrm{Y}_{3}=\tau_{\mathrm{b}, 1}$ e $\mathrm{X}_{3}$.

Para a Figura E.39, percebe-se que os melhores resultados são para o nível 3, que representa um volume de fibra de $60 \mathrm{~kg} / \mathrm{m}^{3}$, que apresenta os maiores valores. A análise indica, pelo teste de Tukey, que só não há interferências entre os grupos 2 e 3. Já para os grupos 1 e 2, e 1 e 3 há interferência de um sobre o outro. Ou seja, apenas para os teores de fibra de $\mathrm{V}_{\mathrm{f}}=40 \mathrm{~kg} / \mathrm{m}^{3}$ e $\mathrm{V}_{\mathrm{f}}=60 \mathrm{~kg} / \mathrm{m}^{3}$, as médias são significativamente diferentes.

Para a Figura E.40, percebe-se que não há interferência de um nível sobre o outro, ou seja, as médias são significativamente diferentes.

\section{Variável resposta $Y_{4}=S_{\tau_{b, \text { máx }}}$}

A primeira análise a ser feita é a dos resíduos, para verificar-se se a amostra tem uma distribuição normal. As Figuras E.41, E.42 e E.43 apresentam os gráficos com plotagem dos resíduos para as variáveis $\mathrm{X}_{1}, \mathrm{X}_{2}$ e $\mathrm{X}_{3}$, respectivamente.
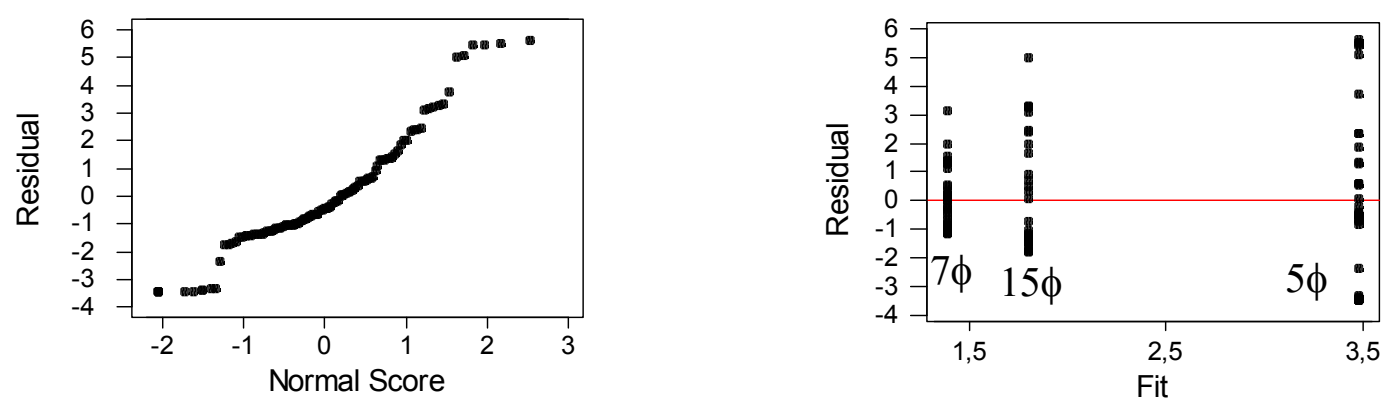

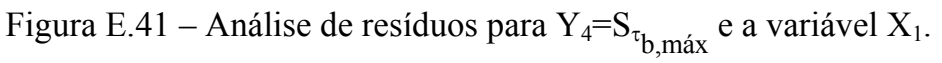



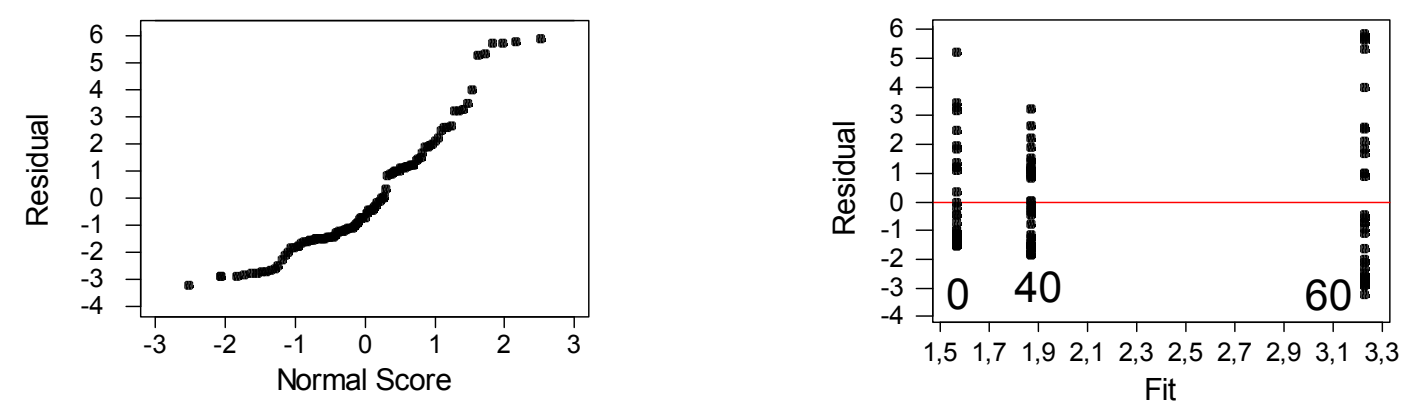

Figura E.42 - Análise de resíduos para $\mathrm{Y}_{4}=\mathrm{S}_{\tau}$ b,máx e a variável $\mathrm{X}_{2}$.
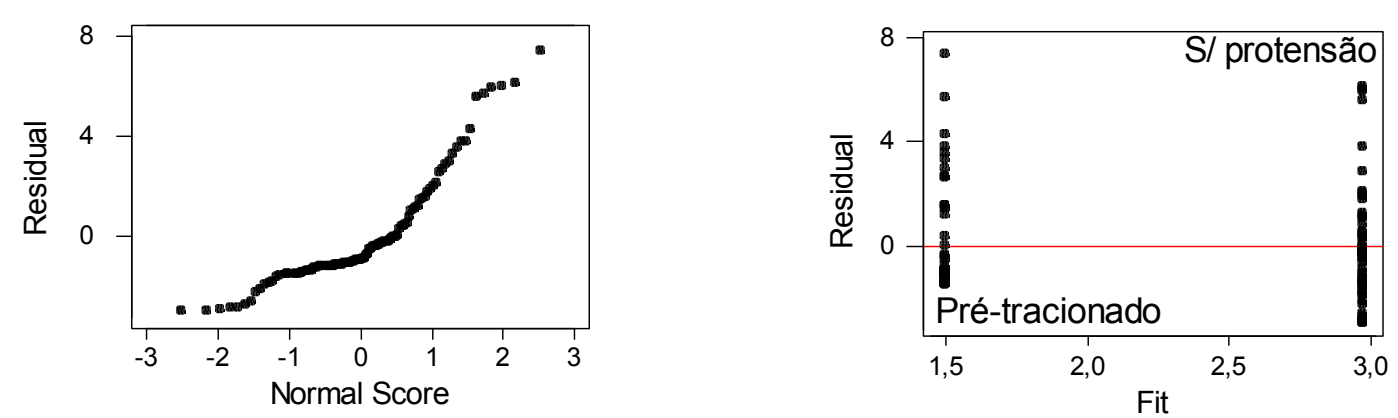

Figura E.43 - Análise de resíduos para $\mathrm{Y}_{4}=\mathrm{S}_{\tau}$ b,máx e a variável $\mathrm{X}_{3}$.

Pelos diagramas, percebe-se que para todas as variáveis, nem a distribuição pode ser considerada normal e nem a variabilidade desses dados é boa. Para que se pudesse analisar melhor esses resultados, elaborando tabelas de variância, seria necessário fazer algum tipo de transformação de dados, do tipo logarítmica por exemplo, para que se obtivesse uma distribuição normal e uma variabilidade mais constante.

\section{b) Bloco 2}

Todos os dados foram avaliados duas vezes: (1) para $\mathrm{X}_{2}$, onde os 36 modelos de cada grupo foram divididos em três sub-grupos de 12, levando-se em conta os volumes de fibra; e (2) para $\mathrm{X}_{3}$, onde os 36 modelos de cada grupo foram divididos em dois sub-grupos de 18, levando-se em conta o grau de protensão. Ou seja, foram construídas duas Tabelas de Análise de Variância para cada variável resposta, cada tabela levando em conta uma variável independente. Para cada sub-grupo também foi feita a plotagem dos resíduos e a avaliação de Tukey, para um intervalo de confiança (CI) de 95\%.

\section{Variável resposta $Y=\tau_{b, \text { máx }}$}

A primeira análise a ser feita é a dos resíduos, para verificar-se se a amostra tem uma distribuição normal. As Figuras E.44 a E.49 apresentam os gráficos com plotagem dos resíduos para as variáveis $\mathrm{X}_{2}$ e $\mathrm{X}_{3}$, levando em conta os diferentes comprimentos de ancoragem disponíveis. 

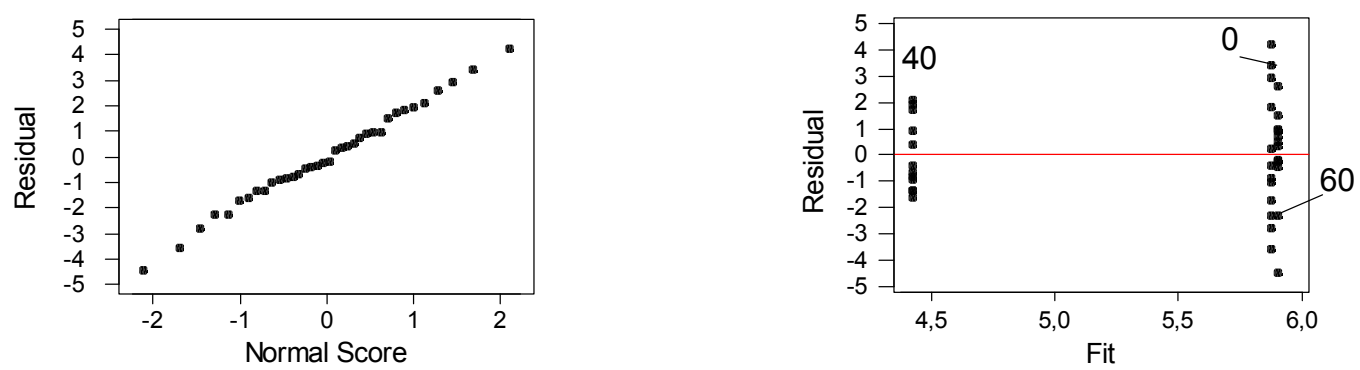

Figura E.44 - Análise de resíduos para $\mathrm{Y}=\tau_{\mathrm{b}, \text { máx }}, \ell_{\mathrm{ef}}=5 \phi_{\mathrm{p}}$ e a variável $\mathrm{X}_{2}$.
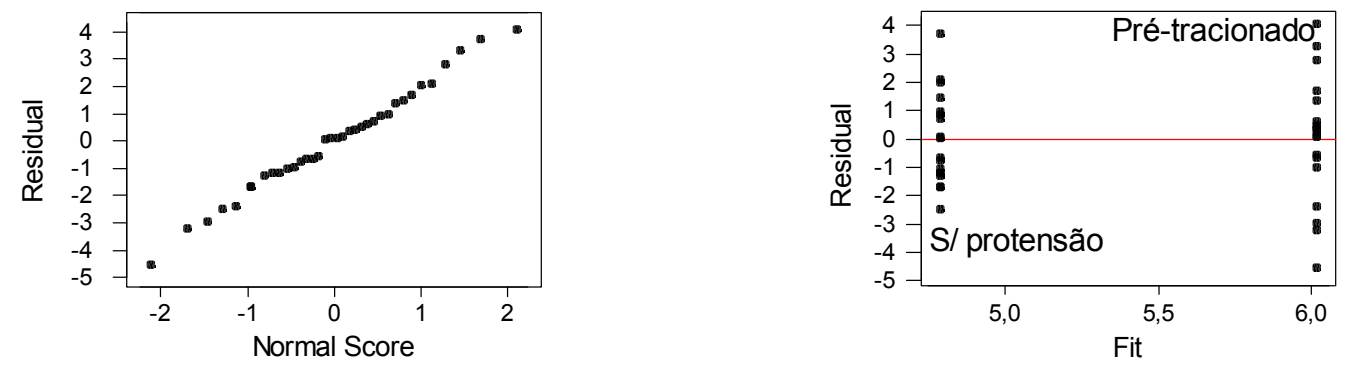

Figura E.45 - Análise de resíduos para $\mathrm{Y}=\tau_{\mathrm{b} \text {,máx }}, \ell_{\mathrm{ef}}=5 \phi_{\mathrm{p}}$ e a variável $\mathrm{X}_{3}$.
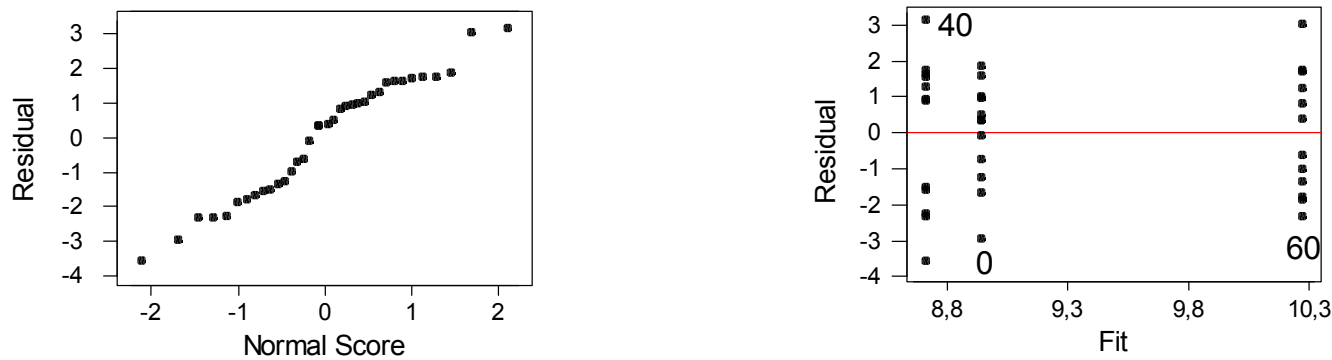

Figura E.46 - Análise de resíduos para $\mathrm{Y}=\tau_{\mathrm{b}, \text { máx }}, \ell_{\mathrm{ef}}=7 \phi_{\mathrm{p}}$ e a variável $\mathrm{X}_{2}$.
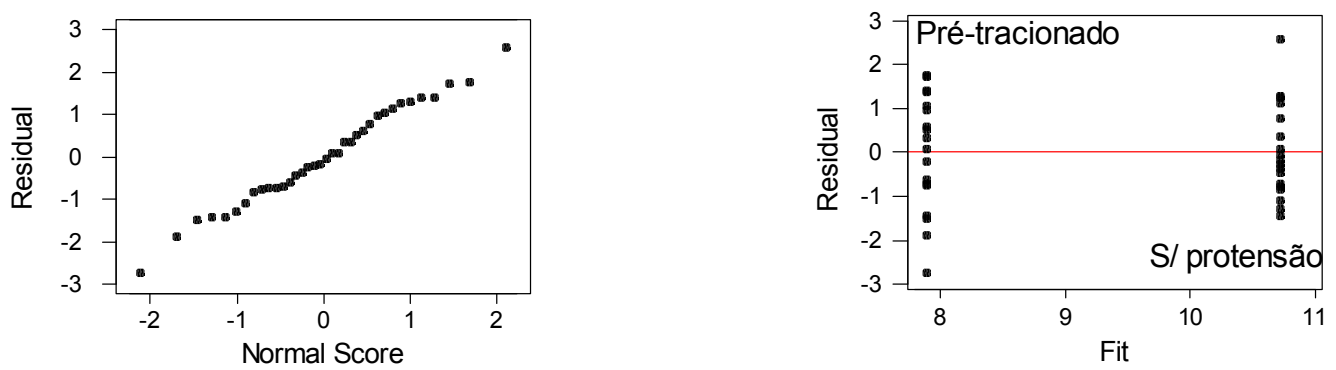

Figura E.47 - Análise de resíduos para $Y=\tau_{\mathrm{b}, \text { máx }}, \ell_{\mathrm{ef}}=7 \phi_{\mathrm{p}}$ e a variável $\mathrm{X}_{3}$.
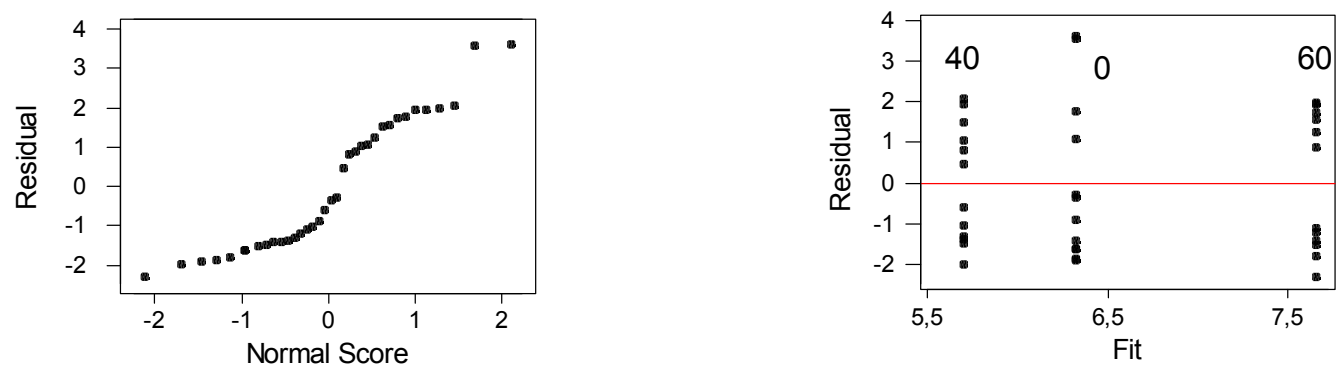

Figura E.48 - Análise de resíduos para $\mathrm{Y}=\tau_{\mathrm{b}, \text { máx }}, \ell_{\mathrm{ef}}=15 \phi_{\mathrm{p}}$ e a variável $\mathrm{X}_{2}$. 

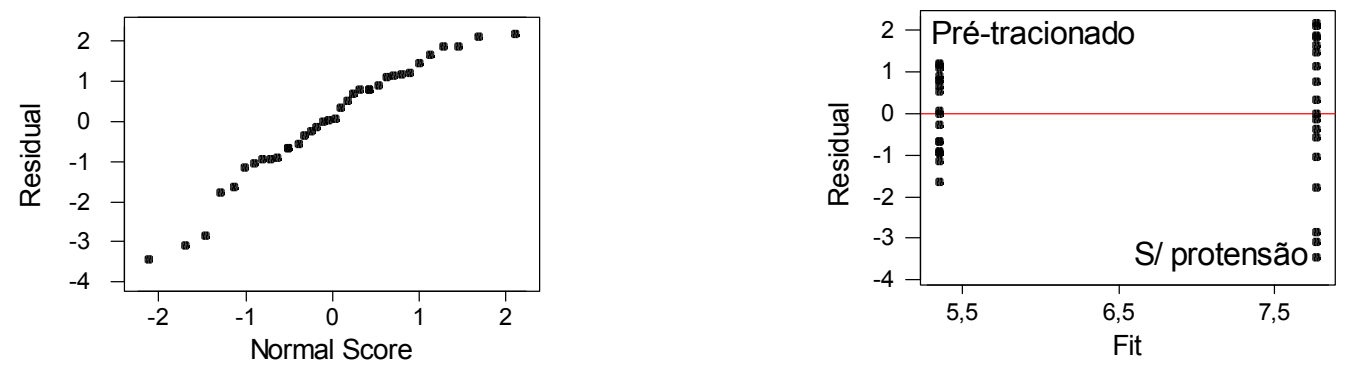

Figura E.49 - Análise de resíduos para $Y=\tau_{\mathrm{b}, \text { máx }}, \ell_{\mathrm{ef}}=15 \phi_{\mathrm{p}}$ e a variável $\mathrm{X}_{3}$.

Para os modelos com $\ell_{\mathrm{ef}}=5 \phi_{\mathrm{p}}$, para as duas variáveis independentes, tanto a distribuição está normal como as variâncias estão bem próximas uma da outra.

Para os modelos com $\ell_{\mathrm{ef}}=7 \phi_{\mathrm{p}}$ há diferenças para as duas variáveis independentes: em relação a $X_{2}$, nem a distribuição está normal nem as variâncias estão próximas uma da outra; para $\mathrm{X}_{3}$, a distribuição está normal, porém as variâncias diferem um pouco.

Para os modelos com $\ell_{\mathrm{ef}}=15 \phi_{\mathrm{p}}$, para as duas variáveis independentes, nem a distribuição está normal nem as variâncias estão próximas uma da outra.

Após a verificação dos resíduos, admitiu-se que as amostras representadas nas Figuras E.44, E.45 e E.47 apresentam distribuição normal, pôde-se, então, montar a tabela de variância dos resultados. Ela indica a variabilidade dos dados. Juntamente com a tabela de variância, fez-se o teste de Tukey, que indica se há interferência de um conjunto de dado sobre o outro, para o intervalo de confiança estabelecido, que neste caso foi de $\mathrm{CI}=95 \%$. As Figuras E.50 a E.52 apresentam os resultados para as duas variáveis independentes analisadas.

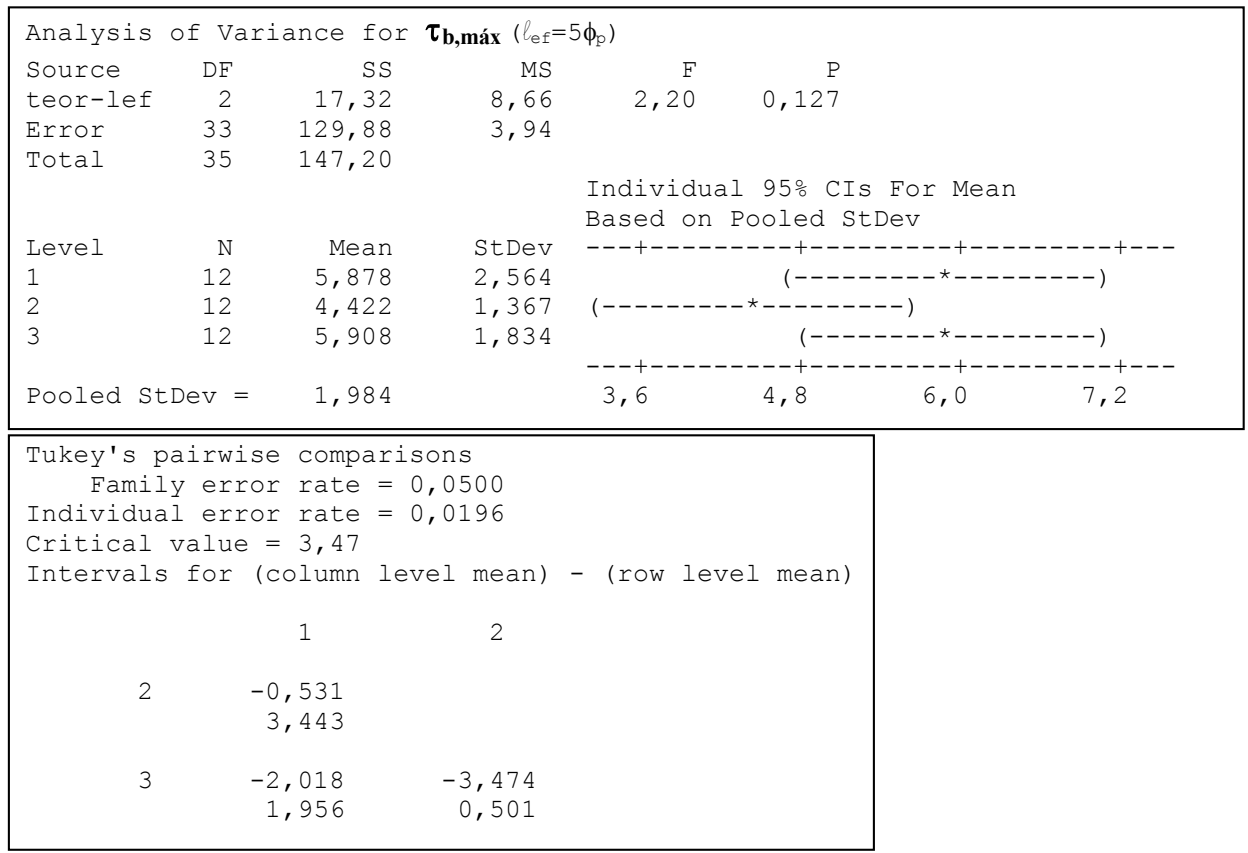

Figura E. 50 - Tabela de análise de variância e teste de Tukey para $Y=\tau_{b, \text { máx }}, \ell_{\mathrm{ef}}=5 \phi_{\mathrm{p}}$ e $\mathrm{X}_{2}$. 


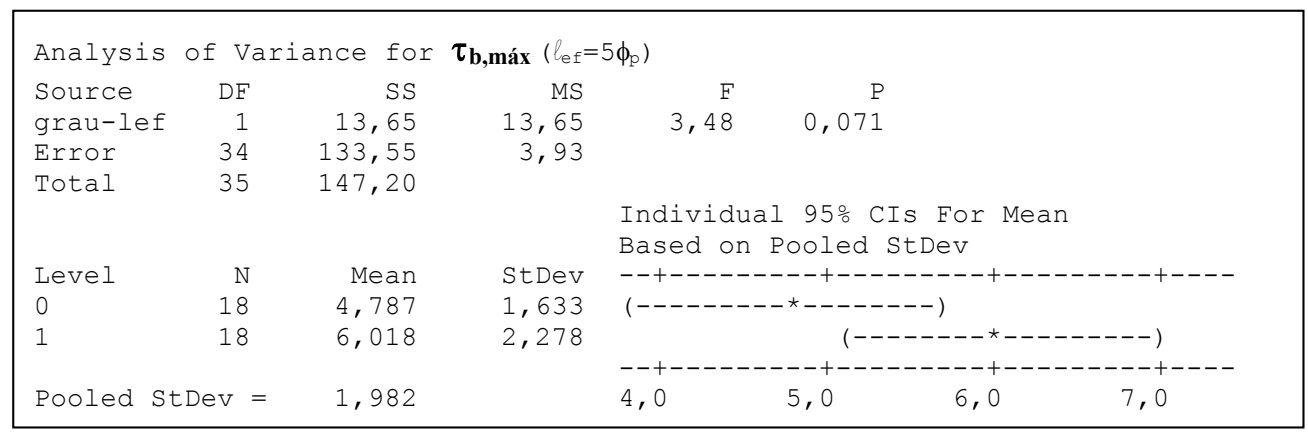

\begin{tabular}{|c|}
\hline Tukey's pairwise comparisons \\
Family error rate $=0,0500$ \\
Individual error rate $=0,0500$ \\
Critical value $=2,87$ \\
Intervals for (column level mean) - (row level mean) \\
0 \\
1 \\
$-2,574$ \\
0,111
\end{tabular}

Figura E.51 - Tabela de análise de variância e teste de Tukey para $Y=\tau_{b, \operatorname{má}}, \ell_{\mathrm{ef}}=5 \phi_{\mathrm{p}}$ e $\mathrm{X}_{3}$.

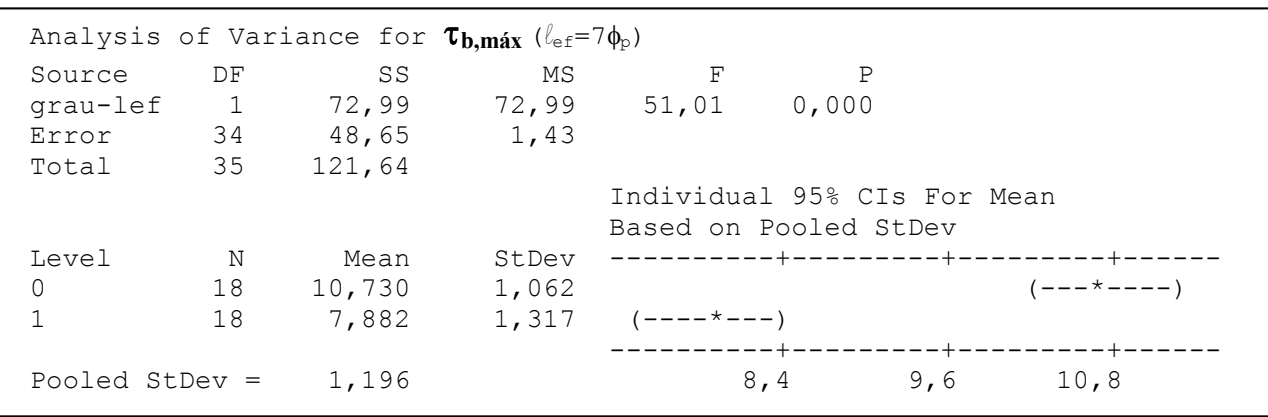

\begin{tabular}{|c|}
\hline Tukey's pairwise comparisons \\
Family error rate $=0,0500$ \\
Individual error rate $=0,0500$ \\
Critical value $=2,87$ \\
Intervals for (column level mean) - (row level mean) \\
0 \\
1 \\
2,037 \\
3,658
\end{tabular}

Figura E.52 - Tabela de análise de variância e teste de Tukey para $Y=\tau_{b, \operatorname{máx}}, \ell_{\mathrm{ef}}=7 \phi_{\mathrm{p}}$ e $\mathrm{X}_{3}$.

Percebe-se que os modelos sem protensão apresentam resultados melhores que os prétracionados, e que os modelos com $\mathrm{V}_{\mathrm{f}}=0$ e $\mathrm{V}_{\mathrm{f}}=60 \mathrm{~kg} / \mathrm{m}^{3}$ apresentam resultados semelhantes, e maiores que os modelos com $\mathrm{V}_{\mathrm{f}}=40 \mathrm{~kg} / \mathrm{m}^{3}$.

\section{Variável resposta $Y_{1}=\tau_{b, 1}{ }^{a}$ fiss}

A primeira análise a ser feita é a dos resíduos, para verificar-se se a amostra tem uma distribuição normal. As Figuras E.53 a E.58 apresentam os gráficos com plotagem dos resíduos para as variáveis $\mathrm{X}_{2}$ e $\mathrm{X}_{3}$, levando em conta os diferentes comprimentos de ancoragem disponíveis. 

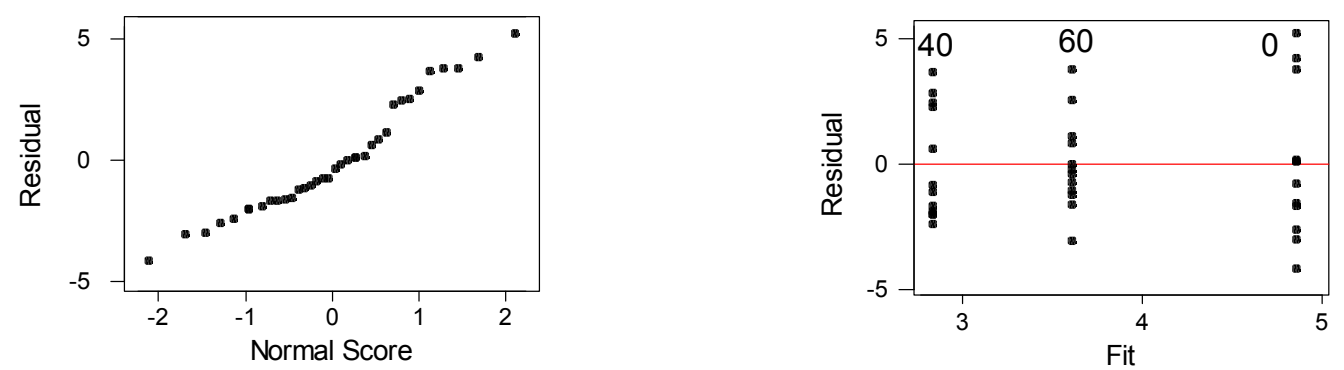

Figura E.53 - Análise de resíduos para $Y_{1}=\tau_{\mathrm{b}, \mathrm{l}_{\mathrm{f}}^{\mathrm{fiss}}}, \ell_{\mathrm{ef}}=5 \phi_{\mathrm{p}}$ e a variável $\mathrm{X}_{2}$.
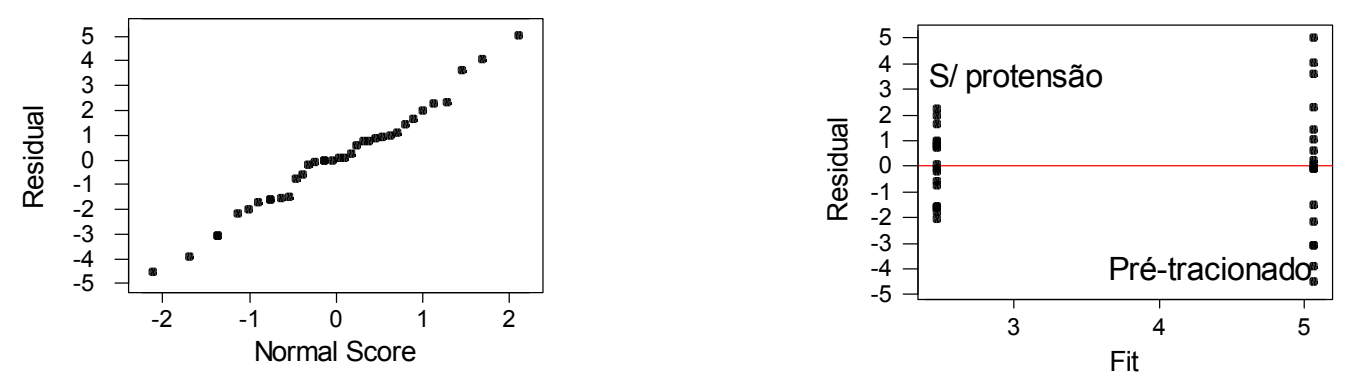

Figura E. 54 - Análise de resíduos para $\mathrm{Y}_{1}=\tau_{\mathrm{b}, 1 \mathrm{a}} \mathrm{fiss}, \ell_{\mathrm{ef}}=5 \phi_{\mathrm{p}}$ e a variável $\mathrm{X}_{3}$.
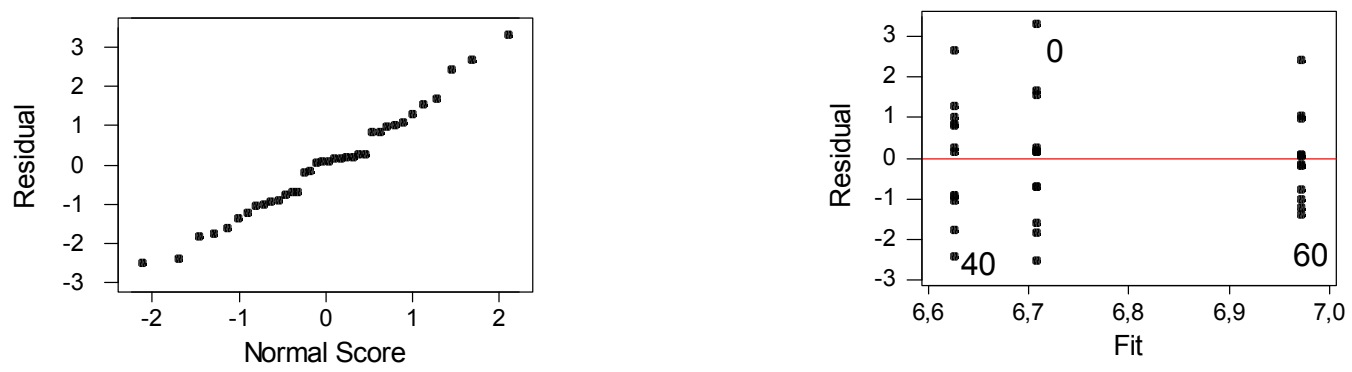

Figura E.55 - Análise de resíduos para $Y_{1}=\tau_{\mathrm{b}, 1}{ }^{\mathrm{a} f i s s}$, $\ell_{\mathrm{ef}}=7 \phi_{\mathrm{p}}$ e a variável $\mathrm{X}_{2}$.
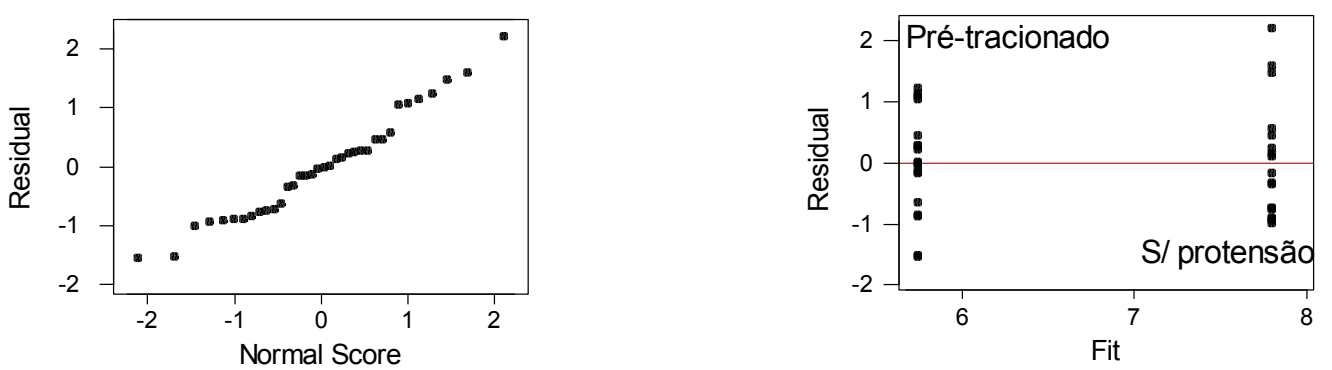

Figura E.56 - Análise de resíduos para $Y_{1}=\tau_{\mathrm{b}, 1}$ afiss, $\ell_{\mathrm{ef}}=7 \phi_{\mathrm{p}}$ e a variável $\mathrm{X}_{3}$.
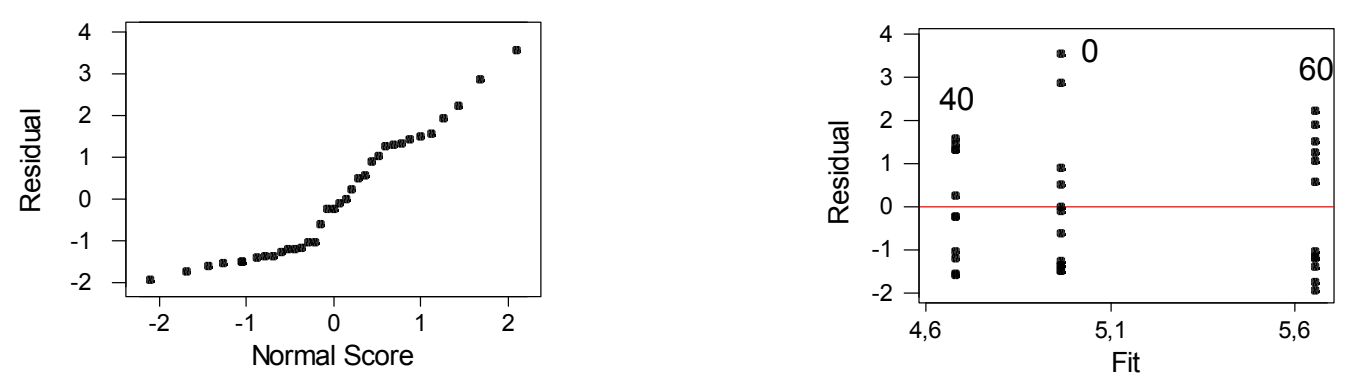

Figura E.57 - Análise de resíduos para $Y_{1}=\tau_{\mathrm{b}, 1^{\mathrm{a}} \mathrm{fiss}}, \ell_{\mathrm{ef}}=15 \phi_{\mathrm{p}}$ e a variável $\mathrm{X}_{2}$. 

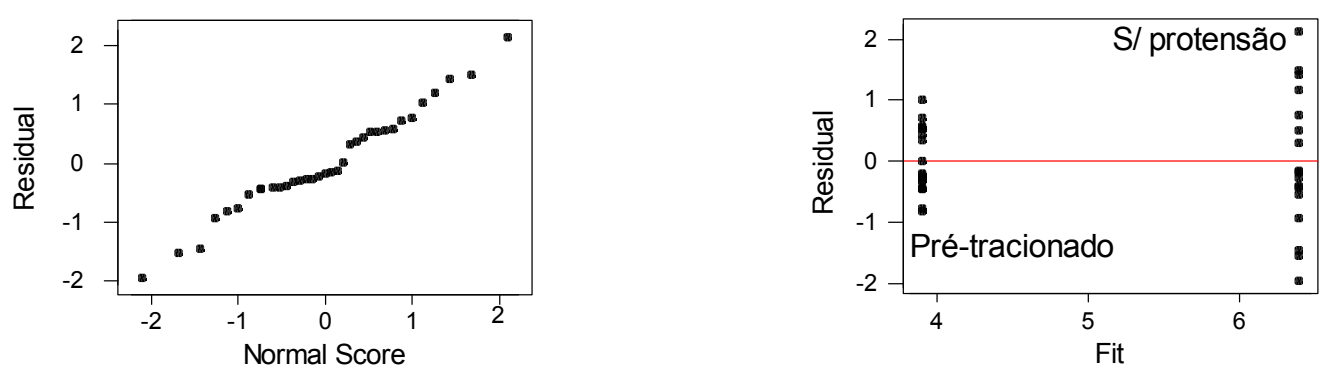

Figura E.58 - Análise de resíduos para $Y_{1}=\tau_{\mathrm{b}, 1^{\mathrm{a}} \text { fiss }}, \ell_{\mathrm{ef}}=15 \phi_{\mathrm{p}}$ e a variável $\mathrm{X}_{3}$.

De maneira geral os dados apresentam distribuição normal e variância constante, exceto as amostras representadas nas Figuras E.54, em que as variâncias são bem diferentes, e E.57, em que nem a distribuição é normal nem as variâncias são constantes. Para as demais amostras, pôde-se montar a tabela de variância dos resultados e fez-se o teste de Tukey, que indica se há interferência de um conjunto de dado sobre o outro, para o intervalo de confiança estabelecido, que neste caso foi de $\mathrm{CI}=95 \%$. As Figuras E.59 a E.62 apresentam os resultados para as duas variáveis independentes analisadas.

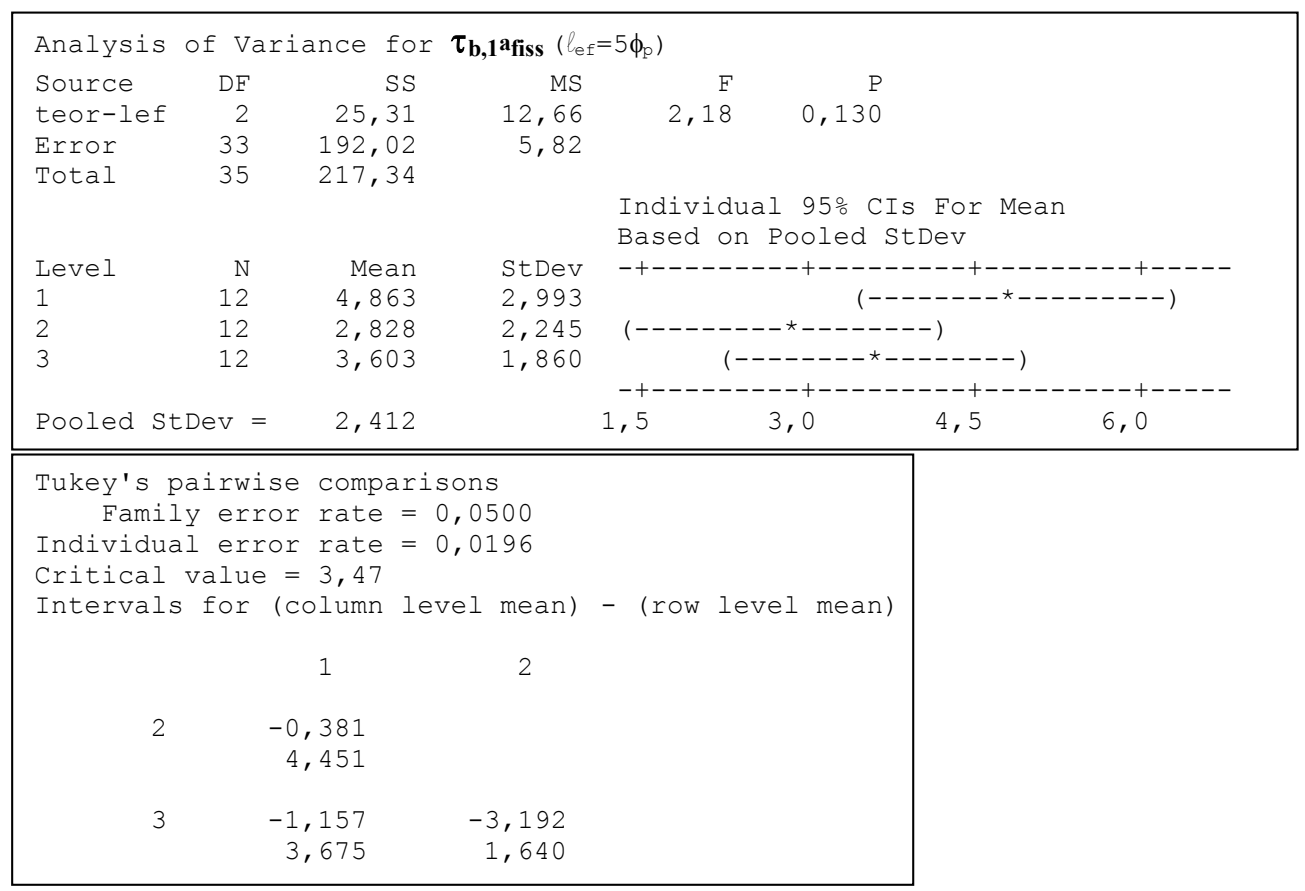

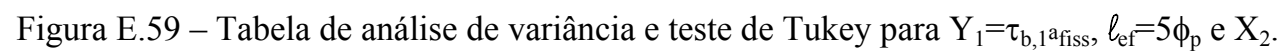

Tanto para os modelos com $\ell_{\mathrm{ef}}=5 \phi_{\mathrm{p}}$ como para os modelos com $\ell_{\mathrm{ef}}=7 \phi_{\mathrm{p}}$, não há diferenças significativas entre os três volumes de fibras utilizados, ou seja, as fibras não influenciaram significativamente na aderência das peças estudadas. Para $\ell_{\mathrm{ef}}=5 \phi_{\mathrm{p}}$ os modelos com $V_{\mathrm{f}}=0$ apresentaram os maiores resultados, e para $\ell_{\mathrm{ef}}=7 \phi_{\mathrm{p}}$ os modelos com $\mathrm{V}_{\mathrm{f}}=60 \mathrm{~kg} / \mathrm{m}^{3}$ apresentaram os maiores resultados. 


\begin{tabular}{|c|c|c|c|c|}
\hline \multicolumn{5}{|c|}{ Analysis of Variance for $\tau_{\mathbf{b}, \mathbf{1}} \mathbf{a}_{\text {fiss }}\left(\ell_{\mathrm{ef}}=7 \phi_{\mathrm{p}}\right)$} \\
\hline Source & $\mathrm{DF}$ & SS & MS & $\mathrm{F}$ \\
\hline teor-lef & 2 & 0,80 & 0,40 & 0,820 \\
\hline Error & 33 & 65,55 & 1,99 & \\
\hline \multirow[t]{2}{*}{ Total } & 35 & 66,35 & & \\
\hline & & & & $\begin{array}{l}\text { Individual 95\% CIs For Mean } \\
\text { Based on Pooled StDev }\end{array}$ \\
\hline Level & $\mathrm{N}$ & Mean & StDev & 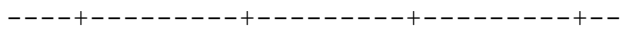 \\
\hline 1 & 12 & 6,708 & 1,638 & $(-------------\star--------------)$ \\
\hline 2 & 12 & 6,625 & 1,445 & $(-----------\star \star-------------)$ \\
\hline 3 & 12 & 6,973 & 1,090 & $(-------------\star--------$ \\
\hline Pooled St & $\mathrm{ev}=$ & 1,409 & & 7,80 \\
\hline
\end{tabular}

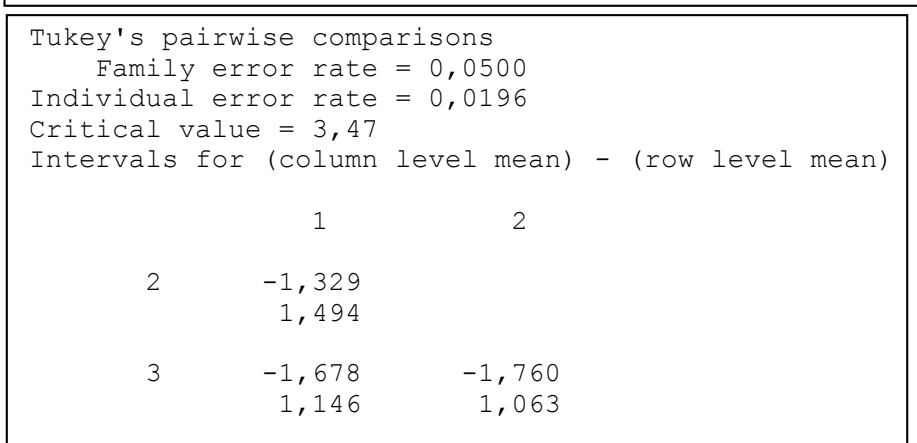

Figura E.60 - Tabela de análise de variância e teste de Tukey para $Y_{1}=\tau_{\mathrm{b}, 1^{\mathrm{a}} \text { fiss }}, \ell_{\mathrm{ef}}=7 \phi_{\mathrm{p}}$ e $X_{2}$.

\begin{tabular}{|c|c|c|c|c|}
\hline \multicolumn{5}{|c|}{ Analysis of Variance for $\tau_{\mathbf{b}, \mathbf{1}} \mathbf{a}$ fiss $\left(\ell_{\mathrm{ef}}=7 \phi_{\mathrm{p}}\right)$} \\
\hline Source & $\mathrm{DF}$ & SS & MS & $\mathrm{P}$ \\
\hline grau-lef & 1 & 38,337 & 38,337 & 0,000 \\
\hline Error & 34 & 28,008 & 0,824 & \\
\hline \multirow[t]{2}{*}{ Total } & 35 & 66,345 & & \\
\hline & & & & $\begin{array}{l}\text { Individual 95\% CIs For Mean } \\
\text { Based on Pooled StDev }\end{array}$ \\
\hline Level & $\mathrm{N}$ & Mean & StDev & -----+-----------+----------+-----------+-- \\
\hline 0 & 18 & 7,8006 & 0,9643 & $(-----\star----)$ \\
\hline 1 & 18 & 5,7367 & 0,8471 & $(-----\star----)$ \\
\hline Pooled St & ev $=$ & 0,9076 & & 5,60 \\
\hline
\end{tabular}

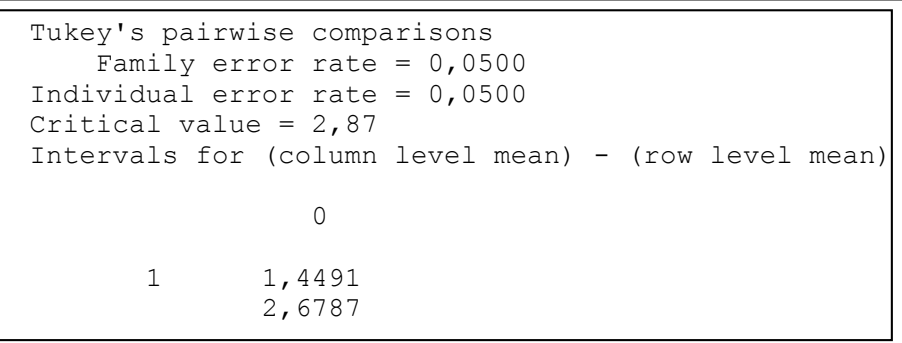

Figura E.61 - Tabela de análise de variância e teste de Tukey para $Y_{1}=\tau_{b, 1}{ }^{a}$ fiss, $\ell_{\mathrm{ef}}=7 \phi_{\mathrm{p}}$ e $X_{3}$.

Para a variável $\mathrm{X}_{3}$, percebe-se que há diferenças bastantes significativas entre os modelos com e sem protensão, sendo que as peças sem protensão apresentaram os maiores resultados. 


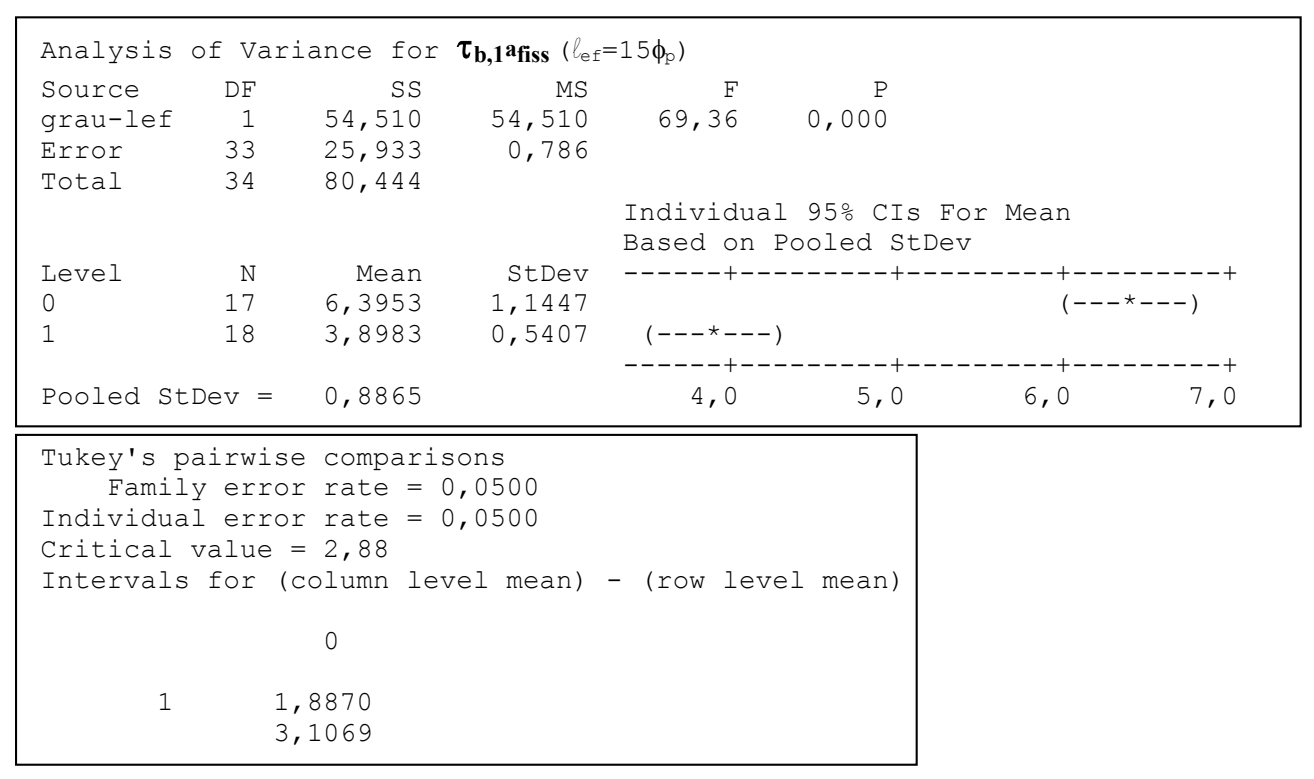

Figura E.62 - Tabela de análise de variância e teste de Tukey para $Y_{1}=\tau_{\mathrm{b}, 1^{\mathrm{fiss}}}, \ell_{\mathrm{ef}}=15 \phi_{\mathrm{p}}$ e $\mathrm{X}_{3}$.

\section{Variável resposta $Y_{2}=\tau_{b, 0.1}$}

A primeira análise a ser feita é a dos resíduos, para verificar-se se a amostra tem uma distribuição normal. As Figuras E.63 a E.68 apresentam os gráficos com plotagem dos resíduos para as variáveis $\mathrm{X}_{2}$ e $\mathrm{X}_{3}$, levando em conta os diferentes comprimentos de ancoragem disponíveis.

Para esses modelos, apenas a amostra representada na Figura E.67 não apresenta nem uma distribuição normal, nem as variâncias são constantes, o que fez com que se descartasse esse grupo. Para os demais, pôde-se montar a tabela de variância dos resultados e fez-se o teste de Tukey, que indica se há interferência de um conjunto de dado sobre o outro, para o intervalo de confiança estabelecido, que neste caso foi de $\mathrm{CI}=95 \%$. As Figuras E.69 a E.73 apresentam os resultados para as duas variáveis independentes analisadas.

Para a variável $\mathrm{X}_{2}$, tanto para os modelos com $\ell_{\mathrm{ef}}=5 \phi_{\mathrm{p}}$ como para os modelos com $\ell_{\mathrm{ef}}=7 \phi_{\mathrm{p}}$ não há diferenças significativas entre os três volumes de fibras utilizados.
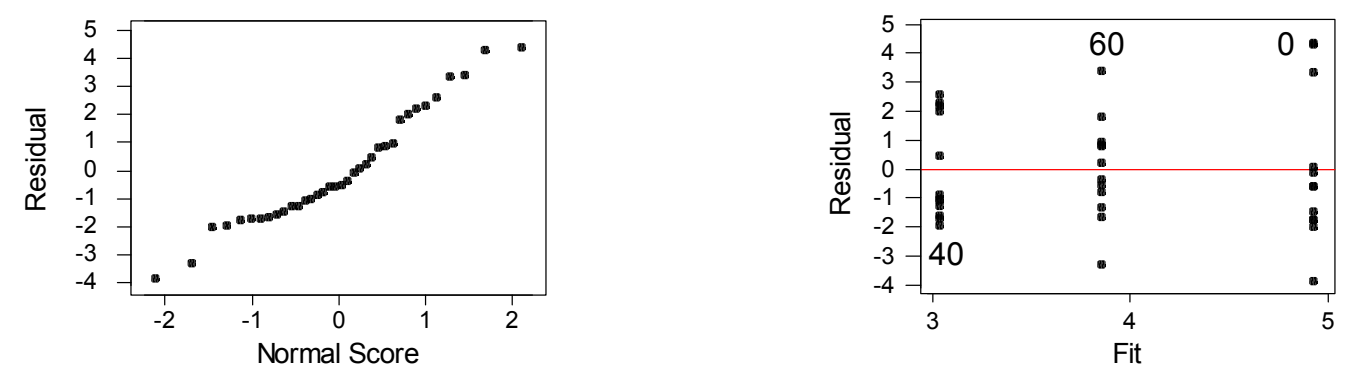

Figura E.63 - Análise de resíduos para $\mathrm{Y}_{2}=\tau_{\mathrm{b}, 0.1}, \ell_{\mathrm{ef}}=5 \phi_{\mathrm{p}}$ e a variável $\mathrm{X}_{2}$. 

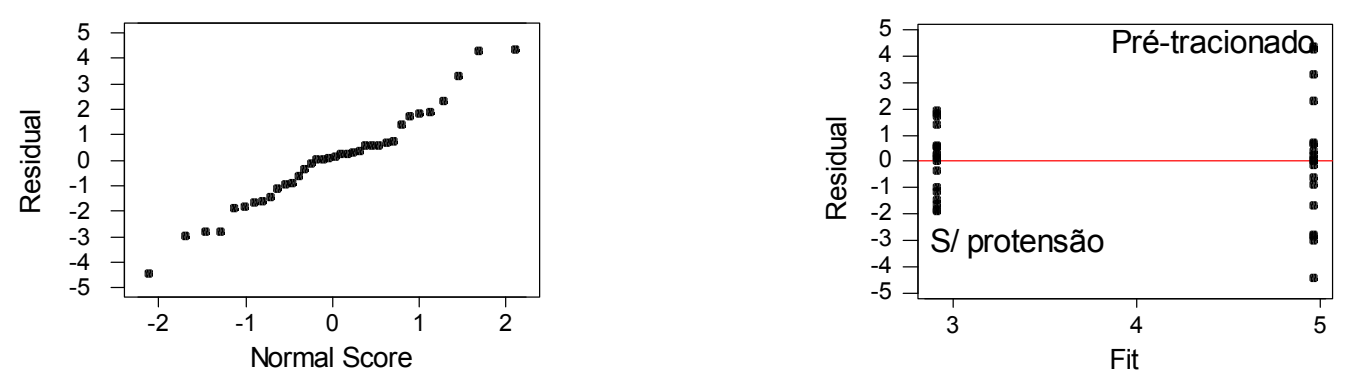

Figura E.64 - Análise de resíduos para $\mathrm{Y}_{2}=\tau_{\mathrm{b}, 0.1}, \ell_{\mathrm{ef}}=5 \phi_{\mathrm{p}}$ e a variável $\mathrm{X}_{3}$.
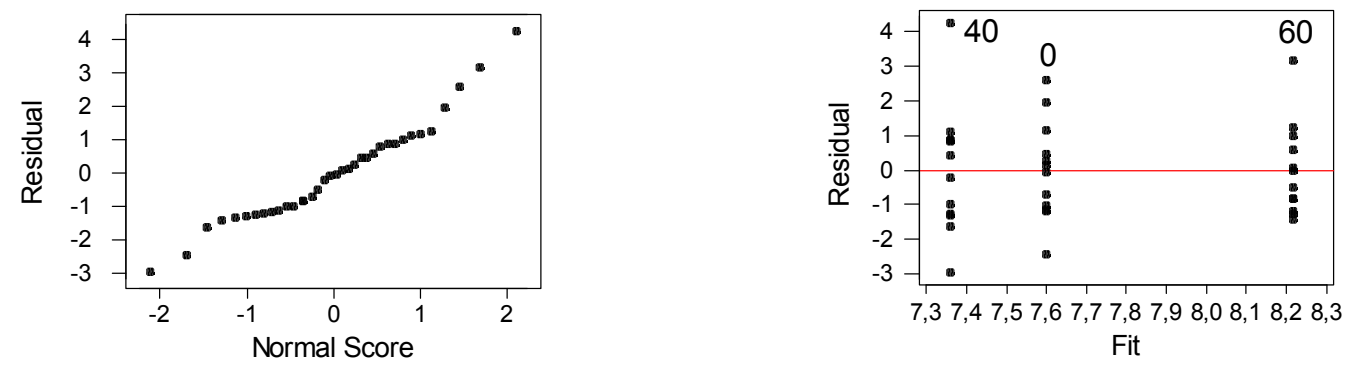

Figura E.65 - Análise de resíduos para $\mathrm{Y}_{2}=\tau_{\mathrm{b}, 0.1}, \ell_{\mathrm{ef}}=7 \phi_{\mathrm{p}}$ e a variável $\mathrm{X}_{2}$.
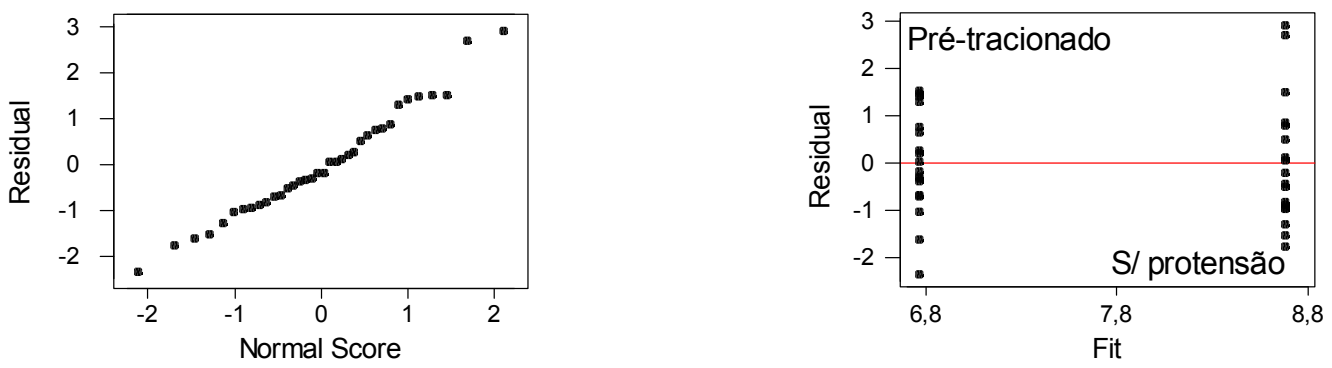

Figura E.66 - Análise de resíduos para $\mathrm{Y}_{2}=\tau_{\mathrm{b}, 0.1}, \ell_{\mathrm{ef}}=7 \phi_{\mathrm{p}}$ e a variável $\mathrm{X}_{3}$.
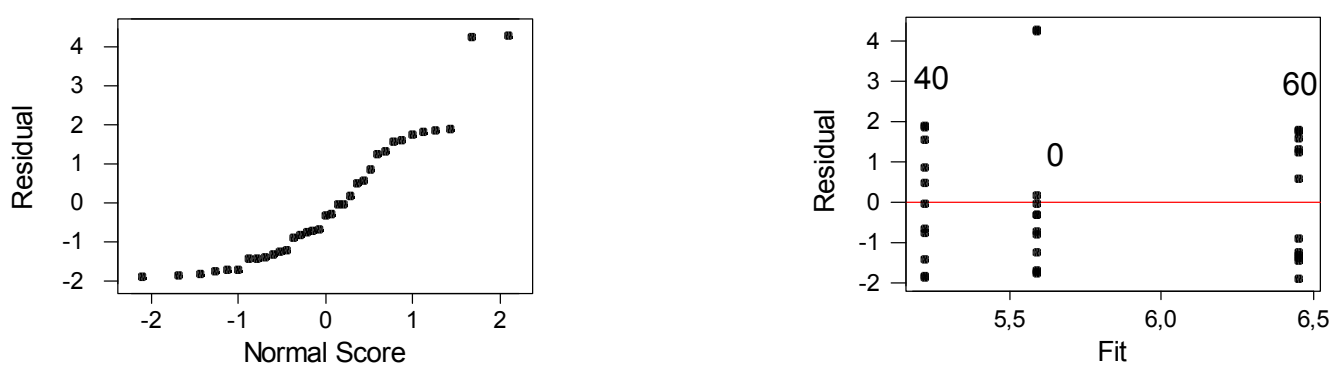

Figura E.67 - Análise de resíduos para $\mathrm{Y}_{2}=\tau_{\mathrm{b}, 0.1}, \ell_{\mathrm{ef}}=15 \phi_{\mathrm{p}}$ e a variável $\mathrm{X}_{2}$.
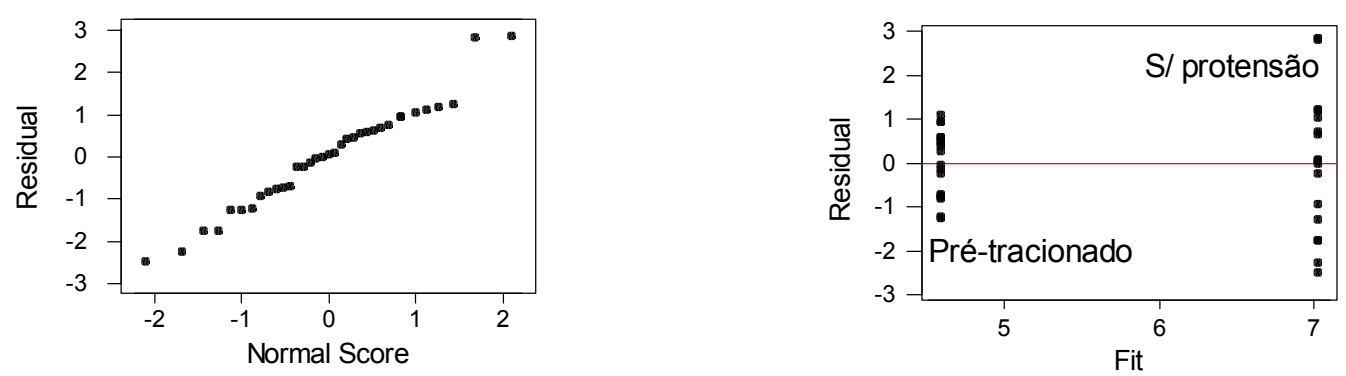

Figura E.68 - Análise de resíduos para $\mathrm{Y}_{2}=\tau_{\mathrm{b}, 0.1}, \ell_{\mathrm{ef}}=15 \phi_{\mathrm{p}}$ e a variável $\mathrm{X}_{3}$. 
Em relação à variável $\mathrm{X}_{3}$, para os modelos com $\ell_{\mathrm{ef}}=5 \phi_{\mathrm{p}}$ as peças pré-tracionados apresentaram um desempenho melhor que as sem protensão, já para $\ell_{\mathrm{ef}}=7 \phi_{\mathrm{p}}$ e $\ell_{\mathrm{ef}}=15 \phi_{\mathrm{p}}$ os modelos sem protensão apresentaram os maiores valores.

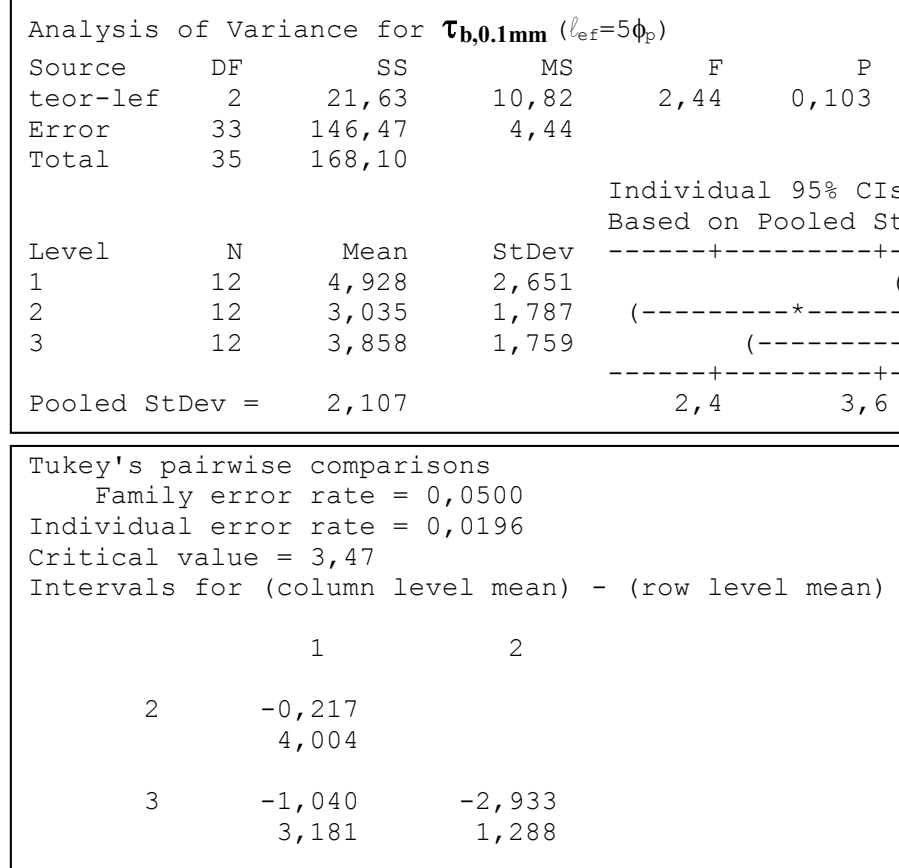

Figura E. 69 - Tabela de análise de variância e teste de Tukey para $\mathrm{Y}_{2}=\tau_{\mathrm{b}, 0.1}, \ell_{\mathrm{ef}}=5 \phi_{\mathrm{p}}$ e $\mathrm{X}_{2}$.

\begin{tabular}{|c|c|c|c|c|}
\hline \multicolumn{5}{|l|}{ Analysis } \\
\hline Source & $\mathrm{DF}$ & SS & MS & $\mathrm{F}$ \\
\hline grau-lef & 1 & 37,97 & 37,97 & 0,003 \\
\hline Error & 34 & 130,14 & 3,83 & \\
\hline \multirow[t]{2}{*}{ Total } & 35 & 168,10 & & \\
\hline & & & & $\begin{array}{l}\text { Individual 95\% CIs For Mean } \\
\text { Based on Pooled StDev }\end{array}$ \\
\hline Level & $\mathrm{N}$ & Mean & StDev & ----+---------+---------+---------+-- \\
\hline 0 & 18 & 2,913 & 1,259 & $(-------\star-------)$ \\
\hline 1 & 18 & 4,967 & 2,464 & $(------*-------)$ \\
\hline Pooled St & $\mathrm{ev}=$ & 1,956 & & 3,6 \\
\hline
\end{tabular}

Tukey's pairwise comparisons
Family error rate $=0,0500$
Individual error rate $=0,0500$
Critical value $=2,87$
Intervals for (column level mean) - (row level mean)
0
1
$-3,379$
$-0,729$

Figura E. 70 - Tabela de análise de variância e teste de Tukey para $\mathrm{Y}_{2}=\tau_{\mathrm{b}, 0.1}, \ell_{\mathrm{ef}}=5 \phi_{\mathrm{p}}$ e $\mathrm{X}_{3}$. 


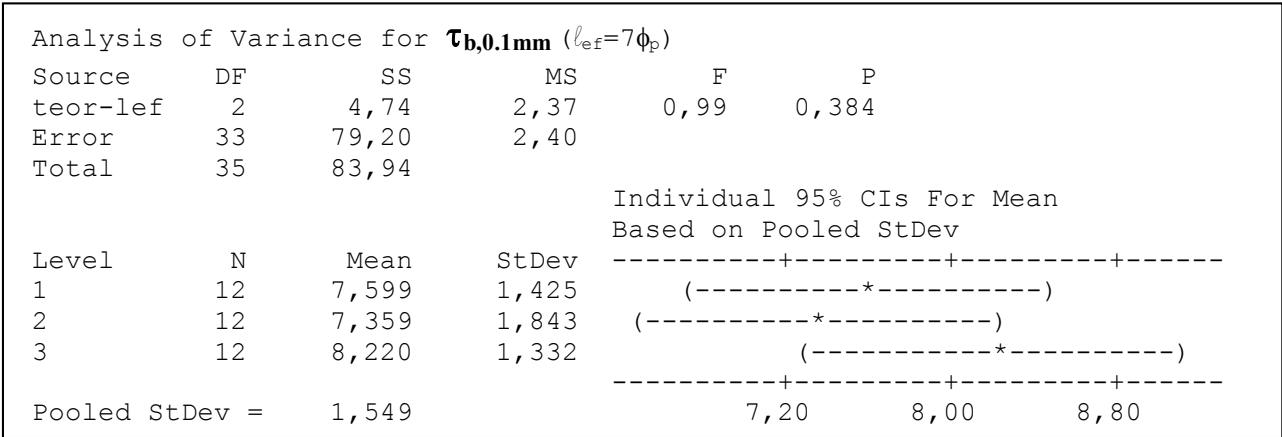

Tukey's pairwise comparisons

Family error rate $=0,0500$

Individual error rate $=0,0196$

Critical value $=3,47$

Intervals for (column level mean) - (row level mean)

$\begin{array}{rrr} & 1 & 2 \\ 2 & -1,312 & \\ 1 & 1,792 & \\ & & \\ & -2,173 & -2,413 \\ & 0,931 & 0,691 \\ & & \end{array}$

Figura E. 71 - Tabela de análise de variância e teste de Tukey para $Y_{2}=\tau_{b, 0.1}, \ell_{\mathrm{ef}}=7 \phi_{\mathrm{p}}$ e $\mathrm{X}_{2}$.

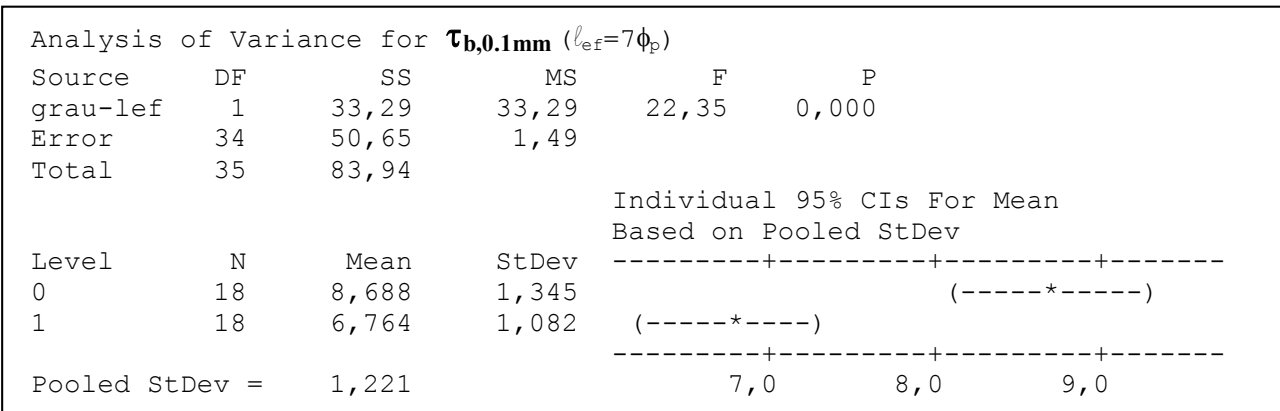

Tukey's pairwise comparisons

Family error rate $=0,0500$

Individual error rate $=0,0500$

Critical value $=2,87$

Intervals for (column level mean) - (row level mean)

$1 \quad 1,097$

2,750

Figura E.72 - Tabela de análise de variância e teste de Tukey para $\mathrm{Y}_{2}=\tau_{\mathrm{b}, 0.1}, \ell_{\mathrm{ef}}=7 \phi_{\mathrm{p}}$ e $\mathrm{X}_{3}$. 


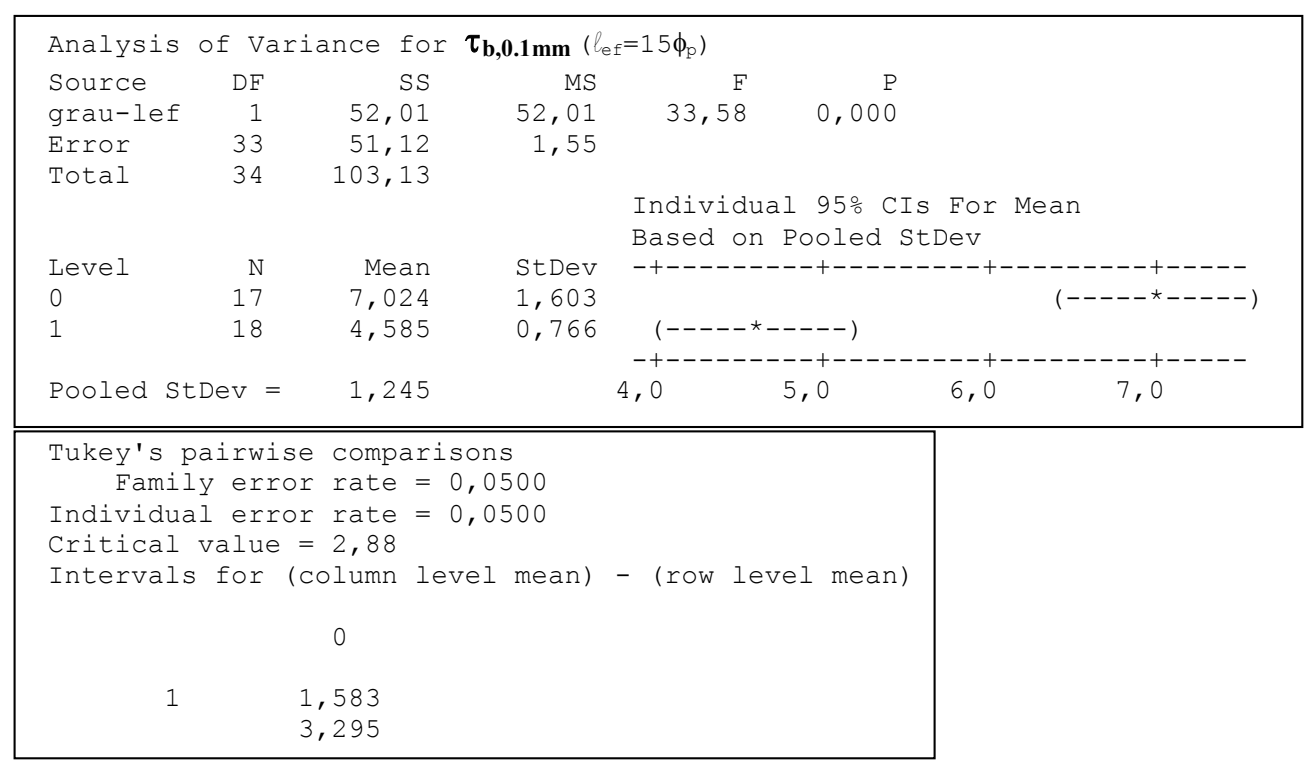

Figura E.73 - Tabela de análise de variância e teste de Tukey para $Y_{2}=\tau_{\mathrm{b}, 0.1}, \ell_{\mathrm{ef}}=15 \phi_{\mathrm{p}}$ e $\mathrm{X}_{3}$.

\section{Variável resposta $Y_{3}=\tau_{b, 1}$}

A primeira análise a ser feita é a dos resíduos, para verificar-se se a amostra tem uma distribuição normal. As Figuras E.74 a E.79 apresentam os gráficos com plotagem dos resíduos para as variáveis $\mathrm{X}_{2}$ e $\mathrm{X}_{3}$, levando em conta os diferentes comprimentos de ancoragem disponíveis. Todas as amostras para $\ell_{\mathrm{ef}}=5 \phi_{\mathrm{p}}$ e $\ell_{\mathrm{ef}}=7 \phi_{\mathrm{p}}$ apresentam distribuição normal e variância constante. As amostras para $\ell_{\mathrm{ef}}=15 \phi_{\mathrm{p}}$ (Figuras E.78 e E.79) não apresentam nem distribuição normal nem variância constante.

Após a verificação dos resíduos, constatado que as amostras apresentam distribuição normal, pôde-se montar a tabela de variância dos resultados para os modelos com $\ell_{\mathrm{ef}}=5 \phi_{\mathrm{p}} \mathrm{e}$ $\ell_{\mathrm{ef}}=7 \phi_{\mathrm{p}}$. Juntamente com a tabela de variância, fez-se o teste de Tukey, que indica se há interferência de um conjunto de dado sobre o outro, para o intervalo de confiança estabelecido, que neste caso foi de $\mathrm{CI}=95 \%$. As Figuras E.80 a E.83 apresentam os resultados para as duas variáveis independentes analisadas.
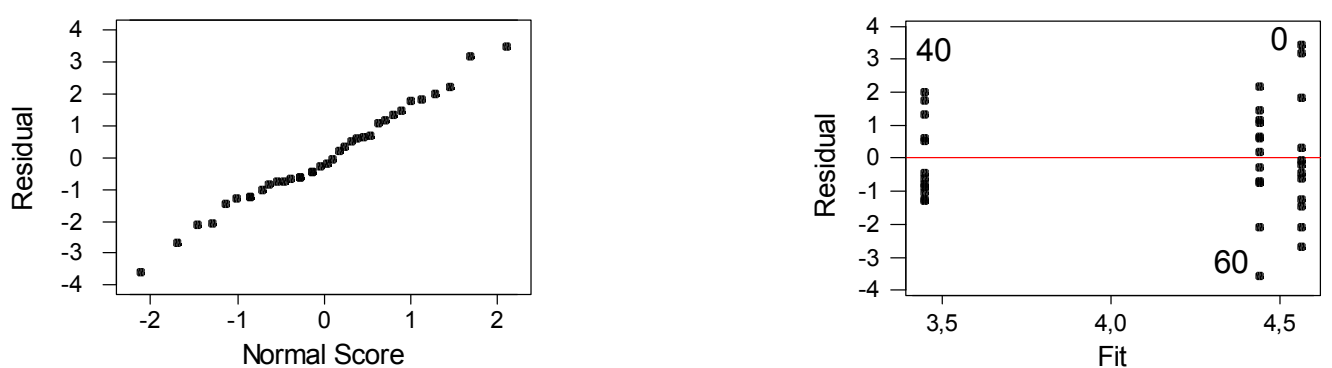

Figura E.74 - Análise de resíduos para $\mathrm{Y}_{3}=\tau_{\mathrm{b}, 1}, \ell_{\mathrm{ef}}=5 \phi_{\mathrm{p}}$ e a variável $\mathrm{X}_{2}$. 

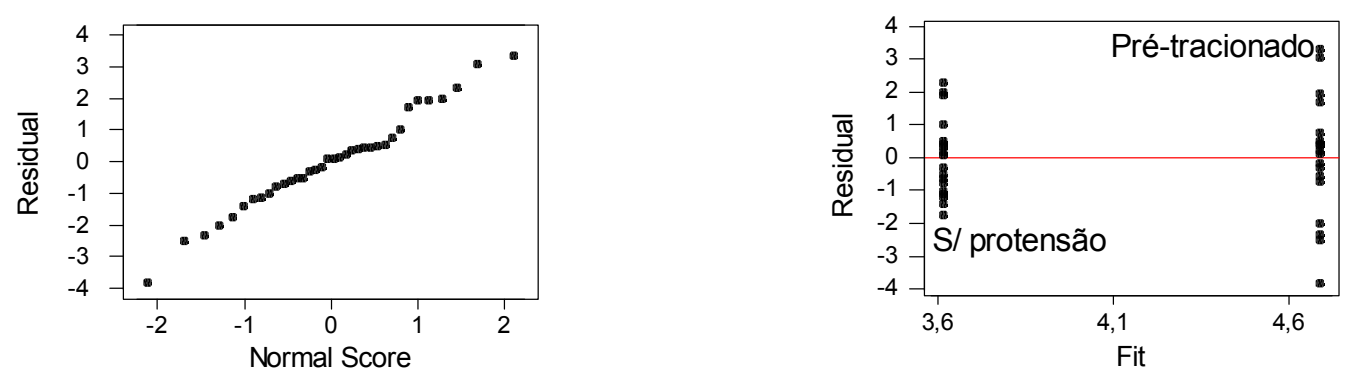

Figura E.75 - Análise de resíduos para $\mathrm{Y}_{3}=\tau_{\mathrm{b}, 1}, \ell_{\mathrm{ef}}=5 \phi_{\mathrm{p}}$ e a variável $\mathrm{X}_{3}$.
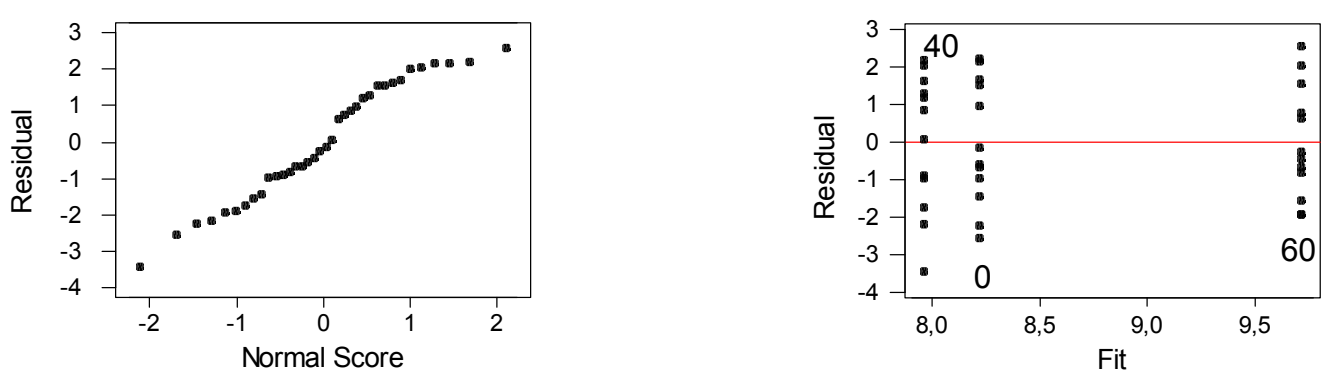

Figura E.76 - Análise de resíduos para $\mathrm{Y}_{3}=\tau_{\mathrm{b}, 1}, \ell_{\mathrm{ef}}=7 \phi_{\mathrm{p}}$ e a variável $\mathrm{X}_{2}$.
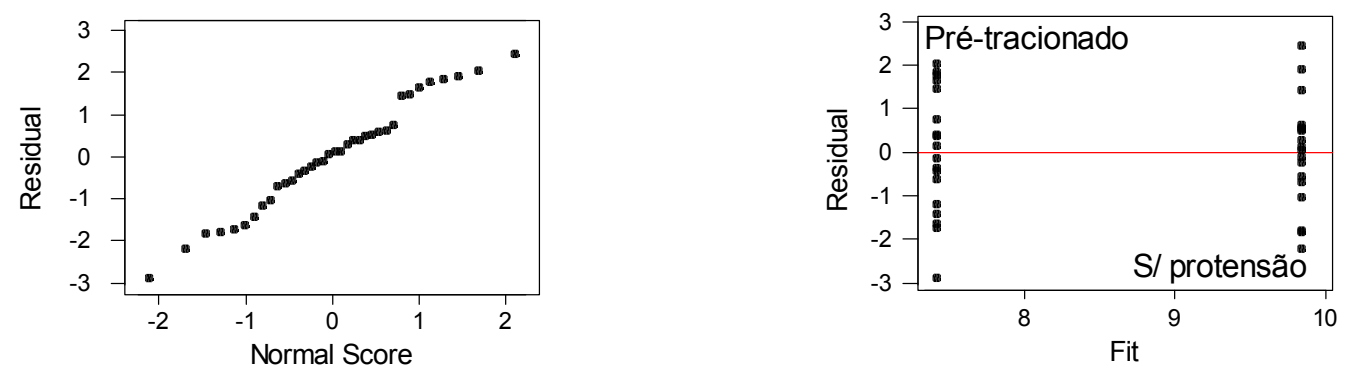

Figura E.77 - Análise de resíduos para $\mathrm{Y}_{3}=\tau_{\mathrm{b}, 1}, \ell_{\mathrm{ef}}=7 \phi_{\mathrm{p}}$ e a variável $\mathrm{X}_{3}$.
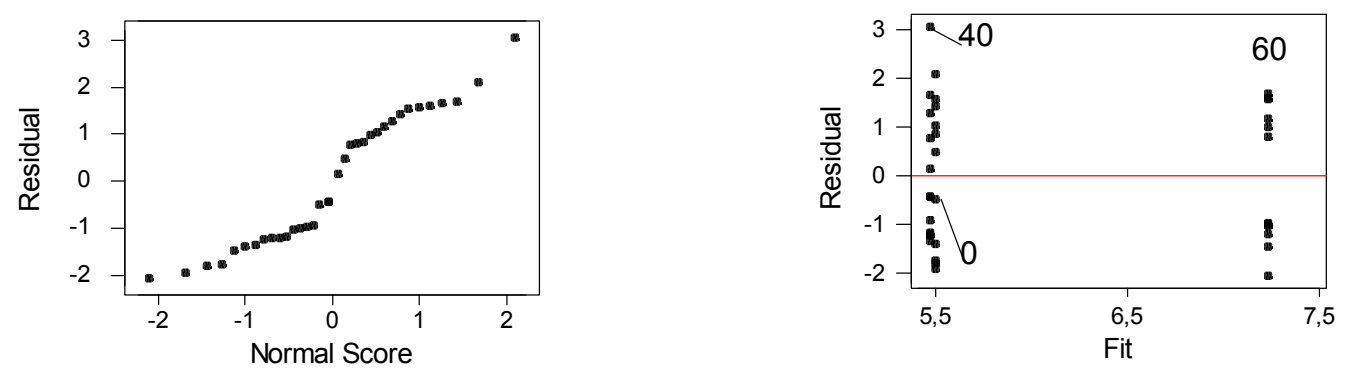

Figura E. 78 - Análise de resíduos para $\mathrm{Y}_{3}=\tau_{\mathrm{b}, 1}, \ell_{\mathrm{ef}}=15 \phi_{\mathrm{p}}$ e a variável $\mathrm{X}_{2}$.
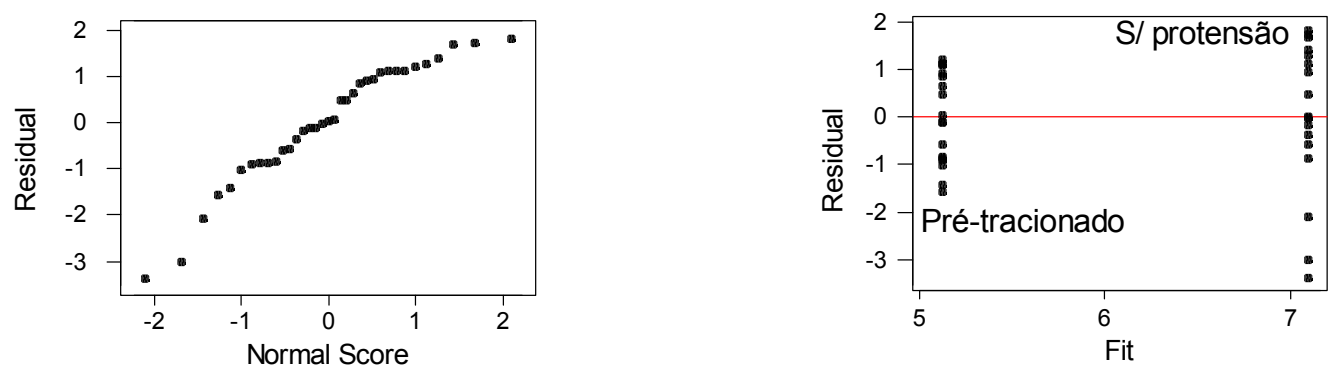

Figura E.79 - Análise de resíduos para $\mathrm{Y}_{3}=\tau_{\mathrm{b}, 1}, \ell_{\mathrm{ef}}=15 \phi_{\mathrm{p}}$ e a variável $\mathrm{X}_{3}$. 


\begin{tabular}{|c|c|c|c|c|}
\hline \multicolumn{5}{|c|}{ Analysis of Variance for $\tau_{\mathbf{b}, \mathbf{1} \mathbf{m m}} \quad\left(\ell_{\mathrm{ef}}=5 \phi_{\mathrm{p}}\right)$} \\
\hline Source & $\mathrm{DF}$ & SS & MS & $\mathrm{F}$ \\
\hline teor-lef & 2 & 9,04 & 4,52 & 0,192 \\
\hline Error & 33 & 86,04 & 2,61 & \\
\hline \multirow[t]{2}{*}{ Total } & 35 & 95,08 & & \\
\hline & & & & $\begin{array}{l}\text { Individual 95\% CIs For Mean } \\
\text { Based on Pooled StDev }\end{array}$ \\
\hline Level & $\mathrm{N}$ & Mean & StDev & ------+---------+---------+---------+ \\
\hline 1 & 12 & 4,566 & 1,941 & $(---------\star--------)$ \\
\hline 2 & 12 & 3,446 & 1,195 & $(--------\star---------)$ \\
\hline 3 & 12 & 4,441 & 1,620 & $(--------\star---------)$ \\
\hline Pooled St & $\mathrm{ev}=$ & 1,615 & & 5,0 \\
\hline
\end{tabular}

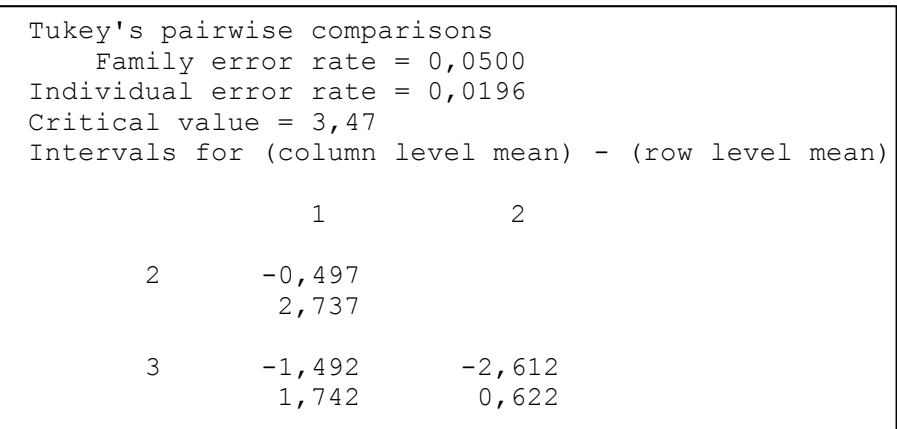

Figura E. 80 - Tabela de análise de variância e teste de Tukey para $Y_{3}=\tau_{\mathrm{b}, 1}, \ell_{\mathrm{ef}}=5 \phi_{\mathrm{p}}$ e $\mathrm{X}_{2}$.

Para a tabela da Figura E.80, percebe-se que não há diferenças significativas entre os três volumes de fibras utilizados, sendo que os modelos com $\mathrm{V}_{\mathrm{f}}=0$ apresentam o maior resultado, que é praticamente igual ao resultados fornecido pelos modelos com $\mathrm{V}_{\mathrm{f}}=60 \mathrm{~kg} / \mathrm{m}^{3}$.

Já para os modelos com $\ell_{\mathrm{ef}}=7 \phi_{\mathrm{p}}$ (Figura E.82), as peças com $\mathrm{V}_{\mathrm{f}}=60 \mathrm{~kg} / \mathrm{m}^{3}$ apresentam o melhor resultado, e o teste de Tukey indica que as diferenças entre os modelos com $\mathrm{V}_{\mathrm{f}}=40 \mathrm{~kg} / \mathrm{m}^{3}$ e $\mathrm{V}_{\mathrm{f}}=60 \mathrm{~kg} / \mathrm{m}^{3}$ são significativas.

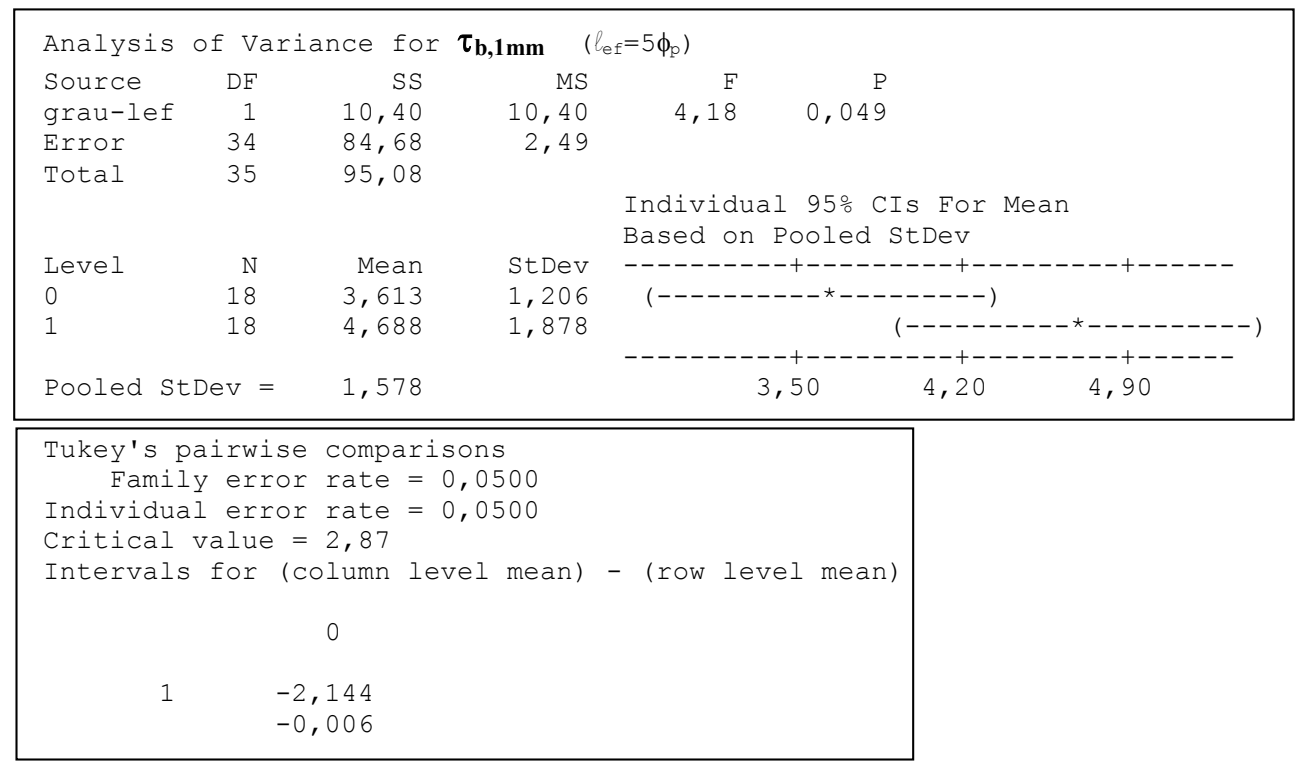

Figura E.81 - Tabela de análise de variância e teste de Tukey para $\mathrm{Y}_{3}=\tau_{\mathrm{b}, 1}, \ell_{\mathrm{ef}}=5 \phi_{\mathrm{p}}$ e $\mathrm{X}_{3}$. 


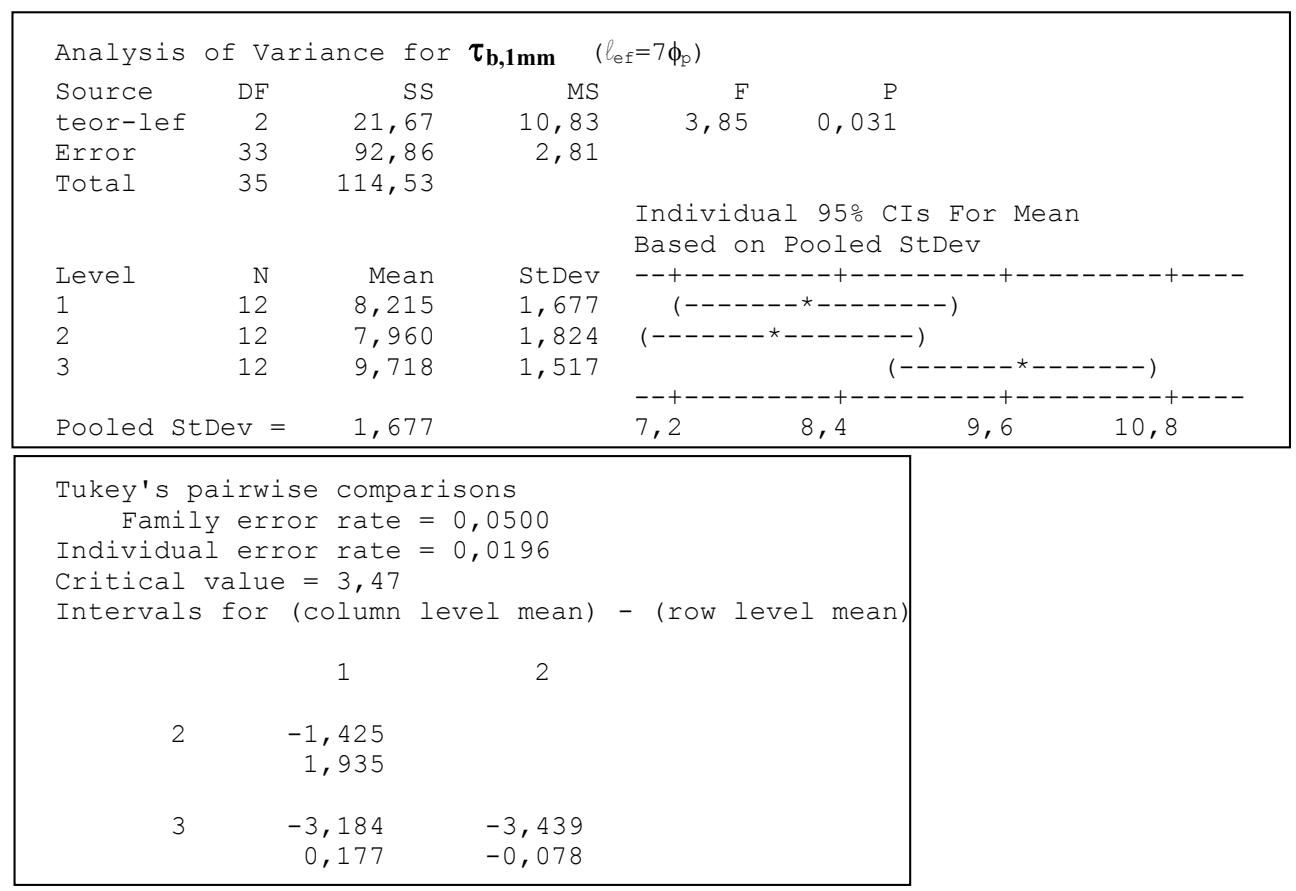

Figura E.82 - Tabela de análise de variância e teste de Tukey para $\mathrm{Y}_{3}=\tau_{\mathrm{b}, 1}, \ell_{\mathrm{ef}}=7 \phi_{\mathrm{p}}$ e $\mathrm{X}_{2}$.

Para os modelos com $\ell_{\mathrm{ef}}=5 \phi_{\mathrm{p}}$ (Figura E.81), as peças pré-tracionadas apresentaram o maior resultado, e o teste de Tukey indica que as diferenças entre os modelos pré-tracionados e os sem protensão são significativas.

Para os modelos com $\ell_{\mathrm{ef}}=7 \phi_{\mathrm{p}}$ (Figura E.83), as peças pré-tracionadas apresentaram o menor resultado, e o teste de Tukey indica que as diferenças entre os modelos pré-tracionados e os sem protensão são significativas.

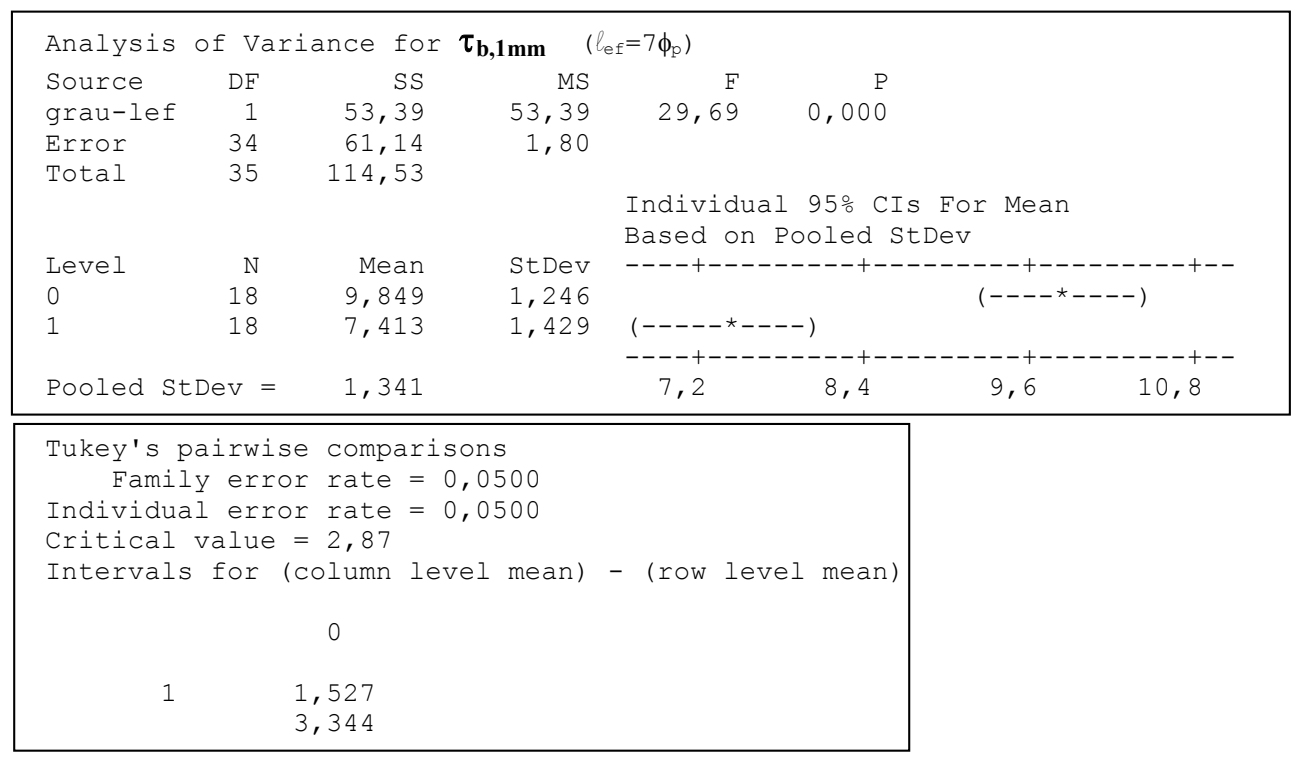

Figura E.83 - Tabela de análise de variância e teste de Tukey para $\mathrm{Y}_{3}=\tau_{\mathrm{b}, 1}, \ell_{\mathrm{ef}}=7 \phi_{\mathrm{p}}$ e $\mathrm{X}_{3}$. 


\section{Variável resposta $Y_{4}=S_{\tau \text { b,máx }}$}

A primeira análise a ser feita é a dos resíduos, para verificar-se se a amostra tem uma distribuição normal. As Figuras E.84 a E.89 apresentam os gráficos com plotagem dos resíduos para as variáveis $\mathrm{X}_{2}$ e $\mathrm{X}_{3}$, levando em conta os diferentes comprimentos de ancoragem disponíveis.
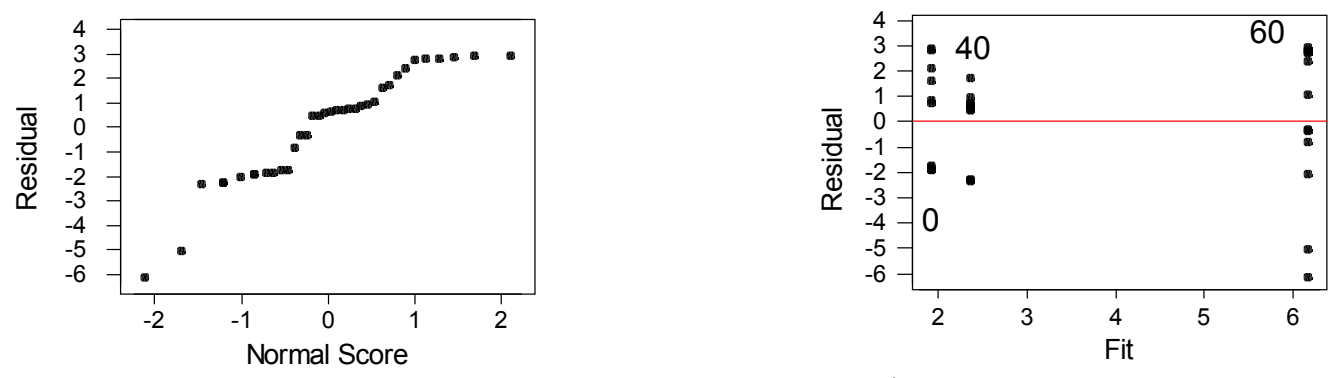

Figura E.84 - Análise de resíduos para $\mathrm{Y}_{4}=\mathrm{S}_{\tau_{\mathrm{b}, \text { máx }}} \ell_{\mathrm{ef}}=5 \phi_{\mathrm{p}}$ e a variável $\mathrm{X}_{2}$.
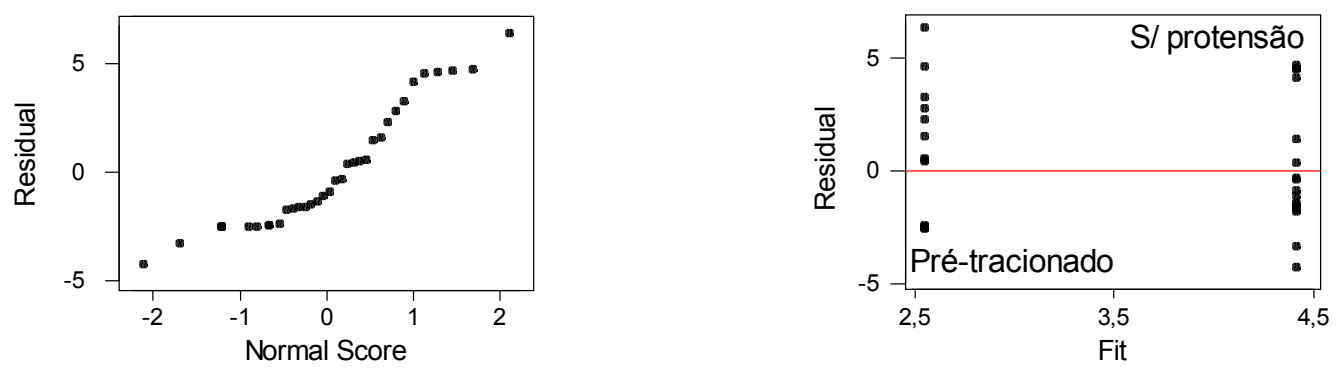

Figura E.85 - Análise de resíduos para $\mathrm{Y}_{4}=\mathrm{S}_{\tau_{\mathrm{b}, \text { máx }}}, \ell_{\mathrm{ef}}=5 \phi_{\mathrm{p}}$ e a variável $\mathrm{X}_{3}$.
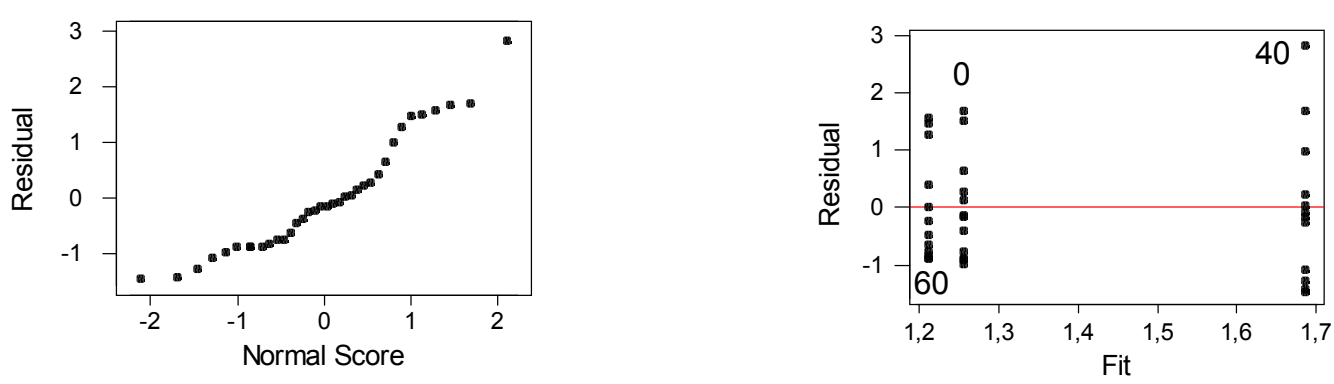

Figura E.86 - Análise de resíduos para $\mathrm{Y}_{4}=\mathrm{S}_{\tau_{\mathrm{b}, \text { máx }}}, \ell_{\mathrm{ef}}=7 \phi_{\mathrm{p}}$ e a variável $\mathrm{X}_{2}$.
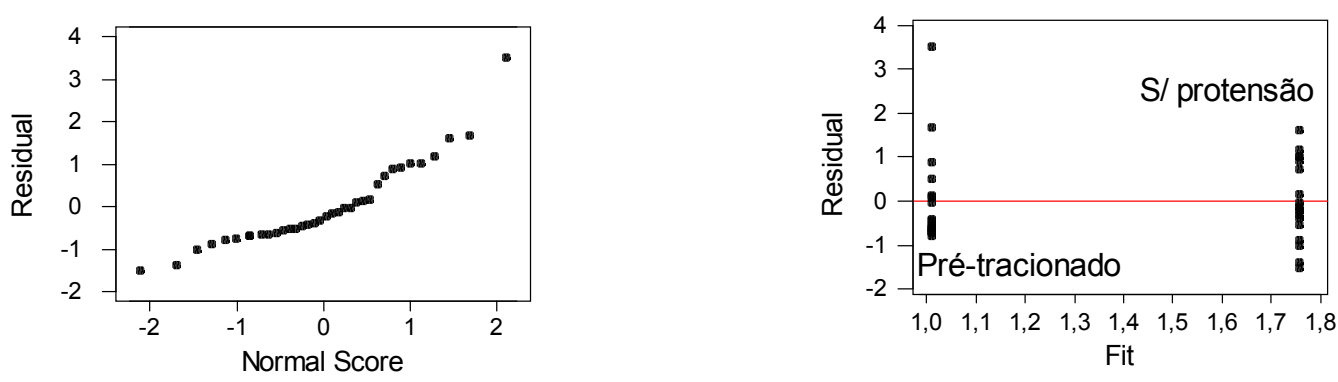

Figura E.87 - Análise de resíduos para $\mathrm{Y}_{4}=\mathrm{S}_{\tau_{\mathrm{b}, \text { máx }}}, \ell_{\mathrm{ef}}=7 \phi_{\mathrm{p}}$ e a variável $\mathrm{X}_{3}$. 

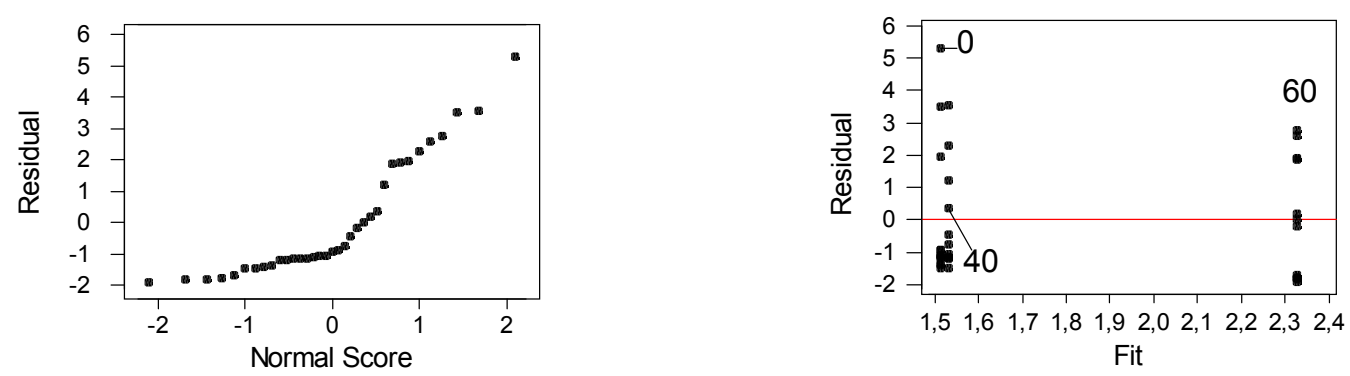

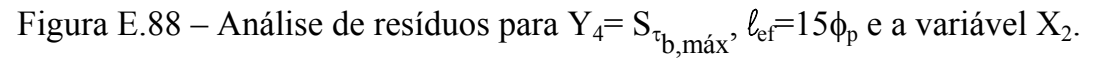
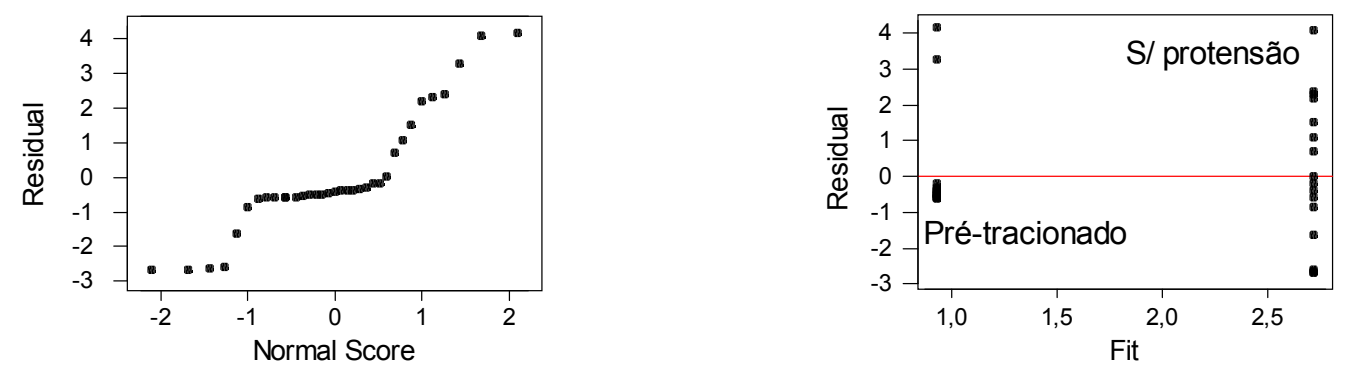

Figura E. 89 - Análise de resíduos para $\mathrm{Y}_{4}=\mathrm{S}_{\tau_{\mathrm{b}, \text { máx }}}, \ell_{\mathrm{ef}}=15 \phi_{\mathrm{p}}$ e a variável $\mathrm{X}_{3}$.

Pelos diagramas, percebe-se que para todas as variáveis, nem a distribuição pode ser considerada normal e nem a variabilidade desses dados é boa. Para que se pudesse analisar melhor esses resultados, elaborando tabelas de variância, seria necessário fazer algum tipo de transformação de dados, do tipo logarítmica por exemplo, para que se obtivesse uma distribuição normal e uma variabilidade mais constante.

\section{c) Bloco 3}

Todos os dados foram avaliados duas vezes: (1) para $\mathrm{X}_{1}$, onde os 36 modelos de cada grupo foram divididos em três sub-grupos de 12, levando-se em conta os volumes de fibra; e (2) para $\mathrm{X}_{3}$, onde os 36 modelos de cada grupo foram divididos em dois sub-grupos de 18, levando-se em conta o grau de protensão. Ou seja, foram construídas duas Tabelas de Análise de Variância para cada variável resposta, cada tabela levando em conta uma variável independente. Para cada sub-grupo também foi feita a plotagem dos resíduos e a avaliação de Tukey, para um intervalo de confiança (CI) de 95\%.

\section{Variável resposta $Y=\tau_{b, \text { máx }}$}

A primeira análise a ser feita é a dos resíduos, para verificar-se se a amostra tem uma distribuição normal. As Figuras E.90 a E.95 apresentam os gráficos com plotagem dos resíduos para as variáveis $\mathrm{X}_{1}$ e $\mathrm{X}_{3}$, levando em conta os diferentes volumes de fibras de aço utilizados. 

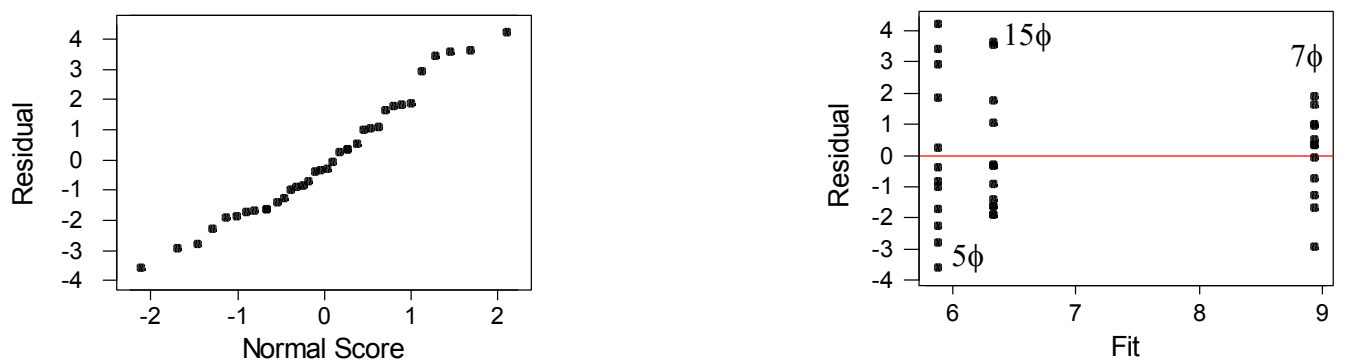

Figura E.90 - Análise de resíduos para $\mathrm{Y}=\tau_{\mathrm{b} \text {,máx }}, \mathrm{V}_{\mathrm{f}}=0$ e a variável $\mathrm{X}_{1}$.
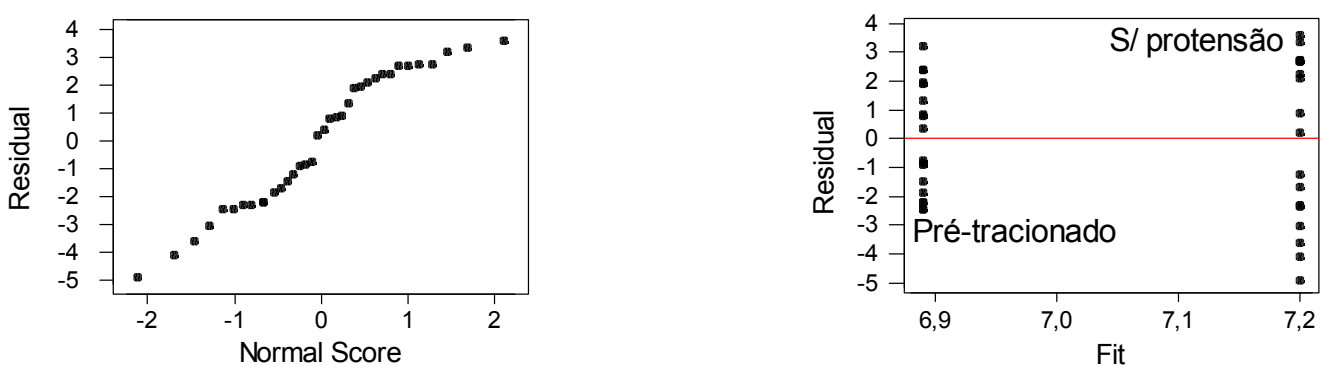

Figura E.91 - Análise de resíduos para $\mathrm{Y}=\tau_{\mathrm{b}, \text { máx }}, \mathrm{V}_{\mathrm{f}}=0$ e a variável $\mathrm{X}_{3}$.
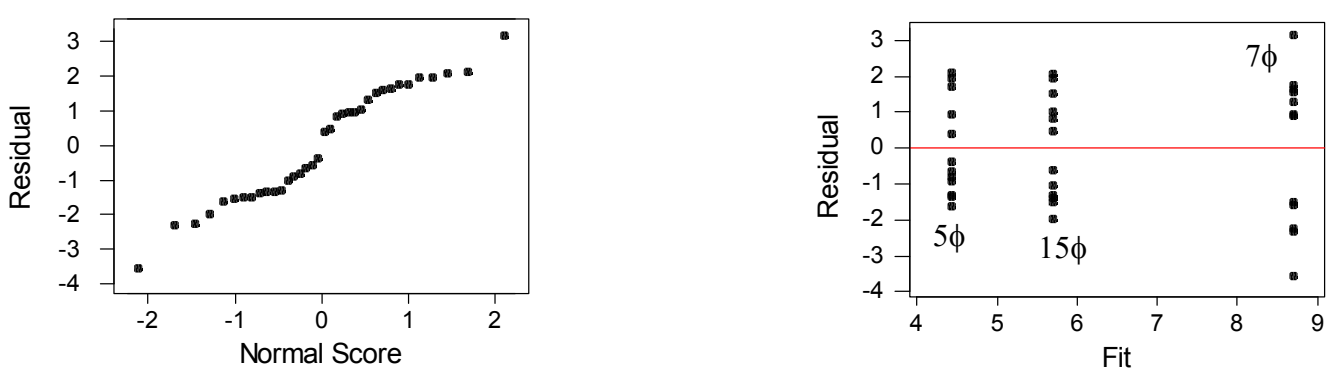

Figura E.92 - Análise de resíduos para $Y=\tau_{b \text {,máx }}, V_{f}=40 \mathrm{~kg} / \mathrm{m}^{3}$ e a variável $X_{1}$.
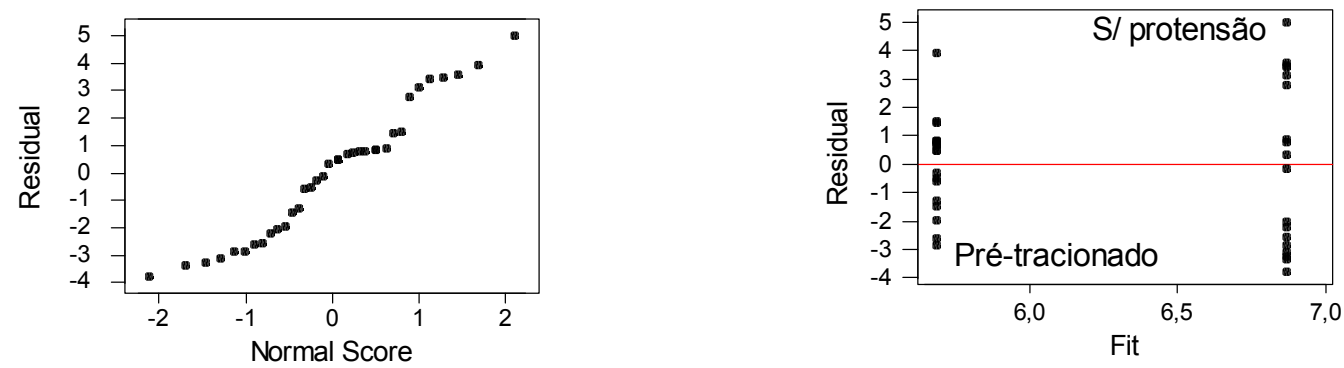

Figura E.93 - Análise de resíduos para $Y=\tau_{b \text {,máx }}, V_{f}=40 \mathrm{~kg} / \mathrm{m}^{3}$ e a variável $X_{3}$.
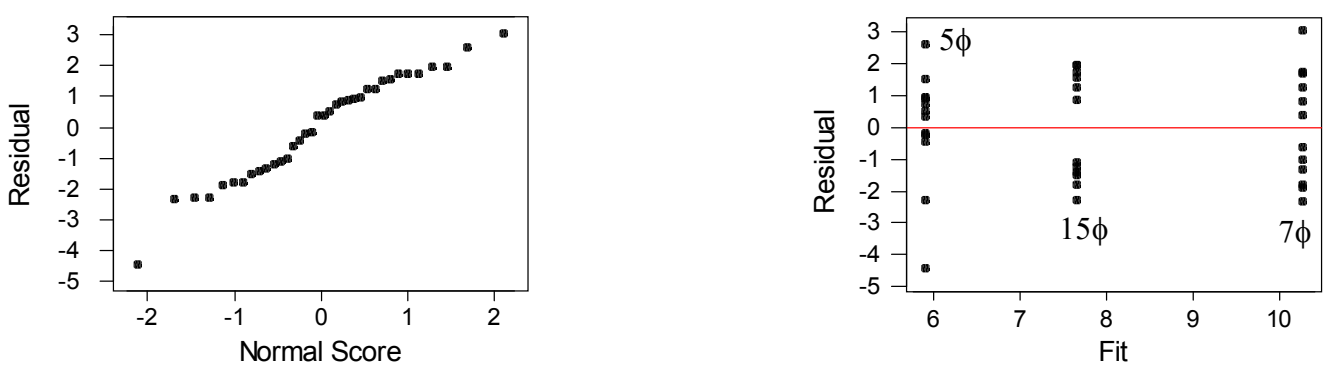

Figura E.94 - Análise de resíduos para $Y=\tau_{b \text {,máx }}, V_{f}=60 \mathrm{~kg} / \mathrm{m}^{3}$ e a variável $X_{1}$. 

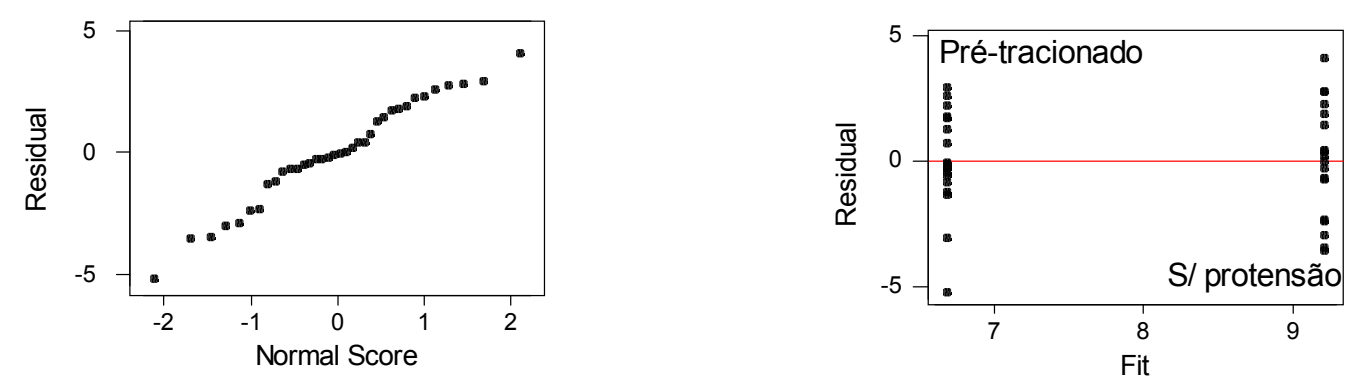

Figura E.95 - Análise de resíduos para $Y=\tau_{\mathrm{b}, \text { máx }}, \mathrm{V}_{\mathrm{f}}=60 \mathrm{~kg} / \mathrm{m}^{3}$ e a variável $\mathrm{X}_{3}$.

Após a verificação dos resíduos, constatou-se que apenas a amostra da Figura E.91 não apresenta distribuição normal. Para as demais, pôde-se montar a tabela de variância dos resultados e fez-se o teste de Tukey, que indica se há interferência de um conjunto de dado sobre o outro, para o intervalo de confiança estabelecido, que neste caso foi de $\mathrm{CI}=95 \%$. As Figuras E.96 a E.100 apresentam os resultados para as duas variáveis independentes analisadas.

Para os três volumes de fibras, os modelos com comprimento aderente de $5 \phi_{\mathrm{p}}$ apresentaram os menores resultados e os modelos com $\ell_{\mathrm{ef}}=7 \phi_{\mathrm{p}}$ apresentaram os maiores resultados, sendo que para todos eles as diferenças entre os valores com $\ell_{\mathrm{ef}}=7 \phi_{\mathrm{p}}$ e os outros são significativas.

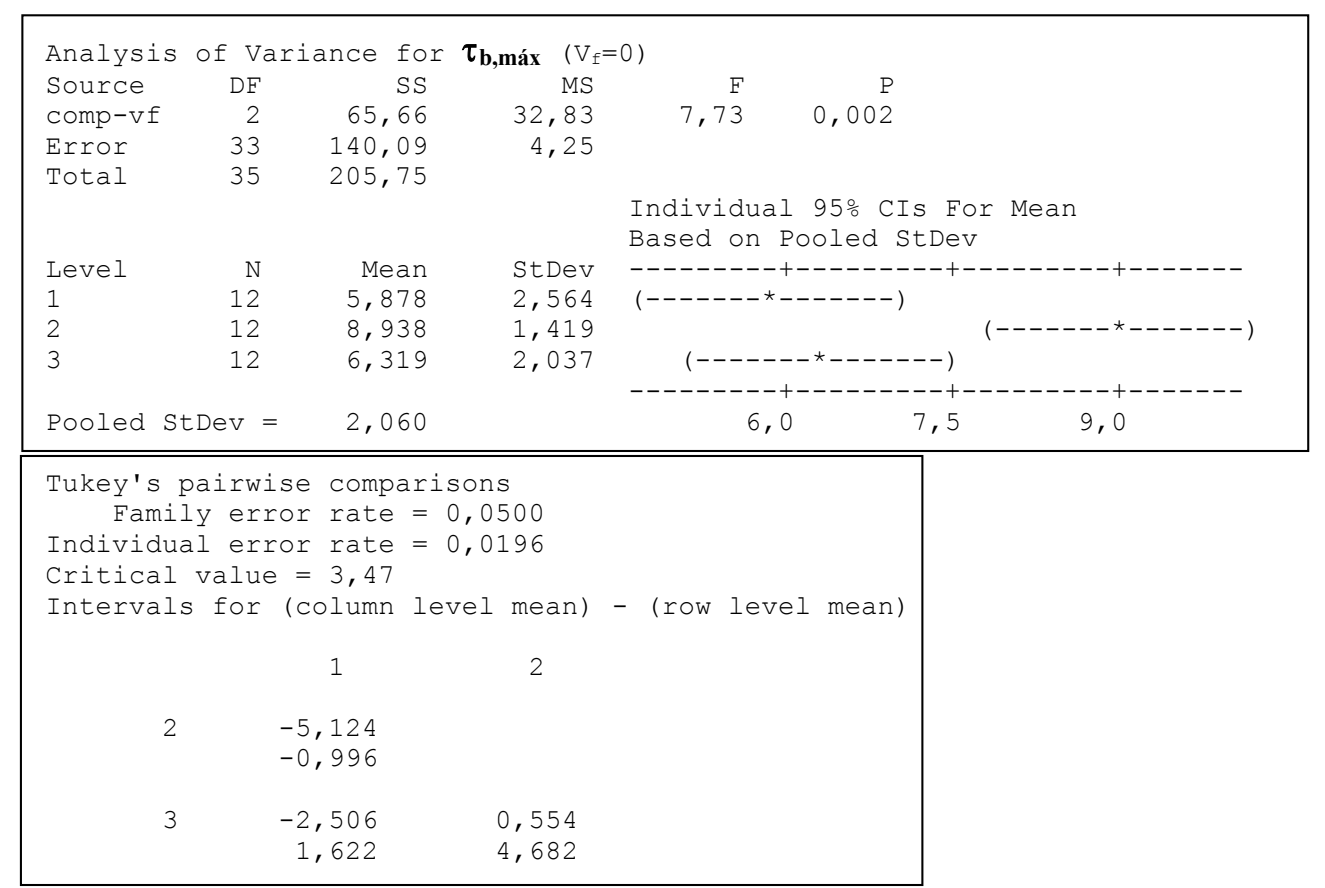

Figura E.96 - Tabela de análise de variância e teste de Tukey para $Y=\tau_{b \text {,máx }}, V_{f}=0$ e $X_{1}$. 


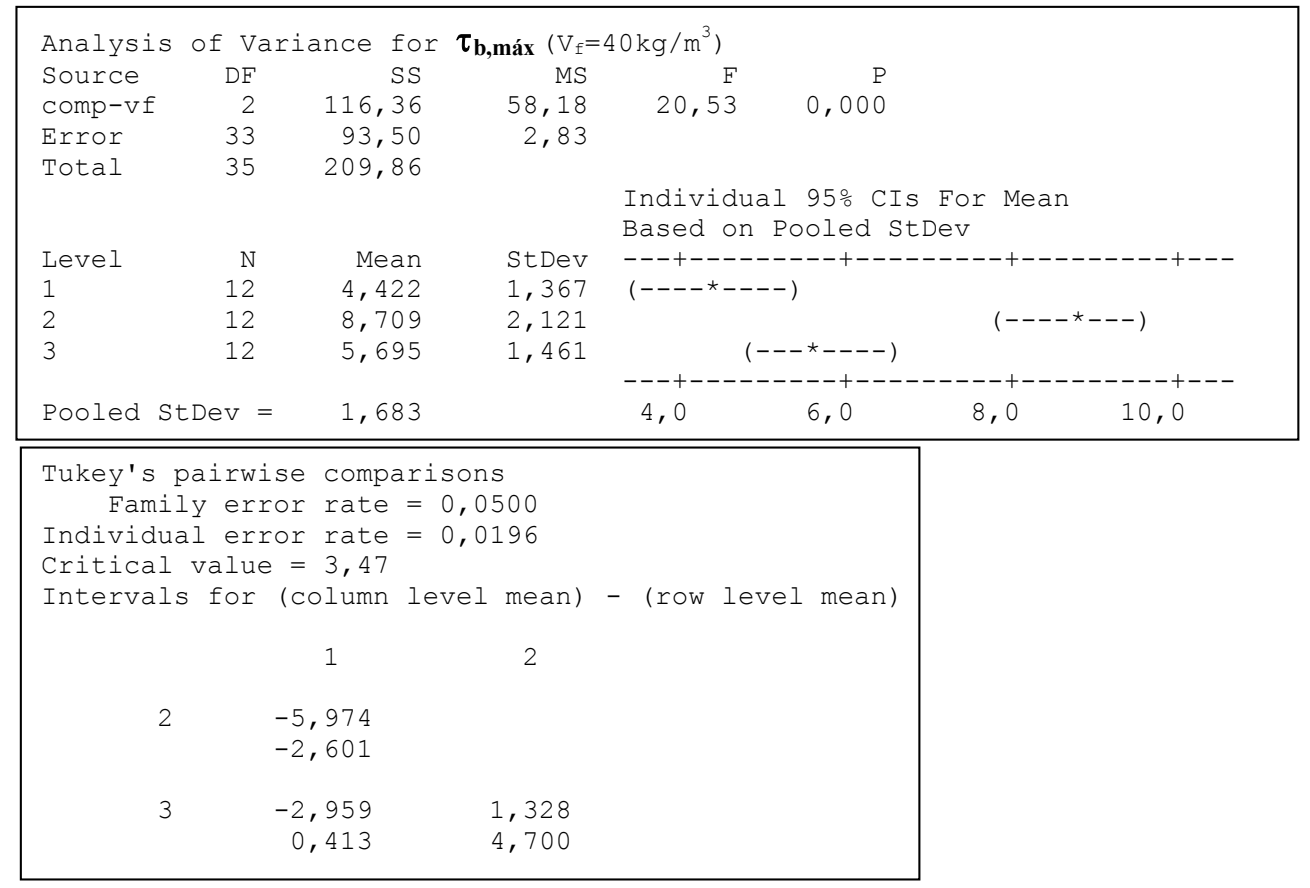

Figura E.97 - Tabela de análise de variância e teste de Tukey para $Y=\tau_{b \text {,máx }}, V_{\mathrm{f}}=40 \mathrm{~kg} / \mathrm{m}^{3}$ e $X_{1}$.

\begin{tabular}{|c|c|c|c|c|}
\hline Analysi & \multicolumn{2}{|c|}{ s of Variance for } & \multicolumn{2}{|c|}{$\tau_{\mathbf{b}, \mathbf{m a ́ x}}\left(V_{\mathrm{f}}=40 \mathrm{~kg} / \mathrm{m}^{3}\right)$} \\
\hline Source & $\mathrm{DF}$ & SS & MS & $\mathrm{F}$ \\
\hline grau-vf & 1 & 12,83 & 12,83 & 0,146 \\
\hline Error & 34 & 197,03 & 5,79 & \\
\hline \multirow[t]{2}{*}{ Total } & 35 & 209,86 & & \\
\hline & & & & $\begin{array}{l}\text { Individual 95\% CIs For Mean } \\
\text { Based on Pooled StDev }\end{array}$ \\
\hline Level & $\mathrm{N}$ & Mean & StDev & -----+---------+---------+---------+- \\
\hline 0 & 18 & 6,872 & 2,973 & $(-----------\star----------)$ \\
\hline 1 & 18 & 5,678 & 1,659 & $(-----------*----------)$ \\
\hline Pooled & StDev $=$ & 2,407 & & $\begin{array}{r}----+- \\
5,0\end{array}$ \\
\hline
\end{tabular}

Tukey's pairwise comparisons
Family error rate $=0,0500$
Individual error rate $=0,0500$
Critical value $=2,87$
Intervals for (column level mean) - (row level mean)
0
1
$-0,437$
2,825

Figura E.98 - Tabela de análise de variância e teste de Tukey para $Y=\tau_{b \text {,max }}, V_{f}=40 \mathrm{~kg} / \mathrm{m}^{3}$ e $X_{3}$. 


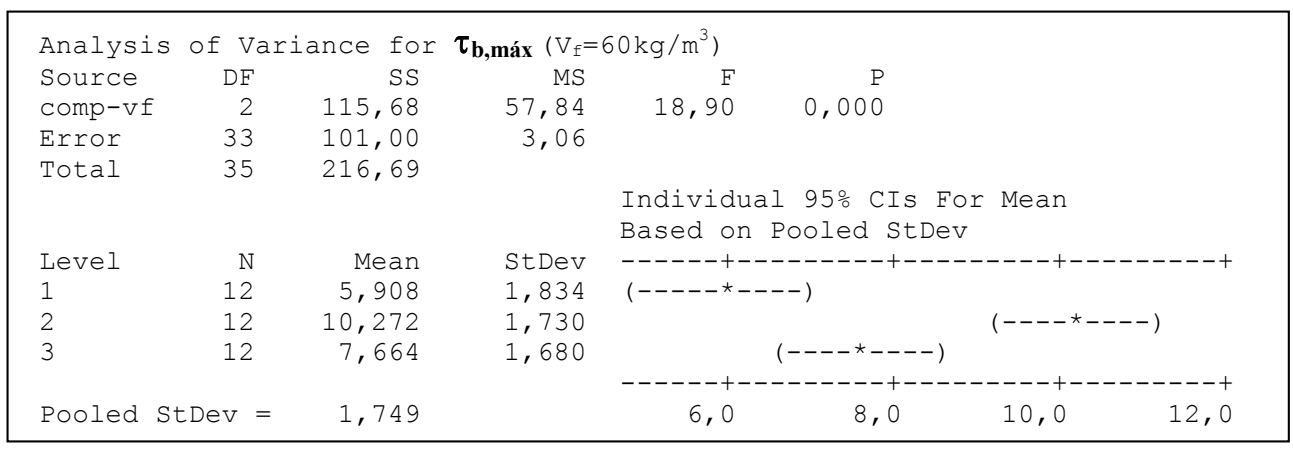

\begin{tabular}{|} 
Tukey's pairwise comparisons \\
Family error rate $=0,0500$ \\
Individual error rate $=0,0196$ \\
Critical value $=3,47$ \\
Intervals for (column level mean) - (row level mean) \\
1 \\
$-6,116$ \\
$-2,611$ \\
$-3,508$ \\
$-0,003$ & 0,855 \\
3 & 4,360
\end{tabular}

Figura E.99 - Tabela de análise de variância e teste de Tukey para $Y=\tau_{b, \max }, V_{\mathrm{f}}=60 \mathrm{~kg} / \mathrm{m}^{3}$ e $X_{1}$.

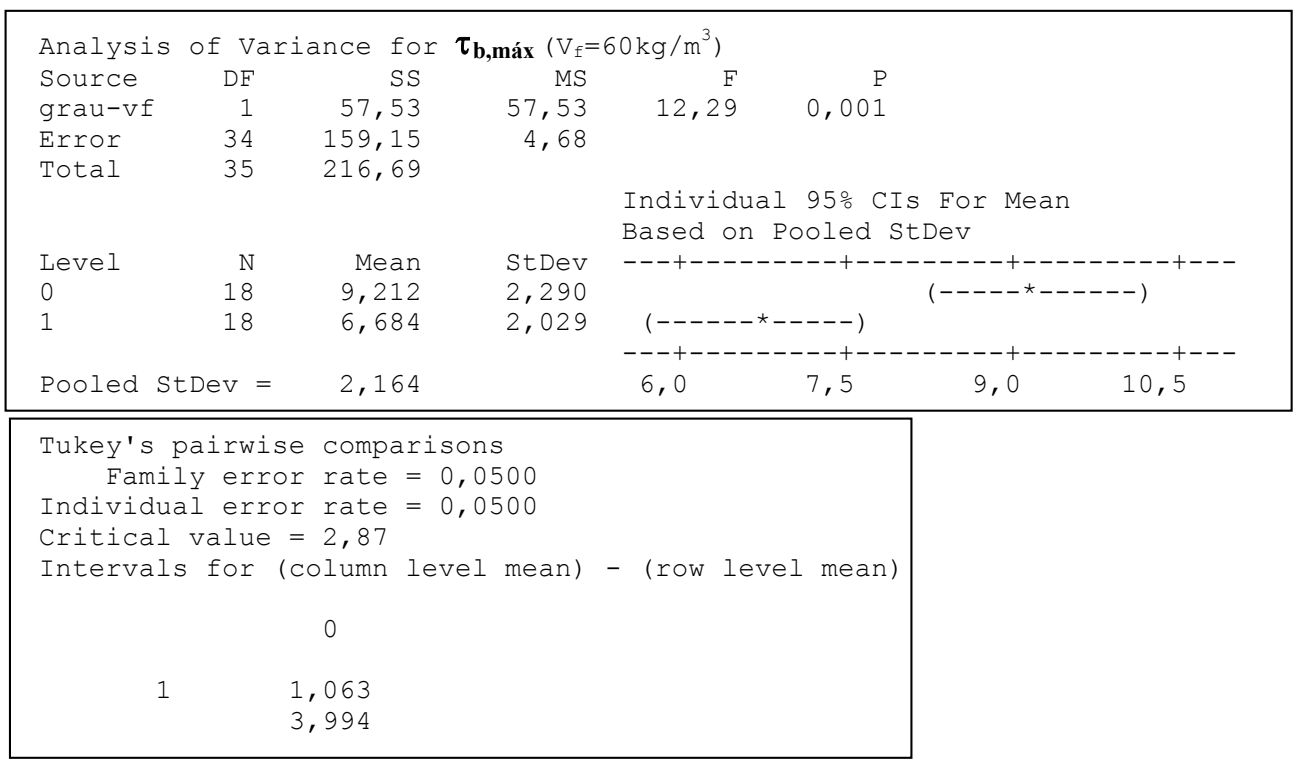

Figura E.100 - Tabela de análise de variância e teste de Tukey para $Y=\tau_{b, \max }, V_{\mathrm{f}}=60 \mathrm{~kg} / \mathrm{m}^{3}$ e $X_{3}$.

De maneira geral, os modelos pré-tracionados apresentam resultados inferiores aos dos modelos sem protensão.

\section{Variável resposta $Y_{1}=\tau_{b, 1}$ afiss}

A primeira análise a ser feita é a dos resíduos, para verificar-se se a amostra tem uma distribuição normal. As Figuras E.101 a E.106 apresentam os gráficos com plotagem dos resíduos para as variáveis $\mathrm{X}_{1}$ e $\mathrm{X}_{3}$, levando em conta os diferentes volumes de fibras de aço utilizados. 
Para esses modelos, apenas as peças com $\mathrm{V}_{\mathrm{f}}=40 \mathrm{~kg} / \mathrm{m}^{3}$ não apresentaram distribuição normal nem variância constante. Para os demais, pôde-se montar a tabela de variância dos resultados e o teste de Tukey. As Figuras E.107 a E.110 apresentam os resultados para as duas variáveis independentes analisadas.
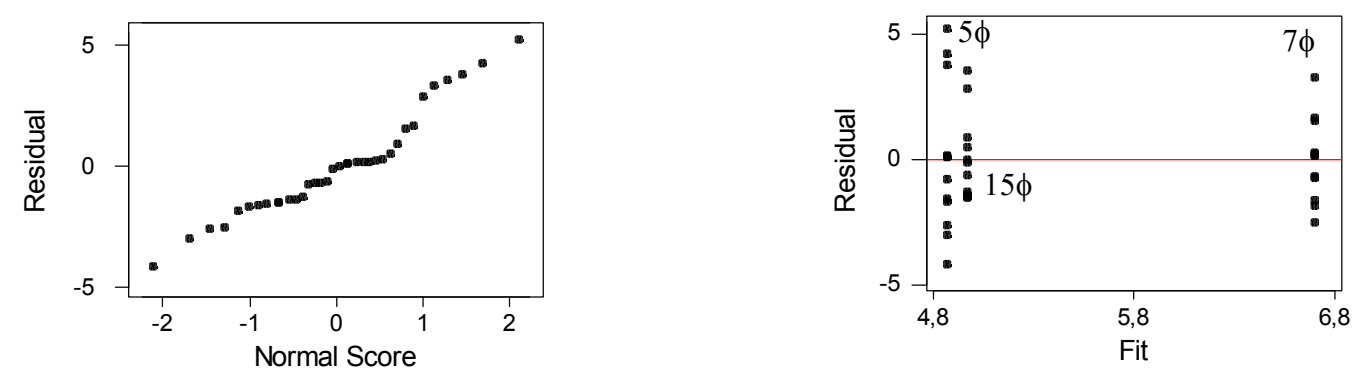

Figura E.101 - Análise de resíduos para $\mathrm{Y}_{1}=\tau_{\mathrm{b}, 1 \mathrm{a}} \mathrm{fiss}, \mathrm{V}_{\mathrm{f}}=0$ e a variável $\mathrm{X}_{1}$.
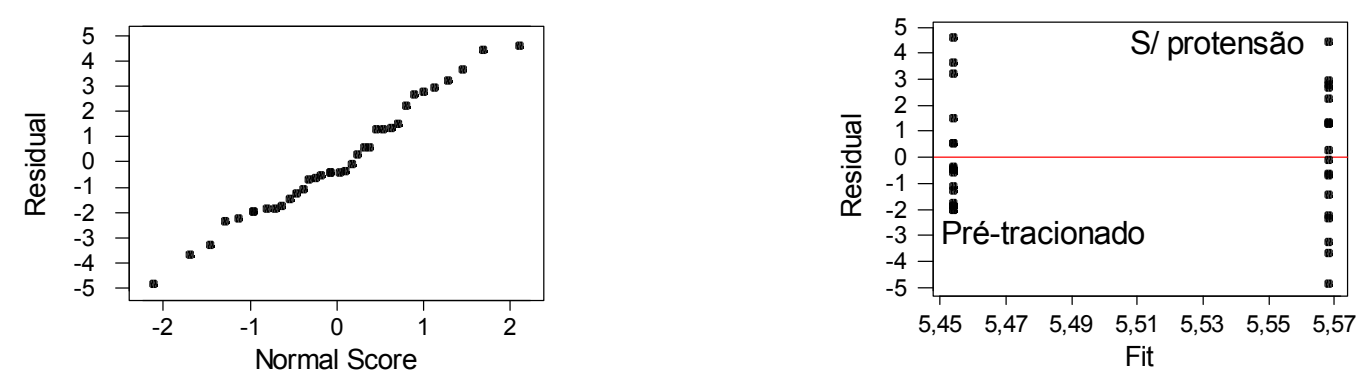

Figura E.102 - Análise de resíduos para $\mathrm{Y}_{1}=\tau_{\mathrm{b}, 1 \mathrm{a}} \mathrm{fiss}, \mathrm{V}_{\mathrm{f}}=0$ e a variável $\mathrm{X}_{3}$.
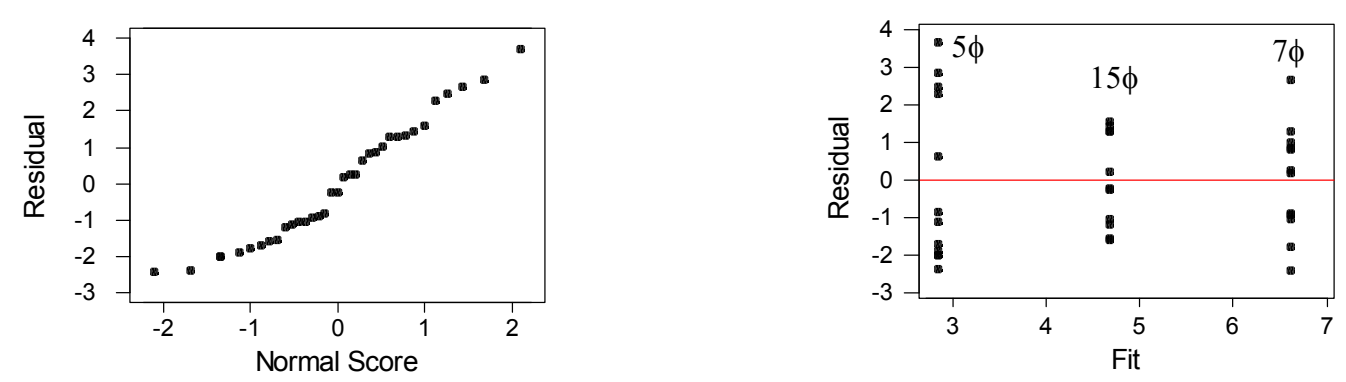

Figura E.103 - Análise de resíduos para $\mathrm{Y}_{1}=\tau_{\mathrm{b}, 1 \mathrm{a}} \mathrm{fiss}_{\mathrm{fs}}, \mathrm{V}_{\mathrm{f}}=40 \mathrm{~kg} / \mathrm{m}^{3}$ e a variável $\mathrm{X}_{1}$.
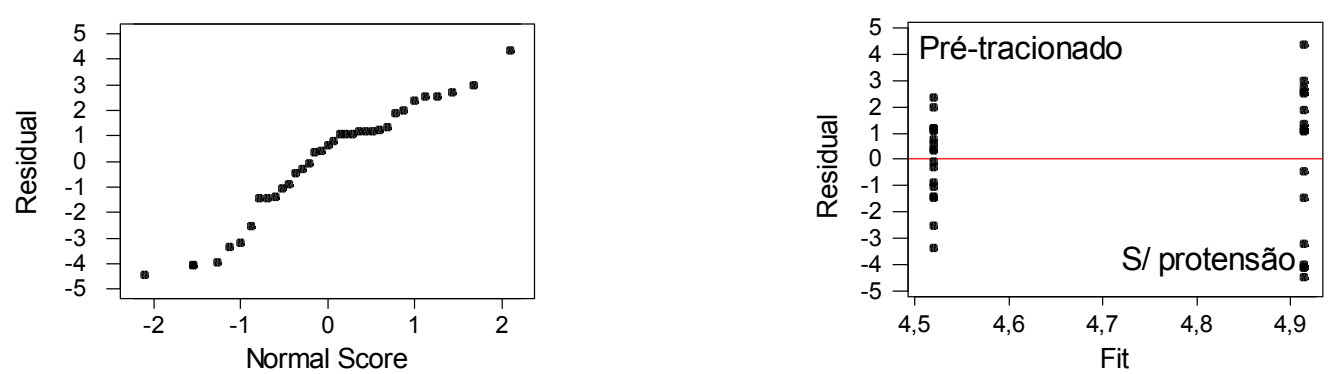

Figura E.104 - Análise de resíduos para $\mathrm{Y}_{1}=\tau_{\mathrm{b}, 1^{\mathrm{a}} \mathrm{fiss}}, \mathrm{V}_{\mathrm{f}}=40 \mathrm{~kg} / \mathrm{m}^{3}$ e a variável $\mathrm{X}_{3}$. 

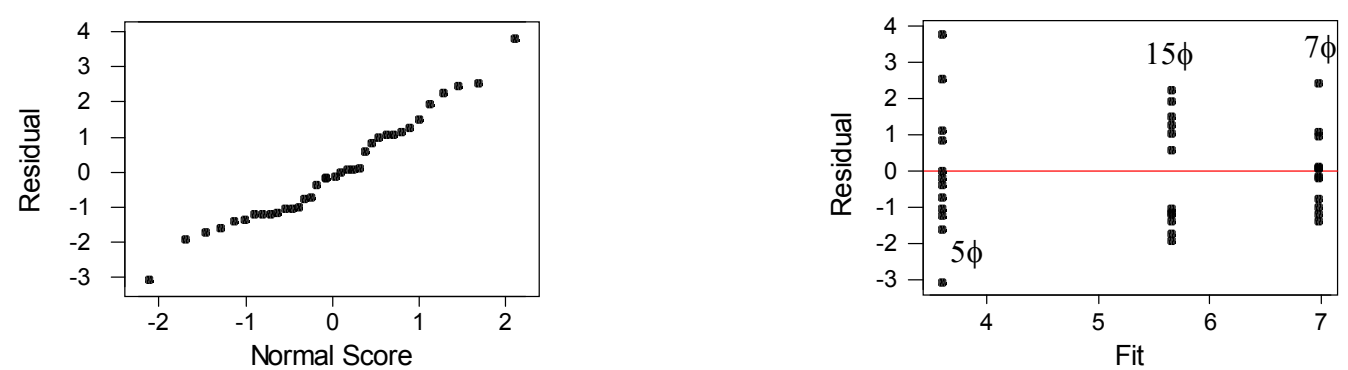

Figura E. 105 - Análise de resíduos para $\mathrm{Y}_{1}=\tau_{\mathrm{b}, 1^{\mathrm{a}} \mathrm{fiss}}, \mathrm{V}_{\mathrm{f}}=60 \mathrm{~kg} / \mathrm{m}^{3}$ e a variável $\mathrm{X}_{1}$.
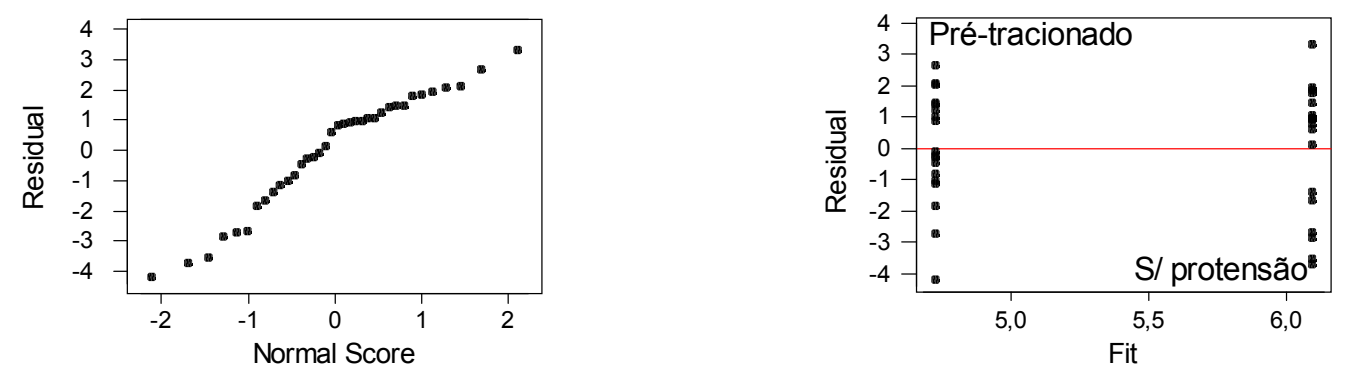

Figura E.106 - Análise de resíduos para $Y_{1}=\tau_{\mathrm{b}, 1^{\mathrm{a} i s s}}, \mathrm{~V}_{\mathrm{f}}=60 \mathrm{~kg} / \mathrm{m}^{3}$ e a variável $X_{3}$.

De maneira geral, percebe-se que os modelos com $\ell_{\mathrm{ef}}=7 \phi_{\mathrm{p}}$ apresentam os melhores resultados, independentemente do volume de fibra, porém para as peças com $\mathrm{V}_{\mathrm{f}}=0$ as diferenças não são significativas. Já para $V_{\mathrm{f}}=60 \mathrm{~kg} / \mathrm{m}^{3}$, apenas a diferença entre $\ell_{\mathrm{ef}}=7 \phi_{\mathrm{p}} \mathrm{e}$ $\ell_{\mathrm{ef}}=15 \phi_{\mathrm{p}}$ são significativas.

As peças sem protensão apresentaram resultados melhores que as pré-tracionadas, porém para as peças com $\mathrm{V}_{\mathrm{f}}=0$ as diferenças não são significativas. Já para $\mathrm{V}_{\mathrm{f}}=60 \mathrm{~kg} / \mathrm{m}^{3}$, a diferença é significativa.

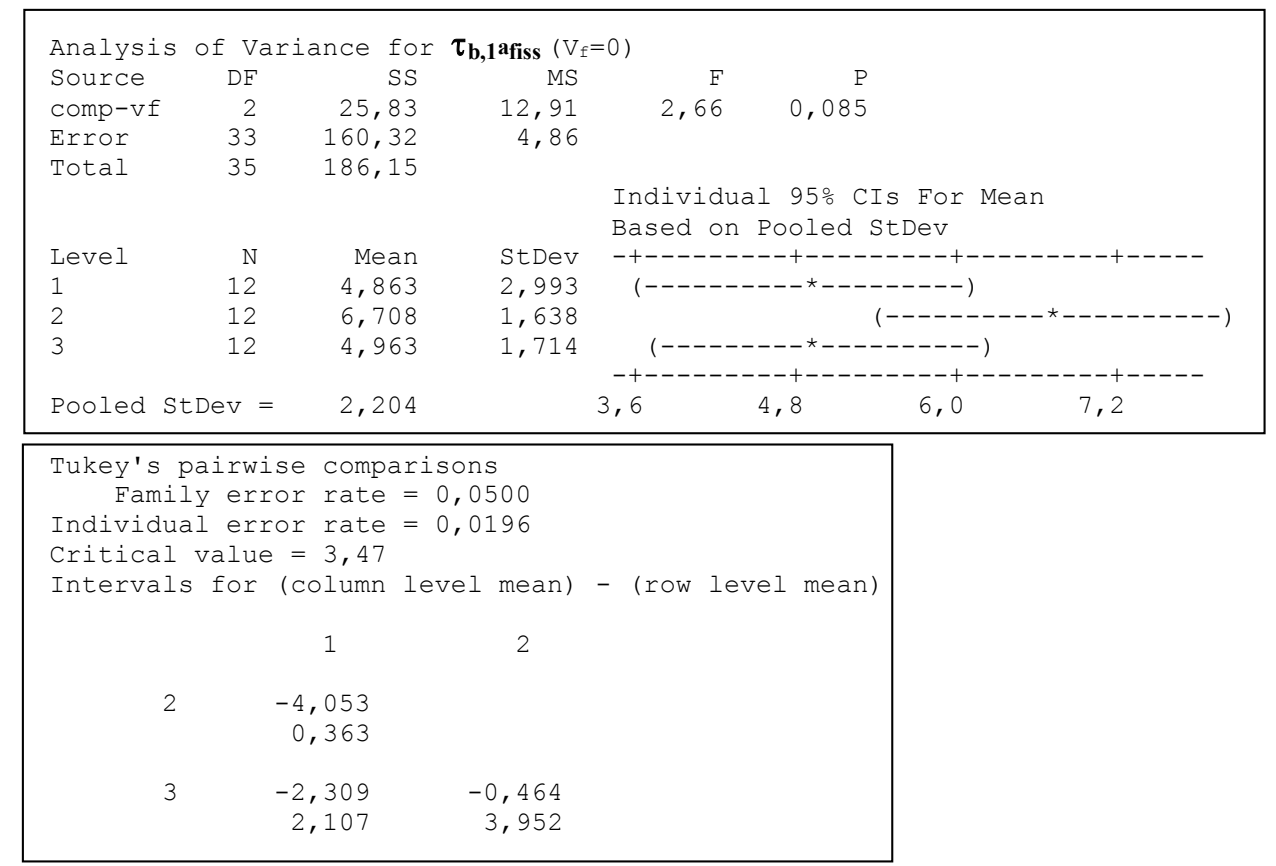

Figura E.107 - Tabela de análise de variância e teste de Tukey para $Y_{1}=\tau_{b, 1}{ }^{a}$ fiss,$V_{f}=0$ e $X_{1}$. 


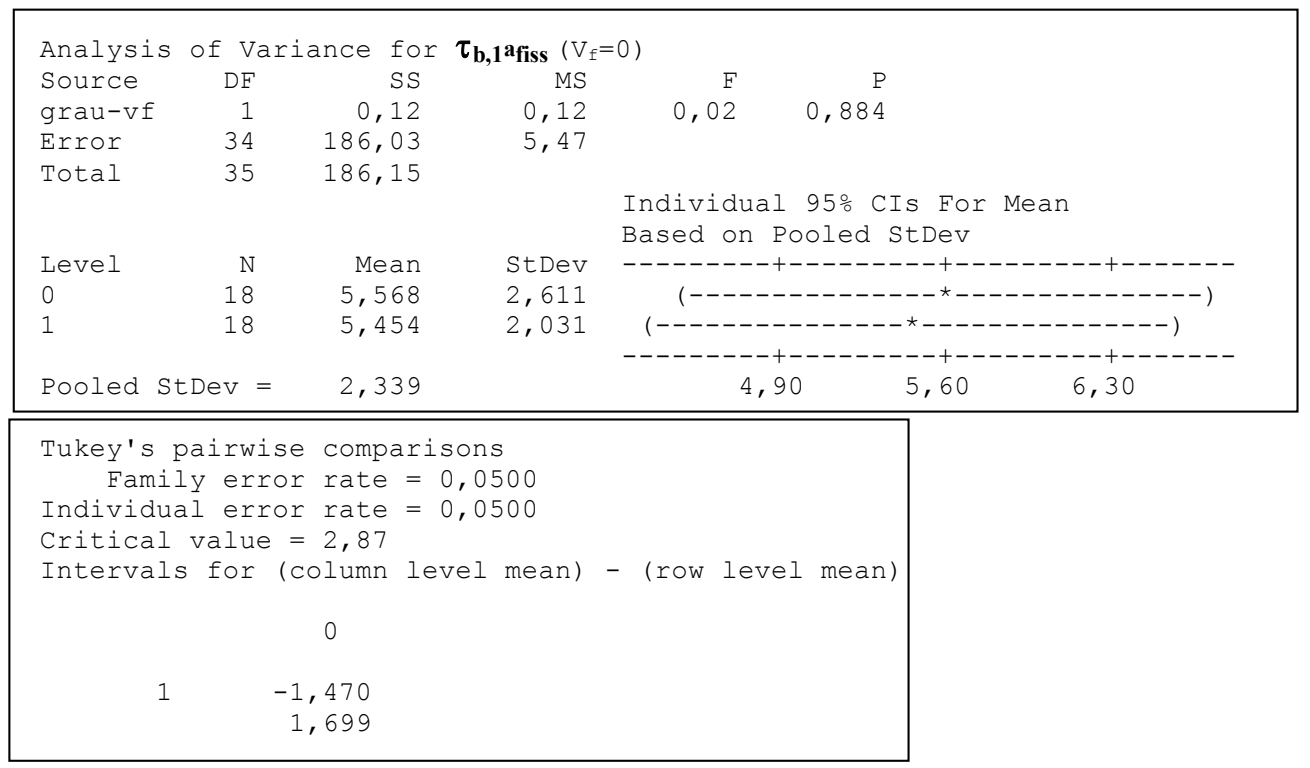

Figura E.108 - Tabela de análise de variância e teste de Tukey para $Y_{1}=\tau_{b, 1}{ }^{a}$ fiss,,$V_{f}=0$ e $X_{3}$.

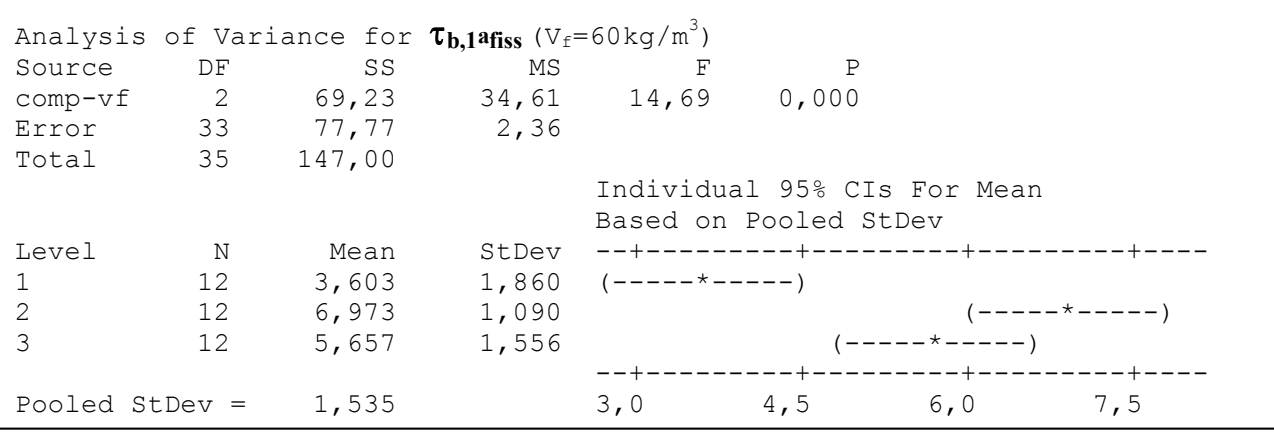

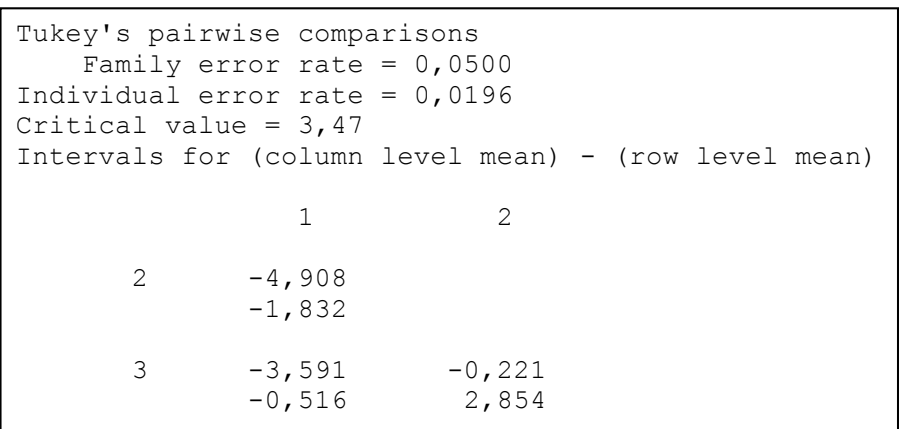

Figura E.109 - Tabela de análise de variância e teste de Tukey para $Y_{1}=\tau_{b, 1}{ }^{a f i s s}, V_{f}=60 \mathrm{~kg} / \mathrm{m}^{3}$ e $X_{1}$. 

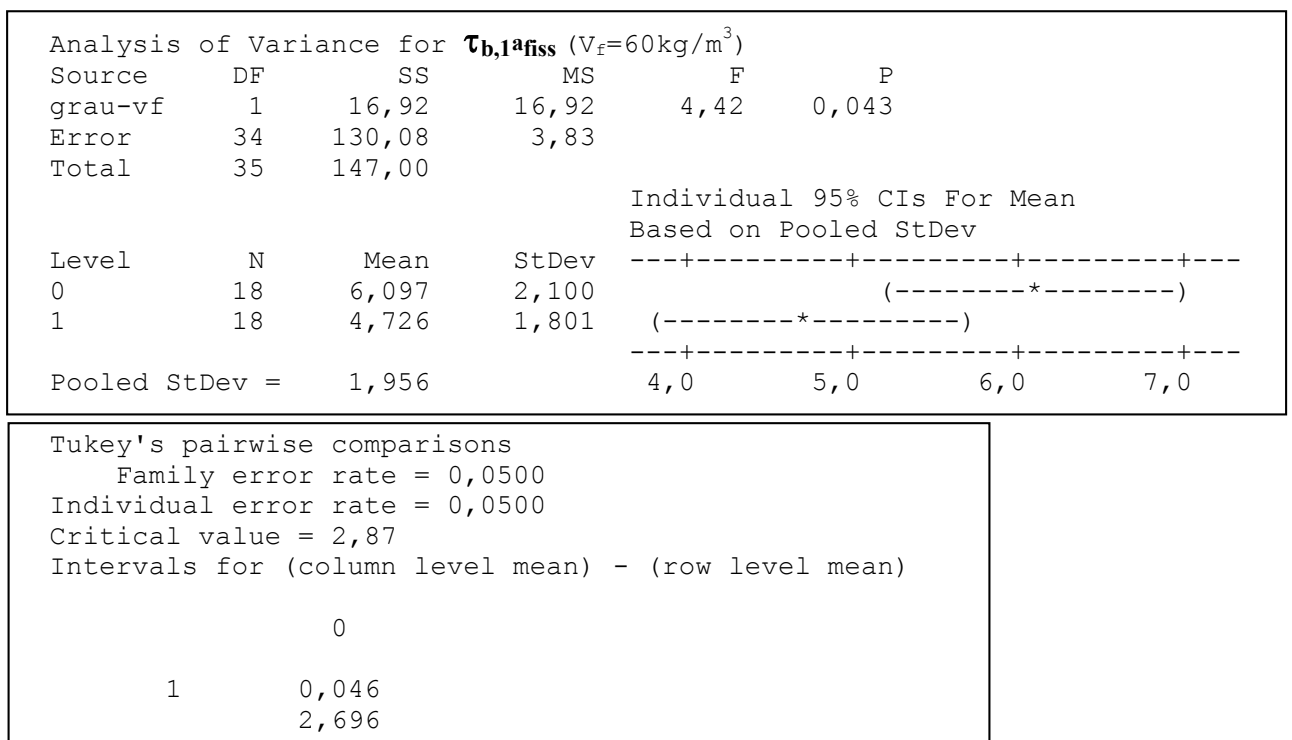

Figura E.110 - Tabela de análise de variância e teste de Tukey para $Y_{1}=\tau_{b, 1}{ }^{a}{ }_{\text {fiss }}, V_{f}=60 \mathrm{~kg} / \mathrm{m}^{3}$ e $X_{3}$.

\section{Variável resposta $Y_{2}=\tau_{b, 0.1}$}

A primeira análise a ser feita é a dos resíduos, para verificar-se se a amostra tem uma distribuição normal. As Figuras E.111 a E.116 apresentam os gráficos com plotagem dos resíduos para as variáveis $\mathrm{X}_{1}$ e $\mathrm{X}_{3}$, levando em conta os diferentes volumes de fibras de aço utilizados.

Para essas peças, apenas a amostra representada na Figura E.111 não apresenta bons resultados. Para as demais, montou-se a tabela de variância e o teste de Tukey. As Figuras E.117 a E.121 apresentam os resultados para as duas variáveis independentes analisadas.
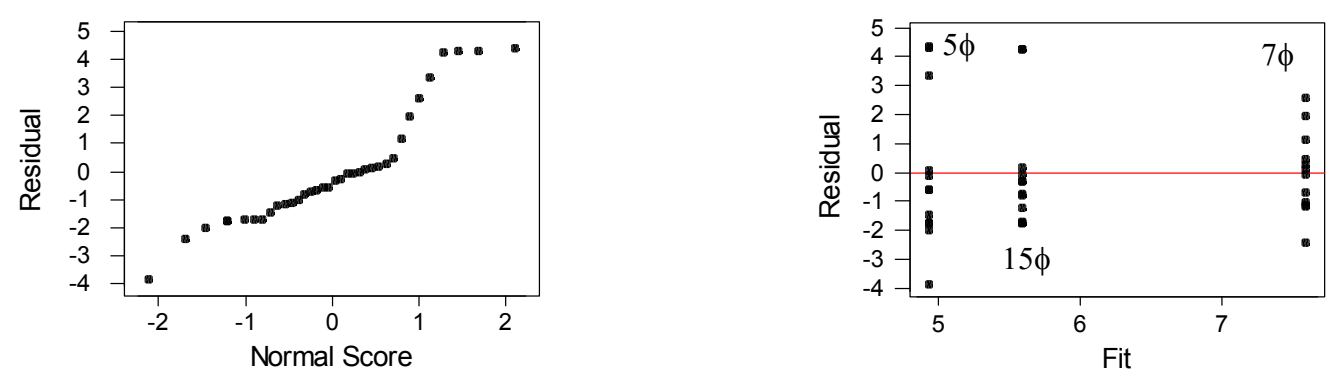

Figura E.111 - Análise de resíduos para $\mathrm{Y}_{2}=\tau_{\mathrm{b}, 0.1}, \mathrm{~V}_{\mathrm{f}}=0$ e a variável $\mathrm{X}_{1}$.
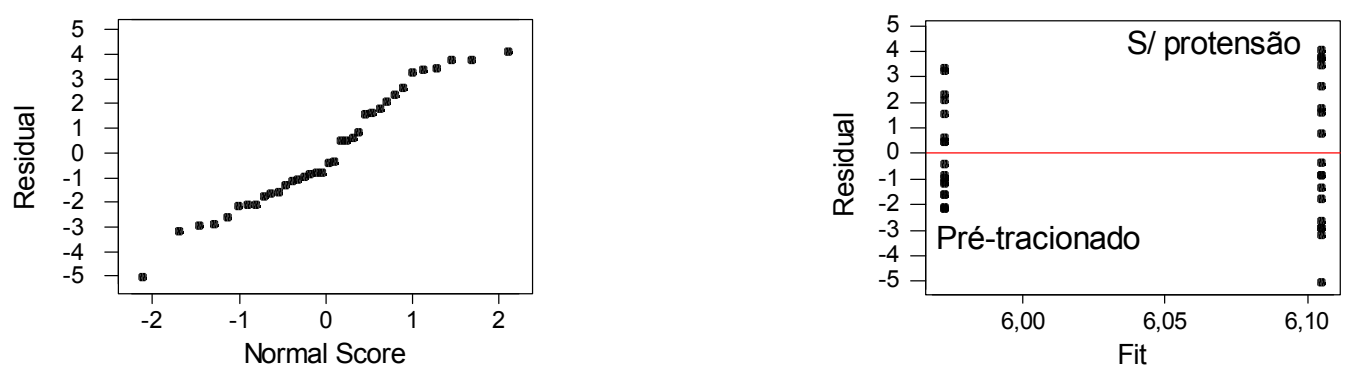

Figura E.112 - Análise de resíduos para $\mathrm{Y}_{2}=\tau_{\mathrm{b}, 0.1}, \mathrm{~V}_{\mathrm{f}}=0$ e a variável $\mathrm{X}_{3}$. 

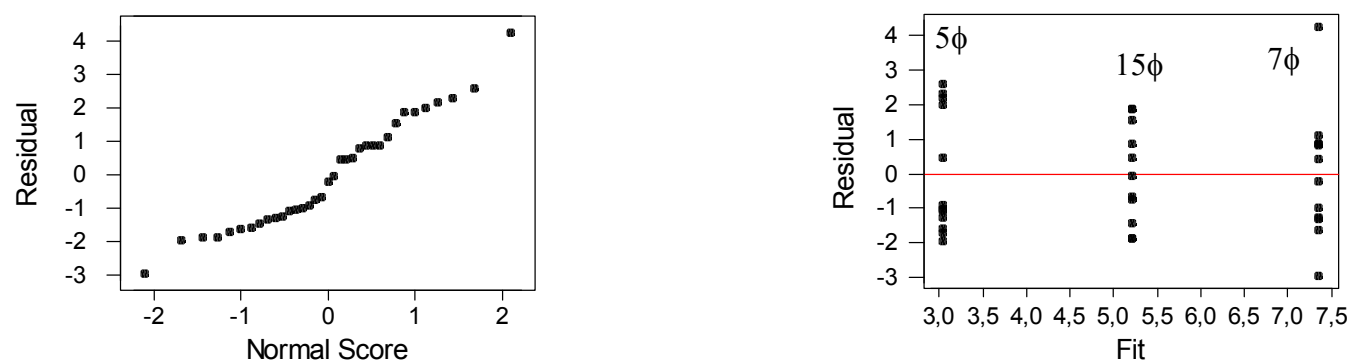

Figura E.113 - Análise de resíduos para $\mathrm{Y}_{2}=\tau_{\mathrm{b}, 0.1}, \mathrm{~V}_{\mathrm{f}}=40 \mathrm{~kg} / \mathrm{m}^{3}$ e a variável $\mathrm{X}_{1}$.
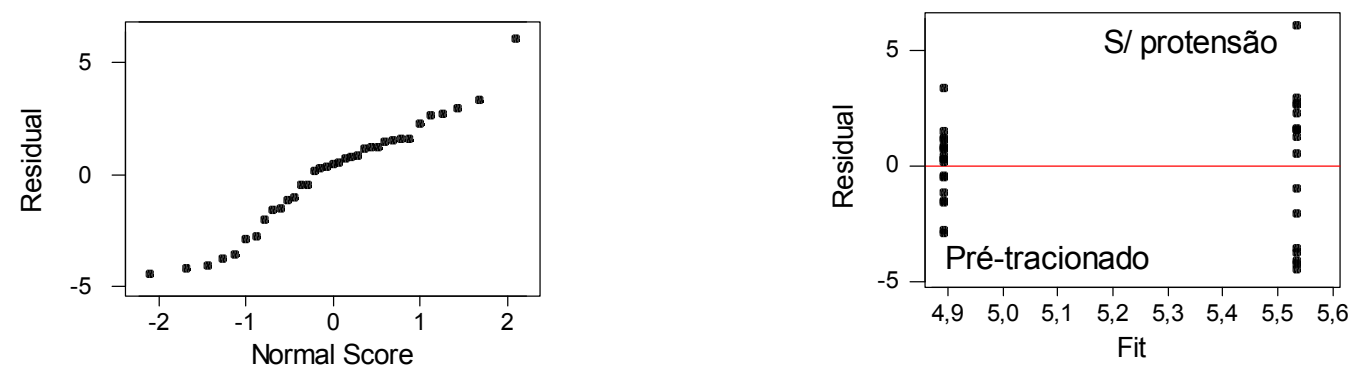

Figura E.114 - Análise de resíduos para $Y_{2}=\tau_{b, 0.1}, V_{f}=40 \mathrm{~kg} / \mathrm{m}^{3}$ e a variável $X_{3}$.
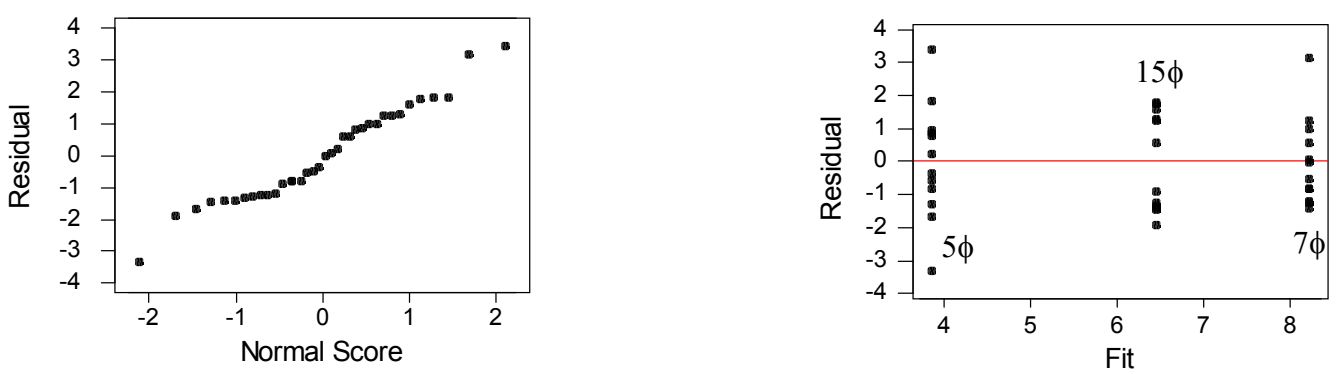

Figura E.115 - Análise de resíduos para $\mathrm{Y}_{2}=\tau_{\mathrm{b}, 0.1}, \mathrm{~V}_{\mathrm{f}}=60 \mathrm{~kg} / \mathrm{m}^{3}$ e a variável $\mathrm{X}_{1}$.
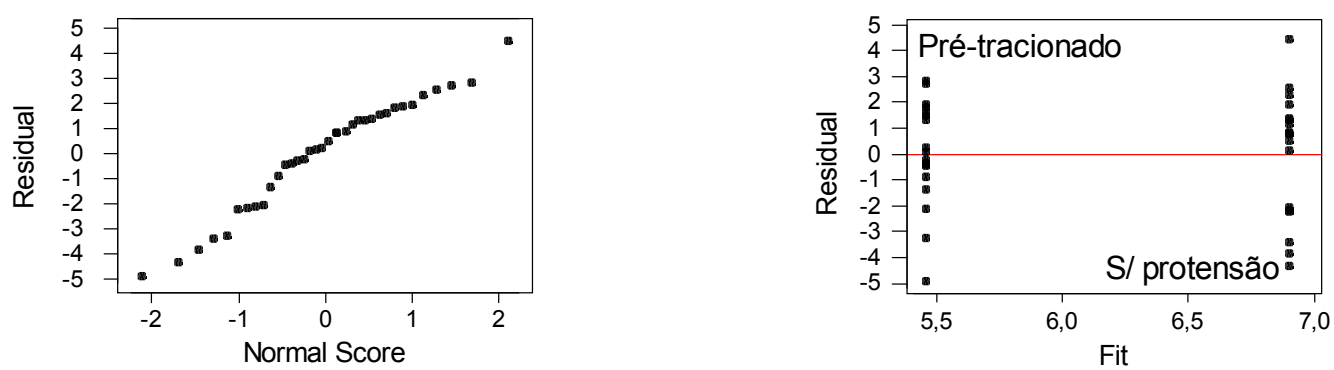

Figura E.116 - Análise de resíduos para $\mathrm{Y}_{2}=\tau_{\mathrm{b}, 0.1}, \mathrm{~V}_{\mathrm{f}}=60 \mathrm{~kg} / \mathrm{m}^{3}$ e a variável $\mathrm{X}_{3}$.

De maneira gera,1 percebe-se que para os três volumes de fibra, os modelos sem protensão apresentam, resultados melhores que os pré-tracionados, porém as diferenças não são significativas.

Tanto para $\mathrm{V}_{\mathrm{f}}=40 \mathrm{~kg} / \mathrm{m}^{3}$ como para $\mathrm{V}_{\mathrm{f}}=60 \mathrm{~kg} / \mathrm{m}^{3}$, os modelos com $\ell_{\mathrm{ef}}=5 \phi_{\mathrm{p}}$ apresentaram os piores resultados e os modelos com $\ell_{\mathrm{ef}}=7 \phi_{\mathrm{p}}$ apresentaram os melhores. As diferenças entre os resultados foram significativas. 


\begin{tabular}{|c|c|c|c|c|}
\hline \multicolumn{5}{|c|}{ Analysis of Variance for $\tau_{\mathbf{b}, \mathbf{0}}$} \\
\hline Source & $\mathrm{DF}$ & SS & MS & F \\
\hline grau-vf & 1 & 0,16 & 0,16 & 0,869 \\
\hline Error & 34 & 194,64 & 5,72 & \\
\hline \multirow[t]{2}{*}{ Total } & 35 & 194,79 & & \\
\hline & & & & $\begin{array}{l}\text { Individual 95\% CIs For Mean } \\
\text { Based on Pooled StDev }\end{array}$ \\
\hline Level & $\mathrm{N}$ & Mean & StDev & --+---------+---------+---------+---- \\
\hline 0 & 18 & 6,105 & 2,834 & $(---------------\star----------------)$ \\
\hline 1 & 18 & 5,972 & 1,849 & $(----------------\star *-----------------)$ \\
\hline Pooled & StDev $=$ & 2,393 & & 6,30 \\
\hline
\end{tabular}

Tukey's pairwise comparisons
Family error rate $=0,0500$

Family error rate $=0,0500$

Individual error rate $=0,0500$

Critical value $=2,87$

Intervals for (column level mean) - (row level mean)

0

$1-1,488$

1,754

Figura E.117 - Tabela de análise de variância e teste de Tukey para $\mathrm{Y}_{2}=\tau_{\mathrm{b}, 0.1}, \mathrm{~V}_{\mathrm{f}}=0$ e $\mathrm{X}_{3}$.

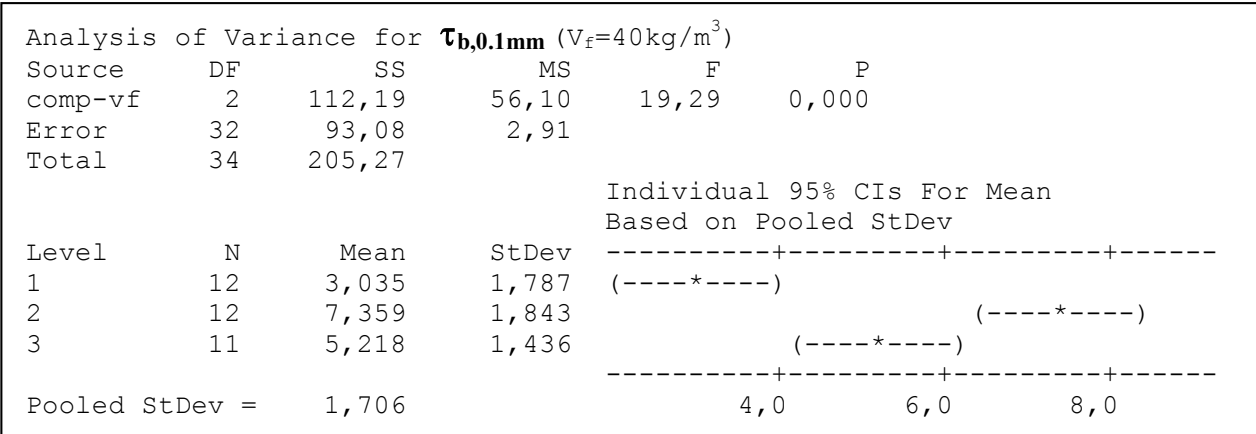

Tukey's pairwise comparisons

Family error rate $=0,0500$

Individual error rate $=0,0194$

Critical value $=3,48$

Intervals for (column level mean) - (row level mean)

1

2

$2-6,038$

$-2,611$

$3-3,935$

0,389

$-0,431$

3,893

Figura E.118 - Tabela de análise de variância e teste de Tukey para $Y_{2}=\tau_{\mathrm{b}, 0.1}, V_{\mathrm{f}}=40 \mathrm{~kg} / \mathrm{m}^{3}$ e $X_{1}$. 


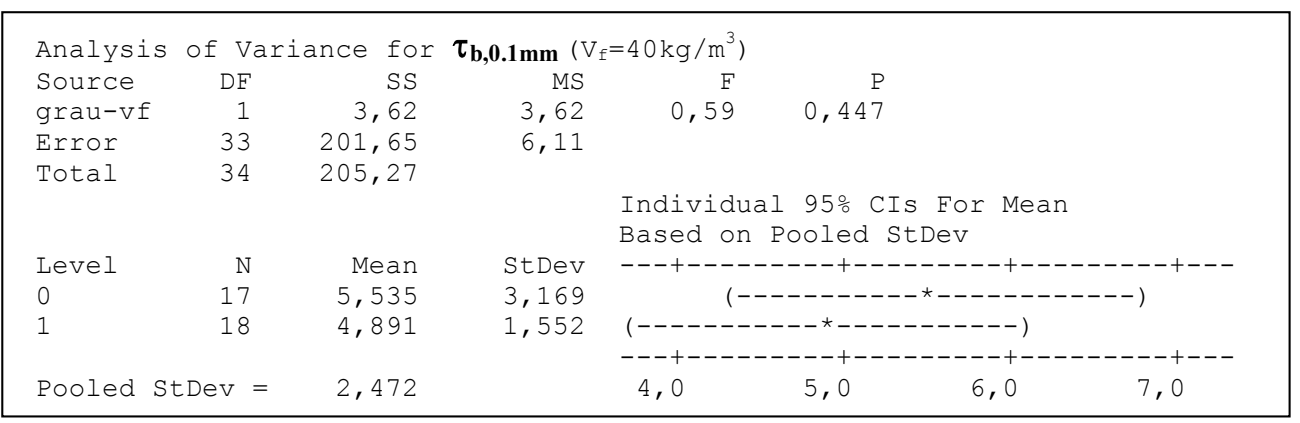

Tukey's pairwise comparisons

Family error rate $=0,0500$

Individual error rate $=0,0500$

Critical value $=2,88$

Intervals for (column level mean) - (row level mean)

0

$$
\begin{array}{rr}
1 & -1,057 \\
2, & 344
\end{array}
$$

Figura E.119 - Tabela de análise de variância e teste de Tukey para $Y_{2}=\tau_{b, 0.1}, V_{\mathrm{f}}=40 \mathrm{~kg} / \mathrm{m}^{3}$ e $X_{3}$.

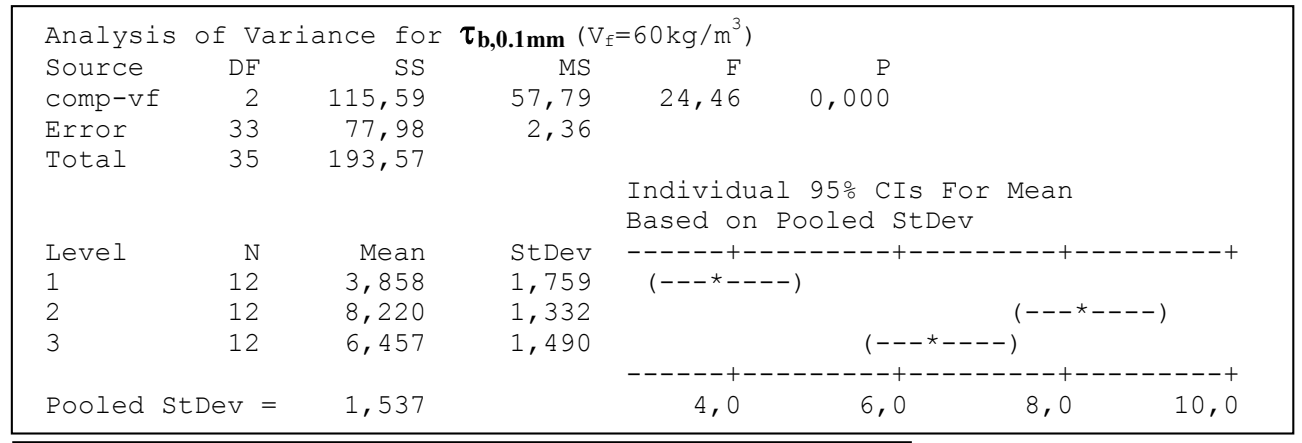

Tukey's pairwise comparisons

Family error rate $=0,0500$

Individual error rate $=0,0196$

Critical value $=3,47$

Intervals for (column level mean) - (row level mean)

12

$2-5,902$

$-2,823$

$3-4,139 \quad 0,223$

$-1,059 \quad 3,303$

Figura E.120 - Tabela de análise de variância e teste de Tukey para $Y_{2}=\tau_{b, 0.1}, V_{f}=60 \mathrm{~kg} / \mathrm{m}^{3}$ e $X_{1}$. 

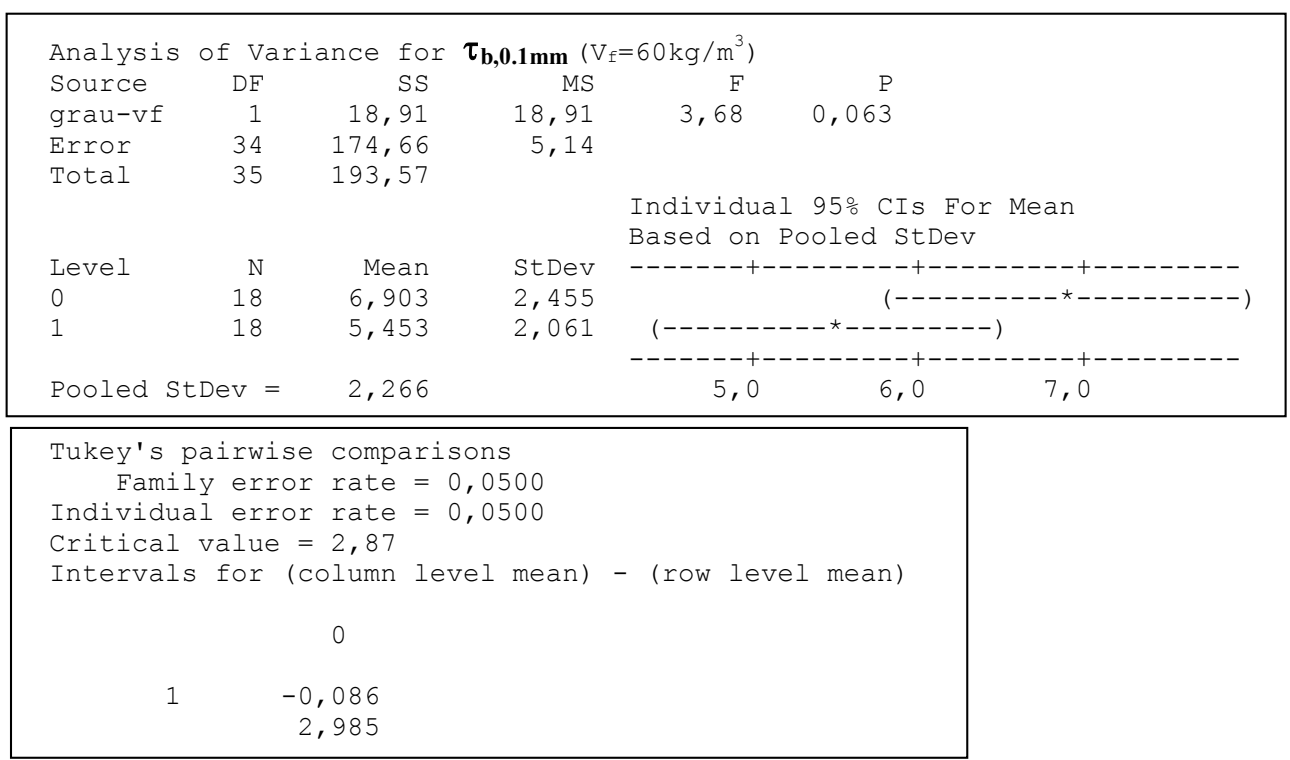

Figura E.121 - Tabela de análise de variância e teste de Tukey para $Y_{2}=\tau_{b, 0.1}, V_{f}=60 \mathrm{~kg} / \mathrm{m}^{3}$ e $X_{3}$.

\section{Variável resposta $Y_{3}=\tau_{b, 1}$}

A primeira análise a ser feita é a dos resíduos, para verificar-se se a amostra tem uma distribuição normal. As Figuras E.122 a E.127 apresentam os gráficos com plotagem dos resíduos para as variáveis $\mathrm{X}_{1}$ e $\mathrm{X}_{3}$, levando em conta os diferentes volumes de fibras de aço utilizados.

Após a verificação dos resíduos, constatado que as amostras apresentam distribuição normal, pôde-se montar a tabela de variância dos resultados e o teste de Tukey. As Figuras E.128 a E.133 apresentam os resultados para as duas variáveis independentes analisadas.
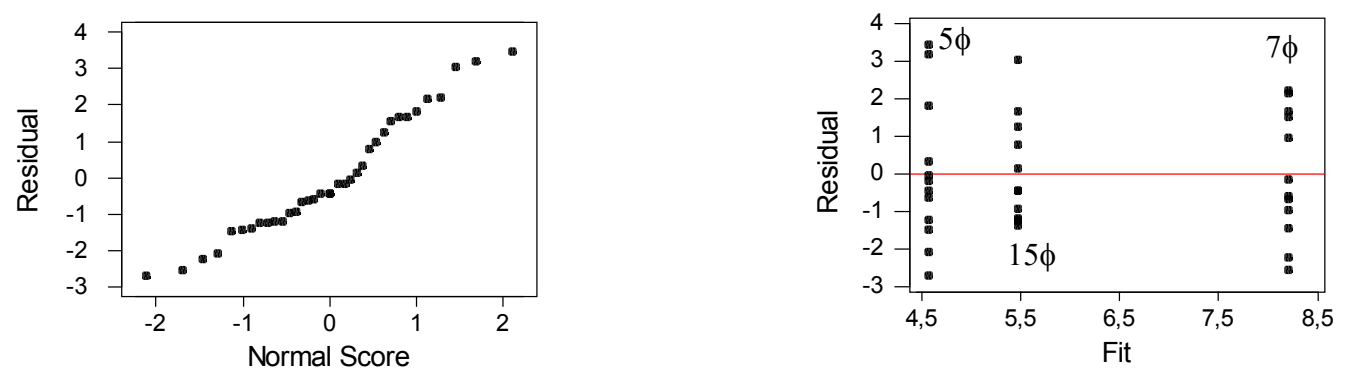

Figura E.122 - Análise de resíduos para $\mathrm{Y}_{3}=\tau_{\mathrm{b}, 1}, \mathrm{~V}_{\mathrm{f}}=0$ e a variável $\mathrm{X}_{1}$.
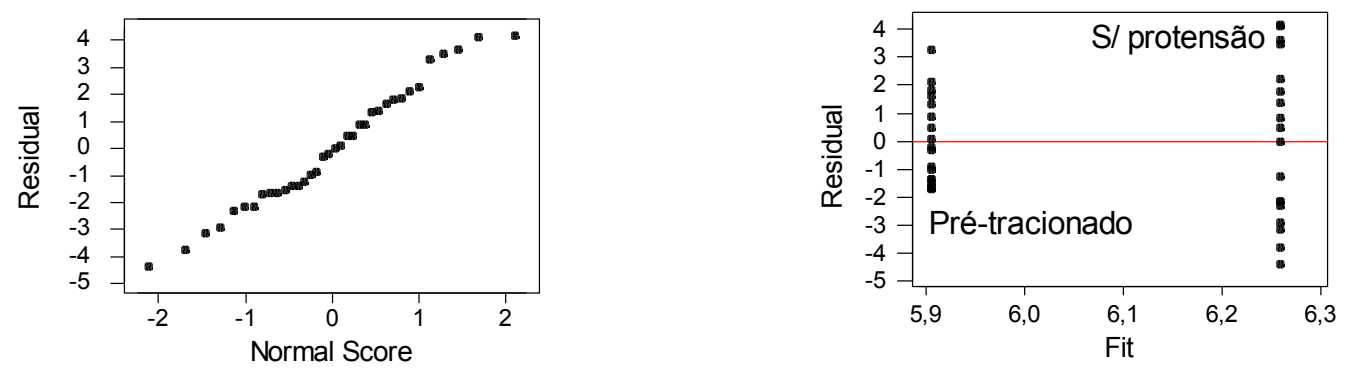

Figura E.123 - Análise de resíduos para $\mathrm{Y}_{3}=\tau_{\mathrm{b}, 1}, \mathrm{~V}_{\mathrm{f}}=0$ e a variável $\mathrm{X}_{3}$. 

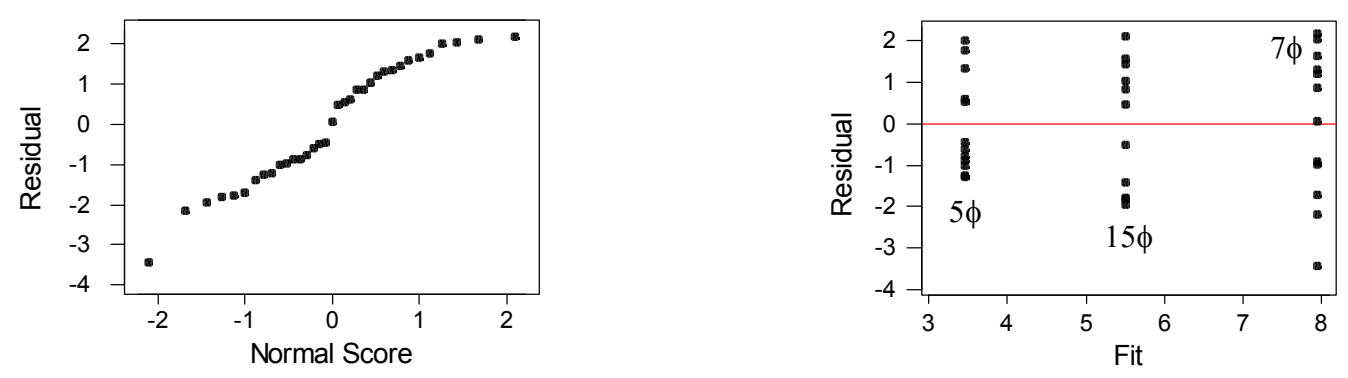

Figura E.124 - Análise de resíduos para $\mathrm{Y}_{3}=\tau_{\mathrm{b}, 1}, \mathrm{~V}_{\mathrm{f}}=40 \mathrm{~kg} / \mathrm{m}^{3}$ e a variável $\mathrm{X}_{1}$.
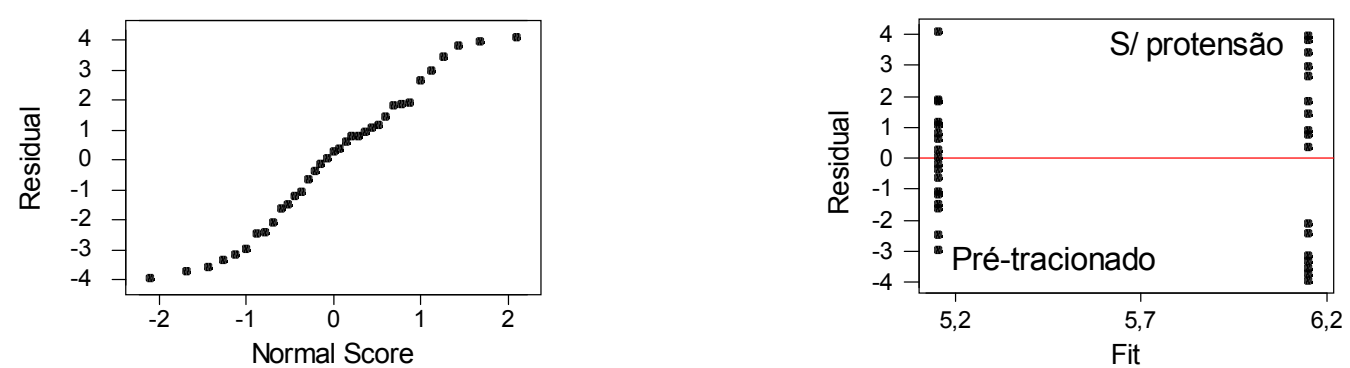

Figura E.125 - Análise de resíduos para $\mathrm{Y}_{3}=\tau_{\mathrm{b}, 1}, \mathrm{~V}_{\mathrm{f}}=40 \mathrm{~kg} / \mathrm{m}^{3}$ e a variável $\mathrm{X}_{3}$.
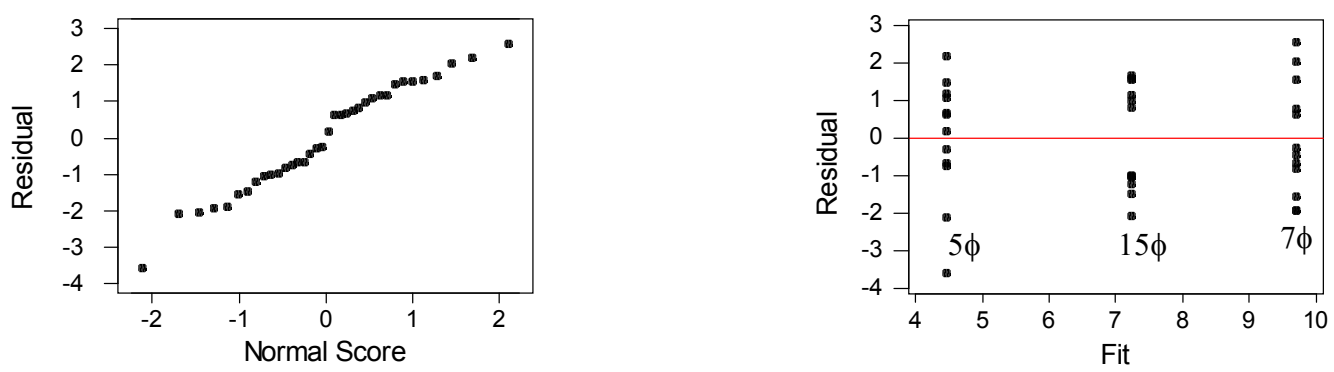

Figura E.126 - Análise de resíduos para $\mathrm{Y}_{3}=\tau_{\mathrm{b}, 1}, \mathrm{~V}_{\mathrm{f}}=60 \mathrm{~kg} / \mathrm{m}^{3}$ e a variável $\mathrm{X}_{1}$.
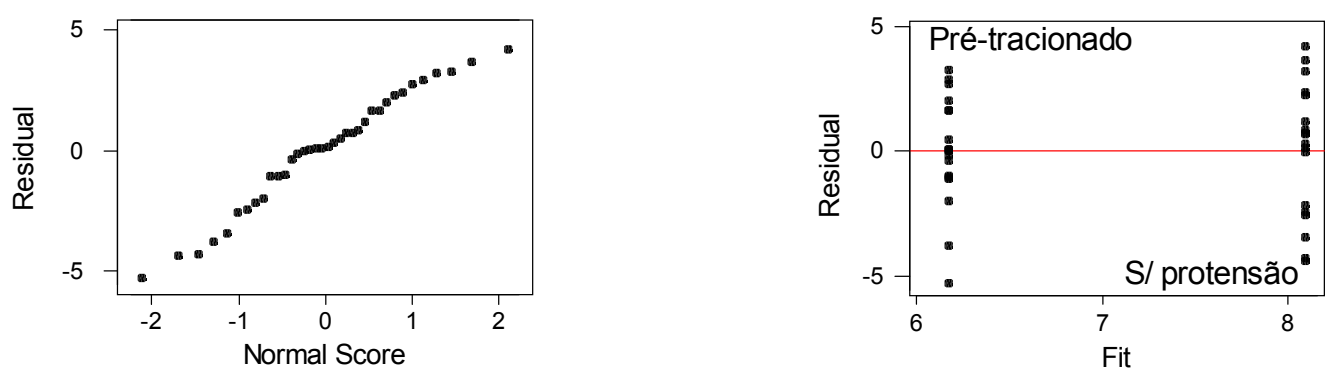

Figura E.127 - Análise de resíduos para $\mathrm{Y}_{3}=\tau_{\mathrm{b}, 1}, \mathrm{~V}_{\mathrm{f}}=60 \mathrm{~kg} / \mathrm{m}^{3}$ e a variável $\mathrm{X}_{3}$.

De maneira geral, percebe-se que os modelos com $\ell_{\mathrm{ef}}=7 \phi_{\mathrm{p}}$ apresentam os melhores resultados, independentemente do volume de fibra, porém para as peças com $V_{\mathrm{f}}=0$ as diferenças entre $\ell_{\mathrm{ef}}=5 \phi_{\mathrm{p}}$ e $\ell_{\mathrm{ef}}=15 \phi_{\mathrm{p}}$ não são significativas. Para todas as outras as diferenças são significativas.

As peças sem protensão apresentaram resultados melhores que as pré-tracionadas, porém para as peças com $\mathrm{V}_{\mathrm{f}}=0$ e $\mathrm{V}_{\mathrm{f}}=40 \mathrm{~kg} / \mathrm{m}^{3}$ as diferenças não são significativas. Já para $\mathrm{V}_{\mathrm{f}}=60 \mathrm{~kg} / \mathrm{m}^{3}$, a diferença é significativa. 


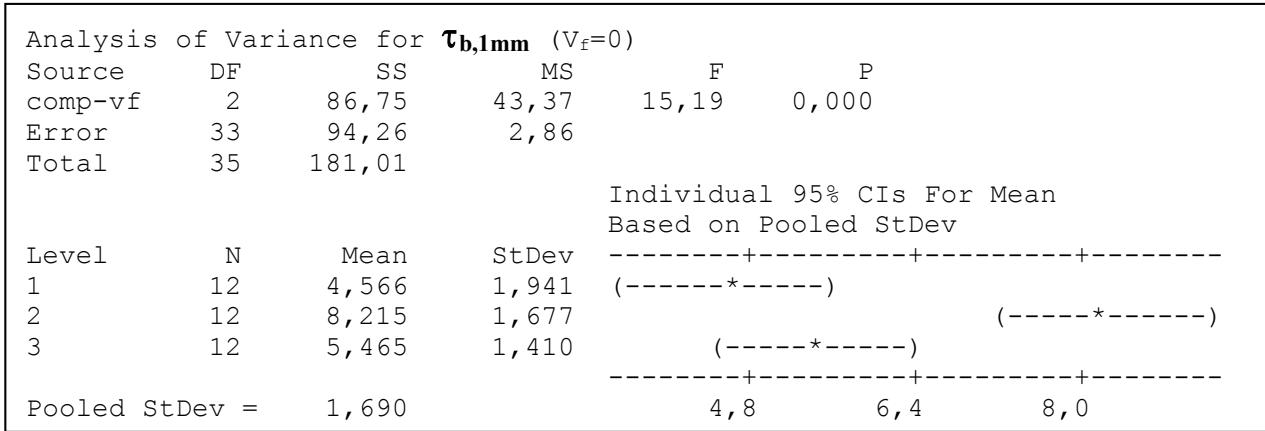

Tukey's pairwise comparisons

Family error rate $=0,0500$

Individual error rate $=0,0196$

Critical value $=3,47$

Intervals for (column level mean) - (row level mean)

$$
\begin{array}{ccc} 
& 1 & 2 \\
2 & -5,342 & \\
& -1,956 & \\
& & \\
3 & -2,592 & 1,057 \\
& 0,794 & 4,443
\end{array}
$$

Figura E.128 - Tabela de análise de variância e teste de Tukey para $Y_{3}=\tau_{b, 1}, V_{f}=0$ e $X_{1}$.

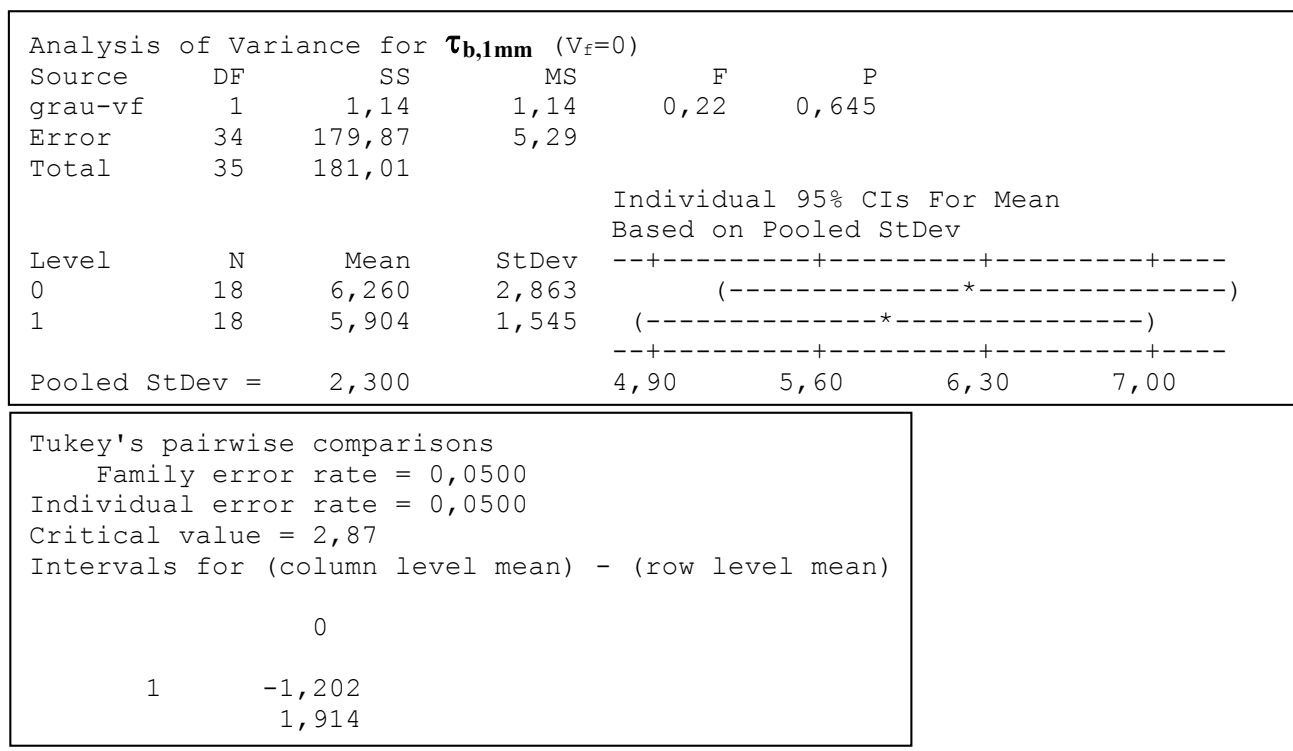

Figura E.129 - Tabela de análise de variância e teste de Tukey para $\mathrm{Y}_{3}=\tau_{\mathrm{b}, 1}, \mathrm{~V}_{\mathrm{f}}=0$ e $\mathrm{X}_{3}$. 


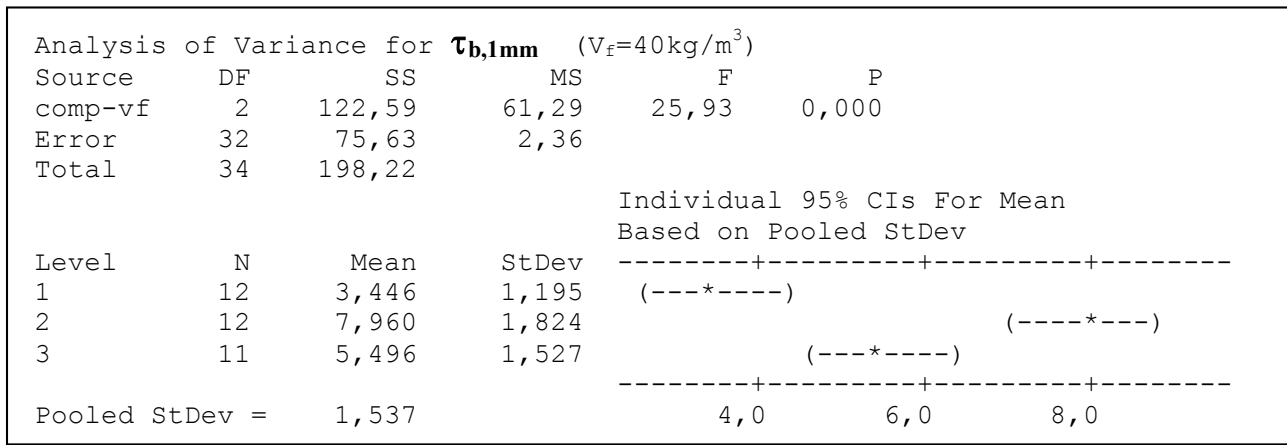

\begin{tabular}{|c|}
\hline Tukey's pairwise comparisons \\
Family error rate $=0,0500$ \\
Individual error rate = 0,0194 \\
Critical value $=3,48$ \\
Intervals for (column level mean) - (row level mean) \\
$\begin{array}{c}1 \\
2 \\
-6,059\end{array}$ \\
$-2,970$ \\
$-3,630$ \\
$-0,471$
\end{tabular}

Figura E.130 - Tabela de análise de variância e teste de Tukey para $\mathrm{Y}_{3}=\tau_{\mathrm{b}, 1}, \mathrm{~V}_{\mathrm{f}}=40 \mathrm{~kg} / \mathrm{m}^{3}$ e $\mathrm{X}_{1}$.

\begin{tabular}{|c|c|c|c|c|}
\hline \multicolumn{5}{|c|}{ 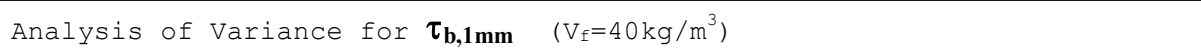 } \\
\hline Source & $\mathrm{DF}$ & SS & MS & $\mathrm{F}$ \\
\hline grau-vf & 1 & 8,77 & 8,77 & 0,225 \\
\hline Error & 33 & 189,46 & 5,74 & \\
\hline \multirow[t]{2}{*}{ Total } & 34 & 198,22 & & \\
\hline & & & & $\begin{array}{l}\text { Individual 95\% CIs For Mean } \\
\text { Based on Pooled StDev }\end{array}$ \\
\hline Level & $\mathrm{N}$ & Mean & StDev & ----------+---------+---------+------ \\
\hline 0 & 17 & 6,153 & 2,949 & $(-----------\star----------)$ \\
\hline 1 & 18 & 5,152 & 1,720 & $(-----------\star----------)$ \\
\hline Pooled S & StDev $=$ & 2,396 & & 7,0 \\
\hline
\end{tabular}

\begin{tabular}{|l}
\hline Tukey's pairwise comparisons \\
Family error rate $=0,0500$ \\
Individual error rate $=0,0500$ \\
Critical value $=2,88$ \\
Intervals for (column level mean) - (row level mean) \\
0 \\
1 \\
$-0,647$ \\
2,650
\end{tabular}

Figura E.131 - Tabela de análise de variância e teste de Tukey para $\mathrm{Y}_{3}=\tau_{\mathrm{b}, 1}, \mathrm{~V}_{\mathrm{f}}=40 \mathrm{~kg} / \mathrm{m}^{3}$ e $\mathrm{X}_{3}$. 


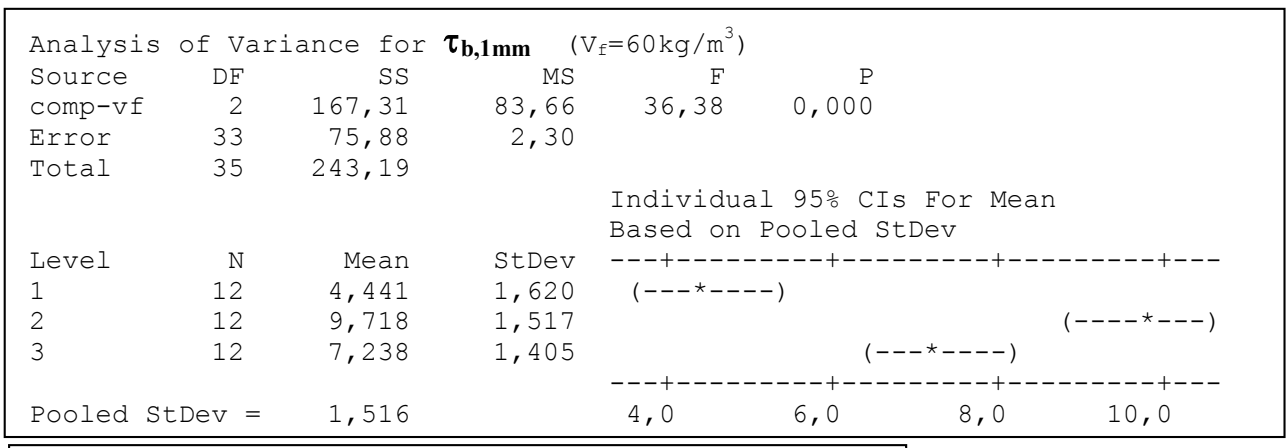

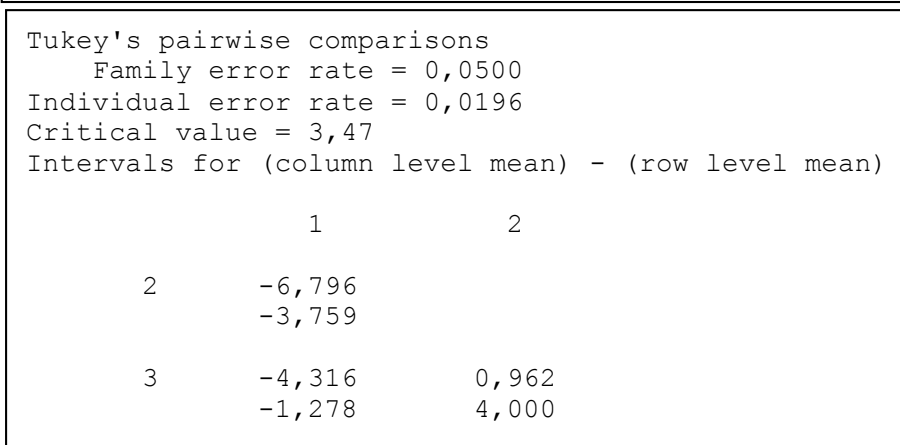

Figura E.132 - Tabela de análise de variância e teste de Tukey para $Y_{3}=\tau_{b, 1}, V_{\mathrm{f}}=60 \mathrm{~kg} / \mathrm{m}^{3}$ e $X_{1}$.

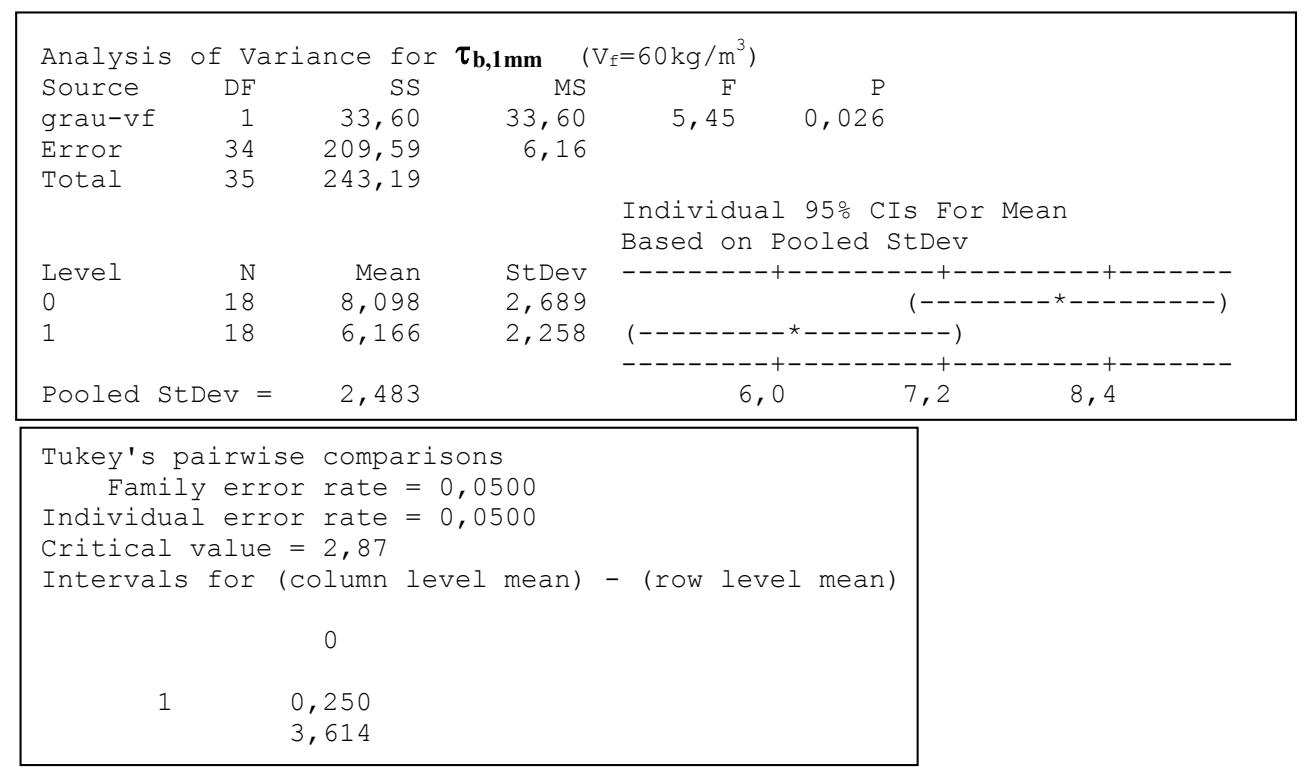

Figura E.133 - Tabela de análise de variância e teste de Tukey para $Y_{3}=\tau_{b, 1}, V_{f}=60 \mathrm{~kg} / \mathrm{m}^{3}$ e $X_{3}$.

\section{Variável resposta $Y_{4}=S_{\tau_{b, \text { máx }}}$}

A primeira análise a ser feita é a dos resíduos, para verificar-se se a amostra tem uma distribuição normal. As Figuras E.134 a E.139 apresentam os gráficos com plotagem dos resíduos para as variáveis $\mathrm{X}_{1}$ e $\mathrm{X}_{3}$, levando em conta os diferentes volumes de fibras de aço utilizados. 

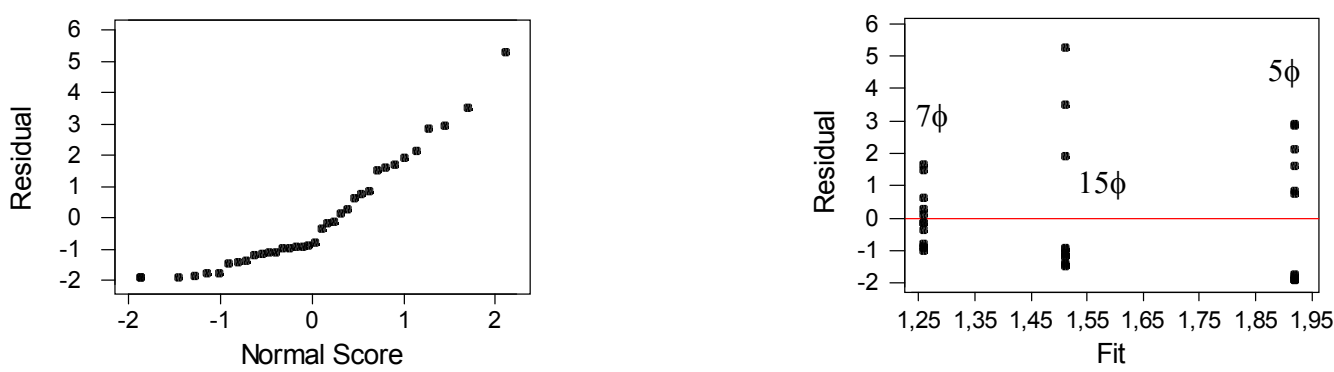

Figura E.134 - Análise de resíduos para $\mathrm{Y}_{4}=\mathrm{S}_{\tau_{\mathrm{b}, \text { máx }}}, \mathrm{V}_{\mathrm{f}}=0$ e a variável $\mathrm{X}_{1}$.
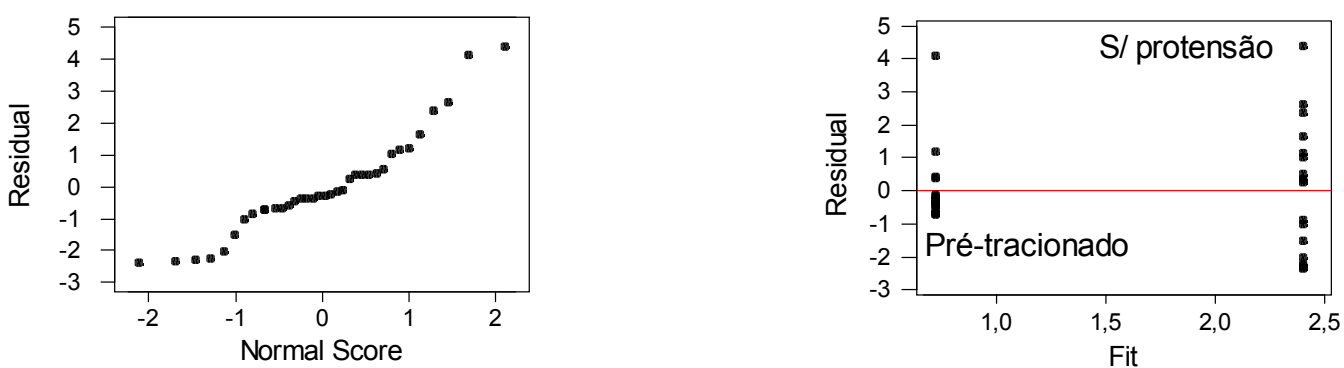

Figura E.135 - Análise de resíduos para $\mathrm{Y}_{4}=\mathrm{S}_{\tau_{\mathrm{b} \text {,máx }}}, \mathrm{V}_{\mathrm{f}}=0$ e a variável $\mathrm{X}_{3}$.
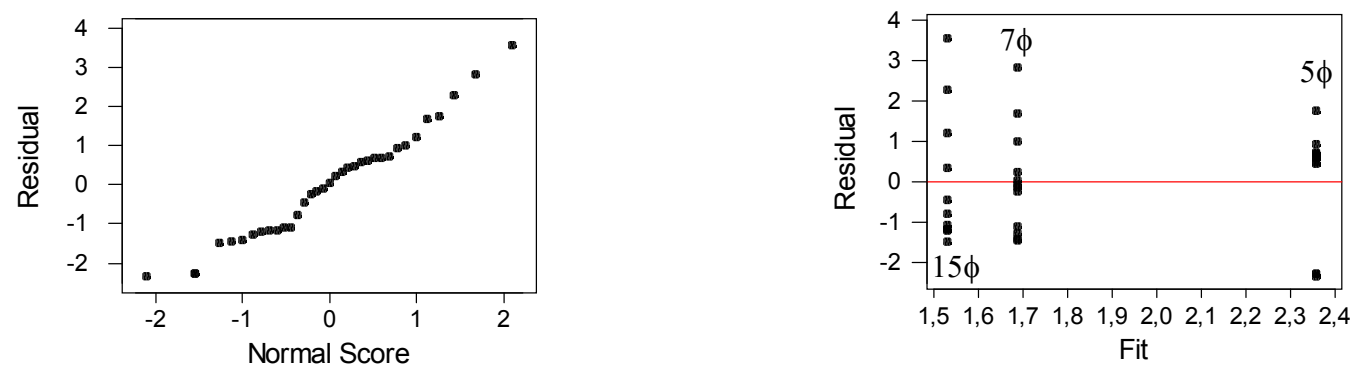

Figura E.136 - Análise de resíduos para $\mathrm{Y}_{4}=\mathrm{S}_{\tau_{\mathrm{b} \text {,máx }}}, \mathrm{V}_{\mathrm{f}}=40 \mathrm{~kg} / \mathrm{m}^{3}$ e a variável $\mathrm{X}_{1}$.
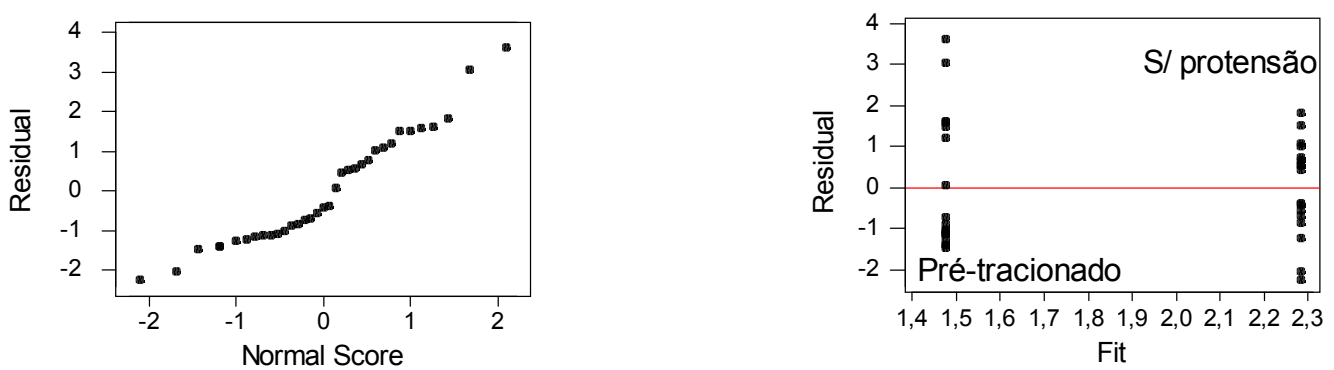

Figura E.137 - Análise de resíduos para $\mathrm{Y}_{4}=\mathrm{S}_{\tau_{\mathrm{b}, \text { máx }}}, \mathrm{V}_{\mathrm{f}}=40 \mathrm{~kg} / \mathrm{m}^{3}$ e a variável $\mathrm{X}_{3}$.
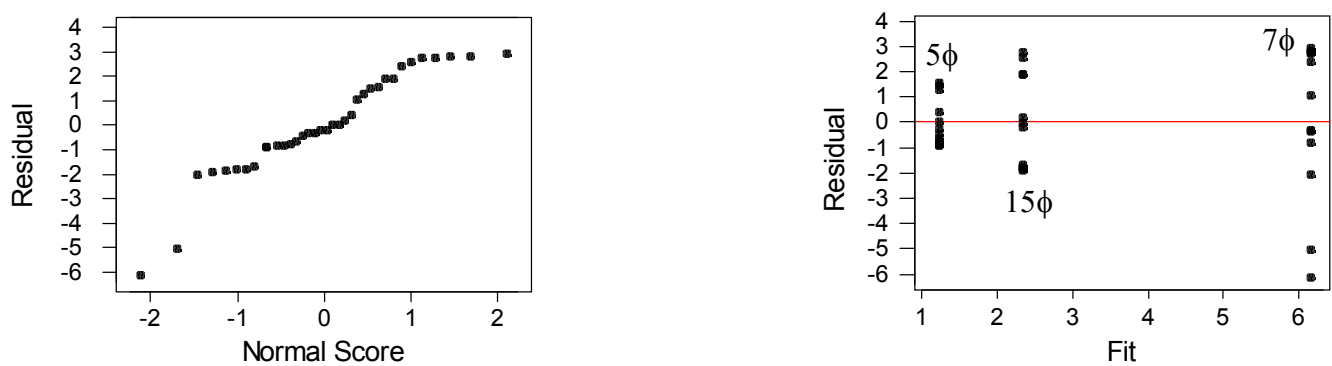

Figura E.138 - Análise de resíduos para $\mathrm{Y}_{4}=\mathrm{S}_{\tau_{\mathrm{b}, \text { máx }}}, \mathrm{V}_{\mathrm{f}}=60 \mathrm{~kg} / \mathrm{m}^{3}$ e a variável $\mathrm{X}_{1}$. 

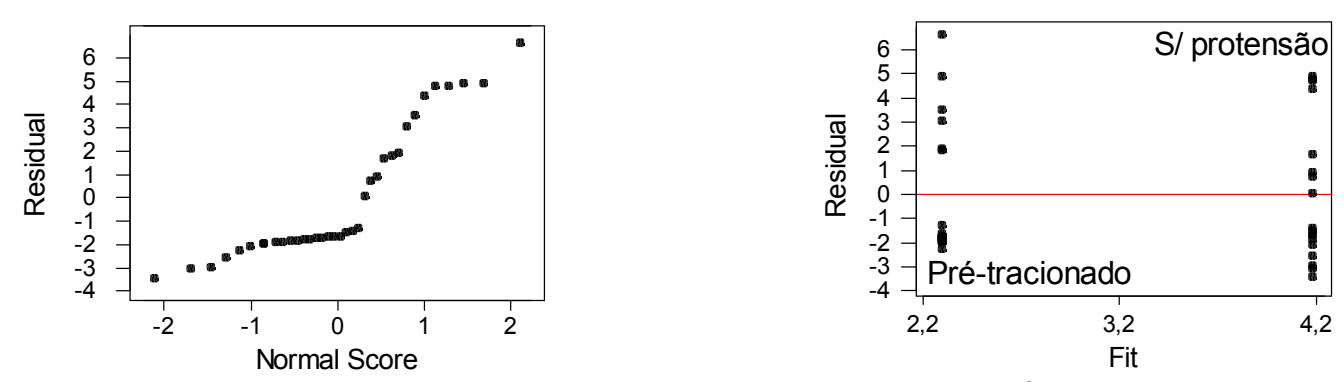

Figura E.139 - Análise de resíduos para $\mathrm{Y}_{4}=\mathrm{S}_{\tau} \mathrm{b \text {,máx }}, \mathrm{V}_{\mathrm{f}}=60 \mathrm{~kg} / \mathrm{m}^{3}$ e a variável $\mathrm{X}_{3}$.

Pelos diagramas, percebe-se que para todas as variáveis, nem a distribuição pode ser considerada normal e nem a variabilidade desses dados é boa. Para que se pudesse analisar melhor esses resultados, elaborando tabelas de variância, seria necessário fazer algum tipo de transformação de dados, do tipo logarítmica por exemplo, para que se obtivesse uma distribuição normal e uma variabilidade mais constante.

\section{d) Bloco 4}

Todos os dados foram avaliados duas vezes: (1) para $\mathrm{X}_{1}$, onde os 36 modelos de cada grupo foram divididos em três sub-grupos de 12, levando-se em conta os comprimentos aderentes; e (2) para $\mathrm{X}_{2}$, onde os 36 modelos de cada grupo foram divididos em três subgrupos de 12, levando-se em conta o volume de fibras. Ou seja, foram construídas duas Tabelas de Análise de Variância para cada variável resposta, cada tabela levando em conta uma variável independente. Para cada sub-grupo também foi feita a plotagem dos resíduos e a avaliação de Tukey, para um intervalo de confiança (CI) de 95\%.

\section{Variável resposta $Y=\tau_{b, \text { máx }}$}

A primeira análise a ser feita é a dos resíduos, para verificar-se se a amostra tem uma distribuição normal. As Figuras E.140 a E.143 apresentam os gráficos com plotagem dos resíduos para as variáveis $\mathrm{X}_{1}$ e $\mathrm{X}_{2}$, levando em conta os diferentes graus de protensão utilizados. Após a verificação dos resíduos, constatado que as amostras apresentam distribuição normal, pôde-se montar a tabela de variância e o teste de Tukey. As Figuras E.164 a E.54 apresentam os resultados para as duas variáveis independentes analisadas.
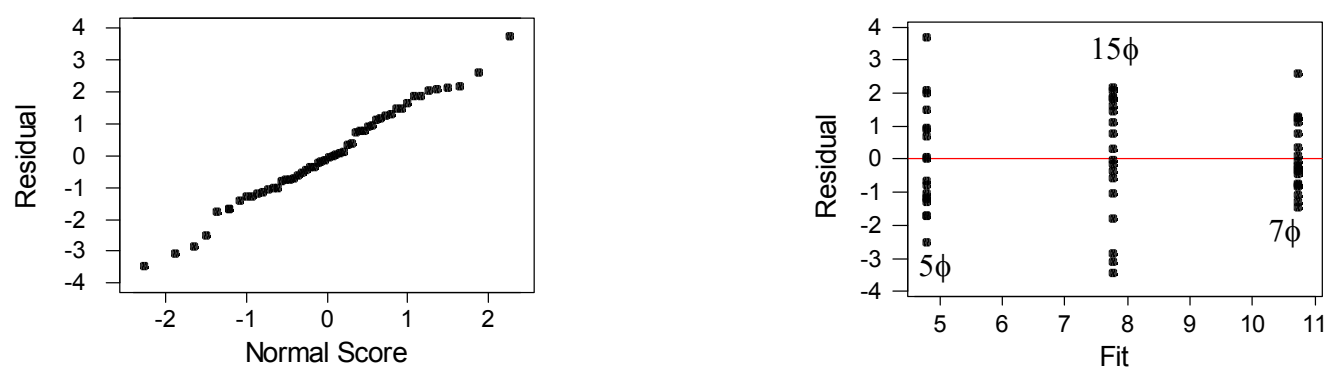

Figura E.140 - Análise de resíduos para $Y=\tau_{\mathrm{b} \text {,máx }}, \sigma_{\mathrm{p}}=0$ e a variável $\mathrm{X}_{1}$. 

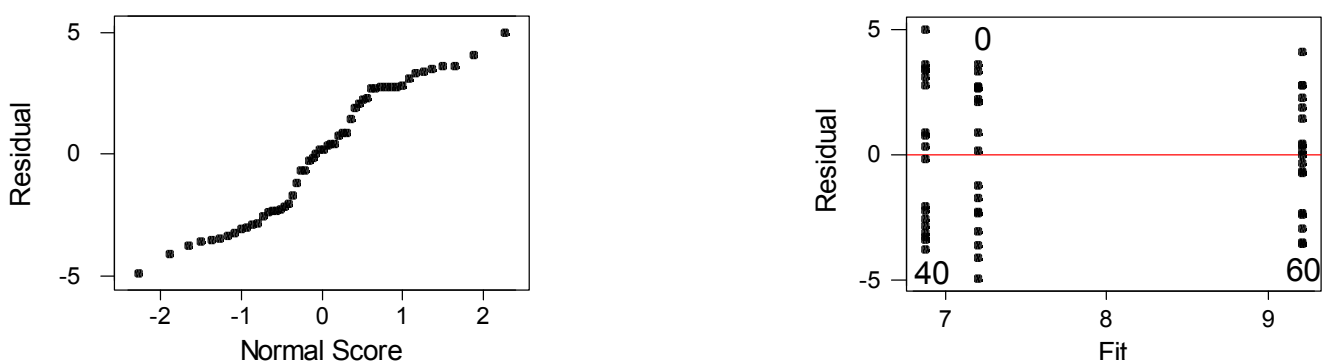

Figura E.141 - Análise de resíduos para $\mathrm{Y}=\tau_{\mathrm{b} \text {,máx }}, \sigma_{\mathrm{p}}=0$ e a variável $\mathrm{X}_{2}$.
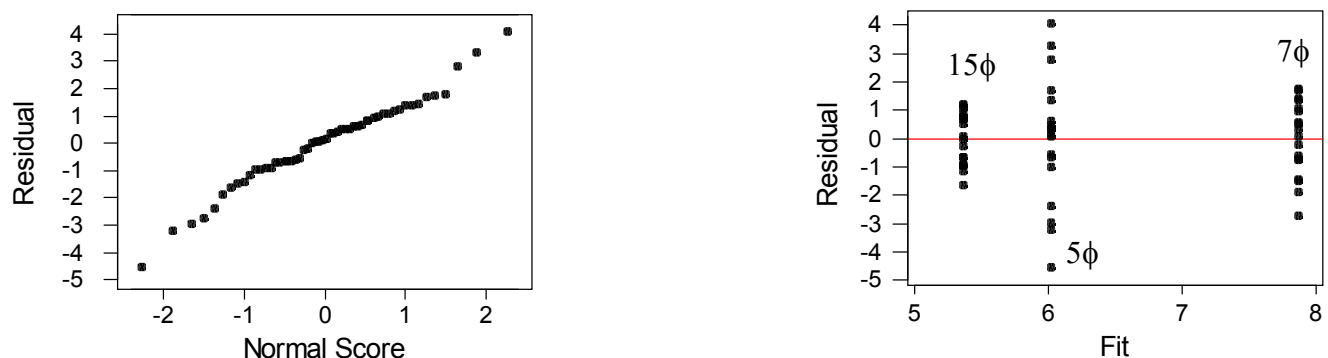

Figura E.142 - Análise de resíduos para $\mathrm{Y}=\tau_{\mathrm{b}, \text { máx }}, \sigma_{\mathrm{p}}=0,8 \mathrm{f}_{\mathrm{ptk}}$ e a variável $\mathrm{X}_{1}$.
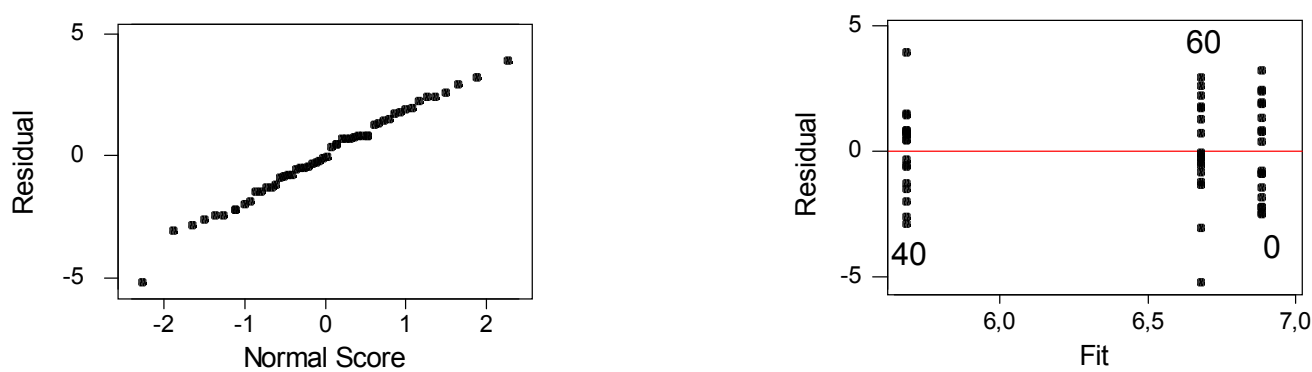

Figura E.143 - Análise de resíduos para $\mathrm{Y}=\tau_{\mathrm{b}, \text { máx }}, \sigma_{\mathrm{p}}=0,8 \mathrm{f}_{\mathrm{ptk}}$ e a variável $\mathrm{X}_{2}$.

\begin{tabular}{|c|c|c|c|c|}
\hline Analysi & is of Var & ance for & $\tau_{\mathbf{b}, \mathbf{m a ́ x}}$ (sem & protensão) \\
\hline Source & $\mathrm{DF}$ & SS & MS & F \\
\hline comp-sp & 2 & 317,91 & 158,95 & 0,000 \\
\hline Error & 51 & 121,93 & 2,39 & \\
\hline Total & 53 & 439,84 & & \\
\hline & & & & $\begin{array}{l}\text { Individual 95\% CIs For Mean } \\
\text { Based on Pooled StDev }\end{array}$ \\
\hline Level & $\mathrm{N}$ & Mean & StDev & ----+---------+---------+---------+-- \\
\hline 1 & 18 & 4,787 & 1,633 & $(--\star--)$ \\
\hline 2 & 18 & 10,730 & 1,062 & $(--\star--)$ \\
\hline 3 & 18 & 7,768 & 1,838 & $(--\star--)$ \\
\hline Pooled & StDev $=$ & 1,546 & & 10,0 \\
\hline
\end{tabular}

Tukey's pairwise comparisons

Family error rate $=0,0500$

Individual error rate $=0,0195$

Critical value $=3,41$

Intervals for (column level mean) - (row level mean)

$\begin{array}{ccc} & 1 & 2 \\ 2 & -7,186 & \\ & -4,701 & \\ & & \\ & -4,224 & 1,719 \\ & -1,738 & 4,205\end{array}$

Figura E.144 - Tabela de análise de variância e teste de Tukey para $Y=\tau_{b \text {,máx }}, \sigma_{p}=0$ e $X_{1}$. 


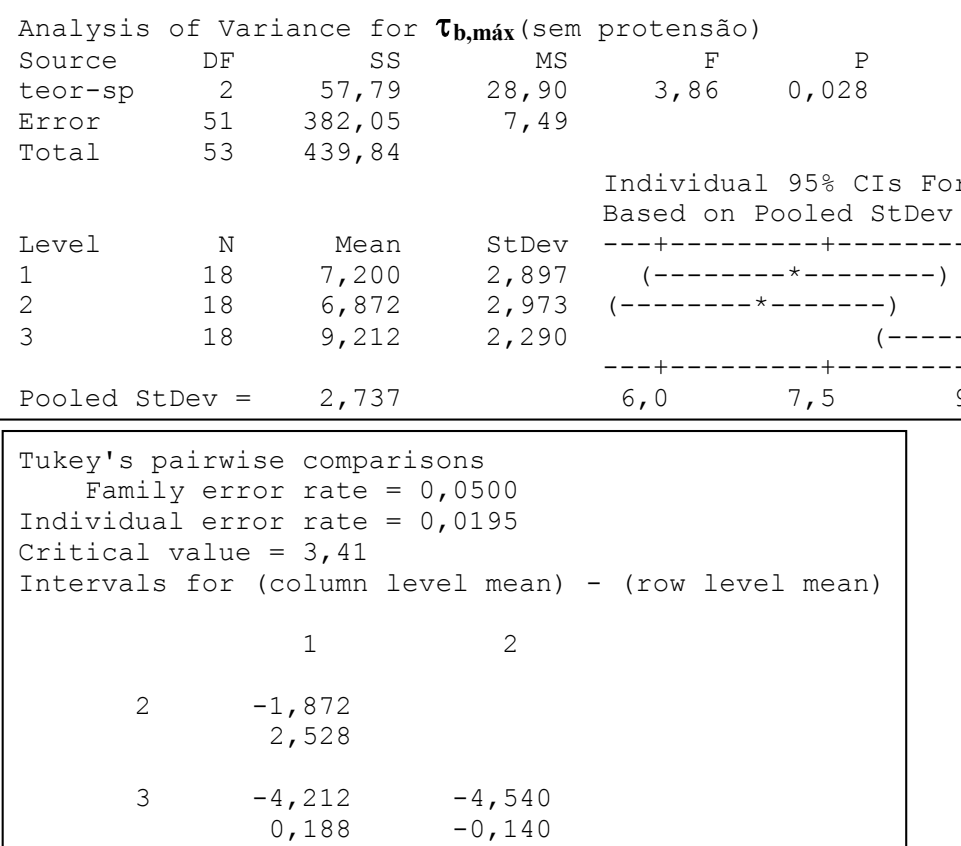

Figura E.145 - Tabela de análise de variância e teste de Tukey para $Y=\tau_{b \text {,máx }}, \sigma_{p}=0$ e $X_{2}$.

\begin{tabular}{|c|c|c|c|c|}
\hline \multicolumn{5}{|c|}{ Analysis of Variance for $\tau_{\mathbf{b}, \mathbf{m a ́}}$ (com protensão) } \\
\hline Source & $\mathrm{DF}$ & SS & MS & $\mathrm{F}$ \\
\hline comp-sp & 2 & 61,95 & 30,98 & 11,95 \\
\hline Error & 51 & 132,18 & 2,59 & \\
\hline \multirow[t]{2}{*}{ Total } & 53 & 194,13 & & \\
\hline & & & & $\begin{array}{l}\text { Individual 95\% CIs For Mean } \\
\text { Based on Pooled StDev }\end{array}$ \\
\hline Level & $\mathrm{N}$ & Mean & StDev & --+---------+---------+---------+---- \\
\hline 1 & 18 & 6,018 & 2,278 & $(-----\star------)$ \\
\hline 2 & 18 & 7,882 & 1,317 & $(------\star-----)$ \\
\hline 3 & 18 & 5,351 & 0,922 & $(------\star-----)$ \\
\hline Pooled S & $\mathrm{ev}=$ & 1,610 & & 4,8 \\
\hline
\end{tabular}

\begin{tabular}{|c|}
\hline Tukey's pairwise comparisons \\
Family error rate $=0,0500$ \\
Individual error rate $=0,0195$ \\
Critical value $=3,41$ \\
Intervals for (column level mean) - (row level mean) \\
$\begin{array}{c}1 \\
2\end{array}$ \\
$-3,158$ \\
$-0,570$ \\
$-0,627$ \\
1,961
\end{tabular}

Figura E.146 - Tabela de análise de variância e teste de Tukey para $Y=\tau_{b \text {,máx }}, \sigma_{p}=0,8 f_{p t k}$ e $X_{1}$.

De maneira geral, os modelos com $\ell_{\mathrm{ef}}=7 \phi_{\mathrm{p}}$ apresentaram os melhores resultados, independentemente do grau de protensão das peças.

Os modelo com $\mathrm{V}_{\mathrm{f}}=40 \mathrm{~kg} / \mathrm{m}^{3}$ apresentaram os piores resultados, independentemente do grau de protensão das peças. 


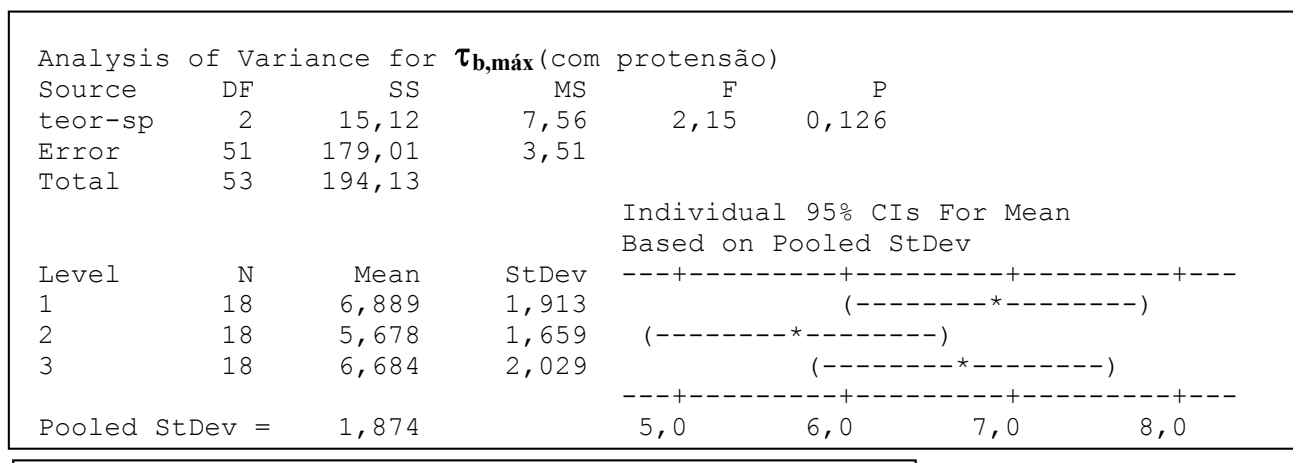

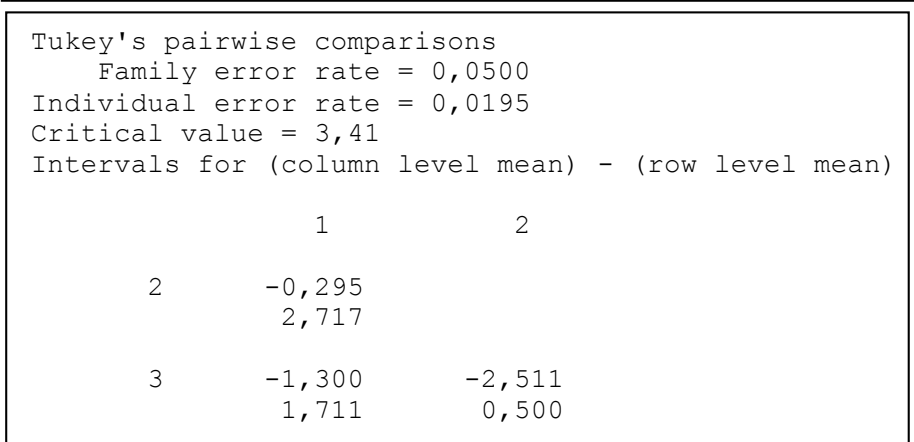

Figura E.147 - Tabela de análise de variância e teste de Tukey para $Y=\tau_{b \text {,máx }}, \sigma_{p}=0,8 f_{p t k}$ e $X_{2}$.

\section{Variável resposta $Y_{1}=\tau_{\mathrm{b}, 1}$ afiss}

A primeira análise a ser feita é a dos resíduos, para verificar-se se a amostra tem uma distribuição normal. As Figuras E.148 a E.151 apresentam os gráficos com plotagem dos resíduos para as variáveis $\mathrm{X}_{1}$ e $\mathrm{X}_{2}$, levando em conta os diferentes graus de protensão utilizados.
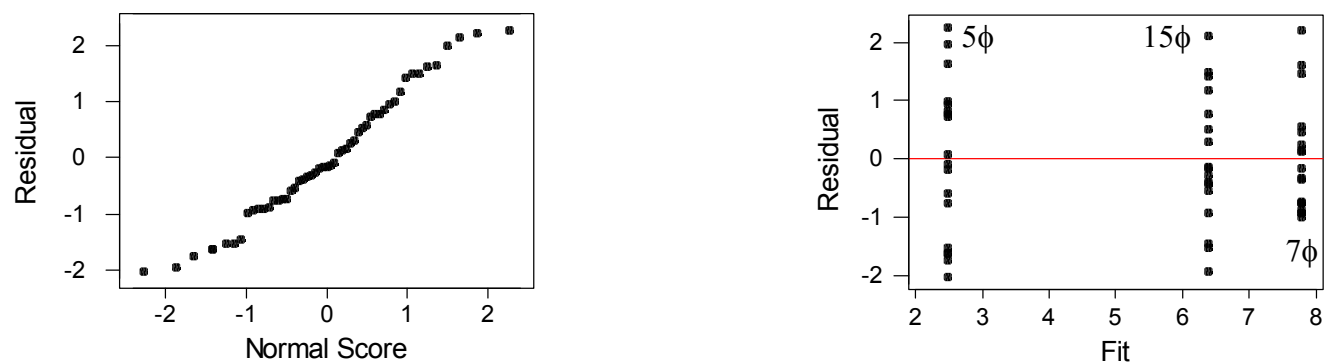

Figura E.148 - Análise de resíduos para $\mathrm{Y}_{1}=\tau_{\mathrm{b}, 1 \mathrm{a} \text { fiss }}, \sigma_{\mathrm{p}}=0$ e a variável $\mathrm{X}_{1}$.
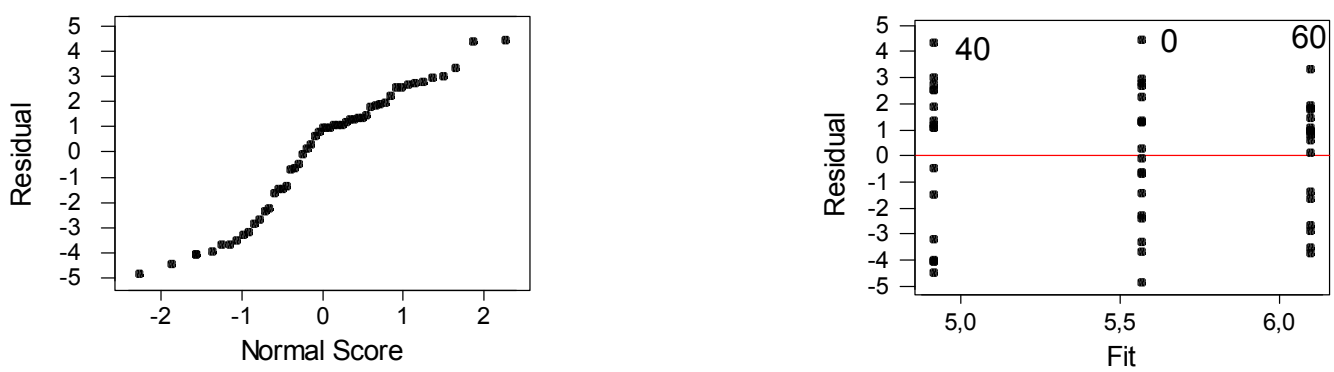

Figura E.149 - Análise de resíduos para $Y_{1}=\tau_{\mathrm{b}, 1^{\mathrm{a}} \mathrm{fiss}}, \sigma_{\mathrm{p}}=0$ e a variável $\mathrm{X}_{2}$. 

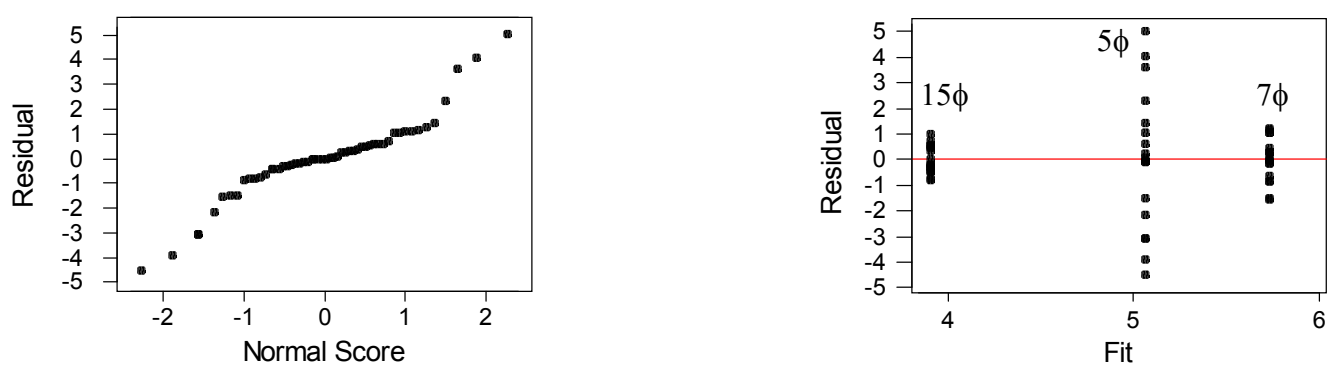

Figura E.150 - Análise de resíduos para $\mathrm{Y}_{1}=\tau_{\mathrm{b}, 1^{\mathrm{a}} \mathrm{fiss}}, \sigma_{\mathrm{p}}=0,8 \mathrm{f}_{\mathrm{ptk}}$ e a variável $\mathrm{X}_{1}$.
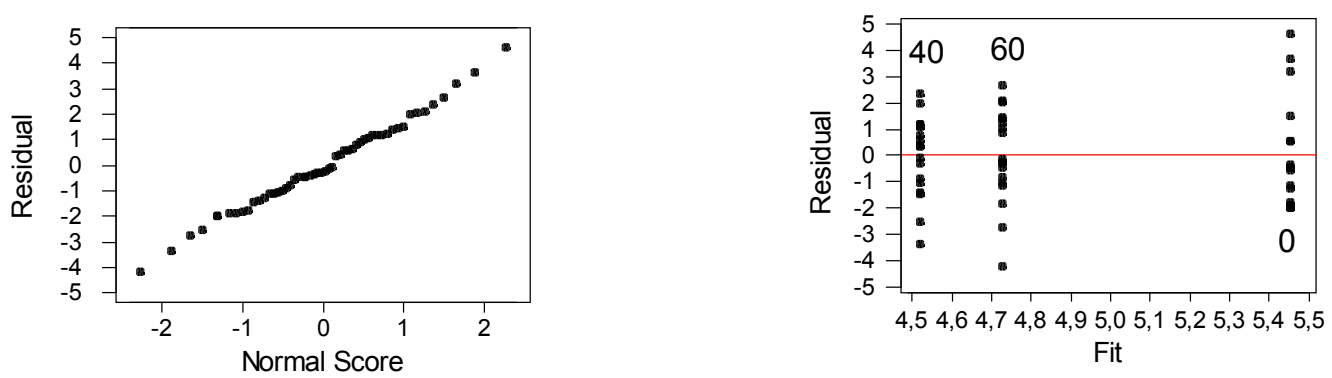

Figura E.151 - Análise de resíduos para $\mathrm{Y}_{1}=\tau_{\mathrm{b}, \mathrm{a}_{\mathrm{f}} \mathrm{fis}}, \sigma_{\mathrm{p}}=0,8 \mathrm{f}_{\mathrm{ptk}}$ e a variável $\mathrm{X}_{2}$.

Após a verificação dos resíduos, constatou-se que apenas a amostra da Figura E.150 não apresentou distribuição normal. Para as demais, pôde-se montar a tabela de variância e o teste de Tukey. As Figuras E.152 a E.154 apresentam os resultados para as duas variáveis independentes analisadas.

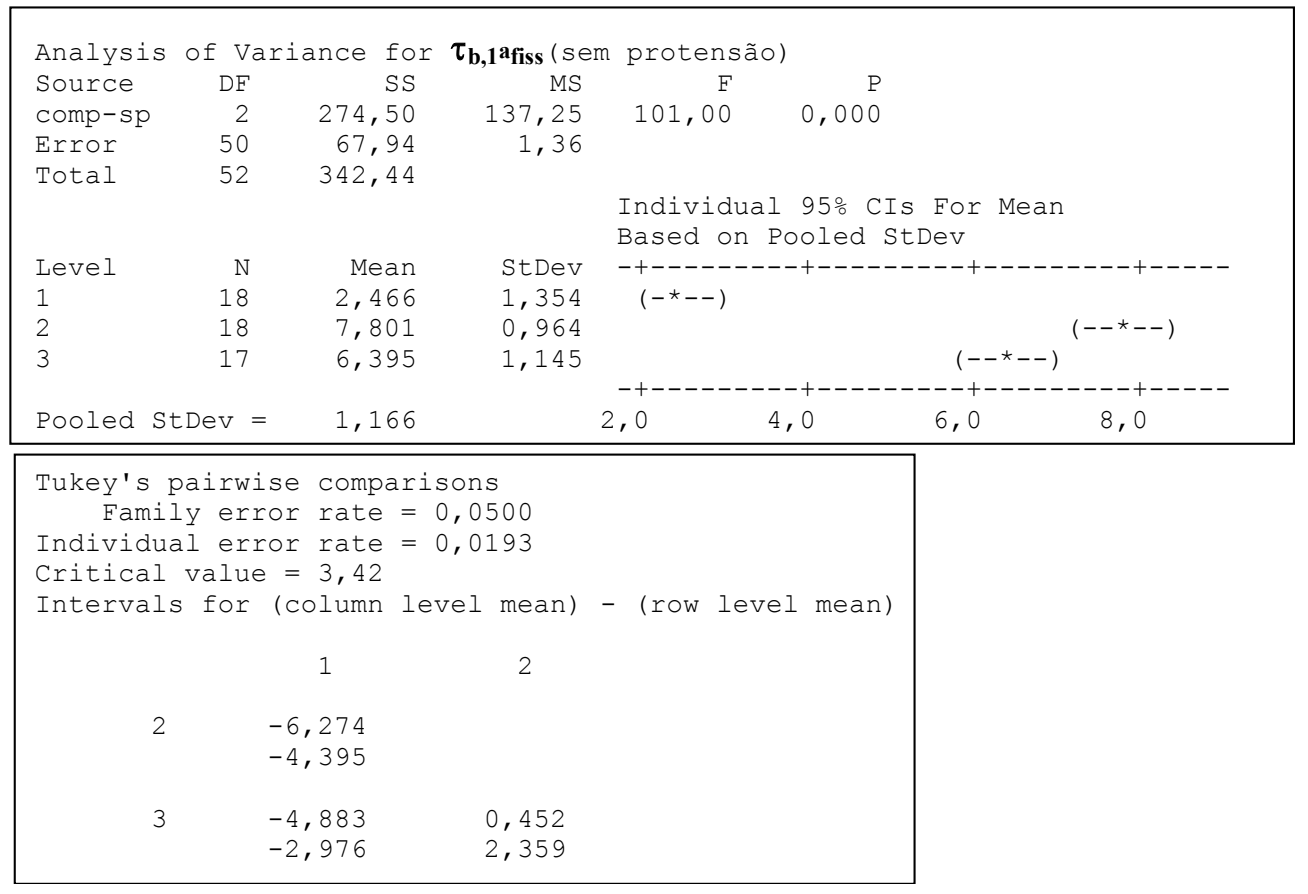

Figura E.152 - Tabela de análise de variância e teste de Tukey para $Y_{1}=\tau_{b, 1}{ }^{a}$ fiss,$\sigma_{p}=0$ e $X_{1}$.

Pelo tabela da Figura E.152 percebe-se que os modelos com $\ell_{\mathrm{ef}}=7 \phi_{\mathrm{p}}$ apresentaram os melhores resultados. 


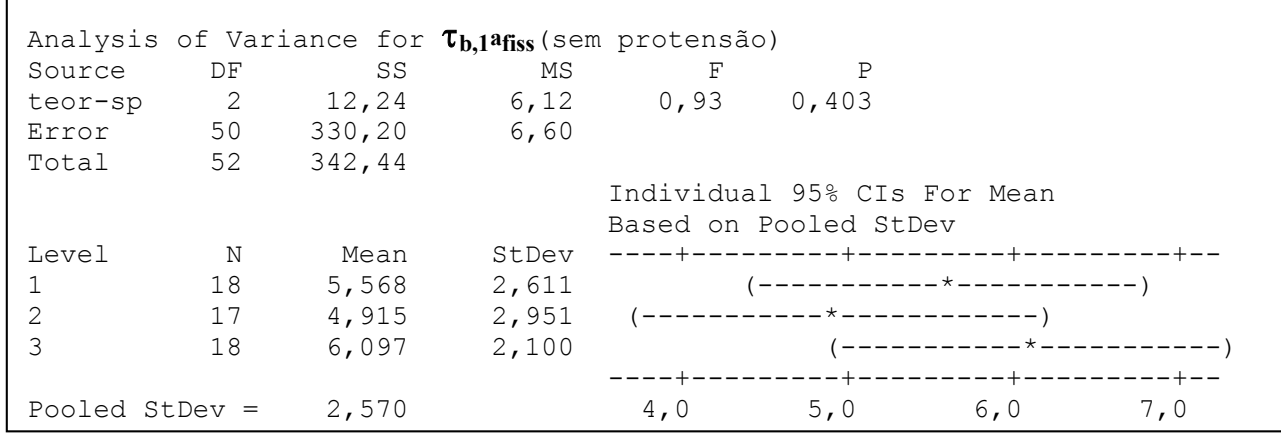

Tukey's pairwise comparisons
Family error rate $=0,0500$
Individual error rate $=0,0193$
Critical value $=3,42$
Intervals for (column level mean) - (row level mean)
$\begin{array}{r}1 \\ 2 \\ -1,448\end{array}$
2,755
$-2,600$
1,543

Figura E.153 - Tabela de análise de variância e teste de Tukey para $Y_{1}=\tau_{b, 1}{ }^{a}$ fiss,$\sigma_{p}=0$ e $X_{2}$.

\begin{tabular}{|c|c|c|c|c|}
\hline Analysis & s of $\mathrm{Va}$ & ance for & $\tau_{\mathbf{b}, \mathbf{1}} \mathbf{a}_{\text {fiss }}(\mathrm{cor}$ & (n protensão) \\
\hline Source & $\mathrm{DF}$ & SS & MS & $\mathrm{F}$ \\
\hline teor-sp & 2 & 8,69 & 4,35 & 0,270 \\
\hline Error & 51 & 165,10 & 3,24 & \\
\hline Total & 53 & 173,79 & & \\
\hline & & & & $\begin{array}{l}\text { Individual 95\% CIs For Mean } \\
\text { Based on Pooled StDev }\end{array}$ \\
\hline Level & $\mathrm{N}$ & Mean & StDev & -----+---------+---------+---------+- \\
\hline 1 & 18 & 5,454 & 2,031 & $(---------\star----------)$ \\
\hline 2 & 18 & 4,518 & 1,531 & $(---------\star----------)$ \\
\hline 3 & 18 & 4,726 & 1,801 & $(-----------\star------------)$ \\
\hline Pooled S & StDev $=$ & 1,799 & & 4,00 \\
\hline
\end{tabular}

\begin{tabular}{|c|}
\hline Tukey's pairwise comparisons \\
Family error rate $=0,0500$ \\
Individual error rate $=0,0195$ \\
Critical value $=3,41$ \\
Intervals for (column level mean) - (row level mean) \\
1 \\
2 \\
$-0,511$ \\
2,382 \\
$-0,718$ \\
2,174
\end{tabular}

Figura E.154 - Tabela de análise de variância e teste de Tukey para $Y_{1}=\tau_{b, 1} a_{\text {fiss }}, \sigma_{p}=0,8 f_{p t k}$ e $X_{2}$.

Os modelos com $\mathrm{V}_{\mathrm{f}}=40 \mathrm{~kg} / \mathrm{m}^{3}$ apresentaram os piores resultados, independentemente do grau de protensão das peças, porém, as diferenças não foram significativas.

\section{Variável resposta $Y_{2}=\tau_{b, 0.1}$}

A primeira análise a ser feita é a dos resíduos, para verificar-se se a amostra tem uma distribuição normal. As Figuras E.155 a E.158 apresentam os gráficos com plotagem dos 
resíduos para as variáveis $\mathrm{X}_{1}$ e $\mathrm{X}_{2}$, levando em conta os diferentes graus de protensão utilizados.
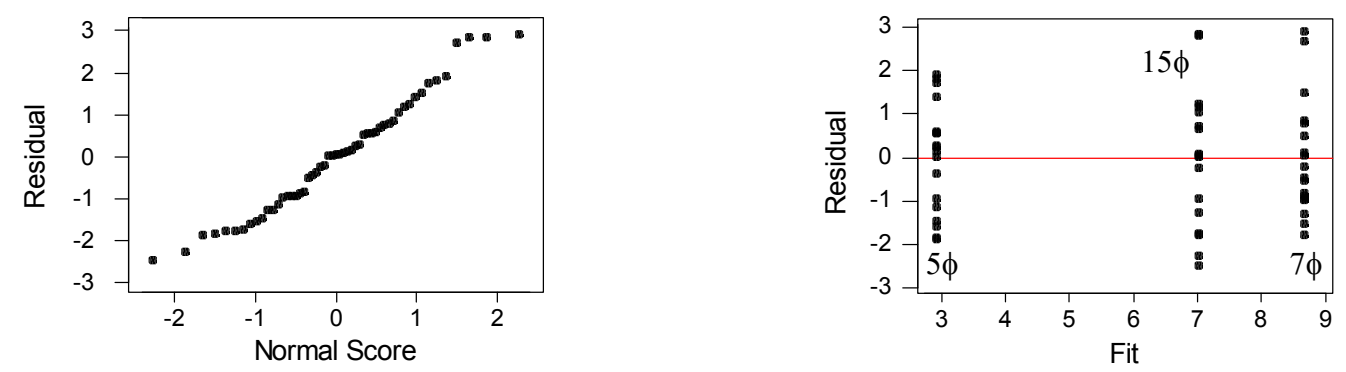

Figura E.155 - Análise de resíduos para $\mathrm{Y}_{2}=\tau_{\mathrm{b}, 0.1}, \sigma_{\mathrm{p}}=0$ e a variável $\mathrm{X}_{1}$.
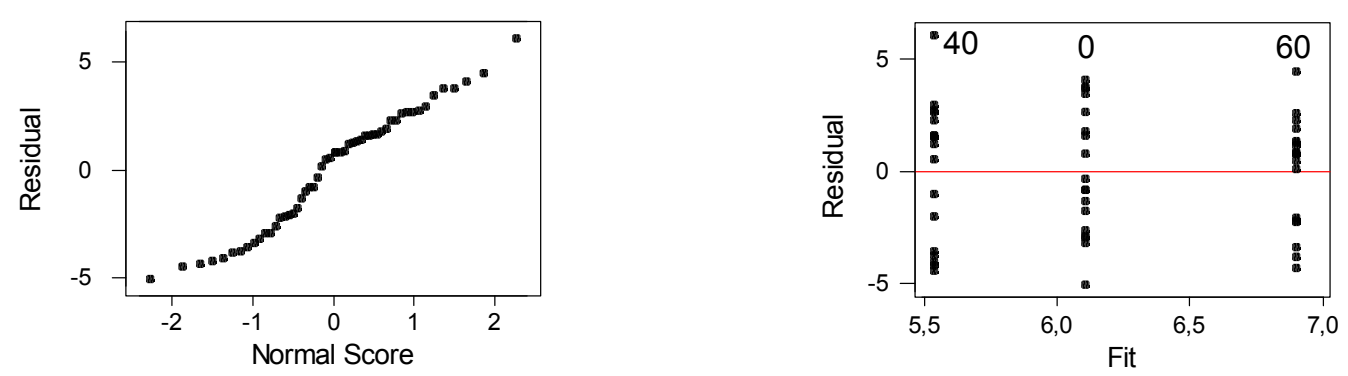

Figura E.156 - Análise de resíduos para $\mathrm{Y}_{2}=\tau_{\mathrm{b}, 0.1}, \sigma_{\mathrm{p}}=0$ e a variável $\mathrm{X}_{2}$.
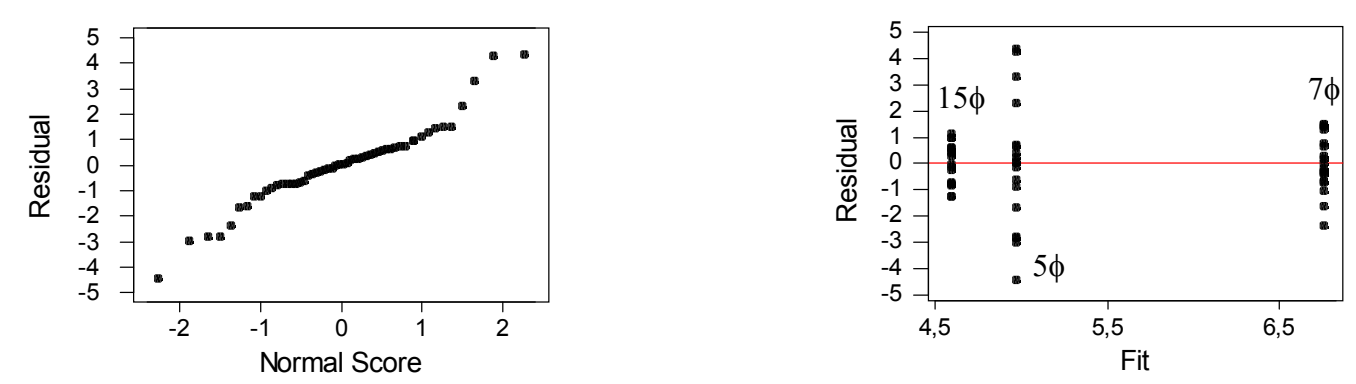

Figura E.157 - Análise de resíduos para $\mathrm{Y}_{2}=\tau_{\mathrm{b}, 0.1}, \sigma_{\mathrm{p}}=0,8 \mathrm{f}_{\mathrm{ptk}}$ e a variável $\mathrm{X}_{1}$.
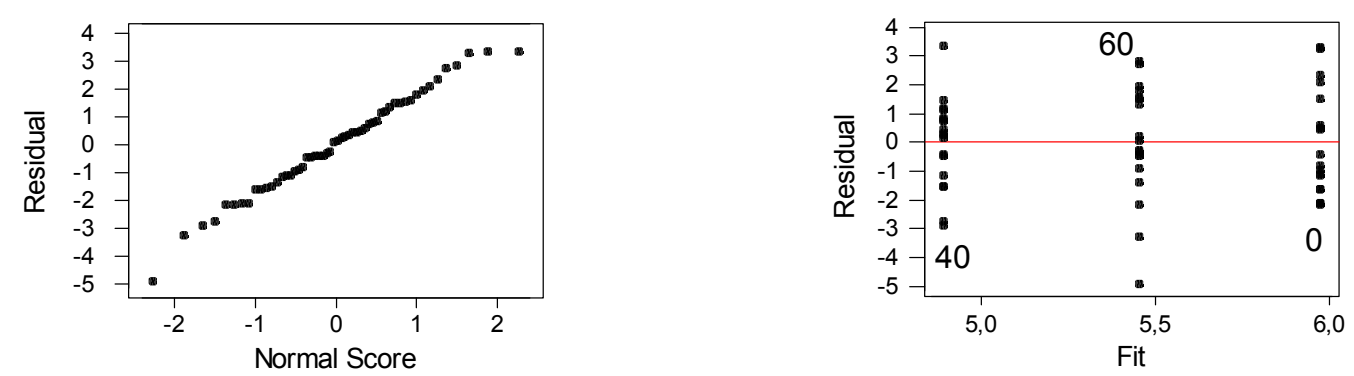

Figura E.158 - Análise de resíduos para $\mathrm{Y}_{2}=\tau_{\mathrm{b}, 0.1}, \sigma_{\mathrm{p}}=0,8 \mathrm{f}_{\mathrm{ptk}}$ e a variável $\mathrm{X}_{2}$.

Após a verificação dos resíduos, constatou-se que apenas a amostra da Figura E.157 não apresentou distribuição normal. Para as demais, pôde-se montar a tabela de variância e o teste de Tukey. As Figuras E.159 a E.161 apresentam os resultados para as duas variáveis independentes analisadas.

Pelo tabela da Figura E.159 percebe-se que os modelos com $\ell_{\mathrm{ef}}=7 \phi_{\mathrm{p}}$ apresentaram os melhores resultados, e as diferenças são significativas. 


\begin{tabular}{|c|c|c|c|c|}
\hline Analysis & \multicolumn{2}{|c|}{ s of Variance for } & \multicolumn{2}{|c|}{$\tau_{\mathbf{b}, \mathbf{0 . 1} \mathbf{m m}}($ sem protensão $)$} \\
\hline Source & $\mathrm{DF}$ & SS & MS & $\mathrm{F}$ \\
\hline comp-sp & 2 & 317,39 & 158,69 & 80,28 \\
\hline Error & 50 & 98,84 & 1,98 & \\
\hline Total & 52 & 416,22 & & \\
\hline & & & & $\begin{array}{l}\text { Individual 95\% CIs For Mean } \\
\text { Based on Pooled StDev }\end{array}$ \\
\hline Level & $\mathrm{N}$ & Mean & StDev & ---------+---------+---------+------- \\
\hline 1 & 18 & 2,913 & 1,259 & $(---\star--)$ \\
\hline 2 & 18 & 8,688 & 1,345 & $(--\star---)$ \\
\hline 3 & 17 & 7,024 & 1,603 & $(--\star---)$ \\
\hline Pooled & StDev $=$ & 1,406 & & $\begin{array}{rrr}----1 & 6,0 & 8,0\end{array}$ \\
\hline
\end{tabular}

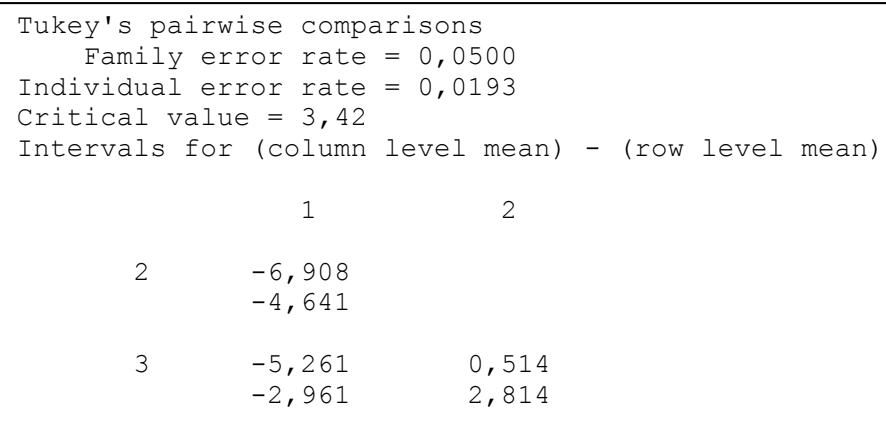

Figura E.159 - Tabela de análise de variância e teste de Tukey para $Y_{2}=\tau_{b, 0.1}, \sigma_{\mathrm{p}}=0$ e $X_{1}$.

\begin{tabular}{|c|c|c|c|c|}
\hline Analysis & s of Var & ance for & $\tau_{\mathbf{b}, \mathbf{0 . 1} \mathrm{mm}}(\mathrm{se}$ & m protensão) \\
\hline Source & $\mathrm{DF}$ & SS & MS & $\mathrm{F}$ \\
\hline teor-sp & 2 & 16,57 & 8,29 & 0,362 \\
\hline Error & 50 & 399,65 & 7,99 & \\
\hline Total & 52 & 416,22 & & \\
\hline & & & & $\begin{array}{l}\text { Individual 95\% CIs For Mean } \\
\text { Based on Pooled StDev }\end{array}$ \\
\hline Level & $\mathrm{N}$ & Mean & StDev & ------+---------+---------+---------+ \\
\hline 1 & 18 & 6,105 & 2,834 & $(----------*----------)$ \\
\hline 2 & 17 & 5,535 & 3,169 & $(----------\star-----------)$ \\
\hline 3 & 18 & 6,903 & 2,455 & $(-----------\star----------)$ \\
\hline Pooled s & StDev $=$ & 2,827 & & 7,2 \\
\hline
\end{tabular}

\begin{tabular}{|c|}
\hline Tukey's pairwise comparisons \\
Family error rate $=0,0500$ \\
Individual error rate $=0,0193$ \\
Critical value $=3,42$ \\
Intervals for (column level mean) - (row level mean) \\
1 \\
$-1,742$ \\
2,883 \\
2 \\
$-3,077$ \\
1,481
\end{tabular}

Figura E.160 - Tabela de análise de variância e teste de Tukey para $\mathrm{Y}_{2}=\tau_{\mathrm{b}, 0.1}, \sigma_{\mathrm{p}}=0$ e $\mathrm{X}_{2}$.

Os modelos com $\mathrm{V}_{\mathrm{f}}=40 \mathrm{~kg} / \mathrm{m}^{3}$ apresentaram os piores resultados, independentemente do grau de protensão das peças, porém, as diferenças não foram significativas. 


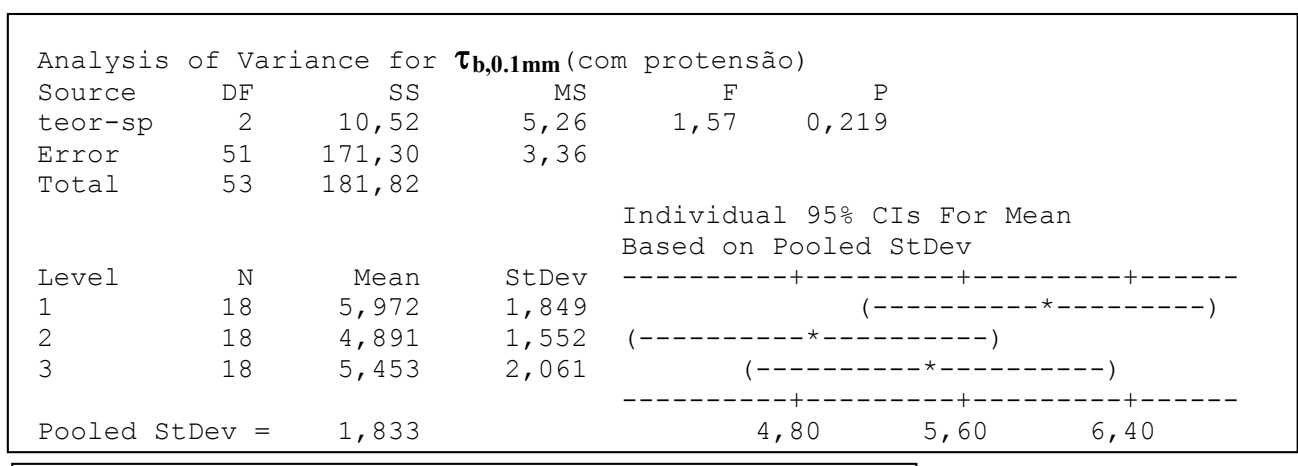

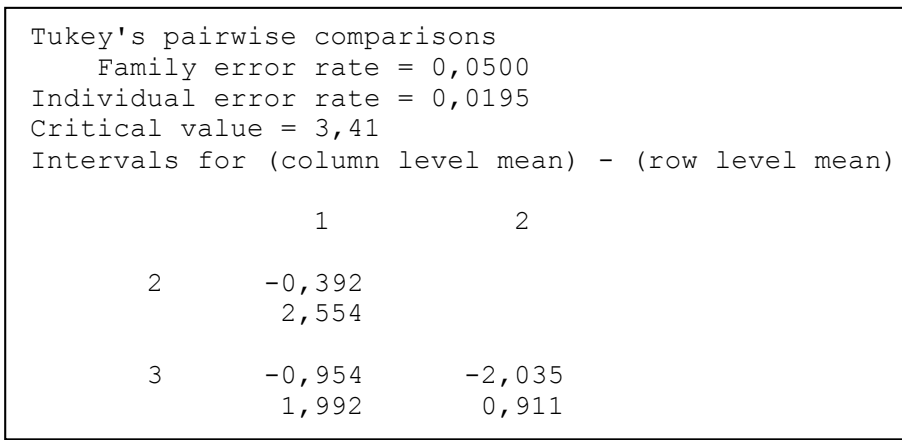

Figura E.161 - Tabela de análise de variância e teste de Tukey para $Y_{2}=\tau_{b, 0.1}, \sigma_{p}=0,8 f_{p t k}$ e $X_{2}$.

\section{Variável resposta $Y_{3}=\tau_{b, 1}$}

A primeira análise a ser feita é a dos resíduos, para verificar-se se a amostra tem uma distribuição normal. As Figuras E.162 a E.165 apresentam os gráficos com plotagem dos resíduos para as variáveis $\mathrm{X}_{1}$ e $\mathrm{X}_{2}$, levando em conta os diferentes graus de protensão utilizados.
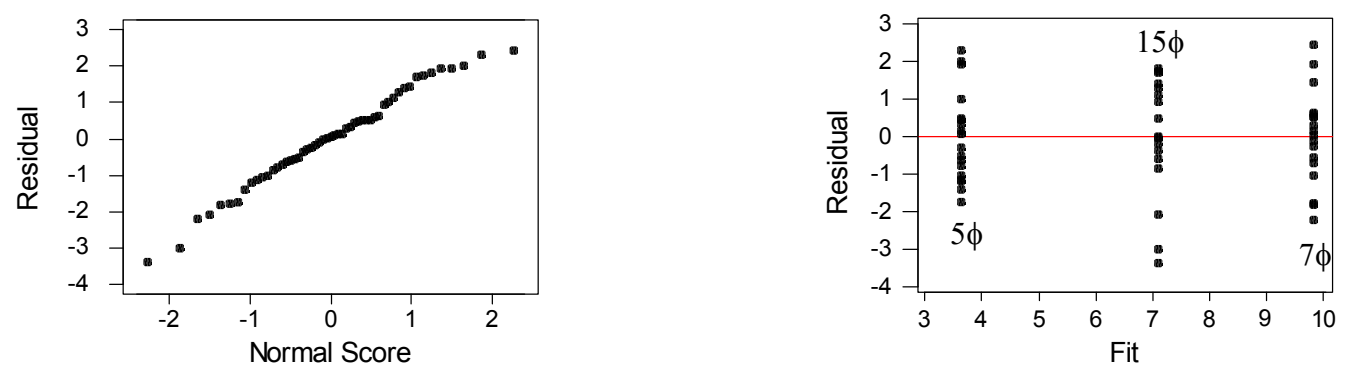

Figura E.162 - Análise de resíduos para $\mathrm{Y}_{3}=\tau_{\mathrm{b}, 1}, \sigma_{\mathrm{p}}=0$ e a variável $\mathrm{X}_{1}$.
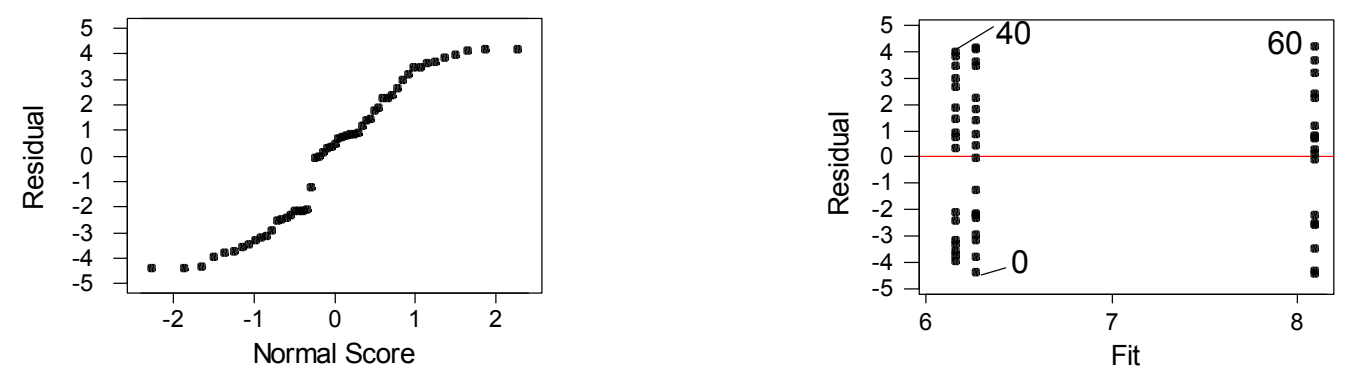

Figura E.163 - Análise de resíduos para $\mathrm{Y}_{3}=\tau_{\mathrm{b}, 1}, \sigma_{\mathrm{p}}=0$ e a variável $\mathrm{X}_{2}$. 

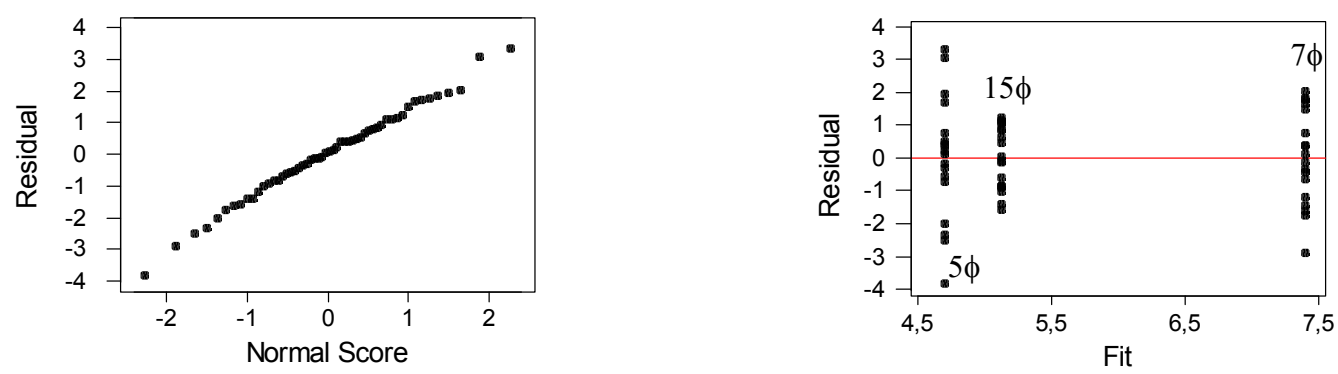

Figura E.164 - Análise de resíduos para $\mathrm{Y}_{3}=\tau_{\mathrm{b}, 1}, \sigma_{\mathrm{p}}=0,8 \mathrm{f}_{\mathrm{ptk}}$ e a variável $\mathrm{X}_{1}$.
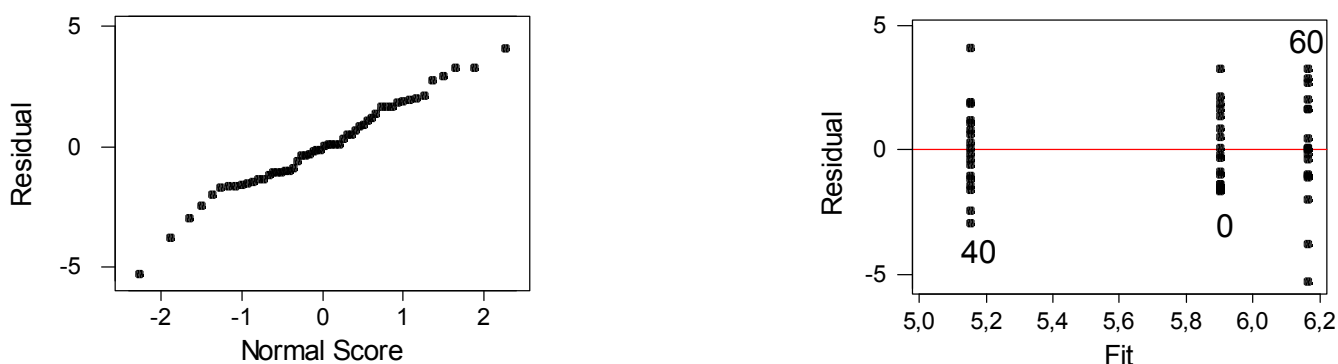

Figura E.165 - Análise de resíduos para $\mathrm{Y}_{3}=\tau_{\mathrm{b}, 1}, \sigma_{\mathrm{p}}=0,8 \mathrm{f}_{\mathrm{ptk}}$ e a variável $\mathrm{X}_{2}$.

Após a verificação dos resíduos, constatou-se que apenas a amostra da Figura E.164 não apresentou distribuição normal. Para as demais, pôde-se montar a tabela de variância e o teste de Tukey. As Figuras E.166 a E.168 apresentam os resultados para as duas variáveis independentes analisadas.

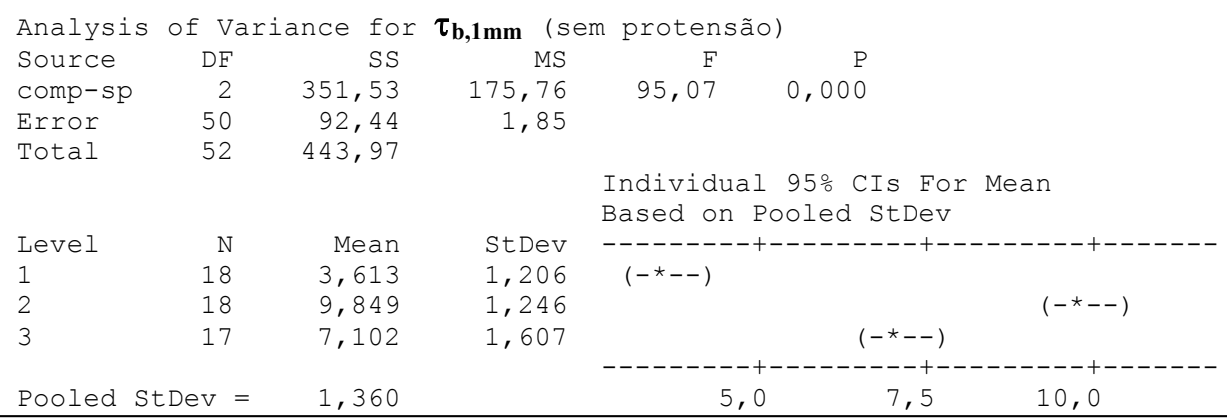

$\begin{array}{ccc} & 1 & 2 \\ 2 & -7,332 & \\ & -5,139 & \\ & & \\ & -4,600 & 1,635 \\ & -2,376 & 3,859\end{array}$

Figura E.166 - Tabela de análise de variância e teste de Tukey para $Y_{3}=\tau_{b, 1}, \sigma_{p}=0$ e $X_{1}$.

Pelo tabela da Figura E.166 percebe-se que os modelos com $\ell_{\mathrm{ef}}=7 \phi_{\mathrm{p}}$ apresentaram os melhores resultados, e as diferenças são significativas. 


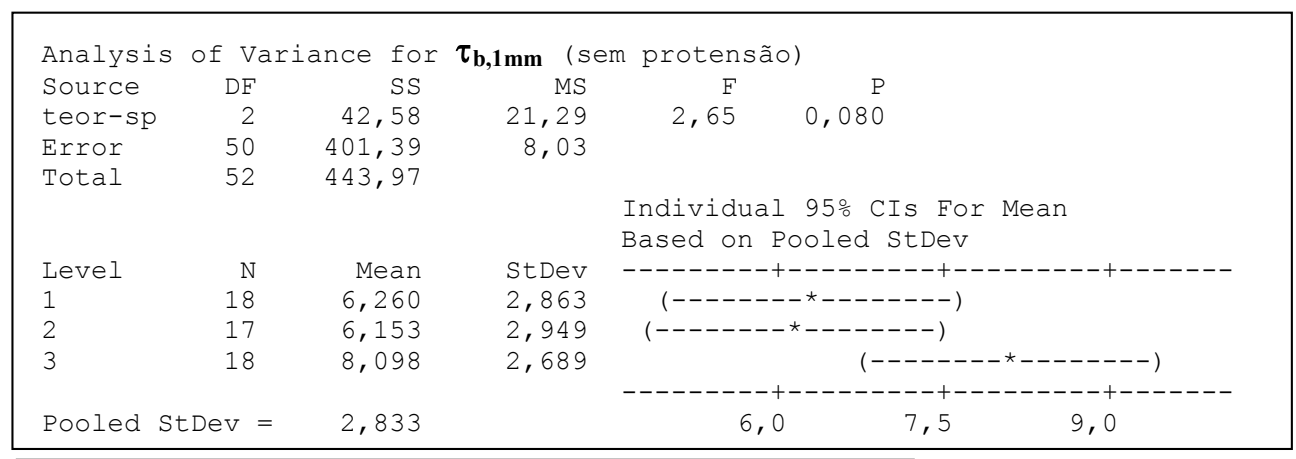

\begin{tabular}{|c|}
\hline Tukey's pairwise comparisons \\
Family error rate $=0,0500$ \\
Individual error rate $=0,0193$ \\
Critical value $=3,42$ \\
Intervals for (column level mean) - (row level mean) \\
1 \\
2,210 \\
2,424 \\
$-4,122$ \\
0,446
\end{tabular}

Figura E.167 - Tabela de análise de variância e teste de Tukey para $Y_{3}=\tau_{\mathrm{b}, 1}, \sigma_{\mathrm{p}}=0$ e $\mathrm{X}_{2}$.

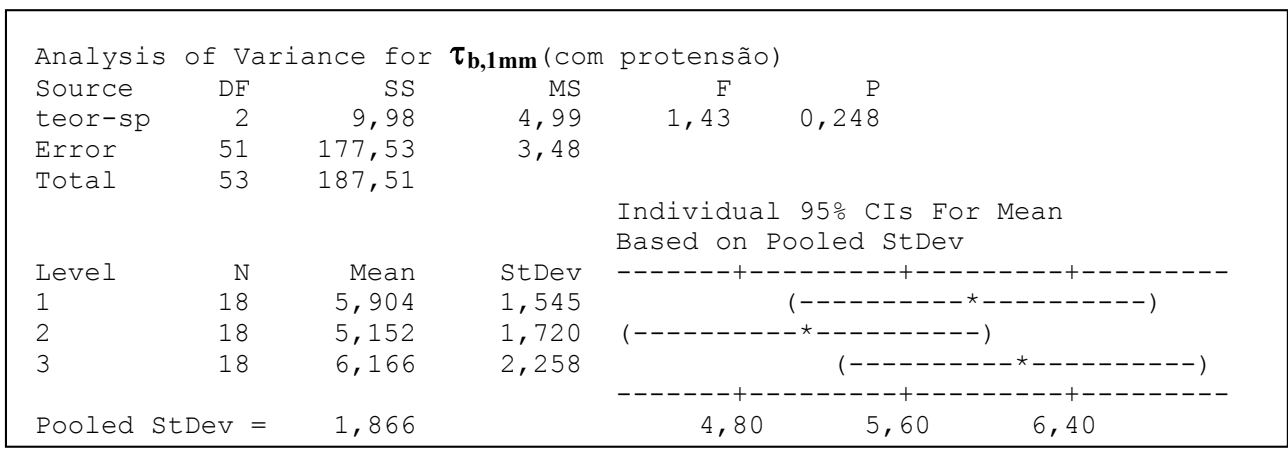

\begin{tabular}{|l|}
\hline Tukey's pairwise comparisons \\
Family error rate $=0,0500$ \\
Individual error rate = 0,0195 \\
Critical value $=3,41$ \\
Intervals for (column level mean) - (row level mean) \\
1 \\
2 \\
$-0,747$ \\
2,252 \\
$-1,762$ \\
1,237
\end{tabular}

Figura E.168 - Tabela de análise de variância e teste de Tukey para $Y_{3}=\tau_{b, 1}, \sigma_{p}=0,8 f_{p t k}$ e $X_{2}$.

Os modelos com $\mathrm{V}_{\mathrm{f}}=40 \mathrm{~kg} / \mathrm{m}^{3}$ apresentaram os piores resultados, independentemente do grau de protensão das peças, porém, as diferenças não foram significativas.

\section{Variável resposta $Y_{4}=S_{\tau_{b, \text { máx }}}$}

A primeira análise a ser feita é a dos resíduos, para verificar-se se a amostra tem uma distribuição normal. As Figuras E.169 a E.172 apresentam os gráficos com plotagem dos 
resíduos para as variáveis $\mathrm{X}_{1}$ e $\mathrm{X}_{2}$, levando em conta os diferentes graus de protensão utilizados.
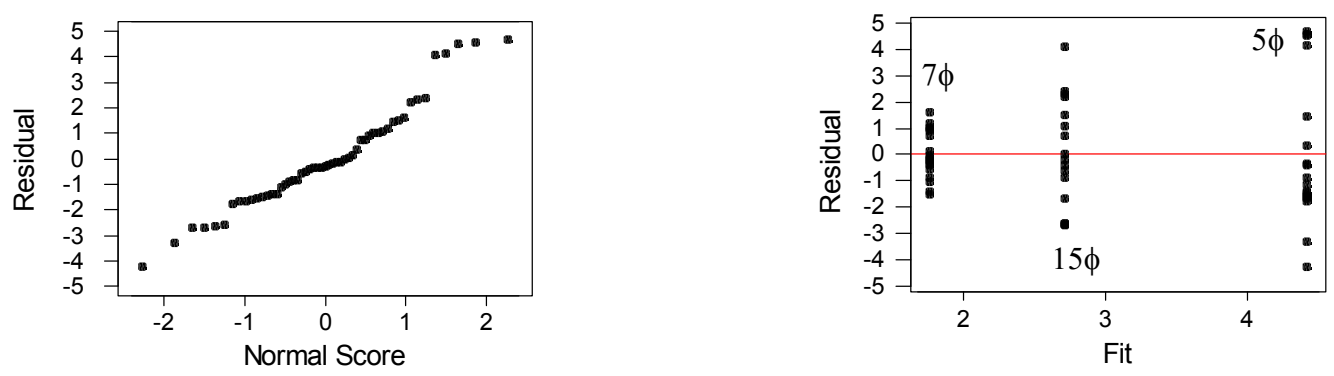

Figura E.169 - Análise de resíduos para $\mathrm{Y}_{4}=\mathrm{S}_{\tau_{\mathrm{b}, \text { máx }}}, \sigma_{\mathrm{p}}=0$ e a variável $\mathrm{X}_{1}$.
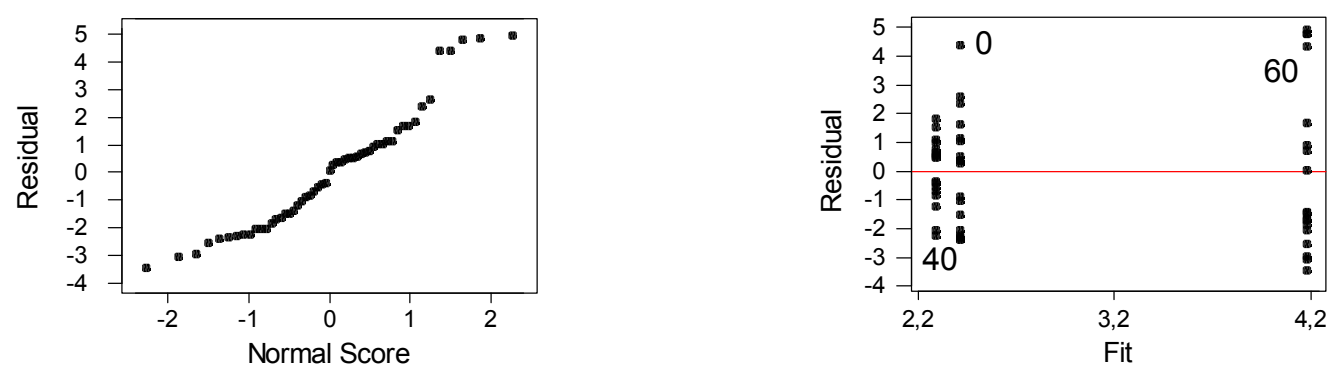

Figura E. 170 - Análise de resíduos para $\mathrm{Y}_{4}=\mathrm{S}_{\tau_{\mathrm{b}, \text { máx }}}, \sigma_{\mathrm{p}}=0$ e a variável $\mathrm{X}_{2}$.
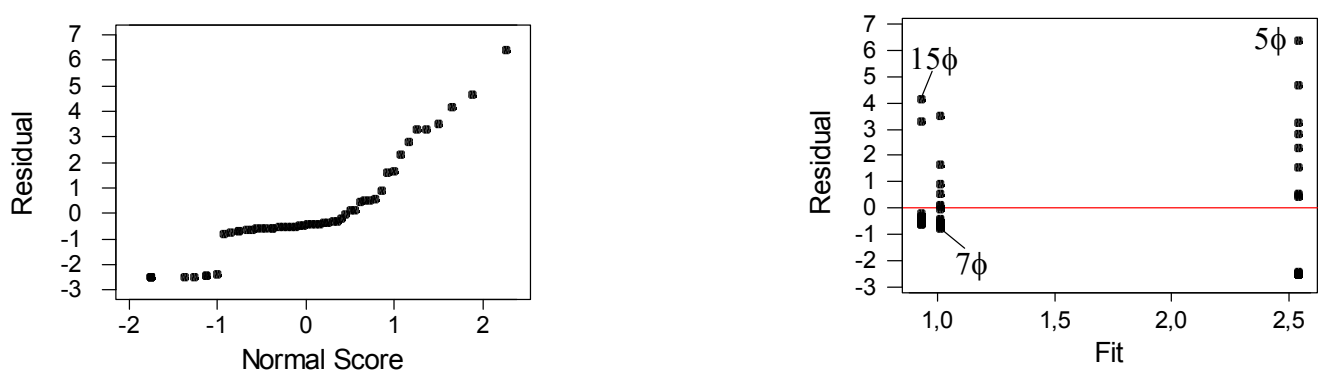

Figura E.171 - Análise de resíduos para $\mathrm{Y}_{4}=\mathrm{S}_{\tau_{\mathrm{b}, \text { máx }}}, \sigma_{\mathrm{p}}=0,8 \mathrm{f}_{\mathrm{ptk}}$ e a variável $\mathrm{X}_{1}$.
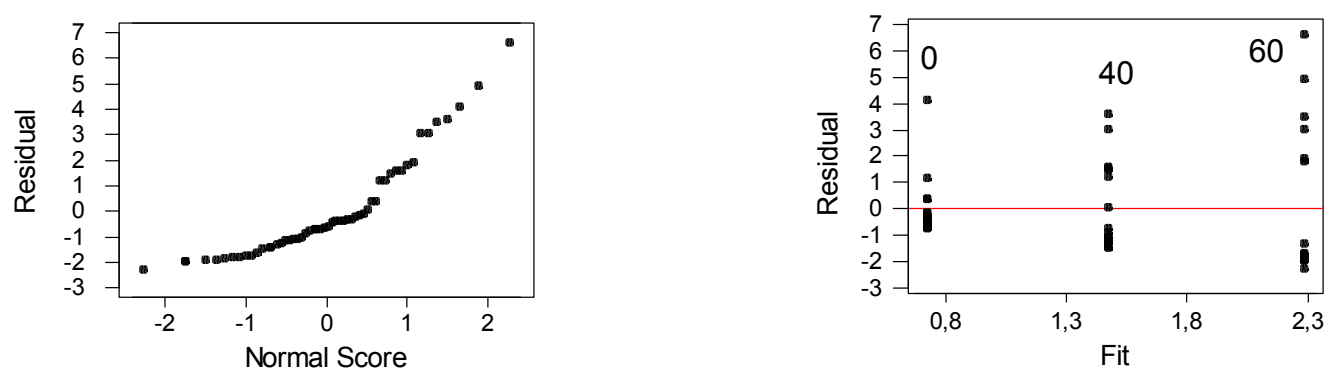

Figura E.172 - Análise de resíduos para $\mathrm{Y}_{4}=\mathrm{S}_{\tau_{\mathrm{b}, \text { máx }}}, \sigma_{\mathrm{p}}=0,8 \mathrm{f}_{\mathrm{ptk}}$ e a variável $\mathrm{X}_{2}$.

Pelos diagramas, percebe-se que para todas as variáveis, nem a distribuição pode ser considerada normal e nem a variabilidade desses dados é boa. Para que se pudesse analisar melhor esses resultados, elaborando tabelas de variância, seria necessário fazer algum tipo de transformação de dados, do tipo logarítmica por exemplo, para que se obtivesse uma distribuição normal e uma variabilidade mais constante. 


\section{APÊNDICE F}

RESULTADOS DOS ENSAIOS DE CARACTERIZACCÃO 


\section{F.1. Ensaios de Caracterização do Concreto}

A seguir são apresentados resultados em forma de tabelas e gráficos, para os ensaios do concreto. As tabelas foram dividas por concretagem.

Os gráficos foram plotados individualmente e, também, agrupados em relação a alguns parâmetros. Os valores indicados em letra vermelha foram descartados, ou por problemas durante o ensaio, ou por apresentarem-se muito acima ou muito abaixo dos demais.

As tabelas F1 a F24 apresentam os resultados obtidos dos ensaios de compressão axial, compressão diametral e tração na flexão para os corpos-de-prova de concreto, para cada concretagem realizada. Os gráficos das figuras F1 e F2 apresentam as curvas de crescimento das resistências à compressão, para as concretagens 1 a 14. Os gráficos da figura F3 apresentam o resultado dos ensaios de compressão axial nos corpos-de-prova de $15 \times 30 \mathrm{~cm}$, onde foram determinados os módulos de elasticidade. As figuras F4 a F8 apresentam os gráficos para o cálculo dos coeficientes de tenacidade. $\mathrm{E}$, as tabelas F25 a F29 apresentam os valores relativos à tenacidade dos compósitos.

Tabela F.1 - Resultados dos ensaios da concretagem 1.

\begin{tabular}{|c|c|c|c|c|c|c|}
\hline \multirow{2}{*}{$\begin{array}{l}\text { Concretagem e tipo do } \\
\text { modelo a ser ensaiado }\end{array}$} & \multirow{2}{*}{$\begin{array}{c}\text { Idade na data de } \\
\text { ensaio } \\
\text { (dias) }\end{array}$} & \multicolumn{2}{|c|}{ CP 10x20 } & \multirow{2}{*}{$\begin{array}{c}\text { CP 15x30 } \\
\mathrm{E}_{\mathrm{c}} \\
(\mathrm{MPa})\end{array}$} & \multicolumn{2}{|c|}{ CP $15 \times 15 \times 50$} \\
\hline & & $\begin{array}{c}\mathbf{f}_{\mathbf{c}} \\
(\mathbf{M P a})\end{array}$ & $\begin{array}{c}\mathbf{f}_{\text {ct,sp }} \\
(\mathbf{M P a})\end{array}$ & & $\begin{array}{c}\mathbf{f}_{\mathrm{ct}, \mathrm{fl}} \\
\text { (MPa) }\end{array}$ & $\begin{array}{c}\mathbf{T}_{\mathrm{b}} \\
(\mathrm{kN} . \mathrm{mm})\end{array}$ \\
\hline \multirow{15}{*}{$\begin{array}{c}\mathrm{C} 1 \\
\text { Viga piloto } \mathrm{V} 1 \\
\mathrm{~V}_{\mathrm{f}}=0 \mathrm{~kg} / \mathrm{m}^{3}\end{array}$} & 1 & 38,83 & --- & --- & --- & --- \\
\hline & 1 & 33,10 & --- & --- & --- & --- \\
\hline & 3 & 59,84 & --- & --- & --- & --- \\
\hline & 3 & 50,93 & --- & --- & --- & --- \\
\hline & 4 & 59,46 & --- & --- & --- & --- \\
\hline & 4 & 61,12 & --- & --- & --- & --- \\
\hline & 7 & 63,53 & --- & --- & --- & --- \\
\hline & 7 & 60,22 & --- & --- & --- & --- \\
\hline & 14 & 65,57 & --- & --- & --- & --- \\
\hline & 21 & 69,77 & --- & --- & --- & --- \\
\hline & 27 & 73,21 & 4,62 & $37.177,00$ & 6,06 & --- \\
\hline & 27 & --- & 4,33 & $37.972,00$ & 5,87 & --- \\
\hline & 27 & --- & --- & --- & 5,49 & --- \\
\hline & 27 & --- & --- & --- & 5,86 & --- \\
\hline & 34 & 70,66 & --- & --- & --- & -- \\
\hline
\end{tabular}

Tabela F.2 - Resultados dos ensaios da concretagem 2.

\begin{tabular}{|c|c|c|c|c|c|c|}
\hline \multirow{2}{*}{$\begin{array}{l}\text { Concretagem e tipo do } \\
\text { modelo a ser ensaiado }\end{array}$} & \multirow{2}{*}{$\begin{array}{c}\text { Idade na data de } \\
\text { ensaio } \\
\text { (dias) }\end{array}$} & \multicolumn{2}{|c|}{ CP 10x20 } & \multirow{2}{*}{$\begin{array}{c}\text { CP 15x30 } \\
\mathrm{E}_{\mathrm{c}} \\
(\mathrm{MPa})\end{array}$} & \multicolumn{2}{|c|}{ CP $15 \times 15 \times 50$} \\
\hline & & $\begin{array}{c}\mathbf{f}_{\mathbf{c}} \\
(\mathbf{M P a})\end{array}$ & $\begin{array}{c}\mathbf{f}_{\text {ct,sp }} \\
(\mathbf{M P a})\end{array}$ & & $\begin{array}{c}\mathbf{f}_{\mathrm{ct}, \mathrm{fl}} \\
\text { (MPa) }\end{array}$ & $\begin{array}{c}\mathbf{T}_{\mathrm{b}} \\
(\mathrm{kN} . \mathrm{mm})\end{array}$ \\
\hline \multirow{15}{*}{$\begin{array}{c}\mathrm{C} 2 \\
\text { Viga piloto } \mathrm{V} 2 \\
\mathrm{~V}_{\mathrm{f}}=0 \mathrm{~kg} / \mathrm{m}^{3}\end{array}$} & 1 & 25,46 & --- & --- & --- & --- \\
\hline & 1 & 31,83 & --- & --- & $\begin{array}{ll}-- \\
\end{array}$ & --- \\
\hline & 4 & 61,12 & --- & $\begin{array}{ll}-- \\
\end{array}$ & --- & --- \\
\hline & 4 & $86,07^{1}$ & --- & --- & --- & --- \\
\hline & 4 & 62,39 & --- & --- & --- & --- \\
\hline & 4 & 63,66 & -- & --- & --- & --- \\
\hline & 7 & 62,77 & --- & --- & --- & --- \\
\hline & 7 & 63,41 & --- & --- & --- & --- \\
\hline & 14 & 66,46 & --- & --- & --- & --- \\
\hline & 21 & 70,92 & --- & --- & --- & --- \\
\hline & 27 & 76,78 & 3,82 & $37.356,00$ & 6,15 & --- \\
\hline & 27 & --- & 3,53 & $38.397,00$ & 6,01 & --- \\
\hline & 27 & --- & --- & $37.963,00$ & 5,82 & --- \\
\hline & 27 & --- & --- & --- & 6,08 & --- \\
\hline & 34 & 73,77 & --- & --- & --- & --- \\
\hline
\end{tabular}

${ }^{1}$ Devido a um erro na entrada de dados, o ensaio foi realizado com uma velocidade muito alta, esmagando o corpo-de-prova em menos de 1 minuto, registrando um pico de carga irreal. 
Tabela F.3 - Resultados dos ensaios da concretagem 3.

\begin{tabular}{|c|c|c|c|c|c|c|}
\hline \multirow{2}{*}{$\begin{array}{l}\text { Concretagem e tipo do } \\
\text { modelo a ser ensaiado }\end{array}$} & \multirow{2}{*}{$\begin{array}{c}\text { Idade na data de } \\
\text { ensaio } \\
\text { (dias) }\end{array}$} & \multicolumn{2}{|c|}{ CP 10x20 } & \multirow{2}{*}{$\begin{array}{c}\text { CP 15x30 } \\
\mathbf{E}_{\mathbf{c}} \\
(\mathrm{MPa})\end{array}$} & \multicolumn{2}{|c|}{ CP $15 \times 15 \times 50$} \\
\hline & & $\begin{array}{c}\mathbf{f}_{\mathbf{c}} \\
(\mathbf{M P a})\end{array}$ & $\begin{array}{c}\mathbf{f}_{\text {ct,sp }} \\
(\mathbf{M P a})\end{array}$ & & $\begin{array}{c}\mathbf{f}_{\mathrm{ct}, \mathrm{fl}} \\
(\mathbf{M P a})\end{array}$ & $\begin{array}{c}\mathbf{T}_{\mathbf{b}} \\
(\mathrm{kN} \cdot \mathbf{m m})\end{array}$ \\
\hline \multirow{11}{*}{$\begin{array}{c}\mathrm{C} 3 \\
\text { Prismas de arrancamento } \\
\text { Série } 1 \\
V_{\mathrm{f}}=0 \mathrm{~kg} / \mathrm{m}^{3}\end{array}$} & 2 & 46,22 & $\overline{---}$ & $\overline{---}$ & $\overline{---}$ & $\overline{---}$ \\
\hline & 2 & 45,84 & --- & --- & --- & --- \\
\hline & 7 & 61,19 & --- & --- & --- & --- \\
\hline & 7 & 61,22 & --- & --- & --- & --- \\
\hline & 14 & 64,25 & --- & --- & --- & --- \\
\hline & 14 & 61,56 & --- & --- & --- & --- \\
\hline & 28 & 64,68 & 3,60 & --- & --- & --- \\
\hline & 28 & 67,65 & 4,00 & --- & --- & --- \\
\hline & 29 & --- & --- & $37.490,00$ & 5,68 & --- \\
\hline & 29 & --- & --- & $35.782,00$ & 6,85 & --- \\
\hline & 29 & --- & --- & $37.916,00$ & --- & --- \\
\hline
\end{tabular}

Tabela F.4 - Resultados dos ensaios da concretagem 4.

\begin{tabular}{|c|c|c|c|c|c|c|}
\hline \multirow{2}{*}{$\begin{array}{l}\text { Concretagem e tipo do } \\
\text { modelo a ser ensaiado }\end{array}$} & \multirow{2}{*}{$\begin{array}{c}\text { Idade na data de } \\
\text { ensaio } \\
\text { (dias) }\end{array}$} & \multicolumn{2}{|c|}{ CP $10 \times 20$} & \multirow{2}{*}{$\begin{array}{c}\text { CP 15x30 } \\
\mathbf{E}_{\mathrm{c}} \\
(\mathrm{MPa})\end{array}$} & \multicolumn{2}{|c|}{ CP $15 \times 15 \times 50$} \\
\hline & & $\begin{array}{c}\mathbf{f}_{\mathrm{c}} \\
(\mathbf{M P a})\end{array}$ & $\begin{array}{c}\mathbf{f}_{\mathrm{ct}, \mathrm{sp}} \\
(\mathrm{MPa})\end{array}$ & & $\begin{array}{c}\mathbf{f}_{\mathrm{ct}, \mathrm{fl}} \\
(\mathrm{MPa})\end{array}$ & $\begin{array}{c}\mathbf{T}_{\mathrm{b}} \\
(\mathrm{kN} \cdot \mathrm{mm})\end{array}$ \\
\hline \multirow{10}{*}{$\begin{array}{c}\mathrm{C} 4 \\
\text { Prismas de arrancamento } \\
\text { Série } 1 \\
V_{\mathrm{f}}=40 \mathrm{~kg} / \mathrm{m}^{3}\end{array}$} & 2 & 48,38 & --- & --- & --- & --- \\
\hline & 2 & 48,00 & -- & --- & --- & -- \\
\hline & 7 & 62,66 & --- & --- & --- & --- \\
\hline & 7 & 70,04 & --- & --- & --- & --- \\
\hline & 14 & 68,07 & --- & -- & --- & --- \\
\hline & 14 & 72,14 & --- & --- & --- & --- \\
\hline & 28 & 70,88 & 5,23 & --- & --- & -- \\
\hline & 28 & 69,85 & 4,61 & --- & --- & --- \\
\hline & 29 & -- & -- & $37.212,00$ & 5,66 & 46,52 \\
\hline & 29 & -- & -- & $37.319,00$ & 5,95 & -- \\
\hline
\end{tabular}

Tabela F.5 - Resultados dos ensaios da concretagem 5.

\begin{tabular}{|c|c|c|c|c|c|c|}
\hline \multirow{2}{*}{$\begin{array}{l}\text { Concretagem e tipo do } \\
\text { modelo a ser ensaiado }\end{array}$} & \multirow{2}{*}{$\begin{array}{c}\text { Idade na data de } \\
\text { ensaio } \\
\text { (dias) }\end{array}$} & \multicolumn{2}{|c|}{ CP 10x20 } & \multirow{2}{*}{$\begin{array}{c}\text { CP 15x30 } \\
\mathrm{E}_{\mathrm{c}} \\
(\mathrm{MPa})\end{array}$} & \multicolumn{2}{|c|}{ CP $15 \times 15 \times 50$} \\
\hline & & $\begin{array}{c}\mathbf{f}_{\mathbf{c}} \\
(\mathbf{M P a})\end{array}$ & $\begin{array}{c}\mathbf{f}_{\text {ct,sp }} \\
(\mathbf{M P a})\end{array}$ & & $\begin{array}{c}\mathbf{f}_{\mathrm{ct}, \mathrm{fl}} \\
(\mathrm{MPa})\end{array}$ & $\begin{array}{c}\mathrm{T}_{\mathrm{b}} \\
\text { (kN.mm) }\end{array}$ \\
\hline \multirow{14}{*}{$\begin{array}{c}\mathrm{C} 5 \\
\text { Prismas de arrancamento } \\
\text { Série } 1 \\
\mathrm{~V}_{\mathrm{f}}=0 \mathrm{~kg} / \mathrm{m}^{3}\end{array}$} & 2 & 43,90 & --- & --- & --- & --- \\
\hline & 2 & 48,98 & --- & --- & --- & --- \\
\hline & 7 & 63,05 & --- & --- & --- & --- \\
\hline & 7 & 58,02 & --- & --- & --- & --- \\
\hline & 14 & 59,22 & --- & --- & --- & --- \\
\hline & 14 & 68,64 & --- & --- & --- & --- \\
\hline & 21 & 66,26 & --- & --- & --- & --- \\
\hline & 21 & 67,88 & --- & --- & --- & --- \\
\hline & 22 & --- & 3,93 & $37.590,00$ & 5,79 & --- \\
\hline & 22 & --- & 3,81 & $37.075,00$ & 5,52 & --- \\
\hline & 22 & --- & --- & $37.280,00$ & 5,54 & --- \\
\hline & 22 & --- & --- & --- & 5,61 & --- \\
\hline & 23 & 73,22 & --- & --- & --- & --- \\
\hline & 23 & 70,94 & --- & --- & --- & --- \\
\hline
\end{tabular}


Tabela F.6 - Resultados dos ensaios da concretagem 6.

\begin{tabular}{|c|c|c|c|c|c|c|}
\hline \multirow{2}{*}{$\begin{array}{l}\text { Concretagem e tipo do } \\
\text { modelo a ser ensaiado }\end{array}$} & \multirow{2}{*}{$\begin{array}{c}\text { Idade na data de } \\
\text { ensaio } \\
\text { (dias) }\end{array}$} & \multicolumn{2}{|c|}{ CP 10x20 } & \multirow{2}{*}{$\begin{array}{c}\text { CP 15x30 } \\
\mathrm{E}_{\mathrm{c}} \\
(\mathrm{MPa})\end{array}$} & \multicolumn{2}{|c|}{ CP $15 \times 15 \times 50$} \\
\hline & & $\begin{array}{c}\mathbf{f}_{\mathbf{c}} \\
(\mathrm{MPa})\end{array}$ & $\begin{array}{c}\mathbf{f}_{\mathrm{ct}, \mathrm{sp}} \\
(\mathrm{MPa})\end{array}$ & & $\begin{array}{c}\mathbf{f}_{\mathrm{ct}, \mathrm{fl}} \\
(\mathbf{M P a})\end{array}$ & $\begin{array}{c}\mathbf{T}_{\mathrm{b}} \\
(\mathbf{k N} \cdot \mathbf{m m})\end{array}$ \\
\hline \multirow{15}{*}{$\begin{array}{c}\text { C6 } \\
\text { Prismas de arrancamento } \\
\text { Série } 1 \\
\mathrm{~V}_{\mathrm{f}}=40 \mathrm{~kg} / \mathrm{m}^{3}\end{array}$} & 2 & 49,53 & --- & --- & --- & --- \\
\hline & 2 & 48,38 & --- & --- & --- & --- \\
\hline & 7 & 68,36 & --- & --- & --- & --- \\
\hline & 7 & 67,15 & --- & --- & --- & --- \\
\hline & 14 & 71,62 & -- & -- & -- & -- \\
\hline & 14 & 73,21 & --- & --- & --- & --- \\
\hline & 21 & 75,94 & --- & -- & -- & -- \\
\hline & 21 & 75,21 & --- & --- & --- & --- \\
\hline & 22 & --- & 4,58 & $38.253,00$ & --- & --- \\
\hline & 22 & -- & 6,07 & $37.008,00$ & -- & -- \\
\hline & 22 & --- & --- & $38.529,00$ & --- & --- \\
\hline & 23 & 77,41 & -- & -- & 5,15 & 38,00 \\
\hline & 23 & 78,55 & --- & --- & 6,29 & 47,31 \\
\hline & 23 & --- & --- & -- & 6,62 & 38,43 \\
\hline & 24 & --- & --- & --- & 5,77 & 47,18 \\
\hline
\end{tabular}

Tabela F.7 - Resultados dos ensaios da concretagem 7.

\begin{tabular}{c|c|c}
\hline $\begin{array}{c}\text { Concretagem e tipo do } \\
\text { modelo a ser ensaiado }\end{array}$ & $\begin{array}{c}\text { Idade na data de } \\
\text { ensaio } \\
\text { (dias) }\end{array}$ & $\begin{array}{c}\text { CP } \\
\mathbf{1 0 x 2 0}\end{array}$ \\
\hline \multirow{4}{*}{$\begin{array}{c}\mathbf{f}_{\mathbf{c}} \\
\text { (MPa) }\end{array}$} \\
\hline \multirow{4}{*}{$\begin{array}{c}\text { C7 } \\
\text { Prismas de arrancamento } \\
\text { Série 1 } \\
\mathrm{V}_{\mathrm{f}}=0 \mathrm{~kg} / \mathrm{m}^{3}\end{array}$} & 2 & 25,54 \\
\cline { 2 - 3 } & 2 & 36,56 \\
\cline { 2 - 3 } & 7 & 34,47 \\
\cline { 2 - 3 } & 7 & 39,21 \\
\cline { 2 - 3 } & 14 & 36,35 \\
\cline { 2 - 3 } & 21 & 35,59 \\
\cline { 2 - 3 } & 21 & 38,97 \\
\hline & 122 & 33,72 \\
\hline & 122 & 45,45 \\
\hline
\end{tabular}

Tabela F.9 - Resultados dos ensaios da concretagem 9.

\begin{tabular}{c|c|c}
\hline $\begin{array}{c}\text { Concretagem e tipo do } \\
\text { modelo a ser ensaiado }\end{array}$ & $\begin{array}{c}\text { Idade na data de } \\
\text { ensaio } \\
\text { (dias) }\end{array}$ & $\begin{array}{c}\text { CP 10x20 } \\
\text { (MPa) }\end{array}$ \\
\hline & 2 & 42,34 \\
\cline { 2 - 3 } & 2 & 42,40 \\
\cline { 2 - 3 } C9 & 7 & 48,49 \\
\cline { 2 - 3 } & 7 & 51,34 \\
\hline Prismas de arrancamento \\
\cline { 2 - 3 } Série 1 \\
$\mathrm{V}_{\mathrm{f}}=0 \mathrm{~kg} / \mathrm{m}^{3}$ & 14 & 54,25 \\
\hline & 14 & 50,93 \\
\cline { 2 - 3 } & 114 & 71,26 \\
\cline { 2 - 3 } & 114 & 69,35 \\
\hline & 114 & 64,40 \\
\hline
\end{tabular}

Tabela F.10 - Resultados dos ensaios da concretagem 10.

\begin{tabular}{|c|c|c|}
\hline $\begin{array}{l}\text { Concretagem e tipo do } \\
\text { modelo a ser ensaiado }\end{array}$ & $\begin{array}{c}\text { Idade na data de } \\
\text { ensaio } \\
\text { (dias) }\end{array}$ & $\begin{array}{c}\text { CP 10x20 } \\
f_{c} \\
(\mathrm{MPa})\end{array}$ \\
\hline \multirow{10}{*}{$\begin{array}{c}\mathrm{C} 10 \\
\text { Prismas de arrancamento } \\
\text { Série } 1 \\
V_{\mathrm{f}}=60 \mathrm{~kg} / \mathrm{m}^{3}\end{array}$} & 2 & 47,51 \\
\hline & 2 & 53,06 \\
\hline & 7 & 61,97 \\
\hline & 7 & 57,78 \\
\hline & 14 & 64,41 \\
\hline & 14 & 66,93 \\
\hline & 99 & 71,14 \\
\hline & 99 & 75,77 \\
\hline & 99 & 72,91 \\
\hline & 99 & 79,94 \\
\hline
\end{tabular}

Tabela F.8 - Resultados dos ensaios da concretagem 8.

\begin{tabular}{c|c|c}
\hline $\begin{array}{c}\text { Concretagem e tipo do } \\
\text { modelo a ser ensaiado }\end{array}$ & $\begin{array}{c}\text { Idade na data de } \\
\text { ensaio } \\
\text { (dias) }\end{array}$ & $\begin{array}{c}\text { CP } \\
\mathbf{1 0 x 2 0}\end{array}$ \\
\hline \multirow{4}{*}{$\begin{array}{c}\mathbf{f}_{\mathbf{c}} \\
\text { (MPa) }\end{array}$} \\
\hline \multirow{4}{*}{$\begin{array}{c}\text { C8 } \\
\text { Prismas de arrancamento } \\
\text { Série 1 } \\
\mathrm{V}_{\mathrm{f}}=40 \mathrm{~kg} / \mathrm{m}^{3}\end{array}$} & 2 & 45,65 \\
\cline { 2 - 3 } & 2 & 47,67 \\
\cline { 2 - 3 } & 7 & 55,56 \\
\cline { 2 - 3 } & 14 & 54,09 \\
\cline { 2 - 3 } & 14 & 60,18 \\
\cline { 2 - 3 } & 115 & 56,77 \\
\cline { 2 - 3 } & 115 & 73,72 \\
\hline & 118 & 70,70 \\
\hline & 118 & 73,41 \\
\hline
\end{tabular}


Tabela F.11 - Resultados dos ensaios da concretagem 11.

\begin{tabular}{|c|c|c|c|c|c|c|}
\hline \multirow{2}{*}{$\begin{array}{l}\text { Concretagem e tipo do } \\
\text { modelo a ser ensaiado }\end{array}$} & \multirow{2}{*}{$\begin{array}{c}\text { Idade na data de } \\
\text { ensaio } \\
\text { (dias) }\end{array}$} & \multicolumn{2}{|c|}{ CP 10x20 } & \multirow{2}{*}{$\begin{array}{c}\text { CP 15x30 } \\
\mathbf{E}_{\mathrm{c}} \\
(\mathrm{MPa})\end{array}$} & \multicolumn{2}{|c|}{ CP $15 \times 15 \times 50$} \\
\hline & & $\begin{array}{c}\mathbf{f}_{\mathbf{c}} \\
(\mathbf{M P a})\end{array}$ & $\begin{array}{c}\mathbf{f}_{\mathrm{ct}, \mathrm{sp}} \\
(\mathbf{M P a})\end{array}$ & & $\begin{array}{c}\mathbf{f}_{\mathrm{ct}, \mathrm{fl}} \\
(\mathrm{MPa})\end{array}$ & $\begin{array}{c}\mathbf{T}_{\mathbf{b}} \\
(\mathbf{k N} \cdot \mathbf{m m})\end{array}$ \\
\hline \multirow{16}{*}{$\begin{array}{c}\mathrm{C} 11 \\
\text { Prismas de arrancamento } \\
\text { Série } 1 \\
\mathrm{~V}_{\mathrm{f}}=60 \mathrm{~kg} / \mathrm{m}^{3}\end{array}$} & 2 & 51,51 & --- & --- & --- & --- \\
\hline & 2 & 53,43 & --- & -- & -- & --- \\
\hline & 2 & $48,52^{2}$ & --- & --- & --- & --- \\
\hline & 2 & 43,72 & --- & --- & --- & --- \\
\hline & 7 & 55,04 & --- & --- & --- & --- \\
\hline & 7 & 59,46 & --- & -- & -- & --- \\
\hline & 14 & 62,88 & --- & -- & $\begin{array}{ll}-- \\
\end{array}$ & --- \\
\hline & 14 & 58,85 & --- & --- & --- & --- \\
\hline & 21 & 65,31 & --- & --- & --- & --- \\
\hline & 21 & 58,45 & --- & --- & --- & --- \\
\hline & 30 & 60,75 & 5,08 & $39.654,00$ & 7,83 & --- \\
\hline & 30 & 67,29 & 5,74 & $41.016,00$ & 7,17 & --- \\
\hline & 30 & 64,89 & 4,88 & $42.428,00$ & --- & --- \\
\hline & 30 & --- & 4,99 & --- & --- & --- \\
\hline & 86 & 72,91 & --- & --- & --- & --- \\
\hline & 86 & 75,94 & --- & --- & --- & --- \\
\hline
\end{tabular}

Tabela F.12 - Resultados dos ensaios da concretagem 12.

\begin{tabular}{c|c|c}
\hline $\begin{array}{c}\text { Concretagem e tipo do } \\
\text { modelo a ser ensaiado }\end{array}$ & $\begin{array}{c}\text { Idade na data de } \\
\text { ensaio } \\
\text { (dias) }\end{array}$ & $\begin{array}{c}\text { CP 10x20 } \\
\text { (MPa) }\end{array}$ \\
\hline \multirow{4}{*}{$\begin{array}{c}\mathbf{f}_{\mathbf{c}} \\
\text { C12 }\end{array}$} & 2 & 50,10 \\
\cline { 2 - 3 } Prismas de arrancamento \\
\cline { 2 - 3 } RILEM \\
\cline { 2 - 3 } Série 2 \\
\cline { 2 - 3 } $\mathrm{V}_{\mathrm{f}}=0 \mathrm{~kg} / \mathrm{m}^{3}$ & 2 & 50,44 \\
\hline & 7 & 70,59 \\
\hline & 14 & 72,42 \\
\hline & 28 & 72,00 \\
\hline & 28 & 79,84 \\
\hline & 29 & 78,85 \\
\hline
\end{tabular}

\begin{tabular}{|c|c|c|}
\hline $\begin{array}{l}\text { Concretagem e tipo do } \\
\text { modelo a ser ensaiado }\end{array}$ & $\begin{array}{c}\text { Idade na data de } \\
\text { ensaio } \\
\text { (dias) }\end{array}$ & $\begin{array}{c}\text { CP 10x20 } \\
f_{c} \\
(\mathbf{M P a}) \\
\end{array}$ \\
\hline \multirow{10}{*}{$\begin{array}{c}\mathrm{C} 13 \\
\text { Prismas de arrancamento } \\
\text { RILEM } \\
\text { Série } 2 \\
\mathrm{~V}_{\mathrm{f}}=40 \mathrm{~kg} / \mathrm{m}^{3}\end{array}$} & 2 & 50,34 \\
\hline & 2 & 49,93 \\
\hline & 7 & 66,76 \\
\hline & 7 & 66,60 \\
\hline & 14 & 65,32 \\
\hline & 14 & 67,32 \\
\hline & 14 & 64,05 \\
\hline & 14 & 69,41 \\
\hline & 15 & 64,38 \\
\hline & 15 & 66,73 \\
\hline
\end{tabular}

Tabela F.14 - Resultados dos ensaios da concretagem 14.

\begin{tabular}{|c|c|c|c|c|c|c|}
\hline \multirow{2}{*}{$\begin{array}{l}\text { Concretagem e tipo do } \\
\text { modelo a ser ensaiado }\end{array}$} & \multirow{2}{*}{$\begin{array}{c}\text { Idade na data de } \\
\text { ensaio } \\
\text { (dias) }\end{array}$} & \multicolumn{2}{|c|}{ CP 10x20 } & \multirow{2}{*}{$\begin{array}{c}\text { CP 15x30 } \\
\begin{array}{c}\mathbf{E}_{\mathrm{c}} \\
(\mathrm{MPa})\end{array}\end{array}$} & \multicolumn{2}{|c|}{ CP $15 \times 15 \times 50$} \\
\hline & & $\begin{array}{c}\mathbf{f}_{\mathbf{c}} \\
(\mathbf{M P a})\end{array}$ & $\begin{array}{c}\mathbf{f}_{\text {ct,sp }} \\
(\mathbf{M P a})\end{array}$ & & $\begin{array}{c}\mathbf{f}_{\mathrm{ct}, \mathrm{fl}} \\
(\mathrm{MPa})\end{array}$ & $\begin{array}{c}\mathbf{T}_{\mathbf{b}} \\
(\mathbf{k N} \cdot \mathbf{m m}) \\
\end{array}$ \\
\hline \multirow{10}{*}{$\begin{array}{c}\mathrm{C} 14 \\
\text { Prismas de arrancamento } \\
\text { RILEM } \\
\text { Série } 2 \\
\mathrm{~V}_{\mathrm{f}}=60 \mathrm{~kg} / \mathrm{m}^{3}\end{array}$} & 2 & 55,26 & --- & --- & --- & --- \\
\hline & 2 & 51,75 & --- & --- & --- & --- \\
\hline & 7 & 66,73 & --- & --- & --- & --- \\
\hline & 7 & 66,05 & --- & --- & --- & --- \\
\hline & 14 & 66,63 & --- & --- & -- & --- \\
\hline & 14 & 70,11 & --- & --- & --- & --- \\
\hline & 15 & 71,09 & --- & --- & --- & --- \\
\hline & 15 & 68,60 & --- & --- & --- & -- \\
\hline & 16 & 73,96 & --- & --- & --- & --- \\
\hline & 16 & 71,17 & --- & --- & --- & --- \\
\hline
\end{tabular}

\footnotetext{
${ }^{2}$ Os corpos-de-prova apresentavam nichos de concretagem (vazios) enormes.
} 
Tabela F.15 - Resultados dos ensaios da concretagem 15.

\begin{tabular}{|c|c|c|c|c|c|c|}
\hline \multirow{2}{*}{$\begin{array}{l}\text { Concretagem e tipo do } \\
\text { modelo a ser ensaiado }\end{array}$} & \multirow{2}{*}{$\begin{array}{c}\text { Idade na data de } \\
\text { ensaio } \\
\text { (dias) }\end{array}$} & \multicolumn{2}{|c|}{ CP $10 \times 20$} & \multirow{2}{*}{$\begin{array}{c}\text { CP 15x30 } \\
\begin{array}{c}\mathbf{E}_{\mathbf{c}} \\
(\mathrm{MPa})\end{array}\end{array}$} & \multicolumn{2}{|c|}{ CP $15 \times 15 \times 50$} \\
\hline & & $\begin{array}{c}\mathbf{f}_{\mathrm{c}} \\
(\mathbf{M P a})\end{array}$ & $\begin{array}{c}\mathbf{f}_{\mathrm{ct}, \mathrm{sp}} \\
(\mathbf{M P a})\end{array}$ & & $\begin{array}{c}\mathbf{f}_{\mathrm{ct}, \mathrm{fl}} \\
(\mathrm{MPa})\end{array}$ & $\begin{array}{c}\mathbf{T}_{\mathrm{b}} \\
\text { (kN.mm) }\end{array}$ \\
\hline \multirow{7}{*}{$\begin{array}{c}\mathrm{C} 15 \\
\text { Determinação de } \\
\text { propriedades para os } \\
\text { traços dos prismas de } \\
\text { arrancamento (Séries } 1 \mathrm{e} \\
2 \text { ) } \\
\mathrm{V}_{\mathrm{f}}=60 \mathrm{~kg} / \mathrm{m}^{3}\end{array}$} & 7 & 56,59 & --- & --- & --- & --- \\
\hline & 7 & 64,07 & --- & --- & --- & --- \\
\hline & 7 & 60,81 & --- & --- & --- & --- \\
\hline & 28 & 70,55 & 5,34 & $43.848,00$ & 7,81 & 63,31 \\
\hline & 28 & 68,31 & 5,71 & $39.800,00$ & 7,30 & 80,34 \\
\hline & 28 & 61,16 & 6,01 & $39.126,00$ & 7,49 & 65,79 \\
\hline & 28 & --- & 5,46 & --- & 7,15 & 86,50 \\
\hline
\end{tabular}

Tabela F.16 - Resultados dos ensaios da concretagem 16.

\begin{tabular}{|c|c|c|c|c|c|c|}
\hline \multirow{2}{*}{$\begin{array}{l}\text { Concretagem e tipo do } \\
\text { modelo a ser ensaiado }\end{array}$} & \multirow{2}{*}{$\begin{array}{c}\text { Idade na data de } \\
\text { ensaio } \\
\text { (dias) }\end{array}$} & \multicolumn{2}{|c|}{ CP 10x20 } & \multirow{2}{*}{$\begin{array}{c}\text { CP 15x30 } \\
\mathbf{E}_{\mathrm{c}} \\
(\mathrm{MPa})\end{array}$} & \multicolumn{2}{|c|}{ CP $15 \times 15 \times 50$} \\
\hline & & $\begin{array}{c}\mathbf{f}_{\mathrm{c}} \\
(\mathbf{M P a}) \\
\end{array}$ & $\begin{array}{c}\mathbf{f}_{\text {ct,sp }} \\
(\mathbf{M P a})\end{array}$ & & $\begin{array}{c}\mathbf{f}_{\mathrm{ct}, \mathrm{fl}} \\
(\mathrm{MPa})\end{array}$ & $\begin{array}{c}\mathrm{T}_{\mathrm{b}} \\
(\mathrm{kN} \cdot \mathrm{mm}) \\
\end{array}$ \\
\hline \multirow{7}{*}{$\begin{array}{c}\mathrm{C} 16 \\
\text { Determinação de } \\
\text { propriedades para os } \\
\text { traços das vigas } \\
\mathrm{V}_{\mathrm{f}}=0 \mathrm{~kg} / \mathrm{m}^{3}\end{array}$} & 2 & 49,78 & --- & --- & --- & --- \\
\hline & 2 & 54,75 & --- & --- & --- & --- \\
\hline & 2 & 50,49 & --- & --- & --- & --- \\
\hline & 28 & 70,06 & 4,67 & $41.433,00$ & 6,19 & --- \\
\hline & 28 & 67,65 & 5,52 & $42.464,00$ & 6,97 & --- \\
\hline & 28 & 66,32 & 5,12 & $39.734,00$ & 7,27 & --- \\
\hline & 28 & --- & 4,88 & --- & 6,35 & --- \\
\hline
\end{tabular}

Tabela F.17 - Resultados dos ensaios da concretagem 17.

\begin{tabular}{|c|c|c|c|c|c|c|}
\hline \multirow{2}{*}{$\begin{array}{l}\text { Concretagem e tipo do } \\
\text { modelo a ser ensaiado }\end{array}$} & \multirow{2}{*}{$\begin{array}{c}\text { Idade na data de } \\
\text { ensaio } \\
\text { (dias) }\end{array}$} & \multicolumn{2}{|c|}{ CP 10x20 } & \multirow{2}{*}{$\begin{array}{c}\text { CP 15x30 } \\
\mathbf{E}_{\mathrm{c}} \\
(\mathrm{MPa})\end{array}$} & \multicolumn{2}{|c|}{ CP $15 \times 15 \times 50$} \\
\hline & & $\begin{array}{c}\mathbf{f}_{\mathbf{c}} \\
(\mathbf{M P a})\end{array}$ & $\begin{array}{c}\mathbf{f}_{\mathrm{ct}, \mathrm{sp}} \\
(\mathbf{M P a})\end{array}$ & & $\begin{array}{c}\mathbf{f}_{\mathrm{ct}, \mathrm{fl}} \\
(\mathbf{M P a})\end{array}$ & $\begin{array}{c}T_{b} \\
(k N . m m)\end{array}$ \\
\hline \multirow{7}{*}{$\begin{array}{c}\mathrm{C} 17 \\
\text { Determinação de } \\
\text { propriedades para os } \\
\text { traços vigas } \\
\mathrm{V}_{\mathrm{f}}=40 \mathrm{~kg} / \mathrm{m}^{3}\end{array}$} & 7 & 61,50 & --- & --- & --- & --- \\
\hline & 7 & 67,74 & --- & --- & --- & --- \\
\hline & 7 & 70,97 & --- & --- & --- & --- \\
\hline & 29 & 73,30 & 4,12 & $41.724,00$ & 7,36 & --- \\
\hline & 29 & 78,52 & 5,22 & $43.546,00$ & 7,14 & 82,26 \\
\hline & 29 & 76,15 & 5,38 & $39.678,00$ & 6,41 & 62,22 \\
\hline & 29 & --- & 4,97 & --- & 7,33 & 38,33 \\
\hline
\end{tabular}

Tabela F.18 - Resultados dos ensaios da concretagem 18.

\begin{tabular}{|c|c|c|c|c|c|c|}
\hline \multirow{2}{*}{$\begin{array}{l}\text { Concretagem e tipo do } \\
\text { modelo a ser ensaiado }\end{array}$} & \multirow{2}{*}{$\begin{array}{c}\text { Idade na data de } \\
\text { ensaio } \\
\text { (dias) }\end{array}$} & \multicolumn{2}{|c|}{ CP 10x20 } & \multirow{2}{*}{$\begin{array}{c}\text { CP 15x30 } \\
\mathbf{E}_{\mathrm{c}} \\
(\mathrm{MPa})\end{array}$} & \multicolumn{2}{|c|}{ CP $15 \times 15 \times 50$} \\
\hline & & $\begin{array}{c}\mathbf{f}_{\mathrm{c}} \\
(\mathbf{M P a})\end{array}$ & $\begin{array}{c}\mathbf{f}_{\text {ct,sp }} \\
(\mathbf{M P a})\end{array}$ & & $\begin{array}{c}\mathbf{f}_{\mathrm{ct}, \mathrm{fl}} \\
(\mathbf{M P a})\end{array}$ & $\begin{array}{c}\mathbf{T}_{\mathbf{b}} \\
(\mathbf{k N} \cdot \mathbf{m m})\end{array}$ \\
\hline \multirow{7}{*}{$\begin{array}{c}\mathrm{C} 18 \\
\text { Determinação de } \\
\text { propriedades para os } \\
\text { traços das vigas } \\
\mathrm{V}_{\mathrm{f}}=60 \mathrm{~kg} / \mathrm{m}^{3}\end{array}$} & 3 & 69,60 & -- & -- & -- & -- \\
\hline & 3 & 62,71 & --- & --- & --- & --- \\
\hline & 3 & 59,36 & --- & --- & --- & --- \\
\hline & 30 & 86,62 & 5,40 & $38.583,00$ & 6,48 & 57,99 \\
\hline & 30 & 84,62 & 6,25 & $39.650,00$ & 6,93 & 60,52 \\
\hline & 30 & 81,85 & 6,26 & $39.893,00$ & 6,47 & 59,81 \\
\hline & 30 & $\begin{array}{ll}-- \\
--\end{array}$ & 6,00 & $\begin{array}{ll}-- \\
--\end{array}$ & 7,65 & 83,61 \\
\hline
\end{tabular}


Tabela F.19 - Resultados dos ensaios da concretagem 19.

\begin{tabular}{c|c|c}
\hline $\begin{array}{c}\text { Concretagem e tipo do } \\
\text { modelo a ser ensaiado }\end{array}$ & $\begin{array}{c}\text { Idade na data de } \\
\text { ensaio } \\
\text { (dias) }\end{array}$ & $\begin{array}{c}\text { CP 10x20 } \\
\text { (MPa) }\end{array}$ \\
\hline & 7 & 64,76 \\
\hline \multirow{2}{C}{19} & 7 & 62,49 \\
\hline $\begin{array}{c}\mathbf{f}_{\mathbf{c}} \\
\mathrm{V}_{\mathrm{f}}=0 \mathrm{~kg} / \mathrm{m}^{3}\end{array}$ & 30 & 73,86 \\
\hline & 30 & 69,75 \\
\hline & 30 & 74,50 \\
\hline
\end{tabular}

Tabela F.20 - Resultados dos ensaios da concretagem 20.

Tabela F.21 - Resultados dos ensaios da concretagem 21.

\begin{tabular}{|c|c|c|}
\hline $\begin{array}{l}\text { Concretagem e tipo do } \\
\text { modelo a ser ensaiado }\end{array}$ & $\begin{array}{c}\text { Idade na data de } \\
\text { ensaio } \\
\text { (dias) }\end{array}$ & $\begin{array}{c}\text { CP 10x20 } \\
f_{c} \\
(\mathrm{MPa})\end{array}$ \\
\hline \multirow{6}{*}{$\begin{array}{c}\mathrm{C} 21 \\
\text { Vigas } \\
\mathrm{V}_{\mathrm{f}}=60 \mathrm{~kg} / \mathrm{m}^{3}\end{array}$} & 3 & 58,16 \\
\hline & 3 & 56,74 \\
\hline & 25 & 71,32 \\
\hline & 25 & 70,07 \\
\hline & 25 & 70,52 \\
\hline & 25 & 74,78 \\
\hline
\end{tabular}

\begin{tabular}{c|c|c}
$\begin{array}{c}\text { Concretagem e tipo do } \\
\text { modelo a ser ensaiado }\end{array}$ & $\begin{array}{c}\text { Idade na data de } \\
\text { ensaio } \\
\text { (dias) }\end{array}$ & $\begin{array}{c}\text { CP 10x20 } \\
\text { (MPa) }\end{array}$ \\
\hline \multirow{4}{*}{$\begin{array}{c}\mathbf{f}_{\mathbf{c}} \\
\text { C20 } \\
\text { Vigas } \\
\mathrm{V}_{\mathrm{f}}=40 \mathrm{~kg} / \mathrm{m}^{3}\end{array}$} & 3 & 51,46 \\
\hline & 3 & 53,51 \\
\cline { 2 - 3 } & 30 & 63,31 \\
\hline & 30 & 66,97 \\
\hline
\end{tabular}

Tabela F.22 - Resultados dos ensaios da concretagem 22.

Tabela F.23 - Resultados dos ensaios da concretagem 23.

\begin{tabular}{c|c|c}
\hline $\begin{array}{c}\text { Concretagem e tipo do } \\
\text { modelo a ser ensaiado }\end{array}$ & $\begin{array}{c}\text { Idade na data de } \\
\text { ensaio } \\
\text { (dias) }\end{array}$ & $\begin{array}{c}\text { CP 10x20 } \\
\text { (MPa) }\end{array}$ \\
\hline & 5 & $\mathbf{\mathbf { f } _ { \mathbf { c } }}$ \\
\cline { 2 - 3 } $\mathrm{C} 23$ & 5 & $61,33^{\mathbf{3}}$ \\
\hline $\begin{array}{c}\mathrm{Vigas} \\
\mathrm{V}_{\mathrm{f}}=40 \mathrm{~kg} / \mathrm{m}^{3}\end{array}$ & 5 & 65,60 \\
\hline & 29 & 73,97 \\
\hline & 29 & 75,12 \\
\hline
\end{tabular}

Tabela F.24 - Resultados dos ensaios da concretagem 24.

\begin{tabular}{c|c|c}
\hline $\begin{array}{c}\text { Concretagem e tipo do } \\
\text { modelo a ser ensaiado }\end{array}$ & $\begin{array}{c}\text { Idade na data de } \\
\text { ensaio } \\
\text { (dias) }\end{array}$ & $\begin{array}{c}\text { CP 10x20 } \\
\text { (MPa) }\end{array}$ \\
\hline & 5 & 62,71 \\
\cline { 2 - 3 } C24 & 5 & 63,08 \\
\cline { 2 - 3 } Vigas \\
$V_{\mathrm{f}}=60 \mathrm{~kg} / \mathrm{m}^{3}$ & 22 & 72,50 \\
\cline { 2 - 3 } & 22 & 70,23 \\
\hline & 25 & 70,13 \\
\hline
\end{tabular}

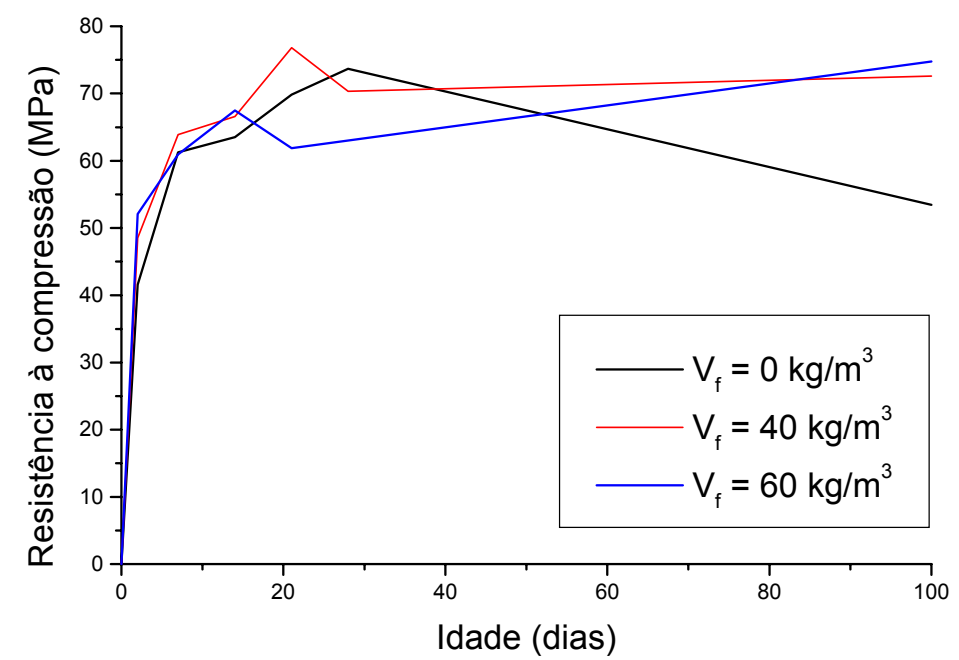

Figura F.1 - Gráficos Resistência do concreto à compressão versus Idade, para os valores médios referentes aos três volumes de fibras, para todas as concretagens,.

\footnotetext{
${ }^{3} \mathrm{O}$ corpo-de-prova apresentava nichos de concretagem (vazios) enormes.
} 

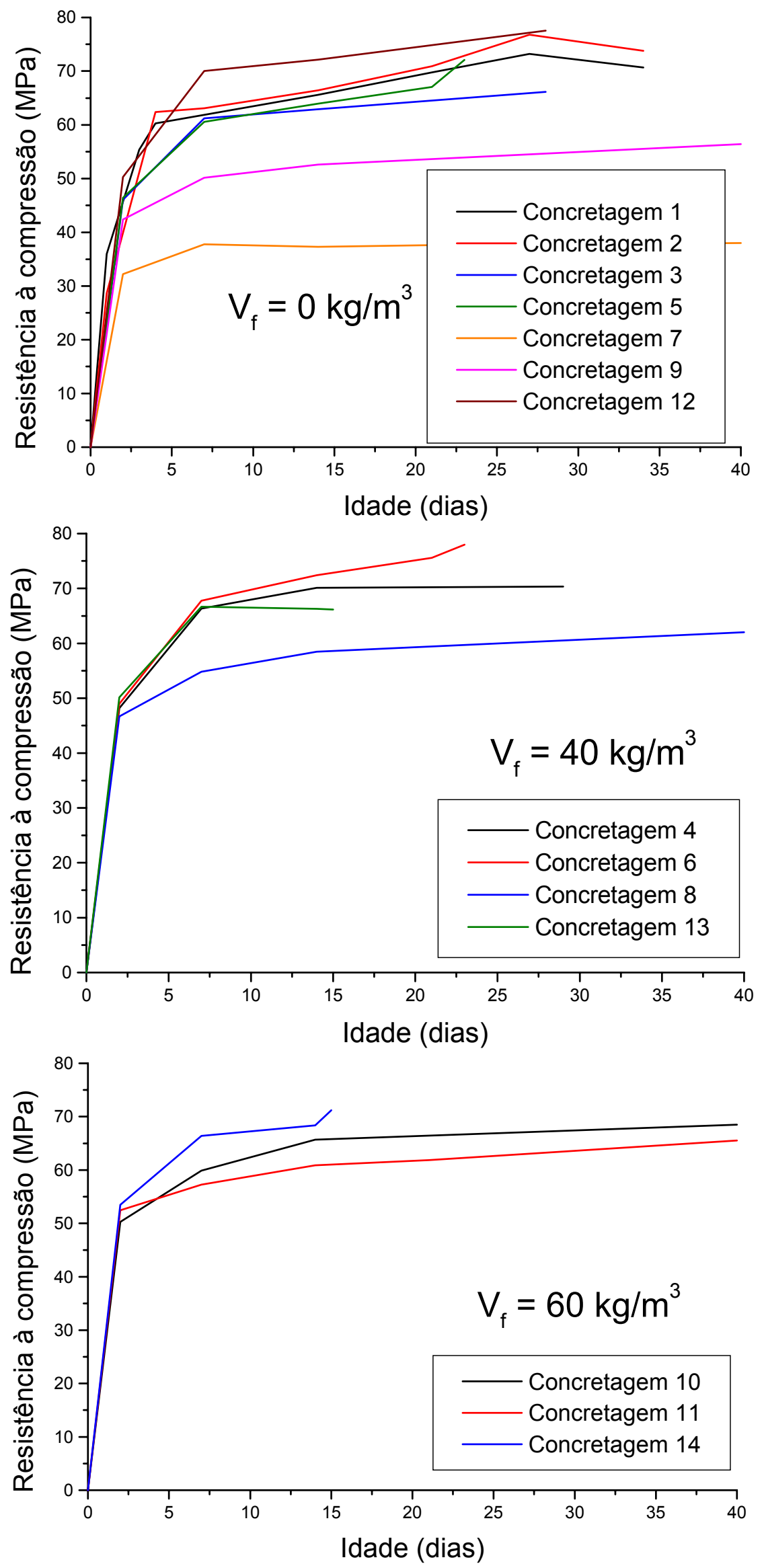

Figura F.2 - Gráficos Resistência do concreto à compressão versus Idade, para todas as concretagens de 1 a 14 . 

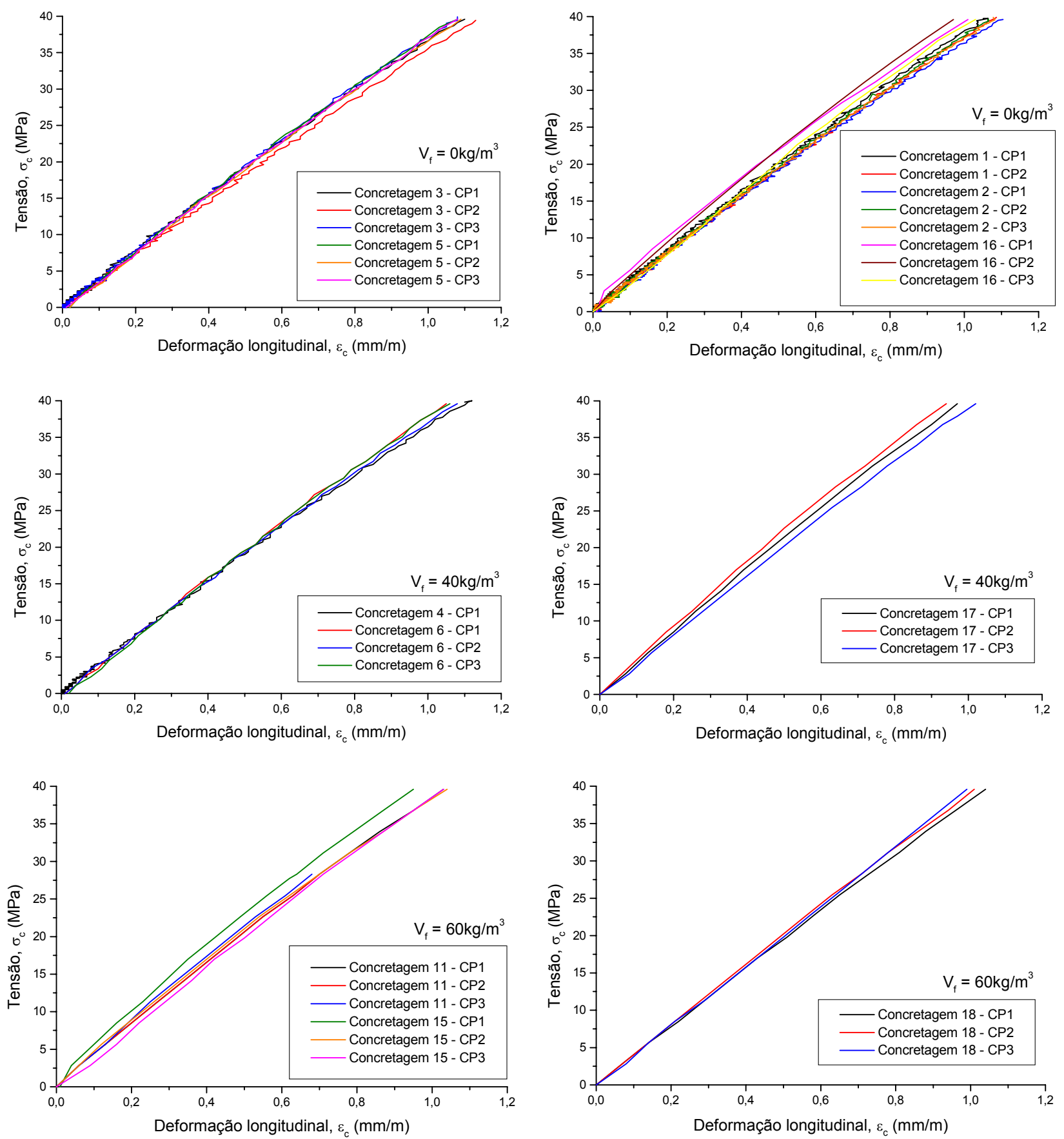

(a) Prismas (Séries 1 e 2)

(b) Vigas

Figura F.3 - Gráficos Tensão versus Deformação longitudinal do concreto, para as diversas concretagens: (a) para as concretagens dos prismas de arrancamento das Séries 1 e 2; (b) para as concretagens das vigas. 


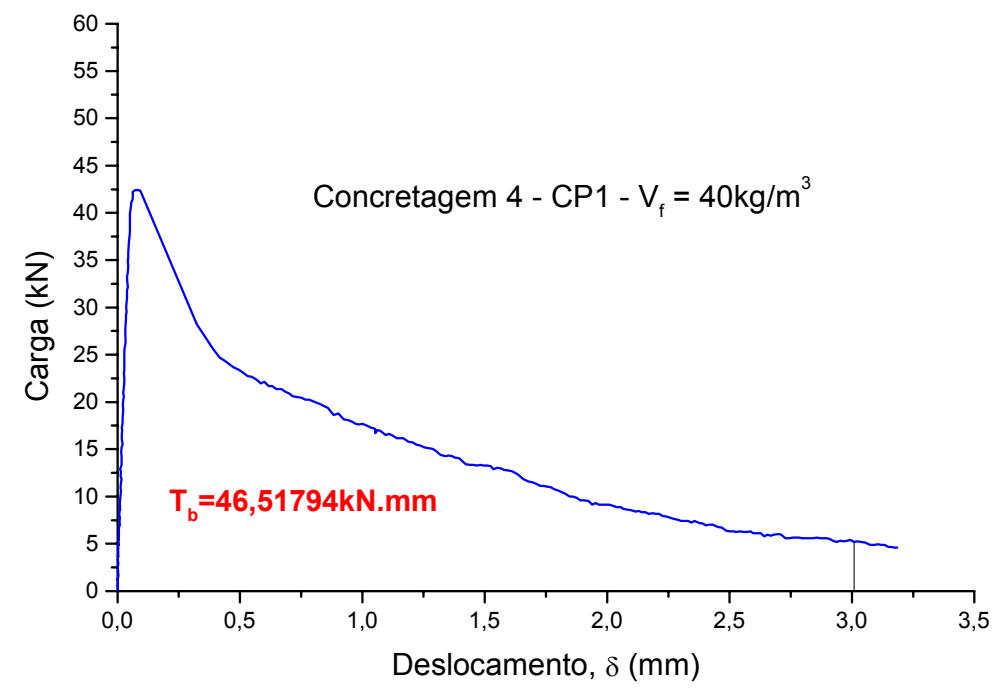

Figura F.4 - Gráfico Carga versus Deslocamento para a concretagem 4.

Tabela F.25 - Resultados do cálculo de tenacidade para a concretagem 4.

\begin{tabular}{c|c|c|c|c}
\hline Modelo & $\mathbf{F}_{\text {máx }}$ & $\mathbf{f}_{\mathbf{r}}$ & $\mathbf{T}_{\mathbf{b}}$ & $\overline{\sigma_{\mathbf{b}}}$ \\
& $\mathbf{( k N )}$ & $\mathbf{( M P a )}$ & $\mathbf{( k N . m m )}$ & $\mathbf{( M P a )}$ \\
\hline $\mathrm{CP} 1$ & 42,42 & 5,66 & 46,52 & 2,07 \\
\hline
\end{tabular}
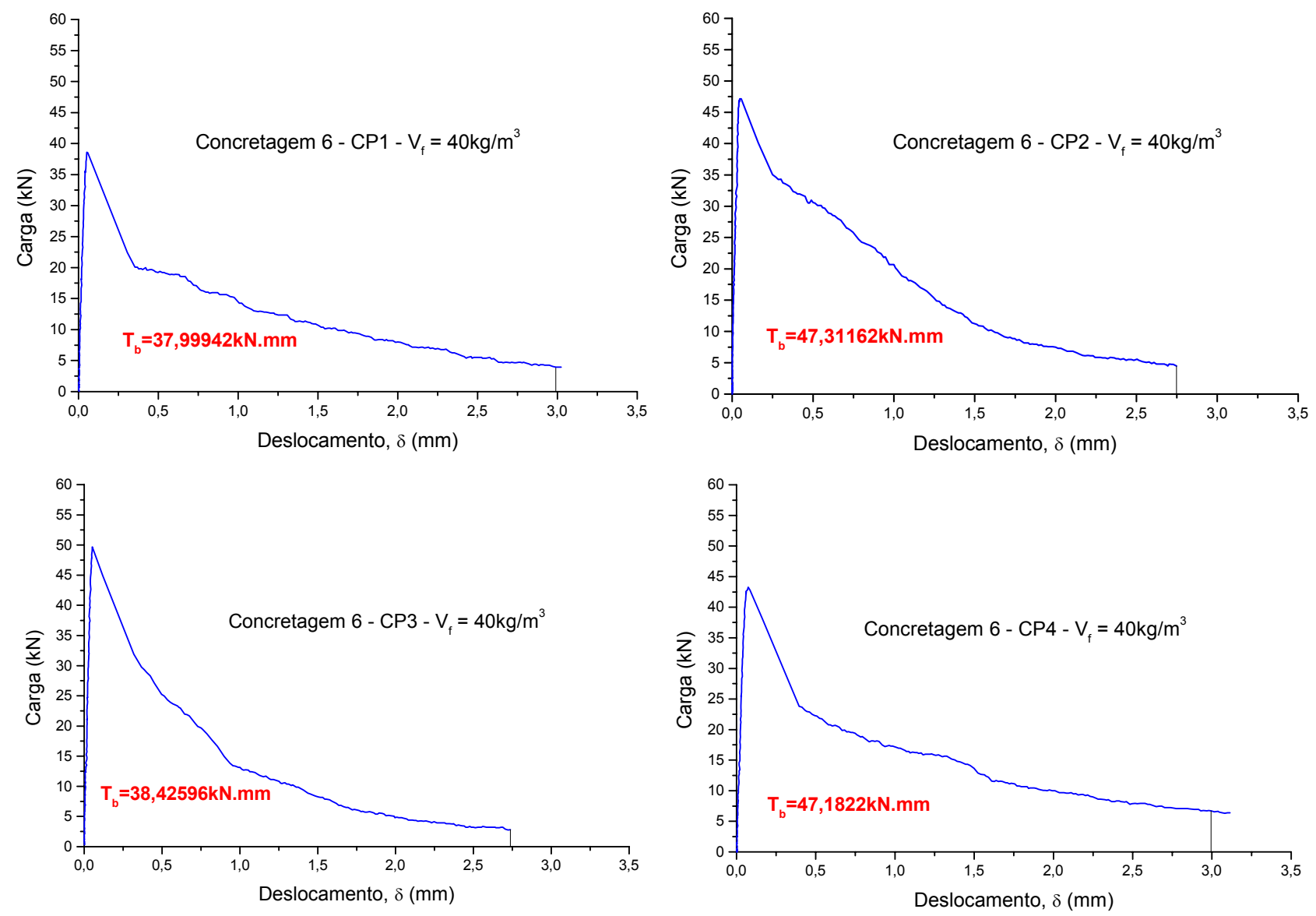

Figura F.5 - Gráficos Carga versus Deslocamento para a concretagem 6. 
Tabela F.26 - Resultados do cálculo de tenacidade para a concretagem 6.

\begin{tabular}{c|c|c|c|c}
\hline Modelo & $\begin{array}{c}\mathbf{F}_{\text {máx }} \\
\mathbf{( k N )}\end{array}$ & $\begin{array}{c}\mathbf{f}_{\mathbf{r}} \\
\mathbf{( M P a )}\end{array}$ & $\begin{array}{c}\mathbf{T}_{\mathbf{b}} \\
\mathbf{( k N . m m )}\end{array}$ & $\begin{array}{c}\overline{\sigma_{\mathbf{b}}} \\
\mathbf{( M P a )}\end{array}$ \\
\hline $\mathrm{CP} 1$ & 38,61 & 5,15 & 38,00 & 1,69 \\
\hline $\mathrm{CP} 2$ & 47,16 & 6,29 & 47,31 & 2,10 \\
\hline $\mathrm{CP} 3$ & 49,67 & 6,62 & 38,43 & 1,71 \\
\hline $\mathrm{CP} 4$ & 43,26 & 5,77 & 47,18 & 2,10 \\
\hline
\end{tabular}
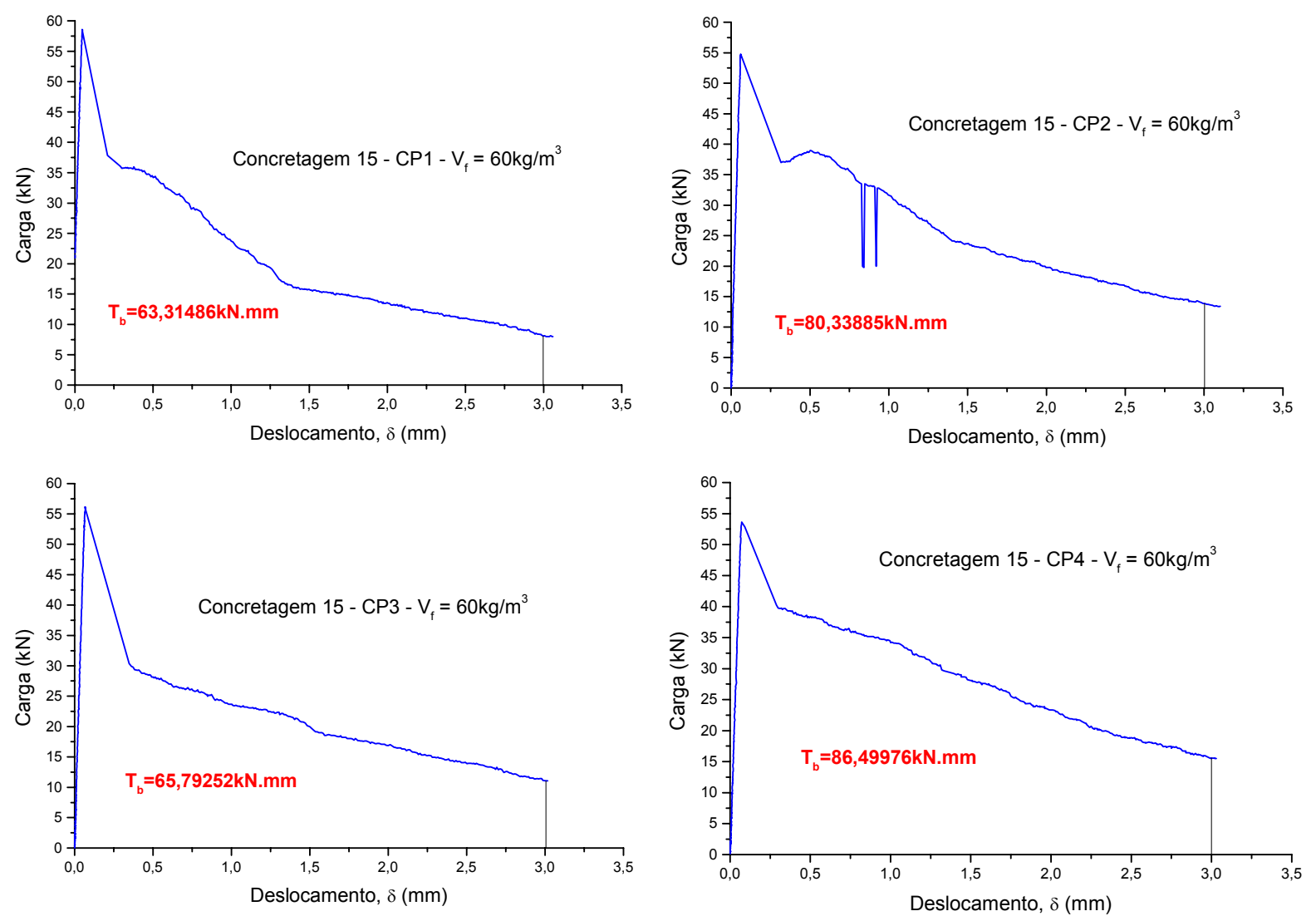

Figura F.6 - Gráficos Carga versus Deslocamento para a concretagem 15.

Tabela F.27 - Resultados do cálculo de tenacidade para a concretagem 15.

\begin{tabular}{c|c|c|c|c}
\hline Modelo & $\begin{array}{c}\mathbf{F}_{\text {máx }} \\
(\mathbf{k N})\end{array}$ & $\begin{array}{c}\mathbf{f}_{\mathbf{r}} \\
\mathbf{( M P a )}\end{array}$ & $\begin{array}{c}\mathbf{T}_{\mathbf{b}} \\
\mathbf{( k N . m m )}\end{array}$ & $\begin{array}{c}\overline{\sigma_{\mathbf{b}}} \\
\mathbf{( M P a )}\end{array}$ \\
\hline CP1 & 58,60 & 7,81 & 63,31 & 2,81 \\
\hline CP2 & 54,79 & 7,30 & 80,34 & 3,57 \\
\hline CP3 & 56,16 & 7,49 & 65,79 & 2,92 \\
\hline CP4 & 53,64 & 7,15 & 86,50 & 3,84 \\
\hline
\end{tabular}



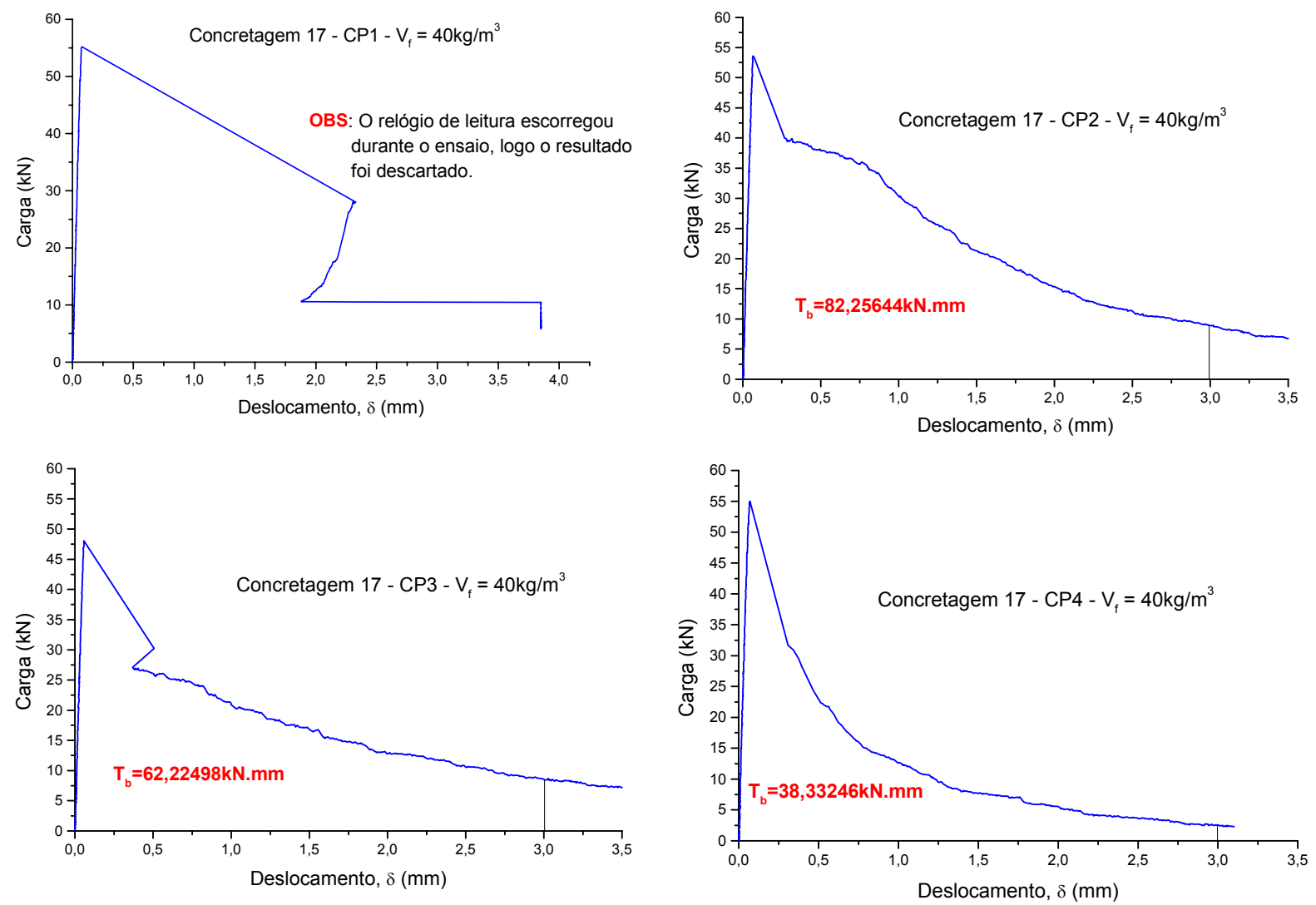

Figura F.7 - Gráficos Carga versus Deslocamento para a concretagem 17.

Tabela F.28 - Resultados do cálculo de tenacidade para a concretagem 17.

\begin{tabular}{c|c|c|c|c}
\hline Modelo & $\begin{array}{c}\mathbf{F}_{\text {máx }} \\
(\mathbf{k N})\end{array}$ & $\begin{array}{c}\mathbf{f}_{\mathbf{r}} \\
\mathbf{( M P a )}\end{array}$ & $\begin{array}{c}\mathbf{T}_{\mathbf{b}} \\
\mathbf{( k N . m m )}\end{array}$ & $\begin{array}{c}\overline{\sigma_{\mathbf{b}}} \\
\mathbf{( M P a )}\end{array}$ \\
\hline $\mathrm{CP} 1$ & 55,17 & 7,36 & --- & -- \\
\hline $\mathrm{CP} 2$ & 53,56 & 7,14 & 82,26 & 3,66 \\
\hline $\mathrm{CP} 3$ & 48,07 & 6,41 & 62,22 & 2,77 \\
\hline $\mathrm{CP} 4$ & 55,01 & 7,33 & 38,33 & 1,70 \\
\hline
\end{tabular}

Tabela F.29 - Resultados do cálculo de tenacidade para a concretagem 18.

\begin{tabular}{|c|c|c|c|c|}
\hline Modelo & $\begin{array}{l}\mathrm{F}_{\text {máx }} \\
(\mathrm{kN})\end{array}$ & $\begin{array}{c}\mathbf{f}_{\mathrm{r}} \\
(\mathrm{MPa})\end{array}$ & $\begin{array}{c}\mathrm{T}_{\mathrm{b}} \\
(\mathrm{kN} . \mathrm{mm})\end{array}$ & $\begin{array}{c}\overline{\sigma_{b}} \\
(\mathbf{M P a})\end{array}$ \\
\hline CP1 & 48,61 & 6,48 & 57,99 & 2,58 \\
\hline CP2 & $\begin{array}{l}51,96 \\
\end{array}$ & 6,93 & 60,52 & 2,69 \\
\hline CP3 & 48,53 & 6,47 & 59,81 & 2,66 \\
\hline CP4 & 57,38 & 7,65 & 83,61 & 3,72 \\
\hline
\end{tabular}



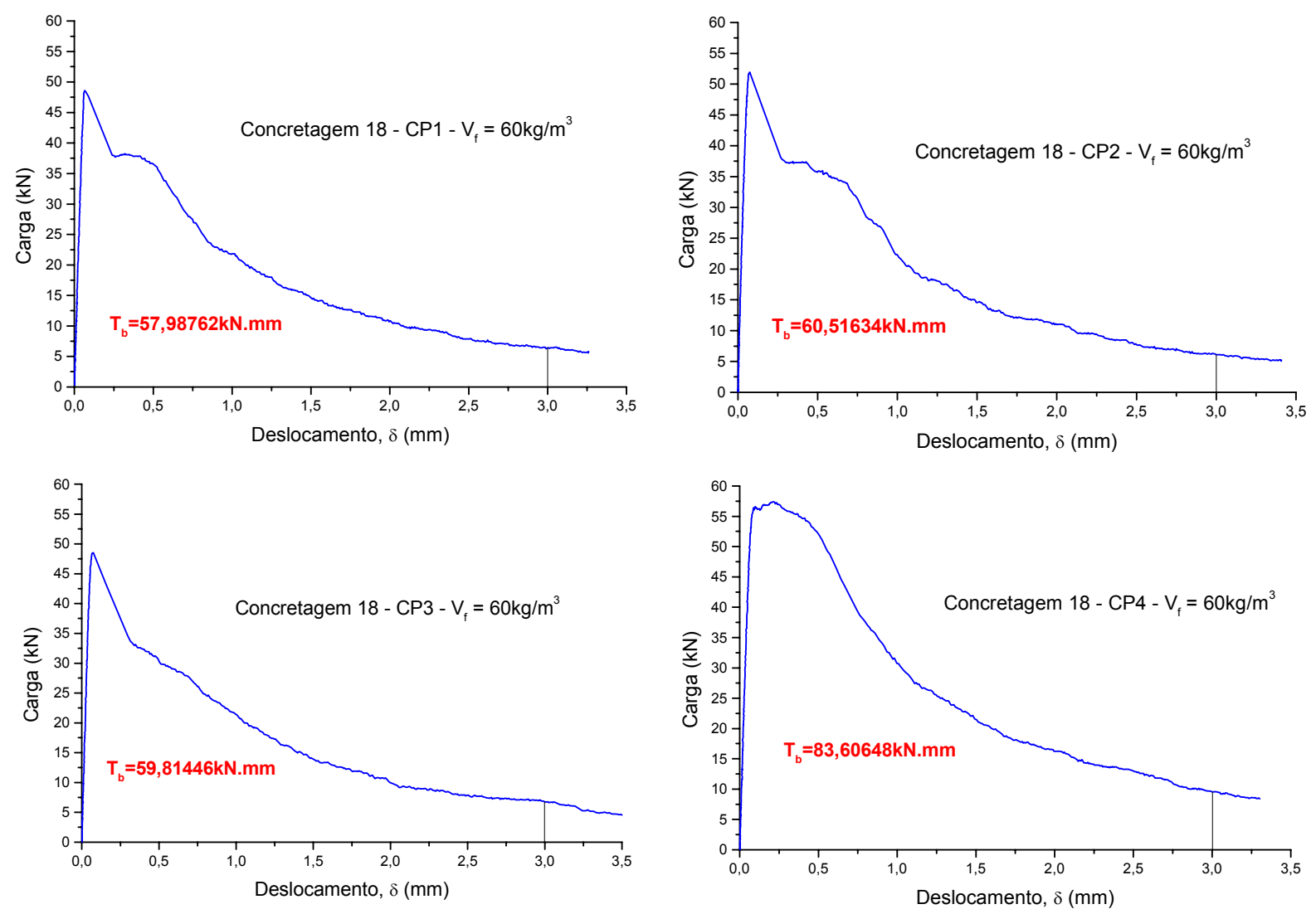

Figura F.8 - Gráficos Carga versus Deslocamento para a concretagem 18.

\section{F.2. Ensaios de Caracterização do Aço}

A seguir são apresentados resultados em forma de gráficos, para os ensaios das armaduras passivas e ativas. Os gráficos foram plotados individualmente e, também, agrupados em relação a alguns parâmetros.

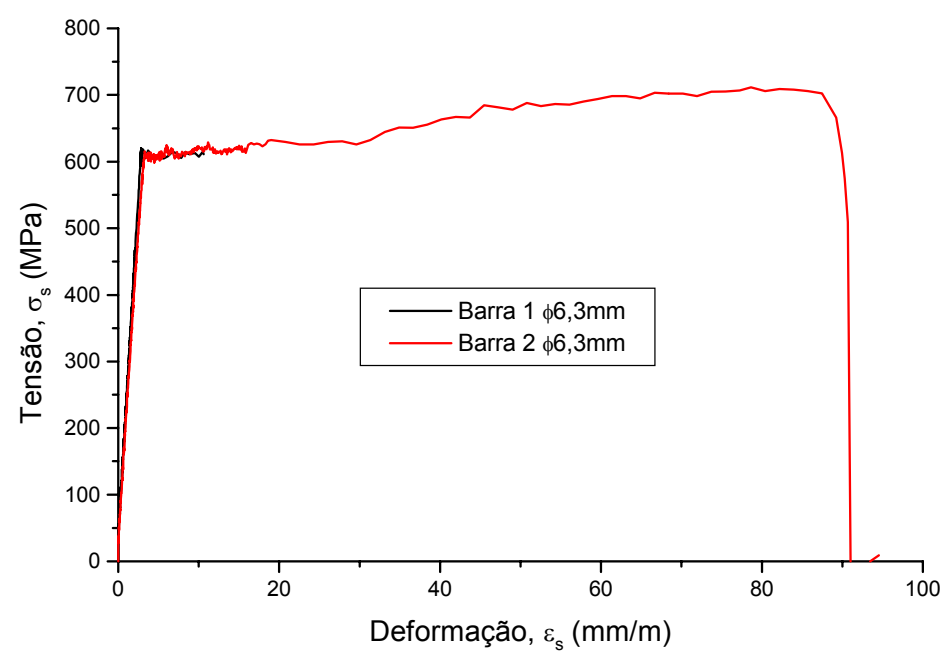

Figura F.9 - Gráficos Tensão versus Deformação para as armaduras passivas de $\phi 6,3 \mathrm{~mm}$. 


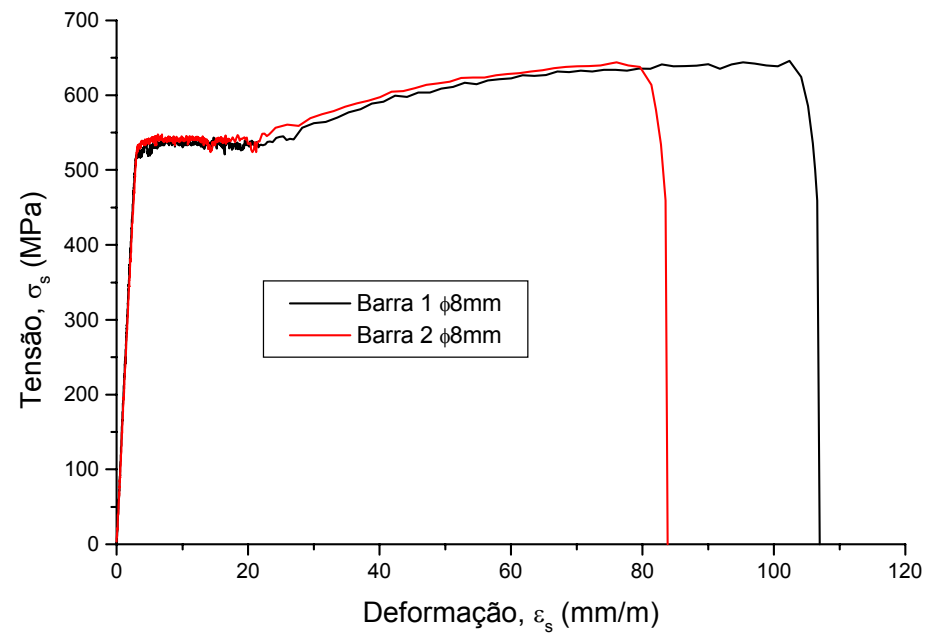

Figura F.10 - Gráficos Tensão versus Deformação para as armaduras passivas de $\phi 8 \mathrm{~mm}$.

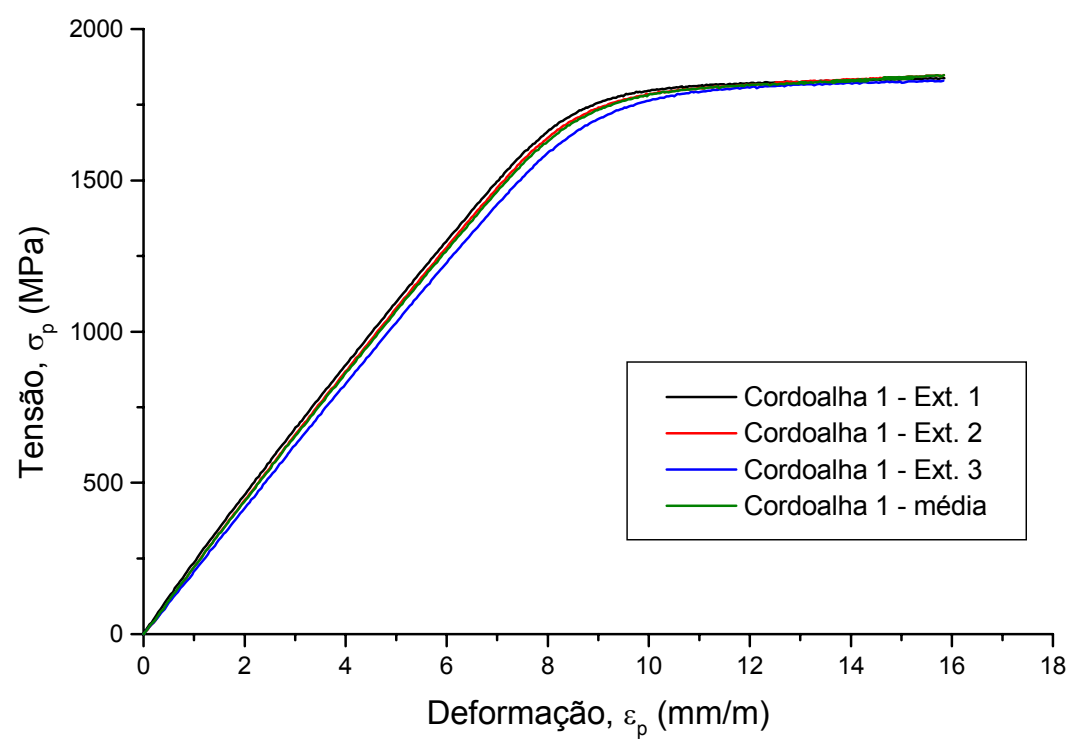

Figura F.11 - Gráficos Tensão versus Deformação para as armaduras ativas de $\phi 12,7 \mathrm{~mm}$, amostra 1.

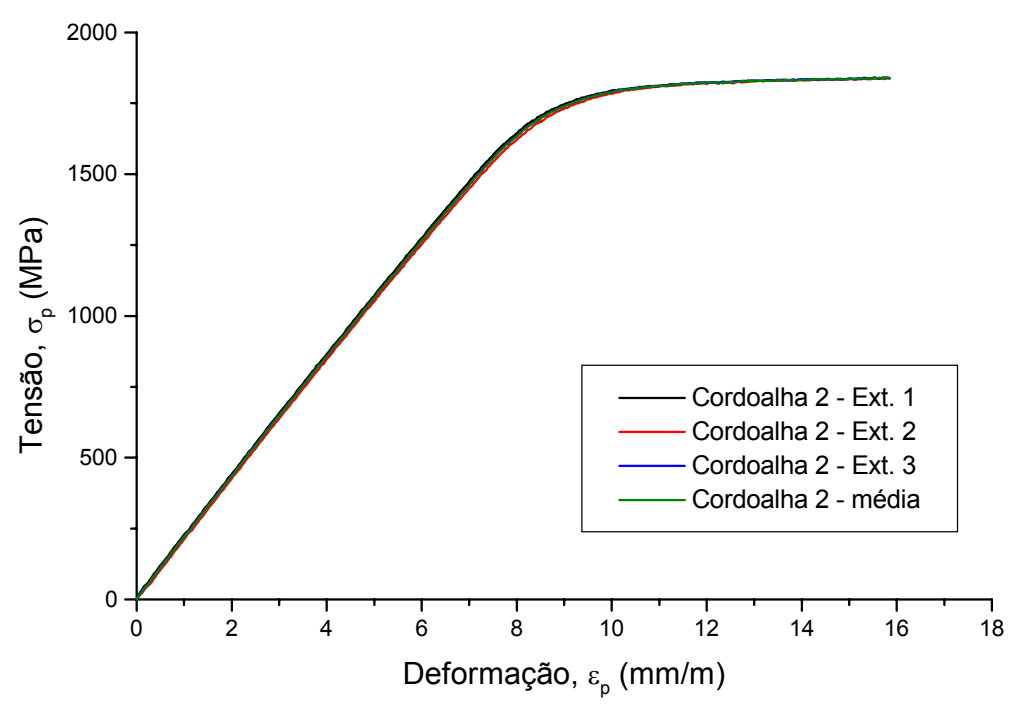

Figura F.12 - Gráficos Tensão versus Deformação para as armaduras ativas de $\phi 12,7 \mathrm{~mm}$, amostra 2. 


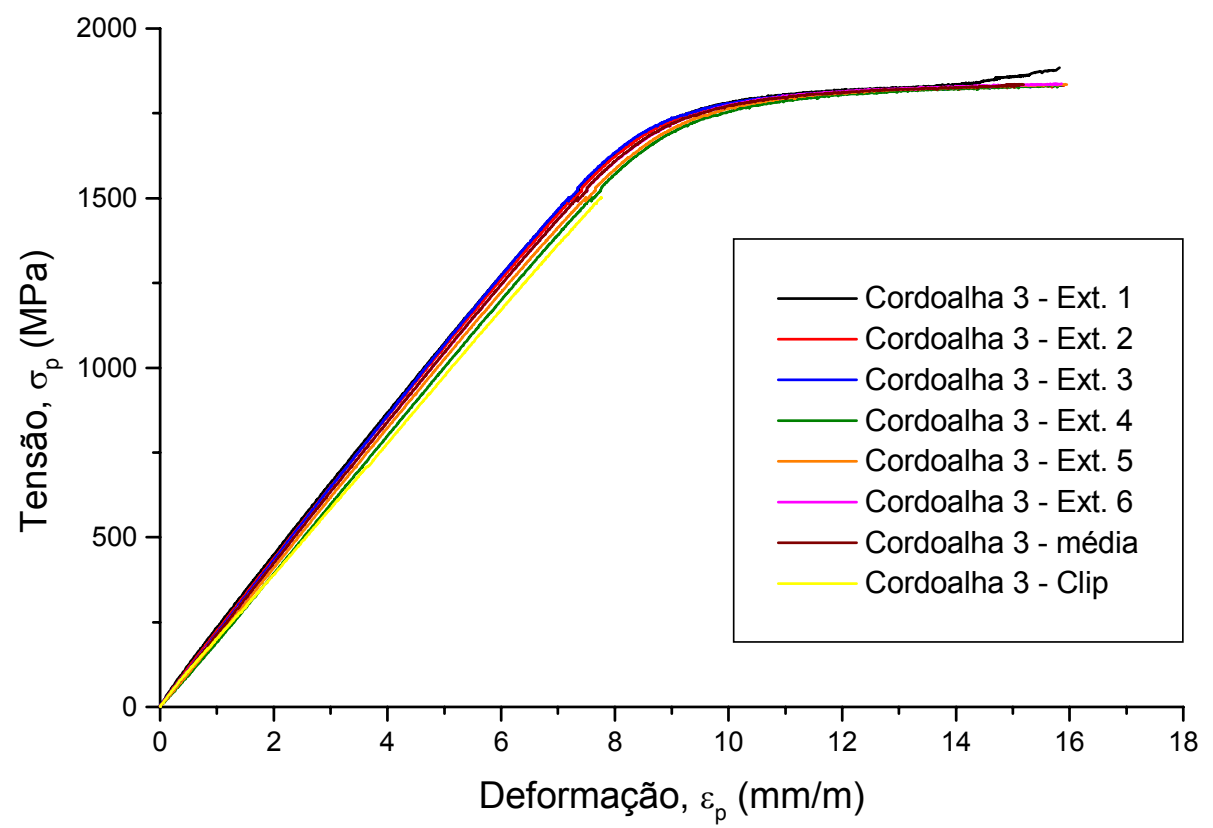

Figura F.13 - Gráficos Tensão versus Deformação para as armaduras ativas de $\phi 12,7 \mathrm{~mm}$, amostra 3. 


\section{APÊNDICE G}

PANORAMA DE FISSURAÇÃO DAS VIGAS SUBMETIDAS AOS ENSAIOS DE FLEXÃO 

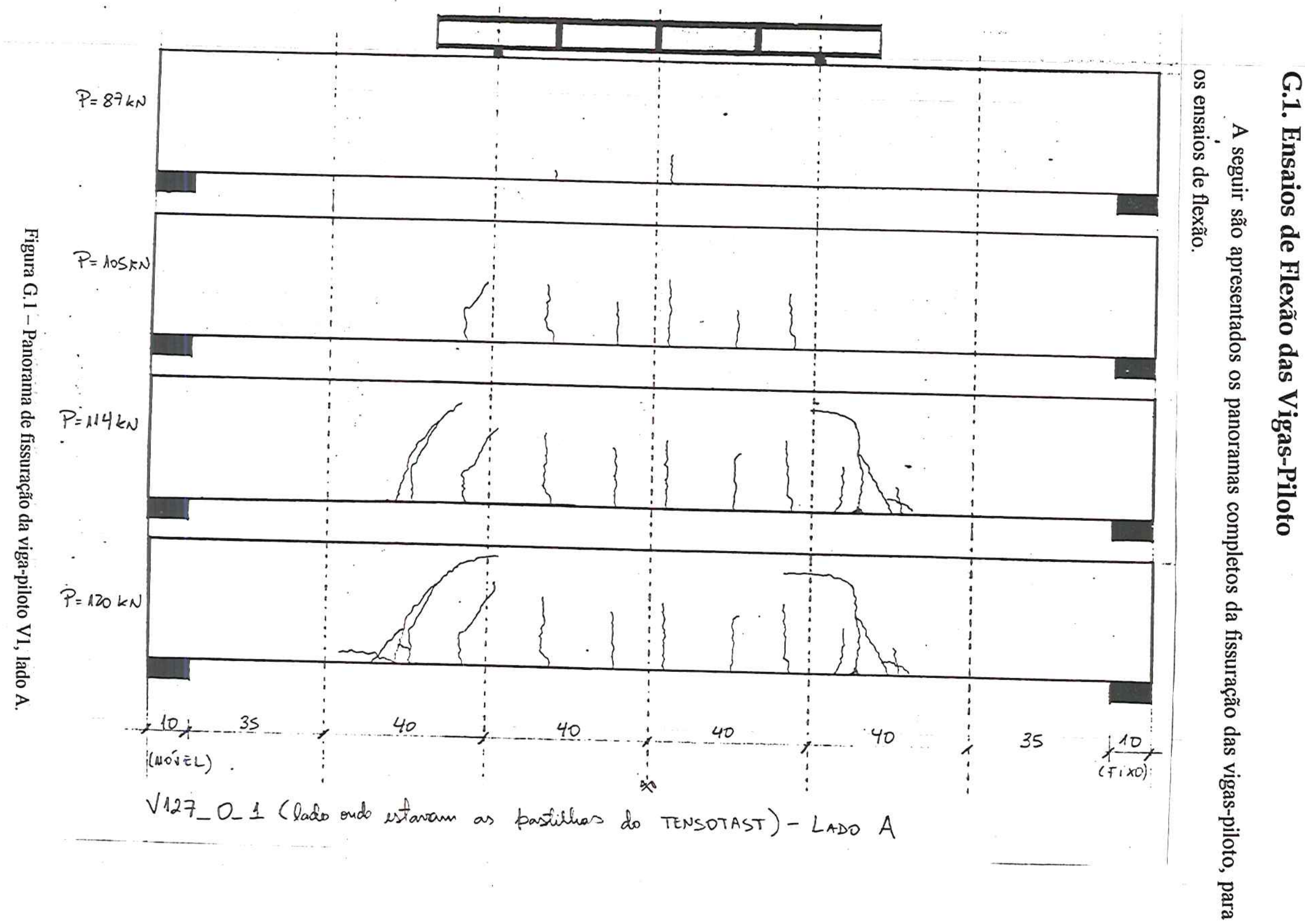


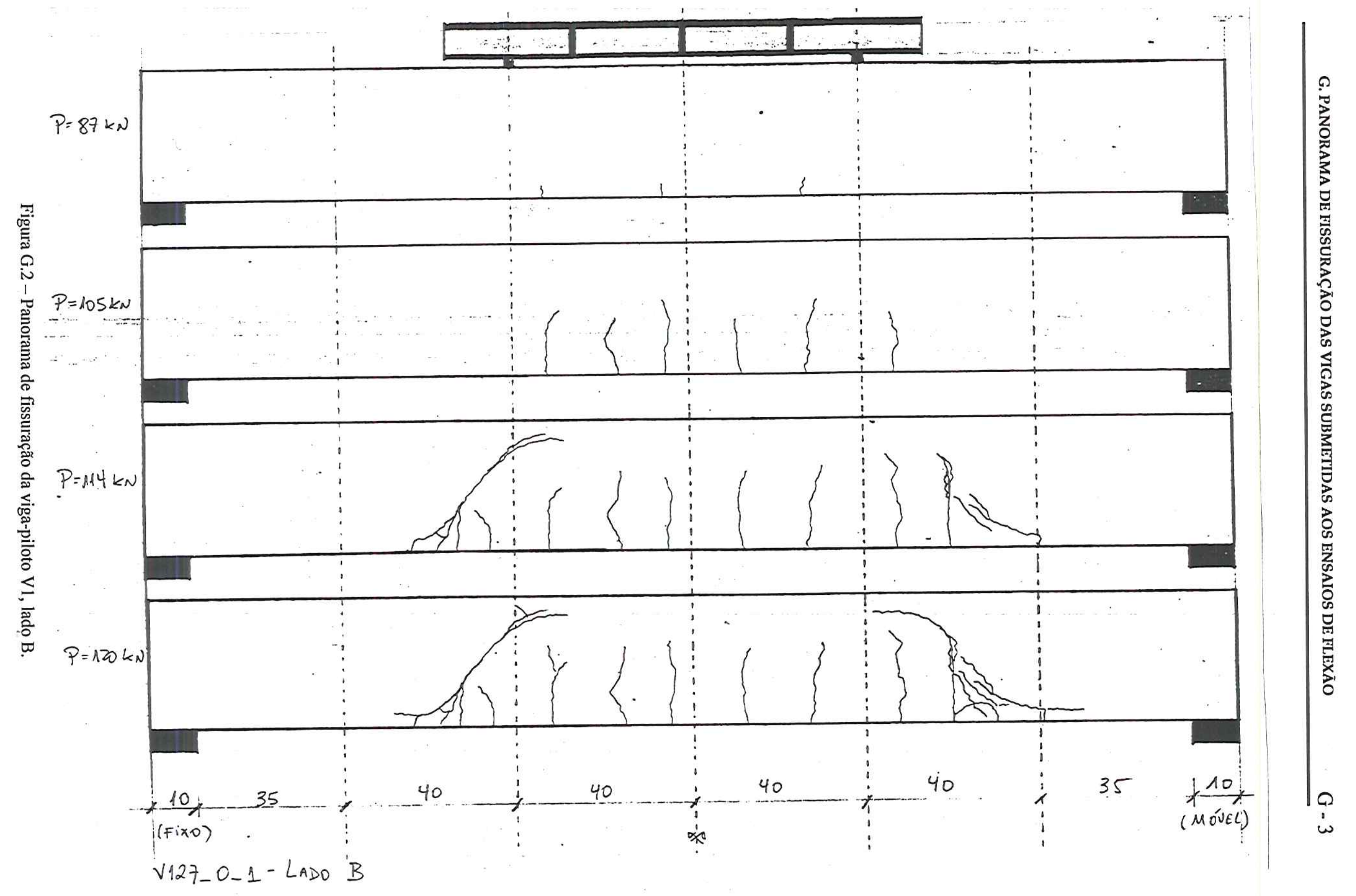




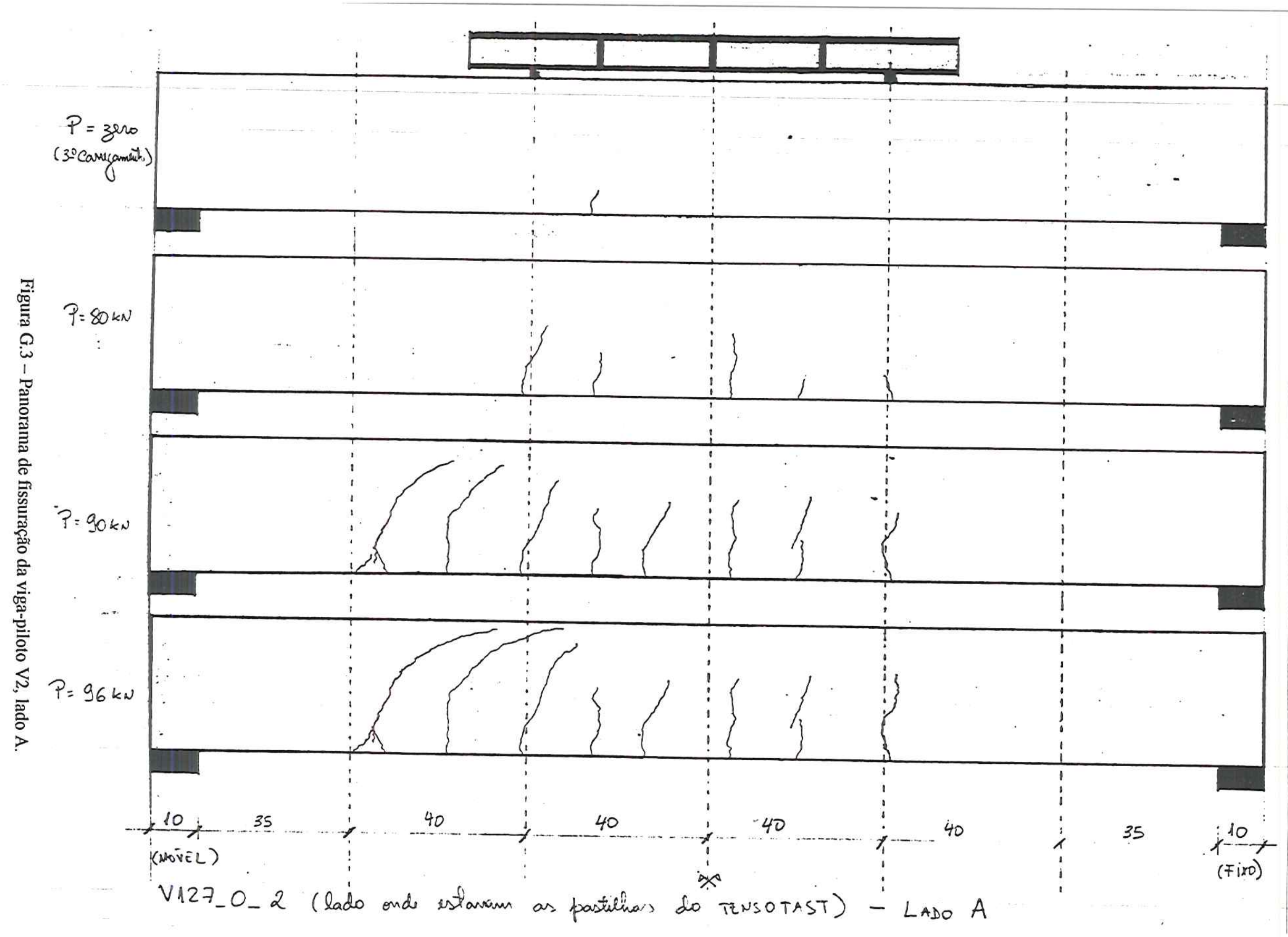




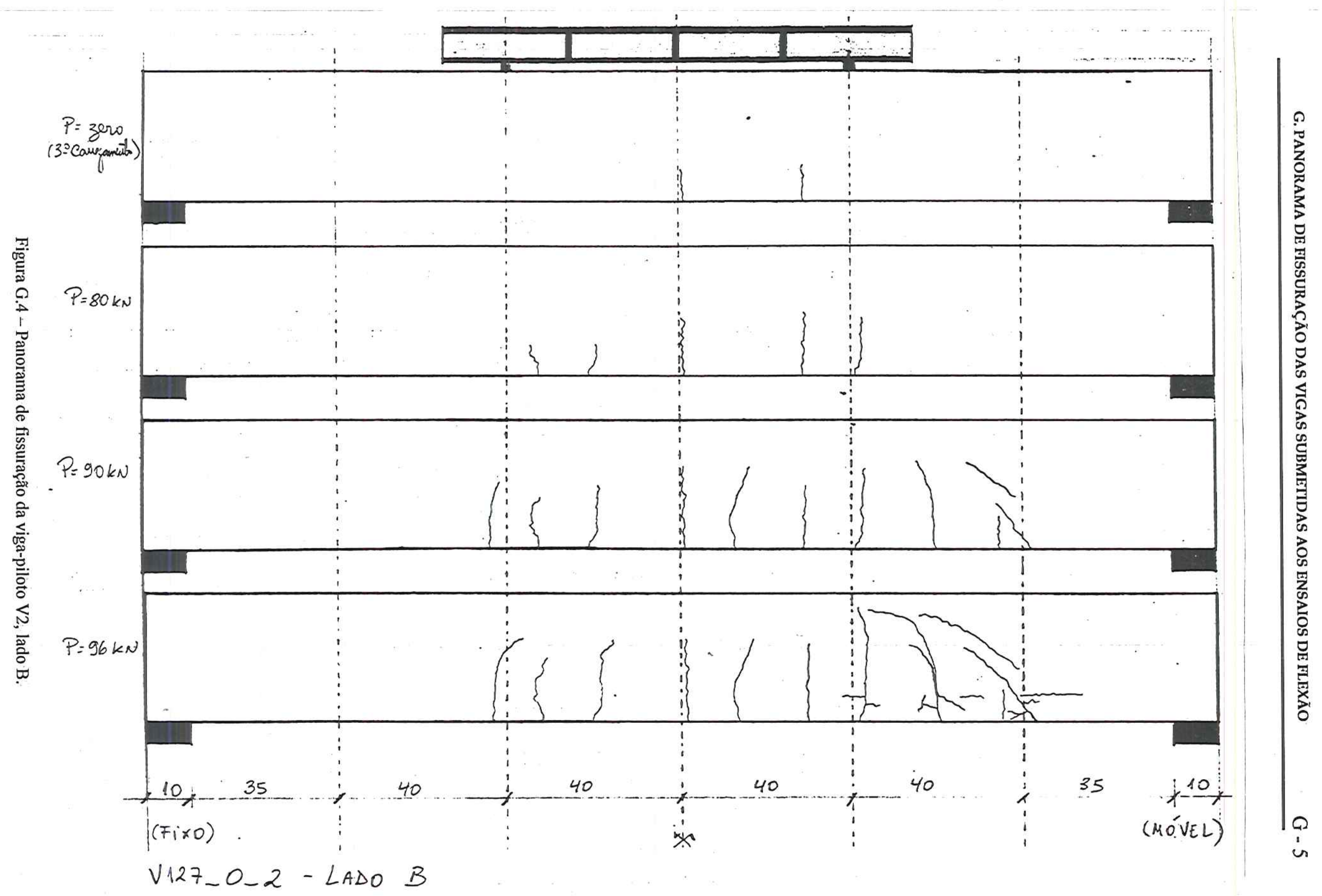




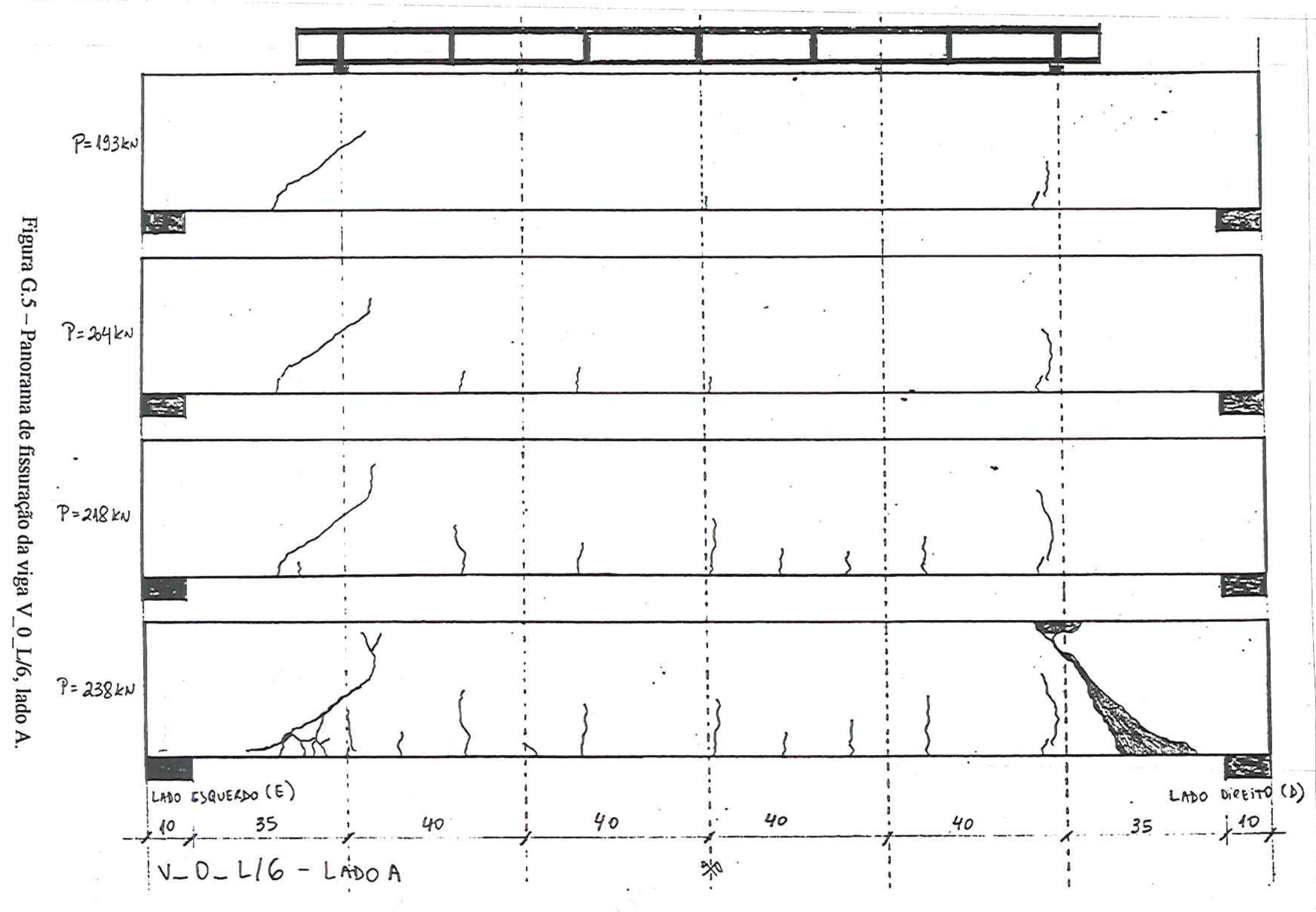

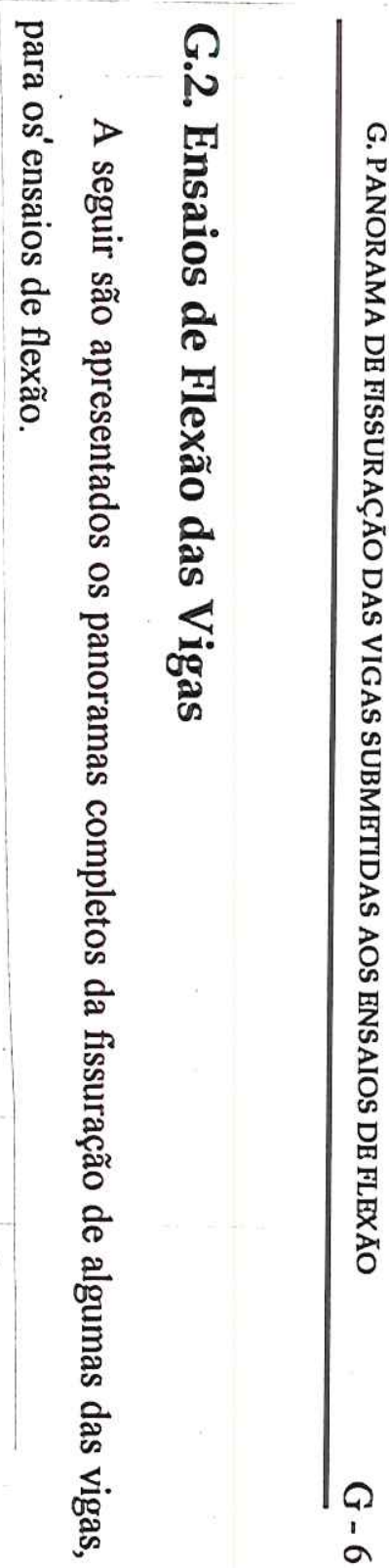




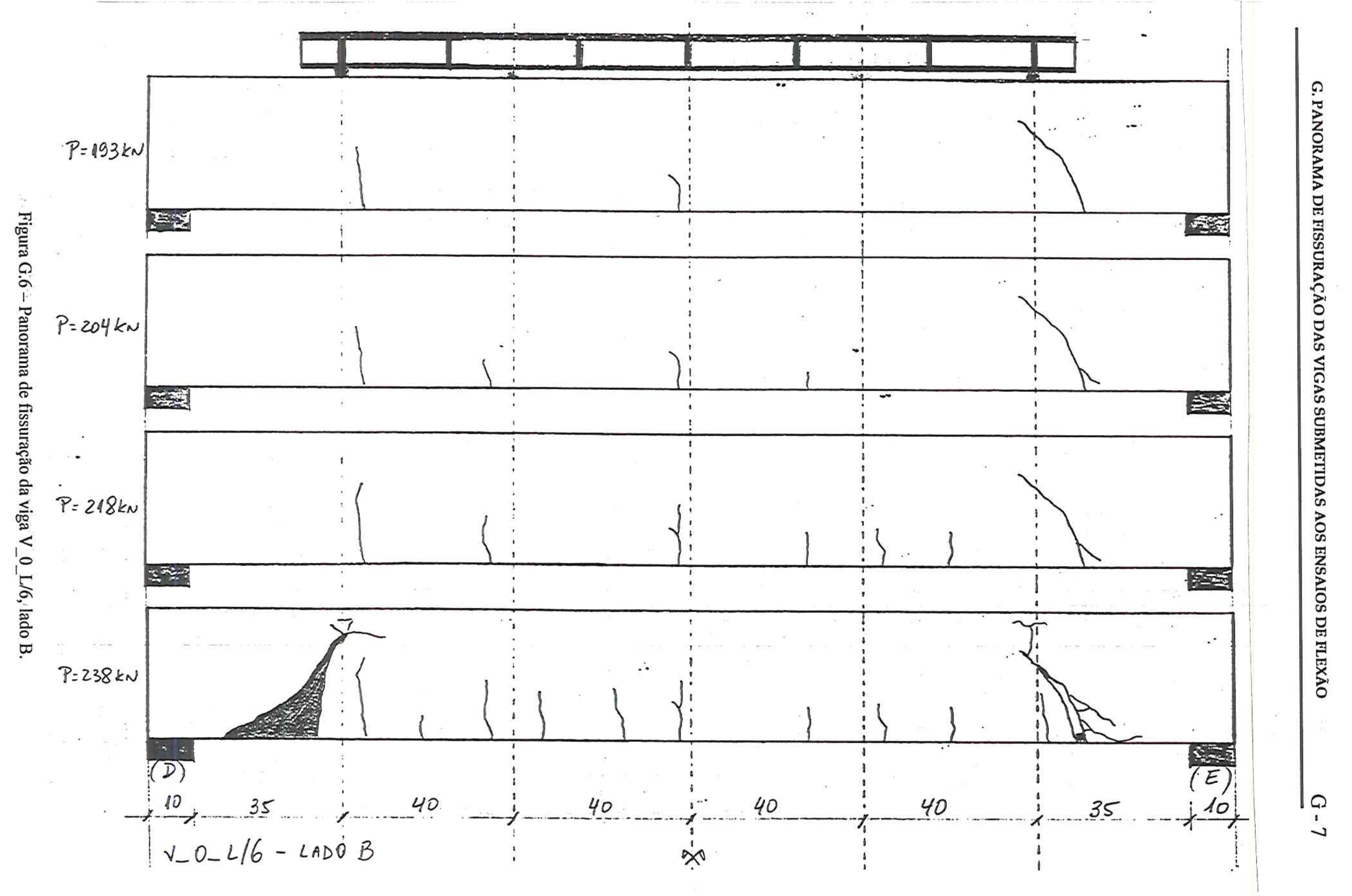




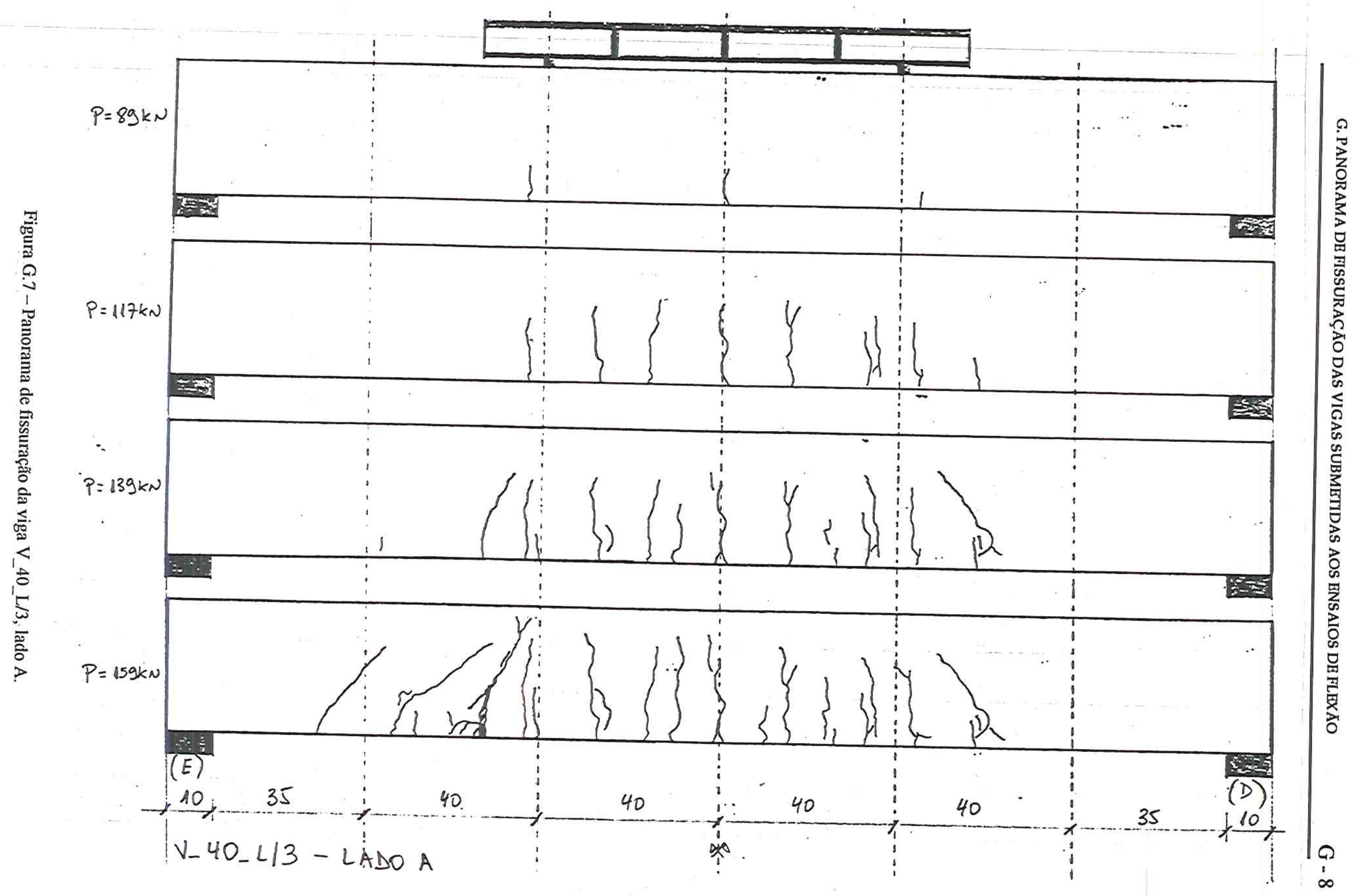




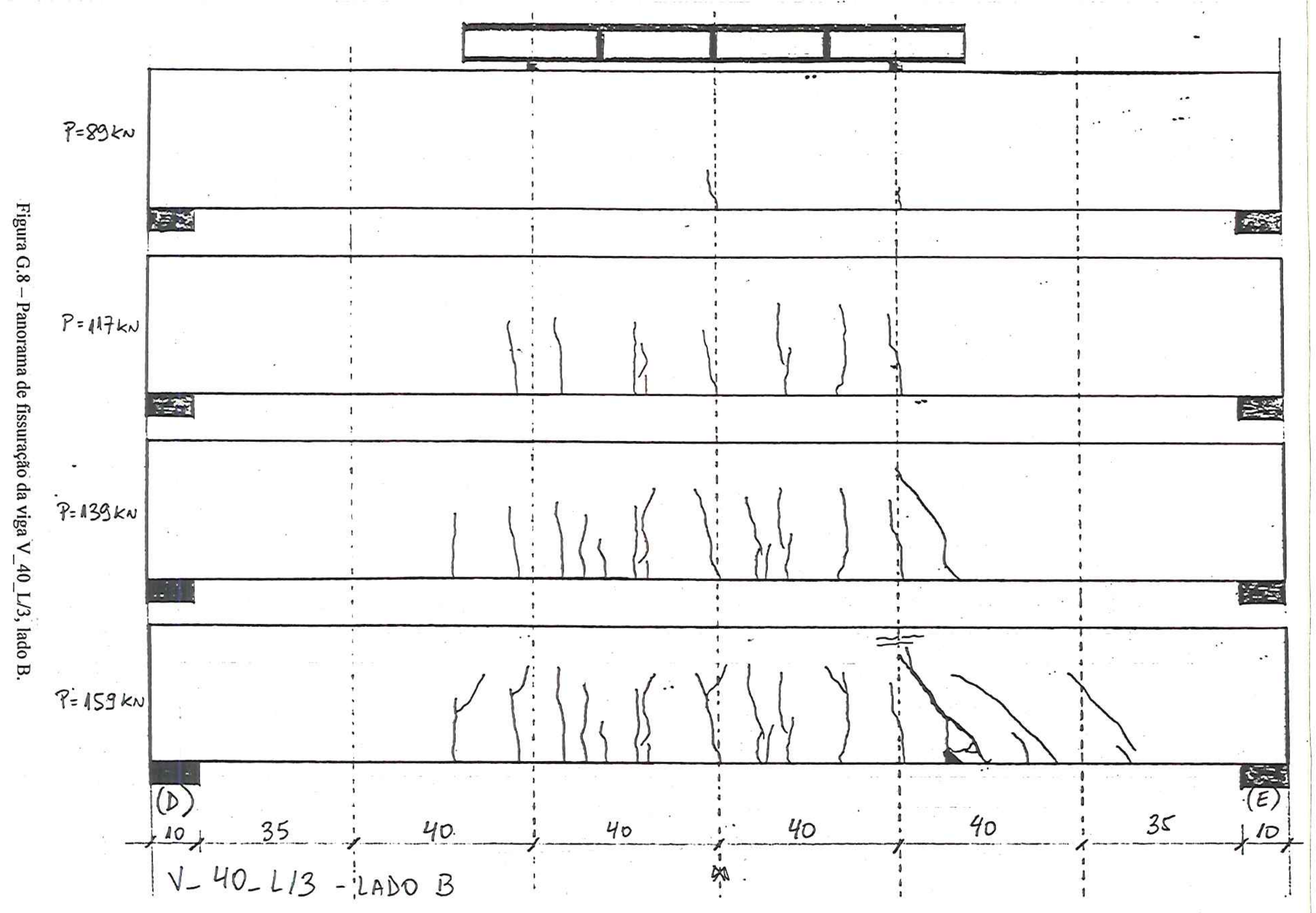




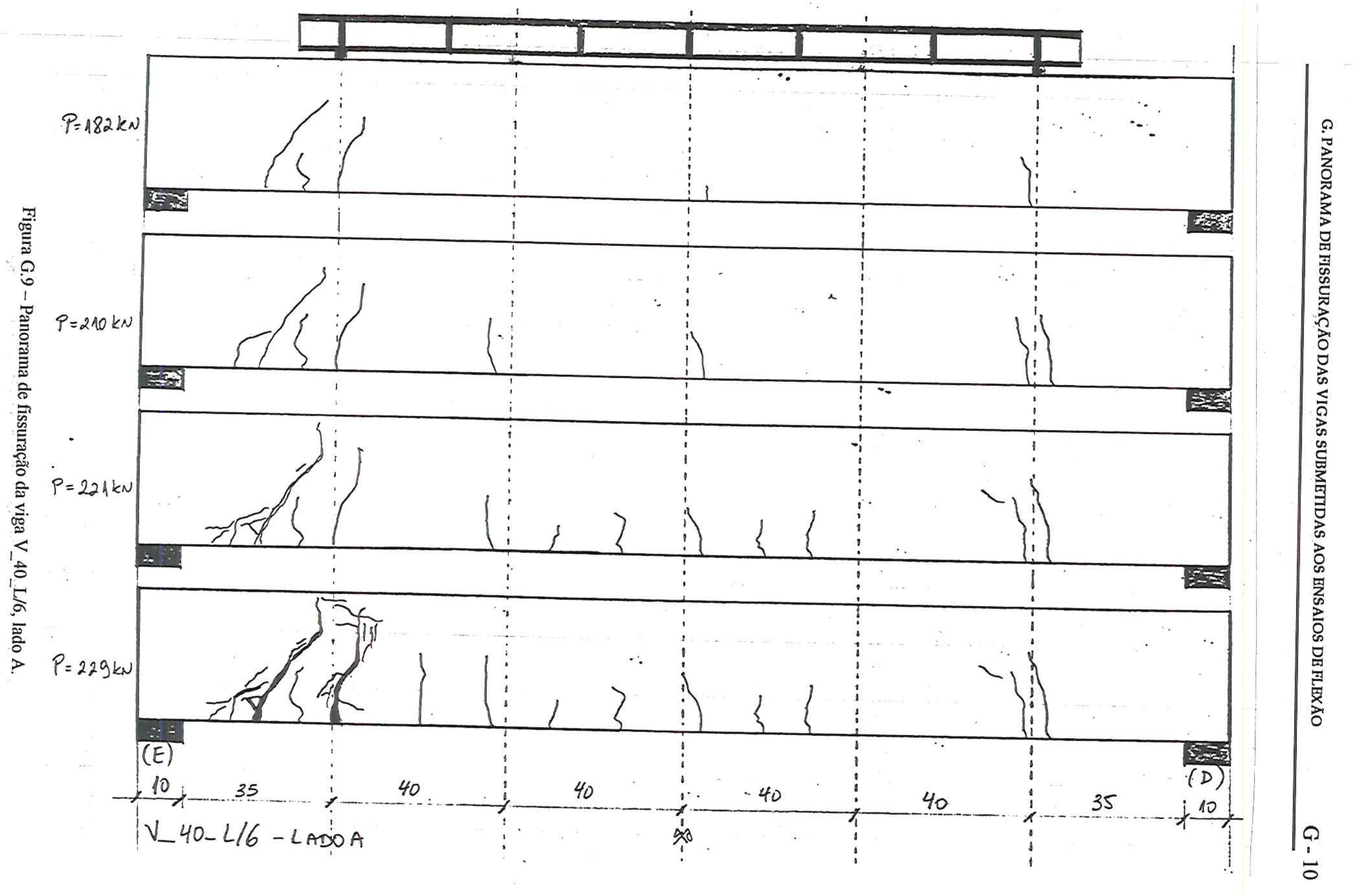




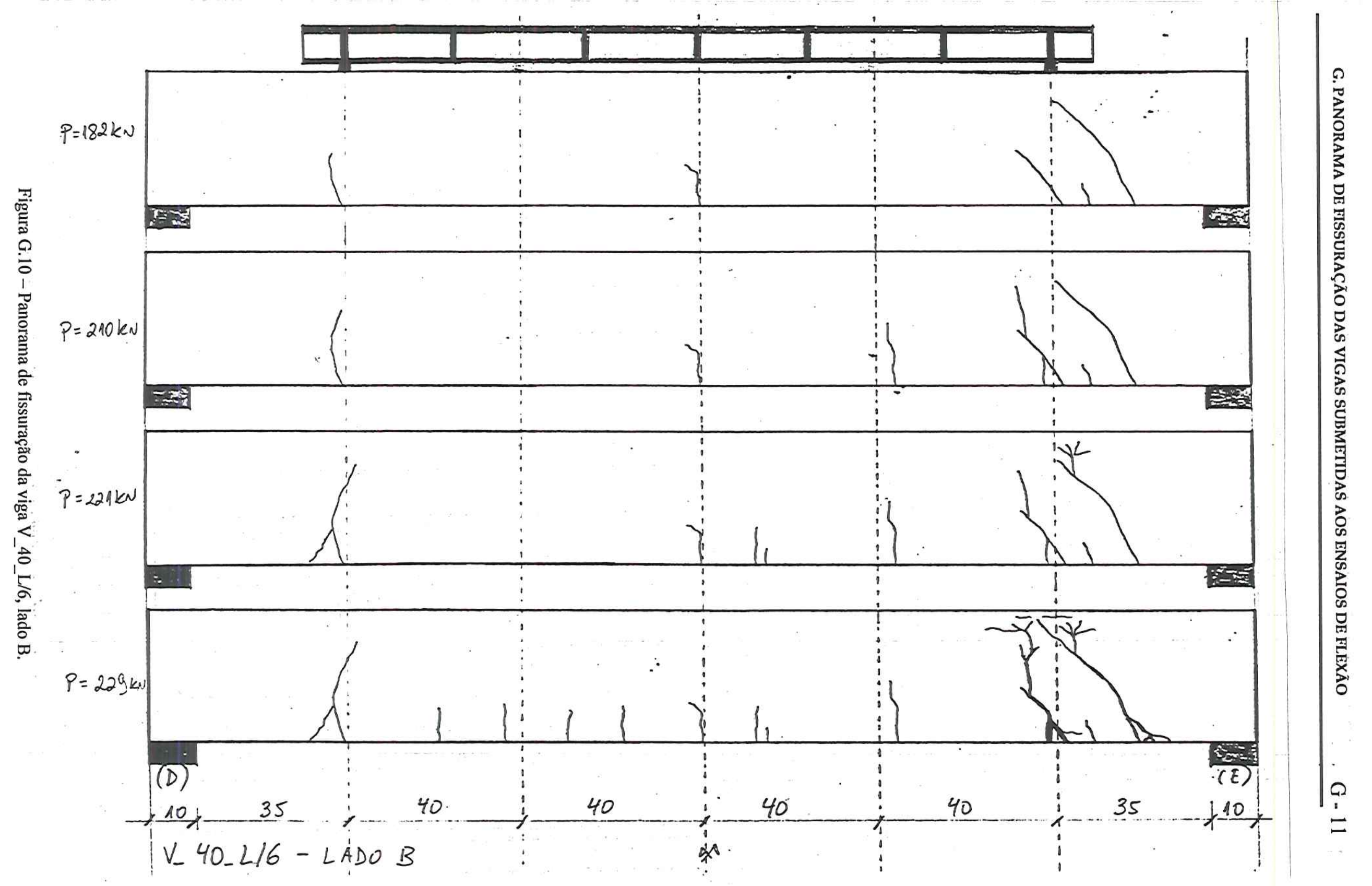




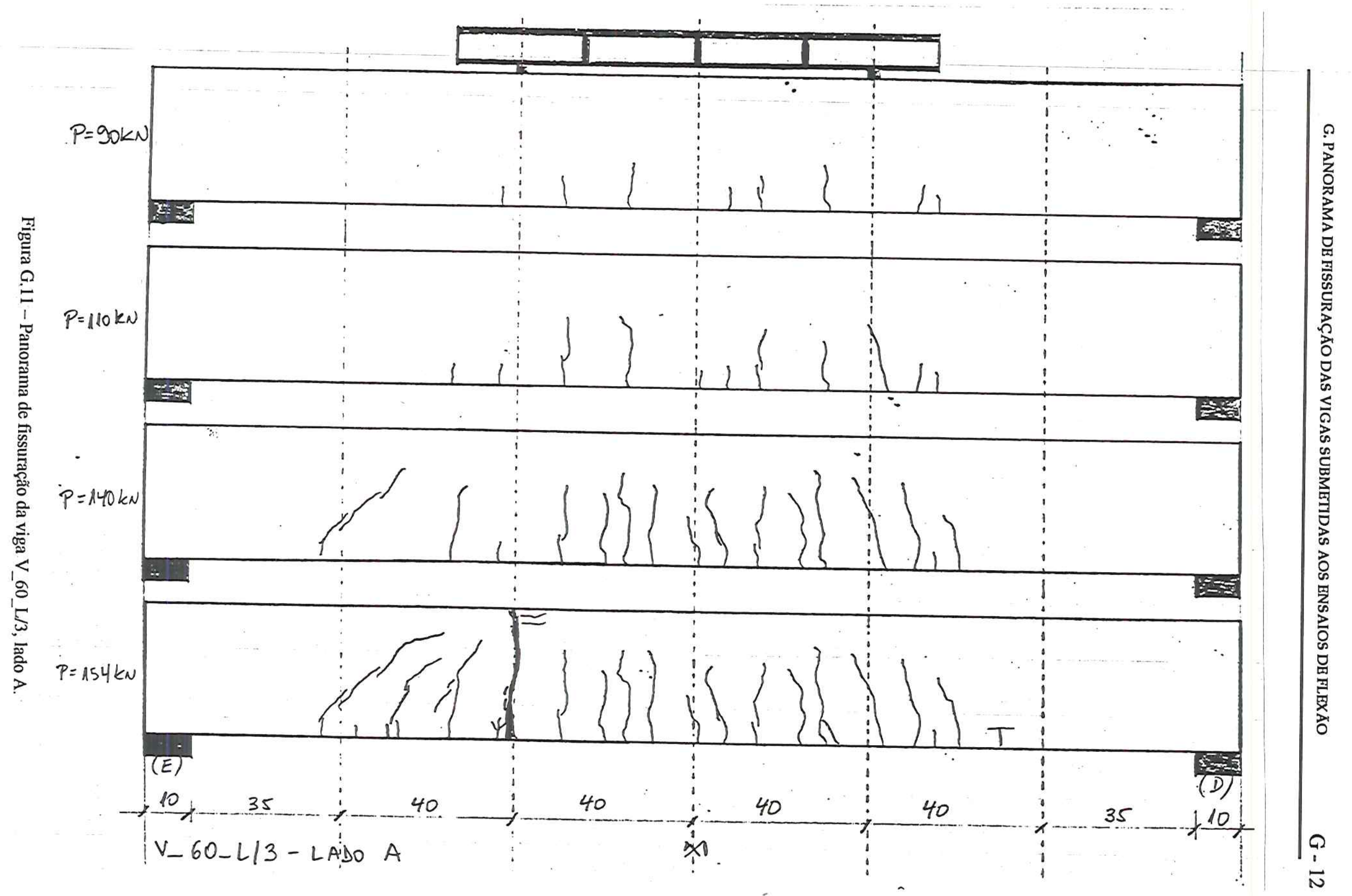




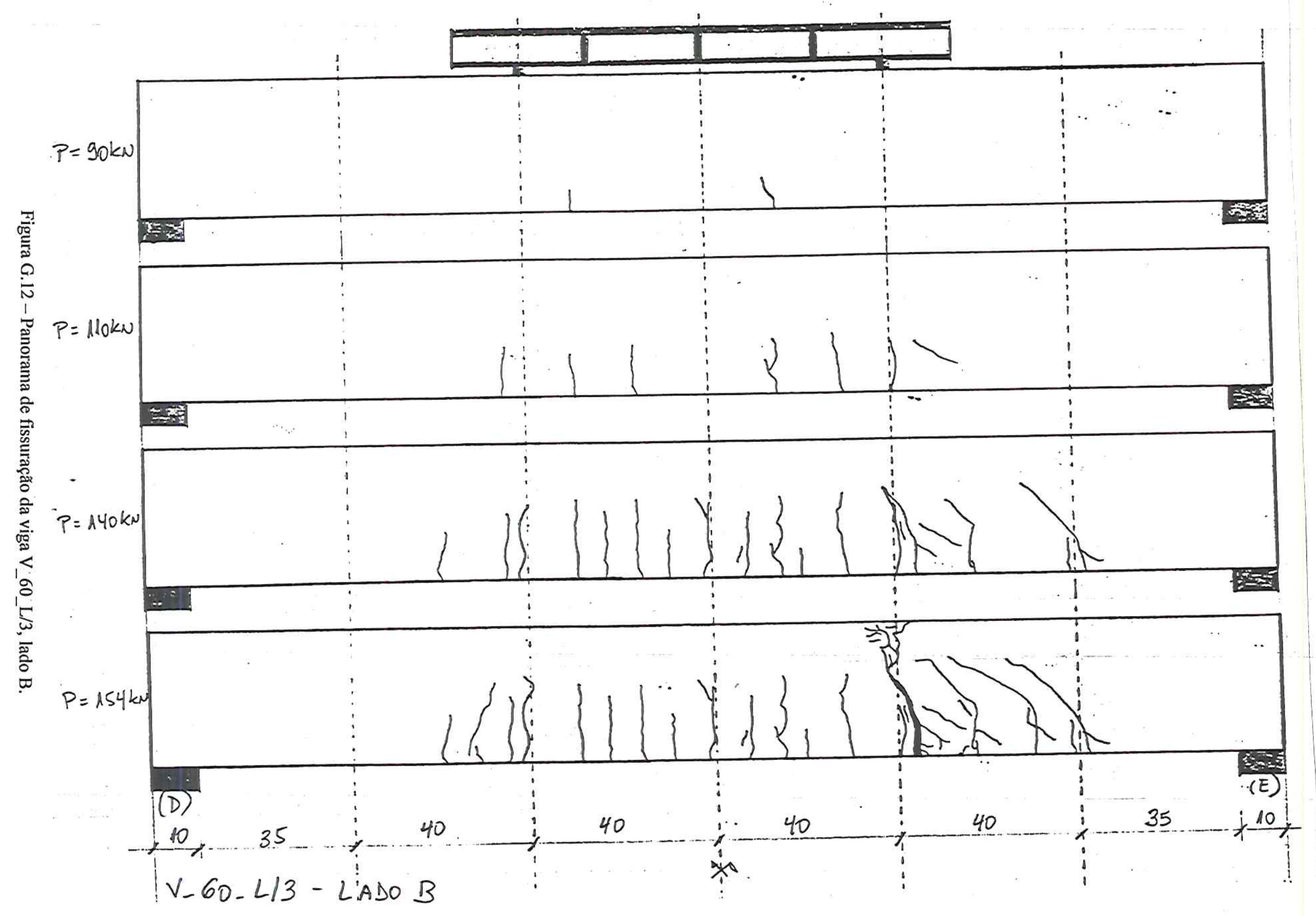




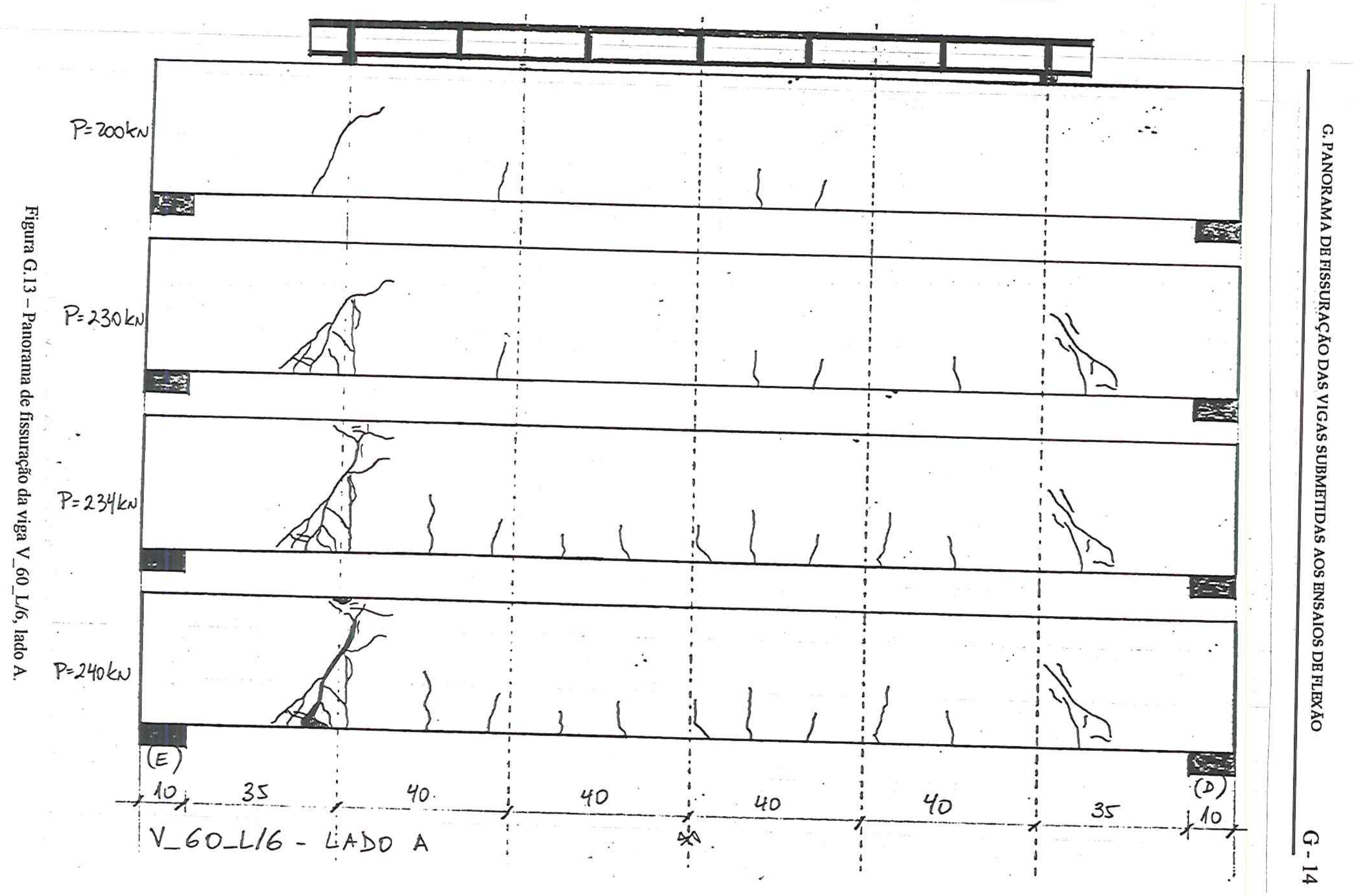




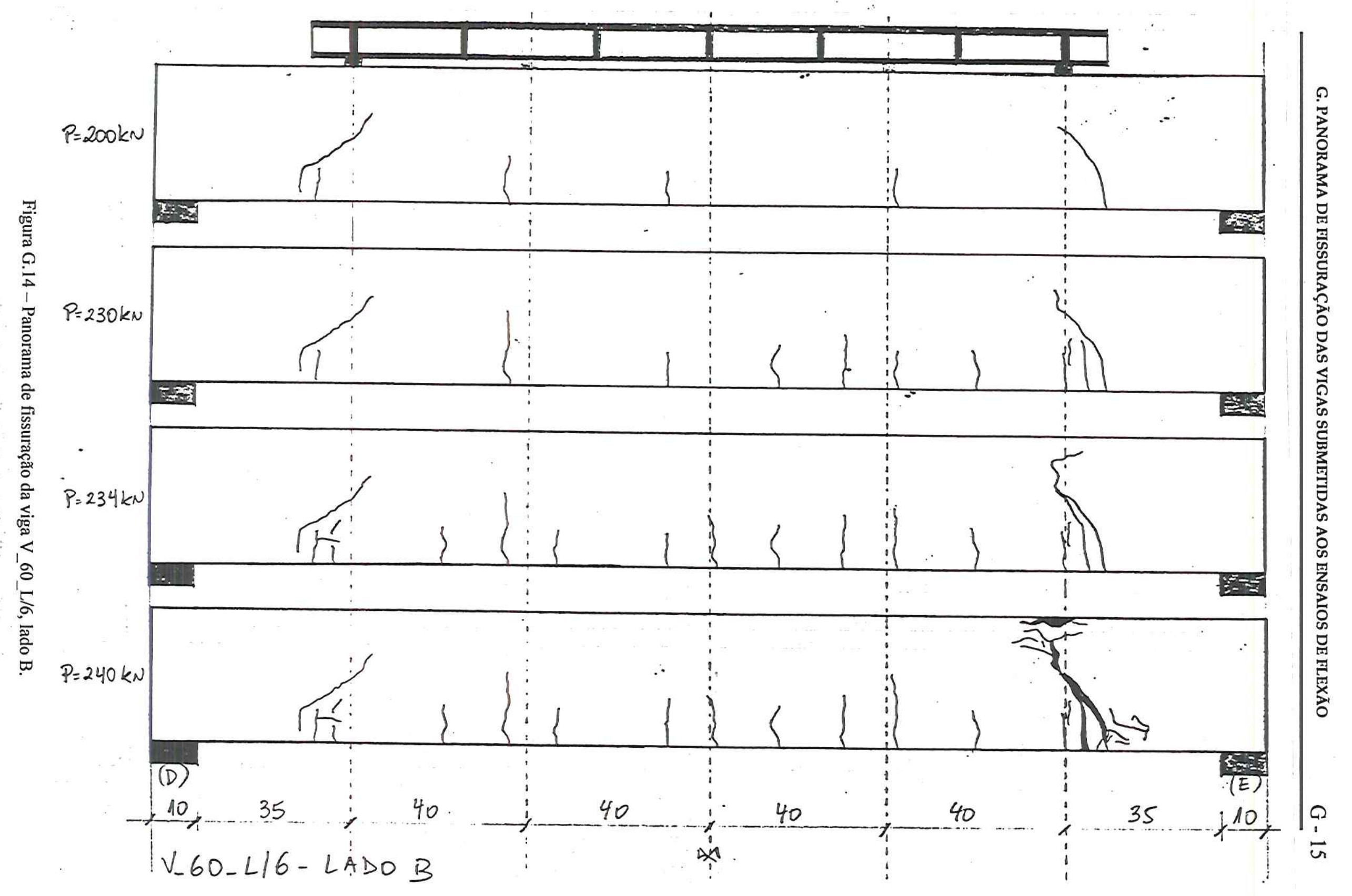




\section{ANEXO A}

RESULTADOS DOS ENSAIOS DE CARACTERIZAÇÃO REALIZADOS PELOS FABRICANTES DOS MATERIAIS 
Mill Test Certificate

Eytice [ Certificado da Qualidade

Belgo Bekaert Asgmes S.A.

Certifioate Number

Certifioado No:

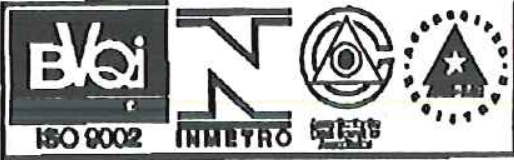

$1876 / 2001$

Page

Página: 1

Diameter

Bitola: $\quad 12,70 \mathrm{~mm}$

Produto:

CORDOALHA ACO PIC.PROT.7 FIOS CP 190 RB

Standard

Norma:

NBR $7483 / 90$

PM

Pedido No:

18628701

Specification

\section{Especificação}

Alongamento $600 \mathrm{~mm} / \mathrm{Elo}$ (ongation (\%):

Area / Steel Area ( nim 2) s i i

Carga1\% A \% stréngth (KN)

Carga ruptura/ Breaking forcs $(\mathrm{kN})$ :

Dịametro coódoálhálidiameter $(\mathrm{mm})$ :

min. 3,5/ máx. -

min. 98,7 / máx. 106,6

mín. $169 /$ máx. -

min. 187 / máx. -

min. 12,50/máx. 13,10

Test Results

\section{Resultado dos Ensaios}

\begin{tabular}{|c|c|c|c|c|c|c|}
\hline N. Rolo/Coil & $\begin{array}{l}\text { NEA Alongamento } \\
600 \mathrm{~mm} / \text { Elongation } \\
\text { (\%) }\end{array}$ & $\begin{array}{c}\text { Area / Steel Area } \\
\text { (mm2) }\end{array}$ & $\begin{array}{c}\text { Carga1\% / } \\
\text { 1\%Strength (kN) }\end{array}$ & $\begin{array}{c}\text { Carga ruptuira / } \\
\text { Breaking Force (kN) }\end{array}$ & $\begin{array}{l}\text { Diametro Cordoalha } \\
\text { I Diameter }(\mathrm{mm})\end{array}$ & $\begin{array}{l}\text { Modulo elasticidade } \\
\text { I Mod. elasticity } \\
\text { (kN/mm2) }\end{array}$ \\
\hline $62 / 2001 / 11876$ & 6,9 & 100,3 & 188 & 206 & 12,88 & 204 \\
\hline N. Rolo / Coil , & $\begin{array}{l}\text { Massa / Mass } \\
(\mathrm{kg} / 1000 \mathrm{~m})\end{array}$ & $\therefore$ & & & & \\
\hline $62 / 2001 \% 11876$ & 790 & & & & & \\
\hline
\end{tabular}

Remarks

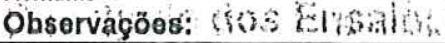

A BMRA nao se responsabiliza por coplas reproduzidas para fornecimento a terceiros. BMBA does not accept responsabity fox goples that may be reproduced to supply third-parties.

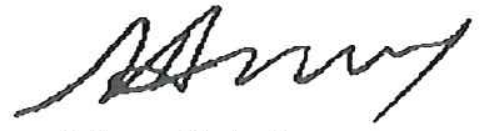

Guilherme Ribeiro Neves Supervisor do Laboratório / Laboratory Controller 
Certificate Number

Certificado No: $1876 / 2001$

Product

Produto: CORDOALHA ACO PIC.PROT.7 FIOS CP 190 RB

Standard

Norma: NBR.7483/90

Coil Number

No do Rolo: 2001/11876

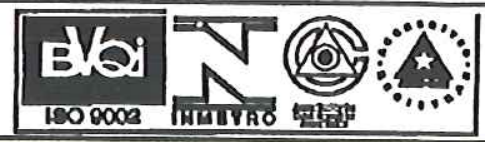

Date

Data: 25/06/2001

Diamoter

Bitola: $12,70 \mathrm{~mm}$

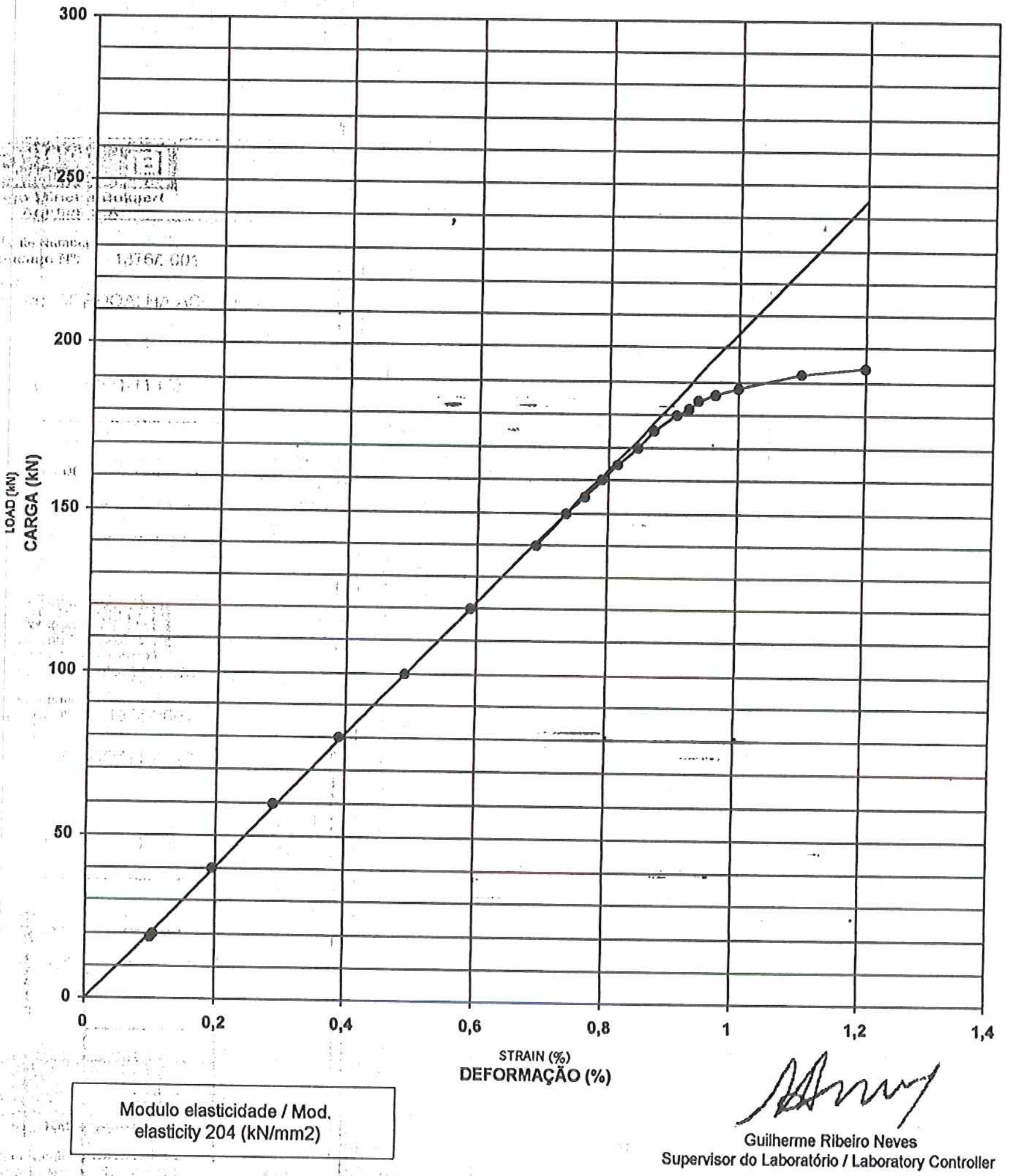


- Descripción: Las fibras Dramix son filamentos de acero, deformados y cortados en determinadas longitudes,

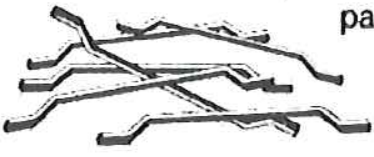
ara el refuerzo del hormigón, mortero u otros materiales compuestos. El Dramix RL- $45 / 30-B N$ es una fibra suelta de alambre estirado en frio, con extremos conformados.

\section{- Aplicaciones:}

- gunitado u hormigón proyectado

- Geometría:

$\leftrightarrow \longrightarrow$

再 Longitud (I)

$30 \mathrm{~mm}$

45 Comportamiento

Clase: 45

${ }_{45}^{65} 5^{60}$ Aspecto o esbeltez

45, $(=V / d): 48$

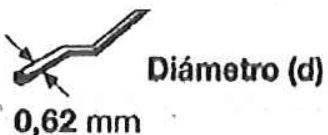

$0,62 \mathrm{~mm}$

- Resistencia a tracción :

- del alambre: mínimo $1100 \mathrm{~N} / \mathrm{mm}^{2}$

- bajo carbono conforme a: - DIN 17 140-D9

- EN 10016-2 - C9D

- Galvanizado: Ninguno

- Certificados de aprobación:

\begin{tabular}{|c|c|c|c|}
\hline $\begin{array}{l}\text { Producto } \\
\text { AJG } \\
1857\end{array}$ & $\begin{array}{c}\text { Conforme } \\
\text { a }\end{array}$ & $\begin{array}{c}\text { Sistema de } \\
\text { calidad on } \\
\text { las Plantas } \\
\text { Bolgas }\end{array}$ & $\mid \begin{array}{c}\text { Certificado } \\
\text { de } \\
\text { aprobación: } \\
\text { Polonia } \\
N^{\circ}\end{array}$ \\
\hline$B 8 \sqrt{\mathrm{DV}}$ & A & T) & Z2:2117/95 \\
\hline
\end{tabular}

- Datos técnicos:

Para gunitado, ... solicitar documentación específica.

\section{Resistencia equivalente a flexión}

- $f_{\text {tctm,eq,300, }} f_{\text {tctk, }, 2 q, 300}=$ resistencia equivalente a flexión, característica y promedia, a una deformación de $1,5 \mathrm{~mm}$, de acuerdo con la NBN B 15-238, 239, y JSCE-SF4.

- $f_{\mathrm{Ictm}, e q, 150,} f_{\mathrm{fctk}, e q, 150}=$ resistencia equivalente a flexión, caracteristica y promedia, a una deformación de $3 \mathrm{~mm}$, de acuerdo con la NBN 15-238, 239, y JSCE-SF4.

Dramix $^{\otimes}$ RL-45/30-BN

\begin{tabular}{|c|c|c|c|c|c|c|c|c|c|c|}
\hline \multirow{2}{*}{ 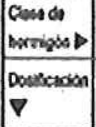 } & \multicolumn{2}{|c|}{ C20/25 } & \multicolumn{2}{|c|}{$\mathrm{C} 25 / 30$} & \multicolumn{2}{|c|}{$\mathrm{C} 30 / 37$} & \multicolumn{2}{|c|}{$\mathrm{C} 35 / 46$} & \multicolumn{2}{|c|}{ C40/60 } \\
\hline & $\begin{array}{c}I_{k+n, e q} \\
300\end{array}$ & $\begin{array}{c}f_{k f k}, e_{4} \\
300\end{array}$ & $\begin{array}{c}I_{\text {Ktaneq }} \\
300\end{array}$ & $\begin{array}{c}t_{\text {terken }} \\
300\end{array}$ & $\mathrm{itceq}^{\mathrm{f}}$ & $I_{300}^{I_{\text {tetk. }}}$ & $\begin{array}{c}\cos n, e x \\
300\end{array}$ & $\begin{array}{c}f_{x \rightarrow k, 68} \\
300\end{array}$ & $\begin{array}{c}\mathrm{f} \in \mathrm{ern}, \mathrm{eq} \\
300\end{array}$ & $\begin{array}{c}\text { thot,er } \\
300\end{array}$ \\
\hline 20 & 1,4 & 1,0 & 1.7 & 1,2 & 1,8 & 1 & 21 & 15 & 2 & 1,5 \\
\hline 25 & 1 & 1,1 & 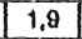 & 1,3 & 2,1 & & & 1,7 & 2 & 1,8 \\
\hline 30 & 1 & 1,2 & 2,1 & 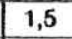 & & $\cdots$ & & & $?$ & 1.9 \\
\hline 35 & 2,1 & & 2,4 & & & & & & & 2,1 \\
\hline 40 & & & .7 & & & & . & - & 3,3 & 2,3 \\
\hline 45 & & & 2,9 & & & & 3,3 & 2,3 & 3,5 & 2,5 \\
\hline 50 & 2,8 & 2,0 & 3,1 & 2,2 & 3,3 & 2,3 & 3,5 & 2,5 & 3.7 & 2.6 \\
\hline
\end{tabular}

\section{Dramix ${ }^{\circledR}$ RL-45/30-BN}

\begin{tabular}{|c|c|c|c|c|c|c|c|c|c|c|}
\hline \multirow{2}{*}{ 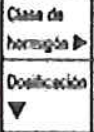 } & \multicolumn{2}{|c|}{$\mathrm{C} 20 / 25$} & \multicolumn{2}{|c|}{$\mathrm{C} 25 / 30$} & \multicolumn{2}{|c|}{ C $30 / 37$} & \multicolumn{2}{|c|}{$\mathrm{C} 35 / 45$} & \multicolumn{2}{|c|}{ C40/60 } \\
\hline & $t_{x \rightarrow 00}$ & $\begin{array}{l}f_{\text {fits, }} \\
150\end{array}$ & $\begin{array}{c}k+n \times 0 \\
150\end{array}$ & $l_{150,00}$ & Isemea & $\begin{array}{c}f_{k x h} \text { an } \\
150\end{array}$ & $t_{100}=0$ & & $I_{\text {kninea }}$ & \\
\hline 0 & 1,1 & 0,8 & 1,2 & 0,8 & 1,3 & 0,8 & 1,4 & 1,0 & 1,6 & 1,1 \\
\hline 25 & 1. & 9 & 1.5 & 1.1 & 1,6 & 1, & 1.7 & 1,2 & 1,9 & 1,3 \\
\hline 30 & 1,4 & 1.0 & 1,7 & 1.2 & 1,8 & 1,3 & 2,0 & 1,4 & 2,2 & 1,5 \\
\hline 35 & 1,8 & 1,3 & 2,0 & 1,4 & 2.1 & 1, & 2,2 & 1.5 & 2,4 & 1,7 \\
\hline 40 & 2,1 & 1,4 & 2.2 & 1,5 & 2,3 & 1,6 & 2,4 & 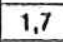 & 2,6 & 1,8 \\
\hline 45 & 2 & 1,5 & 2,3 & 1,6 & 2,4 & 1,7 & 2,5 & 1,8 & 2,7 & 1,9 \\
\hline 50 & 2,3 & 1,6 & 2,4 & 1,7 & 2,5 & 1,8 & 2,6 & 1,9 & 2,8 & 2,0 \\
\hline
\end{tabular}

2 Resistencia equivalente a tracción axial

- Resistencia equivalente a tracción axial = $0,37 \times$ resistencia equivalente a flexión. 


\section{Dramix

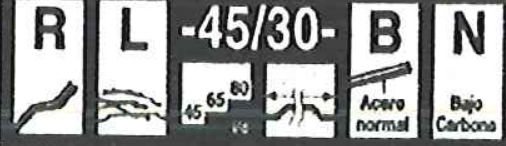

\section{Diagrama de tensión-deformación}

Para hormigón reforzado con fibras de acero, se aplica el síguiente diagrama de tensión-deformación (simbolos conforme al Eurocódigo 2 y a las recomendaciones de Dramix ${ }^{8}$.

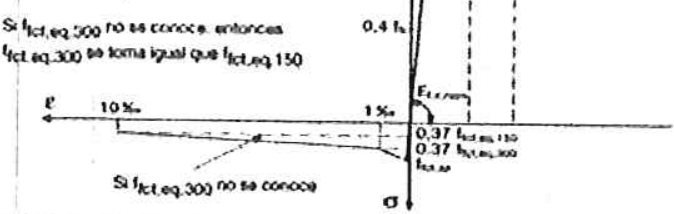

\section{Resistencia equivalente al cortante}

El valor de cálculo del incremento de la resistencia al cortante debido a las fibras de acero es: $\tau_{1 d}\left(\mathrm{~N} / \mathrm{mm}^{2}\right)_{r}$. (el coeficiente de seguridad del material está incluido). La contribución del hormigón y estribos debe añadirse a la de las fibras de acero.

Dramix $\otimes$ RL-45/30-BN

\begin{tabular}{|c|c|c|c|c|c|}
\hline $\begin{array}{l}\text { Claso do } \\
\text { hormigón } D\end{array}$ & $\mathrm{C} 20 / 25$ & $\mathrm{C} 25 / 30$ & $\mathrm{C} 30 / 37$ & $\mathrm{C} 35 / 45$ & C $40 / 50$ \\
\hline Dosidicacion V & $\tau_{\text {fd }}$ & $\tau_{\mathrm{Id}}$ & $\tau_{\text {dd }}$ & $\tau_{\text {ld }}$ & $\tau_{f d}$ \\
\hline 20 & 0,13 & 0,15 & 0,17 & 0,18 & 0,21 \\
\hline 25 & 0,15 & 0,18 & 0,20 & 0.22 & 0,25 \\
\hline 30 & 0,17 & 0,20 & 0,23 & 0,25 & 0,28 \\
\hline 35 & 0,19 & 0,23 & 0.25 & 0,28 & 0,32 \\
\hline 40 & 0,21 & 0,25 & 0,28 & 0.30 & 0.35 \\
\hline 45 & 0,22 & 0,27 & 0,30 & 0,33 & 0,37 \\
\hline 50 & 0,24 & 0,29 & 0,32 & 0,35 & 0,40 \\
\hline
\end{tabular}

Por favor, consulten las recomendaciones de Dramix

\section{Valores de tenacidad}

\section{Dramix ${ }^{\circledast 2}$ RL-45/30-BN}

\begin{tabular}{|c|c|c|}
\hline Dosificacion $\nabla$ & Re1,5 $(\%)$ & Re3 $(\%)$ \\
\hline 20 & 38 & 28 \\
\hline 25 & 43 & 33 \\
\hline 30 & 48 & 38 \\
\hline 35 & 55 & 44 \\
\hline 40 & 61 & 49 \\
\hline 45 & 65 & 51 \\
\hline 50 & 69 & 53 \\
\hline
\end{tabular}

\section{Absorción de energía - ensayo de placa}

La absorción de energia (J) de una placa de gunita de hormigón C30/37, de acuerdo con SNCF:

\section{Dramix ${ }^{\circledR}$ RL-45/30-BN}

\begin{tabular}{|c|c|c|c|}
\hline Dosificación $\nabla$ & S2S (J) & Dosificación $\boldsymbol{~}$ & S25 (J) \\
\hline 20 & 475 & 35 & 690 \\
\hline 25 & 540 & 40 & 775 \\
\hline 30 & 605 & & \\
\hline
\end{tabular}

N.V. Bekaert S.A. - Bekaertstraat 2 - 8550 Zwevegem - Belgium Tel. +32 (0) $56 / 766986$

$\mathrm{Fax}+32$ (0) $56 / 767947$

Reservado el derecho de madificaciones. Todos los detalles describen nuestros productos

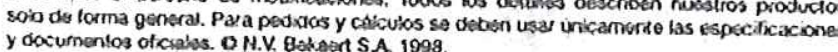

\section{Recomendaciones - mezclado}

\section{General}

$\checkmark$ preferiblemente añadir las fibras en la mezcladora de la planta hormigonera

$\checkmark$ dosificación máxima recomendada:

\begin{tabular}{|l|c|c|c|}
\hline \multirow{2}{*}{$\begin{array}{l}\text { Dosificación } \\
\left(\mathrm{kg} / \mathrm{m}^{\prime}\right)\end{array}$} & \multicolumn{3}{|c|}{$\begin{array}{c}\text { Tamaño do } \\
\text { los éridos }\end{array}$} \\
\cline { 2 - 4 } & $2 / 8$ & $4 / 16$ & $4 / 32$ \\
\hline vertido & 160 & 100 & 80 \\
\hline bombeado & 120 & 75 & 60 \\
\hline
\end{tabular}

$\checkmark$ es preferible una graduación contínua

\section{Adición de fíbras}

\subsection{En la mezcladora de la planta}

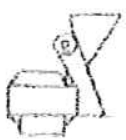

$\checkmark$ no añadir nunca las fibras como primer componente en la mezcladora

$\checkmark$ la fibras pueden introducirse junto con la arena y los áridos o pueden añadirse al hormigón mezclado en fresco

$\checkmark$ solo para hormigonera: se pueden echar directamente en la mezcladora sacos cerrados degradables

\subsection{Camión hormigonera}

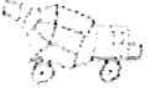

$\checkmark$ poner la mezcladora a la máxima velocidad: $12-18 \mathrm{rpm}$

$\checkmark$ ajustar el cono a un mínimo de $12 \mathrm{~cm}$ (preferiblemente con plastificantes o fluidificantes)

$\checkmark$ añadir fibras con una velocidad máxima de $60 \mathrm{~kg} / \mathrm{min}$

$\checkmark$ los sacos cerrados degradables pueden añadirse, siempre y cuando la velocidad de la hormigonera sea de min. $12 \mathrm{rpm}$

$\checkmark$ equipo opcional: elevador montacargas

$\checkmark$ después de añadir las fibras, continuar mezclando a alta velocidad, durante 4-5 minutos ( \pm 70 rotaciones)

Recomendaciones - almacenaje

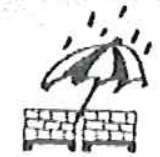

Protojer los palets contra la lluvia

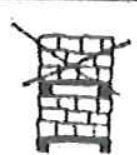

No apilar los palets uno encima de otro 